

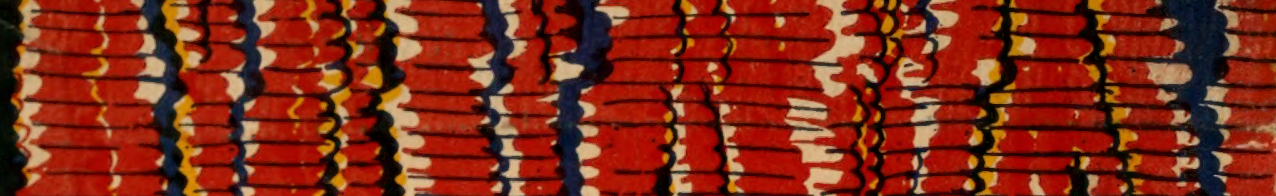
2.3 3 , ह 3 , th

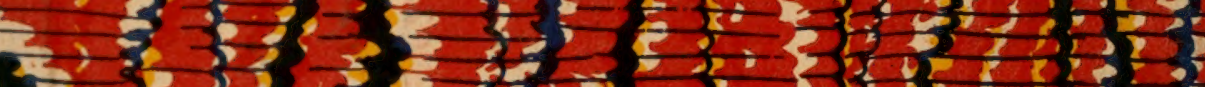
$3,353,3,3,2$ 3343,33013 ?

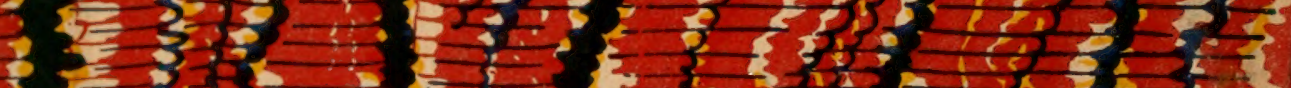
- $30,1,1$,

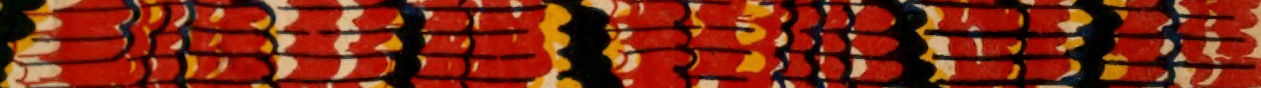

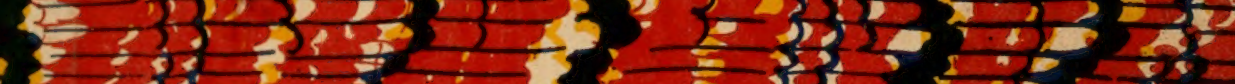

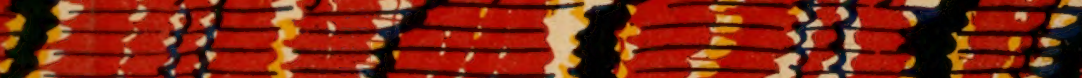
$3: 3=3: 2,53 \div 5$ $+2$

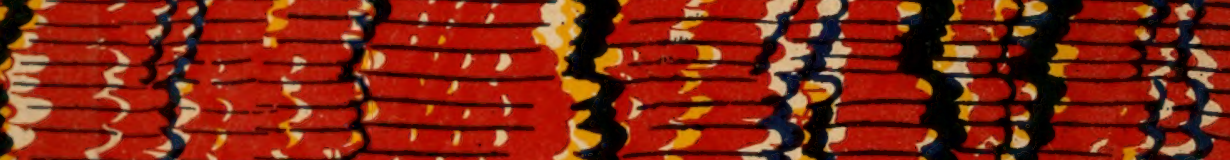
5 (5)

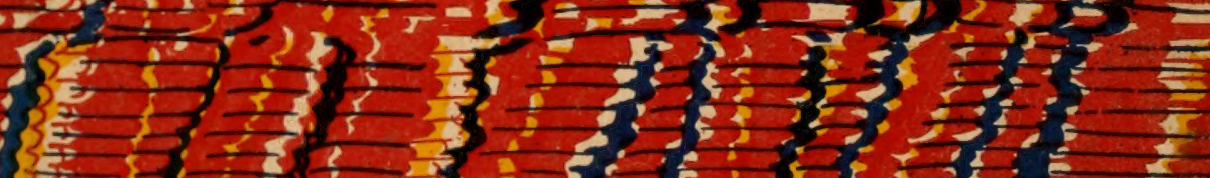

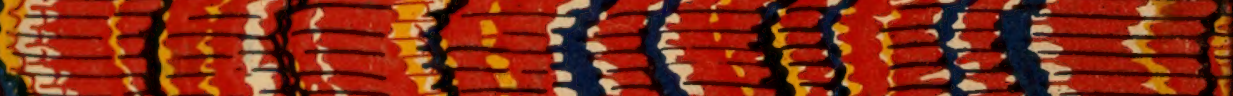

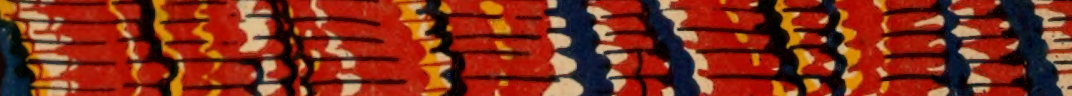

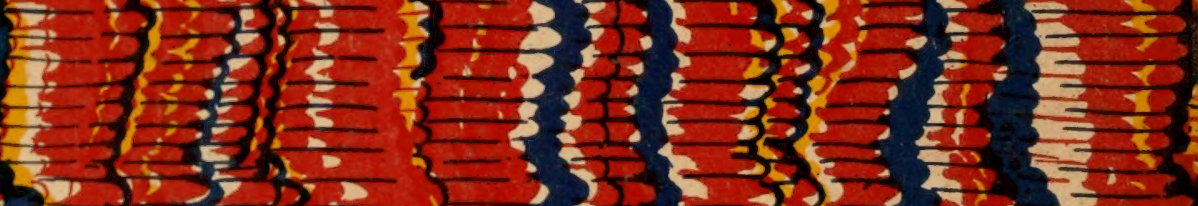

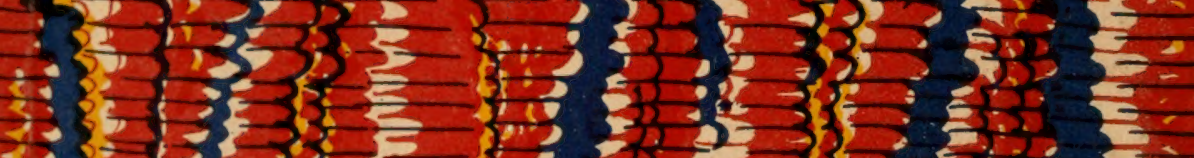

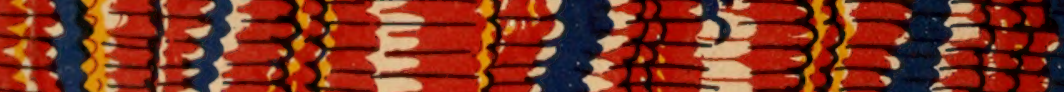
i. $35=2035$

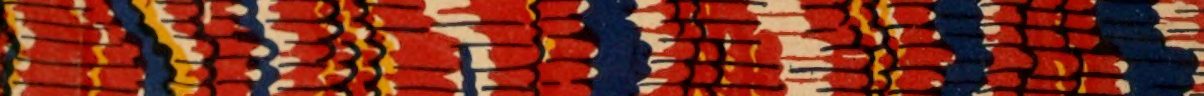

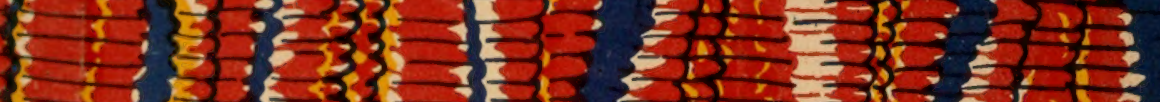

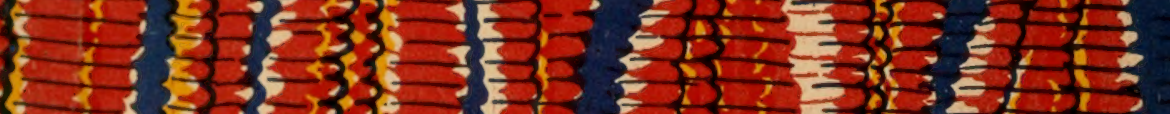

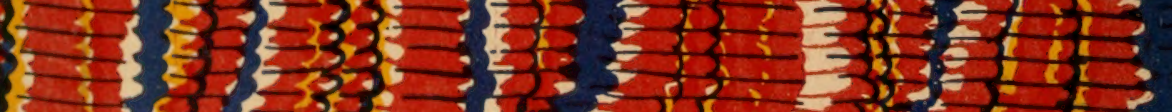

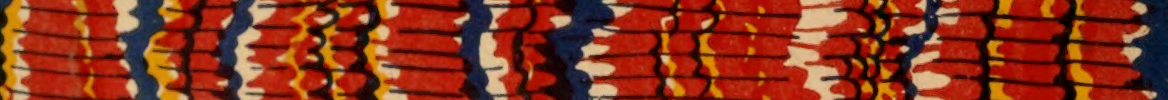

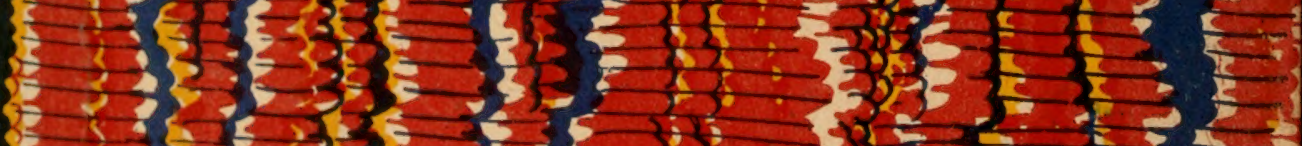

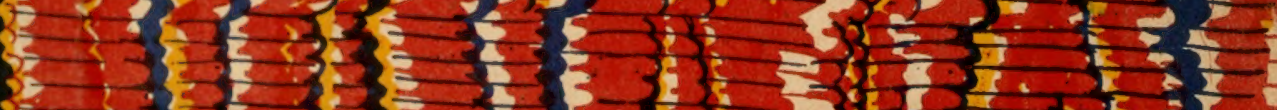

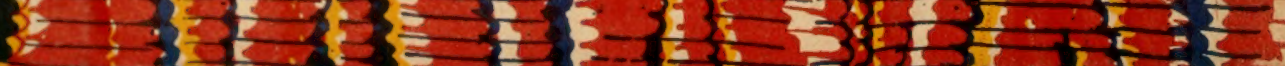

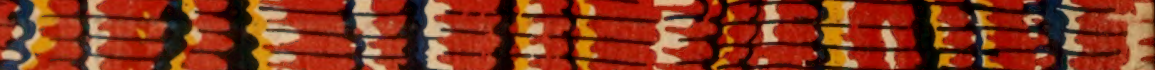

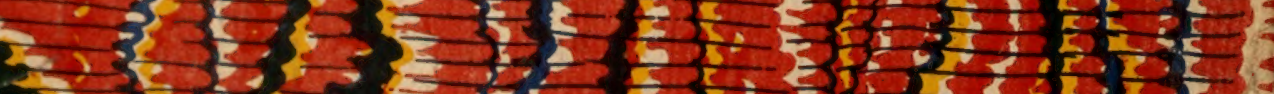



1 




\title{
EOGRAPHICAL BIBLIOGRAPHY
}

OF

\section{BRITISH ORNITHOLOGY}

\author{
FROM THE EARLIEST TIMES \\ TO THE END OF 1918
}

ARRANGED UNDER COUNTIES

BEING A RECORD OF PRINTED BOOKS, PUBLISHED ARTICLES,

NOTES AND RECORDS RELATING TO LOCAL AVIFAUNA

$\mathrm{BY}$

W. H. MULLENS, M.A., LL.M., F.L.S., M.B.O.C.,

H. KIRKE SWANN, F.Z.S., M.B.O.U., AND

REv. F. C. R. JOURDAIN, M.A., M.B.о.ण.

"Men that undertake only one district are much more likely to advance natural knowledge than those that grasp at more than they can possibly be acquainted with; every kingdom, overy province, should have its own monographer."

Gilbert White-" The Natural History of Selborne."

WITHERBY \& CO.

326, HIGH HOLBORN, LONDON 
NoTE.-The parts of this work appeared as follows:Part I., 7 th November, I9I9;

Part II., 5th January, I920 ;

Part III., 25th March, I920

Part IV., 27th May, I920 ;

Part V., Ist July, I920 ; and

Part VI., Ist September, I920. 


\section{PREFATORY NOTE.}

The present volume (which must be regarded as the second of our series of Ornithological Bibliographies, the first, "A Bibliography of British Ornithology," having been published in I9I7) contains all separate works, articles or notes in periodicals, dealing with local faunas, the previous volume having embraced the biographies of those writers who had published a separate work on British birds, together with a list of their writings, excluding short notes. The only ornithological literature we have not dealt with, therefore, consists of these short notes, when not of a local faunistic nature, and longer articles that have not been written by the author of a separate work or pamphlet on British birds. As regards the assistance rendered us for this volume, this is for the most part acknowledged in the preface to the previous, or in the list of counties in the present volume. Our thanks are also due to all those not especially mentioned by name on whose assistance and help we have been able to rely.

W.H.M.

H.K.S.

F.C.R.J.

July $20 t h$, I920. 



\section{INDEX TO COUNTIES.}

The names against the counties in the following list indicate the writers who are responsible for the completion and revision for press of our draft bibliographies of counties.

\section{ENGLAND AND WALES.}

$\begin{array}{lllllll}\text { Bedfordshire-Rev. F. C. R. Jourdain } & \ldots & \ldots & \ldots & \ldots & 9\end{array}$

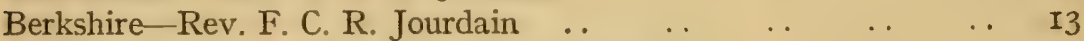

Buckinghamshire - Rev. F. C. R. Jourdain $\ldots \begin{array}{lllll}\text {. } & \ldots & \ldots & \ldots & 20\end{array}$

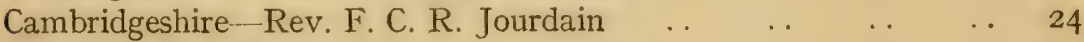

$\begin{array}{llllllll}\text { Cheshire-T. A. Coward } & \ldots & \ldots & \ldots & \ldots & \ldots & \ldots & 3 \text { I }\end{array}$

$\begin{array}{lllllllll}\text { Cornwall-H. Kirke Swann } & \ldots & \ldots & \ldots & \ldots & \ldots & \ldots & 39\end{array}$

Cumberland-H. W. Robinson $\quad \ldots \quad$.

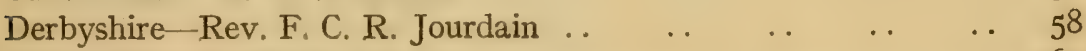

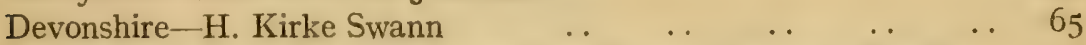

Dorsetshire-Rev. F. L. Blathwayt, with contributions by Rev.

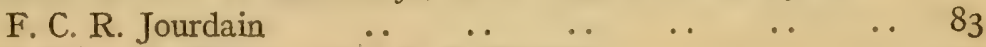

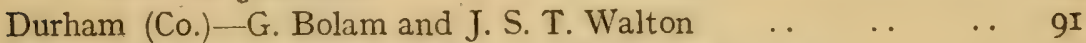

Essex-H. Kirke Swann and Rev. F. C. R. Jourdain _ N $\quad \ldots \quad 9^{6}$

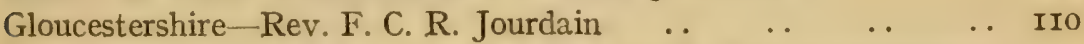

Hampshire \& I. of Wight-Rev. J. E. Kelsall, with contributions

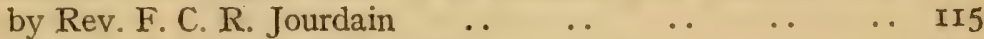

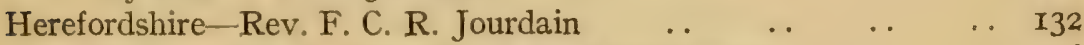

Hertfordshire-Dr. E. Hartert and H. Kirke Swann _. _ . I36

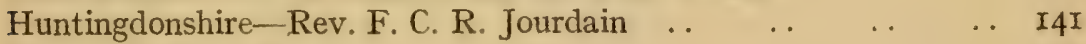

$\begin{array}{llllllll}\text { Kent-H. Kirke Swann } & \ldots & \ldots & \ldots & \ldots & \ldots & \ldots & I_{42}\end{array}$

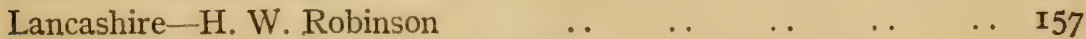

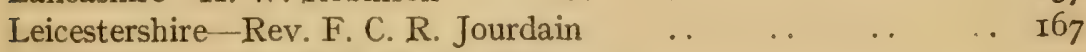

Lincolnshire-Rev. F. C. R. Jourdain _. $\quad \ldots \quad$. $\quad$.. I7I

London \& Middlesex-H. Kirke Swann, with contributions by

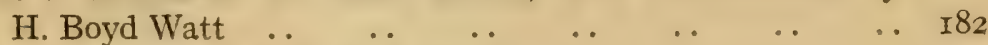

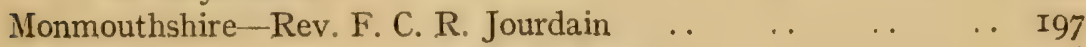

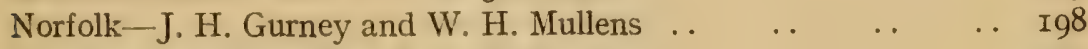

Northamptonshire-Rev. F. C. R. Jourdain _ . $\quad$. . $\quad$.. 22 I

Northumberland-G. Bolam $\ldots \begin{array}{lllllll} & \ldots & \ldots & \ldots & \ldots & \ldots & 226\end{array}$ 
Nottinghamshire - J. Whitaker, with contributions by Rev.

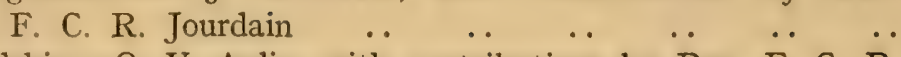

Oxfordshire-O. V. Aplin, with contributions by Rev. F. C. R.

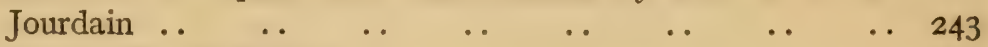

$\begin{array}{lllllll}\text { Rutlandshire-W. H. Mullens .. } & \ldots & \ldots & \ldots & \ldots & \text {. } & 250\end{array}$

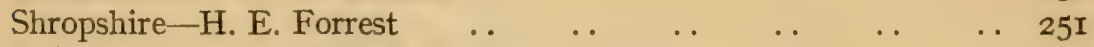

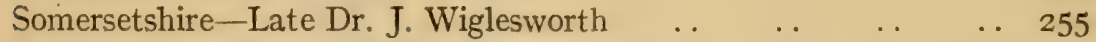

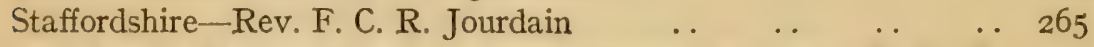

Suffolk-J. H. Gurney, with contributions by Rev. F. C. R.

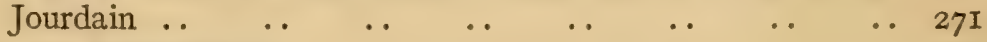

$\begin{array}{llllllll}\text { Surrey-H. Kirke Swann } & \ldots & \ldots & \ldots & \ldots & \ldots & \ldots & 284\end{array}$

$\begin{array}{llllllll}\text { Sussex-W. H. Mullens } & \ldots & \ldots & \ldots & \ldots & \ldots & \ldots & 295\end{array}$

$\begin{array}{llllllll}\text { Warwickshire-H. Kirke Swann } & \ldots & \ldots & \ldots & \ldots & \ldots & 3 \text { I } 8\end{array}$

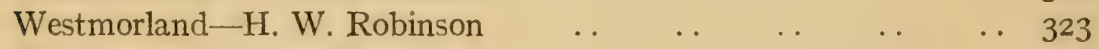

$\begin{array}{lllllllll}\text { Wiltshire-H. Kirke Swann } & \ldots & \ldots & \ldots & \ldots & \ldots & \ldots & 326\end{array}$

$\begin{array}{llllllll}\text { Worcestershire-H. Kirke Swann } & \ldots & \ldots & \ldots & \ldots & \ldots & 332\end{array}$

$\begin{array}{lllllllll}\text { Yorkshire-W. H. Mullens } & \ldots & \ldots & \ldots & \ldots & \ldots & \ldots & 336\end{array}$

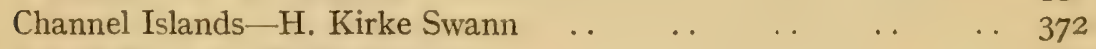

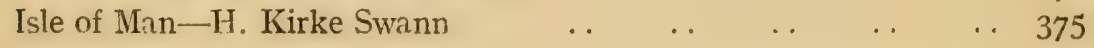

\section{WALES.}

Anglesey-Rev. F. C. R. Jourdain, with contributions by W. H.

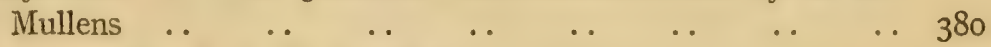

Breconshire-Rev. F. C. R. Jourdain _ A $\quad \ldots \quad \ldots \quad \ldots \quad \ldots 382$

$\begin{array}{lllllll}\text { Cardiganshire-Rev. F. C. R. Jourdain } \quad \ldots & \ldots & \ldots & \ldots & 385\end{array}$

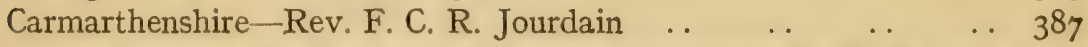

Carnarvonshire-O. V. Aplin, with contributions by W. H. Mullens 388

Denbighshire-Rev. F. C. R. Jourdain _. $\quad \ldots \quad$. $\quad \ldots 390$

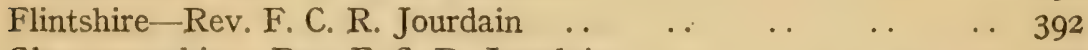

Glamorganshire-Rev. F. C. R. Jourdain _. $\quad$ _. $\quad \ldots \quad$. . 393

Merionethshire-O. V. Aplin, with contributions by W. H. Mullens 396

Montgomeryshire-Rev. F. C. R. Jourdain _. $\quad$. $\quad \ldots 398$

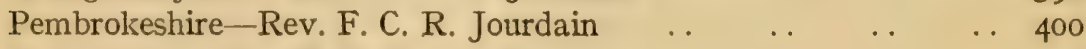

Radnorshire-Rev. F. C. R. Jourdain _ . $\quad \ldots \quad$. . $\quad \ldots 403$

\section{SCOTLAND.}

Aberdeenshire-W. Evans and W. Eagle Clarke _. $\quad \ldots \quad$. $44^{\mathrm{I}} 3$

Argyllshire-W. Evans and W. Eagle Clarke _. $\quad \ldots \quad$. 4 4I

$\begin{array}{lllllllll}\text { Ayrshire-H. Boyd Watt } & \text {. } & \ldots & \ldots & \ldots & \ldots & \ldots & 420\end{array}$

Banffshire-W. Evans and W. Eagle Clarke $\quad \ldots \quad \ldots \quad \ldots \quad \ldots 422$ 
Berwickshire-G. Bolam

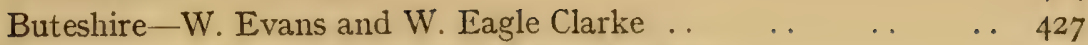

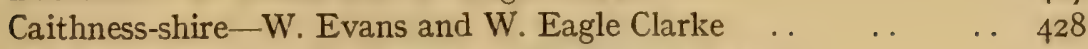

Clackmannanshire-W. Evans and W. Eagle Clarke $\quad \ldots \quad \quad \ldots \quad 429$

Dumbartonshire--H. Boyd Watt $\quad \ldots \quad$.

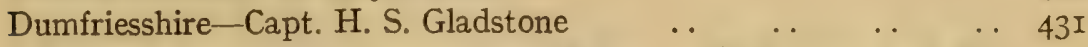

Edinburghshire (Midlothian)-Geo. Bolam, W. Evans and W.

$\begin{array}{llllllllll}\text { Eagle Clarke } & \text {. } & \text {. } & \text {. } & \text {. } & \text {. } & \text {. } & \text {. } & 434\end{array}$

Elgin and Nairn-W. Evans and W. Eagle Clarke . . $\quad \ldots \quad \ldots \quad \ldots 437$

Fifeshire-Geo. Bolam, W. Evans and W. Eagle Clarke _. $\quad$. 439

Forfarshire-W. Evans and W. Eagle Clarke $\quad \ldots \quad$. $\quad$. 442

Haddingtonshire (E. Lothian)-Geo. Bolam, W. Evans and W.

$\begin{array}{lllllllll}\text { Eagle Clarke } & \text {. } & \text {. } & \text {. } & \text {. } & \text {. } & \text {. } & \text {.. } & 443\end{array}$

Hebrides (Outer)-H. Kirke Swann $\quad \ldots \quad$.

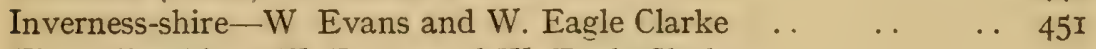

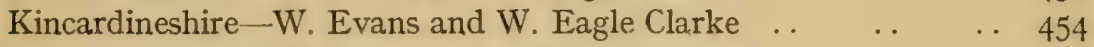

Kinross-shire-W. Evans and W. Eagle Clarke $\quad \ldots \quad \ldots \quad \ldots \quad \ldots 455$

Kirkcudbrightshire-W. Evans and W. Eagle Clarke _. $\quad \ldots \quad 456$

Lanarkshire-H. Boyd Watt ..

Linlithgowshire-W. Evans and W. Eagle Clarke $\quad . \quad 6 \quad \ldots \quad$. . 460

Orkney-H. Kirke Swann, with contributions by H. W. Robinson 46I

Peeblesshire-G. Bolam, W. Evans and W. Eagle Clarke .. $\quad . .467$

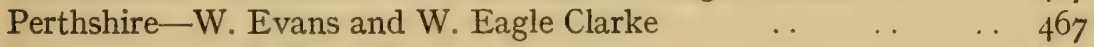

$\begin{array}{llllllll}\text { Renfrewshire-H. Boyd Watt } & \ldots & \ldots & \ldots & \ldots & \ldots & 47 \mathrm{I}\end{array}$

Ross \& Cromarty-W. Evans and W. Eagle Clarke $\quad \ldots \quad \quad \ldots \quad 472$

Roxburghshire-G. Bolam, W. Evans and W. Eagle Clarke _. 474

$\begin{array}{llllllll}\text { St. Kilda-H. Kirke Swann } & \text {. } & \text {. } & \ldots & \ldots & \ldots & \ldots & 476\end{array}$

Selkirkshire-Geo. Bolam, W. Evans and W. Eagle Clarke _. 478

Shetland Islands-H. Kirke Swann

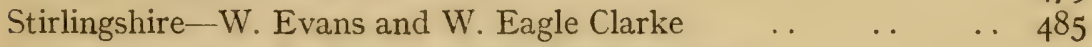

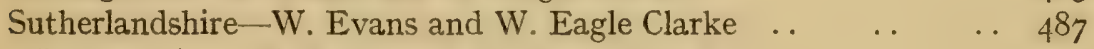

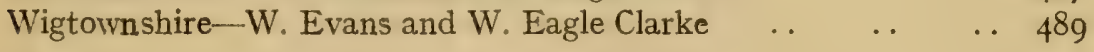

\section{IRELAND.}

Antrim-Nevin H. Foster

$\begin{array}{llllllll}\text { Armagh-Nevin H. Foster } & \ldots & \ldots & \ldots & \ldots & \ldots & \ldots & 504\end{array}$

Carlow-C. J. Carroll

.. 505

Cavan-C. J. Carroll

505

Clare-C. J. Carroll

.. 506

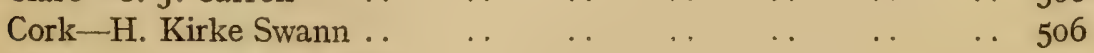

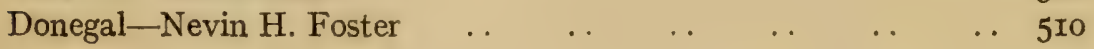


Down-Nevin H. Foster

Dublin-H. Kirke Swann

Fermanagh-Nevin H. Foster

Galway-C. J. Carroll

Kerry-H. Kirke Swann

Kildare-C. J. Carroll

Kilkenny-C. J. Carroll

King's Co.-C. J. Carroll

Leitrim-C. J. Carroll

Limerick-C. J. Carroll . .

Londonderry-Nevin H. Foster

Longford-C. J. Carroll

Louth-Nevin H. Foster

Mayo-H. Kirke Swann

Meath - C. J. Carroll

Monaghan-Nevin H. Foster

Queen's Co.-C. J. Carroll

Roscommon-C. J. Carroll

Sligo-H. Kirke Swann

Tipperary - C. J. Carroll

Tyrone-Nevin H. Foster

Waterford-H. Kirke Swann

Westmeath-C. J. Carroll

Wexford-.H. Kirke Swann

Wicklow-H. Kirke Swann

\begin{tabular}{|c|c|c|c|}
\hline & & & PAGE \\
\hline . & . & . & .. $5 \mathrm{I} 4$ \\
\hline . & . & .. & $\begin{array}{ll}\text {.. } & 519\end{array}$ \\
\hline . & .. & .. & 524 \\
\hline .. & .. & .. & 525 \\
\hline .. & . & . & 527 \\
\hline$\ldots$ & . & . & .. 530 \\
\hline . & . & .. & $53 \mathrm{I}$ \\
\hline . & . & . & $53 \mathrm{I}$ \\
\hline . & . & . & .. $53 \mathrm{I}$ \\
\hline . & . & . & .. 532 \\
\hline . & . & .. & .. 532 \\
\hline . & . . & . & .. 535 \\
\hline . & .. & .. & . 536 \\
\hline .. & . & . & .. 536 \\
\hline . & . & .. & $\begin{array}{ll}\cdots & 54 \mathrm{I}\end{array}$ \\
\hline . & . & . & .. $54 \mathrm{I}$ \\
\hline . & . & .. & ․ 542 \\
\hline . & . & .. & ․ 543 \\
\hline . & . & .. & .. 543 \\
\hline . & . & .. & .. 545 \\
\hline . & . & .. & .. 546 \\
\hline . & . . & . & .. 547 \\
\hline & . & .. & ․ 549 \\
\hline . & . & .. & . 549 \\
\hline . . & . & .. & . $\quad 552$ \\
\hline
\end{tabular}

Addenda . . 
A

\section{GEOGRAPHICAL BIBLIOGRAPHY}

OF

\section{BRITISH ORNITHOLOGY}

FROM THE EARLIEST TIMES

TO THE END OF 1918

ARRANGED UNDER COUNTIES

$\mathrm{BX}$

W. H. MULLENS, M.A., LI.M., F.L.S., M.B.o.ष.,

II. KIRKE SWANN, F.Z.S., AND

Pev. F. C. R. JOURDAIN, M.A., M.B.o.U.

"Men that undertake only one district are much more likely to advance natural knowledgo than those that grasp at more than they can possibly be acquainted with; every kingdom, overy province, should have its own monographer."

Grubent Whitr- "The Natural History of Selborne."

7 th Letter to Barrington:

WITHERBY \& CO.

326, HIGH HOLBORN, LONDON 



\title{
A GEOGRAPHICAL BIBLIOGRAPHY OF BRITISH ORNITHOLOGY.
}

\author{
BRITISH ISLANDS. \\ GENERAL WORKS OF REFERENCE.
}

The principal works on general British ornithology, which should be consulted for county references, with page at which they are described, in the Bibliography of British Ornithology, IgI7.

I544. Turner, W. Avium Præcipuarum. Sm. 8vo. Coloniæ. [599.] I586. HARRISON, W. Description of England [in Holinshed's Chronicle]. [270.]

I6Io. CAMDEN, W. Britain. Folio. Lond. [II6.] And later editions.

I66I. ChILdREy, J. Britannia Baconica. 8vo. Lond. [I28.]

Lovell, R. Panzoologicomineralogia. Sm. 8vo. Oxford. [360.]

I666. MERRETt, C. Pinax Rerum Naturalium Britannicarum. I2mo. Lond. [397.] And later editions.

I668. Charleton, W. Onomasticon Zoicon. 4to. Lond. [I26.]

I674. Ray, J. A Collection of English Words. Sm. 8vo. Lond. [487.]

I677. Charleton, W. Exercitationes ... Animalium. Fol. Oxon. [I26.]

I678. Willughby, F., and Ray, J. Ornithology. Fol. Lond. [65I.]

I713. Ray, J. Synopsis Methodica Avium, etc. 8vo. Lond. [488.]

I73T-38. Albin, E. Natural History of Birds. 4to. 3 vols. Lond. [8.]

I743-64. EDWARDS, G. Natural History of Birds, and Gleanings. 4to. 7 vols. Lond. [r95.]

1752. Hill, J. History of Animals. Fol. Lond. [685.]

I759-63. Martin, B. Nat. Hist. of England. 8vo. 2 vols. Lond. [386.]

I766. Pennant, T. British Zoology. Fol. London. [465.] And later editions.

I769-7I. Berkenhout, J. Outlines of the Nat. Hist. of Gt. Britain and Ireland. 8vo. 3 vols. Lond. [58.] 
I775. HAyES, W. Nat. Hist. of Brit. Birds. Fol. Lond. [287.] I78I-I80I[2]. Latham, J. General Synopsis of Birds. 4to. 3 vols. in 6 pts., with 2 suppl. Lond. [340.] Idem. 2nd. edit. "General History of Birds," I82I-28.

I789. Berkenhout, J. Synopsis of Nat. Hist. of Gt. Britain and Ireland. I2mo. 2 vols. Lond. [58.]

Walcotr, J. Synopsis of Brit. Birds. Sm. 4to. 2 vols. Lond. [607.]

I789-94. LEWIN, W. Birds of Gt. Britain. Fol. 7 vols. Lond. [350.] Idem. 2nd. edit. 4to. 8 vols. Lond.: I795-I80I. [35I.]

I79r. LORD, T. Entire New System of Ornithology. Fol. Lond. [359.]

I794-96. Bolton, J. Harmonia Ruralis. Fol. 2 vols. Halifax. [79.] And later editions.

I794-I8I9. Donovan, E. Nat. Hist. of British Birds. 8vo. Io vols. Lond. [I73.]

I797. Maton, W. G. Observations relative to the Nat. Hist., etc., of the Western Counties. 8vo. 2 vols. Salisbury. [392.]

I797-r804. BEwICk, T. History of Brit. Birds. 8vo. (etc.) 2 vols. Lond. [63.] And subsequent editions.

r8or. Anon. [C. Stewart.] Elements of Nat. Hist. 8vo. Vol. I. (Birds.) Lond., etc. [563.]

I802-r3. Montagu, G. Ornithological Dictionary, and Supplement. 8 vo. 3 vols. Lond., etc. [4IO.] And subsequent editions.

I804-6. Sowerby, J. British Miscellany. Roy. 8vo. Lond. [554.]

I807. TurTon, W. British Fauna. I2mo. Swansea. [600.]

I808[-I6.] Hayes, C. Portraits of Brit. Birds. 4to. Lond. [286.]

I8II-2I. Graves, G. British Ornithology. 8vo. 3 vols. Lond. [246.] Idem. 2nd. edit., I82I.

I8I5[-22.] HUNT, J. Brit. Ornithology. 8vo. 3 vols. Norwich. [305.]

I8r6. LEACH, W. E. Systematic Cat. of Indigenous Mammalia and Birds. Sm. 4to. Lond. [344.]

I82I-34. SELBY, P. J. Illustrations of British Ornithology. Fol. 2 vols., with Letterpress, 8vo. 2 vols. Edinb. [5I9.] And subsequent issues.

I823. Syme, P. Treatise on British Song Birds. 8vo. Edinb. [572.] I823-32. SweEt, R. British Warblers. 8vo. Lond. [57I.]

I828. Fleming, J. History of British Animals. 8vo. Edinb. [2Io.] And re-issue, 1842 . 
I830. Mudie, R. British Naturalist. Post 8vo. 2 vols. Lond. [424.]

I83I-38. Hewitson, W. C. British Oology. Roy. 8vo. 3 vols. Newcastle. [293.] And subsequent issues.

I832-35. Jesse, E. Gleanings in Nat. Hist. Post 8vo. 3 vols. Lond. [3I6.]

I832. Slaney, R. A. Outline of the Smaller British Birds. I2mo. Lond. [542.]

I8[32-]37. Gould, J. Birds of Europe. Fol. 5 vols. Lond. [24I.] I834. Mudie, R. Feathered Tribes of Brit. Islands. Post 8vo. 2 vols. Lond. [424.] And subsequent editions.

1835. Jenyns, L. Manual of Brit. Vertebrated Animals. 8vo. Cambridge. [3I5.]

Cotton, J. Resident Songbirds of Gt. Britain. Roy. 8vo. 2 pts. Lond. [I49.] Idem. Another issue. I vol. I836.

1836. Eyton, T. C. History of the Rarer Brit. Birds. 8vo. Lond. [203.]

MacGillivray, W. Descriptions of the Rapacious Birds of Gt. Britain. Post 8vo. Edinb. [370.]

Wood, N. British Songbirds. Post 8vo. Lond. [663.]

I837-52. MacGillivray, W. History of British Birds. 8vo. 5 vols. Lond. [370.]

I838-43. JARDINE, SIR W. Naturalists' Library-Ornithology. Birds of Gt. Britain and Ireland. I2mo. 4 vols. Edinb. [3II.]

I840-42. MacGillivray, W. Manual of Brit. Ornithology. I2mo. 2 vols. Lond. [37I.]

I842-50. MEYER, H. L. Coloured Illustrations of British Birds and their Eggs. 8vo. 7 vols. Lond. [403.] Idem. New edit., I852-57.

I843. YARRELI, W. History of British Birds. 8vo. 3 vols. Lond. [670.] And subsequent editions.

[r848. ?] Meyer, H. L. Game Birds and their Localities. Obl. 4to. Lond. [404.]

I849. Gosse, P. H. Popular Brit. Ornithology. Post 8vo. Lond. [239.] And 2nd. edit., I853.

I85I. AdAms, H. G. Favourite Song Birds. I2mo. Lond. [2.] And subsequent editions.

I85I-57. Morris, F. O. History of British Birds. Roy. 8vo. 6 vols. Lond. [4I7.] And subsequent editions.

I853-56. Morris, F. O. Nests and Eggs of British Birds. Roy. 8vo. 3 vols. Lond. [4I7.]

I855. Morris, B. R. Brit. Game Birds and Wild Fowl. 4to. Lond. [4I4.] 
I862. Johns, C. A. Brit. Birds in their Haunts. 8vo. Lond. [3I8.] And subsequent editions.

[I862-63.] Adams, H. G. Our Feathered Families. Post 8vo. 3 vols. Lond. [3.]

I862-73. Gould, J. The Birds of Gt. Britain. Fol. 5 vols. Lond. [242.]

I863. GRAY, G. R. Catalogue of Brit. Birds in Collection of Brit. Museum. 8vo. Lond. [248.]

I864-I907. Wolley, J., and Newton, A. Ootheca Wolleyana. Roy. 8vo. 2 vols. Lond. [446.]

I865. More, A. G. On the Distribution of Birds in Gt. Britain during the Nesting Season. 8vo. Lond. [4I3.] [Reprint from Ibis, I865, 3 pts.]

I86\%. GuRNEY, J. H., junr. Summary of Occurrences of the Grey Phalarope during I866. 8vo. [260.]

I868. Anon. [Livingstone, G.] Brit. Birds: Their Haunts and Habits. 8vo. Lond. [2I.]

I87I-85. YARRELL, W., NEwToN, A., and SAUNDERS, H. History of Brit. Birds. Fourth Edition. 8vo, 4 vols. Lond. [67I.]

I87I-96. DREsSER, H. E. A History of the Birds of Europe. 4to. 9 vols. Lond. [r79.]

I872. Harting, J. E. Handbook of Brit. Birds. 8vo. Lond. [274.] Idem. Revised Edit. 8vo. Lond. rgor. [276.]

1874. Adams, H. G. The Smaller Brit. Birds. Roy. 8vo. Lond. [3.] Idem. another edit., I894.

1875. Harting, J. E. Our Summer Migrants. 8vo. Lond. [275.] [I876.] GuRney, J. H., junr. Rambles of a Naturalist. 8vo. Lond. [260.]

I876. Rowley, G. D. Ornithological Miscellany. 4to. 3 vols. Lond. [498.]

1879-89. Brit. Assoc. Migration Committee Reports. 8vo. 2 vols. or 9 pts. Lond. [93.]

I88I-87. BоoтH, E. T. Rough Notes on Birds observed in the Brit. Isles. Fol. 3 vols. Lond. [84.]

I8[8I-]92. Mosley, S. L. History of Brit. Birds. 8vo. 3 vols. Huddersfield. [420.]

I883. Brit. Ornithologists' Union. List of Brit. Birds. 8vo. Lond. [94.] See also I9I5.

I883-85. Seевонм, H. History of Brit. Birds. Roy. 8vo. 4 vols. Lond. [5I7.]

I883-[88.] Swaysland, W. Familiar Wild Birds. Post 8vo. 4 vols. Lond. [570.] And subsequent editions. 
I885. GRIEVE, S. The Great Auk or Garefowl. 4to. Lond., etc. [254.]

Swainson, C. Provincial Names and Folklore of Brit. Birds. 8 vo. Lond. [567.]

I885-97. LILFORD, LORD. Coloured Figures of the Birds of the Brit. Islands. 8vo. 7 vols. Lond. [354.] And 2nd edit.

I886. Butler, A. G. Brit. Birds' Eggs. 8vo. Lond. [rIr.]

Smart, G. Birds on the Brit. List. 8vo. Lond. [544.]

I888. Dixon, C. Our Rarer Birds. 8vo. Lond. [I69.] And other works. [169.]

I889. SAUnders, H. Illustrated Manual of Brit. Birds. 8vo. Lond. [509.] Idem. 2nd. edit., I899. [509.] And additions in Brit. Birds, I907. [See also I907-09, Ticehurst and Witherby.]

I89i. Christy, M. Catalogue of Local Lists of Brit. Birds. 8vo. Lond. [I29.]

I892. Millais, J. G. Gamebirds and Shooting Sketches. Fol. Lond. [405.] Idem. 2nd. edit. Roy. 8vo., I894.

I893. Dixon, C. Gamebirds and Wildfowl of the British Islands. 8vo. Lond. [I69.] And subsequent editions.

I894-97. Sharpe, R. B. Handbook to the Birds of Gt. Britain. Cr. 8vo. Lond. [529.]

1894-99. Wyatr, C. British Birds. Fol. 2 vols. Lond. [667.]

I895. Hudson, W. H. British Birds. 8vo. Lond. [303.] Idem. New edit., I897.

Cornish, C. J. Wild England of To-day and the Wild Life in It. 8vo. Lond. [I 47.]

[JoRdan, D.] "Son of the Marshes." Wild Fowl and Sea Fowl of Gt. Britain. 8vo. Lond. [320.]

Kearton, R. British Birds' Nests. 8vo. Lond. [323.] And later edns.

I895-96. Poynting, F. Eggs of Brit. Birds (Limicole.) 4to. Lond. [479.]

I896. Sеввонм, C. Coloured Figures of Eggs of Brit. Birds. Roy. 8vo. Sheffield. [5I8.]

Swann, H. Kirke. Concise Handbook of British Birds. I2mo. Lond. [569.]

I896-99. LEE, O. A. J. Among British Birds in their Nesting Haunts Fol. 4 vols. or I6 pts. Edinb. [345.]

[VARIous Writers.] British Birds, their Nests and Eggs. 4to. 6 vols. Hull, etc. [III.]

I897. Westell, W. P. Handbook of Brit. Breeding Birds. I2mo. Lond. And other works. [622.]

I897-I909. Maxwell, Sir H. Memories of the Months. Cr. 8vo. 5 vols. Lond. [393.] 
I898. AFlalo, F. G. A Sketch of the Nat. Hist. (Vertebrates) of the British Islands. Post 8vo. Lond. [5.]

I899. KeARTon, R. Our Rarer British Breeding Birds. 8vo. Lond. [324.]

I902. Millais, J. G. Nat. Hist. of British Surface-feeding Ducks. Roy. 4to. Lond. [406.]

Patten, C. J. Aquatic Birds of Gt. Britain and Ireland. 8vo. Lond. [459.]

I902-03. Dresser, H. E. Manual of Palæarctic Birds. Roy. 8vo. 2 pts. Lond. [I8o.]

I903-I4. HARTERT, E. Die Vögel der Paläarktischen Fauna. 8vo. 9 pts. Berlin \& Lond. [27r.]

1905. Westell, W. P. British Bird Life. Cr. 8vo. Lond. [623.] Ig06. Colletr, A. Handbook of Brit. Inland Birds. Cr. 8vo. Lond. [I39.]

rgo6-ri. Stonham, C. Birds of Brit. Islands. 4to. 5 vols. or 20 pts. [566.]

I906-I2. B. O. C. Migration Committee Reports, Ig05-II. 8vo. 7 vols. Lond. [Bull. B. O. C.] [93.]

Jourdain, Rev. F. C. R. Eggs of European Birds. 8vo. 4 pts. Lond. [322.]

I907. Bonнote, J. L. Birds of Britain. Sq. 8vo. Lond. [80.] Thomas, E. [edited by.] British Country Life. 4to. 2 vols. Lond. [69I.]

1907-08. Butler, A. G. Birds of Gt. Britain and Ireland. Order Passeres. 4to. 2 vols. Hull, etc. [III.]

I907-09. Ticehurst, N. F., and Witherby, H. F. On the More Important Additions to our Knowledge of British Birds since I899. 8vo. Lond. [ex British Birds], I907-09. 20 pts. [583.] Forms a supplement to Saunders's Manual, I899.

Ig07-r4. Howard, H. E. British Warblers. Roy. 8vo. 9 pts. Lond. [299.]

I909. Millais, J. G. Nat. Hist. of Brit. Game Birds. Fol. Lond. [406.]

I9Io. Dresser, H. E. Eggs of the Birds of Europe. 4to. 2 vols. Lond. [I80.]

Thompson, A. L. British Birds and their Nests described. Roy. 8vo. Lond. [580.]

I9I0-I3. Kirkman, F. B. B. [edited by.] British Bird Book. Roy. 4to. 4 vols, or I2 Sections. Lond. [330.] 
1912. Clarke, W. Eagle. Studies in Bird Migration. Sq. 8vo. 2 vols. Lond. [I35.]

HARTERT, E. (and others). Hand-list of British Birds. 8vo. Lond. [27I.]

[VARIOUS WrITERs.] Brit. Gamebirds and Wildfowl, in "The Gun at Home and Abroad." 4to. 2 vols. [406.]

I9r3. Millais, J. G. British Diving Ducks. Roy. 4to. 2 vols. [406.] Swann, H. Kirke. Dictionary of English and Folk Names of British Birds. 8vo. Lond. [569.]

I9I4. Walpole-Bond, J. Field Studies of some rarer British Birds. 8vo. Lond.

I9I5. Brit. Ornithologists' Union List of Brit. Birds. 8vo. Lond. [94.]

x915-16. Thorburn, A. British Birds. 4 vols. 4to. Lond. [and subsequent reissues].

\section{PERIODICALS.}

"The List of Periodicals Cited" (Bibliogr. Brit. Ornithology, I9I7, pp. $\mathrm{xv} . \mathrm{xx}$.), gives all the periodicals necessary to be consulted and the following county bibliographies comprise a digest of the local matter contained in such periodicals. 



\section{BEDFORDSHIRE.}

I825. Yarrell, W. Notice of occurrence of some rare British birds [includes L. excubitor in Beds.]. (Zool. Jnl. II, p. 26.) [partim.] 1828. (Essex Herald.) Woodcock's Nest [near Shefford in Beds.] (Loudon's Mag. N. H., I.)

r830. White, W. H. Natural History in the English Counties: Bedfordshire. Cuckoo, Swallows, etc. (Op. cit. III, p. I54.) White, W. H. Northern Diver near Bedford. (T.c.)

1847. Bird, W. F. W. Bohemian Waxwing in Beds. (Zool.) I847-48. Newton, A. Arrivals of Migratory Birds at Everton, Beds. 2 notes. (Op. cit.)

I850. Smith, C. Hervey. Occurrence of Osprey at Toddington, Beds. (Op. cit.)

I85I. Clarke, G. B. Miscellaneous Notes; Greater Black-backed Gull in Beds.; Light Variety of Yellowhammer etc.; Jackdaw; Rare Birds at Woburn ; Predaceous Habit of Rook ; Hawfinch breeding in Beds.; Nesting of Starling; Note on nesting of Jackdaw in Scotch fir, etc. II notes. (Nat. [Morris's,] I.)

I852. Clarke, G. B. Variety of Common Pheasant; Wild Swan; Chiffchaff; Swallow (Op. cit. II.) 4 notes.

I854. Clarke, G. B. Grey Phalarope at Hockliffe, Beds.; Nest of Redpoll in Beds.; Arrival of Summer Birds of Passage. $(O p$. cit. IV.) 3 notes.

Dawson, J. F. Curious Anecdote of Partridges. (Zool.)

I855. [Anon. "T. C."] Mountain Finch; Hawfinch [in Beds.]; Ring Ouzel [in Beds.]. (Nat. [Morris's] V.) 3 notes.

Clarke, G. B. Effects of severe weather, etc. (T.c.)

Davis, F. History of Luton. 8vo. Luton: I855. [I64.]

" J. C. T." Hawfinch [in Beds.]; Honey Buzzard. (Nat. [Morris's] V.) 2 notes.

I856. [Anon.] Occurrence of Bittern in Beds. (Zool.)

Cane, T. Occurrence of Rose-coloured Pastor [in Beds.] ; Green Sandpiper. (Nat. [Morris's] VI.) 2 notes.

I858. Gibbins, R. Several Birds laying eggs in same nest. (Field, June I9.)

Morris, F. O. Occurr. of Quail in winter. [partim.] (T.c.Dec.II).

1859. Lamborn, C. Dunstableogia, etc. Post 8vo. Dunstable: I859. [337.] 
r860. "H. J. J." Waxwinged Chatterer [in Beds. circa, I852]. (Ficld, Dec. I.) Spotted Crake [not rare in Beds.] (T.c., Dec. I.)

I863. Thurnall, W. Capture of Erne or Sea Eagle in Beds. $(O p$. cit. Apr. II.)

1864. Smith, C. H. Bewick's Swan near Woburn; Crossbills in Beds. (Zool.)

I868. [Anon.] Crossbills' [?] Nest with three eggs. (Sci. Gossip.) "Spot." Woodcocks breeding in Beds. (Field, May 2.) Idem by "Squib" (T.c. May 23.)

I870. Chalk, W. J. Red-necked Grebe in Beds.; Quails at Wilden. (Zool.)

Chamberlain, D. \& W. Extraordinary capture of Scoters [at Tempsford]. (Field, July 23.)

"Finder." Occurrence of Red-breasted Snipe [Bar-tailed Godwit] in Beds. (Field, May 28.)

r87r. Chalk, W. J. Cirl Bunting and Long-tailed Duck in Beds.; Arrival of Migrants; Honey Buzzard in Beds. ; Large Flock of Golden Plover at Bedford. 4 notes. (Zool.)

"C. S." Brent Geese in Beds. (Field, Feb. 25.)

Wright, J. S. Peregrine Falcons in Beds. (T.c. Jan. 28.)

I872. Lester, W. H. Curious Site for [Robin's] Nest. (Op. cit. May I8.)

1874. Cane, T. Great Crested Grebe at Luton. (Zool.)

"C. L. H[all]." Goosander near Bedford. (Field, Dec. I2.)

Jessop, A. L. Lapland Bunting [errore] near Bedford. $(O \neq$. cit. Jan. 3I.)

1875. Harting, J. E. Leach's Petrel near Bradford [errore for Bedford]. (Op. cit. Dec. 4.)

" S. G. P." Late Stay of Swallows. (T.c. Nov. 20.)

I876. Prior, C. M. Tree Sparrow and Wood Pigeon [Stock Dove] building in Magpie's Nest; White Starling; Stock Dove building in Oct.; Note on Rooks, etc.; Ducks nesting in Pollard Willows; Migration of Swifts, etc. II notes. (Zool.)

1877. Prior, C. M. Late Arrival of Spotted Flycatcher (Field, - ?) ; Wild Fowl in Beds. ; Starling nesting in Sand Martins' Holes ; Sand Martins nesting in Stone Wall. (Zool.) 3 notes.

1878. "Finder." Little Auk in Beds. (Field, Dec. I4.)

Prior, C. M. Brent Goose in Beds. ; Dunlins in Beds. in Dec. ; Kittiwake in Beds.; Nesting Habits of Kingfisher, etc. 5 notes. (Zool.); Dunlin and other Birds in Beds.; Brent Goose in Beds; (Field, Jan. I9.)

1879. Prior, C. M. Rare Birds in Beds.; Slavonian Grebe, Hobby and Common Scoter and Grey Phalarope in Beds.; Nesting of Stock Dove, etc. 7 notes. (Zool.) 
W[right]. J. S. Common Scoter in Beds. (Field, Aug. 30) ; Goosander near Shefford (T.c. Dec. I3) : Bittern near Shefford (T.c. Dec. 20).

I880. "J. L. A." Shore Larks near Bedford. (Op. cit. Nov. 6.)

Burney, H. Siskin nesting in Beds. [err, for Bucks]. (Zool.)

King, J. Scarcity of Fieldfares. (T.c.)

Mitford, R. N. Siskin nesting in Beds. (T.c.) [vide supra.]

Prior, C. M. Pomatorhine Skua and Peregrine Falcon in Beds. 2 notes. (T.c.)

Wright, J. S. Rednecked Grebe in Beds. (Field, Jan. 24); Stormy Petrel in Beds.; White Bunting. (Op. cit. Nov. 6); Buzzard in Beds. (T.c. Dec. II.)

I88r. Wright, J. S. Common Buzzard in Beds. (Op. cit. Oct. 8.)

I882. "Chilled Shot." White Partridges in Beds. 2 notes. (OP. cit. Sept. 23, 30.)

Higgins, W. F. Little Auk in Beds. (T.c. Dec. 2.)

1883. Hare, W. Sandpipers Inland in Winter. (Op. cit. Jan. I3.)

Wright, J. S. Arrival of Waxwings. (T.c. Jan. 27.)

1885. Wright, J. S. Bittern in Beds. (Op. cit. Feb. I4); Waxwing in Beds. (T.c. Jan. 24.)

I886. Farrell, M. F. Late Stay of Swifts. (Op. cit. Sept. II.)

Rooke, C. H. Quails in Beds. (T.c. Sept. II.)

I887. Wright, J. S. Great Crested Grebe in Beds. (Op. cit. Oct. I.)

I89o. Barnard, J. Hoopoe in Beds. (Op. cit. Oct. Ir.)

I89I. Stewart, D. H. S. Teal breeding in Beds. (Zool.)

I892. Aplin, O. V. On Distribution of Cirl Bunting in Great Britain. (Op. cit.) [partim.] [25.]

Elliott, J. Steele. Bitterns in Beds. (T.c.)

1893. "W. A. N." Bittern in Beds. (Field, Feb. II.)

I894. Covington, A. Pied Variety of Barn Owl. (Beds. Standard, Jan. 26.)

Elliott, J. Steele. Osprey in Beds. ; Nesting of Lesser Redpoll in Beds. (Zool.) ; White Partridges. (Field, Dec. 22.)

"Ptarmigan." [T. W. Storey.] Three White Partridges in Covey. (T.c. Dec. I5.)

1895. Leader, R. R. Thrush's nest lined with feathers (Nat. Jnl.) 1896. "A. A." Scaup in Beds. (Field, Oct. ro.)

Pearse, T. Late Stay of Swift. (T.c. Oct. Io.)

"X. Y. Z." Scaup in Beds. (T.c. Oct. I7.)

1897. Cooper, A. D. Common Buzzard at Hinwick. (Nat. Jnl.)

Orlebar, R. Buzzard in Beds. (Field, Mar. 27.)

I897-I90I. Elliott, J. Steele. Vertebrate Fauna of Bedfordshire. (Birds only). 5 ots. 8vo. I897-Igor. (priv. prtd.) [558.] 
I898. "Halcyon." Rooks nesting in Pollards and Hollies. (Field, May 28.)

Crossman, A. F. Scaup in Beds.; Alleged Kentish Plover in Beds. (Zool.)

Harwood, G. Little Owl in Beds. (Field, Oct. 8). Cf. also T.c. Oct. I5.

Orlebar, R. Late Swallows. (T.c. Nov. I9.)

rgor. Orlebar, R. Hobby in Beds. (Op. cit. June I.)

I903. Allen, J. Little Owl nesting in Beds. (Op. cit. July I8.)

Meade-Waldo, E. G. B. Little Owls in Beds. (T.c. July 25.)

I904. Elliott, J. Steele. [Aves. In] Victoria History of Co. of Bedford, I. 4to. Lond.; I904. [558.]

I905. Bedford, Duchess of. Blackbirds singing in Winter. (Field, Mar. II.)

Elliott, J. Steele. Breeding Habits of Birds. (Zool.)

Pearse, T. Increase of Goldfinches in Beds. (T.c.)

Ig06. Bedford, Duchess of. Black-throated Diver at Woburn; Totanus calidris in Beds. 2 notes. $(O p$. cit.)

Elliott, J. Steele. Extracts from Churchwardens' Accounts of Beds. 2 pts. (Zool.) [558.]

[Harting, J. E.] Hybrid Partridge [errore for Bamboo Partridge!] (Field, Jan. 27 ; cf. T.c. Feb. 3.)

1907. Ainslie, D. Little Owl in Beds. (Zool.)

Bedford, Duchess of. Artificial Additions to British Fauna. (T.c.)

Elliott, J. Steele. Brambling in Beds.; Little Owl in Beds. (T.c.)

Orlebar, R. Lesser Grey Shrike in Beds. (Field, Feb. 2.)

Pearse, T. Movement of Birdsduring Snow. (Zool.)

1908. Witherby, H. F., and Ticehurst, N. F. Spread of Little Owl from Chief Centres of Introduction. (Brit. Birds I.) [partim.]

I909. Atchison, G. T. Nesting Dates of Lesser Redpoll in Cambs., Beds., etc. $(O p$. cit. III.) [partim.]

Bedford, Duchess of. Goosander in Beds. (Op. cit. II.)

Orlebar, R. Crossbills in Beds. (Field, Nov. 27.)

I9ro. Elliott, J. Steele. Stone Curlew in Beds. ; Crossbill nesting in Beds. (Zool.)

Oldham, C., and Bedford, Duchess of. Irruption of Crossbills. (Brit. Birds III.) [partim.]

Paterson, J. Black Tern in Beds. (Op. cit. IV.) [Editorial] Idem. (Op. cit., VI., I9I2).

IgIr. Bedford, Duchess of. Tufted Ducks breeding in Beds. (OP. cit. V.) Idem by F. Sharman. (T.c.)

Fleet, L. Black Tern in Beds. (T.c.) 
Elliott, J. Steele. Decrease of Corncrake and Wryneck; Migration of Coot in Beds. (Zool.)

Lewis, H. Goosanders and Cormorant in Beds.; Shag not Cormorant in Beds. 2 notes. (Brit. Birds IV.)

I912. Bedford, Duchess of. Sanderling and Goosander in Beds. (Op. cit. V.)

Elliott, J. Steele. Snipe nesting in Beds. Common Gull numerous in Beds. ; Slavonian Grebe in Beds. ; Little Auk in Beds.; Increase of Land Rail [partim.] ; etc. 6 notes. (Zool.)

I9r3. Bedford, Duchess of. Crossbills breeding in Beds. (Brit. Birds, VI.)

Igr4. Elliott, J. Steele. Waxwings in Beds. ; Hooded Crow in Beds. ; Status of Blackcap, Garden Warbler and Lesser Whitethroat in Beds., etc. 4 notes. (Zool.)

Elliott, W. J. Food of Little Owl in Beds. (T.c.)

Foster, A. H. Black Tern in Beds. (Field, May 9.)

Rowan, W. Shore Lark in Beds. (Brit. Birds, VII.)

Symonds, J. H. Yellow Wagtail [near Bedford]. (Avicul. Mag. pp. 259-6I.)

I915. Adeny (M.) Little Owl [near Dunstable.] (Selborne Mag. p. I36.)

Bedford (Duchess of). Rough-legged Buzzard in Beds. (Brit. Birds, IX.)

Elliott (J. Steele). Rose-coloured Starling in Beds.; Black Redstart in Beds. ; Hen Harrier in Beds.; Increase of Little Grebes nesting in Beds., etc. 7 notes. (Zool.)

IgI6. Bedford (Duchess of). Firecrest in Beds. (Br. Birds, IX.). Elliott (J. Steele). Gulls in Beds.; Early Autumnal movements of Sandpipers, etc., in Beds.; Migration in Beds., etc. 4 notes. (Zool.)

I9I7. Aitchison, G. T. Large clutch of eggs of Little Owl near Bedford. (Brit. Birds, XI.)

BERKSHIRE.

I825. [Bicheno, - ] [Storm Petrel near Newbury.] (Zool. Jnl. II., p. 3I5).

I827. Yarrell, W. On occurrence of rare British Birds [Hawfinch; Ardea minuta near Windsor.] (Op. cit.)

1832. "A. B." A White Water Rail [in Berks.] (Loudon's Mag. N. H. V., p. 384.)

I833. Morris, F. O. The Cirl Bunting [at East Garston.] (Op. cit. VI., p. I5I.) 
1837. Morris, F. O. Distribution of Cirl Bunting and of Corn Bunting in England. [partim.] 2 articles. (Nat., [N. Wood's,] II.)

1843. Hewett, W. Notes on Screech Owl; Rooks; Royston Crow ; Magpies, Jays and Crows; Magpies and Starlings; Ring Ouzel; Wryneck; Bunting; Shrike; Nesting place of Swallows; Occurrence of Blackcap [?] in Jan.; Occurrence of Quails in Winter; Anecdote of Partridge; Anecdote of Woodcock; Note on Golden Plover; Eggs of Stone Curlew ; Habits of Dotterel. (Zool.)

1844. Jesse, E. [Windsor Park Heronry. In] Scenes and Tales of Country Life. Post 8vo. Lond.: 1844. [3I7.]

1847. Newton, A. Occurrence of Rare Birds, etc. [per C. Lloyd.] (Zool.)

I849. Hewett, W. Heronry at Coley Park, Berks. (Op. cit.)

Matthews, A. \& H. Birds of Oxfords. and its Neighbourhood, 4 parts. [partim.] (T.c.)

I851. McIntosh, J. Heronries in England, etc. [partim.] (Nat. [Morris's], I.)

I852. Norman, A. M. Occurrence of Great Snipe at Botley. (Zool.)

1853. Powys, T. L. Capture of various Birds in Oxfords. ; Occurrence of Sandwich Tern, etc. near Oxford. 2 notes. (Op. cit.)

Wilson, J. C. Rare Birds at Reading. (Nat. [Morris's,] III.)

1855. Collingwood, C. Calendar of Natural Phenomena observed at Purley Park. (Zool.) [I39].

Stubbs, C. Crested and Rednecked Grebes [at Henley]. (Nat. [Morris's], V.)

1856. Buckland, F. Eagle in Windsor Forest. (Nat. [Morris's,] VI., p. I63.)

[Editorial.] Eagle shot in Windsor Park. (Field, Mar. r.)

Rowland, W. H. [Letter on Great Bustard at Hungerford.] (Times, Jan. 3I.)

Yarrell, W. Recent Occurrence of Great Bustard in Berks. (Zool.) Further particulars by A. C. Smith. (T.c.)

1858. Buckland, F. T. The Honey Buzzard [shot in Windsor Forest.] (Field, Nov. 6.)

I859. Mathew, M. A. Notes on the Partridge. (Zool.)

I86I. Ramsden, R. Cuckoo's Egg in Reed Warbler's Nest. $(O p$. cit.)

I862. "W. H. R." [W. H. Rowland ?] Woodcock breeding in England. (Field, May Io.)

Willis, T. Osprey shot near Windsor. (T.c. Oct. 4).

I863. W. H. R[owland.] Solan Goose. (Op. cit. June 20.)

I864. Gurney, J. H. Note on Occurrence of Lesser Spotted Woodpecker at Reading. (Zool.) 
1865. Botting, W. B. Northern Diver [shot on Thames near Marlow]. (Field, Dec. 9.)

Eyre, H. S. Carolina Crake near Newbury. (Zool.)

Moses, H. Great Spotted Woodpecker at Reading. (T.c.)

Newton, A. Exhibition of Carolina Crake killed near Newbury. (P. Z. S., p. Ig6.)

M[arshall], T. Occurrence of Little Bittern on the Thames. (Field, Oct. 7.)

1866. [- ?]. Black Tern at Windsor and Eton. (Naturalist.)

Sharpe, R. B. A Berkshire Ramble. (Nat. [Morris's.])

Stubbs, C. E. Crossbills at Henley-on-Thames. (Zool.)

"W. H. R." Waxwing [near Newbury.] (Field, Dec. I5.)

I867-69. Sharpe, R. B. Birds of Cookham, 8 pts. (Quart. Mag. High Wycombe N.H. Soc. I867-69.) [529.] [partim.]

Gardner, J. Honey Buzzard at Maidenhead (Field, July 27.)

I867. Ashmead, G. B. Little Bittern near Henley. (Zool.)

Gardner, J. Hoopoe in Berks. (Field, June 22.) Honey Buzzard at Maidenhead. (T.c., July 27.)

Kennedy, A. Clark. Ornitholog. Notes from Bucks. (Zool.) [partim.]

Stubbs, C. E. Little Auk, etc., at Henley-on-Thames. (T.c.)

I868. "G." Great or Solitary Snipe [near Reading.] (Field, Oct. Io.)

Garth, T. C. Quail in November [at Twyford.] (T.c. Nov. I4.)

Harcourt, E. W. Little Auk at Ábingdon. (T.c. Nov. I4.)

Kennedy, A. Clark. The Birds of Berks and Bucks. 8vo. Eton, etc. ; r868. [326.] [partim.]

Kennedy, A. Clark. Variety of House Sparrows in Berks; Bittern in Berks.; Kestrel feeding on Slow-worm; Early Thrush's Nest. 4 notes. (Zool.) Birds of Berks, etc. (Field, Feb. 29, Mar. 2I.)

Stubbs, C. E. Quails nesting near Henley-on-Thames. (Zool.)

I869. "H. M." Stork [?] in Windsor Park. (Field, June 5.)

Harting, J. E. Oecurrence of Sooty Tern at Wallingford. June 26); Idem. (Zool.)

I870. "J. W. O." Red-breasted Mergansers at Oxford. (Field. Feb. 26.) Idem. G. O. Pardoe. (T.c. Mar. 5: Zool.)

Smee, A. H. Common Tern in Oxfords. (Zool.)

Stubbs, C. E. Terns at Henley-on-Thames. (T.c.)

I87I. Herbert, W. H. Velvet Scoter near Newbury; Storm Petrel near Wantage. 2 notes. $(O p$. cit. $)$

M[ackenzie]. W. D. Cormorant inland [near Henley.] (Field, June 3.)

Smee, A. H. Goosander in Oxfords. (T.c.)

Stubbs, C. E. Tufted Duck at Henley-on-Thames; Grey Phalarope near Henley-on-Thames; Black Tern at Henleyon-Thames; Twin Nests of Reed Warbler, 4 notes. (T.c.) 
I872. Harting, J. E. British Heronries [Berks.] (Op. cit.) [partim.] [274.]

Herbert, W. H. Notes on some of the rarer Birds observed in Neighbourhood of Newbury. (Tr. Newbury District F. C., I., I870-7I, and $O p$. cit. I872-75. [I878.])

Sheppard, C. A. Northern Diver in Oxfords. (Field, Nov. 30.)

Smee, A. H. Blackheaded Gulls in Oxfords. (Zool.)

1873. Biscoe, C. T. Hawfinches in Berks. (Field, Mar. 22.)

Herbert, W. H. Leach's Petrel and Black Tern near Newbury ; Great Grey Shrike near Newbury, 2 notes. (Zool.)

Smee, A. H. Greenshank and Common Tern in Oxfords. (T.c.)

1874. Carter, C. S. Blackcap at Bray in February. (Field, Feb. 28.)

I875. Herbert, W. H. Marsh Harrier near Newbury. (Zool.)

I876. Cocks, A. H. Common Buzzard [in Berks.] (Op. cit.)

"E. D. C." Early Singing of the Nightingale [Apr. 2]. (Field, Apr. I5.)

Hooper, W. T. Grey Phalarope at Streatley. (Op. cit. Dec. 9.)

1878. Cocks, A. H. Provincial Names in Bucks. and Berks. (Zool.)

Wallis, H. M. Pomatorhine Skua and Puffin in Berks. (T.c.)

I879. [Anon.] The Birds of the Wellington District. (Ninth Rep. of Wellington Coll. N. H. Soc.)

Chapman, T. B. Bittern near Newbury. (Field, Dec. 20.)

"Coccothraustes." Hawfinches near Windsor. (Op. cit. Mar. 8.)

Curtis, E. Scoter on the Thames. (T.c. Mar. 29) ; Peregrine, etc. (Op. cit. Nov. 8) ; Rare Birds in Berks. (T.c. Dec. 27.)

Curtis, E. Scoter on the Thames. (Zool.)

I88o. Baxendale, L. S. Solitary Snipe in Berks. (Field, Dec. I8.) [errore for Common Snipe; $c f$. Op. cit. Jan. I88I.]

Curtis, E. Peregrine Falcon near Windsor. (Zool.)

[Harting, J. E.] Dr. Lamb's 'Ornithologia Bercheria' (T.c.) [partim.] [275.]

I88I. Lousley, J. Woodcock nesting in Berks in March. (Field, Apr. 2.)

Barrett, C. W. S. Unusual site for Swallows' Nest [in pear tree] (Sci. Gossip.)

1882. "A. L. P." Puffin near Hungerford. (Field, Dec. 23.)

1883. Macpherson, H. A. Hobby breeding in Oxfords. [errore for Berks.] (Zool.)

I884. Cordeaux, J. Bittern, Whitefronted Goose and Black Tern in Berks. $(O p$. cit. $)$

Hall, W. F. Spring Migration of the Stork. (Field, May I7.)

Postlethwaite, T. N. Note on the Nightjar; Notes on the Birds of Berks. (Zool.)

Valpy, R. A. Spring Migration of the Stork. (Field, May 3.)

Whitehurst, E. T. Green Sandpiper at Farnborough. (Zool.) 
1885. "A. F. G. S." Bittern in Thames Valley. (Field, Jan. Io.) Hatchwell, R. Gannet at Lambourne. (Op. cit. Oct. I7.)

Hughes, G. M. Crossbill nesting in Berks. (T.c. Jan. Io.)

Ward, $R$. Gannet inland [also near Lambourne.] (Op. cit. Oct. 24.)

Weed, W. Quail near Wallingford. (T.c. Oct. 3.)

I886. Palmer, M. H. C. Birds of Newbury and District. 4 articles. (Newbury Weekly Newes.)

Macpherson, A. H. Brit. Heronries [Buxot Park] (Field, Feb. I2.)

I887. Phillips, G. T. Lesser Redpoll and Hawfinch nesting in Berks. (Zool.)

1888. Aplin, O. V. Sand Grouse in Warwicks., Berks., etc. (Op. cit.) "H. D." Crossbills in Berks. (Field, Nov. I7.)

Reid, Capt. S. G. Great Black Woodpecker in Berks. (Zool.)

I889. Aplin, O. V. The Birds of Oxfordshire. 8vo. Oxford: I889. [partim.] [24.]

Hamilton, R. W. Tern on the Thames. (Field, Oct. 5.)

Lambert, F. W. Sheldrake near Oxford. (Zool.)

Salter, W. Black Tern near Oxford. (Field, June I5.)

Thomson, C. L. Nesting of Lesser Redpoll in Berks. (T.c. June I5.)

Valentine, J. T. T. Black Terns on Upper Thames. (T.c. May I8.)

Weed, W. Pallas's Sand Grouse in Berks. (Op. cit. Oct. I9.)

I890. Aplin, O. V. On Distribution and Period of Sojourn of Spotted Crake in Brit. Isles. [Berks. \& Bucks.] (Zool.) [partim.] [24.]

Cornish, J. G. The Haunts of the Hobby. (Field, May ro.)

"G. E. S." Scoter and Goldeneye on the Thames. (T.c. Dec. 27.)

Palmer, Dr. M. H. C. Birds. [Hawkins' Guide to Newbury.] 8vo. Newbury: I8go. [456.]

Ward, J. Two-barred Crossbill. (Field, Mar. 8.)

I891. Cocks, A. H. Smews in Bucks and Oxon; Destruction of Kingfishers. (Zool.)

[Editorial.] [Bittern at Newbury.] (Field, Jan. 3.)

I892. Aplin, O. V. On Distribution of Cirl Bunting in Gt. Britain. [Berks.] [partim.]; Status of the Woodchat in Gt. Britain. [Berks.] [partim.] (Zool.) [25.]

I893. Bundock, F. C. Great Crested Grebe in Windsor Park. (Field, Mar. I8.)

Cornish, J. G. Puffin inland in October. (Op. cit. Nov. 18.)

I895. Cocks, A. H. Sandwich Terns on Upper Thames. (Zool.)

Cornish, C. J. Wild England of To-day and the Wild Life in It. 8vo. Lond.: I895. [I47.]

Robinson, A. Bittern in Berks. (Zool.) 
I896. Radley College Nat. Hist. Soc. [Aves in] The Fauna and Flora of Radley and the Neighbourhood. Post 8vo. Oxford. I896. [14.]

"W. P. B." Golden Oriole in Berks. (Field, Aug. I.)

I897. "W. H." Sclavonian Grebe in Oxon [near Faringdon, Berks.] (Op. cit. Jan. 30.)

I898. "W. W." White Martin in Berks. (Op. cit. Oct. 29.)

I899. Bradshaw, G. W. Notes from Reading (I898.) (Zool.)

Webb, W. M. [List of Birds in] A Guide to the Museum of Eton College. Eton College: I899. [620.]

I900. Astley, H. D. Storks in England (Field, Aug. 25).

Cooper, T. T. Marsh Harrier in Berks. (Zool.)

"F.M. C[hapman]." Puffin at Henley-on-Thames. (Field, Dec. 8.)

"F. M. C." Puffin at Henley-on-Thames. (Field, Dec. 8.)

Henderson, G. Great Crested Grebe in Windsor Great Park [hapman]. (Op. cit. June 23.)

Igor. Bradshaw, G. W. Peregrine Falcon in Berks; Habits of Alcedo ispida; Regulua cristatus near Reading, 3 notes. (Zool.)

Brown, E. C. Little Auk inland. (Field, Dec. 7.)

Mansfield, J. White Swallow near Reading. (T.c. Aug. 24.)

Rogers, C. M. Pine Grosbeak [in Berks.]. (Nature, Dec. 12.)

Warner, W. H. Bittern in Oxfords. ; (Zool.)

I902. Cornish, C. J. The Naturalist on the Thames. 8vo. Lond.: I902. [147.]

Joy, N. H. Black Redstart in Berks. (Field, Nov. 8.)

I903. Aplin, O. V. Notes on Oxfords. Ornithology by the late C. E. Stubbs. (Zool.) [partim.] (Cf. Zool. I904.) [26.]

Selous, F. C. Grey Wagtail nesting in Berks. (Field, May 9).

Warner, W. H. Late Stay of Swift. (Nat. Notes.)

I904. Duffield, P. T. Black Tern at Oxford. (Field, June Ir.)

Elms, E. F. M. Notes on Nesting of Moorhen and Little Grebe. $\left(\mathrm{Zool}_{.}\right)$[I97.]

Noble, H. Rare Birds in Berks. (T.c.) [450.]

I905. [Editorial.] Leach's Petrel in Berks. (Field, Dec. 9.)

Hay, E. F. A. Lapland Bunting in Berks. (Op. cit. Mar. II.)

Proctor, Maj. F. W. Lesser Redpoll in Berks. (Avic. Mag. N.S. III.)

[Waxwing and Lesser Redpoll in Berks.] (Ball, B. O. C., XV.)

Igo6. Hale, J. R. Three-storied Nest of Reed Warbler. (Field, July I4.)

"H. V. R." Bramblings in Berks. (OP. cit. Jan. I3.)

Joy, N. H. Mimicking Song of Blackcap. (Zool.)

Kerr, G. W. Birds of the District of Staines, 4 papers. [partim.] Idem. (Op. cit. I908.) 
Noble, H. Birds. [In Victoria History of Co. of Berks. I.] 4to. Lond. : Ig06. [450.]

I907. Joy, N. H. Westward movement of Birds during Snow. (Zool).

I908. Astley, H. D. Sand Grouse in Berks. (Op. cit. June 20.)

May, W. N. Nesting of Grey Wagtail in Berks. (Brit. Birds, II.)

Noble, H. Pintail in Berks. (Brit. Birds, I.)

Proctor, Maj. F. W. Lesser Redpoll as a breeding species in Berks. (T.c.)

Witherby, H. F., and Ticehurst, N. F. Spread of the Little Owl. (T.c.) [partim.] [657: 584.]

Igog. Noble, H. Manx Shearwater in Berks. (Op. cit., III.)

Igro. Joy, N. H. Rough-legged Buzzards in Berks; Green Sandpiper in Berks., 2 notes. (Op. cit. IV.)

Stanford, E. F., and Gilroy, N. Crossbills nesting in Berks. 2 notes. (Op. cit. III.)

Tomlinson, A. S. Crossbills nesting in Berks. (Op. cit. IV.)

I9II. Collings, D. W. Puffin in Berks. (Op. cit. V.)

Noble, H. Decrease of Corncrake, Wryneck and Nuthatch. (Zool.)

Van der Weyer, B. Probable breeding of Little Owl in Berks. (Brit. Birds, V.)

Woodhouse, W. M. Red Grouse near Wantage. (Field, Mar. II); Bird Life in Western Berks. (T.c. May 27.)

Woodhouse, W. M. Red Grouse in Berks. (Brit. Birds, V.)

I9I2. Joy, N. H. Marked Starling reported from Finland. $(O p$. cit. VI.)

Noble, H. Spread of Little Owl in Berks. ; Montagu's Harrier in Berks. ( $O p$. cit. V.)

Roalfe-Cox, W. Redshank nesting in Berks. (Field, May 4.)

I9I3. Fletcher, A. B. Early breeding and large clutch of eggs of Barn Owl. (Brit. Birds, VII.)

Ratland, H. S. White Swallow at Wantage. (Field, Sept. I3.)

Turner, C. Great Snipe in Berks. (T.c. Sept. 6.)

IgI4. Burnier, R., and Chubb, P. A. Pintails in Berks. (Brit. Birds, VII.)

Joy, N. H. Puffin in Berks. Recovery of Marked Starlings at Bradfield. (T.c.)

I9r5. Astley, H. D. Sand Grouse in Berks. (Field, June 5, I2.)

Cornish, J. G. Hobby in Vale of White Horse. (Wild Life, VII.)

Pettitt, E. The Woodlark in E. Berks. (Wild Life, VI.)

Wallis, H. M. Central European Barn-Owl (Flammea flammea guttata) killed near Reading. (Bull. B. O. C. XXXVI., p. 43.) Status of Grey Wagtail in Berks., Dark-breasted Barn Owl in Berks. (Brit. Birds, IX.)

Noble, H. Roughlegged Buzzard and Gadwall in Berks. (T.c.) 
I9r6. Jourdain, F. C. R. Quail in Berks. (Brit. Birds, X.)

Joy, N. H. Greenshank and Black Tern in Berks.; Bearded Tit in Berks. (T.c.)

Kerr, G. W. The Lesser Redpoll in Thames Valley. (Wild Life, VIII.)

Meares, C. S. Field Notes on the Hobby. (Brit. Birds, IX.)

I9I7. Jourdain, F. C. R. Unusual Birds in Berks. ; Common Buzzard in Berks. (2 notes): Spread of Little Owl (Br. Birds, X.) Noble, H. Unusual birds in Berks. (T.c.)

Roberts (F.) Bittern near Windsor. (Field, Feb. I7.)

Wallis, H. M. Evolutions of a Peregrine and Starling in Berks. (Brit. Birds, X.)

IgI8. Jourdain, F. C. R. Orn. Rept., I9I5-I7. (Pr. Ashmolean Soc. Oxf., I9I7). [partim.]

Pettitt, E. E. Marsh Warbler breeding in Berks., etc. 2 notes. (Brit. Birds, XII.)

Suffern, C. Hoopoe in Berks. (T.c.)

Wallis, H. M. A Berkshire keeper's larder. (T.c.)

\section{BUCKINGHAMSHIRE.}

1827. Yarrell, W. Little Bittern. (Zool. Jnl.)

I83I. Tatem, J. G. Nat. Hist. in the English Co's.: Bucks. ; the Kingfisher [in Bucks.] (Loudon's Mag. N. H. IV., p. 267.)

1848. Crewe, H. H. White Variety of Hedge Sparrow. (Zool.)

I854. Clarke, G. B. Guillemot at Fenny Stratford, Bucks. (Nat. [Morris's] IV.)

I859. Body, R. B. Hoopoe [one seen W. Wycombe Park]. (Field, May 7.)

Ingatton, T. The Hoopoe [shot at Burnham Gore.] (T.c. May 7.)

Owen, J. W. Egyptian Goose [shot at Marlow]. (Op. cit. Nov. I9.)

I86r. Hassell, G. J. Hooper [Swan] in Bucks. (Zool.) Idem. (Field, Feb. 2.)

"C. W[olley.]" Eggs of Golden Oriole [in Bucks.] (Field, May 25). Idem (Op. cit. Aug. 3.) [err. cf. Ootheca Wolleyana].

I862. Crewe, H. H. [Letters on Dotterel and Cirl Bunting in Bucks ] (Ibis.)

Jones, H. J. Hoopoe [shot at Stewkley]. (Field, May 3.) Willis, J. R. Osprey shot near Windsor. (Op. cit. Oct. 4.)

1863. Curzon, Lord. Blackcock in Bucks. (Op. cit. Sept. I9.) 
I864. Crewe, H. H. Osprey, Great Grey Shrike, and Cirl Bunting in Herts. and Bucks. (Op. cit. Dec. 3.)

"F. W." Late Martin [Nov. 22]. (T.c. Nov. 26.)

Tyrer, R. Bramblings in the Chilterns. (Zool.)

I865. Botting, W. B. Northern Diver shot on the Thames [near Marlow]. (Field, Dec. 9.)

Crewe, H. H. Osprey in Bucks. and Herts. ; Great Grey Shrike and Cirl Bunting in Bucks. (Zool.)

Crewe, H. H. [Letter on Ospreys and Cirl Bunting in Bucks.] (Ibis.)

"J. C. S. P." French Partridges in Bucks. (Field, Oct. 7.)

M[arshall], T. Occurrence of Little Bittern on the Thames. (T.c. Oct. 7.)

I866. High Wycombe Nat. Hist. Soc. Stonechat; Little Bittern. (Ardea Minuta.) (The Naturalist, I866.)

I867-69. Sharpe, R. B. Birds of Cookham, 8 pts. (Quart. Mag. High Wycombe Nat. Soc., I867-69.) [partim.] [529.]

I867. Bowstead, R. M. Pertinacity of Sparrow Hawk. (Field, Jan. 26.)

Clifton, Lord. Savi's Warbler (?), Plover and Lesser Spotted Woodpecker in Bucks. (Zool.)

Gardner, J. Honey Buzzard [at Maidenhead]. (Field, July 27.)

Kennedy, A. Clark. Ornitholog. Notes from Bucks.; Siskin in Bucks.; Ornithology of Berks. and Bucks; Dates of Departure of Immigrants; Lesser Spotted Woodpecker near Windsor. 5 notes. (Zool.)

Kennedy, A. Clark. Lesser Spotted Woodpecker in Bucks. (Field, Nov. 2.)

Ullyett, H. List of Wycombe Birds. [Quart. Mag. High Wycombe Nat. Hist. Soc. No. 3.)

I868. Harcourt, E. W. Little Auk at Abingdon. (Field, Nov, I4.)

Kennedy, A. Clark. The Birds of Berks. and Bucks. Post 8 vo. Eton, etc. : I868. [326.]

Kennedy, A. Clark. Ornitholog. Notes from Bucks and Berks. (Field, Mar. 2I.) Storm Petrel in Bucks. ; Note on Breeding of Bittern in Bucks. (Zool.)

I869. Marshall, T. Common Buzzard [breeding in Bucks.]. (High Wycombe N. H. Soc. Jnl.)

Stubbs, C. E. Great Grey Shrike at Henley-on-Thames : Ornith. Notes from Henley-on-Thames. 2 notes. (Zool.)

I870. Williamson, J. W. Wild Swans [?] in Bucks. (Field, Jan. I.) [Probably tame birds: Cf. "Berea," T.c. Jan. 8.]

I871. "Sept." ..... Wild Swans near Thame. (Field, Feb. II.) "Harry, L." Quails in Britain in I870 [at Townsey]. (T.c. Jan. 28.) 
1872-73. Harting, J. E. British Heronries. (Zool.) [partim.] [274.] 1873. Cocks, A. H. Notes from Berks. and Bucks. [Montagu's Harrier and Bittern.] (Field, Feb. 8.)

I874. Crewe, H. H. House Martin near Aylesbury on 5th Dec. (Zool.) "Head Keeper." Moorhen's Nest in Tree. (Field, May 30.)

1875. Marshall, T. Buzzards in Bucks. (Field, Mar. 2.)

1876. " J. L. H." Late Martins [Nov. I6]. (Sci. Gossip.)

1877. Thurlow, J. Storm Petrel driven inland. (Field, Oct. 20.)

1878. Cocks, A. H. Provincial Names [of British Animals] in Berks. and Bucks. (Zool.)

Crewe, H. H. Albino specimens of Common Snipe and Wryneck. (T.c.)

1879. Curtis, E. Scoter on the Thames. (Field, Mar. 29.) Idem. (Zool.)

White, H. Golden Oriole in Bucks. (Field, May 3I.)

I880. Harting, J. E. [edited by.] Dr. Lamb's Ornithologia Bercheria. (Zool.) [partim.] [275.]

Marshall, T. Rough-legged Buzzard in Bucks. (Field, Dec. I8.)

I881. Crewe, H. H. Storm Petrel near Wendover. (Zool.)

I882. Aplin, F. C. Honey Buzzards in Bucks. (Op. cit.)

1883. Crewe, G. A. Scaup Duck inland [at Drayton Beauchamp]. (Field, Dec. I5.)

Hibbert, L. Osprey shot near Slough. (Field, Oct. 6.)

Travis, T. Arrival of Waxwings [Bucks.]. (T.c. Jan. 27) [partim.]

1884. Aplin, F. C. Grey Form of Tawny Owl in Bucks. (Zool.)

I888. Lilford, Lord. Magpies attacking weakly Donkey. (Zool.)

Marshall, T. Crossbills [at Hughenden] in Bucks. (Field, Dec. 29.)

Odling, E. Hoopoe in Bucks. (Field, Apr. I4.)

Parrott, F. H. Starling nesting in November. (Zool.)

I889. Tomalin, W. Hoopoe in Bucks. (Field, Nov. 30.)

I8go. Knapp, J. M. Velvet Scoter inland [at Linford.] (Field, Nov. I.)

Vyse, H. H. Unspotted Eggs of Spotted Flycatcher. (Field, Aug. I6; Zool.)

I89I. Cocks, A. H. Smews in Bucks. and Oxon; Destruction of Kingfishers. (Zool.)

Marshall, T. Bee Eater in Leicesters. [Golden Oriole near Aylesbury, circa I880.] (Field, May I6.)

1892. Vyse, H. H. Ruddy Sheldrakes in Bucks. (Zool.)

Young, J. Reminiscences of Kite in Bucks. (T.c.)

I893. Dawes, W. J. Little Auk inland. (Field, Dec. 9.) 
1894. Aplin, O. V. Whimbrel in the Midlands. (Zool.)

Barnett, C. J. Little Owl in Bucks. (Field, May 26.)

Marshall, T. Hawfinches in Bucks. (T.c. Jan. 27.)

1894-95. Rothschild, Hon. W. White Swallows of Aylesbury. 2 articles (Nov. Zool. I. \& II.)

1895. Cocks, A. H. Sandwich Terns on Upper Thames. (Zool.)

I897. Marshall, T. Little Owl in Bucks. (Field, Jan. 30.)

Walshe, P. Great Plover in Bucks. (Nat. Jnl.)

I898. "A. A." Californian Quail in Bucks. (Field, Jan. 22.)

Marshall, T. Crossbills in Bucks. (Op. cit. Dec. 3.)

Sole, F. Anslow. Spotted Crake in Bucks. (Op. cit. Jan. I5.)

I899. Athawes, J. P. Partridge's Nest in Straw Stack. (Op. cit. July 22.)

Reid, Sir H. Rae. Night Heron in Bucks. (T.c. Aug. 26.)

Webb, W. M. List of Birds [in A Guide to the Museum of Eton College.] Eton College: 1899. [620.]

Igor. Marshall, T. Little Auk in Bucks. (Standard, Dec. 2I.)

Rothschild, Hon. N. C. [Exhibition of Baer's Pochard shot at Tring.] (Bull. B. O. C. XII.)

I902. Allen, A. Rufous Tinamu in Bucks. (Field, Mar. I.)

1903. Aplin, O. V. Notes on Oxfords. Ornithology, by C. E. Stubbs. (Zool.) [26.] [partim.]

Emson, C. H. Snow Bunting on Chiltern Hills. (Field, Nov. I4.)

I904. Aplin, O. V. Birds of Oxon or Bucks. (Zool.) [26.] Idem by A. H. Cocks. (T.c.)

I905. Hartert, E., and Rothschild, Hon. W. Birds. [In Victoria History of Co. of Bucks, I.] 4to. Lond.: I905. [27I : 497.]

I906. Durham, E. B. Bramblings in Bucks. (Field, Dec. I.)

Farwell, W. Bramblings flocking in winter. (Op. cit. Feb. 3.)

Kerr, G. W. The Birds of the District of Staines [part.] 4 papers. (Zool.)

Lee, H. Boswell. Black Tern near Amersham. (Field, Aug. 4.)

1907. Mackenzie, W. D. Peregrine Falcon in Oxon. (Op. cit. Feb. "M. L." Bittern near Eton. (T.c. Mar. 9.)

Rothschild, Hon. W. Baer's Pochard as a British Bird. (Brit. Birds, I.) [497.] [Cf. also Saunders, H. Additions to the List of British Species since I899. (T.c.)]

Ig08. Kerr, G. W. Birds of the District of Staines [partim.] (Zool.) Vyse, H. H. Stone Curlew in November. (Field, Nov. I4.)

I909. "J. T. A." Summer Birds in N. Bucks. ; Scarcity of Nightingales, 2 notes. (Op. cit. May I, 22.) 
Kerr, G. W. Marsh Warbler in Bucks. (Zool.) [Cf. Brit. Birds, III.]

Vaughan, H. Green Sandpiper in Bucks in January. (Field, Jan. 23.)

I9ro. Oldham, C. Common Scoter and other Ducks in Herts. and Bucks. (Brit. Birds, III.): Irruption of Crossbills. (Op. cit., II.).

Vyse, H. H. Puffin taken in Bucks. (Field, Nov. Io.)

I9II. Allen, A. Little Bittern in Bucks. (Op. cit. Aug. I9.) : Great Shearwater inland. (T.c., Oct. 29).

Aplin, O. V. Peregrine Falcon in S. Midlands. (Zool.) [26.]

Cocks, A. H. Hen Harrier and Little Owl in Bucks. (Field, Dec. 9, I6.) 2 notes. Idem by H. H. Vyse (T.c. Dec. 2, 23.)

Hollis, E. Nutcracker near Aylesbury. (T.c. Oct. I4); Nutcracker in Bucks. (Zool.) ; Slender-billed Nutcracker in Bucks. (Brit. Birds, V.)

IgI2. Bulstrode, R. Crossbill nesting in Bucks. (Brit. Birds, VI.) Horn, P. W. Little Auk (Mergulus alle.) (Zool.)

W[itherby], H. F. The I9I2 "Wreck" of the Little Auk. (Brit. Birds, V.) [partim.]

I9I3. Baynes, G. K. Blackcap in Bucks. in winter. (Op. cit. VI.)

Dowson, E. M. Buzzard at Stoke Poges. (Field, April I9.)

Durham, E. B. Redwing in Sept. [Chesham Bois.] (Field, Sept. 27.)

Oldham, C. Common Scoter in summer in Bucks. (T.c.)

Elliott, J. Steele. Hobby in Bucks. (Zool.)

19I4. Hollis, E. Stone-Curlew breeding in Bucks. (Brit. Birds, VIII.) Idem by A. H. Cocks and by $\mathrm{H}$. Noble. (T.c.)

Rothschild, Hon. W. Kites in Bucks. (Brit. Birds, VII.)

Igr6. Cocks, A. H. Snowy Owl in Bucks. (Zool.)

Gazeley, H. S. The Pochard in Bucks. (Wild Life, VIII.)

Hannett, C. E. J. Hoopoes [breeding] in Bucks. (Selborne Mag., pp. 93-94.)

I9I7. Cocks, A. H. Blackheaded Gulls in Bucks. (Field, May 8.) Jourdain, F. C. R. Little Auk in Bucks. (Brit. Birds, XI.)

\section{CAMBRIDGESHIRE.}

1824-5. [Editorial.] Alpine Accentor [at King's Coll. Cambridge]. (Zool. Jnl. I., p. I34; II. p. 28I, I825.)

1825. [Thackeray, Dr.] [Baillon's Crake near Melbourne.] (Zool. Jnl. II., p. 279.)

I827. Jenyns, L. Observations on the Ornithology of Cambs. (Tr. Cambs. Philos. Soc.) [315.] 
1828. [Thackeray, Dr.] [Little Crake at Barnwell.] (Zool. Jnl. III. p. 605.)

Yarrell, W. Occurr, of rare Brit. birds [Pomatorhine Skua in Cambs.] (T.c. pp. 497-8.)

Yarrell, W. Description of a species of Tringa killed in Cambs. (Tr. Linn. Soc. XVI.) [670.]

1830. J. S. H. Desiderata to the Collection of British Birds in the Museum of the Cambridge Philosophical Society. (Loudon's Mag. Nat. Hist., III., p. I54.)

1832. Jenyns, L. [Fire-crested Wren near Cambridge.] (P. Z. S., p. I39.) [Probably errore.]

I833. Turner, H. The Little Bustard [near Caxton]. (Loudon's Mag. N. H. VI., p. 5I3.)

I836. Ventris, E. Pratincole [shot at Quy.] (Op. cit. IX., p. 202.) (Cambridge Chronicle.) Roller [shot at Oakington.] (T.c., p. 202.)

I838. Jenyns, L. The Ornithology of Cambs. (Nat. [Neville Wood's.]) [3I5.]

I84I. Gray, G. R. Species of Warbler new to Brit. (Amn. Mag. N.H., VI., p. I55).

I843. Yarrell, W. Occurr. of Birds [Savi's Warbler, etc.]. (Zool.)

I845. Fitton, E. B. Occurrence of Alpine Swift near Cambridge. (Zool.)

Newton, A. Arrival of Migratory Birds at Stetchworth in I845. (T.c.) [445.]

I846. Newman, E. Nest and Eggs of Savi's Warbler. (Op. cit.)

I847 Brown, J. Nest of Savi's Warbler near Cambridge. (Op. cit.

I849. Cater, W. E. Occurrence of Ringed Plover, Turnstone, Spotted Crake and Grasshopper Warbler in Cambs. (Op. cit.)

Foster, T. W. Occurrence of Black-tailed Godwit on Guyhirn Wash; Night Heron, White Egret and Stork near Wisbeach ; Gannet near Wisbeach ; Eared Grebe at Wisbeach; Rare Birds at and near Wisbeach. 5 notes. (T.c.)

Marris, R. Occurrence of Crossbill at Wisbeach. (T.c.)

I850. Bond, F. Occurrence of Little Auk at Newmarket; Waxwing in Cambs. and Norfolk; Black-throated Diver at Chesterfield [errore for Chesterford]. 3 notes. (Zool.)

Foster, T. W. Occurrence of Waxwing near Wisbeach; Occurrence of Quail in January; Pink-footed Goose and Brent Goose near Wisbeach; Wild Swan and Bewick's Swan near Wisbeach; Goosander, Red-breasted Merganser and Smew: Eared Grebe on Whittlesea Wash; Black-tailed Godwit near Wisbeach; Dotterel Plover at and near Wisbeach; Black Tern, Lesser Tern and Common Tern at March. 9 notes. (T.c.) 
1851. Foster, T. W. Captures of Rare Birds at and near Wisbech. (Op. cit.)

Julian, R. A., jun. Occurrence of Dotterel [at Bottisham Fen] ; Pinkfooted Goose in Cambs. (Nat. [Morris's] I.).

Newton A. Occurrence of American Waxwing or Cedar Bird in Great Britain. (Zool.)

185I-52 . Julian, R. A., junr. A Trip to Wicken Fen, 2 pts. (Nat. [Morris's] I. \& II.)

1852. Julian, R. A., junr. Snow Bunting and Little Auk near Cambridge; Puffin near Ely, etc. 5 notes. (Op. cit. II.)

Bond, F. Occurrence of Gannet in Cambs. : Egyptian Goose in Cambs. 2 notes. (Zool.)

1853. Thurnall, C. Storm Petrel [in Cambs.] (Nat. [Morris's], III.)

1854. Powys, T. L. Note on late abundance of Spotted Crake. (Zool.) Saville, S. P. Little Stint, Great Grey Shrike, Red-breasted Merganser and Hobby [in Cambs.]. (Nat. [Morris's] IV.) Sealy, A. F. Occurrence of Rough-legged Buzzard and Peregrine Falcon in Cambs. (Zool.)

1855. Bonney, T. G. Bittern in Cambs. (Nat. [Morris's] V.)

He[witson], W. C. Great Spotted Woodpecker [in Cambs.] (T.c.) Savill[e], S. P. Temminck's Stint [at Wisbech]; Grey Phalarope near Cambridge; Egyptian Goose [at Suthery Fen.] (T.c.) Tearle, F. Bartram's Sandpiper near Cambridge. (Nat. [Morris's] V. ; Ill. London Neres, Jan. 20, fig.)

I856. Fuller, A. Occurrence of Storm Petrel at Newmarket and near Cambridge. (Zool.)

Savill[e], S. P. Dotterel in Cambs.; Rose-coloured Pastor in Cambs. ; Stormy Petrel [at Newmarket and Bottisham]. (Nat. [Morris's] VI.)

Salvin, O. Occurrence of Great Bustard in Cambs. (Zool.) Idem by A. F. Sealy. (T.c.)

Thurnall, C. Capture of Little Auk [at Little Shelford]. (Field, Nov. 22.)

I857. Farren, W., junr. Rare birds [in Cambs.]. (Nat. [Morris's] VII.) Saville, S. P. Occurrence of Rare Sea Birds near Cambridge. [Skuas, etc.] (Zool.) Ringtail [Hen] Harrier at Foulmire; Merlin [at Cherry Hinton]; Great Skua [at Cottenham]: Ring Ouzel [at Cherry Hinton]. 5 notes. (Nat. [Morris's] VII.) Smoothy, C., junr. Little Auk in Cambs. (Nat. [Morris's] VII.) Thurnall, C. Idem. (T.c.)

1858. Farren, W. Great Grey Shrike in Cambs. (Zool.)

Salmon, J. D. Exhibition of specimen of Baillon's Crake with 7 eggs. (P. Z.S.)

Savill[e], S. P. Peregrine Falcon [near Newmarket], etc. 3 notes. (Nat. [Morris's] VIII.) 
1859. Saville, S. P. Occurrence of Hoopoe near Cambridge. (Zool.) Sealy, A. F. Occurrence of Baillon's Crake and its nesting in England. (T.c.)

(Stamford Mercury.) [Nutcracker shot near Wisbech.] (Field, Nov. 26.)

I860. Foster, T. W. Occurrence of Nutcracker at Wisbech. (Zool.)

Saville, S. P. Occurrence of Great Ash-coloured Shrike in Cambs. 2 notes. Disappearance of Swallows and Martins; Kittiwake Gull driven inland; Late stay of Fieldfare in Cambs.; Occurrence of Whimbrel in Cambs. ; etc. 8 notes. (T.c.)

I86I. "Heron." Mountain Linnet [in Cambs.]. (Field, Apl. 6.)

Saville, S. P. Rare Birds occurring during late frost ; Destruction of Small Birds; Notice of Discovery and Capture .... of Marsh Warbler; Occurrence of Richardson's Skua in Cambs. 5 notes. (Zool.)

I862. Saville, S. P. Occurrence of Peregrine Falcon in Cambs.: Capture of Merlin in Cambs. ; White Variety of Black-headed [Reed] Bunting; Greater Spotted Woodpecker in Cambs.; Unusual number of Grosbeak in Cambs.; Notes on Great Spotted Woodpecker; Occurrence of Honey Buzzard in Cambs.; Occurrence of Norfolk Plover in Cambs., etc. 9 notes. (Op. cit.)

I863. Allis, T. H. Pallas's Sand Grouse in . . . . Cambs. (Op. cit.) Baker, J. Idem; Osprey in Cambs . . 2 notes. [Latter errore for Hunts.] (T.c.)

Bond, F. Pallas's Sand Grouse in . . . Cambs. (T.c.)

"Cantab." Little Auk shot near Ely. (Field, Nov. 28.) Idem by J. Gillbanks. (T.c. Dec. I2.)

Saville, S. P. Spotted Crake near Cambridge; Egyptian Goose in Cambs. Fens; Rough-legged Buzzard in Cambs.; White variety of House Sparrow ; Pallas's Sand Grouse in Cambs. ; Note on the Short-eared Owl; Slate-coloured variety of Chimney Swallow. (Zool.)

I864. Boulton, W. W. Sternum of Little Crake shot in Cambs. $(O p$. cit.)

Saville, S. P. Scarcity of Summer Migrants; Occurrence of pure Albino Hedge Sparrow ; Little Crake in Cambs. 3 notes. (T.c.)

I865. Newman, E. Lesser Kestrel [errore for Common] at Cambridge. (Op. cit.) Idem. [correction.] (Op. cit. I866.)

I867. Farren, W. Little Owl near Cambridge. (Op. cit.)

I868. Howlett, W. Occurrence of Waxwing near Newmarket. (Field, Jan. 4.) Idem. (Zool.)

Titterton, J. Hoopoe at Ely. (Zool.) 
I869. Farren, W. Late singing of Nightingale and Cuckoo. (Zool.) I870. Butler, W. Bittern shot near Newmarket. (Field, Jan. 8.) "C. L. B." Ring Ouzel in Cambs. (T.c. May 7.)

Smoothy, C. Dartford Warbler in Cambs. (Op. cit. Dec. I7.)

1871. Howlett, W. Rook with deformed Beak; Shore Lark at Newmarket. (Op. cit. Jan. I4.)

Reddie, J. Quails in Britain [breeding near Ely.] (Field, Jan. 2I, 28.)

I87I-2. Harvie-Brown, J. A. Nidification of Tree Sparrow [near Cambridge.] (Scotch Nat. I., I87I-2.)

1872. Harting, J. E. British Heronries. (Zool.) [partim.] [274.]

Howlett, W. Hoopoe near Newmarket. (Field, June 8.)

Smoothy, C. Common Buzzard in Cambs. (T.c. Feb. 3.)

Tuck, J. G. Golden Oriole in Cambs. (Zool.)

1873. Howlett, W. Hobby near Newmarket. (Field, May 24); Hawfinches and Waxwings near Newmarket. (T.c. Jan. 25.) Buzzard, Hobby and Peregrine near Newmarket. (Op. cit. Dec. 6.) Idem. (Zool. I874.)

Penning, W. H. Chaffinches nesting in Broccoli plant. (Field, May 3.)

1874. Fryer, A. Blue-throated Warbler at Chatteris, Cambs. (Zool.) Howlett, W. Bramblings at Newmarket. (Field, Apl. 4.) Moor, G. W. P. Tree Sparrow building in Cambs. (Zool.) Ogilvy, W. T. Buff variety of House Sparrow. (T.c.)

Tuck, J. G. Birds in Cambridge Market. (T.c.)

1875. Bidwell, E. White-tailed Eagle in Cambs.; Idem by J. L. Curtis. (Field, Oct. 30.)

" J. G." Great Grey Shrike near Cambridge. (T.c. Nov. 27.) Howlett, W. Birds dying from Starvation. [Little Auk, Puffin, etc.] (Op. cit. Jan. 2.)

Willmott, C. Golden [errore] Eagle near Chatteris. (Zool.)

1876. Howlett, W. Montagu's Harrier near Newmarket. (Field, June Io.)

Wheeler, F. White Peewit. (T.c. Apr. 8.)

I877. Doggett, F. Little Auk near Cambridge. (Op. cit. Jan. 27); Lapland Bunting near Cambridge. (Op. cit., Nov. I7.)

Upcher, H. M. Spoonbill near Ely. (Zool.)

I878. Greville, F. Bustard Shooting. (Field, Oct. 5, 26.)

Miller, S. H. and Skertchley, S. B. J. The Fen-Lands Past and Present. Roy. 8vo. London: 1878.

"Nemo." Goldcrest nesting in March. (Field, March I6.)

1879. Doggett, F. Bewick's Swan and Little Gull. (Op. cit. Jan. I8) ; Pink-footed Goose in Cambs. (T.c. March 29.)

Newton, A. Exhibition of specimen of Sylvia nisoria believed to have been killed at Cambridge. (P. Z.S. Mar. 4.) 
I880. "F. M. L." Scoters and Grebes near Ely. (Field, Oct. 30.)

Harting, J. E. Common Scoter in Cambs. (Zool.)

Palmer, J. H. Marsh Harrier and Little Bustard in Cambs. (Field, Dec. Ir.)

Travis, T. Great Bustard in Essex and Cambs. (Zool.)

I88I. Howlett, W. Notes from Newmarket. (Field, Jan. 29) Montagu's Harrier near Newmarket. (T.c. June 4.)

I88I-82. Christy, R. M. Short-eared Owl breeding in Cambs. 2 notes. (Zool.)

I882. Doggett, F. Reported Occurrence of Short-toed Lark in Cambs. 2 notes. (Field. Nov, I8 and 25.)

Christy, R. M. Kestrel breeding on the ground. (Zool.)

Moxon, J. H. The Birds of the Fens. 8vo. Cambridge: I882.

I883. Christy, R. M. Occurrence of Pine Grosbeak in Cambs. (Zool.) Harting, J. E. Short-toed Lark near Cambridge; Crested Lark breeding in England; Wild Geese formerly breeding in Cambs. 3 notes. (T.c.)

Whitaker, J. Hybrid between Greenfinch and Linnet. (T.c.)

Waters, A. H. Little Auk; Sea Birds near Cambridge; Redthroated Diver in Cambs; Skua Gull in Cambs. (Sci. Gossip.)

I884. Borstock, E. G. Roller at Newmarket. (Field, June 2I.)

Gurney, J. H., junr. Variety of Yellowhammer. (Zool.)

Titterton, J. Bittern near Ely. (Field, Dec. 20.)

Wilson, S. B. Late Stay of Lesser Whitethroat. (T.c. Nov. 29.)

I885. Collier, R. R. Quail in Cambs. (Op. cit. Oct. I7.)

"Red Post." Birds killed by telegraph wires [Newmarket Heath.] (T.c. Oct. 24.)

"H.E.A.L." Partridge with White Horseshoe. (T.c. Dec. 5.)

I886. Titterton, J. Habits of Coot. (Zool.)

I887. Mann, T. J. Wood Pigeons casting up pellets. (Op. cit.)

Christy, M. Short-eared Owl nesting in Cambs. (Field, July I6.)

I888. Mayd, W. Reappearance of Pallas's Sand Grouse: Cambs. (Zool.)

Howlett, W. Pallas's Sand Grouse. (Field, June I6.)

I889. Gurney, J. H. Status of Firecrest as British Bird. (Zool.) [partim.] [262.]

Lodge, G. E. Notes on Birds in Norfolk and Cambs. (T.c.)

Tuck, J. G. Blue-winged Teal in Cambs. (T.c.)

I890-9I. Aplin, O. V. On Distribution and Period of Sojourn of Spotted Crake. (Op. cit.) [partim.] [24.]

I8gr. Lyles, J. T. Hen Harrier in Cambs. (Field, Nov. I4.) 
1892. M[arshall], J. McL. Great Grey Shrike in Cambs. (Op. cit. March I9.)

Tuck, J. G. Raptorial Migrants in East Anglia. 2 notes. (Zool.) [partim.]

I892-93. Nunn, J. P. Notes and Observations from Royston; Rural Notes and Observations, Royston. (Nat. Jnl. I892-93.)

I892-94. Waters, A. H. The Birds of Cambridgeshire. (Op. cit. I892-94.)

I893. Barrett-Hamilton, G. E. H. Waxwing in Cambs. (Zool.)

Curtis, J. L. Quails in the Fens. (Field, Nov. I8.)

"E. T. S." Golden Oriole. (Op. cit. May 20.)

"Lepus hibernicus." Arrival of Waxwings. Cambs. (T.c. Jan. 28.)

Swainson, F. E. Montagu's Harrier nesting in Cambs. (Zool.)

I894. Barrett-Hamilton, G. E. H. Waxwing near Newmarket. (Op. cit.)

Cheshire, J. G. Eared Grebe in Cambs. (Field, Feb. 24.)

Tuck, J. G. Storm-driven Sea Birds. (Zool.) [partim.]

Whitaker, J. Varieties of Goldfinch, Greenfinch, etc. (T.c.)

I895. " G. C. L." Little Auk in Cambs. (Field, Jan. 5.)

Harting, J. E. Brünnich's Guillemot on Yorks. Coast. (Zool.) [partim.]

Lilford, Lord. Brünnich's Guillemot in Cambs. (T.c.)

r896-rgog. Read, R. H. Birdnesting in August. (Op. cit. I8g6-98 and I906, I909.) 5 notes.

1897. Butler, E. A. Albatross (D. melanophrys) in Cambs. (Field Aug. 28.)

Butler, E. A. [Letter on Albatross in Cambs.] (Ibis.)

Tuck, J. G. Strange Occurrence of Albatross in Cambs. (Zool.)

I900. Dresser, H. E. On a red-throated variety of Emberiza citrinella obtained near Cambridge. (Bull. B. O. C. XI.) [I80.]

Harmer, S. F. On some bones of a Pelican from Cambs. Fens. (Tr. Norf. \& Norw. Soc. VI.)

Igor. Bonhote, J. L. Nesting of Lapwing and Snipe. (Field, May II.) Guillemard, F. H. H. Scarcity of Swallows. (Op. cit. Oct. 5.)

I902. "B." Great Bustard near Cambridge. (Op. cit. Oct. II.) Bonhote, J. L. On Great Bustard in Cambs. (Bull. B. O. C. XIII.)

I903. Jenyns [afterwards Blomefield], L. A Naturalist's Calendar kept at Swaffham Bulbeck. 8vo. Cambridge: I903. [3I5.]

Ig04. Evans, A. H. Birds. [In Marr \& Shipley's Handbook to Nat. Hist. of Cambs.] Cr. 8vo. Cambridge: I904. [199.]

1905. Newman, J. L. Little Owl in Cambs. (Field, Dec. 2.) Oldham, C. Nesting Habits of Swallow. (Zool.) 
Pycraft, W. P. [Letter on Sabine's Snipe.] (Ibis.) Sabine's Snipe in Cambs. (Knoweledge.)

I907. Arnold, E. C. Combined Nest of Whitethroat and Hedge Sparrow. (Brit. Birds, I.)

Frohawk, F. W. Little Owl [in Cambs. \& Hunts.] (Field, Oct. I2.)

Waters, A. H. The Birds of South Cambs. (Zool.)

"W. M." Little Owl in Cambs. (Field, Oct. 5.)

I909. Atchinson, G. T. Nesting Dates of Lesser Redpoll in Cambs., etc. (Brit. Birds, III.)

Duncan, L., and Frost, C. H. Grouse near Newmarket. (Field, Jan. I6.) Idem by "Inquirer." (T.c. Jan. 9.)

zgro. Farren, W. On Nesting of Marsh Warbler in Cambs. (Brit. Birds, IV.) [204.] Red-footed Falcon in Cambs. (Op. cit. III.)

IgII. Cowie, A. G. Black Tern in Cambridge Fens. (Field, May 6.) I9r3. Livesey, T. R. Whitewinged Black Tern on the Cam. (Field, May 17.)

I914. [Farren, W. and others]. Incursion of Waxwings. (Br. Birds, VII.)

I9r5. Elliott, J. Steele. Black Redstart in Cambridge. (Zool.)

I9I6. Haviland, M.D. Sand Martins nesting in drain-pipes [Cambridge] Possible nesting of Quail in Cambs. The nesting of the Grasshopper Warbler [Wicken Fen.] (Brit. Birds, X.)

I9I8. Alexander, H. G. Rock Pipit in Cambs. (Op. cit. XI.)

Haviland, M. D. Little Auk in Cambs. (T.c.)

\section{CHESHIRE.}

I656. King, D. The Vale Royall of England, or the County Palatine of Chester. Sm. fol. Lond: 1656. [329.]

I700. Leigh, C. Natural History of Lancashire, Cheshire, etc. Fol. Oxford : I700. [349.]

17[6I-]66. Pennant, T. British Zoology. Fol. Lond: r766. And later edits. [Reference to several Cheshire Birds.] [465.]

I792. "Adam." Record of a Hoopoe. (Adam's Weekly Courant, Chester.)

1829. Blackwall, J. "Manchester Museum." [Many Cheshire records.] (Loudon's Mag. N. H., II.) [68.]

I83I. Blackwall, J. Nat. Hist. in English Co's., Cheshire; Occurr. of two extremely rare Brit. Birds. [Golden Oriole at Taxall.] (Loudon's Mag. N. H. IV., p. 73.) 
1834. Blackwall, J. Researches in Zoology. 8vo. Lond: I834. 2nd ed. I873. [Cheshire records.] [68.]

1835. Stanley, Bishop E. Familiar History of Birds. 2 vols. post 8vo. Lond: I835. And subsequent edits. [557.]

1838. Rylands, P. Pippin Crossbill in Cheshire. (Nat. [Wood's], III.)

1845. Barlow, T. W. Arrival of Summer Birds at Holmes Chapel; Goldeneye in Cheshire; Migration of Water Rail. (Zool.)

Row, W. H. Arrival of Summer Birds of Passage at Davenport. (T.c.)

I846. Barlow, T. W. On Migratory Birds in Vicinity of Holmes Chapel; Occurrence of Grey Goose and Cornish Chough near Holmes Chapel. (Op. cit.)

I850. Johnson, H. Occurrence of Waxwing and Black Redstart near Liverpool. [Cheshire Records.] (Zool.)

I85I. McIntosh, J. Heronries in England, etc. (Nat. [Morris's], I.) [partim.]

Roberts, S. The Siskin [in Cheshire.] (T.c.)

1854. Byerley, I. Fauna of Liverpool [including W. Chesh.] (Proc. Liverpool Lit. \& Phil. Soc., Appdx.) Separate issue 1856. [II3.]

Cooke, N. Bittern near Warrington. (Zool.)

1855. Cooke, N. Pigmy Curlew and Little Stint near Warrington. $(O p$. cit.)

1856. Hinchcliffe, E. Barthomley, Lond: 1856. [Notes re Ruff, etc.]

1857. Brockholes, J. F. The Teal breeding in Cheshire. (Zool.)

1858. [Anon.] Note on Woodcock. (Field, June 5.)

Mather, T. Barheaded Goose near Chester; Great Snipe. (Zool.)

"Tribune." Hawks; The Solitary Snipe. (Field, Jany. 23.)

1859. (Liverpool Mercury.) [Spoonbill shot near Chester.] (Op. cit. Nov. 26.)

"Peregrine." [Freeman, G. E.] Ring Ouzel. (Op. cit., Jany. 29, Feb. I2.) 2 notes.

I859-6I. Brockholes, J. F. On Birds which nest in the District, 2 pts. (Liverpool Lit. \& Phil. Soc. Pr., I859-60 and I860-6r.)

I860. Jones, O. J. Grosbeak [Hawfinch] near Chester. (Field March Io.)

186r. Shaw, J. Rare Water Birds near Shrewsbury. [Chesh. records.] (Zool.)

Tomlinson, J. Young Cuckoo in Nest of House Sparrow. (Field, July 20.) 
I862. Page, J. Nightingale near Wilmslow. (Op. cit., May 24.)

Plant, J. Nightingale in Wilmslow. (Manchester Guardian, May I3.)

Plant, J. [ex Manchester Guardian.] Nightingale near Manchester. (Field, May I7.)

Williamson, W. C. Another Nightingale in the North. (Manchester Guardian, May 15.)

I863. Fry, T. Nightingale in Cheshire. (Field, May 30.)

Ward, E. Occurrence of Sea Eagle in Cheshire. (T.c., Jany. 3I.)

[I863-64.] [Anon.] Notes upon some of the Anatida of the District. (Naturalists' Scrap Book.) [Probably by C. S. Gregson \& N. Cooke. It is much in cooke's style.]

Cooke, N. Birkenhead Nightingale. (T.c.)

Fry, T. Nightingale in Birkenhead Park. (T.c.)

Gleave, E. Turdus torquatus and Sylvia phomicina. (T.c.)

Gregson, C. S. Nightingale in Birkenhead Park. (T.c.)

Moore, T. J. Sand Grouse. (T.c.)

1864. Cooke, N. Waxwing near Liscard. (Zool.)

Cooper, J. Pallas's Sand Grouse in Cheshire. (T.c.)

Price, J. Hawfinch in Cheshire. (Field, Sept. Io.)

Moore, T. J. Sand Grouse in Cheshire. (Zool.)

1865. Brockholes, J. F. Turtle Dove in Cheshire. (Field, July 22.)

Donald, J. H. Turtle Dove in Cheshire. (T.c., July I5.)

Fox, W. D. Turtle Doves in Cheshire. (T,c., July 22.)

[Heath, R.] A Ger Falcon shot in Cheshire. (Man. Courier, Nov. 4th.)

Price, J. Turtle Dove in Cheshire. (Field, Oct. 7.)

1865-66. Smith, H. E. Notabilia of Archæol. and Nat. Hist. of Mersey District. (Tr. Hist. Soc. Lancs. \& Chesh.) [549.]

I866. Harrison, H. Osprey at Rostherne Mere; Jer Falcon near Biddulph. [Shot in Chesh.] (Zool.)

Hayman, W. L. My Woodpecker. (Field, Jany. 27.)

I867. Buchanan, J. Landrail in January [in Cheshire.] (Op. cit., Mar. 30.)

Leigh, G. Woodcock in July. (Op. cit., Aug. 24.)

McIsaac, D. An albino Swallow. (T.c., Oct. 5.)

1868. Clark-Kennedy, A. Great Northern Diver near Birkenhead. (Zool.)

Donald, J. H. Great Grey Shrike in Cheshire. (Field, Nov. I4.) Holland, R. An Usurper. (Science Gossip.)

I87I. Archer, H. T. Moorhen breeding in trees. (Field, p. 443.)

"C. W. D." [Wolley-Dod, C.] Quails in Britain in I87o. (Op. cit., Jany. 2I.)

Fox, W. D. Quails nesting in Cheshire. (Op. cit., Jany. I4.) Purnell, W. Pied Flycatcher [breeding] in Cheshire. (Op. cit., Oct. 7.) Idem by "Vale Royal." (T.c., Oct. 2I.) 
1872. Durnford, H. Dark Variety of Richardson's Skua. [Shot on Cheshire Coast.] (Zool.)

Harting, J. E. British Heronries. (T.c.) [partim.]

I873-74. Sainter, J. D. [Notes on Cheshire Birds.] (Nature, p. I32.)

I874. Brockholes, J. F. On Birds observed in Wirral, Chesh. (Pr. Chester Soc. Nat. Sci.)

Clark-Kennedy, A. J. Grey Phalarope in Cheshire. (Zool.) Greg, R. H. Orange-legged Hobby. (T.c.)

Nicholson, F. Birds of Lancs. and Chesh., by " Redshank." [Series of Articles]. (Manchester City Newes); Heron and Heronries in Chesh. (T.c.)

Nicholson, F. Honey Buzzard and Orange-legged Hobby in Cheshire. (Zool.)

Smith, J. E. Rare Birds in and near Manchester. (Man. City News, May I6.)

I875. Davies, E. C. Grosbeak [Hawfinch] near Warrington [at Lymm.] (Field, Feb. 13.)

[Egerton, Sir P. G., Bt.] Odd Place for a Snipe. (Field, Nov. 20.)

Vawdry, D. Shoveler in Cheshire. (T.c., Nov. 6.)

I876. Davies, T. Pied Flycatcher near Warrington [at Lymm.] (Field, May 6.)

[Dixon, Col. G.] ("G. D.") Tufted Duck in Cheshire. $(O p$. cit., Jany. 22.)

I877. Bushby, J. Black-throated Diver on River Dee. (Op. cit., Jany. 27.)

I878. Sainter, J. D. Rambles Round Macclesfield. 8vo. I878. [50r.]

I880. Davies, T. Rough-legged Buzzard in Cheshire. (Field, Nov. r3.)

Meredith, M. R. Grey Phalarope in Lancashire. (T.c., Nov. I3.) [Killed at West Kirby in Cheshire.]

I88x. Bell, W. Little Gull on the Mersey. (Zool.)

"J. C. S." Osprey near Chester. (Field, Nov. 26.)

[Nicholson, F.] Heronries of Lancs. and Chesh. (Manchester Guardian.)

I882. Grindon, L. H. Country Rambles. Manchester: I882. [Contains important list of records for both Lancs. and Chesh.] [254.]

Robinson, J. F. Peregrine Falcon and Woodlark in Cheshire; Snow Bunting; Tree Sparrow. (Man. City Neres, July 8, Aug. I9, Oct. I4.)

Woodhouse, S. H. Quails in Cheshire. (Field, Sept. I6.)

Worthington, J. The Nightingale in N. of Cheshire. (Man. City Nerws, May 2oth.) 
I883. Hope, C. Nightingale in Cheshire. (Field, June I6.)

1884. [Anon.] Robbery by a Tomtit. (Land \& Water, May ro.)

I885. Oldham, C. On Breeding of Reed Warbler in Chesh. (Nat., p. I49). Idem by F. Nicholson. (Pr. Manch. Lit. \& PhilSoc.)

1886. Curzon, A. N. Hen Harrier in Chesh. (Field, Dec. I8.)

Oldham, C. Swallows in the late Season. (Nat.)

I887. Pickin, T. Purple Heron in Lancs. [Errore: killed at Alderley Edge in Chesh.] (Zool.)

1888. Moore, T. J. Pallas's Sand Grouse in Chesh. (Field, June 9, I6.)

I889. Beaumont, W. I. Crossbills in Chesh. (Nat.)

Newstead, R. The Heron and Heronries of Chesh. (Research, Mar.)

Wolley-Dod, C. Nightingale at Edge Hall, Malpas. (Field, May 25.)

I89o. Aplin, O. V. Distribution of Spotted Crake. (Zool.) [partim.] [24.]

Comber, E. Hawfinch breeding in Wirral; Spotted Crake in Wirral. (T.c.)

Fryer, A., junr. Rock Thrush in Chesh. (T.c.)

Greening, L. Hawfinch breeding near Warrington. (Young Nat.)

Macdona, C. Sheldrake near Liverpool [Hoylake]. (Field, June I4.)

Stott, C. E. Jackdaws killing Rats. (Zool.)

I89r. Claye, H. S. Little Crake in Chesh. (Field, Oct. I7.)

I892. Aplin, O. V. Distribution of Cirl Bunting. (Zool.) [partim.] [25.]

Moffat, C. B. Migrants and Hibernants, I8gr. (Sci. Gossip.)

Wolley-Dod, C. Cuckoo and Swallow reared in same Nest. (Ibis.)

Wrigley, J. Notes on the Bird Life of Formby. Liverpool: I892. [Contains several Cheshire records.]

1893. Broughton, Sir D. L., Bt. Quails in Chesh. (Field, p. - ?)

Gibson, J. Little Bittern near Liverpool. (T.c., p. 79I.)

Dobie, W. H. Black Tern in Chesh. (Zool.)

Neave, N. Fork-tailed Petrel at Macclesfield. (Nat. Hist. Jnl., Nov. ro.)

Siddall, J. D. Notes on the Starling. (Chester Soc. of Nat. Sci. Chr., p. 206.)

I894. [Anon.] Richardson's Skua at Latchford. (Brit. Nat.)

Brownsword, F. Note on the Cuckoo. (Nat.)

Newstead, R. The Heron and Heronries of Chesh. and N. Wales. (Pr. Chester Soc. Nat. Sci., IV.)

Oldham, C. Varieties of the Starling. (Nat.) 
I896. Baddeley, J. The Hooded Crow. (Man. City Newes, Apr. I8.) Harrison, H. C. Late Swallows. (T.c., Nov. 2I.)

Leighton, G. Wagtail's Nest on Railway Line. (Field, p. 848.)

1897. Congreve, F. Noddy Tern on Dee Marshes. (Zool.)

Gamlin, H. 'Twixt Mersy and Dee, Liverpool. (Chapter on Geese on Dee.)

Moss, F. Redthroated Diver in Chesh. (Man. City Neres, Sep. 25.)

Owen, Rev. L. E. The Nightingale in Cheshire. (Field, p. 80o.)

Wolley-Dod, C. Spotted Flycatcher appropriating Nests of other Birds. (T.c., p. 307.)

I898. Dobie, W. H. Birds of W. Chesh., Denbighs. and Flints. 8vo. Chester: I898. (Reprinted from Pr. Chester Soc. IV., I894.) [I7I.]

1899. Newman, A. A Stormy Petrel [Leach's Fork-tailed Petrel] shot at Frodsham. (Man. Guardian, Sep. 25.)

Wainwright, J. Memories of Marple. Manchester: I899. [Chapter on Birds.]

I899-Ig0o. Dobie, W. H. Ornitholog. Notes. (Chester Soc: Nat. Sci. Rept., 29.)

Igoo. Coward, T. A. and Oldham, C. The Birds of Cheshire. 8vo. Manchester : I900. [I52.]

Oldham, C. Quail in Chesh. (Zool.)

Solly, A. J. [Wrens resting gregariously.] (Field, p. 253.)

I900-0I. Dobie, W. H. Notes. (Chester Soc. Nat. Sci. Rept., 30.)

Igor. Congreve, C. R. Shag in Chesh. (Nat.) Idem by T. A. Coward. (T.c.)

Coward, T. A. Ducks on the Cheshire Meres. (T.c.)

Graves, F. S. Black Tern in Chesh. (Zool.)

Oldham, C. Great Northern Diver in Chesh. (Nat.)

Taylor, F. H. Winter Nidification of the Robin. (T.c.)

Ig0I-02. Shepheard, W. F. J. Record of Bittern. (Chester Soc. Nat. Sci. Chr.)

I902. Cawley, J. Bittern in Chesh. (Op. cit. Rept., 3r.)

Coward, T. A. Knot inland in Chesh. (Zool.)

Newstead, A. Sea Birds Inland. (Field, p. 589.)

Solly, A. J. Quails in Chesh. (T.c., p. 88.)

I903. Coward, T. A. Bird Notes from Cheshire during Autumn of Ig02-3. (Zool.)

Cummings. S. G. Status of the Goldfinch in Britain; Dotterel in Chesh. (T.c.)

Oldham, C. Pintail inland in Chesh. ; Honey Buzzard in Chesh. ; Black Tern in Chesh.; Red-breasted Merganser in Chesh.; Little Stint Inland in Chesh. (T.c.) 
Oldham, C. An Unrecorded Cheshire Sand Grouse; Rednecked Grebe in Chesh. (Chester Soc. Nat. Sci. Rept., 33.)

Tristram, E. Reported Occurrence of Red-breasted Flycatcher. (Field, p. 138.)

1904. Coward, T. A. The Kite in Cheshire. (Zoob.)

Duggan, T. S. Shoveler in Cheshire. (Field, p. IIII.)

Graves, F. S. Great Grey Shrike in Chesh. (Zool.)

Jourdain, F. C. R. Little Gull on the Mersey. (T.c.)

Newstead, A. Hooded Crow. (T.c.)

Oldham; C. Hoopoe in Chesh. (T.c.)

Smith, H. E. Red-backed Shrike. (T.c.)

1905. Coward, T. A. Grey Phalarope in Chesh. (Op. cit.)

Coward, T. A Failure of the Wild Birds Protection Act. (Manchester Guardian, Feb. I7.)

Cummings, S. G. Black-headed Gull assuming the hood in Winter; Abnormal Nests of the Swallow; Curlew Sandpiper on the Dee Marshes in Feb. ; Early Migrants near Chester; White Wagtail in Autumn in Chesh. (Zool.)

Milner, J. A. The Shoveler in Chesh. (Field, p. 32.)

Oldham, C. Oystercatcher Inland in Chesh.; Red-throated Diver in Chesh.; Late nesting of the Great Crested Grebe; Early arrival of the Chiffchaff in Chesh.; Smew in Chesh.; Black Tern in Chesh.; Greenshank and Ruff in Chesh.; Sounds produced by Long-eared Owl. (Zool.)

Stubbs, F. J. List of Birds of Oldham District. (Oldham Micros. Soc. Rept., I903-04) . [Many Cheshire localities.]

I906. Coward, T. A. Shore Lark in Chesh.; Knot inland in Chesh.; Baillon's Crake near Stockport. (Zool.)

Cummings, S. G. Cirl Bunting in Chesh. ; Late stay of Bramblings in Chesh. (T.c.)

Newstead, A. Hobby in Chesh. (T.c.)

Newstead, A. Hoopoe in Chesh. (Field, Sept. I5.) Idem. (Zool.)

Oldham, C. Eider in Chesh.; Common Scoter in Chesh.; Notes on the Little Grebe. (Zool.)

Southworth, J. Wryneck in Chesh. (T.c.)

I907. Graves, F. S. Scaup Duck in Chesh.; Shoveler in Chesh. (Op. cit.)

Newstead, A. Eared Grebe in Chesh.; Ruff near Chester. (T.c.)

Oldham, C. Sanderling in Chesh.; Rough-legged Buzzard in Chesh.; Smew in Chesh. (T.c.)

I908. Coward, T. A. Kentish Plover, Black Tern and Pallas's Sand Grouse in Chesh. 3 notes. (Brit. Birds, II.)

Coward, T. A. On Occurrence of Estrelata neglecta in Chesh. (P. Z. S.) Idem by C. Oldham. (Bull. B. O. C., XXI.)

Cummings, S. G. Bean Geese on the Dee Marshes. (Zool.)

Newstead, A. Ornitholog. Records from Chester. (T.c.) 
Newstead, R. The Food of some British Birds. (Jnl. Bd. Agricult.) [Examination of many Cheshire Birds.]

Newstead, R. and Coward, T. A. Schlegel's Petrel in Chesh. (Brit. Birds, II.)

Pemberton, R. Fulmar at Ince. (Lancs. Nat., p. I05.)

Stubbs, F. J. Bird Notes from the Oldham District. (Nat.)

Yates, J. M. St. J. Woodchat in Chesh. (Brit. Birds, II.)

Ig09. Coward, T. A. Black Grouse in Chesh. (Zool.) Idem by A. Newstead. (T.c.)

Newstead, A. Ornitholog. Records from Chester since Jan. I908. (Op. cit.)

Tollemache, H. Goldfinch in Chesh. (Chester Courant, Aug. Ir.) I909-Io. Stubbs, F. J. The Birds of Oldham. (Lancs. Nat.)

IgIo. Brown, M. W. Breeding of Marsh Warbler in Chesh. (Field-?)

Coward, T. A. Garganey and other Ducks in Chesh. (Brit. Birds III.) Inland Nesting of Sheld-Duck in Chesh. (Op. cit. IV.)

Coward, T. A., and Oldham, C. The Vertebrate Fauna of Cheshire and Liverpool Bay. 2 vols. 8vo., Lond.: I9Io. [I52.]

Newstead, A. Ornitholog. Report from Chester ; Hen Harrier in Chesh. (Zool.)

Ticehurst, N. F., and Jourdain, F. C. R. Distribution of Nightingale. [partim.] (Brit. Birds, V.)

Wenner, M. V. Increase of Tufted Duck in Chesh.; Common Scoter in Chesh. ; Unusual Situation for a Little Grebe's Nest. (T.c.)

IgII. Coward, T. A. Late Stay of Goosanders in Chesh. (Op. cit.) Knowles, R. E. Hoopoe in Chesh. in Winter. (Brit. Birds IV.)

IgI2. Coward, T. A. Scaup in Chesh. in Summer; Night Heron in Chesh. (Op. cit., VI.); Shags inland in Chesh.; Drake Smew in Chesh.; British Willow Tits in Chesh. (Op. cit. V.)

Coward, T. A. and Oldham, C. Hobby and Wryneck in Chesh. Corrections. (T.c.)

Moore, J. Note on Night Heron in Chesh. (T.c., VI.)

Standen, R. Osprey in Chesh. (Lancs. Nat.)

Wenner, M. V. Barnacle Goose inland in Chesh. (Brit. Birds, V.)

I9r3. Boyd, A. W. Marsh Harrier in Cheshire ; (Op. cit. VII.)

Coward, T. A. Willow Tit nesting in Cheshire; Ruddy SheldDuck in Cheshire. (2 notes.) Common Scoters in summer in Cheshire. (T.c.)

Moore, J. Common Scoters in summer in Cheshire. (T.c.)

IgI4. Boyd, A. W. Willow Tit breeding in Cheshire. (Op. cit. VIII.) Butterfield, E. P. Status of Lesser Whitethroat in Cheshire. (Zool.)

Dockray, J. A. Gadwall in Cheshire. (Brit. Birds, VIII.) 
Eason, E. A., jun., Black Terns in Cheshire. (Op. cit. VII.)

Gill, E. L. Status of Blackcap and Garden Warbler in Cheshire. $($ Zool. $)$

Jourdain, F. C. R. Spoonbill in Cheshire. (Brit. Birds, VII.)

Ogilvie Grant, W. R. Schlegel's Petrel (Estrelata neglecta) killed at Tarporley. (Bull. B. O.C., XXXIII., pp. I24-5.)

I9I5. Boyd, A. W. Early nesting of Reed Warbler. (Brit. Birds, IX.) Hendy, E. W. Some habits of Great Spotted Woodpecker in Cheshire, etc., 2 notes. (T.c.)

Moore, J. Little Stint inland in Cheshire: Osprey in Cheshire. (T.c.)

Rutter, W. Golden Oriole in Cheshire. (Lancs. Nat. VIII., p. 297.)

I9I6. Moore, J. Common Scoters in Cheshire in summer. (Brit. Birds, X.)

Wenner, M. V. Crossbills in Cheshire; Little Owl in Cheshire. (T.c.)

IgI6-I8. Coward, T. A. Notes on the Vertebrate Fanna of Cheshire [Birds] (Lancs. Nat. IX. Suppl., IgI6, pp. 6-37; X. I9I7, pp. I89-92, 203-10, 245-52, 275-80; XI. I9I8, pp. I72-3, 229-32, 235-42.)

I9r7. Bruton, F. A. Albinistic Blackheaded Gull and desertion of a Cheshire nesting site. (Brit. Birds, XI.)

Coward, T. A. Shags in Cheshire. (T.c.) Shags and Cormorants inland [Cheshire.] (Lancs. Nat. X., p. I79); Little Auk in Cheshire. (T.c. p. 225.)

Dobie, W. H. Little Owl in Cheshire. (Brit. Birds, X.)

Igr8. Boyd, A. W. Sheld-Ducks and Common Scoters inland in Cheshire. (Op. cit., XII.)

Fisher, K. Black and Sandwich Terns inland in Cheshire. (Brit. Birds, XII.)

CORNWALL.

(AND SCILLY ISLES.)

I602. Carew, R. Survey of Cornwall. 4to. Lond. I602. And later editions. [I20.]

I726. Moyle, Walter. The Works of. 2 vols. 8vo. Lond. : I726. [422.]

1750. Heath, R. Account of the Islands of Scilly. 8vo. Lond. : I750. [289.]

I756. Borlase, W. Ancient and Present State of Islands of Scilly. 4to. Oxford: I756. [86.] 
I757. Botanista, Theophilus. Rural Beauties: or, the Natural History of . . Cornwall, etc. I2mo. Lond.: I757. [87.]

I758. Borlase, W. Natural History of Cornwall. Fol. Oxford : I758. [86.]

I778. Botoner, or Buttoner, W. [William of Worcester.] Itinerarium. [1478.] 8vo. Cantab., I778. [88.]

I808. [Anonymous.] The Literary Repository of Cornwall and Devon. Quadrupeds, Birds, and Fish. 2 pts. Monthly Magazine, 1808. [Said to be by Mr. James of Manaccan-vide D'Urban \& Mathew's "Birds of Devon."]

r8r6. Polwhele, Rev. R. History of Cornwall. 7 vols. 4to. Lond.: I8r6. [477.]

I817-20. Gilbert, C. S. Historical Survey of Cornwall. 2 vols. roy. 4to. Lond., etc. : I8I7-20. [228.]

I823. Bond, T. Topographical Sketches of the Boroughs of East and West Looe. 8vo. Lond.: 1823. [79.]

1824. Drew, S. [Edited by.] History of Cornwall. By F. Hitchens. 2 vols. 4to. Helston, etc. : I824. [I8I.]

I828. Fox, G. T. On appearance of some rare birds in England. [Spur-winged Goose near St. Germain's.] (Zool. Jnl. III., p. 495.)

I830. Jackson, C., Couch, J., and Lakes, J. Rare or Uncommon Birds observed in Cornwall. (Loudon's Mag., N. H. III.) [I50.]

1832. Couch, J. The Grey Phalarope [in Cornwall.] (Op. cit. V., p. 729.)

1833. Couch, J. Little Bustard [on Berry Down, Lanreath.] (Op. cit. VI., p. I4I.)

1836. Martin, T. S. Northern Diver [in Mount's Bay and Falmouth Harbour]. (Op. cit. IX., p. 480.)

S[elby], P. J. Sitta curopaa [at Liskeard.] (Mag. of Zool \& Bot., I.)

I838. Couch, J. A Cornish Fauna. Pt. I. Vertebrates, etc. 8 vo. Truro: I838. 2nd edit., I878. [I50.]

Moore, E. Pied Flycatcher [at Mount Edgecumbe]. (Charlesw. Mag. N. H.)

Redding, C. Birds met with near Plymouth. (Nat. [Wood's], III.)

I839. Bellamy, J. C. Nat. History of South Devon. Post 8vo. Plymouth, etc. : I839. [Notices of Cornish Birds.] [56.]

Mitchell, D. W. Capture of rare birds. [Rose-coloured Pastor, Greyheaded Wagtail and Little Gull in Cornwall.] (Charlesw Mag. N. H.) 
1843. Greenwood, A. Black Redstart near Penzance; Squacco Heron near Penzance; Richard's Pipit in Cornwall. (Zool.) Rodd, E. H. Occurrence of Rare British Birds; Bustard near Lizard Point; Squacco Heron and Wood Sandpiper at Penzance; Dusky Sandpiper and Spoonbill in Cornwall. (T.c.)

1844. Greenwood, A. Hoopoe in Cornwall. (Zool.)

Hore, Rev. W. S. Night Heron in Cornwall. (T.c.)

Rodd, E. H. Note on the Great Northern Diver. (T.c.)

I845. Courtney, J. S. Guide to Penzance, etc. I2mo. Lond., etc. : I845. [I5I.]

Rodd, E. H. Notice of capture of Fire-crested Regulus. (Penzance N. H. Soc. Rept. I845, pp. 30-3I); Norfolk Plover wintering; Little Gull, Hoopoe, Spoonbill, etc., in Cornwall. 5 notes. (Zool.)

I846. Hare, M., junr. Liskeard Ornithology. (R. Cormw. Polytech. Soc. I 4 th rept.)

Rodd, E. H. Notice of Occurrence of Rare Birds in Cornw. (Penzance N. H. Soc. Rept. I846, pp. 86-89) ; Occurrence of Bearded Tit; Purple Heron near Penzance; Crested Lark, Buff-breasted Sandpiper, etc., at Penzance. 5 notes. (Zool.)

I847. [Editorial.] Ivory Gull at Penzance. (Ann. \& Mag. N. H)

Rodd, E. H. Rare Birds in District of Penzance, I846-7. (Penz. N. H. Soc. Rept. I847, pp. I49-50) ; Firecrest near Truro ; Ivory Gull near Penzance; Scops-eared Owl at Scilly; Avocet at Land's End, etc. (Zool.)

I848. Johns, C. A. A Week at the Lizard. Post 8vo. Lond. : I848. Idem, n.d. [I874.] q.v. [3I9.]

Rodd, E. H. Great Plover wintering; White Wagtail near Penzance; Grey-headed Wagtail near Penzance; White Stork at Land's End. (Zool.)

I848-49. Hare, N. Notice of Birds near Liskeard. (Penz. N. H. Soc. Repts. I848, pp. 2II-I2; I849, pp. 3I4-I6.)

I848-65. [Anon.] Ornithological Occurrences. (Op. cit. I848, pp. I76-77; I849, PP. 270-7I ; I850, p. 365 ; I852, p. 62; I853, p. I34; I854, p. 2 II ; I855, p. 278 ; I864-65, P. 37.)

1849. Cocks, W. P. British Birds: Cornwall. Folio. Falmouth : I849. [I37.]

Rodd, E. H. Capture of Woodchat Shrike at Scilly. (Penz, N. H. Soc. Rept. I849, pp. 290-9I.) Squacco Heron, Temminck's Stint and Great Northern Diver at Penzance ; Autumnal Migration at Scilly; Osprey, etc. at Scilly. 8 notes. (Zool.)

I850. Newton, A. Waxwing in Cornwall, etc. (Zool.)

North, J. W. A Week in the Isles of Scilly. 8vo. Penzance: I850. [45I.] 
Rodd, E. H. List of Brit. Birds as a Guide to Ornithology of Land's End District. (Penz. N. H. Soc. Rept. I850, pp. 40034); Waxwing, etc., near Penzance; Purple Heron near Land's End; Black Tern at Mount's Bay; Spoonbill at Scilly. (Zool.)

I85I. Cocks, W. P. Contributions to the Fauna of Falmouth, 4 pts. ; Grasshopper-Warbler near Falmouth; Red-footed Falcon at Falmouth. (Nat. [Morris's], I.)

Jackson, C. Additional Heronries [Trenant Wood]: Note on Green Sandpiper. (T.c.)

Julian, R. A., jun. Snowy Owl [in Cornwall]. (Nat. [Morris's], I.)

Rodd, E. H. Crested Lark, Ortolan Bunting, etc., at Scilly; Osprey, etc., at Land's End, etc. I2 notes. (Zool.)

1852. Britton, W. Ornithology [Firecrest and Hoopoe in Cornwall.] (Nat. [Morris's], II.)

Cocks, W. P. Hen Harrier, Peregrine, Buzzard and Black Redstart at Falmouth, 2 notes. (Nat. [Morris's], II.)

Gatcombe, J. Egyptian Goose [near Launceston.] (T.c.)

Matthews, W. E. Hoopoes near St. Austell. (T.c.)

Rodd, E. H. Additions to Cornish List of Birds. (Penz. N. H. Soc. Rept. I852, pp. 66-67.) Fire-crest, Kentish Plover and White Wagtail near Penzance; Wood Sandpiper at Land's End; Montagu's Harrier at Scilly, etc. 8 notes. (Zool.)

1853. Clogg, S. Mountain Finch at Looe. (Nat. [Morris's], III.) Jackson, C. Notes on Colymbus glacialis, etc., in Cornwall. 5 notes. (T.c.)

Rodd, E. H. Rose-coloured Pastor and Roller near Land's End; Occurrences near Penzance. 8 notes. (Zool.)

1854. Jackson, C. Ornithological Notes [from Cornwall]. (Nat. [Morris's], IV.)

Rodd, E. H. Little Bustard near Land's End and Penzance; White-fronted Goose and Glossy Ibis at Scilly, etc. Io notes. (Zool.)

1855. Rodd, E. H. Ornithological Notes. (Penz. N. H. Soc. Rept. I855, pp. 28I-82.) Honey Buzzard near Truro ; Rose-coloured Pastors near Land's End; Solitary Snipe near Penzance. (Zool.)

1856. Clogg, S. Blackstart [near Looe]. (Nat. [Morris's], VI.) Idem. (Op. cit. VIII.)

Jenkin, S. W. [Localities for Chough in Cornwall.] (Op.cit. VI., p. I40.)

Rodd, E. H. Velvet Scoter at Land's End; Montagu's Harrier near Penryn; Honey Buzzard near Penzance. (Zool.) Little Bustard [in Cornwall]. (Field, Feb. 9.) 
1857. Rodd, E. H. Autumnal Migratory movement at Scilly Isles; Occurrences in Cornwall. I3 notes. (Zool.)

1858. Clogg, S. Little Bittern [near Looe]. (Nat. [Morris's], VIII.) Rodd, E. H. Firecrest, Great Plover, Kentish Plover, etc., at Penzance. 5 notes. (Zool.)

I859. Gatcombe, J. Notes on Occurrence of Rare Birds in Devon and Cornwall in $1857-58$. (Op. cit.) [I88.]

Rodd, E. H. Note on the Skuas. (Field, May 28.) Tree Sparrows at Penzance; Little Bustard near Padstow; Golden Oriole near Land's End. (Zool.)

186o. "Heimdall." Blackcap in Cornwall in Jan. (Field, Jan. I4) ; Glaucous Gull, etc. [at Penzance]. (T.c., Jan. 28.)

Rodd, E. H. Long-tailed Duck in Cornwall. (Op. cit., Nov. I 7$)$; Spotted Eagle in Cornwall. (T.c. Dec. I5); Alpine Swift in Cornwall; Buff-breasted Snipe near Land's End; Wood Warbler near Penzance, etc. (Zool.) Red Lobefoot at the Scilly Isles. (Field, Oct. 20); Cirl Bunting [common near Penzance]. (T.c., July 7.)

I86I. Blight, J. T. A Week at the Land's End. Post 8vo. Lond. : I86I. [7I.]

Holdsworth, E. W. H. Gannet in Cornwall. (Field, Nov. I6.)

Rodd, E. H. Spotted Eagle in Cornwall. (T.c., Nov. I6; Zool.) Firecrested Regulus near Penzance; Golden Oriole at Scilly; Long-tailed Duck near Tregothan. (Zool.)

Rogers, H. Roller near Land's End. (T.c.)

"S. S. S." The Gannet in Cornwall. (Field, Nov. 9, 23) ; Bittern [in Cornwall]. (T.c., Nov. 23.)

I862. [Anon, "W."] Ornithology of Cornish Coast. (Field, May 3.)

Edmonds, R. The Land's End District. 8vo. Lond., etc. I862. [I9I.]

Gatcombe, J. Spoonbills [on St. Germain's river.] (Field, Nov. 22.)

Rodd, E. H. Wild Goose near Penzance; Squacco Heron near Redruth; Common Skua near Land's End. (Zool.) Sabine's Snipe in Cornwall. (Field, Jan. $25 ;$ P. Z. S.)

I863. Rodd, E. H. Addenda to preceding lists of Birds. (Penz. N. H. Soc. Rept., I862-63, pp. 3I-32.) Red-breasted Flycatcher in Cornwall; Pallas's Sand Grouse at Scilly; Pied Flycatcher near Land's End, etc. (Zool.) Red-breasted Flycatcher near Falmouth. (Field, Feb. 2I; Sci. Gossip.)

1864. Holdsworth, E. W. H. Gannets on N. Coast of Cornwall. (Field., Ap. 23.)

Maxwell, J. Capture of Bittern in Cornwall. (Field, Jany. I6.) Rodd, E. H. Great Autumnal Migration of Birds in Penzance; Occurrences in Cornwall. (6 notes.) (Zool.) 
Rodd, E. H. A List of British Birds, as a Guide to the Ornithology of Cornwall. 8vo. Lond., etc.: I864. 2nd. edit. 1869. [495.]

I865. [Anon.] Bonaparte's Gull at Falmouth. (Sci. Gossip.)

Bullmir, W. R. [=Bullmore, W. K.] Forktailed Petrels at Falmouth. (Field, Dec. I6.)

Gatcombe, J. The Purple Sandpiper [in Devon and Cornwall]. (T.c., Nov. 25.)

"H. F." Rare birds in neighbourhood of Falmouth. (T.c., Oct. 28.)

Kelly, R. Forktailed Petrels inland [in Cornwall]. (Op. cit., Feb. 9.)

R[odd], F. R. Ornithological Ramble over Bodmin Moors. (Zool.)

Rodd, E. H. Autumnal Migration at Land's End ; Ornithological Notes from Scilly Isles; Hoopoe and Golden Oriole at Scilly, etc. (T.c.) Rare Birds captured during I865. (Penz. N. H. Soc. Rept., I864-65.) Surf Scoter in the Scilly Isles. (Field, Sept. 30.) Second Occurrence of Red-breasted Flycatcher in Cornwall. (T.c., Nov. I8.) Bartram's Sandpiper in Cornwall. (T.c., Nov. 25.) Occurrences of Golden Oriole[in Scilly.] (Op. cit., May I3.)

1866. Bullmore, W. K. Bartram's Sandpiper near Falmouth. (Zool.) [106.]

Clogg, S. Cornish Chough at E. Looe ; Little Auk at Liskeard. (T.c.)

Gatcombe, J. Grey Phalarope and Black Tern in Cornwall. (T.c.) ; Hoopoe in Cornwall. (Field, May I2) ; Grey Phalarope and Black Tern in Cornwall. (Op. cit., Oct. 6.)

Rodd, E. H. Ornitholog. Notes from Penzance; Occurrences in Cornwall, $x 4$ notes. (Zool.) The Grey Phalarope. (Field, Oct. I3) ; Little Bittern at Scilly. (Op. cit., June 23) ; Glossy Ibis at Scilly. (Op. cit., Oct. 20) ; Honey Buzzard at Scilly. (T.c., Nov. 3.)

1867. "Arundo." Ring Ouzel breeding in Cornwall. (Field, Nov. 9.)

Bullmore, W. K. Cornish Fauna. 8vo. Truro: 1867. (Also in Rept. R. Cornre. Polytech. Soc., I866.) . [106.]

Clogg, S. Black Redstart, Buzzard and Great Northern Diver at I.ooe ; Arrival of Immigrants at Looe, etc. 7 notes. (Zool.)

Cornish, T. Red-throated Diver netted at Penzance. (T.c.)

Furneaux, A. Sabine's Gull in Cornwall. (T.c.)

[Morris, F. O. ex Times.] Sabine's Gull in Cornwall. (Field, Feb. 9.)

Rodd, E. H. Autumnal Migration at Scilly; Surf Scoter, Fire-crested Regulus, etc., at Scilly; Little Bittern, etc., in Cornwall, etc. I3 notes. (Zool.) Lesser Grey Shrike a Brit. bird [shot on Scilly Is.] (Field, Oct. I9.); Greater Shearwater [in Mount's Bay]. (T.c., Oct. 26.) 
I868. "Arundo." Migration of Crossbills [in Cornwall]. (Field, Aug. I.)

Gurney, J. H. Departures and Arrivals of Migratory Birds observed in Cornwall. (Zool.)

Rodd, E. H. Rough-legged Buzzard near Truro; Ornitholog. Notes from Scilly; A Cornish Moorland Walk; Land's End Waders; Tawny and Richard's Pipits at Scilly, etc. (T.c.) Tawny Pipit at Scilly. (Field, Sept. 26.)

r869. Budge, H. Snow Bunting at Camborne. (Sci. Gossip.)

Clogg, S. Terns and Gannets, Bittern, Little Gull at East Looe, etc. 7 notes. (Zool.)

"W. R. E." Garganey in Cornwall. (Field, Apr. 24.)

"G. R. M." Hoopoe in Cornwall. (T.c., Apr. 24.)

Rodd, E. H. Spoonbill, Ray's Wagtail, and Golden Oriole at Scilly. (T.c., May 8); Little Bustard in Cornwall. (Op. cit., Nov. 6) ; Kite in Cornwall. (T.c., Dec. II) ; Dartford Warbler near Truro, Hoopoes at Land's End, Golden Oriole at Scilly, Night Herons in Cornwall, etc. 9 notes. (Zool.)

I870. Rodd, E. H. Sport and Bird Migration in the Scilly Isles. (Field, Nov. I9.) Iceland Falcon in Cornwall. (Op. cit., Jan. 22, Feb. 5.) Idem by C. H. Fisher. (T.c., Feb. 26.) Flock of Golden Orioles near Penzance. (T.c., Apr. 30.) Winter Visitants in W. Cornwall; List of Birds of Cornwall (4 pts.) ; Ornithology of Scilly Isles ; Kite in Cornwall ; Iceland Falcon in Cornwall; Autumn Migration at Scilly, etc. (Zool.)

I870-7x. Rodd, E. H. Notes on the Ornithology of Cornwall for May, I869 and May, I870, 2 pts. 8vo. (Reprinted from Nos. XI. and XII. of Jnl. Roy. Inst. of Cornwall, I870-7I.)

187x. Clogg, S. Egyptian Geese in Cornwall. (Zool.)

Couch, J. History of Polperro. 8vo. Truro: I87I. [I50.]

Drew, J. Notes at Nansladron near St. Austell. (Sci. Gossip.)

Ferris, W. J. Hoopoe in Scilly. (Field, Apl. I.)

Gatcombe, J. Avocet in Cornwall. (Zool.)

Harris, J. American Bittern in Cornwall. (Field, Jan. I4.)

Rickards, M. S. C. Green Sandpiper at Scilly. (Zool.)

Rodd, E. H. Notes from Scilly; Occurrences in Cornwall. I3 notes. (T.c.) Yellow-shanked Sandpiper near Penzance. (Field, Sept. 23.)

Walker, F. A. Notes on Scilly Isles. (Zool.)

1872. Anstey, H. Hoopoe at Helston. (Field, Apl. 6.)

Clogg, S. Razorbills, etc., picked up on the Coast ; Heronry in Cornwall. (Zool.)

Harris, J. Grey Phalarope and Eared Grebe in Cornwall (Field, Jan. I3.)

Harting, J. E. British Heronries. (Zool.) Idem. (Field, Mar. 9.) Supposed Wilson's Snipe in Cornwall. (Zool.) 
Rodd, E. H. Glaucous and Iceland Gulls in Mount's Bay; Wilson's Snipe in Cornwall ; Gull-billed Tern at St. Just, etc. 6 notes. (T.c.)

Rodd, F. R. The Scilly Isles-Migratory Birds, Notes on Shooting, etc. $(T . c$.

1872-87. Gatcombe, J. Ornithological Notes from Devon and Corn wall, 45 contributions. (Op. cit., I872-87.) [I88:-0mit I863-7I and add I872, pp. 30II, 3049, 3099, 3I36, 3I66, 3258.]

1873. Gatcombe, J. New Heronry in Cornwall. (Op. cit.) Black Guillemot at Falmouth. (Field, Feb. 8.)

Rodd, E. H. Iceland Gull at Mount's Bay. (Zool.)

Rodd, F. R. Range of Stockdove. (Field, May ro.)

1874. Bullmore, W. K. Bar-tailed Godwit and Wood Sandpiper at Scilly. (Op. cit., Sept. I9.)

Clogg, S. Black Redstart in Summer Plumage in November; Grey Phalarope in Cornwall. (Zool.)

Gatcombe, J. Greater Shearwater on Coasts of Devon and Cornwall. (T.c.)

Hill, F. V. List of Birds. [In Johns' Week at the Lizard, 2nd. edit.] I2mo. London: $n$. d. [3I9.]

Rodd, E. H. Spring Migrants at Penzance; White's Thrush near Grampound, etc. Io notes. (Zool.) White's Thrush in Cornwall. (Field, Jan. 24.) Pratincole in Cornwall. (T.c., June 27); Montagu's Harrier in Cornwall. (Op. cit., Aug. I5.)

1875. Clage [Clogg ?], S. Short-eared Owl in Cornwall. (Op. cit., Dec. II.)

Clogg, S. Little Bustard near Looe. (Zool.)

Hext, H. Y. Hoopoe in Cornwall. (Field, May I.)

Rodd, E. H. Little Bustard near Lizard. (Zool. ; Field, Jan. 2.) Grey Lag Goose near Penzance; Golden Oriole at Land's End; Spring Migration at Land's End. (Zool.)

"Sarcelle." [= Payton, C. A.] Great Northern Divers on Cornish Coast. (Field, Feb. 6.)

Weanne, J. Bittern in Cornwall. (T.c., Jan. 23.) Idem by W. Borrer, junr. (T.c., Feb. 6.)

1876. Clogg, S. Black Redstart at E. Looe; Migration of Birds (Zool.)

Heaton, W. H. Does Common Gull breed in Scilly Isles? (T.c.)

Rodd, E. H. Dartford Warbler, Green Woodpecker and supposed Lesser Kestrel at Land's End; Sabine's Snipe and Dotterel near Penzance; Golden Oriole in Lizard District; Longtailed Duck near Padstow, etc. (T.c.) Sabine's Snipe in Cornwall. (Field, Mar. II.) 
I877. Rodd, E. H. Pomatorhine Skua in Mount's Bay, etc. ; Iceland and Glaucous Gulls at Land's End; Gannets off Cornish Coast; Buffon's Skua on Cornish Coast; Black-throated Diver on Freshwater; White-tailed Eagle on N. Coast of Cornwall, etc. (Zool.) Summer Migrants at Penzance; Hoopoe at Land's End. (Field, Apr. I4); Summer Snipe breeding in Cornwall. (T.c., May 5); Baillon's Crake near Penzance. (Op. cit., Oct. 20.)

Tyacke, J. Dartford Warbler in Cornwall; Distribution of Green Woodpecker in Cornwall. (Zool.)

I878. Gatcombe, J. Little Crake in Cornwall. (Op. cit.)

Rodd, E. H. Golden Oriole in Cornwall in Winter; Grey Phalarope in Cornwall in May; Purple Heron and Wood Sandpiper at Scilly; Hoopoes at Land's End. (T.c.)

I879. Rodd, E. H. Great Plover at Scilly Isles; Sea Birds breeding at Scilly; Long-tailed Duck and Shore Lark in Cornwall; Hen Harrier at Scilly. $(O p$. cit.)

I880. Gatcombe, J. Skuas off Coast of Cornwall ; Spoonbill in Cornwall. (Op. cit.)

Hart, H. P. Crested Lark, Whinchat and Avocet in Cornwall ; Pied Flycatcher at the Lizard. (T.c.)

Olver, T. Red-legged Partridge in Cornwall. (Field, Nov. 6.)

Rodd, E. H. The Birds of Cornwall and the Scilly Islands. Edited by J. E. Harting. 8vo. Lond.: I880. [495.]

I88I. W._- T. Redwinged Starling in Cornwall. (Field, Aug. 20.) Idem by J. E. Harting. (Zool.)

Cloff [? Clogg], S. Fork-tailed Petrel in Cornwall. (Field, Nov. 26.)

Cornish, T. Garganey, Spotted Redshank and Osprey in Cornwall. 2 notes. (Zool.)

Hart, H. P. Dotterel and Siskin in Cornwall. 2 notes. (T.c.) Vingoe, W. H. Crane at Scilly. (T.c.)

r882. Cornish, T. Eider Duck at Scilly; Kite in Cornwall; Whitewinged Black Tern at Scilly; Totanus solitarius at Scilly. (Op. cit.)

Marquand, E. D. Nidification of the Goat Sucker at Carn Galva. (Penzance N. H. Soc. Trans., p. 283).

Mathew, M. A. Curlew Sandpiper in Cornwall. (T.c.)

1883. Cornish, T. Rare Birds in Cornwall and Scilly. (Op. cit.)

"Isay." Little Bustard in Cornwall. (Field, Jany. 20.)

Tait, S. The Migration of Birds. (Penzance Nat. Hist. Soc. Trans., p. 435).

I884. Cornish, T. Little Gull and Hawfinch at Penzance; Water Rail near Penzance. (Zool.) Jerfalcon found in Cornwall. (Field, Mar. 29, p. 437.) 
1885. Angove, E. Solitary Snipe in Cornwall. (Field, Oct. Io.)

Cornish, T. Solitary Sandpiper in Cornwall; American Killdeer Plover in Cornwall ; Cream-coloured Courser in Cornwall ; Iceland Gull at Scilly. (Zool.)

Dresser, H. E. Bartram's Sandpiper, Little Bustard and Hoopoe in Cornwall. (T.c.) On Egialitis vocifera at Tresco, Scilly Isles. (P.Z.S.)

Smith, C. Wayside Notes during a West Country Drive. (Zool.) I885-86. Smart, Rev. R. W. J. Birds of the Isles of Scilly. (Penz. N. H. Soc. Rept., I885-86, pp. I62-79.)

I886. [Anon. "Auceps."] Peregrine Falcon in Cornwall. (Field, Apr. I7.)

Bidwell, E. Visit to Isles of Scilly during Nesting Season. (Tr. Norf. Norw. Nat. Soc., IV.)

Jenkin, A. H. Hoopoe in Cornwall. (Field, Oct. 23.)

Porter, T. J. The Brambling [in Cornwall.] (Sci. Gossip, April.)

1887. Cornish, T. White's Thrush in Scilly Isles; Esquimaux Curlew at Scilly. (Zool.)

"G. H. F." Great Northern Diver on Cornish Coast in June. (Field, June I8.)

Gurney, J. H. junr. White-winged Tern in Cornwall and Scilly. (Zool.)

Willimott, W. Flock of Ravens [near Liskeard.] (Field, May 7.)

3888. Cornish, T. Sand Grouse at Land's End. (Zool.)

E[lliot], E. A. S. Sand Grouse [in Cornwall.] (Field, June 23.) Idem by G. Brendon. (T.c., June 23.)

Rodd, E. H. Golden Oriole and Stock Dove in Cornwall. (Zool.)

Smart, Rev. R. W. J. Bird-nesting on Scilly. (Trans. Penz. Nat. H. Soc., p. 70-76).

1889. Bidwell, E. Birds of West Cornwall. (In "The Handbook of West Cornwall.") [Doubtful title from Miller Christy, date ?]

Cornish, T. Little Gull near Penzance; Pallas's Sand Grouse in Cornwall. (Zool.)

"Cornwall." Wild Duck nesting in Nov. (Field, Dec. 2r.)

Gurney, J. H. junr. Notes on Isles of Scilly and Manx Shearwater. (Tr. Norf. \& Norw. Nat. Soc.)

"T. W." Scarcity of Fieldfares in Cornwall. (Field, Mar. 2); Pallas's Sand Grouse [near St. Agnes.] (Op. cit., Nov. 9.)

I8go. Aplin, O. V. Distribution, etc. of Spotted Crake. (Zool.) [partim.] [24.]

Brendon, G. Bittern in Cornwall. (Field, Dec. 27.)

Earthy, W. G. N. Pomatorhine Skua in Cornwall. (T.c., Nov. 29.)

F. C. Solitary Snipe in Cornwall. (T.c., Sept. I3.)

Harting, J. E. Ardea virescens in Cornwall; Black Stork in Scilly Isles. (Zool.) 
Jenkinson, J. H. Phylloscopus" superciliosus at Scilly. (Field, Apl. I2.) Idem by H. A. Macpherson. (T.c., Apl, 26.)

"T. W." Forktailed Kite at Scilly. (Field, Sept. 27.)

I89x. Harting, J. E. Bonaparte's Gull in Cornwall. (Zool.)

Jenkinson, J. H. Lesser Kestrel from Scilly. (T.c.) Wild Swans at Scilly. (Field, Mar. I4.) Idem by "Tantara." (T.c., Apl. 4.)

Oats, W. F. Grey Phalarope in Cornwall. (Field, Nov. 2I.) Idem by T. W. (T.c., Nov. 28.)

I892. Aplin, O. V. Distribution of Cirl Bunting; Status of the Woodchat. (Zool.) [partim.] [25.]

Browning, W. G. Blackthroated Diver in Cornwall. (Field, May 2I.) Idem by G. C. Green. (T.c., May 28.)

Cornish, T. H. Sabine's Gull in Cornwall. (Zool.)

1893. Harting, J. E. Whitetailed Eagle in Cornwall. (Field, Dec. 9.) W[right], H. Squacco Heron in Cornwall. (Op. cit., June Io) ; Bewick's Swan in Cornwall. (Op. cit., Dec. 2.)

I895. Weich, H. J. Smew in Cormwall. (Op. cit., Dec. I4.)

1896. Thorbur, A. Sabine's Gull in Cornwall. (Zool.)

I898. Pike, C. J. Solitary Snipe in Cornwall. (Field, Oct. 29.)

"W. D. P." Montagu's Harriers nesting in Cornwall. (T.c., July 30.)

I899. “B. H. D." Seabirds on Cornish Coast. (Op. cit., May 27.)

I900. Hill, J. J. Avocet in Cornwall. (Op. cit., June 9.)

I9or. Clarke, W. Eagle. Visit to Eddystone Lighthouse. (Bull. B. O. C. XII.) Idem by W. E. de Winton. (T.c.)

Evans, H. M. Little Bittern in Cornwall. (Zool.)

I902. Clark, James. The Birds of Cornwall. (Pt. I, Pr. Cornre. Nat. Study Soc. Jnl. Roy. Inst. Cormwall.) [I30.]

Clarke, W. Eagle. A Month on the Eddystone. A Study in Bird Migration. (Ibis) [134.]

Pratt \& Sons. Glossy Ibis in Scilly Isles, etc. (Knoroledge.)

I903. Dorrien-Smith, A. American Bittern in Scilly Isles. (Bull. B. O. C., XIV.)

[I903.] Salmon, A. L. Cornwall. (Little Guides Series.) Lond. n. $d$.

I904. Frohawk, F. W. Bird Life on Scilly Islands. (Field, Sept. 24.)

Howard, H. E. Richard's Pipit in Cornwall. (Zool.)

I905. Bonhote, J. L. Bartram's Sandpiper from Cornwall. (Bull. B. O. C., XV.) 
Ig06. Clark, J. Birds. [In Victoria Hist. of Co. of Cornwall, I.] 4to. Lond.: I906. [I30.]

Clark, J. and Rodd, F. R. The Birds of Scilly. 3 pts. (Zool.) Idem, separately reprinted. [I30.]

Cleave, H. P. O. Breeding of Hen Harrier in Cornwall. (T.c.)

Dorrien-Smith, A. Greater Yellowshanks in Scilly Isles. (Bull. B. O. C., XIX.) Idem by F. W. Frohawk. (Field, Nov. Io.)

[Various Writers.] Some Cornish and other Birds. (Cornish Notes and Queries, Ist. ser. pp. 25I-4.)

I907. Clark, J. Recent Occurrence of Rare Birds in Cornwall. (Zool.) [130.]

Rickett, C. B. Richard's Pipit in Cornwall. (Brit. Birds, I.)

Ig08. Cleave, H. P. O. Peregrine Falcon and Buzzards in Cornwall. (Zool.)

Coles, G. H. Supposed Woodchat in Cornwall. (Field, p. 83I) Idem by H. F. Witherby. (Brit. Birds, II.)

Hudson, W. H. The Land's End. 8vo. Lond. : Igo8. [303.]

Ticehusst, C. B. White Wagtail in Cornwall. (Brit. Birds, II.); Aquatic Warbler in Cornwall. (T.c.)

Welch, H. Glossy Ibis in Cornwall. (Field, Oct. 24; Brit. Birds, II.)

I909. Griffith, H. C. Black Guillemot in Cornwall. (Brit. Birds, III.)

IgIo. D'Urban, W S. M. Increase of Starlings in Cornwall. $(O p$. cit., IV.)

Frohawk, F. W. On a White-breasted variety of Cormorant from Scilly Isles. (Bull. B. O. C. ; Brit. Birds, III.) ; [Idem by Rev. F. C. R. Jourdain, Op. cit., IV.] Food and Feeding Habits of Razorbill. (Brit. Birds, IV.)

Harvey, A. W. H. Grasshopper Warbler in Cornwall; Increase of Starling in Cornwall. (Op. cit., IV.)

Mothersole, J. The Isles of Scilly. Cr. 4to. Lond.: n. $d$. [I9I0.] [42I.]

Pycraft, W. P. Whitetailed Eagle in Scilly Is. (Knowledge.) Seth-Smith, D. American Birds liberated on Scilly Islands. (Brit. Birds, IV.)

Welch, H. J. Little Bittern in Cornwall. (Field, July 23.)

IgII. Beaumont, W. I. Herring Gull and Shag occupying disused Ravens' nests. (Brit. Bds., V.)

Clark, J. American Birds in Cornwall ; Bird Migration in Cornwall. (Jnl. Roy. Inst. Cornw., XVII.) [I30.]

Robinson, H. W. Slaughter of Manx Shearwaters by Blackbacked Gulls, etc. (Brit. Birds., V.)

Ticehurst, N. F. Continental Great Tit in Scilly. (Brit. Birds, IV.)

I912. Joy, N. H. Manx Shearwaters and Storm Petrels at Scilly Isles. (Brit. Birds, VI.) 
I9I3. Graham, R. Murray. Hoopoe in Cornwall. (Field, July II.)

I9I4. Alexander, H. G. Nuthatch in S.W. Cornwall. (Br. Birds, VII.) Robinson, H. W. Size of Song Thrush broods in Scilly Isles; Breeding status of Linnet in Scilly Is. ; Iceland Gull off Cornish coast; Tree Pipit nesting in Scilly Is. Notes from the Scilly Isles. (Brit. Birds, VIII.)

I9I5. Bruce, M. M. Little Auk in Cornwall. (Op. cit., IX.)

I9I7. Edwards, L. A. Curtis. Reeve in Cornwall in March. (Op. cit., XI.)

Foster-Milliar (R. A.) Scops Owl in N. Cornwall. (Field, May I9.)

Wallis, H. M. Mortality among birds during the Feb. frost in W. Cornwall. (Br. Bds., X.)

White, A. Sea and Land Birds of the Isles of Scilly, pp. I04-6 ; King, C. J. Sea Birds of Scilly, pp. Ioo-3. [In Handbook for Isles of Scilly (Homeland Series), N.D. (Ca. IgI6).]

I9I8. Chubb, C. Note on female specimen of Belted Kingfisher from Cornwall. (Bull. B. O. C., XXXIX., pp. 6-7.)

Johnson, T. H. F. Grey Phalarope in Cornwall. (Field, Mar. 9.) Jourdain, F. C. R. Belted Kingfisher in Cornwall. (Brit. Birds, XII.)

\section{CUMBERLAND.}

I709. Robinson, T. An Essay towards a Natural History of Westmorland and Cumberland. 8vo. Lond.: I709. [493.]

I787. Clarke, J. A Survey of the Lakes of Cumberland, etc. Folio. Lond.: I787. [I30.]

I794. Heysham, John. List of Cumberland Birds. [In Hutchinson's History of Cumberland, Vol. I.] 4to. Carlisle: I794. [294.]

1826. [Crosthwaite, D.] Catalogue of Crosthwaite's Museum, Keswick. r8mo. I826. [I9.]

1827-36. [Heysham, T. C.] Arrival of Birds of Passage in Neighbourhood of Carlisle, etc., I827-35. 9 notes. (Phil. Mag., I829-35; Loudon's Mag. N. H., I828-36.) [These articles are all signed "Correspondent."]

I828. Blackwall, J. Manners and economy of Pied Flycatcher. [partim.] (Loudon's Mag. N. H. I., p. 33I.)

1829-30. Stanley, J. Birds in Neighbourhood of Whitehaven. (Loudon's Mag. N. H., I829-30. Vols. II. \& III.)

I832. "G. W." Notes . . . . made in Cumb. (Op. cit.)

I836. [Editorial.] Macrorhampus griseus. [Redbreasted Snipe near Carlisle.] (Mag. Zool. \& Bot., I.) 
Heysham, T. C. Charadrius morinellus breeding in Cumberland. (T.c.)

Yarrell, W. On Dotterel breeding at Skiddaw, and Grey Snipe obtained at Carlisle. (P. Z. S.)

I838. Heysham, T. C. Observations on Habits of the Dotterel. (Charlesw. Mag. N. H., II.)

I846. Cooper, J. White-winged Crossbill near Carlisle. (Zool.)

1847. Hodgkinson, J. B. White-winged Crossbill in Cumb. $(O p$. cit.)

1850. Hodgkinson, J. B. Lesser Whitethroat near Carlisle; Waxwing near Preston. (Op. cit.)

I85I. Greenip, W. Addit. Heronries [Bassenthwaite.] (Nat. [Morris's], I.)

Harrison, J., junr. Egyptian Goose on Derwent Lake. (Zool.) Taylor, T. Arrival of Summer Birds of Passage at Headswood during I85I. (Nat. [Morris's], I.)

1854. Birkbeck, R. Remarks on a List of Birds of W. Cumb. (Zool.) Robson, J. List of Birds of W. Cumb. : Reply to Mr. Birkbeck's Remarks. (T.c.)

1856. Armstrong, T. Great Bustard and Common Bittern in Cumb. (Nat. [Morris's], VI.)

1857. Armstrong, T. Notes on the Nat. Hist. of E. Cumb., 2 parts. (Op. cit., VII.)

I859. Armstrong, T. Occurrence of Rare Birds near Carlisle. (Zool.)

(Carlisle Journal.) [Bittern shot at Egremont.] (Field, June II.)

I86I. "Old Bushman" [H. W. Wheelwright.] Mountain Linnet [breeding at Alston]. (Op. cit., May Ir.)

I862. Mawson, G. Woodcock breeding near Keswick. (Zool.) "T. A." Idem. (Field, July 26.)

I863. A[damson], C. M. Vernal Migration of Stint, etc. (Op. cit, May 30.)

I864. Hancock, H. J. B. Eagles in Cumb. (Op. cit., Nov. 5.)

I865. "Solway." [Note on Bitterns in Cumb.] (Op. cit., Feb. II.)

I868. Watson, S. Roller [near Carlisle.] (Op. cit., Aug. I5.)

1872. Harting, J. E. British Heronries. (Zool.) ; Existing Heronries in Great Britain. (Field, Feb. I7.) [partim.]

I873. Power, F. D. Summer Visitants in W. Cumb. (Zool.)

Rodd, F. R. Range of Stockdove. (Field, May ro.)

I874. Moscrop, R. Woodcock breeding in Cumb. (Op. cit., May 2, I6.)

Yuille, S. Idem. (T.c., May 9.)

1875. Dryden, J. R. Scops-eared Owl in Cumb. (Op. cit., May 22.) 
I876. Bree, C. R. Natural History of Wastdale. (Op. cit., Sept. 23.)

I877. Birkett, J. Notes on .... Migratory Birds of English Lake District. (Tr. Cumb. Assoc. pt. 2.)

I878. Durnford, W. A. Ornitholog. Notes from Lake District. (Zool.) [r89.]

I879. "C. F. S." The Raven's Nest. (Field, June I4.)

"D." Birds of Prey in English Lake District. (T.c., Nov. 22.) Idem by C. Fullerton Smith. (T.c., Dec. I3.)

Dawson, G., and Ward, J. C. List of Cumb. Birds in Carlisle and Keswick Museums. (Tr. Cumb. Assoc., I878-79, pt. IV.)

Duckworth, T. Our Summer Visitors. (T.c.)

Kerr, H. Short-eared Owl breeding in Cumb. (Field, Nov. 29.) Idem by " D." (T.c., Dec. 6.) Idem by F. W. Alwyn. (T.c., Dec. I3.)

Mawson, G. Goosander and Little Grebe in Cumb. (Zool.)

Parker, C. A. Wildfowl in W. Cumb. (T.c.)

Whitaker, J. Scops Owl in Cumb. (Field, Dec. 20.)

I879-8I. Parker, C. A. Ornitholog. Notes from W. Cumb., 3 pts. (Zool., I879-8I.)

I88o. Parker, C. A. Iceland Gull and other Sea Birds in W. Cumb. ; also Bittern. $(O p$. cit. $)$

Westwood, R. W. Woodcocks nesting in Cumb. (Sci. Gossip.)

I88I. Parker, C. A. On the Wing, or Bird Life. (Tr. Cumb. Assoc., I880-8I, Part IV.) ; Osprey in W. Cumb. (Zool.)

Tomlinson, H. G. Ornitholog. Notes from Cumb. (Midl. Nat.)

I883. Duckworth, T. Iceland Falcon in Cumb. (Tr. Cumb. Assoc., I882-83, No. VIII.)

Dykes, L. F. B. Solitary Snipe in Cumb. (Field, Oct. 27.)

[Goodchild], J. G. Lesser Spotted Woodpecker in Cumb. (Tr. Cumb. Assoc., I882-83, No. VIII.)

Macpherson, H. A. Waxwings in Cumb. (Zool.) Idem by W. Duckworth. (Tr. Cumb. Assoc., I882-83, No. VIII.)

Mawson, G. Great Grey Shrike near Cockermouth. (Zool.)

I884. D[uckworth], W. Bird Notes from Carlisle. (Land \& Water, Sept. 13.) [183.]

Macpherson, H. A. Grey Shrike near Carlisle; Long-tailed Duck in Cumb. ; Ornitholog. Notes from Carlisle; Varieties near Carlisle. (Zool.) Smew, Hawfinch and Garganey in Cumb. (Nat.) Grey Shrike in Cumb. (Field, Feb. I6) ; Summer Migrants at Carlisle. (T.c., May 3.)

Morris, F. O. The Raven in Cumb. (Land \& Water, Feb. 2.)

S[mith], C. F. A Cumberland Marsh. (Field, Apr. Ig.) Idem by C. A. P[arker.] (T.c., May 3.) 
1885. Attye, R. J. Ravens in Cumb. (Zool.)

Duckworth, T. Our Summer Visitors. (Tr. Cumb. \& Westm., Assoc., I884-85, No. X.)

Goodall, J. W. The Pied Flycatcher [near Keswick.] (Sci. Gossip.)

Hodgson, W. Curlew in Solway District. (Nat.)

Macpherson, H. A. Whimbrel, Hawfinch and Wildfowl in Cumb. (Nat.) Long-tailed Duck at Monkhill Lough; Wildfowl near Carlisle; Shrikes. (Plate.) (Tr. Cumb. \& Westm. Assoc., 1883-84, No. IX.) Green Sandpiper and Puffin in Winter; Woodpecker and Nuthatch in Cumb. (Field, Jan. IO, I7.)

Marshall, R. D. Grey Phalarope in Cumb. (Op. cit., Oct. 24.)

Watson, J. Eagles' Haunts in N. of England. (Op. cit., Jan. 24.) Idem by W. Duckworth. (T.c., Jan. 3I.)

Watson, J. The Dotterel and its Migrations. (Op. cit., Nov. I4.) $[6 \mathrm{I} 8$.

I885-86. Armistead, A. J. Notes on some Birds occurring in Solway District. (Nat., I885-86.)

I886. Hodgson, W. The Hill Naturalist. (Tr. Cumb. \& Westm. Assoc., I885-86, No. XI.)

Macpherson, H. A., and Duckworth, W. The Birds of Cumberland. 8vo. Lond. \& Carlisle: I886. [See Additions in Zool. I888.] [374.]

Macpherson, H. A., and Duckworth, W. Nesting of Shoveler in Cumb. (Nat.)

Macpherson, H. A. Solway Bird Notes; Breeding of Lesser Redpoll ; Nesting of Shoveler. (T.c.) Cumberland Heronries. (Field, Jan. 29.)

Matthews, R. F. Woodcock nesting near Carlisle. (Field, May 29.)

Postlethwaite, T. N. Ornitholog. Notes from S. Cumb. (Zool.) Thompson, J. Gannet inland [in Cumberland.] (Field, Oct. 30.)

Watson, J. Notes on Eagles of Lake District. (Nat.) [6I8.]

I887. Duckworth, T. Our Summer Visitors. (Tr. Cumb. \& Westm. Assoc., I886-87, No. XII.)

Frere, H. T. Supposed Appearance formerly of Ptarmigan in Cumb. (Zool.)

Macpherson, H. A., Cumberl. Heronries; Habits of Barnacle Goose. (Field, Jan. 29) ; Long-tailed Duck on Solway; Dotterel in Marshes. (Op. cit., Nov. I9) ; Autumn Migration of Shore Birds. (T.c., Dec. 3.) Long-tailed Duck in Cumb. (Zool.)

Macpherson, H. A., and Duckworth, W. Zool. Record for Cumb., I886. (Tr. Cumb. \& Westm. Assoc., I886-87, No. XII.) [374.] 
Saunders, H. Saxicola isabellina near Allonby. (P. Z. S.; Zool. ; Field, Dec. 10.)

1888. Harting, J. E. Sand Grouse breeding in Cumb. (Zool.)

Macpherson, H. A. Grey Shrike in Cumb. ; Reappearance of Pallas's Sand Grouse; Notes on Birds of Cumb. (T.c.) Present Visitation of Sand Grouse. (Field, June 2, 9, I6 ; Aug. II; Nov. 24.) Gyrfalcons in Lake District. (Nat.) Saxicola isabellina at Aigle Gill, Allonby. (Ibis.) Rept. on Pallas's Sand Grouse in N. W. England. (Tr. Cumber. Assoc. I887-8, No. XIII.) [partim.] Addit. Notes. (T.c.)

Macpherson, H. A., and Duckworth, W. Ornitholog. Record for Cumb. Jan., I887, to June, 1888. (Tr. Cumb. \&. Westm. Assoc., I887-88, No. XIII.) [184.]

Pickard, E. S. Birds in Lake District. (Nat. Hist. Jnl.)

Robinson, J. H. The birds of our marshes. (Tr. Cumb. Assoc., I887-8, No. XIII.)

Watson, J. Ornithology of Skiddaw, Scafell and Helvellyn. (Nat.) Notes on birds of the Lake District. (T.c., p. 20I2.) List of Birds of the Lake District. [In Westmorland Note Book \& N. H. Record, pts. I, 2 and 4.] [6r8.]

I889. Carr, M. N. Flock of Bernicle Geese on Solway. (N.H. Jnl.)

Dryden, H. Long-tailed Duck in Cumb. (Field, June 8.)

Macpherson, H. A. Pectoral Sandpiper near Penrith. (Ibis.) Isabelline Chat. in Cumb. (P. Z. S. ; Land \& Water, Dec. I7.) Wintering of Ruff; Crossbills in Lake Counties. (Nat.) Dipper in Cumb. (Field, June 8); The Pied Flycatcher. (T.c., June 22) ; The Dunlin. (T.c., June 29) ; Early Arrival of Scaup Duck. (Op. cit., Oct. I2.) Ornitholog. Notes from Cumb. ; Sand Grouse in N.W. of England; Shoveler nesting in Cumb.; Fire-crest in Cumb. (Zool.) Sand Grouse [in Cumberland]. (Field, May I8); Long-tailed Duck in Cumberland. (T.c., June I5.)

1889-90. Slater, H. H. Crossbills in Cumb. 2 notes. (Nat.)

I890. Aplin, O. V. Distribution, etc., of Spotted Crake. (Zool. [partim.] [24.]

Gurney, J. H. Grey Phalarope in Cumb. (Nat.)

Macpherson, H. A. Wildfowl on the Solway. (Field, Jan. II) ; The Greenshank. (Op. cit., Sept. I3) ; Nocturnal Migrations of Birds. (T.c., Nov. I5) ; Bewick's Swan and its Occurrence in Cumb. (T.c., Dec. 20.) Tree Sparrow in Lake District Shore Lark in Cumb. ; Spotted Redshank in Cumb. ; Garganey in Cumb. ; Eagles in N. of England ; Grey Phalarope in Cumb. (Nat.)

I891. Macpherson, H. A. Fork-tailed Petrel on Solway. (Field, Oct. Io.) Water Rail and Buffon's Skua near Workington. (Nat.) Reported appearance of Snow Goose in England [near the Solway.] (Field, Jan. 3I.) 
I892. Aplin, O. V. Status of the Woodchat. (Zool.) [partim.] [25.]

Armistead, J. J. Sheldrakes on Solway. (Nat.)

Barber, S. Beneath Helvellyn's Shade. Sm. 8vo. Lond. : I892. [37.]

Macpherson, H. A. A Vertebrate Fauna of Lakeland : including Cumberland and Westmorland. Sq. 8vo. Edinb. : I892. [375.]

Macpherson, H. A. The Osprey in Lakeland. (Zool.) Ruddy Sheldrake in so-called Wild State. (Field, Aug. I3, 27.)

1893. Hodgson, W. Great Northern Diver at Workington. (Nat.)

Macpherson, H. A. Sabine's Gull in Cumb. (Zool.)

I894. Archibald, C. F., Denwood, J. R., and Murdoch, G. W. Woodcock breeding in Lake District. $(O p$. cit.)

Macpherson, H. A. Ptarmigan in Lakeland. (T.c.)

Salter, J. H. Nesting of Dotterel in Lakeland. (Zool.)

1895. Day, F. H. Nightingales in Cumb.; Nightjar in Cumb., etc. (Nat.Jnl., IV.)

Johnson, T. Rare Birds at Carlisle. (T.c.)

Macpherson, H. A. Pomatorhine Skua in Mid-winter; Rednecked Grebe on Solway Firth. (Zool.)

ISg6. Macpherson, H. A. Long-tailed Duck on Solway Firth. (Ann. Scott. N. H.) [375.] The Nat. Hist. Museum at Carlisle. (Zool.)

Robson, T. Birds of the Derwent Valley. 8vo. Consett: I896. [494.]

I897. Macpherson, H. A. Spotted Redshank on Solway Firth. (Ann. Scott. N. H.) ; Eared Grebe in Cumb. (Zool.)

I898. Wilson, J. Cumberland Bird Names. (W. Cumb. Times, Oct. 8.) Idem by " T." (Field, Oct. 29.)

I899. Macpherson, H. A. Note on Anthus richardi and Ruticilla titys at Allonby. (Ibis.) Blue-headed Wagtail in Cumb. (Zool.)

I900. Macpherson, H. A. Black Redstart in Solway Area. (Ann. Scott. N. H.) [375.]

Igor. Macpherson, H. A. Aves. [In Victoria Hist. of Co. of Cumberland, I.] 4to. Lond.: I901. [375.]

Macpherson, H. A. Rarer Birds of Solway Firth. (Ann. Scott. N. H.)

I904. Robinson, H. W. Wigeon breeding in Cumb. (Field, June 25.)

I906. Dunlop, E. D. Whooper Swan at Carlisle. (Zool.)

1907. Harrison, T. Hawfinch nesting in Cumb. (Field, July I3.)

Robinson, H. W. Black Tern in Cumb. (Field, June 22.)

I908. Oldham, C. Field Notes on Birds of Ravenglass Gullery. (Zool.); Lesser Whitethroat in Cumb. (Brit. Birds, I.) 
Parker, T. C. Notes from Cumb. 2 pts. (Zool.)

Parkin, P. W. Scops Owl in Cumb. (Field, June I3; Brit. Birds, II.)

Thorpe, D. L., and Hope, L. E. Notes from Cumb. (Zool.)

I909. Hope, L. E. Roller in Cumb. (Op. cit.)

Hope, L. E. and Thorpe, D. L. Bean Goose on Solway. (T.c.)

Robinson, H. W. On Occurrence of Bean Goose and Nesting of Wigeon in Cumb. (T.c.); Leach's Fork-tailed Petrels in Cumb. (Br. Bds., II.) ; Black Tern in Cumb. (Op. cit., III.)

I9Io. Thorpe, D. L., and Hope, L. E. The Museum, Carlisle. (Zool.); Wryneck in Cumb. ; Garganey on the Solway. (T.c.; Brit. Birds, IV.)

I9Ix. Garnett, M. Manx Shearwater in Cumb. (Brit. Birds, V.) Idem by H. W. Robinson. (Op. cit., V. Igr2.)

Hind, H. N. On Whooper Swans which visit River Eden. (Ibis.)

1912. Hope, L. E., and Thorpe, D. L. Natural History Records Bureau, Carlisle Museum : Report for IgII. (Zool.)

Nichol, W. Black-tailed Godwit in Cum. (T.c.)

Robinson, H. W. Sandwich Tern nesting on Walney [and at Ravenglass.] (Brit. Birds, VI.) Idem by E. B. Dunlop. (T.c.)

I9r3. Bolam, G. Grey Lag Geese in Cumb. Turtle Dove in Cumb. (Zool.)

Hope, L. E., and Thorpe, D. L. Nat. Hist. Bureau records, I9I2 at Carlisle. (Zool.)

Mackay, H. Spotted Redshank in Cumb. (Scott.Nat. ; Br. Bds., VII.)

I9I4. Charlton, J. M. Visitation of Black Redstarts in Cumb. (Zool.) Savage, E. U. Longtailed Skua in Cumb. (Brit. Birds, VIII.) Smalley, F. W. Common Gull breeding in Cumb. (T.c.)

I9I5. Andrews, W. J. Unusual nesting sites in Cumb. (Op. cit., IX.)

I9I7. Bolam, G. Late stay of Yellow Wagtail in Cumb. (Op. cit., X.)

Heysham, S. M. Albinistic Bean and Pinkfooted Geese in Cumb. (T.c.)

Hartley, T. Goldeneye Ducks on Bassenthwaite Lake. (Field, Jan. 27.)

Robinson, H. W. Increase of Whinchat in Cumb. (Brit. Birds, XI.)

Robson, C. Woodcock nesting in Cumb. (Field, Mar. I7.)

Garnett, M. Breeding Habits of Willow-Warbler [at Windermere]. (Brit. Birds, XI.)

Witherby, H. F. Raven with only one eye [in Cumb.] (T.c.) 
I9I8. Oldham, C. Goldcrests in the Lake District. (Nat. p. 267.) Robinson, H. W. Return of Common Terns to former nesting site in Cumb. (Brit. Birds, XII.)

\section{DERBYSHIRE.}

I700. Leigh, Dr. C. The Natural History of Lancashire, Cheshire and the Peak of Derbyshire, etc., folio. Oxford. I7oo. [349.]

I789. Pilkington, J. View of the Present State of Derbyshire. 2 vols. 8vo. Derby: I789. [473.]

I8II. Davies, Rev. D. P. A New Historical and Descriptive View of Derbyshire ... . 8vo. Belper: I8Ir. [I63.]

I828. Fox, G. T. Appearance of some rare birds in England. [Rough legged Buzzard, Baillon's Crake, Forktailed Petrel.] (Zool. Jnl., III.. p. 49I.)

I829. Blackwall, J. Manchester Museum. [Waxwings and Crossbills in Derby.] (Loudon's Mag. N. H. II., p. 273.)

Glover, S. The History of the County of Derby. 2 vols. 8vo. Derby: I829. [233.]

183I-33. Glover, S. The History and Gazetteer of the County of Derby. 2 parts. 4to. Derby. [233.]

I836. Williamson, W. C. Nests of Woodcock [at Alderwasley.] (Loudon's Mag. N. H. IX., p. 543.)

Wood, N. On the Rarity of Certain Birds in Derbys. (Analyst, V.) $[663$.

Wood, N. British Song Birds, being Popular Descriptions and Anecdotes, etc. Post 8vo. Lond.: 1836. [663.]

1837. Hewitson, W. C. Distribution of Golden-crowned Kinglet in England. (Nat. [Wood's], II., p. 54.) [partim.]

1843-44. Briggs, J. J. Notes on Capture and Appearance of our Rarer British Birds in Co. of Derby. 4 pts. (Zool. I843-44.)

1844. Bell, R. J. Note on Occurrence of Snow Bunting at Derby; Red-throated Diver and Red-necked Grebe near Derby; On Arrival of Summer Birds at Melbourne. 3 notes. $(O p$. cit.)

Briggs, J. J. Notes on Departure and Arrival of Summer Birds, etc., 2 pts. ; Note on the Curious Manner in which Seeds are sown; Note on Songs of Birds ; Defence of previous statements concerning Wood Wren; Notes on Carrion Crow, Rook, Redwings and Fieldfares; Remarks on Song Thrush, Skylark, Tree Pipit and Starling; Note on Departure of Redwing and Fieldfare. 8 notes. $(O p$. cit.) 
I846. Bell, R. J. Occurrence of White-winged Crossbill at Derby. (Op. cit.)

Briggs, J. J. Partial Migration, etc. (Op. cit.)

Wolley, J. Occurrence of Rough-legged Buzzard in Notts. and Derbys. $(O p$. cit. $)$

I848. Briggs, J. J. Rare Birds in Derbys; Habits of Stock Dove; Is House Sparrow injurious or beneficial? 3 notes. $(O p$. cit.) Cf. Op. cit. I849.

Wolley, J. Long Captivity of Specimen of Little Owl. (T.c.) I849-50. Briggs, J. J. Birds of Melbourne. 6 pts. (Op. cit.)

1850. Garth, J. C. Occurrence of Red-necked Grebe near Burtonon-Trent. $(O p$. cit. $)$

I851. Briggs, J. J. Blackcap Warbler in November ; Note on Singular Assemblage of Birds; Note on Greater Spotted Woodpecker ; Little Gull in Derbys. 4 notes. (Op. cit.)

1852. Evans, J. Occurrence of Osprey near Derby. (Op. cit.)

I853. Brown, E. Occurrence of Sooty Tern in England. (Op. cit.)

Wolley, J. Supposed Occurrence of Severn Swallow (Hirundo bicolor) at Derby, etc. (T.c.)

1854. Briggs, J. J. Note on Hybrid between Black Grouse and Pheasant; Occurrence of Rose-coloured Pastor in Derbys.; Occurrence of Pomarine Skua in Derbys. 3 notes. (Op. cit.)

1855. Briggs, J. J. Note on Congregation of Swallows; Note on Destruction of Swallows by Weather. 2 notes. (Op. cit.)

Burton, F. M. Egyptian Goose [near Repton]; Bittern [near Repton]. (Nat. [Morris's], V.)

I857. Briggs, J. J. The Hooded Crow ; Black Redstart ; Little Auk ; Occurrence of Bittern in Derbys. ; and of Pink-footed Goose in Derbys., 5 notes. (Zool.)

1858. Briggs, J. J. Remarkable Anecdote of Cuckoo. (Op. cit.) Hybrid between Pheasant and Black Grouse [in Derbys.], etc. 7 notes. (Field, Dec. II.)

1859. Briggs, J. J. Nightingale in Derbys. (Field, May 2I) ; Idem by F. Curson. (T.c., June 4.) Quail breeding in S. Derbys. (T.c., June 4 and II. [corr.]) The Peacock at Rowsley [in pts.] (T.c.) [Also reprinted separately, I869.] Siskin [in Derbys.] (Op. cit., Dec. I7.)

Crewe, H. R. Occurrence of Peregrine Falcon in Derbys. (Zool.) "M." Grouse of Strange Colour [near Buxton.] (Field, Aug. 27.)

Sides, W. B. Jackdaw breeding in Rabbit Holes. (T.c., July 9.)

Scarsdale, Lord. Wild Duck nesting in Fir Tree. (Op. cit., May 7.) 
186o. Briggs, J. J. Horned Rook. (Reliquary) ; Curious Malformation in Rook. (Field, Feb. 4.)

(Derby Mercury.) Pine Grosbeak [?] [two seen near Buxton.] (Field, Feb. 4.)

Newton, A. Note on Supposed Occurrence of Hirundo bicolor of N. America in England. (P. Z. S.). Idem (Zool.)

I86I. Briggs, J. J. Rare Birds observed during late severe weather. (Zool. and Field, Feby. I6); Anecdote of Jackdaw. (Field, June 8.)

"C. W." Gannet [near Smalley.] (Op. cit., Sept. 2I.)

I862. Briggs, J. J. Nesting of Lesser Redpoll in Derbys. (Field, May 24.)

I863. Mosley, Sir O. The Natural History of Tutbury, together with the Fauna and Flora of district surrounding Tutbury and Burton-on-Trent by E. Brown. Roy. 8vo. Lond.: 1863. [420.]

Ward, E. Honey Buzzard [in Derbys.] (Field, June 20.)

I864. Briggs, J. J. Oystercatcher in Derbys. (Op. cit., Jan. 30.)

Brown, E. Occurrence of Red-eyed Flycatcher in England. (Zool.) [From Nat. Hist. of Tutbury.]

Crewe, H. H. Bewick's Swan in Derbys. (Field, Jan. 30.) Idem. (Zool.)

Crewe, H. H. [Letter on Bewick's Swan in Derbys.] (Ibis.)

1865. "F. G." Wildfowl on Trent. (Field, Feb. 4.)

Worthington, A. O. Idem. (T.c., Feb. II.)

Worthington, A. O. Occurrence of Shieldrakes on Trent. (T.c., Jan. I4.)

1866. "Tetrao scoticus." Honey Buzzard [killed in Peak.] (OP. cit., Nov. Io.)

[Worthington, A. O.] Birds of Repton and Neighbourhood. In Wild Flowers, etc. of Repton. [666.]

Worthington, A. O. Cuckoo's Egg in Reed Warbler's Nest. (Field, May 12.)

I867. Briggs, J. J. Little Grebe affected by cold. (Zool.) Idem. (Field, Jan. I9); Coal Titmouse [near Melbourne.] ( $O p$. cit., July I3.) ; Hawfinch [in Derbys]. (T.c., July 6.)

I869. Briggs, J. J. The Peacock at Rowsley, where Andrew, Alexis and the Naturalist met, etc. 8vo. Lond. : I869. [Reprinted from Field, I859.]

Briggs, J. J. Supposed Occurrence of Passenger Pigeon [?] near Melbourne; Early Arrival of Grey Wagtail in Derbys. (Field, Sept. II.) Effect of Cold on Birds. (Zool.)

I870. Bree, C. R. Red-eyed Flycatcher in Derbys. (Field, May I4.) Idem, by J. J. Briggs. (T.c., May 7 and 2I.) Idem, by $\mathrm{E}$ Brown. (T.c., May 2I.) 
I870. Briggs, J. J. Blackbird nesting on Ground. (T.c., May I4.)

Crewe, J. H. Smews in Derbys. (T.c., Jan. I5.) Idem, by A. O. Worthington. (T.c., Jan. 8.)

Mosley, Sir O. Golden Plover on the Dove. Great Northern Diver at Burton-on-Trent. 2 notes. (Zool.)

Smith, H. Albatross in Derbys. (Field, Nov. 26, Dec. 4.) Idem. [Exposed. by Editor, Derbys. Times.] (T.c., Dec. I7.)

I87r. Gurney, J. H. Albatross in Derbys. (Zool.)

I872. Briggs, J. J. Quail nesting in Derbys. (Field, Sept. 28.)

Whitaker, J., junr. Little Bittern in Notts. [errore for Derbys.] (Zool.)

1873. Ladd, T. H. Nightingale in Derbys. [Matlock.] (Field, May 3r.)

I874. Briggs, J. J. Summer Birds in Derbys. (OP. cit., May 23.)

Brown, E. Squacco Heron in Staffs. (T.c., June 27.)

King, H. Woodcock nesting in Derbys. (T.c., May r6.) Cf. J. J. Briggs. (T.c., May 30.)

I875. Briggs, J. J. Goosander in Derbys. (Field, Jan. I6.)

Feilden, H. Jackdaws building on branches. (Field, May 22.)

Hewitt, G. R. Red-breasted Mergansers near Chesterfield. (Op. cit., Dec. r8:)

I876. Gurney, J., H. junr. Yellow-nosed Albatross in Derbys. (Zool.)

I877. Dixon, C. Migration of Birds. (Sci. Gossip.)

Lawley, H. Bittern in Derbys. (Field, Jan. 20.)

Whitworth, J. Swallows and their young. (OP. cit., Sept. I.)

I878. Brown, E. A. Song Thrush incubating on the ground. (Zool.)

Jewett, L. Nightingale [?] in Derbys. [Winster.] (Sci.Gossip.)

Sutton, E. Wild Swan on the Trent [? Bewick's.] (Field, Dec. 28.)

Tomlinson, H. G. Nesting Habits of Kingfisher; Nesting Habits of Water Ouzel; Chiffchaff nesting at height from the ground. 3 notes. (Zool.)

I879. Cox, A. Some Notes on Rare Birds. (Jnl. Derbys. Arch. \& $N$. H. Soc.)

Tomlinson, H. G. Disappearance of Skylarks; etc. 3 notes. (Zool.)

Whitaker, J. Rare Birds in Notts. [partim.]; Bee-eater in Derbys. 2 notes. (T.c.)

I880. Poyser, E. J. Unusual Abundance of Landrails in Derbys. (Field, Oct. 30.)

Tomlinson, H. G. Birds and Their Habits, with special reference to the Birds found in .... Burton-on-Trent. (Rep. Burtonon-Trent N. H. Soc., 1879. 2nd. pt.) 
I880-9r. Nowers, J. E., Thornewill, C. F., and Gibbs, T. Calendars of Nature for I877-79 and I882-90. (Op. cit. I880 and I882. 9I.)

I88I. Hine, W. H. Leach's Petrel in Derbys. (Field, Dec. 3.)

"T." Blackcap in Derbys. in Winter. (T.c., Dec. I7.)

[Worthington, A. O.] Contributions to the Flora and Fauna of Repton. [Birds in]. 8vo. Lond.: x88x. 2nd. edit. [666.]

1882. "Deadfall." Nightingale in Derbys. (Field, June 3.) Idem by F. J. Cochrane. (T.c., June Io.)

Hutchinson, A. S. Red-necked Phalarope, etc., on Lincs. Coast. [errore: contains 5 Derbys. records.] (Zool.)

1883. Crewe, G. A. Scaup Duck inland. (Field, Dec. I5.)

I883-84. Pullen, G. W. The Birds of Derby and Neighbourhood. (Young Nat.)

1884. Curzon, A. N. Bittern in Derbys. (Ficld, Feb. I6, 23.)

Hallam, S. R. Curious Birds [hybrid]; Great Grey Shrike. (Nat. World.)

" Snipe." Manx Shearwater [at Walton] near Burton-on-Trent. (Field, Sept. 20.)

1885. Bamford, F. J. Hoopoe in Derbys. (Nat. World.)

Bates, J. C. Longevity of a Bean Goose. (Field, Sept. I9.)

Hallam, S. R. Cormorant near Burton-on-Trent. (Nat. World.)

I886. Cox, A. Bird Eccentricities in Derbys. (Jnl. Derbys. A. \& N. H. Soc.)

Hutchinson, A. S. Green Sandpiper in winter [in Staffs. but notes a Wood Sandpiper near Derby.] (Field, Feb. 20.)

West, E. W. Great Grey Shrike in Derbys. (Field, March 20.)

Whitlock, F. B. Birds of the Derbyshire Peak. (Nat.) 647.

Wilkinson, J. Notes on Birds of the Derbyshire Peak. (T.C.)

1887. Buxton, A. F. Note on the Ring Ouzel. (Zool.)

Curzon, A. N. Goosander in Derbys. (Field, Jan. 29.)

Groves, G. T. Capture of a Golden [corrected to Sea] Eagle. (Op. cit., Dec. 3, I7.) 2 notes. Idem by A. T. H. Evans. (T.c., Dec. Io.)

1888. C[urzon], A. N. Kite in S. Derbys. (Op. cit., Apr. I4.)

Dickenson, F. W. Siskins in N. Derbys. (Nat.)

Doncaster, E. D. Birds of N. Derbys. (N.H.Jnl.)

West, E. W. Siskin in N. Derbys. (Field, Jany. 2I.)

Whitlock, F. B. Pallas's Sand Grouse in Derbys. (Nat.)

I889. Fox, W. Sheldrake in Derbys. (Field, May II.)

Hutchinson, A. S. Uncommon Birds in the Midlands. 2 notes. (T.c., May 23, June 8.)

West, E. W. The Kestrel as a Mole Killer. (Op. cit., Dec. I4.)

Whitaker, J. Golden Oriole in Derbys. (Zool.) 
r890. Cotton, R. Purple Sandpiper in Derbys. (Field, Dec. 6.)

"H.C." Thrush roofing its nest. (T.c., Aug. 30.)

Pullen, G. Manx Shearwater near Derby; Podiceps minor at Derby. 2 notes. (Young Nat.)

Valentine, J. T. T. Little Bittern in Derbys. (Zool.)

I89I. [Anon.] Golden Eagle shot in Derbys. (Land \& Water, Nov. 7.)

Dodgshon, J. J. Late Stay of Swifts. (Field, Oct. 3I.)

$\mathrm{H}[$ ine,] W. H. Grey Phalarope in Derbys. (T.c., Nov. 28.)

Howarth, E. Occurrences of Uncommon Birds in Derbys. and S. Yorks. (Nat.) [partim.]

Hutchinson, A. S. Wildfowl in Derbys. (Field, Apr. 4.)

I892. Aplin, O. V. On Distribution of Cirl Bunting in Gt. Britain; On Status of Woodchat in Gt. Britain. 2 papers. (Zool.) [partim.] [25.]

Cotton, R. C. H. Reeve in Derbys. (Field, Oct. I5.)

Curzon, A. N. White Landrail in Derbys. (T.c., Sept. 24.)

Gisborne, F. [Edited by Rev. C. Molineux.] Register of Birds shot .... from I76I to I784. (Jnl. Derbys. A. \&. N. H. Soc.)

Oldham, C. Great Snipe and Common Buzzard in Derbys. (Nat.)

Pullen, G. Breeding of the Quail in Derbys. (Br. Nat.); Quail nesting in Derbys. (Field, Oct. I.)

Whitlock, F. B. Birds of Derbyshire. (Zool.)

1893. Brownsword, F. Lesser Whitethroat at Bakewell. (Nat.)

Whitlock, F. B. The Birds of Derbyshire; annotated by A. S. Hutchinson. 8vo. Lond. \& Derby.: I893. [648.]

I894. Ball, J. Young Martins in October. (Field, Oct. 27.)

Fitzherbert, R. H. C. Sagacity of the Rook. (Jnl. Derbys. A. \& N.E. Soc.)

Fox, W. Storrs. Buzzard in Derbys.; Dotterel in Derbys. 2 notes. (Zool.)

Whitlock, F. B. Birds of Derbyshire. (T.c.)

I894-5-7. Whitlock, F. B. Bird Notes from the Mid-Trent Valley. (Nat.) [partim.] [648.]

I895. Rose, B. Waxwing in Derbys. (Zool.)

1897. Beeston, H. Robin's Nest in December. (Ornitholog.)

Oldham, C. Greenshank in the Peak. Storm Petrel and Rednecked Grebe in the Peak. 2 notes. (Nat.)

Oldham, C. Night Heron in Derby.; Black-throated Diver in Derby. 2 notes. (Zool.)

I898. Arkwright, W. Hoopoe in Derbys. (Field, Jan. 8.)

Boulsover, W. Pale coloured Dipper. (Zool.)

Jourdain, F. C. R. Early Nesting of Starlings. (Knowledge.)

1899. Cox, A. [Rare Birds in Derbys.] (Jnl. Derbys. A. \& N. H. Soc.) 
Fox, W. Storrs. Nesting Habits of Moorhen; Delinquencies of Starlings. 2 notes. (Zool.)

Hutchinson, A. S. Little Owl [in Rutland] and Dotterel in Derbys. (Field, May 20.)

Jourdain, F. C. R. Breeding of Tufted Duck in S. W. Derbys. (Zool.)

Ig00. Cox, A. Nesting of Spotted Flycatcher. (Field, Sept. I.)

Fox, W. Storrs. The Ring Ouzel in Derbys. (Zool.); Birds of N. Derbys. (Derbys. Nat.)

Hutchinson, J. Bittern in Derbys. (Field, Feb. 3.)

I900-09. Jourdain, F. C. R. Rough Notes on Derbys. Ornithology, I899-I908, 6 pts. (Zool. I900, I902, I904-6, I909.) [32I.]

Igor. Birley, C. Cuckoo's Egg in Song Thrush's Nest. (Field, July 6.)

Fox, W. Storrs. Little Bustard in Derbys. (Zool.)

Jourdain, F. C. R. The Ornithology of Derbyshire: A Retrospect. (Jnl. Derbys. A. \& N.H. Soc.) [32I.]

Jourdain, F. C. R. On the Breeding Habits of the Swift in Derbys. (Zool.) [32I.]

Walton, W. H. Nightingales near Derby. (Field, May 25.)

I902. Gurney, C. R. Breeding of Siskin [?] in Derbys. (Op. cit., Aug. 2.)

I903. Fox, W. Storrs. Rough-legged Buzzard and Montagu's Harrier in Derbys. (Zool.)

Jourdain, F. C. R. On Northern Breeding Range of Dartford Warbler. (T.c.) [322.]

Warner, G. J. E. Magpies in Flocks. (Field, Feb. 2I.)

I904. Jourdain, F. C. R. Wild [Bewick's] Swans in Derbys. 3 notes. (Op. cit., March 5, Apr. 9.)

I905. [Editorial.] Pelican shot near Derby. (Op. cit., Dec. 2.)

Fox, W. Storrs. Nesting of Merlin in Derbys. (Zool.)

Jourdain, F. C. R. Birds. [In Victoria Hist. of Co. of Derby, I.] 4to. Lond.: I905. [322.]

Jourdain, F. C. R. On Rare Migrants to Derbys. (Jnl. Derbys. A. \& N.H.Soc.) [322.]

Ig06. Jourdain, F. C. R. On Hybrids which have occurred in Gt. Britain between Blackgame and Pheasant. (Zool.) [partim.] [322.]

Tomlinson, A. G. Little Owl in Derbys. (Field, Nov. I7.) Tomlinson, H. G. Riverside Birds in Autumn. (T.c., Oct. I3.)

I906-08. Jourdain, F. C. R. Ornithological Notes from Derbyshire for I905-07. 3 pts. (Jnl. Derbys. A. \& N. H. Soc.) [322.]

I907. Howard, B. Blackbirds nesting on ground. (Field, May Ir.) Jourdain, F. C. R. Little Auk in Derbys. (Zool.) 
I908. Tomlinson, E. H. Second Brood [Thrush] in same nest. (Field, May I6.)

Walton, W. H. The Nightingale in Derbys. (T.c., May I6); Idem. (Brit. Birds, II.)

1909. Wells, C. H. Little Owl breeding in Derbys. (Op. cit., III.)

I909-I8. Jourdain, F. C. R. and others. Zoological Record for Derbys. Birds I908-I7. 9 pts. (Jnl.Derbys. A. \& N. H. Soc., I909-I8.) [322.]

I9I0. Jourdain, F. C. R. [Irruption of Crossbills.] (Brit. Birds, III.); [partim.] Golden Orioles in Derbys., etc. (Op. cit., IV.); Green Sandpiper in Derbys. (T.c.)

IgII. Jourdain, F. C. R. Abnormal Song of Wood Warbler; Unusual Nesting Site of Grey Wagtail. (Brit. Birds, V.)

Ticehurst, N. F. and Jourdain, F. C. R. On Distribution of Nightingale during Breeding Season in Great Britain. (T.c.) [partim.] [322.]

I9I2. Jourdain, F. C. R. [in] 'Wreck' of Little Auk, IgI2. (Brit. Birds, V.) [partim.]

Jourdain, F. C. R. Hoopoe in Derbys.; Greenland Wheatear in Derbys. 2 notes. (Op. cit., VI.)

I913. Harrold, C. G. The Marsh Warbler [?] in Derbys. (Field, Aug. 30.)

Jourdain, F. C. R. Brent Goose in Derbys. (Op. cit., VI.)

I9I4. Atkinson, J. Barn Owls in Morley. (Nat.p. 327.)

Butterfield, E. P. Status of Lesser Whitethroat in Derbys. (Zool.)

Fox, D. Storrs. Little Owl in Derbys. (Field, Feb. 2I.)

Jourdain, F.C. R. Kite in Derbys. (Br. Birds, VI.)

I9I8. Grindey, E. Common Buzzard in Derbys. (Brit. Birds, XI.) Cormorant in Derbys. (Op. cit., XII.)

Hull, C. W. The Whinchat in Derbys. (Field, May 25.)

Peat, E. Hen Harriers in N. Derbys. (Br. Birds, XI.)

\section{DEVONSHIRE.}

I757. Botanista, Theophilus. Rural Beauties : ог, the Natural History of .... Devonshire. I2mo. London: I757. [87.]

1795-6. Laskey, Capt. Three Days' Excursion on Dartmoor. (Gent. Mag., I795-6.)

I797. Polwhele, Rev. R. History of Devonshire. 3 vols. fol. London : I797-I806. [476.]

I804. Montagu, G. Observations on some Species of Brit. Quadrupeds, Birds and Fishes; Nesting of the Cirl Bunting. 4to. (Trans. Linn. Soc., VII.) [4II.] 
I808. [Anonymous.] The Literary Repository of Cornwall and Devon. Quadrupeds, Birds and Fish, 2 parts. (Monthly Mag.) [Said to be by Mr. James of Manaccan-vide D'Urban \& Mathew's Birds of Devon.]

Montagu, G. Hen Harrier and Ringtail ; Montagu's Harrier ; Nesting of Dartford Warbler; Occurrence of Little White Heron, Glossy Ibis, and of Red-breasted Snipe [ $=$ Bartailed Godwit.] (Trans. Linn. Soc., IX.)

I809. Tucker, A. G. C. Ornithologia Danmonensis, Nos. I \& 2. 4 to. London: I809. [590.]

[I8ro ?] Turton, W. and Kingston, J. F. Natural History of the District of Teignmouth: I2mo. Teignmouth: [ca. I8ro.] [600.]

1823. Tucker, A. G. C. List of some rare Land-Birds discovered in Neighbourhood of Ashburton. [In Jones's Guide to Scenery in Neighbourhood of Ashburton.] Exeter: I823. [591.]

1825. Yarrell, W. Occurr. of some rare Brit. Birds [Forktailed Petrel in Devon.] (Zool. Jnl., II. p. 25.)

I826. Tucker, R. and C. Birds of Dartmoor. [In Carrington's Dartmoor.] 8vo. London: I826. [59I.]

I829. Blomer, C. Nat. Hist. in the English Co's., Devonshire, the Dartmouth [err. Dartford] Warbler, and other birds. (Loudon's Mag. N. H. II., p. 278.)

I830. Moore, Ed. On Ornithology of S. of Devon. (Trans. Plym. Inst.) [4rr.]

1832. Jordan, W. R. Notes on Gray Phalarope [near Teignmouth], the Imber (Colymbus immer) [on the Teign], 2 notes. (Loudon's Mag. N.H. V., pp. 282, 284.)

I836. Bray, Anna Eliza. A Description of the part of Devon bordering on the Tamar and the Tavy. 3 vols. post 8vo. London: I836. Idem, reissue I838. New edit., 2 vols. 8 vo. 1879 . [9I.]

Martin, T. S. Northern Diver [near Seaton.] (Loudon's Mag. N. H. IX., p. 480.)

I837. Moore, Ed. On the Birds of Devon. 5 pts. (Charlesw. Mag. N.H.) [4II.]

I838. Bellamy, J. C. On Geographical Distribution of Animals, with Account of Species that inhabit S. of Devon. 6 pts. (Macgillivray's Edinb.Jnl.N.H.) ; On Movements of Motacilla in S. Devon. (T.c.) [55.]

Moore, E. Northern Diver in Devon. (Charlesw. Mag. N. H.) Redding, C. Notes on birds met with nr. Plymouth. (Nat. [Wood's], III.)

I839. Bellamy, J. C. The Natural History of S. Devon. Post 8 vo. Plymouth: I839. [56.] 
1840. Hore, W. S. Occurrence of Rare Birds in Devon. (Zool.)

Prideaux, C. Little Bustard shot in Devon. [at Bigbury.] (Charlesw. Mag. N. H.)

I84I. [Editorial.] Note on occurrence of Woodcock near Torrington for five successive years. (P. Z. S., p. 79: idem Zool., I843.)

I843. Jordan, W. R. H. Note on Crossbill [in Devon.]; Red-backed Shrike; Bohemian Chatterer, Rose-coloured Thrush, near Teignmouth. 4 notes. (Zool.)

Jordan, R. C. R. Note on late departure of Swallows; On Common Snipe (T.c.).

"Pine Coffin" [Parkinson, J.] [Partially albinotic] Woodcock near Torrington for five successive years. (T.c.)

Wilcox, W. Early arrival of Martins in I843. (T.c.)

I844. Jordan, R. C. R. Note on Black Redstart. (Op. cit.)

Hore, W.S. Black Redstart: Note on Richard's Pipit ; Correction to Alpine Accentor. 3 notes. (T.c.)

I845. Fitton, E. B. White-winged Crossbill at Exmouth. (Op. cit.)

Hore, W. S. Occurrence of Rare Birds in Devons. (T.c.)

Ross, F. W. L. Occurrence of Osprey in Devon. Occurrence of Nightingale in Devon. (T.c.)

Row, W. H. Arrival of Summer Birds at Devonport. (T.c.)

Scott, W. R. Occurrence of Rare Birds near Exeter in Winter of $1844-45$. (T.c.)

1846. Murch, E. Grey Phalarope near Honiton; Song of Fieldfare ; Nightingale in Devon. (Op. cit.)

I847. Battersby, R. Occurrence of Black Redstart and Harlequin Duck [errore] near Torquay. (OP. cit.)

Nichols, H., junr. Rare Birds occurring at Kingsbridge. (T.c.) [449.] Occurrence of Montagu's Harrier near Kingsbridge. (T.c.)

I848. Moore, E. Ornithology. [In Rowe's Perambulation of Dartmoor.] Roy. 8vo. Plymouth: I848. And later edits. [4II.]

I849. Bulteel, C. J. Eight Night Herons in Devon. (Zool.)

Morris, B. R. Black Grouse breeding in Devon. (T.c.)

Scott, W. R. On some of the Rarer Birds found in Devon. (T.c.)

1850. Newton, A. Black Redstart in Torbay: Forktailed Petrel near Torquay; Great Northern Diver in Tor Bay: Masked Gull on the Dart. $(O p$. cit.) 4 notes.

Crotch, W. D. Black Grouse in Devon. (T.c.)

I85I. Bird, W. F. W. Nightingale in Devon. (Nat. [Morris's], I.)

Cleveland, A. Little White Heron in S. Devon. (Zool.)

Gatcombe, J. Notes on the Black Redstart [near Plymouth.] (Nat. [Morris's], I.) 
Irby, L. H. Red-necked Grebe in Devon. (Zool.)

Jordan, R. C. R. Occurrence of the Black Redstart near Teignmouth. (Zool.)

Julian, R. A., junr. Ornithological Notes and Occurrences. I6 notes. (Nat. [Morris's], I.)

McIntosh, J. Heronries in England, etc. (Nat. [Morris's], I.) [partim.]

Newton, A. Chiffchaff in January; Occurrence of Hoopoe at Torquay. (Zool.)

Nicholls, H. Great Northern Diver in Devon. (Zool.)

I852. Gatcombe, J. Great Bustard in Devon. (Nat. [Morris's], II.)

Julian, R. A., junr. Ornith. Notes [Devon records.] (Nat. [Morris's], II.)

Powys, T. L. Shore Lark breeding in Devon [errore.] (Zool.)

Prideaux, C. Occurrence of Rare Birds near Kingsbridge. (T.c.)

Pulman, G. P. R. [Heronry at Shute Park.] (Nat. [Morris's], II.)

Tombs, W., junr. Records of rare birds, 5 notes. (T.c.)

I853. Barker, J. Rare birds near Plymouth. (Nat. [Morris's], III.)

Burt, E. Occurrence of Ivory Gull, etc., at Torquay. (Zool.)

Gatcombe, J. Rare Birds near Plymouth; Ornitholog. captures near Plymouth, Dec., I852, to April, I853. (T.c.)

Julian, R. A., junr. A Day's Ramble on the Coast of Devon ; Merlin Hawk in Devon; Richard's Pipit in Devon. (T.c.)

Matthews, W. G. Peregrine Falcon near Kingsbridge. (T.c.)

Weeks, C. Ivory Gull near Torquay. (T.c.)

1854. Gatcombe, J. Pied Flycatcher in Devon; rare birds near Plymouth, Hoopoes near Plymouth. (Nat. [Morris's], IV.)

Julian, R. A. A Few Remarks on the Woodcock. (T.c.)

Rodd, E. H. Provincial Names of Birds in Devon and Cornwall. (Zool.)

I855. D'Urban, W. S. Occurrence of Spotted Crake and Avocet on the Exe. (Op. cit.)

Gatcombe, J. Occurrence of Iceland Gull, etc., in Neighbourhood of Plymouth. (T.c.) Singular capture of Peregrine Falcon; Rare birds near Plymouth; Occurr. of Iceland Gull, etc. [near Plymouth]: Note on Canada Goose. (Nat. [Morris's], V.)

Powys, T. L. Occurrence of Red-throated Diver in Plymouth Sound. (Zool.)

I856. D'Urban, W. S. M. White-tailed Eagle in Devon; Bittern in Devon; Note on early Arrival of Sand Martin and Chiffchaff; Little Gull and Common Skua on the Exe; Sclavonian Grebe in Devon. 5 notes. (Op. cit.)

Gatcombe, J. Occurrence of Great Plover and Spotted Crake. (T.c. and Nat. [Morris's], VI.) 
Mathew, G. F. Cream-coloured Courser [in Braunton Marshes.] (Nat. [Morris's], VI.)

Melhuish, J. Grasshopper Warbler [near Tiverton.] (T.c.)

I857. Gatcombe, J. Tree Sparrow in Devon; Rare Birds near Plymouth in 1856 . (2 notes.) (T.c.); Tree Sparrow in Devon. (Op. cit.] VII).

Mathew, M. A. Stray Notes from an Ornithologist's Diary Velocity of Flight of Water Ouzel. 2 notes. (Zool.) [39I.] Nicholls, H. Buff-breasted Sandpiper and Brown Snipe in Devon. (T.c.)

Tugwell, Rev. G. North Devon Handbook. 8vo. London, etc. n.d. [I857.] And later editions. [592.]

I858. Adams, W. H. Breeding places of Sea-birds [Lundy Is.] (Field, Mar. I3.)

Knapp, W. Landrail [near Tavistock, Jan. 20.] (T.c., Jan. 30.) Idem, by " $\mathrm{O}$. G." (Op. cit., Dec. I8.)

Mathew, M. A. Rare Birds near Barnstaple; Little Gull near Barnstaple; Norfolk Plover and Ruff near Barnstaple. 3 notes. (Zool.)

Nicholls, H., junr. Occurrence of Bee-eater at Kingsbridge. (T.c.)

"Sabine." Curious variety of Snipe [on Chudleigh Knighton Heath.] (Field, Mar. I3.)

I859. Gatcombe, J. Occurrence of Rare Birds in Devon and Cornwall in I857-8. (Zool.) The Black Redstart. (Field, Dec. I7.)

Mathew, M. A. Pomarine Skua and other Sea Birds; Fulmar Petrel in Barnstaple; Hoopoe near Barnstaple; Autumn Notes on Birds; Variety of Common Buzzard. (Zool.)

Retlaw, F. L. S. The Redstart [prob. err. for Black Redstart.] (Field, Dec. Io, 24.)

Ross, F. W. L. Black-headed Gull in Devon. (Ann. Mag. N.H.)

"W." Alpine Accentor [near Plymouth.] (Field, Jan. 22.)

"W. B. S." New variety of Partridge [shot near Tavistock.] (Op. cit., Dec. I7.)

I859-87. Gatcombe, J. Ornitholog. Notes from Devon and Cornwall. 5I contributions. (Zool. I859-87.) [I88.]

I860. Gatcombe, J. Tree Sparrow [in Devon.]. (Field, Feb. 25); Hen Harrier, etc. [also Montagu's Harrier and Marsh Harrier in Devon.] (T.c., June 2.)

Mathew, G. F. Cream-coloured Courser at Braunton Burrows. (Zool.)

Ross, F. W. L. Occurrence of Larus ichthyatus in Devon. (T.c.)

Stevenson, H. Stray Notes from the Devonshire Coast. (T.c.) 
I86I. Gatcombe, J. Kentish Plover killed in Devon ; Arrival of Summer Birds; Northern Diver in June. (Op. cit.) Kentish Plover in Devon. (Field, May II.)

"J. S." Egyptian Goose in Devon. (T.c., Jan. 26). Idem, by "G. S. S." (T.c., Feb. r6.) [an escape.]

Mathew, M. A. Spotted Eagle at Lundy Is.; Immense Migration of Larks; Occurrence of Kite near Barnstaple: Brent Geese in April. 4 notes. (Zool.)

(Western Morning Neres.) American Bittern in Devon. (Field, Apr. 20).

I862. Gatcombe, J. Occurrence of Iceland Gull and Red-necked Grebe at Plymouth; Variety of Snipe ; Little Gull at Plymouth ; Iceland Gull at Plymouth. 4 notes. (Zool.) White Spoonbill near Plymouth. (Field, Nov. I7.)

Hore, W. S. Variety of Partridges. (Zool.)

I863. [Anon.] Cirl Bunting near Sidmouth. (Field, XXI., p. 368.)

D'Urban, W. S. M. Sketch of Nat. History of Exeter. [In Besley's Handbook of Exeter, Appdx.] 8vo. Exeter: I863. 2nd. edit. I87I. Also reprinted separately. I2mo. Exeter; n.d. [I87I.] [I89.]

Gatcombe, J. White Spoonbill near Plymouth; Calandra Lark in Devon; Razorbill and Guillemots in Devon. (Zool.) Little Auk and Spotted Crake in Devon. (T.c.) Idem. (Field, Oct. I7.)

Mathew, G. F. Snow Bunting near Barnstaple. (Zool.)

Mathew, M. A. Sabine's Gull in Devon. (T.c.)

Nicholls, H. Kite near Kingsbridge. (T.c.); Pallas's Sand Grouse in Devon. (T.c.) Idem. (Field, July 4.)

Reading, J. J. Rare Birds in Devon. (Zool.)

Rowe, J. Brooking. A Catalogue of the Mammals, Birds, etc. of Devon. 8vo. London: 1863. [497.]

Rowe, J. Brooking. Recent Additions to Fauna of Devon. (Trans. Devon Assoc. Adv. Sci., I.) [498.]

I864. Fox, S. P. Kingsbridge Estuary. [List of Birds by H. Nicholls.] 8vo. Kingsbridge: I864. 2nd. edit. I874. [449.]

Fulford, J. L. L. Pallas's Sand Grouse in Devon. (Zool.)

Jordan, W. H. R. Black Redstart. (T.c.)

Langton, J. Cream-coloured Woodcock [on Lundy Is.] (Field, Jan. 30.)

Mathew, M. A. Pallas's Sand Grouse near Barnstaple ; Redwing singing in England. (Zool.)

Maxwell, J. Bittern in W. of England. [Devon.] (Field, Jan. I6.)

Nicholls, H. junr. Osprey, Kite and Little Bustard in Devon. (Zool.)

I865. "Devoniensis." Osprey in Devon [in estuary of Exe.] (Field, Nov. II.) 
Gatcombe, J. Little Bittern near Plymouth. (Zool.) Idem. (Field, May 20.) Whiskered Tern on the Coast of Devon. (Zool.) Idem. (Field, May 20.) Roller near Plymouth. (Field, July I) ; Purple Sandpiper in Devon and Cornwall. (T.c., Nov, 25.)

Mathew, G. F. Richard's Pipit at Braunton Burrows; Creamcoloured Redwing and pied variety of Blackbird; Eared Grebe near Barnstaple. (Zool.)

Mathew, M. A. Ruff on the Northam Burrows; Egyptian Goose at Barnstaple; Woodcock in July. (T.c.)

Rodd, E. H. Black Woodpecker in Devon. (Field, Oct. 28.)

Stark, A. C. Ring Ouzel breeding on Dartmoor. (T.c., Sept. 2.)

Taylor, W. Sclavonian Grebe in S. Devon. (T.c., Oct. 7.)

I866. Fowler, F. S. Young Puffin and Gannet at Plymouth. (Op. cit., Nov. 3, I7.)

"Balaam." Montagu's Harrier in Devon. (T.c., July 2I.)

Gatcombe, J. Grey Phalarope and Black Tern in Devon and Cornwall. (T.c., Oct. 6.) Idem. (Zool.) ; Purple Sandpiper in Devon and Cornwall. (Zool.) ; Iceland Gull near Plymouth. (Field, May 5); Golden Oriole in Devon. (T.c., May I2.)

Mathew, M. A. Great Auk on Lundy Is. ; Hen Harrier near Barnstaple; An Ancient Raven; Grey Phalarope and Glossy Ibis at Budleigh Salterton. (Zool.)

Napier, C. O. Groom. Eggs of Thrush family and Golden Oriole [latter breeding near Totnes.] (Field, Feb. Io.)

Nicholls, H. junr. Rare Birds near Kingsbridge. (Zool.)

Rodd, E. H. Honey Buzzard in N. Devon. (T.c.)

Rowe, J. Brooking. Fork-tailed Petrel at Plymouth. (T.c.)

Ward, E. Raven [breeding at Crediton.] (Field, June 27.)

1867. "Bee." Nightingale in N. Devon. (Op. cit., May 4.)

Burt, E. Sabine's Gull in Tor Bay. (Op. cit., Nov. 9.)

Gatcombe, J. Woodchat Shrike, Sabine's Gull and Gull-billed Tern in neighbourhood of Plymouth. (Zool. p. 557.)

" H. J. P." Hen Harrier [in Devon.] (Field, Jan. I2.)

Mathew, M. A. Spoonbill on Northam Burrows and Black Redstart at Barnstaple ; Grey Phalarope and Egyptian Goose at Barnstaple. 3 notes. (Zool.)

Norrish, E. C. Lesser Spotted Woodpecker in N. Devon. (Field, July I3.)

Smith, C. Red-throated Diver and Norfolk Plover in ...... Devon; Purple Sandpiper, Little Gull and Fulmar Petrel on S. Coast of Devon, etc. 3 notes. (Zool.)

I868. Adamson, C. M. Solitary Snipe in Devon. (OP. cit., p. I46I.)

Gatcombe, J. Vinous-breasted Pipit near Plymouth. (T.c.) Idem. (Field, May I6.) Eider Duck and Little Auk at Plymouth. (Field, Jan. I8.) 
Gurney, J. H. Departures and Arrivals of Migratory Birds observed in Cornwall and Devon; Iceland Gull off Brixham. (Zool.)

Mathew, G. F. Solitary Snipe, Montagu's Harrier, Osprey, etc. at Barnstaple; Great Northern Diver on the R. Taw; Merlin near Barnstaple; Blacktailed Godwit in Devon; Solitary Snipes near Parracombe; Red-crested Whistling Duck near Braunton; Bittern [at Slapton Lea.], etc. Io notes. (T.c.)

Mathew, M. A. Little Bittern at Braunton; Solitary Snipe on Dartmoor. (T.c.)

Smith, C. Longtailed Duck at Exmouth; Lesser Tern in Devon. (T.c.)

1869. Briggs, T. R. A. Late Stay of Martins. (Op. cit.)

Byne, H. Partridges nesting in January. (T.c.)

Gatcombe, J. Red-necked Phalarope in neighbourhood of Plymouth. (T.c.)

Gunn, T. E. Cirl Buntings and Crossbills in Devon. (T.c.)

Gurney, J. H. junr. Calandra Lark near Exeter. (T.c.)

Mason, J. E. Storm Petrel in fine weather. (Field, July Io.)

Mathew, G. F. Night Heron in Devon; Little Gull [at Braunton]; Richard's Pipit near Barnstaple, etc. 4 notes. (Zool.)

Nicholls, H. junr. Crane on the Devon Coast. (T.c.)

Rickards, M. S. Pomarine Skua at Exmouth. (T.c.)

Rodd, E. H. Ring Ouzel in Cornwall and Devon; American Stint at Northam Burrows. (T.c.) Idem. (Field, Oct. 23.)

Selwood, J. B. Sooty Tern [on the Axe.] (Field, July I7.) [prob, errore.]

Smith, C. Ornitholog. Notes from S. Devon. (Zool.)

Ward, E. Night Heron at Barnstaple. (Field, May 22) ; Black Redstart in N. Devon; Richard's Pipit at Barnstaple. (T.c., Dec. 18.)

I869-70. Hugel, A. de. Ornitholog. Notes from S. Devon. 6 papers • (Zool., I869-70.)

I87o. Adams, H. C. Snow Bunting at Exmouth. (Field, Dec. 24.)

Gatcombe, J. Rare Birds in neighbourhood of Plymouth; Black Redstart; Little Egret and Eared Grebes in Devon Rare Grebes in Devon; Red-throated Diver on Devon Coast ; Bridled Guillemot and Little Auk [near Plymouth.], etc. II notes. (Zool.)

Gurney, J. H. Black Variety of Montagu's Harier in N. Devon. (T.c.)

Hugel, A. de. Scarce Ducks in Torquay; (T.c.)

L- , H. Smew in S. Devon. (Field, Feb. 26.)

Mathew, M. A. Rare Birds at Barnstaple; Sclavonian Grebe, Red-necked Grebe, Goosander, American Wigeon and Gargany on the R. Taw; Nesting of the Hobby in S. Devon; Abundance of Grey Phalaropes [in N. Devon.] (Zool.) 
Rickards, M. S. C. American Stint at Northam Burrows; Grey Phalarope, Little Stint and Snow Bunting at Northam. Burrows; Notes from Northam Burrows. (T.c.)

Smith, C. Red-necked Grebe at Teignmouth; Schinz's Sandpiper in N. Devon. (T.c.)

I87x. Balkwill, F. H. Phalarope in Plymouth Sand. (Op. cit.) Idem. (Field, Oct. 29, I870.)

Chanter, J. R. History of Lundy Island. (Reprinted from Tr. Devon Assoc. Adv. Sci.) 8vo. I87x. [I22.]

Dawson, R. Y. J. Solitary Snipe in S. Devon. (Field, Oct. 7.)

[Editorial.] Latest occurrence of Great Bustard in England. [Two Braunton Sands.] (Op. cit., Jan. 7.)

Escombe, W. Short-eared Owl at Exmouth. (Op.cit., Nov. II.)

Gatcombe, J. Montagu's Harrier and Hoopoe; Eared Grebe in Devon; Quails in Devon, etc.; Early nesting of Ring Ouzel in Devon; Great Bustard in Devon. (Zool.)

Gurney, J. H. Quails in S. Devon; Orntholog. Notes from vicinity of Torquay; Ornitholog. Notes from S. Devon; Late occurrence of Tufted Duck in Devon; Fork-tailed Petrel in S. Devon; Crane seen in S. Devon in I869; Common. Buzzard nesting in Devon. (T.c.)

Gurney, J. H. junr. Notes from Instow, N. Devon. (T.c.)

Harting, J. E. Pectoral Sandpiper in N. Devon. (Field, Sep. 30) ; Immigration of Great Bustard. (Op. cit., Jan. I4.)

Hawley, W. White-fronted Goose at Totnes. (T.c., Feb. 4, II.)

Mathew, M. A. Schinz's Sandpiper at Barnstaple (Zool.) ; Immigration of Great Bustard. (Zool.) Idem, by E. Newman and others. (T.c.)

Percival, C. H. S. Dartford Warbler in Devon. (Field, June ro.)

Rickards, M. S. C. Purple Sandpiper, Grey Phalarope and Snow Bunting at Northam Burrows; White Wagtail, Pectoral Sandpiper and Wood Sandpiper at Braunton Burrows; Greenshank and Green Sandpiper near Barnstaple. 5 notes. (Zool.)

Scougall, H. and others. The Chough in N. Devon. (Field, Jan. 28, Feb. II, I8, 25, Mar. 4.)

Shelley, J. Tufted Duck in Devon. (T.c., Jan. 2I.)

Wilcocks, J. C. Wildfowl on the Exe, etc. 3 notes (T.c., Jan. I4.)

I872. Adams, H. C. Glaucous Gull at Exmouth. (Ficld, Jan. I3.) ; Purple Sandpiper at Exmouth. (T.c., Nov. I6.)

Gatcombe, J. Rare Birds at Plymouth; Ornitholog. Notes, chiefly from Devon; Ornitholog. Notes made in neighbourhood of Plymouth, etc. 6 notes. (Zool.) Leach's Petrel (Field, Dec. 2I); Montagu's Harrier on Dartmoor. (Sci. Gossip.) 
Gurney, J. H. Ornitholog. Occurrences at Torquay; Pomarine Skuas in Tor Bay, etc. 5 notes. (Zool.)

Harting, J. E. British Heronries. (T.c.) [partim.]

Hingeston-Randolph, F. C. Hoopoe in Devon. (T.c.)

Mathew, G. F. Greenshanks, etc. near Newton. (T.c.)

Mathew, M. A. Ornithology of Dartmoor ; Ring Ouzel in Devon, etc. 4 notes. (T.c.)

Rowe, J. Hen Harriers in Devon. (Field, June I5.)

Wilcocks, J. C. The Northern Diver. (Op. cit., Dec. 7 , 28.)

I872-4. Mathew, G. F. Ornitholog. Notes from Devon. 3 papers. (Zool., I872-4.)

1873. Briggs, T. R. A. Cirl Bunting an autumnal songster. (OP. cit.)

Gatcombe, J. Night Heron and Little Bittern (Field, July 5); Glaucous Gull at Plymouth (OP. cit., Jan. II) ; Grey Phalarope in winter. (T.c., Jan. 25.)

Mathew, M. A. Grey Phalarope in winter plumage. (Zool.)

Newman, E. Molothrus sericeus in Devon. (T.c.)

Richardson, J. T. Hoopoes in Devon. (Field, Apr. 26.)

"Timewell." Canada Goose in Devon. (T.c., June 28.)

Wilcocks, J. C. Northern Diver, etc. (T.c., Jan. II); Seafowl off Teignmouth. (T.c., Jan. 25, Feb. I.)

1874. Gatcombe, J. Greater Shearwater on Coasts of Devon and Cornwall. (Zool.)

Hall-Jordan, W. R. Birds of Teignmouth. (Tr. Devon Assoc. $A d v$. Sci., VI.)

Hugel, A. von. Ornitholog. Notes from Torquay, 2 parts. (Zool.) : Migration of Buzzards. (Field, Jan. 3.)

Mathew, G. F. Ornitholog. Notes from Dartmouth; Lesser Spotted Woodpecker at Instow; Green Sandpiper. (Zool.)

Mathew, M. A. Bird Notes from the West. (T.c.)

Nicholls, H. C. Garganey in S. Devon. (Field, Apr. II.)

Rickards, M. S. C. Pomarine Skua in N. Devon; Richardson's Skua at Instow. (Zool.)

Smith, C. Ring Ouzel, etc. at Exmouth. (T.c.)

Taylor, W. Black Gannet [off Sidmouth.] (T.c.)

Wilcocks, J. C. Gannets at Teignmouth. (Field, Apr. 4.)

1875. Adams, H. C. Grey Phalaropes at Exmouth. (Op. cit., Oct. 9.)

Briggs, T. R. A. Chiffchaff in Feb. near Plymouth. (Zool.)

D'Urban, W. S. M. A Sketch of the Natural History of S. Devon. [Besley's Handbook of S. Devon, Appdx.] 8 vo. Exeter : 1875. [189.]

G- , G. C. Garganeys in S. Devon. (Field, May 15.)

Gatcombe, J. Large numbers of Greater Shearwater off Coast of Devon, etc. (Zool.) 
H- , H. G. Shore Larks in Devon. (Field, Jan. r6.)

Mathew, G. F. Ornitholog. Notes from Dartmouth. (Zool.)

Mathew, M. A. Flight of Male Peregrine at an old male Hen Harrier; Rock Dove at Instow; Pomatorhine Skua at Instow ; Rare Birds in N. Devon. 4 notes. (T.c.) American Bittern near Barnstaple. (Field, Dec. 4.)

Newman, E. Shore Lark near Bideford. (Zool.)

Nicholls, R. P. Long-tailed Duck in Kingsbridge Estuary, etc. 3 notes. (T.c.)

Pulman, G. P. R. Book of the Axe. 4th ed. roy. 8vo. I875. [482.]

Rowe, J. American Bittern near Barnstaple. (Field, Nov. 20.)

S-, T. G. Egyptian Geese in Devon. (Op. cit., Feb. 6.)

Smith, C. Rare Birds in Devon. (Sci. Gossip, XI.)

Wilcocks, J. C. Shearwaters at Torquay and Torbay. (Field, Aug. I4, 2I) ; Idem, by F. Pershouse. (T.c., Aug. 28.)

1876. Gatcombe, J. Snowy Owl on Dartmoor ; Great Snipe, Greater Shearwater and Lesser Grey Shrike in Devon; Early Occurrence of Grey Phalarope in Devon. (Zool.)

Gurney, J. H. junr. Calandra Lark a British bird; Goosander at Slapton Ley. (T.c.)

Mathew, G. F. Scarce Birds at Torquay; Baillon's Crake at Braunton Burrows, etc. 6 notes. (T.c.) ; Caspian Tern, etc. at Torquay. (Field, Oct. 2I.) Idem, [errore for Sandwich Tern.] (T.c., Oct. 28.)

Mathew, M. A. Notes from N. Devon; The Exeter Albert Memorial Museum; Hawks in N. Devon; Archibuteo sancti johannis [in N. Devon]; Little Bittern at Plymouth; Herons at Bishop's Lydeard. (Zool.)

Nicholls, H. Night Heron, Bewick's Swan and other Birds at Kingsbridge; Abundance of Short-eared Owl; Rufous Warbler at Slapton. (T.c.)

Nicholls, R. P. Marsh Harrier, Smew and Goosander at Slapton Ley; Black Redstart near Lodeswell; Spotted Gallinule, Grey Phalarope and Great Crested Grebe near Kingsbridge. 7 notes. (T.c.); Rufous Warbler in Devon. (Field, Oct. 28.)

Parfitt, E. The Fauna of Devon: Part XIV., Birds. (Tr. Devon Assoc. Sci., Lit. \& Art.)

Rowe, J. B. Snowy Owl near Barnstaple; Buzzards in Devon. (Field, Apr. I.)

1877. Chanter, J. R. Lundy Island: A Monograph. 8vo. London : I877. [x23.]

Corbin, G. B. Notes from S. Devon. (Zool.)

D'Urban, W. S. M. Rare Birds of the Exe ; Glaucous Gull on the Exe and Teign; Knot in Summer Plumage on the Exe. (T.c.) 
Mathew, M. A. Notes from the West of England; Scarcity of Corncrake in West of England; Wood Sandpiper at Barnstaple; Early Arrival of Wild Geese. (T.c.)

1878. Adams, H. C. Goosander at Exmouth. (Field, Dec. 2I.)

Gatcombe, J. Hybrid Pheasant and Blackcock. (Field, Nov. I6.)

"J. E." Swallows [one House Martin] in January. (Field, Jan. I2.)

Mathew, M. A. Early Appearance of Jack Snipe [and Squacco Heron.] (Zool.)

1879. Mathew, M. A. Dotterel in N. Devon. (T.c.)

Moap, S. J. Goosander and Great Northern Diver in Devon. (Field, Feb. 22.)

r880. "Captain." Abundance of Starlings in Devon. (Op. cit., Dec. 25.)

D'Urban, W. S. M. Goosander on the Exe. (Zool.)

G__, C. G. Jack Snipe in May. (Field, May I5); Shoveler in S. Devon. (T.c., Jan. 3); Avocets in Devon. (Op. cit., Oct. 23.)

Gatcombe, J. Skuas off Coasts of Devon and Cornwall. (Zool.)

Hook, Bryan. Grey Phalarope near Kingsbridge. (T.c.)

Kelly, R. Note on the Cuckoo. (T.c.)

Nicholls, H. American Green-winged Teal in Devon. (Zool.; Field, Jan. 3); Avocet in S. Devon. (Zool.) Idem, by E. Elliot. (Field, Nov. 20.)

Rawson, H. E. Alpine Swift in Devon. (Zool.)

Tuil, E. M. J. Common Kite in Devon. (Field, Dec. II.)

r881. D'Urban, W. S. M. Winter Visitants; White Landrail near Exeter. (Zool.)

Gatcombe, J. Arrival of Garganey. (Field, Apr. 2.)

Holdsworth, E. W. H. White's Thrush in Devon. (Zool.) Idem, by R. N. S. (Field, Feb. I9.)

Mathew, G. F. Little Bustard in N. Devon; Great Northern Diver near Barnstaple. (Zool.)

Norrish, E. C. Landrail in Devon in Dec. (Field, Dec. Io.)

I882. Copp, H. A. Great Northern Diver on Devon Coast. $(O p$. cit., Nov. II.)

D'Urban, W. S. M. Great Grey Shrike in Devon. (Zool.)

M-_, M. F. Nightingale at Torquay. (Field, Apr. 29.)

I883. Adams, H. C. Bittern in Devon. (Field, Mar. Io.)

D'Urban, W. S. M. Ornitholog. Notes from Devon. 2 parts. (Zool.)

Elliot-Tresillian, E. A. S. Great Grey Shrike in Devon. (Field, Nov. 24.)

Rotheram, M. H. Nutcracker in N. Devon. (Zool.)

Vicary, W. Rough-legged Buzzard in S. Devon. (Field, Apr. 28.) 
I884. [Anon: "Jack Snipe."] Osprey in Devon. (Op. cit., Oct. I8.) Ashworth, C. E. Reported Occurrence of Jerfalcon at Sidmouth. (T.c., Oct. I8.)

E-, E. Tree Sparrow in S. Devon. (T.c., Nov. 29); Spoonbill on the Avon. (T.c., Nov. I5.)

Earle, J. R. Grey Wagtail nesting in E. Devon. (Zool.)

Elliot, E. A. S. Great Grey Shrike in Devon. (T.c.)

Evans, H. A. Siskin and Snow Bunting in N. Devon. (T.c.)

Hinchcliff, C. F. List of Birds observed within 7 miles of Ilfracombe. (Field,-?)

I885. [Anon: "Traveller."] Whitefronted Geese on Dartmoor. (Op. cit., Mar. 7.)

Copp, H. A. Notes from N. Devon. (Op. cil., Dec. I9.)

Elliot, E. Spoonbill on the Devonshire Avon; Tree Sparrow in S. Devon. (Zool.); Spotted Redshank in Kingsbridge Estuary. (Field, Aug. 29.)

"G. C. G." [Reported] occurrence of Collared Pratincole in S. Devon. (Field, Aug. 22.)

Gosling, E. Spoonbill in Devon. (T.c., Nov. 2I.)

Nicholls, R. P. Unicommon Birds in Devon. (Zool.)

Smith, C. Wayside Notes during a West Country drive [Devon and Cornwall.] (T.c.)

Wright, J. S. Common Buzzard in Devon. (Field, Jan. 3.)

I886. Adams, H. C. Black Redstart and Skuas at Exmouth. (Op. cit., Feb. 6.)

E[lliot], E. A. S. Ringed Guillemot on Devon Coast. (T.c., Feb. I3.)

G—, G. C. Hoopoe in S. Devon. (T.c., Apr. 24.)

Hamling, J. Egyptian Goose on the Taw. (Zool.)

1887. Aplin, O. V. Birds observed in N. Devon. (Op. cit.)

Elliot, E. The Dartford Warbler in Devon. (Field, June 4.)

$\mathrm{G}-$, G. C. Bittern and Raven in S. Devon. (T.c., May 7.)

Green, G. C. Little Bittern in S. Devon. (Op. cit., Dec. 24.)

I888. Adams, H. C. Avocet and White-fronted Goose at Exmouth. (Op. cit., Nov. 24.)

Crespi, Dr. Lundy Island. (Sci. Gossip, July.)

D'Urban, W. S. M. Parrot Crossbill in Devon. (Zool.)

E[liot], E. A. S. Uncommon Birds in the S. Hams. (Field, Feb. I8.)

Hamling, J. G. Re-appearance of Pallas's Sand Grouse [in Devon.] (Zool.) Idem, by J. K. Newcombe. (Field, June 9.)

Taylor, W. Velvet Scoter at Exmouth. (Zool.)

I889. Drew, H. A. Hoopoe in Devon. (Field, Sept. 2I.)

Dunsford, F. Bittern in Devon. (T.c., Dec. 28.) 
Elliot, E. A.S. Blackcap in Feb. (Op. cit., Feb. 9) ; Uncommon Birds at Kingsbridge. (Op. cit., Nov. 9.)

H- W. E. Scarcity of Fieldfares. (Op. cit., Feb. 23.)

Hamling, J. G. The Avocet in N. Devon; Bittern in Devon. (Zool.)

Knight, F. A. Idylls of the Field. Cr. 8vo. London; I889. [332.]

"Philofusil." Little Auk in Devon. (Field, Sept. 7.)

I8go. Adams, H. C. Little Auk and Ruff at Exmouth. (Op.cit,. Feb. x.)

Clark, C. O. Birds on Dartmoor. (T.c., June I4.)

D'Urban, W. S. M. Reputed Occurrence of Pine Grosbeak in Devon; Black Redstart in Devon; Supposed Occurrence of Orphean Warbler in Devon. (Zool.)

Doveton, - Kite in Devon. (Field, May 24.)

Elliot, E. A. S. Summer Birds in Devon. (T.c., Apr. 5); Birds on Dartmoor. (T.c., June 7.)

Hamling, J. G. Rare Birds in N. Devon. (Zool.)

Harris, T. F. Bittern in Devon. (Field, Jan. 4.)

Kennaway, L. M. Bee-eater in Devon. (Zool.)

Pidsley, W. E. H. Uncommon Birds in Devon. (T.c.)

Rome, J. Marsh Harrier in Devon. (Field, Nov. 8.)

Woollcombe, H. Little [?] Bittern in Devon. 2 notes. (Zool.) I8go-9I. Aplin, O. V. Distribution of Spotted Crake, 2 pts. [partim.] (Op. cit., I890-9I.) [24.]

I89I. Adams, H. C. Grey Phalarope and Buffon's Skua at Exmouth. (Field, Nov. 2I.)

D-, F. B. Goosander in Devon. (Op. cit., Jan. 24.)

D'Urban, W. S. M. Ornitholog. Notes from Devon; Hawfinch breeding in Devon. (Zool.)

Elliot, E. A. S. Grey Phalarope, Sabine's Gull and Buffon's Skua in S. Devon. (Field, Oct. I7, 24, Dec. 5) ; Surf Scoter. (T.c., Oct. 3I.)

Evans, A. H. Marsh Harrier in N. Devon. (Zool.)

Green, G. C. Smew in Devon. (Field, Jan. 3I.)

Hamling, J. G. Eared Grebe, Smew and Bittern in N. Devon. (Zool.)

Palmer, A. H. Leach's Petrel in S. Devon. (Field, Oct. 24); Grey Phalarope in S. Devon. (T.c., Nov. 7.)

Pickthall, C. J. Goosander at Slapton. (Field, Jan. 3I.)

Pidsley, W. E. H. The Birds of Devonshire. Edited by the Rev. H. A. Macpherson. 8vo. London and Exeter: I89I. [47r.]

Pidsley, W. E. H. Wildfowl in Devon during winter of I890$9 \mathrm{r}$; Lesser Whitethroat in Devon ; Egyptian Goose in Devon. (Zool.)

Saunders, H. Supposed Occurrence of Orphean Warbler in Devon. (T.c.) 
Scholfield, H. W. B. The Smew in Devon. (Field, Jan. 24.)

Stubbs, Rev. M. Lesser Whitethroat in Devon. (Zool.)

I892. Aplin, O. V. Distribution of Cirl Bunting; Status of Woodchat. (Op. cit.) [partim.] [25.]

D'Urban, W. S. M. and Mathews, M. A. The Birds of Devon. 8vo. London: I892. Idem. 2nd. edit. with Suppl. London I895. [I89.]

Elliot, E. A. S. Rare Birds at Kingsbridge; Young Rednecked Grebe on Kingsbridge Estuary; White Wagtail, Reed Warbler and Woodchat in S. Devon., etc. 6 notes (Zool.) Red-necked Grebe in Devon. (Field, Aug. I3.)

Evans, H. A. American Stint in N. Devon; Ruddy Sheldrake in N. Devon. (Zool.)

Gould, F. H. C. Ruddy Sheldrake in N. Devon; Nesting of Quail in Devon. (T.c.)

Mathew, M. A. Rare Birds in N. Devon. (T.c.)

$\mathrm{O} \longrightarrow$, J. L. Bittern in N. Devon. (Field, Jan. 23.)

Pidsley, W. E. H. Grey Phalarope, Serin Finch, Buffon's Skua and Bittern; Notes from Devon. 4 notes. (Zool.)

1893. Elliot, E. A. S. Sabine's Gull, etc. in S. Devon. (Field, Oct. 28); Swifts staying till November; Little Gull in S. Devon. (T.c., Nov. 25.)

Gould, F. H. C. Nesting of the Short-eared Owl. (Zool.)

Pidsley, W. E. H. Sheldrake and other Birds at Exmouth. (T.c.)

Still, J. N. Snow Bunting in Devon. (Field, Nov. II.)

8894. Elliot, E. A. S. Lesser Redpoll in S. Devon. (Op. cit., Mar. 24); Scaup Duck in S. Devon. (T.c., Apr. 28); Nesting of the Common Redshank. (Op. cit., July 28.)

Hamilton, E. Supposed Occurrence of Black Stork in Devon. (Zool.)

Harland, H. S. Storm Petrel breeding in Tor Bay. (Field, Feb. 24.)

1895. Biddle, W. R. Bittern in Devon. (Op. cit., Jan. I2.)

Elliot, E. A. S. Pinkfooted Goose in N. Devon. (T.c., Feb. I6.) Hayward, Mrs. Jane, of Sidmouth. Bird Notes. Post 8vo. I895. [289.]

1896. “A. K." Osprey in Devon. (Field, Sept. I9) ; Kingfishers by the Sea. (T.c., Oct. 3.)

Comyns, J. H. Notes from S. Devon. (Ornithologist.)

E[liot], E. A. S. Grey Phalarope in S. Devon. (Field, Oct. Io) ; Idem, by G. C. Green. (T.c., Oct. I7.)

I897. Davenport, H. S. Habits of Lesser Spotted Woodpecker. (Ornithologist.)

D'Urban, W. S. M. Night Heron on the Exe. (Knowoledge.) 
Evans, H. A. Comparative Status of Birds found in the British Isles and in the Co. of Devon. Plymouth: I897. (Reprinted from Rept. Devon Assoc., XXIX.)

Evans, H. W. Apparent Summer Appearance of Shore Lark in Devon. 2 notes. (Zool.) Idem, by C. Dixon. (T.c.)

I898. Balston, R. J. Breeding of the Gannet. (Op. cit.)

Davenport, H. S. A Visit to Lundy Island. (Field, Nov. 6.)

D'Urban, W.S. M. Date of arrival of the House Martin. (Zool.)

Elliot, E. A. S. Common Crossbill in S. Devon; White Stork in Devon. (Field, Oct. 6) ; Idem, by H. D. Astley. (T.c., Oct. I5.)

Green, G. C. Crossbills in Devon and Suffolk. (T.c., Sept. ro.)

Mathew, M. A. Melodious Warblers in S.E. Devon. (Zool.)

1899. Dixon, C. Birds in a Southern County: being Eight Years' Gleanings among the Birds of Devonshire. 8vo. London: I899. [I70.]

Light, W. A. Increase of Goldfinch. (Field, Oct. 28.)

I900. Adams, H. C. Spoonbill and Golden Oriole in Devon. (Op. cit., May I9.)

Blathwayt, F. L. A Visit to Lundy. (Zool.)

D'Urban, W. S. M. Bittern in Devon: Winter visitors in Devon. (Knowledge.)

Elliot, E. A. S. Twelve Months' Notes on Birds in the South Hams District. (Rept. Devon Assoc.); Bitterns in Devon. (Field, Jan. 27) ; Idem, by H. C. Adams. (T.c., Feb. 3) ; Spring Birds in Devon. (T.c., Apr. 28.)

Mead-Briggs, T. H. Birds at Lynmouth, 2 pts. (Sci. Gossip, June and July.)

White, T. D. Scarcity of Cuckoo in Devon. (Field, June 23.)

Igor. Doveton, F. B. White's Thrush at Torquay. (Op. cit., Dec. I4.) Elliot, F. E. Great Snipe in N. Devon. (T.c., Sept. 2r.)

Scott, W. H. Little Bittern in Devon. (Op. cit., May II.)

1902. Braund, E. Buzzard in Devon. (Op. cit., Nov. 8.)

Chichester, C. Rooks nesting in November. (T.c., Nov. 15)

Gregory, A. C. Landrail in Devon in Jan. (Op. cit., Feb. 8.)

Walter, E. Bittern in N. Devon. (T.c., Jan. 25.)

r903. Tegetmeier, W. B. The Nightingale in Devon. (Op. cit., May 30.)

I904. Elliot, E. A. S. Twenty Years' Record of Arrivals of Spring Migratory Birds in neighbourhood of Kingsbridge. (Rept. Devon Assoc.)

"J. H." Bittern in S. Devon. (Field, Feb. I3.).

Knight, F. A. A Corner of Arcady. Cr. 8vo. London: I904. [333.]

Pearson, C. Twite breeding in N. Devon. (Bull. B. O. C., XIV.) Idem, by H. S[cherren.] (Field, July 23.) 
1905. Cox, A. H. M. Common Sandpiper in Winter. (Field, Feb. I8) : Grey Wagtail. (T.c., Mar. I8.)

Cummings, J. Notes from Barnstaple. (Zool.)

Rendell, W. Young Woodcocks in Devon. (Field, Aug. Ig.)

I906. Adams, H. C. Alpine Swift in Devon. (Field, Sept. 22.)

Calmady-Hamlyn, C. H. Bittern in Devon. (Field, Apr. I4.)

Cleave, H. P. O. Ornithological Notes from Plymouth. (Zool.)

Cummings, B. F. Nesting of Short-eared Owl in Devon. (Field, June 30); Winter Ornithological Notes from Barnstaple. (Zool.)

D'Urban, W. S. M. Birds. [In Victoria History of Co. of Devon, I.] 4to. Lond.: Ig06. [I89.]

Erridge, R. Cuckoo mobbed by Small Birds. (Field, May I9.)

Raschen, G. H. Early appearance of Nightjar. (Field, May I9.)

Yerbury, J. W. Migration of Swifts and Swallows in Devon. (Bull. B. O. C., XVI.)

I907. Briggs, T. H. Occuriences of Blue-headed Wagtail at Lynmouth. (Brit. Birds, I.)

Chanter, J. F. History of the Parishes of Lynton and Countisbury. Roy. 8vo. Exeter: I907. [I22.]

Cox, A. H. M. Birds in Mid-winter. (Field, Feb. 9.)

Cummings, B. F. Occurrence of Glossy Ibis and Long-tailed Duck in N. Devon. (Zool.)

Elliott, E. A. S. Melanotic Variety of Honey Buzzard in Devon. (Rept. Devon Assoc.)

Kirkwood, J. D. M. Wild Swans in N. Devon. (Field, Jan. I2.)

I908. Briggs, T. H. Supposed Alpine Swift in N. Devon. (Zool.; Brit. Birds, II.)

Champerowne, A. W. White Wagtail interbreeding with Pied Wagtail in Devon; Grey Phalarope in Summer in Devon. (Brit. Birds, II.)

Cummings, B. F. Captures and Field Report for N. Devon. (Zool.)

Fenwick, N. P. Glossy Ibis in N. Devon. (T.c.)

Smith, K. S. Eiders off S. Devon in April. (Brit. Birds, II.)

Ig09. [Anon.] Spoonbill in Devon. (Field, Nov. 6.)

Barber-Starkey, F. Some Nesting Habits of the Wood-lark, as observed in N. Devon. (Br. Bds., III.)

Cummings, B. F. Ornithological Notes from N. Devon; Notes on the Fauna of Lundy Island. (Zool.)

Gilroy, N. Late nesting of Cirl Bunting. (Brit. Birds, III.)

Jourdain, F. C. R. Shoveler breeding in N. Devon. (Zool.)

I910. D’Urban, W. S. M. Increase of Starlings in ... Devon. (Brit. Birds, IV.)

Knight, F. A. and Dutton, L. M. Cambridge County Geographies : Devonshire. Post 8vo. Cambridge: I9ro. [333.] 
IgII. Banks, A. Roller in Devon. (Br. Birds, V.)

Collier, C. Pied Flycatchers breeding in Devon. (Br. Birds, V.)

Ticehurst, N. F. and Jourdain, F. C. R. Distribution of Nightingale [partim.] (Brit. Birds, V.)

Igr2. Elliott, E. A. S. Ferruginous Duck in S. Devon. (T.c.)

Cox, A. H. M. Little Owl in S. Devon. (T.c.)

Jourdain, F. C. R. Little Bustard in Devon. (Br. Birds, VI.) : Hybrids between Black game and Pheasant. (T.c.) [partim.]

$\mathrm{S}[\mathrm{mith}], \mathrm{H}$. H. Hybrid between Black-game and Pheasant. (Field, Aug. I7.)

I9I3. Brown, S. Quail in N. Devon. (Field, Sept. 6.)

Coward, T. A. Blackcap and Chiffchaff wintering in Devon. 2 notes. (Brit: Birds, VI.)

Cummings, B. F. Little Owl in N. Devon. (Zool.)

Cummings, S. G. Small Clutches of Eggs. (Br. Birds, VII.)

Loyd, L. R. W. Blue-headed Wagtails in S. Devon. (Br. Birds, VII.): Lesser White-throat breeding in S. Devon. (T.c.)

[Editorial.]-White Storks at liberty on the Exe. (Field, Aug. 23.

I9I4. Hale, J. R. and Borrer, C. Kite nesting in Devon. (Br.Birds, VII.)

Loyd, L. R. W. Notes on early nesting. (Br. Birds, VIII.) Unusual nesting place of Mistle Thrush. (T.c.) Unusually large clutch of Redbreast's eggs: Curious break in nesting activities of House Martins: Wrens laying in year-old nests. (T.c.)

I9I5. Hinchliff, F. B. Blackwinged Stilt in Devon. (Field, Nov. 2;.) Idem. (Brit. Birds, IX.)

Taylor, P. Golden Oriole in Devon. (Field, May 22, I9I5.) Idem, by A. J. Butler. (Op. cit., May I3, IgI6.)

IgI6. [Editorial.] Shore Lark in Devon. (Br. Birds, IX.)

Cox, A. H. M. Habits of Young and possible Double Brood of Com. Buzzard. (Br. Birds, X.)

Elliot, E. A. S. Spoonbills in Devon, etc. (Br. Birds, X.)

Hinchliff, F. B. Spoonbill [in Devon.] (Ficld, Nov. 25.)

Hodgkin, C. Spoonbill in Devon. (Br. Birds, IX.)

"P." Disappearance of Swallows and Swifts in Devon. (Field. Sept. 2.)

Wroth, J. S. Increase of Barn Owls in S. Devon. (Op. cit., Feb. 6.)

I9I7. Coles, R. E. Nesting of Jack Snipe [?] [Dartmoor.] (Selborne Mag., pp. 54-55.)

Witherby, H. F. The Nightingale in Devon. (Avicul. Mag., p. 289.) 
I9I8. Grigg, H. L. The Nightingale in Devon. (Field, May 25.)

Harding, J. Rudge. The Whinchat on Exmoor. (Op. cit., July 20.)

Mountain, E. M. Grouse on Exmoor. (Op. cit., Sept. 2I.)

Parker, P. L. Spoonbills in Devon. (Br. Birds, XI.)

\section{DORSETSHIRE.}

I724. Stukeley, W. Itinerarium Curiosium. Fol. Lond. : I724. [Ref. to Dorset : drawing of decoy and manner of catching the fowl.]

I799. Pulteney, R. Catalogues of Birds, [etc.] of Dorsetshire [from Hutchins's History of the County.] Folio. Lond.: I799. Idem. Enlarged edit. I8I3. [482.]

1828. Yarrell, W. Notes of appearance of some Rare Birds in England. [Hoopoes in Dorset.] (Zool. Jnl., III., p. 498.)

1832. Fox, G. T. Ruddy Goose (Anas mutila) [in Dorset.] (Zool. Journ. III., p. 496.)

1834. Morris, F. O. Forktailed Petrel [near Charmouth.] (Loudon's Mag. N.H.V., p. 733.)

Morris, B. R. On a large Sea Gull, with rarer Birds of Charmouth. (Loudon's Mag. N. H.)

1835. Morris, F. O. Hoopoe shot near Charmouth lately. (Op. cit.)

I837. Dale, J. C. Catalogue of Mammalia, Birds, etc. found in Dorsets. (Nat. [Neville Wood's], II.) Egyptian Goose. Blue-throated Fantail, etc., in Dorset. (T.c.)

Morris, B. R. Notes on the Laridæ [of Dorset.] (Nat. [Wood's], II.)

Morris, F. O. Distrib. of Cirl Bunting and Corn Bunting. 2 articles. (T.c.) [partim.]

[Editorial.] Snowy Owl shot in Dorsets. (Nat. [Woad's], III.)

1842. - Fauna of Dorsets. (Ann. Mag. N. H.)

I846. Morris, B. R. Curious deviation from ordinary habits of Kingfisher. (Zool.)

1848. Salter, S. J. A. Extraordinary assemblage of Gold-crested Regulus. (Op. cit.)

Morris, B. R. Note on Great Plover. (T.c.)

I850. Roe, R. Occurrence of Redwing at Abbotsbury on 24th August. (Op. cit.).

1851. Thompson, W. Sea Birds at Weymouth : Occurrence of Hoopoe near Weymouth: Puffin in Winter $(O p$. cit. $)$

1852. Smith, A. C. Supposed Capture in England of the American Black-bellied Darter. (Zool.) 
1853. Fane, F. Quail, and Little Bittern in Dorsets. (Nat. [Morris's], III.)

Cambridge, O. P. Woodcocks breeding in this Country [Dorset.] (Zool.)

Garland, J. Mountain Finch near Dorchester; Dotterel near Dorchester. (Zool.)

Thompson, W. Occurrence of Golden Oriole near Weymouth; Hoopoe in Isle of Portland. 2 notes. (T.c.)

Williamson, J., junr. Nesting of Woodcock [in Dorsets.] : Hoopoe in Dorset. (Nat. [Morris's], III.)

I854. Cambridge, O. P. Occurrence of Hoopoe and Oriole near Blandford; Rare Hawks near Blandford. (Zool.)

Thompson, W. Occurrence of Little Bustard in Dorset: Surf Scoter at Weymouth. 2 notes. (T.c.)

I855. Austen, Rev. John H. A Systematic Catalogue of the Birds of the Isle of Purbeck. [In Papers of the Purbeck Society, pp. 6I-75.] Wareham: I855. [Enumerates about I68 species, a very interesting list.]

Daniel, J. E. The Dartford Warbler [in Dorset.] (Nat. [Morris's], V.)

I857. Thompson, W. Canada Goose, Egyptian Goose, Forktailed Petrel and Longtailed Duck at Weymouth, 4 notes; Shoveler breeding in Dorset. (Zool.)

Smith, R. B. Breeding of Teal in Dorset. (T.c.)

1858. Thompson, W. Pigmy Curlew at Weymouth; Glossy Ibis in Dorset. $(O p$. cit.)

I859. Renny, W. Forktailed Petrel [shot at Poole.] (Field, Dec. Io.) Hart, W. Glossy Ibis [in Dorset.] (Field, Oct. 8.)

Cambridge, O. P. Note on a new British Woodpecker. (Zool.)

Thompson, W. Occurrence of Eagle in Dorsets.; Bohemian Waxwing at Weymouth. (Zool.)

I86o. [Anon. "MS."] Woodcock nesting in Dorset. (Field, Apr. I4) ; " J. W." Idem. (Field, Apr. 2I.)

"Smack." Little Auk in Dorset. (Op. cit., Dec. 29.)

Hogan, A. R. Localities of Sylvia luscinia. (Zool.)

Penny, W. Occurrence of Forktailed Petrel at Poole. (Zool.)

Thompson, W. Waxwing, Ivory Gull, etc. [at Weymouth.] (Field, Dec. I5.) Woodcock and Snipe breed in Dorset. (Op. cit., April 28); Little Auk [near Weymouth.] (T.c., April 28.)

I86r. "A. D. H." Glaucous not Ivory Gull shot near Weymouth, I86o. (Op. cit., Feb. 9.)

Thompson, W. Birds on the Dorset Coast. (Field, Jany. I2.)

I86I-74. Mansel-Pleydell, J. C. Ornithology. [In Hutchin's History of Dorset. 3rd. edit., Vol. I.] Folio. Lond., etc.: I86I-74. [377.] 
I865. Harting, J. E. Visit to the Dorsets. Coast in Nesting Season. (Zool.)

I866. Shorto, J. Food of Wood Pigeon. Stone Curlew near Dorchester. $(O p$. cit.)

Fulford, J. L. L. Great Northern Diver near Bridport.

I867. Elliot, J. Thick-kneed Plover in Jan. (Field, Jan. I2.)

Grant, J. Squacco Heron [in Dorset.] (Field, May 25.)

Hart \& Son. Sabine's Snipe [at Wareham.] (Field, Dec. I4.)

Shorto, J. Great Snipe near Dorchester; Bitterns near Dorchester; Golden and Green Plovers; Pied Wagtails in Jan. $($ Zool.)

Thompson, W. Avocet near Weymouth. (T.c.; Field, March 23, Nov. 30) ; Squacco Heron at Weymouth. (Field, July I3.) Idem. (Zool.)

I868. Lilly, J. P. Bittern shot in Dorset. (Field, Jany. 4.)

Shorto, J. Jack Snipe in August. (Zool.)

I869. Gurney, J. H. List of Rarer Birds obtained by Hart near Christchurch, Hants. [Dorset records.] (Op. cit.); Dartford Warbler at Lyme Regis. (T.c.)

Hart, W. Crane at Wareham. (T.c.)

Thompson, W. Velvet Scoter at Weymouth. (Field, Feb. 6.)

I870. Borrer, W. Shore Lark near Weymouth. (Zool.)

Hart, W. Osprey at Poole. (T.c.) : Idem. (Field, Oct. I.) " J.B." Quail in Dorset. (Field, Sept. Io.)

Thompson, W. Osprey and Little Auk at Weymouth. (T.c., Oct. 29); Sabine's Snipe at Dorchester. (T.c., Dec. 24, 3I.)

I87I. Morrice, F. J. Supposed Scarcity of Landrails. (Field, Oct. 7.) Thompson, W. Bewick's Swan and Eider Duck near Weymouth. (Op. cit., Mar. I8, Dec. 2.)

1872. Cambridge, O. P. Snipe drumming on and Feb. (Zool.) Hart \& Son. Grey Phalarope in Dorsets. (Field, Oct. 26.) Gurney, J. H. Birds attracted by Lighthouses. (Zool.) Harting, J. E. British Heronries. (T.c.) [partim.]

[1873 ?] Mansel-Pleydell, J. C. Ornithology and Conchology of the County of Dorset. 8vo. Lond. etc. : [I873?] [A reprint of I86I-74 article.] [377.]

1874. Thompson, W. Garganey at Weymouth. (Field, Mar. I4) ; Black Guillemot at Weymouth. (Field, Dec. 26.)

Cambridge, O. P. Fieldfares feeding on apples; Late stay of House Martins. (Zool.)

I875. Bullock, G. T. Tufted Duck at Corscombe. (Field, Jan. I6.) P[ike], T. M. Turnstone in Dorset in June. (T.c., June 26.)

Martin, A. J. M. Virginian Colin shot in Dorset. (Op. cit., Oct. I6.)

I876. Martin, A. J. M. Landrail in Dorset in January. (Field, Feb. 5.) 
Lister, A. Woodchat at Lyme Regis. (Op. cit., July 8) : Idem. $($ Zool.)

I877. Mansel-Pleydell, J. C. Ornitholog. Notes from Dorsets. (Zool.) Morres, A. P. Rare Birds in Wilts. and Dorset.; Peregrine Falcons near Wareham. (T.c.)

Pike, J. M. Grey Phalarope and Northern Diver at Poole. (Field, Oct. 27.); Forktailed Petrel at Poole. (T.c., Nov. 24.)

Pike, T. M. Breeding of Pochard and Black-headed Gull in Dorset; Singular Variety of Common Guillemot. (Zool.): Spotted Redshank in Dorset. (Field, Sept. 29.)

Rickards, M. S. C. Shearwater at Poole Harbour. (Zool.)

Smith, Rev. A. C. The Swannery at Abbotsbury. (T.c.)

I878. Dale, C. W. History of Glanville's Wootton. Post 8vo. Lond.: I878. [I59.]

Gurney, J. H. The Swannery at Abbotsbury. (Zool.)

Okeden, J. H. C. Ring Ouzel in Dorset in Winter. (Field, Jan. 5.)

Pike, T. M. Natural History Notes from Poole; Spoonbill in Dorset; Glossy Ibis in Dorset. (Zool.): Hoopoe near Wareham. (Field, July I3.)

1879. Cambridge, O. P. Song of the Ring Ouzel; Fieldfares in May; Oystercatcher in Portland during Breeding Season. (Zool.)

"F. O. P. C." Curlew Sandpiper at Weymouth. (Field, Oct. 4.)

Gurney, J. H. Snipe Catching in Dorsets. (Zool.)

Harting, J. E. Cormorants on the Coast. (T.c.)

$\mathrm{M}[\mathrm{ann}]$, T. J. White-fronted Goose in Poole Harbour. (Field, Dec. 27.)

Mansel-Pleydell, J. C. Reeve in Dorset in Dec. ; Ferruginous Duck in Dorset; Cormorants on the Dorsets. Coast. (Zool.)

Okeden, H. G. P. Ring Ouzels in Dorset in Winter. (Field, Feb. I5.)

Pike, T. M. Wildfowl in Poole District; Cormorants on Dorset Coast. (Zool.)

Morer, H. Skuas on the South Coast. (Field, Nov. 8.) [partim.]

1880. Hart, E. Great Bustard in Dorsets. (Zool.)

Mann, T. J. Hen Harrier in Dorset. (Field, Dec. I8.)

Pike, J. M. Osprey in Poole Harbour. (Field, Oct. 9.)

188I. Cambridge, O. P. Osprey in Dorsets. and Long-eared Owl breeding in Dorsets. 2 notes. (Zool.)

Harting, J. E. On the reported occurrence in England of the American Pied-billed Gr be. (T.c.)

Sharpe, R. B. [Exhibition of American Pied-billed Grebe from Dorset.] (P.Z.S.)

Warry, H. C. Peculiar Nesting of Blackbird. (Zool.) 
I882. Cambridge, O. P. "Churring " of Nuthatch; Notes of Nuthatch and Lesser Spotted Woodpecker. (Zool.)

Newton, A. Breeding of Curlew in Dorsets. (Field, Aug. I9.) ; Idem, by J. C. Mansell-Playdell. (T.c., Aug. 26.)

Stephens, D. Landrail in Dorset in Winter. (Zool.)

M[ann], T. J. Gadwall in Dorset. (Field, Jan. 28.)

Pike, T. M. Wildfowl near Poole. (Field, Oct. 28.)

1883. Cambridge, O. P. Peculiar Habits of Starling. (Zool.)

Clark-Kennedy, A. Osprey and Goosander in Dorset. (Field, Feb. Io.)

Mann, T. J. Ringed Guillemot and Richard's Pipit on Dorset Coast. (T.c., Jan. I3.)

Marriott, C. A. Wildfowl at Poole. (Zool.)

'Rara Avis.' Hoopoe in Dorset. (Field, April 28.)

Smith, C. Wayside Notes [Dorset records.] (Zool.)

I884. Earle, J. R. Kestrel nesting in hole in tree. (Op. cit.)

Mansel-Pleydell, J. C. Hen Harrier breeding in Dorset; Ornitholog. Notes from Dorset. (T.c.)

I885. Buckman, J. Dotterel in Dorset. (Pr. Dorset N. H. \& Antiq. F.C. VI., p. 29.)

I886. Cambridge, O. P. Birds in the severe weather. (Zool.)

Hart, E. Gadwall ... in Hants. [err. Dorset.] (Field, Dec. 25.)

" J. A." Little Bittern in Dorset. (Field, April 3.)

I887. Corbin, G. B. Honey Buzzard in Dorset. (Zool.)

"J. B. L." The Raven in Dorsets. (Field, Aug. 27.)

Mansel-Pleydell, J. C. Nesting of Montagu's Harrier in Dorset ;

Kestrel and Slow-worm. (Zool.) ; Decoys and Swan Marks, Abbotsbury. (Pr. Dorset N. H. \& Antiq. F. C. VIII., p. I.)

Dale, C. W. Slow-worm attacked by Missel Thrush. (Zool.)

Cambridge, O. P. Pied Varieties of Jackdaw. (Zool.)

I888. Butler, E. A. Raven in Dorsets. (Zool.)

Bankes, E. R. Pied Flycatcher in Dorsets. ; (Field, May 5) :

Firecrest in Isle of Purbeck. (T.c., June 2.)

Corbin, G. B. Pallas's Sand-Grouse in Dorset. (Zool.)

Farrer, O. C. Pallas's Sand Grouse [in Dorset.] (Field, June 9.)

Groves, T. B. Royston Crow, Weymouth. (Pr. Dorset N. H. \& Antiq. F. C. IX., p. 24.)

Mansel-Pleydell, J. C. The Birds of Dorsetshire. 8vo. Lond., etc. : I888. [377.]

Mansel-Pleydell, J. C. Long-tailed Duck and Common Skua in Dorset ; Reported Occurrence of Dusky Shearwater ; Ornitholog. Notes from Dorset; Re-appearance of Pallas's Sand Grouse [in Dorset]; Kites in Dorsets; Montagu's Harrier nesting in Dorset. Notes from Dorsets. (Zool.) 7. notes.

Penney, W. Birds of Poole Harbour. (Pr. Dorset N.H.E Antiq. F. C. IX., p. 34.) 
Salmon, E. Visit to Lord Ilchester's Swannery at Abbotsbury. (Zool.)

I889. Bankes, E. R. Golden Oriole in Isle of Purbeck. (Field, May II.)

[Harting, J. E.] The Swannery at Abbotsbury. (Zool.)

White, G. Sand Grouse in Dorset. (Field, Jan. I2.)

Young, J. B. Ravens, Peregrine Falcons and Puffin on Portland Head. (Sci. Gossip, May, June.)

I889-92. Stuart, M. G. Observations on the Appearances of Birds in the County, with notes and records of the rarer species. (Pr. Dorset N. H. \& Antiq. F. C. X.-XIII., I889-92.)

I89o. Aplin, O. V. On Distribution, etc., of the Spotted Crake. (Zool.) [partim.] [24.]

I891. [Editorial.] [Bittern at Weymouth.] (Field, Jan. 3.)

Lister, A. Dartford Warbler in Dorset. (Zool.)

Banks, E. R. Pied Flycatcher in the Isle of Purbeck. (Field, May 9.)

[Editorial.] Great Flight of Small Birds to Westward. (Zool.) [partim.]

Harting, J. E. Recent Visitation of Bustards. (T.c.) [partim.]

I892. Aplin, O. V. On Distribution of the Cirl Bunting; Status of Woodchat. (Zool.) [partim.] [25.]

Cambridge, O. P. Cirl Bunting in Dorset. (T.c.)

I893. Andrews, J. Baillon's Crake in Dorset. $(O p$. cit. and Field, June Io and I7.)

Bankes, E. Woodchat at Bloxworth [errore.] (Field, Apr. 29, May I3.)

Bengough, A. J. Lesser Redpoll nesting in Dorset. (Zool. and Field, June 3.)

Lees, E. Partridge with Black Horseshoe. (Field, Nov. I8.)

Lukin, J. Golden Oriole in Dorset. (Sci. Gossip, July.)

Peck, G. Iceland Gull at Poole Harbour. (Ficld, Feb. II.)

Slade, W. D. Bittern in Dorset. (Zool.)

1893-I9I3. Richardson, N. M. Reports on Observations of First Appearances of Birds, etc. in Dorset, 20 pts. (Pr. Dorset N.H. \&. Antiq. F. C. XIV.-XXXIV., I893-I9I3.)

1894. Cambridge, O. P. Early Arrival of Cuckoo. (Zool.)

Mansel-Pleydell, J. C. Green Woodpecker pursued by Sparrowhawk; Black Guillemot inland in Dorset; Brocid of White Swallows. (T.c.) 3 notes.

'West Lodge.' A Brown Rook [in Dorset.] (Field, March Io.)

I895. Cambridge, Rev. O. P. Jack Snipe in Dorset in May. (Zool.)

Cornish, C. J. Wild England of To-day. 8vo. Lond.: I895. [I47.] [Chapters on Poole Harbour Birds, etc.] 
D'Urban and Mathew's Birds of Devon. 2nd. edit., with Suppl. 8vo. Lond.: I895. [Dorset records; also Notes on Poole. Gullery. Suppl. p. 29]

Harting, J. E. American Yellow-billed Cuckoo in Dorset. (Zool.) Idem, by R. L. Neilson. (T.c.)

I896. Fowler, W. W. Migration of Swallows in Dorset. (Op. cit.)

Colfox, W. [Yellow-billed Cuckoo in Dorset.] (Nat. Notes.)

Macpherson, H. A. Sabine's Gull near Weymouth. (Zool.)

I897. Dresser, H. E. Osprey in Dorset. (Op. cit.)

Lister, A. Early appearance of Martins in Dorset. (Field, April I7.)

Mathew, M. A. Icterine Warbler at Lyme Regis. (Zool.)

Devenish, H. Hoopoe near Weymouth. (Field, Oct. I6.)

Richardson, N. M. [Dorset Birds in] Deacon \& Co's Hants. and Dorset Court Guide. 8vo. I897.

Ward, T. M. Nightingale in Dorset. (Field, June I2.) Idem, by F. L. Blathwayt. (T.c., June I9.)

Ward, T. M. Cuckoo's Egg in Blackbird's Nest. (T.c., May I.)

I898. Cambridge, O. P. Notes on Dorset Birds. (Pr. Dorset N. H. \& Antiq. F. C. XIX., p. 44.) Immigration of Song Thrush. (Zool.)

I899. Banks, J. Bitterns in Dorset. (Field, Dec. 30),

Baylis, E. Avocet in Dorset. (Zool.)

Pope, W. H. Ruff in Dorset. (Field, Mar. 4.)

I900. 'C. E. I.' Ravens in Dorset. (Op. cit., Dec. 22.)

Corbin, G. B. Hoopoe in Dorset. (Zool.)

Jackson, C. Hoopoe in Dorset. (Field, Apr. 28.)

Thompson, W. Early Plovers' Eggs. (Field, Mar. 3I.)

I902. Cambridge, O. P. Migration of Jays; Songs of Birds. (Zool.)

Ford, A. Little Bustard in Dorset. (Field, Feb. I.)

Richardson, N. M. Observations on Nesting of Missel Thrushes. (Pr. Dorset N. H. \& Antiq. F. C. XXIII., p. 67.)

Wallis, R. Honey Buzzard [?] near Weymouth. (Field, Oct. 4) : Taking Pigeons. (T.c., Oct. I8.)

I903. Bankes, A. Hen Harriers in Dorset. (Zool.)

Cambridge, O. P. Black Redstart in Dorset. (T.c.)

Willmore, H. H. Cirl Bunting's Nest in September. (Field, Sept. 26.)

I904. Jourdain, F. C. R. Unusual Nesting-site of Nuthatch. (Zool.)

I905. Andrews, J. Arctic Tern in October. (Field, Oct. I4.)

Norman, I. Increase of Goldfinches in Dorset. (T.c., Nov. 4.)

Smith, R. Bosworth. Bird Life and Bird Lore. Lond. : 1905. [Much information on Dorset Birds.]

I906. Daubenny, W. Young Moorhen swallowed by Trout. (Field, June I6.) 
Lister, G. Fire-crested Wren in Dorset. (Zool.)

Parkinson-Curtis, W. Paper on Ringed Plover. [Poole Harbour.] (Pr. Dorset N.H. \& Antiq. F. C. XXVI.)

Symonds, F. G. White Swallow in Dorset. (Field, Sept. 22.)

Thomas, R. H. Pellets ejected by Woodpigeons. (OP. cit., Jan. 27.)

I907. Cambridge, O. P. Variety of Nightjar. (Zool.)

Grafton-Wignall, J. D. Black-tailed Godwit in Dorset. (Field, Oct. 5.)

Hammond, C. E. Glaucous Gull at Portland. (Field, March 2.) Linton, E. F. Great Grey Shrike in Dorset. (Zool.)

Igo8. Wray, H. G. Swans at Abbotsbury. (Field, Sept. 5.)

I909. [Anon.] Dorset Farmers and Lapwing. (Bird Notes \& Neies, III.)

Hudson, W. H. Afoot in England. Lond. : [Chapter on Abbotsbury Swannery.]

Igro. Parkinson-Curtis, W. The Birds of Poole Harbour. $(\mathrm{Pr}$. Dorset N. H. \& Antiq. F. C. XXXI., p. 44.)

Portman, M. W. Snow Bunting in Dorset. (Br. Birds, III.)

IgII. Ticehurst, N. F. and Jourdain, F. C. R. Distribution of Nightingale. (Brit. Birds, V.) [partim.]

I9I2. Ashford, W. J. Ringed or Bridled variety of Common Guillemot. (Zool.)

Cambridge, O. P. Merlin [in Dorset.] (T.c.)

IgI4. Parkinson-Curtis, W., and Curtis, E. H. Bird Life [in a Natural History of Bournemouth and District, pp. 28r-92.] (Bournemouth Nat. Sci.Soc.; r9I4.) [Refers largely to S. E. Dorset.]

Penrose, F. Blackheaded Gulls and Razorbills. (Br. Birds, VIII.) Chiffchaff in Dec. (T.c.)

IgI4-I7. Parkinson-Curtis, W. Phenological reports on first appearance of birds, etc. in Dorset during I9I3-I6. (Proc. Dorset N. H. Club, I9I4-I7.)

I9I5. Ashford, W. J. Unusual Nesting Site of Cirl Bunting in Dorset. (Br. Birds, IX.) : Notes on pair of Black Redstarts in Dorset. (T.c.)

Penrose, F. Chiffchaff in Dorset in December. (Br. Birds, VIII.)

I9I7. Blathwayt, F. L. Nesting of Marsh-Warbler in Dorset; Roseate Tern in Dorset. (Brit. Birds, XI.)

[Evans, Lt. Col. J. W.] Spoonbills in Dorset. (T.c.)

Sheridan, A. A. The Little Owl in Dorset. (Field, Aug. I8.)

IgI8. Acland, C. M. Golden Oriole in Dorset. (Brit. Birds, XII.)

Ashford, W. J. Little Owl breeding in Dorset; Supposed breeding of Greater Blackbacked Gull in Dorset; Pied Flycatcher in Dorset. (T.c.) 
[Parkinson-Curtis, W.] Continental Coal-Tits in Dorset: British Willow-Tits in Dorset. (Brit. Birds, XI.)

Williams, A. R. Winter birds in mid-Dorset. (Avicult. Mag., pp. $125-30,162-5$.)

\section{DURHAM.}

I8II. Mackenzie, E. View of the County of Northumberland and parts of Durham. 2 vols. 8vo. Newcastle: I8II. Idem. 2nd. edit. 2 vols. 4 to. Ib. I825. [372.]

I8I6. Sharpe, Sir Cuthbert. History of Hartlepool. 8vo. Durham: I8I6. 2nd. edit. 8vo. Hartlepool : I85I. [525.]

1824. Hogg, J. Golden Eagle near Mouth of Tees. [This was probably a White-tailed Eagle, G. B.] (Zool. Jnl., I., p. 276.)

1829. Hogg, J. Catalogue of most of the Birds known to frequent the Country near Stockton. (In Brewster's Parochial History and Antiquities of Stockton-on-Tees, 2nd. edit. appdx., II.) 8vo. Stockton-on-Tees: I829. [296.]

I83I. Selby, P. J. Catalogue of Birds hitherto met with in Northum berland and Durham. (Tr. N. H. Soc. Northumb. \& Durh.) [52I.]

1832. Fox, G. T. Rare Birds recently killed in .... Durham. (Op. cit.)

1837. Hancock, A. Falco rufipes [shot between S. Shields and Marsden Rocks.] (Mag. Zool. \& Bot., I., p. 49I.)

I839. Hancock, J. Lestris parasiticus [shot near Whitburn.] (Ann. N. H. II., p. I59.)

1845. Hogg, J. Catalogue of Birds observed in S. E. Durham and N.W. Cleveland, 3 pts. (Zool.) Addit. by W. Backhouse. (T.c. I846.) Also reprinted separately. 8vo. London : I845. Idem. (Abstract.) (Rep. Brit. Assoc. for 1844.) [296.]

1846. Proctor, W. List of Birds. [In Rev. G. Ornsby's Sketches of Durham.] 8vo. Durham: I846. [48I.]

1848. Bold, T. J. Honey Buzzard near Beamish. (Zool.)

Dale, J. Nesting of Siskin near Durham. (T.c.)

Duff, J. Hoopoe near Sunderland. (T.c.)

1849. Duff, J. Ornithological Observations at Bishop's Auckland; Occurrences at Bishop's Auckland, 7 notes; Avocet at Tees Mouth. (Zool.)

1850. Duff, J. Osprey at Hartlepool ; Crested Tit on Sunderland Moor; Rare Anatidæ near Bishop's Auckland. (Op. cit.)

Grey, J. Waxwing near Stockton-on-Tees. (T.c.) 
185I. Duff, J. Rare Birds at Bishop Auckland; Waxwing near Bishop Auckland. (Op. cit.)

1852. Calvert, R. [Heronry at Gainford.] (Nat. [Morris's], II.)

Martin, W. Rare birds at Stockton-on-Tees. (T.c.)

Newton, A. Cedar Bird in England. (Zool.)

Rudd, T. S. Heronry [near Sedgefield]; Rare birds at Tees Mouth. (Nat. [Morris's], II.)

I853. Martin, W. Jer-Falcon [errore for Peregrine] on the Tees, [and other records of rare Birds.] (Nat. [Morris's], III.) I2 notes. Tristram, H. B. Little Auk in City of Durham; Great Snipe near Durham. (Zool.)

I855. Sowden, G. Late appearance of Ring Ouzel ; Nest of Grasshopper Warbler. (Nat. [Morris], V.)

I856. Bold. T. J. Crossbill breeding in N. of England. (Zool.)

Sowden, G. Wryneck [at Houghton-le-Spring.] (Nat. [Morris's], VI.)

Tristram, H. B. Pelican found dead on coast. (Zool.)

1858. Yellowley, W. Honey Buzzard [near S. Shields.] (Field, Oct. 2.)

"H. H. W." The Hoopoe [at Whitburn.] (Op. cit., May 7.)

I860. "J. S." Cormorant shot in the Wear. (Field, March 3.)

[Anon.] Seafowl at S. Shields. (Op. cit., Dec. 15.$)$

I862. Horsfall, W. C. Black Stork near Hartlepool. (Zool.)

I863. Tristram, H. B. Pallas's Sand Grouse in Durham. (Op. cit. \& Field, June 20.)

1864. (Hartlepool Free Press.) Polish Swan at Hartlepool. (Field, Ap. 2.)

I866. Chipchase, C. Ornitholog. Notes from Barnard Castle. (Zool.) Thorp, R. Northern Diver [at Stockton]. (Field, Feb. I7). Tristram, H. B. Egyptian Geese at Stockton-on-Tees. (Zool.) Yellowley, W. Bernicle Goose and Short-eared Owl at S. Shields. (Field, Oct. 27.)

I868. Gurney, J. H. Rare Captures in Darlington; Rare Sea Birds in Darlington. $(O p$. cit. $)$

Lister, W. Honey Buzzard at Yarm. (T.c.)

I870. Gurney, J. H. junr. Greyheaded Wagtail at Gateshead. (Op. cit.) Idem, by J. Watson. (T.c.) Idem, by J. H. Gurney. (Op. cit., I87I.)

I87I. Abbott, T. W. Waxwings at West Hartlepool. (Field, Sept. I6.)

Crawhall, J. E. Alpine Swift in Durham. (Field, Aug. 5.) Johnstone, J. C. H. Wild Swans in Co. Durham. (Field, Mar. 4.)

Wilcox, L. The Whimbrel in Durham. (Op. cit., Sept. I6.) 
I872. Dunn, J. Large flocks of Wood Pigeons in Durham. (Field, March 2.) Grimshaw, C. Idem. (T.c., Mar. 9.) Sclater, J. Idem. (T.c., Mar. 23.) Description of White's Thrush obtained in Castle Eden Dene. (Zool.)

Harting, J. E. Existing Heronries in Gt. Britain. (Field Feb. I7, Mar. 9.) [partim.]

Sclater, J. White's Thrush in Durham. (T.c., Feb. 24.) Idem by J. C. H. Johnstone. (T.c., Feb. 24.)

1873. Sclater, J. Range of the Stock-Dove [breeding in Castle Eden Dene.] (Field, May 3I.)

1873-76. Sclater, J. Ornitholog. Notes from Castle Eden, 9 papers. (Zool., I873-76.)

1874. Hancock, J. Catalogue of Birds of Northumb. and Durham. (Tr. N. H. Soc. Northumb. \& Durh.) [267.]

1875. Doubleday, H. Critical Notices of Cat. of Birds of Northumb. and Durham by Hancock. (Zool.) Idem. Remarks by J. H. Gunney. (Op. cit., I876.)

Storey, T. J. Siskin nesting near Durham. (T.c.)

1876. Gurney, J. H. Avocet, Pectoral Sandpiper and Black Tern in Durham, 2 notes. (Op. cit.)

1877. Cordeaux, J. On Migration on N.E. Coast in Autumn of 1876 . (Op. cit.)

Clifton, Lord. Supposed Occurrence of Red-throated Pipit in Sunderland. (Field, Apr. 28.)

Sclater, J. Reported Occurrence of Golden Eagle in Durham; Scarcity of Wood Pigeon and Increase of Stock Dove in Durham. (Zool.)

I879. Yellowley, A. Fulmar Petrel on Durham Coast. (Field, Jan. 4.)

I880. Archer, H. T. Buzzard in Co. Durham. (Field, Nov. I3.)

Nelson, T. H. Pomatorhine Skuas on Durham Coast. (Zool.)

Sutton, J. Spotted Crake in Co. Durham. (Field, Sept. Ir.)

Thompson, C. D. Great Grey Shrike [near Seaton Carew.] (Field, Nov. 27.)

[I880-9o ça.] Kerr, H. The Birds of Northumberland and Durham, series of articles. (Newocastle Weekly Chronicle.)

I88I. Archer, H. T. Little Gull on Durham Coast. (Field, Dec. 3.)

I882. Cullingford, J. Great Grey Shrike at Durham. (Zool.)

Nelson, T. H. Baillon's Crake in Durham. (Field, Oct. 7.)

I883. Archer, H. T. Osprey in Co. Durham. (Field, Dec. I.)

1884. Calvert, R. Notes on Geology and Nat. Hist. of Co. of Durham. 8vo. Bishop's Auckland: I884. [II6.]

Clarke, W. E. Hawfinch breeding in Durham. (Nat.) 
Green, W. Bird Notes during Winter of I880-8I. (Tr. N. H. Soc. Northumb. \& Durh.)

Hancock, John. Sabine's Gull in Co. Durham. (T.c.)

Manson, R. T. Zig-zag Ramblings of a Naturalist. Sm. 8vo. Darlington : I884. 2nd. edit., I898. [378.]

Middleton, R. M. Pied Jackdaw at Castle Eden. (Zool.)

Robson, T. Late nesting of Yellowhammers and Sparrows. (Young Nat. Sept.)

Tristram, H. B. Address to Tyneside Nat. F. C. Birds observed at Blanchland and Benfieldside. (Tr. N. H. Soc. Northd. E Durh.)

I885. Backhouse, J. junr. Notes on Avifauna of Upper Teesdale. (Nat.) Idem. Additions. (Op. cit., I888.)

Hancock, J. Sabine's Gull shot at Seaham Harbour. (Tr. N.H. Soc. Northumb. of Durh.)

Lofthouse, R. Notes from the Tees. (Field, Oct. 3I.)

Robson, J. E. Fulmar at Hartlepool. (Young Nat.) Solitary Snipe in Co. Durham. (Field, Oct. Io.)

Thompson, C. Donald. White Grouse at Edmondbyers. $(O p$. cit., Jan.)

Thompson, T. Bird nesting in Sept. (Op.cit., Oct. 3I.)

I886. Cambridge, J. Iceland Gull at Hartlepool. (Young Nat.)

Chapman, Abel. Wood Pigeons. (Field, Apl. I7); BrentGeese. (T.c., Nov. 27.)

Dixon, J. Great Northern Diver at Hartlepool. (Young Nat.) Embledon, D. Note on Birds seen at Nest House, Felling Shore, I884. (Tr. N. H. Soc. Northumb. \& Durh.)

Middleton, R. M. Partial albinism in Corvus monedula at Castle Eden. (Proc. Linn. Soc.)

Lebour, G. A. Outlines of Geology of Northumb. \& Durh. Post 8vo. Newcastle: I886. [345.]

Nelson, T. H. Grouse and the snowstorm. (Field, Feb. 13; Nat.; Zool.) The severe weather of May r 886 and Swallows. (Nat.)

Reed, J. T. T. Pochard and Hooded Crow in Durham. (Nat.) Immense flocks of Skylarks on Durham Coast (T.C.) Grouse and the severe weather. (T.c.)

Robson, J. E. Fulmar Petrels near Hartlepool. (T.c.) ; Stormy Petrel and Red-throated Diver at Hartlepool. (Young Nat.) Little Gull shot near Sunderland. (T.c.)

Summerson, T. R. Whitewinged Rook at Houghton-le-Skern. (Field, Nov. 20.)

1886-87. Chapman, A. Little Gull in Co. Durham, 2 notes. (Zool., I886-87.)

188\%. Chapman, A. Wildfowl, their haunts and habits. (Field, Jan. 22, Mar. 12, 26.) 
Fortune, R. Ornitholog. Notes from .... Durham during I885. (Nat.)

Lofthouse, R. The River Tees : the Marshes and their Fauna. (T.c.)

Robson, J. E. Honey Buzzard at Hartlepool. (T.c.)

I888. Hedworth, T. H. Nesting of Hawfinch at Newcastle. $(O p$. cit.)

Mosley, S. L. Sand Grouse breeding in Durham. (Zool.)

Nelson, T. H. Pallas's Sand Grouse between Bishop Auckland and Byers Green. (Nat.) Idem. (Field, June 9.)

I889. Bolam, G. Visitation of Pallas's Sand Grouse. (Hist. Berw. Nat. $\mathrm{Cl}$., XII. p. 550.)

Cambridge, J. J. Quail at Hartlepool. (Young Nat.)

Lebour, G. A. Handbook to Geology and Nat. Hist. of Northumb. \& Durh. (Brit. Assoc. Handb.) Newcastle-on-Tyne: I889. [345.]

Mann, J. A. Great Northern Diver at Hartlepool. (Young Nat.)

Reed, R. A. The Great Auk in Britian [ref. to remains near Marsden Rock. (Research, May.)

Sutton, J. Nesting of Black Redstart in Durham. (Zool.)

1890. Aplin, O. V. Distribution of Spotted Crake. (Op.cit.) [partim.]

Bolam, G. Occurrence of Pallas's Sand Grouse. (Pr. Berw. Nat. Cl., I889.)

Fawcett, J. W. The Birds of Durham. 8vo. Consett : I8go. [205.]

Fawcett, J. W. Tree Sparrow in Co. Durham, 2 pts. (Nat. Sept.)

Lofthouse, R. Bird Notes from the Tees District, I889-90. (T.c.)

Macpherson, H. A. The Goldfinch [scarcity in Co. Durham.] (Field, Aug. 9.)

Nelson, T. H. Bird Notes from Redcar and Teesmouth for I889-9o. (Nat.; Zool.)

Philipson, J. Pallas's Sand Grouse in Durham. (Tr. N. H. Soc. Northumb. \& Durh.)

Thompson, T. Willow Wren in Jan. (Field, Jan. 25.)

I89I. Cambridge, J. J. Kingfisher at Hartlepool. (Brit. Nat.)

Fawcett, J. W. Notes on the Birds of the Derwent Valley. (Vale of Derwent Nat. F.C. Trans.)

Nelson, T. H. Note as to Crested Tit shot on Sunderland Moor. (Nat.)

I892. Aplin, O. V. Status of the Woodchat. (Zool.) [partim.]

Harting, J. E. Bones of Great Auk found in Caves at Whitburn Lizard. (T.c.)

Hildyard, H. Quail in Durham. (Field, Oct. 8.)

Lydekker, R. On British Fossil birds [ref. to remains of Alca impennis in deposits in Cleadon Hills.] (Ibis, July.) 
Sutton, J. Pied Rooks and Pied Daws near Durham. (Zool.)

I893. Chapman, A. C. Lesser Whitethroat in Co. Durham. (Zool.) Idem, by H. H. Slater. (T.c.)

I896. Backhouse, J. Upper Teesdale, Past and Present. Cr. 8vo. Barnard Castle: I896. [34.]

Robson, T. Birds of the Derwent Valley. 8vo. Consett : I896.

I900. Fawcett, J. W. The Wryneck as a Durham Bird; The Hawfinch as a Durham Bird; Stone Curlew in South Durham. (Nat.) Ritson, F. W. A Ramble in North West Durham. (Nat : May.)

Igor. Fawcett, J. W. The Nuthatch as a Durham Bird; The Waxwing as a Durham Bird; Pink-footed Goose in Co. Durham. (Nat.)

Nelson, T. H. Glossy Ibis in Co. Durham. (Nat. May; Zool. May.)

I902. Braithwaite, C. Little Bunting at Durham. (Zool.)

Milburn, C. E. Occurrence of Little Bunting at Tees Mouth. (Nat.)

Tristram, H. B. Curious accident to a Kingfisher. (Zool.)

Ig03. Nelson, T. H. Little Bunting in Durham. (Ibis.)

Robson, T. Migration of Birds, Fauna of the Derwent Vasu, (Vale of Derwent Nat. F.C. Trans.)

I905. Bidwell, E. Exhibition of Dendraca astiva from Axwell Park. (Bull. B. O. C., XV.)

Tristram, H. B. Birds. [In Victoria Hist. of Co. of Durham, I.] 4to. Lond. : I905. [589.]

I908. [Anon.] [Ref. to Birds in Derwent Valley.] (Vale of Derwent Nat. F. C. Trans.)

I909. Fawcett, J. W. Crossbills in Durham. (Nat.)

IgII. Aplin, O. V. Honey Buzzard breeding in Durham. (Zool.) Fawcett, J. W. A History of the Parish of Dipton, Durham, IgII.

[Contains "The Birds of Dipton Parish."]

IgI8. Thaw, A. Red-legged Partridge in Co. Durham. (Field, Nov. I6.)

ESSEX.

I730. Dale, S. History and Antiquities of Harwich and Dovercourt. 4to. Lond.: I730. 2nd. edit. 4to. Ib. I732. [I60.]

I825. Yarrell, W. Notice of the Occurrence of some rare British Birds. [Little Bustard at Harwich.] (Zool. Journ., II.) 


\section{A PRACTICAL HANDBOOK OF BRITISH BIRDS.}

Edited by H. F. Witherby, M.B.E., F.z.S., M.B.O.U. Contributed to by E. HARTERT, PH.D., M.B.O.U., A. C. JACKSON, H.M.B.O.U., Rev. F. C. R: JoURDAIN, MI.A, M.B.o.U., C. OLDHAM, M.B.o.U., and N. F. TrCenURST, M.A., F.R.C.S., M.B.O.U. With Coloured and Monochrome Plates and many Text Figures. Practical-OriginalUp-to-date. Prospectus on application. In I 8 Parts (2 Volumes). Now in course of Publication. Demy 8vo. Per Part 45 . net.

TROPICAL WILD LIFE IN BRITISH GUIANA.

Being Zoological Contributions to Science, from the Tropical Research Station of the New York Zoological Society, at Kalacoon, igr6. By William Beebe, G. Inness Hartley and Paul G. Howes, with an Introduction by Colonel. THeodore RoOsever. Octavo: Cloth, 504 pages: 4 Coloured Plates, and I 40 other Illustrations, 12s. Gd, net.

\section{A MONOGRAPH OF THE PHEASANTS.}

By William 13eebe. With Numerous Coloured Plates by A. Thorburn, C. R. Ínigit, G. E. Lodge, L. A. Funrtes, H. GronVold, and $H$. Jones. Together with Maps and Numerous Photo. graphs by the Author, depicting the Pheasants of the World, their Haunts, their Changes of Plumage and their Nests and Eggs. Limited Edition of 600 Numbered Sets, only a portion of which are available for sale in the British Empire. Royal 4 to. In Four Volumes, Volume I now ready. Prospectus and Specimen Plate on application $\quad$ Per Vol E12 ros. net.

A HAND-LIST OF BRITISH BIRDS.

By Ernst Hartert, F. C. IR. Jourdain, N. F. Ticenurst, and H. F. Witherby, Demy 8 vo 7 s: $6 \mathrm{~d}$, net. Interleaved Ios. net:

A DICTIONARY OF ENGLISH AND FOLKNAMES OF BRITISH BIRDS.

By H. Krrke Swann. Their History, Meaning, First Usage, the Folklore, Weather-lore, Legends, etc. Demy $8 \mathrm{vo}$. ros. net

GAME BIRDS AND WATER-FOWL OF SOUTH AFRICA:

By the late Major BOYD Horsburgu, r.z.s., M.в.o.v. IVith 67 beautiful Coloured Plates. Half moroccu. ff I 4 s, net, or unbound parts:

INDIAN PIGEONS AND DOVES.

By E. C. StuArT BAKBr, T.z.s., M.B,O.U. With 27 beautiful

Coloured Plates. Imp. Svo. Half bound morocco. f2 Ios, net.

PHOTOGRAPHY FOR BIRD-LOVERS.

By Bentley Bertham, r.z.s. I 6 full-page Plates. A practical guide to the pursuit of bird-photography in all its branches, the author's methods being described in great detail. Demy 8 vo. Cloth.

JUNGLE PEACE

By William BeEbe. Contains " records of extraordinary scientific interest, in language which has all the charm of an essay of Robert Louis Stevenson. The author tells of bird, beast, plant and insect life of the British Guiana jungle. Crown 8vo., illustrated. 8s. net. 
Now Read $y$.

\section{A HANDBOOK TO THE VERTEBRATE FAUNA OF NORTH WALES}

By $\mathrm{H}$ : E: FORREST,

This book not only brings up to date the information contained in the Author's "Vertebrate Fauna of North Wales," but also gives under each species a brief summary showing its status in the district. Just the information required by the Naturalist resident in or visiting North Wales is thus provideu in a concise form.

Demy svo.

Cloth.

68. net:

Now Ready:

\section{METEOROLOGY FOR ALL.}

BEING SOME WEATHER PROBLEMS EXPLAINED

By DONALD. W: HORNER, r.R.MET.SOC., etc.

Author of "Observing and Forecasting the Weather."

"Weather Instruments and How to Use Them."

IVith Text and Half-Tone Illustrations.

A compendium of information abnat the Weather as it daily affects the lives of everyone. The "dry" terseness of the text.book has been avoided, but the information given is comprehensive and reliable, and of a practical nature.

Crown Svo.

Cloth:

Illustrated:

6s. net:

BRITISH BIRDS.

AN ILLUSTRATED MONTHLY MAGAZINE

Devoted to the Birds on the British List.

Edited by .H. F. WITHERBY, M.B.E.; F.Z.S.; M.B.O.U., Assisted by Rev. F. C. R. JOURDAIN, M.A., M.B.O.U., and N. F. TICEHURST, M.A., F.R.C.S M.B.O.U.

ILLUSTRATED IVITH BEAUTIFUL AND USEFUL PHOTOGRAPHS.

Provides a current history of British Birds.

Very few complete sels remain for sale, and early applicalion should be made.

ANNUAL SUBSCRIPTION, 18/- POST FREE; MONTHLY, 1/6 NET.

Vols, I-XII, (unbound), 12/- each; bound, 15/6 each net.

326, HIGH HOLBORN, LONDON, W.C.I. 


\title{
GEOGRAPHICAL BIBLIOGRAPHY
}

\section{BRITISH ORNITHOLOGY}

\author{
FROM THE EARLIEST TIMES \\ IO THE FND OF 1918 \\ ARRANGED UNDER COUNTIES
}

BEING A RECORD OF PRINTEN BOOKS, PUBLISHED ARTICI,A, NOTES AND IRECORDS' REIATING TO LOCAT, AVIFAUNA

Br

W. H. MULLENS, M.A., LL.M., F.L.S., M.B.o.U., H. KIRKE SWANN, F.Z.S, AND REv. F. C. R. JOURDAIN, M.A., M.B.O.U.

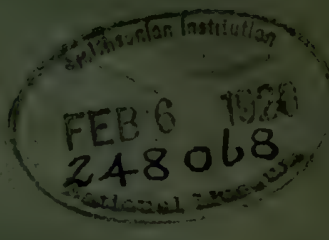

"Men that undertake only one district are much more likely to advance natural knowledge than those that grasp at more than they can possibly be acquainted with; every kingdom, every province, should hrve its own monographer."

Gilber'T White-“The Natural History of Selborp..” 7 th Lotter to Barrington.

IVITHERB \& CO. 3226, HICH HOLBORA, LONDON 

I828. Fox, G. T. Notice of appearance of some rare Birds in England. [Leach's Petrel in Essex.] (Op. cit., III.)

Yarrell, W. On occurr. of rare Brit. birds. [Pomatorhine Skua in Hackney Marsh.] (Zool., Jnl., III., p. 497.)

I829. "Lover of Nature." Remarks on the ... Bearded Titmouse [obs. made near Barking Creek]. (Loudon's Mag. N. H., II., p. 222.) Idem, V., p. 544 .

I830. Hoy, J. D. Nat. Hist. Engl. Co's : Essex. [Golden Oriole near Manningtree, etc.] (Op. cit., III., p. 436.)

I832. Pamplin, J. Alpine Warbler met with in England [nr. Epping Forest]. (Op. cit., V., p. 288.)

I833-35. Hill, W. H. Notes on Black-headed Gull; List of Birds of Southminster. (Loudon's Mag. N. H., I833-35.)

I833. Parsons, C. Black-headed Gull. (Rennie's Field Nat., I.)

I834. “J. G." On Nat. productions of Lexden: Mountain Sparrow at Lexden. (Loudon's Mag. N. H., VII., pp. I7, 5I8.)

IS35. Doubleday, H. Greyheaded Wagtail [shot at Walton-on-Naze]. (Op. cit., VIII., p. 6I7.)

Doubleday, E. Remarks on the Entomology of Epping and its Vicinity. 2 pts. (Entomol. Mag., III.)

I837. Doubleday, H. Note on the Habits of the Hawfinch. (Jardine's Mag. of Zoology, I.)

Clarke, J. Notes on and Notices of the Crossbill [at Saffron Walden]. (Charlesworth's Mag. of Nat. Hist., I. p., I64.)

Hoy, J. D. Notice of Occurrence of Two Species of Genus Tringa ... . with list of rarer Birds killed in Suffolk .. and Essex. (Charlesworth's Mag. Nat. Hist., I., p. II5.) [partim.]

I838. Burnell, E. H. [Little Auk at Witham Lodge.] (Charlesworth's Mag. Nat. Hist., II., p. 53.)

King, W. Doubleday. List of Birds found in Neighbourhood of Sudbury. (Fulcher's Sudbury Mag.) [Essex Records.] [330.]

I839. Clarke, J. Ornithological Notes: Young of Loxia curvirostra [at Saffron Walden]. (Charlesworth's Mag. Nat. Hist., III.)

I843. Atkinson, J. Note on Dates of Migration at Kelvedon; Note on Singular locality for Redstart's nest; Note on Habits of Barn Owl. [3 notes.] (Zool.)

Bond, F. Note on Birds shot at Southend. (T.c.)

Doubleday, H. Note on the Hawfinch. (T.c.)

I843-45. Doubleday, H. Notes on Arrival of Summer Birds of Passage at Epping, 4 notes. (Op. cit., I843-45.) [I76.]

I844. Barclay, $H$. Note on Arrival of Summer Birds. (Op. cit.) 
Barclay, J. G. Note on Habits of Hawfinch. (T.c.)

Greenwood, A. Note on Food of Ringdove. (T.c.)

I845. Parsons, C. Goldcrests breeding twice in same nest. $(O p$. cit.)

I846. Catchpool, T. Singular habit of Swift. (Op. cit.)

Newman, E. Australian Spine-tailed Swallow in England. (T.c.)

I847. Catchpool, T. Partridge destructive to Eggs. (Op. cit.)

I850. Barclay, F. Occurrence of Waxwing at Walthamstow: Bittern at Walthamstow; Golden Oriole near London. [Leyton.] (Op. cit.)

Green, J. Nest and Eggs of Savi's Warbler [at Dagenham]. (T.c.)

Hall, $T$. Occurrence of Redbreasted Merganser in Thames [near Barking]. (T.c.)

Newman, E. Occurrence of Osprey near Colchester. (T.c.)

I85I. "H. J. C." Heronries [Wanstead Park]. (Nat. [Morris's], I.)

Newton, A. Occurrence of Great Black Woodpecker in Essex.[?] $($ Zool.)

1852. "Londoner, A." A Memento of Hainault Forest. (Nat. [Morris's], II.)

Nunn, E. C. Little Bustard [near Chelmsford]. (Nat. [Morris's], II.)

I853. Green, J. Note on the Thrush Warbler. (Zool.)

Stride, E. C. Hawfinch [nesting in Epping Forest]. (Nat. [Morris's], III.)

I854. Catchpool, T. Occurrence of Bee-eater in Essex. (Zool.)

I855. Bramley, T. Hoopoe at Low Leyton. (Op. cit.)

Doubleday, H. White Swallow. (T.c.)

I856. Tuck, E. J. Occurrence of Rose-coloured Pastor and Hoopoe in Essex. (OP. cit.)

i858. Hall, T. [Grey Shrike at Loughton.] (Op. cit.)

"T. S. M." White Jackdaw [in Essex]. (Field, July 3.)

I859. "G. S." Peregrine shot in Essex. (Field, Oct. I5.)

I860. [Various Writers.] Ring Ouzel in Essex. (Field, Sept. I, I5.)

I86I. Bree, C. R. Little Bustard in Essex. (Zool.)

Doubleday, H. Occurrence of Parrot Crossbill at Epping. (T.c.)

Shaw, H. Collared Pratincole [in Essex]. (Field, Aug. 3r.)

I862. Barclay, W. L. Occurrence of Green Sandpiper at Leyton. (Zool.) 
Bree, C. R. Occurrence of Golden Oriole in Essex and Parrot Crossbill near Colchester: Occurrence of Hoopoe in Essex. [3 notes.] (T.c.)

"Essex." Shore Lark [near Maldon]. (Field, Nov. 29.)

I863. Bree, C. R. Pallas's Sand Grouse in Essex. (Zool.; Field, July 4, Nov. 7.) Roughlegged Buzzard. [Harwich.] (Field,
Mar. 7.)

Morris, W. Great Grey Shrike at Leyton Marsh. (Zool.)

Taylor, E. Pallas's Sand Grouse in Essex. (T.c.): Idem. (Field, June 27.)

Withers, J. Pallas's Sand Grouse near London. [Forest Gate. (Zool.)

1864. Bree, C. R. Black Swan in Essex. (Field, June 25): Idem. (Op. cit., July 9.)

Carter, S. H. American Wigeon in Essex. (Zool.): Idem. (Field, Feb. I3.)

Withers, G. Bittern at Wanstead. (Field, Feb. 20.)

1865. "E. L. M." Golden Oriole in Essex. (Op. cit., May I3.)

Jesse, W. Ornitholog. Notes: Hoopoe near Ingatestone : Whinchat's Nests in Mowing Grass. [3 notes.] (Zool.)

Legge, V. Nesting of Birds in Flatlands of Essex. (T.c.)

Ward, E. Little Owl in Essex : King Eider [err. Common Eider] in Essex. (Field, Jan. I4.)

I866. Bree, C. R. Late Stay of Nightingale: Little Bittern at Colchester, [2 notes.]. (Zool.): Idem. (Field, Aug. 25.)

Doubleday, $H$. Variety of Barn Owl at Epping: Late Stay of Lesser Whitethroat: Late Stay of Martins: Shearwater at Epping, [4 notes.] (Zool.)

Hesse, B. Grey Phalarope in Hackney Marshes. (T.c.)

Legge, W. V. Late Nesting of Sparrow: White Starling, [2. notes.] (T.c.)

I866-67. Legge, W. V. Ornitholog. and Oolog. Notes from S.E. Essex, [2 papers.] (Op. cit., x866-67.)

I867. Bree, C. R. Habits of the Rock Pipit. [Colchester.] : Singular position of Cuckoo's Egg. [2 notes.] (Op. cit.): Longtailed Duck [in Essex] ; Fork-tailed Petrel at Colchester. (Field,
Dec. I4.)

Jesse, W. Cuckoo placing Egg in Nest by means of bill : Quail nesting in Essex: Green Sandpiper near Ingatestone, [3
notes.] (Zool. $)$

Newman, E. Visit of Bohemian Waxwing. (T.c.)

I868. Bree, C. R. Egyptian Vulture near Colchester. (OP. cit.) Idem. (Field, Oct. I0, I 7 ); Eider Duck on Essex Coast. (Op. cit., Jan. 4); Idem. (Zool.) ; Fork-tailed Petrel at Colchester. (T.c.); Gannet [near Colchester.] (Field, May
I6.) 
Denny, C. Bee-eater at Kelvedon. (Sci. Gossip, IV.)

Doubleday, H. The Hawfinch at Epping. (Zool.)

I869. Bree, C. R. Fieldfare's [?] Nest at Alresford. (Field, June I2, 26) : Idem. (Zool.) Earliest appearance of Nightingale. (Field, Apr. I7 and May I5, 29.) The Cold and Hirundinidæ. (T.c., June I2.)

Clark, J. A. Little Auk at Loughton. (Zool.) Idem. (Field, I870, Nov. 26.)

Harting, J. E. Heronry at Wanstead Park. (Science Gossip.)

S[cruby], W. Pied Partridge. (Field, Nov. 20.)

Smee, A. H. Redcrested [errore for Red-breasted] Merganser on Thames: Greenshank and Lesser Tern at Leigh, [2 notes.] (Zool.)

I870. Bree, C. R. Martins: Rare Birds captured near Colchester. (Field, May 7.) [2 notes.]

Scruby, W. The Hobby in Essex. (Op. cit., Sept. 24) ; Little Auk inland. (T.c., Nov. 26.)

Smee, A. H. Black-throated Diver and Red-breasted Merganser on the Thames : Little Stint, etc., near Leigh. (Zool.)

187r. Bree, C. R. Alpine Swift seen at Colchester. (Field, June I7) : Hoopoe in Essex. (T.c., April 22): Common Whitethroat. (T.c., May I3) : Whitefronted Goose [at Brightlingsea]. (T.c., Feb. 25, Mar. 4, II.)

Collins, J. P. Pied Flycatcher in Essex. (Field, Apr. 22.)

Fox, W. Eider Duck at Southend. (Op. cit., Dec. I6.)

Glessing, J. Dotterel in Essex. (T.c., Sept. 2.)

Harting, J. E. On the recent occurrence of Red-breasted Goose in Essex. (Zool. and Field, Feb. 4.) : Poole, R. Idem. (Field, Jan. 2I.)

Handley, J. Occurrence of Smew in Essex. (T.c., Jan. I4.)

"L. A. C." Grey. Phalarope at Epping. (Field, Oct. 7.)

Poole, R. Red-breasted Goose in Essex. (Op. cit., Jan. 2I.)

Smee, A. H. Birds observed in the Thames, etc., in Winter of I870-7x : Wild Swans on the Thames. (Zool.)

I872. Doubleday, H. Ring Ouzel at Epping. (Op. cit.)

Harting, J. E. British Heronries. (T.c.) [partim.]

Stephenson, A. C. Cream-coloured Rook [at Chigwell]. (Field, May I8.)

I873. Bree, C. R. Capture of Orange-legged Hobby in Essex. (Field, June 7.); Hawfinch [abundant near Colchester]. (T.c., Feb. I.)

Curtis, E. Golden Plover at Forest Gate. (T.c., May I7.)

[Editorial.] Orange-legged Hobby in Essex: Idem, by C. R. Bree. (Zool.)

Hollis, S. Swallows and Martins in Dec. (Field, Dec. I3) : Idem, by "L." (T.c.) 


\section{ESSEX.]}

1874. Barclay, H. A. Hoopoe at Knotts Green, Leyton. (Zool.)

Bree, C. R. Green Sandpiper in Essex. (Field, May 2.)

Curtis, E., junr. Baillon's Crake [in Essex.] (Field, Oct. Io.)

Doubleday, H. Little Bittern near Epping. (Zool.)

Isaac, S. Eared Grebe in Essex. (Field, Aug. 8.)

Poole, R. Golden Oriole near Maldon. (Op. cit., June 27.)

I875. Bree, C. R. Dotterel in Essex. (Field, Sept. II) : Blackthroated Diver in Essex. (T.c., Nov. 20) : Summer Migrants at Colchester. (Op. cit., May 22) : Idem. (T.c., Nov. I3) : New British Bird [Lanius meridionalis]. (Zool.; Field,
Nov. I3.)

"E. G. D." Grey Phalarope in Essex. (Field, Oct. 9.)

Lockwood, J. A. Rare Birds in Essex. (Op. cit., Jan. 2): Eared Grebe at Walton-on-the-Naze. (T.c., Feb. I3.)

Morris, B. Supposed scarcity of Summer Bir, Feb. I3.)

May 8.)

Norman, A. H. Eider Ducks at Southend. (OP. cit., Dec. 25.)

Poole, R. Reported occurr. of King Duck at Maldon [err.

Common Eider]. (Field, Nov. 6, 20, Dec. II.)
Smee, A. H. Notes of Cruise at Mouths of Thames and Black-
water Rivers. water Rivers. (Zool.)

Townsend, C. T. Little Bustard at Walton-on-the-Naze. (T.c.)

I876. Bree, C. R. Migratory Birds at Colchester. (Field, Apr. 29.)

Grubb, J. Ornitholog. Notes. (Friends' Quart. Examiner.)

Kerry, F. Rare Birds in Essex. (Zool.)

Poole, R. Black-throated Diver in Essex. (Field, Jan. 8.)

I877. Bidwell, E. Tengmalm's Owl in Essex. (Zool.)

Bree, C. R. Golden Eagle in Essex. (Field, Mar. 24.)

Earley, W. Herons and Rooks [at Wanstead Park]. (Sci.

Kerry, F. Ornitholog. Notes from Essex: Rough-legged Buzzard and Peregrine Falcon at Harwich: Little Gulls and Kittiwakes in Essex. (Zool.)

Lee, H. Pied Flycatcher in Epping Forest. (T.c.)

Lister, A. Red-necked Grebe in Essex [Wanstead Park] : Migration of Ring Ouzel. (T.c.)

I878. "A. T. C." Late Stay of Swift. (Field, Oct. 5.)

Bree, C. R. My Summer Visitors. (Op. cit., June 29): [Virginian Quail.] (T.c., June 22.) : Occurrence of Purple Martin and Norfolk Plover at Colchester. (Op. cit., Oct. 5) : Hawfinch [in Colchester]. (T.c., Nov. 30, Dec. 3I): Purple Gallinule [errore for Green-backed] in Essex. (T.c., Nov. I6, 30, I879,
Jan. 4.) Idem, by J. H. Gurney. (T.c., Nov. 23.)

Christy, R. M. Cuckoo laying twice in same nest.

(Zool.) 
Laver, H. Sandmartins nesting in Stone Walls. (Field, June I.)

"Ranger." Early Snipe at Forest Gate. (Op. cit., July I3.) Russell, C. Notes on Common Birds in my Garden. (T.c., June and Aug.)

Strutt, C. H. [Melanistic Partridge in Essex.] (Field, Sept. 2I.)

I879. Baxter, G. H. Skuas and Scops Eared Owl at Southend. (Field, Oct. 25.)

Bevington, H. S. Purple Sandpiper, etc. at Walton-on-Naze. (Field, Nov. 8.)

Bree, C. R. Gallinago major [in Essex]. (Op. cit., Sept. 6, 20.) [2 notes.] Idem, by J. E. Harting. (T.C., Sept. I3.)

Harting, J. E. An ancient decoy [in Essex]. (Field, July I2.)

Kerry, F. Winter Visitants at Harwich: Late Stay of Brent Goose at Harwich: Black Redstart in Essex: Immigration of Rooks, etc. at Harwich. [4 notes.] (Zool.)

Smoothy, C. Great Bustard in Essex. (Field, Dec. I3.)

"T." Rare Birds on the Stour. (T.c., Dec. 27.)

Thompson, G. A. Bittern in Essex. (T.c., Nov. 29.)

Vaughan, M. Distribution of Carrion Crow [in Essex]. (Zool.)

Wallis, H. M. Ring Ouzel nesting in Essex. (T.c.)

I880. Andrews, L. W. H. Fawn coloured variety of Swallow. (Field, Nov. I3.)

Bree, C. R. Notes about Birds. (Op. cit., Jan. Io.) Assemblage of Long-eared Owls. (T.c., Jan. 24.)

"C. F. M." Tree Sparrow in Essex. (Op. cit., Oct. 29.)

Christy, M. Great Bustard in Essex. (Zool.): On occurrence of Great Bustard and Rough-legged Buzzard near Chelmsford. (Tr. Essex F. C., I.)

Clifton, Lord. Hobby nesting in Essex. (Zool.)

Day, George. The Birds of Essex. (Chelmsford Chronicle, Aug. 6th to Sept. I7th, I880.)

English, J. List of Birds of Epping Forest. [In Appdx. to R. Meldola's Inaug. Address.] (Tr. Essex F. C., I.)

Frost, E. Rough-legged Buzzard in Essex. (Ficld, Jan. 3.)

Kerry, F. Rare Birds at Harwich: Singing Powers of the Great Grey Shrike. (Zool.)

Raynor, G. H. Hoopoe in Essex; Early appearance of Fieldfares. (Field, Oct. 2.) [2 notes.]

Reid, S. G. Strange Nesting Community. (Zool.)

Sizer, C. F. Hoopoe near Chichester [errore for Colchester]. (Zool.; Field, May 8.)

Smith, H. Nightingales at Southend. (Field, Apr. 24.) Smoothy, C. Great Bustard in Essex. (Zool.) Idem- by J. E. Harting and T. Travis. (T.c.) [3 notes.]

Travis, T. Great Bustards in Essex. (Field, Feb. I4.) 
I88I. Bree, C. R. Birds taken in neighbourhood of Colchester I880-8I (Field, Apr. 23, 30.) [2 notes.]

Curtis, E., junr. Buzzards in the Thames Marshes [between Barking and Rainham]. (T.c., Jan. 29.)

"C. F. M." Tree Sparrows in Essex. (Field, Oct. 29.)

"J." Honey Buzzard in Epping Forest. (Op. cit., Oct. I.)

Kerry, F. Night Heron at Dovercourt: Autumn Migration of Birds on E. Coast. (Zool.)

1882. Bree, C. R. Solitary Snipe in Essex. (Field, Jan. 7.)

Delf, W. Young Partridges in March. (T.c., March 25.)

Kerry, F. Migration of Birds at Harwich. (Zool.)

Laver, H. Late Stay of House Martins. (Field, Nov. II.)

I883. Christy, R. M. Golden Oriole in Essex. (Zool.)

"E. C." Waxwings in Essex. (Field, Jan, 20.)

"J. H." Nightjar breeding in Epping Forest. (T.c., Jan. I3.)

Kerry, F. Rare Birds at Harwich. (Zool.)

Laver, H. Pale Variety of Jay. (T.c.)

Mann, T. J. Common Tern at Farnham, Essex. (Field, Sept. I5.)

Smoothy, C. Unusual position for Woodpecker's nest. (T.c., Sept. I5.)

Travis, J. Arrival of Waxwings. (Field, Jan. 27.) [partim.]

I884. Buxton, E. N. Epping Forest. I2mo. Lond. : I884. And later editions. [II3.]

Cooper, J. A. Grey Shrike in Essex. (Field, Oct. 25.)

Knights, J. H. H. Black-headed Gull breeding in Essex. (OP. cit., Mar. I5.)

Laver, H. Little Bittern at Colchester. (Zool.)

Williams, E. W. Dun-coloured Rook [at Romford]. (Field, May 24.)

I885. Lister, A. Bird Life in Wanstead Park. (Zool.)

Ward, R. Little Bustard in Essex. (Field, Sept. I9.)

I886. Glessing, J. Sand Grouse [at Wanstead]. (Op. cit., Jan. 23.)

Hanbury, S. Hoopoe in Essex. (Op. cit., Sept. II.)

Smoothy, C. Heronries in Essex. (Op. cit., June I9.)

I887. Bird, M. C. H. Sheldrake or Bar-Goose on Essex Coast. (Zool.)

Christy, M. [edited by.] Durrant's Handbook for Essex. I2mo. Chelmsford: I887. [128.]

Durham, E. B. Long-tailed Duck at Southend. (Field, Nov. rg.)

$\mathrm{H}$ [arting, J. E.] The Birds of Epping Forest. [In Lindley's Walks in Epping Forest.] Oblong 8vo. Lond.: I887.

Laver, H. Solitary Snipe near Colchester. (Field, Sept. I7.) Marriott, C. A. Glaucous and Iceland Gulls on Essex Coast. (Zool.) 
I888. “A. F." Rough-legged Buzzard in Essex. (Field, Dec. 8.)

Brooks, R. Hobby catching a Swift. (Op. cit., June 2.)

Catchpool, E. Present Visitation of Sand Grouse [Essex]. (T.c., June 2.)

Christy, R. M., and Fitch, E. A. Visit to an Essex Gullery. (Essex Nat.)

Cooper, J. A. Pallas's Sand Grouse [in Essex] ; Grey Phalarope in Essex. (Field, Dec. 8.)

Crouch, W. Pallas's Sand Grouse [in Essex]. (Op. cit., June 9.)

Durham, E. B. Jerfalcons at Southend. (Op. cit., Dec. 22.)

Enson, W. C. Scops Owl in Essex. (Op. cit., June 23.)

Fitch, E. A. Summary of Occurrences of the Sand Grouse in Essex, [3 pts.] (Essex Nat.)

Gates, A. F. Pallas's Sand Grouse in Essex. (Zool.) Idem, by M. A. Mathew. (T.c.)

Grant, W. R. Ogilvie. Black Redstart [errore-Robin] nesting in Essex. (Zool.)

Hanbury, C. Golden Oriole and Hawfinch in Essex. (Field, Dec. 8.)

Harting, J. E. Wildfowl Decoys in Essex, [2 pts.] (Essex Nat.)

" J. G." Grey Phalarope in Essex. (Field, Dec. I.)

Marsden, W. Late Swallows in Essex. (T.c., Dec. I.)

Smoothy, C. Honey Buzzard in Essex. (Op. cit., June 2.)

Suckett, W. R. Hoopoe in Essex. (T.c., May 5.)

I889. Battcock, G. A. A day's Hawking with Mr. T. J. Mann. (Field, May II.)

Christy, M. Reported Nesting of Black Redstart in Essex. (Zool.) Black Redstart in Essex. (Field, April 6.)

Crouch, W. Pallas's Sand Grouse in Essex. (Essex Nat.)

Gates, A. F. Thick-knee in Essex in Jan. (Zool.) Uncommon birds in Essex. (Field, Oct. I9.)

Gunn, E. W. Hen Harrier and Red-breasted Merganser in Essex. (Zool.) [2 notes.]

Hatton, L. Sand Grouse in Essex. (Field, July 27.)

Jesse, W. junr. Nesting of Black Redstart in Essex. (Zool.)

Kerry, F. Short-eared Owls breeding in Essex: Spotted Redshanks near Harwich. (T.c.) [2 notes.]

Laver, H. Crane near Colchester. (T.c.)

Mathew, G. F. Occurrence of Crane in Essex. (T.c.)

Sewell, W. Wild [White-fronted] Goose caught in Decoy [at Tillingham]. (Field, April 6.)

I8go. Aplin, O. V. On Distribution and Period of Sojourn in Brit. Isles of Spotted Crake. (Zool.) [partim.]

Cardinall, D. E. Woodcock nesting in Essex. (Field, Apr. I2.)

Christy, R. M. The Birds of Essex. 8vo. Lond.: I8go. [I29.]

Christy, R. M. Former Occurrence of Collared Pratincole in Essex. (Zool.) 
Harting, J. E. Little Gull on the Thames. (T.c.)

Kerry, F. Little Gull and Great Grey Shrike near Harwich [2 notes.] (T.c.)

Russell, Col. Some unpublished Letters on Ornithology. (T.c.)

Sewell, W. Great Bustard in Essex. (Field, Dec. 20.)

I89I. Doyle, F. A. Night Heron in Essex. (Field, Dec. I9.)

Gates, A. H. Grey Phalarope in Essex. (Zool.)

Harting, J. E. The recent visitation of Bustards. (Field, Feb. 28.) [partim.]

Kerry, F. Pied Flycatcher near Harwich: Ornitholog. Notes from Harwich: Short-eared Owls in Essex in May: Dimensions and Weight of Glaucous Gull. (Zool.) [4 notes.]

Laver H. Wildfowl in Essex: Notes from Essex: Capture of Spotted Eagle near Colchester. [3 notes.] (T.c.) : Bitterns near Colchester (Field, Jan. I7) ; Spotted Eagle at Colchester. (Op. cit., Nov. I4.)

Owen, H. G. Skua and Grey Phalarope in Essex. (T.c., Nov. 2I.)

Savory, R. H. Baillon's Crake in Essex. (T.c., Nov. 28.)

1892. Aplin, O. V. On Distribution of Cirl Bunting in Great Britain [partim]: Status of the Woodchat in Great Britain [partim.] (Zool.)

Bryoks, R. White Stork in Essex. (Field, Aug. 27.)

Christy, M. Spotted Eagle in Essex. (Zool.)

Gates, A. F. Bird Life in Wanstead Park. (Nat. Jnl.)

Hawkins, E. W. Quail nesting in Essex. (Field, Nov. I2.)

Owen, H. G. Bittern in Essex. (Op. cit., Feb. I3.)

I893. Bateman, J. Herons and Rooks. (Op. cit., May 20.)

Gates, A. F. A Visit to Thorndon Park. (Nat. Jnl.)

Kerry, F. Iceland Gull and Waxwings at Harwich: Waxwings in Essex. [3 notes.] (Zool.)

Laver, H. Bullfinches and Lilac Seeds. (T.c.)

Smoothy, C. Rough-legged Buzzard in Essex. (Field, Mar. II.)

"W. A. N." Marsh Harrier in Essex. (T.c., Feb. Ir.) ; Idem, by "A " (T.c., Feb. I8) ; by "W. R. B." (T.c., Mar. 4, I8); by J. J. Meakes. (T.c., Mar. II.)

I894. Sapsworth, A. D. Hawfinch in Epping Forest. (Zool.)

Smoothy, C. Rough-legged Buzzard in Essex. (Field, Jan. 20.)

I895. Durham, E. B. Wild Swans in Essex. (Op. cit., Mar. 2.)

"F. C. P." Shorelarks at Felixstowe. (T.c., Mar. 2.)

I896. Cooper, J. A. Woodpeckers near London. (Sci. Gossip, Feb.)

Fitch, E. A. Nesting of Short-eared Owl in Essex. (Zool.)

Sharp, H. Snow Buntings at Mouth of Thames. (T.c.)

Templer, G. A. Great Snipe in Essex. (T.c.) Idem. (Field, Sept. I9.) 
I897. "Ajax." White Variety of Red-backed Shrike in Essex. (OP. cit., Aug. 28.)

Braybrooke, F. Blackbird retaining Pied Plumage. (Op. cit., Jan. 2.)

Fitch, E. A. Long-eared Owl breeding in Essex. (Zool.) "J. B. H." Gannets on Essex Coast (Field, Jan. 30) ; Idem, by H. Sharp (T.c., Feb. 6) : Idem, by J. Cordeaux. (T.c. Feb. 20.)

I898. "D. C. S." Orange-legged Hobby in Essex. (Op. cit., Jan. I5.) Keulemans, J. G. Young Martin in November. (Op. cit., Nov. 26.)

Smoothy, C. Blackthroated Diver in Essex. (Op. cit., Mar. 26.)

r899. Brown, F. Birds in Epping Forest. (Op. cit., Mar. Ir.)

Clark, P. Black-headed Gull in Essex. (Essex Nat.)

Emson, C. H. Stone Curlew at Epping. (Field, May 13.)

I900. Chipperfield, H. Birds of North-east London. (Nature Notes.)

Emson, C. H. Cream-coloured Wood Pigeon [in Essex]. (Field, March 3.)

Frohawk, F. W. Little Gull on the Thames. (Zool.). Idem, (Field, Jan. 6.)

Harting, J. E. Little Owl [in Essex]. (Proc. Linn. Soc.)

Smoothy, C. Hoopoe in Essex. (Field, Apr. 28.)

I90I. Chichester, E. Hybrid Greenfinch and Linnet. (Op. cit., Aug. 24.)

Gurney, J. H. Red-footed Falcon in Essex. (Zool.)

Harting, J. E. On Occurrence of Jer-Falcon in Essex. (Bull. B.O.C.)

Helman-Pidsley, W. E. Little Owl in Essex. (Field, Oct. I9.)

I902. Cornish, C. J. The Naturalist on the Thames. Svo. Lond.: I902. [I 47.$]$

"J. B." Wild Swans [?] at Walton-on-the-Naze. (Field, Dec. 6.)

I903. Christy, R. M. Aves. [In Victoria Hist. of Co. of Essex, I.] 4to. Lond.: I903. [I29.]

Frohawk, F. W. Habits of Green Woodpecker. (Field, May 23.)

Laver, H. Earliest Bird to Sing. (T.c., Mar. 28.)

Meares, C. Summer Blrds in Essex. (T.c., Apr. 25.)

Meares, D. H. Greenfinch as Cuckoo's Foster Parent. (Op. cit., Sept. 26.)

"R. C." Stone Curlew in Essex. (Op. cit., May 2.)

Westell, W. P. Ring Ouzel near London. (Zool.)

I904. Frohawk, F. W. Gannet in Essex. (Field, Nov. 5.)

Hamond, P. Eider Duck on the Essex Coast. (T.c., Nov. 26.)

Potts, C. Hoopoe in Essex. (Op. cit., May I4.) 
I905. Campion, F. W. and H. Hawfinch in Epping Forest. (Zool.)

Campion, H. Golden Oriole [?] in Epping Forest. (T.c.)

Fortescue, W. Egyptian Goose in Essex. (Field, Mar. 4.)

Harting, J. E. White Herring Gull [in Essex]. (T.c., Jan. 2I.)

Hartwell, W. W. Grey Phalarope and White Snipe in Essex. (Op. cit., Dec. 23.)

Pycraft, W. P. Peregrine Falcon in Essex. (Knowledge.)

Witherby, H. F. Lanius major off Essex Coast. (Bull. B.O.C., $\mathrm{XV}$.)

1906. Frohawk, F. W. Late Singing of Willow Warbler. (Field, Aug. I8.)

Harting, J. E. Occurrence of Baikal Teal in Essex. (Bull. B.O.C.)

Tuck, J. G. Great Crested Grebe breeding in Essex. (Zool.)

I907. Christy, R. M. On Breeding of Kite and Buzzard near Maldon in 'fifties' and 'sixties' of last century. (Essex Nat.)

French, J. The last Colony of Ravens in Essex: Notes original and selected-Birds. (T.c.)

Frohawk, F. W. The Little Owl. (Field, Oct. I2.) [partim.] Occurrence of Fieldfare in August. (Brit. Birds, I.)

Nichols, J. B. Rare Birds in ....... Essex. (Brit. Birds, I.)

I908. "A. W." Little Owl in Essex. (Field, Aug. I5.)

Clark, J. A. Ortolan Bunting at Plaistow, E. (Zool.)

Cooper, F. Leach's Petrel at Leigh-on-Sea. (Field, Oct. 3); Avocet on Essex Coast. (T.c., Nov. I4.)

Craig, A. W. Hen Harrier in Essex. (OP. cit., Apr. 4.)

Dresser, H. E. An Old Record of Little Bunting in Essex. (Brit. Birds, I.)

[Editorial.] Pallas's Sand Grouse in Essex. (Brit. Birds, II.) Fryer, J. C. F. Ruddy Sheldrake in Essex. (Field, Feb. I.)

Gray, L. Lesser Redpoll nesting in Essex. (Brit. Birds, II.)

Harting, J. E. Eagles about Tiptree Heath. (Essex Nat.) "J. S." Nesting of Wild Duck in Autumn. (Field, Feb. I5.)

Meeson, P. White-tailed Eagle [seen] in Essex. (T.c., Apr. I8.)

Pycraft, W. P. Remarkable variety of Red-legged Partridge in Essex. (Brit. Birds, II.)

Seabrooke, J. Sand Grouse in Essex. (Field, July 4); Idem, by " R. M." (T.c., Sept. I2.)

Smoothy, C. Red-backed Shrike killing young Pheasants. (T.c., July II.)

I909. Davis, J. and W. Bitterns in Essex and Kent. (Field, Feb. I3.)

Frohawk, F. W. Crossbills in Essex. (Op. cit., Aug. 28.)

Meares, D. H., Fenton, R. H. and Gray, L. Lesser Redpoll nesting in Essex. (Brit. Birds, III.) [3 notes.] 
Smith, J. Beddall. Blue-headed Wagtail in Essex. (Brit. Birds, III.)

Tower, C. J. H. White-tailed Eagle in Essex: Osprey in Essex. (Op. cit., II.) [2 notes.]

Vaughan, M. Bird Life on an Essex Common. (Field, Dec. 4.)

I9I0. Capleton, A. Great Crested Grebe at Wanstead. (Essex Nat.)

Chichester, E. Crossbill in Essex. (Field, Mar. 26.)

Eve, R.H. Jack Snipe in Essex in Aug. (Op. cit., Oct. I5, 22) : Idem, by E. Copland. (T.c., Oct. 22.)

Fitch, E. A. Short-eared Owl nesting in Essex. (Zool.)

Frohawk, F. W. Common Sandpiper in Winter. (Field, Feb. 26.)

Hepburn, T. Nesting of Common Tern and Black-headed Gull in Colchester Harbour. (Zool.)

Smith, J. B. Crossbills nesting in Essex. (Brit. Birds, IV.)

Stubbs, F. J. Kestrel and Starlings. (Zool.)

IgII. Collenette, C. L. Lesser Redpoll nesting in Essex. [Woodford Green.] (Brit. Birds, IV.)

Davenport, H. S. Young Cuckoo in Goldcrest's Nest. (Field, June 3.)

Frohawk, F. W. Cuckoo calling in September. (Field, Sept. 23.)

Green, J. F. Tengmalm's Owl in Essex. (Op. cit., Jan. I4.)

Nichols, W. B. Black Redstart in Essex. (Brit. Birds, IV.)

Owen, J. H. Young Cuckoo in Nest of Bullfinch: Young Great Spotted Woodpeckers. (Op. cit., V.); Scarcity of Summer Birds. (Field, June 24): Abnormally Large egg of Cuckoo. (Op. cit., July 22.)

Thomson, A. L. Probable Snow Geese in Essex, [2 notes.] (Brit. Birds, V.)

Igr2. Becher, H. White-winged Black Terns in Essex. (Op. cit., VI.) ; Idem. (Field, June 8.)

Christy, R. M. Sacred Ibis in Essex. (Brit. Birds, VI.)

Collenette, C. L. 'Twin' Nests of Black-headed Gull. (T.c.)

Fitch, E. A. Golden Eagle. (Zool.)

Gray, L. The I9I2 'Wreck of the Little Auk.' [Essex.] (Brit. Birds, VI.)

Harris, M. Albinistic Reed Buntings. (Brit. Birds, VI.)

Nichols, W. B. Probable Northern Long-tailed Tits in Essex. (Brit. Birds, V.) : Glossy Ibis in Essex. (Op. cit., VI.)

Owen, J. H. Little Owls breeding in Essex: Moorhens' Nests screened with Domes of Reeds: Long-eared Owl entering Building. [3 notes.] (T.c.) : Cuckoo fed by Hedge Sparrow and Wren. (Ficld, July 20.): The Nesting Season, I9I0-Ir. (Rept. Felsted Sch. Sci. Soc., No. 22.)

Stubbs, F. J. Little Auk in Essex: Flight of the Common Snipe. (Zool.) [2 notes.] 
1913. Christy, M. Bearded Tit in Essex. (Brit. Birds, VI.) : Tufted Duck breeding in Essex, etc. (Op. cit., VII.)

Farren, W. Glossy Ibis in Essex. (Op. cit., VI.)

Frohawk, W. Common Sandpipers in winter in Essex. (Op. cit., VII.)

Glegg, W. E. Pintail in Essex. (Op. cit., VI.): Tufted Duck breeding in Essex. (Op. cit., VII.) [2 notes.]

Gurney, C. J. Little Owl breeding in Essex. (T.c.)

Hulton, A. B. Honey Buzzard in Essex. (Field, Oct. 4.)

Loder, B. Quail in Essex. (Field, Sept. I3.)

Nichols, W. B. Black Terns at Manningtree. (Field, May 2.) Cirl Bunting in Essex; Common Tern breeding in Essex [2 notes.] (Brit. Birds, VII.)

Owen, J. H. Willow Tit breeding in Essex; Cuckoo's eggs and nestlings in I9I3 in Essex. (Brit. Birds, VII.) : Cirl Bunting breeding in Essex. (Op. cit., VI.)

Smith, B. J. Gadwall and Little Gull in Essex. (Op. cit., VII.)

I9I4. Elton, A. Waxwing in Essex. (Field, Jan. I7.)

Frohawk, F. W. Common Sandpiper in Feb. [Essex.] (Field, Feb. 28) ; Waxwing in Essex. (T.c., Mar. I4.)

Stubbs, F. J. Corncrake in Essex: A Luminous Owl in Essex. (Zool.)

I9r5. Christy, M. Wigeon diving in Essex. (Brit. Birds, IX.)

Glegg, W. E. Little Owls in Essex. (Brit. Birds, VIII.): Idem, by W. B. Nichols. (T.c.)

Owen, J. H. Long-eared Owl nesting in Essex: Cuckoo eggs and nestlings in I9I5 [at Felsted]. (Op. cit., IX.)

I9I6. Glegg, W. E. Great Spotted Woodpecker breeding in nesting box in Epping Forest. (T.c.)

Howlett, W. J. Great Grey Shrike in Epping Forest. (Field, June 3.) (Brit. Birds, X.)

I9I7. Meares, D. H. Little Owl breeding in Essex. (Brit. Birds, X.)

Owen, J. H. Cuckoo's Eggs and Nestlings in I9I7 [at Felsted]. (Brit. Birds, XI.)

I9I8. Frohawk, F. W. Sudden appearance of Fieldfares and Redwings in Essex. (Field, Apr. 6.)

Jourdain, F. C. R. On breeding of Honey Buzzard in Essex. (Essex Nat., pp. 238-40.)

Murray, C. Common Buzzards in Essex; Eider Duck on River Roding. (Brit. Birds, XI.)

Nichols, W. B. Spoonbill in Essex. (Brit. Birds, XII.)

Owen, J. H. A List of the Birds of Felsted School. (Rept. Felsted Sch. Sci. Soc., I9I6-I7, pp. I6-29.)

Stubbs, F. J. The Corncrake in Essex. (Essex Nat., pp. I8992.) 


\section{GLOUCESTERSHIRE.}

I825. Yarrell, W. Notice of occurr. of some rare Brit. birds. [Roughlegged Buzzard in Gl os.] (Zool.Jnl., II., p. 25.)

I829. Knapp, J. L. Journal of a Naturalist. Post 8vo. Lond. : I829. 2nd edit., I829. 3rd edit., I830. [332.]

I83I. [Hays, Mrs. M.] Annals of My Village. Post 8vo. Lond. : I83I. [288.]

Yarrell, W. Addit. to Cat. of Brit. birds. [Black Redstart near Bristol.] (Loudon's Mag. N. H., IV., p. II8.)

I838. (Bath Post.) Spoonbill near Tewkesbury. (Nat. [Wood's], IV.)

1839. Brown, J. Breeding of Crossbill in Glos. (Charlesw. Mag. N.H.)

I84I. Brown, J. Capture of Rare Birds on Cotswold Hills. (Zool.)

I842. Davies, H. Strangers' Guide through Cheltenham. Post 8vo. Cheltenham: N. D. [I64.]

I847. Beadles, J. N. Occurrence of Grey Phalarope at Mitcheldean. (Zool.)

I848. Beadles, J. N. Provincial Names of Birds in Glos. (Op. cit.)

I85I. Joshua, W. Occurrence of Red-necked Grebe in Glos. (Op. cit.) I857. Bowly, E. List of Birds seen in Liddington, with remarks. (Pr. Cotteswold Nat. F. C., II.)

I858. Guise, W. V. Occurrence of Parrot Crossbill at Cheltenham. (Nat. [Morris's], VIII.)

Nicholls, H. G. Account of the Forest of Dean. 8vo. Lond. : I858. [450.]

1859. (Cheltenham Examiner.) Bohemian Chatterer shot at Winchcombe. (Field, Dec. 3I.)

Newman, H. W. Dates of Arrival of Migratory Birds at Cheltenham. (Zool.)

" N. N. D." Landrail [near Tewkesbury in December]. (Field, Jan. 8.)

I860. "C." Wild Geese [in Glos.]. (Op. cit., Nov. 24.)

"F. S. M." Waxwinged Chatterer [at Cheltenham]. (Field, Dec. I.)

Newman, H. W. Occurrence of Alpine Accentor near Cheltenham, etc. (Zool.)

I86I. "L. A. S." Red-breasted Merganser [at Northwick]. (Ficld, Jan. 26.)

White, H. Rose-coloured Pastor shot near Cheltenham. (Ficld, June 22.)

I862. Guise, W. V. On Parrot Crossbill at Cheltenham. (Zool.) Newman, H. W. Mildness of Winter Season at Cheltenham. (T.c.) 
I863. Jones, J. On Natural History, Geology, etc. of Sharpness Point District. (Pr. Cotteswold N.H. C., I863 [Birds, pp. I47-54.])

I864. Newman, H. W. Scarcity of Singing Birds in Cheltenham; Rare appearance and Scarcity of Kite and other Birds in Cheltenham; Scarcity of Swifts and Snipes in Cheltenham. 3 notes. (Zool.)

Perkins, V. R. Pallas's Sand Grouse in January. (T.c.)

I865. Fisher, C. Hawkins. The Black Redstart [in Glos.]. (Field, Dec. 9.] Idem, by J. Gatcombe. (T.c., Dec. I6.)

Luke, D. W. White Starling and White Swallow. (Field, Nov. I8.)

Tyrer, J.S. Hoopoe in Glos. (Op. cit., May 20.)

I866. Guise, W. V. Forktailed Petrel at Elmore. (Zool.)

I867. "H. J. P." Little Auk, etc. [in Glos.] (Field, Jan. I2) ; Idem. (Zool.)

Harrison, J. W. D. Landrail in January. (Field, Jan. Ig); Idem. (Zool.)

Holland, J. Migration of Quails. (Field, Nov. 23.)

Mathews, M. A. Bee Eater at Stapleton. (Zool.)

I868. Bengough, J. C. Soland Goose [in Glos.]. (Field, Jan. I8.)

[Cheltenham Examiner.] Osprey in Glos. (Op. cit., Sept. 26.)

Gifford, Lord. Rare Birds in the Cotswolds. (T.c., Dec. 26.)

Pruen, H. B. Woodcock in July. (T.c., July II.)

"S." Red-legged Partridge in Glos. (T.c., Oct. Io.)

I869. " J." Occurrence of Crane near Cheltenham. (Op. cit., June 5.)

I87x. "Glan Nant." Hawfinch nesting in Glos. (Op. cit., June 24.)

Hill, W. A. Quails in Britain in I87o [nr. Cheltenham]. (T.c., Jan. 2I.)

Lloyd, J. W. American Meadow Lark near Cheltenham. (T.c., March II.)

Newman, E. On Occurrence of American Meadow Lark in Great Britain. (Zool.)

1872. Ashford, A. R. Peregrine Falcon. (Field, Feb. I0); Idem, by W. Haines. (T.c., Jan. 20, Feb. I7.)

Rickards, M. S. C. White-tailed Eagle in Glos. (Zool.)

I873. "C. H. R." Crossbills and Hawfinches [in Glos.]. (Field, May 3.)

Eycott, F. Green Sandpiper in Glos. (Op. cit., Dec. 20.)

Kempster, J. Redstart nesting on the ground. (Zool.)

I874. Empson, A. R. Cormorant inland [on the Avon]. (Field, Aug. "29.) I2.)

[Whittington, R.] Solitary Snipe in Glos. (T.c., Dec. 
1875. Burge, S. Lesser Spatted Woodpecker at Fairford. (Op. cit., Apr. I7.)

Wheeler, E. [Aves in] Bristol and its Environs. Brit. Assoc. Handb. for Adv. Sci. Lond. etc. : I875. [624.]

1877. Hough, C. Cooper. Woodcocks breeding in Glos. (Field, May 26.)

1878. Davies, R. P. Hoopoe in Glos. (Zool.); Hoopoe near Wottonunder-Edge. (Field, Sept. 2I.)

I879. "D. J. W." Woodcocks nesting in Forest of Dean. (Field, May I7.)

I88o. Evans, E. E. Birds of Gloucestershire, 2 pts. (Midl. Nat.)

White, H. Grey Shrike ; Raven and Goosander in W. of England. $($ Zool.)

I88I. "Durotrix." Red-legged Partridge in Glos. and Dorset. (Field, Dec. 24.)

"Edward, D. H." Hawfinch at Cheltenham. (T.c., Jan. 29.) Holbeck, H. Pied Flycatcher in Glos. (T.c., Apr. 30.)

I882. Davis, F. Red-legged Partridge in Glos. (Op. cit., Jan. 7.)

I883. Newstead, R. Slavonian Grebe [near Gloucester]. (Sci. Gossip.)

I884. "Falcon." Hobby nesting in Glos. (Field, Aug. 23.)

I886. Marsden, H. W. Storm Petrel in Glos. (Zool.)

1887. [Editorial.] Wildfowl taken in the Berkeley Castle Decoys. (Field, March I2.)

Marsden, H. W. Black Tern near Gloucester ; Manx Shearwater in Glos.; Lesser and Black Tern near Gloucester; Nesting of Marsh Warbler in Glos. 4 notes. (Zool.)

I888. Day, F. Pallas's Sand Grouse in Glos. (Op. cit.)

Phillips, J. Pallas's Sand Grouse. 2 notes. (Field, June 9, I6.)

I889. Hanks, G. Sand Grouse in Glos. (Op. cit., Apr. 6.)

Reid, Mayne. The Naturalist in Siluria. Post 8vo. Lond. : I889. [partim.]

Rickards, MI. S. C. Rare Birds in Gloucester, etc. (Zool.)

I89o. Aplin, O. V. Dipper in Glos. (Op. cit.)

Steward, C. H. Bernicle Goose near Tewkesbury. (Field, Feb. 22.)

I89I. Clarke, A. L. Rare Birds in Glos. (Zool.)

"C. H. F." Red Grouse in Glos. (Field, Nov. I4.)

"C. W. H." Great Grey Shrike in Glos. (Op. cit., Jan. 3.)

[Editorial.] [Bittern at Tewkesbury.] (T.c., Jan. 3.)

Marsden, H. W. Blackcap in Glos. in Mid-winter. (Zool.)

I892. Aplin, O. V. On Distribution of Cirl Bunting in Great Britain. (Op. cit.) [partim.] [25.]

Clarke, A. L. Great Grey Shrike in Glos. (T.c.) 
Witchell, C. A., and Strugnell, W. B. Fauna and Flora of Gloucestershire. Roy. 8vo. Stroud: I892. [655.]

I893. Heming, R. Peregrine Falcon in Glos. (Field, Feb. 4.)

White, T. and Son. Albino Whitethroat. (OP. cit., July 29.)

I895. Charbonnier, H. J. Shore Lark and Black Redstart in Glos. (Zool.)

Clarke, A. L. Little Auk in Glos. (Nat. Jnl.)

Cox, H. Cuckoo's Egg in Nest of Nuthatch. (T.c.)

White, T., and Son. Montagu's Harrier near Cheltenham. (Field, Feb. 23.)

1896. Cade, F. J. Eider Duck in Glos. (Zool.)

Neale, E. Distribution of Red-legged Partridge. (Field, Sept. I9.)

Whatley, E. Grey Phalarope at Cirencester. (T.c., Oct. Io.)

I897. Riviere, B. Arrival of Summer Migrants in Glos. (Zool.)

Round, F. W. Solitary Snipe in Glos. (Field, Sept. I8.)

I898. Gibbs, J. A. A Cotswold Village. I898.

Roue, W. B. Coition of Birds in Air. (Zool.)

I899. Price, D. T. Winter Occurrence of Wheatear. (Op. cit.)

Witchell, C. A. The Hobby and its Prey. (Field, Sept. 2.)

I900. [Anon.] Birds of Bristol District. (Pr. Bristol Nat. Soc.)

Bate, D. M. A. Nesting of Woodcock. (Field, May I9.)

I90I. Playne, H. C. Blackcap singing in February. (Zool.)

Witchell, C. A. Night Flight of Swift. (Field, Aug. 3) ; Hobby in Glos. (T.c., Sept. I4) ; Song of the Redwing. (Op. cit., Jan. 26.)

1902. Child, A. G. Sand Martin nesting in Stone Wall. (Op. cit., June I4.)

Mellersh, W. L. Treatise on the Birds of Gloucestershire. Roy. 8vo. Gloucester: I902. [395.]

Witchell, E. N. Swifts flying at Night. (Field, Aug. 30.)

I903. Jolly, L. Storm Petrel inland. (Op. cit., Nov. 28.)

I904. Grant, W. R. O. Asserted Breeding of Goshawk in Glos. (Bull. B.O.C.)

Harting, J. E. Nesting of the Goshawk, II. (Field, May 28.) [276.]

Thomas, A. Little Auk in May. (Op. cit., Aug. I3.)

I905. Jefferys, C. Late Breeding of Barn Owl. (Zool.)

I906. "L. P." Glaucous Gull on the Severn. (Field, March 3.)

Playne, H. C. Some Common Birds of the Neighbourhood of Clifton ..... Clifton: I906.

Thomas, A. Hoopoe in Glos. (Field, May I9.) 
I907. Aplin, O. V. Colymbus glacialis in Glos. (Zool.)

Bengough, A. Quail in Glos. (Field, Sept. 2I.)

Mellersh, W. L. [Wildfowling in] Victoria History of Co. of Gloucester, II. 4to. London: I907.

I908. Aplin, O. V. September Movement of Shearwaters. (Zool.)

Gilroy, N. Nesting Habits of Marsh Warbler. (Brit. Birds, II.)

Grant, W. R. O. Exhibition of Northern Marsh Tit from Tetbury. (Bull. B.O.C., XXIII.) [452.]

Ingram, C. Variety of Great Titmouse. (Zool.)

Thomas, A. Egyptian Geese in Glos. (Field, Jan. I8.)

rgog. Grant, W. R. O. The Northern Marsh Tit in England. (Brit. Birds, II.) [452.]

Mellish, S. Reeve in Glos. (Field, Sept. II.)

Price, M. P. Woodcock nesting in Glos. (Op. cit., May I5.)

Smallcombe, W. A. Downy Woodpecker in Glos. (Brit. Birds, II.)

Witchell, E. N. Crossbills in Glos. (Field, Dec. 25.)

I9I0. Clarke, E. T. Crossbills nesting in Glos. (Brit. Birds, IV.)

Ingram, C. Reeve in Glos. (Zool.)

Ridgway, M. L. Crossbills and Hawfinches in Glos. (Field, Jan. 8) ; Crossbills nesting in Glos. (T.c., March I2.)

Risley, C. S. Ornithological Section. (Rep. Chelienham College N. H. Soc., Igog.)

Robinson, H. W. Redbreasted Goose on Severn. (Brit. Birds, III.)

Witherby, H. F. Irruption of Crossbills. (T.c.) [partim.]

Igrr. De Winton, G. H. White Rook. (Field, June 3.)

Ticehurst, N. F., and Jourdain, F. C. R. On Distribution of Nightingale during Breeding Season in Great Britain. (Brit. Birds, V.) [partim.] [584: 322.]

I9r2. Hooker, C. P. Little Auk alive inland in Glos. (Field, Feb. ro.) Mellersh, W. L. Unrecorded Snow Geese in Glos. (Brit. Birds, VI.)

Witherby, H. F. The IgI2 "wreck" of the Little Auk. (Op. cit., V.) [partim.]

I9I3. Martin, C. Large clutches of Goldfinch's eggs in Glos. (Op. cit., VII.)

Selby, H. J. Young Cuckoo in Starling's nest. (Field, June I4; Brit. Birds, VII.)

Smith, D. M. Firecrest in Glos. (Op. cit., VI.)

Turner, E. Quail on the Cotteswold Hills. (Field, Sept. 20.)

IgI4. Cope, E. V. A Fawn-coloured Rook. [Cirencester.] (Field, July, 25.)

Charlton, J. M. Spotted Crake in winter in Glos. (Brit. Birds, VII.)

Robinson, H. W. Avocets in Glos. (T.c.) 
I9r6. Bennett, C. W. Quail in Glos. (Field, Sept. I6.) I9I8. Ashley, M. On the breeding habits of the Hobby in Glos.
(Brit. Birds, XI.)

Purvois, J. H. Lesser Yellowshank in Glos. (Field, Nov. 23.) Witchell, E. N. Wild Geese in Glos. (Op. cit., Feb. 9.)

\section{HAMPSHIRE.}

I78I. Worsley, Sir R. History of the Isle of Wight. 4to. Lond. : I78 $\mathrm{I}$.

I789. Warner, R. Tour round Lymington. I2mo. Southampton: I789. [6I3.]

White, Gilbert. Natural History of Selborne. 4to. Lond. : I789. [633.]

I79I. Gilpin, W. Remarks on Forest Scenery ....2 vols. 8vo. Lond. : I79I. [And subsequent edits.] [229.]

I793. Warner, R. South Western Parts of Hampshire. 2 vols. 8vo. Lond. : I793. [6r3.]

I795. Warner, R. History of the Isle of Wight. 8vo. Southampton, etc. : I795. [6r4.]

White, Gilbert. A Naturalist's Calendar. 8vo. Lond.: I795. [633.]

I802. White, Gilbert. Natural History of Selborne, with Calendar, etc. 2 vols. 8vo. Lond. : 1802. [And numerous subsequent editions.] [633.]

I824. [Wood, -.] [Golden Oriole at Aldershot.] (Zool. Jnl., I., p. 278.)

1825. Garrow, D. History of Lymington. 8vo. Lond. : I825. [226.] Yarrell, W. Notice of occurrence of some rare Brit. Birds. [Rough-legged Buzzard, Osprey, etc. in Hants. and I. W.] (Zool. Jnl., II., pp. 25-26.)

1827-8. Yarrell, W. On occurrence of some rare Brit. birds [Cirl Bunting in I. W. ; Dartford Warbler at Portsea]. (Zool. Jnl., III., pp. 86, 498.)

I833. "Rusticus." [Newman, E.] Something about Sea birds [of I. of Wight.] (Loudon's Mag. N. H., VI., p. 25.)

I836. Clarke, W. B. The Guide to Hayling. 8vo. Hayling. : I836. [I3I.]

Dale, J. C. Egret, Pratincole, etc. [in Hants.] (Loudon's Mag. $N$. H., IX., p. 598.)

[1840.] Mudie, R. Hampshire: Its Past and Present Condition, etc. 3 vols. Roy. 8vo. Winchester: N.D. [424.]

I843. Dawson, J. F. Note on Black Redstart. (Zool.) 
Lewcock, J. Note on Woodcocks and Crossbills, breeding in Holt Forest, Hants. (Zool.). 2 notes.

I844. Heathcote, W. P. Birds of Prey found in Parish of Hursley, near Winchester. (Zool.)

Sclater, P. L. Note on the Water-Rail. (T.c.)

1844-45. Bury, C. A. Notes on Birds of the Isle of Wight, 4 papers. (Op. cit., I844-45.) [IIO.] Dates of arrival of Summer Birds at Bonchurch, 2 pts. (T.c.)

I845. Sclater, P. L. Arrival of Summer Birds near Odiham in I845; Occurrence of Aquatic Birds near Odiham. (Op. cit.)

I846. Sclater, P. L. Early appearance of Tufted Duck; Occurrence of Sabine's Snipe in Hants. $(O p$. cit.)

Sladen, E. H. M. Arrival of Birds, etc., at Warnford in 1846 . (T.c.)

Smith, H. E. Late stay of House Martin at Alton. (T.c.)

I847. Bell, T. Occurrence of Cirl Bunting at Selborne. (Op. cit.)

I849. Martin, G. A. The Undercliff of the Isle of Wight. Post 8 vo. Lond. : I849. [387.]

More, A. G. Occurrence of Fire-crested Regulus [errore for Gold-crest] and Crossbill at Bembridge. (Zool.)

Wright, J. Occurrence of Bittern at Lymington. (T.c.)

I850. Bell, T. Occurrence of Peregrine Falcon at Selborne. (Op. cit.)

I85I. Bartlett, J. P. Great Northern Diver near Fordingbridge. (Nat. [Morris's], I.)

Guyon, G. Occurrence of Hoopoe in Isle of Wight. (Zool.)

McIntosh, J. Heronries in England. [partim.] (Nat. [Morris's], I.)

Vamham, W. Landrail in February. [Isle of Wight.] (Zool.)

I852. Balshaw, W. D., junr. Notes of the Nat. Hist. of Southampton. (Nat. [Morris's], II.)

D'Arcy, F. H. Spoonbill in Hants. (Nat. [Morris's], II.)

Bell, T. Occurrence of Spotted Redshank at Selborne. (Zool.)

1853. Bell, T. Hoopoe near Selborne; Hawfinch and Brambling at Selborne. (Zool.)

Fane, F. [Pheasant and Greyhen Hybrids and Montagu's Harrier in Hants.] (Nat. [Morris's], IV.)

Hawker, W. H. Note on Woodcocks' Nests in Forest of Bere and Highden Wood; Occurrence of Kite at Horndean, Hants. (Zool.)

More, A. G. Correction of previous error respecting Fire-crested Regulus. Black Redstart at Bembridge; Occurrence of Puffin in Winter off I. of Wight; Note on Black Redstart; (Zool.) 4 notes.

Rose, J. Great Northern Diver on Coast of Hants. (Nat. [Morris's], III.) 
I853-62. More, A. G. Migratory Birds in Isle of Wight. 3 pts. (Zool. I853, I858, I862.) [4I2.]

I854. Dutton, J. Occurrence of Hoopoes in I. of Wight. (Op. cit.) Gardner, J. Glossy Ibis [near Christchurch]. (Nat. [Morris's], IV.)

I855. Dutton, J. Occurrence of Bee-eater in I. of Wight ; Disappearance of Chough from I. of Wight. (Zool.)

Guyon, G. Late stay of Swallows in I855. (Zool.)

Hadfield, H. W. Late stay of Swallow Tribe; Migration of Swallow Tribe; Note on Spotted Crake; Early arrival of Willow Wren; Note on Hoopoe: Scarcity of Song Thrush, etc. (Zool.) 9 notes.

More, A. G. On the three species of Divers or Loons [in Isle of Wight]. (T.c.)

1856. Rake, J. B. Nidification of Honey Buzzard in New Forest. $(O p$. cit. $)$

Sealy, A. F. Honey Buzzard breeding in Hants. (T.c.)

West, P. W. Occurr. of rare birds. (Nat. [Morris's], VI.)

I857. Barron, C. Occurrence of White-tailed Eagle near Haslar. (Zool.)

Hadfield, H. W. Great Abundance of Pied Wagtail; House Sparrows; Nidification of Hedge Sparrow; Notes on Female Brambling; Nidification of House Sparrow. (Zool.) 5 notes.

Longcroft, C. J. Topographical Account of the Hundred of Bosmere. Roy. 8vo. Lond. : I857. [358.]

[.1858.] Bury, C. A. Natural History of the Isle of Wight. 4to. (Reprinted from Topography and Antiquities of the Isle of Wight, by W. H. D. Adams.) Ventnor : n.d. (IIo.]

I858. Berkeley, G. F. Dartford Warbler [in Hants.]. (Field, Nov. 6). Hawker, W. H. Blackbirds nesting in December. (Zool.)

More, A. G. Migratory Birds in the I. of Wight. (T.c.)

" Portsmouth Subscriber." Spoonbill shot [in Langston Harbour]. (Field, April 24.)

Rogers, F. Occurrence of Wild Geese in I. of Wight. (Zool.)

1859. Bell, T. Hawfinch at Selborne. (Op. cit.)

Berkeley, G. F. Grey Hen assuming Male Plumage. [New Forest.] (Field, Jan. 22.) A rare bird [Kildeer Plover? shot nr. Christchurch]. (T.c., April 2, I6, I859; Op. cit., Mar. 3I, I860) ; Migratory Movements of Birds. (Op. cit., Dec. 24.)

Rogers, H. Occurrence of Snow Bunting in I. of Wight. (Zool.)

I860. More. A. G. Rare Birds recently observed in I. of Wight. (Op. cit.) List of Errata. (T.c.) [4I3.]

More, A. G. Outlines of Nat. Hist. of Isle of Wight. [In Venables' New Guide to Isle of Wight.] Post 8vo. Lond.: I860. Idem. Reprinted separately. (4I3.]

"M. B." Does the Little Auk occur in S. of England? (Field, April I4.) 
Simeon, Cornwall. Stray Notes on Fishing and Natural History. 8vo. Cambridge: I860. [Ch. V. Rare Bird Visitors to I. of Wight.]

I86I. Berkeley, G. F. Woodcock in New Forest. (Field, Dec. 2I.)

Gostling, W. Late stay of Swallows and Martins in I. of Wight. (Zool.)

Hadfield, H. Late Stay of Swallows: Migration and Torpidity of Swallows. (Zool.) 2 notes.

Hussey, H. Does the Kittiwake breed in the I. of Wight? (T.c.)

". J. D." Dartford Warbler [at Freshwater, I.W.]. (Field, Jan. 26.)

Rogers, H. Kittiwake does not breed in I. of Wight : Occurrence of Golden Oriole at Shalfleet : Hoopoe in I. of Wight. (Zool.) 3 notes.

Saville, S. P. Grey Phalarope near Southampton. (T.c.)

I862. Bartlett, J. P. Occurrence of Short-toed Lark and other Rare Birds. (Zool.)

Berkeley, G. F. Rare Birds [in Hants.]. (Field, Jan. 4.) Gadwalls [in Hants.]. (T.c., Jan. I.)

Crowley, P. Merlin near Alton; Egyptian Goose at Alton. (Zool.) 3 notes.

Farren, W. Note on Great Black Woodpecker breeding in New Forest [?] ; On Honey Buzzard, Merlin and Dartford Warbler breeding in New Forest. (T.c.) 4 notes.

Goatley, J. On Black Redstart at Southampton. (T.c.)

Hadfield, H. Occurrence of Crossbill in England; Migration of Swallows. (T.c.) 3 notes.

Holdsworth, E. W. H. Occurrence of Great Black Woodpecker in New Forest. (T.c.)

More, A. G. Early Arrival of Wheatear; Early Arrival of Migratory Birds. (T.c.)

Rogers, H. Great Spotted Woodpecker, Little Auk and Crossbills; Grey Phalarope ; and Pomarhine Skua in I. of Wight. 3 notes. (T.c.)

Ward, E. H. Golden Orioles [in I.W.] (Field, May Io.)

Wise, J. R. The New Forest. Roy. 8vo. Lond. : I862. And later edits. [655.]

I863. Bradby, A. S. Migration of Ring Ouzel. (Zool.)

"C." Canadian Geese on Hants Coast. (Field, June 20.)

Johns, C. A. Home Walks and Holiday Rambles. Post 8vo. Lond. : I863. [3I8.]

Johns, C. A. Black Redstart at Winchester. (Zool.)

Mathew, M. A. Pallas's Sand Grouse in Hants. (T.c.)

Radcliffe, C. Delmé. Wilson's Petrel in I. of Wight. (Field, Nov. 28).

Rogers, H. Pied Flycatcher; Golden Oriole ; Black Redstart ; Pomarhine Skua; Golden Oriole; Rock Dove; Hoopoe and Reeves in I. of Wight. 7 notes. (Zool.) 
Seaman, C. E. Frequent Occurrence of Eggs and Young of Cuckoo in Nests of Rock Pipit. (T.c.)

I864. [Anon.] Capture of Bittern in Hants. (Field, Jan. 30.)

Armistead, J. J. Spotted Crake in Hants. (Zool.)

Crowley, P. Peregrine Falcon and Short-eared Owl near Alton (T.c.)

Fox, J. J. The Common Kite [in Hants.]. (T.c.) [partim.]

Hadfield, $\mathrm{H}$. Martins congregating in August. (T.c.)

Radcliffe, C. D. Wilson's Petrel in I. of Wight. (Zool.)

Rake, T. B. Note on Swallow Tribe, their stay, etc. (T.c.)

Reeks, H. Honey Buzzard's Nest in New Forest ; Pine Grosbeak at Thruxton; Fieldfare near Andover in May. (T.c.)

Rogers, H. Little Stint in I. of Wight. (T.c.)

Seaman, C. E. Bittern in I. of Wight. (T.c.)

I865. Bond, F. Early Arrival of Summer Birds at Freshwater. (Zool.)

Bradby, A. S. Pied Blackbird at Moundsmere. (Zool.)

Breton, F. Bittern shot near Portsmouth. (Field, Jan. I4.)

Hart, H. Little Bittern and Osprey at Christchurch. (Field, Oct. 7); Wildfowl in the Solent. (T.c., Nov. 4.)

Jesse, W. Redwinged Starling near Liphook; Snipe nesting at Liphook. (Zool.)

Reeks, H. Scarcity of Winter Migrants. (T.c.)

Rogers, H. Ornitholog. Field Notes from I. of Wight. (T.c.)

Stares, W. Purple Gallinule in Hants. (T.c.)

Ward, E. Capture of a Honey Buzzard [alive near Portsmouth] (Field, June 24.)

I865-85. Hadfield, $H$. Ornitholog. Notes from I. of Wight, 23 papers. (Zool., I865-69, $1876-78,1880-85$.)

I866. Padwick, W. O. Osprey killed at Havant. (Field, Nov. 3.)

Reeks, H. Purple Waterhen at Southampton. (Zool.)

Roach, R. B. Landrail in winter. [I.W.] (Field, Dec. 29.)

I867. [Anon.] Redlegged Partridge at Bournemouth. (Field, March I6.)

Bell, T. Hawfinch breeding at Selborne; Hawfinch at Selborne. (Zool.)

Crowley, P. Young Hawfinch at Alton in June. (T.c.)

Crichton, A. W. Blackthroated Diver at Wickham. (T.c.)

Hart and Son. Bittern [and Hawfinches at Christchurch]. (Field, Dec. I4.)

Hawker, F. A. Purple Gallinule in Hants. (Zool.)

Jesse, W. Redwinged Starling near Liphook. (T.c.) $[c f . o p$. cit., I865, p. 913.]

Rogers, H. Rock Thrush, Hoopoe and Pied Flycatcher; Rock Thrush at Freshwater; Ortolan Bunting and Curlew Sandpiper in I. of Wight, 3 notes. (T.c.)

I868. Bell, T. Scarcity of Hirundines; Three species of Columbidæ breeding at Selborne. (Zool.) 2 notes. 
Gurney, J. H. Great Snipe near Christchurch. (T.c.)

Sanders, W. B. Wildfowl at Southampton. (Field, Aug. 29.)

Williams, T. B. C. A Hoopoe [in I.W.]. (Field, May 30.)

1869. "Fordingbridge." Little Bittern in Hants. (Field, May r.)

[Editorial.] Honey Buzzard in Hants. (Op. cit., Aug. 2I.)

Gurney, J. H., junr. List of Rarer Birds obtained by Mr. Hart in the vicinity of Christchurch. (Zool.)

Hadfield, H. Nest and Eggs of Corn Crake. (T.c.)

Hart, W., and Son. Avocet at Portsmouth. (Zool.) : Sabine's Snipe at Christchurch: Rare Birds at Christchurch. (Field, Oct. I6.)

Wright, J. Summer Duck at Lymington: Black Swans, etc., on the Solent. (Zool.)

I870. Coombe, P. E. Richardson's Skua in Southampton Water. (Field, Nov. I9.)

[Editorial.] Black Water Rail [in New Forest]. (Field, Feb. I2.)

Goatley, T. H. Black Redstart near Southampton: Grey Phalarope near Southampton. (Zool.)

Hadfield, H. Increase of Sea-fowl in I. of Wight ; Green Woodpecker in I. of Wight. (Zool.)

Hart, W., and Son. Ruff and Grey Phalarope in Hants. (Field, Oct. 22.)

Haydon, F. W. Great Grey Shrike [in Hants.]. (Field, Dec. 3.)

Reeks, H. Land Rail found alive in Pea-ride in January. (Zool.)

I870-75. Hadfield, H. Arrival of Migrants in the I. of Wight, 6 notes. (Op. cit., I870-75.)

I87I. Bradby, A. S. Hooded Crow; Food of Quail ; White-fronted Goose at Cliddesden. (Zool.) 3 notes.

Goatley, T. H. Wild fowl in Southampton Water. (T.c.)

Hadfield, H. Swan laying nine eggs. (T.c.)

Harting, J. E. Peregrine and Wild Duck. (Field, Oct. 7.)

Houghton, W. Smew in Hants. (Op. cit., Jan. I4.)

Lambert, J., and Self, J. Stone Curlew in I. of Wight. (Op. cit., Nov. I8, Dec. 23.)

Weaver, J. Eider Duck at Emsworth. (Op. cit., Jan. 28.)

I872. Chalwin, H. Peregrine Falcon in Hants. (Field, Jan. 6.)

Corbin, G. B. Woodcock breeding in New Forest ; Is the Wheatear commoner than usual ?; Starlings building in September. (Zool.)

Feilden, H. W. Collared Pratincole near Gosport; Ospreys in Hants; Woodcocks breeding in Wolmer Forest; Dartford Warbler. (T.c.)

Gurney, J. H. Honey Buzzard in New Forest. (T.c.)

Hadfield, H. Golden Eagle in I. of Wight. (T.c.) Idem, by E. Newman. (Field, Nov. 2.)

Hart, H. Gull-billed Tern in Hants. (Field, July 20.)

Harting, J. E. British Heronries. (Zool.) (partim.) 
Hart, W., and Son. Great Northern Diver in Hants. (Field, Oct. 26.)

Hügel, A. von. Hoopoe in Hants. ; Gull-billed Tern in Hants. ; Woodcock breeding in New Forest. (Zool.)

Rogers, H. Razorbills, Guillemots, etc., picked up in I. of Wight. (T.c.)

Whitaker, J., junr. A visit to Freshwater Cliffs. (T.c.)

1873. [Allingham, William. pseud. "Patricius Walker."] Rambles. Post 8vo. Lond. : 1873. (II.)

Bury, C. A. Stock Doves nesting in I. of Wight. (Field, May 24.)

Corbin, G. B. Wild fowl at Ringwood ; Early nesting of birds ; Hawfinch and Brambling at Ringwood; The Nightingale; Migration of Skylark; Whimbrel in New Forest; Dartford Warbler; Hawfinch breeding in New Forest, etc. (Zool.). I2 notes.

Durnford, H. Ornitholog. Notes from Longparish, 2 papers. (T.c.)

Hart, W., and Son. Cross between Mallard and Tufted Duck [shot at Christchurch]. (Field, Dec. 20.)

Hügel, A. von. Waxwing in Hants.; Eider Duck at Christchurch. (Zool.)

Reeks, H. Little Bustard in Hants. (T.c.)

Sharpe, R. Bowdler. Little Bustard in Hants. (Field, Jan. I8.) Sparrow, W. J. Godwits and Oystercatcher inland. (T.c., Mar. I.)

1874. Aslett, H. S. Dipper nesting in Hants. (Field, July 4.)

Bell, T. Scarcity and Late Stay of Martins and Swallows at Selborne. (Zool.)

Hadfield, H. Common Buzzard in I. of Wight; Peregrines in I. of Wight; Mortality of House Sparrow and Martin; Autumnal Migration of Willow Wren, etc. (Zool.) 4 notes.

Irby, L. H. Stone Curlew in New Forest in Jan. (Field, Feb. I4.)

Weld, A. G. Hoopoes in I. of Wight. (Sci. Gossip, X.)

Willmore, J. H. Lecture on Birds of Queenwood. I2mo. Lond. : I874. (650.)

I875. Bree, C. R. Ornithology at Freshwater. (Field, Oct. 2.)

Corbin, G. B. Swallows, Martins and Fieldfares; Merlin in New Forest; Siskin, Lesser Redpoll, etc. near Ringwood. Nesting of Teal in Hants.; Montagu's Harrier in Hants.; Sheldrake near Ringwood; Bitterns in S.W. Hants.; Osprey in Hants, etc. (Zool.) Io notes.

Hadfield, H. Spring Migrants (3 notes): Additional particulars of Montagu's Harrier breeding in I. of Wight. (T.c.)

Hart, W., and Son. Solitary Snipe near Christchurch. (Field, Sept. I8.) Grey Phalarope and other Birds at Christchurch. (T.c., Oct. I6.) 
Leggatt, H. M. Redfooted Falcon at Titchfield. (Field, Oct. 30); Bittern and Quail near Fareham. (T.c., Dec, I8.)

Peterson, E. F. Chiffchaff in the I. of Wight. (Field, Mar. 27.)

Saunders, H. On Nesting of Montagu's Harrier in I.W. (Field, Sept. I8.)

Smith, H. Arrival of Chiffchaff in the New Forest. (Ficld, April 3.)

Stone, D. F. Curlews in Hants. (Field, June 5.)

I876. Corbin, G. B. Small Birds and Reed Beds; Swallows in December; Rare Birds near Ringwood in Winter, I875-76; Rose-coloured Pastor in Hants. ; Black Grouse in New Forest (Zool.) 6 notes.

Hadfield, H. Migration of Swallows and Martins ; Common Gull ; Arrival of Spring Migrants, etc. ; Rose-coloured Pastor in I. of Wight. (T.c.) 4 notes.

Harting, J. E. Reported Occurrence [errore] of Surf Scoter at Christchurch, Hants. (Field, April 29.)

I877. Bell, T., Curtis, J., and White, G. List of Birds seen in Selborne and Neighbourhood. [In Bell's edition of "Selborne," II.] 2 vols. 8vo. Lond. : I877. [55].

Bidwell, E. American Bittern at Cadnam, New Forest. (Field, Mar. Io.)

Corbin, G. B. Gregarious Habits of Long-eared Owl ; Spotted Redshank in Hants; Hobby Nesting in Hants., etc. (Zool.) 6 notes.

[Editorial.] Purple Gallinules in England. (T.c.)

Feilden, H. W. Hobby nesting in Hants. (T.c.)

Hadfield, $H$. Winter visitors to I. of Wight; Pied Flycatcher and other Birds in I. of Wight ; Crested Lark in I. of Wight. (T.c.)

Lees, G. J. D. Crossbill nesting near Bournmouth. (T.c.)

Morres, A. P. Pied Flycatcher near Salisbury. (T.c.) (partim.) Reid, S. G. Waders near Aldershot. (T.c.)

Rickards, M. S. C. Skua and Shearwater at Christchurch, etc. (T.c.)

I878. Careless, G. A. Hoopoe in I. of Wight. (Op. cit.)

Corbin, G. B. Sparrow-hawks flocking; Grey Phalarope in Hants; Provincial Names (S. Hants.); Bernicle Goose at Ringwood, (T.c.)

[Editorial.] Great Plover shot near Whitchurch. (Field, Oct. 26). Jacobi, H. W. Honey Buzzard in I. of W. (Ficld, Oct. I2).

Tomlinson, H. G. Notes from the New Forest on Woodpeckers. [Zool.]

I879. Dexter, M. Little Bustard in Hants. (Field, Jan. 25.)

Doggett, F. Little Gull [at Christchurch]. (Field, Jan. I8.)

Galloway, A. K. Late Stay of Nightjar. (Op. cit., Oct. 25. Idem. by J. W. N. Jacob. (T.c., Nov. 22.) 
Hadfield, H. Honey Buzzard in I. of Wight; Rare Birds in I. of Wight; Winter Visitors and Spring Migrants to I. of Wight; Summer Migrants in I. of Wight; Wild Geese in I. of Wight in June, etc. (Zool.) 6 notes.

Jacob, T. W. H. Scarcity of Fieldfares in I. of Wight. (Field, Dec. 27.)

M[ann], T. J. Dartford Warbler and Skuas at Bournemouth. (Field, Nov. 29.) Bittern at Christchurch. (T.c., Dec. 27.)

Moser, H. Night Heron and Ruff at Christchurch. (Field, Aug. I6.) Skuas on S. Coast [partim.] (T.c., Nov. 8.)

" O. W." Tufted Duck in N. Hants. (Op. cit., Feb. 8.)

Reid, S. G. Nesting of Black Game in Wolmer Forest. (Zool.). Turner-Turner, J. Rough-legged Buzzard in Hants. (Field, Dec. 27.)

Way, T. E. Great Snipe in I. of Wight. (Field, Oct. 25.)

I880. Carrow, M. Hoopoe near Basingstoke; Peregrine Falcon in Hants. (Zool.)

Crespigny, C. C. de. Hen Harrier in New Forest. (Field, May I.)

Corbin, G. B. On Occurrence of Needle-tailed Swift for second Time in England; Peregrine Falcon in Hants. (Zool.)

Fellowes, A. American Green-winged Teal in Hants. (Zool.) Idem. (Field, Jan. I7.)

"H." Avocet in Langston Harbour. (Field, Oct. 2.)

Hadfield, H. Nesting of Montagu's Harrier. (Zool.)

M[ann], T. J. Great Grey Shrike. (Field, Dec. 4.)

Moser, H. Birds shot near Christchurch. (Field, Jan. 3.)

Newton, A. Exhibition of Needle-tailed Swift from Hants. (P. Z. S.) [Cf. Field, Jan. Io.]

Palmer, W. W. Sabine's Snipe in Hants. (Field, Dec. 4.)

"T. W. B." Blackcock shot near Bournemouth. (Field, Dec. II.)

I881. [Anon.] The Birds of Winchester. (In Fifth Report Winchester Coll. N. H. Soc.)

Brickenden, R. H. L. Honey Buzzard at Farnborough. (Field, Oct. 8).

Corbin, G. B. Great Grey Shrike near Ringwood. (Zool.)

"F.H.S." Great Crested Grebe in I. of Wight. (Field, Feb. I2.)

Hadfield, $H$. Brambling in I. of Wight. (Zool.)

Harting, J. E. Sabine's Snipe in Hants. (T.c.)

Hooper, R. Glossy Ibis in Hants. (T.c.)

M[ann], T. J. Winter Visitors at Bournemouth. (Field, Feb. 5); Uncommon Birds in S. Hants. (T.c., May 2I); Notes from S. Hants. (Op. cit., July 2); Bearded Tit. (T.c., Dec. Io.) "Petrel." Storm Petrel in I. of Wight. (Field, Dec. Io.)

Smith, A. H. Storks in I. of Wight. (Field, July 2.)

Willmore, J. H. Wren's Nest in January. (Zool.) Idem. (Field, Feb. 5.). Storm Petrel near Stockbridge. (T.c., Nov. 5.) 
I882. Corbin, G. B. Fork-tailed Petrel near Ringwood; Hooded Crows in Hants. (Zool.)

Austen, J. H. Great Grey Shrike in Hants. (Field, Dec. I6.) Hadfield, $\mathrm{H}$. Uncommon Birds in I. of Wight. (Zool.) Idem, by F. Smith. (Field, Dec. 2.)

M[ann], T. J. Hen Harrier in New Forest. (Field, Jan. 28.) Spring Migrants at Bournemouth. (T.c., March 25) ; Solitary Snipe in Hants. (Op. cit., Nov. II); Great Grey Shrike in Hants. (T.c., Dec. I7.)

Moser, H. Orange-legged Hobby in Hants. (Field, May 20.)

Smith, F. C. Spotted Crake in I. of W. (Op. cit., Sept. 23.)

"Z." Young Rooks in Hants. in October. (Field, Nov. Ir.)

I883. Corbin, G. B. Migration of the Jay ; Late Nesting of Nightjar ; Early Appearance of Wigeon. (Zool.)

"Cover." White-winged Black Tern in Hants. (Field, May 5.)

I884. Aplin, O. V. Records of Hoopoe in Hants. (Zool.)

Austen, J. H. Great Grey Shrike in Hants. (Field, Feb. r6.)

Hadfield, H. Gulls in I. of Wight. (Zool.)

Hart, E. Kite in the New Forest. (Field, Nov. I); Rare Birds at Christchurch. (T.c., Dec. 20.)

Jeffery, W. Scops Owl in Hants. (Field, July 5.)

Mann, T. J. Great Reed Warbler at Ringwood. (Zool.) Great Grey Shrike in Hants. (Field, Feb. 9).

Scott, Lord H. J. Flamingo shot in Hants. (Zool.)

Smyth, W. T. Roller in the I. of Wight. (Field, June I4.)

Willmore, J. H. Lesser Spotted Woodpecker near Stockbridge; Wild Duck laying in Rook's Nest. (Zool.)

I885. Corbin, G. B. Short-eared Owl in the S. of England. (Op. cit.)

Hadfield, H. Uncommon Birds in I. of Wight. (T.c.)

Hart, E. Uncommon Birds near Christchurch. (Field, Oct. 24.)

Mann, T. J. Bittern in Hants. (T.c., Dec. I2.)

Reid, S. G. Squirrels destroying Eggs of Picus Major. (Zool.)

Richards, A. J. Quail in December. (Field, Jan. 3).

Willmore, J. H. Stock Dove Appropriating Song Thrush's Nest. (T.c.)

I886. Corbin, G. B. Brent Goose and Fork-tailed Petrel near Ringwood. (Zool.)

Dewar, G. Woodcock nesting in Hants. (Field, June 26.)

Hart, E. Grey Phalarope in Hants. (Op. cit., Oct. 23.)

Penny, F. J. Wounded Bittern found in Hants. (Field, Feb. I3).

Renshaw, A. G. Nutcracker in Hants. (Zool.)

Salter, J. Alpine Swift in Hants. (Field, May I5.)

1887. Aplin. O. V. Roller and other Birds in I. of Wight. (Zool.)

Corbin, G. B. Dark Variety of Montagu's Harrier in Hants. (T.c.)

Hart, E. Montagu's Harrier in Hants. (Field, July 30.) Longtailed Duck and other Birds at Christchurch. (T.c., Nov. 26.) 
"J. B." Shorteared [errore for Long-Eared] Owl nesting in Hants. (Field, June II, I8.)

I888. Aplin, O. V. Cirl Bunting in Hants. (Zool.)

Butler, E. A. Pallas's Sand Grouse in Hants. (T.c.) Idem, by W. Jeffery. (T.c.)

Corbin, G. B. Wildfowl at Ringwood; Pallas's Sand Grouse in Hants.; Hoopoe in Hants. (T.c.)

Fane, F. Redlegged Partridge in Dorset [status in Hants. noticed]. (Field, Mar. I7.)

Hart, E. Osprey at Christchurch. (Field, Nov. 24.)

Henry, J. S. Hoopoe in I. of W. (Op. cit., April 2I.)

Lilford, Lord. Pallas's Sand-Grouse [near Bournemouth]. (Field, June 9.)

Willmore, J. H. Cirl Bunting in Hants. (Zool.)

I889. Corbin, G. B. Scarcity of House Martin in Hants. (Zool,)

[Editorial.] Crossbills Nesting in Suffolk, etc. [and Hants.] (T.c.)

Frogatt, A. P. Little Gull at Bournemouth. (Field, Nov. I6.)

Gurney, J. H. Wilson's Petrel in I. of Wight. (Zool.)

Hadfield, H. Rare Birds in I. of Wight ; Rooks in I. of Wight, Correction. (Zool.)

Hart, E. Rare Birds in Hants. (Zool.)

Houghton, W. Sabine's Snipe in Hants. (Field, Nov. r6.)

Jeffery, W. Pallas's Sand Grouse in Hants. (Zool.)

Kelsall, J. E. Reported Nesting of Dipper in Hants. (Field, March 9.)

I89o. Aplin, O. V. On Distribution, etc., of the Spotted Crake. (Zool.) [partim.] [24.]

Corbin, G. B. Hybrid Mallard and Shoveler. (T.c.)

Gurney, J. H. Martinique Gallinule in Hants. (T.c.)

Hart, E. Note on American Killdeer Plover shot at Christchurch. (T.c.)

Kelsall, J. E. A Briefly Annotated List of Birds of Hampshire and the Isle of Wight. ( $P r$. Hants. Field Cl.) Also reprinted separately. 8vo. Southampton: I8go. [325.] Idem. Supplement. (T.c., I898 ?)

[date?] Kelsall, J. E. Birds [in Roger's Guide to the New Forest, 7 th edit.) 8vo. Southampton: n.d. (325.)

I89I. Baring, A. H. Tufted Duck nesting in Hants. (Zool.) Idem. (Field, July II.)

"B. B." Grey Phalarope in I. of Wight. (Field, Nov. 2x.)

Bourne, J. Great Bustard in Hants. (Op. cit., Jan. Io.)

Corbin, G. B. Landrail in Hants, in Winter: Rednecked Phalarope in Hants. (Zool.)

Coles, R. E. Sabine's Gull in Hants. ; (Field, Nov. 7 and 28); Idem, by H. Saunders. (T.c., Dec. I9.)

Davies, Sutton A. List of Birds of Winchester, I89I. [vide Kelsall and Munn, p. XIV.] 
Gurney, J. H. Melanism of Water Rail. (Zool.)

Hart, E. Notes from Christchurch. (Zool.)

Harting, J. E. The recent visitation of Bustards. (Field, Feb. 28.) [partim.]

Lathy, P. T. Black Redstart in Hants. (Zool.)

Leach, H. R. Grey Phalaropes in I. of Wight. (Field, Oct. 24.)

Meinertzhagen, D., junr. Eagle Owl in Hants. (Field, May 2.)

Stares, G. Grey Phalarope in Hants. (Field, Nov. 2I.)

Tuck, W. H. Mortality of small birds during recent frost. (Zool.)

Young, J. Manx Shearwater inland in Hants. (Field, Oct. 24.)

I892. Aplin, O. V. On Distribution of Cirl Bunting; Status of Woodchat. (Zool.) [partim.] [25.]

Coburn, F. Sabine's Gull near Bournemouth. (T.c.)

Corbin, G. B. Hobby preying on Swallows; Variation in plumage of Woodpeckers; Bitterns in S.W. Hants. (T.c.)

Davies, S. A. Roughlegged Buzzard in Hants. (T.c.); Dipper in Hants. (Field, Dec. Io.)

[Editorial.] Ruddy Sheldrake in Hants. (T.c.)

1893. Anderson, Mrs. Reported Occurrence of Black Woodpecker in New Forest. (Zool.)

Corbin, G. B. Birds of Prey in New Forest; Coot on Hampshire Avon; Short-eared Owl in Hants. in summer. (T.c.)

Davies, S. A. Ornitholog. Notes from Mid-Hants., 2 pts. (Op. cit., I893-4.) ; Nesting of Coot. (Op. cit., I893.) Bittern in Hants. (Field, Dec. 2.); Common Buzzard in Hants. $(O p$. cit., March II.)

Hawker, Col. Peter. Diary. 2 vols. 8vo. Lond. : I893. [286.]

Leaton-Blenkinsopp, R. C. Woodcock in Bournemouth. (Field, Jan. 7.)

Owen, J. A. On Birds of Christchurch Bay and New Forest. [In Forest Field and Fell.] Cr. 8vo. Lond.: I893. [454.]

Stares, J. Quails in Winter in S. Hants. ; Spoonbill in S. Hants. $($ Zool. $)$

Styan, G. V. S. Grey Phalarope and Great Northern Diver near Southsea. (Field, Jan. 7.)

Wyatt, H. R. P. Hoopoe in Hants. (Field, May 6.)

I893-4. Atkins, E. F. [Articles in] Sussex and Hants. Naturalist Vol. I. and Vol. II., Nos. I-5 (all pub. 8vo. Andover: I893-4.

I894. Atkins, E. F. A Visit to Southampton. (Nat. Jnl.)

Corbin, G. B. Montagu's Harrier in Hants. (Zool.)

Davies, S. A. Nesting of Bittern in Hants. (T.c.)

"Dabchick." Little Gull in Hants. (Field, Feb. 3.)

"Durham." Blackgame in Hants. (Field, Feb. I7.)

Gurney, J. H. Black-backed purple Gallinule in Hants. (Zool.) 
Hart, E. Hart's Museum, Christchurch. An Annotated List of the Birds and Animals. 8vo. Southampton: I894. Reissue, I9I3. [270.]

Mathew, M. A. Lesser Grey Shrike in Hants; Occurrence of "Cape Pigeon" at Bournemouth. (Zool.)

Murrill, W. K. Eared Grebe in Hants. (Field, Feb. I7.)

Orchard, C. Hoopoe in I. of Wight. (Field, April 28.)

Witherby, H. F. Forest Birds. I2mo. Lond.: I894. [656.]

1895. Corbin, G. B. The Hawfinch in Hants; Purple Gallinule in Hants. (Zool.)

Langdale, H. M. Greenfinch appropriating Thrush's Nest; Quail in I. of Wight. (T.c.)

Murrill, W. K. Red-necked Grebe in Hants. (Field, Dec. 28.)

Stares, J. Snipe drumming in January. (Zool.)

I896. Bucknill, J. Rose-coloured Pastor in Hants. (Op. cit.)

Bridger, M. L. Grey Phalarope in Hants. (Field, Oct. 3.)

Corbin, G. B. Disease in Wood Pigeons; Purple Gallinule in Hants; Variety of Barn Owl, etc. (Zool.) 5 notes.

Curtis, W. Short History and Description of the Town of Alton. 8vo. Winchester : I896. [I58.]

Headley, A. G. Quails in England in Winter. (Zool.)

Moir, G. The Birds of the Haven. (Ornithologist.)

Marshall, T. Late Swallow. (Field, Nov. I4.) Idem, by "L. E. G." (T.c., Nov. 28.) by A. Pell and "W. H. R." (T.c., Dec. 5.)

Smith, G. W. Flight of Peewits ; Notes from Hants. ; Unusual Abundance of Larus camus in Hants. (Zool.)

Templer, G. A. Reeve in Hants. (T.c.) Idem. (Field, Sept. I9.)

Watkins, W. Bonaparte's Gull (?) at Freshwater, I. of Wight. (T.c., Oct. 24, 3I.)

1897. Coburn, F. Redlegged Partridge Migrating. (Zool.)

Coles, R. E. Pied Flycatcher in I. of Wight. (Field, May 8.)

Corbin, G. B. White Eggs of Hedge Sparrow; Crossbills near Bournemouth. (Zool.)

Pratt, J. Aquatic Warbler in Sussex and Hants. (Knowledge.)

Sclater, P. L. Ornithology (of Hants.) ; and Cowper, J. Birds of the I. of Wight. (In Deacon's Hants. and Dorset Court Guide, etc.) 8vo. I897.

Scott, S. G. Aquatic Warbler in Hants. (Zool.) Idem, by J. E. Kelsall. (T.c.)

Smith, G. W. Winter Notes from Winchester Water-Meads; Yellow-billed Cuckoo in I. of Wight; Note on Pied and Grey Wagtail in Itchen Valley. $\left(T . c_{\text {. }}\right)$

I897-98. Smith, G. W. Notes from Mid-Hants; Spring and Summer; I897; Autumn and Winter, I897, 2 pts. (Op. cit., I897-98. 
I898. "A. M. S." Pigeon [Stockdove] laying more than Two Eggs. (Field, May 28).

Bankes, A. Crossbills in Hants. (Zool.)

Clutterbuck, R. H. Notes on the Parishes of Fyfield, Kimpton, Penton Mewsey, etc. 8vo. Salisbury: I898. [I37.]

Corbin, G. B. The Brambling in Hants.; Roughlegged Buzzard near Ringwood; Crossbills in S.W. Hants. in I898. (Zool.)

Horsbrugh, C. B. Nesting of Hobby in Hants. (Zool.) Idem, by J. J. Armistead. (T.c.) Idem, by G. B. Corbin. (T.c.)

Medley, H. F. Dipper in Hants. (Field, Nov. Ig.)

Riviere, B. Ornitholog. Notes of Alum Bay, I.W. (Zool.)

Westell, W. P. Scoters in Hants. and I. of Wight. (T.c.)

Yonge, C. M. John Keble's Parishes. Cr. 8vo. Lond. : I8g8. [672.]

I899. Dewar, G. B. Wild Life in Hampshire Highlands. Cr. 8vo. Lond.: I899. [I67.]

Corbin, G. B. Variety of Song Thrush in New Forest ; Swallows and Hobbies. (Zool.)

"C. L." Storm Petrel in Hants. (Field, Dec. 9.)

Gore-Browne, D. Habits of Nuthatch. (Field, Feb. 25).

Headley, A. G. Scoters in S. Hants. (?) (Zool.) Idem, by W. P. Westell. (T.c.)

Langdale, H. M. Scoters in Hants. and I. of Wight. (Zool.)

Nias, J. B., and Waddilove, E. G. Reported Siberian Thrush in Hants. (Field, July 22, Aug. I2.) Idem, by Editor [dissent]. (T.c., July 22); by H. L. Popham. (T.c., July 29).

Starkie, F. C. Bitterns in Hants. (Field, Dec. 30.)

Ig00. [Anon.] Collection of Hampshire Birds (I863-1900) in Winchester College Memorial Buildings. Warren : Igoo.

Aylmer, C. C. Early Nest of Kingfisher. (Field, April 28.)

Bucknell, Lt.-Col. Hoopoe in Wilts. [Hants.] (Field, May 26.)

Corbin, G. B. Early Appearance of Swift; Hoopoe in Hants. and Dorset; Hybrid Pheasant. (Zool.)

Corbin,G. B. Our Hampshire Birds. Reprinted from Dent's County Guide. Fcap 8vo. Lond. : I9oo. [I43.]

Meade-Waldo, E. G. B. Aves. (In Victoria Hist. of Co. of Hampshire and the Isle of Wight. (I.) 4to. Lond. Igoo. [395.]

Stares, J. Black-tailed Godwit in Hants. (Zool.)

I901. Corbin, G. B. Variety of Pied Wagtail; Wildfowl on the Hampshire Avon during Winter, I900-I; Osprey in Hants.; American Yellow-billed Cuckoo at Ringwood; Great Snipe and Variety of Swallow in Hants. (Zool.) 5 notes.

Long, C E. P. Pied Flycatcher [nesting] in Hants. (Field, June 22.)

Pain, J. E. Arrival of Wigeon [in Hants.]. (Field, June 22.) Talbot-Ponsonby, C. G. The Cirl Bunting in Hants. (Field, Dec. 2I.) 
I902. "C. J. M." Stork in the Isle of Wight. (Field, June 7.)

Corbin, G. B. Varieties of Blackbird, etc.; Wild Duck Female in Male Plumage; Migration of Jays; Long-eared Orvl. (Zool.)

Deane, L. Blackbird's Nest on Ground (with Cuckoo's Eggs). (Field, June 7.)

Hudson, W. H. Last Hampshire Ravens. (Animal Life, I.)

Kelso, J. E. H. Unusual Nest of Ringed Plover. (Zool.)

Sclater, P. L. [Porphyrio poliocephalus from Hants.] (Bull. B.O.C., XIII.).

Tillard, T. A. Crossbills in Hants. (Field, Jan. 25.)

I903. Corbin, G. B. Abundance of Swifts in S. Hants. ; Note on the Kestrel; Note on Shoveler in Valley of Avon; Sea Birds Inland. (Zool.)

Hudson, W. H. Hampshire Days. 8vo. Lond. : 1903. [303.]

Kelso, J. E. H. Nesting of Ringed Plover. (Zool.)

Rawnsley, W. F. Parrot Building in Open at Park Hill, New Forest. (Zool.)

Witherby, H. F. Hoopoe in Hants. (Knowledge.)

I904. Corbin, G. B. Honey Buzzard; Abundance of Coot in S. Hants. ; Wildfowl on Hampshire Avon during Winter of I903-04; The Hobby and its Prey ; Roller in Hants., etc. 7 notes. (Zool.) Chalkley, W. Great Skua in Hants. (Field, March I2.)

Kelso, J. E. H. Nesting of the Ringed Plover. (Zool.)

Kingdom-Murrill, W. Eared Grebe in Hants. (Field, Dec. Io.) Noble, H. Gadwall in Hants. (Zool.)

Trevor-Battye, A. Short-eared Owl nesting in Hants. (Avicult. Mag. ; Knowledge.)

I905. Corbin, G. B. Wildfowl on Hants Avon during winter of I904I905; Red-backed Shrike and its prey ; Black Tern near Ringwood; Summer Migrants in S.W. Hants., etc. (Zool.) 5 notes. Fergusson, E. J. Tit Building in Magpie's Nest. (Field, June 3.) Kelsall, J.E., and Munn, P. W. The Birds of Hampshire and the Isle of Wight. 8vo. Lond. : I905. [325.]

Kelso, J. E. H. Peculiar Nests and Nesting Sites of Lapwing. (Zool.)

Leigh, J. H. Cuckoo's Egg in Wren's Nest. (Field, June Io.)

Langdale, H. M. Late Stay of Swift. (Zool.)

Pattinson, H. L. Sandwich Tern in November. (Field, Nov. 25.)

Witherby, H. F. On Occurrence of Aquatic Warbler and Icterine Warbler in Isle of Wight. (Bull.B.O.C., XVI. ; Ibis.)

1906. Barnes, W. M. Landrail in January (in I. of Wight). (Field, Feb. I7.)

Corbin, G. B. Notes from Ringwood; Small Sparrow-Hawk, etc. 4 notes. (Zool.)

Leigh, H. Early appearance of Sand Martine (Field, April I4.) 
Nicholl, A. M. C. Ring Ouzel (?) nesting in I. of Wight (Field, June 23); Yellow Hammer nesting in September. $(O p$. cit., Sept. 22.)

Sclater, P. L. Brambling in Hants. (Bull. B.O.C., XVI.)

I907. Beeston, H. Observations of an Attempt of the Swallow Tribe to winter in S. Hants. during I906-07, 3 pts. ; Extended breeding-range of Marsh Warbler into Hants. (Zool.)

Corbin, G. B. Hybrid Pheasant; Dartford Warbler in Hants. ; Hen-Harrier in S.W. Hants.; Winter Notes from Ringwood, etc. 6 notes. (Zool.)

"C. J. M." Rough-legged Buzzard in Isle of Wight. (Field, Dec. 2I.)

Marshall, C. J. Swallows [House Martins] in December. (Field, Dec. I4.)

Scott, S. G. Swallows and Martins in Winter. (Field, Jan. I9.)

I908. Bonhote, J. L. On Occurrence of Phylloscopus collybita abietina in I. of Wight. (Bull. B.O.C., XXIII. ; Brit. Birds.)

Corbin, G. B. Rough-legged Buzzard in Hants.; Notes from S.W. Hants. (Zool.)

Cowie, A. G. Sandmartins in November. (Field, Nov. I4.)

Dewar, G. A. B. Life and Sport in Hampshire. 8vo. Lond. : I908. [167.]

Frohawk, F. W. Reported nesting of Merlin in Hants. [correction]. (Field, March 28.)

"M. I." Sandgrouse in Hants. (Field, June 20); Idem by H. B. Roper. (Op. cit., July I8.)

Paterson, J. M. Hoopoe in I. of Wight. (Field, May 9.)

"W. N. G. E." Cuckoo in Southsea. (Field, Sept. 26.)

I909. Corbin, G. B. Notes from S. W. Hants ; Early appearance of Cypselus apus; Unfortunate Swifts. (Zool.)

Fox, R. H. Birds [in F. Morey's Guide to Natural History of Isle of Wight]. 8vo. Lond.: 1909. [222.]

Kelso, J. E. H. Where are our Nuthatches? (Zool.)

Kelsall, J. E. Nesting records of Kittiwake in Isle of Wight. (Brit. Birds, II.)

Marriage, A. W. Little Owl in Hants. (Brit. Birds, II.)

Rose, J. White Chaffinch. (Zool.)

Trevor-Battye, A. Water Rail in Hants. (Avicult. Mag.)

I909-IO. Goodchild, H. A September Ramble in the I. of Wight, 2 pts. (Bird Notes, I909-10.)

I9I0. Clarke, G. V. Crossbills nesting in Hants. (Brit. Birds, III.); Davies, D. Idem. (T.c.)

Coles, R. E. Crossbills nesting in England [Hants.]. (Brit. Birds, IV.)

Cotton, T. A. Chiffchaff in Hants. (Zool.)

Corbin, G. B. Notes from S.W. Hants. ; Late Eggs of Nightjar. (Zool.) 
[Editorial.] Presumed Breeding of Pintail in Hants. (Field, Oct. 8.)

Green, W. P. Crossbills in Hants. (Field, Apr. 23.)

Kelsall, J. E. On some I. of Wight Birds. (Brit. Birds, IV.) Crossbills in Hants. (Zool.)

Kelso, J. E. H. Havoc wrought by Starling. (Zool.)

Lynes, H. Black Tern in Hants.; On Nesting of Hobby in Hants; Nesting of Little Owl in Hants. (Zool.)

Medlicott, W. S. Irruption of Crossbills. [Hants.] (Brit. Birds, III.) ; Late Stay of Brambling. (Op. cit., IV.)

Munn, P. W. Great Bustard in Hants. (Brit. Birds.)

Nicholl, A. M. C. Black Redstart in I. of Wight. (Field, April 23.)

Troubridge, T. H. C. Crossbills nesting in Hants. (Brit. Birds.)

Witherby, H. F. Crossbills nesting in Hants. (Op. cit., III.)

IgII. Austen, J. H. Puffin near Lyndhurst. (Field, Dec. 2.)

"A. C. W." Supposed Montagu's Harrier trapped near Beaulieu. (Field, Jan. 7.) [cf. T.c., Jan. I4.]

Charlton, J. M. Snipe pursued by Falcons. (Brit. Birds, IV.) Coles, E. Night Heron in Hants. (Brit. Birds, V.)

Corbin, G. B. Decrease of Corncrake, Wryneck and Nuthatch ; Notes from S.W. Hants. (Zool.)

D[avies], D. Habits of the Hobby. (Field, Jan. 7.)

Mitford, R. S. Alpine Swift in Hants. (Zool.)

Nicholl, A. M. C. Siskin in I. of Wight. (Field, Mar. 25.)

Troubridge, T. H. C. Notes on Hants. Birds. (Brit. Birds, IV.)

I9I2. Corbin, G. B. Varieties of Woodcack, Starling, etc., in S.W. Hants. ; Notes from the Avon Valley. (Zool.)

Chawner, E. F. Gannet inland. (Field, Nov. 9.)

Munn, P. W. Madeiran Fork-tailed Petrel in Hants. (Brit. Birds, V.)

Troubridge, T. H. C. Crossbill nesting in Hants. $(O p$. cit., VI.)

Witchell, E. N. Swallows still at Bournemouth. [Nov.] (Field, Nov. 9.)

I9I3. Corbin, G. B. Notes from the Avon Valley. (Zool.)

Lambert, H. B. Quail in ..... Hants. (Field, Sept. 6.) Marriage, A. W. Grey Wagtail breeding in Hants. (Brit. Birds, VII.) Idem, by P. W. Munn. (T.c.)

Smith, K. S. Probable Scarlet Grosbeak in Hants. (T.c.) Troubridge, T. H. C. Crossbills breeding in Hants. (Brit. Birds, VI.)

I9I4. Cole, W. P. Great Skua in Hants. (Field, Oct. 3.)

I9I5. Colthrup, C. W. Screened and open nests of Redshanks in Hants. (T.c.) 
Imrie, E. M. Nightjar double-brooded in Hants. (T.c.) Black Redstart in Hants. (Brit. Birds, VIII.)

Langdale, H. M. Hobby in Petersfield District. (Zool.)

I9r6. Blagg, F. E. Rough-legged Buzzard in Hants. (Brit. Birds, IX.)

Imrie, E. M. Spoonbill in Hants. (Brit. Birds, X.)

I9I7. Cumberbatch, C. P. Curlews in the New Forest. (Field, June 2.)

Iremonger, H. E. W. Lesser Grey Shrike in Hants. (T.c., April 2I.)

Stillwell, V. E. Redfooted Falcon in Hants. (Field, May I9.)

I9I8. Ashley, M. On the breeding habits of the Hobby [in Hants.]. (Brit. Birds, XI.)

Coles, R. E. Rollers in Hants. and I. of Wight. (Brit. Birds, XII.) Idem, by F. C. R. Jourdain. (T.c.)

Jourdain, F. C. R. Little Auk in Hants. (Brit. Birds, XI.)

Kelsall, J. E. Grey Phalarope in Hants. (T.c.)

Shaw, C. A. Green Woodpecker in I. of Wight. (Op. cit., XII.)

\section{HEREFORDSHIRE.}

I829. Hill, W.H. Nat. Hist. in English Counties. Herefordshire : Picus minor [common $\mathrm{n}$ the Co.]. (Loudon's Mag. N.H., II., p. 387.)

I830. Harvey, J. A. Idem : A Snipe of a Novel Colour. (Op. cit., III., p. 436.)

I832. H[arvey], J. A. Fork-tailed Petrel and sp. of Tern found dead inland. (Op. cit., V., p. 283.)

I833. Evans, J. Puzzling Specimen of Oystercatcher. (Op. cit., VI., p. I52.)

r840. Lingwood, R. M. Short Outline of Fauna for Part of Herefords. (Ann. Nat. Hist.)

1846. Lingwood, R. M. Brambling near Ross. (Zool.)

I850. Biddulph, J. Black Grouse in Herefords. (Op. cit.)

I85I. Cordeaux, W. H. [ex Worcester Jnl.] Occurrence of Golden Eagle in Herefords. (Op. cit.)

Evans, W. E. The Songs of the Birds. Post 8vo. I85I. [202.] Stride, E. E. Addit. Heronries ["The Moor" near Hay]. (Nat. [Morris's], I.)

I860. Belfrage, J. H. Notes on Birds observed in Herefords. (Zool.) Buddicom, W. S. Nuthatch [in Herefords.]. (Field, Dec. 8.)

"Solitaire." Idem. (T.c., Dec. 22.)

I86r. Boyce, W. S. Partridge with Curious Beak. (Op. cit., Jan. I2.) 
[I862.] Lingwood, R. M. List of Animals, Birds, etc. of Herefords. (Tr. Woolhope Nat. F. C., IV.). Re-issued I907.

I862. "Ornithophilus." Keeping Woodcock [bred in Herefords.] in Confinement. (Field, Sept. 20.)

I863. Clutterbuck, J. W. Cuckoo laying in a Greenhouse. (Zool.)

I864. Newman, E. Abundance of Swift at Leominster. (Op. cit.)

I866. Lloyd, J. Crossbill in Herefords. (Tr. Woolhope Nat. F. C.) : Idem. (Field, Sept. I.)

I867. "D." Storm Petrel in Herefords. (Field, Oct. 5.)

I869. Armitage, A., and Ley, C. Occurrence of Rare Birds and their Nidification in County. (Tr. Woolhope Nat. F.C.)

Blight. R. List of Birds observed at Bredwardine. (T.c.)

Lloyd, J. W. Notes on Rare Birds in Herefords. and Radnors. (T.c.) Kittiwake in Herefords. (Field, Mar. 30.)

I870. Armitage, A., and Ley, C. Occurrence of Rare Birds in Herefords., etc. (Tr. Woolhope Nat. F.C.)

I871. Lees, E. Birds of the Malvern District, etc. (Repr. from Malvern Nat. F. C.) 3 pts. (Zool.) [partim.] [347.]

Lloyd, J. W. Pied Flycatcher nesting in Herefords. ; Hawfinch nesting in Herefords. 2 notes. (Field, July I.) Idem. 2 notes. (Zool.) Quails in Britain in I870 [status in Herefords.]. (Field, Jan. 28, Feb. II.)

I872-73. Harting, J. E. British Heronries. (Zool.) [partim.] [274.] I872. Lloyd, J. W. Green Sandpiper in Herefords. (Field, Dec. I4.) I873. Bailey, H. J. Tufted Ducks in Herefords. (Op. cit., Feb. 22.) Mathews, D. Range of Stock Dove in England [breeding W. Herefords.]. (Op. cit., May 3I.)

Middleton, C. H. List of Birds observed at Lingen. (Tr. Woolhope Nat. F. C.)

I875. Pilly, J. B. Hobby and Egyptian Goose near Hereford. (Zool.)

I876. Bailey, H. J. Tufted Duck in Worcestershire [err. for Herefords.]. (Field, Aug. I9, 26.)

Heaton, W. H. The Worcestershire [sc. Herefords.] Tropic Bird. (Zool.)

I877. " $\mathrm{P}$ " and "R.S." Woodcock nesting in Herefords. (Field, May 5.) 2 notes.

Rocke, J. White-tailed Eagle in Herefords. (Zool.)

I879. Chapman, D. R. Hoopoe in Herefords. in November. (Field, Nov. 29.)

Pilley, J. B. Honey Buzzard nesting in Herefords. (Zool.) 
I880. Chapman, D. R. Uncommon Birds near Hereford. [Gannet, Pink-footed Goose and Leach's Petrel.] (Field, Dec. II.); Great Crested Grebe near Hereford. (Op. cit., April 17.)

Wood, H. H. Woodcock nesting in Herefords. (Op. cit., Aug. I4.)

I88I Armitage, E. Red-legged Partridge in Herefords. (Op. cit., Oct. I5.)

Elmes, W. Honey Buzzard in Herefords. (T.c., Aug. 20.)

1882. Chapman, D. R. Pomarine Skua in Herefords. (Op. cit., March II.)

Ridley, H. N. Gadwall in Radnors. [and Tufted Duck in Herefords.]. (Zool.)

I884. "Kington." Manx Shearwater Inland. (Field, Sept. 27.)

I885. Mynors, A. B. Late Nesting of Wood-Pigeon. (Op. cit., Oct. I7.)

I886. Wood, H. W. Black Game in Herefords. (Zool.)

I887. Blake, W. Manx Shearwater in Herefords. (Op. cit.)

Marsden, H. W. Nesting of Common Sandpiper. (T.c.)

I888. Bull, H. G. Notes on the Birds of Herefordshire. 8vo. Lond., etc. : I888. [106.]

[Editorial.] The Game Birds of Herefords. (Field, July 2I.)

I889. Ashdown, C. Fulmar Petrel and Grey Phalarope near Hereford. (Op. cit., Oct. I9.)

Horne, G. An Authenticated List of the Birds of Herefordshire. 8vo. Hereford : I889. [297.]

Partridge, W. Woodcock's Nest in Herefords. (Field, May 4.)

Phillips, E. C. Great Black Woodpecker in England. (Zool.) [partim.] Idem. (Tr. Woolhope Nat. F. C.)

Reid, Mayne. The Naturalist in Siluria. Post 8vo. Lond. : r889. [partim.]

I8go. Aplin, O. V. On Distribution and Period of Sojourn in Britich Islands of Spotted Crake. (Zool.) [partim.] [24.]

I890-92. Ashdown, W. C. Ornithology in Herefords., I889-I893. (Tr. Woolhope Nat. F. C.)

I89I. Ashdown, W. C. Manx Shearwater on Wye. (Field, Oct. Io.); Skuas and Phalaropes in Herefords. (T.c., Oct. 3I.)

Bund, J. W. W. Syst. List of Birds most met with in Counties of Worcester, Hereford, etc. 8vo. [25.]

Millichamp, C. Bittern in Herefords. (Field, Jan. 24.)

Pashley, R. Bewick's Swan in Herefords. (T.c., Jan. I7.)

Pilley, J. B. Nesting of Magpic and Carrion Crow. (Zool.)

I892. Aplin, O. V. On Distribution of Cirl Bunting in Great Britain. (Zool.) [partim.] [25.]

I893. Ashdown, W. C. Uncommon Birds in Hereford. ; Green Sandpiper in November, 2 notes. (Field, Nov. 25. Dec. 9.)

Horne, G. Intelligence of Tits. (T.c., Dec. 9.) 
I894. Ashdown, W. C. Stone Curlew in Herefords. (Op. cit., Dec. I5.) Gurney, J. H. Occurrence of Tropic Bird in England. (Tr. Norf. \& Norw. Nat. Soc., V.) [Cf. Zool., I876.]

"W. A. F." Tree Pipit in winter in England. (Field, Jan. 27.)

I895. Blake, W. Honey Buzzard in Hertfords. [errore for Herefords.]. (Nat. Jnl.)

de Winton, W. E., and Davenport, H. S. Honey Buzzard nesting in Herefords. (Zool.)

I896. Blake, W. Notes from Herefords. (Ornithologist.)

Robinson, M. G. Nightingales on Welsh Border. (Zool.)

Williams, R. Curious Experiences in Birds' Nesting. (T.c.)

I897. D'Urban, W. S. M. Isabelline Variety of Meadow Pipit in Herefords. (Knowledge, Nov.)

I898. Edwards, A. Night Flying Habits of Swift. (Field, July 23.)

I898-99. Hutchinson, T. Birds of Herefords. (Tr. Woolhope Nat. F. C.)

r899. " R. C. D." A Brookside Ramble in Herefords. (Field, July I.)

I900. Blathwayt, F. L. Pied Flycatcher in Somerset and Herefords. (Zool.)

Watkins, M. G. Scarcity of Corncrake in Herefords.; Absence of Nightjar from Herefords. (Field, Sept. I5.)

Igor. Bulmer, E. F. Woodpigeon's Eggs in Jay's Nest. (Field, May II.)

I902. Forrest, H. E. Nutcracker in Herefords. (Zool.)

Hansard, H. L. Glossy Ibis in Herefords. (Field, Oct. 25.)

Pratt \& Sons. Glossy Ibis in Herefords. (Knoreledge.)

Townsend, G. Great Black Woodpecker in Herefords. (Zool.)

1903. Watkins, S. C. Summer Birds in Herefords. (Field, Apr. 4.)

I905. Norton, J. H. Merganser in Herefords. (Op. cit., Feb. II.)

I906. Philpott, F. O. Nightingales in Herefords. (Op. cit., May 26.)

I908. Phillips, E. C. [Birds. In] Victoria History of Co. of Hereford, I. 4to. Lond.: I908. [47I.]

I909. Farn, A. B. Phylloscopus sibilatrix [in January]. (Zool.)

Forrest, H. E. White-tailed Eagle in Herefords. (Brit. Birds, II.) Idem by W. P. Pycraft. (Knowledge.)

I9I0. Forrest, H. E. Irruption of Crossbills. (Brit. Birds, III.) [partim.]

I9II. Alexander, C. J. Willow Tit in Worcesters. and Herefords.; Little Owl in Herefords. and Worcesters. 2 notes. (Op.cit., V.) Medlicott, W. S. Nightingale nesting in Herefords. ; Siskins in Herefords. 2 notes. (T.c.)

Palmer, W. C. Breeding of Honey Buzzard in England. (Zool.)

Phillips, E. C. Golden Oriole in Herefords. (Field, Oct. 30.) 
Ticehurst, N. F., and Jourdain, F. C. R. On Distribution of Nightingales during Breeding Season in Great Britain. (Brit. Birds, V.) [partim. $] \quad[584,322$.

I9I2. Passingham, G. A. Large Flight of Swifts. (Field, June I.) Philips, E. C. Hooded Crow in Herefords. (T.c., May II.)

I9I4. Twyman, R. S. Avicultural Notes from Leominster. (Zool.)

I9I5. Astley, H. D. Greater Spotted Eagle in Herefords. (Brit. Birds, IX.)

"G. M. M. S." Destruction of Heronry. (Field, May I.)

Harting, J. E. Spotted Eagle in Herefords. (Field, Dec. 4.)

Ogilvie-Grant, W. R. Greater Spotted Eagle in Herefords. (Brit. Birds, IX.)

I9I6. Astley, H. D. Wagtails in Herefords. (Avicult. Mag., p. 345.) Watkins, S. C. The Barn Owl in N. Herefords. (Field, Mar. I8.)

I9I7. Watkins, S. C. Alpine Swift in Herefords. (Op. cit., July 28.) I9I8. Watkins, S. C. Black Redstart in Herefords. (Op. cit., Nov. I6.)

\section{HERTFORDSHIRE.}

1825. Yarrell, W. Notice of occurr. of some rare Brit. Birds [Forktailed Petrel and Osprey in Herts.]. (Zool. Jnl., II., pp. 25-26.)

1849. Crewe, H. H. Hawfinch at Tring and Berkhamsted. (Zool.) Lucas, W. Water Ouzel and Bearded Tit near Hitchin. (T.c.) Williams, Rev. J. Bearded Tit near Tring; Garganey and Goldeneye at Tring. (T.c.)

I852. J-, C. A. Roller in Herts. (Nat. [Morris's], II.)

I856. Tuck, E. J. Occurrence of Rose-coloured Pastor and Woodchat Shrike. (Zool.)

1857. Farewell, F. Young Landrails in Lord Grosvenor's Park, near Watford. (Field, Aug. I.)

I858. [Anon.] "W. F." Golden Eagle shot at Nazing Park. (Op. cit., Nov. 27.) ; "Bessie" Blackbirds and Thrushes singing Dec. I-3, near Hitchin. (T.c., Dec. II.)

1859. "C. H." Buzzard [at Hatfield]. (Field, Dec. Io.)

1860. "Ranger." Peregrine Falcon [shot at Hatfield]. (Op. cit., Jan. 7.)

1862. Brunton, T. Short-eared Owl and Rough-legged Buzzard near Bishop Stortford. (Zool.)

1864. Crewe, H. Harpur. Cirl Bunting in Herts. (Field, Dec. 3, Io) ; Osprey shot in Herts. (T.c., Dec. 3, Io.)

1865. Crewe, H. H. Osprey in Herts., etc. (Zool.) 
I867. Clear, W. Quail in January [near Royston]. (Field, Jan. 26.) Grout, J. Common Skua Gull [at Braughin]. (Field, Nov. 2.) Hooper, W. T. Tufted Pochard on R. Lea. (Zool.)

I868. "W. T. H." Notes from Herts. (Field, Oct. 24.)

I869. Fairlie, E. Extraordinary Migration of Pigeons. (Field, Jan. I6.)

I87I. "W. F." Bittern near Hertford. (Field, Jan. I4.)

Holford, C. E. Great Grey Shrike at Ware. (Zool.)

I872. "E. S. F." Mountain Finch in Herts. (Field, Jan. 20.)

I875. "W. H. H." Gannet and Little Auk in Herts. (Op. cit., Dec. II.)

I876. "H. F. G." Honey Buzzard near Ware. (Field, May I3.)

Norman, W. Storm Petrel near Royston. (Op. cit., Nov. I8.)

I877. Norman, W. Little Owl near Royston. (Op. cit., May 26.)

I878. Brett, A. T. Notes on the Cuckoo; Notes on the Owls. (Tr. Watford N. H. Soc., I. [1875-77]) Watford: I878.

I879. Bryer, J. Goshawk in Herts. (Field, Oct. I8); Hen Harrier in Herts. (T.c., Sept. 27.)

I880. [Anon.] White Swallow in Herts. (Field, p. 79.)

Beningfield, $\mathrm{H}$. Woodcock nesting at Hertford Heath. (Field, June 5.)

Littleboy, J. E. The Birds of Our District; Further Notes on Our Birds; Notes on Birds observed in I878. (Tr. Watford N. H. Soc., II [1877-9] I88o.)

Tuke, J. H. Notes on Birds observed near Hitchin. (T.c.)

Vaughan, M. Woodcock breeding in Herts. (Zool.)

1881. Ewing, J. A. Honey Buzzard in Herts. (Op. cit.) Idem by J. Langton. (T.c.)

Littleboy, J. E. Red-winged Starling in Herts. (T.c.)

Ralli, P. Glossy Ibis in Herts. [Bull's Park.] (Field, Nov. 26.)

I882. Littleboy, J. E. Notes on Birds observed in I879 and r880-8I. 2 pts. (Tr. Herts. N. H. Soc., I. [I879-8I]) Lond. : I882.

I884. Beningfield, E. N. Little Bittern near Broxbourne. (Field, Nov. I.)

Kingston, A. Leaves from My Notebook for I884, 2 pts. (Sci. Gossip, June and Oct.)

Littleboy, J. E. Uncommon Birds in Herts. (Zool.); The Migration of Birds; Notes on Birds observed in Herts. during I88I and I882, 2 pts. (Tr. Herts., N. H. Soc., II. [I88I-83])

Manser, H. Pochards reared by Diver Duck. (T.c.)

Rooper, G. Cuckoo laying in Swallow's Nest. (T.c.)

I886. Hopkinson, J. Repts. on Phenological Phenomena observed in Herts., I883 and I884, 2 pts. (Op. cit., III. [I883-85]) Lond,: I886. 
Littleboy, J. E. Notes on Birds observed in Herts. during I883 and I884, 2 pts. (Op. cit., III. [I883-85])

I887. "C. W. T." Manx Shearwater inland [at St. Albans]. (Field, Sept. 3.)

Littleboy, J. E. Osprey in Herts. (Zool.)

1888. Campbell, F. M. Reappearance of Pallas's Sand Grouse [in Herts.]. (Field, May 26.) Idem by M. C. Thompson. (Op. cit., July 7.)

Fordham, H. G. Naturalist's Calendar for N. Border of Herts. (Tr. Herts. N. H. Soc., IV. [I885-87])

Headley, F. W. Fauna and Flora of Haileybury, pt. I. 8vo. Hertford : I888. [289.]

Hopkinson, J. Rept. on Phenological Phenomena, I885-86, 2 pts. (Tr. Herts. N. H. Soc., IV. [I885-87])

Jackson, H. O. Crossbills in Herts. (Field, July 2I.)

Littleboy, J. E. Notes on Birds observed in Herts. during I885 and I886, 2 pts. (Tr. Herts. N. H.Soc., IV. [1885-87])

I889. Bannerman, A. Crossbills in Herts. (Field, Jan. 26.)

Hopkinson, J. Notes on Birds observed in Herts. during 1888 ; A Naturalist's Calendar for S.W. Herts.; Report on Phenological Phenomena during I887 and I888. (Tr. Herts. N. H. Soc., V. [I887-89])

Littleboy, J. E. Notes on Birds observed in Herts. during 1887 , and on the Birds frequenting Tring Reservoirs. (Op. cit., V., pt. 3 [I888].)

Powell, J. Note on Rearing of Cuckoos at Cassiobury. (Op. cit., V., pt. 7, 1889.)

I89o. Aplin, O. V. Distribution of Spotted Crake. (Zool.) [partim.] [24.]

Doggett, H. Rare Birds at Tring. (Field, Jan. I8.)

Larken, E. P. Thick-knee in Herts. (Zool.)

Roe, C. M. Hoopoe at Elstree. (Field, Apr. 26.)

Rooper, G. Notes on Birds observed in Herts, during I889. (Tr. Herts. N. H. Soc., VI., pt. 3.)

I89I. Hopkinson, J. Report on Phenological Phenomena during r88990. (Op. cit., VI., pt. 4.)

Rooper, G. Notes on Birds observed in Herts during I890-gI. (T.c.)

Salter, J. H. Abundance of Hawfinch in Herts. (Field, Mar. 7.)

1892. Aplin, O. V. Distribution of the Cirl Bunting; Status of the Woodchat. (Zool.) [partim.]

Ayres, W. H. M. Baillon's Crake in Herts. (T.c.)

"E. J. W." Bittern in Herts. (Field, Mar. 5.)

Fordham, E. S. Quails in Herts. [near Ashwell]. (Op. cit., Oct. I5.)

Lewis, H. Notes on Birds observed in Herts. during I89I. ( $T r$. Herts. N. H. Soc., VII., pt. 2.) 
"Rambler." Notes and Observations from Royston, 7 pts. (Nat.Jnl., I.)

I893. Lewis, H. Notes on Birds observed in Herts during I892. (Tr. Herts. N. H. Soc., VII., pt. 5.)

Mawley, E. Report on Phenological Phenomena during I89I-92. (Op. cit., VII., pts. 3 and 6.)

Rivers, H. S. Supposed occurrence of Loxia lencoptera in Herts. $($ Zool. $)$

Willis, J. J. A Naturalist's Calendar for Mid-Herts. (Tr. Herts. N. H.Soc., VII., pt. 3.)

I893-94. "Rambler." Notes from Royston, 2 pts. (Nat. Jnl., II.)

I894. Lewis, H. Notes on Birds observed in Herts. during I893. (Tr. Herts. N. H. Soc., VIII., pt. 2.)

Mawley, E. Report on Phenological Phenomena during I893. (Op. cit., VIII, pt. I.)

I895. Blake, W. Honey Buzzard in Herts. (Nat. Jnl.)

Lewis, H. Notes on Birds observed in Herts. during I894. (Tr. Herts. N. H. Soc., VIII., pt.6.)

Mawley, H. Report on Phenological Phenomena during I894. (T.c., pt. 7.)

Verey, A. S. Notes on Birds frequenting Neighbourhood of Heronsgate. (T.c., pt. 6.)

1896. Campbell, F. M. Honey Buzzard in Herts. [errore = Common Buzzard in Montgomeryshire]. (Zool.)

I896-Igor. Crossman, A. F. Notes on Birds observed in Herts. during I895-I900, 7 pts. (Tr. Herts. N.H. Soc., IX.-XI., I896-Igor.) [156.]

I896-Ig08. Mawley, E. Report on Phenological Phenomena during I895 to I906. (Op. cit., IX.-XIII., I896-I908.)

I897. Nunn, J. P. Notes on the Birds of N. Herts. (Op. cit., IX., pt. 4.) Roberts, T. V. Survival of the Kingfisher. (Zool.)

Verey, A. S. Notes of the Observation of Swallows. (Tr. Herts. N. H.Soc., IX., pt. 4.)

I8g8. Atkinson, J. Rare Birds shot near London. [Oyster-catchers at Rickmansworth.] (Nat. Chron., Dec.)

Hartert, E. [Blackheaded Weaver-Finch at Tring Reservoir.] (Bull. B.O.C., VIII.)

Howard-Vyse, H. Californian Quail turned out near Hertford. (Field, Jan. I.)

I899. Crossman, A. F. List of the Birds of Herts. (Tr. Herts. N.H. Soc., X., pt.3.)

I900. Emson, C. F. Grey Shrike in Herts. (Field, Mar. 24.)

I901. Rothschild, Hon. N. C. [Baer's Pochard at Tring Reservoir.] (Bull. B.O.C., XII.) 
I902. Crossman, A. F. Aves. [In Victoria Hist. of Co. of Herts., I.] 4to. Lond.: I902. [I56.]

I902-I2. Bickerton, W. Notes on Birds observed in Herts during IgOI to IgII, II pts. (Tr. Herts. N.H.Soc., Ig02-I2.) [65.]

I903. Steele-Elliott, J. Purple Heron in Herts. (Zool.)

I904. Bickerton, W. A Review of Herts. Ornithology. (Tr. Herts. N. H.Soc., XII., pt. I.)

I905. Hartert, E. An enormous Increase in Number of Wood-Pigeons near Tring in Autumn of I905. (Bull. B.O.C.)

Westell, W. P. Hooded Crow at St. Albans. (Zool.)

Ig06. Westell, W. P. Lesser Spotted Woodpecker and Whinchat in Herts. (Zool.)

I907. Malcolmson, V. A. Little Owl nesting in Herts. (Field, July 20.) Steele-Elliott, J. Cirl Bunting in Herts. (Zool.)

Igog. Oldham, C. Sclavonian Grebe and Black-necked Grebe in Herts. (Brit. Birds, II.)

Lydekker, R. Birds [in Cambridge County Geographies : Hertfordshire, pp. 45-47.] Camb. Univ. Press : Ig09.

Rothschild, Hon. W. Unusual Birds in Herts. (Brit. Birds, II.)

I909-I0. Witherby, H. F. Irruption of Crossbills. (Op. cit., III.) [partim.]

I9ro. Lydekker, R. Little Auks near Harpenden. (Field, Dec. 3.) Talbot-Ponsonby, C. G. Little Owls in Herts. (Brit. Birds, III.)

IgI2. Bedford, Duchess of. Grey Wagtail breeding in Herts. $(O p$. cit., VI.)

Bickerton, W. Aves [of St. Albans and its Neighbourhood]. (Tr. Herts. N. H. Soc., XIV., pp. 240-43.) [65.]

1913. Bedford, Duchess of. Chiffchaff wintering in Herts. (Brit. Birds, VI.)

Oldham, C. Rednecked Grebe in Herts. (T.c.) Common Scoters in summer in Herts. (Op. cit., VII.)

I9I3-I8. Bickerton, W. Notes on Birds observed in Herts. during I9IrI6. 6 pts. (Tr. Herts. N. H. Soc., XV., pp. 49-63, I55-68, 209-24; XVI., pp. 9-3107, I4I-56 ; XVII., pp. 35-46.)

I9I5. Hartert, E. Early nesting of Reed-Warbler in Herts. (Brit. Birds, IX.)

Oldham, C. Black Redstart in Herts. (T.c.)

I9I6. Ellison, A. Robins building in spruces at Watton. (Op.cit., X.) Hartert, E. Early nest of Reed-Warbler with Cuckoo's egg in Herts; Late nesting of Reed Warblers. (T.c.)

Oldham, C. A day with the Birds in N.W. Herts. (Tr. Herts. N. H. Soc., XV., pp. 5I-2.)

Rowan, W. Dipper in Herts. (Brit. Birds, X.)

Smith, J. B. Lesser Redpolls breeding in Herts. (T.c.) 
Westell, W. P. Pied Flycatcher in Herts.; Supposed Rufous Warbler in Herts. ; Lesser Redpoll breeding in Herts. (T.c.); Roughlegged Buzzard in Herts. (Op. cit., IX.)

I9I7. Cookson, C. Early appearance of Corncrake. [Herts.] (Field, April 24.)

Foster, A. H. A List of Birds which have occurred in N. Herts. with notes on each species. (Tr. Herts. N. H.Soc., XVI., pp. I89-220.)

Hartert, E. A striking increase in number of Lesser Whitethroats at Tring; On practical extinction of Goldcrest and Longtailed Tit at Tring. (Bull. B.O.C., XXXVIII, pp. 57-8.) Oldham, C. Blue-headed Wagtail in Herts. (Brit. Birds, XI.) Smith, J. B. Common Buzzard [at Hitchin]. (Op. cit., XI.)

I9I8. Oldham, C. Dusky Redshanks in Herts. (Op. cit., XII.)

Smith, J. B. Cuckoo's eggs in nests of Chiffchaff and Wood Warbler in Herts; Blue-headed Wagtails in Herts. (T.c.)

\section{HUNTINGDONSHIRE.}

I825. Yarrell, W. Notice of occurr. of some rare Brit. birds. [Pygmy Curlew and Little Stint in Hunts.] (Zool. Jnl., II., pp. 25, 27.)

I845. Aikin, W. O. Birds of Somersham. (Zool.)

Frere, H. T. Occurrence of Bewick's Swan near Somersham and Godmanchester. (T.c.)

1849. Wolley, J. Occurrence of Buffon's Skua in Hunts. (Op. cit.)

1855. Bonney, T. G. [Bittern at Earith, Hunts.] (Nat. [Morris's], V.)

I858. Saville, S. P. Norfolk Plover [near Yelling]. (Nat. [Morris's], VIII.) 186r. Saville, S. P. Cormorant out for a tour. [sic.] (Zool. and Field, Aug. I7.)

1863. Baker, J. Osprey in Cambs. [errore for Hunts.]. (Zool.)

Rowley, G. D. Nest of Wren with Eggs in Oct. at St. Neots. (Field, Nov. 7.)

1865. Rowley, G. D. Letter on Cuckoo's Eggs. (Ibis.)

I867. Rowley, G. D. Nesting of Kingfisher : Hawfinches' Nests and Eggs. (Zool.) 2 notes.

1875. Rowley, G. D. On British Birds: Milvus ictimus; Pernis apivorus; Circus cineraceus ; Strix aluco; Ardea stellaris ; Anas boschas; Stercorarius longicaudus. 7 notes. (Orn. Miscellany, I.)

Wallis, F. Spoonbill in Hunts. (Field, May I5.)

Heathcote, J. M. Reminiscences of Fen and Mere. 8vo. Lond. : $1876 . \quad$ [290.] 
I877. Rowley, G. D. On Bird Nests. (Orn. Miscell., II.) [partim.] I878. Miller, S. H., and Skertchley, S. B. J. The Fenland: Past and Present. Roy. 8vo. Cambridge: I882. [407.]

Rowley, G. D. A Few Words on Fen-Land. (Orn. Miscell., III.) [partim.]

I880-93. Lilford, Lord. Notes on the Birds of Northants. 34 pts. (Jnl. Northants. N. H. Soc., I880-93.) [partim.] [353.]

188I-96. Lilford, Lord. Notes on Ornithology of Northants. I9 pts. (Zool., I88I-96) [partim.] [354.]

1882. Moxon, J. H. H. The Birds of the Fens. 8vo. Cambridge: 1882. [422.]

I884. Bainbridge, H. W. Bittern near St. Ives. (Field, Dec. I3.)

1888. Harrison, F. R. Gannet inland. (Field, Sept. 29.)

Warner, R. Pallas's Sand Grouse in Hunts. (Op cit., June 9.)

I89I. Aplin, O. V. Distribution in Brit. Isles of Spotted Crake. (Zool.) [partim.] [24.]

1895. Lilford, Lord. Notes on the Birds of Northamptonshire and Neighbourhood. 2 vols. 8vo. Lond.: I895. [partim., $c f$. p. vii.] [355.]

I897. Harting, J. E. Disappearance of the Kite. (Field, Dec. II.) [partim.]

I90I. Steele-Elliott, J. An Unrecorded Kite in Hunts. (Zool.)

I902. Saunders, J. C. Great Grey Shrike in Hunts. (Field, Nov. 8.) 1907. Frohawk, F. W. The Little Owl [in Cambs. and Hunts.]. (OP. cit., Oct. I2.)

1908. Witherby, H. F., and Ticehurst, N. F. Spread of the Little Owl. (Brit. Birds, I.) [partim.]

I9I0. Farren, W. Glossy Ibises in Hunts, etc. (Op. cit., III.)

I9I2. Loyd, L. R. W. Breeding Habits of Cuckoo: Food of Little Owl : On Removing Lapwing's Eggs, (Op. cit., VI.) 3 notes. Ticehurst, C. B. Willow Tits in Norfolk and Hunts. (T.c., VI.)

I914. Mace, H. The Little Owl in Hunts. (Field, Mar. 7.)

I9I7. Atchison, G. T. Marsh Warbler breeding in Hunts. (Brit. Birds, XI.)

\section{KENT.}

I7[88-]92. Boys, W. Collections for an History of Sandwich. 4to. Canterbury: I7[88-]92. [89.]

1825. [Sec. Zool. Club. Linn. Soc.] Sabine's Snipe near Rochester. (Zool. Jnl., I., p. 586.) 
I826. [Anonymous.] Synopsis of Museum of Philosophical and Literary Institution, Canterbury. 8vo. Canterbury: I826. [I9.]

I828. "T. F." The Hawfinch's Nest [at Chelsfield]. (Loudon's Mag. N. H., I., p. 374.)

Yarrell, W. On Occurr. of Some Rare Brit. Birds [Pomarhine Skua] at Dover. (Zool. Jnl., III., p. 497.)

I829. Jennings, J. Ornithologia ; or The Birds: A Poem. and edit. I2mo. Lond. : I829. [3I4.]

Hill, W. H. The Small Dover [request for identif. of Diving Duck thus called]. (Loudon's Mag. N. H., II., p. 403.)

Hunter, P. Nat. Hist. in English Co.'s [Ampelis garrula, etc., in winter]. (T.c., p. 267.)

I830. Hurst, J. C. Birds Collected in Vicinity of Dartford. (Loudon's Mag. N. H., III.)

I83I. Rennie, J. The Architecture of Birds. (Libr. Enter. Knowl.) Post 8vo. Lond.: I83r. [Relates to Lee.] [490.]

I832. "J. D." Nat. Hist. in English Co's. [Bearded Tit: in Erith Marshes]. (Loudon's Mag. N. H., V., p. 544.)

I834. Hart, S. Of the Little Bustard [near Chatham]. (Op. cit., VII., p. 458.)

1839. [Anonymous.] Topography of Maidstone. I2mo. Maidstone : 1839.

I84I-44. Mummery, S. Birds of Kent, 4 pts. ; Kentish Birds, 3 pts. (Ann. Mag. N. H., I84I-42, I844.)

I842. Mummery, S. Anthus richardi. [I. of Thanet.] (Op.cit., I842.)

I843. Thomas, W. H. Note on the Reed Warbler. (Zool.)

1844. Bartlett, J. P. Notes on Ornithology of Kent; and Correction of Same; Summer Birds on Barham Downs. (Zool.)

Sladen, E. H. M. Golden Oriole in Kent; Hoopoe in Kent. (T.c.)

Spencer, J. B. Capture of Great Grey Shrike. (T.c.)

I844-47. Hutchinson, M. Arrival of Summer Birds of Passage at Shooter's Hill, I844-5-6. 3 notes. (Op. cit., I844, I846-47.)

I845. Thompson, E. P. Notebook of a Naturalist. Post 8 vo. Lond. : I845. [577.]

Bartlett, J. P. Nesting of Golden Oriole in Kent ; Gadwall in Kent. (Zool.)

I846. Plomley, F. Frequent Occurrence of White Wagtail in Kent ; Egyptian Goose in Kent. (Op. cit.)

I847. Fry, H. D. Glaucous Gull at Ramsgate. (Op. cit.)

Plomley, F. Purple Heron near Lydd. (T.c.)

Sladen, E. H. M. Supposed New Brit. Lark. (T.c.)

White, R. O. Gannet near Dartford. (T.c.)

1848. Plomley, F. Melodious Willow Wren in Britain. (Op. cit.) 
1849. Benson, H. Avocet near Ramsgate. (Op. cit.)

Bird, W. F. W. Red-necked Grebe in Medway.

Ellman, J. B. Golden Oriole in Kent. (T.c.)

Hulke, J. W. Dates of Arrival of Winter Visitors at Deal; Summer Duck, Snow Bunting, Kingfisher and White-tailed Eagle near Deal, etc. Io notes. (T.c.)

1850. Delmar, C. A. Pied Flycatcher and Baillon's Crake in Marshes near Deal. (Zool.)

Green, J. Wood Sandpiper at Woolwich. (T.c.)

Hulke, J. W. Waxwing, Curlew Sandpiper and Temminck's Stint near Deal; Golden Oriole at Elmstone; Spoonbill at Sandwich. (T.c.)

Plomley, F. Great Bustard in Romney Marsh; Waxwing, etc., in Kent. (T.c.)

1851. Cordeaux, W. H. Hoopoe at Walmer ; Mocking-Bird of America in Kent. (Zool.)

Harper, J. O. Avocet at Sandwich. (T.c.)

Hulke, J. W. Golden Oriole nesting near Deal ; Baillon's Crake near Deal. (T.c.)

I85I-3. McIntosh, J., Bartlett, J. P., and Lukis, J. W. Heronries in England, etc. 3 pts. [partim.] (Nat. [Morris's], I.-III.).

r852. Briggs, J. J. Notes on Birds, etc., observed near St. Margaret's Bay. (Zool.)

Newman, E. Thrush Nightingale near Dartford. (T.c.)

I853. Bramley, J. Golden Oriole at Eltham. (Op. cit.)

Cooke, M. C. Ring Ouzel [nesting at Addiscombe], etc. 6 notes. (Nat. [Morris's], III.)

Green, J. Bluethroated Warbler in Kent; Nest and Eggs of Savi's Warbler; Montagu's Harrier in Woolwich Marshes. (Zool.)

1855. Adams, F. C. Crossbill [at Beckenham]. (Nat. [Morris's], V.) Collingwood, C. Birds in Neighbourhood of Blackheath in I854. (Zool.) [I39.]

Hussey, A. White Swallow in E. Kent. (T.c.)

I856. Baker, W. Little Owl at Maidstone. (OP. cit.)

Dennis, Rev. R. N. Black Stork in Kent. (T.c.)

Gardner, J. Common Crossbill and Little Owl [near Maidstone]. (Nat. [Morris's], VI.)

1857. Gardner, J. Avocet in Kent. (Zool.)

Hadfield, Capt. H. W. Fork-tailed Petrel near Tunbridge ; Notes on the Woodchat, etc. (T.c.)

Shepherd, C. W. Avocet and Rose-coloured Pastor near Rochester. (T.c.)

"Vesper." Extraordinary Flights of Larks [at Cudham]. (Field, Feb. 7.) 
I858. Gardner, J. Avocet in Kent. (Zool.) Idem. (Nat. [Morris's], VIII.)

Greene, T. W. Hawfinch breeding at Tonbridge. (Zool.)

Shepherd, C. W. Peregrine Falcon in Kent. (T.c.)

"Young Naturalist." The Tippet [Crested] Grebe on Medway. (Field, Dec. 4.)

I859. [Anon.] Great Bustard shot in Kent. (Field, Feb. I9; Sussex Express.)

Collingwood, C. Fauna of Blackheath and its Vicinity. 8vo. Lond. ; I859. [I39.]

"E. S. H." Osprey near Dartford. (Field, Oct. 8.)

I860. "A. C." Little Auk [near Ramsgate]. (Field, April 2I); Knot [near Ramsgate]. (T.c., May 5.)

Hutchinson, M. Dates of Arrival of Migratory Birds. (Zool.)

(Thanet Advertiser.) Little Bustard [shot at Minster]. (Field, Dec. I5.)

[Various Writers.] Hoopoe shot in Kent. (Field, Nov. IO, Nov. I7) ; Snipe near Tonbridge. (T.c., Aug. I8.) Crossbills [and White-winged Crossbills?] at Tunbridge Wells. (T.c., July 28.)

I86x. Hutchinson, M. Arrival of Summer Birds at Blackheath. (Zool.) Jell, G. Smew, Little Auk, etc. [shot at Lydd]. (Field, Feb. 9.) Mathews, G. F. Shore Lark at Woolwich. (Zool.)

Whitely, H. Hoopoe killed on Plumstead Common. (T.c.)

I862. Hammond, W. O. Little Gull in Kent ; Orange-legged Hobby near Hythe. $(O p$. cit. $)$

Harding, H. J. Abundance of Young Cuckoos and Occurrence of Hoopoe at Deal. (T.c.)

Saxby, H. L. Curlew Sandpiper at Rochester; Manx Shearwater at Sheerness. (T.c.)

1863. Ward, E. Hoopoe shot in Kent. (Field, May I6.)

Whitely, H., junr. Dartford Warbler at Woolwich. (Zool.) Young, E. Pallas's Sand Grouse in Kent; Richardson's Skua in Kent. (T.c.)

1864. Clarke, J. A. Fieldfare in July; Sanderlings at Gravesend. (Op. cit.)

Newman, E. Bittern in Kent. (T.c.) “ H. B.” Idem. (Field, Feb. I3.)

I865. “A. B. H." Hoopoe near Ramsgate. (Field, April 22.) (Times). Redwinged Starling [in Romney Marsh]. (Field, July r.)

I866. " A. C.," Breeding of Plovers and Terns at Romney Marsh. (Field, June 9.)

Clifton, Lord. Ortolan Bunting in Kent; Hobby near Rochester; Stock Dove breeding in Kent. (Zool.): Ortolan Bunting in Kent. (Field, April 2r.)

Denne, A. Rare Birds at Lydd. (Field, May I9.) 
Gates, J. R. Hoopoe [at Newington]. (Field, May Ig.)

Gurney, J. H. American Bittern in Kent. (Zool., also Field, Jan. 20.)

Harding, H. J. Cream-coloured Courser at Sandwich. (Zool.) Hutchinson, II. Arrival of Migrants at Blackheath. (T.c.)

Legge, W. V. On Nesting of Redshank in Kent., etc., 2 notes. (Ibis.)

Power, W. H. Notes on Birds observed at Rainham. (Zool.) I867. Clark-Kennedy, A. Waxwings near Woolwich. (Zool.)

Clifton, Lord. Peregrine Falcon in Kent; etc., I2 notes. (T.c.) Woodlarks in severe weather [at Cobham]. (Field, Apr. 6.)

Hutchinson, M. Arrival of Summer Birds at Shooter's Hill. $($ Zool. $)$

Power, F. D. Extraordinary Flock of Wood Sandpipers at Rainham. (T.c.)

Power, W. H. Gulls in Kent, etc. (T.c.)

Smee, A. H. Arctic Tern near Gravesend; Skua on the Thames. (T.c.)

Weir, J. Jenner. Lapland Bunting at Lewisham; Snow Bunting on Blackheath. (T.c.)

I868. Ashmead, G. B. Little Gull in the Thames below Gravesend. (Op. cit.)

Clifton, Lord. Uncommon Birds at Cobham. (Zool.)

Crichton, A. W. Eider Duck on Thames. (T.C.)

Gordon, C. Richard's Pipit at Dover. (T.c.)

Hadfield, H. Diagnostics of Rough-legged Buzzard. (T.c.) Reply by Lord Clifton. (T.c.)

Hammond, W. O. Crossbill at Wingham. (T.c.)

Hunter, J. Gannet on Kentish Coast. (T.c.)

Hutchinson, M. Birds on Blackheath. (T.c.)

Morland, W. C. Woodcocks nesting in Kent. (Field, Apr. I8.) Stephenson, J. W. Virginian Colin at St. Mary Cray. (Zool.) Ward, J. Rare Birds in Kent. (Sci. Gossip, IV.)

I869. Clark-Kennedy, A. Woodchat in Kent. (Zool.)

Clifton, Lord. Peregrine Falcon in Kent; Grey Wagtail and Pied Flycatcher in Kent, etc., 4 notes. (T.c.)

"C. H. S." Whitetailed Eagle in Kent. (Field, Jan. 23.)

Gurney, J. H., junr. Great Grey Shrike at Dover. (Zool.)

Hunter, J. Pomatorhine Skua and Fork-tailed Petrel, Merlin, Golden Oriole, Redthroated Diver, Little Auk, etc., at Faversham, 6 notes. (T.c.)

Power, F. D. Notes on Rainham. (T.c.)

Skinner, A. Occurrences at Faversham, II notes. (T.c.)

"W. L. O." Egyptian Goose in Kent. (Field, Jan. 30.)

Ward, E. Golden Oriole in Kent. (T.c., June 5.) Idem [Anon.] (T.c., June I2.)

1870. Clifton, Lord. Supposed Occurrence of American Mottled Owl at Cobham. (Zool.) Idem by J. H. Gurney. (T.c.) 
Coast, S. E. Golden Oriole, etc., in Kent. (Field, May 7.)

Hunter, J. Hoopoe in Kent. (Zool.)

Mathew, G. F. Garganeys, etc., near Sheerness. (T.c.)

Price, W. St. Helena Finch at Blackheath. (Field, Apr. 30.) Ullyett, H. Golden Oriole near Folkestone. (Sci. Gossip.) [Various Writers.] Black Montagu's Harriers. (Field; Zool.);

Richardson's Skua at Dover. (Field, Nov. 26) ; Hooded Crow in Kent during Summer. (T.c., July 2.)

Ward, E. Sea Eagle in Kent. (OP. cit., Mar. I9.)

I87I. "F. S. T." Blackthroated Diver shot at Folkestone. (Op. cit., Feb. I8.)

"Heron." Buzzard in Kent. (T.c., Mar. II, I8.)

" O. G. S. E." Golden Oriole in Kent. (T.c., May I3.)

Clifton, Lord. Buzzards at Cobham; Ornitholog. Notes from Cobham. (Zool.)

[Editorial.] Goosanders in Mid-Kent. (Field, Jan. 2I.)

Gordon, C. Common Buzzard near Canterbury; Little Auk, etc., near Dover ; Blackthroated Diver at Folkestone. (Zool.) Gurney, J. H., junr. Aquatic Warbler at Dover; Dotterel at Dungeness. (T.c.)

Harding, H. J. Black Swan and Hooper near Deai. (T.c.)

Knight, V. Nocturnal Flight of Birds at Folkestone. (T.c.) Power, G. E. Osprey and Red-necked Phalarope in Kent. (T.c.)

I872. Button, D. T. Hawks, etc., at Gravesend. (Op. cit.)

Clifton, Lord. Buzzard, etc., at Cobham. (T.c.)

"D. B." Osprey at Tonbridge. (Field, May II.)

"Frank." Solitary Snipe in Kent. (Op. cit., Sept. 28.)

Harting, J. E. British Heronries. (Zool.) Idem. (Field, Feb. I7, Mar. 9.) [partim.]

Tomlin, B. Golden Orioles in Kent. (Field, June I.)

1873. Burney, Rev. H. British Heronries. (Zool.)

"H." Waxwing in Kent. (Field, June II.)

Jackson, A. J. Flamingo in I. of Sheppey. (Op. cit., Aug. I6.) Idem by W. B. Tegetmeier (T.c., Aug. 23.)

Newman, E. The Flamingo killed in I. of Sheppey. (Zool.)

Smith, C. J. Erith: Its Natural, Civil, etc., History. 8vo. Lond. : I873. [548.]

Tomlin, B. Woodcocks in I. of Thanet. (Field, Dec. I3.)

I874. "Frank." Pelican near Faversham. (Op. cit., Oct. Io, I7.) Idem by A. Reeve. (T.c., Oct. I7.)

Harting, J. E. On Nesting of Golden Oriole in Kent. (T.c., Oct. $3 ;$ Zool.)

Rawson, H. E. List of Birds which breed within Four miles of Keston Mark, Bromley. 8vo. Priv. ptd., I874. [486.]

Smith, H. Summer Birds at Southborough. (Field, May 9.) Idem by C. R. Bree. (T.c., May I6, 23.)

1875. Butler, A. G. Notes on Birdsnesting in Kent. (Zool.) 
Clifton, Lord. Supposed Sylvia aquatica in Kent. (Zool.); Supposed Occurrence of Lesser Kestrel in Kent. (Field, Oct. r6). Further Note on the small variety of Kestrel seen in Kent. (T.c., Oct. 23.)

"F. S. T." Bitterns in Kent. (Op. cit., Jan. 2.)

Harting, J. E. Our Summer Migrants. [chap. on Golden Oriole in Thanet.] 8vo. Lond.: I875. And subsequent edits.

Smith, H. Summer Birds at Southborough. (Field, May 22.) Tomlin, B. Golden Oriole nesting in Kent. (Op. cit., Aug. I4.)

I876. Clifton, Lord. Notes on Birds at Cobham. (Field, Apr. 29, Nay 6, 20); Rough-legged and Common Buzzards at Cobham. (Op. cit., Dec. 23.) Hooded Crow and Hobby in Kent. (T.c., Oct. I4); Firecrested Wren at Cobham. (T.c., Dec. 2.)

Gurney, J. H. Black Stork at Lydd. (Zool.)

Hall, W. T. T. Hoopoe near Faversham. (Field, Oct. 7.)

Harting, J. E. On Occurrence for first time in England of American Redbreasted Thrush. (Field, Dec. 23, I876; Zool., I877; vide also Field, Jan. 6, I877.)

Lamb, H. Rare Birds [Eagles at Eastwell]. (Sci. Gossip.) Notes on Birds of Maidstone. (T.c.)

Smee, A. H. Great Northern Diver off Erith. (Zool.)

1877. Clifton, Lord. Ornitholog. Notes from Cobham; Merlins in Kent. (Zool.) ; Rough-legged Buzzard in Kent. (Field, Feb. I0) ; Buzzards, etc. in Kent. (T.c., Mar. I7); Supposed Bonelli's Warbler [or New Brit. Willow Warbler] in Kent. (Op. cit., May 5, I2, 26 ; June 2, I6 ; July 7, I4; Oct. I3.)

Cooper, J. Avocets on the Thames [near Gravesend]. (Op. cit., Jan. 6.)

Gordon, C. Lesser Kestrel near Dover. (Zool.)

Morland, W. C. Green Sandpiper in Kent. (Field, Aug. 25.)

I878. Booth, E. T. Habits of Kite as observed in Scotland. [Ref. to Canterbury.] (Field, Oct. I2.)

Green, R. Peregrine Falcon at Rainham. (Sci. Gossip.)

Greville, F. Herons on upper Waters of Medway. (Field, Sept. 2I.)

I879. Clifton, Lord. Greenland Wheatear [in Kent]. (Ibis.)

Prior, C. M. Little Stint and other Birds in Sheppey. (Zool.)

Pugh, W. T. Early appearance of Rednecked Grebe. (Field, Oct. 4.)

"W. S. N." Wild Swan on the Medway. (Op. cit., Feb. 22.)

. I880. Clifton, Lord. Hoopoes in Kent. (Zool.; Field, May 8) ; Migration of Siskin and Grey Wagtail. (Field, Oct. 2.)

Crosfield, J. B. Visit to Haunts of Kentish Plover. (Proc. Holmesdale N. H. Club, I879-80.) Reigate [I880.]

Dombrain, H. A. Great Bustard in Kent; Habits of the Kentish Plover. (Zool.)

Smith, H. Spring Migrants at Chobham. (Field, Apr. 3.) 
Ullyett, H. Rambles of a Naturalist round Folkestone. Post 8vo. Folkestone. I880. [6or.]

Way, N. F. Golden Oriole at Walmer. (Field, May I5.)

I88I. Clifton, Lord. Autumnal migration of Birds in Kent. (Field, Oct. I5.)

Davis, W. Blue-throated Warbler [Redspotted] at Dartford. (Zool.; Field, Sept. Io, I7; Oct. I) ; Tengmalm's Owl near Dartford. (Field, Nov, 26.)

Hammond, W. O. Occurrence of Great Reed Warbler. (Zool.)

"Orielensis." Shore Larks near Dover. (Field, Feb. 5.)

I882. Clifton, Lord. White Stork in Kent. (Op. cit., Nov. I8.) Buzzards in Kent. (T.c., Dec. 9.)

Ewing, J. W. Some Materials for a Flora of Wrotham and its Neighbourhood. 8vo. West Malling: I882. [202.]

Ewing, J. W. Bee-eater in Kent. (Field, July I.)

Fielding, C. H. Handbook of Higham. 8vo. Rochester, etc. : I882. [206.]

Flower, J. On Nesting of Red-breasted Flycatcher [?] in Kent in Summer of I88I. (Pr. and Tr. Croydon Micr. and N. H. Chıb, I88I-82, pp. II 8-20.)

Lamb, H. Local Names. [Kent.] (Sci. Gossip.)

Marsden, W. Pomatorhine Skua in Kent. (Field, Nov. II.)

I883. Astley, H. D. Storks on migration. (Field, Mar. 3I.) ; Clifton, Lord. Idem. (T.c., Apr. 7.)

Hammond, W. O. Shore Lark, Lapland and Snow Buntings in Kent; Black Redstart in Kent in May. (Zool.)

I884. Clifton, Lord. Passage of Birds in Thanet. (Field, Sept. I3, 20, Nov. I.) ; Pied Flycatcher [near Ramsgate]. (T.c., Aug. I6.)

Denne, A. Hoopoe in Kent. (Op. cit., May 3.)

Hardy, C. Peregrine at Dover. (Op. cit., Oct 4.)

Parkin, T. Ruddy Sheldrake on Romney Marsh. (Zool.)

Prentis, W. Little Gull at Rainham; Red-throated Pipit in Kent; Black Stork near Rainham. (T.c.)

Ullyett, H. Fieldfare [breeding near Folkestone ?]. (Sci. Gossip, July.)

I885. Blomfield, E. M. Black-throated Diver in Kent. (Field, Nov. I4.)

Clifton, Lord. Kite in I. of Thanet. (Op. cit., Apr. I8, 25.)

Dowker, G. The Birds of East Kent. (Land \& Water, Oct. 3, 24.) [I76.]

Fisher, T. Short-toed Lark in Kent. (Zool.)

Harting, J. E. A Marsh Walk in May. (Field, May 30.)

Willmot, C. Nutcracker in Kent. (Op. cit. Nov. 28.)

I886. Coombe, P. E. Recent Occurrence of Sea Eagle in Kent. (Zool.) Idem. (Land \& Water, Jan. 28.)

Fortune, R. Redshank breeding in Kent. (Zool; Field, May I5.) Peregrine on Kentish Coast. (Zool.) 
Hardy, C. S. Osprey in Kent. (Field, May 29.)

Kennard, A. Redwing [?] nesting in Kent. (Zool.)

Mathew, G. F. Redshanks and Lapwings breeding in Chatham Dockyard. (T.c.)

Rice, W. Golden Oriole in Kent. (Field, May 22.)

Russell, F. Norfolk Plover in Kent. (Op. cit., Oct. 30.)

I887. Clifton, Lord. Kite in Kent. (Op. cit., Apr. 30.)

Feilden, H. W. Cliff Birds at Dover. (Zool.)

Gunge-Buteman, M. G. Golden Oriole in Kent. (Field, May 28.)

Lamb, H. Great Grey Shrike in Kent. (Zool.); Crossbills in Kent. (Rochester Nat., Oct. ; Zool.)

I888. Byron, H. S. D. Pallas's Sand Grouse in Kent. (Zool.)

Clifton, Lord. Notes from I. of Thanet. (Field, Apr. 28, May I9, 26, July 2I, Dec. 22) ; Rough-legged Buzzard in Kent. (T.c., Nov. I7.) Spring migration of Black Redstart. (Op. cit., Apr. 7.) Bonaparte's Gull in I. of Thanet. (T.c., Apr. I4.) $\mathrm{H}-$, R. W. Crossbill breeding in Kent. (T.c., Nov. 24.)

Nicholl, D. S. W. Nutcracker in Kent. (Zool.)

Nickalls, H. P. Rough-legged Buzzard in Kent. (Field, Mar. 3.) Stunt, W. Pallas's Sand Grouse in Kent. (Op. cit., Nov. I7.) Idem by Lord Clifton. (T.c., Dec. 22.)

I889. Bateman, - - Red-legged Partridge in City Garden, Canterbury. (Op. cit. July 20.)

Carrington, J. T. Golden Oriole in Kent. (Zool.)

Clifton, Lord. Sand Grouse, etc., in Thanet. (Field, Jan. I2) ; Golden Oriole in Thanet. (T.c., May I8.)

Dowker, G. Notes on Birds of East Kent. (N.E. Kent N.H. Soc.) [I76.] Spotted Redshank and Hoopoe in Kent. (Zool.)

Groves, W. Birds of My Garden [Shortlands]. (Rept. N. Kent N. H. Soc., 1889-90.)

"R. W. H." Crossbills in Kent. (Field, May II.)

Hammond, W. O. Rose-coloured Pastor in Kent. (Zool.)

"Philofusil." Little Auk at Appledore. (Field, Aug. Io.)

Prentis, W. Roller at Rainham; Sand Grouse in Kent. (Zool.)

I89o. "J. S. A." Bittern in Kent. (Field, Dec. 27.)

Clifton, Lord. Notes from Thanet. (Op. cit., Apr. I9.)

Dowker, G. Tabulated List and Description of Birds of East Kent. 8vo. Lond.: N.D. [I89o.] [I76.]

Hammond, W. O. Richard's Pipit and Spotted Redshank in Kent. (Zool.)

Mathew, G. F. Blue-throated Warb]er at Sheerness. (T.c.)

Verner, W. Bird Life in Romney Marsh. (National Rev.)

I89I. Aplin, O. V. Distribution, etc., of Spotted Crake. (Zool.) [partim.] [24.] 
Gurney, J. H. Greater Shearwater and Dipper in Kent. (T.c.) Grey Phalarope in Kent. (Field, Nov. I4) ; Notes from N. Kent. (T.c., Nov. 2I) ; Blackthroated Diver in Thanet. (T.c., Nov. 28.)

I892. Andrews, H. Great Grey Shrike in Kent. (Op. cit., Jan. 9.) Idem by P. J. Lathy. (T.c. Feb., 20.)

Aplin, O. V. Distribution of Cirl Bunting; Status of the Woodchat. (Zool.) [25.] [partim.]

I893. “B. A." Montagu's Harrier in Kent. (Ficld, June 28.)

Dyer, C. F. Waxwings in Kent. (T.c., Jan. 7.) Idem by G. Gray. (T.c. Feb. II.)

Fielding, Rev. C. H. Memories of Malling and its Valley. 8vo. West Malling: I893. [206.]

Hammond, W. O. Little Gull in Kent. (Zool.)

Jackson, H. J. Crossbills in Kent. (Field, Dec. 2.)

Swann, H. K. Birds of London. Post 8vo. Lond.: I893. [569.]

1894. Alexander, B. Fulmar Petrel in Kent. (Field, Nov. 3.)

Allchin, J. H. Rare Birds in Kent. (Sci. Gossip, N.S., I., I894-5.)

"G. E. T." Crossbills in Kent. (Op. cit., July I4.)

Haigh, G. H. Caton. Black Redstart in Kent. (Zool.)

Hale, J. R. Bittern in Kent. (Field, Jan. 20.)

Hammond, W. O. Great Snipe in Kent. (Zool.)

Prentis, W. Notes on the Birds of Rainham. Post 8vo. Lond. : I894. [480.]

"S." Hoopoe in Kent. (Field, Apr. I4.)

"T." Red-throated Diver in Kent. (T.c., Jan. I3.)

I895. Briggs, C. A. Supposed Breeding of Crested Lark in Kent. (Zool.)

Davies, S. A. Ornitholog. Notes from E. Kent. (T.c.)

Davis, J. Waxwing in Kent. (Field, Feb. I6.)

Hammond, W. O. Avocet in Kent. (Zool.)

Mead-Briggs, H. Bird Notes from Canterbury. (Sci. Gossip, Mar.); Nesting Places of the Sedge Warbler. (T.c., Aug.); Golden Eagle [?] in Kent; Stone Curlew in Kent. (T.c., Dec.) Millard, F. M. Seagulls in Kent on Migration. (Field, Feb. 23.)

I896. Alexander, B. On a New British Petrel. (Zool.) Ornitholog. Notes from Rye. (T.c.; Field); Ornitholog. Notes from Romney Marsh. (Ornithologist.) Idem. (Zool.) Notes on Birds in Kent. (Zool.) [10.]

Bradshaw, G. W. Eared Grebe in Kent. (T.c.)

Edwards, L. A. Curtis. Broad-billed Sandpiper in Kent. (Ornithologist.)

Harting, J. E. Eagles in Kent. (Zool.)

Izzard, F. Sabine's Gull in Kent. (Field, Oct. 24.)

Mathew, M. A. Greater Nightingale in Kent. (Zool.) 
Saunders, H. [Exhibition of Oceanodroma cryptoleucura.] (Bull. B.O.C., V.)

I897. Alderson, H. Wonderful egg-producing powers of the Wryneck. (Zool.)

Farn, A. B. Common Bittern at Darenth Wood. (Zool.)

Frohawk, F. W. Lesser Grey Shrike in Kent. (T.c.; Field, May 29.)

Hammond, W. O. Alleged Nesting of Montagu's Harrier in Kent; Flight of Green Sandpiper. (Zool.)

Kennard, A. S., and Collinge, A. E. Aves of the Bromley District. (Bromley Nat. Soc. List.)

Ticehurst, N. F. Breeding of Snipe in Romney Marsh. (Zool.) Tillyard, R. Golden Oriole in Kent. (Nat. Jnl.)

I898. Alexander, B. Little Gull in Kent. (Zool.)

[Editorial.] Destruction of Ospreys [one noted at Belvedere]. (Field, May 2I.)

Green, J. F. Nat. Hist. Notes from Folkestone. (T.c., Feb. I2.) Hudson, W. H. Birds in London. 8vo. Lond. : I898. [303.]

Seth-Smith, D. Bramble Finch in Kent in April. (Field, May 2I.)

Ticehurst, N. F. Exhibition of Pectoral Sandpiper. (Bull. B.O.C., VIII.) Idem. (Zool.)

1899. Booth, H. T. A Day on the Kentish Marshes. (Nat. Chron., Feb.)

Copeland, A. J. I.ittle Bittern in Kent. (Field, Apr. 29.)

Webb, S. [Birds in] Brit. Assoc. Handbook to Dover. Cr. 8vo. Dover: 1899. [679.]

1900. Berry, W. Bittern in Kent. (Field, Jan. 20.)

Green, J. F. Kite in Kent. (Knoweledge.)

Meade-Waldo, E. G. B. On the Results of Providing Nestingboxes for Birds in Kent. (Bull. B.O.C.)

Ticehurst, N. F. Breeding of Shoveler and Garganey in Kent. (Zool.)

I90I. Edwards, L. A. Curtis. Broad-billed Sandpiper in Kent; Rosecoloured Pastor in Kent. (Op. cit.)

Ingram, C. Scops Owl from Broadstairs. (Bull. B.O.C., XII.) Mannell, H. T. House-Martins at Margate in November. (Zool.)

Nunn, J. R. Siberian Ruby-Throat observed near Westgateon-Sea. (Ibis.)

Ticehurst, N. F. Garganey breeding in Kent. (Bull. B.O.C., XI.)

Walpole-Bond, J. A. The Birds of Bromley, Kent. 8vo. Bromley: IgoI. [6II.]

I902. Cornish, C. J. The Naturalist on the Thames. 8vo. Lond.: I902. [I 47.$]$ 
Hepburn, T. Notes on Birds made on three short visits to the Beach at Dungeness. (Zool.)

Nicoll, M. J. Exhibition of White-spotted Bluethroat from Dungeness Lighthouse. (Bull. B.O.C., XIII.)

Ticehurst, N. F. Exhibition of Whitewinged Larks from Kent. (T.c.) ; Do. of Blueheaded Wagtails from Kent. (T.c.)

Webster, A. D. Greenwich Park. 8vo. Lond.: Ig02. [62I.]

I903. Alexander, B. Visit of Pratincoles to South of England. (Field, Nov. 2I.)

Balston, R. J. Woodcock breeding in Kent. (Zool.)

Hepburn, T. The Birds at Dungeness. (T.c.)

Ogilvie-Grant, W. R. Waxwings caught at Ramsgate. (Bull. B.O.C., XIV.)

Ticehurst, N. F. On Occurrence of White-winged Crossbill in Kent. (Op. cit., XIII) ; Exhibition of Collared Pratincole and Blackwinged Pratincole from Romney Marsh. (T.c.); Some Notes of Rare Birds from Kent. (Zool.)

I904. Brain, R. F. Flamingo reported on the Medway. (Field, Dec. 24.)

Davis, W. J. Birds of the Dartford District. 8vo. Dartford : I904. [I65.]

Elms, E. F. M. Observations and Notes on Birds in the Neighbourhood of New Romney and Littlestone-on-Sea, May I620, IgO2. (Zool.)

Hepburn, T. The Birds of North Kent. (T.c.)

Nicoll, M. J. Thrush-Nightingale in Kent. (Bull. B.O.C., XV.) Idem by E. Hartert. (T.c.)

Rothschild, N. C. On Larus cachimmans seen at Dover Harbour. (Op. cit., XIV.)

Seth-Smith, D. Serin Finch at Dover. (Field, Nov. 26).

Ticehurst, N. F. Spotted Sandpipers at Romney Marsh. (Bull. B.O.C., XIV.)

I905. Carroll, C. J. Meadow Bunting in Kent. (Ibis.)

Ingram, C. On Nesting of Marsh Warbler in Kent. (Bull. B.O.C., XV.)

Meade-Waldo, E. G. B. On Nesting of Lesser Redpoll in Kent. (T.c.)

Nicoll, M. J. Lanius mubicus in Kent. (Op. cit., XVI.)

Ticehurst, N. F. Little Dusky Shearwater in Kent. (T.c.); Nutcracker in Kent. (Op. cit., XV.)

I906. [Anon.] Baillon's Crake near Lydd. (Kentish Express, Dec. 22.) Idem (Hastings and E. Sussex Nat., I.)

Bunyard, P. F. Nesting of Motacilla borcalis in Kent. (Bull. B.O.C., XIX.)

Davis, A. R. Hoopoe in Kent. (Field, Apr. I4.)

Green, J. F. Birds of "The Cedars," Lee, Blackheath. (Tr. Kent Nat. Hist. Soc., I903-4.) 
Ogilvie-Grant, W. R. Firecrest at Abbey Wood, Kent. (Bull. B.O.C., XVI.)

Ticehurst, C. B. Western Black-throated Wheatear in Kent. (T.c.)

Ticehurst, N. F. Oceanodroma castro at Hythe. (Op. cit., XIX.)

Warde, D. F. Spring Arrivals at Canterbury. (Zool.)

I907. Alexander, H. G. Woodchat in Kent. (Brit. Birds, I.)

Balston, R. J., Shepherd, C. M. and Bartlett, E. Notes on the Birds of Kent. 8vo. Lond.: I907. [37.]

Bunyard, P. F. Nesting of Lesser Redpoll in Kent. (Brit. Birds, I.)

Davis, W. J. The Birds of Kent. 8vo. Dartford and Lond.: I907. [I65.]

Hepburn, T. The Birds of North Kent. (Zool.)

Howe, E. E. Bird Life in the Vicinity of S.E. London. (Nature Notes.)

Nichols, J. B. Rare Birds in Kent. (Brit. Birds, I.)

Payne, G. The Wildfowl of our Local Rivers. (Rochester Nat.)

Ticehurst, C. B. Vanellus gregarius in Kent. (Bull. B.O.C., XIX.) ; Sociable Plover in Kent. (Brit. Birds, I.) ; On Occurrence of Black Lark on Kent Coast. (Hastings Nat.)

Ticehurst, N. F. Sylvia nisoria in Kent. (Bull. B.O.C., XIX.); On Nesting of a Pair of Herons on Dungeness Beach; Lesser Grey Shrike in Kent; Snow-Finch in Kent; Red-breasted Snipe in Kent; Bonaparte's Sandpiper in Kent. (Brit. Birds, I.)

I908. Alexander, Boyd. Birds [In Victoria Hist. of Co. of Kent, I.] 4to. Lond. : Igo8. [II.]

Alexander, H. G. Pallas's Sand Grouse in Kent. (Brit. Birds, II.) Bedford, Duchess of. Solitary Sandpiper and other Waders in Kent. (T.c.)

Butterfield, W. R. Sooty Shearwater in Kent. (T.c.)

Carroll, C. J. Killdeer Plover, Solitary Sandpiper and Bartram's Sandpiper from Kent. (Bull. B.O.C., XXIII.)

Clarke, W. Eagle. Little Bunting in Kent. (Brit. Birds, I.) Hardy, A. H. Dipper in Kent. (Ficld, Dec. I9, Igo8; Brit. Birds, II., Igog.)

Hepburn, T. The Birds of North Kent. Autumn Passengers. (Zool.)

Ingram, C. Some Rare Kentish Birds. (T.c.); Nesting of Marsh Warbler in Kent. (Field, Apr. 4; Brit. Birds, I.)

Nichols, J. B. Black-headed Wagtail in Kent. (Brit.Birds, II.) ; Grey-backed Warbler in Kent. (Bull. B.O.C., XXI.; Brit. Birds, I.); [Corrected to Brown-backed Warbler.] (Brit Birds, IV., IgIr.)

Nicoll, M. J. Large-billed Reed Bunting in Kent. (Bull.B. O.C., XXI. ; Brit. Birds, II.) ; Pectoral Sandpiper and Bartram's Sandpiper in Kent. (Brit. Birds, II.) 
Payne, G. The Shore Birds of our Local Rivers. (Rochester Nat.)

Richardson, N. F. Nutcracker in Kent. (Field, Apr. 4; Brit. Birds, I.) Idem, by G. M. Beresford-Webb. (Brit. Birds, II.)

Sparrow, R. Pochard nesting in S.W. Kent; Black-tailed Godwit and Spotted Redshank in Kent. (Brit. Birds, II.)

Ticehurst, C. B. Nesting of Common Snipe in Kent. (T.c.)

Ticehurst, N. F. Sooty Shearwater in Kent. (Brit. Birds, I.); A hitherto unrecorded Levantine Shearwater from Kent; Killdeer Plover in Kent; Solitary Sandpiper in Kent. (Brit. Birds, II.)

Witherby, H. F., and Ticehurst, N. F. Spread of the Little Owl from Chief Centres of Introduction. (Brit. Birds, I.) [partim.]

Ig09. Alexander, C. J. Marsh Warbler in Kent. (Op. cit., III.)

Bunyard, P. F. Marsh Warbler breeding in Kent. (T.c.; Bull. B.O.C., XXV.)

Nicoll, M. J. The Brown Flycatcher in Kent; A New British Bird; Red-rumped Swallow in Kent. (Brit. Birds, III.; Bull. B.O.C., XXIII.)

Parkin, T. Black-throated Thrush in Kent. (Brit. Birds, II. ; Bull. B.O.C., XXIII.)

Ticehurst, C. B. The Greenland Wheatear. (Brit. Birds, II.); White Stork in Kent. (Op. cit., III.) Blue-headed Wagtail from Kent. (Bull. B.O.C. XXIII.)

Ticehurst, N. F. A History of the Birds of Kent. 8vo. Lond. : Igog. [585.]

Todd, W. A. Bird Notes from a London Suburb [Putney] for Igo8. (Selborne Mag.)

Turner, H. J. [Aves in] A Survey and Record of Woolwich and West Kent. 8vo. Woolwich: I909. [596.]

Walpole-Bond, J. Pochard nesting in N. Kent. (Brit. Birds, II.)

Ig09-IO. Witherby, H. F. Irruption of Crossbills. (Op. cit., III., IV.) [partim.]

I9I0. Alexander, C. J. Little Gull in Kent. (Op. cit., III.) ; Notes of the British Willow-Tit. (Op. cit., IV.)

Allchin, J. H. Bittern in Kent. (Op. cit., III.)

Bonhote, J. L. Ring Ouzel and Blackbird interbreeding in Kent. (Op. cit., IV.)

Dodd, P. V. Montagu's Harrier in Kent. (Op. cit., III.)

Farwig, H. H. Late Ring Ouzel in Kent. (Op. cit., IV.)

Green, J. F. Kestrel nesting near London. (Op. cit., IV.)

Ingram, C. Late Fieldfare in Kent. (Zool.)

Meade-Waldo, E. G. B., Stedman, R. F., and others. Crossbills nesting in Kent. (Brit. Birds, IV.)

Power, F. D. Ornitholog. Notes from a S. London Suburb, I874-I909. 8vo. Lond. : I9Io. [479.] 
Ticehurst, C. B., and Jourdain, F. C. R. Corsican Woodchat in Kent: A New British Bird. (Brit. Birds, III.)

Ticehurst, N. F. Continental Jay in Kent. (Op. cit., IV.)

Todd, W. A. Observations in N.E. Surrey, I909. (Zool.) [partim. $]$

Turner, E. L. Grey Wagtail nesting in Kent. (Brit. Birds, IV.) Witherby, H. F. Wood Sandpiper and Ruffs in Kent in June. (T.c.)

IgII. Ford-Lindsay, H. W. Long-tailed Duck in Kent. (Op. cit., IV.) Ingram, C. Marsh Harrier in Kent. (Zool.)

Nicoll, M. J. The Slender-Billed Curlew: A New British Bird. (Brit. Birds, V.)

Ticehurst, N. F. Continental Goldcrests in Kent, etc. $(O p$. cit., IV.) ; Black-throated Thrush in Kent. (Op. cit., V. ; Bull. B.O.C., XXVII.) ; Long-tailed Duck in Kent in March. (Brit. Birds, V.)

I9I2. Alexander, H. G. Sooty Shearwater off Kent. (Op. cit., VI.) Cheeseman, R. E. Snipe breeding in Kent. (T.c.) Parkin, T., Witherby, H. F., and Jourdain, F. C. R. Terek Sandpiper in Kent; A New British Bird. (T.c.)

Ticehurst, N. F. Great Shearwater in Kent. (T.c.)

I9I3. Alexander, H. G. Firecrests in Kent ; Ferruginous Duck in Kent ; Unusual Birds at Dungeness; Siberian Chiffchaff in Kent (Brit. Birds, VII.) ; Remarks on supposed Occurrence of Siberian Chiffchaff. (Bull. B.O.C., XXXIII.)

Borrer, C., and Baynes, G. Linnets nesting on the Ground on Kentish Coast. (Brit. Birds, VII.)

Ford-Lindsay, H. W. Cream-coloured Coursers in Kent. (Op. cit., VI.) ; Eastern Desert Wheatear in Kent ; Stilts in Kent ; Tengmalm's Owl in Kent. (Op. cit., VII.)

Lucas, N. S. Little Auk picked up at Ramsgate. (Field, Feb. 8.) Ticehurst, N. F. Little Dusky Shearwater in Kent (Brit. Birds, VI.) ; Slender-billed Nutcrackers in Kent; Continental CoalTits in Kent. (Op. cit., VII.)

I9I4. Alexander, H. G. Iceland Gull in Kent. (Op. cit., VIII.)

Bodenham, H. L. Crossbills in Kent. (Field, Jan. 24.)

Cheesman, R. E. Breeding Habits of Willow-Tit in Kent; Redshanks Breeding inland. (Brit. Birds, VIII.)

Ford-Lindsay, H. W. Slender-Billed Curlew in Kent. (T.c.)

Meade-Waldo, E. G. B. Down and breast-feathers of Garganey from near Hever. (Bull. B.O.C., XXXIII., p. I42.)

Woodward, C. T. Waxwing in Kent. (Field, Feb. 7.)

19r5. Alexander, H. G. Notes on Migration at Dungeness, Autumn ; Surf Scoter in Kent. (Brit. Birds, VIII.); Sea-birds and Oil in Kent; Yellow-browed Warbler seen in Kent. (Brit. Birds, IX.) 
Barnes, S. K. Great Grey Shrike in Kent. (Op. cit., VIII.)

Ford-Lindsay, H. W. Caspian Terns in Kent; Roseate Tern in Kent. (Op. cit., IX.)

Mathew, A. H. Large Flock of Alpine Swifts in Kent. (T.c.)

Mathew, A. H. Alpine Swifts in Kent. (Field, July 3I.)

Nichols, J. B. Sooty Terns in Kent. (T.c.)

Parkin, T. Rare Birds in Kent. (Brit. Birds, IX.)

I9I6. Barnes, S. K. Breeding habits of Wryneck in Kent. (OP. cit., IX.)

Ford-Lindsay, H. W. Asiatic Golden Plovers in Kent. (T.c.)

Nichols, J. B. Madeiran Little Shearwater in Kent. (T.c.)

I9I6-I7. Alexander, H. G. Birds at Dungeness in IgI5 and IgI6. (Op. cit., IX., X.)

I9I7. Farwig, H. H. Great Grey Shrike in Kent. (Op. cit., X.)

Meade-Waldo (E. G. B.). Crossbill Breeding in Kent. (Op. cit., XI.)

Vincent, J. Black Tern in Kent in Oct. (T.c.)

I9I8. Alexander, H. G. Doubtful Phylloscopi in Kent. (Op. cit., XI.)

Blest, W. W. Little Bittern in Kent. (Field, Sept. I4.)

Jourdain, F. C. R. Little Auk in Kent. (T.c.) Idem by S. Webb. (Field, Nov. 24.)

Medlicott, W. S. Hen-Harriers in Kent. (Brit. Birds, XI.)

Phillips, M. A. The Butcher Bird's Larder [Broadstairs]. (Field, Jan. 26.)

Welch, F. D. Thrush with White Tail Tips [Kent]. (Nat., p. 30I.)

\section{LANCASHIRE.}

I700. Leigh, C. Natural History of Lancashire, etc. Folio. Oxford: I700. [349.]

I787. Clarke, J. Survey of the Lakes. Folio. Lond. : I787. [I30.] 1823. Blackwall, J. Tables of Periodical Birds observed in Neighbourhood of Manchester. (Mem. Lit. \& Phil. Soc. Manch.) Also repr. separately. 8vo. Manch.: I823. [68.]

I828. Blackwall, J. Manners and economy of Pied Flycatcher. [partim.] (Loudon's Mag. N. H., I., p. 33I.)

Yarrell, W. Occurr. of some rare Brit. birds. [Ortolan Bunting nr. Manchester. (Zool. Jnl., III., p. 498.)

I829. Blackwall, J. Manchester Museum. [Notice of Rarer Brit. Birds in Collection.] (Loudon's Mag. N. H.) [68.]

I83o. Blackwall, J. Extracts from a Zoological Journal kept at Crumpsall Hall. (Zool. Jnl:, V., p. Io.) [68.] 
I83I. Blackwall, J. Nat. Hist. in English Co's., Cheshire. [Rosecoloured Pastor near Eccles.] (Loudon's Mag. N. H., IV., p. 73.)

Whittle, P. New Description of Blackpool. Svo. Preston: I83x. [648.]

Whittle, P. Marina, or Hist. Acct. of Southport, Lytham, etc. 8vo. Ib. : I83I. [648.]

I833. "T. G." Dates of Appearance of Spring Birds in I832, in Neighbourhood of Clitheroe; Sandpipers breeding about Clitheroe. (Loudon's Mag. N.H.)

I834. Berry, H. [Dunlin] breeding at Martin Mere. (Op. cit.); hybrid birds produced between Throstle and Blackbird in a state of nature. (T.c.)

" J. O." Plectrophanes lapponica captured near Preston. (T.c.)

I835. “T. G." Supposed Sabine's Snipe in Lancs. (Op. cit.)

I836. Salmon, J. D. Purre [Dunlin] breeding at Martin's Mere. (Op. cit.)

r837. Rylands, P. Cat. of Birds found in Lancs. (Nat, [Neville Wood's])

Skaife, J. Green Sandpiper in Aug.; Fork-tailed Petrel in Lancs. (Charlesw. Mag. N. H.)

I838. Rylands, P. Additional locality of Red Grouse [near Warrington]. (Nat. [Wood's], III.)

Skaife, J. Miscellaneous Ornitholog. Notes. (Op. cit.) : On Ornithology of Blackburn and N. of Lancs. (T.c.)

I839. (Bolton Chronicle.) Peregrine Falcon shot in Lancs. (Nat. [Wood's], IV.)

I843. Banister, J. D. On Occurrence of Rare Brit. Birds near Garstang. (Zool.)

I845. Banister, J. D. Arrival of Birds at Pilling in I845. (Op. cit.)

Clark, H. Pine Grosbeak near Rochdale. (T.c.)

Webster, T. Anthus aquaticus at Fleetwood; Dartford Warbler at Lytham. (T.c.)

I846. Cooper, J. American Bittern near Fleetwood; Grey Phalarope near Preston. $(O p$, cit. $)$

I848. Cooke, M. Description of Sandpiper shot near Bootle. (Op. cit.)

I849. Johnson, H. Rare Gulls near Liverpool. (Op. cit.)

Webster, T. Little Bittern near Manchester. (T.c.)

I850. Johnson, H. Waxwing and Black Redstart near Liverpool. (Op. cit.)

Jones, J. M. The Snipe in S. Lancs. (T.c.)

Naylor, W. Waxwing near Whalley. (T.c.)

Plant, J. Horned Grebe at Manchester: (T.c.) 
I85I. Balshaw, W. D. Habitat ... of Blackheaded Gull [at Pilling Moss]. (Nat. [Morris's], I.)

I852. Byerley, I. List of Animals found in Neighbourhood of Liverpool. Long I2mo. Liverpool : I852. [II3.]

Leeming, J. G. Curlew Sandpiper and Little Stint at Fleetwood. (Zool.)

1853. Bost, J. Night Heron at Blackpool. (Nat. [Morris's], III.)

I854. Byerley, I. The Fauna of Liverpool. (Pr. Lpool Lit. \& Phil. Soc., $A p p d x$. ) Idem. Sept. issue. 8vo. Lond., etc.: I856. [II3.]

Eccles, J. W. Brambling at Preston. (Nat. [Morris's], IV.)

I858. [Anon. “M. D."] Birds of Morecambe Bay. (Field, Dec. 24.) Grindon, L. H. Manchester Walks and Wild Flowers. ISmo. Manch.: n.d. [I858.] And later edits. [254.]

I859. McNicholl, D. H. Handbook for Southport. 8vo. Lond. : I859. 2nd edit., I86r. 3rd edit., I883. [373.]

"W. B." Quails [near Lancaster]. (Field, Jan. I.) Idem by E. G. Hornby. (T.c., Jan. I5.)

I860. "E. H. S." Snow Bunting in Lancs. (Field, Apr. 28.) Buxton, E. C. Great Flocks of Scoters in July. (Zool.)

i86r. Page, J. Unusual Visitors in Manchester. (Field, March 30.)

I862. Blakiston, T. Occurrence of the Knot. (Zool.)

Ranson, J. Nightingale at Manchester. (T.c.) Plant, J. [ex Manchester Guardian.] Idem. (Field, May I7.) Page, J. Idem (T.c., May 24.)

I863. Allis, T. H. Pallas's Sand Grouse in Lancs. (Zool.)

Carter, S. White-bellied Swift near Manchester. (T.c.)

Schollick, E. J. Pallas's Sand Grouse in Lancs. (T.c. also Field, May 30, [ex Times.])

I864. Alcock, D. White-bellied Swift near Manchester. (Zool.)

Hodgkinson, J. B. Osprey near Preston. (T.c.)

Smith, H. E. Other Notes on the Birds which breed upon Walney and Adjacent Islands. (T.c.)

I864-65. Harting, J. E. The Birds of Walney Island, and Further Notes. (Op. cit., I864-65.) [273.]

1865. Davis, F. Ornithological Notes from Manchester, 2 papers. (Zool.)

Hodgkinson, J. B. Great Grey Shrike at Preston. (T.c.)

I866. [Anon,] Bittern in Lancs. (Field, Dec. 29.)

Saunders, H. A Visit to Walney, the Lakes, etc. $(O p$. cit.) [508.]

1867. Cooke, N. Lapland Bunting in Lancs. (Zool.)

Fielden, H. W. Breeding of Blackheaded Gull at Pilling Moss; Spotted Crake on Longridge. (T.c.) 
Smith, H. E. Notabilia of the Mersey District. 8vo. Liverpool : I867. [549.]

I868. " J. J. H." Snow Bunting at Bootle. (Field, Dec. I9.)

I869. [Anon. "Seagull."] Scoter at Ulverstone. (Field, Oct. I6.) Gregson, C. S. Peregrine Falcon breeding in Lancs. (Zool.)

1871. [Anon.] Egyptian Goose at Preston. (Field, Apr. 29.)

Bedwell, $\mathrm{H}$. Woodcock in Manchester. (Op. cit., July I5.)

"G. H. H." Sea Birds in Manchester. (Sci. Gossip.)

Tysoe, C. Woodcock killed in Manchester. (Field, Oct. 28.)

I872. Davenport, R. List of Birds of Bury and District. (Rept. Bury N. H. Soc., I868-7I.)

Durnford, H. Sanderling at Mouth of Mersey; Scaup Ducks in Sept. (Zool.)

Harting, J. E. British Heronries. (T.c.) Idem. (Field, Mar. 9.) [partim.]

Hornby, H. P. Tufted Ducks near Garstang in July; Redbreasted Goose. (Zool.)

Hügel, Baron A. von. Redpoll breeding in Lancs.; Ornitholog. Notes from Lancs. (T.c.)

Newman, E. Great Black Woodpecker. (T.c.)

Tuck, T. G. Spring Arrivals at Bury. (T.c.)

Wood, J. H. List of Birds breeding in Neighbourhood of Bury. (Rept. Bury N. H. Soc., I868-7I.)

"W. P. P." Avocet at Morecombe Bay. (Field, Sept. 28.)

I872-73. Hügel, A. von. Ornitholog. Notes from Lancs., 2 pts. (Zool.)

I873. Durnford, H. Ornitholog. Notes from Lancs., 2 pts. ; Arrival of Spring Migrants; Nesting of Sandwich Tern on Walney Is., etc. $(O p$. cit.) Range of Stock Dove [breeding near Liverpool]. (Field, May 3I.)

Gregson, C. S. Abundance of Snow Buntings, Song Thrushes and Bramblings in the North. (Zool.)

Hornby, H. P. Notes from N. Lancs.; Birds observed at St. Michael's on the Wyre. (T.c.)

Hügel, A. von. Ornitholog. Notes from Lancs. (T.c.)

Shaw, J. Solitary Snipe in Lancs. (Field, Oct. 24.)

I874. Durnford, H. Ornitholog. Notes from Lancs.; Ornitholog. Notes; Notes on Birds of Walney Island. (Zool.)

Hodgkinson, J. B. Glossy Ibis in Lancs. (Op. cit.)

Wrigley, J. Richardson's Skua, etc., at Formby. (Ficld, Oct. 3I.)

I875. Barchard, C. Great Spotted Woodpecker nr. Manchester. (Op. cit., Jan. 30.)

Butterfield, E. Pied Flycatcher near Bolton. (Zool.)

Davies, E. C. Grosbeak near Warrington. (Ficld, Feb. I3.)

Hodgkinson, J. B. Brown Snipe near Southport. (Zool.) 
Shaw, H. Hoopoe in Lancs. (Field, Aug. 28.)

Wrigley, J. Richardson's Skua and Storm Petrel at Formby. $($ Zool.)

I876. Cordeaux, J. Ornitholog. Notes on E. and W. Coasts in Spring of 1876 . [ref. to Walney Is.] (Field, Nov. I8.)

Durnford, W. A. Ornitholog. Notes from N.W. Coast. (Zool.)

Mitchell, B. S. Wall-Creeper in Lancs. (T.c.)

I877. Baldwin, E. T. Purple Gallinule in Lancs. (Op. cit.)

Bushby, J. Blackthroated Diver in Lancs. (Field, Jan. 27.)

Durnford, W. A. Ornitholog. Notes from the Lake District and Walney Is. (Zool.)

Standen, R. Spotted Crake in Lancs. (Sci. Gossip.)

I878. Baldwin, E. T. Fauna of the Lake District; Provincial Names. [N. Lancs.] (Zool.)

Durnford, W. A. Ornitholog. Notes from Lake District; Provincial Names. [N. Lancs.] (T.c.)

1879. [Anon. "D.'] Birds of Prey in English Lake District. (Field, Nov. 22.)

D[urnford], W. A. A Day amongst the Gulls. (Op. cit., Apr. I9.) Gregson, C. S. Sabine's Snipe in Lancs. (Zool.)

Harting, J. E. Black-throated Wheatear in Lancs. (T.c.)

I880. [Anon. "A."] A Visit to Walney Island. (Field, June I9.)

Betts, R. H. Osprey at Clitheroe. (Op. cit., Oct. 8.)

Bushby, J. Leach's Petrel at Liverpool. (T.c., Dec. 3.)

Durnford, W. A. Ornitholog. Notes from N. Lancs. (Zool.)

De Trafford, S. C. Rough-legged Buzzard in Lancs. (Field, Oct. 30.)

Howard, R. J. Rough-legged Buzzards near Blackburn. (Zool.)

Meredith, M. R. Grey Phalarope in Lancs. (Field, Nov. 13.)

Minton, J. Woodcock nesting in Lancs. (Zool.)

I88I. Bushby, J. Forktailed Petrel in Lancs. (Field, Dec. 3.) Idem by J. Ashworth. (T.c., Dec. Io.)

Mitchell, F. S. Ornitholog. Notes from Lancs. (Zool.)

Rose, W. Great Grey Shrike in Lancs. (Field, Apr. 2.)

Wrigley, J. Rough-legged Buzzard and Snow Bunting near Liverpool. (T.c., Jan. I5.)

I882. Mitchell, F. S. Redlegged Partridge in Lancs. (Op. cit., May 26, June 2.)

Standen, R. A Ramble on the Fells in Search of Eggs. (Sci. Gossip, April.)

Wrigley, J. Peregrine Falcon in Lancs. (Field, Mar. 4.)

I883. Durnford, W. A. List of Birds found in Neighbourhood of Walney Is. 8vo. Barnsley: I883. [I89.]

Durnford, W. A. The Birds of Walney Island. (Zool.)

Rose, W. Landrail in Nov. (Field, Nov. 24.) 
I884. Harting, J. E. Gulleries [in Lancs.]. (Field, Feb. I6.) Idem, by E. J. Gibbins and T. Jackson. (T.c., Mar. I.)

Howard, R. J. Breeding of Ruff in Lancs., 2 notes; Reported Occurrence of Cranes near Clitheroe. (Zool.)

Murray, H. Rare Birds at Carnforth. (Young Nat., Mar.)

Nelson, T. H. Velvet Scoter near Manchester. (Zool.)

Picken, T. Solitary Snipe in Lancs. (Field, Oct. 4.)

Thompson, R. H. Surf Scoter on Coast of Lancs. (Zool.)

Wrigley, J. Fulmar Petrel near Liverpool. (Field, Feb. 9.)

1885. Brockholes, W. F. Common Buzzards in Lancs. ; Hairy Variety of Moorhen at Claughton. (T.c.)

Graham, J. W. Colony of Black-headed Gulls [at Cockerham Moss]. (Nat. Hist. Jnl.)

Heathcote, W. H. Knot [in Summer Plumage near Preston]. (Sci. Gossip, Dec.)

Higgins, H. H. Bird Life under the Shrubs. [Rainhill, Liverpool.] (Pr. L'pool Nat. F. C., I884-85.)

Mitchell, F. S. The Birds of Lancashire. 8vo. Lond. : I885. Idem, and edit., revised by $\mathrm{H}$. Saunders. 8vo. Ib.: I892. [408.]

Watson, J. The Dotterel and its migrations. (Field, Nov. I4.) [partim.]

1886. De Trafford, S. C. Dotterel in Lancs. (Field, May 8.)

Jeffrey, W. Knot near Preston. (Sci. Gossip.)

Nicholson, F. Fork-tailed Petrel on Lancs. Coast. (Pr. Manch. Lit. \&ँ Phil. Soc., XXVI.)

Pearson, H. G. Quail in N. Lancs. (Nat.)

I887. Jackson, J. A. Notes on Black-headed Gull near Garstang. (Op. cit.)

Picken, J. Purple Heron in Lancs. (Zool.)

I888. Harper, R. P. Notes on Birds in Lancs. (Op. cit.)

Hornby, H. R. The present visitation of Sand Grouse. (Field, June 2.)

[Howard, R., and Mitchell, F. S.] Birds of the Stonyhurst District. (Stonyhurst Mag.) Also repr. separately Svo. I88S. [408.]

Jackson, J. A. Notes on the Lapwing near Garstang. (Nat.)

Macphers?n, H. A. Rept. on Pallas's Sand Grouse in N.W. of England. [partim.] (Trans. Cumb. \& Westm. Assoc., No. XIII., I887-8.)

Nitchell, F. S. Reported Occurrence of Cream-coloured Courser in Lancs. (Zool.)

Nicholson, F. Fork-tailed Petrel at Formby. (Nat.)

I889. Archibald, C. F. Dusky Redshank in Summer Plumage in Lancs. (Zool.)

De Trafford, S. C. Hawfinch in Lancs. (Field, Apr. 20.) 
Howard, R. J. On Occurrence of Pallas's Sand Grouse in Lancs. (Zool.)

Hulton, W. W. H. The Preservation of Rookeries. (Ficld, Apr. 6, 20.)

Peaples, F. W. Rough-legged Buzzard [at Guarlton, etc.]. (Sci. Gossip.)

Seebohm, H. Exhibition of Vanellus gregarius shot near St. Michael's on Wyre. (P. Z. S.; Zool.)

Stott, C. E. Rough-legged Buzzard in Lancs. (Zool.)

Worthington, W. Bittern in Lancs. (T.c.)

Wrigley, J. Goosander in Lancs. (Field, Oct. 4.)

I890. Aplin, O. V. Distribution, etc., of Spotted Crake. (Zool.) [partim.] [24.]

Curtis, F. Bird Notes for March. (Nat. Hist. Jnl.)

Hamond, C. A. Little Stint on the N.IV. Coast. (Field, Oct. I8.)

Macpherson, H. A. Notes on Birds from Lancs. extracted from Letters of late J. Cooper [I840-44]; Shore Lark on Walney Is. (Nat.)

Salter, J. H., and Neave, N. Manchester Notes. (Nat. Hist. $J n l$.

I89I. Brook, R. G. Bittern near St. Helens. (Nat.)

Curtis, F. Shore-shooting by the Ribble. (Nat. Hist. Jnl.)

Nelson, T. H. Great Northern Diver and Long-tailed Duck near Morecambe. (Nat.)

Woodcock, W. H. Bittern at Warrington. (T.c.)

Wrigley, J. Spotted Crakes and Phalaropes in Lancs. (Field, Nov. 2I.)

I892. Aplin, O. V. Distribution of Cirl Bunting. (Zool.) ; Status of the Woodchat. (T.c.) [partim.] [25.]

Brown, C. R. Leach's Petrel on Lancs. Coast. (Land \& Water, Dec. 24.)

Brownsword, F. Black Redstart in Lancs. (Zool.)

Macpherson, H. A. A Vertebrate Fauna of Lakeland Including ........ Lancashire North of the Sands. Sq. 8vo. Edinb. : I892. [375.]

Macpherson, H. A. On Pelagodroma marina at Walney Is. (Ibis) ; Fauna of the English Lake District. (Field, May 28.)

Oldham, C. Supposed Occurrence of Purple Heron in Lancs. $($ Zool.)

Stott, C. E. Spotted Crake in S.W. Lancs. (T.c.)

Wrigley, J. Bittern and Tufted Duck in Lancs. (Field, Jan. 30.)

1893. Macpherson, H. A. Rare Birds. (Zool.)

Oldham, C. Black Tern in S. Lancs. (T.c.)

Wheldon, J. A. Meadow Pipit [at Walton Gaol]; Common Sheldrake [in Lancs.]. (Sci. Gossip, Aug.)

I894. Gee, G. F. Grey Phalarope on Lancs. Coast. (Nat. Jnl., III.) 
Sanders, J. The Birds of Manchester, 2 pts. (Nat. Jnl., II., May, June.)

I895. Clitheroe, W. Gull inland, Cockerham, Lancs. (Op. cit., IV.)

Fairhurst, T. Common Buzzard in S. Lancs. (T.c.)

Greening, L. Rough-legged Buzzard near Warrington. (Sci. Gossip, Nov.)

I8g6. Cox, W. Osprey in Lancs. (Field, Oct. 3.)

Forbes, H. O. Vertebrate Fauna of Liverpool District. [In Brit. Assoc. Handbook to Liverpool.] Post 8vo. Liverpool : I896. [212.]

Howard, R. J. Black Game in Lancs. (Zool.)

Smith, J. H. Notes from Wigan; Lancs. Bird Names. (Ornithologist.)

I897. Freeman, R. Hawfinch in S. Lancs. (Nat. Jnl.)

Oldham, C. Scaup inland in Lancs. (Zool.)

1898. Archibald, C. F. Spotted Crake in Furness. (Zool.)

Watts, W. Notes on the Birds in Piethorn Valley. (Tr. Rochdale Lit. E Sci. Soc.)

1899. Robinson, H. A. Bittern near Lancaster. (Field, Dec, 20.)

IgoI. Saunders, H. Exhibition of Sooty Tern from Hulme, near Manchester. (Bull. B.O.C., XII.)

Townsend, G. White Wagtails near Southport. (Zool.)

1902. Hepburn, T. Sea-birds and Plovers noticed in Lancs. (Zool.)

Oldham, C. Sooty Tern in Lancs. (Zool.)

Stott, J. Birds of Hollingworth I.ake. (Tr. Rochdale Soc.)

I903. Collins, J. Fire-crested Wren in Lancs. (Zool.) [Errore, cf. Zool., I904, p. 382.]

Robinson, H. W. Grey Phalarope in N. Lancs. (Field, Oct. 30.)

I904. Archibald, C. F. Spotted Crake in Furness. (Zool.)

Coward, T. A. Night Heron in Lancs. (T.c.)

Graves, F. S. Great Grey Shrike in Lancs. (T.c.)

Jourdain, F. C. R. Little Gull on the Mersey. (T.c.)

Robinson, H. W. Lanner Falcon in Lancs. (Zool.) ; Fulmar Petrel in N. Lancs. (Field, Apr. 23) ; Black-necked Grebe near Lancaster. (Op. cit., Aug. I3, Nov. 5 ; Zool. Sept.)

1905. Crabtree, J. H. A Lancs. Gull Moss. (Field, Mar. I8.)

Robinson, H. W. Bittern near Lancaster. (Lancs. Observer, Feb. Iо.)

Stubbs, F. Birds of the Oldham District. 8vo. 20 pp.

I906. Forbes, H. O. Birds. [In Victoria Hist. of Co. of Lancs., I.] 4to. Lond. : I906. [212.]

Jackson, A. Notes on the Nesting of Tringa alpina. (Zool.) Robinson, H. W. Golden Plover in summer plumage in Feb. in Lancs. (Field, Mar. 3.)

I907. Booth, H. B. Birds of Walney Is. (Nat.) 
I908. Bell, E. Chough in Lancs. (Field, Sept. 26 ; Brit. Birds, II.) Robinson, H. W. Wrynecks in N. Lancs. (Zool.)

Ig09. Charnley, J. R., and Heathcote, W. H. Birds of the Ribble Estuary, 4 pts. (Nat.)

Robinson, H. W. Leach's Fork-tailed Petrels in Lancs. ; Fulmar Petrel in N. Lancs. ; Black-necked Grebe in N. Lancs. (Brit. Birds, II.)

Smalley, F. Pomatorhine Skua in Lancs. (T.c.)

Stubbs, F. J. Dotterel near Oldham; Birds on the Lancs. Coast ; Dunlin near Oldham. (Lancs. Nat.)

Witherby, H. F. Irruption of Crossbills. (Brit. Birds, III.) [partim.]

Wood, W. M. Short-eared Owl breeding in Lancs. (T.c.) Idem, by H. W. Robinson. (T.c.)

I9I0. Bunyard, P. F. Eggs of Reeve from Lancs. (Bull. B.O.C., XXVII. ; Brit. Birds, IV.)

Dunlop, G. A. Bird Notes near Warrington. (Lancs. Nat.)

Greaves, W. The Birds of Todmorden. (T.c.)

Robinson, H. W. Line of Migration of Spotted Crake in N. Lancs, 2 notes. (Brit. Birds.)

Stubbs, F. J. Nightingale in Lancs. : A New Record. (Zool.; Lancs. Nat.) ; Breeding of Greater Black-backed Gull in Lakeland. (Lancs. Nat.)

IgIo-II. Stubbs, F. J. The Birds of Oldham, 3 pts. (Op. cit., III. and IV.)

IgII. Coward, T. A. Willow-Tit in Lancs. (Brit. Birds, IV.)

Stubbs, F. J. Decrease of the Corncrake. (Zool.)

I9I2. Robinson, H. W. Black-tailed Godwit and Pomatorhine Skua in N. Lancs. (Op. cit.)

Rodgers, A. Arctic Tern in Oldham. (Lancs. Nat.)

Igr3. Digby, S. White Swallow at Liverpool. (Field, Sept. 20.)

Robinson, H. W. Sclavonian Grebes in Lancs.; Lesser Blackbacked Gulls in Lancs. in winter; Black Guillemot in Lancs. (Brit. Birds, VII.)

Williamson, F. Peregrine Falcon in S. Lancs. (Lancs. Nat., VI., p. 234.)

I9I4. Robinson, H. W. Muscovy Duck in N. Lancs. (Zool.) : Rare birds in N. Lancs. (Lancs. Nat., VI., p. 40I): Waxwing in N. Lancs. (Field, Jan. 3I.) Does the Arctic Tern nest in Lancs.? (Lancs. Nat., VI., p. 442.)

Smalley, F. W. Little Gull in Lancs. (Brit. Birds, VIII.)

Taylor, A. Birds of a County Palatine, being a camera record of birds found infrequently for the most part in the county of Lancashire. Folio. London: I9I4.

Wheldon, J. A. Birds at Rinsdale. (Lancs. Nat., VII., p. I27.) Gannet in Lancs. (T.c., p. 87.) 
I9I5. Baddeley, T. Little Stints and Curlew Sandpipers inland in Lancs. (Brit. Birds, IX.)

Few, J. Increase of Turtle Doves breeding in Lancs. (T.c.)

Hopwood, A. T. Great Bustard -or what? [Blackburn.] (Lancs. Nat., VIII., p. 23I.) Bustard reported in Lancs. (Field, Oct. I6.)

Jourdain, F. C. R. Probable Eastern Black-eared Wheatear in Lancs. (Brit. Birds, IX.)

Parkin, W. H. Birds in the Morecambe district. (Lancs. Nat., VIII., pp. 8I-82.)

Peaples, F. W. Dipper in the Bolton District. (Op. cit. VII., p. 424); Bird notes from the Bolton district. (Op. cit. VIII., p. 38.)

Robinson, H. W. The Birds of Lancashire. A criticism of art. in Victoria Co. History. (T.c., pp. I28-30.)

Taylor, F. Arctic Terns on the Lancs. coast. (T.c., p. 229.)

Wheldon, J. A. South Lancs. bird notes. (T.c., p. II7.)

IgI6. Baddeley, T. Early movement of Waders on Lancs. coast. (Brit. Birds, X.) Idem, by H. W. Robinson. (T.c.)

Coward, T. A. Longtailed Skua in Lancs. (Lancs. Nat., IX., p. 27.) Notes on the Vertebrate fauna of S. Lancs. (Op. cit., Vol. IX., Suppl., pp. 6-37; X., pp. I89-92.)

Robinson, H. W. Blacktailed Godwits in Lancs.; Swallows and House Martins in Lancs. in IgI5-I6. (2 notes); Arctic Skua in N. Lancs. (Brit. Birds, X.)

I9I7. Baddeley, T. Birds on the Bury Reservoir. (2 notes.) (Lancs. Nat., X., pp. 42-3I7.)

Coward, T. A. Shags in Lancs. (Brit. Birds, XI.); Storm Petrel inland [Mossley.] (Lancs. Nat., X., p. 2 II) ; Leach's Forktailed Petrel near Manchester. (T.c., p. 225.)

Robinson, H. W. Little Gull in Lancs.; Leach's and Storm Petrels in N. Lancs.; Numbers in Swallow broods in I9I7, N. Lancs. ; Glossy Ibis in N. Lancs. ; Large numbers of Redthroated Divers in N. Lancs. (Brit. Birds, XI.)

Witter, R. R. Wild Swans [River Mersey.] (Selborne Mag., p. 45.)

Wrigley, J. H. Bird Life in S.W. Lancs. (Field, July 28.)

I9I8. Baddeley, T. Manchester resort of Water-fowl. (Lancs. Nat., X., pp. 297-300.)

Boyd, A. W. Curlew Sandpiper inland in S. Lancs.; SheldDucks and Common Scoters inland in Lancs. (Brit. Birds, XII.)

Robinson, H. W. Unrecorded Long-tailed Duck in Lancs.; Numbers in Swallow broods in 1918 in N. Lancs. (Brit. Birds, XII.)

Bird Notes for I9I7. (Lancs. Nat., X., pp. 333-4.) 


\section{LEICESTERSHIRE.}

I828. Fox, G. T. [Cream-coloured Courser in Leics.] (Zool. Jnl., III., p. 492.)

I840. Harley, J. A Catalogue of the Land Birds of Leics. In MacGillivray's History of British Birds. 8vo. Lond.: I840.

I842. Babington, C. The Ornithology of Charnwood Forest (also Supplement). In T. R. Potter's History of Charnwood Forest, Appendix. 4to. Lond. : I842. [33.]

I843-44. Harley, J. Note on Arrival of Summer Birds near Leicester in I843-44. (Zool., I843-44.)

I848. Evans, A. Leics. Names of Birds; Caprice of Kestrel. 2 notes. (Op. cit.)

I850. Bond, W. Note on the Fieldfare; Occurrence of the Waxwing in Leics. 2 notes. $(O P$. cit.)

I852. Bond, W. Peregrine Falcon [in Leics.]. (Nat. [Morris's], II.)

I853. Turner, T. [Redbreasted Merganser in Leics.] (Op. cit., III.)

I856. Wolley, G. Occurrence of Avocet in Notts. [on Leics. border]. (Zool.)

I858. Briggs, J. J. Spotted Flycatcher [nesting on hinge]. (Field, July Io); Storm Petrel in Leics. (T.c., Nov. 27.)

I859. “T. R. P.” Hobby [Nesting near Hathern]. (Field, Aug. I3.)

I860. "Meltonian." Spotted Crake [near Melton Mowbray]. (Op. cit., Oct. 20.)

Ellis, A. Fieldfare [absent]. (Field, Dec. I8.)

I862. Hildebrand, A. H. Goosander and Spotted Rail in Leics. (Zool.)

"Meltonian." Spotted Crake near Melton Mowbray. (Field, Nov. 22.)

I864. Ellis, J. H. Fieldfare in Leics. in July. (Zool., also Field, Aug. 6.)

I866. Mina, F. Tern shot in Leics. (Field, May 5.)

Widdowson, R. Red-footed Falcon [near Leicester]. (T.c., Mar. Io.)

I867. Goatley, T. Little Stint and Little Gull at Leicester. (Zool., also Field, Sept. 2I.)

Harting, J. E. Occurrence of Sylvia aquatica for the second time in England. (Zool.) Aquatic Warbler at Loughborough. (Ibis.)

r868. "R. S.", Little Bittern shot in Leics. (Field, Jan. 4.)

"R. W." Solitary Snipe and Shoveler Duck [in Leics.]. ( $O p$. cit., Oct. I7.)

Stuart, G. Green Sandpiper in Leics. (Op. cit., Jan. 4.) 
Walker, T. C. Birds occurring in Leics. in r868. (Zool.); Crossbills at Leicester. (T.c.)

I869. Walker, T. C. Curious Position of Nest of Waterhen: Anecdote of Owls. (Op. cit.) 2 notes. [Stamford Mercury.] Cape Pigeon and Gannet in Leics. (Zool.)

I8jo. Potter, T. H. Egyptian Goose in Leics. (Field, Apr. 30.) Idem. (Zool.)

187x. Peterson, E. F. Pied Flycatcher [breeding in Leics.]. (Field, May 13.)

1873. Brown, G. Green Sandpiper in Leics. (Op. cit., Jan. 4.)

Browne, J. Earle. Landrail in Leics. (T.c., May 3.)

Gillett, G. Pied Flycatcher near Melton Mowbray. (T.c., May 10.)

Matthews, H. Rare Birds in Leics. [Golden Eagle, Rosecoloured Pastor, Sand Grouse seen ; Temminck's Stint, Grey Phalarope, Scoter, Goosander, Black Tern, etc., shot.] (T.c., Jan. 25.)

Peterson, E. F. Swallow Tribe in Leics. (T.c., May Io.)

1874. Briggs, J. J. Woodcock nesting in Leics. (Op. cit., May 30.)

I875. D[avenport], H. S. Brambling in Leics. (Op. cit., Apr. 3.)

"F. C. L." Nests in juxtaposition. (T.c., May 22.)

Vores, C. Little Auk inland. (Op. cit., Dec. 4.)

1879. Beaumont, G. H. Golden [errore for White-tailed] Eagle in Leics. (Op. cit., Nov. 22.)

Macaulay, T. Rare Ornithological Occurrences in S. Leics. (Midl. Nat.)

Weatherhead, J. E. Occurrence of Honey Buzzard and Crested Grebe. (T.c.)

1879-80. Nacaulay, T. Notes on Ornithology. 4 notes. (Op. cit.)

ז880. "H. G." Rough-legged Buzzard near Ashby. (Field, Feb. 2I.)

I88I. Davenport, H. S. Crow, Kestrel and Owl using same nest. (Field, May 2I.)

Powys-Keck, H. L. Late Swallow [Nov. 28]. (Op. cit., Dec. 3.)

I882. Browne, M. On Occurrence of Reed Warbler. (Midl. Nat.)

Davenport, H. S. Summer Migrants in Leics. (Field, June Io.)

Macaulay, T. Osprey in Leics. (Midl. Nat.)

1883. Davenport, H. S. Ornitholog. Notes from Leics. (Field, Aug. 25, Sept. I.) 2 notes.

Macaulay, T. Birds of Leics. 4 pts. (Midl. Nat.)

I885. Browne, M. Little Stint in Leics. (Field, Oct. Io); Solitary Snipe near Melton Mowbray. (T.c., Sept. I2.)

Lever, E. O., and Moss, W. Canada Goose and Merlin in Leics. (Zool.) 
I885-86. Browne, M. Notes on the Vertebrate Animals of Leics. 9 pts. (Zool., I885-86.) [99.]

I886. Browne, MI. Cuckoo feeding its Young. (Op. cit.) Arrival of Spring Migrants. (Tr. Leics. Lit. \& Phil. Soc.)

Whitaker, J. Exhibition of Specimen of Wilson's Phalarope from near Market Bosworth. [??] (P.Z.S.)

I888. Millard, C. S. Present Visitation of Sand Grouse. (Field, June 2.)

I889. Browne, M. Vertebrate Animals of Leicestershire and Rutland. Sm. 4to. Birmingham and Leicester: I889. [99.]

D[avenport], H. S. Red-throated Diver in Leics. (Field, Mar. I6.)

Matthews, A. Velvet Scoter in Leics. (Zool.)

Stott, C. E. Jackdaws nesting on open boughs. (T.c.)

I89o. Davenport, H. S. Early Arrival of Fieldfares. (Field, Oct. II, I8 ; $c f$. also Nov. I). 3 notes.

Frere, H. L. Gadwall in Leics. (Zool.)

I890-9I. Aplin, O. V. On Distribution and Period of Sojourn in Brit. Isles of Spotted Crake. (Op. cit.) [partim.] [24]

I89I. Davenport, H. S. Great Grey Shrike in Leics. (Field, Nov. 2I.) Drummond, R. H. T. Bee-eaters in Leics. (Field, May 2, 9.) 2 notes.

[Editorial.] Blackcap in Leics. in March (?). (Zool.)

Macaulay, T. Scaup in Leics.; Common [?] Skua in Leics. (Zool.)

Whitlock, F. B. Notes on the Birds of Leics. ; Wood Warbler and White Wagtail in Midlands. (T.c.) 2 notes.

Whitaker, J. Unusual Nesting Place for Magpie. (T.c.)

I892. Aplin, O. V. On Distribution of Cirl Bunting in Great Britain. (Op. cit.) [partim.] [25.]

Matthews, A. Grey Phalarope in Leics. (T.c.)

I893. Davenport. H. S. Red Grouse perching on Trees [in I860]. (Field, Jan. 7.)

Fieldsend, A. Arrival of Waxwings. (T.c., Jan. 28.)

Lister, G. Wild Duck's Nest in November. (Field, Nov. I8.)

Whitlock, F. B. Ornitholog. Notes from Leics. (Zool.)

1894. Hornsby, J. W. Bittern in Leics. (Field, Mar. 3.)

Langdale, H. N. American Red-breasted Thrush in Leics. (Zool.)

1895. Matthews, Rev. A. Waxwing and Crossbills in Leics. (Op. cit.)

I896. Horwood, A. R. Cirl Bunting's Nest [near Leicester] ; Varieties, etc. 3 notes. (Nat. Jnl.)

1897. Davenport, H. S. Nesting of Grey Wagtail in Leics. (Zool.) 
I898. Davenport, H. S. Late Stay of Wheatear. (Field, Oct. 15.)

I899. Hind, W. R. Storm Petrel in Leics. (Op. cit., Sept. 30.)

I900. Davenport, E. Appearance of Fieldfare in September. $(O p$. cit., Sept. I5.)

Davenport, H. S. Mistle Thrush singing on the wing. (OP. cit., April I4.) Golden Plover in Leics. (Op. cit., Sept. I5.)

Whitaker, W. Curious place for young Cuckoo. (Op. cit., June 23.)

IgoI. Davenport, H.S. Redwing singing in England. (Op.cit., Jan. I2.)

I902. Davenport, H. S. Early nesting of Skylark; Arrival of Redbacked Shrike, etc., 3 notes. (Op. cit., Apr. I9, 26.)

Neale, J. Hooked Gull dying inland. (Op. cit., March 22.)

Ig03. Davenport, H. S. Siskin in Leics. (Op. cit., Sept. 26, Oct 3.)

Ig04. Davenport, H. S. Late Swallow in Leics. (Op. cit., Nov. 26.)

Dixon, O. M. Bewick's Swan in Leics. (Op. cit., Mar. I2.)

Roberts, T. N. Late Appearance of Blackcap in Leics. (Zool).

I905. Davenport, H. S. Little Owl in Leics. (Field, Apr. I5.)

Horn, W. J. Little Owl in Leics. (T.c., Apr. 22.)

I907. Browne, M. [Birds. In] Victoria Hist. of Co. of Leicestershire, I. 4to. Lond.: I907. [99]

I908. [Editorial.] Curious Sites for Swallows' Nests. (Field, Sept. I2.) [partim.]

I909. Davenport, H. S. Cuckoos and their Eggs. (Op. cit., June 26.)

IgII. Bidwell, E. Exhibition of N. American Peregrine. (Bull. B.O.C., XXVII.)

Davenport, H. S. Twite in Leics. (Field, Dec. 23.)

Ticehurst, N. F., and Jourdain, F. C. R. On Distribution of Nightingale during Breeding Season in Great Britain. (Brit. Birds, V.) [partim.] [584.]

I9I2. Davenport, H. S. Bittern in Leics. (Field, Feb. Io.)

Pilgrim, S. H. Pied Flycatcher in Leics. (Brit. Birds, VI.)

W[itherby], H. F. The IgI2 "Wreck" of the Little Auk. [partim.]; American Peregrine in Leics. (T.c.)

I9I3. Davenport, H. S. Cirl Bunting in Leics. (Field, Feb. 22.) Knot in Leics. (T.c., Nov. 8.)

I9I4. Ellis, G. Waxwing in Leics. (Field, Jan. 3I.)

Pilgrim, S. H. Mealy Redpoll in Leics. (Brit. Birds, VII.)

I9I6. Barrow, W. H. Hobby breeding in Leics. (Brit. Birds, X.)

Forrest, H. E. Marsh Harrier in Leics. (T.c.)

I9I8. Atlee, H. G. Tufted Duck breeding in Leics. (Op. cit., XII.) 
LINCOLNSHIRE.

1586. [Anon.] A most wonderful and true report . . . . . . of divers unknown Foules . . . . . taken lately at Crowley in the Countie of Lyncolne. [Ruffs.] Lond. : 1586.

I6ro. Camden, W. Britain, or a Chorographicall Description, etc. Folio. Lond. : I6Io. [II6.]

1622. Drayton, M. A Chorographicall Description of ...... Great Britaine. Folio. Lond.: I622. [I77.]

I77I-90. Pennant, T. Birds of the Fens [in Tour in Scotland, MDCCLXIX. Ist and 2nd edit. 8vo. Lond.: I77I, I772. 3 rd edit. I774; 4 th edit. I776; 5 th edit. I790.] [466-67.]

I825. Yarrell, W. Notice of Occurrence of some Rare British Birds. [Charadrius himantopus from Lincs., etc.] (Zool. Jnl., II., p. 24.)

I826. Yarrell, W. Notice of Occurrence of Species of Duck new to British Fauna. [Anas mufuna.] (Op. cit., III, p. 492.)

I827. Yarrell, W. On Occurrence of some rare British Birds. [Platalea lencorodia and Scolopax major in Lincs.]. (Op. cit., IV., p. 88.)

I834. Allen, Thom., and Saunders, J., junr. History of the County of Lincoln. 2 vols. 4to. Lond., etc. : I834. [Short passages on Birds at pp. 60-6I quoted from Thompson's Collections for the Historical Account of Boston.]

[Anon.] Notitice Luda, or Notices of Louth. [List of Birds: Cf. Harting, Zool., I878.] I834.

1838. Alington, R. P. Distribution of Corn Bunting [in Lincs.]. (Nat. [Wood's], III.)

[Editorial.] American Wigeon taken in Lincs. (T.c.)

I839. Stonehouse, W. B. History and Topography of the Isle of Axholme. 4to. Lond. : I839. [565.]

Strickland, A. Great White Heron [in Lincs. ?]. (Mag. N. H., p. 3I.)

I843. Willoughby, S. Note on Occurrence of Rare Birds in Lincs.; Note on Occurrence of young Cuckoo in Reed-Warbler's Nest; Note on Snow Bunting; Note on Occurrence of Arctic Tern in Lincs. 4 notes. (Zool.)

I844. Drayton, M. On the Birds of Lincolnshire and the Fens. From the Polyolbion, with Notes by W. Yarrell. (Ann. Mag. N. H.) [I77.]

I848. Newman, E. Further Note on the Bustard shot in Lincs. (Zool.) Roberts, A. Occurrence of the Little Bustard [errore] at KirtonLindsey, Lincs.; Occurrence of the Houbara in Lincs. 2 notes. (T.c.)

I849. Morris, B. R. Note on the Partridge. (Op. cit.)

1850. Cooper, W. W. Occurrence of Gannet near Great Grimsby. (Op. cit.) 
Foster, T. W. Occurrence of Whimbrel at Sutton. (T.c.)

Matthews, $\mathrm{H}$. Occurrence of Waxwing in Lincs. Black-throated Diver in Lincs. (T.c.)

Newman, E. Occurrence of Bimaculated Duck in Fens of Lincs. (T.c.)

Peacock, E., junr. Ducks nesting in Trees. (T.c.)

I85I. Alington, R. P. On Incubation and Rearing of Young of MoorHen ; Capture of Rare Birds ; Additional Heronries ; Singular Situations for Nests of Blue Tit and Common Moor-Hen; Nidification of Moor-Hen ; Habit of Ring Dove ; Mistle Thrush. 7 notes. (Nat. [Morris's], I.)

I85I-52, 55. Alington, R. P. Ornithological Notes, 4 pts. (Op. cit., I., II. and V.)

I852. Alington, R. P. Ornithology of Lincs. (Op. cit., II.)

M[orris], B. R. Ruffed Bustard or MacQueen's Bustard [in Lincs.]. Col. pl. (Op. cit., II.)

I853. Cooper, W. W. The Woodcock [breeding in Lincs.]; Note on an Owl, etc. (Op. cit. III.)

Foottit, W. F. Occurrence of Caspian Tern in Lincs. (Zool.)

Tristram, H. B., and Gurney, J. H. Occurrence of Galbula ruficauda in Lincs.: 2 notes. (T.c.)

1854. Alington, R. P. Snow Bunting [in Lincs.]; [Bramblings in Lincs.] ; Note on Cormorant. (Nat. [Morris's], IV.)

Cooper, W. W. Curious conduct of Hooded Crow. (T.c.)

Foottit, W. F. Occurrence of Little Bustard in Lincs. (Zool.)

Newman, E. Occurrence of Red-crested Whistling Duck at Boston. (T.c.)

I855. Brown, J. Spoonbill near Louth; Grey Phalarope near Louth. 2 notes. (Nat. [Morris's), V.]

Burton, F. M. Grey Phalarope: Purple Heron [in Lincs.]. 2 notes. (Op. cit.)

Roberts, A. Occurrence of Honey Buzzard near Scarboro' [and Louth]. (Zool.)

Gould, J. MacQueen's Bustard in Lincs. (Pr. Yorks. Phil. Soc.)

I856. Alington, R. P. Odds and Ends; Fieldfare. 2 notes. (Nat. [Morris's], VI.)

"Observer." Little Bustard [in Lincs.]. (T.c. ; Field, Feb. 2.) [Lincoln Herald.] Cormorant at Boston. (OP. cit., Sept. 22.)

I858. "A. C." Snipe sitting on rail. (Field, Dec. 4, I8.) 2 notes. "Glis." Curious Jackdaw [Partial albino]. (T.c., Sept. 25.) Morris, F. O. Occurrence of Quail in Winter. (T.c., Dec. II.) [partim.]

Stevenson, H. Little Bustard [in Lincs.] (T.c., Dec. Ir.)

I860. "A. C." Dotterel in Lincs. (Field, June 2.)

I86I. Tennant, J. Montagu's Harrier shot in Lincs. (Op. cit., Oct I2.) 
I862. Wilson, W. Occurrence of Little Gull, etc. (Zool.)

I863. Allis, T. H. Pallas's Sand Grouse in Lincs., etc. (Op. cit.)

"A. R. A." Sand Grouse [near Boston]. (Field, June I3.)

Gravil, H. Rough-legged Buzzard near Epworth. (T.c., Feb. 2I.)

Holland, C. G. Pallas's Sand Grouse in Lincs. (Zool.)

Hudson, S. Great Spotted Woodpecker near Epworth. (Field, Feb. 2I.)

Morris, F. O. Pectoral Sandpiper [errore for Ruff ?]; Sand Grouse, etc. (Op. cit., Nov. 7.)

Roberts, A. Pallas's Sand Grouse in Lincs., etc. (Zool.)

1864. "Constant Subscriber." Rare Birds in Lincs. [Waxwing, Bittern, Eared Grebe, Bewick's Swan and Brent Goose.] (Field, Feb. I3.)

Cordeaux, J. Migration of Golden-crested Wren; Abundance of Kingfisher in Lincs. ; Grey Plover on Lincs. Coast ; Whimbrel on Lincs. Coast; Curlew Sandpiper and Dunlin on Lincs. Coast; Appearance of Ruff and Reeve in Lincs.; Appearance of Little Stint in Humber, etc. Io notes. (Zool.)

"C. P." [Pallas's] Sand Grouse at Boston. (Field, Feb. 6.) Hudson, S. Abundance of Wild Fowl in Lincs.; Ruddy Sheldrake [errore,] Spotted Sandpiper [?] and Bittern near Epworth; Spotted Sandpiper and Ruddy Shieldrake. 3 notes. (Zool.)

Newton, A. Ruddy Sheldrake [recorded in error] at Epworth. (T.c.)

I865. Allis, T. H. Roller in Lincs. (Op. cit.)

Boulton, W. W. Red-footed Falcon ...... at mouth of Humber, (T.C.)

Cordeaux, J. Ornitholog. Notes from Ulceby and N. Lincs. 9 papers. Red-necked Grebe in Lincs. (T.c.) [I44.]

Gravil, H. Peregrine Falcon and Merlin at Epworth. (T.c.)

Hudson, S. Bittern near Epworth. (T.c.)

Hudson, W. Goosander near Epworth. (Field, Nov. II.)

"Snowflake." Snow Bunting [Ulceby.] (T.c., Dec. 2.)

Young, J. F. Bohemian Chatterer [in I864]. (Op. cit., Feb. 4.)

I866. Hall, J. C. The Hawk Owl [in Lincs.]. (Op. cit., July I4.)

Richardson, J. F. Great Grey Shrike at Stamford. (T.c., Oct. 27)

"S. H." Bohemian Waxwing [at Laughton]. (T.c., Dec. 8.)

"W. F. R." Bustard in Lincs. (Op. cit., Apr. I4.)

I866-88. Cordeaux, J. Ornitholog. Notes from N. Lincs., 58 contributions. (Zool., I866-76, I879-80, I882, I884, I888.) [I44.]

I867. “C. E. R." Black Redstart at Gedney. (Sci. Gossip, III.)

Harrison, J. W. Fork-tailed Petrel [in Lincs.]. (Field, Dec. I4.)

"Observer." Golden Eagle [seen ?] in Lincs. (Op. cit., June I5.)

I868. Cordeaux, J. The Ashby Decoy [I44]; Further Remarks on Green Sandpiper breeding in N. Lincs., 2 notes. (Zool.) 
"C. R." Rare Birds in Gedney Marsh. (Sci. Gossip, IV.) Harrison, J. W. Fork-tailed Petrel near Spalding. (Zool.)

I869. "A. J. P." Partridge's Nest on Straw Stack. (Field, July I7.)

Cordeaux, J. Dates of Arrival of Spring Visitors at or near Great Cotes. (Zool.)

Gravil, J. F., junr. Osprey at Epworth; Peregrine Falcon at Epworth; Merlin near Epworth; Hen Harrier at Epworth; Bittern near Epworth, 5 notes. (T.c.)

Hudson, S. Breeding of Ruff [in Lincs.]. (Field, Oct. 30); Rough-legged Buzzard at Epworth. (T.c., Dec. 4.)

I870. Sutton, R. Black Swans shot in Lincs. (Field, Nov. I2.) Idem. (Zool.)

I87r. Adrian, G. Rare Birds in Lincs. [Rough-legged Buzzard and Bittern.] (Field, Jan. 28.)

Cordeaux, J. Summer and Winter Visitants in Lincs. (T.c., May 27); Snow Buntings in Lincs. Marshes. (OP. cit., Nov. I8.)

Evans, J. Roller in Lincs. (Op. cit., June 3.)

Livesey, T. Pied Flycatcher at Horncastle. (T.c., May 6.)

I872. Cordeaux, J. Birds of the Humber District. Post 8vo. Lond. : I872. [I 44.]

Cordeaux, J. Notes from the Lincs. Coast, etc. (Zool.) [I44.]

Harting, J. E. British Heronries. (T.c.) [partim.] [274.]

1873. Cullingford, J. Notes from Lincs. (Field, Feb. I5.)

Evans, J. Arctic Skua in Lincs. (Op. cit., Nov. 8.) Idem. (Zool. I874.)

I874. "Coo-eh." Bittern and other Birds in Lincs. (Field, Jan. 24.)

"W. H. H." Hoopoe in Lincs. (Op. cit., Nov. I4.)

I875. "C." Brown Rook at Louth. (Op. cit., Jan. 30.)

Cordeaux, J. Arrival of Summer Migrants in N.E. Lincs. (T.c., May 29); Migration of Birds in N.E. Lincs. (Op. cit., Sept. 25.)

Garret, H. S. Bitterns in Lincs. (Op. cit., Jan. 23.)

Lundy, W. H. Little Auk in Lincs. (Op. cit., Dec. II.)

I876. Cordeaux, J. On some abnormal Migrations of Birds. (Op. cit., March II, I8), 2 papers; Dipper in Lincs. (T.c., Jan. 22.) Goshawk in Lincs. (Zool.)

Elliott, A. C. Rare Birds in Lincs. (Zool.)

Elliott, A. E. Rare Birds in Lincs. (Field, Jan. 8.)

Evans, J. Rare Birds in Lincs. (T.c., March 25.)

"Hyems." Landrail in Lincs. in Jan. (T.c., Jan. 22.)

Rowley, G. D. A Few Words on Fenland. 4to. (Rowley's Ornithological Miscellany.) [499.]

I877. Cordeaux, J. Rare Birds in the Humber District. (Zool.)

Hawley, H. W., and Prior, C. M. White Rook in Lincs. (Field, June 2, 9.) 2 notes.

"Punt Gun." Increase of Stock Dove in Lincs. (T.c., June 2.) 
I878. Cordeaux, H. W. Curious Position of Wild Duck's Nest. (OP. cit., June I.)

Cordeaux, J. Reeves in Lincs. (T.c., Sept. 7); Probable Occurrence of Kite in N. Lincs., 2 notes. (Ibid.); Odd Habits of the Kite. [Com. Buzzard in Lincs.] (T.c., Oct. 26); Some Notes on Decoys past and present; Ashby Decoy. (Op. cit., Apr. 6.)

Harting, J. E. An Old List of Lincs. Birds. (Zool.)

Miller, S. H., and Skertchley, S. B. J. The Fenland, Past and Present. 8vo. Lond.: I878. [407.]

I879. Cordeaux, J. Some Recent Notes on Avifauna of Lincs. (Tr. Norf. \& Norw. Soc.) [I45.]

Cordeaux, J. Nightingales in N. Lincs. (Field, June 7.)

Cullingford, J. Eagle Owl in Lincs. (Zool.)

Harting, J. E. The Great Bustard formerly in Lincs. (T.c.)

Nicholson, J. O. Notes from Lincs. (Field, Jan. 4.)

I880. Alder, F. J. Bittern in Lincs. (Op. cit., Dec. 4.)

Cordeaux, J. Bee-eater, Grey Phalarope and Tengmalm's Owl in Lincs. (Zool.)

"H. F. A." Bee-eater in Lincs. (Field, Sept. II.)

Harting, J. E. Bartram's Sandpiper in Lincs. (Zool.)

Hawkins, W. Uncommon Birds in the Midlands. (Field, Nov, 27.)

" P." Large Flight of Woodcocks in Lincs. (T.c., Nov. 27, Dec. I8.)

Topham, J. E. Tengmalm's Owl and Rough-legged Buzzard in Lincs. (T.c., Nov. 27.)

I88r. Allison, H. F. Osprey in Lincs. (Op. cit., Oct. 8.)

Brown, J. H. Habit of the Redshank. (T.c., Oct. I.)

Dixon, C. Petrels on the Lincs. Coast. (Zool.)

I882. Barber, W. Osprey in Lincs. (Field, Feb. 4.)

Castor, A. Common Buzzard in Lincs. (Op. cit., July I5.)

Cordeaux, J. Red-breasted Snipe in N.E. Lincs. (Zool.)

Cullingford, J. Glossy Ibis; Osprey, Honey Buzzard; Little Gull and Black Tern in Lincs., 3 notes. (T.c.)

Fowler, W. W. Osprey and Buzzard in Lincs. (T.c.)

Hutchinson, A. S. Red-necked Phalarope, Little Gull, and Kentish Plover on the Lincs. Coast, 2 notes. (T.c.)

Thompson, A. Common Crane and Greater Shearwater in Lincs. (T.c.)

Thomson, A. Common Crane in Lincs. (Field, Nov. 4.)

I883. Cordeaux, J. Ortolan Bunting in Lincs. ; Shore-birds on Humber Flats in May. (Zool.)

Cullingford, J. Great Snipe and Honey Buzzard in Lincs.; Hobby breeding in S. Lincs.; Waxwing in S. Lincs.; Redbacked Shrike and Osprey in Lincs.; White-tailed Eagle in S. Lincs. (T.c.) 
Elliott, A. Woodchat near Stanford. (Field, Jan. I3.)

Evans, J. Rare Birds killed in Lincs. [Sea Eagle at Edenham near Bourne; Rough-legged Buzzard, Storm Petrel, Sclavonian Grebe, etc., in Lincs.] (Op. cit., Dec. I5.)

Fisher, T. Ivory Gull on Lincs. Coast. (Zool.)

Hill, W. Coggan. Hoopoe in Lincs. (Field, Sept. 22.)

I884. Cordeaux, J. Ruffs and Reeves in Lincs. ; Probable Occurrence of Lapp Bunting near Grimsby, 3 notes. (Zool.) Notes from the Humber in Autumn of I884. (Ficld, Nov. 22.) The Birds of the Yorks. and Lincs. Coasts. (Rotherham Nat. Soc. Rec. \& Obs., No. I, July.)

Ford, T. Notes from N. Lincs. (Field, June I4; Dec. 6.)

Masham, J. F. Rare Birds in Lincs. (Zool.)

I885. Besant, F. Swallows Nesting in a Tree. (Field, Sept. 5.)

Evans, J. Rare Birds killed in Lincs. (Op. cit., Jan. I\%.)

Haigh, G. H. Caton. Winter Visitors to Lincs. (Op. cit., Oct. 3I.)

Kew, H. W. Nature near Louth; Nightingale at Naltby; Mablethorpe Birds; Heronry at Muckton Wood; Rambles near the Coast. (Nat. World.)

Marsden, L. D. Pied Woodcock in Lincs. (Field, Dec. 5.)

Masham, J. F. Albino Rooks. (Zool.)

Reeve, T. G. Ring Ouzel feeding on Cherries. (Zool.)

Watson, J. The Dotterel and its migrations. [partim.] (Ficld Nov. I4.)

I886. Beckwith, W. E. The Green Sandpiper. (Op. cit., Mar. r3.)

Cordeaux, J. Tree Sparrow in N. Lincs.; Lincolnshire (with mention of Birds). (Nat.) Notes on Birds of Lincs. Fens from Drayton's Polyolbion, Song 25. (T.c.).

[Editorial.] Gannet Inland. (Field, Oct. I6.)

Elmhurst, E. Hen Harrier in Lincs. 60 years ago. (T.c., Nov. 27.)

Haigh, G. H. Caton. Green Sandpiper in Winter [in Lincs.]. (Op. cit., Feb. 6.)

Kew, H. W. In the Woods; On the Lincs. Wolds. (Nat. World.)

Mason, J. E. Pied Flycatcher in N. Lincs.; Quail nesting in Lincs. (Nat.)

I887. Aplin, O. V. Ornitholog. Notes from Lincs. (Op. cit.)

Boyes, F. The Geese of the Humber District. (Field, Feb. 5, I9.) Idem by W. E. Clarke. (T.c., Feb. I2, 26.)

Cordeaux, J. Bird Notes from the Humber District. (Nat.) Geese of the Humber District, 2 pts. (Field, Jan. 29, Feb. I2.) Distribution of White bellied Brent Goose. (Zool.)

Ford, T. Late Arrival of Swallows in N. Lincs. (Field, May 2I.)

Stock Dove nesting in Rabbit's Hole. (T.c., May 28.)

Haigh, G. H. Caton. Habits of Green Sandpiper. (Zool.)

Kew, H. W. Bittern in Lincs. (Nat.)

I888. Allison, H. F. A Lincolnshire Gullery. (Field, June I6.) 
Candler, C. Rough-legged Buzzard in Lincs. (Op. cit., Nov. 24.) Cordeaux, J. Field Notes from N. Lincs. in Spring of I888; Notes on Occurrence of Pallas's Sand Grouse in Lincs. (Zool.) Pallas's Sand Grouse. (Field, June 9.)

Evans, J. Gannet and Rough-legged Buzzard in Lincs. cit., Dec. 29.)

Haigh, G. H. Caton. Long-tailed Duck and Grey Phalarope in Lincs. (Zool.) Sand Grouse. (Field, June 23.)

Harrison, J. W. Pallas's Sand Grouse in N. Lincs. (Op. cit., Oct. 27).

Hudson, S. Present Visitation of Sand Grouse [Lincs.]. $(O p$. cit., June 2.)

Loft, J. E. Wallis. Pallas's Sand Grouse. (T.c., June 9, 30) 2 notes. Idem by J. O. Nicholson. (Op.cit., Aug. 4.)

Mason, J. E. Pied Flycatcher and Osprey near Alford. (Nat.)

I889. Allison, H. F. Sand Grouse in Lincs. (Zool.)

Cordeaux, J. Migration of the Woodcock. (Field, July 6, 27, Aug. 3) ; Notes from Yorks. and Lincs. Coasts in Autumn of I888; Bird Notes from the Humber District; Ornitholog. Notes from N.E. Lincs. and Holderness [I45.] ; Pallas's Sand Grouse in Humber District. (Nat.) Nutcracker in Lincs. (N. H.Jnl.) A Day amongst the Birds on the Lincs. Coast. (Field, Sept. 2I.) Pallas's Sand Grouse in Lincs. (Zool.)

Evans, J. Goshawk and Little Owl in Lincs. (Field, Mar. 23.) Ford, T. Scarcity of Winter Birds in N. Lincs. (T.c., Jan. I2.) Haigh, G. H. Caton. Night Heron in Lincs.; Nutcracker in Lincs. (Zool.)

Harrison, J. W. Oystercatcher within the Humber. (Nat.) Mason, J. E. Pallas's Sand Grouse near Skegness; Blackthroated Diver near Alford. (T.c.)

Peacock, E. Glossary of Words used in the Wappentakes of Manby and Corringham. 2nd edit. (Eng. Dialect Soc. : 1889.)

1890. Allison, H. F. Great Grey Shrike, Peregrine Falcon; Shore Lark; and Hawfinch in Lincs., 3 notes. (Zool.)

Cordeaux, J. Wheatear in N. Lincs. in March. (T.c.); Ruff and Reeve in Lincs. (Field, Apr. 26; Zool.) Two-barred Crossbill in Lincs. (Nat.)

Delmar, C. Eagle in Lincs. (Field, Nov. I5.)

"F. W. H." Buzzard in Lincs. (T.c., Oct. II, I8.) 2 notes. Haigh, G. H. Caton. Grey Shrike and Peregrine in Lincs.; Wheatear in N. Lincs, in March. (Zool.); Arrival of Fieldfares. (Field, Nov. I5.)

Harrison, J. W. Wheatear in March; Increase of Jack Snipe in N. Lincs. 2 notes. (Zool.)

Mason, J. E. Great Spotted Woodpecker and Storm Petrel near Alford. (Nat.)

Topham, J. G. Manx Shearwater [at Wootton.] (Field, Sept. 5.) 
Waite, E. R. Red-throated Diver at Alford. (Nat.)

I890-9I. Aplin, O. V. On Distribution and Period of Sojourn in British Islands of Spotted Crake. (Zool.) [partim.] [24.]

I890-99. Cordeaux, J. Notes from the Humber District, I9 parts. (Nat., I890-99.) [I46.]

I89I. Benoni, G. O. Ducking: A Lincs. Sketch. (Sci. Gossip, Jan.Mar.)

Carnegy, A. St. Clair. Reeve's Pheasant in Lincs. (Field, June 27.)

Cordeaux, "E. K." Bewick's Swan in Lincs. (T.c., Jan. 24.)

Cordeaux, J. Wild Geese and Swans in Lincs. (T.c., Jan. Io); Notes from the Humber. (T.c., Jan. IO); Notes from the Humber. (T.c., Feb. 2I) ; Bird Notes from N. Lincs. March, April and May, I89I. (Nat.) Reeve's Pheasant in Lincs (Field, June 6); Letter on Coracias indicus in Lincs. (Ibis.) Rare Brit. Birds in Humber District; Reminiscences of the Kite in Lincs. ; Spring Migration in Humber District. (Zool.)

Ford, T. Late Stay of Swifts at Caistor. (Field, Sept. 26.)

Haigh, G. H. Caton. Lapland Bunting in Lincs. (Zool.)

Harrison, J. W. Bittern in N. Lincs.; Ornitholog. Notes from Humber District, 2 notes. (Nat.)

Loft, H. W. G. Rough-legged Buzzard and Buff-coloured Snipe in Lincs. (Field, Jan. 24.)

Rose, B. Rough-legged Buzzard in Lincs. (Op. cit., Dec. 5.) Waite, E. R. Marsh Harrier in Lincs. (Nat.)

I892. Aplin, O. V. On Distribution of Cirl Bunting in Great Britain. (Zool.) [partim.] [25.]

Cordeaux, J. Migration in Humber District in Autumn of IS92. (Zool.); Approaching Extinction of the Lapwing [denied]. (Sci. Gossip.); September Woodcocks in Humber District. (Field, Oct. 8.)

Haigh, G. H. Caton. Ruddy Sheldrake in Lincs.; Yellowbrowed Warbler in Lincs. (Zool.)

Harrison, J. W. Ruff in N. Lincs. (Nat.)

Mason, J. E. Notes from N. Lincs. (T.c.)

Yarborough, Lord. White Woodcock in Manby Woods. (Field, July 2.)

I893. Cordeaux, J. Nutcracker and Green Sandpiper in Lincs. 2 notes. (Zool.); Notes on Pink-footed and Bean Geese. (Field, June $3, \mathrm{I} 7)$; Disappearance of the Great Bustard in Lincs. (Nat.)

Fieldsend, A. Nutcracker in Lincs. (Zool.) Arrivals of Waxwings [Lincs.]. (Field, Jan. 28.)

Larder, R. Waxwings near Louth. (Nat.)

I894. Cordeaux, J. Cuckoo seen in March. (Zool.) 
Haigh, G. H. Caton. Lapland Bunting in Lincs. (T.c.)

Wilson, H. Hoopoe in Lincs. (Field, Oct. 6.)

I895. Anderson, M. Lesser Spotted Woodpecker's Nest at Gainsborough. (Nat. Jnl.)

Boyes, F. Hen Harier in Lincs. (Field, Jan. 5.)

Cordeaux, J. Water Pipit in N. Lincs. (Nat.); Rare British Birds in Humber District. (Zool.)

Haigh, G. H. Caton. Stone Curlew in Lincs. in Winter; Water Pipit at Tetney Haven. (Zool.)

Sclater, P. L. Spotted Redshank from Spalding. (Bull. B.O.C., V.)

I896. Anderson, M. L. Nesting of Hawfinch and Increase of Turtle Dove in Lincs., 2 notes. (Zool.) ; Lincs. Notes. (Ornithologist.)

Cordeaux, J. Hawfinch and Turtle Dove in Lincs. (Zool.)

Ford, T. Late Stay of Swifts. (Field, Oct. 3I.)

Haigh, G. H. Caton. Occurrence of Phylloscopus viridanus in Lincs. (Zool.; Bull. B.O.C., VI.); On Occurrence of Water Pipit in Lincs. (Op. cit., V.)

I897. Anderson, M. L. Where Blackbirds breed. (Nat. Notes, July.)

Calvert, R. W. Nesting of Great Plover. (Zool.)

Cordeaux, J. Nesting of Grey Wagtail in Lincs., 2 notes. (T.c.)

Welby, C. Green Sandpiper in December. (Field, Jan. 2.)

I898. Allison, H. F. Early Arrival of Cuckoo in Lincs. (Op. cit., May 2I.)

Cordeaux, J. Food of the Barn Owl ; Disappearance of Lapwing in N. Lincs. 2 notes. (Zool.) Carrion Crows capturing Lark. (Knowledge.) Rooks nesting on Poplars. (Field, June 4); Migration of Red-legged Partridge. (T.c., June II.)

Haigh, G. H. Caton. Barred Warbler in Lincs. (T.c.) Idem. (Knowledge.) Exhibition of a specimen of Lusciniola schwarzi killed in Lincs.; Exhibition of a specimen of Sylvia nisoria from Lincs. (Bull. B.O.C., VIII. ; Ibis, I899.)

Vincent, J. L. Late Stay of Swift. (Field, Sept. 24.)

I899. Cordeaux, J. A List of British Birds belonging to the Humber

District (having special reference to their migrations). Revised to April, I899. 8vo. Lond. : I899. [I46.]

Cordeaux, J. Note on Syrrhaptes paradoxus in Lincs. (Ibis) ;

Migration of Red-legged Partridge. (Field, Apr. 15); Sand Grouse in Lincs. (Knowledge); Early Spring Migrations. (Zool.) ; Food of Partridges on grass-lands. (Field, Feb. 25.) Haigh, G. H. Caton. Radde's Bush Warbler (Lusciniola schwarzi) in Lincs. (Tr. Norf. \& Norw. Soc., VI.) Idem. (Knowledge,
Feb.)

Moore, C. T. J. Honey Buzzard in Lincs. (Field, June I9.)

Ig00. Anderson, M. L. Bird Notes from Lea, near Gainsborough, Jan. to June I899. (Nat.) 
Brogden, T. J. H. Birds of Spalding and S. Lincs. Fenland. (T.c.)

Haigh, G. H. Caton. Bird Notes from N.E. Lincs. during the Autumn of I899. (Zool.)

Peacock, M. Late Nesting of Spotted Flycatcher. (Field, Sept. 29.)

I90I. Haigh, G. H. Caton. Red-necked Phalarope in Lincs. (Zool.)

Marsden, L. D. Roller in N. Lincs. (Field, Oct. 5.)

IgOI-04. Haigh, G. H. Caton. Migration of Birds in N.E. Lincs. during Autumn of Igoo to I903, 4 pts. (Zool., IgOI-04.)

I902. Blathwayt, F. L. Little Owl and Shore Lark in Lincs. (Op. cit.)

[Editorial.] Flamingo shot in Lincs. (Field, Dec. 13.) [Cf. T.c., Dec. 20.]

Roebuck, W. D. List of Yorks. and Lincs. Birds. (Nat.)

I902-08. Peacock, M. The Birds of N.W. Lindsey, 4 pts. (Op. cit., I902, I906, I908.)

igo3. Blathwayt, F. L. Notes from Lincs. 2 notes. (Zool.)

I904. Blathwayt, F. L. "Xanthochroism" in Greenfinch; Little Owl and Waxwing in Lincs. 2 notes. (Op. cit.)

Cooper, R. Woodcock nesting in Lincs. (Field, May 7.)

I905-08. Blathwayt, F. L. Birds of Scotton Common; Birds of a Ballast Pit near Lincoln. (Lincs. Nat. Union Tr., I905-08.)

I906. "A. L. C." Gullery at Twigmoor. (Field, Dec. I.)

Boyes, F. Early Arrival of Redwing in Lincs. (T.c., Oct. 6.)

"B. S." A Gannet Inland. (T.c., Dec. I.)

Wade, E. W. Food of the Brown Owl. (Op. cit., Apr. 28.)

I908. Blathwayt, F. L. Wild Ducks near Lincoln City ; Honey Buzzards in Lincs. ; Notes on Heronries, Lincs. ; Rough-legged Buzzards in Lincs. (Zool.) Stock Doves nesting on Lincoln Minster (Brit. Birds, I.); Inland Nesting of Sheld-duck and Nesting of Pochard, Shoveler and Teal in Lincs. (Brit. Birds, II.) Burton, F. M. Golden Oriole in Lincs. (Nat.)

Haigh, G. H. Caton. Barred Warbler in Lincs.; Yellow-browed Warbler in Lincs.; Buff-breasted Sandpipers in Lincs.; Sabine's Gull in Lincs. (Brit. Birds, II.)

Ig09. Blathwayt, F. L. Lincolnshire Gulleries. (Zool.)

Blathwayt, F. L. Notes on Owls and Hawks of Lincs. (Lincoln City of Co. Mus. Publ., No. 6.) 8vo. Igog.

Duncan, S. Black-tailed Godwits in Yorks. and Lincs. (Brit. Birds, III.)

Haigh, G. H. Caton. Yellow-browed Warbler in Lincs.; Redbreasted Flycatcher in Lincs. (Op. cit.; III.)

Suggitt, W. E. Rose-coloured Starling in Lincs. (T.c.) 
I9Io. Blathwayt, F. L. Probable Nesting of Crossbill in Lincs. (T.c., IV.)

Durham, T. G. Wild Swan in Lincs. (Field, Jan. I.)

Haigh, G. H. Caton. Lanceolated Warbler in Lincs: a new British Bird. (Brit. Birds, III.) Yellow-browed Warbler in Lincs. (Op. cit., IV.)

I9II. Blathwayt, F. L. Report on Birds of Lincs. for IgII. (Tr. Lincs. Nat. Union, I9II.)

Bolam, G. Little Owl and (?) Wood Sandpiper in Lincs. (Zool.)

Clitherow, C. E. S. Little Owls in Lincs. (Brit. Birds, V.)

Haigh, G. H. Caton. Squacco Heron in Lincs. (Op. cit., IV.)

Suggitt, W. E. Barred Warbler in Lincs. (Op. cit., V.)

Ticehurst, N. F., and Jourdain, F. C. R. On Distribution of Nightingale during Breeding Season in Great Britain. (T.c.) [partim.] [584-322.]

Tunnard, C. N. Spoonbills in Lincs. (Field, Nov. 18.)

Witherby, H. F. British Willow Tit in Lincs. (Brit. Birds, IV.)

I9I2. Blathwayt, F. L. The Birds of Lincs. : Additions to the County List. (Zool.) [7I.] Report on Birds of Lincs. for IgII. (Tr. Lincs. Nat. Union, Igrr.)

Haigh, G. H. Caton. North American Peregrine in Lincs. (Brit. Birds, V.)

Tunnard, C. N. Little Auk in Lincs. (Field, Feb. 3.)

W[itherby], H. F. The IgI2 "Wreck" of the Little Auk. (Brit. Birds, V.) [partim.]

I9r3. Haigh, G. H. Caton. Richard's Pipit in Lincs. ; Yellow-browed Warbler in Lincs. $(O p$. cit., VI.); Barred Warbler in Lincs. (Op. cit., VII.)

Medlicott, W. S. Waxwing in Lincs. (Field, Dec. I3.)

I9I4. Blathwayt, F. L. Status of Blackcap and Garden Warbler in Lincs. (Zool.); Black Redstart in Lincs. (Brit. Birds, VII.) Charlton, J. M. Visitation of Black Redstarts in Lincs. (T.c.)

I9I5. Allison, J. S. Little Gull caught in Lincs. (Brit. Birds, VIII.)

I9r6. Blathwayt, F. L. Rough-legged and Common Buzzards in Lincs.; White-tailed Eagle and Rough-legged Buzzards in Lincs. (Brit. Birds, IX.); Woodcock breeding in Lincs. (Field, May

6.) Idem by J. Nicol. (T.c., April 29.)

I9I8. Allison, J. Red-throated Diver inland in Lincs. (Brit. Birds, XI.)

Blathwayt, F. L. Ortolan Bunting in Lincs. (Field, Nov. 2.) Haigh, G. H. C. Yellow-browed and Barred Warblers in Lincs. (Brit. Birds, XI.)

Jourdain, F. C. R. Black Grouse in N. Lincs. (Brit. Birds, XII. 


\section{LONDON AND MIDDLESEX.}

(London is taken to mean the County of London, or a radius of roughly 4 miles from Charing Cross, and the whole County of Middlesex is added. Essex, Irent and Surrey should also be consulted for the suburban area.)

I555. Belon, P. [On London Kites.] (Hist. Oy'seaux, p. I3I) [Vide also Obs. de Plus. Singull., bk. II., ch. xxxvi., note by Clusius, and Bibl. Lit. Ver. Stuttgart, VII., p. 40, for remark on Kites around London Bridge about I46I, by Schaschek.]

[I665.] Evelyn, John. [I620-I706.] Diary. [Under date Feb. 9, I664-5, describes the Birds kept in St. James's Park, including wild fowl breeding about the decoy.]

I768. Smith, R. Universal Directory for Taking Alive and Destroying Rats [etc.]. I2mo. Lond. : I768. [Mention of London Ravens, etc.] [55I.]

I8II-2I. Graves, G. British Ornithology. 3 vols. Lond. : I8II-2I. [246.]

I8I7. Forster, T. I. M. Natural History of the Swallow Tribe. (including Journal of Nat. Hist. at Clapton). 8vo. Lond. : I8I7. [2I4.]

1824. [Vigors, N. A.] Anthus richardi near London. (Zool. Jnl., I., pp. 280, 4II, pl. XIV.)

1825. Yarrell, W. Notice of Occurrence of Some Rare Brit. Birds. [Battersea, etc.] (Op. cit., II., pp. 24-27.)

I828. Yarrell, W. Idem. [Fork-tailed Petrel at Chelsea and Dartford Warbler at Finchley.] (Op. cit., III., p. 498.)

Jennings, J. Ornithologia, or The Birds: A Poem. I2mo. Lond.: I828. 2nd edit. I829. [313.]

I829. Jennings, J. Ornithology of the Metropolis. (Loudon's Mag. N. H., II.) [Unimportant.]

Jordan, W. Cuckoo. [Breeding at Old Brompton.] (T.c., p. 242.)

1830. Gould, J. On Occurrence of a New Brit. Warbler. [Black Redstart at Kilburn; also Lapland Bunting near London.] (Zool. Jnl., V., p. I02.)

I83I. Yarrell, W. Addit. to Catalogue of Brit. Birds. [Richard's Pipit in Copenhagen Fields, etc.] (Loudon's Mag. N. H., IV., p. II6.)

1832-35. Jesse, E. Gleanings in Natural History. 3 Series. Post 8vo. Lond. : I832-35. [3I6.]

I838. Torre, H. J. A List of Birds found in Middlesex. (Nat. [Neville Wood's], III.)

1839. Blyth, E. On Wild Fowl in St. James's Park. (Charlesw. Mag. N.H.) 
I843. Bond, F. On Occurrence of Rare Brit. Birds at Kingsbury; On Water-birds occurring at Kingsbury Reservoir. (Zool.)

I844. Bond, F. Arrival of Summer Birds at Kingsbury in I844; Rare Waders at Kingsbury Reservoir. (Op. cit.)

Chennell, F. A. Crested Grebe in Middx. (T.c.)

I846. Hall, T. Great Horned Ovl at Hampstead; Stormy Petrel in London in I824. $(O p$. cit. $)$

I847. Prentice, C. Curious Ornitholog. Record. [Clusius on Kites in London.] (Op. cit.)

I848. Bond, F. Young Little Bittern near Enfield. (Op. cit.)

I849. Atkinson, W. Cole-Titmouse in London. (Op. cit.)

I850. Bond, F. Great Grey Shrike near London. [Kentish Town and Kilburn]; Scolopax brehmi (?) near London; Kite at Kingsbury; Black Redstart near London; Forktailed Petrel near London. (Op. cit.)

Newman, E. Waxwings near London. 2 notes. (T.c.)

Smith, C. H. Osprey at Teddington. (T.c.)

I852. Loames, F. D. Ring Ouzel near Peckham Rye. (Nat. [Morris's], II.)

Wood, C. Hobby at Clapham. (Zool.)

"W. F. W. B." Hoopoe near London [Whetstone]. (Nat. [Morris's], II.)

I853. Carter, S. H. Snow Bunting at Tottenham. (Op. cit., III.)

Cooke, M. C. Honey Buzzard [caught at Westminster]. (T.c.) Hesse, B. Great [Grey] Shrike near Hackney; Dartford Warbler [on Hackney Marsh]. (T.c.)

I854. Dutton, J. Note on Ring Ouzel, etc. ; Bittern at Chiswick ; Lesser Spotted Woodpecker at Turnham Green. (Zool.)

Hauynaught, C. Hooded Crow in London [on National Gallery]. (Nat. [Morris's], IV.)

I855. Akerman, J. Y. Birds of London. (Zool.)

Beresford, G. Smew near London. (T.c.)

Kidd, W. Progress of Seasons-January. (Nat. [Morris's], V.)

1856. Dutton, J. Mealy Redpoll at Hammersmith. (Op. cit., VI.)

I857. [Anon.] Extraordinary Flight of Larks. [Regent's Park.] (Op. cit., VII.)

1858. Harting, J. E. Dartford Warbler in Middx. (Field, Nov. 6.) Newman, E. Cream-coloured Courser in Hackney Marshes. (Zool. and Field, Oct. 30.)

Russell, W. Landrails [one shot New Cross in Jan.]. (Field, Feb. 6.)

I859. Altham, J. Kite Flying over London [Piccadilly]. (Zool.)
"E. W. C." Naturalist's Notes at Hendon. (Field, July I6.) 
"F. S. D." Hobby [at Hampstead]. (Op. cit., June 4); Raven [two seen at Hampstead]. (T.c., June I8); Crossbills and Hawfinches at Hampstead. (OP. cit., Dec. 3I.)

Gilbert, R. H. T. Woodcock in Hyde Park. (T.c., Nov. Ig.) Idem by "Sparrow-Hawk" (T.c., Dec. 3.)

Gray, J. H. Hawfinch breeding at Muswell Hill. (Zool.)

1860. Crewe, H. H. Wild Fowl in the Ornamental Waters of London. (OP. cit.) Idem by H. Hussey. (T.c.)

"F. S. D." Ring Ouzel at Hampstead. (Field, Oct. 6.)

"J. D." Hawfinch [breeding at Chiswick]. (Op. cit., Feb. I8.)

Lewis, F. Cuckoo in St. James's Park. (Field, Aug. I8.)

I86r. "Somerset." Wood Pigeons in Kensington Gardens. (Op. cit., June 22.)

I862. [Anon. " J. H."] Cuckoo in London. (Op. cit., May 3I) ; "Curiosity Seeker" Great Grey Shrike near Dulwich. (Op. cit., Dec. 27.)

$\mathrm{H}[$ arting], J. E. Winter Visitants and Ornithological Gossip [from Kingsbury]. (Op. cit., Nov. I.)

Hussey, H. Pochards in the Serpentine. (Zool.)

I863. Fraser, L. List of Birds Captured or Observed by Mr. E. Bartlett in the Society's Garden. (P. Z. S., pp. 159-60.)

Govett, A. F. Woodcock [breeding near Staines]. (Field, May 9.)

Harting, J. E. List of Waders that have occurred at Kingsbury Reservoir; Osprey near Uxbridge. (Zool.) Summer visitants at Kingsbury. (Field, May 9.)

Huckett, T. Spotted Crakes in Hackney Marshes. (Zool.)

"M. A. D." Flycatchers Building in London. (Field, June 20) ; "N. R. G." Terns seen in the London Parks and Neighbourhood. (Op. cit., Aug. 8.) ; Ward, E. Idem, Aug. I5 ; "C. M. A[damson]." Idem, Aug. 22.

I864. Bridgeman, F. C., and G. O. M. Birds of Harrow. [In J. C. Melville's Flora of Harrow.] Post 8vo. Lond., etc. : I864. New edit. I876. [92.]

Dewey, W. F. Nightingale in Battersea Park, etc. (Field, May 2r.) Leigh, J. H. Idem. (T.c., May 28.)

Harting, J. E. Little Ringed Plover at Kingsbury. (Zool.)

Hussey, H. Wild Fowl in the London Waters. (T.c.)

Power, W. H. Ruff and Curlew Sandpiper at Kingsbury Reservoir. (T.c.)

1865. Adamson, C. M. Wildfowl in the London Parks. (Field, Apr. I.) Button, D. T. Hoopoes on Streatham Common. (Zool.) Eedle, T. Shore Lark near London [Hackney Marshes]. (T.c.)

Hibberd, S. London Birds. (Intellectual Observer, VII., pp. ז67-75.) 
Power, F. D. A List of Birds noticed in London [Bloomsbury] during I863-64. (Zool.)

Power, W. H. Curlew Sandpiper at Kingsbury Reservoir. (T.c.)

Wharton, C. B. Snow Bunting at Kingsbury Reservoir. (T.c.)

1866. [Anon. and Editorial.] White Stork in London. (Field, July 2I.) "G. T." Bohemian Waxwing [at Ealing]. (Field, Dec. 8.)

Harting, J. E. Birds of Middlesex. Post 8vo. Lond. : I866. [273.]

Harting, J. E. On Occurrence of Spoonbills in Middlesex. (Zool.)

Power, F. D. Wood Sandpiper at Kingsbury Reservoir. (T.c.) Reddall, - Nightingales [near Stamford Hilll. (Sci. Gossip.)

1867. Austin, H. Dunlins at Kingsbury Reservoir. (Zool.)

Francis, F. Great Plover at Feltham. (Field, March 30.)

Newman, E. Hirundines in London. (Op. cit., Oct. Ig.)

"I. E. B. C." Ring Ouzel in Middlesex. (T.c., Oct. I2.)

Harting, J. E. Stock Doves Breeding in a Church [at Kingsbury]. (Field, Mar. 30.)

Hooper, W. T. Tufted Pochard on the Lea. (Zool.)

Wharton, C. B. Rock Pipit Inland [Willesden]. Ring Ouzel in Middlesex in March. (T.c.)

I868. Davy, C. R. Black Redstart near Hampstead. (Field, April I8.)

Mitford, R. H. Reed Warbler [at Hampstead]. (Zool.)

Tegetmeier, W. B. Crossbills near London. (Field, Dec. 26.)

I869. [Anon.] Waterfowl in St. James's Park. (Zool.)

Blomfield, A. [Barn] Owl on Bishopsgate Church. (T.c.)

Harting, J. E. Greenshank and Temminck's Stint near London [Brent Reservoir]. (Field, Nov. 27.)

"M. J. T." Crossbills and Hawfinches [at Winchmore Hill]. (Op. cit., Jan. I6.)

Roberts, T. V. Ring Ouzel in Kensington Gardens. (Zool.)

Smith, W. Ring Ouzel at Muswell Hill. (T.c.)

Sterland, W. J. Nesting of Honey Buzzard [within 6 miles of Metropolis]. (Field, July 24.) [errore.]

I870. [Blyth, E.- "Z."] Undetermined semi-Bullfinch taken near Hampstead. (Field, Oct. I5, 22, 29.)

Bond, F. Little Gull in the City [Cornhill]. (Zool.); Second Occurrence of Scarlet Bullfinch near London. (T.c.)

Crystal, A. The Grey Phalarope [at Chiswick and Barnes]. (Field, Nov. 5.)

Gurney, J. H., junr. Dabchicks in Kensington Gardens. (Zool.)

" J. G." Partridge in Regent Street. (Field, June II.)

Newman, E. Shore Larks near London [Hackney Marshes]. $(Z o o l$. 
Smee, A. H. Redthroated Diver in London [Clerkenwell]; Blackthroated Diver and Redbreasted Merganser on the Thames. (T.c.)

Wharton, C. B. Nightjar near London. (T.c.)

I871. "B." Rooks in London. (Field, Apr. I5.)

Barraud, A. F. Bittern and Peregrine in Middlesex [Edgware]. (T.c., Feb. 25.)

[Blyth, E.- "Z."] Kestrels Breeding on Nelson's Column. (T.c., Apr. 29) ; Quails near London. (Op. cit., July I5, 29) ; Small birds near the Metropolis; Passer montanus breeding in Hampstead Parish. (Op. cit., June Io.)

Bond, F. Quail nesting between Hampstead and Kentish Town. (Zool.)

Dutton, J. Bustard in Middlesex [Feltham]. (T.c.) [Editorial.] Idem. (Field, Jan. 7.)

Harting, J. E. Orphean Warbler near Holloway. (Field, Apr. 22.)

Mitford, R. H. Quails breeding near Hampstead; Ruff and Reeve in Middlesex. (Zool.)

Smee, A. H. Birds observed in the Thames. (T.c.)

Smith, W. Peewits in Finsbury Park. (Field, Dec. 2.)

Todd, C. J. Green Woodpecker in Middlesex [Harrow]. $(O p$. cit., June 24); Redwing [?] nesting in Middlesex [Harrow]. (T.c., June 24, July I.)

I872. "A. L." Bittern near Uxbridge. (Op. cit., Jan. I3.)

"B." Bohemian Waxwing at Highgate. (T.c., Dec. 2I.)

[Blyth, E.- "Z."] Kites formerly in England. (T.c., July 27.)

Harting, J. E. Existing Heronries in Great Britain. (Op. cit., Feb. I7.)

Houghton. W. Owl in the City. (Op. cit., Oct. 26, Nov. 9.)

Murray, J. G. Nightjars near London [Hendon]. (T.c. Sept. 28.) "I. J. G." Idem. (T.c., Oct. I2.)

Smith, H. Kingfishers in London [Regent's Park]. (T.c., Sept. 28.)

Wilshin, H. Ring Ouzel in Middlesex [Little Stanmore]. (T.c., Nov. 2.)

I873. Adams, H. C. Cuckoos in London [Regent's Park]. (Op. cit., July 5.) Idem by H. Smith. (T.c., July 26.)

Bond, F. Goshawk at Hampstead. (Zool.)

[Blyth, E.- "Z."] Snowflecks and Larkheels near London [Regent's Park]. (Field, Feb. 8.)

"C. P. B." Woodcock caught in London Cabstand [St. John's Wood]. (Op. cit., Nov. 22.)

Finch, W. G. Plovers passing over London [Bishopsgate]. (Op. cit., Feb. 8.)

Fox, W. Nightjar in London [Holborn Viaduct]. (Op. cit., Sept. 6.) 
Gurney, J. H., junr. Osprey at Hampstead. (Zool.)

"J. B. M." Woodcock in London [St. James's Park]. (Field, Mar. I.)

Macdonald, G. F. J. Nightingale in Battersea Park. (T.c.,

May I7.)
Rolle, H. W. Woodcock in London [Upper Clapton]. (T.c., Apr. Ig) ; Idem by F. Streatfield [Regent's Canal]. (T.c., May 3.)

Salter, J. Nightingale in Temple Gardens. (T.c., May 24.)

Young, L. Lesser Spotted Woodpecker at Fulham. (T.c., May 10.)

1874. Smith, H. Birds frequenting Botanic Gardens, Regent's Park.

(Op. cit., Nov. 28.)
Ward, E. Barn Owl in Kensington Gardens. (Op. cit., Feb. 28.)

I875 Adams, A. Leith. The Birds of London, 2 pts. (Op. cit., Jan. I6, 23.)

"Constant Reader." White Martin at Tottenham. (Op. cit., Oct. 23.)

Field, Basil. Strange Visitors in the City of London. (Op. cit.,

" Resident of Gray's Inn." The Rookery in Gray's Inn Gardens. (T.c., Apr. 24.)

Sherborn, F. Norfolk Plover at Hounslow. (Op. cit., Sept. 25.)

Sterland, W. J. Alpine Swift in Middlesex. (Op. cit., Mar. I3.)

"W. B." Whinchat near London. (T.c., May 8.)

Ward, E. Wildfowl near London. (Op. cit., Dec. II.)

"Y." Birds of London. (Op. cit., Jan. 30.) Idem by "A. L. A." (T.c., Jan. I 6, 23.)

1876. Eedle, T. Great Grey Shrike at Fulham. (Zool.)

Harting, J. E. London Rookeries. (Field, Apr. 22.)

Holden, A. Rare Birds in Middlesex. (Op. cit., Nov. 25.)

"Resident of Gray's Inn." The Birds of Gray's Inn Gardens. (Op. cit., Mar. II); The Rookery in Gray's Inn. (T.c., Feb. 26.)

Smith, H. Birds in the Botanic Gardens, Regent's Park. (T.c., Jan. 8, Feb. I9.)

1877. Atkins, G. Pochards breeding in Regent's Park. (Zool.)

Bailey, H. F. Herons near London [Peckham]. (T.c.)

Harting, J. E. Tree Sparrow nesting in Middlesex. (T.c.)

Mennell, H. T. Barn Owl in the City. (T.c.)

Moore, G. P. Black Tern at Hampton. (Field, May 12.)

1878. Biddle, C. H. Heron at Willesden. (Op. cit., Sept. 28.)

Blackett, A. S. Tree-creeper in Hyde Park. (Sci. Gossip.)

Elliot, E. Gulls and Terns on London Waters. (Field, July 27.)

Hamilton, E. Spotted Flycatcher nesting in Hyde Park. (Zool.)

Harting, H. Red-backed Shrike nesting near London. (T.c.)

Harting, J. E. Former Nesting of the Kite in London. (T.c.)

Hawkins, J. L. Kingfisher in London. (Sci. Gossip.) 
Legge, W. H. Birds in London. (T.c.)

Richardson, J. F. Woodpeckers in Kensington Gardens. [Lesser Spotted Woodpecker.] Idem by Ed. [Greater Spotted Woodpecker.] (Field, May II.)

Richardson, J. J. Woodcock in Hyde Park. (T.c., Jan. I2.)

Shipp, W. Water Rail in Victoria Park. (Op. cit., Dec. I4.)

Smith, F. F. H. Wheatears in Regent's Park. (Op. cit., Apr. I3.)

Smith, H. W. Kingfisher in Botanic Gardens, Regent's Park. (Op. cit., Sept. 28.)

"T." Redwings in London [Thames Embankment]. (T.c., Dec. 2I.)

I879. "A. J. C." Birds in London Suburbs. (Op. cit., Dec. I3.)

Hamilton, E. Birds in Hyde Park; Birds of London. (Zool.)

Harting, J. E. The Ferce Nature of the London Parks. (Pop. Sci. Review.) [Reprinted in his Essays on Sport and Natural History. 8vo. Lond. : 1883.] [275.]

Legge, W. H. Birds in London. (Sci. Gossip.)

Sterland, W. J. Alpine Swift at Finchley. (Zool.)

"T. G." Bittern in Middlesex [near Brent]. (Field, Feb. 8.)

Walters, R. Kingfishers in London. (Zool.)

1880. Hargitt, E. Occurrence of Hen Harrier in London. (Op. cit.)

Harting, J. E. Rooks in the Temple Gardens. (T.c.)

Morris, T. R. Hobbies in mid-winter [one shot at Edmonton]. (Field, Jan. 3.)

I88 I. "A. M. D." Nightingale in London [Chelsea]. (Op. cit., May 2r.)

Durham, E. B. Peregrine Falcon in London [Chancery Lane]. (Op. cit., Sept. ro.)

Harting, J. E. Ospreys in Middlesex. (T.c., Oct. 8.)

Macpherson, H. A. London Zoology. (Sci. Gossip.)

"P. M. M." Hawfinch at Teddington. (Field, Feb. 5.)

Rudd, C. J. W. Birds in London. (Sci. Gossip.)

I882. Brooke, A. Ring Ouzel at Highgate. (Field, Sept. 23.)

C- J. E. Wheatear on Primrose Hill. (OP. cit., Apr. 29) ; Cuckoo in London [Primrose Hill]. (T.c., May 20.)

Hadler, L. W. Shore Lark near London. (Zool.); Shore Lark near Stamford Hill. (Sci. Gossip.)

M_- M. O. Manx Shearwater near Staines. (Field, Sept. 2.)

Nitford, R. H. Dipper breeding in Middlesex. (Zool.)

I883. Bagot, E. Shore Lark at Staines. (Field, Feb. Io.)

Fisher, E. L. Kingfishers at the Serpentine. (T.c., Jan. 20.)

Harmer, H. F. S. Woodcock in London [Marylebone Road]. (Op. cit., Oct. 20.)

Lilford, Lord. Rustic Bunting near London. (Zool.)

Lucas, E. L. Woodcock at Kensington. (Field, Nov. I7.) Idem by J. J. R. (T.c., Nov. 24.)

Middleton, W. F. Woodcock in Kensington Gardens. (Op. cit., Apr. I4.) 
Wharton, T. Rookeries in London. (Zool.)

White, G. F. Kingfishers in London [Grosvenor Canal]. (Field, Dec. 22.)

I884. Beadnell, H. C. V. Sandpipers at the Serpentine. (Op. cit., May Io.)

Burness, A. J. Nightingales in London [Addison Road]. (T.c., May I7.)

Lawrie, A. A. Herons in London [Hyde Park]. (T.c., May 3.)

Marsland, W. E. Woodcock in London [Constitution Hill]. (Op. cit., Nov. I.)

Pigott, T. Digby. London Birds and London Insects. Post 8vo. Lond.: N.D. New edits., I892, I902. 8vo. [472.]

Tegetmeier, W. B. The Cuckoos of Charterhouse Square. (Field, Aug. 30.)

Whymper, C. Kingfisher in London. (Zool.)

I885. Godfrey, A. H. [Green] Woodpecker in London [Kensington Gardens]. (Field, Dec. I9.)

Harting, J. E. Woodcocks in London. (Op. cit., May 8.) Idem by A. Mannoch. (T.c., Feb. I4.)

Hesse, B. Wood Sandpiper on Hackney Marsh. (Zool.)

Lawrie, A. D. [and others]. Seagulls in London. 3 notes. (Field, Feb. I4.)

Lloyd, J. M. Cuckoo in Lincoln's Inn. (Op. cit., July 4.)

Macpherson, F. E. Birds in the London Parks. (T.c., Oct. IO.)

I886. Harting, J. E. On Former Nesting of Spoonbill in Middlesex [Fulham]; Black Redstart in London; Nightingale near London. (Zool.); Song-birds round London. (Field, May 8.) Macpherson, A. H. Redstarts in London [Kensington Gardens]. (Field, Apr. Io.)

Macpherson, H. A. Breeding of Lesser Redpoll [Highgate Cemetery]. (Zool.)

Selby, H. Woodcock in Mark Lane. (Field, Oct. 30.)

Tuck, W. H. Woodpeckers [Green] in London [Holland Park]. (Op. cit., Jan. 2) ; Brambling in London [Kensington Gardens]. (T.c., Apr. 24) ; Birds in London. (T.c., June I2); Idem by H. Smith. (T.c., June I2.)

Wilbey, J. E. Wild Duck breeding near London [Kingsbury]. (T.c., Apr. 24.)

1887. "Civis." Birds observed in London. (Op. cit., Oct. I.)

Dalsey, T. N. Bittern in Middlesex [near Uxbridge]. (Op. cit., Jan. 29.) Idem by A. Belt [at Perivale and Northolt]. (T.c., Feb. I2.)

Festing, H. Sandpiper at the Serpentine. (T.c., Apr. 30.)

Harting, J. E. Storm Petrel in London. (Zool.)

Ireland, D. C. Woodpeckers in Kensington Gardens. (Field, Nov. 26.) 
Lilford, Lord. Puffin in London. (Zool.)

Rice, T. H. Cormorant near London [Hendon]. (Field, Sept. I7.)

Vine, J. Lesser Redpoll in Middlesex. (Zool.)

Walker, J. E. Spotted Flycatcher nesting in London [Westbourne Park]. (Field, June 25.)

I888. Barker, V. [and others]. Partridge in Hyde Park. (Op. cit., Mar. I0, I7.)

Barrett-Hamilton, G. E. H. Tree Sparrow breeding at Harrow ; Golden Oriole at Harrow. (Zool.)

Brown, F. E. Stonechat in Hyde Park. (Field, Mar. 24.)

Harris, S. Nature near London Forty Years Ago [Tottenham to Ponders End]: (T.c., Mar. I7.)

Harting, J. E. Bird Life in Kensington Gardens. (T.c., Jan. I4) ; Cormorant in St. James's Park. (T.c., June 2.)

"Juvenis." Disappearance of Rookeries in London Parks. (T.c., Mar. 3I.)

L_- F. W. Hoopoe at Streatham. (T.c., May 5.)

P_, A. H. Golden Oriole at Harrow. (T.c., May 26.)

Smith, H. London Rookeries. "J. Y." Idem. (T.c., Apr. 28.)

I889. [Anon.] "E. T. B." Herons in London (Op. cit., Jan. 26); "S. R. G." Birds in London. (T.c., May II); "A. R." Little Grebes in St. James's Park. (T.c., June 29) ; "E. C." Golden Plover in London Park. (Op. cit., Oct. I9.)

Bond, F. Sand Grouse in Middlesex. (Zool.)

Collison-Morley, J. L. Osprey on the Thames [at Barnes]. (T.c.)

Cooper, J. Wild Geese near London. (Field, Jan. I2.)

Gossett, P. H. Terns on the Thames. (Op. cit., Aug. Io.) Idem by R. W. Hamilton. (T.c., Oct. 5.)

Hamilton, E. The Wild Birds of London. (Murray's Mag., May.)

Harting, J. E. The Birds of Hampstead Hill [and of Royal Botanic Society's Gardens]. [In J. L. Lobley's Hampstead Hill.] Post 4to. Lond.: I889. [275.]

Harting, J. E. Wood-pigeons in Leicester Square. (Field, May 18.)

Henderson, J. Wild Birds in London. (Op. cit., Dec. 2I.)

Hoare, F. Hawfinches at Hampstead. (Op. cit., May 4.)

Macpherson, H. A. Birds in London (T.c., Apr. I3); Notes on London Birds. (Zool.)

Rushen, W. N. Birds in London (Field, May x8, Oct. I2) ; Bird Life near London. (T.c., Dec. 7.)

Tristram-Valentine, J. T. Cormorant on Thames at Westminster. (Op. cit., Feb. 16) ; Wood-pigeons in London parks. (T.c., Apr. 20.)

Young, J. Birds in the London Parks. (Zool.) 
I890. [Anon.] "S. R. G." Bird Life in London. (T.c., Mar. 29); "S. H. W." Snipe in London (T.c., Apr. I9) ; "E. T." Summer Snipe in London Parks (T.c., Aug. 2) ; "W. W. K." Heron crossing the Green Park (T.c., Aug. 9).

Aplin, O. V. Distribution, etc., of Spotted Crake. [Middx.] (Zool.)

Bayley, F. C. Snipe in the Strand. (Field, Nov. 22.)

Blake, G. Hooded Crow in London. (T.c., Dec. I3.)

Elsmore, W. H. Redstart in London. (Op. cit., May I7.)

Harting, J. E. Osprey in Middlesex [at Barnes]. (Zool.)

Hyde, E. L. Birds in St. James's Park. (Field, June 7.)

Ireland, D. C. Wheatears and Wood-pigeons in London. (T.c., Apr. 5.)

Kennedy, E. T. A. Woodcock in London. (Op. cit., Oct. 25.)

Lee, B. B. Sea Gulls on the Thames. (Op. cit., Mar. 8.)

Macpherson, E. Birds in Kensington Gardens. (T.c., Apr. 26, May 3); Macpherson, A. H. Idem. (T.c., May 3, 24.) Sedge Warbler in Kensington Gardens. (T.c., May ro.)

Swann, H. Kirke. White Wagtail in Middlesex. (Nat. Gazette.)

Tate, D. F. The Hobby in Middlesex. (Field, May 3I.)

Tegetmeier, W. B. Woodcock in London. (Op. cit., Nov. I.)

Tristram-Valentine, J. T. Skylarks and Seagulls in London. (T.c., Dec. 6.)

Tuck, W. H. Wood-pigeons in Hyde Park. (T.c., Oct. 4.)

I89r. [Anon.] "C. R. T." Swifts in Pall Mall ( $O P$. cit., May 30) ; Forrester - and " J. T. C." Wood-pigeons in London (T.c., Aug. I) ; 2 notes. "E. P." Cormorant on the Thames. (T.c., Aug. 22) ; " J. E. C." Magpie in London Parks. (T.c., Dec. I2.)

Belt, A. Water Rail in Middlesex. (Zool.)

D'Aguilar, C. Woodcock in London. (Field, Oct. 3I.)

Eyre, W. H. Wheatear in Kensington Gardens. (Op. cit., May 23.)

Hantley, H. S. Bittern in Middlesex. (T.c., Jan. 3.)

Kidd, B. The Wild Birds of London. (Engl. Illus. Mag., Oct., pp. 38-45.)

Morris, B. Hawk in Temple Gardens. (Field, May I6.)

Sich, A. Hawfinch in Middlesex. (Zool.)

r89I-[92]. Barrett-Hamilton, G. E. H. Harrow Birds. 8vo. I892. [4I.]

r892. [Anon.] Magpies in St. James's Park. (Field, Nov. 5, I2.)

Aplin, O. V. Distribution of Cirl Bunting [Middlesex]. (Zool.)

Benson, C. W. Willow Warbler in London. (T.c.)

Cockerell, T. D. A. Natural History of Bedford Park. (Sci. Gossip, Aug.)

Dawes, W. E. Red-footed Falcon near London. (Nat. Jnl.)

Gardner, J. Moorhen and Willow Wren in London. (Field, Aug. 27.) 
$\mathrm{H}$ C. E. Woodcock in the City. (T.c., Oct. I5.)

Harrison, B. R. Birds of Highgate Woods. (Nat. Jnl.)

Harting, J. E. Manx Shearwater in Middlesex. (Field, Sept. Io.)

Lucas, R. C. Redbacked Shrike at Guy's Hospital. (Op. cit., May 2I.)

$\mathrm{T}$ July I6.)

Tuck, W. H. Bullfinches in Kensington Gardens. (Zool.) I892-[IgI8]. Macpherson, A. H. Notes on London Birds in I8gr [to I9I7], 27 pts. (Nature Notes \& Selborne Mag., I892I9I8.)

I893. [Anon.] Magpies in Regent's Park. (Field, Mar. II, I8); London and Surrey Rooks. (Op. cit., Dec. 23.)

B-_, W. R. Peewits in London. (Op. cit., Mar. I8); Wheatears near London. (T.c., Apr. I5.)

Gibbons, G. H. Wild Geese near London. (Op. cit., Nov. I8.)

Green, J. F. Guillemots in the Thames. (T.c., Nov. 25.)

Gurney, J. H. Former Abundance of Kite in London. (Zool.) Hyde, E. L. Rooks in Kensington Gardens. (Field, Mar. I8.)

Meinertzhagen, R. Black Stork in Middlesex. (Zool.; Field, Aug. 5.)

Pigott, T. D. Cormorants in St. James's Park. (Zool.)

St. Quintin, W. H. Mongrel Duck in London Parks. (Field, Apr. I5.)

Saunders, H. Redstart in Kensington Gardens. (T.c., Apr. 8.) Reid, C. Lapwings passing over London. (Zool.)

Swann, H. Kirke. The Birds of London. Fcap 8vo. Lond. : I893. [569.]

Trevor-Battye, A. Mongrel Ducks in the London Parks. (Zool.)

I894. Adams, J. Wood-pigeons in London. (Field, May 26.) Idem by A. S. Gaye. (T.c., Feb. 24); Idem by H. Read. (T.c.; May I2.)

Borrer, C. H. Woodcock in London. (Op. cit., Oct. 27.)

Bridger, E. H. Hoopoe in Middlesex. (T.c., Sept. I5.)

Brown, F. Seagulls in London Parks. (Op. cit., Mar. Io.)

Henderson, G. Turtle Dove in Kensington Gardens. (T.c., $\mathrm{N} \frac{\text { June 9.) }}{\text { Apr. 2I.) }}$ C. F. M. Crows in Kensington Gardens. (T.c., Swann, H. Kirke. Nesting of the Spotted Flycatcher. (Zool.); April in a London Park. (Nat. Jnl.)

I895. Addison, O. L. Heron passing over London. (Field, June 22.) Biddle, F. H. Quails near London. (T.c., June I.)

Brooke, A. Snow Bunting passing over London. (T.c., Feb. 2.)

Burton, J. Gulls in London. (Sci. Gossip, Apr.)

Harting, J. E. Seagulls in London. (Field, Mar. 9.)

Penrose, F. G. London Birds. (T.c., June 29.) 


\section{Selection of Books from WITHERBY \& CO.'S List.}

BRITISH BIRDS.

An Illustrated Monthly Magazine devoted to the Birds on the British List. Eclited by H. F. WitheRBY, M.B.E., F.Z.S., M.B.o.U. Assisted by Rev. F. C. R: Jourdain, M.A., M.B.o.U., and N. F. "TICEHURST, M.A., F.R.C,S., M.B.O.U." Illustrated with beantiful and useful photographs. Provides a current history of British Birds Annual Subscription, $18 \mathrm{~s}$, post free; Monthly, Is. Gd. net. Vols. I-XII. (unbound), r2s. each; bound, I5s. $6 \mathrm{~d}$. each nct

TROPICAL WILD LIFE IN BRITISH GUIANA.

Being Zoological Contributions to Science, from the Tropical Re. search Station of the New York Zoological Socicty, at Kalacoon Igr6. 'By. Williak Beebe, G. Inness Hartley and Paul G. Howes, with an Introduction by COLONEL THEODORE ROOSEvELT. Octavo. Cloth. 504 pages: 4 Coloured Plates, and 40 other Illustrations. I2s, $6 \mathrm{~d}$; net.

A MONOGRAPH OF THE PHEASANTS.

By William Bexbe. With Numerous Coloured Plates by A. THorburn, C: R. INIGHT, G: E. LODGE, L: A: FuerTes, H. GRoNvolD, and $H$. Jones. Together with Maps and Numerous Photographs by the Author, depicting the Pheasants of the World, their Haunts, their Changes of Plumage and their Nests and Eggs. Limited Edition of 600 Numbered Sets, only a portion of which are available for sale in the British Empire. Royal 4to. In Four Volumes, Volume I now ready. Prospectus and Specimen Plate on application. Per Vol, fI23ios, net:

A HAND-LIST OF BRITISH BIRDS.

By Ernst Hartert, F. C. R. Jourdain, N. F. Ticemurst, and H. F. Witherby. Demy 8vo, 7s. 6ol, net. Interleaved ros. net

THE BIRD-LOVER'S HOME-LIFE SERIES.

I. The Home-life of the Golden Eagle. 2. The Home-life of the Spoonbill, the Stork and some Herons, 3i The Home-life of the Osprey. 4. The Home-life of the Terns or Sea-Swallows. Each Volume contains 32 beautiful plates, artistically 'mounted; from PHOTOGRAPHS DIRECI FROM NATURE, with $40-60$ pages of letterpress. Crown 4 to. Cloth 7s. 6.1. net each.

GAME BIRDS AND IVATER-FOWL OF SOUTH AFRICA.

By the late MAJOR BOyd HORSBURGH, F.z.S., M.B.o.u. With 67 beautiful Coloured Plates: Hilf morocen. fA I 4s. net, or unbound parts.

\section{INDIAN PIGEONS AND DOVES.}

By E. C. Stuart Bakier, F.z.S., M.B.o.U. With 27 beautiful Coloured Plates. Imp. Svo. Half bound morocco. $\quad € 2$ ros. net. PHOTOGRAPHY FOR BIRD-LOVERS.

By Bentrey Bertham, F.z.s. I6 full-page Plates. A practical guide to the pursuit of bircl-photography in all its branches. Demy svo. Cloth. 5s. net.

JUNGLE PEACE.

By WILLIAM EEBE. Contains " records of extraordinary scientific interest, in language which has all the charm of an essay of Robert Louis Stevenson. The author tells of bircl, beast, plant and insect life of the British Guiana jungle. Crown 8vo., illustrated. 8s, net. 
Now Ready.

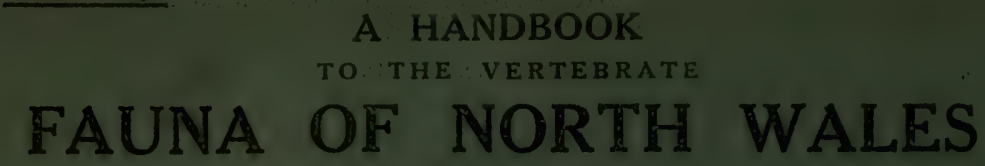

By H, E. FORREST.

This book not only brings up to date the information contained in the Author's "Vertebrate Fauna of North Wales," but also gives under each species a brief summary showing its status in the district. Just the information required ly the Naturalist resident in or visiting North Wales is thus provicled in a concise form.

Demy sio.

Clath.

6s, met.

Now Ready.

\section{METEOROLOGY FOR ALL.}

BEING SOME WEATHER PROBLEMS EXPLAINED

By DONALD W. HORNER, F.R.MET.SOc., etc. Author of "Observing and Forecasting the Weather." "Weather. Instruments and How to Use Them."

With Text and. Half-Tone Illustrations.

A compendium of information about the Weather as it daily affects the lives of everyone. The "dry" terseness of the text-book has been avoided, but the information given is comprehensive and reliable, and of a practical nature.

Crown svo.

Cloth:

IIlistrated.

6s. net.

\section{A PRACTICAL HANDBOOK OF BRITISH BIRDS.}

Edited by H. F. WITHERBY, M.B.E., M.B.O.U., F.Z.S., F.R.G.S. Contributors:-E.. HArtert, Ph.D., M.B.o.U., F.z.s. Annif. C. Jackson, н.м.в.о.U. Rev. F. C. R. Jourdär, M.A., M.в.о.U. C. Ödham, F.z.s., M.B.o.U. N. F. TICEHURST, M.A., F.R.C.s., M.B.O.U:

Specially arranged for quick reference. Distinguishing characters simplifying identification, full description of all plumages. Breeding habits (nest, eggs, sensm, incubation, etc.). Food. Distribution and Migration.

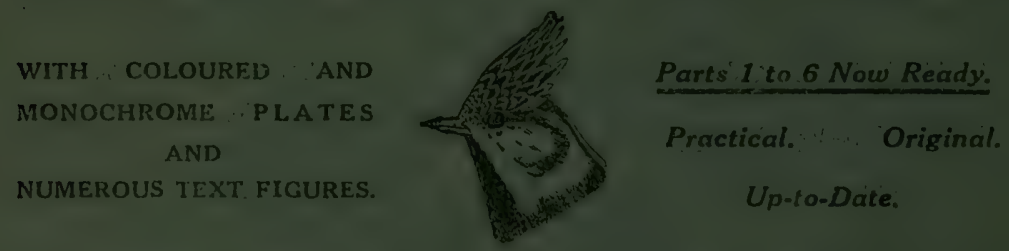

Demy 8vo. 4S. net per part. (Special Edition Printed on India Paper. Price:59. net per part.)

326, HIGH HOLBORN, LONDON, W C.I. 
Part 3.

$A$

\title{
GEOGRAPHICAL BIBLIOGRAPHY
}

OF

\section{BRITISH ORNITHOLOGY}

\author{
FROM TITE EARLIEST TTMES \\ $\therefore$ TO THE : END OF 1918 \\ ARRANGED UNDER COUNTIES
}

BEINA A RECORD OF PRINTED BOOKS, PUBLISHED ARTICLES, NOTES AND RECORDS RELATING TO LOCAL AVIFAUNA.

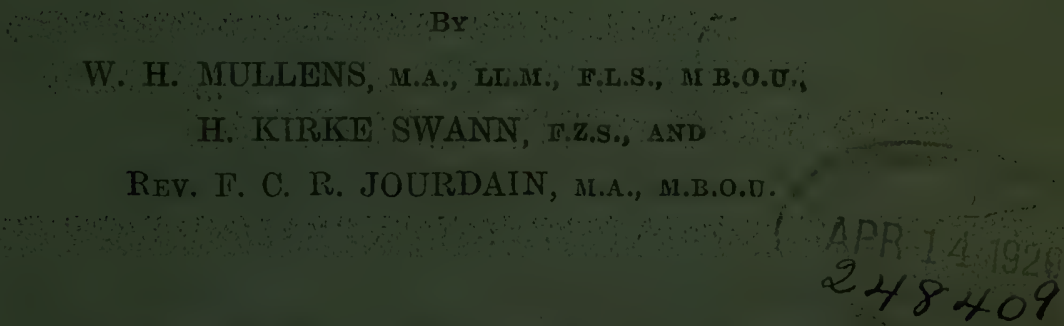

"Men that undertake only one district are much more likely to advance natural knowledge than those that grasp at more than they can possibly be acquainted with; evory kingdom, every province, should have its own monographer."

Gurbert Wurne-“The Natural History of Selborna." 7 thi Lotter to Barrington.

WIHERBY \& CO.

326, HIGH IIOLBORN, LONDON 

Pettitt, E. E. Alpine Swift in Middlesex [at Staines]. (T.c., June I5.)

Tristram-Valentine, J. T. London Birds and Beasts. Post 8vo. Lond. : r895. [589:]

Young, J. Rooks in London. (Zool.)

I896. Addison, O. L. Kingfishers in London [Regent's Canal]. (Field, Oct. Io.)

Booth, H. T. Bearded Titmouse in Middlesex. (Ornithologist.)

Kerr, G. W. Arrival of Summer Migrants at Staines; Notes from the Thames. (T.c.)

Read, R. H. Birds of Lower Brent Valley. (Rept. \& Tr. Ealing Nat. Sci. Soc.) Also issued separately, 8vo.

Sinclair, W. F. Terns on the Thames. (Field, Oct. Io.)

Swann, H. Kirke. Eggs of the Tree Sparrow. (Zool.); The Hawfinch in Middlesex. (Ornithologist.)

Teesdale, J. H. Great Black-backed Gull in London. (Zool.)

1897. [Anon.] Wild Geese in London. (OP. cit., ex Westminster Gazette.)

Anon.--"Alcedo." Kingfisher at Twickenham. (Field, Nov. I3.)

Swann, H. Kirke. Lesser Redpoll in St. James's Park [on June I2]. (Nat. Chron., Aug.)

Young, J. The Wood-pigeons in the London Parks; Rooks in the West End of London. (Zool.)

I898. [Anon.] The Birds of London. (Edinb. Review, CLXXXVII, pp. I79-202.)

Cundall, J. W. London: A Guide for the Visitor, etc. 2nd edit. Lond.: I898. And later edits. [I57.]

Harting, J. E. Ospreys near London. (Field, Dec. 3.)

Hudson, W. H. Birds in London. 8vo. Lond. : 1898. [303.] King, C. M. Birds which nest in London. (Zool.) Idem by A. H. Macpherson. (T.c.) Idem by W. E. de Winton. (T.c.) Whiting, J. E. Where Wild Birds Sing. Cr. 8vo. Lond.: I898. [647.]

1899. Brown, F. Landrail in London [Horseguards Parade]. (Field, July 8.)

Emson, C. H. Wheatear in Hyde Park. (Op. cit., May I3.) F——, H. J. Woodcock in London [Hyde Park]. (Op. cit., Nov. I8.)

Rushen, W. N. London Birds in I899. (Op. cit., May I9.)

Russell, H. Birds in Kensington Gardens, 1897-98. (Zool.)

I900. Chipperfield, H. Birds of N.E. London. (Nature Notes, XI.)

Martin, B. W. Cuckoo breeding in London District. (Zool.)

Whiting, J. E. Notes on the Birds of Hampstead. (Hampstead Annual.) Large 8vo. Lond.: I900. [647.]

Igor. Lodge, R. B. Ringed Plover nesting in Middlesex. (Zool.) 
Martin, B. W. Starling [cinnamon variety], House Sparrow [albino] and Kittiwake from Hampstead; Chough, Common Teal, Little Grebe and Common Bittern from Hendon. (Rept. Hampstead Sci. Soc.)

I902. Cornish, C. J. The Naturalist on the Thames. 8vo. Lond.: I902. [I 47.$]$

Martin, B. W. Willow Warbler and Kingfisher from Hampstead. (Rept. Hampstead Sci.Soc.)

Webster, A. D. Greenwich Park. 8vo. Greenwich, etc. : I902. [62I.]

Whiting, J. E. Blackheaded Gull, Kittiwake and Pied Flycatcher from Hampstead. (Rept. Hampstead Sci. Soc.)

I903. Cornish, C. J. The London Carrion Crow. (Country Life, June I3.)

Martin, B. W. Lesser Redpoll from Hampstead. (Rept. Hampstead Sci. Soc.)

Ray, M. S. Lesser Redpoll nesting in Middlesex. (Zool.)

I904. [Anon.-."R. G. B."] Woodcock in Regent's Park. (Field, Nov. 5.)

Atlee, H. G. Sandpiper in St. James's Park. (T.c., Sept. Io.)

Chubb, E. C. Occurrence of Bluethroat near London. (Zool.) Emson, C. H. Red-backed Shrike and Wheatears in Hyde Park. (Field, Sept. 3.)

Meade-Waldo, E. G. B. Green Woodpecker in St. James's Park. (T.c., July 2.)

Russell, H. Great Crested Grebe in Middlesex. (T.c., July 2.)

I905. [Anon.] The London Sea-Gulls. (Westminster Gazette, Jan. 2I.) Beavan, A. H. Birds I have known. 8vo. Lond. : 1905. [50.] Hyde, E. L. Tufted Ducks in Battersea Park. (Field, Feb. I8) ; Kingfisher in London [St. James's Park]. (Op. cit., Sept. 23.)

I906. [Anon.- “ H. S."] The Kites of Old London. (Op. cit., Mar. 24.) Blackett, J. S. W. Sparrowhawk in London. [Lord's Cricket Ground.] (Op. cit., Aug. 25.)

Hudson, W. H. Aves [in Wild Fauna and Flora of Roy. Bot. Gardens, Kew]. (Kew Bull. Add., Ser. V., pp. 2-Io.)

Rawlinson, W. G. Kestrel in London. (Field, May I2.)

Tegetmeier, W. B. Arrival of Nightjar [at Finchley]. (T.c., May I2.)

I906-08. Kerr, G. W. Birds of District of Staines, 2 pts. (Zool., I906, I908.)

I907. Bladen, W. W. Pallas's Sand Grouse in Middlesex. (Brit. Birds, I.)

Cecil, Evelyn. London Parks and Gardens. Roy. 8vo. Lond. : I907. [Contains information about the Birds.]

Daybell, G. Sparrowhawk in Hyde Park. (Ficld, May 25.) 
Hubbard, Rose. Ornamental Waterfowl. 8vo. 2nd edit. Lond. : I907. [Refs. to St. James's and Battersea Parks.]

Warre, E. L., Borrer, A. H. and Russell, F. Kestrels in London [St. James's Park and near]. (Field, Jan. I2, Mar. 9, I6.)

Webb, W. M. The Brent Valley Bird Sanctuary. (Selborne Soc., Brent Valley $\mathrm{Br}$.) 8vo. I907. Later edits. (enlarged) I9Io, IgII. [620-2I.]

I908. Clark, J. A. Ortolan Bunting at Plaistow. (Zool.)

Hall, K. M. Nature Rambles in London. Sm. 8vo. Lond. : I908. [264.]

Meyrick, H. Lesser Redpoll nesting in Middlesex. (Zool.; Brit. Birds, I.)

Pycraft, W. P. Chiffchaff in London. (Brit. Birds, I.)

Watt, H. Boyd. Changes in the London Avifauna. (Nature Notes.)

I909. [Anon.] Wild Birds of London. (Times, Mar. 27.)

Dixon, C. The Bird Life of London. 8vo. Lond. : Igog.

London County Council. Wild Birds Protection (Administrative County of London) Order, I909. 3 pp.

Maxwell, Sir H. Memories of the Months. 8vo. Lond. : I909. [393.] [partim.]

Oldham, C. Smew in London. (Zool.)

Todd, W. A. Bird Notes from a London Suburb for Igo8 [Putney]. (Selborne Mag., XX.)

Vos, G. H. Birds and Their Nests and Eggs found in and near Great Towns. 8vo. Lond.: N. D. [605.]

I909-Io. Meyrick, H. The Lesser Redpoll at Hampstead, 2 notes. (Zool., I909-IO.)

Watt, H. Boyd. Bibliography of London Birds, and Supplement. (Op. cit., I909-IO.)

Igro. Goodchild, H. Sparrowhawk and Tawny Owl from Hampstead. (Rept. Hampstead Sci. Soc.)

Green, J. F. Kestrel nesting [at Lee]. (Brit. Birds, IV.)

Johnson, W. Battersea Park as a Centre for Nature Study. Cr. 8vo. Lond. : I9ro. [3I9.]

Power, F. D. Ornitholog. Notes from a S. London Suburb. 8vo. Lond. : I9Io. [479.]

Todd, W. A. Ornitholog. Observations in N.E. Surrey, Igog. (Zool.) [partim.]

I9II. Bentham, H. Jays in London [between New Cross and Bermondsey]. (Brit. Birds, V.)

Dewar, G. A. B. An Open Air Diary. (Field, Dec. 30.)

Webster, A. D. The Regent's Park and Primrose Hill. 8vo. Lond. : I9II. [62I.] 
Whiting, J. E. A Collection of Hampstead Birds. (Reader's Guide and Student's Review, IV., Hampstead Publ. Libr.) [647]; The Feathered Denizens of Hampstead [abstract]. (Rept. Hampstead Sci. Soc.)

I9I2. [Anon.] Birds in London. (Sat. Reviere, Feb. 3, II, 24, Mar. 2.)

Bosworth, G. F. West London. (Cambridge County Geographies.) 8vo. Lond.: IgI2. [Birds at pp. 69-72.]

Crook, W. M. The Corvida in London. (Westm. Gazette, Apr. 20.)

Dewey, W. F. Great Crested Grebe breeding in Co. of London. (Zool.)

Glegg, W. E. Great Crested Grebe breeding near London. [Stoke Newington.] (Brit. Birds, VI.) "Wreck" of Little Auk. (T.C.)

Lodge, R. B. Little Owl breeding in Middlesex. (Brit. Birds, VI.)

Nevin, J. L. Bird Life in London. (Northern Whig, Nov. 30.)

Watt, H. Boyd. London Birds in IgII. (Selborne Mag.)

Whiting, J. E. Bird Life of Hampstead. [In T. J. Barrett's Annals of Hampstead, III.] 4to. Hampstead: I9I2. [647.]

I913. Dewey, W. F. Great Crested Grebe nesting in London. (Field, May 24); Great Crested Grebe at Stoke Newington. (Op. cit., Aug. 2.)

Eardley-Beecham, D. Brambling in London. (Brit. Birds, VII.) Goodchild, H. [Birds in] Hampstead Heath : Its Geology and Natural History. 8vo. Lond. : [I9I3.]

Harding, J. Rudge. Notes on London Birds. (Selborne Mag., pp. II6-I7.)

Lansdowne, Marquis of. Sandpipers in London. (Field, Aug. I6.)

Macpherson, A. Holte. Great Crested Grebe in Hyde Park. (Op. cit., Jan. 4.)

Swann, H. Kirke. Notes from Hadley Wood [Middlesex]. (Zool.)

Watt, H. B. Rednecked Grebe at Hampstead Heath. (Field, Mar. I.)

Yorke, D. Notes on London Birds. (Selborne Mag., p. I36.)

1914. Borrer, C. Glaucous Gull in London. (Brit. Birds, VIII.)

Dewey, W. F. Great Crested Grebes in London. (Ficld, Aug. 8.)

Eardley-Beecham, D. Tree Creeper in London. (Brit. Birds, VIII.)

Harding, J. Rudge. London Birds in 1912. (Selborme Mag., pp. 90-9I.)

Mackintosh, J. S. Waxwing near London. (Field, Jan. I7.)

Noble, E. The Kestrel in London. (Field, Sept. 5.)

Russell, H. Sedge Warblers in Kensington Gardens. (Field, May 9.)

Swann, H. Kirke. Redbreast's Nest in a tree at Highgate; London Notes at Highgate. (Zool.) 
Watt, H. B., and Yorke, D. G. London Birds in IgI3. (Selborne Mag., p. 77.)

I9I5. Cuming, E. D. Heron in London. (Field, Dec. Ir.)

Dewey, W. F. Carrion Crow nesting in London. (Op. cit., Apr. I7.)

Harding, J. Rudge. Notes on London birds. (Selborne Mag., pp. 40-43.)

Macpherson, A. Holte. Gulls in London. (T.c., p. II4.)

Newmarch, C. F. Ringnecked Parrakeets at large in London. (Zool.)

Read, R. H. The Little Owl in Middlesex. (Selborne Mag., pp. I23-4.)

Springett, H. K. Starlings in the Temple. (T.c., p. I4.)

Watt, H. B. Starlings roosting in London. (T.c., p. 9.)

White, R. F. H. Woodcock in Hyde Park. (Field, Mar. 27.)

I9r6. Astley, H. D. Birds in the London Parks. (Avicult. Mag., pp. 45-7.)

Baldwin, E. T. A Cormorant in London. (Field, Jan. I.)

Cuming, E. D. Arctic Skua in London. (T.c., May 27.) Brown Owl in London. (Op. cit., Oct. I4.)

Harding, J. Rudge. London Birds in I9I5. (Selborne Mag., pp. I7-I9.)

Hercy, F. Sparrowhawk in London. (Field, Feb. I2.) Idem, by E. J. Soares. (T.c., Feb. 26.)

Russell, H. Heron in Kensington Gardens. (Op. cit., Dec. 2.)

I9I7. Giles, A. B. Woodcock in Hyde Park. (Op. cit., Feb. Io.)

Harding, J. Rudge. Redwing singing in London. (T.c., Apr. I4.)

Notes on London birds in IgI6. (Selborne Mag., pp. I8-20.)

Sitzler, G. C. Grebe on the Thames. (Field, Mar. I7.) Idem, by C. Hope. (T.c., Mar. 24.)

Strang-Watkins, W. The Brambling in London. (T.c., Feb. Io.)

I9I8. Craven-Sykes, J. Young Cuckoo in Blackbird's nest at Norwood. Idem, by R. E. Vaughan. (Brit. Birds, XII.)

Cox, H. The Little Owl in Middlesex. (Field, Nov. I6.)

Pearce, J. London Ravens. (T.c., Sept. 2I.)

Silver, A. Summer birds at Roehampton. (Avicult. Mag., pp. 4-5.)

\section{MONMOUTHSHIRE.}

I834-5. Conway, C. Sketches of Nat. Hist. of My Neighbourhood, Nos. 2 \& 3. (Fragments of Ornithology.) (Loudon's Mag. N. H., VII. \& VIII., I $834-5$.)

1846. Bree, C. R. Nightingale in Monmouth. (Zool.)

1853. Knapp, W. Woodcock breeding in England. (Op. cit.) 
1855. Falconer, R. W. Heronries [in Monmouthshire]. (Nat.[Morris's], V.)

I859. "Ty Mawr." Birds of passage [Monmouth]. (Field, Sept. I0.) 1866. Read, J., junr. Grey Phalarope at Newport. (Field, Nov. Io.) I867. Bree, C. R. Nightingale in Monmouth. Idem, by W. Downing Evans. Idem by E. W. Hill. (Field, Apr. 20, 27.)

"Coo-eh." Arrival of Nightingale. (T.c., Apr. I3.)

I87I. Bree, C. R. Nightingale in Wales. (Op. cit., June Io.) I872-3. Harting, J. E. British Heronries. (Zool.) [partim.] 274. I894. Matthews, B. St. J. A. Swimming Powers of Water Ouzel. (Op. cit.)

I895. Williams, A. H. Nesting of Woodcock in Monmouth. (Field, June 15. .)

I90I. Wilson-Way, W. H. Quail in Monmouth. (Op. cit., Oct. 5.)

I903. Rickards, R. W. Pied Flycatcher in Monmouth. (Op. cit., June 6.)

I907. Bannerman, R. M. Tufted Duck on the Wye. (Op.cit., Feb. I6.)

I9I0. Ecutt, A. W. Strange Nest of Blackbird. (Zool.)

IgII. Ticehurst, N. F., and Jourdain, F. C. R. On Distribution of Nightingale during Breeding Season in Gt. Britain. (Brit. Birds, V.) [partim.] [584.]

I9I2. Banks, R. C. Actions of Kingfisher on Water. (Op. cit., V.)

I9I5. Banks, R. C. Black-throated Diver in Mon. (Brit. Birds, VIII.) Black Terns in Mon. (Op. cit., IX.)

I9I6. Banks, R. C. Unusual site for Kingfisher's nest [Newport]; Goosander in Mon. (Op. cit., X.)

Bentham, H. Probable nesting of Lesser Redpoll in Mon. (T.c.)

Proger, T. W., and Paterson (D. R.) Ornithol. notes for IgI6. [Black-tailed Godwit at Pergam Moors]. (Trans. Cardiff Nat. Soc., XLIX., p. 67.)

I917. Banks, R. C. Goosander in Mon. (Brit. Bds, X.)

19I8. Banks, R. C. Little Owl in Mon. (Brit. Birds, XII.)

\section{NORFOLK.}

[1567.] List of Fenbirds "out of Marshland in Norfolk." (Archceologia, vol. XXXVI.)

I76r. Stillingfleet, B. Calendar of Flora, made at Stratton in Norfolk, Anno I755. 8vo. I76r. [565.] 
I789. Marsham, R. Indications of Spring as observed at Stratton. (Phil. Trans.)

I8I2. Richards, W. Hist. of King's Lynn. [List of Birds, Vol. I., p. I94].

I8I5[-22]. Hunt, John. British Ornithology. 3 vols. 8vo. Norwich: I8I5[-22]. [305.] [partim.]

1826. Sheppard, R., and Whitear, W. Catalogue of Norfolk and Suffolk Birds. (Tr. Limn. Soc.) [Republished in German in I829.]

I826-8. Yarrell, W. Occurrence of some rare Brit. Birds, etc. 4 pts. [partim, Norfolk occurrences.] (Zool. Jnl., II., pp. 25-26 ; III., pp. 85-6, 497, 604.)

1828. “T. W. S." Nat. Hist. in Engl. Co.'s: Rare birds in neighbourhood of Yarmouth. (Loudon's Mag. N. H., I, p. 290.)

I829. Hunt, John. List of Birds. [In Stacy's General History of Co. of Norfollk.] 2 vols. Post 8vo. Norwich, etc: I829. [306.]

1830. Hoy, J. D. Nat. Hist. in Engl. Co.'s; Suffolk; Rare birds killed during autumn and winter of $1829-30$ in Suffolk, Norfolk, etc. (Loudon's Mag. N. H., III.)

I83I. Yarrell, W. Additions to Catalogue of British birds [important Norf. records]. (Zool. Jnl., IV.)

1833. [Gurney, D.] Extracts from Household and Privy Purse Accounts of the Lestranges of Hunstanton, I5I9-78. (Trans. R. Soc. Antiquaries.)

Hoy, J. D. Short-eared Owl breeding in Norf. (Loudon's Mag. N. $H_{\text {., }}$ VI.)

Stock, D. Whitebellied Swift shot in Norf. (T.c., p. 286.)

I834. Paget, C. J., and J. Natural History of Yarmouth. 8vo. Yarmouth: I834. [See also I863.] [455.]

Salmon, J. D. Of the Great Bustard [nesting on Great Massingham Heath]. (Loudon's Mag. N. H., VII.)

I835-6. Browne, Sir Thos. Natural History of the County of Norfolk. [In Wilkins' edition of his Works.] 4 vols. 8vo. Lond. : 1835-6. Idem, in Bohn's Library, 3 vols. Post 8vo. I85I-2. [See also under I902.] [I00.]

1836. (Bury and Suffolk Herald.) Sea Eagle [at Hunstanton Hall]. (Loudon's Mag. N. H., IX.)

Salmon, J. D. Arrivals of Migratory Birds in Neighbourhood of Thetford, etc. I834-6. (T.c.)

I837. Hancock, A. Regulus ignicapillus [killed off Norfolk coast]. (Mag. Zool. and Bot., I., p. 49I.)

[Editorial.] Tringa pectoralis Bon. near Yarmouth. (T.c.) Hoy, J. D. Tringas new to Brit. Isles and rare birds killed in Suffolk, Norfolk, etc. (Charlesw. Mag. N.H.) 
Salmon, J. D. New Tringa ( $T$. platyrhyncha] shot near Yarmouth ; Migration of Swifts. (T.c.)

I838. [Editorial.] Otis tarda [shot near Dereham]. (Ann. N. H., I., p. 334.)

I839. Dugmore, H. Capture of Eagle at Swaffham. (Charlesw. Mag. N. H.)

(Norwich Mercury.) Peregrine Falcon shot at Norwich. (Nat. [Wood's], IV.)

Paine, T., junr. Rare Birds in Vicinity of Yarmouth. (Ann. N. $H$.)

I840. Gurney, J. H. Redbreasted Snipe near Yarmouth. (Op. cit.)

I842. Gurney, J. H. Norfolk Birds, 2 parts. (Op. cit.)

1843. Dowell, E. W. Cassian [Purple] Heron in Norf. (Zool.)

Fisher, W. R. Arrival and Departure of Summer Birds of Passage at Yarmouth in I843; Avocet near Yarmouth; Buff-breasted Sandpiper at Yarmouth; Rare Birds near Gt. Yarmouth. (T.c.)

Gurney, J. H. Red-winged Ictenus near Norwich. (T.c.)

1844. Burlingham, D. C. Occurrence of Grey Shrike and Spoonbill at Lynn. (Zool., p. 444.)

Denny, H. Ortyx virginiana in Norf. (Amn. Mag. N. H.)

Fisher, W. R. Arrival and Departure of Winter Birds at Yarmouth in I844; Richardson's Skua at Gt. Yarmouth; Iceland Gull at Yarmouth ; Capture of two Fulmar Petrels off Gt. Yarmouth; Migration of Larks; Breeding of Birds at Yarmouth in I844. (Zool.)

Gurney, J. H. Red-crested Whistling Duck in Norf. (T.c.)

Newton, A. Sea Eagle at Elden, near Thetford. (T.c.)

I845. Frere, H. T. Snow Bunting near Aylsham. (Op. cit.)

Lubbock, Rev. R. Observations on the Fauna of Norfolk. 8vo. Norwich : I845. And later edits. [363.]

I846. Frere, H. T. Occurrence of Anthus arboreus in Feb. [at Aylsham]; Norfolk Swan-fatting. (Zool.)

Gurney, J. H. and Fisher, W. R. Account of Birds found in Norf., 2 pts. (T.c.) Also repr. separately 8vo. Lond. : I846. [209.]; Red-necked Phalarope in Norfolk. (Zool.)

Hunter, C. B. Little Auk near Downham; Lesser Redpoll in Norf. ; Nesting of Montagu's Harrier; White-winged Crossbill near Thetford. (T.c.)

Newton, A. Arrival of Migratory Birds in Norf.; Redpolls staying at Thetford throughout the Summer. (T.c.)

I847. Bird, W. F. W. Capture of the Little Crake in Norf.; Pochard breeding in Norfolk. (Zool.)

Coulcher, C. Occurrence of Osprey and Grasshopper Warbler's Nest near Downham Market. (T.C.)

Fitch, S. E. Little Auk near Cromer. (T.c.) 
Hunter, C. B. Little Auk near Downham; Grey Phalarope at Wretham ; Great Grey Shrike at Downham. (T.c.)

Tomes, R. F. Bimaculated Duck at Yarmouth. (T.c.)

I847-9. Gurney, J. H. and Fisher, W. R. Ornithological and other Observations in Norf., Dec. I846 to Oct. I848. I6 pts. (OP. cit., I847-9.) [209.]

Newton, A. Rare Birds near Thetford, 3 papers. (Op. cit., I847-9.) [445.]

1848. Frere. H. T. Dates of Arrival of Migratory Birds at Aylsham in I847. (Op. cit.)

Newton, A. Woodcocks breeding in Norf. ; Buffon's Skua near Thetford. (T.c.)

I849. Bird, W. F. W. Common Bittern in Norf. (Zool.)

Burroughes, T. H. Tufted Duck and Rough-legged Buzzard in Norf. (T.c.)

Burton, W. D. Caspian Tern near Gt. Yarmouth. (T.c.)

Frere, H. T. Little Bittern at S. Walsham. (T.c.)

Gurney, J. H. Supposed Occurrence of Pectoral Sandpiper near Yarmouth; Fork-tailed Petrel, Eared Grebe and Grey-legged Goose in Norf., 3 notes; Avocet near Lynn; Spoonbill near Yarmouth; Gull-billed Tern near Yarmouth, 2 notes. (T.c.)

Hansell, P. E. Jack Snipe breeding [?] in Norf. (T.c.)

Lukis, J. W. Great Grey Shrike at Heacham. (T.c.)

Smith, Rev. Jas. Little Bittern, Little Gull and Caspian Tern at Yarmouth. (T.c.)

I850. Gurney, J. H. Cirl Bunting, Black Redstart, Crane, Snowy Owl, Glaucous Gull and Fork-tailed Petrel in Norf., 5 notes; Gullbilled Tern, Caspian Tern and Shore Lark near Yarmouth, 2 notes. (Zool.)

Harper, T. O. Rare Birds near Norwich. (T.c.)

Newman, E. Swan Goose in Norf. (T.c.)

Rising, R. Ferruginous Duck near Gt. Yarmouth. (T.c.)

Smith, J. Gull-billed Tern in Norf. (T.c.)

I85I. Buxton, T. F. Gyrfalcon in Norf. (Op. cit.)

Green, J. Egyptian Goose and Eared Grebe at Yarmouth, 2 notes. (T.c.)

Gurney, J. H. Osprey in Norf.; Caspian Tern at Yarmouth. (T.c.)

Hansell, P. E. Great Snipe breeding [?] in Norf. (T.c.)

Harper, J. O. Osprey and Little Bittern in Norf., 2 notes; Avocet at Yarmouth. (T.c.)

Irby, L. H. Wood Sandpiper at Yarmouth. (T.c.)

King, E. L. Greater Shearwater at Lynn. (T.c.)

McIntosh, J. Heronries in England, etc. [partim.] (Nat. [Morris's], I.)

Newton, A. Parrot Crossbill in Norf. (Zool.)

Smith, J. Grey-headed Wagtail at Gt. Yarmouth. (T.c.) 
Southwell, T. Cinereous Shearwater and Tree Sparrow near Lynn; Waxen Chatterer [near Lynn]. (Nat. [Morris's], I.) Strangewayes, R. Great Crested Grebe in Norf. (Zool.)

1852. Buxton, T. F., junr., Great Ash-coloured Shrike in Norf. (OP. cit.)

Harper, J. O. Ornitholog. notes [Caspian Tern, etc., in Norf.] ; Iceland and Glaucous Gulls at Yarmouth, etc., 3 notes. (Nat. [Morris's], II.)

Irby, L. H. Notes on Arrival and Departure of Migratory Birds in Norf.; Avocet, Wood Sandpiper and White Stork at Yarmouth, 3 notes; Little Crake in Norfolk. (Zool.)

Newman, E. Eared Grebe at Yarmouth. (T.c.)

Newton, A. Account of a Petrel killed at Southacre. (T.c.)

Nunn, E. C. Bohemian Chatterer [near Diss]. (Nat. [Morris's], II.)

Southwell, T. The Great Bustard; Rare Birds near Lynn; [Heronry at Wolverton Wood, near Lynn]. (T.c.)

I853. Barlow, W. Peregrine Falcon, etc, in Norf. (Op. cit., III.) Cooke, M. C. Waxwing [and Ring Ouzels in Norfolk]. (T.c.) Frederick, G. White-winged Black Tern near Yarmouth. (Zool.) Gurney, J. H. Pectoral Sandpiper and Nutcracker near Yarmouth; Knot Sandpiper on Norf. Coast in Summer Plumage. (T.c.)

Harper, J. O. Rose-coloured Pastor in Norfolk. (Nat. [Morris's], III.)

Irby, L. H. Stone Curlew near Thetford. (Zool.)

King, E. L. Green Sandpiper near Lynn. (T.c.)

Newton, A. Supposed Abundance of Woodcocks in Norf. (T.c.) Southwell, T. Montagu's Harrier [nesting near Lynn]. (Nat. [Morris's], III.)

Stevenson, H. Late Appearance of the Common Scoter in Norf. (Zool.)

Stride, E. E. The Hobby [at Dickleborough]. (Nat. [Morris's], III.)

I854. Harper, J. O. Nutcracker at Yarmouth, ctc., 3 notes. (OP. cit, IV.)

King, E. L. Richardson's Skua at Lynn. (Zool.)

Southwell, T. Rollesby Gullery; Nutcracker, etc., in Norfolk, 7 notes. (Nat. [Morris's], IV.)

I855. Bonney, T. G. [Bitterns at Dersingham Hall.] (Op. cit V.)

Gurney, J. H. Rare Birds in Norf. (Zool.)

Southwell, T. A Spring Ramble; Ornithological Occurrences, in Norf. (Nat. [Morris's], V.)

Stevenson, H. Winter Visitors to Norf. Coast; Wild Fowl on Norf. Coast; Late Appearance of Common Scoter in Norf.; Lapland Bunting in Norf. (Zool.) 
Twinn, G. R. Nesting of Water-Ouzel in Norf.; [errore?] (Nat. [Morris's], V.)

1856. Cooke, M. C. Peregrine Falcon near Norwich. (Zool.) Idem [and Goshawk at Matishead]. (Nat. [Morris's], VI.)

Gurney, J. H. Rare Birds Procured in Norf.; Remarkable Destruction of Sea Birds on Norf. Coast. (Zool.)

Stevenson, $H$. Occurrence of Rose-coloured Pastor, Merlin and Peregrine; Note on Iceland Gull and Shore Lark; Golden Oriole near Norwich; Note on Savi's Warbler; Waxwing, Sea Eagle and Broadbilled Sandpiper in Norf., 3 notes. (T.c.)

Southwall, T. Golden Oriole and Broadbilled Sandpiper in Norf. (Nat. [Morris's], VI.)

I857. Gurney, J. H. Honey Buzzards at Northrepps and Lowestoft, 2 notes. (Zool.)

Salvin, O. Note on Sabine's Snipe killed in Norf. (T.c.)

Savill, S. P., junr. Pomarine Skua in Norf. (Nat. [Morris's], VII.)

Stevenson, H. Little Auk on Norf. Coast in Summer. (Zool.)

I857-64. Stevenson, H. Occurrences in Norf., 3 I notes. (Op. cit., I857-64.)

1858. Baker, W. and E. Osprey [at Castle Rising]. (Field, May 8.)

Dix, T. Buzzard at West Harling. (Zool.)

Southwell, T. Falco peregrinus and Picus major near Fakenham. (Nat. [Morris's], VIII.).

Stevenson, H. The Reed and Grasshopper Warblers in Norf., 2 notes. (Field, July 3, Io.)

I859. Buxton, T. F. Woodcock's Nest in Norf. (Zool.)

"B." Osprey [in Norfolk]. (Field, Nov. I2.)

Currie, F. Sand Grouse in Norf. (Zool.)

E_- H. Hied Flycatcher [at Hunstanton]. (Field, May 2I.)

Stevenson, H. Ornitholog. Notes from Norwich. (Zool.); The Pied Flycatcher [in Norf.]. (Field, May 28.)

I86o. "D." The Waxen Chatterer [at Attleborough]. (Field, Dec. 8.)

Playford, J. Rare Birds near Yarmouth. (T.c., Dec. I5.)

Stevenson, H. Rare birds near Yarmouth. (Field, Dec. 22.)

Wilson, W. Rough-legged Buzzard at King's Lynn. (Zool.)

I860-6r. Stevenson, H. Ornitholog. Notes from Norf., 2 pts. (Zool., I860-6I.)

I861. [Editorial.] Eagles in Norf. (Field, April 20.)

Playford, J. Rare birds shot near Yarmouth. (T.c., Jan. 5.)

Saville, S. P. Red-necked Phalarope in Norf. (Zool.)

I862. [Editorial.] Yellow-shanked Sandpiper near Gt. Yarmouth. (Field, April I2.)

"Botaurus Stellaris." Purple Heron in Norf. (Op. cit., July I2.)

Stevenson, H. Otocorys alpestris in Norf. (Ibis, pp. I89, 303.)

Wilson, W. Common Buzzard at Rifley, near Lynn ; Little Gull and Little Auk near Lynn. (Zool.) 
I863. Baker, J. Marsh and Montagu's Harriers in Norf. (Op. cit.)

"Bittern." Spoonbill in Norf. (Field, June 20.)

Crichton, A. W. Pallas's Sand Grouse in Norf. (Zool.)

Dresser, H. E. White Redwing in Norf. (T.c.)

"F. A. M." Spotted Gallinule wintering and breeding. (Field, Dec. I2.)

Harting, J. E. Curlew Sandpiper near Yarmouth. (Zool.)

Lowne, B. T. Popular Natural History of Great Yarmouth. 8vo. Gt. Yarmouth : 1863. [2nd edn. of Paget's work, I834.] [363.]

Stevenson, H. Leach's Petrel at Salthouse. (Ibis, p. 235.)

[Various writers.] Sand Grouse [in Norf.]. (Field, June I3, 20, 27, July. 4.)

I864. Gunn, T. E. White-tailed Eagle near Wymondham; Spotted Crake in Norf. ; Abundance of Bittern in Norf. ; Occurrences in Norf., Io notes. (Zool.) Notes on Ornithology, Norfolk, 5 pts. (Nat., I.)

"M. D." Goosander and Bittern near Lynn. (Ficld, Jan. I6.) Saville, S. P. Ornithological Notes from Norfolk. (Nat., I.)

Stevenson, H. List of Birds of Norfolk. In White's Hist. and Directory of Norfolk. 8vo. Sheffield: I864. (Also reprinted separately 8 vo. and in Zool., I864. Addit. by Thos. Southwell, I890.) [56r.]

Stevenson, H. Notes on Ornithology of Norf.; Has the Great Woodpecker occurred in Norf.?; Norf. Ornithology. (Zool.)

I865. Cooke, M. G. A Tit in moustaches [Bearded Tit]. (Science Gossip.)

Gunn, T. E. Arrival of Summer Migrants near Norwich; Norf. occurrences, II notes. (Zool.) Notes on Ornithology of Norfolk, 4 pts. (Nat., I., II.)

King, E. L. Arrival of Summer Birds at Lynn. (Zool.)

O[verend], J. G. Stork, Spoonbill and Hoopoe in Norf. (Field, June 3.)

Pryor, M. R. Solitary Snipe near Thetford. (Zool.)

Rocke, J. Squacco Heron near Yarmouth. (T.c.)

I865-85. Stevenson, H. Ornitholog. Notes from Norf. [about Ioo contributions]. (Op. cit., I865-85.) [J. H. Gurney, junr., collaborated for $1872-73$.$] [56r.]$

1866. Gunn, T. E. Invasion of the Waxwing in I866. (Nat.) Notes on Ornithology of Norfolk, 7 pts. (OP. cit., II., III.)

Lowe, J. Temminck's Stint at King's Lynn. (Zool.)

Nall, J. G. Great Yarmouth and Lowestoft. Post 8vo. Lond. : I866. And subsequent edits. [429.]

Overend, J. Eggs of Baillon's Crake at Great Yarmouth. (Zool.) ; Little Gull at Yarmouth. (Field, Nov. 3.) Eared Grebe on Breydon Water. (Field, Apr. 2I.)

Sharp, W. B. Rare Eggs [in Norf.]. (Nat., II., p. 366.) 
I866-9o. Stevenson, H. and Southwell, Thos. Birds of Norfolk. 3 vols. 8vo. Lond., etc. : I866-70-9o. [56r.]

I867. [Anon.] Bittern on Barton Broad. (Science Gossip.)

Buxton, T. F. Storm Petrel at Cromer. (Zool.)

Clark, W. Ring Ouzel [nesting near King's Lynn]. (Field, Oct. 26.)

Clark-Kennedy, A. Snow Buntings at Hunstanton. (Zool.)

Griffith, J. R. Blue-throated Warbler off Norf. Coast. (T.c.)

Gunn, T. E. Storm Petrel, Red-necked and Sclavonian Grebes, Red-throated Diver, Bohemian Waxwing [and various other birds] in Norf. ; Buffon's Skua on Norf. Coast. (T.c.)

Gunn, T. E. Waxwings in Suffolk and Norf. (Nat.)

Hamond, A. Cicona nigra in Norf. (Ibis.)

Moor, E. C. Storm Petrel at Aldeburgh. (Zool.)

Overend, J. G. Bohemian Waxwing, Shore Lark, Richard's Pipit, Fork-tailed Petrel, Montagu's Harrier near Gt. Yarmouth. (T.c.) ; Rare Birds near Gt. Yarmouth, etc., 4 notes. (Field, Jan. 26, June I, July I3, Oct. 26.)

Reeks, Henry. Rare Birds [in Norf.]. (Nat. III., p. 4.) Idem. [Editorial.] (T.c.)

Rising, T. A. Great Bustard at Horsey. (Op. cit., Jan. r9.)

Sharpe, R. B. Rare Eggs [in Norf.]. (Nat., III., p. 22.) Idem. by H. Stevenson. (T.c., pp. 22, 45.)

1867-68. Gunn, T. E. Ornithological Notes. (Naturalists' Circular, I867-68.) [257.]

I868. Gunn, T. E. Osprey, Glossy Ibis, Red-necked Phalarope, in Norf.; Spoonbill, Pomarine Skua on Norf. Coast; Bittern breeding in Norf. (Zool.)

Gurney, J. H., junr. Rare Norfolk Birds. (Land and Water, Dec. 26.)

Harmer, F. Rose-coloured Pastor [near Gt. Yarmouth]. (Field, Aug. I5.)

M[ann], T. J. Golden Eagle in Norf. (Field, Dec. I9.) Idem by H. Stevenson. (T.c., Dec. 26.)

I869. [Anon.] Crane at Lynn. (Zool.)

"E. A." Glossy Ibis near Stalham. (Sci. Gossip.)

"Grus." Cranes shot in Norf. (Field, June I2.) Idem by H. Stevenson. (T.c., June Ig.) Idem [Anon.]. (T.c., May I5.)

Gunn, T. E. Great Grey Shrike, Glossy Ibis, Velvet Scoter, Osprey, Rough-legged Buzzard, in Norf. ; Greenshank, etc, near Yarmouth; Black Tern's Egg in Norf., etc. [various notes]. (Zool.)

Gurney, J. H. Black-tailed Godwit at Hickling; Long-tailed Duck near Lynn. (T.c.)

Southwell, T. Bittern in Norf. ; Crane in Norf. ; Rare Birds in Norf. (Sci. Gossip.) 
Stevenson, H. Golden Eagle in Norf. (Field, Jan. I6.) On the Meres of Wretham Heath; Miscellaneous Observations. (Tr. Norf. \& Norw. Soc.) [56r.]

Tegetmeier, W. B. Capture of the Great Eagle Owl in Norf. (Field, Sept. II.) [An Escape?] T. F. Buxton and H. Stevenson. (T.c., Sept. I8.)

1870. "East Anglia." Little Bittern in Norf. (Field, May I4.)

Gunn, T. E. Solitary Snipe, Ruff, Harriers, Wood Sandpipers, Greenshanks, Sclavonian Grebes in Norf. ; Smew at Yarmouth ; Abundance of Little Gull and Fulmar Petrel on Norf. Coast, [various notes]. (Zool.)

Gurney, J. H., junr. Grey Plover at Blakeney. (T.c.)

Hunt, A. Leigh. Thetford. 8vo. Lond. : I870. [304.]

Lowe, J. Little Gull at Lynn. (Field, Feb. 26.)

Mathew, M. A. Lesser Grey Shrike, Shore Lark and Temminck's Stint near Gt. Yarmouth. (Zool.)

Overend, J. G. Little Gulls, etc., near Yarmouth. (T.c.) Rare Birds near Gt. Yarmouth. (Field, Feb. 5, I2, Mar. 5.)

" R. J." Bittern in Norf., 2 notes. (Sci. Gossip, VI.)

Southwell, T. On the Ornitholog. Archæology of Norf. (Zool.) Richard's Pipit in Norf. (Sci. Gossip.)

I87I. Dowell, E. W. Quails in Britain in I870 [status in Norf.]. (Field, Jan. 28.)

Gunn, T. E. Raptorial Birds in Norf; Rough-legged Buzzard near Yarmouth; Goosanders, Smews, Red-necked Grebes in Norf. (Zool.)

Gurney, J. H., junr. Spoonbills near Yarmouth. (T.c.)

Harting, J. E. Goosanders and Wild Swans at Yarmouth. (Field, Jan. I4.)

Redder, J. Eider Duck at King's Lynn. (T.c., Jan. 2I.)

[Salvin, O.] Notice of Stevenson's "Birds of Norfolk." (Ibis.) Southwell, T. Ornitholog. Archæology of Norf. (Tr. Norf. \& Norw. Soc., I.) [552.]

Stevenson, H. Abundance of Little Gulls and Quails. (Tr. Norf. \& Norw. Soc., I870-7I.) [56r.]

1872. Durnford, H. Richardson's Skua in Norf. (Zool.)

Gunn, T. E. Marsh Harrier, etc., in Norf. (T.c.); Great Grey Shrike near Yarmouth. (T.c.)

Gurney, J. H. Notes on Heronries of Norfolk and Suffolk; Purple Heron, Squacco Heron and Night Heron in Norf. (T.c.)

Gurney, J. H., junr. Snowy Owl at Southrepps ; Purple Heron, etc. in Norf. (T.c.) ; Ortolan Buntings at Yarmouth; Snowy Owl at Southrepps; Birds at Cromer Lighthouse; Lapland Bunting at Cley. (Tr. Norf. \& Norw. Soc., I.)

Leach, H. R. Snow Bunting between Hunstanton and Thornham. (Zool.)

Overend, J. G. Alpine Swift at Gt. Yarmouth. (Field, Sept. 28.) 
Stevenson, H. Scoulton Gullery. (Tr. Norf. \& Norw. Soc., $I 87 I-72)$

I872-3. Gurney, J. H., junr. Ornithological Notes from Norf. (Zool.) [260.]

I873. Bulteel, C. J. C. Eagle Owl in Norf. (Field, Nov. 29.) Idem by J. Walker. (T.c., Dec. I3.)

Davies, G. C. Mountain, Meadow and Mere. Post 8vo. Lond. : I873. [I63.]

[Editorial.] Lombe Collection in the Norwich Museum. (Field, Aug. 23.)

Gurney, J. H. Osprey in Norf. (Zool.)

Ogilvy, W. Sclavonian Grebe and Great Black Woodpecker in Norf. (Zool.)

Overend, J. G. White Stork near Yarmouth. (Field, June I4) ; Great Grey Shrike at Gt. Yarmouth. (Op. cit., Nov. 8) ; Birds at Yarmouth and locality. $(O p$. cit., Jan. I8.)

[1873 ?]. Bayne, A. D. Royal Illustrated History of Eastern England. ... 2 vols. Roy. 8vo. Gt. Yarmouth : N.D. [50.]

I873-85. Stevenson. H. Ornitholog. Notes from Norf., II pts. (Tr. Norf. \& Norw. Soc., I.-IV.) [562.]

I874. Gunn, T. E. Lesser Redpoll breeding near Norwich; Buzzards, etc., in Norf. (Zool.)

Gurney, J. H., junr. Shore Birds on Cley and Blakeney Muds. (T.c.)

Howell, J. A. Shoveler breeding in Norf. (Field, Aug. 29.)

Norgate, F. Red-necked Phalarope at Salthouse, Norf. (Zool.) Idem. (Field, Aug. I.)

I875. Bagot, C. F. Greater Spotted Woodpecker in Norf. (Field, Feb. 6) ; Solitary Snipe at Castle Rising. (Op. cit., Oct. I6) ; Long-tailed Duck at Hunstanton. (T.c., Nov. 6.)

Bell, T. Wall Creeper at Stratton Hall. (Zool.)

Clark-Kennedy, A. J. White-tailed Eagle in Norf.

Green, H. Gyr Falcon near Norwich. (Field, Jan, (T.c.)

Greville, F. Egyptian Geese on Oulton Broad. (Op. cit., Nov. 27.)

Gunn, T. E. Wild Fowl, Little Bustard, Bitterns, Black-throated Diver, Solitary Snipe and Spotted Redshank in Norf.; Montagu's Harrier breeding in Norf. Various notes. (Zool.)

Gurney, Anna. Notes on Norf. Birds, I820-56. (Tr. Norf. \& Norw. Nat. Soc., II., p. I9.)

Gurney, J. H. Tichodroma phcenicoptera in Norf. (T.c.)

Gurney, J. H., junr. The last native Great Bustard; Green Sandpiper at Northrepps. (T.c.); Glaucous Gulls and Goosander [near Yarmouth]. (Field, Dec. II.)

Kimberley, Earl of. Birds observed on the Kimberley Estate since I847. (Tr. Norf. \& Norw. Soc., II. ; Land \& Water, Oct. 3I, I874.) 
Stevenson, H. Second Occurrence of Lesser Grey Shrike in Norf. ; Stilt Plover in Norf. (Field, Oct. 9.)

I876. Bagot, C. F. A. Long-tailed Duck at Hunstanton. (Zool.)

[Editorial.] Recent Occurrence of Great Bustard in Norf. [ill.] (Field, Apr. 8.)

Eedle, T. Peregrine Falcon, Great Northern Diver and Wild Geese near Merton Hall. (Zool.)

Gould, J. Snowy Owl in Norfolk [at Burnham Overy Marshes]. (Field, Nov, 18.)

Gould, W. Snowy Owl in Norf. (T.c., Nov. I8.)

Gunn, T. E. Notes on Occurrence of Rare Bircls. (Zool.)

Gurney, J. H., junr. Peregrine in City of Norwich; Redshank and Green Sandpiper at Northrepps; Notes from Blakeney. (T.c.) ; Rough-legged Buzzard near Cromer. (Field, Jan. 29.) Marsham, R. Correspondence of, with Gilbert White. (Tr. Norf. \& Norw. Soc.) [55.]

Stevenson, H. Avocets at Yarmouth. (Ficld, April 29.)

Upcher, H. M. Great Bustard at Feltwell. (Zool.) .

1877. Gould, W. White-tailed Eagle in Norfolk. (Field, Jan. 6.)

Gurney, J. H., junr. Kite at Northrepps; Hooded Crow in Norf. in August; Purple Gallinule at Hickling Broad. (Zool.) Greenshanks in Norf. (Field, Sept. 29.)

Rowley, Hon. G. D. On Scoulton Mere and the Black-headed Gull. (Rowley's Ornitholog. Miscell.) Account of Netting Seabirds in Norf. $(O p$. cit.)

Stevenson, H. Black-tailed Godwit in Norf. (Field, Apr. 28) ; Little Owl in Norf. (T.c., June 2.)

Styan, F. W. Montagu's Harrier in Norf. (Op. cit., Aug. 25, Sept. I.)

I878. Doggett, F. Early Arrival of Short-eared Owl. (Field, Sept. 2I.) Gurney, J. H. Provincial Names in Norf. (Zool.)

Gurney, J. H., junr. Purple Gallinule in Norf. (T.c.)

M[ann], T. J. Montagu's Harrier and Little Auk in Norf. (Field, Dec. I4.)

Pennie, C. B. Little Auk near Norwich. (Field, Nov. 23.)

I879. Dack, C. Golden [errore for White-tailed] Eagle in Norf. $(O p$. cit., Nov. 22.)

Gunn, T. E. Fulmar Petrel off Norf. coast. (T.c., Nov. 22.)

Gurney, J. H. Sclavonian Grebe near Cromer. (Zool.)

Gurney, J. H., junr. Little Auk near Norwich; Green-backed Porphyrio at Barton; Shore Birds on the Coast. (T.c.) Pomatorhine Skuas on Norf. Coast. (Field, Nov. 8.)

Gurney, J. H., junr. Birds of the District. [In Jarrold's Illustrated Handbook to Cromer.] Norwich: N.D. I879. Idem. Many later edits. N.D. [26I.]

Harting, J. E. Virginian Colin in Norf. (Field, Dec. I3.) 
Munford, Rev. G. The Ornithology of Hunstanton. [In Philip Wilson's "Hunstanton and its Neighbourhood," 6th edit.] 8vo. Lynn, etc. : I879. [428.]

Newton, A. Notes on Hawking in Norfolk. In Appdx. to Lubbock's Fauna of Norfolk. 8vo. Norwich: I879. [363.] [Orig. ed. I845.]

Newton, A. On Hawking near Yarmouth. (Tr. Norf. E Norw. Soc., III.)

Norgate, F. Natural History Notes [Sparham]. (T.c.); Hobby in March. (Field, April 26.)

Southwell, T. Norfolk Decoys. (Trans. Norf. Soc., II.) ; Whitetailed Eagle in Norf. (Field, Nov. 29.) Wilkinson, G. Idem. (T.c., Nov. 29.)

I880. Benson, C. W. Snow Bunting at Cromer. (Zool.)

Bingham-Crabbe, A. Purple Sandpipers at Cley. (Field, Nov. 20.)

Dack, C. B. Hoopoe in Norf. (T.c., Oct. 2.) Gt. Grey Shrike in Norf. (T.c., Nov. 20 and Dec. I8.)

Gurney, J. H. Bewick's Swan, Goldeneye Duck and Green Sandpiper in Norf.; Autumn Migration at Cromer. (Zool.)

Gurney, J. H., junr. Late Nesting of Barn Owl and Water Hen ; Herons nesting at Hempstead. (T.c.); Autumnal migration of Siskin [Cromer]. (Field, Oct. 30.)

Harting, J. E. Virginian Colin in Norf. (Zool.); Notes on Hawking as formerly practised in Norf. (Tr. Norf. \& Norw. Soc., III.)

Lowne, W. Solitary Snipe in Norf. (Field, Sept. II.)

Lucas, C. B. Osprey in Norf. (Field, June I9.)

M[ann], T. J. The Peregrine in Norf. (Field, Nov. 13.)

Norgate, F. On Nesting of Nuthatch. (Zool.)

Poyser, E. J. Rough-legged Buzzard and Velvet Scoters in Norf. (Field, Nov. I3.)

Stevenson, H. Abundance of Skuas on Norf. Coast. (Tr. Norf. E Norw. Soc., III.) [562.]

I880-88. Gunn, T. E. Ornitholog. Notes from Norf. and Suffolk, 6 pts. (Zool., I880, I884-5-6-7-8.)

I88I. "Aquila." Golden Eagle in Norf. (Field, Dec. 24.) [Disputed by T. Southwell and H. Stevenson.] (T.c., Dec. 3I.)

"A.D." Osprey and Honey Buzzard in Norf. (T.c., Oct. 22.)

Dack, C. B. Shore Larks in Norf. (Op. cit., Jan. I.)

Fisher, W. W. Honey Buzzards in Eastern Counties. (Field, Oct. 8.)

Gurney, J. H., junr. Ornitholog. Notes from Neighbourhood of Cromer; Raptorial Migrants near Cromer. (Zool.)

Lilford, Lord. Roseate Tern on the Coast. (T.c.)

Lowne, W. Buzzards and Harriers in Norf. (Field, Oct. 8.)

Lucas, C. B. Honey Buzzard in Norf. (T.c., Oct. I). Idem by J. E. Harting. (T.c., Oct. 8.) 
Southwell, T. Glossy Ibis in Norf. (Zool.)

Ward, W. E. Grey Phalarope near King's Lynn. (Field, Nov. 5.)

Whitear, W. Extracts from Calendar of [Starston]. (Tr. Norf. \& Norw. Soc., III.)

r88I-86. Power, F. D. Ornitholog. Notes from Cley-next-the-Sea, 3 pts. $(O p$. cit., I88I-86.)

I88I-I9I2. Gurney, J. H., junr. Ornitholog. Notes from Norf., 32 pts. (Zool., I88I-I9I2.) [26I.]

I882. Dack, C. B. Waxwings in Norf. (Field, Dec. 23.)

Norgate, F. Nesting of the Hobby. (Tr. Norf. \& Norw. Soc., III.)

Stevenson, H. Occurrence of Sabine's Gull in Norf. ; Tengmalm's Owl in Norf. (Zool.); Occurrence of Sabine's Gull, Dusky Petrel and Sooty Shearwater. (Tr. Norf. \& Norw. Soc., III.) [562.]

Tuck, J. G. Notes from Hunstanton. (Zool.)

I883. Chase, R. A. White-winged Black Tern in Norf. (Op. cit.)

Davies, G. C. Norfolk Broads and Rivers. Cr. 8vo. Edinb. : I883. [I63.]

Davies, G. C. Handbook to Rivers and Broads of Norfolk. Post 8 vo. N.D. 2nd to I8th edits. N.D. [I64.]

Gurney, J. H. Ornitholog. Notes from Norf., Winter I882-83. (Tr. Norf. and Norw. Soc., III.)

Gurney, J. H., junr. Red-legged Partridge in N. Norf. (Zool.)

Lowne, W. Manx Shearwater in Norf. (Field, Sept. I5.)

P-, F. G. C. Roller near Yarmouth. (T.c., Oct. I3.)

Southwell, T. Sooty Shearwater in Norf. (Zool.)

Travis, J. Arrival of Waxwings. (Field, Jan. 27.) [partim.]

Walter, J. H. Eider Duck inland [near Norwich]. (Op. cit., Dec. 22.)

I884. Dresser, H. E. Hypolais icterina at Blakeney. (P.Z.S.)

Gunn, T. E. Ornithological Invasions of E. Anglia. (East Anglian Handbook, I884.) Also repr. separately 8vo., I885. [257.]

Gurney, J. H. Catalogue of the Birds of Norfolk. [In R. Mason's History of Norfolk, I.] Roy. 4to. Lond. : I884. Also repr. separately cr. 8vo., I884. [26r.]

Gurney, J. H., junr. Occurrence of a Flock of Blue-throated Warblers in Norf. (Tr. Norf. and Nore. Soc.)

L_-, W. H. Grey Shrike in Norf. (Field, Nov. I5.)

Tuck, J. G. Eared Grebe and Velvet Scoter at Hunstanton, (P.Z.S.)

Upcher, A. H. Occurr. of Wryneck in Winter. (Ficld, Jan. I2.)

I885. Bird, M. C. H. Notes from Norf. (Field, Aug. 22.)

[Editorial.] Sale of Rising's Collection of Birds [Norf. Records]. (Field, Sept. 26.) 
Gunn, T. E. Roller near Norwich. (Zool.); Blue-throated Warbler. (Linn. Soc. Jnl., XVIII.)

Gurney, J. H., junr. Tree Sparrow nesting near Cromer. (Zool.)

Harting, J. E. Icterine Warbler and Barred Warbler in Norf. (T.c.)

Latter, O. H. Little Auk in Norf. (Field, Jan. 24.)

Southwell, T. White-tailed Eagle in Norf. (Op. cit., Dec. 5.)

Tuck, J. G. Notes from Hunstanton; Eared Grebe at Hunstanton. (Zool.)

I886. Chase, R. W. Woodchat and Serin Finch in Norf. (Op. cit.)

Gurney, J. H., junr. New Colonies of Black-headed Gulls in Norf. (T.C.)

Mackenzie, W. D. Black Game in Norf. (Field, Mar. 6.)

Power, G. E., and F. D. Ornitholog. Notes at Cley. (Tr. Norf. \& Norw. Soc., IV.)

I886-r9o9. Gurney, J. H., and Southwell, T. Fauna and Flora of Norfolk: Part IX., Birds. And Additions, 6 pts. (Op. cit., I886-I909. [553.]

I887. Aplin, O. V. Ornitholog. Notes from Norf. (Nat.)

Bird, M. C. H. Bluethroat in Norfolk; White-eyed Pochard and Bewick's Swan in Norf. (Zool.)

Chase, R. W. Pectoral Sandpiper in Norf. (T.c.)

[Editorial.] Great Sale of Norfolk Birds. (Field, Sept. 24.)

Gurney, J. H., junr. On Periodical Movements of Gulls on Norf. Coast. (Tr. Norf. \& Norw. Soc., IV.)

Morrice, F. Woodcock sitting in Norf. (Field, May 7.)

Purdy, R. J. W. Bittern in Norf. (Zool.)

Saunders, H. Mediterranean Black-headed Gull in England. (Field, Feb. 5.)

Smith, G. Mediterranean Black-headed Gull on Norf. Coast. (Zool.)

I888. Brind, F. White Stork at Yarmouth. (Field, Sept. I.)

Butler, A. Pallas's Sand Grouse in Norf. ; Supposed Nesting of Green Sandpiper, in Norf. (Zool.)

Candler, C. Birds of the Harleston District. [In Rev. F. W. Galpin's Flowering Plants, etc., of Harleston.] 8vo. Lond. etc. : I888. [II8.]

Candler, C. Manx Shearwater in Norf. (Field, Sept. I5); Osprey in S. Norf. (T.c., Nov. 24); Ring Ouzel in S. Norf. (T.c., Dec. 8.)

Davey, G. Waxwings in Norf. (Op. cit., May 5.)

Eldred, E. J. Pallas's Sand Grouse near Norwich. (Zool.)

Gunn, T. E. Reported Occurrence of Goshawk in Norf. (T.c.); Fish Eating Birds of Norf. (East Anglian Handbook, I888). Also repr. separately 8vo., I889. [257.] 
Gurney, J. H., junr. Some Notes on Common Birds. (Ficld, Dec. I) ; Pallas's Sand Grouse in Norf. (Op. cit., June 9, Aug. II, Nov. 3.)

Pycraft, W. P. Ornitholog. Notes from Neighbourhood of Yarmouth. (Tr. Norf. \& Norw. Soc., IV.)

Pashley, H. Black Stork near Salthouse. (Field, April 28.)

Southwell, T. Occurrence of Pallas's Sand Grouse in Norf. (Zool.)

Spelman, W. W. Catalogue of Birds shot in Norf. \& Suffolk. 8vo. Brundall: I888. [555.]

Tuck, J. G. Fulmar Petrel and Gull-billed Tern at Hunstanton. (Zool.)

Wilson-Upcher, A. Bittern and Peregrine in Norf. (Field, Dec. 8.)

I888-8g. Aplin, O. V. Ornitholog. Notes from Norfolk Coast, 2 pts. (Zool., I888-8g.)

I889. Aplin O. V. Scarcity of Carrion Crow in Norf. (Op. cit.)

Dack, C. B. Nutcracker, Crossbill and Sand Grouse in Norf. (T.c.)

Gurney, J. H., junr. Ornithology ........ of Cromer. [In Rye's Cromer, Past and Present.] 4to. Norwich, etc.: I889. [262.]

Gurney, J. H., junr. Wood Warbler at Cley; Loxia mibrifasciata in Norf. (Zool.) Pallas's Sand Grouse [in Norf.]. (Field, June 5, x.)

Hardy, J. Honey Buzzard at Downham, Norf. (Op. cit., Sept. 7.)

Kimberley, Earl of. Additions to List of Birds observed on the Kimberley Estate. See I875. (Tr. Norf. \& Norw. Soc., IV., pp. 604-5.)

Lodge, G. E. Notes on Birds in Norfolk. (Zool.)

Lowne, W. Little Bustard in Norfolk. (T.c.) ; Little Gull and Sabine's Gull in Norf. (Field, Oct. I2); Little Bittern in Norf. (T.c., Oct. Ig.)

Southwell, T. King Eider as a Norf. Bird. (Zool.)

Tegetmeier, W. B. Early occurrence of Little Bustard. (Field, Sept. 7.)

Upcher, H. M. A Day's Birds Nesting in Norf. (Tr. Norf. E Norw. Soc., IV.)

189o. Bird, M. C. H. Pied Flycatcher in Norf.; Jack Snipe in Norf. (Zool.)

Butler, E. A. Asiatic [Caspian] Plover in Suffolk [err. for Norf.]. (Field, June 2r, 28.)

Dowell, E. W. Puffin inland in Norf. (Zool.); Notes from Norf. (Field, Mar. 8.)

Emerson, P. H. Wild Life on a Tidal Water. 4to. Lond.: I890. [I97.] 
Gayford, T. J. Sea Eagle in Norf. (Field, Jan. I8.)

Smith, A. White-fronted Goose in Norf. (Zool.)

Smith, G. King Duck at Hunstanton. (T.c.)

Southwell, T. Occurrence of Egialitis asiatica in Norf. ; Little Bustard in Norf. (T.c.) ; King Eider as a Norf. Bird. (Tr. Norf. \& Norw. Soc.)

[I89o.] L[eathes], H. M. Rough Notes in Norf. and the Eastern Counties. Post 8vo. Lond. : N.D. [344.]

I890-9I. Aplin, O. V. Distribution, etc., of Spotted Crake, 2 pts. (Zool., r890-9r.) [partim.] [24.]

I89I. Aplin, O. V. Autumn Notes from Norf. Coast. (Op. cit.)

Bird, M. C. H. Bird Life on the Norfolk Broads, 8 pts. (Field Club, II.)

Feilden, H. W. Scops Owl in Norf.; Manx Shearwater in N. Norf. (Zool.)

Harting, J. E. The recent visitation of Bustards. [partim.] (Field, Feb. 28.)

L[aw], H. H. B., and others. Little [err. for Great] Bustard in Norf. (T.c., Jan. 24, 3I.)

Ogilvie, F. M. On a Norfolk Specimen of Red-breasted Flycatcher. (Tr. Norf. \& Norw. Soc.)

Patterson, A. Notes from Great Yarmouth. (Zool.)

Southwell, T. Falconry in Norf. ; On Some Rare Birds obtained in Norf. in I890-9I. (Tr. Norf. \& Norw. Soc.) ; King Duck at Hunstanton; Broad-billed Sandpiper in Norf. (Zool.)

I892. Aplin, O. V. Distribution of Cirl Bunting; Status of Woodchat. (Zool.) [partim.] [25.]

Bidwell, E. Eared Grebe in Norf. (T.c.)

Bird, M. C. H. Bird Life on Norfolk Broads, I2 pts. (Field Club, III.) Hoopoe in Norf. (Zool.)

Creaghe-Haward, L. Notes on Some E. Anglian Birds. (Tr. Leics. Soc., II.)

Feilden, H. W. Sabine's Gull in Norf. (Zool.)

Gunn, T. E. Tufted Duck in Norf. (T.c.)

Gurney, J. H. [formerly junr.] Cat. of Collections of British Birds. 8vo. Lond. : I892. [262.]

Seebohm, H. Exhibition of Siberian Pectoral Sandpiper from Norf. (Bull. B.O.C., I., I892-93.)

Southweil, T. Siberian Pectoral Sandpiper in Norf. (Zool.) St. Helen's Swan-pit. (Tr. Norf. \& Norw. Soc.)

Whitlock, F. B. Notes from Norf. in I8gr. (Zool.)

I893. Bird, M. C. H. Bird Life on the Norfolk Broads, I2 pts. (Field Club, IV.)

Crowley, P. Buff-coloured Whinchat near Cromer. (Bull. B.O.C., III., I893-94.) 
Gurney, J. H. Reported Occurrence of Two-barred Crossbill and Scarlet Grosbeak, Ruddy Sheldrake and Purple Gallinule in Norf., 3 notes. (Zool.)

Seebohm, H. On Occurrence of Sharp-tailed Sandpiper in Norf. (Ibis.)

Southwell, T. On Occurrence of Siberian Pectoral Sandpiper. (Tr. Norf. \& Norw. Soc.)

Tuck, W. H. Fauna of a Suffolk Village. (Field Club, IV., Nov. Io.) [partim.]

I894. Clarke, W. G. A Breckland Ramble, 2 pts. (Nat. Jnl., Oct., Nov.)

Gunn, T. E. Recent Occurrence of Great Bustard in Norf. ( $T r$. Norf. \& Norw. Soc., V.) Idem (Op. cit., VI., I898) [257.]

Harting, J. E. On Recent Occurrence of Yellow-browed Warbler in Norf. (Zool.)

Tuck, J. G. Wildfowl on Norf. Coast. (T.c.)

I894-96. Yarmouth Naturalists' Society. Papers [on Norfolk Birds]. By A. Patterson and F. D. Palmer.

I895. Andrews, W. H. M. Ornitholog. Notes, I3 notes. (Nat. Jnl.) Clarke, W. G. The Breckland Plover. (Nat. Jul., Jan.); Thick-knee in Norf. in Dec. (T.c.)

Emerson, P. H. Birds, Beasts and Fishes of the Norfolk Broadland. 8vo. Lond. : I895. [I98.]

Gurney, J. H. On Recent Abundance of Little Auk in Norfolk. (Tr. Norf. \& Norw. Soc.)

Hudson, T. M. Black-winged Stilt in Norf. (Zool.)

Patterson, A. Man and Nature on the Broads. Sq. 8vo. 1895.

Sapsworth, A. D. Grey Shrike, Pomatorhine Skua and Spoonbill in Norf. (Zool.)

I8g6. Cooper, E. P. Black Tern in Norfolk. (Op. cit.)

Dresser, H. E. Pallas's Willow Warbler in Norf. (P.Z.S.)

Griffiths, A. F. White-billed Northern Diver in Norf. (Zool.)

Gurney, J. H. On the Flight of Gulls from Observations made in Norf. (Ornithologist, I.); Black-throated Diver in Norf. (Field, Jan. 25.)

Gurney, R. Icterine Warbler in Norf. (Op.cit., Sept. I9; Zool.)

Newton, A. Early Notice of Spoonbill breeding in Norf. (Tr. Norf. \& Norw. Soc.)

Sharpe, R. B. Exhibition of Icterine Warbler from Wells. (Bull. B.O.C., V., I895-96, p. xxxvii.)

Southwell, T. On Occurrence of Pallas's Willow Warbler in Norf. (Zool.)

1897. Clarke, W. G. Stone Curlews as observed round Thetford; Curious Nests and Nesting Sites near Thetford ; Inland Breeding of Ringed Plover in Norf. (OP. cit.) ; List of Vertebrated Animals found in Neighbourhood of Thetford. (Tr. Norf. \& Norw. Soc.) 
Farman, L. C. Amongst the Birds of Norf. ; Twenty Years on the Norf. Fens; "Kentish Crow." (Zool.)

Gurney, J. H. Green-backed Gallinule in Norf. (Field, July 3, Aug. 7.)

Slater, H. H. Exhibition of Barred Warbler from Norf. (Bull. B.O.C., VII., I897-98.)

Southwell, T. On Occurrence of Pallas's Willow Warbler in Norf. ; Fen versus Marsh; Occurrence of Mediterranean Herring Gull in Norf.; An unrecorded Norf. Great Bustard. (Zool.)

I897-98. Patterson, A. Notes from Gt. Yarmouth, 2 pts. (Nat. Chron., July I897, May I898) ; A Pigmy Curlew and a Godwit ; Notes from Breydon. (Op. cit., Oct. I898) ; Autumn Migrants at Breydon. (Op. cit., Nov. I898.)

I898. Butler, E. A. Little Bustard in Norf. (Zool.)

Clarke, W. G. The Wretham Meres. (Zool.)

Farman, L. C. Winter Notes from Haddiscoe. (Zool.)

Ffolkes, Sir W. H. B. [Black-bellied] Dipper at Hillington. (Field, Nov. I2.)

Gunn, T. E. Great Bustard in Norf. (Tr. Norf. \& Norw. Soc., VI.)

Newman, J. L. Pectoral Sandpiper in Norf. (Zool.; Field.)

Southwell, T. Exhibition of a Norfolk Bustard. (Tr. Norf. \& Norwe. Soc.)

Southwell, T. Catalogue of British Birds in Collection of $\mathrm{Mr}$. E. M. Connop, of Rollesby Hall. 8vo. Norwich (privately printed) : I898. [553.]

Weakes, J. Peregrine Falcon captured in Norf. (Field, Nov. 5.)

I899. Davenport, H. S. In a Norfolk Fen. (Op. cit., Feb. 25.)

Farman, L. C. Notes from the Haddiscoe Marshes. (Zool.)

Gurney, J. H. The Bearded Titmouse. (Tr. Norf. \& Norw. Soc.)

Patterson, A. Spoonbills near Gt. Yarmouth. (Zool.)

"R., H." Osprey in Norf. (Field, Oct. 28.)

Tuck, J. G. Demoiselle Crane on Norf. Coast. (Zool.)

Igoo. Farman, L. C. Winter Notes from Haddiscoe. (Zool.)

Gurney, J. H. Short History of the Bearded Titmouse. $(O p$. cit.)

Noble, H. Bearded Tit and other Birds in Norf. (T.c.)

Patterson, A. Migration Notes from Gt. Yarmouth. (T.c.)

Pollard, E. H. The Birds of My Parish [Haynford]. 8vo. Lond. : I900. [476.]

I900-0I. Patterson, A. Birds of Great Yarmouth and Neighbourhood, 5 papers. (Zool., Ig00-0I.) [460.]

I900-04. Patterson, A. Natural History Notes from Yarmouth, 5 pts. (Tr. Norf. \& Norw. Soc., VII.) [460.]

Igor. Coburn, F. Lesser White-fronted Goose in Norf. (Zool.) 
Coburn, F. [Exhib. of Lesser White-fronted Goose from Norf.] (Bull. B.O.C., XII.)

Gurney, J. H. Coot Shooting on Hickling Broad. (Tr. Norf. \& Norw. Soc.)

Newton, A. On some Crane's Bones found in Norf. (T.c.)

Patterson, A. Spoonbills at Gt. Yarmouth. (Zool.)

Southwell, T. Birds. [In Victoria Hist. of Co. of Norfolk, I.] 4to. Lond. : I90I. [553.]

Southwell, T. On Breeding of Crane in East Anglia. (Tr. Norf. \& Norw. Soc.) Attempt to reintroduce the Great Bustard in Norf. (Knoweledge.)

I902. Browne, Sir T. Notes and Letters on the Natural History of Norfolk [I605-82]. Ed. T. Southwell. 8vo. Lond. : I902. [100.]

Gunn, T. E. Discovery of Aquatic Warbler in Norf. (Field.) Gurney, J. H. Allen's Gallinule. (T.c., Feb. 8.) Lesser Whitefronted Goose in Norf. (Ibis, p. 269.)

Lodge, G. E. Exhibition of specimen of Lanius minor shot in Norf. (Bull. B.O.C., XIII., I902-03.) Idem. (Zool.)

Patterson, A. Waxwings at Gt. Yarmouth. (Zool.)

Saunders, H. On the Protection and possible Nesting of Spoonbill in Norf. (T.c.)

Southwell, T. Great Bustard in Norf. (Tr. Norf. \& Norv. Soc.)

Ig02-I2. Gurney, J. H. Ornith. Notes and Repts. from Norf. II pts. $\left(Z \circ o l^{\circ}\right)$ [263.]

Ig03. Bird, M. C. H. Green-backed Gallinule in Norf. (Ficld Nat. Qtly, II., No. 5.)

Farren, W. Bird Life of the Breck District. (Animal Lifc, II., Nov. I3.)

Harting, J. E. Bird Life on the Broads. (Field, Sept. 26.)

Hoare, S. T. G., and Milburn, W. H. Honey Buzzard in Norf. (T.c., Oct. 3.)

Noble, H. Birds and other Animals of Thetford Warren. (Zool.)

Patterson, A. Uncommon Birds in Norf. (Field, Oct. 3.)

Pigott, T. D. [Great Black Woodpeckers in Norf.] (Bull. B.O.C., XIV.)

Watson, H. C. Hoopoe in Norf. (Field, Sept. r9.)

I904. Gunn, T. E. Aquatic Warbler in Norf. (Op. cit., Oct. 8.)

Montagu, E. S. On Nesting of the Lesser Redpoll in Norf. (Bull. B.O.C., XIV., I903-04.)

Patterson, A. Notes of an East Coast Naturalist. Post 8vo. Lond. : I904. [460.]

Patterson, A. Bird Notes from Yarmouth. (Field, May 7); Nat. Hist. Notes from Yarmouth. (Tr. Norf. \& Norw. Soc.)

I905. Harting, J. E. Bird Life on the Broads (Reprinted from the Field) [in his "Recreations of a Naturalist"]. 8vo. I905. [276.] 
Patterson, A. Nature in Eastern Norfolk. Post 8vo. Lond. : I905. [460.]

Patterson, A. Glaucous Gull at Yarmouth. (Field, Nov. 4); Among Norfolk Terns; On a Norfolk Heronry. (Zool.)

Pycraft, W. P. Immigration of Lapland Buntings. (Knowledge.)

Saunders, H. On Occurrence of Pratincola maura and Emberiza aureola in Norf. (Bull. B.O.C., XVI., I905-06.)

Tuck, J. G. Blacktailed Godwit in Norf., etc. (Zool.)

Witherby, H. F. [Black Redstart from Inner Dowsing Light on April I4.] (Bull. B.O.C., XV.)

I906. Bird, M. C. H. Blue-throated Warbler in Norf. (Field, May 26.)

Dutt, W. A. Wild Life in East Anglia. 8vo. Lond. : Igo6.

Gurney, J. H. Wild Swans in Norf. (Zool.)

Knights, J. E. Crane near Gt. Yarmouth. (Zool.)

Mouritz, L. B. Hoopoe in Norf. (T.c.)

Patterson, A. H. Interesting Birds in Yarmouth Market; Redcrested Pochard at Yarmouth. (T.c.)

Smith, N. H. Red-crested Pochard in Norf. (Field, Sept I5.)

I907. Arnold, E. C. A Bird Collector's Medley. 4to. Lond. : I907. Arnold, E. C. Occurrence of Icterine Warbler in Norf. (Bull. B.O.C., XXI., I907-08.) Idem. (Brit. Birds, I.)

Dye, B. Smew, etc. at Yarmouth. (Zool.)

Gurney, J. H. Southern Grey Shrike in Norf. (Tr. Norf. \& Norw. Soc.)

Pycraft, W. P. The Bearded Tit [in Norf.]. (Knowledge.)

Patterson, A. H. Wild Life on a Norfolk Estuary. 8vo. Lond.: N.D. [460.]

Patterson, A. H. Some Holiday Notes from Breydon. (Zool.)

Penrose, F. G. [Exhib. of Yellow-breasted Bunting from Wells.] (Bull. B.O.C., XXI.)

Southwell, T. Black Tern in Norf. (Field, June 8.)

Turner, Miss E. L. Reappearance of Ruff as a Nesting Species in Norf. (Brit. Birds, I.); Some Notes on Coot and Great Crested Grebe. (Tr. Norf. \& Norw. Soc.)

I908. Arnold, E. C. Barred Warbler in Norf. (Brit. Birds, II.; Zool.) Idem by F. G. Penrose. (Brit. Birds, II.)

Arnold, F. A. Sandwich Tern on Breydon; Sabine's Gull on Breydon; Bird Notes from Yarmouth. (Zool.)

Bird, M. C. H. Green-backed Gallinule in Norf. (Brit. Birds, II.)

Borrer, C. Richard's Pipit in Norf. (T.c.)

Clark, J. A. Peregrine Falcon in Norf. (Zool.)

Dye, B. Little Auk captured alive near Yarmouth; Spotted Crake at Gt. Yarmouth; Honey Buzzard in Norf, (T.c.)

Gurney, J. H. Sabine's Gull in Norf. (Brit. Birds, II.)

Heatherley, F. Visit to Ternery at Wells-by-Sea. (Zool.)

Patterson, A. H. Incursion of Godwits at Yarmouth. (T.c.)

Pycraft, W. P. Marsh Harrier in Norf. (Brit. Birds, II.) 
Richards, F. I. Red-breasted Flycatcher in Norf. (Bull. B.O.C., XXIII., I908-09.) ; Yellow-browed Warblers in Norf. ; Blueheaded Wagtail in Norf. (Brit. Birds, II.)

Richardson, N.F. Richard's Pipit in Norf. (Field; Brit. Birds, II.)

Tuck, J. G. Red-footed Falcon in Norf., 2 notes. (Zool.)

Witherby, H. F. Little Bunting and Blue-headed Wagtail in Norf. (Bull. B.O.C., XXIII., I809-09.) Idem. (Brit. Birds, II.)

I909. Borrer, C. Northern Willow Wren in Norf. (Bull. B.O.C., XXIII., I908-09; Brit. Bird, II.) [Exhib. of three Ortolan Buntings from E. Norf.] (wull. B.O.C., XXV.)

Clarke, W. G. Bird Life of the Meres. (Tr. Norf. \& Norw. Soc.) Mackie, A. C. Bird Notes at Wells-next-the-Sea. (Nature Notes.)

Montagu, E. S. [Exhib. of Sabine's Gull from Breydon Water.] (Bull. B.O.C., XXIII.)

Patterson, A. H. Some Migration Notes from Yarmouth. (Zool.) ; Nat. Hist. Notes from Yarmouth. (Tr. Norf. E Norw. Soc.)

Southwell, T. Wild Bird Protection on Norf. Coast. (T.c.)

Turner, E. L. Ruffs in Norf. (Brit. Birds, III.)

Witherby, H. F. Richard's Pipit in Norf. ; Two Norfolk Levantine Shearwaters. $(O p$. cit., II.)

I9I0. Arnold, E. C. Bluethroats in Norf. (Op. cit.)

Borrer, C. Barred Warbler in Norf.; Tawny Pipit in Norf. (T.c., also Bull. B.O.C., XXVII., IgIo-II.)

Dye, B. Lapland Bunting near Gt. Yarmouth ; Honey Buzzard near Yarmouth; Glossy Ibis at Yarmouth. (Zool.)

Harding, J. R. Probable Black-headed Wagtail in Norf. (Field, -..)

Holland, Capt. S. E. Supposed Bee-eater in Norf. (Field.)

Noble, H. Crossbills nesting in Norf. (Brit. Birds, III.)

Patterson, A. H. Nat. Hist. Notes from Yarmouth. (Tr. Norf. E Norw. Soc.)

Ready, O. G. Life and Sport on the Norfolk Broads in the Golden Days. 8vo. Lond. : Igro. [488.]

Stanford, E. F., Gilroy, N., and Tracey, N. Crossbills nesting in Norf. (Brit. Birds, III.)

Tracey, N. Curlew nesting in Norf. (T.c.)

Witherby, H. F. [Exhib. of nestling Crossbill from Norf.] (Bull. B.O.C., XXV.)

I9II. Borrer, C. Late date for Cuchoo's Egg; Blue eggs of Common Tern; Sabine's and Little Gulls and Grey Phalaropes in Norf. (Brit. Birds, V.)

Cummings, S. G. Red-necked Phalarope in Norf. (Op. cit., IV.)

Gurney, J. H. White-winged Black Terns in Norfolk; Migration of Slender-billed Nutcrackers in Norf. (Op. cit., V.) 
Penrose, F. Icterine Warbler in Norf. (T.c.)

Portal, W. Montagu's Harrier in Norf. (Op. cit., IV.)

Riviere, B. B. Crossbills breeding in Norf. (T.c.)

Ticehurst, C. B. Continental Robins, Song Thrushes, Goldcrests and Great Tits in E. Anglia, etc. (T.c.)

Turner, E. L. Return of the Bittern to Norf. (Op. cit., V.)

Witherby, H. F. Supposed Southern Grey Shrike in Norf. (T.c.)

I9I2. Edwards, L. A. Curtis. Possible Occurence of Sprosser in Norf. (T.c.)

Gurney, J. H. Little Bustard in Norf.: Supposed former abundance of Glossy Ibis. (T.c.) ; Emigration through Norf. of Rook and Grey Crow. (Zool.); Nutcrackers in Norf. (Tr. Norf. \& Norw. Soc., IX.)

Patterson, A. H. Miscellaneous Notes from Gt. Yarmouth. (Zool.)

Riviere, B. B. Early Nesting of Lesser Redpoll in Norfolk. (Brit. Birds, VI.)

Robinson, H. W. Squacco Heron in Norf. (Brit. Birds, VI.) Rowan, W. Unpigmented Eggs of Ringed Plover [at Blakeney]. (Brit. Birds, VI.)

Taylor, E. C. The Great Reed Warbler [seen in Norf.]. (Knowledge.)

Turner, E. L. Notes on the Bearded Tit. (Brit. Birds, VI.)

I9r3. Arnold, E. C. Yellow-breasted Bunting in Norf.; Barred Warbler in Norf. (Brit. Birds, VII.)

Dye, B. Rough-legged Buzzard at Great Yarmouth. (Zool.)

Gurney, J. H. Glossy Ibises in Norf. (Brit. Birds, VI.); Willow Tit in Norf. (Zool.)

Long, S. H., and Riviere, B. B. Fauna and Flora of Norf., addit. to pt. XI. Birds. (6th list) Igog-I3. (Tr. Norf. \& Norw. Soc.,

IX., pp. 784-97.)
Meares, C. S. Crossbills breeding in Norf., etc. (Brit. Birds, VI.) Patterson, A. H. Some miscellaneous Notes from Gt. Yarmouth. (Zool.)

Riviere, B. B. Probable Scandinavian Lesser Black-backed Gulls in Norf. (Brit. Birds, VII.) Notes on Autumn migration on Norf. Coast. (Tr. Norf. \& Norw. Soc., IX., pp. 77073.)

Rowan, W. Breeding habits of Oystercatchers in Norf. (Brit. Birds, VII.)

Ticehurst, C. B. Scandinavian Lesser Black-backed Gulls in Norf., etc. (T.c.)

I9I3-I6. Gurney, J. H. Ornithol. Reports from Norf. IgI2-I5, 4 pp. (Zool., I9I3-I6.)

I9I4. Alexander, H. G. Willow Tit in N.E. Norf. (Brit. Birds, VIII.) Charlton, J. M. Visitation of Black Redstarts in Norf. (Zool.) 
Chasen, F. N. Norfolk Redshanks. (T.c.)

Dye, B. Glossy Ibis in Norf.; Waxwings in Yarmouth and neighbourhood. (Zool.)

Gurney, J. H. Cormorant nesting in Norf. ; Birds migrating northwards in Oct.; (Brit. Birds, VIII.) The Redshank in Norf. Marshes (Zool.); Nesting of Long-eared Owl on ground at Hickling. (Tr. Norf. \& Norw. Soc., X. pp. 38-40, pl.)

Johnson, T. H. F. Waxwing and Snow Buntings in Norf. (Field, Jan. Io.)

Patterson, A. H. Notes from Gt. Yarmouth. (Zool.)

Riviere, B. B. Birds migrating northwards in Oct. (Brit. Birds, VIII.)

Turner, E. L. Cormorants in Norf. (T.c.)

Williams, H. P. Firecrest in Norfolk. (Op. cit., VII.)

I9I5. Gurney, J. H. The Blakeney Point Ternery (Op. cit., VIII.); The Norf. Ashy-headed Wagtail now identified as a Greyheaded Wagtail ; Birds in Norf. in IgI4. (Op. cit., IX.); Bitterns in Norf. (Ficld, Jan, 2.) Immigration of Roughlegged Buzzards in I9I5-I6. (Trans. Norf. E Norw. Soc., X., pp. $168-70$.

Gurney, J. H. and Turner, E. L. Notes on Long-eared Owl nesting on ground in Norf. (Brit. Birds, IX.)

Patterson, A. H. Ornitholog. War Notes from Gt. Yarmouth. (Zool.) ; Notes from Gt. Yarmouth. (T.c.)

Rowan, W. The Blakeney Point Ternery. (Brit. Birts, VIII.)

Tracy, N. Crossbills breeding in Norf. (T.c.)

Igr6. Borrer, C. Arctic Skua in pursuit of Terns. (Op. cit., IX.); Parrot Crossbill in Norf. (Op. cit., X.) ; Clutch of 4 eggs of Nightjar from Norf. (Bull. B.O.C., XXXVII.) Idem (Brit. Birds, X.)

Chasen, F. N. Observations on the Whimbrel [Norf.]. (Zool.)

Glegg, W. E. Spoonbill in Norf. (Brit. Birds, X.)

Gurney, D. Grey Phalarope in Norf. (Field, Oct. 28.)

Gurney, J. H. Rough-legged Buzzards in Norfolk. (Brit. Birds, IX.) The irruption of Waxwings into Norf. during winter of I9I3-I4. (Avicult. Mag., VII.) Rough-legged Buzzards in Norf. (Zool.)

Morris, S. Bramblings in Norf. (Field, June 3.)

Patterson, A. H. Notes from Gt. Yarmouth. (Zool.)

Sykes, R. C. Firecrested Wren in Norf. (Brit. Birds, IX.)

Upcher, H. M. Cormorants nesting in Norf. (Brit. Birds, X.)

Winckworth, R. Bluethroat off Norf. in May. (Op. cit., IX.)

I9I7-I8. Gurney, J. H. Ornitholog. Notes from Norf. for Igr6-I7, 2 pts. (Brit. Birds, X., XI.)

I9I7. Borrer, C. Unusually small immature Dusky Redshank from Norf. (Bull. B.O.C., XXXVII.) 
Buxton, D. A. J. Skuas and Bearded Tits in Norf. (Brit. Birds, X.)

Gurney, J. H. Breeding of Bittern in Norf. (Avicult. Mag., IX.) ; Little Auks in Norf. ; (Brit. Birds, XI.)

Long, S. Bearded Tit almost extinct in Broadwater dist. owing to severe winter. (Bull. B.O.C., XXXVIII.)

Pashley, H. N. Black-tailed Godwits in Norf. (Brit. Birds, XI.)

Riviere, B. B. On a migration of Swallows in Norf. (T.c.)

Rowan, W. Annotated List of Birds of Blakeney Point. (Blakeney Point Hand Lists, No. I.)

Smalley, F. W. Occurr. of Buff-backed Heron in Norf. (Brit. Birds, XI.)

Wormald, H. Spotted Redshank in Norf. (T.c.)

IgI8. Borrer, C. Richard's Pipit at Blakeney. (Op. cit., XII.)

Gurney, J. H. Ornitholog. Report from Norf. (Avicult. Mag., IX.); Little Auks in Norf. (Brit. Birds, XI.); Crossbills in Norf.; Winter Breeding of Moorhen in Norfolk. (Brit. Birds, XII.)

Jourdain, F. C. R. Reappearance of Fieldfares in Norf. (T.c.)

Long, S. H. Osprey in Norf. (T.c.)

Pigott, T. D. Iceland not Glaucous Gull in Norf. (Op. cit., XI.) Idem by H. M. Upcher. (Op. cit., XII.)

Riviere, B. B. Continental Jays in Norfolk. (Op. cit., XI.) ; Ring Ouzels in Norf. (Op. cit., XII.)

Rowan, W. Annotated List of the Birds of Blakeney Point. (Trans. Norf. \& Norw. Soc., X.)

\section{NORTHAMPTONSHIRE.}

I7I2. Morton, J. Natural History of Northants. Fol. Lond.: I7I2. [4I9.]

I822-4I. Baker, G. History and Antiquities of the Co. of Northants. 2 vols. Roy. fol. Lond. : I822-4I. [36.]

I825. Cole, J. History and Antiquities of Ecton. 8vo. I825. [I38.]

I850. Powys, Hon. T. L. Smew in Northants. (Zool.)

I85I. Powys, T. L. Occurrence of Black Grouse and Quails in Northants. $(O p$. cit.)

I853. Bonney, T. G. Additional Heronry. [Bulwick.] (Nat. [Morris's], III.)

I854. Gates, W. B. Little Auk; Kittiwake in Northants. (Op. cit., IV.)

I855. Powys, T. L. Occurrence of Bittern and Goosander in Northants., etc. (Zool.) 
1856. Church, Rev. W. M. H. Nightingale near Oundle. (Op. cit.)

[Editorial.] Oystercatcher [at Weston Favell.] (Nat. [Morris's], VI.)

Gates, W. B. Golden-Eye and Shag [in Northants.]. 2 notes. (T.c.)

1857. Gostling, W. Wagtails' Nest in Scarlet Geranium Pot. (Zool.) 1858. Maunsell, C. The Smaller Bustard [shot at Rowell]. (Field, Dec. 4.)

1859. "F. T." Late Swallows at Kettering. (Op. cit., Nov. I9.)

Hensman, A. Hobby in Northants. (T.c., Aug. 13.)

$\mathrm{H}[$ ensman], H. P. A Pair of Stormy Petrels. (T.c., Dec. 24.)

I86o. H[ensman] H. P. Bramblings in Northants. (Op. cit., Mar. I7.) Saville, S. P. Note on Variety of Chaffinch; Common Tern shot during late Gale. (Zool.) 2 notes.

I86r. Hensman, H. P. Great Spotted Woodpecker in Northants. (Op. cit. and Field, Mar. 23.)

I865. Hopkinson, J. Duck Decoy [at Peakirk]. (Field, Jan. 28.) "M. W. G." Ring Ouzel at Northampton. (Op. cit., Oct. 28.)

I866. Hensman, J. B. Occurrence of Grey Phalarope and Manx Shearwater in Northants. (Op. cit., Sept. 22.)

"Old Sportsman." Black Tern seen inland. (Op. cit., May 26.)

I867. Hensman, H. P. Rare Birds in Northants. 2 notes. (Zool.)

"Old Sportsman." Quail in January. (Field, Jan. 26.)

I869. Eden, F. M. Wagtail nesting in January. (Op. cit., Jan. 30.)

I870. Cole, J. W. Wood Sandpiper in Northants. (Op. cit., Aug. 6.)

I87I. Ashby, G. A. Hobby and White Sparrowhawk in Northants. (Op. cit., Aug. I2.)

I872. "A. C." Bean Goose [at Aynhac] near Banbury. (Op. cit., Jan. 6.)

Harting, J. E. British Heronries. (Zool.) [partim.] [274.]

Warren, W. Bernicle Goose in Northants. (Field, Feb. 24.)

I873. Treeton, J. Virginian Quail in Northants. (Op. cit., Dec. 6.)

I875. "G. A. W." Hen Harrier in Northants. (Op. cit., Nov. I3.)

Hamel, E. D. Pigeons laying in Magpie's Nest. (Zool.)

"Venator." White-tailed Eagle in Northants. (Field, Jan. I6.) Idem. (Zool.)

I876. Bannerman, G. Rough-legged Buzzard in Northants. (Ficld, Feb. I2.)

Lilford, Lord. Rough-legged Buzzard in Northants. 2 notes. (T.c., Feb. I9, 26.)

Vipan, J. M. Leach's Petrel inland. (T.c., Jan. 8.)

I877. Ashby, G. A. Cormorant in Northants. (OP. cit., Jan. 20.)

Lilford, Lord. Purple Gallinule in Northants. (Zool.) 
I878. Bree, C. R. Spine-tailed Swift [possible occurr. in Northants.]. (Field, Nov. 23, 30.)

"In Vita Fortuna." Hoopoe in Northants. (T.c., Sept. 28.) Prior, C. M. Manx Shearvater in Oxon and Northants. (Zool.)

I879. Aplin, O. V. Skuas and Cormorant in Oxon and Northants. (Op. cit.)

Beardsley, A. B. Bittern in Northants. (Field, Jan. I8.)

Lilford, Lord. Green Shag, Manx Shearwater and Common Scoter in Northants., 3 notes. (Zool.)

Prior, C. M. Manx Shearwater in Oxon and Northants. ; Scoter and Shag in Northants. 2 notes. (T.c.)

Tomalin, W. Buffon's Skua near Northampton. (Field, Nov. I5.)

I880. Lilford, Lord. White-fronted Goose and Solitary Snipe in Northants. 2 notes. (Zool.) Rough Notes on Collection of Northants. Birds. (Midl. Nat.) [353.]

Tomalin, W. Wild Geese near Northampton. (Field, Jan. Io) ; Winter Birds at Northampton (OP. cit., Oct. 30) ; Cormorant [errore for Shag] perching on Church Spire. (T.c., Dec. In $\& \mathrm{I} 8$.

r880-93. Lilford, Lord. Notes on the Birds of Northants, 34 pts. (Jnl. Northants. N. H. Soc., I880-93.) Idem. Reprinted separately I880, I880-83 and I893. Privately printed. [353.]

I88I. Lilford, Lord. Ornitholog. Notes from N. Northants.; Ornitholog. Notes from Northants. (Zool.)

Tomalin, W. Rough-legged Buzzard in Northants. (Field, Oct. I5) ; Black-throated Diver in Northants. (T.c., Nov. 5) ; Thick-knee in Northants. (T.c., Nov. I9.)

I882-96. Lilford, Lord. Notes on Ornithology of Northants. I9 pts. (Zool. 1882-96.) [354.]

1882. Aplin, F. C. Peregrine in Northants. (Zool.)

Tomalin, H. F. Ring Ouzel in Northants. (T.c.) Teal in Northants in June. (Field, June 24.)

I883. Elliott, A. Woodchat near Stamford. (Field, Jan. I3.)

$\mathrm{H}[$ ensman], J. B. Little Auk in Northants. (Op. cit., Dec. 29.)

Lilford, Lord. Ornitholog. Notes from N. Northants. (Zool.)

Tomalin, W. Pied Flycatcher in Northants. (T.c.) Idem. (Field, June r6.)

I884. Aplin, O. V. Great Grey Shrike in Northants, etc. (Zool.)

Slater, H. H. Black Redstart in Northants; Breeding of

Lesser Redpoll in Northants. 2 notes. (T.c.)

I885. Elliott, A. C. Bittern in N. Northants. (Field, Jan. 3.)

Lilford, Lord. Hoopoe in Northants. (Zool.)

I886. Lilford, Lord. Notes on Ornithology of Northants., I879-86. (Reprinted from Zool.) 8vo. I886. [355.] 
I887. Aplin, O. V. Partridges with white horseshoes. (Zool.)

Tomalin, A. [Pied] Flycatcher near Northampton. (Field, May I4, 2I.) 2 notes.

I888. Cottingham, E. R. Rose-coloured Pastor near Weedon. (Op.cit., Oct. 6.)

Lilford, Lord. Black-backed Indian Tree Goose in Northants. (T.c., July 28) : Note of Jack Snipe. (T.c., Nov. 24.)

I889. Bazeley, W. Sand Grouse in Northants. (Zool.)

Tomalin, W. Snipe nesting in Northants. (Field, May Ir.)

I8go-9r. Aplin, O. V. On Distribution and Period of Sojourn in Brit. Islands of Spotted Crake. (Zool.) [partim.] [24.]

I89I. [Editorial.] [Bittern at Weedon.] (Field, Jan. 3.)

Lilford, Lord. Eagle in Warwickshire [records Sea Eagle at Kettering]. (T.c., Mar. 7.)

I892. Aplin, O. V. On Distribution of Cirl Bunting in Great Britain. (Zool.) [partim.] [25.]

Aplin, O. V. Status of the Woodchat in Great Britain. (T.c.) [partim.] [25.]

Tomalin, W. Quail in Northants. (Field, Oct. 8.)

I893. "J. W." Quails in Northants. (Op. cit., Oct. 2I.)

Lilford, Lord. Idem. (T.c., Nov. I8); Peregrine and Tame Ravens. (T.c., Dec. 2.)

T[omalin], W. Rooks nesting in November [I872]. (Field, Nov. I8.)

I894. Wickham, E. C. Pheasant nesting in Tree (Zool.); Idem by Lord Lilford. (T.c.)

I895. Lilford, Lord. Notes on the Birds of Northamptonshire and Neighbourhood. 2 vols. 8vo. Lond.: I895. Idem. Large Paper 2 vols. 4 to. [355.]

Wright, C. E. Late Nesting of Starling. (Nat. Jnl.)

I896. Aplin, O. V. Birds at a Northants. Reservoir. (Ornithologist.) Lilford, Lord. Black-throated Diver in Northants. (Field, Jan. I8.)

1897. Bazeley, W. Gannet in Northants. (Op. cit., Jan. 23.)

Lilford, Lord. Black Scoters in Northants. (T.c., May I5, 29.) 2 notes. Idem by J. E. H[arting]. (T.c., May 22); Idem by F. J. Coleridge. (T.c., June I2.)

Tomalin, W. Great Northern Diver in Northants. (T.c., Jan. 9) ; Early arrival of Swift. (T.c., June I2.)

I898. Beaumont, W. I. Crossbills in Northants. (Op. cit., Nov. 26.) I898-Igor. Slater, H. H. Birds of Northants. and Neighbourhood. Reports for I897-I900. 5 pts. (Jnl. Northants. N. H. Soc., I898-Ig0i.) [543.]

I899. Clarke, J. R. P. Scoter inland. (Field, Jan. 28.) 
I900. Bagshaw, E. T. Little Owl in Northants. (Op. cit., Apr. 28.), Smith, H. Nelson. Storm Petrel [near Peterborough]. (Op. cit. Oct. I3.)

Stockburn, R. W. Little Owl at Kettering. (T.c., Dec. 8.) Whitton, H. W. Rooks nesting in November. (T.c., Nov. I7.)

Igor. Aplin, O. V. The Ivory Gull in Northants. (Ibis.)

Saunders, H. Exhibition of American Bluebird from near Oundle. (Bull. B.O.C., XII., IgOI-02.)

I902. Gurney, J. H. Tengmalm's Owl in Northants. (Zool.)

Slater, H. H. [Aves. In] Victoria Hist. of Co. of Northants., I. 4to. Lond.: I902. [543.]

Stockburn, R. N. Hobby near Kettering in Dec. (Field, Jan. II.)

I904. Aplin, O. V. Little Bunting in Northants. (Ibis.)

Cartwright, F. W. Bittern in Northants. (Field, Jan. 23.)

Milne-Redhead, R. H. Bittern in Northants. (T.c., Jan. 2.)

Tomalin, W. Nutcracker in Northants. (T.c., Apr. 2.) Idem by W. P. Pycraft. (Knowledge.)

I905. Aplin, O. V. White Wagtail in Northants. (Zool.)

Haines, R. Little Owl in Midlands. (Field, May 20.) [partim.] Jourdain, F. C. R. Breeding of Crossbill in Northants. (Zool.)

Wright, C. E. Breeding of Crossbill in Northants. (Jnl. Northants. N. H. Soc.)

I905-IO. Shaw, W. A. Birds of Northants and Neighbourhood: Reports for I902-9, 6 pts. (Jnl. Northants. N. H. Soc., I905-I0.)

1907. Aplin, O. V. Tringa alpina in Northants. (Zool.)

I908. Witherby, H. F., and Ticehurst, N. F. Spread of Little Owl from chief Centres of Introduction. (Brit. Birds, I.) [partim.] $[584,657$.

I909. Aplin, O. V. Hoopoe in Northants. (Zool.)

O'Beirne, A. J. L. Hoopoe in Northants. (Field, May 29.)

I9I0. Cattell, W. C. Rose-coloured Starling in Northants.; Spotted Crake in Northants., 2 notes. (Brit. Birds, III.)

IgII. Aplin, O. V. Habits of the Crested Grebe; Pied Flycatcher in Northants.; Willow Grouse in Northants. 3 notes. (Zool.) Fletcher, J. H. Bird Notes. (Jnl. Northants. N. H. Soc.)

IgII-I2. Cotton, J. D. Birds of Northants. and Neighbourhood: Reports for IgIo-II. 2 pts. (Jnl. Northants. N. H. Soc.)

I9I2. Aplin, O. V. Dark-throated Quail in Northants. (Zool.) Loyd, L. R. W. Breeding Habits of Cuckoo. (Brit. Birds, VI.) W[itherby], H. F. The I9I2 "Wreck" of the Little Auk. (Brit. Birds, V.) [partim.]

Wright, C. E. Little Auks at Kettering. (Zool.)

rgr3. Crisp, J. Little Bittern in Northants. (Field, Jan. 4.) 
IgI4. Aldous, A. E. Tree Creeper hatching Eggs of Redstart. (Brit. Birds, X.)

Sartoris, A. H. Gannet near Kettering. (Field, May I6.)

I9r6. Parker, P. L. Hobby breeding in Northants. (Brit. Birds, X.)

I9I7. Aplin, O. V. Richardson's Skua in Northants. (Field, Nov. I7.)

I9I8. Aplin, O. V. Arctic Skua in Northants. (Brit. Birds, XI.)

\section{NORTHUMBERLAND.}

I769. Wallis, John. Natural History of Northumberland. 4to. Lond. : I769. [6ro.]

I790. Pennant, T. Birds of Farn Islands. [In his Tour in Scotland, MDCCLXIX., 5th edit.] 4to. Lond.: I790. [467.]

I8Ir. Mackenzie, E. View of Co. of Northumberland, etc., 2 vols. 8vo. Newcastle-on-Tyne: I8Ir. Idem. 2nd edit. 2 vols. 4to. I825. [372.]

I826. Selby, P. J. Cat. of Various Birds which at present inhabit or resort to Farne Islands. (Zool. Jnl., II., p. 454.) [See also under 1856 .]

I828. Fox, G. T. Notice on appearance of some rare birds [Red-spotted Bluethroat near Newcastle]. (Zool. Jnl., III., p. 497.)

(Tyne Mercury.) Rare birds shot in neighbourhood of Newcastle. (Loudon's Mag. N. H., I.)

1830. Maddison, D. History and Descriptive Account of Prestwich Carr and Environs. 8vo. North Shields: 1830. [376.]

I83I. Headlam, E. Birds shot in Winter of I829-30 at Greenhow, N. Shields. (Loudon's Mag. N. H., IV.).

Selby, P. J. Cat. of Birds hitherto met with in Counties of Northumb., etc. (Tr. Nat. Hist. Soc. Northumb., Durh., etc.)

I83I-8. Hewitson, W. C. British Oology. 2 vols. Newcastle: N.D., Suppl., I840. And later edns. [293.] [Northumb. refs.]

1832. Fox, G. T. Notice of Some Rare Birds recently killed in Northumb., etc. (Tr. Nat. Hist. Soc. Northumb. \& Durh.)

Greenhow, E. H. Birds of Passage visiting Tynemouth. (Loudon's Mag. N. H., V.).

I834. Selby, P. J. Pres. address. (Hist. Berw. Cl., I., pp. 33-39).

1835. Embleton, R. Pres. address. (T.c., pp. 65-69.)

Selby, P. J. On the instinct of the Water Hen. (T.c., p. 84.) 
I836. Jardine, Sir W., Bt. Pres. address. (T.c., pp. IoI-6.)

Selby, P. J. Capture of Pernis apivorus, etc. (Hist. Berw. Nat. Cl., I., pp. Iog-Io) ; First Report on Fauna of Twizell. (T.c., pp. I33-6.); Scolopax major [nr. Twizell]. (Mag. Zool. \& Bot., I.)

1837. Hancock, A. Motacilla neglecta [shot near Newcastle]; Larus mimutus [at mouth of Tyne]. (Mag. Zool. \& Bot., I., p. 49I.)

Selby, P. J. Distrib. of Corn Bunting in Britain. (Nat. [Wood's], II.) [partim.] ; The Common Crossbill in Northumb. (T.c.) On the Great or Solitary Snipe. (T.c., p. I60.) Fauna of Twizell. (Mag. Zool. \& Bot., Vol. II.)

1838. Hancock, J. Occurr. of Falco islandicus in England (Ann. N. H., II., p. I59) ; Regulus modestus Gould, a Brit. Bird [shot at Hartley]. (T.c., p. 3IO.)

S[elby], P. J. Larus mimutus [shot near Newton]. (Op. cit., I., p. 238.)

1839. Selby, P. J. On effects of Winter of I838. (Hist. Berw. Cl., I., pp. I88-93.)

I840. Embleton, R. On the Little Gull. (T.c., p. 232.)

Forster, W. The Mountain Sparrow. (T.c., pp. 229-30.)

Selby, P. J. On a curious hybrid [Blackgame and Pheasant]. (T.c., pp. 230-2.)

Selby, P. J. Cat. of Generic, etc., types of class Aves. Newcastle : I840. [52I.]

I84I. Selby, P. J. Rept. on ornithology of Berwickshire and district. (Hist. Berw. Cl., I., pp. 250-62.)

1843. Embleton, R. Ciconia alba and Pastor roseus at Newton-by-Sea, 2 notes. (Op. cit., II., p. 78 .)

I844. Bold, T. J. Honey Buzzard rearing its young in this Country. (Zool.)

Carr, R. On flight of Peregrine Falcon. (Hist. Berw. Cl., II., pp. 89-98.)

Selby, P. J. Table of Arrival of Summer Birds of Passage in Neighbourhood of Twizell House for last 20 years. (Zool.) Idem. (Hist. Berw. Nat. Cl., II., 1843, pp. 70-73.)

1845. Bold, T. J. Goshawk in Northumb, ; Iceland Falcon and Rough-Legged Buzzard in Northumb. (Zool.)

I846. Bold, T. J. Richard's Pipit near Newcastle. (Zool.)

Forster, G. J. On habits of the Honey Buzzard. (Hist. Berw. Cl., II., pp. I73-4.)

I847. Johnston, G. Miscellaneous. (T.c., pp. 2I9-20.)

Selby, P. J. Observations and Notes made during I846. (T.c., pp. 205-II.) 
I848. Bold, T. J. Waxwing, near Newcastle and at Earsdon; Bittern at Prestwick Car and Blagdon; Green Sandpiper at Cambo ; Black-throated Diver at Cullercoats. (Zool.)

Broderick, W. On Sclavonian Grebe. (Hist. Berw. Cl., II., p. 278.)

I850. Bold, T. J. Goshawk, Waxwing, Osprey, etc., in Northumb., 6 notes. (Zool.)

Lewins, R. Black-throated Diver, etc., in Northumb. (T.c.)

I85I. Bold, T. J. Waxwings in Northumb. (Op. cit.)

Moffat, A. S. Heronries [Chillingham Park]. (Nat. [Morris's], I.)

1853. Bold, T. J. Hobby near Newcastle-on-Tyne. (Zool.)

I854. Bold, T. J. Rough-legged Buzzard killed on North Tyne. (OP. cit.)

"H. S." Wood Sandpiper breeding near Newcastle. (Nat. [Morris's], IV.)

1855. Bold, T. J. Ruff at Prestwick Car, etc., 3 notes; Pectoral Sandpiper on Coast; Crossbills in Northumb. (Op. cit.)

I856. Selby, P. J. Cat. of Birds which inhabit Farne Islands. (Hist. Berw. Nat. Cl.)

Tate, G. The Farne Islands, with Account of their Zoology, etc. (Op. cit., III., I850-56., pp. 222-50.)

I858-68. Embleton, R. Miscellanea Zoologica, 7 pts. (Op. cit., IV., pp. 9I-2, 459, V., pp. 59, I20, 2I9-20, 34I-4, 407-8).

I859. "D. C." Rare Birds killed in Northumb. (Field, May 7.)

"Culverduck." A Visit to the Farne Islands. (T.c., June 4.)

Tristram, H. B. Hobby in Farne Islands. (Zool.)

"Windham." Jer Falcon in Northumb. (Field, Dec. 3I.)

I860. Embleton, R. On a Turtle Dove. (Hist.Berw. Cl., IV., p. 205.) I86I. Hancock, J. Breeding of Tufted Duck in Northumb. (Zool.) I862. Broderick, W. Note on Noctua tengmalmi. (Hist. Berw. Cl., IV., p. 459.)

Hancock, J. Notice on Occurrence of Red-necked Goatsucker (C. ruficollis) in England. (Ibis.)

I862-77. Adamson, C. M. Ornitholog. Papers reprinted from the Field, I862-77. 8vo. Privately printed.

I863. Embleton, R. Syrrhaptes paradoxus. (Hist. Berw. Cl., V., p. 58).

Tate, G. Notice of Falco nufipes. (T.c., pp. 4-39.)

Wilkinson, W. Sand Grouse near Rothbury. (Field, June I3.)

I865. A[damson], C. M. Green Sandpiper [at Newcastle]. (Op. cit., Aug. 26.)

"R. T." Brambling at Alnwick. (Sci. Gossip.)

Tate, T. Heronry in Chillingham Park. (Hist. Berw. Cl., V., pp. $223-4$.) 
I866. A[damson], C. M. Little Bittern, etc. [in Northumberland]. (Field, Sept. I.)

Brown, W. Short Account of Visit to Farne Islands. (Zool.)

Langlands, J. C. On History and Nat. Hist. of old Berwick. (Hist. Berw. Cl., V., pp. 249-6I.)

Saunders, H. A Visit to ... the Farne Islands. (Zool.)

Yellowley, W. The Waxwing [in Northumberland]. (Field, Dec. 22.)

I866-69. Embleton, R. C. Birds of Alnwick District. [In G. Tate's History of Alnwick.] 2 vols. 8vo. Alnwick: 1866-69.

I867. A[damson], C. M. Water Rail's Nest in Northumb. (Field, July 20.)

Collingwood, F. J. W. Notice of Thalassidroma Bullockii. (Hist. Berw. Cl., V., p. 37I.)

Hancock, J. Black Kite and Phylloscopus superciliosus in Northumb. (Ibis.); Ornitholog. Notes. (Tr. Nat. Hist. Soc. Northumb., I.)

"T. S." Turtle-Doves in Northumb. (Field, July 27.)

I867-8. Simpson, Rev. F. W. Zoological Jottings. (Hist. of Berw. Cl., V., pp. 370-I, 437-8.)

I868. Stuart, C. Notes about Gt. Spotted Woodpecker. (T.c., pp. 407-IO.)

I869. Gurney, J. H., junr. Black Kite at Alnwick. (Zool.)

I870. Charlton, E. The Great Spotted Cuckoo [in Northumberland]. (Field, Sept. 3.)

Gibb, T. H. Notice of Night Heron. (Hist. Berw. Cl., VI., p. I74.)

Ravensworth, Lord. Notice of Some Rare Birds. (Zool.)

Thompson, T. Dates of Breeding of Birds on Tyneside. (Zool.)

I87I. Gregson, G. Bittern in Northumb. (Field, Dec. 30.) Idem by W. S. Ilderton. (T.c., Dec. 9.)

Gurney, J. H. Great Bustard in Northumb. ; Cream-coloured Courser in Northumb., 2 notes. (Zool.)

Newman, E. Nightingale in Northumb. (T.c.)

Watson, J., junr. Great Bustard in Northumb. (T.c.)

I87I-78. Gibb, T. H. Zoological and Ornitholog. Notes. 5 pts. (Hist. Berw. Cl., VI., pp. 248-9, 433-4; VII., pp. 2I0-I3; VIII., pp. I33-4I, 5II-I4.)

I87I-8I. Hardy, J. Zoological Memoranda and Migration Notes. II pts. (Hist. Berw. Cl., VI., pp. 247, 384, 424-33; VII., 290-98, 509-I9; VIII., I89-97, 527-32 ; IX., I22, I57, 387-409, 549-63.)

1872. B[old], T. I. Cormorants of the Farne Islands. (Sci. Gossip.) Elliot, Sir W. Notice of Rare Birds. Hist. Berw. Cl., VI., 3I8-25.)

Gibb, T. H. Ornitholog. Notes from Northumb. (Zool.) 
Hardy, J. On Langleyford Vale and the Cheviots. (Hist. Berw. Cl., VI., 353-75.)

Harting, J. E. Existing Heronries in Gt. Britain. (Field, Feb. I7, Mar. 9.)

Simpson, Rev. F. R. Migratory Birds. (Hist. Berw. Cl., VI., 382-3) ; Supposed reappearance of Sand Grouse. (T.c., 344-5.)

I872-79. Brotherston, A. Zoological Notes. 7 pts. (Op. cit., VI., pp. 434-5 ; VII., pp. I32-5, 285-9, 500-6 ; VIII. ; pp. I8o-8, 520-6; IX., pp. 175-7.)

I873. "C. R. C." Stock-Dove in Northumberland. (F ield, May Io.)

Jobling, J. S. Range of Stock-Dove. (Field, May 3.)

Johnston, G. Our Visit to Holy Island in May I854 [list of birds]. (Hist. Berw. Nat. Cl., VII., pp. 27-52.)

I874. Bolam, R. G. Arrivals, etc., of Birds at Weetwood Hall. (T.c., VII., 283; VIII., I3I.)

Hancock, J. Cat. of Birds of Northumberland and Durham. (Tr. Nat. Hist. Soc. Northumb. \& Durh.) Also separately, I vol. 8vo. Lond., etc. : I874. Idem. Critical Notes by H. Doubleday. (Zool., I875.)

Scott, J. Stork near Berwick. (Hist. Berw. Cl., VII., p. I8o.)

1875. Elliot, Sir W. Rough-legged Buzzard on Borders. (Hist. Berw. Cl., VII., p. 524.) Idem by R. G. Bolam. (T.c., p. 5IO.)

Humble, W. J. Stock-Dove in Northumb. (Zool.) Idem by V. Knight. (T.c.)

I876. A[rcher], H. T. Capercaillie in Northumb. (Field, Oct. 2I.)

Adamson, C. M. On habits of Knot, etc., as observed in Northumb. (T.c., Dec. 9.)

Bolam, R. G. Common Buzzard, etc. (Hist. Bcrw. Cl., VIII., P. I90.)

Evans, A. H. Birds .... observed near Scremerston. (Hist. Berw. Nat. Cl., VIII., pp. I20-22.)

Gurney, J. H., junr. The Farne Islands. (Zool.)

Knight, V. Rare birds in Kelso district. (Hist. Berw. Cl., VIII., pp. IO9-IO.)

Smith, H. A First Peep at the Bird-breeders on Old Farne. (Zool.)

Thompson, T. Shore Lark in Holy Island. (T.c.)

Yuille, S. Hen Harrier in Northumb. (Field, July 8.)

I876-I903. Bolam, G. Ornitholog. Notes. II pts. (Hist. Berw. Cl., VIII., pp. III-I2, 495-8; IX., I65-70, I42 ; X., 384-96, 58I-90 ; XI., 258-63; XIII., 345-68; XVII., 89-I08; XIX., 69-72.)

1877. Archer, H. T. Sea Eagle in Northumb. (Field, Mar. 3I.)

Bolam, R. G. Pied Flycatcher at Linden. (Hist. Berw. Cl., VIII., 274.)

Embleton, D. A Paper on Eggs. Newcastle: I877 [also in N. H. Trans.] 
Knight, V. Ornitholog. Notes. (Hist. Berw. Cl., VIII., pp. 258-63.)

Sutton, J. Purple Sandpiper breeding in Gt. Britain? (Field, May I2) ; Turnstone breeding in Gt. Britain? (T.c., June 2.) Yuille, S. Woodcocks breeding in Northumb. (T.c., May 26.)

I878. Adamson, C. M. Wading Birds in Autumn in Holy Island. (Zool.)

Archer, H. T. Bean-Goose near Newcastle. (Field, Nov. 9.)

Bigge, Rev. J. F. Nightingale in Northumb. (Hist. Berw. Cl., VIII., p. 446.)

Gurney, J. H. Notes on the Farne Islands and some of the Birds which are found there. (Pr. Nat. Hist. Soc. Glasg., I878.)

I879. Bolam, G. Bartram's Sandpiper in Northumb. (Field, Dec. 20.) Davis, G. C. A Visit to the Farne Islands. (Field, Oct. I8.)

I880. Archer, H. T. Grey Plover in summer plumage [in Northumb.]. (Field, Aug. 2I.)

Adamson, C. M. Scraps relating to Nat. Hist. in N. Northumb. (Hist. Berw. Cl., IX., pp. 353-65.)

"D." A Visit to the Farne Islands. (Field, July I6.)

[ $1880-90 \mathrm{ca}$.] Kerr, H. The Birds of Northumberland and Durham, series of articles. (Newcastle Weekly Chronicle.)

I880-8I. Cordeaux, J. King Eider in Farne Islands. (Zool., I880.) Idem by T. H. Nelson. (Op. cit., I88I.) Idem by J. Sutton. (Field, Sept. II, I880.)

I88r. Archer, H. T. Osprey [near N. Shields]. (Field, Oct. I.)

Clarke, W. Eagle. Bird Life at Farne Islands. (Nat.) Also separately.

Cordeaux, J. Notes from Farne Islands. (Zool.)

Dickinson, F. W. Shore Larks on Farne Islands. (Field, Jan. 29.)

Nelson, T. H. Reported Occurrence of Roseate Tern in Farne Islands. (Zool.)

1882. Aitchison, J. Arrivals, etc., of birds. (Hist. Berw. Cl., X., pp. 202-5.)

Archer, H. T. Alpine Swift at Alnmouth. (Field, July 29.)

Smail, J. Rooks and Rookeries. (Hist. Berw.Cl., X., pp. I59-84.)

I883. Archer, H. T. Blue-throated Warbler in Northumb. (Field, Oct. 6, I3); Great Snipe near Newcastle. (T.c., Oct. I3.) 3 notes.

Bidwell, E. On Birds of the Farne Islands. (Pr. E Tr. Croydon Micro. \& Nat. Hist. Cl., I88I-82, pp. I59-67.)

Chase, R. W. Hoopoe at Farne Islands. (Zool.)

Smail, J. Border Heronries. (Hist. Berw. Cl., X., pp. 330-34.) [partim.]

[I883 ?] Clarke, W. Eagle. The Farne Islands and Their Bird Life. Reprinted from The Leodensian. 8vo. Leeds: N.D. 
I884. Bolam, G. Occurrence of Red-breasted Flycatcher. (Nat.)

Chase, R. W. Notes on Terns breeding at Farne Islands. (Midl. Nat.)

Cordeaux, J. In Upper Coquetdale. (Field, Aug. 2.) (Nat., Dec.)

Fox, H. E. Destruction of Bird Life at Farne Is. (Nat., Nov.) ; Gulleries. (Field, Mar. I.)

Harting, J. E. Gulleries in Northumb. (Field, Feb. I6.)

Hardy, J. Ornith. Notes made at Holy Is. (Proc. Berw. N. Cl., June.)

Parsons, J. W. Ornithology of Farne Islands. (Rec. \& Observ. Rotherham Nat. Hist. Soc., I, July.)

Slater, H. H. Ornithology of Riding Mill-on-Tyne and Neighbourhood. (Zool.) ; Winter visit to Farne Islands. (Nat.)

Turnbull, R. Eider Duck on Farne Is. (Sci. Gossip, June.)

I884-5. Aitchison, J. Arrival and Departure of Migratory Birds in Belford District, 2 pts. (Hist. Berw. Cl., X., pp. 579-8I ; XI., pp. 246-7.)

I885. Archer, H. T. Spotted Eagle in Northumb. (Field, Nov. I4.)

Surtees, F. R. Idem. (T.c., Nov. 2I.)

Bowman, J. The Water Ouzel in Northumb. (Sci. Gossip, June.)

Chapman, A. Bird Life on the Border Moors, 6 pts. (Field, Aug. 22, Sept. 26, Oct. I0, 24, Nov. 2I, Dec. I2.)

Chapman, A. Ornithology of Upper Coquetdale. (Nat.)

Chase, R. W. Avifauna of Farne Islands. [In Address to Midland Union.] (Midl. Nat., July.) King Eider shot at Farne Is. (T.c., June.)

Cordeaux, J. Ornitholog. Notes from Upper Coquetdale. (Nat.) "Cheviot's Mountains Lone." (Field, Oct. 3, I7.)

"J. W." Pied Flycatcher breeding in Northumb. (Op. cit., June I3.)

Jewell, R. D. Winter Visitors in Northumb. (Zool.)

Vervart, P. Bittern in Northumb. (Field, Jan. 24.)

I886. Aitchison, J. Occurrences and Migration in Belford District for I885. (Nat.)

Archer, H. T. Peregrine Falcon in Northumb. ; Early Appearance of Snow Bunting; Spotted Eagle in Northumb. (T.c.)

Chapman, A. Brent Geese. (Field, Nov. 27); Wildfowl of N.E. Coast. (Op. cit., Dec. 25.)

Chapman, A. C. Notes from Northumb. Coast; Pied Flycatcher in Northumb. (Nat.); Lesser White-fronted Goose on Northumb. Coast. (Field, Dec. II.) Notes on the Cuckoo. (Nat., Aug.)

Chase, R. W. King-Eider at Farne Islands. (Zool.)

Clarke, W. E. Breeding of Hawfinch in Northumb. (Nat., Aug.) 
Hancock, J. On Indian form of Spotted Eagle shot near Cresswell. (Tr. Northumb. \& Durh., etc., Soc., VIII., pt. 2.)

Lebour, G. A. Outlines of the Geology of Northumberland and Durham. Post 8vo. Newcastle: I886.

Seebohm, H. Lesser White-fronted Goose shot near Holy Island. (P.Z.S.)

Tuck, J. G. Harlequin Duck on Northumb. Coast. (Field, Dec. II.)

1887. Archer, H. T. Grey Plover and Greenshank in Northumb. (Nat.)

Chapman, A. Wildfowl, their Haunts and Habits. (Field, Jan. and Mar.)

Chapman, A. C. On Habits of Wildfowl. (Zool.)

Chase, R. W. Harlequin Duck on Northumb. Coast. (Zool.)

Fortune, R. Ornitholog. Notes from Northumb., etc. (Nat.)

Macpherson, H. A. Distribution of the Goldfinch [Northumberland]. (Field, Dec. I7.)

Nelson, T. H. Naturalist's Ramble on Farne Islands. (Nat.)

Reed, J. T. T. Local Specimens in the Museum at Newcastleon-Tyne. (T.c.)

Robson, C. Red-backed Shrike in Northumb. (Sci. Gossip.)

Saunders, H. Harlequin Duck near Farne Islands. (P.Z.S.; Zool.; Field, Mar. I9.)

Thompson, W. Nat. Hist. notes in Upper Coquetdale. (Hist. Berw. $\mathrm{Cl}$., XII., pp. I28-9.)

1888. Adamson, C. M. Pallas's Sand-Grouse near Newcastle. (Field, Oct. 20.) Idem on Holy Is. by L. M. Crossman. (Op. cit., June I6.)

Barclay, H. Preservation of Sea Birds on Farne Islands. (Field, Oct. $6 ;$ Zool.)

Butler, E. A. Pallas's Sand-Grouse in Northumb. (Zool.)

Chapman, A. C. Breeding of Pallas's Sand-Grouse. (Field, April.)

Culley, M. T. Notes on Birds at Coupland Castle. (Hist. Berre. Cl., XII., p. 393.)

Hancock, J. On two wild Hybrids captured in Northumb. (Tr. Northumb. \& Durh. Soc.)

Pigott, T. D. Birds of Outer Farnes. (Contemp. Rev., Aug.)

Seebohm, H. Young Lesser White-fronted Goose shot at Holy Is. (P.Z.S., Nov.)

I889. [Anon.] Grouse Hawking in Northumb. (Land \& Water, Aug. 24.)

Archer, H. T. Hawfinches in Northumb. (Nat.); Birds at the Northumb. Lakes. (T.c.)

Backhouse, J. Notes on the Sandwich Tern. (Nat.)

Barclay, H. G. Protection of Birds on Farne Islands. (Land $\mathcal{E}$ Water, Sept. 29 ; Dec. 7 ; Field, Dec. 28.) 
Bolam, G. Visitation of Pallas's Sand-Grouse. (Hist. Berw. $\mathrm{Cl}$, XII., pp. 542-5I.)

Chapman, A. Bird-Life of the Borders. Lond.: I889. 8vo. Idem. New edit. Ib. I907. 8vo.

Chapman, A. C. Long-tailed Duck Inland. (Field, Dec. 2I.)

Crossman, L. M. A Rookery on Holy Island. (Op. cit., April 13.)

Duncan, R. Birds of Newcastle-on-Tyne Town Moor. (Nat.)

Newton, A. On irruption of Syrrhaptes paradoxus. (Rept. 58th meeting of Brit. Assoc.) [partim.]

Gurney, J. H., junr. Adams' Diver at Embleton. (Ibis) ; Status of the Firecrest [ref. to Northumb.]. (Zool.)

Hancock, J. On Indian form of Spotted Eagle shot on Northumb. Coast. (Northumb. N. H. Soc. Trans., VIII.)

Howarth, R. Pallas's Sand-Grouse. (Research Mag.) [partim.]

Lebour, G. A. Geology and Natural History of Northumberland and Durham. (Brit. Assoc. Handbook.) Cr. 8vo. Newcastle-on-Tyne: I889.

1890. Aplin, O. V. Distribution of Spotted Crake. (Zool.)

Archer, H. T. Late Breeding of Starling. (Nat.)

Barclay, H. G. Protection of Birds on Farne Islands. (Zool.)

Bolam, G. Birds at Beauly. (Hist. Berve. Cl., XIII., p. 25.)

"Beacons." A day's Bird nesting in Northumb. (Field, Oct. II.)

Chapman, A. C. Long-tailed Duck inland in Northumb. (Nat.) ; Nat. Hist. Notes from the North. (Field, Aug. 2.)

Gurney, J. H. On Birds of Farne Islands. (Tr. Norw. Soc., V.) Hedley, R. C. Birds which frequent Hallington Reservoirs. (Tr. Northumb. \& Durh. Soc., X., pt. 2.)

Macpherson, H. A. Eagles in North of England. (Nat.)

Philipson, J. Matters of Interest to the Naturalist; Pallas's Sand-Grouse in Northumb.; A Raid on Rooks. (Tr. North. \& Durh. Soc., X.)

$\left[\begin{array}{ll}1890 & c a\end{array}\right]$ Duncan, J. Birds of Northumberland and Durham. Series of articles reprinted from Newcastle Weekly Chronicle. [Not seen.]

I89I. Archer, H. T. White-tailed Eagle in Northumb. (Nat.)

Evans, A. H. Prelim. list of Birds of Melrose Dist., 2 pts. (Scott. Nat., XI.) [partim.]

Saunders, H. Dipper nesting in March in Northumb. (Field, April.)

Swinburne, H. Wild Swans in Northumb. (Field, Mar. 7.)

1892. Aplin, O. V. Status of the Woodchat. (Zool.)

[Anon.] Hen Harrier in Northumb. (Land \& Water, Mar. 2I) ;

The Dipper. (T.c., Apr. 9.)

Avery, J. Bird Notes from the North. (Land \& Water, Jan. 2.)

Bolam, G. Snow Goose in Northumb. (Nat.)

Cordeaux, J. A Recent Visit to Farne Islands. (Zool.) 
Norman, G. C. Geograph. Distrib. of Crested Cuckoo. (Ibis, Oct.) [partim.]

Paynter, H. A. Protection of Birds on Farne Islands. (Field, May 7.)

Pigott, T. Digby. Birds of the outer Farnes. (Contemp. Reviere, Aug.)

Warren, R. Birds on the Farne Is. (Field, May 2I.)

I893. Whitlock, F. B. Northumb. Bird Notes. (Nat.)

1894. Chapman, A. C. Short-eared Owls in Northumb., 2 notes; Hooded Crow breeding in Northumb. (Zool.)

I895. Thewe, E., junr. List of Birds of parish of Warkworth. (Hist. Berw. Cl., XV., pp. 307-8.)

Tristram, H. B. Roller in Northumb. (Zool.)

Tristram-Valentine, J. T. The Farne Islands. [In his London Birds and Beasts, pt. III.] Post 8vo. Lond. : I895.

I896-99. Bolam, G. List of Birds of Berwick-on-Tweed, 4 pts. (Ann. Scott. N. H., I896-97, I899.)

I898. Pemberton, B. R. S. Little Gull in Northumb. (Field, Oct. 29.) I899. Bolam, G. Farne Island Birds. (Hist. Berw. Cl., XVII., pp. 38-42.)

I900. Archer, H. T. Buzzards and Hen Harrier in Northumberland. (Nat.)

Fawcett, J. W. Little Tern near Rothbury; Great Spotted Woodpecker in N. of England. (Nat.)

I90I. Fawcett, J. W. Raven in the Cheviots. (Nat.)

1902. Blathwayt, F. L. Roseate Tern on Farne Islands. (Zool.)

Douglas, Sir Geo. Bt. The Farne Islands. (Hist. Berw. $\mathrm{Cl}$., XVIII., pp. 2I9-22.)

Gill, E. L. Early Flycatcher in Northumb. (Zool.)

I903. Blathwayt, F. L. Rambles among the Wild Birds-A Visit to Farne Islands. (Avicult. Mag.)

Bolam, G. Occurrence of Lesser Whitethroat near Berwick. (Hist. Berw. Cl.)

I905. Chapman, A. Montagu's Harrier in Northumb. (Field, Sept. 2.)

Sowerby, J. G. Rooks and their Neighbours. Roy. 8vo. Newcastle; and prev. edn. [555.]

Thompson, W. Rustic Bunting in N. of England. (Zool.)

Walton, J.S. T. Nesting habits of the Wren. (T.c.)

Ig06. Charlton, H. V. Chiffchaff in Northumb. in Dec. (Zool.)

I907. Fortune, R. Birds of Farne Islands. (Nat.)

Walton, J. S. T. Hawfinch breeding in Northumb. (Brit. Birds); Chaffinches, Greenfinches and Yellowhammers, etc. (Zool.) 
I908. Gill, E. L. Niscellanea: Bird Notes for I907-08. (Tr. Nat. Hist. Soc. Northumb., etc.); Glossy Ibises on Northumb. Coast. (Zool.)

Temperley, G. W. Northumb. Coast in September: An Ornithological Ramble. (Tr. N. H. Soc. Northd.)

Walton, J. S. T. Smew inland in Northumb. (Zool.; Brit. Birds, I.); Increase of Starling in Northumb.; Crossbill nesting in Northumb. (Brit. Birds, I.)

I909. Halliday, W. Guide to Holy Island. Post 8vo. Newcastle: Ig09.

IgII. Booth, H. B. Common Gull breeding on Farne Island. (Nat.)

Charlton, J. M. Rough-legged Buzzard in Northumb. (Brit. Birds, IV.) ; Birds of N.E. coast of Northumb. (Zool.)

Ticehurst, N. F. Northern Great Spotted Woodpecker in Northumb. (Brit. Birds, V.)

I9I2. Bolam, G. The Birds of Northumberland and the Eastern Borders. 8vo. Alnwick: I9I2.

Booth, H. B. Nesting of Common Gull on Farne Islands. (Nat.) Chapman, A. Spring Notes on the Borders (IgII-I2.) (Zool.) Charlton, J. M. Uncommon Birds on S.E. Coast of Northumb. ; Little Auks in Northumb.; Movements of Brent Geese on Coast of Northumb. (Brit. Birds, V.); Tengmalm's Owl captured in Northumb.; Hen-Harrier in S.E. Northumb. (Op. cit., VI.) ; Birds of N.E. Coast between Tynemouth and Seaton Sluice, 4 pts. (Zool.)

Halliday, W. The Book of Migratory Birds met with on Holy Island and the Northumbrian Coast. 8vo. Lond.: I9I2.

I9I3. Atkinson, J. Strangers at the Farnes. (Naturalist.)

Blathwayt, F. L. Black Redstarts in Northumb. (Brit. Birds, VII.)

Bolam, G. Black-headed Gull in breeding plumage in Northumb. (Zool.)

Charlton, J. M. Movements of Little Auks on Northumb. Coast. (Brit. Birds, VI.)

Fortune, R. Notes on the Farne Islands for IgI2. (Nat.)

Hodgkin, C. Little Tern breeding in Northumb. (Brit. Birds, VI.)

Knott, S. C. Woodcock alighting in Newcastle. (Ficld, Oct. I8.)

I9I4. Charlton, J. M. Visitation of Black Redstarts in Northumb. (Zool.)

Portal, M. Increase of Tufted Duck breeding in Northumb. (Brit. Birds, VIII.)

Turner, E. L. White's Thrush in Northumb. (T.c.)

I9r5. Robinson, J. W. Garganey in Northumb. (Field, Mar. 20.) Turner, E. L. On "Wait and See Photography." pt. II. [Northumberland.] (Brit. Birds, IX.) 
I9I6. Hodgkin, C. Spoonbill in Devon [and Northumb.]. (Op. cit., IX.)

I9I7. Bolam, G. Unusual nesting sites of Pied Wagtail in Northumb. $(O p$. cit., X.) ; Late Stay of Cuckoo. (T.c.)

I9I8. Miller, E. List of Summer Birds observed on outer Farne Islands. (Op, cit., XII.)

\section{NOTTINGHAMSHIRE.}

1837. (Ex Analyst.) Yellow-nosed Albatross, a British Bird [one shot in Notts.]. (Nat. [Wood's], II.)

I839. Enfield, R. Black Scoter and Crested Grebe near Nottingham. (Op. cit., IV.)

I846. Wolley, J. Occurrence of Rough-legged Buzzard in Notts., etc. (Zool.)

I848. Foottit, W. F. Provincial Names of Birds, Notts. (Op. cit.)

I85I. Hannaford, S., junr. Great Spotted Woodpecker [near Worksop]. (Nat. [Morris's], I.)

I854. Milner, W. M. E. Tufted Duck breeding at Osberton. (Zool.) Idem by D. Graham. (Nat. [Morris's], IV.)

Foottit, W. F. Occurrence of Little Bustard in Lincs. [and Notts.], (Zool.).

1856. Foottit, W. F. Avocet near Newark. (Op. cit.)

Wolley, C. Avocet in Notts. (T.c.)

1857. [Editorial.] Capture of Eagle [near Worksop]. (Field, Jan. 3I.) "J. H." Blackstart [near Nottingham]. (Op. cit., Dec. 26.)

Matthews, H. Avocet near Newark. (Zool.)

1859. "W." Quails [in Notts.]. (Field, Jan. I.)

"W. H." Pied Flycatcher [shot at Southwell.] (T.c., May 28.)

I86I. [Editorial.] Buzzard [shot at Newstead Abbey]. (Op. cit., Apr. 6.)

I863. "C. M." Pallas's Sand-Grouse [near Farnsfield]. (Op. cit., June 6.)

I865-67. Sterland, W. J. [Ob. Aug. 20, I88I.] Birds of Sherwood Forest. (Ficld, XXVI, pp. 320, 432-3,480; XXVII, Jan. I3, 27, Feb. Io, 24, Mar. 24, Apr. 7, May 5, June 2, July 28, Aug. II, Dec. I5, 22 ; XXIX, pp. 33, 57, I05, I68, 226, 347, 470 ; XXX, pp. 73, II8, 2I0.)

I866. Felkin, W., junr. Ornithology of Nottinghamshire. [In Allen's Handbook and Guide.] 8vo. Nottingham, etc. : 1866.

Tillery, W. Birds visiting Sherwood Forest. (Field, Jan. 27.) 
1867. “H. T." Little Bustard at South Clifton. (Sci. Gossip.)

I868. Hedderly, J. S. Red-necked Grebe near Nottingham. (Zool.) I869. Sterland, W. J. The Birds of Sherwood Forest. Post 8 vo. Lond.: I869. [559.]

1870. Boyes, F. Little Bittern in Notts. (Zool.)

I87x. "F. W. H." Hawfinch in Midland Counties. (Field, Aug. 26.) Idem by E. F. Peterson. (T.c., Sept. 2.)

"F. F. M." Quails in Britain [near Mansfield]. (Op. cit., Feb. II.) Whitaker, J. Rare Birds in Notts. (Zool.; Field, Aug. 26.)

1872. Harting, J. E. British Heronries. [partim.] (Zool.)

Whitaker, J. Quails breeding in Notts. ; Rare Birds in Notts. ; Spotted Crake near Nottingham; Abundance of Short-eared Owls, Waxwings and Little Bittern in Notts.; [Escaped] Virginian Colin in Notts., etc. (Zool.)

Wild, H. Storm Petrel in Notts. (Field, Nov. 30.)

I872-5. Whitaker, J. Spring Arrivals, 4 notes. (Zool, I872-5.)

I873. "C. W. M." Waxwing near Newark. (Field, Feb. I5.)

Whitaker, J. Short-eared Owl in Notts.; Great Grey Shrike ; Spotted Redshank; Glaucous Gull in Notts. (Zool.) 4 notes.

I874. Sterland, W. J. Egyptian Geese near Nottingham. (Field, Jan. 3.)

Whitaker, J. Siskins near Mansfield; Chiffchaff, Swift and Fieldfare [at Calverton]; Egyptian Geese and Bar-tailed Godwit in Notts.; Ducks breeding in Rainworth Water; White Swallow in Notts. (Zool.) 6 notes. Bar-tailed Godwit in Notts. (Field, Sept. 19.)

1875. Whitaker, J. Capercaillie [error, afterwards corrected], Grey Phalarope, Bitterns, Peregrine Falcon and Curlew in Notts., 5 notes. (Zool.) Arrival of Spring Birds. (Field, May 22.)

1876. [Anon.- "H. F. C."] Great Grey Shrike near Newark. (Field, Jan. I.)

Moore, C. Rough-legged Buzzard in Notts. (Field, Feb. 5.) Prior, C. M. White Starling in Notts. (Zool.)

Whitaker, J. Common Skua near Mansfield; Kite, Hen-Harrier and Hobby in Notts.; Birds near Rainworth; Rough-legged Buzzard at Rufford. (Zool.)

1877. Whitaker, J. Ornitholog. Notes from Notts. (Op. cit.); Tufted Duck breeding in Notts. (Field, May I9, July I4.)

I878. Whitaker, J. Little Auk in Notts. ; Provincial Names (Notts.). (Zool.)

1879. Howes, H. V. Gannet inland. (Field, Dec. 20.)

Mellish, H. Buzzard in N. Notts. (Midl. Nat.)

Sterland, W. J., and Whitaker, J. Descriptive List of the Birds of Nottinghamshire. 8vo. Mansfield : I879. [559.] 
Whitaker, J. Rare and Uncommon Birds in Notts. (Zool.) Rare Birds in Notts. (Field, Feb. 15) ; Tufted Duck in Notts. (Field, Aug. 30.)

I880. Becher, E. F. Garganey in Notts. (Field, Aug. 28.)

Padley, G. E. B. Great Grey Shrike in Notts. (Field, Nov. I3.)

Dufty, J. N. Rough-legged Buzzard and Great Grey Shrike in Notts. (Field, Nov. 27.)

"C___.." Rough-legged Buzzard and Spotted Crake in Notts. (T.c., Oct. 30.)

Sterland, W. J. Breeding of Tufted Duck in Notts. (T.c., Nov. I3.; $c f$. also Aug. I4.)

Whitaker, J. Breeding of Tufted Duck. (Zool.); Grey Lag Geese in Notts. in June ; White Jay in Notts. (Field, Nov. 27.) Notes from Notts. (T.c., Dec. I8.); Osprey in Notts. (T.c., May 22.)

I88r. Dufty, J. N. Buffon's Skua in Notts. (Field, June, 25; Sci. Gossip.)

Mellish, H. Rough-legged Buzzard in Notts. (Field, Jan. I.)

Parkinson, C. Grosbeaks at Cotham. (Sci. Gossip.)

Whitaker, J. Notes on Birds in Notts. (Field, Feb. I9) ; Wood Sandpiper in Notts. (Op. cit., Aug. 20) ; Long-tailed. Duck in Notts. (T.c., Nov. I2.)

I882. Brown, J. H. Ornithological Notes from Nottingham. (Field, June I7.)

Dufty, J. N. Nightingale North of the Trent. (Ficld, June 3.) Stephenson, A. Ornithology of Notts. [In Address to Midl. Union N. H. Soc.] (Midl. Nat.)

Whitaker, J. Notes on Birds in Notts. ; Abnormally coloured Birds in Notts.; Wildfowl breeding at Rainworth. (Zool.) Chiffchaff in Notts. [on Feb. 28.] (Field, Mar. 4, rI) ; Manx Shearwater in Notts. (Op. cit., Sept. 9); Eider Duck in Notts. (T.c., Nov. 25); Solitary Snipe in Notts. (T.c., Nov. I8.)

I883. Harting, J. E. Egyptian Nightjar at Rainworth. (Field, Sept. I5.)

Whitaker, J. Red-backed Shrike, Manx Shearwater, Great Snipe, Eider Duck and Egyptian Nightjar in Notts. (Zool.) Scaup-Duck in Notts. (Field, Dec. 8); Common Buzzard in Notts. (T.c., Dec. 22.)

1884. Cordeaux, J. Nesting of Tufted Duck in Notts. (Field, Nov. I.)

Gurney, J. H. Egyptian Nightjar in Notts. (Ibis.)

"Histos. C." Puffin in Notts. (Field, Nov. 29.)

Matthews, A. J. Golden Oriole in Notts. (Field, May 3I); Idem. (Land \& Water, May 3I.) 
Whitaker, J. Scaup-Duck, Common Buzzard, Montagu's Harrier, Dotterel and Wood Sandpiper in Notts., etc. (Zool.); Notes from Rainworth. (Nat.)

1885. Lee, L. Sand-Martins and their Nests [in Nottingham Park]. (Sci. Goss., Sept.)

Whitaker, J. Puffin, Grey Lag Goose, Little Owl and Purple Sandpiper in Notts.; Redshanks nesting in Notts; Grey Phalarope at Mansfield, etc. (Zool.) ; Notes from Rainworth; Grey Lag Goose in Notts.; Puffin in Notts.; Woodcock in Notts. (Nat.)

1886. Ashworth, J. R. Emberiza melanocephala in Notts. (Zool.)

"Avis." Redshank breeding in Notts. (Field, April 24.)

Byron, A. W. Woodcock shooting in Notts. (Field, Dec. 25.)

Dufty, J. N. Varieties of Common Birds. (T.c., Oct. 23.)

Whitaker, J. Velvet Scoter and Bittern in Notts. ; Breeding of Shoveler in Notts., etc. (Zool.)

Whitlock, F. B. Dunlins and Black Tern near Nottingham. (Nat.)

I887. Aplin, O. V. A Visit to Rainworth Lodge. (Nat.)

Becher, W. Montagu's Harrier in Notts. (Zool.)

Whitaker, J. Male Tufted Duck retaining breeding plumage, etc. ; Norfolk Plover nesting in Notts. 6 notes. (Zool.); Varieties of Wild Duck and Peregrine in Notts. (Nat.)

Walker, C. Long-tailed Duck near Newark. (Field, Nov. I9.)

1888. Bidwell, E. Pallas's Sand-Grouse [in Sherwood Forest.] (Op. cit., Aug. 4.)

Gainsborough, Lord. Pallas's Sand-Grouse in Notts. (T.c., July 2I.)

Terry, C. E. Storm Petrel Inland. (T.c., Nov. 24.)

Whitaker, J. Sand-Grouse [in Notts.] (Field, June 23, 30, July 7 , Sept. 22) ; Crossbills in Notts. (T.c., Dec. I) ; Note of the Jack Snipe. (T.c., Dec. I.)

Whitlock, F. B. Nanx Shearwater near Nottingham; Irruption of Pallas's Sand-Grouse; Notes on the Reed Warbler. (Nat.)

I889. Aplin, O. V. In Sherwood Forest, 2 pts. (Midl. Nat.); Black Grouse in Mansfield Forest. (Nat. Hist. Jnl.)

Kershaw, B. Little Bittern in Notts. (Field, Aug. 3I.)

Nicholl, D. S. W. Black-winged Stilt in Notts. (Zool.) [errore cf. Zool., I890.]

Phillips, E. C. The Great Black Woodpecker in England. [ref. to Notts.] (T.c.)

Whitaker, J. Stone Curlew breeding in Notts.; Goldeneyes at Rainworth ; Grey Shrike in Notts. ; Sand-Grouse in Notts. (Zool.): The Kingfisher, as observed in Notts. (Land \& Water]; Arrival of Summer Birds. (Field, Apr. 20, 27, May II.) Sand Grouse in Notts. (Op.cit., July I3.)

Whitlock, F. B. Autumn and Winter Notes from Notts. (Nat.) 
Wright, S. H. Golden Oriole in Notts. (Nat. Hist. Jnl.) [? Derbyshire.]

I89o. Whitaker, J. Osprey and Pine Grosbeak in Notts.; Arrival of Fieldfares (Field, Oct. 25); Arrival of Snipe. (T.c., Nov. I5) ; Pine Grosbeak in Notts. (T.c., Dec. 6.)

Whitlock, F. B. Notes on the Tree Sparrow, 3 notes; Dunlins and Ringed Plovers; Autumn Bird Notes from Notts. (Nat.)

I890-9I. Aplin, O. V. Distrib. of Spotted Crake [in Notts.] 2 pts. (Zool., I890-9I.)

I89I. Buttress, L. Little Auk in Notts. ; Manx Shearwater inland in Notts. (Zool.)

Elliott, A. C. Grey Phalarope in Notts. (Field, Oct. 3I.)

Harting, J. E. Wood Warbler in the Midlands. (Zool.)

Platt, T. E. Great Spotted Woodpecker in Notts. (Nat.)

Walker, C. Wildfowl in Notts. (Field, Jan. Io.)

Whitaker, J. Arrival of Sum.ner Birds. (T.c., May 9); Redthroated Diver and other Birds in Notts. ; Redwings singing in April; Tufted Ducks nesting in Notts.; Wildfowl on Rainworth Water. (Zool.)

Whitlock, F. B. Pine Grosbeak in Notts. ; Ornitholog. Notes from Notts., Autumn and Winter, I890-9r; The Pied and White Wagtail in Notts. (Nat.); Manx Shearwater inland. (Zool.)

1892. Aplin, O. V. Distrib, of Cirl Bunting; Status of Woodchat. (Zool.) [partim.]

Buttress, L. Puffin inland in Notts. (Zool.) ; Tufted Duck in Notts. (Nat.)

Petty, L. The Nightingale in Notts. (Nat.)

Rose, B. Buff-coloured Woodcock in Notts. (Field, Feb. 6.)

Whitaker, J. Ruff in Notts. (Zool.); Hen Harrier in Notts. (Field, Feb. I3.)

Whitlock, F. B. Pallas's Grey Shrike in Notts. ; Marsh Warbler in Notts. (Zool.) ; Notes on the Great Crested Grebe in Notts. ; The Nightingale in Notts. (Nat.)

I893. Buttress, L. Baillon's Crake in Notts. (Zool.); Ornitholog. Notes from N. Notts. for I89I-92. (Nat.)

Cordeaux, J. Manx Shearwater in Notts.; Nesting of Hawfinch near Retford. (Nat.)

Elliott, A. C. Avocet in Notts. (Zool.): Idem. (Field, July r5.)

Whitaker, J. Little Gull, Black-tailed Godwit, Hen Harrier and Baillon's Crake in Notts., 4 notes. (Zool.)

Whitlock, F. B. Bird Notes from Notts., 1892-3; Migratory Birds in Trent Valley; Little Gull in Notts.; Cormorant at Newark-upon-Trent. (Nat.)

Whitlock, F. B. Birds [in Brit. Assoc. Handbook to Notts.] Cr. 8vo. I893.

I894. Buttress, L. Ornithological Notes from N. Notts., I893. (Nat.) 
Whitaker, J. Garganey at Rainworth. (Zool.)

Whitlock, F. B. Caspian Tern on the Trent. (Nat.)

I894-7. Whitlock, F. B. Bird Notes from Mid-Trent Valley, 3 pts. (Nat., I894-5-7.)

1895. Musters, P. Grey Lag Geese breeding in Notts. (Zool.)

Swann, H. Kirke. Some Birds in Nottingham Museum. (Nat. Journ.)

Whitaker, J. Quails in Notts. (Zool.)

I8g6. Musters, J. P. C. Sea Eagle in Notts. (Op. cit.)

Whitaker, J. Spring Birds in Notts. (Ornithologist.)

Whitlock, F. B. Breeding Habits of the Sparrowhawk. (T.c.)

I897. Whitaker, J. Little Owl near Newark-on-Trent. (Zool.)

I898. Whitaker, J. Scoters in Notts. ; Heron's Nest of Wire; Great Skua in Notts. (Zool.) 4 notes.

I899. Whitaker, J. Peregrine Falcon and Rough-legged Buzzard in Notts. (Field, Apr. I) ; Tree Creeper nesting in Roof ; Notes from Rainworth. (Zool.) 2 notes.

1900. Whitaker, J. Buzzard in Notts. (Field, Feb. 3); Mistle Thrush nesting near the ground. (T.c., May 5.); Partridges in Notts. (Zool.)

Igor. Whitaker, J. Rare Birds in Notts. (Zool.)

I902. Whitaker, J. Two-barred Crossbill in Notts. (Op. cit.)

I903. Whitaker, J. Wild Swans at Rainworth; Great Crested Grebe on Mansfield Reservoir; Osprey, Rough-legged Buzzards, Hen Harrier and Honey-Buzzard in Notts. (Op. cit.) ; Osprey and Buzzard in Notts. (Field, Nov. I4.)

I904. Whitaker, J. Scribblings of a Hedgerow Naturalist. 8vo. Nottingham: rgo4. [626.]

Whitaker, J. Kentish Plover at Rainworth. (Field, Apr. 23.); Kestrel laying in artificial Nesting Box, etc.; Kentish Plover at Rainworth. (Zool.) 2 notes.

rg05. Whitaker, J. Occurrence of Turdus dubius in Notts. (Field-?) Idem by P. C. Musters. (Bull. B.O.C.. XVI., I906.)

Whitaker, J. Birds. [In Victoria History of Co. of Nottinghamshire, I.] 4to. Lond. : I906. [627]

Whitaker, J. Wood-Pigeons and Stock-Doves: Montagu's Harrier at Rainworth in June; A New Notts. Bird. (Zool.) 3 notes.

1907. Whitaker, J. Notes on the Birds of Nottinghamshire. 8vo. Lond. : 1907. [627.]

rg08. Whitaker, J. Short-eared Owl nesting at Rainworth ; Interesting Ducks in Notts. (Zool.); Supposed Black Woodpecker in Notts.; Blue-headed Wagtail in Notts.; Short-eared Owl breeding in Notts. (Brit. Birds.) 
I909. Carr, J. W. Notts. Bird Notes. (Zool.)

Whitaker, J. Glossy Ibises in Notts. (Brit. Birds.)

Igro. Pearson. H. J. Hoopoe in Notts. (Op. cit., IV.)

IgIr. Ticehurst, N. F., and Jourdain, F. C. R. Distrib. of Nightingale. $(O p$, cit., V.) [partim.]

Igr2. Jourdain, F. C. R. The I912 "Wreck" of the Little Auk: Nottingham. (Brit. Birds, V.)

Whitaker, J. Little Auk in Notts. (Field, Feb. 24; cf. Brit. Birds, V., p. 3Ir.)

I9r3. Pearson, C. E. Little Owl breeding in Notts. (Brit. Birds, VII.) Whitaker, J. Baer's Pochard in Notts. (Zool.)

I9r4. Pearson, C. E. Probable Yellow-browed Warbler in Notts. (Brit. Birds, VIII.)

Proger, T. W., and Paterson, D. R. Ornithol. Notes IgI4 [on Waxwing in Notts.]. (Rept. \& Trans. Cardiff Nat. Soc., XLVII., pp. 45-49.)

Reid, J. L. Bittern in Notts. (Field, Feb. 28.)

Whitaker, J. Baer's Pochard in Notts. (Brit. Birds, VII.); Idem by Duchess of Bedford. (T.c.)

I9I5. Dawes, W. Dunlin in N. Notts. in Summer Plumage ; Little Owl in N. Notts.; Albino Pheasant at Welbeck Abbey. (Zool.) [Editorial.] Increase of Little Owl in Notts. (Brit. Birds, IX.)

IgI6. Mullens, W. H. Stock Dove using Thrush's nest. (Field, Sept.)

I9I7. Colley, F. H. Quail in Notts. (Field, Oct. I3.)

\section{OXFORDSHIRE.}

I677. Plot, R. Natural History of Oxfordshire. Folio. Oxford: I677. Second edit. Ib. I705. [475.]

I829. "H." A variety of the Moor Buzzard [near Bicester]. (Loudon's Mag. N.H., II.)

I832. G[oatley], T. The Fork-tailed Petrel and Grey Phalarope taken near Chipping Norton. $(O p$. cit., V.)

I833. Hunter, P. Pair of Ferruginous Ducks [on Otmoor Common]. (Op. cit., VI.)

1836. [Anon.] A Falco haliaëtıs L. shot near Oxford. (Op. cit., IX.)

I84I. Beesley, A. The History of Banbury. 8vo. Lond. : I84I. [52.] Goatley, T. On a specimen of the Shearwater Petrel; Kite, etc. (Ann. Mag. Nat. Hist, VI.)

I842. Goatley, T. The Hoopoe: the Arctic Gull. (Ann. \& Mag. Nat. Hist., VIII.)

I843. Holme, F. Note on Kestrel ; Note on Occurrence of Eared Grebe at Oxford. (Zool.) 
I844. Wilmot, J. P. Note on Honey Buzzards breeding in England. (Zool.)

I845. Goatley, T. Migration of Water Rail. (Op. cit.)

Holme, F. Habits of Kestrel ; Notes on Sand Martins at Oxford, etc. $(O p$. cit.)

Newman, E. Occurrence in Oxon of Andalusian Quail ; Description of New British Quail. (Op. cit.)

Wyatt, F. Rooks breeding in November. (Op. cit.)

I847. Goatley, T. Occurrence of Grey Phalarope near Chipping Norton; of Stormy Petrel near Chipping Norton ; of Little Auk. (Zool.) 3 notes.

Roundell, $\mathrm{H}$. Nesting of Tree Sparrow in Oxon. (Op. cit.)

I848. Gcatley, T. Occurrence of Merlin in Oxon. ; Note on Great Plover; Migration of Golden Plover. (Op. cit.)

Prater, T. Occurrence of Roseate Tern near Bicester. (T.c.) Roundell, H. Occurrence of Temminck's Stint near Oxford; Black Tern. (T.c.)

I849-5I. Matthews, Rev. Andrew, and H. Birds of Oxon. and its neighbourhood. (Zool. I849.) Suppl. (Op. cit., I85I.)

I85I. Matthews, A. Dates of Arrival and Departure of Migratory Birds during 1850 . (Op. cit.)

1852. Stubbs, C. Black Scoter [at Henley]. (Nat. [Morris's], II.)

I853. Norman, A. M. Note on late Nidification of Birds. (Zool.)

Powys, T. L. Occurrence of Sandwich Tern, etc., near Oxford. (Zool.) Captures of Various Birds. (T.c.)

Stone, S. Notes on the Tree Sparrow [Colony at Standlake]. (Nat. [Morris's], III.)

Stubbs, C. Waxwings and Spotted Rail; Crested Grebe and Red-necked Grebe [at Henley]. 2 notes. (Nat. [Morris's], III.)

I854. Powys, T. L. Occurrence of various Birds in Oxon. Note on late abundance of Spotted Crake. (Zool.)

Stubbs, C. Notes from Henley-on-Thames. (Nat. [Morris's], IV.)

1854-5. Stone, S. Feathered Residents in Grounds of Terrick House, Brighthampton, 6 pts. (Op. cit., IV., V.)

I855. Whiteaves, J. F. Birds near Oxford. (Op. cit., V.)

I859. "C. A." A hen Hobby [near Chipping Norton]. (Field, Apr. 9.) Body, R. B. The Hoopoe [in Oxon.]. (Field, May 7); Raræ Aves in Oxon. (T.c., May I4.)

Mathews, M. A. Little Bustard near Oxford. (Zool.) [errore: Berks.]

"R. T." Little Bustard [near Oxford.] (Ficld, Oct. I5.)

I862. "Gairloch." Black Stork near Bicester. (Field, Nov. I5.) Hollis, W. Snipe's Nest in Oxon. (Zool.) 
I865. Sheppard, C. A. Occurrence of Hoopoe. (Field, Apr. 29.)

Stubbs, C. E. Snipes and Wagtails at Henley-on-Thames. $($ Zool.)

I868. "Cosmopolite." Bittern in Oxon. (Field, Nov. I4.)

Harcourt, E. W. Little Auk at Abingdon. (T.c., Nov. I4.)

I869. Im Thurn, E. F. Rare Birds in Oxon. (Field, June 5.) Painted Bunting in Oxon. (T.c., June I2.)

Stubbs, C. E. Ornithological Notes from Henley-on-Thames. (Zool.)

I870. "Cosmopolite." The Goosander in Oxon. (Field, Mar. I9.)

" J. W. O." Red-breasted Mergansers at Oxford. (Ficld, Feb. 25.) Idem by G. O. Pardoe. (T.c., Mar. 5.)

I87I. M[ackenzie], W. D. Cormorant inland. (Field, June 3.)

I872. "A. C." Bean Goose near Banbury. (Field, Jan. 6.)

Dale, T. Goosander in Oxon. (T.c., Feb. I7.)

"E. H." Rose-coloured Pastor in Oxon. (T.c., Mar. 23.)

Sheppard, C. A. Northern Diver in Oxon. (Op. cit., Nov. 30.)

I873. Smee, A. H. Greenshank and Common Tern in Oxon. (Zool.)

1874. Dale, T. Peregrine near Witney. (Field, Apr. 4.)

1875. Dale, T. Hoopoe in Oxon. (Op. cit., May 8.)

I876. Prior, C. M. Kestrels near Banbury; Large Flock of Magpies. (Zool.)

Worley, J. Hen Harrier at Brize Norton. (Field, Aug. 5.)

1876-7. Prior, C. M. The Birds of North Oxon. (Banbury Guardian, I876-77.)

I877. Prior, C. M. Black Stork in Oxon. (Zool.; Field, Mar. I0); Hobby in Oxon. (Zool. ; Field, Aug. II.)

1878. Falcon, T. W. Bittern in Oxon. (Field, Dec. 2I.)

Prior, C. M. Manx Shearwater in Oxon. ; Singular Immigration of Jays into Oxon. (Zool.)

I879. Aplin, O. V. Skuas and Cormorant in Oxon. (Op. cit.); Unusual Departure of Birds; Ornitholog. Notes, 5 notes. (Mid. Nat.)

Ellis, A. J. Quail found in Oxon. (Field, May 24.)

Prior, C. M. Ornitholog. Notes from Oxon.; Nesting of Grey Wagtail ; Manx Shearwater in Oxon. (Zool.)

I880. Aplin, O. V. Peregrine Falcon and Curlew in Oxon. ; Spotted Woodpecker near Banbury; Rare Birds in Oxon. (Op. cit.) Autumn and Winter Migratory Birds of Bodicote. (Mid. Nat.)

I880-8I. Aplin, O. V. Ornitholog. Notes from Oxon, 8 notes. (OP. cit., I880-8r.) 
I88I. Aplin, F. C. Hobby Nesting in Oxon. (Zool.)

Aplin, O. V. Ornitholog. Notes: Shoveler in Oxon. Late stay of Swifts in N. Oxon. ; Chough in Oxon. (2 notes.) (Op. cit.); Arrival of Migratory Birds in N. Oxon.; Alpine Chough in Oxon. (Mid. Nat.)

Purnell, W. Late stay of Swifts. (Zool.)

Matthews, A. On Food and Habits of Bittern. (Op. cit.)

I882. Aplin, F. C., O. V., and B. D. List of Birds of Banbury District. 8vo. Banbury: I882. Idem (Jnl. Northants. N. H. Soc., I883.) [24.]

Aplin, F. C. Chiffchaff in Oxon. in Winter. (Zool.)

Aplin, O. V. Supposed Occurrence of Hairy Woodpecker in Oxon. ; Leach's Petrel in Oxon. ; Dipper Nesting in N. Oxon. ; Firecrest in Oxon. ; Early Arrival of Jack Snipe, etc., (6 notes.) (T.c.) Arrival of Migratory Birds in N. Oxon. ; Breeding of Great Crested Grebe in N. Oxon. ; Leach's and Stormy Petrels in Oxon. (Mid. Nat.)

Macpherson, H. A. Tufted Duck near Oxon. (Field, Feb. 4.) Goshawk near Oxford. (Op. cit., Oct. 28.)

Whitaker, J. Alpine Chough in Oxon. (Zool.)

I883. Aplin, O. V. Great Crested Grebe breeding in Oxon.; Migration of Jay; Grey Phalarope in N. Oxon. ; Tufted Duck and Common Tern in Oxon.; Jack Snipe in Oxon. in Summer. (Zool.) Arrival of Migratory Birds in N. Oxon. in Spring of 1882 ; Summer Migrants. (Mid. Nat.)

Arnatt, A. Common Buzzard in Oxon. (Field, Nov. I7.)

Battye, A. B. R. Fire-crested Wren at Oxford. (Zool.)

Macpherson, H. A. Lesser Redpoll breeding near Oxford; Goshawk near Oxford; Hobby breeding in Oxon. [errore: Berks.]; Food of Bittern; Marsh Tit in Oxford; Goldfinch in Oxon. (T.C.)

1884. Aplin, F. C. Hobby in Oxon. (Zool.)

Aplin, O. V. Wild Fowl in N. Oxon. ; Great Grey Shrike in Oxon. ; Fieldfares and Redwings; Rare Visitors to N. Oxon. (T.c.)

Loveday, J. E. T. Pied Flycatcher at Banbury. (Field, May 3.)

I884-7. Aplin, O. V. Ornitholog. Notes from Oxon., 4 pts. (Zool., I884-7.)

I885. Aplin, O. V. Unusual Congregation of Carrion Crows; Grey Shrikes in Oxon.; Late stay in Autumn of Green Sandpiper. $(O p$. cit. $)$

Fowler, W. W. Black Redstart in Oxon. (T.c.)

Haldane, C. Quail in Oxon. (Field, Oct. 3.)

Newton, W. Green Sandpiper and Dunlin in Oxon. (Op. cit., Jan. 24.)

I886. Aplin, O. V. Habits of Coot; Swallows dying of cold; Variation in size of Water Rail. (Zool.) 
Fowler, W. Warde. Year with the Birds. 8vo. Oxford : I886. 2nd edit. Lond. : I886. 3rd edit. I89I. [220.]

Macpherson, Arthur H. Buzzard and Bittern near Oxford. (Zool.)

I887. Aplin, O. V., and Macpherson, A. H. Ornitholog. Notes from Oxon. in I886. (Op. cit.)

Harcourt, G. W. Notes from Oxon. (Op. cit.)

I888. Aplin, O. V. Food of Hawfinch; Sand Grouse in Oxon. (Zool.)

Bartholomew, H. J. Dipper in Oxon. (Field, Oct. 6.)

Brandreth, H. W. Rough-legged Buzzard in Oxon. (T.c., Nov. 24.)

Macpherson, A. H. Hoopoe in Oxon. (Op. cit., May I9.)

Newton, W. Great Grey Shrike in Oxon. (Op. cit., Nov. 24); Reappearance of Pallas's Sand Grouse. (Op. cit., May 26.)

1889. Aplin, O. V. The Birds of Oxfordshire. 8vo. Oxford: I889. [24.]

Hamilton, R. W. Terns on the Thames. (Field, Oct. 5.)

Lambert, F. W. Sheldrake near Oxford. (Zool.)

Salter, W. Black Tern near Oxford. (Field, June I5.)

I890. Aplin, O. V. Distribution and Period of Sojourn in British Isles of Spotted Crake. [partim.] (Zool.); The Grey and White Wagtails in Oxon. (T.c.); Blackcap in Winter [Bloxham]. (Field, Dec. 27.)

"G. E. S." Scoter and Golden Eye on the Thames. (T.c., Dec. 27.)

I89I. Dale, T. Night Heron in Oxon. (Op. cit., June 6.)

I892. Aplin, O. V. Supplementary Notes on the Birds of Oxfordshire ; Blue-headed Wagtail and Little Owl in Oxon. (Zool.). On distribution of Cirl Bunting in Great Britain. [partim.] (T.c.) Dotterel in Oxon. (Field, May 7.)

I892-8. Fowler, Rev. W. W. Marsh Warbler in Oxon., 3 pts. (Zool., I892-3, I898.)

I893. Aplin, O. V. Ornitholog. Notes from Oxon. (Op. cit.)

Fowler, W. Warde. The Marsh Warbler in Oxfordshire and Switzerland. 8vo. Lond. : I893. [22I.]

I894. Climenson, E. J. History of Shiplake, Oxon. 4to. Lond. : I894. [I36.]

Swann, H. Kirke. Marsh Harrier nesting near Oxford. (Zool.) Idem by O. V. Aplin and J. E. Harting. (T.c.)

[Leonard Buttress, who stated he had taken the egg recorded, withdrew his assertion.]

Wykeham, H. W. Robin nesting in Church. (Zool.)

I894-Igro. Aplin, O. V. Notes on the Ornithology of Oxon., I5 pts. (Zool., I894, I895, I899, I900, I903-Io.) [25.] 
I895. Fowler, W. W. Date of Arrival in England of Marsh Warbler. (Op. cit.)

I896. Fowler, W. W. On the meeting of the Marsh Warbler; Rookery destroyed by Crows. (Zool.)

I897. Calvert, R. W. Spotted Flycatcher's nest constructed in nest of Hawfinch, etc. (3 notes.) ( $\left.\mathrm{Zool}_{\text {. }}\right)$

Greaves, A. Flycatcher appropriating Greenfinch's nest. (Field, July 3 I.)

Sidgwick, F. Birds of Oxford District. (Rep. Rugby Soc.)

I898. Fowler, W. W. Tree Pipit in January; On date of arrival of House Martin, etc. (3 notes.) (Zool.)

I899. Aplin, O. V. Barred Warbler in Oxon. in Nov. (Ibis.)

Fowler, W. W. Regularity of Greenfinch in beginning Song; Songs of Birds affected by Temperature; Swallows and Hobbies. (Zool.)

Marshall, J. W. Hobby nesting in Oxon. (Field, Aug. 26.)

I900. Crawshay, W. T. Bittern near Reading. (Field, Jan. 6.)

"F. M. C." Puffin at Henley-on-Thames. (Op. cit., Dec. 8.)

Fowler, W. W. Lateness of Summer Migrants. (Zool.)

rgor. Bradshaw, G. W. Little Owl at Henley. (Op. cit.)

Warner, W. H. Bittern in Oxon. (Zool.)

I902. Aplin, O. V. Eared Grebe probably breeding in Oxon. (Ibis.) Cornish, C. J. The Naturalist on the Thames. 8vo. Lond. : I902. [I47.]

I903. Aplin, O. V. Notes on Oxfordshire Ornithology by the late C. E. Stubbs. (Zool.) Migration of Jays. (Op. cit.)

Elms, E. F. M. Early Autumn Notes in Oxon., in neighbourhood of Witney. (T.c.)

Fowler, W. Warde. An Unknown Warbler in Oxon. (T.c.)

I904. Cocks, A. H., and Aplin, O. V. Birds of Oxon. or Bucks. (Op. cit.) (3 notes.)

Elms, E. F. M. Notes on Nesting of Moorhen and Little Grebe on River Isis, Bablockhythe, May 2oth-24th. (T.c.)

Fowler, W. Warde. The Marsh-Warbler in Oxfordshire: A New Position for the Nest. (T.c.)

Long, F. P. Black Redstart in Oxford. (Field, Dec. 3.)

1905. Aplin, O. V. Peregrine Falcon in Oxon. (Zool.)

Fowler, W. W. Late nesting of Linnet. (T.c.)

I906. Aplin, O. V. Bramblings in April. (Zool.)

Cocks, A. H. Pelicans reported in Oxon. (T.c.)

Fowler, W. Warde. The Marsh Warbler : a breeding record of I4 years. (T.c.)

1907. Mackenzie, W. D. Peregrine Falcon in Oxon. (Field, Feb. 23.) "F. M. C." Little Owl in Oxon. (Op. cit., Nov. 30.) 
I908. Aplin, O. V. American Wood Duck in Oxon. (Zool.) Idem by Duchess of Bedford. (T.c.)

I909. Aplin, O. V. Little Bittern in Oxon.; Brown-throated Quail in Oxon. $(O p$. cit. $)$

Fowler, W. Warde. Little Owl in N.W. Oxon. (Brit. Birds, II.) Where are our Nuthatches? (Zool.)

Lawson, H. Woodchat's [?] Nest in Oxon. (Rep. Ashmol. Nat. Hist. Soc. for I908.)

I9I0. Aplin, O. V. Daphne berries eaten by Birds. (Zool.) Fowler, W. W. Albino Bunting. (Zool.)

Ritchie, A. Black Terns in Oxon. (Brit. Birds, IV.)

IgIr. Aplin, O. V. Decrease of Corncrake, Wryneck and Nuthatch. (2 notes.) (Zool.); White and other varieties of Birds. (T.c.)

I9I2. Aplin, O. V. Supposed Occurrence of Scarlet Grosbeak in Oxon. (Zool.)

Fowler, W. W. An unlucky pair of Stonechats. (Zool.)

Monckton, F. A. Turnstone in Oxon. (Brit. Birds, V.)

I9I3. Aplin, O. V. Birds in Oxon. (Brit. Birds, VII.); Crane in Oxon.; Dark var. of Red-legged Partridge; Notes on Ornithology of Oxon. Igro-r2. (Zool.)

Igr4. Aplin, O. V. Notes on Ornithol. of Oxon. ; Blackcap wintering in Oxon. (Zool.)

Moreton, Lord. Status of Land Rail in Oxon. (Brit. Birds, VIII.)

Noble, H. Status of Blackcap and Garden Warbler. (Zool.) Phillips, C. E. L. Ruddy Sheld-Ducks on the Move. [Bicester.] (Field, Apr. 25.)

I9I5. Aplin, O.V. Notes on Ornithol. of Oxon. (Zool.)

Atlee, H. G. Bird Notes from Oxford district in I9I3-I4. (Zool.) Stanford, J. K. Grey Wagtail breeding in Oxon. (Brit. Birds, IX.)

I9I6. Aplin, O. V. Notes on an August Nightingale. (Zool.)

Fowler, W. W. Unknown Warbler in Oxon. (Zool.)

Kerr, G. W. Lesser Redpoll in Thames Valley. (Wild Life, VIII.)

May, W. N. Glossy Ibis in Oxon. (Brit. Birds, X.)

Noble, H. Rough-legged Buzzard in Beds. [and Oxon.]. (Brit. Birds, IX.); Early Laying of Reed Warbler and Cuckoo. (Brit. Birds, X.)

Robinson, H.W. Spotted Flycatcher wintering in Oxon. (Zool.)

I9I7. "A. J. B." Quail in Oxon. (Field, Nov. 3.)

Atlee, H. G. Unusual Birds in Oxon. in I9I5. (Brit. Birds, X.)

Collett, A. Sandmartins nesting in drain pipes. (T.c.)

[Editorial.] Great Skua in Oxon. (Brit. Birds, XI.) Idem. (Land \& Water, Nov. I.) 
Jourdain, F. C. R. Spread of Little Owl in S. Oxon., etc. (Brit. Birds, X.) White Stork in Oxon. (T.c.)

I9I8. Fowler, W. Warde. Tail Motion of Red-backed Shrike. (Brit. Birds, XII., p. 67.)

Jourdain, F. C. R. Snowy Owls reported in Oxon. : Breeding of Common Sandpiper in Oxon. (Brit. Birds, XI.) Strange Nesting site of Sand Martin in Oxon. (Op. cit., XII.) Ornitholog. Report, I9I5-I7. (Proc. \& Rep. Ashmol. Soc., I9I7.) Newton, W. Quail in Oxon. (Field, Dec. I4.)

Smith, J. Beddall. Breeding Habits of Hobby. (Brit. Birds, XI.)

\section{RUTLANDSHIRE.}

I736. W[hite], G[ilbert]. [Note in] Notebook of Thos. Barker of Lyndon Hall, Rutland. (Vide Haines's Birds of Rutland, p. xxviii).

I736-I80I. Barker, T. Various observations in Notebook above mentioned. (Vide Op. cit.)

1844. Turner, Rev. W. Swift at Uppingham; Ring Dove's nest with 3 eggs. (Zool.)

1845. Turner, W. Nest of Grasshopper Warbler. (Zool.)

I846. Turner, Rev. W. Occurrence of Swallow new to Britain at Uppingham. (Zool.); White Starling, etc. (T.c.)

I848. Turner, W. Curious anecdote of Kestrel. (Zool.)

I869. Rowley, G. D. White Woodcock shot [at Exton]. (Zool.)

I870. Elliott, A. C. Bewick's Swan in Rutland. (Field, Jan. 8.)

I87I-85. Yarrell, W. Tree Sparrow at Uppingham. (Hist. Brit. Birds, 4th ed., II., p. 83.)

1879. Cullingford, J. Eagle Owl in Lincs. [errore=Rutland]. (Zool.)

I885. Gainsborough, Earl of. Great Crested Grebe in Rutland. (Zool.); White Wagtail at Exton. (Field, May 2.)

I887. Gainsborough, Earl of. Summer Birds in Rutland. (Field, May I4.)

Haslam, S. Gannet inland [near Uppingham]. (T.c., April 23.)

I888. Betts, H. W. Hoopoe in Rutland. (Op. cit., Sept. 22.) Idem by Earl of Gainsborough and E. Clayton. (Op. cit., June 9.)

Gainsborough, Earl of. Notes from Rutlandshire. (Zool.); Pallas's Sand-Grouse [in Rutland]. (Field, June 9.)

Horn, W. J. Notes from Rutland. (Op. cit., April r4.)

I889. Browne, M. Vertebrate Animals of Leicestershire and Rutland. 4to. Birmingham : I889. [99.] 
Gainsborough, Earl of. Quail in January. (Field, Feb. 9.) Sand-Grouse in Rutland. (T.c., Apr. I3.)

Lilford, Lord. Nestling Hobbies from Rutland [in Notes on Ornith. of Northants.]. (Zool, p. 428.)

I89o. Gainsborough, Earl of. Notes from Rutland. (Zool.)

1895. Lilford, Lord. Notes on Birds of Northants. 2 vols. 8vo. Lond. : I895. [Many references to Rutland birds.]

I898. "W. J. C." Waxwing near Uppingham. (Field, Mar. 26.)

[Anon]. Gannet on Luffenham Heath. (Field, Nov.)

I905. Haines, C. R. Dotterel in Rutland. (Op. cit., June 3.)

I907. Haines, C. R. Notes on the Birds of Rutland. Post 8vo. Lond. : I907. [264.]

Haines, C. R. Notes on the Birds of Rutland. (Zool.)

I908. Haines, C. R. Birds. [In Victoria Hist. of Co. of Rutland, I.] 4to. Lond. : Ig08. [264.]

\section{SHROPSHIRE.}

I770. Pennant, T. Avocet, etc., in Shropshire. British Zoology. Chester: I770. [466.]

I789. Walcott, J. Synopsis. Lond. : I789. [607.] [Spotted Falcons at Longner.]

I797. Aikin, A. Journal of a Tour through North Wales and Part of Shropshire. 8vo. Lond. : I797. [5.]

I832. Slaney, R. A. Smaller British Birds. 8vo. Lond. : I832. [Contains numerous Shropshire records including breeding colony of Cormorants near Shrewsbury.] [542.]

I836. Eyton, T. C. [Mealy Redpoll, etc., in Shropshire in] Rarer Brit. Birds. [203.]

Salway, T. Notice of discovery of skeletons of Swifts and Starlings in tower of church at Oswestry. (Loudon's Mag. N. H., IX.)

I838. Eyton, T. C. An attempt to ascertain the Fauna of Shropshire and N. Wales, 3 pts. (Mag. Zool \& Bot., I838;Ann. Nat. Hist., I838. Vols. I. \& II.) [203.]

I839. Dovasson, J. F. M. [I782-I854.] Lecture on Natural History. Shrewsbury: I839. [Mentions amongst other items the "ringing " of Swallows which returned year after year to their nesting place.]

I845. Bree, W., junr. Arrival of Summer Birds near Newport in I845. (Zool.)

I854. Franklin, W. [I8I4-85.] Glossy Ibis near Shrewsbury. (Op. cit.) 
Riddell, J. The Greater Spotted Woodpecker [nesting near Shrewsbury]. (Nat. [Morris's.], IV.)

[1855.] Cathrall, W. History of Oswestry. Post 8vo. Oswestry: N.D. [I2I.]

I859. [Anon.-." P. W."] Siskin [at Smethcote]. (Field, Dec. Io.) "Clee Hill." Rare Birds in Salop. (T.c., Nov. I2.)

Slaney, W. H. Hoopoe near Shrewsbury. (Zool.)

I860. Buddicom, W. S. The Waxwing Chatterer [two shot at Shrewsbury]. (Field, Dec. 22.)

Shaw, H. Black-throated Diver in Shropshire. (T.c., Dec. 29.)

I86I. Shaw, J. [I8I6-88.] Rare Water Birds occurring near Shrewsbury. (Zool.)

Shaw, H. Bohemian Waxwing in Salop [near Shrewsbury]. (Field, Jan. I2.)

I863. Buffon and Wilson. Sand-Grouse [near Oswestry]. (Op. cit., June I3.)

I864. Shaw, H. O., junr. Rare Birds in Shropshire and District [Great Northern Diver shot near Shrewsbury, Hoopoe in Salop, etc.]. (Field, Feb. 6.)

I865. Wright, E. D. M. A White Martin [near Oswestry]. (Op. cit., Aug. I2.)

I865-66. Rocke, J. [I8I7-8I.] Notes on Shropshire Birds, 4 parts. [Actually an annotated list.] (Zool., I865-66.)

I866. Shaw, J. Rare Birds in Shropshire. (Ficld, Nov. 3.)

I867. Beckwith, W. E. Fire-crested Wren, Richard's Pipit and Velvet Scoter in Salop. (Zool.)

I868. Start, A. Bohemian Waxwing [at Oswestry]. (Field, Feb. I5.)

I869. Selous, P. S. Ger-Falcon shot in Salop. (Op. cit., Oct. 9.)

"T. E. H." Landrail in January [near Ludlow]. (Op. cit., Jan. 30.)

I87I. Bridgeman, F. C. Great Grey Shrike at Shifnal. (Op. cit., Jan. 28.)

Lloyd, J. W. American Bittern near Ludlow. (T.c., Jan. 28.)

I872. Harting, J. E. Tengmalm's Owl near Shrewsbury. (Op. cit., Apr. 27) ; Existing Heronries in Britain. (T.c., Feb. I7.)

Rocke, J. Tengmalm's Owl, Rough-legged and Common Buzzards and Dotterel in Salop. (Zool.)

I873. "F. N." Woodcock nesting in Salop. (Field, Apr. 26.)

1874. Cooke, N. Eagle Owl at Bridgnorth. (Zool.)

Shaw, J. Little Gull near Shrewsbury. (Ficld, Oct. 3I.)

I875. Rocke, J. Sabine's Gull. (Zool.)

Shaw, J. Rare Birds in Salop. (Field, Oct. 30.) 
1876. Forrest, H. E. Ornithological Visitors near Shrewsbury. (Sci. Gossip.)

1878. Beckwith, W. E., and others. Guide to Botany, Ornithology, etc., of Shrewsbury and Vicinity. I2mo. Shrewsbury: I878. [5I.]

Elliot, W. Snipe Breeding [Church Stretton]. (Midl. Nat., I.)

1879. Beckwith, W. E. Birds of Shropshire. (Tr. Shrops. Arch. \& N.H.Soc.) [5I.]

Cholmondeley, R. Great Skua near Shrewsbury. (Zool.)

I880. Male, A. S. Old English Kite or Glead [at Bishop's Castle]. (Midl. Nat.)

I88I. " Tantara." Pomatorhine Skua near Oswestry. (Field, Oct. 29.)

I883. B- , R. B. Breeding Haunts of the Curlew. (Field, May I2.)

Bagot, L. R. C. Idem. (T.c., May Ig.) Rope, G. T. Idem. (T.c., May 26.)

Beckwith, W. E. Late Landrail [near Ellesmere, Nov. Io]. (Op. cit., Nov. I7.)

I884. Beckwith, W. E. Common Sandpiper in winter. (Field, Jan. 5.)

Bond, F. Manx Shearwater inland in Salop. (Zool.)

Hodgson, T. V. Ornitholog. Notes [from Salop]. (Midl. Nat.)

Wright, C. H. Manx Shearwater inland [near Oswestry]. (Field, Oct. 4.)

1885. Potts, C. Quail in Salop. (Op. cit., Oct. 24.)

I885-86. Beckwith, W. E. Notes on Shropshire Birds. (Field, I885, Dec. I9; I886, Jan. 2.) [5I.]

1886. Beckwith, W. E. Montagu's Record of White-tailed Eagle in Salop. (Zool.); Sea Birds Inland [in Shropshire]. (Field, Dec. II.)

I886-93. Beckwith, W. E. Shropshire Birds. (Tr. Shrops. Arch. \& N. H. Soc., I886-93). [Also reprinted separately for private distribution. An amplification of the List 1879. Never completed owing to author's death.] [5I.]

I887. Benson, R. B. Manx Shearwater in Salop. (Field, Oct. 8.) Idem by W. E. Beckwith. (T.c., Oct. I5.)

I888. Horton, R. J. Pallas's Sand-Grouse [in Salop]. (Field, June I6, 30.)

1889. Sandford, R. Osprey near Shrewsbury. (Op. cit., Nov. 23.) "W. G." Hoopoe in Salop. (T.c., Sept. 2I.)

I892. Aplin, O. V. Distribution of Cirl Bunting. (Zool.) [partim.] Cooke, G. White's Thrush near Shrewsbury. (Field, Jan. 30.)

I893-94. Blackmore, E. H. Oological Notes from Ludlow, Io pts. (Nat.Jnl., II.)

1894. Tegetmeier, W. B. Chestnut variety of Partridge from Salop. (Bull. B.O.C., III., I893-94.) 
I896-[IgI8.] Forrest, H. E. Birds of Shropshire, Annual Record, 23 pts. (Rec. Caradoc F. C., I896-[I9I8].)

I897. Blackmore, E. H. An Ornitholog. Note from Ludlow. (Nat. Chron., June.)

Paddock, G. H. Shropshire Birds. Privately printed : I897.

I898. Dickin, G. V. Spotted Crake in Salop. (Field, Oct. 29.)

I899. Forrest, H. E. [nat. I858.] Fauna of Shropshire. Cr. 8vo. Shrewsbury : I899. [213.]

I900. Forrest, H. E. Breeding of Tufted Duck in Salop. (Zool.); Movements of Starlings : with List of Roosts in Salop. (T.C.)

Igor. Forrest, H. E. Red-footed Falcon in Salop. (Op. cit.)

I903. Forrest, H. E. Dartford Warbler in Salop. (Op. cit.) [2I3.]

rg05. Forrest, H. E. Shropshire Birds in Shrewsbury Museum. (Tr. Caradoc F. C.) [2I3.]

I907. Forrest, H. E. Annotated List of Birds in Peplow Hall Museum (formerly at Hawkstone). Cr. 8vo. Shrewsbury: 1907. [213.] Oldham, C. Gadwall in Salop. (Zool.)

I908. Forrest, H. E. Birds [In Victoria Hist. of Co. of Shropshire, I.] 4to. Lond: I908. [2I3.]

Forrest, H. E. Golden Oriole in Salop; Hoopoe in Salop; Honey Buzzard in Salop. (Brit. Birds, II.)

I909. Forrest, H. E. Nightingale breeding in Salop. (Zool.); Velvet Scoter in Salop; Red variety of Common Partridge. (Brit. Birds, II.); Additions to Shropshire Avifauna. (Op. cit., III.)

I9I0. Forrest, H. E. Shropshire Names of Animals. (Tr. Caradoc F. C.); Two old Shropshire Naturalists-Dovasson and Slaney. (T.c.)

IgII. Forrest, H. E. Iceland Falcons, Manx Shearwater, Fork-tailed Petrel, White-tailed Eagle in Salop, 4 notes. (Brit. Birds, IV). ; Cranes, and Hoopoe in Salop; Abundance of Nightingales. (Op. cit., V.)

Steele-Elliott, J. Black Grouse in Salop, etc. (Zool.)

Ticehurst, N. F., and Jourdain, F. C. R. Distribution of Nightingale. (Brit. Birds, V.) [partim.]

I9I2. Forrest, H. E. Spread of Little Owl in Salop; Little Auk, Sclavonian Grebe and Cormorant in Salop, etc. (T.c.); Night Heron, Common Tern and Arctic Skua in Salop. (Op. cit., VI.)

Owen, J. H. Landrail calling in Aug. ; Quails in Salop. (T.c.)

I9I3. Forrest, H. E. Late Sivifts [in Salop]. (Op. cit., VI.) ; Bewick's Swan in Salop; Nightingales in Salop; Supposed Little Bittern in Salop; Crossbills breeding in Salop. (Brit. Birds, VII.) 
Meares, C. S. Crossbills breeding in Salop. (Brit. Birds, VI.) Owen, J. H. Lapwing's nest with 5 eggs in Salop. (Op. cit., VII.) I9I4. Blathwayt, F. L. Ring Ouzel as Foster-parent of Cuckoo. (Brit. Birds, VII.)

Elliott, J. S. Nesting of Golden-crested Wren at Salop. (Zool.) Forrest, H. E. Arctic Skua in Salop. (Brit. Birds, VII.); Little Owl in Salop; Twites in Salop in summer; Cuckoo in House Sparrow's nest; Night Heron in Salop. (Brit. Birds, VIII.)

Owen, J. H. Mud-daubed eggs of Jackdaw ; Sparrow ejecting eggs ; Moorhen covering eggs. (Brit. Birds, VIII.)

I9r5. Forrest, H. E. Fork-tailed Petrel and Roseate Tern in Salop. (Op. cit., VIII.); Crossbill nesting in Salop. (Op. cit., IX.)

Owen, J. H. Curious position of Dipper's nest. (T.c.)

IgI6. Elliott, J. S. Early arrival of Swifts in Salop. (Brit. Birds, X.) ; Common Scoter in Salop. (Zool.)

Forrest, H. E. Common Scoter in Salop in summer; Unusual Birds in Salop ; Little Owl in Salop. (Brit. Birds, X.)

Mayall, A. Blackcap in winter in Salop. (T.c.)

I9I7. Forrest, H. E. Arctic Tern in Salop. (Op. cit., XI.)

I9I8. Forrest, H. E. Cormorants in Salop; Red-necked Grebe in Salop. (Op. cit., XI.) ; Raven nesting again in Salop; Wryneck in Shrewsbury. (Op. cit., XII.); Bitterns in the West [Salop]. (Nat.)

Pitt, F. Pied Redwing [Bridgnorth]. (Nat.)

\section{SOMERSETSHIRE}

I825. Yarrell, W. Notice of occurrence of some rare Brit. Birds [Great Skua in Somerset]. (Zool. Jnl., II, p. 26.)

1826. [Leadbeater.] Squacco Heron near Bridgwater. (T.c., p. 548.) I827. Brackenridge, G. W. Yearly Appearance of Swallow and Cuckoo near Bristol, I80I-26. (Zool. Jnl., III,, p. 3I9.)

1828. Fox, W. T. Notice on Appearance of some rare Birds in England [Egyptian Vulture near Bridgwater]. (T.c.. p. 496.)

I829. Rutter, John. Delineations of the N.W. Division of Co. of Somerset. 4to. Shaftesbury, etc. : 1829. [500.]

1837. (Taunton Courier.) Whiteheaded Osprey [at Sandhill Park]. (Nat. [Wood's], II.)

I838. (Taunton Courier.) Rare Birds captured during the late frost. (Op. cit., III.)

1844. Jesse, E. Scenes and Tales of Country Life. Post 8vo. Lond. : I884. [3I7.] 
1849. Garth, J. C. White-tailed Eagle in Som. (Zool.)

Morris, B. R. Black Grouse breeding in Devon [ref. to Som.]. (T.c.)

1850. Baker, W. Occurrence of Rare Birds near Bridgwater; On Capture, etc., of Black Stork. $(O p$. cit.)

Crotch, W. D. Black Grouse in Devon [refers chiefly to Som.] ; Little Auk at Weston-super-Mare. (T.c.)

I85I. Baker, W. The Somersetshire Fauna: Birds. (Pr. Som. Archaol. \& N.H. Soc., I.)

Clarke, G. B. Alpine Swift [in Somerset]. (Nat. [Morris's], I.)

Crotch, W. D. List of Birds' Eggs found in Som. (Pr. Som. Soc., I849-5I.) [I57.]

Crotch, W. D. The Birds of Somersetshire. No. I. 8vo. Taunton: I851. [157.]

Duck, J. N. Little Gull at Weston-super-Mare. (Zool.)

Higgins, E. T. Bona-fide British-killed Hawk Owl. (T.c.)

M'Intosh, J. Heronries in England, etc. [partim.] (Nat. [Morris's], I.)

Norman, A. M. Regularity of Movements of Barn Owl; Piebald Varieties of Hedge Sparrow. (Zool.)

1852. Dew, C. Hoopoe at Sparkford. (Nat. [Morris's], II.)

Duck, J. N. Natural History of Portishead. I2mo. Bristol : 1852. [183.]

Prideaux, C. Rare Birds near Kingsbridge [ref. to Som.]. (Zool.)

I854. Gatcombe, J. Black Redstart in Som. (Nat. [Morris's], IV.)

1856. [Anon.] The Gannet. (Field, June 28.)

Melhuish, J. Wood Warbler [nr. Taunton]; Bittern [seen near Taunton]. (Nat. [Morris's], VI.)

1857. Melhuish, J. White-tailed Eagle [near Bridgwater]. (Op. cit.. VII.)

I859. "Botanicus." The Nightingale [regularly heard in Som.], (Field, June 25.)

Clark, T. Dates of Arrival of Migratory Birds; Black Swan in Som. (Zool.)

"C. L. D." Osprey [shot at Dunster]. (Field, Nov. I2.)

Farbrother, J. E. Shepton Mallet. Post 8vo. Shepton Mallet : I859. [204.]

Haddon, C. Pied Flycatcher [shot near Taunton]. (Field, June II.)

R-—, J. R. Hoopoe and Fork-tailed Petrel. (Field, May 7.)

Rodbard, J. R. The Black Tern [two killed at Burnham]. (Op. cit., May I4.)

I860. Dewey, W. F. Little Bittern near Taunton. (Zool.)

Newman, H. W. Glossy Ibis in Som. (T.c.)

Parfitt, E. Snipes in Summer. (T.c.)

S- - F. Hoopoe in Som. (Field, Nov. I7.) 
I86I. Compton, T. American White-headed Eagle in Som. (Zool.) Idem by W. D. Crotch. (T.c.)

Higgins, E. T. Rare Birds at Weston-super-Mare. (T.c.)

Marshall, J. White variety of Song Thrush and Bullfinch. (T.c.)

I862. Fuller, F. Nightingale and Martins in Som. (Field, Apr. I9.) Rutter, J. Hoopoe at Keynsham. (Zool.) Idem by H. L. and E. H. Ward. (Field, May Io.)

S-, H. A. Buffon's Skua, etc., in Som. (Op. cit., Dec. 13.)

1863. Douglas, - . Great Black-backed Gull and Little Auk at Westonsuper-Mare. (Op. cit., Feb. 7.)

Mathew, M, A. Great Grey Shrike and Spotted Crake near Taunton; Buffon's Skua near Wellington; Little and Sabine's Gulls at Weston-super-Mare. (Zool.)

Smith, C. Arrival and Departure of Summer Birds at Taunton. (T.c.)

I864. Bidgood, W. Great Grey Shrike in Som. (Field, Apr. 9.)

Clark, T. Egyptian Goose near Glastonbury. (Zool.)

Fitzgerald, G. A. R. Bittern in Som. (Field, Jan. 30.)

Mathew, M. A. Ruff and Montagu's Harrier at Weston-superMare. (Zool.)

Smith, C. Little Auk in Som. ; Egyptian Goose and Great Grey Shrike in Som. (T.c.)

Valpy, R. A. Great Spotted Woodpecker in Som. (Field, March I9.)

1865. Haddon, C. Crane in Som. (Op. cit., Dec. 2.)

$\mathrm{M}-$ - T. Arrival of Summer Birds. (Op. cit., Apr. 8, I5.) Idem by "W. T." (T.c., Apr. 22.)

Mathew, M. A. Little Bittern, etc., near Weston-super-Mare, 3 notes; Snipe in Middle of July. (Zool.)

Smith, C. List of Birds observed in Parish of Bishop's Lydeard ; Crane at Stolford. (T.c.)

I866. Byne, H. Serin Finch in Som. (Field, Apr. 28.)

Ireland, A. C. The Grey Phalarope [at Weston-super-Mare]. (Op. cit., Oct. 6.)

Mathew, M. A. An Ancient Raven; Lesser Tern, Black Tern and Grey Phalarope at Weston. (Zool.)

Smith, C. Black Tern in Som. (T.c.)

I867. A-, H. Arrival of Spring Migrants. (Field, Apr. 6.)

Gurney, J. H. Tithys Redstart at Minehead. (Zool.)

"Inyati." Shoveler Ducks. (Field, Feb. I6.)

Mathew, M. A. Sabine's Gull at Weston. (Zool.)

Smith, C. Red-throated Diver and Norfolk Plover in Som.;

Lesser Tern at Taunton. (T.c.)

West, E. Does the Yellow Wagtail always Migrate? (T.c.) 
I868. A-, H. Migration of Rooks. (Field, Oct. Io.)

Collins, J. Occurrence of Bittern. (OP. cit., Feb. I.)

Cridland, T. Mortality among Swallows. (Op. cit., Aug. 22.)

Gurney, J. H. First Arrivals of Spring Visitors at or near Minehead. (Zool.)

"Riorpe Nilste." The Crossbill. (Field, Nov. 2I.)

Smith, C. Blacktailed Godwit, Chough, and Black Tern in Som. (Zool.)

1869. [Anon.] A Rare Bird. [Rose-coloured Pastor at Laverton.] (Field, Aug. 7.)

C - - T. Song of the Cuckoo. (T.c., July 24.)

Mathew, M. A. Slaughter of Sea-Forwl at Weston-super-Mare; Dotterel near Weston. (Zool.)

Rickards, M. S. C. Purple Sandpiper at Weston. (T.c.)

Smith, C. The Birds of Somersetshire. Post 8vo. Lond.: I869. [546.]

Smith, C. Common Crossbill near Taunton. (Zool.)

T-_, G. T. Arrival of Summer Migrants. (Field, Apr. I7.)

I870. Bidgood, W. White's Thrush in Som. (Op. cit., Jan. 29.)

C_- T. T. The Hirundines. (T.c., May 2I.)

Chalk, W. J. Ornitholog. Notes from Taunton; Sclavonian Grebe at Taunton. (Zool.)

Cridland, T. Arrival of Cuckoo. (Field, Apr. 9.)

Mathew, M. A. Glaucous Gull at Weston. (Zool.)

Rickards, M. S. C. Canada Goose at Glastonbury; Greyheaded Wagtails near Clevedon. (T.C.)

Smith, C. Japanese or White's Thrush in Som. ; Iceland Gull in Som.; Occurrences of Fulmar Petrel, Little Auk, Ruff, Little Crake and Grey Phalarope in Som.; Grey Phalarope at Bishop's Lydeard. (T.c.)

I87x. Halliday, J. Hoopoe near Taunton. (Field, Aug. I9.)

Harting, J. E. Immigration of Gt. Bustard [one seen Shapwick]. (Op. cit., Jan. I4.)

Power, F. D. Occurrence of Pied Flycatcher and Dotterels. (Zool.)

Porch, J. A. Canada Goose near Glastonbury. (Field, Feb. II.) Rickards, M. S. C. Green Sandpiper at Scilly [=Som.] ; Canada Goose at Glastonbury; Great Grey Shrike in Som. (Zool.)

Rodbard, J. R. Quails in Britain [Som.]. (Field, Feb. 4.)

Smith, C. Marsh Harrier, Red-necked Grebe, White's Thrush, Bittern, Wood Sandpiper, Grey Phalarope, Iceland Gull, etc., in Som.; Grey Phalarope near Taunton; Canada Goose near Glastonbury ; Cormorant inland in Som. (Zool.)

Smith, C. List of Birds of Somerset. (Som. Arch. \& N. H. Pr., XVI.)

"W. B." and others. Rose-coloured Pastor in Som. (Field, Aug. 5, 12, I9.) 
I872. Gatcombe, J. Occurr. of Whiteheaded Longtailed Tit. (Zool.)

"H. B." Nesting of Hobby in Som. (Field, May I8.)

Rickards, M. S. C. Occurr. of Spotted Crake. (Zool.)

Smith, C. Hen Harrier, Norfolk Plover and Red-breasted Merganser in Som. ; Early Arrival of Chiffchaff. (T.c.)

1873. Blathwayt, C. P. Blackcap in winter [near Bath]. (Field, Jan. II.)

Mathew, M. A. Waxwing at Bishop's Lydeard. (Zool.)

Melvill, T. C. Nutcracker seen near N. Petherton. (Field, Aug. I6.)

Ogilvy, W. T. Lesser Spotted Woodpecker at Taunton. (Zool.)

Smith, C. Range of Stock Dove in England [increasing in Som.]. (Field, June 7.)

I873-5. Gatcombe, J. Ornitholog. Notes, 3 notes. (Zool., I873-5.)

Smith. C. Ornitholog. Notes from Som., 3 notes. (Op. cit., I873-5.) [546.]

1874. Bidgood, W. Great Grey Shrike in Som. (Field, Nov. 2I.)

Filleul, S. E. V. Spotted Crake at Weston-super-Mare. (OP. cit., Apr. II.)

Hunt, W. H. Kite near Yeovil. (T.c., June 20.)

Mathew, M. A. Bird Notes. (Zool.)

Rickards, M. S. C. Richardson's Skua near Clevedon.

Smith, C. Temminck's Stint in Som. (Field, Dec. I9.)

(T.c.)

I875. Gurney, J. H. Som. Egyptian Vulture. (Zool.)

Mathew, M. A. Somersetshire Moors in the Spring; Notes on Cuckoo, etc. ; Heronries at Bishop's Lydeard. (T.c.)

Rickards, M. S. C. Hobby at Portishead and Goldeneye near Axbridge. (T.c.)

Smith, C. Ornitholog. Notes from Som.; Marsh Warbler in Som. (Zool.) Canada Geese in Som. (Field, Jan. 30); Marsh Warbler in Som. (OP. cit., Nov. 20.)

Stansell, F. Scoter at Minehead; Occurr. of Smew. (Zool.)

Wheeler, E. Bristol and its Environs. 8vo. Lond., etc.: I875. [624.]

I876. Mathew, M. A. Notes from W. Som., 3 pts. ; Herons at Bishop's Lydeard. (Zool.)

Prince, H. R. Smew at Taunton. (Zool.)

Smith, C. Blackthroated Diver in Som. (Zool., Field, Jan. I.)

Stansell, F. Common Scoter at Minehead; Female Smew near Curry Rivel. (Zool.)

Wheeler, E. List of Resident Birds, Summer and Winter Visitors and occasional stragglers obser. in Bristol district. (Pr. Brist. Nat. Soc., N.S., I., pt. 3, I875-6.)

I876-77. Smith, C. Purple Gallinule in Som. (Sci. Gossip, I876; Zool., I877.) 
I877. Mathew, M. A. Purple Gallinule in Som., 2 notes; Notes from Som., 2 pts.; Marsh Warbler near Taunton; Corncrake in Som.; Bartram's Sandpiper in Som.; Notes from W. of England. (Zool.)

Smith, C. Purple Gallinule in Som. (T.c.); Idem by $\mathrm{H}$. Saunders. (T.c.)

Smith, C. Summer Snipe breeding in Som. (Field, May 5.)

I878. Shore, J. H. Landrail in Feb. (Op. cit., Mar. 2.)

Smith, C. Pied Flycatcher and Black Redstart in Som. (Zool.)

1879. Brackenridge, G. W. Little Owl in Som. (Op. cit.)

Edwards, C. L. F. Red-legged Partridge in Som. (Field, Oct. II.) Ford, R. Bean Geese in Som. (T.c., Dec. I3.)

Mathew, M. A. Ornitholog. Notes from Som.; Bewick's Swan. (Zool.)

Porch, J. A. Wild Swans near Glastonbury. (Field, Feb. 22.)

Smith, C. Wild Swans in Som. (T.c., Mar. 8); Pomatorhine Skuas in Som. (Op. cit., Nov. I.)

I879(?). Wells Nat. Hist. and Archæological Soc. Reports. 8vo. [Contain bird records of some importance.]

I880. Harvie-Brown, J. A. Green Woodpecker in Som. (Zool.)

Mathew, M. A. Unusual Abundance of Green Woodpecker; Pomatorhine Skuas in Bristol Channel; Chiffchaff in Winter. (T.c.)

Smith, C. Pomatorhine Skua and Green Woodpecker in Som. (T.c.)

White, - . Occurr. of Grey Shrike, Ravens, etc. (T.c.)

I881. Ford, R. Great Northern Diver in Som. (Op. cit.)

Mathew, M. A. Rare Birds in Som. (T.c.)

1882. Compton, T. Winscombe Sketches. 8vo. Lond. : I882. and edit., I839. [I4I.]

Mathew, M. A. Marsh Warbler's Nest near Taunton. (Zool.) Smith, C. Iceland Gull and Great Grey Shrike in Som. (T.c.); Manx Shearwater in Som. (Zool., Field, Oct. 2I.)

Stansell, F. Marsh Warbler near Taunton. (Zool.)

Waugh, A. Scoter inland [near Bath]. (Field, May 6.)

I883. Andrew, H. D. Little Gull in Som. (Op. cit., Feb. 3.)

Butler, E. A. Hybrid between Black Grouse and Pheasant in Som. (Field, Dec. 8.)

Mathew, M. A. Marsh Warbler in Som. (Zool.)

Smith, C. Heronries in Som.; Demoiselle in Som. (Zool.)

Young, - - On Marsh and Reed Warblers. (T.c.)

I884. Edwards, C. L. F. Red Grouse in Som. (Field, Oct. 4.)

Ford, R. Great Grey Shrike, Snow Bunting and Leach's Petrel in Som. (Zool.) 
Smith, C. On Distinction between various nearly allied Birds, with ref. to those known to have occurred in Co. (Proc. Som. Soc.) Fulmar Petrel in Som. ; Great Grey Shrike and Snow Bunting in Som. (Zool.)

Spark, H. S. Solitary Snipe in Som. (Field, Oct. 4.)

I885. Hammond, W. O. Red Grouse in Som. (Zool.) Idem by C. Smith and by - Phillips. (T.c.)

Hobbs, E. Cirl Bunting in Som. (Field, Feb. I4.)

Smith, C. Ornitholog. Notes from Som., 2 pts. (Zool.)

I886. Smith, C. Occur. of Green Sandpiper in winter. [partim.] (Field, Feb. 6.)

I887. Goldsmith, H. St. B. Puffin, etc., in Som. (Zool.)

Morris-Risley, S. Snowy Owl near Bridgwater [an escape]. (Field, Feb. I9, Mar. I2.)

Pring, J. L. Ravens on the Quantocks. (Op. cit., Sept. Io.)

I888. E[dwards], C. L. F. Reeve in Som. (Field, Oct. 6.)

Goldsmith, H. St. B. Whimbrel in Som. ; Pallas's Sand-Grouse in Som. (Zool.)

Gyngell, W. Reported Occurrence of Lesser White-fronted Goose in Som. (Zool.) Idem by C. Smith. (T.c.)

Mathew, M. A. Additions to List of Som. Birds. (T.c.) Idem by C. Smith. (T.c.)

Smith, C. Pallas's Sand-Grouse in Som. (T.c.) Idem by M. A. Mathew. (T.c.)

Terry, C. Aves [in Brit. Assoc. Handbk. to Bath]. Cr. 8vo. Bath : I888. [679.]

I889. [Anon.] List of Birds of Bristol District. (Bristol Nat. Soc. Pr., Vol. IX., I889.)

Bidgood, W. Crane in Som. (Field, Dec. 2I.)

Read, R. H. Marsh Warbler in Som. (Zool.)

Rickards, M. S. C. Rare Birds in Som. (T.c.)

Smith, C. Gadwall in Som. (T.c.)

I890. Jefferys, T. B. Rose-coloured Pastor in Som. (Field, Sept. I3.) Mathew, M. A. Crane near Bridgwater. (Zool.)

Norman, G. The Fauna of Bath. (Pr. Bath N. H. \& Antiq. F.C.)

I890-9I. Aplin, O. V. Spotted Crake [in Som.]. 2 pts. (Zool., r890-9I.) [24.] (partim.)

I8gI. Goldsmith, H. St. B. Bittern in Som. ; Notes from Som. (Zool.) Knight, F. A. Long-tailed Duck on Coast; Spotted Crake in Som. (T.c.)

Mathew, M. A. Great Frost in S.W. (T.c.)

Mellor, J. P. Bewick's Swans in Som. (Field, Jan. 3.)

Read, R. H. Lesser Whitethroat in Som. (Zool.)

Tagewell, F. W. Bittern in Som. (Field, Jan. 3.) 
1892. Aplin, O. V. Cirl Bunting and Woodchat [in Som.]. 2 articles. [partim.] (Zool.) [25.]

Goldsmith, H. St. B. Hoopoe in Som.; Uncommon Birds in Som. (T.c.)

Gould, F. H. C. Manx Shearwater in Som. (T.c.)

I893. Goldsmith, H. St. B. Red-throated Diver, Spotted Crake and Quail in Som., 2 notes; Snowy Owl on Exmoor. (Op. cit.)

Knight, F. A. Fork-tailed Petrel in Som. (T.c.)

Mathew, M. A. A Revised List of the Birds of Som. Som. Soc., XXXIX.)

Rickards, M. S. C. Richard's Pipit in Som. (Zool.)

Swanton, A. E. List of Birds observed in Wincanton District. (Wincanton Field Club.) 4 pp. 8vo. I893.

I894. Goldsmith, H. St. B. Uncommon Birds in Som.; Lesser Redpoll breeding in Som., 3 notes; Shag on Som. Coast; Nesting of Grey Wagtail and Hawfinch in Som. (Zool.) Addenda to List of Birds of Som. (Pr. Som. Soc., X.)

Horsbrugh, C. B. Lesser Redpoll breeding in Som. (Zool.)

Mathew, M. A. Crossbills in Som. (T.c.)

Playne, H. C. Nesting of Marsh Warbler near Bath; Lesser Redpoll breeding in Som. (T.c.)

Swanton, E. W. Fauna and Flora of a Som. Village. (Nat. Jnl.)

I895. Harting, J. E. Two-barred Crossbill in Som. (Zool.)

Horsbrugh, C. B. Lesser Spotted Woodpecker in Som. (T.c.)

Wollaston, A. F. R. Nesting of Marsh Warbler near Bath. (T.c.)

1896. Goldsmith, H. St. B. Great Skua and Black-throated Diver in Som. ; Eared Grebe in Som. $(O p$. cit.)

Horsbrugh, C. B. Shoveler in Som.; Hawfinch in Som. ; Abundance of Golden Plover near Bath. (T.c.)

Hutton, L. Sabine's Gull in Som. (Field, Oct. 3.)

1897. Lewis, S. Black-winged Stilt in Som. (Zool.)

1898. Horsbrugh, C. B. Great Spotted Woodpecker [in Som.]. 2 notes. (Zool.)

Lewis, S. Nightingale, Great Spotted Woodpecker, Nuthatch, Swallow and Flycatcher in Som. (Op. cit.)

Tucker, C. W. H. Stone Curlew and Crossbill in Som. (Field, Sept. 24.)

I898-99. Andrews, C. W. Remarks on Bird-remains from the Lake Dwellings of Glastonbury. (P. Z. S., I898; Ibis, I899.)

I899. Lewis, S. Occur. of Crossbills, etc., 5 notes. (T.c.)

I900. Blathwayt, F. L. Occur. of Pied Flycatcher. (Op. cit.)

Horsbrugh, C. B. Gannet in Som. (T.c.)

I90I. Horsbrugh, C. B. Nesting of Marsh Warbler in Som. (Op. cit.) Idem by O. V. Aplin. (T.c.)

Lewis, S. Lesser Spotted Woodpecker in Som. (T.c.) 
Read, R. H. Yellow-billed Cuckoo in Som. (Bull. B.O.C., XII., I9OI-02; Zool., I902.)

Westell, W. P. Honey Buzzard [errore] nesting in Som. (Ibis.) Idem by F. C. R. Jourdain. (T.c.)

I902. Blathwayt, F. L. White Wagtail on Som. Coast ; Lesser Redpoll in Som. (Zool.)

Knight, F. A. The Sea Board of Mendip. Cr. 8vo. Lond.: I902.

Lewis, S. Notes on Nesting of Green Woodpeckers at Wells. (Zool.)

Read, R. H. Marsh Warbler in Som. (T.c.)

I903. Aplin, O. V. Rock Dove in Som., 2 notes. (Op. cit.)

Lewis, S. Rock Dove [errore] inland in Som. ; Nightingale's Late Arrival in Som.; Goldfinch in Som. (T.c.)

Meyrick, H. Lesser Redpoll in Som. (T.c.)

Read, R. H. Fork-tailed Petrel in Som. (T.c.)

I904. Blake, A. W. Bittern in Som. (Field, Jan. I6.)

Blathwayt, F. L. Notes on Birds found on Coast; Shore Birds. (Zool.)

Lewis, S. Buffon's Skua in Som. (T.c.)

1905. Blathwayt, F. L. Buffon's Skua and Cirl Bunting in Som. $10 p$. cit.)

Read, R. H. On Nesting of Red-legged Partridge in Som. (Bull. B.O.C.)

I905-7. Castellain, A. List of Birds . . . of Bath and Neighbourhood, with Periods of their First Appearance, 3 pts. (Pr. Bath Club. I905-7.)

I906. Blathwayt, F. L. Birds [In Victoria Hist. of Co. of Somerset, I.]. 4to. Lond. : I906. [7I.]

Blathwayt, F. L. Notes on the Kite in Som. (Zool.)

Lewis, S. Bittern in Som. ; Great Tits, etc., 4 notes. (T.c.)

Meyrick, H. Rough-legged Buzzard in Som. (T.c.)

I907. Fox, W. Little Bustard in Som. (Field, July I3.)

Turner, J. Merlin nesting in Som. (T.c., July I3.)

r908. Blathwayt, F. L. Wildfowl in Som., 2 pts.; Somerset Heronries. (Zool.)

Bunyard, P. Nesting habits of Marsh Warbler [in Som.]. (Brit. Birds, II.)

Dalgleish, J. Goldeneye in Som. (Zool.)

Ig09. Knight, F. A., and Dutton, L. M. Cambridge County Geographies: Somerset. Post 8vo. Cambridge : 1909. [333.]

I9I0. Mapleton, H.W. On late nesting of Cirl Bunting in Som. (Brit. Birds, IV.)

Percival, P. Crossbills in Som. (Field, Aug. 13.) Kempe, W. J. Crossbills breeding in Som. (Field, June 4.) 
I9II. Blathwayt, F. L. Breeding of Shoveler, Tufted Duck, Garganey and Great Crested Grebe in Som., 2 notes. (Brit. Birds, IV.)

Ticehurst, N. F., and Jourdain, F. C. R. Distrib. of Nightingale. (Op. cit.) [partim.]

I9r2. Coward, T. A. Blackcap wintering in Som. (Op. cit.)

Lewis, S. Occurrences in Som., 4 notes. (T.c.)

Smith, Amy. The Rarer Birds of Somerset. Sm. 8vo. Taunton : I9I2.

Smith, D. M. Abnormal Breeding Habits of Sheld-duck. (Brit. Birds, VI.)

Turner, J. Notes on Som. Birds from I865 to I9II. [Typed. for members of Ornitholog. Sect. of Som. Arch. \& N. H. Soc.]

Whish, F. H. L. Uncommon Occurrences in Som. (Brit. Birds, V.); Little Bittern in Som., 2 notes. (Op. cit., VI.)

I9I3. Mapleton, H. W. Blackcap wintering [in Som.]. (Op. cit., VI.) Newton, A. E. Black Redstart near Taunton. (Field, Oct. I8.) Smith, D. M. Redshank nesting in Som. (Brit. Birds, VII.)

I9I4. Charlton, J. M. Visitation of Black Redstarts in Som. (Zool.) Lewis, S. Little Owl breeding in Somerset. Idem. by H. L. Popham. - (Zool.)

Royle, F. G. Bittern in Som. (Field, Feb. 28.)

Wollaston, A. F. R. Kite in Som. (Brit. Birds, VII.)

I9I5. Castellain, A. Snow Bunting in Bath. (Field, Mar. 20.)

Lewis, S. Buffbacked Heron in Som. (Zool.)

Symes, J. H. Late nesting of Cirl Bunting in Som. (T.c.)

Turner, A. W. Little Bustard in Som. (Field, Feb. 6.)

rgr6. Dougall, F. M. Increase of Barn Owls in Som. (Op. cit., Mar. 25.) Hendy, E. W. Pied Flycatcher in Som. (Brit. Birds, X.)

Lewis, S. Some Bird Notes from Somerset Coast. (Zool.)

Mapleton, H. W. Land Rails in Som. (Brit. Birds, X.)

Symes, J. H. Scarcity of Corncrakes in Som. (Zool.)

Wiglesworth, J. Ruddy Sheld-Drakes in Som. (Brit. Birds, X.)

I9I7. Lewis, S. Sand Martins nesting in Drain pipes. (Op. cit., X.); Waxwings in Som. (Op. cit., XI.)

Wiglesworth, J. Shag inland in Som. $(O p$. cit., X.); Arctic Skua in Som. in June; Communal Laying by Sheld-duck. $(O p$. cit., XI.) ; The Little Owl in Som. (Proc.Som. Arch. \& N.H. Soc., LXIII., pp. I52-I6r.)

Igr8. Bruton, F. A. Waxwing in Somerset. (Brit. Birds, XI.)

[Editorial.] Little Owl in Som. (Op. cit., XII.)

Lewis, S. Supposed Occurrence of Buff-backed Heron in Som. (Op. cit., XI.) Evolutions of Male Raven. (Op. cit., XII.) Wiglesworth, J. Bitterns in Som. (T.c.) The Heronries of Som. (Proc. Som. Arch. \& N. H. Soc., LXIV., pp. 68-85.) 


\section{STAFFORDSHIRE.}

I686. Plot, R. Natural History of Staffordshire. Folio. Oxford: I686. [476.]

I798 [-I80I.] Dickenson, J. H. Sketch of Zoology of Staffs. [In Shaw's History and Antiquities of Staffs.]. Folio. I798-I80I. [I67.] Idem, Reprinted (as far as relating to Birds) in Trans. N. Staffs. F. C., XXVII., pt. 2, I893.

I8I7. Pitt, W. A Topographical History of Staffordshire. 8vo. Newcastle-under-Lyme: I8I7. [474.]

I829. Blackwall, J. Extracts from Zool. Journal. [Roosting of Fieldfares near Tamworth.] (Zool. Jnl.) ; Manchester Mus. [Honey Buzzard in Staffs.]. (Loudon's Mag. N. H., II.)

I833. "J. D." The Virginian Partridge [on naturalization]. (T.c.)

I839. [Anon.] Sheld-drake shot near Eccleshall. (Mag. N. H., II., p. 56.)

I843. Brown, E. Note on more frequent occurrence of Woodcock. (Zool.)

I844. Sladen, E. H. M. Note on Occurrence of Hoopoe, etc. (Op. cit.) I844-6o. Garner, R. Natural History of the County of Stafford. 8vo. Lond. : I844. [226.] Supplement, I860.

I846. Mosley, Sir O. Occurrence of Great Ash-coloured Shrike and Snow Bunting near Burton-on-Trent [420.] ; Remarks on Nuthatch. 2 notes. (Zool.)

I85I. Hawkins, R. W. Occurrence of Pied Flycatcher, etc., near Rugeley. (Op. cit.)

1852. Hawkins, R. W. Nest and Eggs of Black Redstart [?]; Nesting of Woodcock in Staffs. 2 notes. $(O p$. cit.)

1853. Brown, E. Occurrence of Sooty Tern in England. (Op. cit.)

McIntosh, J. Sterna fuliginosa [near Burton-on-Trent]. (Nat. [Morris's], III.)

1856. Buchanan, C. Honey Buzzard breeding in Britain. (Op. cit.)

I858. Buckley, H. Occurrence of Wood Sandpiper near Birmingham. (Op. cit.)

I859. "Astur." Nesting place of the Lesser Redpoll [in Staffs.]. (Field, May I4.)

"W." White Flycatchers [at Burton-on-Trent]. (Field, July 30.)

I860. "H. H." Waxen Chatterer [near Trentham]. (Op. cit., Dec. 8.)

I863. Mosley, Sir O. The Natural History of Tutbury, together with the Fauna and Flora of the District surrounding Tutbury and Burton-on-Trent, by E. Brown. Roy. 8vo. Lond.: I863. [420.] 

"Rowlstone." The Rough-legged Buzzard [on Cannock Chase].
(Field, Mar. 2r.)

Shaw, H. O. Rare Birds in Shropshire and District [including Bittern from Rugeley]. (Field, Feb. 6.)

Smith, T. Fulmar Petrel near Birmingham. (Zool.)

Yates, S. [Letter on Pallas's Sand-Grouse at Eccleshall.]
May 28.)

(Times,

1864. MacMeikan, J. Canada Geese. (Field, June 25.)

I865. "F. G." Wildfowl on Trent [at Burton]. (Op. cit., Feb. 4.)

Worthington, A. O. Idem. (T.c., Feb. II.)

"W. J. B." Occurrence of Bittern. (T.c., Feb. I8.) I867. Bailey, A. B. Bramblings near Eccleshall. (Zool.) Idem.
(Field, Jan. 26.)

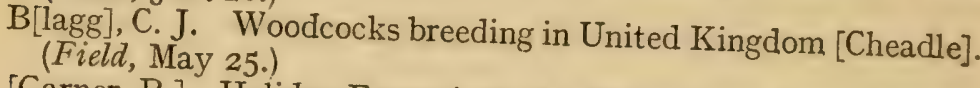

[Garner, R.] Holiday Excursions of a Naturalist. 8vo. Lond.: I867. [226.]

Millard, E. S. The Brambling [at Eccleshall]. (Field, Jan. I9.)

I868. "G. N. M." Goosanders, Redcrested Whistling Duck and Bittern. (T.c., Jan. I8.)

"M." Tree Creeper's Nest. (T.c., May 23.)

Mosley, Sir O. Nidification of Bohemian Waxwing [!] in England.

"P. L. S." Nightingales in Ingestre Park. (Field, Apr 8 ) Idem by " C. F. L." (T.c., Apr. 25.)

I869. Mosley, Sir O. Effect of Cold on Birds. (Zool.) [420.]

Wilkins, J. The Cuckoo. (Field, Aug. 7.)

I870. Browne, A. M. Great Northern Diver in Midland Counties.

Mosley, Sir O. Golden Plover on the Dove; Great Northern

Diver at Burton-on-Trent. 2 notes. (T.c.)

I87I. Beale, C. Spotted Crake near Birmingham. (Field, Nov. 25)

Hamel, E. D. Golden Oriole near Tamworth. (Zool.)

Walsh, W. H. White House Martin. (T.c.)

I873. Brown, E. Red-headed Weaver Bird in Staffs. (Field, Mar. I.)

Hamel, E. D. Ornithological Notes from Tamworth. (Zool.)

1874. Ashworth, H. Stock-Dove breeding in Rabbit Warren. (Field, May $\mathbf{6 .}$.)

Brown, E. Squacco Heron in Staffs. (T.c., June 27.)

Wardle, T. Shoveler near Leek. (T.c., Apr. 25.)

I875. Browne, M. Little Auk near Birmingham. (Op. cit., Dec. Ir.)

I877. Lucas, J. B. Woodcock's Nest in Staffs. (Op. cit., Apr. 28.)

Round, W., junr. Great Northern Diver in Staffs. (T.c., Jan. 20.) 
I878. Sainter, J. D. Jottings of some .... Rambles round Macclesfield. 8vo. Macclesfield : I878. [50I.]

I879. "Observer." Arrival of Whitethroat and Blackcap in Staffs. (Field.)

Tomlinson, H. G. Birds and their Habits, with special reference to Birds found in the Neighbourhood of Burton-on-Trent. I879. Pt. I. (Midland Nat.) Idem, Pt. II. (Rept. Burtonon-Trent N.H. Soc., I88o.)

Tomlinson, H. G. Disappearance of Skylarks. (Zool.)

I880. Paget, B. Rough-legged Buzzard in Staffs. (Field, Dec. II.)

I88x. "Observer." Summer Birds at Uttoxeter. (Op. cit., Mar. 26.)

Tomlinson, H. G. Our Summer Migrants. (Midl. Nat.)

Wragge, C. L. Autumn of 1879 on the Staffs. Moorlands. (N. Staffs, F. C. Trans.)

I882. "K. D." Pintailed [Pallas's] Sand-Grouse in Staffs. [in I863]. (Sci. Gossip, Oct.)

Pickering Clarke, C. Nightingale North of the Trent. (Field, May 27.)

Richardson, M. Manx Shearwater inland [near Burton-on-Trent]. (Op. cit., Sept. 9.)

Vickers, V. W. Nightingale in Staffs. (Op. cit., May 20.)

Wayte, W. Partridges with white horseshoe [near Burton]. (Field, Nov. 4.)

1883. "L." Wildfowl in Staffs. [Black Tern and Wild Goose.] (Op. cit., Jan. I3.)

1884. Bladen, W. Wells. Stray Notes on Birds. (Tr. N. Staffs. F. C., I884.)

“J.C. P." Wren's Nest in Cabbage. [Stoke-on-Trent.] (Field, Apr. 26.)

"K. D." Cormorant in Worcs. [and Manx Shearwater in Staffs.] (Sci. Gossip.)

"Snipe." Manx Shearwater near Burton-on-Trent. (Field, Sept. 20.)

I885. B[aden], W. W. Nidification in Staffs. ; Osprey at Copmere. 2 notes. (Sci. Gossip.)

Brockholes, W. F. Common and Honey Buzzards in Lancs. and Staffs. (Zool.)

Lewisham, Lord. Black Tern near Wolverhampton. (Field, Sept. 26.)

I885-I9I8. Masefield, J. R. B. Reports on Zoology. (Tr. N. Staffs. F. C., I885-I9I8.) [390.]

I886. Blagg, E. W. H. Pheasant, Partridge and Wild Duck laying in Same Nest. (Zool.)

Hutchinson, A. S. Occurrence of Green Sandpiper in Winter [near Burton-on-Trent]. (Field, Feb. 20.) 
I887. Blagg, E. W. H. Jackdaw taking possession of Magpie's Nest ; Redstart laying Spotted Eggs; Manx Shearwater in Staffs., etc., 5 notes. (Zool.)

Lewisham, Lord. Scaup inland [near Wolverhampton]. (Field, Nov. 26.)

I888. Bird, E. A. Deformed Beak in Partridge. (Op. cit., Oct. 6.)

Elliott, J. S. Honey Buzzard in Staffs. (Zool.)

I889. Blagg, E. W. H. Jackdaws Nesting in old Magpie's Nest ; Eggs of Grey Wagtail, etc. 4 notes. (Op. cit.)

Dilworth, F. Bittern in Staffs. (Field, Jan. I9.)

McAldowie, A. Notes on Rookeries near Stoke. (Rept. \& Tr. N. Staffs. F. C., I889.)

1890. Blagg, E. W. H. Sand-Grouse in Staffs.; Nesting Habits of Dipper. 2 notes. (Zool.)

White, A. R. Fork-tailed Petrel in Staffs. (Field, Mar. 8.)

I89I. Blagg, E. W. H. Varieties of Eggs of Birds which nest in N. Staffs. (Rept. E Tr. N. Staffs, F. C.)

Bund, J. W. W. Systematic List of Birds met with in Counties of Worcs...... Staffs, etc. 8vo. [riro.]

Tye, E. Spotted Crake in Staffs. (Zool.)

I892. Hutchinson, A. S. Catalogue of the Birds in the Museum at Rolleston Hall.

1893. Blagg, E. W. H. Waxwing in Staffs. (Zool.)

"C. T. M." Quails in Staffs. (Field, Oct. 28.)

McAldowie, A. M. The Birds of Staffordshire. (Tr. N. Staffs. F. C., I893.) Also reprinted for the Author. 8vo. Stoke-onTrent : I893. [365.]

I894. Coburn, F. Grey Phalarope in Staffs. (Zool.)

1897. Baylis, E. Honey Buzzard in Staffs. (Op. cit.) Idem by J. Steele Elliott. (T.c.)

Hutchinson, A. S. Spangled Variety of Partridge. (Field, Mar. 6.)

I898. Bahr, P. H. Birds of Staffs. and N. Wales. (Rept. Rugby N. H. Soc.)

Bladen, W. Wells. Occurrence of Colony of Jackdaws having Domed Nests. (Knowledge, Jan.)

IgoI. Bladen, W. Wells. Jackdaws with Domed Nests. (Rept. N. Staffs. $F . C$.)

Masefield, J. R. B. On Occurrence of Petrels in Staffs. (T.c.) ; Dark Variety of Partridge. (Field, Dec. I4.)

Sopwith, R. S. Partridges in the Water. (T.c., Aug. Io.)

I902. Masefield, J. R. B. Rufous Variety of Common Partridge in Staffs. (Rept. N. Staffs. F. C.) [390.] 
I903. Jourdain, F. C. R. On Northern Breeding Range of Dartford Warbler. (Zool.) [322.]

Masefield, J. R. B. Notes from Chartley Park. (Field, June I3.)

I904. Jourdain, F. C. R. Dartford Warbler and its Allies. (Rept. N. Staffs. F. C.) [322.]

Orgill, W. L. Redshank nesting in Staffs. (Field, June I8.)

I904-I2. Bladen, W. W. Bird Notes, chiefly taken at Stone. (Rept. N. Staffs. F. C., I904-I2.) [69.]

I905. Masefield, J. R. B. Nesting of Lapwing. (Zool.)

I906. Clarke, G. H. Birds of the Pool, Chasetown. 8vo. [68I.]

Masefield, J. R. B. White-tailed Eagle in Staffs. (Zool.)

Tomlinson, H. G. Riverside Birds in Autumn. (Field, Oct. I3.)

I907. Coussmaker, J. O. Brambling and Owls in Staffs. (Op. cit., Jan. 26.) 2 notes; Present Status of Woodlark. (T.c., June 29.)

Masefield, J. R. B. Short-eared Owl in Staffs. (T.c., Jan. I2.) Idem. (Zool.)

Worthington. A. O. Owls in Staffs. (Field, Feb. 2.)

I908. Bladen, W. Wells. Greenshank in Staffs. (Brit. Birds, I.); Nesting of Shoveler in Staffs. (Field, Aug. I); Idem. (Brit. Birds, II.)

Dartmouth, Lord. Nesting of Shoveler in Staffs. (Fiell, Aug. I5.)

Masefield, J. R. B. Birds [In Victoria Hist. of Co. of Staffs., I.]. 4to. Lond.: I908. [390.]

Wolferstan, E. S. P. Honey Buzzard near Tamworth. (Field, Oct. 3I.)

I909. Bladen, W. Wells. Shoveler nesting in Staffs. (Brit. Birds, III.)

Coussmaker, J. O. Pied Flycatcher in Staffs. (Field, July 3.)

Duncalfe, A. H. Nesting of Nightingale on Borders of Staffs. and Shropshire; Nesting of Lesser Spotted and Great Spotted Woodpeckers in Staffs. 2 notes. (Zool.)

Masefield, J. R. B. Nesting of Nightingale in Staffs.; Honey Buzzard in Stafis.; Redshank carrying young (?). 3 notes. (T.c.)

IgIo. Bladen, W. Wells. Pintails in Staffs. (Brit. Birds, IV.)

Chadwick, M. Leach's Petrel at Tamworth. (Field, Oct. 22.)

Coburn, F. On Some Rarer Birds of Staffs. and their Migration across the County. (Rept. N. Staffs. F. C.)

Jourdain, F. C. R., and Witherby, H. F. Recent Records from Staffs., etc. (Brit. Birds, IV.) [322.]

Leigh, A. J. Little Owl in Staffs. (Op. cit., III.)

Monckton, F. A. Crossbill nesting in Staffs. (T.c.) ; Wigeon in Summer in Staffs. $(O p$. cit., IV.)

Smith, T. Red-backed Shrike in N. Staffs. (Op. cit., V.) Idem by F. C. R. J[ourdain]. (T.c.) 
IgII. Bryan, B. Wild Life around Longton. (Rept. N. Staffs. F. C.) Masefield, J. R. B. Pintails in Staffs (Brit. Birds, IV.) Rare Birds in Staffs. $(O p$. cit., V.); Decrease of Corncrake and Wryneck; Range of Twite, 2 notes. (Zool.)

Ticehurst, N. F., and Jourdain, F. C. R. On Distribution of Nightingale during Breeding Season in Great Britain. (Brit. Birds, V.) [partim.] [322; 584.]

I9I2. Bladen, W. Wells. Little Auk in Staffs. (Field, Feb. Io.)

Masefield, J. R. B. Return of Marked Swallow to its Breeding Place ; Hooded Crow in Staffs. ; Birds breeding in old Nests. 3 notes. (Brit. Birds, VI.); Nesting of Tree Creeper. (Zool.) Monckton, F. A. Crossbills in Staffs.; Great Northern Diver in Staffs. 2 notes. (Brit. Birds, , V.)

W[itherby.] H. F. The IgI2 "Wreck" of the Little Auk. (T.c.) [partim.]

Worthington, A. O. Little Owl near Lichfield. (Field, Jan. 6.)

I913. Jourdain, F. C. R. Breeding of Willow Tit in Staffs. (Rept. \& Trans. N. Staffs. F. C., XLVIII., pp. 88-90.)

Leigh, G. Razorbill in Staffs. (Brit. Birds, VI.)

Masefield, J. R. B. Pomatorhine Skua in Staffs.

Witherby, H. F. Swallow ringed in Staffs. recovered in Natal. (Brit. Birds, VI.)

I9I3-I5. Bladen, W. Wells. Bird Notes chiefly taken at Stone, I9I2-I4. 3 pts. (Rept. \& Trans. N. Staffs, F. C., XLVII., pp. 7I-8, I9I3; XLVIII., pp. 8I-7, I9I4; XLIX., pp. 83-6, I9I5.)

r9r4. Bladen, W. Wells. Hoopoe in Staffs. (Brit. Birds, VII.)

Forrest, H. E. Hairy Variety of Moorhen in Staffs. (T.c.)

Monckton, F. A. Uncommon birds in Staffs. (Op. cit., VII.)

Masefield, J. R. B. Gannets in Staffs. ; Little Gull in Staffs., etc., 4 notes. (Brit. Birds, VIII.)

[Editorial.] Mealy Redpolls in Staffs. (Brit. Birds, VIII.)

Worthington, A. O. Wild Swans in Staffs. (Field, Feb. 28.)

I9I5. [Editorial.] Dartford Warbler in Staffs. (Brit. Birds, IX.)

Masefield, J. R. B. Tawny Owl nesting on ground; Land Rails in Staffs. (T.c.) ; Reeve in Staffs. (Zool.)

I9r6. Davies, W. Marsh Warbler observed in Staffs. (Brit. Birds, X.) Jourdain, F. C. R. Status of Little Orvl in Staffs. (T.c.)

Masefield, J. R. B. Reeve in Staffs.; Little Owl in Staffs.; Woodcock perching. (Op. cit., IX.)

Smith, T. Sand Martins roosting in trees. (Op. cit., X.)

I9I7. Davies, W. Marsh Warbler [in Staffs.]. (Field, June 9.) [Editorial.] Hooded Crows breeding in Staffs. (Brit. Birds, X.) Forrest, H. E. Unusual Birds in Salop. (T.c.) [partim.] Masefield, J. R. B. Martin feeding young Swallows. (Op. cit., XI.) Smith, T. Common Partridge perching on Wall. (Op. cit., X.) Wenner, M. V. Crossbills in Staffs. (T.c.) 
Igr8. Coussmaker, J. O. Snowy Owl in Staffs. (Field, Jan. I9.)

Davies, W. Marsh Warbler breeding in Staffs. (Brit. Birds, XII.) [Editorial.] Old Record of Goshawk in Staffs. (Op. cit., XI.) ; Late Stay of Swift. (Op. cit., XII.) [partim.]

Eyton, C. E. M. Marsh Warbler breeding in Staffs. (Op. cit., XI.) Forrest, H. E. Spotted Crake in Staffs. (Op. cit., XII.)

Grindey, E. Cormorant in Staffs., etc. (T.c.)

Jourdain, F.C. R. Snowy Owl reported in Staffs., etc. (Op.cit., XI.) ; Critical Notes on Staffs. Ornithology. (Rept. \& Trans. N. Staffs. F. C., LII., pp. 97-Ior.)

Masefield, J. R. B. Little Auk in Staffs. ; Cormorants in Staffs. (Brit. Birds, XI) ; Spotted Crake in Staffs. (Field, April 20.) Smith, T. Brent Geese in N. Staffs.; Late Stay of Common Sandpiper in Staffs. (Brit. Birds, XI.)

\section{SUFFOLK.}

I686. Plot, R. Nat. Hist. of Staffs. Fol. Oxf. : I686. [Avocet found in Suffolk, p. 23I.]

I826. Sheppard, Rev. R., and Whitear, Rev. W. A Catalogue of Norfolk and Suffolk Birds, with Remarks. (Tr. Linn. Soc.) [partim.]

I830. Hoy, J. D. Rare Birds killed I829-30 in Suffolk, etc. (Loudon's Mag. N. H., III., pp. 34, 436.)

I83I. Acton, E. List of Scarce Birds killed in Suffolk since Autumn of I827. (Op. cit., IV., p. I62.)

Nicholls, J. Birds in Neighbourhood of Great Finborough Hall. (T.c.)

Turner, H. First appearance of Wryneck. (T.c., p. 449); Kingfisher at Bury. (T.c., p. 450.)

I832. Hoy, J. D. Honey Buzzard [at Stoke Nayland]. (Op. cit., V.) " J. G." Notice of Reed Warbler [at Sudbury]. (T.c.)

I833. Hoy, J. D. Rose-coloured Ouzel, Hoopoe and Great Bustard in Suffolk in I832. (Op. cit., VI.)

Hodson, H. S. Great Bustard [at Icklingham]. (T.c.)

1834. Hoy, J. D. Rare Birds observed or killed in Suffolk during Winter of I832-33. (Op. cit., VII.)

"W. B. C." Ferruginous Duck or Ruddy Goose [shot at Iken, near Orford.] (T.c.)

1835. Turner, H. Peregrine Falcon and Bohemian Waxwing [in Suffolk]. 2 notes. (OP. cit., VIII.)

1836. Hoy, J. D. Capture of Grey-headed Yellow Wagtail at Stoke Nayland, Suffolk. (Op. cit., IX.) 
Brown, J. S. Bohemian Waxwing and Crossbill [near Bury St. Edmunds]. (T.c.)

[Editorial.] Motacilla neglecta Gould [in Suffolk]. (Mag. Zool. \& Bot., I.)

I837. Hoy, J. D. Occurrence of Two New Species of Tringa, with List of Rarer Birds killed in Suffolk, I835-6. (Charlesw. Mag. N. H.)

I838. I K[ing, W. D.] List of Birds found in Neighbourhood of Sudbury. 4to. 1838. [330.] (Reprinted from Fulcher's Sudbury Journal, 1838.)

Townsend, T. Capture of White-tailed Eagle on Suffolk Coast. (Charlesw. Mag. N. H.)

I839. Wake, R. Southwold and its Vicinity. Post 8vo. Yarmouth : I839.

Clarke, B. Remarks on Redlegged Partridge [introd. in Suffolk]. (Charlesw. Mag. N.H.)

I84I. Townsend, C. T. Little Auk in Suffolk. (Ann. Mag. N. H.)

I843. Fisher W. R. Note on occurrence of rare Birds near Great Yarmouth, etc. 9 notes. $\left(Z_{0 o l}\right)$

Atkinson, J. C. Note on Habits of Nuthatch. (T.c.)

1844. Fisher, W. R. Goshawk off Yarmouth. (Zool.)

Jesse, E. Scenes and Tales of Country Life. Post 8vo. Lond. : I844. [3I7.]

Newton, A. Dates of Nidification of Birds at Elden [Elveden.] (Zool.) [445.] Sea Eagle at Elden; Black Grouse at Elveden, 2 notes. (T.c.)

I844-49. Newton, A. Arrival of Migratory Birds at Elveden in Suffolk in $1844-48,9$ notes. (Op. cit., I844-49.) [445.]

I845. Newton, A. Spotted Redshank at Elden. (Op. cit.)

Newton, E. Early Nest of the Blackcap. (T.c.)

Sladen, E. Supposed occurrence of the Chanting Falcon in Suffolk. (T.c.) Correction by J. H. Gurney. (T.c.)

I846. Bree, C. R. Dates of Arrival of Summer Visitants at Stowmarket. $(O P$. cit.) Grosbeak [Hawfinch] at Stowmarket. (T.c.)

Gurney, J. H., and Fisher, W. R. Account of Birds found in Norfolk. [partim.] (Zool., and separate reprint.) [259.]

Spalding, T. M. List of Birds rarely and occasionally met with in the County of Suffolk. [In Suckling's History of Suffolk.] 4to. Lond. : I846. [555.]

I \& 47. Johnson, F. W. Occurrence of Rare Birds near Ipswich. (Zool.) Newton, A. Occur. of rare birds near Thetford. [partim.] (T.c.) Ransome, G. Rare Birds occurring near Ipswich. (T.c.); Hoopoe near Ipswich. (T.c.) 
1847-49. Newton, A. Nidification of Birds at Elveden, 3 notes. $(O p$. cit., I847-49.) [445.]

I848. Fisher, W. R. Orn. Notes in Norf. [Waxwings near Lowestoft.] (Zool., p. 20I7.)

Johnson, F. W. Ring Ouzel in Suffolk; Bohemian Waxwing in Suffolk; Spoonbill at Aldborough; Masked Gull at Aldborough; Extreme abundance of Mealy Redpoll near Ipswich ; Rough-legged Buzzard, Velvet Scoter and Common Scoter in Suffolk; Ferruginous Duck in Suffolk, 3 notes; Common Bittern at Ipswich. (Zool.)

I849. Bree, C. R. Occurrence of Great Grey Shrike in Suffolk ; Nesting of Linnet and Nightingale; Two-barred Crossbill in Suffolk; Occurrence of Smaller Spotted Woodpecker near Stowmarket; Occurrence of Hooded Crow at Drinkstone; Late Appearance of Swallow. (Op. cit.) 5 notes.

Newton, A. Dates of Singing of Birds at Elveden; Dates of Departure of Migratory Birds at Elveden in I848; Rare birds near Thetford. [partim.] (T.c.) [445.]

Gurney, J. H. Ring Ouzel nesting near Lowestoft. (T.c.)

1850. Lingwood, H. Pied Flycatcher at Battisford. (Zool.)

Bond, F. Little Auk at Newmarket. (T.c.)

Bree, C. R. Goshawk near Stowmarket; Hoopoe near Stowmarket. (T.c.)

Gurney, J. H. Glossy Ibis near Lowestoft. (T.c.); Rosecoloured Pastor at Lowestoft. (T.c.)

Newton, A. Waxwing in Norfolk, Suffolk, etc.; Gannet near Bury St. Edmunds. (T.c.)

I85r. Harper, J. O. Fork-tailed Petrel at Lowestoft. (Op. cit.)

Gurney, J. H. Golden Oriole [near Bungay]; Rose-coloured Pastor in Suffolk. (T.C.)

Newton, A. Parrot Crossbill in Suffolk, etc. (Zool.)

Newton, E. Spotted Redshank in Suffolk. (Zool.)

"R. P. C." Purple Sandpiper [in Suffolk]. (Nat. [Morris's], I.)

1852. Creed, H. K. [Heronry at Henham Hall.] (Op. cit., II.)

Gurney, J. H. Red-breasted Merganser at Lowestoft in July. $($ Zool. $)$

Nunn, E. C. Hoopoe near Bungay. (Nat. [Morris's], II.) ; Egyptian Goose [near Woodbridge]. (T.c.)

I853. Gurney, J. H. On white var. of Common Tern. (Zool.)

Newton, A. Note on singularly placed Nests of Pheasant and Red-legged Partridge. (Zool.)

Farr, J. The Hobby [nesting near Wangford]. (Nat. [Morris's], III.)

I854. Gurney, J. H. Occurrence of Grey-headed Wagtail at Lowestoft. $($ Zool.)

Crisp, Dr. Exhibition of Grey Shrike shot in east Suffolk. (P. Z. S.) Idem. (Zool.) 
Stevenson, H. Honey Buzzard in Norfolk and Suffolk. (Zool.) Harper, J. O. King Duck on the Suffolk coast. (Nat. [Morris's], IV.)

I855. Bree, C. R. Rare Birds captured near Stowmarket; Birds killed by cold, Stowmarket. (Zool.)

Stevenson, H. Roller in Suffolk. (T.c.)

I856. Fuller, A. Storm Petrel at Newmarket, etc. (Op. cit.)

Gurney, J. H. Rare Birds procured in ..... Suffolk; Instance of Honey Buzzard feeding on Blackbirds' Eggs. (T.c.)

Savill, S. P. Hoopoe [at Great Thurlow]. (Nat. [Morris's], VI.)

I857. Crisp, E. On a nest found in Suffolk, supposed to be that of Lanius excubitor. (P.Z.S.)

Gurney, J. H. Honey Buzzard near Lowestoft. (Zool.)

Stevenson, H. Hawfinches breeding in Suffolk. (T.c.)

I858. "Crichton." Golden Oriole [breeding near Ipswich]. (Field, Aug. I4.)

Neave, E. Spoonbill near Aldborough. (Zool.)

Stevenson, H. Little Bustard at Gorleston. (T.c.)

Thirtle, - . Occurrence of Motacilla flava Ray at Lowestoft. (P. Z.S.)

I859. Stevenson, H. Goshawk, Woodchat Shrike and Ortolan Bunting in Suffolk; Unusual number of Hoopoes and Ring Ouzels; Occurrence of Red-throated Diver in Suffolk. 4 notes. (Zool.)

I860. "R. D. G." Sea-Eagle shot in Sussex [err. for Suffolk, near Bury St. Edmunds]. (Field, Mar. 3.)

Gough, R. L. Crossbills [near Bury St. Edmunds]. (Op. cit., Aug. 4.)

Savill, S. P. Red-necked Phalarope [Lakenheath Fen]. (T.c., Dec. 8.)

I86I. Grubb, J. Ornithological Notes from Felixstowe. (Zool.)

Neave, E. Little Bustard in Suffolk. (T.c.) Idem by "Midwinter." (Field, Feb. 23.)

Sclater, P. L. American Meadow Starling shot in Suffolk. (P.Z.S.)

Winter, W. Ornitholog. Notes from Aldeby, near Beccles. (Zool.) [partim.]

1862. Barclay, W. L. On three Ravens feeding on a dead Hare at Higham. $(O p$. cit.)

King, S. Little Auk at Sudbury. (T.c.)

Tyrer, R., junr. Crossbill near Eye. (T.c.)

Ward, E. H. [Hoopoe at Ipswich.] (Field, May Io.)

I863. Allis, T. H. Osprey near Bury St. Edmunds. (Zool.)

Bree, C. R. Varicty of Grey Partridge [in Suffolk]. (Ficld, Aug. 29.)

Dix, T. Pallas's Sand Grouse in Suffolk. (Zool.) 
Harting, J. E. Great Grey Shrike near Newmarket. (T.c.)

Hele, N. F. Pallas's Sand Grouse in Suffolk (T.c.); Garrulous Roller in Suffolk. (T.c.; Field, July 4.)

Huckett, T. Parrot Crossbills at Brandon. (Zool.)

Neave, E. Pallas's Sand Grouse in Suffolk. (Zool.)

Roberts, A. W. Shore Lark near Lowestoft. (Zool.)

Stevenson, H. Pallas's Sand Grouse in Norfolk and Suffolk, 3 notes; Orange-legged Hobby in Suffolk (Zool.); Spoonbills in Suffolk Coast. (Zool.) Idem. (Field, June 6.) "J. M." Idem. (Field, May 9), "C. M. A[damson.]" Idem. (T.c., May 30.)

I863-86. Hele, N. F. Notes from and Jottings about Aldeburgh. (Field, I863, Jan. I0, Apr. I8, July I8, Sept. 26, Nov. 21, 28 ; I864, Jan. I6, 30, Mar. I9, June 25, Aug. 20, Oct. 22, Nov. I9, 26 ; I865, Feb. 4, 25, Apr. 29, July 22, Sept. I6, Oct. 28, Nov. II ; I866, May I9, 26, June 2, Aug. 4, Oct. 6, Nov. Io. I7 ; I867, Feb. 9, Apr. 20, May 25, July I3, 20, Aug. 24, Oct. 26; I868, Jan. II, Mar. 2I, Sept. 5, Nov. 28; I869, Feb. I3, June I9, Oct. 30 ; 1870 , Feb. 26, Mar. 26 , Nov. 5 ; I87x, Jan. 7, 28, Oct. I4, Nov. II ; I872, Oct. I2; I873, Nov. I, 9; I874, Apr. 25, May 9, Dec. I9, 26 ; I876, June 17 , Oct. 14, Nov. 25 ; I880, Jan. 3I ; I886, July 24.)

I865. "C. F. T. D." Lesser Kestrel [errore for Common] in Suffolk. (Field, Nov. 4.) Idem. (Op. cit., Jan. 20, I866.)

Gunn, T. E. Great Grey Shrike in Suffolk; Hoopoe near Lowestoft. (Zool.)

" J. P." Late Swallows and Martins [to Dec. 5]. (Field, Dec. 9.)

"J. O." Goosander in Suffolk. (Field, Feb. II.)

I866. Gunn, T. E. Solitary Snipe, Peregrine Falcon, Rough-legged Buzzard, Golden Oriole and Honey Buzzard in Suffolk, 6 notes. (Zool.)

Hele, N. F. Grey Phalarope, Wood Sandpiper and Black Tern near Aldeburgh. (T.c.)

[Editorial.] Supposed new British Swan [Cygnus buccinator, at Aldeburgh.] (Field, Nov. I7.)

I867. Gunn, T. E. Bohemian Waxwing in Norfolk and Suffolk; Smew, Green Sandpiper, etc., in Suffolk. (T.c.)

"G. K." Bittern and Waxwing near Ipswich. (Field, Jan. I9.)

Hele, N. F. Little Gull, Canada Goose and Spoonbill at Aldeburgh. (Zool.)

Kennedy, A. Clark-. Greenshank, Wood Sandpiper, Curlew Sandpiper and Pigmy Curlew near Aldeburgh. (Zool.)

Moor, E. C. Ornitholog. Notes from Aldeburgh; Storm Petrel at Aldeburgh. (T.c.)

Rowley, G. D. Shore Larks in Suffolk. (T.c.)

1868. Gibson, W. Rare Birds at Southwold. (Op. cit.)

Hele, N. F. Bittern [in Thorpe Fen]. (Field, Feb. I.) 
Gunn, T. E. Black-throated Diver at Lowestoft. (Zool.)

Kennedy, A. Clark. Hawfinches breeding in Suffolk. (Field, June 20, 27.)

Peto, L. J. Roller in Suffolk. (Op. cit., Oct. 3I.)

I869. Bree, C. R. White-tailed Eagle in Suffolk. (Zool.) Idem. (Field, Jan. 2.)

Clarkson, W. Ring Ouzel in Suffolk. (Field, May 22.)

Durnford, F. M. Spoonbill in Suffolk. (T.c., Jan. 9.)

Gunn, T. E. Rough-legged Buzzard in Suffolk; Purple Sandpiper in Suffolk; Black Swan on Suffolk Coast. (Zool.)

"H. C." Spoonbill in Suffolk [at Benacre]. (Field, Jan. 2.)

Hart, W., and Son. Spoonbill at Benacre. (Zool.)

Kennedy, A. Clark. Notes on rare birds noticed in Suffolk in I868; Ornithol. Notes from Suffolk. (T.c.)

Wallis, H. M. Pomarine Skua at Aldeburgh. (Zool.)

1870. Clarke, W. Rednecked Grebe at Bury St. Edmunds. (Field, Feb. 26.)

Gunn, T. E. Hen Harrier in Suffolk. (Zool.)

Hele, N. F. Notes or Jottings about Aldeburgh. 8vo. Lond. : I870. 2nd edit. I89o. [29I.]

Hele, N. F. Pectoral Sandpiper [at Thorpe Mere, Aldeburgh]. (Field, Oct. 15) ; Alpine Swift at Aldeburgh (T.c., Sept. I7); Grey Phalarope at Aldeburgh (T.c., Nov. 5); Great Northern Diver in Suffolk. (Op. cit., Jan. I.)

Moor, E. C. Green Sandpiper at Hasketon. (Zool.) ; Bramblings near Woodbridge (T.c.); Quails nesting (T.c.); Bustards in Suffolk. (T.c.)

Smee, A. H. Shore Lark at Southwold. (T.c.)

Wallis, H. M. Snow Bunting at Aldeburgh. (T.c.)

I870-75. Tuck, J. G. Notes on Sea and Shore Birds of Aldeburgh, 5 pts. (Op. cit., I870-75.) [589.]

I87x. Gurney, J. H. Departure of Summer Migrants ; Early Occurrence of Snow Bunting in Suffolk; Tithys Redstart in Suffolk. (Op. cit.)

Clarke, W. Blackwinged Stilt in Suffolk. (Field, May 20.)

Leach, H. R. Temminck's Stint at Aldeburgh; Spoonbill near Aldeburgh. (Zool.)

Miller, H. Golden Oriole at Martlesham. (Sci.Gossip.)

Moor, E. C. Arrival of Migrants, 2 notes. (Zool.)

Rope, G. T. Bewick's Swan, etc., at Leiston. (Field, Dec. 30.) Tuck, J. G. Spotted Sandpiper near Bury St. Edmunds. (Zool.) T- , E. R. Ornithological Notes from Lowestoft. (Field, Nov. I8.)

I87I-8I. Tuck, J. G. Ornitholog. Notes from Aldeburgh, 7 pts. (Zool., I87I-8I.)

I872. Gurney, J. H., junr. Notes on Heronries of Norf, and Suffolk. (Zool.) 
Durnford, H. Ornitholog. Notes from Southwold; Heronry in Suffolk. (Op. cit.)

Harting, J. E. British Heronries. (Zool.) [partim.]

Foster-Millar, A. Waxwings at Redgrave. (Field, Nov. 23.)

Tuck, J. G. Honey Buzzard in Suffolk; Birds observed at Aldeburgh (Zool.) Pectoral Sandpiper in Suffolk. (Field, Sept. 28.)

Rope, H. J. Bearded Tit in Suffolk. (Field, May 4.)

Rope, G. T. Nesting of Spotted Crake. (Field, June 8) Idem by Ed. (T.c., June 22.) Nesting of Garganey [in Suffolk]. (Field, May 4.)

I873. Durnford, H. Ornitholog. Notes from Suffolk. (Zool.) Glaucous Gull at Southwold; Blackthroated Diver in Suffolk. (Zool.) Harting, J. E. Brit. Heronries. [partim.] (Zool.)

R[ope], H. J. Rare birds in Suffolk. (Field, Mar. 8.)

Howlett, W. Bustard in Suffolk. (Field, Aug. I6.)

Rope, G. T. White Stork in Suffolk; Nesting of Woodcock in Suffolk. (Zool.) ; White Stork in Suffolk. (Field, June 7.)

Mathew, W. E. B. Shore Lark at Felixstowe. (Sci. Gossip.)

[Editorial.] Gt. Bustard in Suffolk; Rare birds at Walton. (T.c.)

[1873 ?] Bayne, A. D. Royal Illustrated History of Eastern England. 2 vols. Roy. 8vo. Great Yarmouth: N.D. [50.]

I873-74. Rope, G. T. Notes from Leiston, 2 notes. (Zool, I873-74.)

1874. Gunn, T. E. Marsh Harrier in Suffolk. (Op. cit.)

Hele, N. F. Iceland Gull and White-tailed Eagle at Aldeburgh. (Field, Jan. 24) ; Osprey near Aldeburgh. (Op. cit., Oct. 3I.)

Rope, G. T. Early Nesting of Skylark in Suffolk. (Zool.); Garganey nesting in Suffolk. (Field, May 23.)

Stevenson, H. Dartford Warbler in Suffolk. (Zool.)

1875. Green, H. Gyr Falcon and Snow Bunting near Ipswich. (Field, Jan. 9.)

Hele, N. F. Shore Lark at Aldborough. (T.c., May I5) ; Migratory Birds. (Op. cit., Nov. 6.)

Howlett, W. Hoopoes in Suffolk. (Op. cit., May 5.)

Kennedy, A. J. Clark-. White-tailed Eagle and Osprey in Suffolk. $($ Zool. $)$

1876. Gunn, T. E. Notes on the Occurrence of Rare Birds. (Zool.) [partim.)

Hele, N. F. Spoonbill and Peregrine at Aldeburgh. (Field, Oct. 28.) Decrease of Wildfowl at Aldborough. (Field, Feb. I9) ; Great Snipe and Pied Flycatcher at Aldborough. (T.c., Oct. 7.)

Kennedy, A. J. Clark-. White-tailed Eagle in Suffolk. (Zool.)

Kerry, F. Iceland Gull, Knot and Green Sandpiper at Aldeburgh. (Zool.) 
Miller, H., junr. Roller in Suffolk. (Field, July I5.)

Roberts, H. J. Sandwich Tern in Suffolk. (T.c., Oct. 7.)

1877. Creed, H. K. Hawks in Suffolk. (T.c.)

Kennedy, A. J. Clark-. Honey Buzzard in Suffolk. (Zool.)

Kerry, F. Spoonbills and Canada Geese in Suffolk. (T.c.)

Moor, C. Goldlen Eagle, Rough-legged Buzzard, etc., near Woodbridge. (T.c.)

"W. H. T[uck.]" Rednecked Phalarope in Suffolk. (Field, Dec. I.)

Moore, G. P. Blue-throated Warbler near Lowestoft. (Zool.)

Rope, G. T. Dartford Warbler in Suffolk ; Jack Snipe in Suffolk in May. (T.c.)

1878. Hele, N. F. Black Redstart at Alciborough. (Field, Jan. 5.)

$\mathrm{K}$ [nights], J. H. H. Brent Goose on Orwell in May. (T.c., May I8) ; Grey Phalarope, etc., on Orwell. (Op. cit., Dec. 7.)

Rope, G. T. Spotted Crake in Suffolk. (Zool.)

Tracy, F. W. White Stork in Suffolk. (Field, April 20.)

I879. Gunn, T. E. Golden Oriole in Suffolk. (Zool.)

[Standard.] Golden [?] Eagle in Suffolk. (Ficld, Jan. II.)

Ogilvie, F. M. Glaucous Gull at Aldeburgh ; Ornitholog. Notes from Thorpe. (Zool.)

Moore, G. P. White-tailed Eagle in Suffolk. (Field, Feb. 8.) Hele, N. F. Polish Swan at Aldeburgh. (Ficld, Dec. I3.)

I880. Gurney, J. H., junr. Ornitholog. Notes from Lowestoft. (Zool.) "G. F." Rough-legged Buzzard in Suffolk. (Field, Nov. 26.)

Beales, J. D. Solitary Snipe in Suffolk. (Field, Sept. 25.)

Rope, G. T. Snow Bunting, Spotted Crake and Bittern at Leiston. (Zool.)

I880-88. Gunn, T. E. Ornitholog. Notes from.... Suffolk, 6 contributions. (Zool., I880, I884, I885-86-87-88.)

I88r. Fisher, W. W. Honey Buzzard in the Eastern Counties. (Field, Oct. 8.)

Hele, N. F. Honey Buzzards and Sea Eagles in Suffolk. (T.c., Oct. 8.)

Tuck, J. G. Orn. Notes from Aldeburgh. (Zool.)

I882. Angove, W. T. Breeding of Short-eared Owl in Suffolk. (Zool.) Hamond, C. A. Black Tern in Suffolk. (Field, May 27.)

Macphersor, H. A. Snow Bunting and Pigmy Curlew at Aldeburgh. (Field, Sept. 23.)

Stevenson, H. Ornitholog. Notes from Lowestolt, 2 pts. (Zool.) S- J. J. Black Stork near Woodbridge. (Field, Oct. 7.)

Knights, J. H. H. Uncommon Birds on the Orwell. (Zool.)

1883. Macpherson, H. A. Nat. Hist. Notes from Aldeburgh; Iceland Gull at Aldeburgh. (Zool.)

Hele, N. F. Pink-footed Goose in Suffolk. (Field, Feb. 24.) 
Rope, G. T. Shoveler breeding in Suffolk; Ring Ouzel in Suffolk. (Zool.)

Melliar, A. F. Pied Flycatcher in Suffolk. (Field, May 5.)

Taylor, J. E. Great Grey Shrike in Suffolk. (Zool.); Idem. (Sci.Gossip.)

Knights, J. H. H. Little Gull in Suffolk. (Field, Sept. 29.); Shag or Crested Cormorant on R. Orwell. (T.c., Oct. 6.)

I884-86. Babington, C. Catalogue of the Birds of Suffolk. (Proc. Suff. Inst. Archaol. \& Nat. Hist., V, I884-86). Idem. Reprinted in book form. 8vo. London: 1884-86. [33.]

I884. Knights, J. H. H. Spoonbills in Suffolk. (Zool.)

L[eathes], H. M. L. Unnatural History. 8vo. Lond. : I884. [Incl. birds of Herringfleet.]

Lister, T. Wildfowl at Aldeburgh. (Zool.)

Moor, E. C. Great Grey Shrike in Suffolk. (T.c.)

Sandberg, G. Bittern in Suffolk. (T.c.)

Tilney, R. H. Quails in Suffolk. (Field, Oct. I8.)

I885. Moor, E. C. Notable Birds' Nests. (Zool.)

Candler, C. A New Heronry in Suffolk. (Zool.)

Poyser, E. J. Little Bittern in Suffolk. (Field, Sept. 26.)

Seebohm, H. On occurr. of White-billed Diver on Brit. coasts. [partim.] (Zool.)

1886. Bunn, H. Purple Heron in Suffolk. (Field, Oct. 30.)

Mackenzie, W. D. Blacligame in Norfolk and Suffolk. (Op. cit., Mar. 6.)

Tibrcy, R. Uncommon Birds in Suffolk. (T.c., Jan. 23.)

Edwards, S. Spotted Redshank in Suffolk. (Op. cit., Nov. I3.)

I887. Zincke, F. B. Materials for the History of Wherstead. 8vo. Ipswich : $1887 . \quad[673$.

Boyes, F. Grey Lag Goose at Lowestoft. (Field, Nov. 26.)

Knights, J. H. H. Long-tailed Duck on the Orwell. (T.c., Nov. 26.)

Mason, G. Purple Heron and Little Bittern near Lowestoft. (Op. cit., Mar. 5.)

Newton, S. E. Migrants at Lowestoft. (Norf. E Norw. Nat.Tr., IV., p. 520.)

I888. Cordeaux, J. Probable Occurrence of Chough in Suffolk. (Zool.)

Tuck, J. G. Reappearance of Pallas's Sand-Grouse; Honey Buzzard near Bury St. Edmunds; Food of the Kestrel (2). (Zool.) 4 notes.

"Al. Ca." Cock Partridge brooding. (Field, Sept. I5.)

Tate, W. R. Cuckoo calling in July. (Zool.)

Gunn, E. W. Storm Petrel at Ipswich. (Zool.)

Butler, E. A., and others. Pallas's Sand-Grouse in Norfolk and Suffolk. (Zool., vide also Ficld, June 2, 9, I6, Aug. I8.) 
I889. Butler, E. A. Ornitholog. Notes from Lowestoft. (Zool.); Tengmalm's Owl and Bitterns near Lowestoft. (Field, Mar. 30.) Crowley, P. Crossbills nesting in Suffolk. (Zool.)

Gunn, E. W. Great Grey Shrike near Ipswich. (T.c.)

Morres, A. P. Tengmalm's Owl in Suffolk. (T.c.)

Spelman, W. W. A Descriptive Catalogue of Collection of Birds shot in Norfolk and Suffolk prior to Oct. I888. 8vo. I889. [555.]

Tuck, J. G. Kite, Wood Sandpiper and Montagu's Harrier in Suffolk; Recollections of the Bustard in Suffolk; Crossbills in Suffolk, etc. (Zool.) 6 notes.

I89o. Butler, E. A. Hen Harrier and Norfolk Plover in Suffolk. (Field, Oct. 25.)

Rope, G. T. Natural History Notes from Suffolk, 2 parts. (Zool.)

Ogilvie, M. Montagu's Harrier breeding in Suffolk. (Op. cit.)

Neave, E. Sand-Grouse still in Suffolk. (Sci. Gossip, Aug., Oct.)

Tuck, J. G. Birds Flying against Windows; Attacks by Owls ; Notes on Birds' Nests. (Zool.) 3 notes.

I89I. Aplin, O. V. Distribution in British Isles of Spotted Crake. (Zool.) [partim.] [24.]

Jourdain, F. C. R. Rooks nesting in November. (Field, Nov. 2I.) Tuck, J. G. Ornithology of Suffolk. 8vo. Sheffield: I8gI. [590.]

Knights, J. H. H. Late Stay of [Black] Tern. (Field, Nov. 2I.) Tuck, J. G. Notes on Great Bustard in Suffolk. (Tr. Norf. E Norw. Soc., V.); Swans in Suffolk; Interbreeding of Pied and White Wagtails. (Zool.) 2 notes.

Harland, H. S. Spotted Eagle in Suffolk. (Field, Nov. 28.)

Harting, J. E. Recent Visitation of Bustards. (Zool.) [partim.] Idem. (Field, Feb. 28.)

Rope, G. T. Natural History Notes from East Suffolk. (Zool.) Butler, E. A. Golden Oriole in Suffolk. (Field, July I8.)

I892. Ogilvie, F. M. Long-tailed Duck off Suffolk Coast in Summer; Iceland Gull near Aldeburgh. (Zool.) On Recent Occurrence in Brit. Isles of Ruddy Sheldrake. (Op. cit.) [partim.]

Creaghe-Haward, L. Shrike killing Sand-Martin. (Zool.)

Pratt and Son. Spotted Eagle in Suffolk. (T.c.)

Aplin, O. V. Status of Woodchat in Great Britain. (T.c.) [partim.] [25.]

Tuck, J. G. Raptorial Migrants in East Anglia (2) ; Buffon's Skua in W. Suffolk; White Wagtail in Suffolk ; Birds nesting in Suffolk. (T.c.) 5 notes.

I893. Butler, E. A. Crane in Suffolk. (Op. cit.)

Tuck, J. G. Velvet Scoter, Waxwings and Purple Gallinule in Suffolk. (T.c.) 
[1894.] Tuck, W. H. Avifauna of a Suffolk Village, I847-93. Post 8vo. Bury St. Edmunds: N.D. (Orig. pub. in the Field Club, IV., I893.) [590.]

Harting, J. E. Hybrid Sparrows. (Zool.)

Butler, E. A. Late Nesting of Goldfinch. (T.c.)

Tuck, J. G. Storm driven Sea Birds. (T.c.)

1895. Butler, E. A. Early Laying of Cuckoo; Fearlessness of Spotted Flycatcher. (Zool.) 2 notes.

Tuck, J. G. Waxwing in Suffolk. (Zool.)

1896. Edwards, S. Black Redstart in Suffolk. (Field, Nov. I4, 28.) 2 notes.

I897. Butler, E. A. Honey Buzzard in Suffolk. (Zool. ; Field, Aug. 28.)

Clarke, W. G. Inland breeding of Ringed Plover in Norf. \& Suff. (Zool.)

Butterfield, W. R. Swallow-tailed Kite in Suffolk. (Zool., pp. 270, 363.)

Haward, W. Red-legged Partridge Nesting in Tree. (Field, May. 29.)

Candler, C. Hoopoe in Suffolk. (Field, Nov, 13.)

Nightingale, R. C. Reptd. occurr. of Rock Thrush in Suff. (Nat. Chronicle, May.)

Tuck, J. G. White Wagtail breeding in Suff. (Zool.)

I898. Green, G. C. Crossbills in Devon and Suffolk. (Field, Sept. Io.) Harrison, D. P. Partridges with white horseshoes. (Field, Jan. 29.)

Poyser, E. J. White-tailed Eagle in Suffolk. (Op. cit., Jan. 22) ; Return of Redshank. (Op. cit., Mar. 26.)

Heywood, N. A. Purple Gallinule in Suffolk. (Op. cit., Jan. 8.) Ram, F, R. Sabine's Snipe in Suffolk. (Op. cit., Oct. I8.)

Butler, E. A. White French Partridges in Suffolk. (Op. cit., Jan. I5.)

Green, J. F. Bewick's Swans in Suffolk. (Knoweledge.)

I899. Gooding, D. R. Reported Occurrence of Glossy Ibis. (Field, Oct. 28.)

Butler, E. A. Blackgame in Suffolk. (T.c., Dec. I6 and 23); Idem by W. D. Mackenzie. (Field, Dec. 23.)

Roberts, E. Purple Heron in Suffolk. (Op. cit., Nov. 4.)

Southwell, T. Little Bustard and Great Shearwater at Lowestoft. (Zool.)

Tuck, J. G. Cuckoo's Eggs in Nest of Red-backed Shrike.

I900. Arnold, E. C. Pectoral Sandpiper at Aldeburgh. (Zool.)

Tuck, J. G. Nesting Habits of Great Tit; Great Grey Shrike in Suffolk; Peregrine in Suffolk; Pectoral Sandpiper in Suffolk. (Zool.) 4 notes. 
Butler, E. A. Black game in Suffolk (Zool.); Idem by Heatley Noble. (T.c.)

Horn, W. J. Solitary Snipe in Suffolk. (Field, Jan. 20.)

I900-0I. Patterson, A. The birds of Gt. Yarmouth and neighbourhood. [partim.] (Zool.)

Igor. Tuck, J. G. Shag in W. Suffolk; Early Breeding of Wood-pigeon and Snipe; Cucloo's Eggs; Birds in Nest Boxes. (Zool.) 4 notes.

1902. Tuck, J. G. Green Woodpecker boring in winter: Notes from Suffolk. (Zool.)

Gurney, J. H. Ornith. Notes for IgoI from Norfolk and the North of Suffolk. (Zool.)

I903. Bidwell, E. Coracias garrulus in Suffolk. (Bull. B.O.C., XIII., I902-03.)

Butler, E. A. Nesting of Pied Wagtail ; Nesting of Grey Crow in Suffolk. (Zool.) 3 notes.

Clarke, W. G. Occurrence of Sooty Tern in Suffolk. (Zool.)

Dutt, W. A. Sooty Tern in Suffolk. (Field, Oct. 3.)

Tuck, J. G. Wood Lark in W. Suffolk; White-tailed Eagle in Suffolk; Great Grey Shrike in W. Suffolk; Nesting of Grey Crow in Suffolk. (Zool.) 4 notes.

Rope, G. T. Redshank carrying her young. (T.c.)

I904. Ogilvie, F. M. On Red-crested Pochards in Suffolk. (Bull. B.O.C., XIV., p. 62.)

Tuck, J. G. Pomatorhine Skuas in Suffolk: Waxwings in E. Anglia ; Crossbill in W. Suffolk; Notes on Nest Boxes. (Zool.)

Rope, G. T. Peewit Swimming. (T.c.)

Butler, E. A. Curious variety of Robin. (T.c.)

r905. Selous, E. Bird Life Glimpses. [Observations at Icklingham.] Cr. 8vo. Lond. : 1905. [522.]

Tuck, J. G. Notes from Suffolk: Hairy Variety of Moorhen; Notes on Tawny Owl; Albino Starling in Suffolk; Notes on Nest Boxes. (Zool.) 5 notes.

Whistler, H. Birds noticed during a Short Visit to Suffolk. (Avicult. Mag.)

1906. Cadogan, L. Ferruginous Duck in Suffolk. (Field, Fcb. 3.) Gurney, J. H. Flamingo in Suffolk. (Zool.)

Murie, J. Supposed Flamingo near Aldeburgh. (Zool.) Idem by J. H. Gurney. (T.c.)

Tuck, J. G. Tawny Owl in Chimney; Notes on Nest Boxes. (T.c.) 2 notes.

I907. Tuck, J. G. Bitterns in Suffolk; Plumage of Young Cuckoo; Notes on Nest Boxes. (Zool.) 3 notes.

Patterson, A. H. Fulmar on the Suffolk Coast. (T.c.) 
I908. Dye, B. Honey Buzzard in Suffolk. (Op. cit.)

Tuck, J. G. Effect of Recent Late Snow on Bird Life; Notes on Nest Boxes; Honey Buzzard in Suffolk, etc. (Zool.) 3 notes.

I909. Ogilvie, F. M. Goldeneye killed in Suffolk, probably Clangula islandica. (Bull. B.O.C., XXIII., I 908-09. [Merely a Common Golden-eye. Cf. Ogilvie-Grant, W. R. Op. cit., XXXI., I9I2-I3, p. I8.])

Tuck, J. G. Notes on Nest Boxes. (Zool.)

Rope, G. T. Redshank carrying young. (T.c.)

I9I0. Stanford, E. F., and Gilroy, N. Crossbills nesting in Suffolk. (Brit. Birds.)

Rope, G. T. Reappearance of Bearded Tit in old haunt. (Zool.)

Stanford, J. K. Bird Life in a Garden in Suffolk. (Rep. Rugby Sch. Nat. Hist. Soc.)

Tuck, J. G. Yellow-browed Warbler in Suffolk. (Brit. Birds.) Notes on Nest Boxes. (Zool.)

IgIr. Ticehurst, C. B. Continental Robins, Song Thrushes and Great Tits in E. Anglia ; British Willow Tit in Suffolk. (Brit. Birds.) Tuck, J. G. [Birds. In] Victoria Hist. of Co. of Suffolk, I. 4to. Lond. : IgII. [590.]

Tuck, J. G. Shag in Suffolk. (Brit. Birds, IV.) Notes on Nest Boxes. (Zool.)

I9II-I2. Bunyard, P. F. Crossbill breeding in Suffolk in I9II. (Brit. Birds, IV.) ; In I9I2. (Op. cit., VI., I9I2.)

I9I2. Gray, L. Crossbills nesting in Suffolk. (Op. cit., VI.)

Ticehurst, C. B. Migration and other Notes from Lowestoft. (Tr. Norf. \& Norw. Soc.)

Tuck, J. G. Spoonbills in Suffolk. (Brit. Birds, VI.) Nutcracker in Suffolk; Wood Sandpiper; Food of Tawny Owl; Note on Caprimulgus europaus ; Notes on Nest Boxes ; Fulmar in Suffolk; Spoonbills in Suffolk. (Zool.)

I9I3. Bunyard, P. F. Crossbills breeding in Suffolk for fourth year in succession. (Brit. Birds, VII.)

Cook, F. C. Migratory and other ornithological notes from Lowestoft. (Zool.)

Nicoll, M. J. Whiskered Tern in Suffolk. (Brit. Birds, VI.)

Ticehurst, C. B. Migration and other ornithological notes from Lowestoft and district, IgII-I2. (Tr. Norf. \& Norw. Nat. Soc., IX., pp. 607-22.)

Tuck, J. G. Syrnium aluco in Suffolk. (Zool.)

I9I4. Cook, F. C. Migratory, etc., notes from Lowestoft. (Op. cit.)

Davies, R. A White Swallow. (Field, Sept. 5.)

[Editorial.] Young Crossbills in January. (Field, Jan. I7.) Idem by P. F. Bunyard. (T.C., Jan, 24.)

Harrison, G. R. Great Skua in Suffolk. (Field, Dec. I2.) 
Tuck, J. G. Waxwings in Suffolk. (2 notes.) Hybrid Ducks in Ipswich (2 notes); Early arrival of Stone Curlew at Rougham; Nesting of Reed Warbler at Bury St. Edmunds. (Zool.)

Witherby, H. F. Avocet in Suffolk. (Brit. Birds, VIII.)

r915. Bunyard, P. F. Crossbills breeding in Suffolk. (Op. cit., IX.)

Cook, F. C. Birds travelling north in autumn at Lowestoft. (Zool.) ; Migration, etc., notes from Lowestoft. (T.c.)

Laver, H. Green Sandpiper in Stow Valley. (T.c.)

Peoples, F. W. The Crossbill [Lakenheath, Suff.]. (Lancs. Nat., April, I9r5.)

Rope, G. T. Rough-legged Buzzard in Suffolk; Grey Shrike in Suffolk; Norfolk Plover in Suffolk in Nov. (Zool.)

Stanford, J. K. Lapland Buntings in Suffolk, Yellow-browed Warbler in Suffolk. (Brit. Birds, IX.)

Tuck, J. G. Return of summer migrants to old haunts; Localised occurr. of Black-headed Gulls at Lowestoft. (Zool.)

I9I6. Gurney, J. H. Rough-legged Buzzards in Suffolk. (Zool.)

Tuck, J. G. Bird notes from Bury St. Edmunds. (T.c.)

I9I7. [Editorial.] Great Skua in Suffolk. (Brit.Birds, XI.) (2 notes.) Spragge, R. Four Eggs in Nightjar's nest. (Op. cit., X.)

I9I8. Gurney, J. H. Little Auks in Suffolk. (Brit. Birds, XI.)

\section{SURREY.}

I719. Aubrey, J. Natural History and Antiquities of Surrey. 5 vols. 8vo. Lond. : I7I9. [32.]

I736. Salmon, N. Antiquities of Surrey .... with an Account of the ..... Natural History of the County. 8vo. Lond. : I736. [503.]

I8II-2I. Graves, G. British Ornithology. 3 vols. 8vo. Lond. : I8II-2I. [Contains many records from S. London and Surrey.] [246.]

I825. [Pownall and Everest's] History of Epsom. 8vo. I825. [Not seen.]

1832. Newman, E. The Sedge Bird [at Godalming]; Nightingale singing on rath Dec. (Loudon's Mag. N. H., V.)

I832-33. [Newman, E. "Rusticus."] Something about Birds and Birdsnesting. (T.c., V.); More About Birds. (OP. cit., VI.) [44I.]

I832-35. Jesse, E. Gleanings in Natural History. 3 vols. Post 8 vo. Lond. : I832-35. [3I6.] 
I833. Blyth, E. On the British Fruit-eating Warblers. (Rennie's Field Nat., I., pp. 306-I8.) [Surrey records.] [73.]

"Rusticus." [E. Newman.] Notices on Natural Objects observed in a Ramble on St. Valentine's Day. (Loudon's Mag. N. H., VI.)

1834. Blyth, E. Birds at Tooting. (Rennie's Field Nat., II., p. 53, I72) ; Notes on Arrival of Summer Birds of Passage in I834. (Loudon's Mag. N. H., VII.) [74.]

I835. Blyth, E. Notice of a very remarkable individual of Common Shrike $[L$. collurio $]$. (Op. cit., VIII.)

Tulk, A. The Storm Petrel [at Richmond]. (T.c.)

1836. Blyth, E. On Birds observed during the last Four Years in Vicinity of Tooting. (Op. cit., IX.) [74.]

1837. Blyth, E. On Woodcocks, Fieldfares, Redwings breeding within British Islands. (Charlesw. Mag. N. H., I.) [74.]; The Green Sandpiper [probable breeding near Godalming]. (T.c.) ; Relative abundance of the Warblers in Surrey. (Nat. [Wood's], II.)

[Anon. Nervman, E., and Others.] Some Account of the Birds of Godalming. (Entom. Mag., IV.) [44I.]

I838. Blyth, E. Notice of Rare Birds obtained during Winter of I83738. (Nat. [Wood's], III.) [74.]

1839. Blyth, E. Fieldfare breeding [?] at Merton. (Charlesw. Mag. N. H., III.)

Long, H. L. Discovery of Nests and Eggs of Crossbill near Farnham, 2 notes. (T.c.) Idem, Letter by Yarrell. (T.c.)

Salmon, J. D. Birds in neighbourhood of Godalming. (Nat. [Wood's], IV.)

I842-50. Meyer, H. L. Coloured Illustrations of British Birds, etc. 7 vols. 8vo. Lond. : 1842-50. [Contains Surrey Records.] Idem. New edit. I853-57. [403-4.]

1843. Kidd, W. Enquiry respecting the Water Rail. (Zool.)

Lewcock, J. [ob. I850.] Brambling near Farnham. (T.c.) ; Tree Sparrow at Tilford. (T.c.)

1844. Bartlett, J. P. Hoopoe nesting in Surrey. (Zool.)

Bull, H. Early Arrival of Fieldfare near Godalming. (T.c.)

Mansell, T. Osprey, Ring Ouzel and Scoter at Farnham. (T.c.) 3 notes.

1845. Lewcock, J. Spoonbill at Frensham Pond. (Zool.)

I846. Borrer, W., junr. Virginian Colin in Surrey. (Zool.)

Chennell, F. A. Oystercatcher Inland [near Guildford]. (T.c.)

Horne, G. Curious Capture of a Goshawk. (T.c.)

1847. Spicer, Rev. W. W. Scaup Duck near Godalming. (Zool.)

I848. Salmon, J. D. Redthroated Diver near Guildford. (Zool.) 
I849. [Anon. Newman, E., and Others.] The Letters of "Rusticus" on the Natural History of Godalming. 8vo. Lond. : I849: And later edits. [442.]

Bird, W. F. W. Black Tern at Chertsey. (Zool.)

Chennell, F. A. Great Crested Grebe near Reigate; Ring Ouzel near Esher. (T.c.)

I850. Salmon, J. D. Waxwing near Godalming. (Zool.)

Webb, G. J. Nutcracker in Surrey. (T.c.)

I85I. McIntosh, J. Great Black Woodpecker at Claremont. (Nat. [Morris's], I.) Idcm. Criticisms by Doubleday. (Gardener's Chronicle); Heronries in England, etc. [partim.] (Nat. [Morris's], I.)

Strangwayes, R. The Redbacked Shrike [breeding near Croydon]. $\left(T . c_{0}\right)$

Wood, C. Kittiwake Gull on Wandsworth Common. (Zool.)

1852. Gurney, S., junr. Occur. of Grey Phalarope at Carshalton. (Op. cit.)

"H. J. C." Heronry [at Cobham Park]. (Nat. Morris's], II.).

Wood, C. Hobby at Clapham. (Zool.)

I853. Gardner, J. Osprey at Weybridge. (Zool.)

Webb, G. J. Osprey in Surrey. (T.c.)

1854. Hewitson, W. C. Hawfinch at Oatlands. (Op. cit.)

Kidd, W. Golden Oriole at Godalming. (T.c.)

Newman, E. Hoopoe at Barnes Common. (T.c.)

Round, C. S. Grey Phalarope [in Surrey]. (Nat. [Morris's], IV.)

Spicer, J. W. G. Little Bittern and other Rare Birds in Surrey. (Zool.)

I856. Brewer, J. A. New Flora of Reigate. I2mo. Lond. : I856. [Appdx. of Fauna.] [9I.]

Rodd, E. H. Letters on Natural History. [Swallow-tailed Kite at Farnham, etc.] (Zool.)

1857. [Anon.] Ring Ouzel near Guildford. (Field, Apr. 25.)

IIcIntosh, J. Great Black Woodpecker [in Surrey]. (Nat. [Morris's], VII.)

Round, C. S. Alpine Swift in Surrey. (T.c.) Idem by J. E. Harting. (Zool., r889.)

1858. Kidd, W. Supposed Variety of Partridge. (Zool.)

Wood, C. Great Spotted Woodpecker at Dulwich. (T.c.)

" W. B. M. L." Landrail [shot in Surrey in Dec.]. (Field, Feb. 27.)

I859. Wood, C. Hoopoe at Dulwich. (Zool.)

I860. [Anon.] Carrion Crows in Richmond Park. (Ficld, Mar. Io.)

I86r. Bridger, W. Little Auk near Guildford. (Zool.) 
Bush, J. Woodcock flushed near London [Clapham]. (Field, Jan. 5.)

[Editorial.] Golden Oriole at Witley Park. (Field, Aug. 3.)

Gurney, S. Hoopoe at Carshalton. (Zool.)

Marchant, - . Solitary Snipe in Surrey. (Field, July 6.)

I862. [Anon.] Great Grey Shrike at Dulwich. (Field, Dec. 27.)

Bridger, W. Hoopoe and Spoonbill in Surrey. (Zool.)

1863. Nicholson, J. [Blackcock in Surrey.] (Field, Sept. 26.)

I865. Bartlett, W. A. History and Antiquities of Parish of Wimbledon. 8vo. Lond. : 1865.

Button, D. T. Hoopoe on Streatham Common. (Zool.)

Tate, W. R. Birds at Witley. (Field, July 22.)

I866. Dilke, C. W. On Occurrence of Falco gyrfalco near Farnham. (P. Z.S.)

I867. Hewitson, W. C. Siskin at Oatlands; Breeding of Kingfisher. (Zool.)

I869. Gunn, E. H. Crossbills in Surrey. (Zool.)

Jones, J. A. Longhorned Owls near Epsom. (Field, May 29.)

Tate, W. R. Tern at Sydenham. (Sci. Gossip.)

Yearley, F. Eggs of Barn Owl in March. (Field, Mar. 20.)

I870. [Ashmead, G. B.] Golden Oriole in Surrey. (Field, Apr. 30.)

Blyth, E. Siberian Thrush in Surrey. (T.c., Sept. 24.)

Bond, F. Lapland Bunting near London. (Zool.)

Horne, C. Jack Snipe in Norwood Garden. (T.c.)

"J. B. C." Rare Birds in Surrey. (Field, Apr. 23.)

Marden, S. Oyster Catcher at Frensham Pond. (Field, Feb. 26.)

Newman, E. Golden Oriole at Redhill. (Zool. ; Field, Apr. 30.)

Smee, A. H. Sclavonian Grebe on the Wandle; Migration at Carshalton. (Zool.)

Smither, J. H. Great Northern Diver in Surrey [Frensham]. (Field, Jan. 8.)

I87I. Acton, E. B. Ornitholog. notes from Bagshot. (Op. cit., June 24.)

[Blyth, E. - “Z."] Woodcock and Fieldfare nesting near London [Merton]. (Field, June I7.)

D[ilke], C. W. Grouse on Bagshot Heath. "Effessea." Idem. (T.c., Jan. 2I.)

Elliman, W. Wood Sandpiper in Surrey. (Op. cit., Sept. 23.)

Peterson, E. Birds at Richmond, 2 notes. (Op. cit., May I3, 25.)

Saunders, H. Blackcap in March. (T.c., Mar. II, I8.)

Smee, A. H. Smew on the Wandle; Arrival of Migrants. (Zool.)

I872. C_, J. L. Montagu's Harrier [near Guildford]. (Sci. Gossip.)

G , I. J. Nightjars near London [Clapham]. (Field, Oct. I2.) 
Harting, J. E. British Heronries. (Zool.; Field, Feb. I7.)

Lunnon, T. Woodcocks at Haslemere in June. (Op. cit., Newman, E. [Lesser Redpoll nesting near Godalming.] (Zool.) Smee, A. [Birds of Wallington in] My Garden. 2nd edit. Roy. 8vo. Lond.: I872. [544.]

Smee, A. H. Spring Arrivals at Carshalton. (Zool.)

I873. Gillington, Rev. J. M. [Ring Ouzel and Whimbrel at Woking.] (Field, May 24.)

"Nuthatch." Herons in Richmond Park. (Op. cit., Dec. 6.) Stafford, W. [0b. I889.] Ornitholog. Notes from Godalming.
(Zool.)

1874. Czarnikow, C. Baillon's Crake in Surrey. (Field, May 30.)

Hammond, H. Quail nesting near Worthing. (T.c., May 30.)

Legg, W. W. Greater Spotted Woodpecker near Farnham. (Zool.) Wakley, J. Idem at Chertsey. (Field, June I3.)

Stafford, W. Hobby at Godalming; Black Redstart near Godalming. (Zool.)

Thomas, W. Yellow Wagtail and Wild Goose near Guildford. (T.c.)

1875. Gibbs, W. Summer Migrants near Bagshot. (Field, June 26.)

Jones, J. A. Buzzard in Surrey. (Op. cit., Oct. 2.) Idem by E. J. Rhodes. (T.c., Oct. 9.)

Legg, W. H. Little Gull in summer plumage in Feb. [near Frensham]. (Zool.)

1875-78. Crosfield, J. B. Some Notes on Ornithological Observations. (Proc. Holmesdale N. H. Chib, I875-78.)

I877. Bailey, H. F. Herons near London [Peckham]. (Zool.)

S- Field, June 2, G.) Woodcocks nesting in Wilts. [= Surrey.]

Smith, H. Songbirds in Surrey. (T.c., June 2.)

I878. Flower, J. The Birds of Croydon and its Immediate Neighbourhood. (Croydon Micro. \& N. H. Club, 8th Rept. \& Proc., pp. 67-76.) [Unimportant.]

I879. [Anon.- "B.'] Nightjar nesting on Barnes Common. (Field, June 25.)

[Editorial.] Hawking on Wimbledon Common. (T.c., Apr. 5.)

1880. Crosfield, J. B. Notes on Ornithology. (Proc. Holmesdale N. H. Club, $1879-80$.

Jones, J. A. Alpine Swift seen near Charlwood. (Field, Nov. 27.)

Legg, W. H. Goshawk [= Marsh Harrier] near Guildford. (T.c., Nov. 27, Dec. I8.)

Townsend, R. G. Great Grey Shrike [near Cranleigh]. (T.c., Nov. I3.) 


\section{Selection of Books from WITHERBY \& CO.'S List.}

BRITISH BIRDS.

An Illustrated Monthly Magazine devoted to the Birds on the British List. Edited by. H. F. WITHERBY, M.B.E., F.Z.S., M.B.O.U. Assisted by REv. F.-C. R. JOURDAIN, M.A., M.B.o.U., and N. F. TICEHURST, M.A., F.R.C.S., M.B.O.U. Illustrated with beautiful and useful photographs. Provides a current history of British Birds. Annual Subscription, ISs. post free; Monthly, Is. 6d. net. Vols. I-XII. (unbound), I2s. each; bound, I5s. 6d, each net.

\section{TROPICAL WILD LIFE IN BRITISH GUIANA.}

Being Zoological Contributions to Science, fron the Tropical Research Station of the New York Zoological Society, at Kalacoon, igr6. By William Beebe, G. Inness Hartley and Paul G. Howes, with an Introduction by COLONEL THEODORE ROOSEvelt. Octavo. Cloth. 504 pages. 4 Coloured Plates, and Ifo other Illustrations. 12s. 6d. net.

\section{A MONOGRAPH OF THE PHEASANTS.}

By IVilliam Beebe. With Numerous Coloured Plates by A. Thorburn, C. R. Knigit, G. E. Lodge, L. A. Fuertes, H. GronVOLD, and $H$. Jones. Together with Maps and Numerous Photo. graphs by the Author, depicting the Pheasants of the World, their Haunts, their Changes of Plumage and their Nests and Eggs. Limited Edition of 600 Numbered Sets, only a portion of which are available for sale in the British Iimpire. Royal 4 to. In Four Volumes, Volume I now ready. Prospectus and Specimen Plate on application. Per Vol. £ra: ros, net.

\section{A HAND-LIST OF BRITISH BIRDS.}

By Ernst Hartert, F. C. R. Jourdain, N. F. Ticeliurst, and H. F. Witherby. Demy 8 vo, 7s, 6d net. Interleaved ios, net.

THE BIRD-LOVER'S HOME-LIFE SERIES.

I. The Home-life of the Golden Eagle. 2. The Home-life of the Spoonbill, the Storls and some Herons, 3. The Home-life of the Osprey. 4. "The Home-life of the Terns or Sea-Swallows. Each Volume contains 32 berutiful plates, artistically mounted, from PHOTOGRAPHS DIRECT FROM NATURE, with 40-60 pages of letterpress. Crown 4 to. Cloth 7 s. $6 \mathrm{~d}$. net each.

GAME BIRDS AND WATER-FOWL OF SOUTH AFRICA.

By the late Major Boyd Horsburgir, F.z.S., M.B.o.v. IVith 67 beautiful Coloured Plates. Half morocco. $\ell_{4} \mathrm{r} 4 \mathrm{~s}$. net, or unbound parts.

INDIAN PIGEONS AND DOVES.

By E. C. Stuart Baker, F.z.s., M.B.O.U. IVith 27 beautiful Coloured Plates. Imp. 8vo. Half bound morocco. $\quad \ell^{2}$ 10s. net. PHOTOGRAPHY FOR BIRD-LOVERS.

By Bentley Beethan, F.z.s. I6 full-page Plates. A practical guide to the pursuit of bird-photography in all its branches. Demy 8 vo. Cloth. 5 s. net.

JUNGLE PEACE.

By William BeEBe. Contains " records of extraordinary scientific interest, in language which has all the charm of an essay of Robert Louis Stevenson. The author tells of bird, beast. plant and insect life of the British Guiana jungle. Crown 8vo., illustrated. Ss. net. 


\section{- BOOKS PUBLISHED by WITHERBY \& CO.}

\section{Completion of Volume I. (Passeres)}

\section{A PRACTICAL HANDBOOK OF BRITISH BIRDS.}

Edited by H. F. WITHERBY, M.B.E., M.B.O.U., F.Z.S., F.R.G.S. Contribusors:- E. Hartert, PH.D., s.B.o.u., r.z.s. ANine C. Jackson, H.M.B.o.U. ReviF.C.R.jourdain, M.A.g.M.B.o.v. C. Ódham, F.Z.S., M.B.o.U. N. F. TICFHURST, M.A., F.R.C.S., M.B.O.U.

Specially arranged for quick reference. Distinguishing characters simplifying identification, full description of all plumages. Breeding habits (nest, eggs, scason, incubation, etc.). Food. Distribution and Migration.

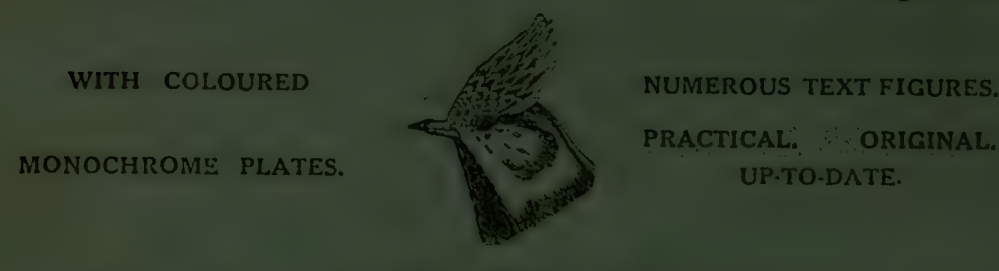

BOUND VOLUMES.-Vol. I. will be ready during April. Price (bound in buckram, gilt top) ... $\quad . \quad 40$ s. Thin Paper Edition (bound in rexine) _ . . 48s.6d.

A HANDBOOK TO THE VERTEBRATE
This book not only brings "ip to date the information contained in the Author's
"Vertebrate Fauna of North Wales," but also gives under each species a lirief
summary showing'its status in the district.
Demy 8 vo. Clotli

6s, net:

\section{METEOROLOGY FOR ALL.}

BEWG SOME WEATHER PROBLEMS EXPLAWED By DONALD W. HORNER, F.R.MET.SOc., etc. Author of "Observing and Forecasting thè Weather."

"IVeather Instruments and Ifow to Use Them."

With Text, and Half-Tone Illustrations.

A compendium of information about the Weather as it daily affects the lives of everyone. The "dry" terseness of the text-bools has been proided, but the information given is comprehensive and reliable, and of a practical nature.
Crown svo.
Clath.
illustrated.
6s. net:

326, HIGH HOLBORN, LONDON, W.C.I. 
$A$

GEOGRAPHICAL BIBLIOGRAPHY

OF

\title{
BRITISH ORNITHOTAGY
}

\author{
FROM THE EARLIEST' TIMLS \\ TO THE END OF 1918
}

ARRANGED LNDER ('OLNTIES

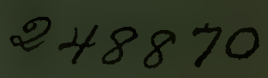

BEIYG A RECORD OF PRINTED BOOKS, PUBLISHED ARTICLES, NOTES ANU RECORDS RELATING TO LOCAL AVIFAUNA.

$\mathrm{By}$

IV. H. MUILENS, M.A., Lr..M., F.T.S., M.B.o.G.,

$\therefore$ H KIRKE SWANN T.Z.S AND

_. REV. 1. C. R. JOUPDAIN, M.A., M.B.O.V.

"Ien that undertako only ono district are much more likely to advance natural knowledge than those that grasp at noro than they can possibly be acquainted with; every lingdom, every. provinee, should have its own monographer."

Cilisert WHTE- "The Natural History of Selborno.": 7th Lotter to Barrington,

WITHER I \& C O O.

326, HIGH HOLBORN, LONDON 

I88I. Crowley, P. Roughlegged Buzzard, Hen Harrier and White Partridges in Surrey, 3 notes ; Common Buzzard near Croydon. (Zool.); Notes on a Collection of Nests selected by Cuckoo for deposit of its Eggs. (Proc. \& Tr. Croydon Micro. \& N. H. Chub, I878-8I, pp. 38-4I.)

Flower, J. Ornitholog. Notes. (T.c., pp. 34-37.)

Gurney, J. H., junr. Winter Birds near Reigate. (Zool.)

Hamilton, E. Avifauna of Wimbledon Common. (T.c.)

Townsend, R. G. Forktailed Petrel near Guildford. (Field, Dec. 3.) I882. C- (Op. cit., Nov. Ir.).

I883. Berney, F. L. Great Grey Shrike near Croydon. (Zijl.)

Bidwell, E. Cuckoo's Eggs [Richmond]. (T.c.)

Crowley, P. Great Grey Shrike near Croydon. (T.c.)

Jefferies, Richard. Nature near London. Cr. 8vo. Lond. : I883. [312.] I884. Bright, J. S. History of Dorking. 8vo. Dorking, etc. : I884.

Crosfield, J. B. Ornithology in Wray Park. (Proc. Holmesdale N.H.Chib, I88I-83.) Reigate: I884.

Warren, S. F. Little Auk at Chertsey. (Field, Jan. 26.)

I885. Aldridge, W. A Gossip on Birds of Norwood and Crystal Palace District. Cr. 8vo. Upper Norwood: 1885. [Io.]

I886. Frohawk, F. W. Snipe in a London Suburb [Norwood]. (Field, Jan. I6.)

Harting, J. E. Songbirds round London. (T.c., May 8.)

Phillips, C. Bittern near Godalming. (T.c., Jan. 23.)

Teschemaker, E. Surrey Nightingales. (T.c., May I5.)

I887. Benson, H. Cirl Bunting breeding near Godalming. (Zool.) Birley, F. H. Lesser Redpoll nesting in Surrey. (T.c.)

Rice, D. J. Hawfinch nesting in Surrey. (T.c.)

I888. Batten, H. H. Sand Grouse at Wimbledon. (Field, June 23.)

Benson, H. Nuthatch nesting in a Sandbank. (Zool.)

Crowley, P. Manx Shearwater near Croydon. (T.c.)

Fitzgerald, F. R. Shoveller and Rough-legged Buzzard in Surrey.
(T.c.)

"F. W. L." Hoopoe at Streatham. (Field, May 5.)

Hart, E. [Whitetailed Eagle near Bagshot.] (T.c., Jan. 7.)

Roberts, W. Redlegged Partridge in Anerley. (T.c., May 26.)

Theobald, F. V. Birds of Kingston-on-Thames. (Garner,
XXXII.)

I889. Benson, H. Cirl Bunting breeding near Godalming. (Zool.)

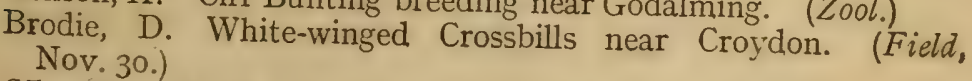

C[handler], J. B. Sand Grouse [at Shirley]. (T.c., Feb. 23.) 
Collison-Morley, J. L. Osprey on the Thames [Barnes]. (Zool.)

[Jordan, D.] Woodland, Moor and Stream. 8vo. Lond.: I889. [320.]

Reeve, H. K. Osprey in Richmond Park. (Zool.)

Rushen, W. N. Birds on Wandsworth Common. (Field, Nov. I2, Dec. 7.)

Salmon, E. Sand Grouse in Surrey. (Zool.)

Williams, A. T. Pallas's Sand Grouse [in Surrey]. (Field, Jan. 5.) Idem by J. B. C[rosfield.] (T.c., Feb. 23.)

1890. [Anon.] Lesser Redpoll breeding near Chobham. (Field, June 2I); Hobby at Kew. (T.c., May 3I.)

Benson, H. Two-barred Crossbill in Surrey. (Zool.)

Burr, M. Golden Oriole in Surrey. (Zool. ; Field Club, I.)

Larken, E. P. Red-necked Grebe in Surrey. (Zool.)

I89I. [Anon.] Redwing nesting at Croydon Park. (Land \& Water, Aug. I.)

Burr, M. Golden Oriole in Richmond Park; Hoopoe in Surrey. (Zool.)

Eastwood, G. H. Common Buzzard in Surrey. (T.c.)

"E. P." Cormorant on the Thames [near Hampton Court]. (Field, Aug. 22.)

[Jordan, D.] On Surrey Hills. Cr. 8vo. Lond., etc. : I8gI. [320.]

Larken, E. P. Little Auk at Godstone. (Zool.)

Thorpe, C. Great Grey Shrike at Chetsham. (Field, Dec. I9.)

1892. Alcock, G. Hawfinch nesting in Surrey. (Field, Oct. I.)

Aplin, O. V. Distribution of Cirl Bunting; Status of the Woodchat. (Zool.) [25.] [partim.]

[Anon.] Hen Harrier near Camberley. (Field, Jan. 30); Redthroated Diver near Cobham. (T.c., Mar. I9.)

Burr, M. The Fauna and Avifauna of Bellagio. (Nat. Jnl.)

Dawes, W. R. Redfooted Falcon near London. (T.c.) Idem. (Field, Oct. 22.)

[Editorial.] The Stafford Collection of British Birds. (Ibis.)

[Jordan, D.] "Son of the Marshes." Within an Hour of London Town: Among Wild Birds and their Haunts. 8vo. Lond.: I892. [320.]

[Jordan, D.] With the Woodlanders and by the Tide. 8vo. Lond,, etc. : I892. [320.]

Swann, H. Kirke. Bird Life on Epsom Common; Winter Notes from Epsom. (Nat. Jnl.) [569.]

r892-I9ro. Macpherson, A. Holte. Notes on London Birds in I89 [to I909], I9 pts. (Nature Notes \& Selborne Mag., I892-Igro.)

I893. H. S. D[avenport]. Great and Lesser Spotted Woodpeckers in Surrey. (Field, Jan. 2I.)

Macpherson, A. H. Wood Warbler at Churt. (T.c., April 22.) 
Read, R. H. Nesting of Grey Wagtail and Dipper in Surrey. (Zool.)

Salmon, E. S. Great Grey Shrike in Surrey. (T.c.)

Swann, H. Kirke. Birds of London. Post 8vo. Lond. : I893. [569.]

"T. S. T." Hoopoe at Camberley. (Field, Nov. 25.)

I894. [Anon.] Scarce Birds in E. Surrey. (Sci. Gossip, N.S., I., I89495.)

Bucknill, J. A. Notes from Epsom; Birds nesting near Epsom. (Zool.)

Frohawk, F. W. List of Birds observed at Tooting Bec Common. (T.c.)

Marten, C. J. Siskin [nesting ?] at Capel, near Leith Hill. (Nat. $J n l .$, III.)

Rice, D. J. Hawfinches in Surrey; Green Woodpecker at Leith Hill. (Sci. Gossip, N.S., I., I894-95.)

Robertson, R. S. Ornitholog. Notes from W. Surrey. (Zool.) "W. K. S." Curlew Sandpiper near Epsom. (Field, Oct. 6.)

I895. Bucknill, J. Quail in Surrey. (Zool.)

Kerr, G. W. Raven in Surrey [at Egham]. (Field, Apr. 27.) Idem by E. E. Pettitt. (Nat. Jnl., IV.)

Penrose, M. Birds at Wimbledon. (Field, June 22, 29.)

I895-I903. [Various Writers.] List of Birds, and List of Ornitholog. Notices. (Epsom College N. H.Soc. Repts., Nos.7-I5.) Epsom: r895-I903. [All seen.]

I896. Borrer, W. Purple Gallinule in Surrey. (Zool.)

[Jordan, D.] "Son of the Marshes." In the Green Leaf and the Sere. 8vo. Lond. : I8g6. [32I.]

Kerr, G. W. Notes from the Thames. (Ornithologist.)

I896-99. Butler, A. G. [Notes on Birds of Penge District. In] British Birds, their Nests and Eggs. 6 vols. 4to. I896-99. [III.]

I898. "B. O. U." Crossbills in Surrey. (Field, Nov. I2.) Idem by "Sylvanus." (T.c., Nov. I9.)

Comber, A. T. Hawfinch near Reigate railway station. (Zool.) Hudson, W. H. Birds in London. 8vo. Lond. : I898. [303.] Read, W. R. Nightjar in Richmond Park. (Field, May 14.)

Russell, H. The Kingfisher in Surrey. (Zool.)

Wilson, J. R. Woodcock near London [Wandsworth Common]. (Field, Dec. I7.)

I899. Cushing, F. Osprey in Surrey. (Field, Oct. 28.)

Rushen, W. N. Bird Life in Richmond Park. (T.c., Mar. 4, May 29) ; Great Crested Grebe on Richmond Ponds. (T.c., Apr. 29.) Idem by W. R. Read. (Op. cit., July I5.)

Tegetmeier, W. B. Buff-coloured Partridge. (T.c., Oct. 2I.)

Wright, T. Hind Head: The English Switzerland. 8vo. 1899. 
Igoo. Bidwell, E. Curlew breeding in Surrey. (Bull. B.O.C., XI.) Bucknill, J. A. The Birds of Surrey. 8vo. Lond.: I900. [105.]

Fruen, C. Little Auk in Surrey [Nunhead]. (Field, Apr. 7.)

Le Marchant, S. H. Curlew nesting in Surrey. (Zool.)

Russell, H. The Great Spotted Woodpecker in Surrey. (Zool.)

Saunders, H. Curlew breeding in Surrey. (Bull. B.O.C., XI.)

rgor. Bingham, C. T. Hoopoe at Reigate. (Zool.)

IgoI-02. Bucknill, J. A. Ornitholog. Notes from Surrey, 3 pts. $10 \dot{p}$. cit., I90I-02.) [106.]

Ig02. Bucknill, J. A. Aves. [In Victoria Hist. of Co. of Surrey, I.] 4to. Lond. : I902. [I06.]

Cornish, C. J. The Naturalist on the Thames. 8vo. Lond.: I902. [I47.]

Dalgleish, G. Rare Birds in Surrey. (Zool.)

Le Marchant, S. H. Red Grouse in Surrey (T.c.) ; Idem by J. A. Bucknill. (T.c.)

Nicoll, M. J. Breeding of Linota mifescens on Wimbledon Common. (T.c.)

Ig04. Bickerdyke, J. Ospreys in Surrey. (Field, Sept. 17, Oct. r.)

Chubb, E. C. Bluethroat near London [on Sheen Common]. (Zool.)

Dalgleish, G. Great Crested Grebe in Richmond Park; Longeared Owl at Esher; Ornitholog. Notes from Richmond. (Zool.)

Olive, C. D. Birds of Wimbledon [in Wimbledon and Mierton Annual]. 8vo. Ig04.

I905. Dalgleish, G. Great Crested Grebes in Richmond Park. (Zool.)

Bentham, C. H. Spatula clypeata in Surrey. (Zool.)

Bradshaw, G. W. Peregrine Falcon in Surrey. (T.c.)

Russell, H. Notes on Ornithology of Richmond Park. (T.c.)

I905-06. Mouritz, L. B. Notes on Ornithology of Richmond Park, 4 pts. (Zool.)

Igo6. Dalgleish, G. Ornitholog. Notes from Surrey. (Op. cit.)

Eastwood, G. H. Pied Flycatcher in Surrey. (T.c.)

Hudson, W. H. Aves [In Wild Fauna and Flora of the Royal Botanic Gardens]. (Kere Bull. Add., Ser. V.) [303.]

Renaut, W. E. Occurrence of Firecrest at Wimbledon. (Bull. B.O.C., XVI.)

Russell, H. Brambling in Surrey. (Zool.)

I907. Bentham, C. H. Ring Ouzel in Surrey. (Zool.)

Bidwell, E. Heron nesting in Kew Gardens. (Bull. B.O.C., XIX.)

Cundall, J. W. London: A Guide for the Visitor, Sportsman and Naturalist. I6mo. Lond. : I907. [I58.]

Hewat, G. G. Waxwing in Surrey. (Field, Mar. 23.) 
Kerr, Graham W. Marsh Warbler nesting in Surrey. (Brit. Birds, I.)

Mouritz, L. B. Ornitholog. Observations in Surrey, Igo6. (Zool.) Pycraft, W. P. Sea Eagle in Surrey. (Knowledge.)

"T. F." Montagu's Harrier nesting in Surrey. (Field, Dec. 2I.)

I908. Attlee, H. G. Notes on Ornithology of Richmond Park. (Zool.) Bentham, C. H., and Mouritz, L. B. Breeding of Hen Harrier and Hobby in Surrey in I907. (Brit. Birds, I.) Idem. [Hen Harrier, corrected to Montagu's Harrier by H. F. Witherby.] (T.c.)

Ingram, C. Nontagu's Harrier in Surrey. (Zool.; Brit. Birds, II.)

Oldham, C. Lesser Redpolls nesting in Surrey. (Brit. Birds, II.) Sargent, J. Black-throated Diver in Richmond Park. (Bull. B.O.C., XXI.)

Watt, H. B. Birds in Kew Gardens and Richmond Park. (Nature Notes.)

I909. Acland, C. M. Puffins in Surrey. (Brit. Birds, III.) Idem by W. F. Noakes. (Field, Nov. 6.)

Bentham, C. Breeding of Hen Harrier near Frensham Ponds. (Proc. \& Tr. Croydon N. H. \& Sci. Soc., I907-08, p. xxxiv.)

Dalgleish, G. Goldeneye in Surrey, 2 notes. (Zool.)

Dixon, C. The Bird Life of London. 8vo. Lond.: I909. [I70.]

Eastwood, G. H. Roughlegged Buzzard in Surrey. (Zool.)

Hawkins, C. Woodcock breeding in Surrey. (Brit. Birds, III.)

Igog-Io. Todd, W. A. Bird Notes from a London Suburb, 2 pts. (Nature Notes, I909-Io); Some Ornitholog. Notes from N.E. Surrey, 2 pts. (Zool., Igog-Io.)

Witherby, H. F. Irruption of Crossbills. (Brit. Birds, III., IV.)

I9ro. Alexander, C. J. Notes of the British Willow-Tit. (Op. cit., IV.) Arnold, E. C. Rciords of rare birds. [Black Terns in Surrey.] (Zool.)

Bentham, H. Goosanders in Surrey. (Brit. Birds, III.); Ringed Plover nesting in Surrey. (T.c.); Black Tern in Surrey; Dartford Warblers nesting in Heather. (Op. cit., IV.)

Colthrup, C. W. Crossbills nesting in Surrey. (T.c.)

Parkin, T. Supposcd Occurrence of Swallow-tailed Kite in Surrey. (Zool.; Brit. Birds, IV.)

Power, F. D. Ornitholog. Notes from a S. London Suburb, I874-Igog. 8vo. Lond. : r9Io. [479.]

Todd, W. A. Ornithological observations in N.E. Surrey, Igug. (Zool.)

I9II. Bentham, H. Gadwall in Surrey. (Brit. Birds, IV); Blackthroated Diver in Surrey. (Op. cit., V.) 
Bunyard, P. F. Grey Wagtail breeding in Surrey, 2 notes. (Op. cit., V.)

Russell, H. Migration of Linnets in Surrey. (Zool.)

I9I2. Bunyard, P. F. Attempted Breeding of Grey Wagtail in Surrey. (Brit. Birds, VI.)

Johnson, W. Wimbledon Common. 8vo. Lond. : I9I2. [320.]

I9I3. Bradshaw, G. W. Great Blackbacked Gull in Surrey. (Field, Jan. 4.)

Coward, T. A. Slender-billed Nutcracker in Surrey. (Brit. Birds, VII.)

Frohawk, F. W. Common Sandpiper in winter in Surrey. (T.c.) Harding, J. Rudge. Quail in Richmond Park. (Field, July I9.) Miller, A. A White Robin [Surbiton]. (Selborne Mag., p. 54.)

Parker, E. Common Buzzard in Surrey. (Field, June 28.)

Shore, A. C. Redwings in Sept. [Croydon.] (Field, Oct. 4.)

Silver, A. Black Redstart in Surrey. (Brit. Birds, VI.)

I9I4. [Anon.] Spring round London [Birds at Richmond and Wimbledon]. (Times, March 30.)

Mennell, E. N. Nutcracker in Surrey. (Zool.)

Russell, F. Redbreasted Merganser in Surrey. (Brit. Birds, VII.)

Stapylton-Smith, G. Waxwing in Surrey. (Field, April 4.)

Stevenson, E. P. Kingfisher on River Wandle. (Selborne Mag., p. I96.)

Stubbs, F. J. A January Corn-Crake in Surrey. (Zool.)

I915. Baynes, G. K. Great Grey Shrikes in Surrey. (Op. cit., VIII.) Bentham, H. Large clutch of Little Grebe's Eggs ; Redshank nesting in Surrey; Unusually large clutch of Moorhen's eggs. (Op. cit., IX.)

[Anon.] Report on Waterfowl [at Kew]. (Bull. Roy. Bot.Gdns., Kew.)

Finn, F. Paget's Pochard at Kew ; Quadruple Duck Hybrids at Kew. (Zool.)

Goldsmith, St. B. Blackcap in Surrey in Jan. (Field, Jan. I6.) Wenner, M. V. Adult Smew in Surrey; Dipper in Surrey. (Brit. Birds, VIII.)

r9ı6. Close, H. S. Great Grey Shrike near Croydon. (Field, Mar. 25.)

Harding, J. Rudge. Mergansers in Richmond Park. (Field, Feb. 26.)

I9I7. Bower, G. Quail in Surrey. (Field, Sept. 22.)

Farwig, H. H. Great Tit nesting in Sand Martin's hole [in Surrey]. (Brit. Birds, X.)

Harding, J. Rudge. The Grebes in Richmond Park. (Field, Sept. 29.)

Gibb, J. G. Bluethroated Warbler at Sydenham. (T.c., Oct. 6.) 
Lambert, G. C. Cuckoo's egg in nest of Song Thrush [at Bookham]. (Brit. Birds., XI. ; Bull. B.O.C., XXXVII., p. 57.)

Parker, E. Black Redstart in Surrey. (Field, Mar. I7.)

I9I8. Hall, E. C. Kingfishers in Richmond Park. (Op. cit., Sept. I4.) Lambert, G. C. Continental Jay at Cobham. (Bull. B.O.C., XXXVIII., p. 6I.)

Sitzler, G. C. Hawfinches in Bushy Park. (Field, April 20.)

\section{SUSSEX.}

I752. Hill, J. History of Animals. Fol. Lond. : I752. [Sussex references.] [685.]

I768-92. Markwick, W. Naturalist's Calendar at Catsfield near Battle in Sussex. (In G. White's Natural History of Selborne, I802.) [385.]

I782. [Tunstall, M.] Great Horned Owl : "The 29th December last (I782) one was shot in England, at Hurst-monceaux, near Lewes in Sussex." (Tunstall MS. Fox's Synopsis of Newcastle Museum [I827], p. 53.) [22I.]

I787. [Latham, J.] Black-toed Gull near Horsham in Sussex. (Latham's Synopsis, Supplement, I., p. 296.)

I789. Walcott, J. Synopsis of Brit. Birds, 4to. I789. [607.] [At p. 3, a Golden Eagle taken in Sussex and kept in Tower.]

White, G. Nat. Hist. of Selborne. 4to. Lond. : I789. [633.] [Letters from Ringmer.]

I79I. Markwick, W. On Migration of Certain Birds, etc. (Tr. Linn. Soc., I.) [384.]

I798. Markwick, W. Aves Sussexienses, or a Catalogue of Birds found in the County. (Op. cit., IV.) [Vide infra, I89o.] [385.] [Includes Golden Eagle killed at Bexhill.]

I80I. Daniel's Rural Sports [Partridge, p. I22 ; Woodcock, pp. I84, I97]. Lond. : I80r.

1813. Montagu, G. Gullbilled Tern at Rye. (In Orn. Dict. Suppl. 8vo. I8I3.) [4IO.]

I8I5. [Whitear, Rev. W.] Great Auk taken at Hastings. (Extracts from the Calendar of the Rev. William Whitear, in Tr. Norf. \& Norw. Nat. Soc., Vol. III., p. 258.)

I8I8. Bullock, W. An undescribed Gull, much allied to the Arctic, but greatly superior in size. Killed at Brighton. (Cat. of Sale. Bullock's Museum, Lot 62, Fifth day's sale.) 
I8I9. Forster, Thos. The Calendar of Flora, Fauna and Pomona .. . kept at Hartwell, by Tunbridge Wells, Sussex. (Researches about Atmospheric Phenomena. 3rd Ed. I823.)

I824. Mantell, G. Outlines of Natural History of Environs of Lewes. 4to. Lewes: I824. Also in Appdx. to Horsfield's Hist. of Lewes. 4to. Ib. I824.

I825-8. Yarrell, W. On occurrence of some rare British birds, 3 pts. [Sussex records.] (Zool. Jnl., II. p, 26 ; III., pp. 88, 497.)

I827. [Fox, G. T.] Wild Duck in Sussex. (Fox's Synopsis Newcastle Museum [1827], p. 98); Wheat Ears about Eastbourne in Sussex. (T.c., p. I08) ; Siskin, in Sussex called the BarleyBird. (T.c., p. 203) ; Little Bustard in Sussex. (T.c., p. 83.)

I828. [Anon.] Note about Cuckoo at Goring. (Loudon's Mag. N. H., I., p. II2.)

I83I. Yarrell, W. Addit. to Cat. of Brit. birds [Black Redstart near Brighton]. (Op. cit., IV.)

I833. $\mathrm{D}$ [enson], J. A Duck that strayed from Denmark (?) shot in Sussex. Loudon's Mag. Nat. Hist., VI., p. 278.)

I835. Strickland, A. [Charadrius minor a Brit. bird?] (Op. cit., VIII.) Idem by A. Doubleday. (T.c.)

I836. Blyth, E. Osprey shot in Sussex. (Op. cit., IX., p. 622.)

I843. Bond, F. On occurr. of rare Brit. birds [Buff-breasted Sandpiper and Wilson's Petrel in Sussex]. (Zool.)

Kidd, W. Water-rail [caught on Brighton Chain Pier]. (T.c.)

Swaysland, G. Black Redstart near Brighton. (T.c.)

I843-44. Knox, A. E. Notes on the Birds of Sussex. 3 pts. (Zool., I843-4.)

1844. Peachey, W. Arrival of Summer Birds at Northchapel, near Petworth, in I844. (Op. cit.)

Sladen, E. H. M. Waxen Chatterer in Sussex. (T.c.)

1845. Borrer, W. Nutcracker and Golden Oriole in Sussex; Lapland Bunting near Brighton. (Op. cit.)

Hussey, A. Hoopoe in summer [Rottingdean]. (T.c.)

Knox, A. E. Occurrence of Sabine's Snipe in Sussex. (T.c.)

Thorncross, T. Sea-birds at Beachy Head. (T.c.)

I846. Borrer, W., junr. Occurrence of Broad-billed Sandpiper and Red-necked Phalarope in Sussex. $(O p$. cit. $)$

I848. Borrer, W., junr. Egyptian Goose in Sussex; White Spoonbill in Sussex. (Op. cit.)

Ellman, J. B. Bittern at Battle; Little Bittern at Ewhurst and Ledlescomb [errore for Sedlescombe] ; Stormy Petrel at Hailsham (Sussex); Little Crake at Seaford, etc., 6 notes. (T.c.) 
I849. [Anon.] The Southern Coast of England. 8vo. Lond.: N.D. [I849]. [Sussex Birds, pp. I36, I45, 217.]

Borrer, W., junr. Great Grey Shrike near Shoreham. (Zool.); Fork-tail Petrel near Brighton. (T.c.)

Ellman, J. B. Dates of Arrival of Migratory Birds at Rye; Golden Eagle [poss., errore], Avocet, Little Stint, etc., at Rye, I4 notes. (T.c.)

Fitton, E. B. Swallows hibernating in cliff at Hastings. (T.c.)

Knox, E. A. Ornithological Rambles in Sussex. Post 8vo. Lond. : I849, and later editions. [335.]

Knox, E. A. Capture of Sea Eagle in Sussex. (Zool.)

May, W. Roller in Sussex. (T.c.)

Thorncroft, J. Tree Pipit at Shoreham. (T.c.); Peregrine Falcons at Beachy Head. (T.c.)

Unwin, W. C. Great Grey Shrike near Lewes. (T.c.)

I850. Borrer, W., junr. Waxwing near Horsham. (Op. cit.)

Ellman, J. B. Rare Anatidæ in Sussex; Glossy Ibis at Piddinghoe; Idem, Correction of Date ; Fork-tailed Petrel at Brighton; Ash-coloured [Hen] Harrier near Arundel, etc. I8 notes. (T.c.)

Grantham, G. Egyptian Goose in Sussex. (T.c.)

Potter, C. Firecrested Regulus and Waxwing near Lewes; Black Redstart at Piddinghoe; Black Tern at Bulmer. (T.c.)

I851. Ellman, J. B. Arrival of Migratory Birds at Lewes; Habits of Dartford Warbler near Lewes (2 notes) ; Greý-headed Wagtail at Eastbourne; Jer Falcon at Mayfield ; Crane, Blackthroated Diver and Little Stint at Pevensey; Wood Sandpiper at Newhaven; Red-necked Phalarope and Little Gull at Lewes; Spoonbill at Hailsham, etc. I8 notes. (Zool.)

Hussey, A. Woodcock Breeding in Sussex. (T.c.) Idem by W. W. Reeves. (T.c.)

McIntosh, J. Heronries in England, etc. [partim.] (Nat. [Morris's], I.)

Potter, C. Little Gull at Lewes; Black Redstart near Lewes ; Great Northern Diver at Beddingham. (Zool.)

Thorncroft, T. Richardson's Skua at Brighton. (T.c.)

I852. [Anon.] Woodcock's Nest. (Sussex Express.) 3I July.)

Ellman, J. B. Purple Heron at Catsfield and Great Grey Shrike at Hailsham; Ross's Rosy Gull at Pevensey; Pomarine Skua at Hastings; Montagu's Harrier at Eastbourne; Alpine Swift at St. Leonards; Black Grous in Sussex, etc. 9 notes. (Zool.)

"W. F. W. B." Ortolan Bunting at Worthing. 2 notes. (Nat. [Morris's], II.) Idem by J. W. Stephenson. (Zool.)

I853. Borrer, W., junr. Continental White Wagiail in Sussex; Masked Gull in Sussex; Summer Duck in Sussex; Glaucous Gull in Sussex, etc. 5 notes. (Zool.)

Hussey, A. Red-necked Phalarope at Rottingdean. 
Matthews, A. Remarks on Scolopax delanotti [shot near Hastings]. (T.c.)

Newton, A. Occurr. of Aquatic Warbler at Hove. (Yarrell's Brit. Birds, ed. 4, I., p. 380.)

Stephenson, J. W. Blue-throated Warbler, Little Auk and Black Redstart near Worthing. (Zool.)

Stone, G. Jottings at Brighton [Birds]. In (Morris's Nat., III., p. II8 et seq.)

1854. Borrer, W., junr. Continental White Wagtail in Sussex; Crane in Sussex; Lanus Sabinei, Leach, in Sussex; Sylvia galactotes on Downs near Brighton. (Zool.)

Cavafy, J. Dotterel [and other rare birds] at Brighton. (Nat. [Morris's], IV.)

Jackson, G. Blackstart near Chichester. (T.c.)

Newman, E. Hoopoe at Chichester. (Zool.)

1855. Cavafy, J. On Occurrence of Rufous Warbler near Brighton (vide W. Borrer, junr., in Zool. 1854, p. 45II). (Nat. [Morris's], IV.) Additions to ornithology of Sussex. (T.c.)

Grantham, G. Little Ringed Plover and Smew near Brighton. (Zool.; Nat. [Morris's], V.)

Hussey, A. Short-toed Lark and Lapland Bunting in Sussex. (Zool.) Richardson's Skua in Sussex. (T.c.)

1856. Dennis, R. V. Snow Bunting [near Seaford, on April Io]. (Field, May. 3; Nat. [Morris's], VI.); Bewick's Swan [near Seaford], etc., II notes. (T.c. VI.)

Grantham, G. Bittern at Lewes. (Zool.)

Newman, E. Occurrence of Stilt Plover at Bosham in Sussex. (T.c.)

Woodroffe, A. A young Spoonbill shot at Shoreham. (T.c.)

r857. D'Alquen, F. C. The Crested Grebe shot off Brighton. (Morris, B., Nat., Vol. VII., p. 9I.)

1858. [Anonymous (from West Sussex Gazette).] An Eagle [Whitetailed] shot at Arundel. (Morris, B., Nat., VIII.) Idem illustrations. (Ill. Lond. Neres.)

Borrer, W., junr. Occurrence of Tengmalm's Owl in Sussex. (Zool.) Fulmar Petrel at Brighton. (T.c.)

Dutton, John. Occurrence of Hoopoes in Sussex. (Zool.) Idem (Nat. [Morris's], VIII.); Marsh Harrier on Pevensey Levels. (T.c.; (Zool.)

Curties, E. B. The Bittern [shot near Rye]. (Field, April 24.)

Grantham, G. Fulmar Petrel near Brighton. (Zool.) Honey Buzzard [at Barcombe]. (Nat. [Morris's], VIII.)

Thorncroft, T. Fulmar Petrel near Brighton; Hobby near Brighton. (Morris's Nat., VIII.)

Porter, John, junr. Alpine Accentor near Lewes. (Morris, B. Nat., Vol. VIII., p. 99, also Zool.)

1859. [Anon.] Parrot Crossbill near Brighton. (Zool.) 
Dennis, R. N. Pomarine Skua near Brighton. (Zool.)

[Anon.] Sabine's Gull at Brighton. (T.c.)

Dutton, J. Rock Doves at Beachy Head ; Pomarine Skua at Birting (Birling) Gap [near Eastbourne]. (T.c.); Peregrine Falcon [Eastbourne]. (Field, Dec. 24.)

Kent, R. Little Crake and Schintz Sandpiper at Hastings. (Zool. Knox, A. E. On Habits of Black-winged Stilt as observed on its occurrence in Sussex. (Ibis, I859; Zool., I860.)

Rowley, G. D. Parrot Crossbill, Pomarine Skua and Sabine's Gull near Brighton. (Zool.) Short-toed Lark at Brighton. (Ibis, p. 330.)

"S. R." Kingfisher in the streets [Brighton]. (Field, Jan. I.) (Sussex Express.) Raræ Aves [Blackwinged Stilt near Midhurst, etc.]. (Op. cit., June 25.)

Dutton, J. White-tailed Eagle near Eastbourne. (Field, Dec. 24.)

Wilson, J. C. Rare Birds near Worthing. (Zool.)

I860. Kent, R. Birds shot on the Sussex Coast. (Field, Jan. 2I.)

"R. D. G." Sea Eagle in Sussex [errore for Suffolk]. (T.c., March 3, p. I76.)

Bond, F. Serin Finch in England. (Zool.)

Dutton, J. Rare Birds at Eastbourne; White-tailed Eagle near Eastbourne; Peregrine Falcon near Eastbourne ; Richardson's Skua at Eastbourne. 4 notes. (T.c.)

Gray, R., and Hussey, A. Tree Sparrows [near Worthing]; Migration of and Trade in Goldfinches [Sussex statistics]. (Zool.)

Kent, R. Birds shot on Sussex Coast. (Field, Jan. 2I.)

Merrifield, Mrs. A Sketch of the Natural History of Brighton. and its Vicinity. Post 8vo. Brighton: I860 and I864.

Rowley, G. D. Letter from Brighton on some Charadride (Ibis.) Letter on Falco peregrinus, etc., observed at Brighton. (T.c.)

I86r. ["W. G."] Birds in Chichester Town. (Field, Apr. I3.) J. D." Quail in Sussex. (T.c., January I9) ; The Dartford Warbler [Common near Beachy Head]. (T.c., Jan. 26.)

Dutton, J. Little Gull at Eastbourne, (Zool.)

Kent, R. Rare birds observed during late severe weather [near. St. Leonards]. (Field, Feb. I6); Hoopoe, etc., near St. Leonards. (T.c., April 27.)

Pratt, H. Bewick's Swan at Pagham Harbour ; Little Gull in Sussex. (T.c.); Greyheaded Wagtail and Temminck's Stint near Brighton. (T.c.)

Rowley, G. D. Serin Finch near Brighton. (Ibis, p. II3.)

Thorncroft, T. Hooper near Brighton. (Zool.)

I862. ["J. D."] Egyptian Goose near Eastbourne. (Field, Dec. 27.) at Brighto. Occurr. of Skuas at Brighton; Whalebird [seen others. (T.c., Nov. 29.) 
Dutton, J. Great Grey Shrike at Jevington. (Zool.)

Erredge, J. A. History of Brighthelmston. 8vo. Brighton: I862. [I98.]

Pratt, H. Blue-throated Warbler at Brighton. (Zool.)

Rowley, G. D. Shore Lark at Brighton. (Ibis, p. 88.)

"Sussex Blackthorn." Sea-Eagles [in Sussex]. (Field, Nov. 22.)

I863. [Anon.] "M. C." American Bittern near Lewes. (Field, Nov. 7) : "C. S. R." Egyptian Goose in Sussex. (T.c., Dec. I9); "M. C." Osprey, near Lewes. (T.c., Nov. 7.)

Dutton, J. Honey Buzzard near Eastbourne and other occurrences in Sussex. Io notes. (Zool.)

Harting, J. E. On Dartford Warbler [in Sussex, corr. of error]. (T.c.)

Jeffery, W., junr. Scarcity of Summer Birds; Red-necked Phalarope near Chichester. (T.c.)

Kent, R. Common Buzzard at Battle; Rough-legged Buzzard and Hen Harrier at Ashburnham Park; Fire-crested Regulus off St. Leonards. (T.c.)

Newton, A. On Fringilla incerta of Risso [caught near Brighton]. (Zool., ex P. Z.S.)

Rowley, G. D. Tawny Pipits at Brighton. (Ibis, p. 37.)

Willes, C. S. Sand Grouse [in Sussex]. (Field, June I3.) Iden by "E. B." (T.c., June 20). Idem by F. Russell. (Zool.)

I864. [Anon. "T. B."] Swallows at Brighton on Nov. I6. (Field, Nov. I9.)

Dutton, J. Peregrine Falcons taken at Beachy Head; Smew near Eastbourne, and other occurrences. I4 notes. (Zool.)

Gould, J. Exhibition of Specimens from Brighton. (Ibis.) Little Bunting at Brighton. (P. Z. S., p. 377.)

Jeffery, W., junr. Honey Buzzard at Goodwood; Red-winged Starling in Sussex and other occurrences ; 7 notes. (Zool.)

Jenner, E. Razorbill at Lewes. (T.c.)

Maurice, C. S. Brambling in Sussex; Hooded Crows at Brighton. (T.c.)

Pratt, J. Water Pipit near Brighton. (Zool.)

Pratt, H., junr. White-tailed Eagle at Shoreham. (T.c.)

Rowley, G. D. Letter on Various Birds from Brighton. (Ibis). Water Pipit near Brighton; Anthus campestris or $A$. mufescens at Brighton. (Zool.) Crested Lark near Shoreham. (Ibis, p. 224).

I865. "R. W. C." Hoopoe in Sussex. (Field, Apr. 29.)

"Arctic Tern." Occurr. of Purple Sandpiper at Eastbourne. (Field, Nov. II.)

Borrer, W. White-tailed Eagle in Sussex. (Zool.)

Dutton, J. Merlin near Hailsham; Ornitholog. Notes from E. Sussex. (Zool.)

[Editorial.] Water Pipit near Brighton. (Science Gossip). 
Gurney, J. H. Leach's Stormy Petrel at Worthing; Note on the Purple Sandpiper [in Sussex]; Arrival of Vernal Immigrants at Worthing; Slavonian Grebe at Worthing. (Zool.) Grey Phalarope, Purple Sandpipers, etc. [near Worthing]. (Field, Nov. 25.)

Jeffery, W., junr. Great Northern Diver on Sussex Coast. (Zool.) Arrival of Summer Birds in I864 [near Chichester]. (T.c.)

Rowley, G. D. Emberiza pusilla and Anthus rufescens at Brighton. (Ibis.) Richard's Pipit at Brighton; Firecrested Regulus at Brighton. (Zool.)

[Various writers.] Red-legged Partridges in Sussex. (Field, Sept. 23, 30.)

I865-8I. Jeffery, W., junr. Ornithological Notes from W. Sussex. 20 Contributions. (Zool., I865-8, I870, 1874, I876, I879, I88I.)

I856. "Arctic Tern." Great Grey Shrike [at Pevensey]. (Field, Jan. I3.)

Dutton, J. Great Grey Shrike at Pevensey; Purple Sandpiper and Grey Phalarope at Eastbourne; Snow Bunting at Beachy Head. (Zool.); Iceland Gull [at Eastbourne]. (Field, Feb. I7) : Golden Oriole in Sussex. (T.c., May 12, 26.)

Jeffery, W., junr. Eagle Owls at Arundel. (Field, April 28.)

Kirby, H. T. M. Grey Phalarope at Mayfield, Sussex. (Zool.) Gottwaltz, J. F. White Stork at Eastbourne. (Field, April 28.) Lang, C. Osprey in Sussex. (Zool., Field, Oct. 6.)

May, W. Golden Oriole at E. Grinstead. (Zool.)

Monk, T. J. Red-winged Starling at Brighton; Serin Finch near Brighton; Little Ringed Plover near Lewes. (T.c.)

Newman, E. Ixos obscurus in England [purch. at Hastings poulterers]. (T.c.)

Pratt, J. Woodchat Shrike and Golden Oriole at Brighton. (T.c.)

Rowley, G. D. Richard's Pipit at Brighton. (Field, Nov. I7.)

Smee, A. H. Purple Sandpiper and Leach's Petrel at Shoreham. (Zool.)

Sterland, W. Long-eared Owls at Arundel. (Field, May 5.)

Wharton, C. B. Pied Flycatcher in Sussex. (Zool.)

I867. Barker, J. Grey Phalarope in Sussex [Pagham]. (Field, Dec. 2I.)

Bond, F. Water Pipit and Wood Lark at Brighton. (Zool.)

Dugmore, F. S. Rare Birds [Honey Buzzard near Eastbourne]. (Field, June 29.)

Dutton, J. Peregrine Breeding at Beachy Head; Snow Bunting, etc., at Eastbourne, 4 notes. (Zool.) ; Avocets near Eastbourne. (Field, June 8) ; Rare Larks at Eastbourne. (T.c., Mar. 20) ; Woodlarks at Eastbourne. (T.c., April 20.)

Hawker, T. A. Grey Phalarope at Shoreham. (Zool.)

Jeffery, W., junr. Woodlarks in West Sussex. (T.c.; Field, May 4.) 
Monk, T. J. Great Snipe and Other Rare Birds near Brighton. (Zool.) Rustic Bunting in Sussex. (Field, Nov. 2.); Great Snipe [near Lewes]. (T.c., Oct. 26.)

Rowley, G. D. Montagu's Harrier at Brighton. (Field, Nov. I6) ; Richard's Pipit at Brighton. (T.c., Oct. I9) ; Destruction of Woodlarks [near Brighton]. (Op. cit., Jan. I2); Stormy Petrels at Brighton. (Op. cit., Nov. 23.)

Taylor, N. Goldeneye, Shore Lark and Little Gull at Eastbourne. (Zool.; Field, Jan. I9.)

Weir, J. J. Scarlet Bullfinch in Sussex? (Zool.)

1868. Kennedy, A. Clark. Snow Bunting at Hastings. (Zool.)

Dutton, J. American Bittern in Pevensey Marshes; Pomarine Skua at Eastbourne; White Lark near Eastbourne; Notes of Rare Birds at Eastbourne; Purple Sandpiper near Beachy Head. (Zool.)

Gurney, J.H., junr. Rare Captures for May I868 [Little Bittern at St. Leonards]. (Zool.)

Rowley, G. Dawson. Sea Eagle at Lewes; Birds on the South Coast. (Field, Nov. I4) ; Richard’s Pipit at Brighton. (Zool.; Field, Oct. I7.)

Stephenson, J. W. Solitary Snipe in Sussex; Abundance of Little Grebe in Sussex. (T.c.)

White, H. J. Bittern at Steyning, Sussex. (T.c.)

1869. [Anon.] Serin Finch at Wartling. (Land \& Water, p. 392.)

Bissenden, J. Black-throated Diver at St. Leonards. (T.c.)

Bell, A. S. Rare Birds near Hastings. (Zool.)

Booth, E. T. Richard's Pipit, etc. (Field, Oct. 9.)

C[hapman], H. V. C. Rare Birds at Rye. (T.c., Nov. 20.)

Frewen, M. The Kite [near Rye]. (T.c., Mar. 20.)

Gould, J. Black-headed Bunting at Brighton; Black-throated Thrush at Lewes. (Ibis.)

Gurney, J. H., junr. Firecrested Regulus near St. Leonards. (Zool.)

Harting, J. Occurrence of Grey Phalarope in Sussex. (Field, Nov. I3.)

[Lucas, F. W.] Serin Finch at Worthing. (Field, June I2.)

Monk, T. J. Black-throated Thrush [near Lewes.] (Field, Jan. 2 ; Zool.)

Pigott, T. N. Golden Oriole near Horsham. (Field, May 22; Zool.)

Rowley, T. G. The Water and Rock Pipit. (Field, Apr. Io, I7; Zool.)

"W. J. V." Serin Finch [at Eastbourne]. (Field, May I.)

Wonfor, T. W. Rosy Bullfinch, Richard's Pipit, Tawny Pipit, Firecrest and Little Gull at Brighton; Whitetailed Eagle, Crossbills, and Peregrine in Sussex, etc. (I6 notes.) (Zool.) Dartford Warbler at Brighton. (Science Gossip.) 
1870. Bates, H. Bartailed Godwits [at Beachy Head]. (Field, June 4.) The Grey Phalarope [Sabine's Gull and Roseate Tern in Sussex]. (Op. cit., Nov. 5.)

Bell, A. S. Avocet and Little Auk at Rye; Avocet, Bittern and Grey Phalarope at Hastings; Wildfowl at Hastings. (Zool.)

Bond, F. Tawny Pipit, Ortolan Bunting, and Lapland Bunting near Brighton; Rare or new Brit. birds [near Brighton]; correction of error (2 notes); Siberian Lark at Brighton. (Zool.)

Harting, J. E. On Immigration of Grey Phalarope and recent occurrence in Sussex. (T.c.)

H. V. C[hapman]. Avocets and Hoopoes in Suffolk [= Sussex]. (Field, Apr. 30) ; Herons and Heronries. (T.c., June II.)

"J. R." Grey Phalarope near Littlehampton. (Science Gossip.)

Monk, T. J. Garganey near Lewes ; Shore Lark near Newhaven; Roller near Lewes; Quail's eggs near Lewes. (Zool.)

Rowley, G. D. Correction of an Error (Zool.); Shore Larks and Grey Phalarope near Brighton. (Zool.; Field, Nov. I2); Forktailed Petrel at Brighton (Field, Dec. 3); Whitewinged Lark at Brighton (P. Z.S., p. 52); Rose-coloured Pastor near Brighton. (Field, Aug. 27.)

"Taffy." Roller in Sussex. (Field, June II.) "J. H." Idem. (Op. cit., July 2.)

Ward, E. Californian Quail in Sussex. (T.c., Oct. I.) Idem by S. M. Wilson. (T.c., Oct. 8.)

I87I. Bates, B. Schinz's Sandpiper at Eastbourne. (Zool.); Wild Swans at Eastbourne. (Field, Feb. I8.)

C[hapman], H. V. Hooper Swans [near Rye]. (T.c., Feb. 25.)

Gurney, J. H., junr. Gray-headed Wagtail at Brighton. (Zool., p. 2639) ; Dipper at Rye. (T.c.)

Frewen, M. Rare birds in Sussex. (Field, Feb. I8.)

Kent, R. Rose-coloured Pastor nr. Bexhill. (Zool.)

Rowley, G. D. Fork-tailed Petrel at Brighton. (T.c.; Field, Dec. 3, I870) ; Sabine's Gull at Brighton. (Field, Oct. 7.)

Monk, T. J. Preservation of the Woodcock in E. Sussex. $(O P$. cit., Feb. 25.)

1872. Bates, B. White Stork seen at Eastbourne. (Field, Apr. 27.) C[hapman], H. V. White-tailed Eagle near Rye. (Op. cit.,
Nov. 30.)

Grantham, W. Manx Shearwater in Sussex. (Field, Oct. I2.)

Harting, J. E. Pectoral Sandpiper killed at Eastbourne [in his Handbook Brit. Birds, p. I4I] ; British Heronries [partim.] (Zool.)

Rowley, G. D. Spoonbill and Dotterel at Brighton. (Field, Oct. 26.) Leach's Petrel. (T.c., Dec. I4); American White throated Sparrow near Brighton. (P. Z. S., p. 68I.)

Stevens, S. Spotted Redshank near Arundel. (Zool.)

Tuck, J. G. Richardson's Skua at Rye. (Zool.) 
I873. [Anonymous.] Eastbourne Nat. Hist. Soc. Lists of the local Fauna and Flora. [Aves, pp. 2, 3 and 4.] (Reprinted from Chambers Handbook for Eastbourne. Post 8vo. I873.)

Coombe, R. E. Common Kite in Sussex. (Field, Feb, 15.)

Rowley, G. D. Tawny Pipit at Brighton. (Field, Oct. II.) Short-toed Lark at Brighton. (T.c., Nov. 22.) Serin Finch at Brighton. (Op.cit., Apr. I9.) Redlegged Falcon at Brighton. (T.c., May 24.) [See also Op. cit., Nov. 22.] Snow Buntings, etc., at Brighton. (Op. cit., Dec. 27.)

I874. Clark-Kennedy, A. J. Baillon's Crake near Eastbourne; Iceland Gull [near Rye]; Rare Birds at Eastbourne. (Zool.)

Clark-Kennedy, A. W. M. On occurr. of Emberiza nivalis in summer plumage [near Eastbourne]. (T.c.)

Howell, J. On the Nightingale. (Brighton \& Sussex Nat. His... Soc., p. 3I.)

L'Estrange. Heronry in Sussex. (Zool., p. 3953.)

Roper, F. C. S. Birds of Sussex. (Trans. Eastbourne Nat. Hist. Soc.)

Rowley, G. D. Short-toed Lark and other Birds at Brighton. (Zool.) Migration of Birds over Brighton (Field, Dec. 26.); Singular var. of Barn Owl [near Eastbourne]. (T.c., Aug. I5.)

I875. [Anon. "G. S."] Snow Bunting, etc., at Brighton. (Field, June I6.)

[Anon. "G. W. A."] Pied Robin at East Grinstead. (T.c., Feb. 13.)

Boyd, A. J. Dotterel near Horsham. (Op. cit., Oct. r6.)

Colgate, T., junr. White-winged Black Tern in Sussex. (Ficld, Nov. I3.) Idem by A. J. Clark-Kennedy. (Op. cit., Jan. I6.)

"G. E. B." Little Gull in summer plumage in Jan. [near Lewes]. (Op. cit., Jan. I6.)

Green, W. J. Grey Phalarope in Sussex. (Field, Nov. 27.)

Nicholls, H. Ornithology of the Eastbourne District. (Trans. Eastbourne Nat. Hist. Soc.)

[Parish, W. D.] Dialect names of some Sussex Birds [in W. D. Parish's Dictionary of the Sussex Dialect].

Roper, F. C. S. Notes on a specimen of the Great Bustard lately shot in Sussex. (Trans. Eastbourne Nat. Hist. Soc.)

Rowley, G. D. Cuckoo at Brighton [in August]. (Field, Aug. I4.)

Swaysland, G., junr. Pied Flycatcher, Tawny Pipit and Lapland Bunting at Brighton. (Zool.)

Sawyer, F. E. The Birds and Mammals of Sussex. (Brighton E Sussex Nat. Hist. Soc., I875, p. 99 et seq. Birds, pp. I02-IIo.) Also in pamphlet. I2mo. pp. 23, reprinted from Brighton Daily News. April 9, I875. [510.]

1876. Arnold, Rev. F. H. Sussex Heronries. (Chichester \& West Sussex Nat. Hist. Soc., I876.) (Not seen.) Idem. (Science Gossip.) 
Bozes, G. R. Golden Oriole nr. Brighton. (Field, May 27.)

Butler, E. A. List of Hastings Birds. (In Second Annual Report of the University Schools Naturalists' Field Club, pp. 3I-2.)

Ellis, W. B. Glossy Ibis near Arundel. (Field, Aug. 26.)

[Editorial.] Mr. Booth's Collection of Brit. Birds [Rye records]. (T.c., Sept. I6.)

Gurney, J. H. Little Crake at Hastings. 2 notes. (Zool.)

Lloyd, T. Bittern in Sussex. (Field, Nov. I8.)

"Nuthatch." Bustards on the South Downs [near Brighton]. (Field, Jan. 15.) Idem by J. F. Gottwaltz. (T.c., Jan. 22.)

Rowley, G. D. Migration [on South Coast]. (Field, op. cit., Oct. 2I.) Montagu's Harrier nesting in Sussex [near Brighton]. (T.C., July I.)

"St. T. H." Heronries near Hastings. (Science Gossip.)

1877. Bell, T. [in his edn. White's Selborne, I., p. 48I.] Peregrine Falcon killed Jan. I8I2 in Sussex.

Bond, F. Tawny Pipit at Brighton. (Zool.)

Borrer, W. Little Owl in Sussex. 2 notes. (T.c.) Summer Snipe breeding in Sussex. (Field, May 5.)

Byerley, A. Egyptian Geese in Chichester Harbour. (Field, Sept. I.)

Harting, J. E. On Former Nesting of Spoonbill in Sussex. (Zool.)

Mathew, M. A. Tawny Pipit in Sussex. (T.c.)

Mitford, R. Roller in Sussex. (Field, Sept. 8.)

Pratt and Sons. Glaucous Gull at Brighton. (Field, Mar. 24.)

Rowley, G. D. Sabine's Gull at Brighton. (Field, Jan. I3.) Notes from Brighton. (T.c., Feb. 3.)

Trangmar, H. Glaucous Gull at Brighton. (T.c., Feb. 3.)

"W. S. B." Pochard breeding in Sussex. (T.c., May I2.)

Weaver, J. Birds of the District around Harting. (In Gordon's History of Harting.) 8vo. Lond.: I877. [120.]

I878. Freeland, F. S. The Hoopoe [notices of nidification and occurrences of this bird in Sussex]. (Chichester \& West Sussex Nat. Hist. Soc., Oct., I878.)

Glennie, W. R. Black Redstart near Brighton. (Field, Dec. I4.) Jeffery, W. Hoopoes on Sussex Coast. (Zool.)

Rowley, G. D. On Sussex Heronries. (R. O. M., III., pt. XII., p. 65, etc.)

Sclater, P. L., and Salvin, C. The Dyke Road Museum, Brighton. (Ibis.)

I878-98. Parkin, T., and Gurney, J. H. Birds of Hastings and St. Leonards.) In Nat. Hist. of Hastings. 8vo. I878. Suppl. $\mathrm{I}-3, \mathrm{I} 883-98$.)

I879. Clifton, Lord. On some Races of Birds observed near Brighton. (Ibis.) Fire Crest and Great Grey Shrike at Brighton. (Zool.) British killed specimen of Bonelli's Warbler. (Field, Mar. 29, Apr. I9.) Probable occurr. of Emberiza cresia [near Brighton]. (Zool.) 
Gurney, J. H. Ornitholog. Notes from St. Leonards. (Zool.) Summer Birds at Hastings. (Field, Apr. I2.)

Hardcastle, A. Curlew Sandpiper in Sussex. (Op. cit., Sept. 27.) Napier, C. O. Groom. A ramble among the Marsh Birds of Sussex. (Natural History Rambles, Lakes and Rivers, pp. 48-6I.) [430.]

Spiller, M. Little Bustard at Eastbourne. (Ficld, Dec. 20.)

T. J. M[onk]. Nesting of Woodcock in Sussex. (Field, May I7.)

Wordley, F. Uncommon Birds at St. Leonards. (Field, Dec. 27.)

I880. Borrer, W. Great Skua at Brighton. Long-eared Owl in Sussex. (Zool.)

Chapman, H. S. Unusual number of Landrail in Sussex. (Field, Oct. 23.)

Clark-Kennedy, A. J. Black-winged Stilt near Eastbourne. (Zool.) Idem. (Field, May I8.)

Clifton, Lord. Hoopoes in Sussex. (Zool.) Idem. (Field, Oct. 23.)

Gurney, J. H. Notes from St. Leonards. (Field, Apr. IO.)

Langton, H. Shore Lark near Brighton. (Zool.)

Pratt and Sons. Spoonbills in Sussex. (Field, Oct. 30.)

Sizer, C. F. Hoopoe near Chichester. (Zool.; Field, May 8.)

Spiller, M. Little Bustard at Eastbourne. (Zool.)

I88I. [Anon.] Honey Buzzard at E. Grinstead.

Borrer, W. Crested Lark in Sussex. (Zool.)

Clifton, Lord. Autumnal Migration in Kent and Sussex. (Ficld, Oct. I5.)

Fuller, Rev. A. Occurrence of fork-tailed Petrel, Curlew Sandpiper, and Little Stint in Sussex. (Chichester \& West Sussex Nat. Hist. Society, Dec. I88I.)

Gurney, J. H., junr. On Spring Migration at St. Leonards. (Tr. Norf. \& Norw. Soc.)

Jeffery, W. Eider Duck in Sussex. (Zool.)

Langton, H. Hoopoe near Brighton, Eider Duck on the Sussex Coast. (T.C.)

Parkin, T. Grey Phalarope in Sussex. (T.c.) Woodcock in Hastings [Town]. (Hastings \& St. Lconards Observer, Nov. 7); The Bittern in Sussex. (Sussex Epxress, Feb. 5.)

Wordley, F. Uncommon birds at St. Leonards-on-Sea. (Field, Dec. 27.)

I88I-3. Parkin, T. Rare Birds in Sussex, 3 notes. (Zool., I88I-3.)

I882. Clark, S. V. Osprey near Worthing. (Zool.)

Clifton, Lord. Red-throated Pipit [errore] and other birds at Brighton. (Field, Apr. 29.); Supposed New Willow Warblers [captured in Sussex]. (T.c., May 27, June I0). Serin Finch and Wild Canary, etc., 2 notes. (T.c., July I5, Dec. 9.)

Fuller, F. Gyrfalcon in South of England. (T.c., Oct. I4.)

Nicholls, H. Pomatorhine Skua in Sussex. (Zool.)

Weir, J. Jenner. Kentish Plover in Sussex. (T.c.) 
I883. Ellis, W. B. American Bittern in Sussex. (Field, Dec. 8.)

Fuller, Rev. A. Pomatorhine Skua Gulls at Selsey. (Chichester \& West Sussex Nat. Hist. Soc., No. I, pp. 33-49.)

Gurney, J. H. Greenland Falcon in Sussex. (Zool.)

Monk, T. J. Gyr Falcon in Sussex. (T.c.)

Parkin, T. The Tawny Pipit in Sussex. (T.c.); Spotted Redshank at Rye. (T.c.)

Sawyer, F. E. Bird Folk Lore. (In Sussex Natural History, Folk Lore and Superstition, pp. 6-9.)

Smith, C. Bonaparte's Gull at St. Leonards-on-Sea. (Zool.)

1884. Borrer, W. American Bittern in Sussex. (Zool.)

Clifton, Lord. Willow Wrens [varieties near Brighton]. (Field, June 28, Aug. I6, Sept. I3.)

Gurney, J. H., junr. Red-throated Pipit at Brighton. (Zool.)

Gurney, J. H. Note on a Gyr Falcon obtained in Sussex in I85I. (T.c.)

Harting, J. E. Hoopoe in Sussex. (T.c.)

Nelson, T. H. White Stork at Pevensey. (T.c.; Field, Nov. 8.)

Parkin, T. Dipper in Sussex. (Zool.)

"D. R." Little Auk inland [at Thakeham]. (Field, Dec. 20.)

I885. Aplin, O. V. Late stay in spring of Shore Lark. (Zool.)

Chapman, H. V. Woodcocks in Sussex. (Field, May I6.)

Parkin, T. Barn Owl and Wild Duck breeding in Nov. [near Hastings]. (Field, Jan. 24.)

Southwell, T. Unrecorded occurr. of Roseate Tern [nr. Eastbourne]. (Zool.)

Terrell, J. H. Tufted Duck and Pochard nesting at Lewes. (Field, Feb. 2I.)

I886. Gordon, H. D. Among the Birds of Harting. 8vo. Petersfield: I886. [236.]

Swaysland, H. Tawny Pipit near Brighton. (Field, Oct. I6.)

Langton, H. Tawny Pipit and Citril Finch [errore for Cape Canary] at Brighton. (Zool.) Cf. Harting. (OP. cit., I887.)

1887. Burton, - - Broad-billed Sandpiper at Rye. (Field, Sept. 3.)

C[hapman], H. V. Wild Fowl at Rye. (Field, Feb. 5.)

Chase, R. W. Tawny Pipit near Brighton. (Zool.)

Coombe, P. E. Little Bustard in Sussex. (T.c.)

Harting, J. E. Reported Occurrence of Citril Finch near Brighton. (T.c.) Pagham Harbour, past and present. (Field, July 2, I6.)

Jeffery, W. Little Bustard in West Sussex. (Science Gossip, March.)

"J. S." Bittern in Sussex. (Field, Jan. I5); Idem by R. T. Godman. (T.c., Feb. 26.)

Theobald, F. V. Phalaropes, Fulmar Petrel and Montagu's Harrier near Hastings. (Zool.)

I888. Barclay, F. H. Fire-crest and Grey-headed Wagtail at Brighton. (Op. cit.) 
Brazenor, C. Great Spotted Woodpecker and Grey Shrike at Brighton. (T.c.)

Chase, R. W. The occurrence of Serimus canicollis near Brighton. (Zool.)

Gurney, J. H., junr. Ornitholog. Notes from St. Leonards. (T.c.) Lucas, C. J., and others. Pallas's Sand-Grouse [in Sussex]. 4 notes. (Field, June 9, Aug. 4.)

Saunders, H. Short-toed Lark in Sussex. (Zool.)

Newberry, W. H. Birds observed at Rye. (T.c.)

Monk, T. J. Purple Heron in Sussex. (Field, Nov. I7.) Idem by Lord Lilford. (T.c., Nov. 24.)

Wyatt, H. R. P. Hoopoe in Sussex. (Field, Apr. 28, May 5.)

I889. Brazenor, C. Lapland Bunting near Brighton, 2 notes. (Zool.)

Hart, E. An unrecorded Squacco Heron [near Horsham]. (Zool.)

Morris, R. Little Bittern in Sussex. (T.c.)

Parkin, T. Little Bittern in Sussex. (T.c.)

I89o. Aplin, O. V. The Shore Lark [at Rye, Apr. 22.] (Field, Dec. I3.)

Blackett, P. Hoopoe in Sussex. (Op. cit., Apr. 26.)

Borrer, W. Sooty Shearwater at Hastings. (Zool.)

Burr, M. Honey Buzzard in Sussex. (T.c.)

Cosstick, W. Golden Oriole in Sussex. (Field, Apr. 26.)

Gordon, H. D. Ruddy Sheldrake in W. Sussex. (Op. cit., Sept. 20.)

Harden, T. R. Manx Shearwater inland in Sussex. (Zool.)

Harland, H. S. Iceland Gull near Brighton. (Field, Apr. I9.) Idem by T. H. Nelson. (T.c., Apr. 26.)

Harting, J. E. On an unpublished MS. of W. Markwick on the Birds of Sussex, 2 pts. (Zool.)

Langton, H. Ruddy Sheldrake in W. Sussex. (T.c.)

Parkin, T. Little Gull at Hastings. (T.c.)

I89I. Anderson, J., junr. Ornithological Notes from Chichester. (Sci. Gossip, May.) Black Scoter. (T.c., Nov.)

Bradshaw, G. W. Grey Phalarope in Sussex. (Field, Nov. 7.)

Borrer, W. The Birds of Sussex. 8vo. Lond.: I89I. [87.]

C[hapman], H. V. Wildfowl at Rye. (Field, Jan. 24, p. I23) ; Gt. Bustard in Sussex (T.c., Feb. 7); Notes from Rye. (OP. cit., Oct. 3I.)

Gordon, H. D. Goosander in W. Sussex; Montagu's Harrier breeding in Sussex; Notes from W. Sussex. (Zool.)

Harting, J. E. Former Value of Sea Gulls in Sussex. (T.c.) The recent Visitation of Bustards. [partim.] (Field, Feb. 28.)

Head, F. Winter Notes from Shoreham. (Zool.)

Jörgensen, E. L. G. Eider Duck at Brighton. (Field, Dec. I9.)

Nelson, T. H. Notes from Sussex. (Zool.)

Nicholls, $\mathrm{H}$. Notes on the Birds in the District during the Frost of I8go-I. (Trans. Eastbourne Nat. Hist. Soc.) 
I892. Anderson, J., junr. Nesting of Black Scoter [?] in Sussex. $(O p$. cit.) Idem by C. Fowler. (T.c.)

Aplin, O. V. Distribution of the Cirl Bunting. (Zool.) Status of the Woodchat. (T.c.) [partim.]

Bradshaw, G. W. Notes from Sussex. (Zool.)

Burr, M. Quail in Sussex. (T.c.)

Gordon, H. D. Rough-legged Buzzard and Quail in Sussex. 2 notes. (T.c.)

Parkin, T. Woodchat and Bittern in Sussex. (T.c.)

Swaysland, H. Great Northern Diver off Brighton. (T.c.)

I893. [Anon.] Ruddy Sheldrake on Crumbles, Eastbourne. (Sussex \&. Hants. Nat., I., p. I3.)

Bates, B. Eastbourne Notes. (T.c., p. 84.)

Bradshaw, G. W. Willow Wren in Winter-Ruff, Garganey and Long-tailed Duck in Sussex, 4 notes. (Zool.)

Brazenor Bros. Waxwing and Firecrest in Sussex. (T.c.)

Clark, S. V. Quail nesting in Sussex. (T.c.)

Gordon, H. D. Hoopoe in Sussex. (T.c.)

Harting, J. E. Nesting of the Black Scoter [?]. (T.c.)

Morris, R. Waxwing at Framfield. (Sussex \& Hants. Nat., I., p. I3.)

Parkin, T. Garganey near Hastings. (Zool.)

Pratt and Sons. Bittern in Sussex. (T.c.). Lapland Buntings ... and Spoonbill [in Sussex]. (T.c.)

Saunders, H. [Supposed breeding of CEdemia nigra in Sussex.] (Bull, B.O.C., I.)

Whitaker, J. Purple Gallinule in Sussex. (Zool.)

Idem by Lord Lilford, E. G. B. Meade-Waldo and J. H. Gurney, junr. (T.c.)

Wise, F. Ruddy Sheldrake at Beachy Head; Notes on Sussex Birds; Savi's Warbler said to have been seen at Eastbourne; Eastbourne Notes (2 notes). (Sussex \& Hants. Nat., I.)

1894. Bradshaw, G. W. Uncommon Birds in Sussex; Notes from Hastings; Avocet in Sussex. (Zool.)

Coombe, P. E. Leach's Petrel in W. Sussex. (Sussex \& Hants. Nat., II., p. 2.)

Etherton, P. An Ornitholog. Ramble in Sussex. (Nat. Jnl.)

[Editorial.] Bonaparte's Gull reported from Sussex. (Sussex E. Hants. Nat., II., p. I9.)

Ellis, W. B. Notes from Arundel. (Sussex \& Hants. Nat., II., p. IO.)

Cordeaux, J. Sea Eagle in Wadhurst Park. (T.c., p. Io.)

Griffith, A. F. Baillon's Crake at Brighton. (Zool.)

Harting, J. E. The Wheatear on the S. Downs. [Illus.] (Field, July 28.)

Macpherson, H. A. Lapland Bunting in Sussex. (Zool.)

Jeffrey, H. O. Little Gull at Hastings. (Sussex \& Hants. Nat., II., p. 2.) 
Popham, H. L. Leach's Petrel on the Sussex Coast ; Wildfowl on the Sussex Coast. (Zool.)

Pratt and Sons, Wildfowl on Sussex coast. (T.c.)

Wise, F. Eastbourne Notes. (Sussex \& Hants. Nat., II., p. 2.)

I895. Bradshaw, G. W. Ornithological Occurrences in Sussex. 6 notes. (Op.cit.)

Butterfield, W. R. Increase of Hawfinch in Sussex. (T.c.)

Carrington, J. T. Rare Sussex Birds. (Science Gossip, N.S., I.) Gordon, Preb. Nutcracker near Chichester. (Zool.)

Harting, J. E. The Ruff in Sussex in Winter; Waxwing in Sussex; Redshank breeding in Sussex. (T.c.)

Langdale, H. M. Quails in W. Sussex. (T.c.)

Lilford, Lord. Hen Harrier in Sussex. (T.c.)

"O. J. P." Bittern shot at Powder Mill Pond, Battle. (Field, Dec. 2I.)

Parkin, T. Little Crake in Sussex. (Zool.)

I896. Alexander, B. Ornithological Notes from Rye. [partim.] (Zool.)

Ornitholog. Notes from Romney Marsh. [partim.] (T.c.)

Bradshaw, G. W. Osprey in Sussex; Red-necked Phalarope and Skuas near Hastings; Stone Curlew in Sussex. (T.c.)

Butterfield, W. R. Scarcity of Black Crow in Sussex. (Ornithologist.) Ornitholog. occurrences in Sussex. (7 notes.) (Zool.)

Coburn, R. Red-throated Pipit in Sussex, 2 notes. (T.c.) Exhibited by R. B. Sharpe. (Bull. B.O.C., V.)

Lewis, L. Local Bird Names from Arundel. (Ornithologist.)

Parkin, T. Pomatorhine Skua and Peregrine Falcon in Sussex. (Zool.)

Sharpe, R. B. [Exhibition of Wall-Creeper from Winchester.] (Bull. B.O.C., VI.)

I897. Saunders, H. Note on Hypolais polyglotta in Sussex. (Ibis.) Exhibited by N. F. Ticehurst. (Bull. B.O.C., VI.)

Bradshaw, G. W. Rare Birds at Hastings; Common Roller in Sussex. (Zool.)

Butterfield, W. R. Black-headed Bunting in Sussex. (T.c.) Hypolais polyglotta in Sussex. (Zool.)

Field, W. Bird Notes from Hastings. (Nat. Chronicle, May, June.)

Langdale, H. M. Hawfinches in W. Sussex; Quails in Sussex. (Zool.)

Marten, C. J. Bitterns in Horsham. (Science Gossip, N.S., I.). White Stork at Horsham. (Knowledge.)

Ticehurst, N. F. Rare Warblers in Sussex. (Zool.)

Overton, E. P. Little Gull and Red-necked Phalarope in Sussex. (Zool.)

Pratt, J. Aquatic Warbler in Sussex. (Knowledge.) 
I898. Bradshaw, G. W. [Another] Common Roller in Sussex; Woodchat Shrike in Sussex [nr. St. Leonards]. (Zool.)

Field; W. Hastings Notes. (Nat. Chron.)

Morris, S. Little Owl in Sussex. (T.c.)

Ticehurst, N. F. Exhibition of a Pectoral Sandpiper from Sussex. (Bull. B.O.C., VIII., I898-99.)

Turner, E. L. Hoopoe in Sussex. (Knowledge.)

I899. Ticehurst, N. F. On the two-barred Crossbill in Sussex. (OP. cit., VIII., I898-99.)

I900. Bryant, C. H. Black Redstart at Brighton [in December]. (Zool.)

Butterfield, W. R. Occurrence of Melodious Warbler in Sussex. (T.c.)

Leigh-Smith, W., junr. Occurr. of White Stork in Brede Level. (Field, Mar. 24.)

Hartert, E. [Exhib. of Baird's Sandpiper from Rye.] (Bull. B.O.C., XI.); Willow Tit in Sussex. (T.c.)

Ticehurst, N. F. Occurrence of Water Pipit in Sussex. (Zool.)

Hudson, W. H. Nature in Downland. 8vo. Lond. : I9oo.

I90I. Ashburnham, Hon. J. Little Bustard shot at Ashburnham Place. (Field, Jan.)

Bradshaw, G. W. Little Bustard in Sussex. (Zool.)

Butterfield, W. R. Occurrence of Willow Tit in Sussex; Breeding of Blue-headed Wagtail in Sussex. (Op.cit.) On occurrence of Puffinus obscurus bailloni in Sussex. (Bull. B.O.C., XI.)

Eastwick-Field, C. Lesser Redpoll nesting in Sussex. (Zool.)

Langdale, H. M. Nutcracker in Sussex. (Zool.)

Nicoll, M. J. Baird's Sandpiper in Sussex; Siskins in Sussex ; Osprey at Rye Harbour; Ring Ouzel at St. Leonards. (Zool.)

Parkin, T. Common Roller in Sussex. (Zool.)

Pratt and Sons. Little Bustard in Sussex. (Zool.; Field, Dec. I4.)

Saunders, H. On a specimen of Anthus cervinus from Sussex. (Bull. B.O.C., XII.)

Ticehurst, W. C. Occurrence of Squacco Heron in Sussex. (T.c.)

I902. Bonhote, J. L. Occurrence of Acrocephalus aquaticus in Sussex. (Op. cit., XIII.)

Butterfield, W. R. On occurrence of Plegadis falcinellus in Sussex. (Op. cit., XIII.); On Saxicola caterina in Sussex. (Op. cit., XII.) ; Motacilla beema in Sussex. (Zool.)

Edwards, L. A. Curtis. Red-throated Pipit in Sussex. (Zool.)

Saunders, H. [for Nicoll, M. J.] Exhibition of Anthus spipoletta from Sussex. (Bull. B.O.C., XIII. Idem. Zool.)

Ticehurst, N.F. On occurrence of ... Emberiza rustica in Sussex. (Bull. B.O.C., XIII.); Exhibition of Blueheaded Wagtails. (T.c.)

Wright, J. E. Birds : Rare and Irregular Visitors. (In Bygone Eastbourne, pp. 6-9.) 
I903. Alexander, Boyd. On occurrence of Black-winged Pratincole in Sussex. (Bull. B.O.C., XIV. ; Field, Nov. 2I.)

Arnold, E. C. Bluethroat near Eastbourne. (Zool.)

Bannerman, D. A. Late appearance of House-Martins at Eastbourne. (T.c.)

Butterfield, W. R. On occurrence of Motacilla borealis and M. feldeggi in Sussex. (Bull. B.O.C., XIII.) Exhibition of Orphean Warbler from Sussex; On Nesting of Peregrine Falcon near Hastings. (Bull. B.O.C., XIV.); Black-winged Pratincole in Sussex. (Zool.)

Field, W. Marsh-Warbler nesting in Sussex. (Bull. B.O.C., XIV.)

Nicoll, M. J. On occurrence of Great Reed Warbler and Tawny Pipit in Sussex. (T.c.); Tawny Pipit in Sussex. (Zool.)

Sharpe, R. B. [Meadow Bunting near Shoreham.] (Bull. B.O.C., XIII.)

Ticehurst, N. F. On occurrence of Bulwer's Petrel in Sussex. On Breeding of Motacilla flava in Sussex. (Bull. B.O.C., XIII.) ; Some Notes of Rare Birds from Sussex. (Zool.)

Tweedie, M. Glossy Ibis in Sussex. (Field, Nov. 2I.)

I904. [Anon.] Some Sussex birds. (Argus, July 9.)

Butterfield, W. R. Bulwer's Petrel in Sussex. (Bull. B.O.C., XIV.)

Bannerman, D. A. Hoopoe at Beachy Head. (Zool.)

Morris, R. Late appearance of House-Martins at Eastbourne. (Zool.)

Nicoll, M. J. Cetti's Warbler in Sussex; Motacilla borealis in Sussex. (Bull. B.O.C., XIV.) ; Tawny Pipit and Lapland Bunting in Sussex; Broad-billed Sandpiper in Sussex; Water Pipits in Sussex. $(O p$. cit., XV.) The Tawny Pipit as a visitor to England. [partim.] (Zool.)

Robinson, E. The Birds of Brighton and Neighbourhood. (Brighton \& Hove Nat. Hist. Soc., I904, pp. I7, I8.)

Ticehurst, C. B. [Exhibition of Solitary Sandpiper from Rye Harbour.] (Bull. B.O.C., XV.)

Walpole-Bond, J. A. White Wagtail breeding in Sussex. (Field, June II.)

I905. Arnold, E. C. Water-Pipit at Eastbourne. (Zool.)

Butterfield, W. R. On occurrence of Lesser Grey Shrike in Sussex. (Bull. B.O.C.); Exhibition of Western Blackeared Chat from Hove. (Op. cit., XV.)

Griffith, A. F. [Exhibition of Lesser Grey Shrike from Bosham.] (Op. cit., XVI.)

Morris, R. Nesting of Dartford Warbler in Sussex. (Zool.)

Millais, J. G. Birds (In Victoria Hist. of Co. of Sussex, I.). 4to. Lond.: I905. [406.]

Nichols, J. B. Night Heron, etc., in Sussex; Icterine Warbler in Sussex. (Zool.) 
Nicoll, M. J. Snow-Finch in Sussex. (Bull. B.O.C., XV.) On occurrence of Saxicola stapazina and Acrocephalus aquaticus in Sussex. (Bull. B.O.C., XVI.)

Parkin, T. Leach's Petrel in Sussex. (Zool.)

Ticehurst, C. B. On occurrence of White-spotted Bluethroat and Orphean Warbler in Sussex. (Bull. B.O.C., XVI.)

Igo6. Alexander, H. G. Avocet near Rye. (Zool.)

[Anon.] Additions to Sussex Birds since I89I. (Hastings \& E. Sussex Nat.)

Butterfield, W. R. Occurrence of Wall-creeper in Sussex; On occurrence of Puffinus kuhli in Sussex. (Bull. B.O.C., XVI.) Comparison between the Sussex and British Lists of Birds. (Trans. S.E. Union of Scientific Societies.)

Morris, R. Firecrest in Sussex. (Zool.)

Morson, J. C. F. Honey Buzzard in Sussex. (Field, Nov. Io.)

Nicoll, M. J. The Water Pipit as a visitor to England. [partim.] (Zool.)

Parkin, T. Visit to the Heronry at Alder Shaw, Beckley, Sussex. (Hastings \& E. Sussex Nat.)

Ticehurst, C. B. On occurrence of Pine Grosbeak in Sussex. (Bull, B.O.C., XVI.)

Ticehurst, N. F. Status of Blue-headed Wagtail in Sussex avifauna. Hastings \& E. Sussex Nat., pp. 38-4I.)

Toogood, C. Ornitholog. Notes from Lewes. (Zool.)

I907. Alexander, H. G. Late appearance of Bramblings in Sussex. (Zool.)

Arnold, E. C. On American Pectoral Sandpiper near Eastbourne; Tringa maculata near Eastbourne. (Bull. B.O.C., XXI.) Idem. (Brit. Birds, I.)

Butterfield, W. R. Variety of Rediving from Sussex. On occurrence of Melanocorypha yeltoniensis in Sussex. (Op. cit., XIX.) Unusual Movement of Birds on Sussex Coast in Dec. I906. (Hastings \& E. Sussex Nat.)

Langton, H. Supposed Serin Finches in Sussex; Golden Oriole in Sussex. (Brit. Birds, I.)

Millais, J. G. Roller in Sussex. Rare Birds in Sussex. (T.c.) Morris, R. Nesting of Lesser Redpoll in Sussex. (Zool.)

Overton, E. P. The Dartford Warbler in the Hastings District. (Hastings \& E. Sussex Nat., I., p. 76.)

Parkin, T. On occurrence of Sylvia melanocephala in Sussex. (Bull. B.O.C., XIX.) The Sardinian Warbler in Sussex. (Brit. Birds, I.) Idem. '(Hastings \& E. Sussex Nat., I908.) Occurrence of Sardinian Warbler in Sussex. (Zool.) Rare Birds in Hastings and Neighbourhood. (Hastings \& $E$. Sussex Nat.)

Ticehurst, C. B. Occurrence of Melanocorypha yeltoniensis in Sussex. (Bull. B.O.C., XIX.) On occurrence of the Black Lark on Sussex Coast. (Hastings \& E. Sussex Nat.) 
Ticehurst, N. F. On the Grey Wagtail as a Sussex Bird. (T.c.) American Pectoral Sandpipers in Sussex. (Brit. Birds, I.)

I908. Arnold, E. C. Notes on Eastbourne, I899-I906. (Op. cit.) Aquatic Warbler near Eastbourne. (Zool.); Aquatic Warbler in Sussex. (Brit. Birds, II.)

Bryden, H. A., and Walpole-Bond, J. The Ornithology of Sussex. (Brit. Birds, II.)

Bloomfield, E. N. Annual Notes on Local Fauna, etc. 2 pts. (Hastings \& E. Sussex Nat., Ig08-9.)

Bryden, H. A. Herons and Heronries. Description of Sussex Heronries. (Globe, May 4.)

Butterfield, W. R. Sooty Shearwater in Sussex. (Brit. Birds, II.)

Carroll, C. J. On occurrence of Bulwer's Petrel near Hastings. (Bull. B.O.C., XXIII.)

Gurney, J. H. Grey-headed Wagtail in Sussex. (Brit. Birds, II.)

Morris, R. Nesting of Lesser Redpoll in Sussex. (Zool.)

Nichols, J. B. Two-barred Crossbill in Sussex. White-winged Lark in Sussex. (Brit. Birds, II.) Melanocorypha sibirica in Sussex. (Bull. B.O.C., XXI.)

Nicoll, M. J. A Sussex Rufous Warbler. (Brit. Birds, II.)

Parkin, T. On the Heronry at Windmill Hill Place, Wartling. (Hastings of E. Sussex Nat.)

Ticehurst, C. B. Spotted Crake in Sussex. (Brit. Birds, II.)

Walpole-Bond, J. White Wagtail nesting in Sussex. (T.c.) See also under Bryden, supra. Sussex Hobbies. (Countryside.)

Whistler, H. Rough Notes in E. Sussex. (Zool.)

I909. Alexander, H. G. Lesser Redpoll in Sussex. (Brit. Birds, III.) Arnold, E. C. The Eastbourne Crumbles. (Zool.) WoodSandpiper in Sussex. (Brit. Birds, III.)

Feilden, H. W. Some Sussex Ravens. (Brit. Birds, II.)

Langton, H. American Bittern in Sussex. (T.c.)

Monck, E. F. B. Redstart in Sussex. (T.c.)

Mullens, W. H. Dartford Warbler in Sussex. (Brit. Birds, III.)

Nicoll, M. J. Some Notes on the Pipits which occur in Hastings District. (Hastings of E. Sussex Nat.)

Parkin, T. Among the Nesting Boxes at Westfield Place, May 30, I908. (T.c.) Common Buzzard in Sussex. (Brit. Birds, III. ; Zool.)

Walpole-Bond, J. The Lesser Redpoll in Sussex. The Redstart in Sussex. Notes from Sussex. The Ornithology of Sussex. (Brit. Birds, III.)

W[itherby], H. F. Bulwer's Petrel in Sussex. (Op. cit., II.)

I9Io. Bonnett, F. Some Ancient Heronries: the Windmill Hill Place Heronry. (Ill. Sporting \& Dramatic Newes, Apr. 9.)

Farwig, H. H. Crossbills in Sussex. (Brit. Birds, IV.)

Ford-Lindsay, H. W. Golden Oriole in Sussex. Avocets in Sussex. Large Clutch of Eggs of the Wryneck, Pett, Sussex. (Op. cit.) 
Joy, Norman H. Pied Flycatchers in Sussex. (Brit. Birds, IV.) Langford, B. C. R. Firecrested Wren in Sussex. (Field, Sept. Io.) Langton, H. Rough-legged Buzzard in Sussex. Short-toed Lark in Sussex. (Brit. Birds, III., IV.)

Molineux, H. P. Bittern in Sussex. (Brit. Birds, III.)

Morris, R. Crossbills nesting in Sussex. (T.c.) Idem by J. G. Millais. (Op. cit., IV.)

Mullens, W. H. Birds of Westfield. (Westfield Parish Magazine, July. I4I species.)

Nichols, J. B. Black-headed Bunting in Sussex. Nutcracker in Sussex. Pectoral Sandpipers in Sussex. Rare Birds in Sussex. (Brit. Birds, III, IV.)

Parkin, T. Notes on some East Sussex Ravens. (Hastings \& E. Sussex Nat.)

Shenstone, Miss A. Crossbills in Sussex. (Brit. Birds, III.)

Ticehurst, C. B. Rare Birds in Sussex. (Brit. Birds, III.)

Ticehurst, N. F. Pintail in Sussex. Black Wheatear in Sussex. (Brit. Birds, III).

Walpole-Bond, J. Crossbills in Sussex. (Brit. Birds, III.) IgIo-II. Griffith, A. F. Sociable Plovers in Sussex. (Bull. B.O.C., XXVII., IgIO-II). Grey-backed Warbler in Sussex. (T.c.) Correction by H. F. Witherby. (Brit. Birds, IgII.) Sooty Tern in Sussex. (T.c., also Bull. B.O.C., XXVII., IgIo-II.)

Igrr. Butterfield, W. R. Handbook to collections Hastings Museum. 8vo. Hastings: I9II. [Local Birds, pp. 42-49.]

Ford-Lindsay, H. W. Ornitholog. occurrences in Sussex, I2 notes. (Brit. Birds, IV., V.)

Ticehurst. N. F. Black-winged Stilt, Common Eider, Isabelline Wheatear, Long-tailed Duck and Northern Great Spotted Woodpecker in Sussex. Continental Goldcrest in Sussex, 6 notes. (Brit. Birds, IV., V.)

Nichols, J. B. Rare Birds in Sussex; Southern Grey Shrike and White-spotted Bluethroat in Sussex. (Op. cit., V.)

Nicoll, M. J. The Alpine Ring Ouzel ; A New British Bird. (T.c.)

I9I2. Bloomfield, E. N. Annual Notes on Local Fauna, etc., for IgIr. (Hastings and E. Sussex Nat., II.)

Ford-Lindsay, H. W. Migration of Slender-billed Nutcrackers in Sussex. Ferruginous Ducks, Little Dusky Shearwater, Isabelline Wheatear in Sussex. (Brit. Birds, IV., V.)

Langdale, H. M. Nesting of Grey Wagtail in Sussex. (Zool.) Nichols, J. B. Little Bustard in Sussex. (Brit. Birds, V.)

Ticehurst, N. F. Little Auk in Sussex. (Brit. Birds, V.)

Igr3. Bloomfield, [E. N.] Ann. notes on local fauna, etc., for Igr2. (Hastings \& E. Sussex Nat., II., pp. 4I-6.)

Ellis, W. B. Nutcracker in Sussex. (Field, Oct. 25.)

Feilden, H. W. Snipe and Redshank nesting in Sussex. (Brit. Birds, VII.) 
Ford-Lindsay, H. W. Slender-billed Nutcracker in Sussex; Purple Sandpiper in Sussex. (Op. cit., VI.); Redthroated Pipits, Blackwinged Pratincoles, Spotted Sandpipers, Caspian Tern, Gullbilled Terns, etc., in Sussex, I7 notes. (Op. cit., VII.) Hatfield, G. C. A White Swallow [Hastings]. (Sclborne Mag., p. I88.)

Millais, Geoffrey. Pied Flycatcher in Sussex. (Field, Sept. 6.) Millais, J. G. Pied Flycatcher on Migration in Sussex. (Brit. Birds, VII.)

Morris, R. The Grey Wagtail in Sussex. (Zool.)

Nichols, J. B. Alpine Ring-Ouzel in Sussex. (Brit. Birds, VII.) Ticehurst, N. F. Slender-billed Nutcrackers in Sussex. (T.c.); Some further notes on Grey Wagtails [Sussex]. (Hastings \& E. Sussex Nat., II., pp. 47-8).

I9 4. Ashburnham, F. Waxwing in Sussex. (Field, Jan. I7.)

Bloomfield, E. N. Ann. Notes on local fauna, etc., for IgI3. (Hastings \& E. Sussex Nat., II., pp. 98-104.)

Ford-Lindsay, H. IV. Alpine Swifts, Bartram's Sandpiper, Rose-coloured Starlings, Yellowshank, Dusky Thrushes, etc., in Sussex, Io notes. (Brit. Birds, VIII.)

Gill, E. L. Status of Blackcap and Garden Warbler in Sussex. (Zool.)

Langdale, H. M. Osprey in Sussex. (T.c.)

Morris, R. Notes on Nightingale; Grey Wagtail in Sussex. (T.c.)

Nichols, J. B. Rare vagrants in Kent and Sussex. (Brit. Birds, VIII.)

Parkin, T. Asiatic Golden Plover in Sussex. (T.c.)

Ticehurst, N. F. On Recent Incursion of Waxwings [Sussex]. (Hastings \& E. Sussex Nat., II., pp. Io6-7, pl. x.)

Ticehurst, C. S. Swallow in Sussex in Feb. (Field, Feb. 2I.)

Wells, H. Little Bustard in Sussex. (T.c., Jan. I7.)

Witherby, H. F. Rüppell's Warbler in Sussex. (Brit. Birds, VIII.)

I9r5. Butterfield, W. R. Notes on the local fauna, etc., for Igr4. (Hastings \& E. Sussex Nat., II., pp. I70-77.)

Colthrup, C. W. Curlew and Common Snipe nesting in Sussex. (Brit. Birds, IX.)

Castellain, C. Chiffchaff in Jan. [Sussex]. (Field, Feb. 6.)

Ford-Lindsay, H. W. Great Blackheaded Gull, American

Pectoral Sandpiper, Western Large-billed Bunting, Western

Black-throated Wheatear, Brown-backed Warbler, Moustacherl

Warbler, etc., in Sussex, II notes. (Brit. Birds, IX.)

IKleinwort, M. L. White-winged Lark in Sussex. (T.c.)

Nichols, J. B. Rustic Bunting, Little Ringed Plover, Lesser Kestrel, Eastern Blackeared Wheatears, Sociable Plovers, etc., in Sussex, 7 notes. (T.c.)

Parkin, T. Rare Birds in Sussex. (T.c.) 
IgI6. Arnold, E. C. Bluethroat in Sussex. (Op. cit., X.)

Atlee, H. G. Spotted Redshank in Sussex in Winter. (T.c.)

Biggs, H. E. J. Nesting notes from Sussex. (Zool.)

Butterfield, W. R. Notes on the local fauna, etc., for IgI5. (Hastings \& E. Sussex Nat., II., pp. Ig6-206.)

Colgate, T. Nutcracker in Sussex. (Selborne Mag., pp. II7-I8.)

Colthrup, C. W. Common Buzzards in Sussex. (Brit. Birds, X.)

Feilden, H. W. Snipe and Redshank nesting in Sussex. (Hastings \& E. Sussex Nat., pp. I93-5.)

Ford-Lindsay, H. W. Grey-rumped Sandpipers, etc., in Sussex. (Brit. Birds, IX.)

Langton, H. Rooks building in chimneys [Brighton]. (Brit. Birds, IX.)

Morris, R. The Little Owl in Sussex; A Sussex Marsh Harrier ; Notes from Sussex. (Zool.)

Nichols, J. B. Cape Verde Little Shearwater, etc., in Sussex. (Brit. Birds, IX.) ; Collared Flycatchers, Savi's Warbler, Calandra Lark, Eastern Great Reed Warbler and White's Thrushes in Sussex, 5 notes. (Brit. Birds, X.)

Parkin, T. Semi-palmated Ringed Plover in Sussex. (T.c.); Olivaceous Warbler in Sussex; N. African Black Wheatear in Sussex; Mediterranean Black-headed Gull in Sussex. $(O p$. cit., IX.); Mediterranean Blackheaded Gull in Sussex. (Hastings Nat., II., p. 207, pl. xxi.)

Swaysland, W. Firecrested Wren in Sussex. (Field, Dec. 2.)

Webster, G. V. Cetti's Warbler in Sussex. (Brit. Birds, X.)

Whistler, H. Breeding of Lesser Redpoll in Sussex. (Zool.)

Witherby, H. F. Two Black Wheatears obtained in Sussex. (Bull. B.O.C., XXXVI., p. 46.)

rgr7. Butterfield, W. R. Notes on local fauna, etc., for I9r6. (Hastings Nat., II., pp. 246-50.)

Nichols, J. B. Rare birds in Sussex; Bonaparte's Sandpiper in Sussex. (T.c.)

I9I8. Alexander, H. G. On breeding of Garganey in Sussex. (Bull. B.O.C., XXXVIII., pp. 78-9) ; Doubtful Phylloscopi in Sussex. (Brit. Birds, XI.)

Arnold, E. C. Marsh Warblers breeding in Sussex. (T.c.)

Dalgleish, J. J. Ortolan Bunting near Brighton. (Field, Oct. I2.)

Jourdain, F. C. R. Little Auk in Sussex. (Brit. Birds, XI.)

Nichols, J. B. Snow-Finches, Wall-Creeper, Meadow-Bunting, Solitary Sandpiper, Caspian Tern, etc., in Sussex, 7 notes. (Brit. Birds, XII.)

Shore, A. C. The Chiffchaff in Sussex. (Field, Mar. 23.) 


\section{WARWICKSHIRE.}

I828. Bree, W. T. Least Woodpecker not rare near Coventry. (Loudon's Mag. N. H., I.)

1829. Bree, W. T. On arrival of the Brit. Hirundines. (Op. cit., II.)

I830. Bree, W. T. Dates of appearances of Hirundines, Allesley Rectory, for I829. (Op. cit., III.)

I83I. Bree, W. T. Nat. Hist. in the English Co.'s, Warwickshire, Waxwing near Allesley. (Op. cit., IV.)

I832. [Anon.-."C."'] Two Stormy Petrels taken at Birmingham. (Loudon's Mag. N. H., V.) Idem, correction by Bree, W. T. [Forktailed Petrel.] (T.c.)

Bree, W. T. Stormy Petrels in interior of the island [Coventry]. (T.c.)

1836. Christy, W. Egret and Little Bittern [at Sutton Coldfield]. (Op. cit., IX., p. 647.)

I844. Wilmot, J. P. Honey Buzzards breeding in England. [partim.] (Zool.)

I845. Bree, W. T. Arrival of Summer Birds near Allesley. (Op. cit.)

I848. Evans, Rev. A. Nesting of Ring Ouzel. (Op. cit.)

I850. Amhurst, Rev. F. H. Waxwing near Coventry. (Op. cit.)

Tomes, R. F. Greater Northern Shrike in Warwicks., 2 notes;

Forktailed Petrel in Warwicks. (T.c.)

1852. Torre, H. J. Occurrence of Hawfinch in Warwicks. (Nat. [Morris's], II.)

"W. B." Additional Heronry [Warwick Castle]. (T.c.)

I854. More, A. G. Bartram's Sandpiper as a British Bird. (Zool.)

I857. [Anon. ex Davenport Journal.] Rara Avis [Harlequin Duck errore for Scaup Duck near Coleshill]. (Nat. [Morris's], VII., p. I63.)

Twinn, G. R. Addenda to Bird-Retreating. (T.c.)

I858. Buckley, H. Wood Sandpiper near Birmingham. (Zool.; Nat. [Morris's], VIII.) ; Harlequin Duck [correction]. (T.c., p. I24.)

I859. Tomes, R. F. On occurrence of White's Thrush near Stratfordon-Avon. (Ibis, I.)

Willoughby de Broke, Lord. Black Tern and Bartram's Sandpiper [at Compton Verney]. (Field, Apr. 30.)

I86o. [Editorial.] [Goosander at Stratford-on-Avon.] (Op.cit., Jan. 7.) "S. S. S." Great Crested Grebe and Spotted Crake [at Sutton Park]. (Op.cit., Oct. 6.) Spotted Crake [in Warwicks.]. (T.c., Oct. 20); Goosander [at Sutton Park]. (T.c., Dec. I.)

I861. "S. S. S." Woodcock in Warwicks. (Op. cit., May II.)

Buckley, H. Ringed Plover at Birmingham. (Zool.)

I863. Atkins, A. H. Little Auk near Birmingham. (Ficld, Dec. 26.) 
I864. "H. H." Cormorant near Birmingham (Field, Aug. 20) ; Hobby and Ringed Plover [near Birmingham]. (T.c., Sept. 24.)

Rake, T. Beaven. Lesser Redpolls' Nests near Birmingham. (Zool.)

I865. Hodgson, C. B. Great Crested Grebe in Warwicks.; Arrival of Vernal Immigrants at Birmingham; Snipe nesting in Warwicks. (Zool.)

I866. Jephcott, S., junr. Merlin at Erdington; Gt. Crested Grebe nr. Birmingham. (Op. cit.)

Wheler, E. G. Tree Sparrows near Leamington. (Sci. Gossip.)

I867. Ward, H. Honey Buzzard [nesting near Coventry]. (Field, July 20.)

I868. " "F.A.S." Appearance of Shoveler in Warwicks. (Op. cit., May 9, I6.)

I869. B- E. A. Lesser Spotted Woodpecker near Rugby. (Field, Mar. 6.)

Morgan, J. Spotted Crake [at Stratford-on-Avon]. (Op. cit., Sept. 4.)

I869-75. [Various Writers.] Observations at Rugby. (Repts. Rugby Sch. N. H. Soc., I868, I873, I874.)

I870. Morgan, J. Golden Orioles in Warwicks. (Field, May 7.)

I87I. Beale, C. Spotted Crake near Birmingham. (OP. cit., Nov. 25.) Peterson, E. F. Golden Oriole in Warwicks. (Op. cit., June 24.) Idem by "M. E. M." (Op. cit., July 8 ; Zool.)

I872. Gurney, J. H., junr. Whimbrel near Stratford and Dunlin near Leamington. (Zool.)

Harting, J. E. Brit. Heronries. (T.c.) [partim.] Idem. Corrections. (Op. cit., I873); Existing Heronries in Gt. Britain. (Field, Feb. 7, Mar. 9.) [274.]

W-_, E. G. Sclavonian Grebe in Warwicks. (Field, Dec. I4.)

Willoughby de Broke, Lord. Leach's Petrel in Warwicks. (T.c., Dec. 7.)

I873. Hamel, E. D. Orn. Notes from Tamworth [Pallas's Sand Grouse at Swinfen]. (Zool.)

Verney, W. R. Woodcock nesting near Warwick. (Field, May 24.)

Winter, W. S. P. Little Auk and Manx Shearwater near Birmingham. (Zool.)

1874. Taylor, W. Caspian Tern [?] at Birmingham. (Op. cit.)

Yarrell's Brit. Birds. Edn. IV., Vol. I. [Bluethroat at Birmingham, p. 322.]

I875. Browne, M. Osprey, Hobby and Spotted Crake near Birmingham. (Field, Nov. 6) ; Little Auk near Birmingham. (T.c., Dec. II.) 
Morgan, J. Common Bittern and Pied Blackbirds at Stratfordon-Avon. (Op. cit., Jan. I6.)

Southall, W. Birds in My Garden [Birmingham]. (Zool.)

r876. Bodington, E. Honey Buzzard at Kenilworth. (Field, Oct. 7.)

Browne, M. Bittern near Birmingham. (T.c., Nov. 25); Hoopoe near Birmingham. (T.c., Oct. 2I.)

1877. B-—, G. T. Bittern at Sutton Coldfield; Hoopoe near Birmingham. (Sci. Gossip.)

Bloxham, T. Roughlegged Buzzard in Warwicks. (Field, Jan. 6.)

Browne, M. Shag Inland. (T.c., Jan. I3) ; Oyster Catcher in Birmingham. (T.c., Feb. IO); Great Crested Grebe in Birmingham. (T.c., Mar. 3I); Uncommon Birds in Neighbourhood of Birmingham. (Op. cit., Nov. I7.)

Chapman, A. C. List of Birds. (Rept. Rugby Sch. N. H. Soc., I876.) [The ornithological contributions appear irregularly in these Repts.]

Gibbs, J. C. Buzzard [shot at Coombe Abbey]. (Field, Sept. I5.) I878. B- A. M. Waterfowl [near Birmingham]. (Midland Nat., I.)

Gulson, J. Black-backed Gull [Coventry]. (T.c.)

I878-80. Gulson, J. Ornitholog. Notes from Coventry, 7 notes. (OP. cit., I.-III.)

1879. Browne, M. Seabirds in Birmingham. (Op. cit.)

Gulson, J. Honey Buzzard, etc. (T.c.)

1880. Poyser, E. J. French Partridge in Warwicks. (Field, Nov. 6.)

I88I. [Anon.- "C."] Hoopoe near Birmingham. (Op. cit., Nov. 26.)

Aplin, O. V. Great Crested Grebe in Warwicks. (Zool.)

I882. Chase, R. W. Waxwing near Birmingham. (Op. cit.)

Morgan, J. Hoopoe in Warwicks. (Field, Dec. 30.)

I883. Chase, R. W. Grey Crow nesting in Warwicks, ; Leach's Petrel picked up in Birmingham. (Zool.)

Savidge, W. Seabirds inland [at Birmingham]. (Field, Sept. I5.)

Whitaker, J. Grey Crow nesting in Warwicks. (Zool.)

I884. Betteridge, J. Birds of the Neighbourhood of Birmingham. (Midl. Nat.)

Hodgson, T. V. The Heron [at Middleton]. (T.c.)

I885. Bath, W. Harcourt. Notes on Nat. Hist. of Sutton Park. (OP. cit.)

"W. H." The Jackdaw [in Birmingham]. (T.c.)

I886. [Anon.] Eagle in Warwicks. (Field, Jan. 2.)

Chase, R. W. Birds of the Birmingham District. (In Brit. Assoc. Handbook of Birmingham.) Post 8vo. Birmingham: I886. [I27.] [See also I9I3.]

M- , T. Bee-eater near Stratford-on-Avon. (Field, June 5.) 
1886-9r. [Various Writers.] Lists of Rugby Birds and Lists of Rooks' Nests in the Close. (Repts. Rugby Sch. N. H. Soc., I885-9o.) Rugby: I886-9r.

I888. Aplin, O. V. Sand Grouse in Warwicks. (Zool.)

1889. Aplin, O. V. Garganey and Other Birds in Warwicks. (Op. cit.) Craig, A., junr. Notes on an Ornitholog. Visit to Warwicks. (Tr. Edinb. F. N. Soc., II.)

Timmins, S. History of Warwickshire. 8vo. Lond. (E. Stock) : I889.

1890. Aplin, O. V. Distribution, etc., of Spotted Crake. (Zool.) Suppl. Notes. (Op. cit., I8gr.) [24.] [partim.]

I89I. Coburn, F. Grey-headed Wagtail in Warwicks. ; Rose-coloured Pastor in Warwicks. (Op. cit.)

Steele-Flliott, J. Osprey in Warwicks. (T.c.)

Quartermaine, G. W. An Eagle [seen in Warwickshire]. (Field, Feb. 28.) Idem by Lord Lilford. (T.c., Mar. 7.)

I892. Aplin, O. V. Distribution of Cirl Bunting. (Zool.) [25.] [partim.]

Coburn, F. Grey Phalarope and Arctic Tern in Warwicks. (T.c.)

I893. Steele-Elliott, J. Black Tern in Warwicks. (Op. cit.)

Etches, A. H. Tufted Duck breeding in Warwicks. (T.c.)

1894. Chase, R. W. Exhibition of Nightjar and Eggs from Sutton Park. (Jnl. Birmingham N. H. \& Phil. Soc., July-Sept.)

Coburn, F. Common Scoter in Warwicks.; Hooded Crow breeding in Warwicks. (Zool.)

Loveday, W. T. Birds of Rugby. (Rept. Rugby Soc.)

1895. [Anon.] Canadian Geese at Middleton Hall, Tamworth. (Jnl. Birmingham N.H. \& Phil. Soc., July-Dec.)

Chase, R. W. Exhib. of Rough-legged Buzzard from Hay Mills. (T.c., April.)

Coburn, F. Ornithology of the City of Birmingham 8 vo. pamphlet. I895. [68I.]

Steele-Elliott, J. Oystercatcher in Warwicks. (Zool.)

Wells, W. C. Dartford Warbler and Cirl Bunting in Warwicks. (Nat.Jnl.)

1896. Coburn, F. Manx Shearwater and White Stork in Warwicks. (Zool.) ; Vertebrate Fauna of Sutton Coldfield Park, 4 pts. (Jnl. Birmingham N. H. \& Phil. Soc., Jan.-Dec.)

I897. Steele-Elliott, J. Black Terns and White Wagtails in Warwicks. $($ Zool.) ; Stray Notes from Our Neighbourhood. (Jnl. Birmingham N. H. \& Phil. Soc., Mar.-Apr.).

I898. Coburn, F. Brent Goose in Warwicks. (Zool.)

Spicer, P. White's Thrush in Warwicks. (Field, Nov. 5.) 
I899. Coburn, F. Early Appearance of Chiffchaff in Warwicks. and Late Stay of Whitethroat. ( $\left.\mathrm{Oool}_{\text {. }}\right)$

Steele-Elliott, J. Gt. Grey Shrike in Warwicks. (T.c.)

I902. Coburn, F. Grey Plover in Birmingham. (Op. cit.); Dusky Redshank. (T.c.)

Steele-Elliott, J. A former Warwicks. Heronry. (T.c.)

I903. Aplin, O. V. Hobby in S. Warwicks. (Op. cit.)

I904. Aplin, O. V. Emberiza pusilla near Rugby. (Ibis.)

Carroll, C. J. The Little Bunting in England. (Zool.)

Ground, T. Lapland Bunting at Warwick. (Zool.)

Spicer, E. H. Cranes in Warwicks. (Field, Jan. 9.)

Tomes, R. F. Aves [In Victoria Hist. of Co. of Warwicks., I.], 4 to. Lond. : I904. [584.]

I905. Aplin, O. V. Peregrine Falcon in Warwicks. (Zool.)

I907-08. Etches, A. H. Redshank breeding in Warwicks. (Brit. Birds, I., r9o7). Idem by W. Davies. (T.c.) Idem by F. Smalley. (T.c.) Idem by A. G. Leigh. (Op. cit., II.)

Ig08. Aplin, O. V. Cormorant in Warwicks., 2 notes; Bittern in Warwicks. (Zool.)

Leigh, A. G. Little Owl in Warwicks. (Brit. Birds, II.)

Ig09. Butler, A. L. Manx Shearwater in Warwicks. (Op. cit., III.)

Coburn, F. Little Owl in Warwicks. (Op. cit., II.) Idem by A. G. Leigh. (Op. cit., III.)

Leigh, A. G. Whitewinged Black Tern in Warwicks. (Op. cit., III.)

Smalley, T. Cormorant in Warwicks. (Zool.)

I9Io. Jourdain, F. C. R., and Witherby, H. F. Recent Records from Warwicks., etc. (Op. cit., IV.) [322.]

I9I1. Leigh, A. G. Little Owl in Warwicks. (T.c.); Spotted Crake in Warwicks.; Grey Phalarope in Warwicks. (Op. cit., V.) Idem. Correction to Red-necked Phalarope. (T.c.)

Steele-Elliott, J. Former nesting of Shoveler Duck in Warwicks. $($ Zool.)

Starley, B. Pied Flycatcher in Warwicks. (T.c.)

Ticehurst, N. F., and Jourdain, F. C. R. Distribution of Nightingale. (Brit. Birds, V.) [partim.]

I9I2. Leigh, A. G. Crossbills in Warwicks.; British Willow Tits in Warwicks. (Brit. Birds, V.)

Starley, B. Common Gull in Warwicks. (T.c., V.)

I9r3. Chase, R. W. Ornithology. [In A Handbook for Birmingham and the Neighbourhood. Ed. by G. A. Auden. Cr. 8vo. B'ham: I9I3.]

Leigh, A. G. Longtailed Duck in Warwick; Pied Wagtails rearing two broods in one nest. (Brit. Birds, VII.)

Starley, J. R. Little Owl breeding in Warwicks. (T.c.) 
I9I3-I8. House, H. V., and others. Repts. of Zoolog. section [observations on birds near Rugby, etc.]. (Repts. Rugby School N.H. Soc. for IgI2-I7.) 6 pts.

I9I4. Hudson, R. Dartford Warbler in Warwicks. (Brit. Birds, VIII.) I9I7. Bevington, C. C. The Tawny Owl [Rugby]. (Rept. Rugby School, N. H. Soc., I9I6, p. 8I, plate.)

Carter, B. A. Common Scoter in Warwicks. (Brit. Birds, XI.)

IgI8. Alexander, H. G. Marsh Warbler breeding in Warwicks. (Bril. Birds, XI.)

Carter, B. A. Bewick's Swan in Warwicks.; Sheld Duck and Shoveler in Warwicks. (T.c.)

Hamel, E. de. Whoopers in Warwicks. (T.c.)

Leigh, A. G. (late). Hooded Crow in Warwicks. (T.c.)

Baillie, R. H. Bewick's Swan in Warwicks. (Op. cit., XII.)

Ground, T. The Redshank in Warwicks. (T.c.)

Leigh, A. G. (late). Gt. Crested Grebe in Warwicks. (T.c.)

\section{WESTMORLAND.}

I709. Robinson, Rev. T. Essay towards a Natural History of Westmorland, etc. 8vo. Lond. : I709. [493.]

I787. Clarke, J. Survey of the Lakes. Folio. Lond. : I787. [I30.]

I829. "J. W." Nat. Hist. in the Engl. Co.'s: Westmorland ; Crossbills as occasional visitants at Ambleside. (Loudon's Mag. N.H., II.)

[I839.] Pearson, W. Notes on Natural History in Neighbourhood of Crosthwaite and Lythe. [Letters, Papers, etc., of W. Pearson.] Lond. : 1863.

I843. Gough, T. Effect of Mild Weather on Occurrence of Birds near Kendal. (Zool.)

Haslam, S. H. Occurrence of the Lark Bunting [Lapland Bunting] near Milnthorpe. (T.c.)

1848. Gough, T. On Arrival of Migratory Birds in Neighbourhood of Kendal ; Capture of Velvet and Common Scoters on Windermere. (Op. cit.)

1850. Pearson, W. Immigration of Black Grouse in vicinity of Bowness. (T.c.)

I85I-3. McIntosh, J., and others. Heronries in England, etc. [pariim.] 4 notes. (Nat. [Morris's], I.-III.)

1859. Mason, A. Whimbrel [breeding? in Westmorland]. (Field, Mar. 5.)

“T. K. A." Goosander, Hoopoe, etc. [near Staveley]. (Op. cit., Sept. 24.) 
I86I. Gough, T. Birds of the Kendal District. [In Cornelius Nicholson's Annals of Kendal, 2nd edit.] 8vo. Lond., etc.: r86r. [239.]

I866. Harrison, H. Jerfalcon at Crosby Ravensworth. (Zool.)

Saunders, H. A Visit to Walney, the Lakes, etc. (T.c.) [508.]

I867. Cordeaux, J. Notes on Ornithology of English Lakes. (Op. cit.) Garnett, S. E. Great Spotted Woodpecker [in Westmorland]. (Field, Nov. 9.)

I872. [Anon.--“A. R.'] Goosander on Grasmere. (Op. cit., Nov. I6.) Harting, J. E. Existing Heronries in Gt. Britain. (Op. cit., Feb. 17 ; Zool.) [partim.]

I874. Nicholson, J. Woodcock Nesting in Westmorland. (Field, May 30.)

1877. Birkett, J. Notes on Migratory Birds of English Lake District. (Tr. Cumb. Assoc., Part II.)

r878. Arlosh, J. The Local Museum and its relation to the Nat. Hist. of the District. (Tr. Cumb. \& Westm. Assoc.)

Gough, T. Provincial names of Brit. animals-Westmorland. (Zool.)

1879. [Anon.- "D."] Birds of Prey in English Lake District. (Field, Nov. 22.)

Durnford, W. A. Gulls breeding in Westmorland. (Zool.)

Nelson, T. H. Buzzards in the Lake District [Roughlegged Buzzards at Rydal]. (Field, Dec. 6.)

I88I. Goodchild, J. G. Note on Occurrence of Iceland Falcon in Edenside [in I845], with plate. (Tr. Cumb. Assoc., I880-8I, No. VI.)

Gough, T. Observ. on Heron and Heronry at Dallam Tower, Kendal, I880.

I882. Backhouse, J., junr. Pintail breeding in Westmorland. (Zool.)

I883. G[oodchild], J. G. Plate of Greenland Falcon shot at Crosby Ravensworth, I864 (See No. VI., p. I68). (Tr. Cumb. Assoc., I882-3, No. VIII.)

1884. L-, R. B. Bittern in Westmorland. (Field, Dec. 20.)

I885. L-, R. B. Herons and Rooks at Dallam Tower. (Op. cit., Jan. I7.)

Macpherson, H. A. The Hawfinch in Westmorland. (T.c., May 2); Pied Flycatcher in Westmorland. (Nat.)

Watson, J. Eagle's Haunts in the N. of England. (Field, Jan. 24.) Idem by W. Duckworth. (T.c., Jan. 3I.) The Dotterel and its migrations. (Op. cit., Nov. I4.) [6r8.]

I 886. Macpherson, H. A., and Duckworth, W. Birds of Cumberland, including some Notes on the Birds of Westmorland. 8vo. Lond., etc. : 1886 . [374.] 
Thompson, J. Gannets Inland. (Field, Oct. 30.)

Watson, J. Notes on Eagles of Lake District. (Nat.) [6I8.]

I887. Watson, J. Westmorland Heronries. (Field, Jan. 22.)

I888. Harting, J. E. Dotterel in Lake District. (Zool.)

Macpherson, H. A. Report on Pallas's Sand Grouse in N.W. of England. (Tr. Cumb. \& Westm. Assoc., I887-8, No. XIII.) [partim.]

Pickard, E. S. Birds in Lake District. (Nat. Hist. Jnl.)

Watson, J. List of Birds of Lake District. (Westmorland Note-Book \& Nat. Hist. Record, Vol. I., Nos. I, 2, 4.) Kendal : I888. [6I8.]

Watson, J. Notes on Birds of Lake District. (Nat.) [6I8.]

I889. Ainslie, W. G. Woodcock nesting in Westmorland. (Field, Apr. 27.)

Macpherson, H. A. Crossbills in Lake Counties. (Nat.); On Former Nesting in England of the Osprey. (Zool.)

Walcot, Bailie. Hoopoe in Westmorland. (Tr. Edinb. F. N. Soc.)

I8go. Macpherson, H. A. Montagu's Harrier in Westmorland. (Nat.)

Murdoch, G. W. Swallows in March at Kendal. (Field, Mar. 29); Woodcock nesting in Lake District. (T.c., Apr. Ig.)

I89I. Macpherson, H. A. The Forktailed Petrel [in Westmorland]. (Op. cit., Oct. Io.)

1892. Barber, S. Beneath Helvellyn's Shade. Sm. 8vo. Lond.: I892. [37.]

Collins, W. Red-throated Diver at Windermere. (Field, Jan. 30.)

Macpherson, H. A. A Vertebrate Fauna of Lakeland. Sq. 8vo. Edinb. : I892. [375.]

More, A. G. The alleged former nesting of Osprey in English Lake District. (Zool.) Idem by H. A. Macpherson. (T.c.)

Watson, J. Westmorland Heronries. (Westm. Note-Book \& Nat. Hist. Record, Vol. I., No. 6). List of Birds of the Lake District. (T.c.)

Wintringham, W. H. Birds of Wordsworth. 8vo. Lond. : I892. [654.]

1896. Armitt, M. L. The Pied Flycatcher in Westmorland. (Nat.)

Denwood, J. R. Cuckoo : mode of feeding. (Zool.)

I897-Igor. Armitt, Mary L. Studies of Lakeland Birds. 2 vols. 8 vo. Ambleside : I897-I90I. [676.]

I899. Macpherson, H. A. Hobby in Westmorland. (Zool.)

I904. Grierson, W. Osprey at Windermere. (Field, Apr. 23.)

I908. Parker, T. C. Notes from Lakeland: Cumberland and Westmorland. 2 pts. (Zool.) Idem by D. L. Thorpe and L. E. Hope. (T.c.) 
I9ro. Garnett, D. G. Black-throated Diver in Westmorland. (Brit. Birds, IV.)

Witherby, H. F. Golden Oriole in Westmorland. (Op. cit., IV.)

I9II. Wilson, H. Green Woodpecker in Westmorland. (Op. cit., V.) Idem by E. B. Dunlop. (T.c.)

I9I5. Garnett, D. G. Colouring of Soft Parts of Slavonian Grebe. (Op. cit., VIII.)

Robinson, H. W. Large increase of nesting Pied Flycatchers in Westmorland. (Op. cit., IX.)

I9r7. Robinson, H. W. White Wagtail nesting in Westmorland; Evidence for Breeding of Green Sandpiper in Westmorland; Leach's and Storm Petrels in Westmorland, 4 notes. (T.c.)

I9I8. Astley, A. Green Woodpecker in Westmorland. (Op. cit., XII.) Garnett, D. G. Blackthroated, Redthroated and Great Northern Divers on Lake Windermere, (Op. cit., XI.); Blacknecked Grebe in Westmorland. (Op. cit., XII.)

Jourdain, F. C. R. Reappearance of Fieldfares in Westmorland. (T.c.)

Oldham, C. Greater Spotted Woodpecker in Westmorland. (Nat., p. 267.)

\section{WILTSHIRE.}

I797. Maton, W. G. Observations relative chiefly to Nat. Hist. . . . . of the Western Counties of England. 2 vols. 8vo. Salisbury: I797. [392.]

I8I0-I9. Hoare, Sir R. C. Ancient Hist. of Wilts. 2 vols. Folio. Lond. : I8I0-I9. [Bustards, Vol. I., p. 94.]

I8I8. Chafin, W. A Second Edition of the Anecdotes and History of Cranbourne Chase. 8vo. Lond. : I8I8.

I843. Holme, F. Occurrence of Orange-legged Hobby. (Zool.)

Maton, G. Natural History of a Part of the County of Wilts. 8vo. Salisbury, etc. : I843. [393.]

I847. Aubrey, J. Natural History of Wilts. Written between 1656 and I69I. Edited by John Britton. 4to. Lond.: I847. [32.]

[Anon., ex Berks. Chronicle.] Occurrence of Golden Eagle near Hungerford. (Zool.)

1849. Waterhouse, G. R. Bustard on Salisbury Plain. (Zool.)

I850. Webb, G. J. Peregrine Falcon near Marlborough. (Op. cit.)

I85I. Kemur, T. Rough-legged Buzzard on Marlborough Downs. (Op. cit.) 
Maysmor, R. Waxen Chatterer at Devizes. (Nat. [Morris's], I.) " B. R. M"[orris.] Idem. (T.c.)

I852. Ferris, H. [Heronry at Beanwood, near Melksham]. (Op. cit., II.)

1853. Smith, A. C. Collared Pratincole in Wilts., etc. (Zool.)

I854. Smith, A. C. Great Northern Diver in Wilts. (Op. cit.)

I855. Gardiner, J. Cream-coloured Courser on Salisbury Plain. (Op. cit.)

S[wayne], J. The Bustard. (Wilts. Arch. \& N. H. Mag., II.)

I856. Smith, A. F. Further particulars of occurrence of Great Bustard near Hungerford. (Zool.)

I857. Smith, A. C. The Great Bustard. (Wilts. Arch. \& N. H. Mag., III.)

Smith, R. B. Hawfinch breeding at Marlborough. (Zool.)

1857-69. Smith, A. C. Ornithology of Wilts., I5 pts. (Wilts. Archaol. \& N. H. Mag., I.-XII.) Idem reprinted separately. 8vo. Devizes: H. Bull. [545.]

1859. Marsh, G. S. Occurrence of Goldenwinged Woodpecker in England [Amesbury Park]. (Zool.) Sea birds found inland. (T.c.)

I860. Hogan, A. R. Localities of Sylvia luscinia. [partim.] (Zool.) Phillips, E. C. Great Northern Diver [near Chippenham]. (Field, Dec. I5.)

1863. Smith, R. B. Birds of Marlborough. [In Preston's Flora of Marlborough, etc.] I2mo. Lond.: I863. [550.]

I864. Blackmore, H. Hawfinch, Tufted Duck and Sclavonian Grebe near Salisbury, 3 notes. (Zool.)

Blackmore, H. P. Remains of Bird's Eggs found at Fisherton, near Salisbury. (Edinb. Nere Philos. Jnl.)

Bradby, A. S. Longeared Owl at Stratford St. Anthony. (Zool.) Crichton, A. W. Hoopoe shot near Salisbury. (Field, Apr. 28.)

Fox, J. J. Common Kite [in Wilts.] (Zool.)

Rowland, W. H. White-tailed Eagle in Savernake Forest. (T.c.) [Editorial.] Idem. (Field, March I2.)

Smith, A. C. Pallas's Sand-Grouse in Wilts. (Zool.)

I865. Blackmore, H. Merlin and Tufted Duck near Salisbury. (Zool.)

Morres, A. P. Lesser Spotted Woodpecker and Sclavonian Grebe near Salisbury. 2 notes. (T.c.)

Preston, T. A. Dates of Oviposition of Birds in the Neighbourhood of Marlborough. (T.c.)

I865-90. Almack, A. C. [and Others.] Ornithological Section. [Birds observed in Neighbourhood.] (Rept. Marlborough Coll. N. H. Soc., 1865-90.) 
I866. Blackmore, H. Fork-tailed Petrel near Salisbury. (Zool.)

Harris, S. Ash-coloured Shrike in Wilts. (Field, Jan. 6); Astley, A. F. Bee-eater in Wilts. (Op. cit., July 2I); Grant, J. Great Grey Shrike in Wilts. (T.c., Dec. 8.)

Smith, A. C. Lanius excubitor, etc., in Wilts. 2 notes; Beeeater in Wilts. (Zool.)

1867. Blackmore, H. Bohemian Waxwing in Wilts.; Canada Goose at Coombe Bissett. (Zool.)

Clark-Kennedy, A. Goosander in Wilts. (T.c.)

Grant, J. Fork-tailed Petrel and Hawfinches in Wilts. (Field, Feb. 2.)

Im Thurm, E. Little Auk in Wilts. (Op. cit., Oct. 5.)

I868. "G. S." Great Snipe in Wilts. Powell, A. P. E. Idem. (Field, Oct. 3.)

Grant, J. Rednecked Grebe and Black-toed Gull [Richardson's Skua] in Wilts. (Op. cit., Jan. 25.)

I869. Francis, A. Velvet Scoter at Salisbury. (Op. cit., Oct. 9.)

Grant, J. Spurwinged Goose in Wilts. (T.c., Sept. I8.)

"J. G. W." Little Bittern in Wilts. (T.c., Sept. I8.)

Pocock, E. Speckled Diver in Wilts. (T.c., Dec. 25.)

Preston, T. A. Rednecked Phalarope and Winter Puffin at Marlborough. (Zool.)

I870. Blackmore, H. Rock Doves at Salisbury. (Op. cit.)

[Blyth, E.- "Z."] Greenshank in Wilts. (Field, June 4.)

Grant, J. Rare Birds in Wilts. (Zool. ; Field, Mar. 5) ; Notes on Birds near Devizes; Late Quail's Nest. (Field, Sept. I7.)

Im Thurm, E. F. The Birds of Marlborough. Post 8vo. Marlborough, etc. : I870. Appdx. I876. (Rept. Marlb. Coll. Soc.) [307.]

Mioses, $\mathrm{H}$. Occurrence of Spurwinged Goose in Wilts. (Sci. Gossip.) Idem by P. L. Sclater. (T.c.)

Powell, A. F. The Grey Phalarope [near Salisbury]. (Field, Oct. 29.)

Preston, T. A. Little Gull, etc., near Marlborough. (Zool.)

Smith, A. C. Great Grey Shrike, Little Owl and Waxwing in Wilts. (T.c.)

I871. [Anon-"Wiltshire Man."] Great Bustard in Wilts; Harting, J. E. Idem. (Field, Jan. I4.)

Blackmore, H. Great Bustards in Wilts. 2 notes. (Zool.)

Hussey-Freke, A. D. Goosander in Wilts. (Field, Feb. I8.)

Newbury, -. Little Bustard in Wilts. (T.c., Jan. 28.) $[?=$ Great Bustard, see J. E. Harting, T.c., Feb. 4.]

Newman, E. Two more Bustards [in Wilts.]. (Zool.)

Preston, T. A. Quail nesting in Wilts. (T.c.)

Spicer, W. W. Ring Ouzel on Salisbury Plain. (Sci. Gossip.)

Sutton, A. Reported [errore] occurrence of Alpine Swift in Wilts. (Field, Aug. I2, $26 ;$ Zool.) 
"W. S." Great Bustard on Salisbury Plain. (Sci. Gossip.)

Wyndham, J., Stratton, F., Harting, J. E., and Brown, W. Great Bustard on Salisbury Plain. (Field, Jan. 28, Feb. 4.)

I872. Grant, J. Ornitholog. Notes from Wilts. (Op. cit., Jan. 6.)

Harting, J. E. Existing Heronries in Great Britain. (T.c., Feb. I7; Zool.) [partim.]

1873. Aubrey, H. W. W. Heronry near Salisbury. (Zool.)

Harting, J. E. British Heronries. (T.c.) [partim.]

I874. Bennett, H. Sabine's Snipe near Salisbury. (Field, Jan. 24.)

I875. "Observer." Bittern, etc., at Bradford-on-Avon. (Op. cit., Jan. 23.)

1876. Balfour, T. G. Whimbrel in Wilts. (Zool.)

Corbin, G. B. Fieldfares, etc., on Salisbury Plain ; Crossbills on Salisbury Plain. (T.c.)

I877. Balfour, T. G. The "Curlew" of the Wilts. Downs. (OP. cit.) Idem by G. B. Corbin. (T.c.)

[Editorial.] Bustards on Salisbury Plain. (Field, Aug. II.)

Morres, A. P. Rare Birds in Wilts.; Curlews breeding near Salisbury; Merlin in S. Wilts. ; Peregrine Falcons near Wareham; Roughlegged Buzzards near Tisbury; Pied Flycatcher near Salisbury; Peregrine Falcons on the Spire of Salisbury Cathedral. (Zool.)

Smith, A. C. South American Rail in Wilts. (T.c.); Reported Occurrence of Great Bustard in Wilts. (Field, Aug. 25.)

I878. Morres, A. P. Hoopoes near Salisbury; Great Grey Shrike Nesting [errore ?] near Salisbury. (Zool.)

1878-85. Morres, A. P. The Occurrence of Some of the Rarer Species of Birds in the Neighbourhood of Salisbury. [Ex Wilts. Arch. E N. H. Mag.] 8vo. I878-85. Idem in Wilts. Arch. \& N. H. Mag., Vols. XVII-XXII., 7 pts. [4I4.]

1879. Norwood, T., and Others. Peregrines Nesting on Salisbury Cathedral. (Field, May I7, June 7, 28, July 5.)

I880. Baker, E. Great Grey Shrike [in Wilts.]. (Op. cit., Nov. 27.) Cambridge, O. P. Peregrine Falcons on Salisbury Cathedral Spire. (Field, May $8 ;$ Zool.)

Hart, E. Roughlegged Buzzards in Wilts. (Zool.)

Lyddon, F. S. Bustard at Salisbury. (Sci. Gossip.)

Smith, A. C. Immigration of Long-eared Owls. (Zool.)

I88I. Baker, E. Spotted Crake Nesting in Wilts. (Field, June I8.)

Gale, J. H. Storm Petrel in Wilts. (Op. cit., Dec. I7.)

Morres, A. P. Ornitholog. Notes from Salisbury. (Zool.)

I882. Morres, A. P. The Peregrines of Salisbury Cathedral; Whitewinged Black Tern near Salisbury. (OP. cit.) 
I883. White, G. Storks on Migration [one shot at Codford]; Sea birds inland. (Field, Apr. I4.)

1884. Jacob, E. Merlins in Wilts. (Field, Jan. 5.) Idem by C. H. Fisher. (T.c., Jan. Ig.)

White, G. Great Grey Shrike [in Wilts.]. (Op. cit., Dec. 20.)

1885. Gater, C. W. Quail in Dec. [near Salisbury]. (Op cit., Jan. 3.)

Olivier, D. Raven in Wilts. (Op. cit., May 3o.)

Ward, J. Grey Phalarope in Wilts. (Op. cit., Oct. Io.)

White, G. Roughlegged Buzzard in Wilts. (Op. cit., Jan. 3); Canada Geese at Salisbury. (T.c., Mar. I4, 2I.)

[I885.] Preston, T. A. Results of 20 Years' Observations on Botany, Entomology, Ornithology, etc., taken at Marlborough College, I865-84. (Marlb. Coll. N. H. Soc.) Obl. 4to.

I886. Smith, C. Green Sandpiper in Winter [in Wilts.]. (Field, Feb. 6.) I887. Gardner, J. S. List of Marlborough Birds. (Rept. Marlb. Coll. Soc.)

Smith, A. C. The Birds of Wiltshire. 8vo. Lond., etc. : r887. [545.]

White, G. Sea Eagle near Salisbury. (Field, Nov. 5.)

I888. Baker, E. Pied Flycatcher and Manx Shearwater in Wilts. (Field, May I9.)

Macpherson, A. H. Woodchat in Wilts. (Zool.)

White, G. The Present Visitation of Sand Grouse. (Field, June 2.)

I889. Nield, A. W. Pochard Breeding at Chippenham. (Op cit., Aug. 3.)

Morres, A. P. Whitewinged Black Tern near Salisbury. (Zool.)

I8go. Aplin, O. V. Distribution, etc., of Spotted Crake. (Zool.) Suppl. Notes. (O.p. cit., I89r.) [24.] [partim.]

Ward, J. Twobarred Crossbill in Wilts. (Field, Mar. 8.)

I89I. Harting, J. E. The present visitation of Bustards. [partim.] (Op. cit., Feb. 28.)

Smith, A. C. Recent Occurrence of the Great Bustard in Wilts. (Wilts. Arch. \& N. H. Mag., XXV.) Blackcap in Wilts. in midwinter. (Zool.)

IS92. Aplin, O. V. Distribution of Cirl Bunting. (Zool.); Status of the Woodchat. (T.c.) [25.] [partim.]

I893. Harris, J. M. Storm Petrel in Wilts. (Field, Dec. 2.)

Smith, A. C. Bitterns in Wilts. (Zool.)

I895. Horsbrugh, C. B. Hobby in Wilts. (Op. cit.)

Meyrick, E. List of Birds of Marlborough District. (Rept. Marlb. Coll. Soc., I895.)

I896. Morres, A. P. Peregrine Falcons on Salisbury Spire. (Field, Oct. 3.) 
Smith, A. C. Cream-coloured Courser in Wilts. (Zool.) Id mn. (Ibis, Jan. I897.)

I897. Morres, A. P. Kite in Wilts.; Sea Eagle in Wilts. (Nat. Jnl.) I897-98. Morres, A. P. Bird Life in Salisbury, 2 papers. (Wilts. Notes \& Queries, II.)

I898. Hext, R. F. A. Supposed Woodchat in Wilts. (Field, Aug. 20.) I90o. Hall, H. S. Nesting of Marsh Warbler in Wilts. (Zool.)

Morres, A. P. Ornitholog. Notes from Salisbury. (Field, Jan. 27.)

I906. Artindale, R. H. Blackgame in Wilts. (Op. cit., Apr. I4.)

Bankes, A. Knot in Wilts. [near Salisbury]. (Zool.)

I907. Dent, G. Breeding of Blue-headed Wagtail in Wilts. (Brit. Birds, I.) Idem. (Rept. Marlb. Coll. Soc., Igog.)

Meyrick, E. List of Birds of Marlborough District. (Rept. Marlb. Coll. Soc., I907.)

I908-I5. Meyrick, E. Ornithological List, 8 pts. (Op. cit., I908-I5.) Igog. Bradley, A. G. Cambridge County Geographies: Wiltshire. (Nat. Hist., pp. 43-48.) Cr. 8vo. Lond. : Igog.

Mathews, R. O. Nesting of Snipe in Wilts. (Brit. Birds, III.)

I9I0. Alexander, C. J. Notes of the British Willow-Tit. (Op.cit., IV.)

Harrison, D. P. Manx Shearwater in Wilts. (Field, Sept. I3.)

Penrose, F. Black Redstart in Wilts. (Brit. Birds, IV.)

Reynolds, F. Little Owl in Wilts. (T.c.)

IgIr. Mathews, R. O. Peregrine Falcon in Wilts. (Op. cit., IV.)

IgI2. Disney, H. A. P. Notes on Birds in IgrI. (Rept. Marlb. Coll. N. H. Soc., LX.)

Hony, G. B. The Igra Wreck of the Little Auk (Brit. Birds, VI.); Wilts. Birds. (Zool.)

Young, B. Lesser Redpoll Nesting in Wilts. (Field, June I6) ; Idem. (Brit. Birds, VI.)

Igr3. Gosset, A. C. V. Notes on Birds. (Rept. Marlb. Coll. N. H. Soc. for I9I2, p. 58.)

Lambert, H. B. Quail in Wilts. (Field, Sept. 6.)

Newham, R. Quail on Salisbury Plain. (T.c., Aug. 30.)

I9I4. Bury, L. American Swallow-tail Kite in Wilts. (Field, Sept. 26.) Hony, G. B. Notes on the Birds of Wilts. (Brit. Birds, VII.) Jourdain, F. C. R. Breeding of Dipper in Wilts. (Brit. Birds, VII.)

Robinson, H. W. Pomatorhine Skua in Wilts. (Brit. Birds, VIII.)

I9I6. Hony, G. B. Status of Little Owl in Wilts.; Glossy Ibis in Wilts. $(O p$. cit., IX. $)$; Status of the Common Curlew and Black Grouse in Wilts. (T.c.) [2 notes.]

Harrison, D. P. Little Owl Breeding in Wilts. (Op. cit., X.) 
Start, H. H. Ornithological List. (Rept. Marlb. Coll. N. H. Soc., IgI5, No. 64, pp. 48-5I.)

I9I7. Ashley, M. Breeding Habits of the Hobby in Wilts. (Brit. Birds, XI.)

Cruttenden, C. Ornithological List. (Rept. Marlb. Coll. N. H. Soc., IgI6, No. 65 , pp. 42-4.)

Hony, G. B. Little Auk in Wilts. (Brit. Birds, X.)

Kelsall, J. E. Great Grey Shrike in Wilts. (Brit. Birds, XI.)

I9I8. Alsop, J. C. Ornithol. List. (Rept. Marlb. Coll. N. H. Soc., No. 66, pp. 40-2.)

\section{WORCESTERSHIRE.}

I829. " J. W." Flocks of Crossbills near Worcester. (Loudon's Mag. N. H., II.)

Lees, E. Nat. Hist. in the English counties. [Worcs.] $(O p$. cit., I., p. 394.)

I832. "J. W." Rarer Birds near Worcester. (Op., cit., V.)

I833. Lees, E. Larus marinus shot near Worcester; The Spoonbill [near Malvern]; Coccothraustes vulgaris [near Worcester]. (Op. cit., VI.)

I834. Hastings, C. Illustrations of the Natural History of Worcestershire. 8vo. Lond.: I834. [284.]

I835. (Berrow's Worcester Journal.) Bohemian Waxwings [at Radford and Claines]. (Loudon's Mag. N. H., VIII.)

Perrot, Mrs. C. L. E. Selection of British Birds frequenting Worcestershire. Pt. I. Folio. I835. [470.]

1837. Pearson, J. and T. Statistical and General History .... Fasc. I., Parish of Great Witley. 8vo. Lond.: 1837. [463.]

1843. Reece, G. Blackcap in Jan.; Herring Gull near Worcester. (Zool.)

I846. Birch, W. Hooded Crow near Stourbridge. (Zool.)

Evans, J. Quail in Worcs. in Jan. (T.c.)

Reece, G. Occurrence of Wild Geese, etc., near Worcester. (T.c.)

I847. Beadles, J. N. Arrival of Summer Birds at Broadway; Grey Phalarope at Mitcheldean. (Op. cit.)

I848. Beadles, J. N. Provincial Names of Birds in Worcs. (Op. cit.) Cooper, Rev. W. W. Redthroated Diver at Worcester, 2 notes. (T.c.)

Curtler, M. Short-eared Owl near Worcester; Summer Duck?at Tenbury ; Cirl Bunting, etc., near Worcester. (T.c.) 
I849. Bird, W. F. W. Ring Ouzel supposed nesting in Worcs. (Op. cit.) ; The New Brit. Woodpecker [records Hairy Woodpecker in Worcs.] (T.c.)

Curtler, M. Honey Buzzard, Oystercatcher and Cormorant in Worcs., 3 notes. (T.c.)

I850. Curtler, M. Peregrine Falcon, Black Tern, Arctic Gull, Forktailed Petrel, Waxwing, etc., near Worcester, Io notes. (Op.cit.)

[I853.] Curtler, M. List of Worcester Birds. [In Stanley's Worcester and Malvern Guide Book.] I2mo. Worcester: N.D. [I59.]

I855. Beadles, J. N. Rare birds near Worcester. (Nat. [Morris's], V.) 1856. Lees, E. Pictures of Nature around Malvern and the Vale of Severn. Post 8vo. Malvern: 1856. [347.]

1858. "F. A." The Blackcap [near Worcester in Jan.]. (Field, May I5.)

I860. Knapp, W. Lesser Redpoll at Wolverley. (Field, June I6.) I86r. Jones, C. Great Grey Shrike and Merganser [near Evesham]. (Op. cit., Mar. 9.)

1862. Edmunds, A. Rare Birds near Worcester. (Zool.)

I870. Gillbanks, G. Quail's Nest in Worcs. (Field, Aug. 6.)

I87I. Bannel, J. Californian Quail in Worcs. (Op. cit., Jan 2I.) Idem by Lord Stamford. (T.c., Feb. 4.)

Gurney, J. H., junr. Birds of the Malvern District. (Zool.)

Lees, E. Birds of Malvern District. 3 pts. (T.c.) Idem in Tr. Malvern Nat. F. C. [Also reprinted separately? Lond. : I87I.] [347.]

I872. Edwards, W. Leach's Petrel near Malvern. (Field, Dec. 7.) Harting, J. E. British Heronries. (Zool.) [partim.]

I873. "Frater." Hawfinch in Midland Counties. (Field, Jan. 25.) Mathews, D. Range of Stock Dove in England. (T.c., May 3I.)

I874. Empson, A. R. Cormorant on the Avon. (Op. cit., Aug. 29.)

I875. "Frater." Summer Migrants in Worcs. (Op. cit., May I, I5.)

I876. Bailey, H. J. Tufted Duck in Worcs. [Errore for Herefordshire.] (Op. cit. Aug. I9, 26.)

Gurney, J. H., and Heaton, W. H. The Worcs. Tropic-bird. $($ Zool.)

I877. Harding, I. Ring Ouzel nesting near Malvern ; Pied Flycatcher nesting near Malvern. (Op. cit.)

Pike, T. M. Wild Geese at Malvern (Field, Oct. 5) ; Northern Diver, etc., at Malvern. (T.c., Nov. 23.)

Edwards, W. Nat. Hist. Notes from Malvern. (T.c., May 5.)

I878. Heaton, W. H. Provincial names of Brit. Animals: Worcs. (Zool.) 
Pike, T. M. Northern Diver and other captures at Malvern. (Field, Nov. 23.)

1879. Edwards, W. Hawfinch at Malvern. (Midl. Nat.)

George, H. Manx Shearwater near Worcester. (Field, Nov. I5.)

Harding, I. Rare Visitors to Malvern Hills. (Zool.)

Pike, T. M. Canada Geese at Malvern [flock of 36]. (Field, Feb. I5.)

I880. "Frater." Ornitholog. Notes from Worcester. (Op. cit., July 24.) Partridge, J. A. Great Grey Shrike in Worcs. (T.c., Nov. 27.)

I88I. Edwards, W. Arrival of Migratory Birds at Malvern. (Midl. Nat.)

I882. "D." Common Buzzard in Worcs. (Field, Dec. 30.)

Wallace, P. Manx Shearwater in Worcs. (T.c., Sept. I6.)

I885. D[eakin], K. Seabirds in Worcs. (Sci. Gossip, Dec.)

Edwards, W. Uncommon birds near Malvern. (Field, Jan. I7.) Stone, W. Bittern near Worcester. (T.c., Feb. 7.)

I886. Hadfield, H. Ring Ouzel breeding on Malvern Hills. (Zool.)

I887. De Winton, W. E. Hawfinch breeding near Stourport. (Field, Oct. I.)

I888. D[eakin], K. Temminck's Stint near Cofton. (Sci. Gossip, Feb.)

I889. D[eakin], K. Pallas's Sand Grouse in Worcs. (Op, cit., Apr.)

"F. G. S. A." Notes on Worcs. Birds. (Sci. Gossip, Nov.Dec.) Idem, Additions. (Op. cit., Feb. I890.)

I8go. Barker, D. W. Birds of Worcestershire [Snow Bunting]. (OP. cit., Apr., Aug.) Idem by " H. W. M[arsden.]" (T.c., June.) Macbean, E. C. Blackgame in Worcs. (Field, Nov. 8.)

I8gr. Aplin, O. V. Distribution, etc., of the Spotted Crake. (Zool.) [24.] [partim.]

Bund, J. W. W. List of the Birds of Worcestershire, etc. 8vo. Worcester: I89I. [IIO.]

Coburn, F. Greyheaded Wagtail in ..... Worcs. (Zool.)

"C. P." The Rarer Birds of Worcs. (Field, Feb. 7.)

Grubb, J., and others. The Birds of Worcestershire. (T.c., Feb. I4, 2I, 28, Mar. I.4.)

"W. G." Bitterns in Worcs. (T.c., Jan. Io.)

I892. Aplin, O. V. Distribution of Cirl Bunting; Status of the Woodchat. (Zool.) [25.] [partim.]

Coburn, F. Ornitholog. Notes from Worcs. (T.c.)

Steele-Elliott, J. Woodcocks breeding in Worcs. (T.c.)

1893. Coburn, F. Woodchat in Worcs. [at Alvechurch]. (Op. cit)

Steele-Elliott, J. Quail and Hobby in Worcs. (T.C.) 
I894. Coburn, F. Great Grey Shrike, White Wagtail, Waxwing and Mealy Redpoll in Worcs., etc., 6 notes. (Op. cit.)

1896. Deakin, K. A. Teal Nesting in Worcs. (Ornithologist.)

Steele-Elliott, J. Local Names in Nat. Hist. (Jnl. B'ham N. H. \& Phil. Soc., Nov.-Dec.)

I897. Doeg, T. E. Hawfinch in Worcs. (Nat. Jnl.)

Rea, C. Common Tern, Waxwing (nesting [?]), Nightjar and Woodcock in Worcs. (Tr. Worcs. Nat. Cl., II.)

[Various Observers.] Dipper in Worcs. 2 notes; Black Grouse and Grouse in Forest of Wyre; Killing of Choughs. $(O P$ cit., I. [I847-96], I897.)

I898. Lewis, L. Hawfinch in Worcs. (Nat. Chron., Feb.)

I899. Howard, H. E. Notes on Some Birds from N. Worcs. (Zool.)

Steele-Elliott, J. Crossbill in Worcs. (T.c.)

Igor. Howard, H. E. Grasshopper Warbler in N. Worcs. $(O p$. cit.)

Tomes, R. F. Birds. [In Victoria Hist. of Co. of Worcs., I.] 4to. Lond: I90I. [584.]

I902. Coburn, F. Dusky Redshanks in Worcs.; Breeding of Ringed Plover in Worcs. (Zool.)

I903. Lowe, W. W. Birds of the Malvern District. 8vo. Igo3. [362.]

I904. Steele-Elliott, J. Cirl Bunting in Worcs. (Zool.)

I905. Ground, T. Manx Shearwater in Worcs. (Zool.)

Pycraft, W. P. Immigration of Lapland Buntings [one caught Acock Green]. (Knowledge.)

I907. Duckworth, T. Bibliography of Natural History, with Special Reference to Works of Local Interest. (Tr. Worcs. Nat. Cl., IV., pt. I.)

Ig09. Beeston, T. J. Birds of the Stour Valley. (Op cil., pt. 2.)

Bunyard, P. F. Marsh Warbler breeding in Worcs. (Brit. Birds, III.) Idem, Exhib. of Clutch with Cuckoo. (Bull. B.O.C., XXV.)

Coburn, F. Marsh Warbler breeding in Worcs. (Brit. Birds, III.) Little Owl in Worcs. $(O p$. cit., II.)

Igog-Io. Witherby, H. F. Irruption of Crossbills. (Op. cit., III., IV.) [partim.]

I9I0. Jourdain, F. C. R., and Witherby, H. F. Recent Records from ...... Worcs. (Op. cit., IV.)

Steele-Elliott, J. Sclavonian Grebe in . . . . . W Worcs. (Zool.)

I9II. Alexander, C. J. Willow Tit in Worcs.; Little Owl in Worcs.; Whimbrel in Worcs. (Brit. Birds, V.) 
Davies, W. Marsh Warbler breeding numerously in Worcs. (Op. cit., V.)

Ground, T. Eared Grebe in Worcs. (Zool.)

Mayall, A. Birds and Birds' Nests of Bromsgrove. 8vo. Lond : I9II. [394.]

Steele-Elliott, J. Former Occurrence of Black Grouse. (Zool.)

Ticehurst, N. F., and Jourdain, F. C. R. Distribution of Nightingale. (Brit. Birds, V.) [partim.]

Igr2. Hadden, N. G. Little Stints, Forktailed Petrel, Little Auks, and Blackheaded Gulls in Worcs. 4 notes. (Op. cit., V.)

Steele-Elliott, J. Redthroated Diver in Worcs. (Zool.)

Starley, B. Shag in Worcs. (Brit. Birds., V.)

I9I3. Leeke, E. Dorothy. Notes from Worcestershire, the Nightjat. (Avicult. Mag., pp. 280-8r.)

I9I4. Stenning, J. C. Swifts [Apr. 29 in Worcs.]. (Selborne Mag., p. IIO.)

I9I5. Ground, T. Leach's Petrel in Worcs. (Zool.)

I9I6. Steele-Elliott, J. Common Scoter in Worcs. (Op. cit.)

I9I8. Ground, T. Pallas's Sand Grouse in Worcs. in I888. (Brit. Birds, XII.) Idem by A. Mayall. (T.c.)

Vaughan, R. E. Young Cuckoo in Blackbird's Nest : Cuckoos' eggs in nests of Red-backed Shrike [in Worcs.]. (T.c.)

\section{YORKSHIRE.}

[I590.] Churchwarden's Accounts, Ecclesfield, near Sheffield. ["Item for vij. bulspynke heades, vjd. ; item for vj. crowe heades, jd."] (Vide Nelson's Birds of Yorkshire, p. I93, I907.)

I678. Willughby, F. Ornithology. Transl., etc., by John Ray. Fol. Lond. : I678. [65I.] [Among Willughby's correspondents were F. Jessop of Broom Hall, Sheffield, and Ralph Johnson of Brignall, near Greta Bridge, Yorks., who supplied many particulars of Yorks. birds.]

I685. Lister, Dr. Martin. [Record of Waxwing at York, in letter to John Ray.] (Phil. Trans., No. I75, p. II6I, fig. 9.)

I702. Nicholson, Bishop. Extract from Diaries of [Blackcap Mews breeding at Thornton Bridge.] (Trans. Cumb. E. Westm. Antiq. Soc., New Ser., II., p. 1656.)

I7I3. Ray, J. Synopsis Methodica Avium. 8vo. Lond. : I7I3. [488.] [Many Yorks. birds specified.]

Richardson, R. Several Observations in Natural History made at North Bierley. (Phil. Trans., XXVIII., p. I67.) 
I726. Moyle, Walter. Works. 2 vols. 8vo. Lond. : I726. [423.] [Letter from Dr. Sherrard to Moyle concerning a Coal Tit, Tree Sparrow, etc., received from Dr. Richardson of N. Bierley.]

I727. Stovin, G. Kites about Hatfield Chase. (Gent.'s Mag., I727, p. 23.)

I752. Hill, J. History of Animals. Folio. Lond. : I752. [685.] [Many notices of Yorks. birds.]

I764. Edwards, G. Gleanings. Vol. III. Lond. : I764. [Grey Phalarope near Halifax, pl. 308.]

I77I. Pennant, T. Tour in Scotland. 8vo. Chester: I77I. [466.] [Cormorants, etc., at Flamborough, p. I5.]

I776. Pennant, T. Brit. Zoology. Fourth edn. 4 vols. 8vo. Lond. : 1776. [466.] [Beam Bird in Yorks. =Spotted Flycatcher.]

I797. Lewin, W. Birds of Great Britain. 8 vols. 4to. Lond. : I795-I80x. [35I.] [Crested Tit in Yorks., Vol. IV., p. 46.]

I799. Fothergill, C. Ornithologia Brit. Folio. York: I799. [2I9.] [Little Owl in Yorkshire, White Stork at Howden, p. 7, and other Yorks. Birds.]

I802-I3. Montagu, G. Ornithological Dict. 2 vols. 8vo. and Suppl. Lond. : I802-I3. [Lesser Redpoll from Yorks. Scops Owl near Wetherby.]

I804. Dodsley's Annual Register. [Eagle shot at Stockfield Park, near Wetherby.]

Miller's Hist. of Doncaster. I804. [Contains List of Birds.]

I808. Graves, J. History of Cleveland. 4to. Carlisle : I808. [247.]

I8I2. Whitaker's Hist. of Craven. 2nd ed., I8I2.

[I8I5.] [Anon.] The Swallows; or Observations ... upon their late Assemblage at Rotherham. 32mo. Rotherham, N.D. [I9.]

I8I7. Young, G. History of Whitby and Streoneshall Abbey; 2 vols. 8vo. Whitby: I8I7. [672.]

1820. Atkinson, J. Compendium of Brit. Ornithology, I vol. 8vo. Lond. [29.] [p. 68, Brambling and Cream coloured Courser near Wetherby.]

I823. Latham, J. General History of Birds. II vols. 4to. Winchester: I82I-8. [34I.] [Vol. VII., p. 278. House Martin at Halifax.]

Whitaker's Hist. of Richmondshire. I823. [Contains list of birds of Wensleydale by Fothergill.]

I824. Sims, Dr. [Swallow-tailed Falcon, etc., taken near Hawes in Wensleydale.] (Zool. Jnl., I., pp. I30-3I ; Tr. Limn.Soc., XIV., p. 583.)

I827. Fox, G. T. Synopsis of the Nervcastle Museum, I vol. 8vo. Newcastle: I827. [22I.] [Many records of Yorkshire birds from Tunstall MS. (592) also Allan MS. Reed Bunting in Yorkshire $=$ Nettle Monger.] 
I827. Northumberland, A. P., Fifth Earl of. The Regulations... for his Castles of Wressill and Lekinfield in Yorkshire. (Edited by Bishop Percy.) I vol. 8vo. Lond. : 1827 .

I829. [Cole, J.] The Scarborough Natural Historians. I8mo. Scarborough : I829. [I38.]

Leyland, R. Rare Birds observed in Neighbourhood of Halifax. (Loudon's Mag. N. H., I.)

"L.E.O." Swallows remaining during the Winter. (Loudon's Mag. Nat. Hist., II.)

I83r. Allis, T. Natural History in the English Counties: Yorkshire. Early Appearance of Swallows. (Op. cit., IV.)

I832. [Anonymous-“"M.R." [errore] and "M.P."] Birds found in Neighbourhood of Wensleydale. 2 notes. (Loudon's Mag. N. H., V.) Additions by W. G. Barker. (T.c.)

Allis, T. Inland Specimens of the Forked-tail Petrel; Grey Phalarope near York. 2 notes. (Loudon's Mag. N. H., V.) Foljambe, H. S. Redfooted Falcon at Doncaster. (Tr. Linn. Soc., XVII., p. 533.)

Hinderwell's Hist. of Scarborough. 1832. [Contains birds.]

Strickland, A. Occurr. of Puffinus fuliginosus, n. sp., in Yorks. (P.Z.S.) Idem Rep. Br. Assoc. for I832.

1833. Blyth, E. Winchat on Yorkshire Coast; Nightjar alighting on Ship. (Rennie's Field Nat., Nov. I833.)

1835. Backhouse, $T$. The Brambling [shot near York in May]. (Loudon's Mag. N. H., VIII.)

Waterton, C. Visit to Haunts of the Guillemot [in Yorks.] Visit to Haunts of the Cormorant [inYorks.]. 2 papers. (T.c.)

1836. Morris, F. O. Facts on the Habits of the Crossbill [near Doncaster]. (Op. cit., IX.)

Williamson, W. C. On Appearance of Rare Birds in Vicinity of Scarborough. (P.Z.S. I836.) Idem. (L. E E. Phil. Mag. I837.)

I837. Allis, T. Capture of the Jer Falcon near York. (Nat. [Wood's], II., pp. 53 \& I63.) 2 notes; Greenland Falcon in York. (T.c.)

Denny, H. Snowy Owl at Selby. (P.Z.S.) Idem. (Mag. Zool. \& Bot., II., p. 93.)

[Editorial.] The Cirl Bunting in Yorks.; The Sibilous Brakehopper (L. sibilatrix) in the North of England; Comparative Distribution of the Buntings [near Doncaster]. (Nat. [Wood's], II.)

Hawkridge, P. The Cinereous Sea-Eagle a straggler in Yorks.; An Osprey taken near Flamborough; The Peregrine Falcon near Scarborough, etc. Io notes. (T.c.)

Morris, F. O. The Fuscous Gull (L. fuscus) near Doncaster, (T.c.) 
Wheatear in Yorkshire. (Rennie's Field Nat., Nov. I837.) Read, W. H. Rudston. Woodcock shot in July [near Thirsk]. (Charlesw. Mag. Nat. Hist.)

Wood, N. Siskin at Campsall. (Nat. [Wood's], June I837.)

1838. Athorpe, J. C. [ex Doncaster Gazette.] Curiosities in Natural History. [Pomarine Skua \& Purple Tringa in Yorks.] (Nat. [Wood's], III.)

[Editorial.] The Nightingale to the North of Doncaster. (T.c.) Hancock, J. Occurrence of Falco islandicus in England [at Normanby]. (Ann. Nat. Hist. II., p. I59.)

Hawkridge, P. Rough-legged Buzzard near Scarborough; The Hen Harrier near Scarborough; Scarcity of Merlin Falcon near Scarborough; Capture of Eagle Owl off Flamborough Head, etc., Io notes. (Nat. [Wood's], III.)

Strickland, A. Great White Heron at Hornsea Mere. (Rept. Brit. Assoc. Newcastle Meeting, I838.)

(York Courant.) Eagle trapped at Beningborough.

1839. [Editorial.] Localities for the Nightingale in Yorks. (Nat. [Wood's] V.)

Hawkridge, P. Kestrel Falcon near Scarborough; Golden Eagle shot near Holderness; Buzzard near Scarborough, etc. 4 notes. (Nat. [Wood's], IV.) ; Dipper on Yorks. Coast; Ring Ouzel near Scarborough; Garden Fauvet near Scarborough; Sibilous Locustell near Scarborough, etc. Io notes. (Op. cit., V.)

Strickland, A. Upon claims of Ardea alba-Great Egret or White Heron-to be considered a British Bird. [Occurrences at Hornsea Mere and Scarboro.] (Loudon's Mag. Nat. Hist.)

I840. Denny, Henry. Sketch of Nat. Hist. of Leeds and its Vicinity for Twenty Miles. (Ann. Nat. Hist., V.)

1842. Lankester, E. [I8I4-74.] Account of Askern and its Mineral Springs. Post 8vo. London : I844. [339.]

1843. Denny, H. Gullbilled Tern near Leeds. (Ann. \& Mag. Nat. N.H., p. 297.)

Yarrell's Brit. Birds, Vol. III. Lond. : I843. [Bulwer's Petrel at Tanfield, p. 5I4.]

I843-4. Heppenstall, J. Appearance of Migratory Birds, etc., near Sheffield, I2 notes. (Zool., I843-4.)

I844. Booth, M. Occurrence of Osprey and Other Birds in Neighbourhood of River Swale. (Op. cit.)

(Eastern Counties Herald.) Capture of a Red-legged Falcon [near Selby]. (T.c.)

Heppenstall, J. Note on Pied Flycatcher. (T.c.)

Norman, G. Arrival of Summer Birds at Hull in I844; Roughlegged Buzzard at Hull. (T.c.) 
1845. Allis, T. Report on Birds of Yorkshire. (Rep. Br. Assoc. Adv. Sci., I844.)

Booth, M. Bearded Titmouse in Cleveland and Note on Osprey. (Zool.)

Briggs, J: J. Birds at Spurn Head. (T.c.)

Hogg, J. [1800-69.] Catalogue of Birds observed in South Eastern Durham and N. W. Cleveland. 8vo. Lond. : I845. Idem in Zool. 3 pts., I845. Addit. by W. Backhouse, Op. cit., I 846.

Norman, G. Waxen Chatterer and Great Grey-backed Shrike near Hull. 2 notes. ( $Z$ ool.)

1846. Bell, R. J. Steller's Western Duck at Filey. (Op. cit.)

Garth, J. C. Crossbill near Knaresborough; Great Black Woodpecker near Knaresborough. (T.c.)

Morris, B. R. Effects of the Mild Weather [in Yorks.]. (T.c.) Morris, F. O. White Stork near Driffield. (T.c.)

I847. Charlesworth, E. Occurrence of Ross's Gull. (Pr. Yorks. Phil. Soc. I.)

Garth, J. C. Stormy Petrel near Knaresborough. (Zool.)

Milner, W. M. E. Occurrence of Rare Birds near Tadcaster. (T.c.)

Morris, F. O. Rare Birds occurring near Bridlington in Winter of $1846-7 . \quad$ (T.c.)

I848. Garth, J. C. Hawfinch at Knaresborough. (Zool.)

Higgins, E. T. Spotted Sandpiper in Yorks.; White Stork near York. (T.c.)

Inchbald, P. Lesser Spotted Woodpecker near Huddersfield. (T.c.)

Johnson, J. Provincial Names of Birds in Yorks. (T.c.)

Milner, W. M. E. Collared Pratincole near Scarborough; Great Shearwater near Robin Hood's Bay; White Stork near York. (T.c.)

Ray, J. Correspondence of. (Edited by E. Lankester). 8vo. Lond. : I848. [Contains Letters from Dr. Lister of York and Mr. Jessop of Sheffield with reference to Yorkshire birds, also from Ralph Johnson of Brignall near Greta Bridge and Mr. Thoresby of Leeds on same.]

Rudd, T. S. Roller near Shelton Castle. (T.c.)

Webb, J. S. White Wagtail near York. (T.c.)

I849. Bird, W. F. W. New Brit. Woodpecker killed in Yorks. (Zool.) Garth, J. C. Occurrence of Green Cormorant and Hooded Crow near Borobridge. (T.c.)

Higgins, E. T. Spotted Sandpiper near York; Supposed New Brit. Woodpecker near Whitby ; Rare Birds in York. (T.c.)

Milner, W. M. E. Great Grey Shrike near York; Spotted Sandpiper at Whitby; Sylvia orphea in Yorks. (T.c.) 
Morris, F. O. Purple Heron near Driffield; Fulmar Petrel near Bridlington; Tengmalm's Owl. (Zool.)

1850. Bree, C. R. Honey Buzzard at Bridlington Quay. (Zool.)

Cook, R. B. Tufted Duck breeding at Malham Water. (T.c.) Garth, J. C. Occurrences at Knaresborough, etc. 5 notes. (T.c.)

Milner, W. M. E. Pink-footed Goose near York. (T.c.)

Morris, B. R. Occurrences in Yorks. 5 notes. (T.c.)

Morris, F. O. Little Gull near Bridlington Quay. (T.c.)

Rudd, T. S. Little Gull at Redcar; Waxwing at Redcar; Ferruginous Duck near Redcar. (T.c.)

I85I. Duff, J. King Eider at Bedlington, Northumberland [crrore, Bridlington, Yorks.] (Zool.)

Ferguson, D. Capture of Rose-coloured Pastor [near Redcar]. Nat. [Morris's] I.)

Gibbes, F. R. Bohemian Waxwing near Northallerton. 2 notes (T.c.)

Graham, D. Green Sandpiper at Escrick; Shoveller, etc. [near York.] (T.c.)

Milner, W. M. E. Spoonbill in Yorks. (Zool.)

M[orris], B. R. Spoonbill in Yorks; Red-necked Grebe near York. (Zool.) Turnstone at Bridlington in May; The Nightingale [near Leeds]; Purple Heron near Leeds; Gadwall in Yorks. (Nat. [Morris's], I.)

Morris, F. O. Brit. Birds, Vol. I. London: 1851. [4I7.] [Bee-eater at Sheffield, p. 3I3.]

McIntosh, J. Heronries in England, etc. (Nat. [Morris's], I.) [partim.]

Rudd, T. S. Rose-coloured Pastor at Redcar. (Zool.)

1852. Evans, J. American Teal at Scarborough. (Zool.)

Ferris, H. Ornitholog. Ramble, near Leeds. (Nat. [Morris's], II.)

Ferguson, D. Capture of Red-necked Phalarope [near Redcar] ; Capture of Stormy Petrel [near Redcar]; Bar-tailed Godwit [at Redcar]. (Nat. [Morris's], II.)

M[orris], B. R. Honey Buzzard near Bridlington (col. pl.) (T.c.)

I853. Braim, J. Rare Birds near Whitby. (Nat. [Morris's], III.)

Dixon, J. Ornithology of Leeds District. (T.c.)

Graham, D. Occurrence of Goshawk. (T.c.)

"H. S." Rare Birds near Richmond. (Nat. [Morris's], III.)

M[orris], B. R. Black Stork in Yorks. ; Peregrine Falcon near York; Hawfinch near York. (Nat. [Morris's], III.)

Morris, F. O. [Little Auk near Driffield.] (T.c.)

Rudd, T. S. [Little Bittern at Redcar]; Pectoral Sandpiper near Redcar. (T.c.)

1853-4. Lister, T. Summer Birds observed about Barnsley. 2 pts. (Op. cit., III. \& IV.) 
I854. Allis, T. H. Shore Lark in Yorks. Little Bustard in Yorks. (Zool.)

Barker's Three Days of Wensley Dale. I854. [Contains Birds.]

Braim, J. Little Auk near Whitby. (Nat. [Morris's], IV.)

Davies, J. H. Names of Birds in the North Riding. (T.c.) Fothergill, W. \& C. Correspondence of, I799-I8I3. 2 pts. (T.c.)

Graham, D. Rednecked Phalarope [near York]. (T.c.)

Lister, T. Note on Greater and Lesser Spotted Woodpecker [near Barnsley]; Observations upon Birds about Barnsley; Observations on Weather for January [around Barnsley]; Nightingale near Barnsley; Nightjar near Barnsley. (Nat. [Morris's], IV.)

Milner, W. M. E. Red-necked Phalarope killed near York. (Zool.)

Roberts, A. Rare Birds at Scarborough; Crossbill near Scarborough. (Zool.)

Rothery, C. W. Little Auk at Harrogate. (Nat. [Morris's], IV.)

Rudd, T. S. Bernacle Goose at Redcar; Sclavonian Grebe at Redcar. (T.c.)

Smurthwaite, H. Red-breasted Merganser near Richmond; Birds occurring near Richmond (2 pts.) (T.c.)

Stears, T. W. Early occurrences of Stone Curlew near Hull. (T.c.)

1854-5. [Anon.] Great Shearwater taken in Leeds. [Leeds Phil. Soc. Rept.)

1855. Braim, J. Montagu's Harrier near Whitby. (Nat. [Morris's], V.)

Cooke, B. B. Gyr Falcon near Robin Hood's Bay. (Op. cit., V.)

Graham, D. Night Heron in Yorks.; Supposed Breeding of Common Crossbill in Yorks. (T.c.)

Hobson, R. Greater Shearwater at Leeds. (T.c.) On Occurrence of American Mottled Owl (Strix asio) near Leeds (Plate) ; Description of Hawk shot in I85I on Chevet Park Estate (Plate). (T.c., also I856.) Morris, F. O. Idem (T.c., also I856.) Gurney, J. H. Idem. (Op. cit., I856.)

Lister, T. Little Auk at Barnsley, etc. 2 notes. (Nat. [Morris's] V.)

Norman, G. Large Flocks of Crossbills near Hull. (Zool.)

Roberts, A. Rare Birds near Scarborough; Lesser Whitewinged Gull, etc., near Scarborough (2 notes) ; Honey Buzzard near Scarborough; Shag, American Scaup [errore? Cf. Newman, Zool, I856], etc., near Scarboro. (Zool.)

Rudd, T. S. Occurrence of Rare Birds at Redcar. (Nat. [Morris's], V.) 
I856. Bedlington, T. Rose-coloured Pastor [near Middlesbro'] ; Mountain Finch [in Tees estuary]; Long-tailed Tits [in Middlesbro']; Partridges [in Middlesbro']; Rock Thrush [seen near Robin Hood's Bay] ; Ring Ouzel [nesting near Robin Hood's Bay]. (Nat. [Morris's], VI.) 6 notes.

Daykin, R. Mealy Redpole [near Richmond]. (Nat. [Morris's], VI.)

Grant, J. B. The Ring Ouzel [near Keighley on Feb. 2.] (T.c.)

Graham, D. Rose-coloured Pastor at York. (Zool.)

Hewitson (W. C.) Eggs of Brit. Birds. 3rd edn. 2 vols. Lond. : I856. [294.] [Ref. to various birds breeding in Yorks. : Common Pochard, etc.]

Hobson, R. The Mealy Redpole [near Leeds.] (Nat. [Morris's], VI.)

Lister, T. Notices of Rarer Birds about Barnsley. (Zool.)

Stephenson, J. Rare Birds [near Beverley]. (Field, Dec, I3.)

Tinker, T. S. The Ring Ouzel [at Hepworth on Dec. 24]. (Nat. [Morris's] VI.)

(Yorkshire Gazette.) Peregrine Falcon [in Yorks.]. (T.c.)

I857. [Anon.] Ornithological Notes. (Nat. [Morris's], VII. ; and Wakefield Express.)

Graham, D. Great Snipe shot near York. (Zool.)

Maude, E. J. Migratory Birds at Kilnsey in Craven. (Nat. [Morris's], VII.)

Morris, F. O. [Knot at Nunburnholme.] (T.c. p. 33.)

Smith, C. E. Rare Birds at Ackworth. (T.c.)

Walsh, J. Land Rail [near Halifax in November]. (T.c.)

Wilson, J. J. Great Grey Shrike near Leeds. (Zool.)

I858. "Auceps." The Bohemian Chatterer [shot at Cottingham]. (Field, April I7.)

Atkinson, J. C. Contributions towards a Biography of the Red Grouse. (Zool.)

"Black Swan." The Bohemian Chatterer [in Yorks.]. (Field, Apr. 24.)

"G. F." Rara Avis. [Eagle shot near Beverley.] (Field, Dec. II.)

Graham, D. Rare Birds [in Yorks.]. (Nat. [Morris's], VIII.) Milligan, W. J. The Hoopoe [on East Witton Fell]. (Field, May 8.)

Milner, W. M. E. Glossy Ibis and Yellow-legged Sandpiper killed in Yorks. (Zool.)

Morris, F. O. Nat. Hist of Nunburnholme. 4 pts. (Nat. [Morris's], VIII.) ; Glaucous Gull [at Scarborough]. (Field, Dec. II) ; Rara Avis-The Eagle killed in East Riding [and Purple Heron]. (Field, Dec, 24.)

Norman, G. Hooded Crows at Flambro' Head. (Zool.)

Richardson, J. Peregrine Falcon in Yorks. (T.c.)

"Skoulasticos." The Solitary Snipe [in Yorks.]. (Field, Oct. 23.) 
Smurthwaite, H. Hoopoe and Pied Flycatcher in Yorks.; Spotted Crake near Richmond ; Crossbills in Yorks. ; Motacilla campestris and $M$. boarula [in Yorks.]. (Zool.)

I859. Briggs, J. J. Landrails [on Migration near Spurn Head]. (Field, Jan. 8.)

[Editorial.] The Osprey [captured near Driffield]. (Field, July 2.)

Gisburne, - A Appearance of Pied Flycatcher. (Field, May 28.)

Hobkirk, C. C. P. Huddersfield: Its History and Natural History. 8vo. Lond. : I859. 2nd edit., I868. [295.]

"H. S." The Peregrine Falcon [captured near Hovingham]. (Field, Dec. 3.)

Lister, T. The Turnstone [shot near Barnsley]; the Pied Flycatcher. (Field, May 28.)

Roberts, A. Kite, Hoopoe and Golden Oriole shot near Scarborough. (Zool.)

Smurthwaite, H. Nesting of Dipper. (Zool.)

I860. Bell, A. S. Surf Scoter near Scarborough. (Zool.)

"Eboracum." Birds shot in Yorks. (Field, Jan. I4.)

Ferguson, D. Natural History of Redcar and Neighbourhood. 8vo. Lond., etc. : I860. [206.]

"J. S." Snow Bunting shot in Yorks. (Field, Ap. I4.)

Milligan, W. The Waxwinged Chatterer [in Yorks.]. (Field, Dec. I.)

Milner, Sir W. M. E. Sparrow Owl in Yorks. (Zool.)

"Philornis." Seafowl shooting at Flamboro" Head. (Field, July 7.)

Roberts, A. Rare birds at Scarboro'; Osprey at Sherburne. $($ Zool.)

I86r. "A Constant Reader." The Cinereous [errore, Golden] Eagle shot near Driffield. (Field, Dec. I4.)

Allis, T. H. Bustard near York. (Zool.)

Atkinson, J. C. Brit. Birds Eggs. I2mo. Lond. : I86I. [30.] [Refs. to Yorks. birds.]

Bell, A. S. Surf Scoter near Scarborough. (Zool.)

Boulton, W. W. The Gannet [shot at Waikington]. (Field, Oct. 5); Great Spotted Woodpecker at Beverley. (Field, Nov. I6.) ; Rare Birds at Beverley. (Field, Nov. I6.)

"C.H.D." The Spotted Crake [at Hanxwell, Bedale]. (Field, Sept. 2I.)

Dobree, A. Occurrence and Breeding of Lesser Tern at Spurn Point. (Zool.)

Dobree, N. F. The Reed Warbler near Hull. (T.c.)

"E. F." Eagle shot near Driffield [pronounced a Golden Eagle]. (Field, Dec. 2I.)

"E. S." Little Auks [in Yorks.]. Lees, J. Idem. (Field, Dec. I4.) 
"F. H." Pomarine Skua in Humber. (Field, Nov. 23.)

"G. H." Rare Birds, etc. [Smew at Catton.] (Field, Feb. I6.) Graham, D. Gyr Falcon (Falco islandicus) and Bustard near York. (Zool.) 2 notes.

Ranson, J. Rose-coloured Pastor near York; Tree Sparrow near York. (Zool.)

Reid, H. Eared Grebe killed at Doncaster. (T.c.)

Roberts, A. Rare Birds at Scarborough. (Zool.)

I862. Bell, A. S. Black-throated Diver near Scarborough. (Zool.)

Boulton, W. W. Little Bustard in Yorks. (Zool. ; Field. Feb. 8.)

Chambers, E. Rose-coloured Pastor [near Scarborough]. (Field, July I2.)

Grimston, M. J. Ring Ouzel near Hull. (Field, May 3.)

Hobson, R. Birds seen in grounds of Walton Hall. (Field, Aug. 2.)

Horsfall, W. C. Great Snipe near Malham. (Zool.)

"M. B." and others. Local Names of Birds [in Yorks.]. (Field, Nov. I5.)

Parke, G. H. Sclavonian Grebe at Halifax. (Zool.)

"R. D." Eagle shot at Flamborough Head. (Field, Feb. 8.)

Roberts, A. Golden Eagle near Driffield. (Zool.)

Varley, J. Occurrence of Manx Shearwater, Thick-knee and Crossbills in neighbourhood of Huddersfield. (Zool.)

I863. Allis, T. H. Pallas's Sand Grouse in Yorks. (Zool.) Idem by C. Doncaster, E. Wright, A. Roberts and W. W. Boulton. (T.c.)

Atkinson, J. C. Ortolan Bunting at Guisborough. (T.c.)

Boulton, W. W. Occurrences in Yorks, I5 notes. (T.c.)

Horsfall, H. W. Hawfinch breeding in Yorks. (T.c.)

Horsfall, W. C. Solitary Snipe and Kite near Leeds. 2 notes. (T.c.)

Liversedge, W. Pin-tailed Sand-grouse in Yorks. (Zool.)

Norman, G. Alleged Scarcity of Swifts and Swallows [at Beverley]. (T.c.)

Ranson, J. Scarcity of Certain Small Birds; Goshawk nesting in Yorks ; N. Yorks. haunts of Kingfisher. (T.c.)

Rawson, C. African Sand Grouse in Yorks. Correction by W. C. Horsfall. (Zool. ; Field, June 6.)

Roberts, G. Dates of arrival of Summer Birds in Wakefield. (Zool.)

Wright, G. Pallas's Sand Grouse [in Yorks.]. (Field, June 27.)

Young, J. Freeland. Little Auk [near Cottingham]. (Field, Dec. I2, I9.)

1864. (Anon. ex Sheffield Daily Telegraph.) Goshawk on Filey Brigg. (Zool.)

Armistead, J. J. Little Stint near Leeds. (Zool.)

Atkinson, J. C. Nesting of Mountain Finch or Brambling in Yorks.[?] (Zool.) Idem. (Field, July 23.) 
Boulton, W. W. Occurrences at Beverley, Flamborough, Filey and Bridlington, 47 notes. (Zool.)

Cordeaux, J. Remarks on Birds seen during a Visit to Flamborough; Notes on Ornithology of Flamborough. (T.c.)

Dobree, N. F. Waxwing near Hull; Decrease of Birds at Flamborough. (T.c.)

Graham, D. Rare Birds near York. (T.c.)

Harting, J. E. Bridled Guillemot at Flamborough Head. (T.c.)

Newman, H. W. The Sea-Birds at and near Filey. (T.c.)

Norman, G. Ring Ouzel near Malton; Migration of GoldenCrested Wrens; Eggs of Thick-knee Plover [near Market Weighton]. (T.c.)

Roundall, H. Waxwing killed in Craven. (Field, March I2.)

Tyrer, R. Fieldfares in Yorks. in May. Ring Ouzel nesting in Yorks. (Zool.)

Wright, G. Rare Birds [Waxwing, Rough-legged Buzzard and Golden Eagle] shot near York. (Field, Jan. I6.) Smews shot on the Derwent. (T.c., Jan. 30.) Bewick's Swan shot in Yorks. (T.c., March 26.)

I865. Boulton, W. W. Ornithological Notes from Beverley, 4 notes. Red-footed Falcon at mouth of Humber; Merlin near Beverley; Honey Buzzard near Beverley; Great Grey Shrike near Beverley. (Zool.)

Horsfall, W. C. Red-necked Grebe near Leeds. (Zool.)

Ranson, J. Ornitholog. Notes from N. Yorks. (T.c.)

Roberts, G. Notes on Birds taken during a Few Days' Ramble in Craven. (T.c.)

Simpson, G. Rough-legged Buzzard in Cleveland. (Field, Dec. 2.)

Tyrer, R. Sand Grouse, etc. near Keighley; Backwardness of the Season at Keighley. (Zool.)

Whitehead, G. Fork-tailed Petrel Inland [near Escrick]. (Field, Dec. 9.)

Young, J. Freeland. The Bohemian Chatterer [near Hull]. (Field, Feb. 4.)

-. Nesting of Hawfinch in Yorks. (Ibis.)

I865-68. Cordeaux, J. Notes from Flamborough, 4 pts. (Zool., r865-8.)

I866. Allanson, P. B. Crossbill in Yorks [at Bedale]. (Ficld, Aug. II.) Armitage, G. D. Little Gull at Bridlington. (Zool.; Field, Sept. 8.)

Boulton, W. W. Ornitholog. Notes from East Coast. (Zool.) Ornitholog. Notes from Beverley. 2 pts. (Op. cit., I866-67.)

Ewart, J. Bohemian Waxwing near Sheffield. (Ficld, Dec. I.) Gould, J. Andalusian Hemipode near Huddersfield. (P.Z.S., p. 2IO.)

" M. D." Great Grey Shrike [in Wensleydale]. (Ficld, Apr. I4.) 
Morris, G. S. The Waxwing [in Cleveland]. (Field, Dec. 15.)

Mosley, S. L. Red-breasted Pipit [seen near Huddersfield]. (Sci. Gossip.)

Pilkington, E. Great Grey Shrike [in Yorks.]. (Field, Jan. I3.)

Smith, H. E. Rough-legged Buzzard in S. Yorks. (Zool.)

I867. "C. W. W." and others. Occurrences of Bittern in Yorks. (Field, Feb. 2, 9, I6.)

Dobree, N. F. Pied Wagtails near Hornsea in Jan. (Zool.)

Gurney, J. H. Little Gull at Flamborough Head. (Zool.)

Knight, J. Masked, Iceland and Glaucous Gulls [in Yorks.]. (Field, Jan. 26.) Quails breeding near Scarborough, etc. (Field, Oct. I9.)

Lucas, J. Studies in Nidderdale, I867-72. 8vo. Lond. : N.D. [363.]

Roberts, G. Dates of Arrival of Summer Migrants near Wakefield; Nesting of Peregrine; Yorks. haunts of the Pied Flycatcher. (Zool.)

Smee, A. H. Sandwich Tern at Whitby. (T.c.)

Stephenson, W. Egyptian Goose in Yorks. (Field, Jan. 26; (Zool.) Idem by G. Alderson and others. (Field, Feb. 9, I6.)

Young, J. F. The Ring Ouzel [near Hull]. (Field, March 30.)

1868. Boynton, H. Honey Buzzard and Brown Snipe near Hull. (Field, Oct. 24.)

Clark-Kennedy, A. Storm Petrel at Bridlington Quay; Waxwing in Yorks.; Bittern near Pontefract; Spoonbill in N. Yorks. (Zool.)

Gurney, J. H., junr. Little Gull near Bridlington, at Filey and at Flamborough ; Occurrences at Flamborough, etc. II notes. (T.c.)

Lister, W., junr. Honey Buzzard at Yarm. (T.c.)

Littlewood, T. A. Woodcocks in July [in Yorks.]. (Field, July I8.)

Ranson, J. Kingfisher at Linton-on-Ouse. (Sci. Gossip.)

Roberts, G. Ornitholog. Notes [from Lofthouse near Wakefield.] (Zool.)

I868-9. Cordeaux, J. Notes on Ornithology of Spurn Point. 2 pts. (Zool, I868-9.)

I869. Bell, A. S. White Partridges [Ptarmigan ?) [in Yorks.]. (Zool.) Idem by J. E. Harting. (Op. cit., I870.)

Boyes, F. Notes from East Yorks. (Field, Oct. 30.)

Boynton, T. Shore and Sea-Birds [in Yorks.]. (Zool.)

Gurney, J. H., junr. Fulmar Petrels at Scarborough and Whitby ; Lesser Kestrel near York; Bewick's Swan at Flamborough. (Zool.)

Hall, J. C. Nest of Red-backed Shrike near Sheffield. (Field, May 22.)

Lister, T. Spring Notes from Yorks. (Field, May 22.) 
Lucas, J., junr. Birds of Nidderdale. (Field, May I.) The Pied Flycatcher [in Yorks.]. (Field, June 5.)

Ranson, J. Arrival of Summer Migrants near York. (Zool.) Smew near York. (Sci. Gossip.)

Roberts, G. Nightingale in Yorks. (Zool.)

I87o. Atkinson, J. C. Occurrence of Red-necked Grebe and White's Thrush. (Zool., p. 2142 [om. ind.].) Idem. (Field, Mar. I9.) Bell, A. S. Probable Ptarmigan in Yorks.; Great Bustards on Yorks. Wolds (2 notes); Little Gulls on Yorks. coast. (Zool.) Boyes, F. Notes from E. Yorks. ; Common and Sandwich Terns at Spurn; Nesting of Quail in E. Yorks. (T.c.) Shore Larks in East Yorks. (Field, Feb. 5.)

Boynton, T. Pennsylvanian Pipit, etc., at Bridlington, 3 notes. (Zool.) Little Gulls, etc., at Bridlington Bay. (Field, Feb. 26.)

Feilden, H. W. Increase of Rock Birds at Flamborough; Nesting of Great Bustard in England. (2 notes.) (Zool.)

Gurney, J. H., junr. Lesser Kestrel near York. (T.c.)

Liversidge, W. Quail's nest near Leeds. (Sci. Gossip.)

Vyner, F. G. Sclavonian Grebe in Yorkshire. (Field, Feb. 26.)

Wesley, J. S. Puffin in Winter [on the Wharfe]. (Field, Nov. I9.)

I87I. " B. G. J." Wild Swans near Hull. (Field, Jan. 2I.)

Boyes, F. Occurrences in Yorks. 22 notes. (Zool.)

Boynton, T. Hoopoes at Hull ; Rare Gulls, etc., at Bridlington ; Goosander, Glaucous Gull and Iceland Gull in Yorks. ; Hoopoe near Bridlington. (Zool.)

Carter, J. Quails, Spotted Crake, etc., in Bedale. (Field, Feb. 25.)

Cordeaux, J. Flamborough and the Bird Act. (Zool.)

Dawson, G. R. Canadian Goose near Brigham. (Sci. Gossip.)

Gurney, J. H., junr. Yorks. occurrences. 5 notes. (Zool.)

"G." Whooper near Bedale. (Field, Mar. 25.)

Inchbald, P. The Pied Flycatcher near York. (Field, June Io.)

Page, G. Rare Birds at Guisborough. (Field, Nov. II.)

Roberts, G. A List of Uncommon Birds in Yorks. ; Miscellaneous Rural Notes; Arrival of Migrants, etc. 4 notes. (Zool.) Hooper Swan near Whitby. (Field, Mar. 4.)

" R. S"[tevenson]. Hen Harrier near Beverley. (Field, Oct. 2r.) Marsh Harrier at Beverley [correction]. (T.c. Oct. 28.)

Simpson, M. Whitby Wader ( 2 notes) ; Collared Pratincole at Whitby. (Zool.)

Theakst on's Guide to Scarborough. Ioth ed. I2mo. Scarborough: I87I. [576.]

1872. Bethell, W. British Heronries. (Zool.)

Bond, F. The Whitby Wader. (T.c.)

Boyes, F. Waxwings, Bittern, Great Grey Shrike, etc., in E. Yorks., 6 notes. (T.c.)

Cordeaux, J. Birds of the Humber District. Post 8vo, Lond. : I872. 
Gurney, J. H., junr. Sabine's Gull at Bridlington. (Zool.)

Harting, J. E. British Heronries. (Zool.) [partim.] Idem Additions. (Op. cit., I873.)

Inchbald, P. Goldeneye at Hovingham. (Field, Nov. 9.)

Lister, T. Hooper [etc.] near Barnsley. (Field, Jan. 6) ; Notes from Barnsley. (T.c., June 22.)

Porritt, G. T. Redpoll breeding at Huddersfield. (Zool.)

Simpson, M. Shore Lark and Crested Tit near Whitby. (Zool.)

Stephenson, R. Eared Grebe in Yorks. (Field, Dec. 28.)

1873. Beck, T. Peregrine near Scarborough. (Zool.)

Boyes, F. Heronries in E. Yorks. ; Red-necked Phalarope and other Birds in E. Yorks. 4 notes. (Op. cit.)

Cordeaux, J. Common Cormorant and Herring Gull returning to nest at Flamborough. (Zool.)

Edson, G. Common Buzzard at Malton. (Field, Nov. 8.)

Feilden, H. W. Nesting of Redwing [?] in N. Yorks. (Zool.

Gurney, J. H. Note on Rare Birds obtained near Flamborough Head. (T.c.)

Lister, T. Rare Birds near Barnsley. (Zool. ; Field, Jan. 4.)

I874. Beswick, J. Glossy Ibis in Yorks. (Field, June I3.)

Boyes, F. Glaucous Gulls and Little Bittern in E. Yorks. 2 notes. (Zool.)

Brooksbank, A. Nightingale in Yorks. (Field, June 6.)

Gurney, J. H. Greater Shearwater in Bridlington Bay. (Zool.)

Lister, T. Birds observed in West Riding. (Rep. Br. Assoc.)

Hodgkinson, J. B. Roller in Yorks. (Zool.)

Palmer, J. E. Honey Buzzard and Baillon's Crake near Huddersfield. 2 notes. (Zool.)

Roberts, G., and others. Marsh Sandpiper [said to have been shot near Malton]. (Zool.; Field, Nov. 2I.)

I875. [Anon.] Purchase of Leach's Forktailed Petrel in Leeds Market in I863. (Yorks. Post, Feb. 6.)

Boyes, F. Hobbies and Sclavonian Grebe in E. Yorks., etc. 5 notes. (Zool.)

Butterfield, E. Pied Flycatcher, Golden Oriole and Hoopoe near Bradford; Roller at Bingley. (T.c.)

Carter, J. Black-throated Diver at Masham. (Field, Dec. II.) Clarke, W. E. Great Northern Diver in Bridlington Bay. (Zool.)

Cope, W. J. Bridlington Birds. (Nat.)

"Eboracum." Bittern in Yorks. (Field, Jan. I6.)

Gurney, J. H., junr. Pratincole [at Bridlington]. (Zool.) Sabine's Gull at Flamborough. (Nat.) Supposed occurr. of Jugger Falcon off coast. (Zool.) [Errore. cf. Zool., I876, p. 4759.]

Gurney, J. H. Pomatorhine Skuas and Black Guillemots at Flamborough. (Zool.)

Harting, J. E. Leach's Petrel near Bradford. (Field, Dec. 4.) 
Jackson, A. Goosander near Market Weighton. (Field, Dec. 4.)

Lister, T. Rare Birds near Barnsley. 2 notes. (Nat.)

Machen, R. Rare Birds at Bridlington. (Nat.)

Nelson, T. II. Sclavonian Grebe near Redcar. (Ficld, Mar. 20.)

Palmer, J. E. Birds olserved near Huddersfield. (Zool.); Nightingale near Huddersfield. (Nat.; Zool.)

Rawson, 1. G. S. Rare Birds near Halifax. (Nat.)

lichardson, W. Roughlegged Buzzard in Yorlis. (Field, Nov, 6.) Idem by S. Guille. (T.c. Nov. I3.)

Talbot, W. Great Northern and Red-throated Divers at Wakefield. (Nat.)

Tuck, J. G. Rare Birds at Flamborough. (Zool.)

Varley, J. Lare Birds cccurring at Huddersfield. (Nat.)

Weskiy, J. \&. Montagu's Harrier near York. (Ficld, Oct. 23.)

1875-76. Talbot, W. The Birds of Waliefield, 8 parts. (Nat., 1875-76.) Also reprinted separately, $\left.8 v^{\circ}\right)$, Hudclersfield: 1877 . [573.]

1876. [Anon.] Hoopoe at Tockwith. (Sci. Gossip.)

Buyes, 1. (ecurrences at beverley and Bridlington. 2I notes. (Zool.)

Butterfield, li. P. P. Pied Flycatcher breeding in Wharfeclale, etc. 5 notes. (T.c.)

Cordeaux, J. Manx Shearwater on N. E. Coast. (T.c.)

Cope, W. J. Peregrine Falcons breeding on Coast. (T.c.)

Edson, (x. Rare Birds near Malton. (T.c.) Smew on the Derwent. (Field, Feb. I9.)

Gripper, J. E. Rare Birds, etc., near York. (Zool.)

Gurney, J. H., junr. The Muscum at York; Sabine's Gull at Bridlington Quay; Common Buzzard at Scarboro'; Hooded Crows at 1 lamborough in Summer. (T.c.)

I.ister, T. Birds for Autumn Months at Barnsley. (Nat.)

Mosley, S. L. Red-winged Starling in Yorks. (T.c.)

lioberts, G. Goshawk near Whitby. (Yorkshire Post, Mar. I4.) Theb $[=$ Tuck], J. (i. Sandwich Tern, ete., at Iiley. (Ficld, Jan. x.) Idem by J. H. Gurney, junr. (T.c., Jan. 8.)

Tuck, J. G. Sea Birds at Ilamborough ; Black-brcasted Dipper, Black-throated Diver and Sandwich Tern near Filey; Glaucous Gull and Little Gulls at Flamborough; Blue-throated Warbler in Yorks.; Ivory Gull, etc. [in Yorks.]; Notes from Flamborough. (Zool.)

I877. "Beverley." Great Grey Shrike in E. Yorks. (Field, Sept. 8.) Boyes, F. Autumual Migration of Birds on Yorks. Coast; Buff Varicty of Song Thrush; Scandinavian form of Dipper in E. Yorks. ; Ornitholog. Notes from Beverley ; Rough-legged Buzzards in E. Yorks. (Zool.)

Boulton, W. W. Nesting of Shoveler in Yorks. [errore]. (Ficld, May I2, June 2.)

Butterficld, E. P. Eagle Owl in Yorks.; Pied Flycatcher Nesting in Yorks. 2 notes. (Zool.) 
Carter, J. Birds Nesting at Bedale, etc. 2 notes. (Field, May $19,26$.

Christy, R. M. White Sky Lark and other Birds near York. $($ Zool. $)$

Cordeaux, J. On Migration on N. E. Coast in autumn of 1876 ; Rare Birds of the Humber District. [partim.] (T.c.)

"Eboracum." Rough-legged Buzzard in Yorks. (Ficld, Apr. 28.) [Editorial.] Passenger Pigeon in Yorks. (Zool.)

Gurney, J. II., junr. On Flamborough Head. (Zool.) Idem by G. D. Rowley. (T.c.)

Howarth, E. Bewick's Swan and Canada Goose near Sheffield. (T.c.)

Hutchinson, J. H. Osprey near Bridlington. (T.c.)

"J. H. H." Osprey near Bridlington. (Field, July 7.)

Lister, T. Notes on Birds in Barnsley and S. Yorks. (Nal.)

Mosley, S. L. Red-winged Starling in Yorks. (Zool.)

Nelson, T. H. The Ornithology of the District round Redcar. 8vo. Bishop Auckland: 1877 .

"R. C." Pomatorhine Skua on Yorks. Coast. (Ficld, Oct. I3.)

Wesley, J. S. Hoopoe in Yorks. (Zool.)

Tuck, J. C. Goshawk, etc., in Yorks. (Zool.)

I878-86. Clarke, W. Eagle. The Birds of Yorkshire; Sheets I-5. (Tr. Yorks. Nat. Union, I., III., IV., IX.)

1878. Atkinson, J. C. I'rovincial Names of British Animals [in Cleveland]. (Zool.)

Cordeaux, J. Autumnal Migration on N.E. Coast. [partim.] (Zool.)

"Beverley." Rose-coloured lastor in E. Yorks. (Ficld, Feb. 9.)

Butterfield, E. P. P. Provincial Names [West Riding]. (T.c.); Notes on Birds of Bingley; Kite at Bingley; Grasshopper Warbler near Bingley ; Arrival of Spring Migrants ; Stonechat, etc., in Winter. (Nat.)

Foster, T. Peregrine Falcon near Selby. (Nat.)

Gurney, J. II., junr. On the Birds of l'lamborough. (Roweley's Orn. Miscell., III.)

Raine, W. Hawfinch near Leeds; Ornitholog. Notes. (Nat.)

Lee, R. Common Buzzard and Grey Shrike in Yorks. (Field, Nov. 30.)

N[elson], T. H. Notes from Redcar. (Ficld, Sept. 28.)

Rawson, I. G. S. Common Scoter in Ryburne Valley. (Nat.)

Roberts, A. Sabine's Gull at Scarborough. (Zool.)

Varley, J. Notes on Nat. Hist. of Bingley. (Nat.)

Whitaker, J. Harlequin Duck at Filey, etc. (Zool.)

1879. "Beverley." Wild Swans in E. Yorks. ; Pink-footed Geese [in E. Yorks.]. (Field, Feb. I5.)

Backhouse, J., junr. Supposed Nesting of Redwing near York. (Zool.) 
Butterfield, E. P. P. Nesting of Pied Flycatcher; Great Grey Shrike in Yorks. ; Hawfinch, Montagu's Harrier and Goosander Nesting in Yorks. 5 notes. (Nat.)

Canon, H. C. Nightingale near Patrington. (Field, June 2I.)

Carter, J. Wild Swan near Masham. (Field, Feb. 22); Note from N. Yorks. (T.c., Mar. 29.)

Clarke, W. E., and Others. Buzzard v. Kite at Bingley ; Yorks. Ornitholog. Notes for I878. (Nat.)

Cordeaux, J. Autumnal Migration in 1878 ; Further Notes on Migration. [partim.] (Nat.)

Hay, W. H. List of Birds in Township of Scarcroft. (Nat.) Additions. (T.c.)

Gurney, J. H. Fulmar Petrel in Yorks. (Zool.)

Ingleby, J. Nightingale near Ripon. (Sci. Gossip.)

Lucas, J. The Naturalist in Nidderdale. 2 pts. (Zool.)

Lee, R. Bewick's Swan in Yorks. (Field, Jan. II.) Idem by "S. K." (T.c., Feb. 22.)

Nelson, T. H. Ornitholog. Notes from Redcar; Shoveler, Bartailed Godwit and Fulmar Petrel at Redcar. (Zool.) Rare Birds near Redcar. (Field, Feb. I5) ; Migration of Skua Gulls. (Op. cit., Nov. I.) Ferruginous Duck at Coutham Marsh. (Zool.)

Willis, R. A. Caspian Tern at Filey. (Field, Nov. I5.)

Lister, T. Summer Migrants in S. Yorks. (Field, Aug. 9.) Notes from S. Yorks. (T.c., Aug. I6.)

Stamper, W. Grouse Quitting the Moors. (Zool.)

Raine, W. Ornitholog. Notes; Crossbill, etc., breeding near York; Montagu's Harrier nesting near York. (Nat.)

Thompson, E. Snowy Owl near Scarborough. (Land \& Water, Dec. 27.)

1879-89. B.O.U. Migration Reports. [Yorks, refs.] [93.]

I880. Atkinson, C. S. Nightingale in Yorks. (Field, June 5.)

Backhouse, J., junr. Skuas in Yorks. (Zool.)

"C. F. S." Bempton Cliffs in the mating season. (Field, Oct. 2.)

Clarke, W. E. Ornitholog. Notes from Yorks. (Zool.)

Carter, J. Turtle Dove in N. Yorks. (Field, June Io, 26); Quail in Yorks. $(O p$. cit., July 3I); Notes from N. Yorks. (T.c., Oct. 30) ; Storm Petrel in Yorks. ; Hooded Crow nesting in Yorks. (T.C., Nov. 20.)

Hanson, C. C. Black-throated Diver at Halifax. (Nat.)

"F. B." Turtle Dove, Osprey, Bee Eater and Green Sandpiper in Yorks., 4 notes. (Field, July 3.)

Hay, W. H. List of Birds in Township of Scarcroft. (Nat.)

Hewitt, W. Storm Petrel at York. (Field, Nov. 13.)

Lee, R. Rare Birds in Yorks. (Field, Dec. 4.)

Nelson, T. H. Extraordinary Arrival of Skuas on the Coast; Pomatorhine Skuas on Yorks. Coast. (Zool.) Hoopoe near Redcar. (Field, Nov. 6.) 
Mussell, G. Ornithol. Notes from Middlesbrough. (Field, Feb. I4.)

Raine, W. Nesting of Montagu's Harrier, Crossbill and TurtleDove near York; Hawfinch and Great Crested Grebe breeding near Leeds. (Zool.) Great Crested Grebe near Leeds; Water Rail Breeding near Selby. (Nat.)

Roberts, A. Hoopoe in Yorks. (Field, Sept. 25.)

Stamper, W. Great Grey Shrike in N. Yorks. (Field, Dec. II.)

Simpson, M. White's Thrush near Whitby. (Zool.)

Spurling, J. Manx Shearwater inland [near Wakefield]. (T.c.)

Tuck, J. G. The Cliffs at Flamborough. (T.c.)

West, L. H. Nightingale in E. Yorks; Alpine Swift in Yorks. (T.c.)

Widdas, G. A. Nesting of Montagu's Harrier ; Crossbills breeding near York. (T.c.)

Woodd, B. R. Jack Snipe in Yorks. in Aug. (Field, Jan. 3, In.) 188r. Backhouse, J., junr. Occurrence of Storm Petrels and Ivory Gull, 2 notes. (Zool.)

Bunker, T. Little Bittern near Goole. (Nat.)

Butterfield, E. Pied Flycatcher at Bingley. (Nat.)

Carter, J. Notes from N. Yorks. (Field, Jan. 29) ; Nests near Masham. (Op. cit., Aug. 27.)

Carter, J. W. Great Crested Grebe near Leeds. (Nat.)

"C." Buzzard in Yorks. (Field, Feb. I9.)

Clarke, W. Eagle, and Roebuck, W. D. Vertebrate Fauna of Yorks. 8vo. Huddersfield: I88I. (See also Supplements, Zool., I884; Nat., I884.) [132.]

Clarke, W. E. Occurrence of Rustic Bunting. (Zool.; Nat.)

Cordeaux, J. Spring Migration of Waders along E. coast in I88I. [partim.] (Zool.)

Hanson, C. C. Jack Snipe's Nest at Barkisland. (Nat.) Idem by W. E. Clarke. (T.c.)

Harper, R. P. Shore Lark near Scarborough; Little Egret in Yorks. (Zool.)

Higgins, W. H. Mergansers near Hull. (Field, Oct. I5.)

Hewett, W. Teal nesting in Yorks. (Zool.)

Lofthouse, R. Fauna of Cleveland (in Brit. Assoc. Handbook to Middlesbrough.) Post 8vo. Middlesbrough : I88I.

Nelson, T. H. Ivory Gull, Hoopoe, etc., at Redcar. (Zool.)

Lambert, T. M. Gadwall in Yorks. (Field, Jan. I5.)

Milligan, W. J. Grey Phalarope near Wetherby. (Field, Jan. I4.)

Robinson, W. Great Grey Shrike at Scarborough. (Nat.)

Salter, J. H. Great Grey Shrike in Yorks. (Zool.)

Sorby, A. E. Osprey near Sheffield. (Field, Oct. I5.)

Tuck, J. Uncommon Sea-Birds at Flamborough. (Zool.)

Varley, J. Osprey near Huddersfield; Snow-Buntings at Huddersfield. (Nat.)

I882. Backhouse, J., junr. White's Thrush in Yorks. (Zool.) 
"Beverley." Supposed Honey Buzzard near Beverley, etc., 3 notes. (Field, Sept. 23.)

Brady, W. E. Great Grey Shrike near Barnsley. (Zool.)

Butterfield, E. P. P. Ornitholog. Notes; Arrival of Spring Migrants, etc. (Nat.)

Carter, J. Shoveler nesting in Yorks. (Field, May I3); Notes from N. Yorks. (Op. cit., Dec. 23.)

Clarke, W. E. Ornitholog. Notes from Yorks. (Zool.; Nat.); Emberiza nustica near Easington. (Ibis.)

Dobree, N. F. Fork-tailed Petrel, etc. near Beverley. (Zool.)

Hewett, W. Teal and Redshank breeding in Yorks. ; Firecrest in Yorks. (Zool.)

Inchbald, P. White's Thrush in Yorks. (Field, Feb. II.)

Raw, W. H. Hoopoe in Yorks. (Field, Oct. 7.)

Slater, H. H. Pilmoor : Occurrence of the Twite's Nest. (Nat.) Idem by F. G. S. Rawson. (T.c.)

[1882.] Lucas, J. Studies in Nidderdale. 8vo. Lond. : N.D. [363.]

I882-93. Nelson, T. H. Ornitholog. Notes from Redcar, 5 pts. (Zool., I882, I888, I890, I89I, I893.)

I882-85. Roberts, G. Topography and Nat. Hist. of Lofthouse and Neighbourhood. 2 vols. Post 8 vo. Lond. : etc., I882-85. [492.]

I883. Backhouse, J., junr., Occurrence of American Kestrel in Yorks. ; Uncommon Birds near York. (Zool.)

"Beverley." Arrival of Waxwings. (Field, Jan. 27, Feb. 24.) Grey Geese. (T.c., Feb. I7.)

Butterfield, E. P. P. Local Birds of Wilsden District. (Nat.)

Carter, J. Ornithol. Notes from N. Yorks. (Field, Jan. 20, May 26) ; Redbreasted Merganser on the Yare. (T.c., Mar. Io.) Inchbald, P. Breeding of Nightingale near Harrogate. (Field, June 30.)

Lister, T. On Distribution and Dates of Spring Migrants in Yorks., compared with West of England and Ireland. (Rep. Br. Assoc. Adv. Sci.) ; List of Birds of Barnsley District. (Tr. Barnsley Nat. Soc.); Uncommon Birds near Barnsley. (Field, May I2) ; Rare Birds in S. Yorks. (Op. cit., Dec. I.)

Macpherson, H. A. Sooty Shearwater at Bridlington. (Zool.) Norcliffe, F. B. Solitary Snipe in Yorks. (Field, Sept. I5.) Smith, C. F. Ornithol. Notes from Yorks. (Field, Jan. I3.) Wolstenholme, C. D. Uncommon Birds near York. (Zool.)

I883-85. Clarke, W. E., and Roebuck, W. D. [The Birds of Washburndale. In] Notes on Physical Features and Nat. Hist. of Washburndale. (Nat., I883.) Idem. Additions. (Op. cit., I885.)

I884. Addyman, J. W. Bittern in Yorks. (Field, Feb. 2.)

Backhouse, J., junr. Great Grey Shrike at York; American Kestrel in Yorks. (Zool.) 
Bailey, M. Notes from Flamborough. (Land \& Water, Oct. II ; Nov. 8,22 .)

Carter, J. Oystercatchers inland. (Field, Mar. I.)

Carter, T. Green Sandpiper in N. Yorks. (Zool. ; Field, Sept. I3); Breeding of Hawfinch in N. Yorks. (Zool. ; Field, Aug. 30) ; Notes from N. Yorks. (Field, Feb. 23 ; Oct I8) ; Egging on Coast of Yorks. ; Breeding of Redshank in N. Yorks. (Zool.)

Clarke, W. E., and Roebuck, W. D. Notes on Vertebrate Fauna of Yorks, 2 pts. (Nat.) Idem, I pt. (Zool.)

Clifton, Lord. Arrival of Woodcocks. (Field, Oct. 25.)

Cordeaux, J. The Sea Birds at Flamborough. (Nat.); Notes from the Humber in autumn of 1884 . [partim.] (Field, Nov. 22.)

Eskholme, G. W. Large Colony of House Martins. (Field, Sept. 13.)

Fisher, T. Blue-throated Warbler on Spurn Head. (Zool.)

Fountain, J. A Pure White Herring Gull. (Field, Oct. 4.)

Gibbins, E. J. Pied Lapwing. (Sci. Gossip, Aug.)

Harding, I. Migratory Birds on Yorks. Moors. (Zool.)

Harting, J. E. Gulleries [in Yorks.]. (Field, Feb. I6.)

Hewett, W. Terns and Gulls inland in Yorks. (Zool.)

Hopkinson, R. G. Quail on Yorks. Wolds. (Field, Oct. I8.)

Howard, R. J. Reported Cranes near Clitheroe. (Zool.)

Inchbald, P. Breeding of Hawfinch in Yorks. (Field, Aug. 23.)

Jackson, J. J. Woodcocks near Whitby. (Land \& Water, Nov. I5.)

Lister, T. Natural History Notes from Barnsley, etc. 4 pts. (Nat.) Idem, 3 pts. (Nat. Hist. Journ.)

Nelson, T. H. Sooty Shearwater at Redcar. (Zool.); Black Pomatorhine Skua at Redcar. (Zool. ; Field, Oct. II.)

Pullan, H. N. Nightingales in Yorks. (Sci. Gossip, July.)

Rawson, F. G. Birds near Halifax. (Nat.)

Romyn, J. R. D. Quail in Yorks. (Field, Oct. II.)

Seebohm, H. Falco sparverius shot in Yorks. (P.Z.S.)

Saunders, H. Puffinus griseus at Redcar. (P.Z.S.; Zool.; Field, Mar 8.)

Slater, H. H. Barred Warbler in Yorks. (Zoob.; P.Z.S.)

Storey, W. Dotterel near Leeds; the Stonechat in Nidderdale. (Field, Oct. I8.)

Thompson, E. V. Grey Phalarope in Yorks. (Zool.)

Tinkler, J. E. Ornitholog. Notes from N.W. Yorks., 2 pts. (T.c.)

Tuck, J. G. Lesser Blackbacked Gull on Yorks. Coast. (T.c.)

West, E. W., and others. Tufted Duck Breeding in Yorks. (Field, Aug. 2, 9, I6.)

Whitaker, J. Little Owl captured off Scarborough. (Nat.)

I884-9I. [Various Writers.] Birds observed by Yorks. Naturalists' Union [various localities]. (Nat., I884-9r.)

I885. Astley, H. D. Pied Flycatcher, etc, at Bolton. (Zool.) 
Angus, W. C. Common Bittern near Leeds. (Pr. Nat. Hist. Soc. Glasg., I.)

Backhouse, J., junr. Notes on Avifauna of Upper Teesdale; Capture of Bittern in Yorks. (Nat.)

Bailey, M. Notes from Flamborough, etc. (Land \& Water, Feb. 2I, Apr. 25, May 2, Sept. 26, Oct. 3I.)

Carter, T. Lesser Black-backed Gull on Yorks. Coast, 2 pts. (Zool.)

Clark, J. E. Yorks. Rookeries. (Nat. Hist. Joum., Apr.)

Clarke, W. E. Lesser Black-backed Gull and Rock Dove on Yorks. Coast. (Zool.); Desert Wheatear in Yorks. (T.c.); Arrival of Summer Visitants. (Nat.)

Erskine-Stuart, J. A. Herons and Heronries. (Nat. World, Nov.)

Foljambe, F. J. S., and F. H. Ross's Gull in England. (Field, Nov. 21, 28.)

G[arwood], C. R. Idem. (T.c., Dec. 5.)

Fortune, G. Redwing [?] nesting in Yorks. (Zool.)

Inchbald, P. Arrival of Fieldfare and Redwing. (Field, Oct. 24.)

J[ackson], J. J. Kingfishers near Whitby. (Land \& Water, Jan. I7.)

Lister, T. S. Yorks. Notes. (Nat. Hist. Journ., Mar.); Nat. Hist. Notes from Yorks. (Zool.)

Nelson, T. H. Reported Occurrence of Blue-winged Teal [errore for Garganey] near Redcar. (Zool.)

Raine, T. Great Grey Shrike near Leeds. (Nat., Aug.; Nat. World, Sept.)

Rawson, F. G. S. Birds near Halifax. (Nat.)

Salter, J. H. Yorks. Coast Bird Notes, ete., 4 pts. (Nat. Hist. Journ.)

Sclater, P. L. Curious Duck shot in Yorks. (P.Z.S., Mar. I7; Zool., May.)

Southwell, T. Unrecorded occurr. of Whiskered Tern. (Zool.)

Stephenson, T. Notes from Whitby. (Nat.)

Storey, W. Bird Notes from Nidderdale. (T.c.)

Whitaker, J. Little Owl in Yorks. (Zool.)

IS85-96. Bailey, M. Flamborough Bird Notes. [var. pts.]. (Nat., I885-96.)

1886. Backhouse, J., junr. Little Gull at Whitby. (Op. cit.)

Bailey, M. Shore Lark, etc, at Flamborough. (Land \& Water, Mar. 6, Apr. 3.)

Carter, J. Gannet Inland. (Ficld, Oct. 9.) Idem by M. O. Mathews. (T.c., Nov. I3.)

Carter, T. Notes from N. Yorks. (Zool.; Field, May 22, Oct. 23.) ; Marfield Pond, Masham, and its Bird-Life. (Nat.)

Chapman, E. List of Wensleydale Birds. (Nat.)

Clarke, W. E. On Saxicola descrti in Yorks. (Ibis.) 
Clarke, W. E., Roebuck, W. D., and Storey, W. Birds of Upper Nidderdale. (Nat.)

Emmet, J. Hawfinch nesting at Boston Spa. (T.c.)

Fortune, R. The Turtle-Dove in Yorks. (T.c.)

Gallwey, Sir R. P., Bt. Wigeon nesting in Yorks. (Zool.); Former Occurrence of Black Game on the Blubberhouses MIoors. (Nat.)

Gurney, J. H., and Backhouse, J. junr. Sturmus unicolor in Yorks. (T.C.)

Hanson, C. E. Eagle Owl near Huddersfield. (T.c.)

Harper, R. P. Tengmalm's Owl in Yorks. (Zool.)

Lister, T. S. Yorks. Bird Notes for 1885. (Nat. Hist. Journ.) ; Birds observed near Barnsley in I885. (Field, Feb. 6.)

Mitchell, F. S. Raven in Bowland. (Nat.)

Mortimer, R. Stone Curlews on the Yorks. Wolds. (T.c.)

Nelson, T. H. Grouse and the Snowstorm. (Field, Feb. I3; Zool.; Nat.) ; Autumn Migration on Yorks. Coast. (Field, Oct. 23.)

Paterson, A. Orange-legged Hobby near Doncaster. (Nat.)

1887. "Auceps." Habits of Pink-footed Goose in E. Yorks. (Field, Jan. I, I5, 29).

Backhouse, J. Sooty Shearwater at Flamborough Head. (Nat.) Boyes, F. The Green Sandpiper. (Field, Mar. I2) ; Wild Geese in E. Yorks. (T.c., Sept. I7) ; Solitary Snipe and Greenshank in E. Yorks. (T.c., Sept. I7) ; Sooty Shearwaters at Flamborough Head. (T.c., Oct. 29); Dotterel in Marshes. (T.c., Nov. I2, 26) ; Long-tailed Ducks at Flamborough. (T.c., Nov. 26) ; Off Flamborough Head; Solitary Snipes in E. Yorks. (T.c., Oct. 29) ; Sabine's Gull on Yorks. Coast. (T.c., Oct. I) ; Habits of Pink-footed Goose in E. Yorks. (Field, Jan. 8, 22) ; Habits of Bernacle Goose. (T.c., Jan. 22) ; Fulmar Petrel, Little Gull, etc., at Flamborough, 2 notes. (Op. cit., Nov. 26.)

Bunker, T. List of birds observed near Goole. (Goole Sci. Soc., I887.)

Carter, J. Cirl Bunting nesting in Yorks. (Field, Oct. I.)

Carter, T. Notes from N. Yorks. (T.c., Apr. 16, 23; May 7, 28 ; June 4 ; Oct. I.)

Christy, M. Birds of Our Premises [Bootham School, York]. (Nat. Hist. Journ., Mar. \& Apr.)

Clarke, W. E. An old Yorks. Decoy. (Field, Nov. 26.)

Clarkson, W. C. Great Grey Shrike in Nidderdale. (Nat.)

Cordeaux, J. Geese of Humber District. (Field, Jan. 29, Feb. I2.) Idem by F. Boyes. (T.c., Feb. 5, I9.) Idem by W. E. Clarke. (T.c., Feb. I2, 26.)

$\mathrm{D}[$ enham, ] T. E. Robbing the Skouts at Flamborough. (Nat. World, Apr. \& May.)

Fitzgerald, F. R. Hawfinch at Harrogate. (Zool.); Great Spotted Woodpecker and Hawfinch near Harrogate. (Nat.) 
Fortune, R. The Birds of Harrogate and District. Reprinted from the Garner: 1887 . [218.]

Fortune, R. Rare Birds near Harrogate, etc. (Nat. World); Hawfinch in Yorks. (Zool.) ; Hawfinch and Pink-footed Goose at Harrogate. (Nat.)

Gurney, J. H., junr. Little Gulls at Flamborough Head. (Nat.) "J. F." Great Northern Diver near Thirsk. (Field, Jan. 8.)

Harper, R. P. Sooty Shearwater at Flamborough; Uncommon Birds near Scarborough. (Zool.)

Inchbald, P. Nightingales in Yorks. (Field, May I4); Birds at Hornsea Mere. (Op. cit., Nov. I2.)

Lofthouse, R. The River Tees: Its Marshes and their Fauna. (Nat.)

Nelson, T. H. Ornitholog. Notes from Redcar, I886. (T.c.) Autumnal migration at Teesmouth. [partim.] (Zool.) Curlew Sandpiper, Little Stint, Long-tailed Ducks and Scoters near Redcar, 2 notes. (Field, Nov. 26.)

Prodham, H. Unrecorded Occurrence of Golden Eagle in Yorks. (Nat.)

Roberts, G. Corn Bunting with Crossed Bill. (Sci. Gossip, Mar.)

Storey, W. The Hawfinch in Nidderdale. (Field, Sept. 3.)

—. Bulwer Petrel as a Yorks. bird. (P.Z.S., pp. 562-33.

I888. Backhouse, J. Additions to Avifauna of Upper Teesdale. (Nat.) Barchard, G. Pallas's Sand Grouse. (Field, June 9, I6; July I4.)

Boyes, F. Reappearance of Pallas's Sand Grouse. (Op. cit., May 26; June 23; Nov. Io; Dec. 8.)

Brown, C. E. Rough-legged Buzzard near Leeds. (Op. cit., Nov. Io.)

Burtt, A. H. Goosander near Sherburn. (Nat. Hist. Journ.)

Butterfield, E. P. Crested Tit near Keighley. (Nat.); Blackthroated Diver near Bingley. (T.c.)

Byers, H. S. Bittern near Ripon. (T.c.)

Carter, J. Notes from Masham. (Field, Apr. 7, 2I ; June 2, 9); Golden Oriole in Yorks. (T.c., May I9); The present visitation of Sand Grouse. (T.c. June 2.)

Clarke, W. E. White Stork near Scarborough ; Nightingale near Beverley; Purple Heron in W. Yorks; Arrival of Crossbills. (Nat.)

Clarke, W. E., Cordeaux, J., and others. Irruption of Pallas's Sand Grouse. (T.c.)

Cole, E. M. Nesting of Norfolk Plover on the Wolds. (T.c.)

Cordeaux, J. Occurrence of American Pectoral Sandpiper on Yorks. Coast ; Pallas's Sand Grouse in Spurn district. (T.c.)

Fortune, R. Pied Flycatcher, Hawfinch, Redshank and Pallas's Sand Grouse, etc., near Harrogate, 5 notes. (Zool.); Pallas's Sand Grouse [in Yorks.]. (Field, June 9, I6); Idem by other writers. (T.c., June 9, I6, 23, 30 ; July 21 ; Oct. 27 ; Dec. I, 22.) 
Gurney, J. H., junr. Reported Occurrence of Little Egret in Yorks. (Zool.)

Harper, R. P. Pallas's Sand Grouse in Yorks. 2 notes; White Stork at Scarborough. (T.c.)

Harting, J. E. On Reappearance of Pallas's Sand Grouse. [partim.] (Zool.)

Inchbald, R. Great Crested Grebe in Yorks.; Spotted Crake in Holderness. (Nat.)

Nelson, T. H. Pallas's Sand Grouse in N. Yorks. (T.c.)

Newton, A. Bulwer's Petrel [in Yorks.]. (Zool. ex P.Z.S.) St. Quentin, W.H. Preservation of Indigenous Animals. (Ficld, Sept. I.)

I889. "Auceps." The Hawfinch in E. Yorks. (Field, May II.)

Backhouse, J. Black Redstart at Scarborough. (Nat.)

Boyes, F. Pallas's Sand Grouse-a disclaimer. (Field, Feb. 9); Nightingale in E. Yorks. (Field, May 25) ; Variety of Ring Ouzel. (T.c., Aug. 3I) ; Migration of Whimbrel ; Crossbills in E. Yorks. ; Great Spotted Woodpecker near Hornsea. (T.c., Sept. 28) ; Spotted Crake breeds near Beverley; Little Stints in E. Yorks., etc. (T.c., Oct. I2.)

Carter, J. Arrival of Summer Birds at Masham, var. notes. (T.c.)

Chase, R. W. Embcriza cioides at Flamborough Head. (Midland Nat.)

Clarke, W. E. Emberiza cioides, first occurrence in Europe. [Flamborough.] 3 notes. (Nat.); Wintering of the Ruff; Woodcock at Spurn Head. (T.c.)

Clifton, Lord. Two-barred Crossbill in Yorks. (Field, Dec. 7.) Cooke, G. Little Gull in Yorks. (T.c., Nov. I6.)

Cordeaux, J. Notes from the Yorks .... Coast in Autumn I888; Notes from ... Holderness. (Nat.)

Fortune, R. Little Gull and Sclavonian Grebe near Scarborough. (T.c.) ; Nightingale at Ripley. (T.c.; Field, June I.)

Harding, I. Rare Birds in Yorks. (Wesl. Nat., Oct.)

Harper, R. H. Ornitholog. Notes from Yorks. (Zool.)

Hewett, W. Sand Grouse near York; Hawfinch near York. $(N a t$.)

Howarth, E. Pallas's Sand Grouse on Yorkshire Wolds. (T.c.)

Hume, D. E. Bittern on the Humber. (Field, Mar. I6.)

Inchbald, P. Great Grey Shrike in Holderness. (Zool.) Great Spotted Woodpecker in E. Riding. (Field, Sept. 2I.)

Ingleby, J. Crossbills in Nidderdale. (Nat.)

Ismay, J. Some Account of Parish of Mirfield in I755. (Yorks. Notes \& Queries, pt. Io, Jan., I888.)

Jefferson, J. J. D. Great Plover near York. (Field, Jan. 5) ; Idem by F. Boyes. (T.c., Jan. I2.)

Knubley, E. P. Nightingales near Knaresborough. (Nat.)

Lambert, T. W. Sabine's Gull at Bridlington. (Field, Aug. 3r.) 
Mosley, S. L. Nightingale near Owston Stones and Knaresborough, 2 notes. (Nat.)

Nelson, T. H. Sand Grouse in N. Yorks. ; Sand Grouse near Redcar. (Zool.) ; Sand Grouse in Cleveland. (Nat.)

Prodham, H. Dotterel on Pickering Moors. (T.c.)

Roberts, G. Hawfinches and Crossbills at Stapleton Park. (Sci. Gossip.)

Slater, H. H. Two-barred Crossbill near Essington. (Nat.) Smith, C. W. Notes on Birds of Central Ryedale. (T.c.)

Stephenson, T. Ruff and Goshawk near Whitby. (T.c.)

Tristram, H. B. Emberiza cioides at Flamborough. (P.Z.S., pt. I ; Field, Jan. I9; Ibis, p. 293:)

Wheldon, J. A. Bearded Tit on Banks of Ouse. (Sci. Gossip.)

I\$89-92. Nelson, T. H. Ornitholog. Notes from Redcar and Teesmouth, I887-8 to r89r-92, 4 pts. (Nat. I889-92.)

I889-99. Cordeaux, J. Bird Notes from Humber District, var. pts. (Nat., I889-99.)

1890. Aplin, O. V. Distribution, etc., of Spotted Crake. (Zool.) [partim.]

Backhouse, J. Eastern Turtle Dove in Yorks. ; Yellow Wagtail in Swaledale; Yorkshire Notes on the Tree-Sparrow. (Nat.) Barchard, G. Stork in Holderness. (Field, Aug. 9.)

Barkley, S. Sabine's Gull at Flamborough. (T.c., Sept. I3.) Booth, H. B. Bird Notes from Malham District. (Nat.)

Bowers, J. W. Destruction of Plovers' Eggs. (Field, Apr. I9.)

Boyes, F. Great Plover or Thick-knee near York. (T.c., Jan. I2) ; Migration of Woodcocks. (T.c., Nov. 22) ; Swifts Rising from the Ground. (T.c., Dec. 6); Abundance of Snipe near Beverley. (T.c., Dec. 20) ; Little Grebe in E. Yorks. (T.c., Dec. 20); Bittern in Yorks. (T.c., Dec. 27.)

Carter, B. Great Grey Shrike in N. Yorks. (T.c., Mar. 8.)

Carter, J. Notes from N. Yorks. (T.c., Apr. 12) ; Goosander near Masham. (T.c., Mar. 8.)

Chapman, J. Alpine Swift at Scarborough. (T.c., Oct. I8.)

Cordeaux, J. Woodcocks. (T.c., Nov. I5, 29.) Probable Occurrence of Phylloscopus superciliosus; White-tailed Eagle at Spurn. (Nat.)

Crabtree, A. Hen Harrier at Blackstone Edge. (Halifax Nat.)

Fortune, R. Notes on the Starling; Notes on Migrants about Harrogate. (T.c.)

Goodchild, J. G. Birds Observed in Upper Swaledale. (T.c.)

Gurney, J. H., junr. White Variety of Little Gull [near Flamborough]. (Zool.) Red-breasted Flycatcher at Scarborough. (Nat.; Field, Jan. I8.)

Harper, R. P. Notes from Scarborough; Eared Grebe and Little Auk near Scarborough. (Zool.) 
Inchbald, P. Grey Shrike near Hornsea. (Field, Feb. I); Supposed Blue Thrush near Scarborough. (T.c., Oct. I8); Rock Pipit in Holderness. (T.c., Nov. 8.)

Lofthouse, R. Bird Notes from Tees District. (Nat.)

Macpherson, H. A. Dotterel in Yorks. (T.c.)

Nelson, T. H. Great Skua on the Yorks. Coast. (Zool.)

Phillips, J. H. Waxwing and Dotterel in Central Ryedale. (Nat.)

Slater, H. H. Yorks. Records for Great Black Woodpecker. (Nat.) Loxia bifasciata in Yorks. (Zool.)

Tuck, J. G. Seafowl at Scarborough. (Zool.)

Ward, J. Cirl Bunting nesting near Wakefield, 2 notes. (Nat.)

I8gI. Atkinson (J. C.) Forty Years in a Moorland Parish. 8vo. Lond. : I89I. [3I.]

Backhouse, J. Hawfinches near Harrogate. (Nat.)

Boyes, F. Supposed Snow Geese in E. Yorks. (Field, Jan. 3I ; Feb. 7) ; Woodcock in Snow. (T.c., May 9) ; Autumn Migration of Thrushes. (T.c., Nov. 28) ; Spotted Redshanks in E. Yorks. (T.c., Nov. 28.)

Carter, J. Habits of the Water Ouzel. (Field, Mar. 7.)

Clarke, W. J. Red-necked Grebe, Spotted Crake and Whitetailed Eagle at Scarborough, 3 notes ; Supposed Occurrence of Kentish Plover at Scarborough. (Zool.)

Cordeaux, J. Great Grey Shrike at Spurn; Icterine Warbler in Holderness. (T.c.) Notes from the Humber. (Field, Feb. 2I) ; Probable Occurrence of Snowy Owl. (Op. cit., Oct. 3) ; Late Stay of Swifts. (T.c., Oct. 3I) ; Migration of Barn Owl. (T.c., Nov. I4) ; Icterine Warbler at Easington. (Nat.)

Crosland, J. H. Ornithology in the Holidays, etc., 3 notes. (Nat. Hist. Journ., Apr.-June.)

Fortune, R. Shoveler, Grey Phalarope and Cream-coloured Variety of Skylark near Harrogate. (Nat.) ; Manx Shearwater and White Variety of Thrush in Upper Nidderdale. (Nat.) Gurney, J. H. Red-breasted Flycatcher at Scarborough. (Zool.) Hall, A. B. Thirsk Notes. (Nat. Hist. Journ., Mar.)

Harland, H. S. White Stork in Yorls. (Field, Nov. 2r.)

Harper, R. P. Bernacle Goose near Scarborough. (Zool.)

Hewett, W. Eared Grebe near York. (Nat. ; Sci. Gossip.)

Hill, R. H. Curiosities in Eggs [Halifax]. (Sci. Gossip.)

Howarth, E. Uncommon Birds in S. Yorks. (Nat.)

Lydekker, R. Former occurrence of Chough in Yorks. (Ibis, p. 385.)

Macpherson; H. A. The Chough in Yorks. (Nat.)

Mills, E. E. Red-legged Partridges in Cleveland. (Field, Mar. 2I.)

Morley, J. Manx Shearwater Inland. (T.c., Sept. 5 ; Zool.)

Nelson, T. H. Red-legged Partridges in Cleveland. (Field, Mar. I4; Apr. 4) ; Forktailed Petrel [in Cleveland]. (Op. cit., Oct. Io) ; Wood Lark near Redcar. (Zool. ; Nat.) 
Ormerod, G. F. Grey Phalarope inland in Yorks. (Field, Nov. 7.)

Parkin, G. Great Northern Diver near Wakefield. (Nat.)

Sharp, H. Wildfowl at Beverley [supposed Snow Geese]. (Field, Jan. 24, p. I23; Feb. 7) ; Spotted Redshank. (Op. cit., Nov. 28.)

Summerfield, R. A. Water Rail, Brambling, Goosander and Spotted Crake near Ripon. (Nat.)

Waite, E. R. Vertebrates of the Western Ainsty. (T.c., Apr. and June). [Also reprinted separately?]

Woodd, C. H. B. Vertebrate Fauna of Langstrothdale. (T.c.)

I892. Aplin, O. V. Distribution of Cirl Bunting. (Zool.); Status of the Woodchat. (T.c.) [partim.]

Backhouse, J. Gadwall in Yorks. ; Baillon's Crake near Pocklington; White variety of Jay near York. (Nat.)

Bell, Major. Solitary Snipe in Yorks. (Field, Oct. I5.)

Booth, H. B. Notes from W. Yorks., 2 pts. (Garner.)

$\mathrm{B}[$ ooth, ] B. B. H. Reed Warbler nesting at distance from Water. (Field, June 27.)

Chapman, E. Pomarine Skua in Wensleydale. (Nat.)

Clarke, W. J. Ornitholog. Notes from Scarborough; Bernacle Goose at Scarborough. (Zool.)

Cordeaux, J. Garganey in Holderness; Rare Wheatear seen near Spurn; Barred Warbler in Holderness; Migration of Yellow Wagtail. (Zool.) ; Large Raptorial Birds in Humber District. (Nat.) ; September Woodcocks in Humber District. (Field, Oct. 8.)

Doncaster, E. D. Manx Shearwater at Sheffield. (T.c., Sept. 24.)

Fortune, R. Great Grey Shrike at Harrogate. (Nat.)

Harland, H. S. Iceland Gull near Scarborough. (Field, Nov. 12.)

Harting, J. E. "Belated Swallows" [near Halifax in Feb.]. (Field, Jan. 30.)

Hewett, W. Woodcock breeding in S.E. Yorks. (Nat.)

Howse, R. Macqueen's Bustard near Marske. (T.c.)

Inchbald, P. Snow Bunting and Shore Larks at Spurn. (Field, Jan. 30.)

Lee, R. Eagles [Whitetailed ?] seen at Thirsk; Lesser Kestrel in Yorks. (Field, Apr. 23.)

Mosley, S. L. Ortolan Bunting near Bedale. (Nat.)

Nelson, T. H. Macqueen's Bustard near Redcar. (Field, Dec. I7; Nat.)

Newton, A. Bulwer's Petrel. (P.Z.S. ; Nat. ; Zool.)

Seebohm, H. Barred Warbler in Yorks. (Bull. B.O.C., I.)

Stevenson, T. Bird Notes from Whitby. (Nat.)

Tinkler, J. E. The Avifauna of Askengarthdale, Swaledale, etc., 2 pts. (T.c.)

I893. Bailey, M. Great Shearwater at Flamborough. (Nat.) 
Cordeaux, J. Garganey in Holderness; Black Redstart at Flamborough. (Zool.); American White-throated Sparrow in Holderness; Stray Notes from Yorks. Coast. (Nat.) ; Lapland Bunting in Yorks; White-throated Bunting. (Zool.)

Evans, C. J. Black Tern in Yorks. (Zool.)

Hewett, W. Spotted Crake at Otterington; Bittern near Driffield. (Nat.)

Howse, R. Macqueen's Bustard on the Yorks. Coast. (Zool.) Peek, E. Green Sandpiper wintering near Settle. (Nat.)

Slater, H. H. Garganey in Holderness. (Zool.)

1894. Boyes, F. Barred Warbler at Skirlaugh. (Field, Dec. 29) ; Yellow-browed Warbler near Beverley. (T.c., Oct. 27.)

Cordeaux, J. Lapland Bunting at Flamborough. (Zool.); Linota exilipes on E. Coast of Yorks.; Barred Warbler in Holderness. (Nat.)

Harting, J. E. Barred Warbler in Yorks. ; On Recent Occurrence of Yellow-browed Warbler in Yorks. (Zool.) Exhib. of Yellow-browed Warbler shot near Beverley. (Bull. B.O.C., IV.)

Percival, J. Grey Plover on Yorks. Moors in Aug. (Zool.)

Stephenson, T. Nat. Hist. Notes from Whitby, I892-4. (Nat.)

1895. [Anon.] Marsh Harrier near Bradfield. (Sheffield Daily Tclegraph, Sept. I9.)

Charles, W. G. Notes from Wakefield. (Nat. Joum., IV.)

Clarke, W. J. Dotterel at Scarborough. (Zool.)

[Editorial.] Egyptian Goose near Huddersfield; Gannet and Little Auk on Coast, etc., 8 notes. (Nat. Journ., IV.)

Grabham, O. Brünnich's Guillemot at Filey. (Zool.)

Cordeaux, J. Rare Brit. Birds in Humber district. [partim.] (T.c.)

Harting, J. E. Brünnich's Guillemot on Yorks. Coast. (T.c.)

Irby, L. H. Great Bullfinch on Yorks. Coast. (P.Z.S.)

Lilford, Lord. Possible occurr. of American Wigeon on Yorks. coast. (Field, Mar. 9.)

Storey, W. Ornitholog. Notes from Yorks. ; Grebes and Goldeneye in Washburn Valley. (Zool.)

1896. Audas, T. Guide to the Birds, Hull Museum. (Hull Lit. \& Phil. Soc., 1896.)

Backhouse, J. Upper Teesdale, Past and Present. Cr. Svo. Barnard Castle : 1896.

Cordeaux, J. Macqueen's Bustard in Holderness. (Zool.); Northern Bullfinch in Yorks. (Nat.)

Clarke, W. J. Nightingale at Scarboro'; Ornithol. Notes from Scarboro'. (Zool.)

Haworth-Booth, B. B. Little Bustard in Holderness; Barred Warbler in E. Yorks. (T.c.)

Howarth, E. Rare Birds at Bridlington. (T.c.)

Peake, E. Avifauna of Settle and Upper Ribblesdale. (T.c.)

Stephenson, T. Nat. Hist. Notes from Whitby, I894-6. (T.c.) 
St. Quintin, W. H. Hoopoe in E. Yorks. in Winter. (Field, Jan. 25).

Swailes, G. C., and others. Swallows wintering in England. (Field, Nov. 28, Dec. 5.)

Swann, H. Kirke. Dartford Warbler nesting in Yorks. (Ornithologist.) Idem by W. R. Butterfield. (Nat.)

Witherby, H. F. Macqueen's Bustard in Yorks. (Knowledge, Nov.)

I897. [Anon.] Nat. Hist. Records of Scarborough District. [Pt. I, Sec. ii., Birds.] (Scarboro' Field Nat. Soc.)

Backhouse, J. Little Owl in Yorks. (Nat.)

Clarke, W. J. Little Auks and Little Gulls at Scarborough; Notes from Scarborough. (Zool.)

Cordeaux, J. Migration at Spurn Lighthouse in I896; Nightingale near Scarborough. (T.c.) Pectoral Sandpiper in Holderness. (Knowl.)

Ely, G. F. On the Yorks. Moors. (Nat. Chron., Sept.)

Harting, J. E. Former occurrence of Gt. Bustard in Yorks. (Field, Mar. 6.) Idem by W. H. St. Quentin. (T.c., Mar. 27.)

Milburn, C. Birds of a Yorks. beck. (Nat. Chron., Sept.)

Swailes, G. C. Serin at Beverley. (Field, June 5.)

Tegetmeier, W. B. Hybrid Black Grouse-Pheasant near Whitby. (Field, Jan. 23.)

I898. Arundel, W. B. Ackworth Birds, being a List of Birds of the District. Lond. : I898. 8vo. [28.]

Boyes, F. Osprey at Beverley. (Field, May 7, I4, June II) ; Arrival of Redwings. (Op.cit., Oct. 29) ; Great Spotted Woodpecker in Yorks. (Op. cit., Dec. I 7$)$. Idem. at Beverley. (T.c., Dec. 3I.)

Carter, J. Hawfinch in Yorks. (Op. cit., May 7.)

Cordeaux, J. Migration at the Spurn Lighthouse in I897-8; Forktailed Petrel on Yorks. Coast. (Zool.); Longtailed Duck in Holderness. (Knowledge.)

[Some of Cordeaux's papers on the Humber District under Lincs. refer also to the Spurn district of Yorks.]

Crowther, Beynon V. B. Pied Flycatcher in Yorks. (Sci. Gossip, June.)

Clarke, W. J. Notes from Scarborough. (Zool.) Wigeon nesting in Yorks. (Knowledge.)

Grabham, O. Rough Nesting-notes from Yorks. (Zool.)

Milburn, C. Birds of Teesmouth, 2 pts. (Nat. Chron., Dec. I897, Sept. I898.) Notes from Cleveland. (T.c., Nov. I898.)

Saunders, H. [Exhib. of Levantine Shearwater from Scarboro'.] (Bull. B.O.C., VIII.)

1899. Butterfield, E. P. Arrival of Spring Migrants in Yorks.; Hawfinches near Bradford. (Zool.)

Clarke, W. J. Iceland Gull at Scarboro'. (T.c.) 
Boyes, F. Sabine's Gull at Flamborough Head. (Field, Oct. 2I) ; Solitary Snipe and Blacktailed Godwit near Beverley. (Op. cit., Oct. 7); Wild Swan in E. Yorks. : Longtailed Ducks in E. Yorks. (Op. cit., Jan. I4); Common and Honey Buzzards in E. Yorks. (Op. cit., Oct. I4.)

Grabham, O. Wild Swans in Yorks. (Op. cit., Jan. 2I.)

Mason, G. W. Sea Birds of Bempton Cliffs. (Nat. Chron., Jan.) McLean, K. Avifauna of Stathes and Loftus-in-Cleveland. (Nat.) Milburn, C. Ornithol. Notes from Middlesbrough. (Nat. Chron., Feb.)

Morley, J. Osprey near Scarborough. (Field, Nov. 4.)

Meiklejohn, A. H. Appearance of Great Spotted Woodpecker in Yorks. (Zool.)

Saunders, H. Twelve occurr. of Tengmalm's Owl in Yorks. (Man. Brit. Birds, ed. ii.) I899.

Sliarp, H. Redlegged Partridge near Scarborough. (Field, Apr. I.)

Southwell, T. Nesting of Goshawk in Yorks. (Zool.)

St. Quintin, W. H. Wild Swans in Yorks. (Field, Dec. 30.) Ward, R. Grey Plover in summer plumage in Yorks. (Zool.)

Igoo. Atkinson, F. R. Little Bunting in Yorks. (Field, Jan. 6.) Editorial correction (T.c., Mar. 3I.)

Boyes, F. Bittern in E. Yorks. (Field, Jan. 20.)

Butterfield, E. P. Birds of Bradford (in Br. Assoc. Handbook). Cr. 8vo. Bradford : I9oo.

Butterfield, E. P. Ornitholog. Notes from Wilsden District. (Zool.)

Clarke, W. J. Levantine Shearwaters at Scarborough. (Zool.)

Fortune, R. Levantine Shearwater near Scarboro'. (Nat.)

Grabham, O. Nat. Hist. Notes from Yorks. for I899. (Zool.) Bird Migration Returns from Spurn and Flamborough Lighthouse. (Nat.)

Harewood (Lord). Wild Swans in Yorks. (Field, Feb. I7.)

Morley, J. Bittern near Scarboro'. (Zool.)

Sharpe, R. Bowdler. Exhib. of Levantine Shearwater from Bridlington Quay. (Bull. B.O.C., X.)

Nelson, T. H. Redcrested Pochard in Yorks. ; Stone Curlew in Cleveland in winter. (Zool.)

Ig0I. Butterfield, E. P. Distribution of Stonechat in Yorks. (Zool.)

Butterfield, WV. R. Nutcracker at Ilkley. (Ibis, p. 737.)

Clarke, W. J. Notes from Scarboro'. (Zool.)

Duncan, S. Notes on bird life from Redcar and district, 2 notes. (T.c.)

McLean, K. Bearded Reedlings at Hornsea Mere. (Nat.)

Meiklejohn, A. H. Waxwing at Scarboro'. (Zool.)

Newstead, R. Little Egret in Yorks. (T.c.)

Loten, P. W. Early appearance of Dotterel in Yorks. (Knowledge.) 
[YoRKs.

IgoI-2. Clarke, W. E., and Nelson, T. H. The Birds of Yorkshire. (Tr. Yorks. Nat. Union.)

I902. Butterfield, E. P. Lesser Redpoll breeding in Yorks.; Notes from Wilsden. (Zool.)

Ogilvie-Grant, W. R. [Exhib. of Little Bunting from Teesmouth.] (Bull. B.O.C., XIII.)

Roebuck, W. D. List of Yorks. and Lincs. Birds. (Nat.)

I903. Arundel, W. B. Glossy Ibis in Yorks. (Ibis.)

de Winton, W. E., for Clarke, W. E. Exhibition of Motacilla borealis from Yorks. (Bull. B.O.C. XIII.)

Clarke, W. J. Sabine's Gull near Scarborough. (Zool.)

Crabtree, A. White's Thrush in Halifax. (Halifax Nat.)

Morley, J. Large Flight of Rough-legged Buzzards near Scarborough. (Zool.)

Tuck, J. G. Sabine's Gull in Yorks, 2 notes; Notes from Bridlington. (T.c.)

I904. Arundel, W. B. Ferruginous Duck and Tufted Duck in Yorks. (Op. cit.)

Morley, J. Shorteared Owl breeding near Scarborough. (T.c.)

I905. Boyes, F. Nigration of Waders; Summer Birds in E. Riding: Black-throated Diver at Beverley. (Field, Mar. I8; June 3 ; Sept. 9.)

Clarke, W. J. Zoological Notes from Scarborough, I904. (Zool.)

Robinson, H. W. Bee-eaters in Yorks. (T.c.)

rgo6. Alexander, H. G. Continental Long-tailed Tit in Yorks. $(O p$. cit.)

[Anon.] List of Birds of Whitby and District. (Whitby Lit. of Phil. Soc., 84th Rept.) [Ig06 ?]

Boyes, F. Dotterel in E. Yorks. (Field, June 9.)

[Clark, W. Eagle.] Lesser Grey Shrike near Whitby. (Nat.)

Grabham, O. [Birds in] Auden's Survey of York and District. (Brit. Assoc. Handbook.) Cr. 8vo. York: Igo6.

Nelson, T. H. Nesting of Ruff in Yorks. (Ibis.)

Pycraft, W. P. Hoopoe at Whitby. (Knowledge.)

Rodwell, R. Animated Nature in Thirskland. [In E. Bogg's Richmondshire and the Vale of Mowbray, I.] 8vo. Lond., etc. : 1906.

St. Quintin, W. H. Rough Notes on Birds at Scampston Hall. (Avicult. Mag.)

Smith, S. Yorkshire Notes on Tufted Duck. (Zool.)

I907. Boyes, F. Goosander and Mealy Redpolls in E. Yorks., 2 notes. (Field, Mar. 30.)

Brierley, H. A Nesting Haunt of the Redshank. (T.c., May 4.)

Butterfield, E. P. Bird Notes from Wilsden District. (Zool.

Coward, T. A. Brambling in June in Yorks. (Brit. Birds, I.) 
Grabham, O. Birds [In Victoria Hist. of Co. of Yorks., I.] 4to. Lond. : I907. [243.]

Haworth-Booth, B. Red-breasted Flycatcher in Yorks. (Field, May 25.)

Nelson, T. H. White-spotted Bluethroat from Yorks. [Scarborough, 1876.] (Bull. B.O.C., XXI. ; Zool.)

Nelson, T. H., Clarke, W. Eagle, and Boyes, F. The Birds of Yorkshire. 2 vols. 8vo. Lond. : I907; and L.P. 4to.

Wade, E. W. The Birds of Bempton Cliffs. Post 8vo. Lond., etc. : N.D. [605.]

I908. Blathwayt, F. L. Rambles among Wild Birds, No. V. The Chalk Cliffs of Yorks. (Nat.)

Booth, H. B. Extraordinary Immigration of Redwings in W. Riding; Brit. Willow Tit in Yorks. (Nat.)

Gale, A. R. Yellow-browed Warblers in Yorks. (Brit.Birds, II.) Idem by H. F. Witherby. (T.c.)

Nelson, T. H. Pallas's Sand Grouse in Yorks. (Zool.)

St. Quintin, W. H. Pallas's Sand Grouse in Yorks. (Nat.; Brit. Birds.)

Smith, S. H. Great Grey Shrike near York. (Zool.)

Steward, E. S. Common Bittern in Yorks. (Brit. Birds, I.)

Wade, E. W. A Yorkshire Peregrine. (Nat.)

Witherby, H. F. On occurrence of Puffimus yelkouanus in Yorks. (Bull. B.O.C., XXIII.) Sooty Shearwater in Yorks. (Brit. Birds, II.)

Igog. Booth, H. B. Changing Distribution of Long-tailed Titmouse in W. Riding. (Nat.)

Butterfield, E. P. Breeding of Coal-Tit in Wilsden district; Notes from Wilsden; Whinchat at Wilsden. (Zool.)

Corbett, H. H. Common Scoter at Doncaster ; Cream-coloured Variety of House Sparrow ; Glossy Ibis near Doncaster. (Nat.)

Duncan, S. Notes on Spoonbill in Yorks. ; Blacktailed Godwits in Yorks. (Brit. Birds, III.)

Fortune, R. Nordmann's Pratincole in Yorks. (Zool.)

Grabham, O. Oystercatcher nesting at Spurn. (Nat.). The Colony of Little Terns at Spurn Point. (Brit. Birds, II.). Brünnich's Guillemot in Yorks. (OP. cit., III.)

Gyngell, W. Late stay of Brambling; Wryneck in Yorks. (Zool.)

Kempsey, E., and others. Glossy Ibises in Yorks. (Brit. Birds, III.)

Morley, J. Ornitholog. Notes from Scarborough. (Zool.)

Nelson, T.H. Irruption of Crossbills [Yorks.]. (Brit. Birds, III.)

Sapsworth, A. D. Peregrine Falcon on Yorks. Cliffs. (Brit. Birds, III.) Idem by E. W. Wade and W. J. Clarke. (T.c.)

St. Quintin, W. H. The Reported Great Bustard in Yorks. (Zool.). Nesting Notes from Scampston for Igo8. (Avicult. Mag.). Garganey breeding in E. Yorks. (Nat.) 
Stephenson, T. Glossy Ibis at Whitby. (Nat.)

Wade, E. W. On Status of Stone Curlew in Yorks. (T.C.)

Wilson, W. Albino Carrion Crow in Yorks. (T.c.)

IgIo. Booth, H. B. Vertebrates of Craven. (Trans. Caradoc F. C.)

Butterfield, R. Birds of Craven and N. Wales. (T.c.)

Butterfield, E. P. Notes from Yorks. ; Willow-Wren in Yorks. ; Migration of Linnets. (Zool.)

Duncan, S. Little Terns nesting at Teesmouth. (Brit. Birds, IV.)

Fortune, R. Gannets in Yorks. (Nat.)

Grabham, O. Black Terns in Yorks. (T.c.)

Greaves, W. Vertebr. Fauna of Hebden Bridge Dist. 8vo. Pr. ptd.

Nelson, 'T. H. Peregrine Falcons at Bempton. (Brit. Birds, IV.)

Smith, S. H. Ornitholog. Notes from Yorks. (Nat.)

Ticehurst, C. B. [Exhib. of Lesser Kestrel from Holderness.] (Bull. B.O.C., XXV.) Idem. (Brit.Birds, III.)

Wade, E. W. Glossy Ibis in Holderness. (Nat.)

Witherby, H. F. Black-winged Pratincole in Yorks. (Brit. Birds, III.)

IgII. Arundel, W. B. Common Scoter in W. Yorks. (Brit. Birds, V.)

Boyes, F. Blackbellied Dipper in Yorks. (Field, Dec. 23.)

Clarke, W. J. Hoopoe in Winter in Yorks. (Nat.; Brit. Birds.)

Fortune, R. Little Auks in Yorks. (Nat.)

Greaves, W. Supposed Spotted Sandpiper in Yorks. (T.c.)

Nelson, T. H. Arctic and Pomatorhine Sliuas and Sabine's Gull in Yorks. (Brit. Birds, V.)

Stephenson, T. Night-Heron in Yorks. (Field, Nov. II ; Nat.)

Ticehurst, C. B., and Witherby, H. F. Continental Robins [etc.] in .... Yorks. (Brit. Birds, IV.)

St. Quintin, W. H. Bearded Tit in Holderness. (Nat.)

Ticehurst, N. F., and Jourdain, F. C. R. Distribution of Nightingale. (Brit. Birds, V.) [partim.]

Wade, E. W. Glossy Ibis in Yorks. (Nat.)

Witherby, H. F. Introduction of Bearded Tits in Yorks. (Brit. Birds, V.); Northern Bullfinch in Yorks. (Op. cit., IV.)

I912. Booth, H. B. The Bearded Tit Experiment at Hornsea Mere. (Nat.)

Charlton, J. M. Baillon's Crake in Yorks. (Zool.)

Clarke, W. J. Feeding Habits of Gulls in Scarborough District. (Nat.) ; Levantine Shearwater in Yorks. (T.c.)

Coward, T. A. Shags inland in .... Yorks. (Brit. Birds, V.); Continental Hedge Sparrow in Yorks. (Op. cit., VI.)

Duncan, S. Black-tailed Godwits in Yorks. (Op. cit., V.)

Durnford, W. A. Hoopoe in Yorks. (Field, May II.)

Fortune, R. Fork-tailed Petrel near Harrogate. (Nat.)

Stanford, J. K. Rare Migration in Yorks. (Brit. Birds, VI.)

Stephenson, T. Bird Notes from Whitby. (Nat.)

Wade, E. W. Black Guillemot in Yorks. (Nat.) 
IgI2-I5. Mosley, S. L., and F. O. Birds of the Huddersfield District. 8vo. Priv. ptd. N.D. [I9I2-I5.]

IgI3. Bolam, G. Notes on Nat. Hist. of Hornsea Mere. (Nat.)

Booth, H. B. Decrease in number of Starlings [Yorks.]. (T.c.)

Boyes, F. Glossy Ibis in E. Yorks. (Field, Jan. I8); Waxwings in E. Yorks. (T.c., Mar. 8.)

Butterfield, E. P. Status of Starling at Northallerton; Notes from Wilsden; Ornithological Notes from Yorks. (Zool.)

Compton, M. W. Whinchat wintering in Yorks. (Brit. Birds, VII.)

Duncan, S. Bitterns in Holderness. (Nat.)

Falconer, W. Bird Notes from Slaithwaite, S.W. Yorks. (T.c.)

Fortune, R. Occurr. of Sand Grouse in Yorks. (T.c.)

Nelson, T. H. Little Bunting in Yorks. (Brit. Birds, VII.)

Stephenson, T. Bird Notes from Whitby. (Nat.); Little Bunting at Whitby. (T.c.)

Wade, E. W. Peregrines at Bempton; Glossy Ibis in Holderness ; Little Auks in Holderness. (Nat.) Diminution of Starlings in Yorks. ; Unusual winter migration of Woodcocks. (Brit. Birds, VII.)

IgI4. Boyes, F. Waxwings in E. Yorks. (Field, Jan. IO); Little Owl in Yorks. (T.c., Apr. 4.)

Butterfield, E. P. Ornitholog. Notes from Yorks. ; Status of Lesser Whitethroat; Relative abundance of Garden Warbler and Blackcap; Waxwings in Yorks. (Zool.)

Fortune, R. Decrease of Starlings at Harrogate; Early arrival of Swifts. (Nat.)

Gill, E. L. Status of Blackcap and Garden Warbler in Yorks. (Zool.)

Greaves, W. Bird Notes from Hebden Bridge; Manx Shearwater at Halifax; Blueheaded Wagtail at Mytholmroyd. (Nat.) Longtailed Skua in Yorks. (Brit. Birds, VIII.)

Griffith, A. F. [Exhib. of Blackheaded Bunting from Halifax.] Bull. B.O.C., XXXIII.)

Malone, M. L'Estrange. Waxwing in Yorks. (Avicult. Mag.) Idem by P. Saltmarshe. (Field, Jan. 3.) Idem by J. T. Sewell, E. W. Wade, and others. (Nat.)

Muirhead, J. E. A Grey Rook [Wetherby]. (Field, May I6.)

Nelson, T. H. Destruction of Grouse in a Storm. (Brit. Birds, VIII.)

Proger, T. W., and Paterson, D. R. Ornitholog. Notes, IgI4 [on the Waxwing in Yorks.] (Rept. \& Trans. Cardiff Nat. Soc., XLVII., pp. 45-49.)

Smith, S. H. Nesting of Pochard near Selby; Crossbills and Waxwings near Yorks; York Bird Notes. (Nat.)

Verity, W. R. Manx Shearwater at Halifax. (Nat.)

Igr5. Bacon, C. H. Roughlegged Buzzard in Yorks. (Field, Sept. II.)

Barraclough, W. White Blackbird at Barnsley. (Nat.) 
Booth, H. B. Birds travelling north in autumn. (Zool.); A New West Riding Heronry. (Nat.)

Butterfield, E. P. Birds travelling north in autumn; Blue variety of Cuckoo's egg in Hedge Sparrow's nest. (Zool.)

Clarke, W. J. Unusual migration of Seabirds off Yorks. Coast; Overlooked record of Surf Scoter in Yorks. (Brit. Birds, IX.)

Corbett, H. H. Hen Harriers near Doncaster. (Nat.)

Fortune, R. Early arrival of Swifts ; Black Game in Wharfedale. (Nat.)

Greaves, W. Grasshopper Warbler at Mytholmroyd; Hen Harrier and Stonechats at Hebden Bridge. (Nat.)

Lee, R. Hoopoe in Yorks. (Field, Oct. 2.)

Medlicott, W. S. Eastern Blackeared Wheatear seen in Yorks. (Brit. Birds, IX.)

Middlemost, W. Storm Petrel inland [Huddersfield]. (Field, Jan. 2.)

Musham, J. F. Black Game near Selby. (Nat.)

Shield, W. Arrival of Snow Bunting in Sept. [Lodmoor]. (Field, Oct. 2.)

Taylor, F. Cuckoo's method of oviposition in Yorks. (Brit. Birds, IX.)

IgI6. Booth, H. B. Notes on nesting of Grasshopper Warbler in WV. Riding; Reported nesting of White Wagtail in Yorks. (Nat.) Status of Stonechat in N.W. Yorks. (Zool.)

Butterfield, E. P. Various bird notes from Bradford District; First nesting of Grasshopper Warbler and Chiffchaff near Bingley; Status of Lesser Whitethroat and Stonechat in N.W. Yorks ; Bird Notes from Bolton Woods, etc., 5 notes. (Zool.) Dawson, J. Little Auk inland [near Doncaster]. (Field, Mar. II.) Durnford, W. A. Decreases in Yorks. Birds. (Nat.)

Greaves, W. Shelduck near Hebden Bridge; Notes from Hebden Bridge. (T.c.)

Horsfall, P. M. White-tailed Eagle in Yorks. (Brit. Birds, IX.) Mosley, C. Kingfisher at Slaithwaite. (Nat.)

Roose, T. Little Auk in Wharfedale. (T.c.)

Tuck, J. G. White Wagtail nesting in Yorks. (T.c.)

I9I7. Arundel, W. B. Breeding-habits of Willow Warbler in Yorks. (Brit. Birds, XI.)

Booth, H. B. Turnstones in Upper Wharfedale; Nesting of Longtailed Tit in Upper Wharfedale. (Nat.)

Butterfield, E. P. Pied Wagtails, etc., on Migration, etc. 3 notes. (T.c.)

Falconer, W. Bird Notes from Huddersfield Dist. (T.c.)

Fortune, R. The Storm and Gulls, etc. 3 notes. (T.c.) Greaves, W. Bird Notes from Hebden Bridge. (T.c.)

IgI8. Alexander, H. G. Albinistic Yellow Wagtail in Yorks. (Brit. Birds, XI.) 
Arundel, W. B. Abnormal breeding of Redbreast at Pontefract. (Op. cit., XII.)

Booth, H. B. Pied Wagtails in winter and on migration in Bradford Dist. Reported nesting of Stonechat in Upper Wharfedale. (Nat.)

Butterfield, E. P. Puffin caught alive at Cullingworth; Status of Pied Wagtail in winter in Wilsden Dist.; Scarcity of Bullfinch in Upper Airedale; White Wagtail in Nidderdale (Nat.)

Fortune, R. Rare Ducks and Wildfowl in Upper Nidderdale, 2 notes; Ring Plover nesting in Nidderdale, etc. 6 notes. (T.c.)

Greaves, W. Long-eared Owl nesting on the Ground. (Nat.) Gyngell, W. Notes on Nesting, Singing, etc., of Common Wild Birds of Scarborough Dist. 3 pts. (Nat.)

Robinson, H. W. Great Skuas on Yorks. Coast. (Brit. Birds, XI.) Sewell, J. T. Cirl Bunting near Whitby. (Brit. Birds, XII.; Nat.)

Wade, E. W. The Bempton Peregrines. (Nat.) 


\section{CHANNEL ISLANDS.}

I8I7. Plees, W. An Account of the Island of Jersey. 4to. Southampton: I8I7. [Zoology at pp. 38-43, but contains only a paragraph on Birds.]

1830. Jacob, J. Annals of some of the British Norman Isles, constituting the Bailiwick of Guernsey. Pt. I. Roy. 8vo. Paris: 1830. [Account of Storm Petrel at p. 56, with cut.]

I84I. Duncan, J. History of Guernsey. 8vo. Lond: I84I. [I85.] I855. [Anon.] Rambles among the Channel Islands. By a Naturalist. Lond.: N.D. Post 8vo. [A paragraph on Birds at p. 304.] I862. Ansted, D. T., and Latham, R. G. The Channel Islands. 8vo. Lond. : I862. 2nd edit., I865. 3rd [abridged] edit., I893. [23.]

I863. " J. D. R. D." Woodcock's Nest in Guernsey. (Field, May 2.) MacCulloch, E. Bustard in Guernsey. (Field, Dec. 26.)

I864. [Anon.] Egg Collecting in the Channel Islands. (Op. cit., XXIII., pp. I90, 2II.)

I865. Wilcocks, J. C. Grebes and Divers in Guernsey. (Field, Mar. II.) I866. Austin, H. E. Migratory Flight of Swallows. (Field, Oct. I3); Nat. Hist. Notes in Jersey. (Op. cit., Nov. I7.)

“ J. H. R." Bee-eater shot in Jersey. (T.c., Oct. 20.)

Smith, C. List of Birds observed during Six Weeks' Summer Visit to Channel Islands, exclusive of Jersey. (Zool.)

Willcocks, J. C. Lesser Bustard killed in Guernsey. (Field, Feb. I7.)

I868. [Anon.] Osprey in Guernsey. (Op. cit., XXXII., p. 30I.)

I869. Harvie-Brown, J. A. Dartford Warbler; Notes from Jersey; Rough Notes from Channel Islands (2 parts.) (Zool.)

I870. Montgomery, J. Hoopoe in Alderney. (Field, Apr. 23.)

I87I. Carey, C. B. Ornithological Notes from Guernsey; Whitetailed Eagle in Alderney. (Zool.)

Couch, J. Woodcock, Wood Pigeon and Ring Ouzel in Guernsey. (T.c.)

Smith, C. White-tailed Eagle in Alderney. (Field, Nov. I8); In Guernsey. (T.c., Nov. 25) ; American Bittern in Guernscy. (Zool.)

I87I-73. Carey, C. B. Ornitholog. Notes from Guernsey, 4 papers. (Zool., I87I-73.) 
I872. Carey, C. B. Spring Arrivals in Guernsey ; Another White-tailed Eagle in Guernsey. $(O p$. cit.) ; Are Guernsey Birds British? 2 notes. (T.c.) Idem by E. Newman, Lord Clermont and $\mathrm{O}$. Pickard Cambridge. (T.c.)

Green, C. A. Sea Eagle at Jersey. (Field, Nov. 30.)

"J.H. R." The Glaucous Gull [in Jersey]. (T.c., Dec. 2I.)

Smith, C. A Few Ornitholog. Notes from Guernsey. (Zool.)

I873. Broughton, H. T. Spoonbill in Guernsey. (Field, Oct. 25.)

Carey, C. B. Montagu's Harrier at Alderney. (Zool.)

"H. T. B." Montagu's Harrier in Channel Isles. (Field, July 26.)

“ J. N. R." Night Heron in Jersey. (T.c., June 2I.)

Luff, W. A. The Channel Islands Fauna. (Zool.) Idem by H. T. Mennell and J. J. Weir. (T.c.)

1874. Carey, A. C. Little Bustard in Guernsey. (Field, Dec. 5.)

Couch, J. Birds in Guernsey; Mute Swan in Guernsey. (Zool.)

1875. Couch, J. Rare Birds in Guernsey, 2 notes. (Op. cit.)

I876. Couch, J. Greenland or Iceland Falcon in Guernsey. (Op. cit.) Smith, C. A Few Ornitholog. Notes from Guernsey, 2 pts. (T.c.) : Iceland Falcon in Island of Herm. (Field, July 8.)

1877. Smith, Cecil. Little Bittern in Guernsey. (Zool.)

I879. " J. H. R." Great Bustard in Jersey. (Field, Dec. I3) ; Abundance of Landrails in Jersey. (T.c., Oct. I8.)

Smith, Cecil. The Birds of Guernsey and the Neighbouring Islands, etc. Post 8vo. Lond. : I879. [546.]

I880. " C. V. G." Little Bittern in Jersey. (Field, Dec. 4.)

Harting, J. E. Great Bustard in Jersey; Red-legged Partridge in Guernsey. (Zool.)

Sinel, J. Great Bustard in Jersey. (Sci. Gossip.)

Smith, C. Long-eared Owls and Red legged Partridge in Guernsey. 2 notes. (Zool.)

Vaughan, J. Ornitholog. Notes from Guernsey. (T.c.)

1882. Lovett, E. Notes on the Nat. Hist. of Jersey-Land Plants and Animals. (Sci. Gossip, Mar., July.)

R-, J. H. Rose-coloured Pastor in Jersey. (Irish Nat.; Field, June 24.)

Sinel, J. Manx Shearwater in Jersey; Ornitholog. Notes from Jersey ; Rose-coloured Pastor in Jersey ; Fire-crested Regulus in Jersey. (Zool.)

Smith, C. Buffon's Skua in Channel Islands; Marsh Harrier in Herm. (T.c.); The Birds of Jersey. (Sci. Gossip, May.)

1884. Sinel, J. Birds [etc.] in Jersey. (Sci. Gossip, Apr.)

I885. Smith, C. Little Gull in Guernsey. (Zool.) 
I886. Caplin, T. Night Heron in Jersey. (Field, Feb. 6) ; Golden Oriole in Jersey. (T.c., May I5.)

Harting, J. E. Golden Oriole in Channel Islands. (Zool.)

I887. Nicoll, J. Purple Sandpiper in Channel Islands. (Op. cit.)

I888. Smith, C. Pallas's Sand Grouse in Guernsey. (Zool.) Idem by M. F. Struthers [in Jersey]. (Field, June 9.)

I890. "R. G. B." Grey Geese in Guernsey; Scarcity of Goldfinch in Guernsey. (Field, Sept. 20.)

I896. Harting, J. E. Cream-coloured Courser in Jersey. (Zool.)

I898. Blathwayt, F. L. Ornithological Notes from Sark. (Zool.)

I899. Clarke, W. Eagle. Ushant as an Ornitholog. Station; Notes on Birds observed at Ushant . . . and at Alderney. (Ibis.)

I902. Bidwell, E. Occurrence of Muscicapa parva [?] in migration at Casquets. (Bull. B.O.C., XII.) Idem by R. W. Llewellyn. (Ibis.)

Howard, H. E. The Birds of Sark; and Variation in Song. $($ Zool.)

I903. Dalgleish, G. Ornitholog. Notes from Guernsey. 2 pts. (OP. cit.)

Elms, E. F. M. Bird Notes in Sark, I903. 2 pts. (T.c.)

Marquand, E. D. The Birds of Alderney. (Rep. Guernsey Soc.)

I904. Mackay, H. Bird Life in Jersey. 2 pts.; Dotterel in Jersey ; Swallows in Jersey. (Zool.)

Marquand, E. D. On Occurrence of Birds in Guernsey in Igo4. (Rep. Guernsey Soc.)

I908. Ticehurst, C. B. Purple Sandpiper in Channel Islands. (Brit. Birds.)

I909. Marquand, E. D. Report of Ornitholog. Section. (Rep. \& Tr. Guernsey Soc.); The Guernsey Dialect Names of Birds, etc. (T.c.)

Igro. Marquand, E. D. Report of Ornitholog. Section. (Op. cit.)

I9I2. Rowswell, B. T. Report of Ornitholog. Section. (Op. cit., I9II); Are Guernsey Birds British? (T.c.) 


\section{ISLE OF MAN.}

1656. Chaloner, J. A Short Treatise on the Isle of Man, 1656. (Manx Soc., Vol. X.)

King, D. The Vale-Royall of England ..... also Discourse of the Island of Man. Sm. folio. Lond. : I656. [329.]

I79r. Townley, R. Journal kept in the Isle of Man. 2 vols. 8vo. Whitehaven : I79I. [585.]

Wilson, Bishop T. History of the Isle of Man. (Manx Soc., Vol. XVIII.)

I8II. Woods, G. Account of Past and Present State of Isle of Man. 8vo. Lond. : I8II. [665.]

I83I. Murray, J. The Cuckoo [calling at midnight]. (Loudon's Mag. N. H., IV.)

I845. Forbes, E. [Natural History. In] Quiggin's Guide to the Isle of Man. I2mo. Douglas: I845. And later edits. [2II.]

Train, J. Hist. and Statist. Account of the I. of Man. 2 vols. 8vo. Douglas: I845. [587.]

I847. [Anon.] Letters from the Isle of Man in I846. I2mo. Lond. : I847. [2I.]

1856. Hadfield, H. W. Little Crake in I. of Man. (Zool.)

I862. Stowell, H. A. Chit-chat, Chiefly Ornithological. (Op. cit.)

I875. Thompson, G. Peregrine Falcons in I. of Man. (Field, June 26.) I88I. Kermode, P. M. C. Birds of I. of Man, 2 notes. (Sci. Gossip.) I883. " J. W. T." Breeding Haunts of Curlew [in I. of Man]. (Field, July 7.)

I886. Cain, W. J. Manx Rhyme about the Cuckoo; Manx Ballad. (Manx Note Book, Nos. 6, 7.)

I888. Gurner, R. Notes on Nat. Hist. of I. of Man. (Tr. I. of Man N. H. Soc., I. [I879-84].)

Kermode, P. M. C. Pallas's Sand Grouse in the I. of Man. (Zool.) Idem by T. H. Nelson. (T.c.) List of Birds of I. of Man. (Tr. I. of Man N. H. Soc., I. [I879-84].)

Macpherson, H. A. Report on Pallas's Sand Grouse in N.W. of England. [partim.] (Tr. Cumb. \& IVestm. Assoc., No. XIII., I887-8.)

Ralfe, P. Black Guillemot in I. of Man. (Zool.)

I889. Bailey, W. S. Occurrence of Mergus serrator; Ornitholog. Notes. (Yr Lioar Manninagh, Nos. 2, 3.) 
J[effcott], J. M. Snipe in I. of Man. (Op. cit., 3.)

Kermode, P. M. C. Phenological Observations, 3 pts.; Pallas's Sand Grouse at N. Ramsay; Report of Zool. Sect. I888; Preservation of Wild Birds. (Op cit., Nos. I-4.)

I89o. Bacon, J. C. Fieldfare killed by Peregrine. (Field, May 24.)

Kermode, P. M. C. Phenological Observations. ( $Y r$ Lioar Manninagh, No. 7.)

Ralfe, P. Bird Life at Douglas Bay. (Zool.)

I8gI. Nicholson, F. Wild Swans in the I. of Man. (Op. cit.)

Roeder, C. R. Folklore Concerning the Wren. (Yr. Lioar Manninagh, 9.)

I892. Crellin, J. C. Zoological Reports. (Tr. I. of Man N. H. E Archaolog. Soc., 1892 et seq.)

Hannah, J. Birds of I. of Man. (Nat. Jnl., I.)

Moffat, C. B. Birds of the I. of Man. (Zool.)

Ralfe, P. Petrels and Phalarope in the I. of Man; Birds of the I. of Man. (T.c.) [485.]

I893. Kermode, P. M. C. Contributions to a Vertebrate Fauna of the I. of Man. (Op. cit.)

I894. Ralfe, P. Uncommon Birds in the I. of Man; Naturalist's Visit to Calf of Man; Sea-bird Colonies in I. of Man. (Op. cit.)

I895. Ralfe, P. Winter Notes from I. of Man. (Op. cit.)

I8g6. Ralfe, P. Ornitholog. Notes from I. of Man. (Op. cit.); The Magpie in the I. of Man. (Irish Nat., June.)

1897. Ralfe, P. The Birds of Lonan. (Nat.); On Manx Bird Names. (Zool.)

I898. Ralfe P. Notes from I. of Man, I897. (Zool.) ; Glaucous Gull [in I. of Man]. (Knowledge.)

I899. Ralfe, P. Terns in I. of Man. (Zool.)

Townsend, G. White Wagtail in I. of Man. (Field, Apr. 29.)

Igor. Grant, C. H. B. Yellow Wagtails wintering in I. of Man. (Zool.)

Graves, F. S., and Ralfe, P. Birds Observed on Calf of Man. (T.c.)

Kermode, P. M. C. List of Birds of I. of Man, with Notes. (Jnl. I. of Man Soc.)

Ralfe, P. Bird Life in Neighbourhood of Douglas; Some Further Notes on Manx Birds. (T.c.)

I902. Graves, F. S. Wood Warbler in I. of Man. (Zool.)

I903. Graves, F. S. Grasshopper Warbler in I. of Man; Tree Sparrow in I. of Man; Stock Dove in I. of Man; Water Rail in I. of Man (Op. cit.)

Nelson, T. H. Stock Dove in I. of Man. (Zool.)

Ralfe, P. Black Tern in I. of Man; White Wagtail in I. of Man. (T.c.) 
I904. Ralfe, P. Great Skua in I. of Man. (Op. cit.)

I906. Patterson, R. Birds of Ireland and I. of Man. (Irish Nat.) Ralfe, P. The Birds of the I. of Man. 8vo. Edinb.: Igo6. [485.]

Ralfe, P. G. Leach's Forktailed Petrel in I. of Man; White Wagtail and Common Redstart in I. of Man. (Zool.)

1907. Ralfe, P. G. Common Buzzard on the Calf of Man; Notes on Manx Sea-Birds. (Zool.) 2 notes.

Ig08. Ralfe, P. G. Bird Life in I. of Man; A Comparison with Neighbouring Countries. (Tr. I. of Man N.H. \& A. Soc., N.S., I., I908.)

I909. Ralfe, P. G. Manx Ornitholog. Notes, I905-08. (Brit. Birds, III.)

I91o. Graves, F. S. Hen Harrier in I. of Man. (Op cit., III.)

Ralfe, P. G. Sea-bird Life on our South-western Coast. (Tr. I. of Man N. H. \& A. Soc., N.S., I.)

Igr. Wenner, M. V. Nesting of Common Tern in I. of Man. (Brit. Birds, V.)

I9r2. Ralfe, P., and Graves, F. S. Manx Ornitholog. Notes (I909-I2.) (T.c.)

Ralfe, P. G., and Graves, F. S. Manx Birds. Peel, I. M. : IgI2.

IgI4. Wheldon, J. A. Manx Birds. (Lancs. Nat., June.)

I9r6. Ralfe, P. G. Manx Ornitholog. Notes, I9r4-I5. (Brit. Birds, IX.)

I9I8. Ralfe, P. G. Manx Ornithol. Notes, IgI6-I7. (Op. cit., XI.) 


\section{WALES.}

I585. Giraldus de Barri (Cambrensis). Itinerary of Bishop Baldwin through Wales [I207]. I vol. I2mo. Lond. : I585. And subsequent edits. [230.]

I7I2. Lywyd, E. Letters containing Observations in Natural History of Birds made in Travels through Wales. (Phil. Trans.)

I778-83. Pennant, T. A Tour in Wales, MDCCLXX. and a Tour in Wales, MDCCLXXIII. 2 vols. Sm. 4to. Lond. : I778-83. [468.]

I797. Aikin, S. Journal of a Tour through Wales, etc. 8vo. Lond. : I797. [5.]

I804. Bingley, W. North Wales. 2 vols. 8vo. Lond. : I804. [66.] I838. Eyton, T. C. Attempt to ascertain Fauna of Shropshire and N. Wales. 2 pts. (Ann. Nat. Hist., I. \& II.)

1857. Bladon, J. Nightingale in Wales. (Nat. [Morris's], VII.)

I859. "Silurian." The Nightingale in Wales. (Field, June II.)

I866. Cordeaux, J. Ornitholog. Notes from N. Wales. (Zool.)

I88I. More, A. G. On alleged former existence of the Ptarmigan in Cumberland and Wales. (Zool.)

I884. Postlethwaite, T. N. Birds of S. Wales. (Op. cit.)

I889. Swainson, E. A. Kite and Raven nesting in S. Wales. (Op. cit.) ; Notes from S. Wales. (T.c.)

Wolley-Dod, C. Nightingale in Wales. (Field, May 25.)

I8gI. Swainson, E. A. [Ornitholog.] Notes from Wales. (Zool.)

I893. Darlington, R. Birds of North Wales. [In Darlington's Naturalist Series.] Post 8vo. Llandudno, etc.: N.D. [I6I.]

Newstead, R. The Heron and Heronries of Cheshire and N. Wales. (Pr. Chesh. Soc. Nat. Sci.)

Salter, J. H. Preservation of Kite. (Zool.)

Swainson, E. A. Distribution and Habits of Pied Flycatcher in Wales. (T.c.)

I894. Hasted, A. W. Great Spotted Woodpecker, Pied Flycatcher and Grey Wagtail in N. Wales. (Op. cit.)

Raeburn, H. Birds Observed in Mid-Wales. (T.c.)

I895. Salter, J. H. Observations on Birds in Mid-Wales. (Op. cit.) I8g6. Aplin, O. V. Kites in Wales. (Ornithologist.)

Priestly, A., and Ruddy, T. On Birds of N. Wales in Parl. Comm. Report on Land in Wales, 1896. 
I8g6-98. Bucknill, J. A. Rough Notes from N. Wales, 3 pts. (Omithologist, I., I896-7.) Idem. Continuation, 2 pts. (Nat. Chron., Aug. I897, March I898.)

I8g6-I904. Salter, J. H. Ornitholog. Notes from Mid-Wales, 5 pts. (Zool., I896, I898, I900, I902, I904.)

I898. Bahr, P. H. Birds of Staffs. and N. Wales. (Rep. Rugby Soc.)

I903. Forrest, H. E. The Birds of N.W. Wales and Opposite Counties of Ireland. (Zool.)

Walpole-Bond, J. A. Bird Life in Wild Wales. Cr. 8vo. Lond. : I903. New ed., IgI5.

I904. Butterfield, W. R. Photographs of a Welsh Kite's Nest, etc. (Bull. B.O.C.)

Forrest, H. E. Birds of N.W. Wales and S.E. Ireland. (Tr. Caradoc F. Club.)

Salter, J. H. On Nesting Habits of Common Buzzard; On Boldness of Common Buzzard. (2 notes.) (Zool.)

I906. Swainson, E. A. Distribution of Corn-Bunting in Wales. $(O p$. cit.)

Aplin, O. V. Idem. (T.c.)

I907. Forrest, H. E. Vertebrate Fauna of North Wales. Sq. 8vo. Lond. : 1907.

Forrest, H. E. Birds of Shropshire and N. Wales. (Rec. Caradoc Club.)

Hay, E. F. A. Notes on Welsh Birds in Igo5 and I906. (Zool.)

I908. Cummings, S. G. Notes on Habits and Distribution of Cirl Bunting in N. Wales. (Brit. Birds, I.)

J[ourdain], F. C. R. The Vertebrate Fauna of North Wales. Review. (Op. cit.)

I908-9. Newstead, A. Ornitholog. Records from Chester and N. Wales. 2 pts. (Zool., Ig08-9.)

I909. Owen, D. E. [Account of efforts made to protect the Kite in Wales.] (Bull. B.O.C., XXIII.) Idem by A. G. Vaughan. (T.c.)

I9Io. Butterfield, R. Birds of Craven and N. Wales. (Tr. Caradoc Club.)

I9I4. Butterfield, E. P. Status of Lesser Whitethroat in Wales. (Zool.) Charlton, J. M. Visitation of Black Redstarts in Wales. (T.c.)

I9I5. Butterfield, E. P. Distrib. of Thrushes in Winter [in Wales]. (Op. cit.)

IgI6. White, S. W. Bird Notes from S. Wales. (Zool.) 


\section{ANGLESEY.}

I802-I3. Montagu, G. Little Egret in Anglesey. [Orn. Dict., Vol. I.] ; Glossy Ibis in Anglesey. (Op. cit., Suppl.) 8vo. 1802-I3. I862. "R. L." Variety of Moorhen. (Field, Aug. 2I.)

1863. Shaw, H. O. Rare Birds in Shropshire, etc. [Bittern from Holyhead]. (Op. cit., Feb. 6.)

I866. Gurney, J. H. American Bittern in Kent [and Anglesey]. (Zool. ; Field.)

I873. Durnford, H. Ornithological Expedition to Holyhead Island. $($ Zool.)

I875. Shaw, J. Rare Birds in Shropshire [sic] [Greenshank from Holyhead]. (Field, Oct. 30.)

Saunders, S. F. Great Northern Diver at Holyhead. (Ficld, Feb. 27.)

1879. Ascroft, R. White-fronted Goose in Anglesey. (Field, Nov. 8; Knowledge.)

"H. G." Bittern in Anglesey. (Field, Dec. 27.)

I882. Pickin, T. Little Bittern in Anglesey. (Op. cit., Sept. 23.)

I883. "T. P." Distribution of Red-legged Partridge. (Op.cit., Mar. 3.) I884. Eyre, W. E. Little Bustard in Anglesey. (Op. cit., Dec. 20.) I885. "R. H." Little Stint and Richardson's Skua in Anglesey. (Op. cit., Oct. I7.)

I886. Forsyth, W. C. E. Wild Swans near Holyhead. (Op. cit., Jan. 2.)

I888. "E. J. R." A White Curlew. (Op. cit., Nov. 3.)

I89I. Pickin, T. Wild Swans in Ireland and N. Wales. (Op. cit., Jan. 3r.)

I892. Banks, W. Eared Grebe in Anglesey. (Zool.)

Coward, T. A. Eared Grebe and Tufted Duck in Anglesey. (T.c.)

Craig, A. Stray Notes on Birds of Anglesey. (Tr. Edinb. Nat. F. C., II., I886-9I.)

Ellison, A. Eared Grebes in Anglesey. (Zool.)

1893. Clulow, E. Wild Swans in Anglesey. (Field, Nov. 25.)

Horton, R. J. Quails in Anglesey. (T.c., Nov. I8.)

Wilkinson, W. M. Red-necked Phalarope in Anglesey' (Zool.)

I894. Dobie, W. H. White Wagtail in Anglesey. (Op. cit.)

Thompson, E. A. Bittern in Anglesey. (Field, Mar. Io.)

1894-95. Newstead, R. Birds of Puffin Island. (Rept. of Puffu Is. Biol. Stn. 8vo. Bangor.) 
I895. Oldham, C. Grasshopper Warbler in North Wales. (Zool.) [partim.]

Speed, H. Rare Birds [Bittern]. (Avicult. Mag., I.)

I8g6. Bulkeley, R. W. Peregrine Falcon and Homing Pigeons. (Field, Aug. 8.)

I897. Evans, T. R. White Lark in Anglesey. (Op. cit., Sept. II.)

Oldham, C. Black Tern in Anglesey. (Zool.)

Saunders, H. Nesting of Sterna dougalli in Wales. (Bull. B.O.C.)

I899. Dickinson, G. American Cuckoo in N. Wales. (Field, Nov. IS.)

Platt, H. Bitterns in Anglesey. (T.c., Dec. 30.)

Igoo. Coward, T. A. Hoopoe in Anglesey. (Zool.)

Dickinson, G. [Letter on Yellow-billed Cuckoo in Menai Straits.] (Ibis.)

Dobie, W. H. Little Owl in N. Wales. (?) (Zool.)

I902. Cummings, S. G. Red-backed Shrike in Anglesey. (Op. cit.)

Rucker, F. W. Spring Plumage of Golden Plover. (Field, Mar. 8.)

I902-05. Coward, T. A., and Oldham, C. Notes on Birds of Anglesey, 4 pts. (Zool., I902, I904-05.) [I52, 453.]

I903. Cummings, S. G. Purple Sandpiper (Tringa striata) in Anglesey. (Op. cit.)

1904. Boraston, J. M. Birds by Land and Sea. 8vo. London. [partim.] [84.]

I905. Cummings, S. G. Red Grouse in Anglesey. (Zool.)

Hodgson, A. Sabine's Snipe in Anglesey. (Field, Feb. 4.)

Pycraft, W. P. Sabine's Snipe in Anglesey. (Knowledge.)

I906. Cummings, S. G., and Oldham, C. Anglesey Bird Notes. (Zool.) I907. Forrest, H. E. The Vertebrate Fauna of N. Wales. 8vo. Lond. : I907. [partim.] [2I3.]

Phillips, E. C. Snow Bunting in Anglesey. (Field, Apr. 6.)

I908. Cole, H. S. Occurrence of Crane in Anglesey. (Op. cit., May 30.) Newstead, A. Common Crane in Anglesey. (Brit. Birds, II.) Newstead, R. The Food of Some British Birds. (Suppl. to Jnl. of Bd. of Agricult. 8vo. Lond.: I908.) [partim.] [442.]

Ig09. Forrest, H. E., Ticehurst, C. B., and Siddall, C. K. Black Terns in N. Wales. (Brit. Birds, III.)

Jourdain, F. C. R. Little Owl in Anglesey, etc.; Common Terns on Holyhead Skerries. (T.c.)

Noble, H. Common Terns on Holyhead Skerries. (T.c.)

I9I0. Bickerton, W. British Nesting Terns. (P.Z.S.) [partim.] [65.]

Forrest, H. E. Nuthatch in Anglesey. (Brit. Birds, IV.) [2I3.]

Oldham, C. American Wigeon in Anglesey. (T.c.)

Owen, T. Ramble with the Birds in Anglesey and Carnarvon. (Zool.)

IgII. Jones, R. W. Little Stints in Anglesey. (Brit. Birds, IV.) 
I9I2. Bickerton, W. The Home Life of the Terns or Sea Swallows. 4to. Lond. : I9I2. [partim.] [65.]

Forrest, H. E. Pied Flycatcher; Barnacle Goose; Longtailed Duck in Anglesey. 3 notes. (Brit. Birds, V.) ; Brent Goose in Anglesey. (Op. cit., VI.)

Jourdain, F. C. R. The Roseate Tern [in Kirkman's British Bird Book. 4to. Section 7]. [322.]

Oldham, C. Black Redstarts in Anglesey. (Brit. Birds, VI.)

Owen, T. A Season with the Birds of Anglesey, etc. 2 pts. (Zool.)

I9I3. Cummings, S. G. Goldcrest nesting in N. Anglesey. (Brit. Birds, VII.) Idem by H. E. Forrest. (T.c.)

Vivian, C. P. Bittern in Anglesey. (Field, Mar. I.)

I9I4. Jones, R. W. Lesser Whitethroat and Nuthatch in Anglesey; Ringed Guillemot in Anglesey. (Brit. Birds, VIII.)

Oldham, C. Siskins in Anglesey. (Op. cit., VII.)

I9I5. Oldham, C. Sandwich Tern nesting in Anglesey. (Op. cit., IX.)

I9I7. Cummings, S. G. Hawfinch in Anglesey. (Op. cit., XI.)

Forrest, H. E. Present Status of Nuthatch in ...Anglesey. (T.c.) Pownall, J. A. Garganey in Anglesey. (T.c.)

IgI8. Forrest, H. E. Bitterns in the West [Anglesey]. (Nat.)

\section{BRECONSHIRE.}

I850. McIntosh, J. White-breasted Partridges. (Zool.)

I859. " Keeper." Osprey [caught in Brecons.]. (Field, Nov. I2.)

I87I. Lockwood, E. Ornitholog. Notes from Brecons. (Field, May 27.)

I872. Harting, J. E. British Heronries. (Zool.) [partim: see under Hereford.] [274.]

I873. "Bramah." Early Appearance of Common Sandpiper. (Field, Mar. I5.)

I875. Lloyd, T. Conway. Goosander near Brecon. (Field, Mar. I5.) I88I-82. Phillips, E. C. The Birds of Breconshire, 5 pts. (Zool., I88I-82.) (Also reprinted separately for the author. Lond.: I882.) [47I.]

I882. Phillips, E. C. Great Grey Shrike in Brecons. (Zool.)

1883. Phillips, E. C. Breeding Places of Curlew [in Brecons.]. (Field, June I6.)

I884. Phillips, E. C. White Carrion Crow; Supplemental List of Birds of Brecon. (Zool.) ; The Birds of Pembrokeshire. (Zool., I884, p. 38I.) [Mainly refers to Brecons.]

I884-9o. Phillips, E. C. Ornitholog. Notes from Brecons. 8 notes. (Op. cit., I884-90.) [47I.] 
I885. Crawshay, A. Garganey Teal in Brecons. (Field, Feb. 7.)

Egerton, R. Pied Flycatcher, Kite, etc. (Sci. Gossip.)

Phillips, E. C. Nesting of Curlew in Wales [Brecons.]. (Field, Feb. 28, May I6.)

I886. [Anon.] Pied Flycatcher near Brecon. (Field, May 8.)

Phillips, E. C. Grasshopper Warbler in Brecons. (T.c., June Ig.)

I888. Phillips, E. C. Cirl Bunting in Brecons. (Zool.)

Swainson, E. A. Parrot Crossbill near Brecon. (Field, June 2) ; Merlin Breeding near Brecon. (Zool.)

I889. Lilford, Lord. The Great Black Woodpecker in England. (Field, July 27.) Idem by E. C. Phillips. (Zool.) [partim.] (Cf. Tr. Woolh. Nat. F. C.)

Phillips, E. C. Destruction of Kites in Brecons. (Field, July I3.)

Swainson, E. A. Kite and Raven nesting in S. Wales; Notes from S. Wales. (Zool.)

I89o. Swainson, E. A. Tree Pipit in N. Wales; Cirl Bunting nesting near Brecon. (Zool.)

I891. Swainson, E. A. Garden Warbler, Lesser Whitethroat and Lesser Redpoll in S. Wales. (OP. cit.)

I892. Aplin, O. V. On Distribution of Cirl Bunting in Great Britain. (Op. cit.) [partim.] [25.]

I893. Ashdown, W. C. Hybrid Pheasant and Blackgame. (Field, Dec. 9.)

Swainson, E. A. Grasshopper Warbler near Brecon. (Zool.)

I894. Swainson, E. A. Nesting of Pied Flycatcher. (Field, Aug. II.)

1895. Crawshay, A. Jerfalcon in Brecons. (Op. cit., Mar. 23.)

Swainson, E. A. Black Tern in Wales. (Zool.)

1897. Phillips, E. C. Green Sandpiper in Brecons. (2 notes); Green Sandpiper in Brecons. in June and July; Increase of Stock Dove in Brecons. (Field, June 26 ; July 3I ; Sept 4) ; Possible Breeding of Green Sandpiper in Brecons. (Knoroledge.)

1898. Phillips, E. C. Hobby in Brecons. (Field, Sept. I7) : Habits of the Nightjar. (T.c., Aug. I3 27.) 3 notes.

Swainson, E. A. The Cirl Bunting in Brecons. (Zool.)

V[aughan,] A. G. Arrival of Sand Martin. (Field, Mar. 26.)

I899. Phillips, E. C. The Birds of Breconshire. Cr. 8vo. Brecon. : I899. [47I.]

Phillips, E. C. Fire-crested Wren in Brecons. (2 notes). (Field, Mar. 4, I8.) Idem. (Knowoledge.)

Swainson, E. A. Grasshopper Warbler in Brecons. (Zool.)

I900. Llewellyn, J. T. D. Short-eared Owl and Kite in S. Wales. (Field, Dec. I5.)

V[aughan,] A. G. Arrival of Wheatear. (Field, Mar. 24.) 
I90I. Phillips, E. C. Ornitholog. Notes from Brecons. (Op. cit., July 20.)

1902. Neale, J. J. Peregrine breeding in Brecons. (Op. cit., Sept. r3.) Phillips, E. C. Scarcity of Woodlark in Brecons.; Summer Birds in S. Wales; Bar-tailed Godwit in Brecons. (Op. cit., May 3I ; July 5 ; Sept. 20.)

Swainson, E. A. Nesting of Woodlark in Brecons. (2 notes.) (Op. cit., May ro ; June I4.) Nesting of Hawfinch in Brecons. (Zool.)

Vaughan, A. Gwynne. Scarcity of Corncrake in S. Wales. (Field, June 2I.)

Ig03. Jourdain, F. C. R., and Salter, J. H. [Letters on Preservation of Kite in Wales.] (Bull. B.O.C., XIII.) [322.]

Phillips, E. C. White Peewit in Brecons. (Field, Jan. 3.)

Swainson, E. A. Spotless Curlew's Egg. (Zool.)

Vaughan, A. Gwynne. Ferruginous Duck on the Wye. (Field, Apr. 25.)

I904. Phillips, E. C. Warblers in S. Wales; White Crows. (Op. cit., June II.) 2 notes.

Swainson, E. A. Autumn Song of Cirl Bunting and Dipper; Stock Dove in Brecons. (Zool.)

Vaughan, A. Gwynne. Occurrence of Green Sandpiper in Winter. (2 notes.) (Field, Jan. 30 ; Dec. I7.)

1905. Meade-Waldo, E. G. B. Report on Fund for Preservation of Kite in Wales. (Bull. B.O.C., XV.) [395.]

Phillips, E. C. Summer Birds in Brecon. (Field, July I); Curiously coloured Grouse. (T.c., Sept. 9.) 2 notes.

Swainson, E. A. Nesting of Merlin in Brecons.; Autumn Song of Birds. (Zool.)

Vaughan, A. Gwynne. Eared Grebe near Builth. (2 notes.) (Field, Apr. 15, 22.)

I906. Jourdain, F. C. R. On Hybrids which have occurred .... between Black-game and Pheasant. (Zool.) [partim.] [322.]

I907. Phillips, E. C. Notes from Brecons. (2 notes); Hybrid; White and Hybrid Crows in Brecons.; Destruction of Kite in Wales. (Field, Apr. 6, Feb. 9, Aug. 24, Sept. 7.) 6 notes. Swainson, E. A. Scaup Duck in Brecons. (Op. cit., Mar. 2.) Vaughan, J. W. Spotted Crake in Brecons. (Op. cit., Sept. I4.)

I908. [Editorial.] The Pink-footed Goose. (Op. cit., Feb. I.) Idem by E. C. Phillips. (T.c., Mar. 7.)

Phillips, E. C. White Carrion Crows in Brecons. (Op. cit., Oct. Io); Supposed Breeding of Dunling in Brecons. (T.c., Sept. I9.)

"E. C. P" thillips]. Carrion Crows Congregating. (Op. cit., Jan. II.) 


\section{Selection of Books from WITHERBY \& CO.'S List.}

\section{BRITISH BIRDS.}

An Illustrated Monthly Magazine devoted to the Birds on the British List. Edited by H. F. WITHERBY, M.B.E., F.z.S., M.B.O.U. Assisted by Rev. F. C. R. JourdaIN, M.A., M.B.o.U., and N. F. TICEHURSI, M.A., F.R.C.S., M.B.O.U. Illustrated with beautiful and useful photographs. Provides a current history of British Birds. Annual Subscription, 20s. post free; Monthly, Is. 9d. net. Vols. I-XII. (unbound), I2s. each ; bound, I5s, 6d. each net.

TROPICAL WILD LIFE IN BRITISH GUIANA.

Being Zoological Contributions to Science, from the Tropical Research Station of the New York Zoological Society, at Kalacoon, igi6. By Williaji Berbe, G. Inness Hartley and Paul G. Howes, with an Introduction by COLONEL THEOdORE ROOSEvelt. Octavo. Cloth. 504 pages. 4 Coloured Plates, and $\mathrm{I}_{4} \mathrm{O}$ other Illustrations: I2s. Gd: net:

\section{A MONOGRAPH OF THE PHEASANTS.}

By Williass BeEbE. With Numerous Coloured Plates by A. Thorburn, C. R. Knight, G. E. Lodge, L. A. Fuertes, H. GronvolD, and $H$. Jonrs. Together with Maps and Numerous Photographs by the Author, depicting the Pheasants of the World, their Haunts, their Changes of Plumage and their Nests and Eggs. Limited Edition of 600 Numbered Sets, only a portion of which are available for sale in the British Empire. Royal 4 to. In Four Volumes, Volume I now ready. Prospectus and Specimen Plate on application:

\section{A HAND-LIST OF BRITISH BIRDS.}

By Frnst Harterr, F.C. R. Jourdain, N. F. Ticenurst, and H. F. WirinerBy. Demy 8vo 7s. 6d, net. Interleaved ros. net.

THE BIRD-LOVER'S HOME-LIEE SERIES.

1. The Home-life of the Golden Eagle. 2. The Home-life of the Spoonbill, the Stork and some Herons. 3. The Home-life of the Osprey. 4. The Home-life of the Terns or Sea-Swallows. Each Volume contains 32 beautiful plates, artistically mounted from PHOTOGRAPHS DIRECT FROM NATURE, with 40-60 pages of letterpress. Crown 4to. Cloth 75. Gd. net each.

GAME BIRDS AND WATER-FOWL OF SOUTH AFRICA:

By the late Major BOyd Horsburgh, F.z.s., M.B.O.U. With 67 beautiful Coloured Plates: Half morocco $\ell_{4}$ I 46. net; or unbound parts.

INDIAN PIGEONS AND DOVES.

By' E. C. STUART BAKER, F.z.S., M.B.O.U. With 27 beautiful Coloured Plates. Imp. 8vo. Half bound morocco. $£_{2}^{2}$ ros. net.

PHOTOGRAPHY FOR BIRD-LOVERS.

By Bentley Beetras, r.z.s. I6 full-page Plates. A practical guide to the pursuit of bird-photography in all its branches. Demy 8vo: Cloth 5s. net.

JUNGLE PEACF.

By William Beebe. Contains records of extraordinary scientific interest. The author tells of bird, beast, plant and insect life of the British Guiana jungle. Crown 8 vo, illustrated. 8s, net.

THE BUZZARD AT HOME.

By Arthur Brook. The photographs, which are here first published, have special intercst to Ornithologists. Twelve plates. 3s. 6 d. net. 


\section{Completion of Volume 1. (Passeres).}

\section{A PRACTICAL HANDBOOK OF BRITISH BIRDS.}

Edited by H. F. WITHERBY, M.B.E., M.B.O.U., F.Z.S., F.R.G.S.

Contributors :-E. Hartert, PH.D., s.r.o.u., f.z.s. Annie. C. Jackson, H.M.B.o.U. Rev. F. C.R. Jourdain, M.A., M.B.o.U. C. OldiaM, F.z.s., M.B.o.U, N. F. TıсенURst, M.A.; F.R.c.s, M.в.o.U.

Specially arranged for quick reference. Distinguishing characters simplifying identification, full description of all plumages. lireeding habit; (nest, cggs, season, incubation, etc.). Food. Distribution and Migration.

WITH COLOURED

MONOTHROKE: PV ATES,

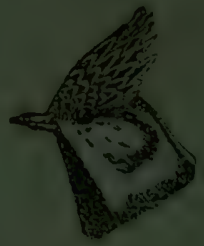

NUMEROUS TEXT FIGURES.

PRACTICAL. ORIGINAL. UP.TO-DATE.

VOL. I. (Now Ready). Bound in Buckram, Gilt Top, Price 408. Thin Paper Edition (bound in rexine) Price 48s, $6 \mathrm{~d}$. VOL. II, 10 parts (completing the work) now in progress. Price 4s. 6d. (5s, 6d. Thin Edition) each.

FAUNA OF NOF NORTH WERTE WALS

By H. E. FORRES':

This book not only lorings up to date the information contained in the Author's "Vertebrate Fauna of North Wales," but also gives uncles each species a briel summary showing its stalus in the district.

Demy. Svo.

Cloth.

65. net.

\section{METEOROLOGY FOR ALL.}

\section{BEING SOME WEATHER PROBLEMS EXPLAINED}

By DONALD W: HORNER, Y.R.MET,SOc, etc.

Author of "Observing and Forecasting the Weather."

"Weather Instruments and Ilow to Use Them."

With: 'Text and: Half:Tone Illustrations.

A compendium of information atout the Weather as it daily affects the lives of everyone. The "dry" terseness of the text-Look has been avoided, but the information given is comprehensive and reliable, and of a practical sature.

Crown svo.

Cloth:

Illustrated.

6s. net.

326, HIGH HOLBORN, LONDON, W.C.I. 
A

\title{
GEOGRAPHICAL BIBLIOGRAPHY
}

OF

\section{BRITISH ORNITHOLOGY}

\author{
FROM THE EARLIEST TIMES \\ TO THE END OF 1918 \\ ARRANGED UNDER COUNTIES
}

BEING A RECORD OF PRINTED BOOKS, PUBLISHED ARTICLES, NLTES AND RECORDS RELATING TO LOCAL AVIFAUNA.

\section{$\mathrm{BY}$}

W. H. MIULLENS, M.A., LL.M., F.L.S., M.B.O.U., H. KIRKE SWANN, T.Z.S., AND REV. F. C. R. JOURDAIN, M.A.; м.в.о.б.

"Mlen that undertake only one district aro much more likely to advance natural knowledgo than those that grasp at more than they can possibly be acquainted with, every lingdom, every province, should have its own monographer."

GicberT WHite- "Tho Natural History of Selborne." 7th Lotter to Barrington.

IVITHERBY \& CO. 326, HIGH HOLBORN, LONDON 

I909. [Editorial.] Protection of Kite in Wales. (Op. cit., June Ig.)

Wright, M. A. Bittern in Brecons. (T.c., Jan. 30.)

Igro. Evans, J. D. D. Ring Ouzel nesting in Brecons. (Op. cit., Sept. 3.)

Meade-Waldo, E. G. B. On Preservation of Kites in Wales. (Bull. B.O.C., XXV.) [395.]

Phillips, E. C. Crossbills in Brecons. (Field, Sept. Io) ; Ring Ouzel nesting in Brecons. (T.c., Sept. IO.)

IgII. Phillips, E. C. Bird Notes from Brecons. (Op. cit., July 8.)

Ticehurst, N. F., and Jourdain, F. C. R. On Distribution of Nightingale during Breeding Season in Gt. Britain. (Brit. Birds, V.) [partim.] [322, 584.]

IgI2. Phillips, E. C. Notes from Brecons.; Hawfinch in Brecons. (Field, May II, Aug. 24.)

I9r3. Phillips, E. C. Note on the Birds of Brecons. (Rept. and Trans. Cardiff Soc., XLVI., p. 94.) Lesser Spotted IVoodpecker in Brecons. (Field, Aug. 30.)

Igr4. Phillips, E. C. Bird Notes from Brecons. (Rept. \& Trans. Cardiff Soc., XLVII., pp. 52-3.)

Igr5. "J. G. G." Landrail in Jan.; Goosander on Wye. (Field, Jan. 30.) Idem by E. C. Phillips. (T.c., Feb. I3.)

Phillips, E. C. The Hooded Crow in Brecons. (Field, Jan. 23) ; Idem by R. M. Thorneley. (T.c., Jan. I6.)

IgI6. Evans, J. D. D. Longeared Owl in Brecons. (Wild Life, VIII.)

Williams, J. R. Woodlark in Brecons." (T.c.)

I917. Phillips, E. C. Bird Notes from Brecons. (Field, Jan. 20); Buzzards in Brecons. (T.c., Jan. 27.)

\section{CARDIGANSHIRE.}

I848. Parry, E. W. Account of a Hooper or Wild Swan. (Zool.)

I863. Shaw, H. O. Rare Birds in Shrops,, etc. [incl. Bittern from Aberystwyth]. (Field, Feb. 6.)

I870. Browne, A. M. Curlew Sandpiper near Aberystwyth; Grey Phalarope in Wales. (Zool.)

Cosens, G. W. Yellow-billed American Cuckoo [and Phalaropes near Aberystwith]. (Field, Nov. 5 ; Zool.)

Dix, T. Quails in Pembrokes. (Zool.) [partim.]

[Editorial.] The Snow Bunting [on Plinlimmon]. (Field, Nov. I2.)

I87I. Dresser, H. E. Exhibition of British Specimen of American Yellow-billed Cuckoo. (P.Z.S., I87I.) 
Jebb, R. C. Kites, Nightingales and Landrails. (Field, June 7.)

Phillips, $\mathrm{T}$. Influx of Common Quail in S. Wales in 1870 . (T.C., June 3.)

1872. Harting, J. E. British Heronries. (Zool.) [partim.] [274.]

1875. Cosens, G. W. Egyptian Goose in Cardigans. (Field, Dec. I8.)

" L. G. T." Notes from Cardigans. (Op. cit., June 26.)

r876. [Bund], J. W. Solitary Snipe in Wales, Cardigan and Carmarthen borders. (Op. cit., Sept. I6.)

I878. B[und], J. W. Early Appearance of Jack Snipe. (2 notes.) (Op. cit., Sept. 7, 2I.)

"W. R. H." A Large Cormorant. (Op. cit., June 8.)

I879. Cosens, G. W. Nesting of Short-eared Owl in Cardigans. (Op. cit., Dec. 27.)

Garnett, S. E. Notes from Aberystwith. (2 notes.) (T.c., Nov. I5, 29.)

Maclean, N. Unusual Arrival of Quail in Cardigans. (T.c., Nov. 22.)

I882. [Bund], J. W. Manx Shearwater inland [near Tregaron.] (Field, Sept. I6.)

"Mid-Cardiganshire." Woodcock in Cardigans. (Op. cit., Oct. I4.)

I885. Green, H. L. Bittern in S. Wales. [Tregaron.] (Op. cit., Jan. I7.)

I886. Bund, J. W. Solitary Snipe in Cardigans. (Op. cit., Sept. I8.)

Hooton, J. Reported Occurrence of Cream-coloured Courser near Aberystwith. (T.c., Oct. I6.)

1887. Hooton, A. Cream-coloured Courser in Cardigans. (Zool.)

Nelson, T. H. Cream-coloured Courser near Aberystwith. (Field, Apr. 6.)

I889. Miles, S. H. Late Landrail in S. Wales. (Op. cit., Jan. 26.)

I89o. Harting, J. E. Occurrence on the Welsh Coast of Estrelata torquata. (Zool.)

I89I. S[alter], J.H. Grey Phalaropes at Aberystwyth. (Field, Nov. 7.)

Salvin, O. Note on the Collared Petrel (E. torquata) killed on Welsh Coast. (Ibis.)

Swainson, E. A. Cirl Bunting in Cardigans. (Zool.)

1892. Aplin, O. V. On Distribution of Cirl Bunting in Great Britain. (Op. cit.) [partim.] [25.]

1893. Salter, J. H. Breeding of Dunlin in Wales; Notes from Aberystwith. (Op. cit.)

I894. "Cambrian Naturalist." Nightingales in Cardigans. (Field, June 2.)

I895-I904. Salter, J. H. Observations on Birds in Mid-Wales. 9 papers. (Zool.) 
I896. Salter, J. H. Sabine's Gull at Aberystwith. (OP. cit.); Idem. (Field, Oct. Io.)

1898. "Cardy." Quail in Cardigans. (Field, Oct. 15.)

I900. Salter, J. H. List of the Birds of Aberystwith. 8vo. Aberystwith ; N.D. [504.]

I902. Cummings, S. G. Cirl Bunting in Carnarvons, and Cardigans. (Zool.)

Salter, J. H. Tree Sparrow in Cardigans. (T.c.)

Vaughan, A. Gwynne. Red Jackdaw. (Field, Nov. I5.)

I903. Salter, J. H. Lesser Redpoll in Cardigans. ; Lesser Whitethroat in Cardigans. 2 notes. (Zool.)

rg04. Walpole-Bond, J. A. Goshawk in Wales. (Field, June II.)

I905. "M. A. W[right]." Quail in S. Wales. (Op. cit., Nov. 4.)

I9I0. Davies, B. Ring Ouzel in Cardigans. (Op. cit., Aug. 27.)

Harford, J. C. Blackgame in Cardigans. (Op. cit., Jan. I.)

"Portcullis." Idem. (T.c., Jan. 8.)

Wright, M. A. Western Limit of Nightingale. (Op. cit., July 9.)

IgII. Evans, H. Nightingales in W. Wales. (Op. cit., July 8.)

Salter, J. H., and Galloway, S. V. The Mammals, Birds and Butterflies of North Cardigans. N.U.T. Souvenir. Aberystwith : I9II.

Ticehurst, N. F., and Jourdain, F. C. R. On Distribution of Nightingale during Breeding Season in Great Britain. (Brit. Birds, V.) [partim.] [322, 584.]

I9I3. Edwards, S. Quails in Cardigans. (Field, June I4.)

\section{CARMARTHENSHIRE.}

I846. Hughes, E. J. R. Habits of Raven. (Zool.)

I858. Hall, T. Occurrence of Glossy Ibis in S. Wales. (Zool.)

I859. " Cattymulcock." Arrival of Summer Migrants. (Field, May 2I.)

I860. "F. D." Nesting of Moorhen. (Op. cit., Aug. 4.)

I864. "E. B." Black Redstart Shot in Carmarthens. (Op. cit., Mar. I2.)

1865. Dix, T. Notes on Birds of Carmarthens. (Zool.)

1869. "Scolopax sabini." Hen Harrier in Carmarthens. (Field, Jan. 30.)

I876. Andrews, T. Notes from Swansea. [Marsh Harrier near Carmarthen.] (Op. cit., Feb. 5.)

"J. W. B." [und] Solitary Snipe in Wales [borders of Carmarthen and Cardigan]. (Op. cit., Sept. I6.) 
I878. "J. W. B[und.]" Spotted Crake in Carmarthens. (Op. cit., Sept. 28.)

I88I. " J. W. B [und.]" Spotted Crake in Carmarthens. (Op. cit., Oct. 8.)

I883. Phillips, E. C. Breeding Places of Curlew [in Carmarthens.]. (Op. cit., June I6.)

1888. "Midget." Heron's Nest in Rookery, Llandovery. (Op. cit., May 5.)

Richardson, R. E. Spotted Crake in Carmarthens. (OP. cit., Sept. 22.)

I889. "Towy." Avocet in S. Wales [near Ferryside]. (Op. cit., Feb. 2.) I89o. Aplin, O. V. On Distribution and Period of Sojourn in Brit. Isles of Spotted Crake. (Zool.) [partim.] [24.]

I89I. Harting, J. E. The Recent Visitation of Bustards. [partim.] (Field, Feb. 28.)

I895. Aplin, O. V. On Birds observed in South Wales. (Zool.) [25.] Oldham, C. Grasshopper Warbler in North Wales. (Zool.) [partim.]

I900. Cazalet, R. H. Notes from Carmarthens. (Field, July 28); Late Nesting of Yellow Hammer. (T.c., Sept. I5.)

IgIx. Ticehurst, N. F., and Jourdain, F. C. R. On Distribution of Nightingale during Breeding Season in Great Britain. (Brit. Birds, V.) [partim. $] \quad[322,584$.

\section{CARNARVONSHIRE.}

I783. Pennant, T. A Tour in Wales, MDCCLXXIII. Sm. 4to. Lond. : 1783 .

I835. Williams, R. History and Antiquities of Town of Aberconway. 8vo. Denbigh : 1835 .

I855. Parry, R. Llandudno Visitor's Handbook. Post 8vo. Llandudno: I855.

I859. Moore, T. J. Occurrences of the Sand Grouse in Wales [near Tremadoc.] (Zool.)

"F. S. D." Eagles, Buzzards, etc. (Field, Aug. 6) ; Rare Birds. (T.c., Sept. Io.)

I86r. Parry, R. Llandudno, its History and Natural History. Cr. 8vo. Llandudno: I86r.

[—?] Williams, T. Williams' Complete Guide to Llandudno. 8vo. Llandudno : N.D.

I864. Martin's Week's Wanderings in Wales. [Chapter on Birds of Menai Straits.] 8vo. Bangor: I864. 
I866. Cordeaux, J. Chough nesting in Carnarvons. (Zool.)

I867. Platt, H. Rose-coloured Pastor in Wales [near Bangor]. (Field, Aug. 24.)

1870. More, A. G. Eagles in North Wales. (Zool.)

I871. Kerr, W. J. Quails and Siskins in Wales [Siskins in Denbigh only]. (Zool.)

I875 (?) Price, J. Llandudno and how to enjoy it. [Chap. on Nat. Hist. and list of Vertebrates.] 8vo. Llandudno: N.D.

I875. Brooke, G. B. Longtailed Duck on the Conway. (Field, Nov. 27.) I878. "W. E." White-fronted Goose in N. Wales. (Op. cit., Nov. 2.) I879. "F. S. O." Pied Flycatcher in Carnarvons. (Field, Sept. ro.) I880. Tuck, J. G. Gannet at Llanberis. (Zool.)

r883. Inchbald, P. Garden Warbler and Grasshopper Warbler at Llandudno. (Field, May I2.)

r8go. Caton-Haigh, G. H. Tree Pipit in N. Wales. (Zool.) [partim.] Cordeaux, J. Idem. (T.c.)

1893. Coward, T. A. Lesser Whitethroat breeding in Carnarvon. (Op. cit.)

I895. Blagg, E. W. H. Manx Shearwater in Carnarvons. (Op. cit.) Idem by T. A. Coward. (T.c.)

I897. Caton-Haigh, G. H. Alpine Pipit in Carnarvons. (Zool.)

Saunders, H. [Exhib. of Water Pipit from Carnarvons.] (Bull. B.O.C., VI.) Idem. (Op. cit., VII.)

I898. Caton-Haigh, G. H. Water Pipit in Carnarvons. (Zool.)

I899. Aplin, O. V. Cirl Bunting in Carnarvons. (Op. cit.)

Newstead, R. Crossbill in North Wales. (Zool.)

Oldham, C. Pied Flycatcher in North Wales. (Zool.) [partim.] Pentland, G. H. Nesting of Crossbills in Carnarvons. (Zool.)

I900-or. Aplin, O. V. Birds of Lleyn, W. Carnarvons., 2 pts. (Op. cit., I900-or.)

Igor. Dobie, W. H. Grasshopper Warbler at Llanbedrog. (Zool.)

I902. Cummings, S. G. Cirl Bunting in Carnarvons., etc. (Op. cit.) I902-3. Aplin, O. V. Birds of Bardsey Is., with Additional Notes on Birds of Lleyn, 3 pts. (Op. cit., I902-3.)

I905. Aplin, O. V. Winter Notes from Lleyn, 3 pts. (Op. cit.) I908. Forrest, H. E. Nuthatches breeding at Llandudno. (Brit. Birds, II.)

I9ro. Aplin, O. V. Summer in Lleyn, 2 pts. (Zool.)

Coward, T. A. Blue-headed Wagtail in Carnarvons. (Brit. Birds, IV.)

Jones, R. W. Black-throated Diver in Carnarvons. (T.c.) Owen, T. Ramble with the Birds in .... Carnarvon. (Zool.) 
IgII. Forrest, H. E. White-tailed Eagle in Carnarvons. (Brit. Birds, IV.)

Jones, R. W. Black Redstart, Hooded Crows, Black-throated Diver in Carnarvons. 4 notes (T.c.); Fork-tailed Petrel in Carnarvons. (Op. cit., V.)

Newstead, A. Immature Glaucous Gull [in Carnarvons.]. (Zool.) I9I2. Jones, R. W. Black Redstart in Carnarvons. (Brit. Birds, V.) ; Blue-headed Wagtails, Redbreasted Mergansers, Blackthroated Diver, Arctic Skua and Great Skua in Carnarvons., etc. 6 notes. (Brit. Birds, VI.)

Owen, T. A Season with the Birds of Anglesey and N. Carnarvons., 2 pts. (Zool.)

Wells, C. H. Goosanders in Carnarvons. (Brit. Birds, V.)

Igr3. Jones, R. W. Chiffchaff in Winter in Carnarvons. (OP. cit., VI.) Common Scoters off Carnarvons. in Summer; Sandwich Terns in Carnarvons. (Op. cit., VII.)

Igr4. Jones, R. W. Slavonian Grebe in Carnarvons. (T.c.)

Oldham, C. Ferruginous Duck in Carnarvons. (OP. cit., VIII.)

I9I5. Cummings, S. G. Nuthatch in Carnarvons.; Pomatorhine Skua in Carnarvons.; Great Skua in Carnarvons. $(O p$. cit., IX.)

I9I7. Cummings, S. G. Blacktailed Godwit and other Waders in Carnarvons; Dotterel in N. Wales. (Op. cit., X.)

Forrest, H. E. Present status of Nuthatch in Carnarvons. and Anglesey. (Op. cit., XI.)

\section{DENBIGHSHIRE.}

I778. Pennant, T. A Tour in Wales, MDCCLXX. Sm. 4to. Lond. : I778. [partim.] [468.]

I830. Williams, John. Faunula Grustensis, being an outline of the Natural contents of Llanrwst, with a catalogue of Animals. I2mo. Llanrwst : 1830.

I844-48. Blackwall, J. Periodical Birds observed in I842-3, I843-4, I844-5, I846-7, nr. Llanrwst. (Rep. Brit. Assoc. Adv. Sci., I843-4 and I847.) [68.]

1845. Blackwall, J. Anecdote of Pied Flycatcher. (Ann. \& Mag. N. H., sect. 2, IV., pp. I8-25.) Idem. (Zool.)

1866. W[ynne,] J. L. Occurrence of Hoopoe in Denbighs. (Field, May 12.)

1867. "Investigator." Spoonbill at Rhyl. (Op. cit., July 20.)

I868. Kerrison, E. P. Orange-legged Hobby [near Wrexham]. (OP. cit., May 23.) 
I870. Kerr, W. T. Solitary Snipe and Quail in Denbighs. (Zool.)

$\mathrm{K}[\mathrm{err}$,$] W. Solitary Snipe in Denbighs. (Field, Sept. I7.)$

Newman, E. Orioles in Gt. Britain [one in N. Wales]. (Zool.)

Preston, W. Conway. Golden Oriole in North Wales [near Ruthin]. (Field, Apr. 30.)

I87I. Jebb, R. G. Kites, Nightingales and Landrails. [Nightingales only in Denbighs.] (Field, June I7); Pied Flycatcher [in Denbighs.]. (T.c., June 3.)

Kerr, W. J. Quails and Siskins in Wales. [Siskins only in Denbighs.] (Zool.)

I87I-74. Kerr, W. J. Notes from Denbighs., 4 pts. (Zool., I87I, $I 872, I 873,1874$.)

I873. Harting, J. E. British Heronries. (Op. cit.) [partim.] Errata, W. H. Heaton. (T.c.)

Kerr, W. J. Heronries in Denbighs, etc. Crossbills in Denbighs. (Zool.)

I874. Kerr, W. J. Ruff at Rhyl in Aug. (Zool., p. 39r3.)

Kerrison, E. P. Bittern and Great Grey Shrike near Wrexham. (Field, Dec. 5.)

Wynne, B. W. Roller near Abergele. (Op. cit., Nov. 7.)

I875. Brook, G. P. Longtailed Duck on the Conway. (Op. cit., Nov. 27.)

1876. Jesse, J. F. Greenland Falcon in N. Wales [at Rhiwlas]. $(O p$. cit., Apr. I.)

I883. " $T$. R" $\mathrm{R}$ "uddy.] Red-legged Partridge in Denbighs. (Op. cit., Apr. 2I.)

I887. Blezard, G. Woodcock breeding in N. Wales [near Ruthin]. (Op. cit., May I4.)

I892. Evershed, S. Quail in Denbighs. (Op. cit., Oct. I.)

Aplin, O. V. On Distribution of Cirl Bunting in Gt. Britain. (Zool.) [partim.] [25.]

Jebb, A. T. Birds of Llansilen, Denbighs. (Bygones relating to Wales, etc., I892.)

I893. Mesham, A. Quails in N. Wales. (Field, Oct. 2I.)

I895. Mainwaring, C. S. Black Terns in N. Wales. (Zool.; Field, Aug. 3.)

I898. Dobie, W. H. Birds of W. Chesh., Denbighs., etc. (Reprint from Chester Nat. Soc. Pr., IV., I894.) [partim.] [I7I.]

I899. Howard, C. White-fronted Goose at St. Asaph. (Field, Dec. 30.)

Oldham, C. Pied Flycatcher in N. Wales. (Zool.) [partim.]

I900. Congreve, W. M. Stock Dove laying three eggs. (Field, May 5.)

I905. Forrest, H. E. Baillon's Crake in N. Wales. (Zool.) 
I907. Forrest, H. E. The Vertebrate Fauna of N. Wales. Large 8vo. Lond.: 1907. [partim.] [213.]

Oldham, C. Tree-Sparrow in Denbighs. (Zool.)

I908. Forrest, H. E. An early recorded Waxwing. (Brit. Birds, II.)

Head, C. D. Honey Buzzard in N. Wales. (Zool.)

I909. Forrest, H. E. Greenland Falcon. (Brit. Birds, II.)

I9II. Heasman, G. C. Great Snipe in Denbighs. (Field, Sept. 30.)

Ticehurst, N. F., and Jourdain, F. C. R. On Distribution of

Nightingale during Breeding Season in Gt. Britain. (Op. cit.,

V.) [partim.] $[322,584$.

r9r3. Coward, T. A. Eider in N. Wales. (Op. cit., VII.)

Williams, R. W. Quail in Denbighs. (Field, Sept. 20.)

I9I4, Jones, R. W. Sandwich Terns in Denbighs. (Brit. Birds, VIII.)

I9I5. Owen, J. H. Snipe laying five eggs [in Denbighs.] (Op. cit., IX.)

\section{FLINTSHIRE.}

I778. Pennant, T. A Tour in Wales, MDCCLXX. Sm. 4to. Lond. : I778. [partim.] [468.]

I856. Walker, A. O. Occurrences of the Eared Grebe in Flintshire. (Zool.)

1858. Mather, T. Roller in Flints. (Zool.)

r860. ["Kat."] Roller in Flints. (Field, Dec. I.) Idem. (T.c., Nov. 24.)

Shaw, J. Black-throated Diver. (T.c., Dec. 29.)

1861. [ex Eddowes' Shreresbury Journal.] Pastor roseus shot in Flint. (Op. cit., Aug. 3I.) [Cf. Lond. Jnl., Sept. 2I, I86I; T. A. Coward, Brit. Birds, IX. ; F. C. R. Jourdain, Op. cit., XI.]

I865. Dod, Whitehall. Turtle Dove in Vale of Clwyd, North Wales. [Llanerch Park.] (Field, July 22.)

I867. "Investigator." Spoonbill at Rhyl. (Op. cit., July 20.)

Smith, H. Ecroyd. A Day among the Bird Breeders at the Point of Air. (Zool.) [Cf. also Idem in L'pool Nat.Jnl., I866.]

I870. "R. L." Occurrence of Hooper at St. Asaph. (Field, Jan. 22.) I87I. Mather, M. E. Nightingale in N. Wales. [Holywell.] (Op. cit., June I7.)

I872. Harting, J. E. British Heronries. (Zool.) [partim.] [274.] I874. Mostyn, R. Curious Retreat for Corkcrake. (Field, May 9.) I875. Price, R. J. Lloyd. [Little] Bittern in N. Wales. (Op. cit., Jan. I6.) 
I877. Bushby, J. Black-throated Diver on River Dee. (Op. cit., Jan. 27.)

I879. Mesham, A. Water Rail feeding on Trout [at Rhyl]. $(O p$. cit., Jan. I8.)

I886. Dobie, W. H. Exhibition of Specimen of Sabine's Gull shot at Mostyn, Flints. (P.Z.S.)

I893. Mather, T. The Summer Warblers of Flints., 4 pts. (L'pool Nat. Jnl.)

"P. T. G." Quail [in Flints.] (Field, June 24.)

I895. Ashton, R. Wood Pigeon nesting in November. (Op. cit., Nov. I6.)

r898. Cuming, J. S. Hawfinch in N. Wales. (Op. cit., Apr. 2.)

Dobie, W. H. Birds of W. Chesh., Denbighs., and Flints. 8vo. Chester : I898. (Reprint from Pr. Chester Nat. Soc., I894.) [partim.] [I7I.]

1899. Howard, C. White-fronted Goose at St. Asaph. (Field, Dec. 30.)

rgoo. Forrest, H. E. Little Owl in Flints. ? (Zool.) [2I3.]

rgor. Forrest, H. E. Richard's Pipit in N. Wales. (Op. cit.)

I903. Cummings, S. G. Cirl Bunting in Flints. (Op. cit.)

Wrigley, J. H. Albino Swallow at St. Asaph. (Field, Aug. 8.)

1905. Coward, T. A. Shoveler on Dee Estuary. (Op. cit., Jan. 7.)

Cummings, S. G. Curlew Sandpiper on Dee Marshes in Feb. (Zool.)

I907. Forrest, H. E. The Vertebrate Fauna of North Wales. Large 8vo. Lond.: I907. [partim.] [213.]

I9Io. Coward, T. A., and Oldham, C. The Vertebrate Fauna of Cheshire and Liverpool Bay. [partim.] (Including J. A. Dockray. The Dee as a Wildfowl Resort.) [I52.]

IgIr. Ticehurst., N. F., and Jourdain, F. C. R. On Distribution of Nightingale during the Breeding Season in Gt. Britain. (Brit. Birds, V.) [partim. $[322,584$.

I9I6. Coward, T. A. Rose-coloured Starling in Flints. (Op. cit., IX.) Forrest, H. E. Pochard breeding on Welsh border. (T.c.)

\section{GLAMORGANSHIRE.}

I840. Dillwyn, L. W. Contributions towards a History of Swansea. Roy. 8vo. (Priv. printed.) Swansea: I840. [I68.]

Gutch, J. U. G. Hoopoe; Little Stint [near Swansea]. (Ann. Mag. N. H., VI., pp. 236-7.)

I84I. Gutch, J. U. G. On Rare Species of Birds taken near Swansea. (Op. cit.) 2 notes. 
1848. Dillwyn, L. W. Materials for a Fauna and Flora of Swansea. Roy. 8vo. (Priv. printed.) Swansea: 1848. [I68.]

I851. Falconer, R. W. Heronries [in Glamorgans.]. (Nat. [Morris's], I.)

1853. Knight, E. Doddridge. List of the less common Birds of Newton Nottage. (Arch. Camb., Oct. 1863.)

1856. [Editorial.] Occurrence of Bittern in Beds. [and Glamorgan]. (Zool.)

I858. "Tir-y-Cwm." Arrival of Summer Birds. (Field, May I.)

1859. Drane, R. Little Bittern near Cardiff. (Zool.)

"Portia." Nightingale in Wales. [Cardiff, common.] (Field, May I4.)

"Tir-y-Cwm." Nightingales in Glamorgans. (Op. cit., May 28.)

1860. Hale, G. M. Grey-Hen shot in Glamorgans. (Op. cit., Oct. I3.) Idem by "R. H. H." (T.c., Oct. 20.)

Williams, D. Grey Phalarope at Swansea. (Zool.)

I86r. Williams, D. Buzzard near Swansea; Wild Swans at Swansea, 2 notes. (Op. cit.)

1862. Morgan, A. Pied Woodcock. (Field, Feb. 8.)

I866. Llewellyn, J. D. Great Grey Shrike in S. Wales. (Field, Mar 24.)

I868. Kemeys-Tynte, Sir D. Occurr. of Bittern [near Cardiff]. $(O p$. cit., Feb. I.)

1872. Carne, W. N. Honey Buzzard in South Wales. Bridgend. (Op. cit., Sept. 7.)

Harting, J. E. British Heronries. (Zool.) [partim.] [274.]

1875. Andrews, T. Variety of Common Swift. Swansea. (Field, Aug. 2I.)

Gough, R. D. Reported Occurrence of Jack Snipe in June. (T.c., July 3.)

1876. Andrews, T. Notes from Swansea. (Op. cit., Feb. 5); Rare Birds near Swansea and Cardiff. (Op. cit., Oct. 2I.)

1877. "Rambler." Stock Dove frequenting Rocks. (Op. cit., Mar 3.)

I879. Crawshay, T. Cuckoo singing late at night [Cardiff]. (Op. cit., May .7.)

I880. Morris, G. L. Hobbies in mid-winter [one shot at Bridgend]. (Op. cit., Jan. 3.)

1882. Gibbins, E. J. Teal and Marsh Harrier nesting in Glamorgans. (Zool.)

Seebohm, H. Rusty Grackle and Pallas's Grey Shrike in Wales. (T.c.)

Young, J. Reed Warbler and Nightingale in S. Wales. (T.c.)

I885. Morgan, H. Little Bustard in Wales. (Ficld, Nov. 28.) 
1887. Marsden, H. W. Nesting of Marsh Warbler in Glamorgans. (Zool.)

Shakespeare, W. Osprey near Cardiff. (Field, Oct. 22.)

I888. Nicholl, D. S. W. Kite in Glamorgans.; Albino Skỳlark and Starling; Pied Flycatcher in Glamorgans. 3 notes. (Zool.)

Peel, H. M. The present visitation of Sand Grouse. (Field, June 2.)

I889. Allen, W. E. R. Cirl Bunting in Glamorgans. (Field, May 4.)

Beckwith, W. E. Nightingale in Wales. (T.c., May 23.)

Nicholl, D. S. W. Little Gull in Glamorgans. (2 notes) ; Green Sandpiper, Sand Grouse, Cirl Bunting and Lesser Tern in Glamorgans. 6 notes. (Zool.)

Nicholl, D. S. W. Notes on the Rarer Birds of Glamorgans. (T.c.) (Also reprinted separately for Author.) [448.]

I89o. Aplin, O. V. On Distribution and Period of Sojourn in Brit. Isles of Spotted Crake. (Zool.). [partim.] [24.]

Nicholl, D. S. W. Goosander near Cardiff; Hawfinch in Glamorgans. (T.c.) 2 notes.

I89I. Allen, W. E. R. Cirl Bunting nesting in Glamorgans. (Field, Aug. I5.)

Drane, R., and Proger, T. W. The Rarer Birds of Cardiff, in Brit. Assoc. Handbook for Cardiff. Post 8vo. Cardiff : I89I. [I76.]

[Editorial.] [Bittern in Glamorgans.] (Field, Jan. 3.)

Nicholl, D. S. W. Bittern in Glamorgans. (Zool.)

I892. Aplin, O. V. On Distribution of Cirl Bunting in Great Britain. (Op. cit.) [partim.] [25.]

Nicholl, D. Quail in Glamorgans. (Field, Oct. 8.)

I893. Llewellyn, R. W. Cream-coloured Woodcock. (Op. cit., Nov. I8.)

I894. "W. F. E." Nightingale in Glamorgans. (Op. cit., June I6.) I895. Rees, G., "A. A. B.," and Watney, H. E. Gower and its Birds. (Nat. Notes.)

I896. Evans, W. F. Grey Phalarope in Glamorgans. (Field, Oct. 3.) I899. Jenner, G. White Swallow. (Op. cit., Sept. 9.)

I900. Cardiff, Nat. Soc. (Committee of). The Birds of Glamorgan. 8vo. Cardiff : I900. [II9.]

Potter, L. B. White Storks in Glamorgans. (Field, May I9.)

I90I. Evans, W. F. Nightingales in S. Wales. (Op. cit., June 8.)

I902-I2. Proger, T. W., and Paterson, D. R. Ornitholog. Notes for Ig02 to IgII, 9 pts. (Tr. Cardiff Nat. Soc., IgO2-I2.) [II9.]

I905. [Editorial.] Great Crested Grebe at Cardiff. (Field, Jan. 2I.) I908. Wright, M. A. Bird Protection around Cardiff; Some Existing Anomalies. (Tr. Cardiff Nat. Soc.) 
I909. Wright, M. A. Escaped Flamingo in Glamorgans. (Field, Jan. 30.)

I9I0. Jenner, B. St. A. Increase of Kite in Wales. (Op. cit., Apr. I6.)

I9II. Evans, H. Nightingales in W. Wales. (Op. cit., July 8.)

Evans, W. F. Grey Phalarope seen in S. Wales. (T.c., Nov. I8.) Ticehurst, N. F., and Jourdain, F. C. R. On Distribution of Nightingale during Breeding Season in Great Britain. (Brit. Birds, V.) [partim.] [322, 584.]

Wright, M. A. Long-tailed Duck in Glamorgans. (Field, Dec. 9.)

I9I2. Evans, W. F. Green Sandpiper in Glamorgans. (Op. cit., Feb. 3.)

Norton, F., and Delhanty, J. Abnormal Clutch of Great Crested Grebe in Glamorgans. (Zool.)

I9r3. Proger, T. W., and Paterson, D. R. Ornitholog. Notes [on the Hobby and Cuckoo at St. Fagans]. (Rept. \& Tr. Cardiff Soc., XLVI., pp. 90-9I.)

Salmon, H. M. Notes on Arrivals of Migrants, Igr3. (T.c., pp. 92-93.)

I9I4. Ingram, G. C. S. Note on Breeding of Redshank in Glamorgans. (Op. cit., XLVII., pp. 5-I2.)

Proger, T. W., and Paterson, D. R. Ornith. Notes I9I4. [Common Bittern at Pendoylan.] (T.c., pp. 45-49.)

Salmon, H. M. The Nightjar in Glamorgans. (Wild Life, III.) Wright, M. A. Waxwing in Glamorgans. (Field, Mar. I4.)

I9I5. Blake, J. Notes on Birds around Cardiff. (Zool.)

Blake, J. S. Bird Notes from Cardiff in I9I5. (T.c.)

Proger, T. W., and Paterson, D. R. Ornithol. Notes [on the Merlin at St. Fagans and Porthkerry]. (Rept. \& Trans. Cardiff Soc., XLVIII., pp. 59-62.)

IgI6. White, S. W. Bird Notes from S. Wales. (Zool.)

\section{MERIONETHSHIRE.}

I859. "F. S. D." Rare Birds [Honey Buzzards seen near Towyn]. (Field, Sept. Io.)

I864. Pamplin, W. Osprey in N. Wales. (Zool.)

I870. “J. A. J." Bittern in Merioneths. (Field, Jan. I5.)

Kerr, W. J. Great Snipe in Merioneths. (Zool., p. 2345.)

I87I. "C. F. T." Abundance of Chough on coast. (Field, Mar. I8.) Kerr, W. J. Quails and Siskins in Wales. [Siskins in Denbigh only.] (Zool.)

Ruddy, T. Pied Flycatcher Nesting in Wales. (Ficld, June 3, I87I, May I7, I873.) Idem by "W. J. K." (Op. cit., June 24 , I87I.) 
I872. Harting, J. H. British Heronries. (Zool.) [partim.]

I874. Kerr, W. J. Shieldrakes Breeding in Merioneths. (Zool.)

Ruddy, T. Common Buzzard in N. Wales. (Field, Jan. I7.) Idem by J. A. Jones. (T.c., Jan 24.)

Edwards, C. E. M. Reported Nesting of Solitary Snipe in N. Wales. (Op. cit., Oct. 24, 3I.)

I875. [Various writers.] Bitterns in Merioneths. (Op. cit., Jan. I6, 23, 30, Feb. 27.)

1876. Partridge, J. A. Honey Buzzard and Dusky Petrel in Merioneths. (OP. cit., Oct. 28.)

I877. Partridge, J. A. White-fronted Geese near Merioneths. $(O p$. cit., Dec. I.)

I879. Backhouse, J., junr. Uncommon Birds at Barmouth. (Zool.) Beckwith, W. E. Birds of Shropshire. 8vo. Shrewsbury: I879. [Greenland Falcon at Llanbedr, Merioneths. ? errore for Llanbedr, Ruthin, vide Forrest, p. 234.]

I880. "W. E. S." Hen Harrier resident in Merioneths. (Field, Nov. 20.)

I884. Wynn, C. H. Gt. Spotted Woodpecker in N. Wales [nesting]. (Field, Apr. 26.)

1885. Ruddy, T. Green Sandpiper in N. Wales in Winter. (Field, Jan. I7) : Nesting of Curlew in Wales. (T.C., Mar. 7.)

I886. Birley, F. H. Notes from Merioneths. (Zool.)

"H. C. T. B." Black Redstart in Merioneths. (Field, Jan. 30.)

I887. Rawlings, F. C. List of Birds of the Barmouth District. 8 vo. Aberystwith: I887. (Reprinted from the Cambrian Neros.)

Ruddy, T. Hooded Crow in N. Wales; Crossbills in N. Wales. (Field, Nov. 26.)

I888. Haigh, G. H. Caton. Black Redstart in Merioneths. (Zool.)

Phillips, E. C. A Visit to the Bird Rock, Towyn. (Zool.)

Ruddy, T. Hawfinch in N. Wales; Blackheaded Gull breeding in Merioneths. (Field, Aug. I8.)

1890-92. Haigh, G. H. Caton. Eared Grebe in Merioneths. 2 notes. (Zool., I8go and I892.) Tree Pipit in N. Wales. [partim.] (Op. cit., I8go.)

I892. Haigh, G. H. Caton. White Wagtail in N. Wales. (Zool.)

I894. Haigh, G. H. Caton. Wildfowl in Merioneths. (Op. cit.)

Rawlings, F. C. A List of Birds observed in the District of Barmouth. (T.c.)

I895. Davenport, H. S. Nesting of the Dunlin in Wales. (Op. cit.) Haigh, G. H. Caton. The Black Guillemot in Merioneths. $(O p$. cit.)

Salter, J. H. Grasshopper Warbler. (T.c.) 
I896. Rawlings, F. C. Notes from Barmouth. (Ornithologist.)

Davenport, H. S. Bird Life on a Welsh Stream. (Field, Sept. I2.)

Edwards, C. E. M. Black Game in Merioneths. (Zool.)

I898. Davenport, H. S. Buzzards in Merioneths. (Field, Sept. I2.)

I899. Haigh, G. H. Caton. Flamingo in Merioneths. (Zool.)

I90I. Backhouse, J. White Wagtail at Barmouth Bridge. (Zool.) Forrest, H. E. Rednecked Phalarope in N. Wales. (Op. cit.) Idem. (Op. cit., I904.)

I902. Haigh, G. H. Caton. Gadwall in Merioneths. (Op. cit.)

I903. Aplin, O. V. Tufted Duck in Merioneths. (Op. cit.)

Forrest, H. E. Stone Curlew in Merioneths. (T.c.)

I908. Forrest, H. E. Black Redstarts in Merioneths. (Brit. Birds, II.)

I909. Forrest, H. E. Lesser Spotted Woodpecker [breeding], and Hoopoe [occurring], in Merioneths. 2 notes. (Op. cit., II.) Millais, J. G. [Exhib. of Red Grouse and Black Grouse hybrids killed near Bala. (Bull. B.O.C., XXIII.)

Rawlings, F. C. Sooty Tern near Barmouth. (Zool.)

I9I0. Forrest, H. E. Longtailed Duck in Merioneths. (Brit. Birds, III.)

Siddall, C. K. Red-backed Shrike Breeding in Merioneths. (Op. cit.)

IgII. Forrest, H. E. Hoopoe in Merioneths. (Brit. Birds, V.)

r9I2. Cummings, S. G. Notes on Cirl Bunting in Merioneths.; Lesser Whitethroat in Merioneths. (Op. cit., VI.)

I9r4. Whish, F. H. L. Sabine's Snipe in Merioneths. (Brit. Birds, VIII.)

r9I6. Bolam, G. Pochard breeding in N. Wales. (Brit. Birds, X.) Forrest, H. E. Black Redstart in Merioneths. (Op. cit., IX.) Hooded Merganser in Merioneths. (Op. cit., X.) Harding, J. Rudge. Goosander on Deeside. (Field, July 8.)

I9I7. Bolam, G. Unusual Nesting Sites of Pied Wagtail in Merioneths. (Brit. Birds, X.)

\section{MONTGOMERYSHIRE.}

I834. Jones, J. Eggs of Carrion Crow sometimes covered. (Loudon's Mag. N. H.)

I850. Jones, J. M. Occurrence of Merganser ( $M$. serrator) near Montgomery. (Zool.)

I852-53. Jones, J. M. Local Jottings, Nos. I. and II. Montgomery, N. Wales. (Nat. [Morris's], II., III.) 
I858. Issard, T. E. Wood Pigeon's Nest [in November]. (Field, Dec. 24.)

Smith, T. Occurrence of Landrails in Winter. (T.c., Dec. I8.) "W. G." Idem. (T.c., Dec. 24.)

I863. Shaw, H. O. Rare Birds in Shrops., etc. [includes Bitterns from Welshpool and Llanfyllin]. [Op. cit., Feb. 6.)

I865. Thurston, C. F. Stormy Petrel at Machynlleth. (Op. cit., Dec. 2.)

I868. "A." The Water Ouzel. [On R. Verniew.] (Op. cit., May 2.) Beadnell, H. C. T. Crossbills in Montgomerys. (Op. cit., Nov. 28.)

I87I. [Anon.] Cormorant Inland. (Op. cit., Oct. 7.)

Williams, F. Quails in Britain [near Newtown]. (Op. cit., Feb. II.)

1872. Harting, J. E. British Heronries. (Zool.) [partim.] [274.]

I873. L[eslie], H. Greenshank in Montgomerys. (Field, Sept. 20.)

I877. Adams, W. H. Early Appearance of Jack Snipe. (Op. cit., Sept. 29.)

I880. "20-Bore." Quail in Montgomerys. (Op. cit., Oct. 9.)

I88I. Philpott, F. O. Nightingale in Wales. (Op. cit., June 25.)

I882. George, A. Wyrneck in Montgomerys. (Op. cit., Dec. 23.)

I883. [Anon.] Reed Warbler in Montgomerys. (Field, Jan. I3.) Philpott, F. O. Wryneck and Nightingale in Montgomerys. (Op. cit., Jan. I3.)

I884. "F. W." Tawny Owl Nesting in Burrow. (Op. cit., Apr. 26.) Simpson, H. H. Osprey in Montgomerys. (Op. cit., Nov. 8.) Smith, H. Idem. (Op. cit. Nov. I5.)

"Tantara." Hawfinch Nesting in Montgomerys. and Shrops. (T.c., Sept. 20.)

I885. "J. H." Blackgame in Montgomerys. (Op. cit., Oct. 3I.)

I886. "F. W." Gannet Inland near Welshpool. (Op. cit., Oct. I6.) George, A. Summer Birds in Montgomerys. (Op. cit., May I5.) Smith, H. L. Solitary Snipe in Montgomerys. (T.c., Jan. 9.)

I887. "J." Pied Flycatcher in Montgomerys. (Op. cit., May 28.) Jerman, H. Golden [Sea] Eagle in Montgomerys. (Op. cit., Nov. 26.)

I89I. Archibald, C. F. Squacco Heron in Wales. (Zool.)

I892. George, A. Pied Flycatcher in Wales. (Field, Oct. I5.)

I894. Raeburn, H. Garden Warbler nesting near Llanidloes. (Zool. p. 406.)

I896. Campbell, F. M. Common Buzzard in Montgomerys. 2 notes. (Zool.) 
I898. Harrison, G. D. Crossbills in Montgomerys. (Field, Nov. 5.) I90I. Twentyman, A. H. Lesser Spotted Woodpecker in Montgomerys. (Op. cit., July 20.)

I903. "L." Magpies in Flocks; Late Breeding of Wood Pigeons. (Op. cit., March 2I, Dec. 5.)

Igo6. Forrest, H. E. Pernis apivorus in Montgomerys. (Zool.) Haines, R. Late Breeding of Birds in Igo6. (Field, Sept. 22.) Harrison, G. D. Honey Buzzard in Montgomerys. (T.c., Nov. 24.)

I907. Forrest, H. E. The Vertebrate Fauna of N. Wales. 8vo. Lond.: I907. [partim.] [213.] Pernis apivorus in Montgomerys. (Zool.)

I909. Forrest, H. E. Smew in Montgomerys. (Brit. Birds, II.)

Millais, J. G. Exhibition of Hybrid Red and Black Grouse. (Bull. B.O.C., XXIII.)

I9I0. Forrest, H. E. New Nesting Colony of Blackheaded Gulls in Montgomerys. (Brit. Birds, IV.)

IgII. Forrest, H. E. Hoopoe and Spoonbill in Montgomerys; Great Grey Shrike in Montgomerys. (T.c.); Forktailed Petrel in Montgomerys. (Op. cit., V.)

Ticehurst, N. F., and Jourdain, F. C. R. On Distribution of Nightingale in Breeding Season in Great Britain. (Op. cit., V.) [partim.] [322, 584.]

Igr2. Evans, P. M. Sclavonian Grebe in Montgomerys. (Field, Mar. I6.)

Forrest, H. E. Sclavonian Grebe in Montgomerys. (Brit. Birds, V.)

Upcher, A. H. Early Brood of Partridges. (Field, June I.)

I9I6. Rattigan, G. E. Stray Notes on the Birds of the Countryside [Montgomerys.]. (Avicult. Mag., VII., pp. 226-32.)

[V. D.] Powysland Club Collections. Pub. annually. 8vo. Welshpool.: V.D. [Contain notes on nat. hist. of Co.]

\section{PEMBROKESHIRE.}

1603. Owen, G. The Description of Penbrokeshire. (Pt. I.) [Cf. Zool., I895, p. 24I.]

I8II. Fenton, R. Historical Tour through Pembrokeshire. 4to. I8II. [Plate and Description of Hoopoe, p. I7.]

I840. McLauchlan, H. Hoopoe taken at Fishguard. (Charlesw. Mag. N. H.)

1850-5I. Tracy, J. Catalogue of Birds taken in Pembrokes. 2 pts. (Zool., I850-5I.) 
I852. "E. R. B." Appearance of the Hoopoe [on Skomer]. (Nat. [Morris's], II.)

I853. "E. K. B." Do the Hawk Tribe Drink? The Kestrel. (OP. cit., III.)

1857. Gurney, S. The Cornish Chough near Tenby. (Zool.)

I858. "Gamekeeper." Several Birds Laying in Same Nest. (Field, June I9.)

I859. "F." Snow-Bunting [at Fishguard]. (Op. cit., Mar. 26.)

I860. "Islander." Jackdaws [breeding in burrows on Skomer]. (Field, June 2.)

I863. Harting, J. E. Peregrine Falcon at Haverfordwest. (Zool.)

1864. "Fishguard." Sand Grouse shot in Pembrokes. (Field, Feb. 20.)

I865. Andrews, T. O. Red-legged Crow shot at Haverfordwest. (Op. cit., Jan. I4.)

I866. Dix, T. A List of Birds observed in Pembrokes. (Zool.)

I869. Dix, T. Ornitholog. Notes. (Op. cit.)

I870. Dix, T. Quails in Pembrokes. $(O p$. cit. $)$

"R. C." Golden Oriole [?] at Goodwich. (Field, Apr. 30.)

I87x. Phillips, J. Influx of Common Quail in S. Wales in 1870. (Field, June 3.)

"T. R." Quails in Britain. (T.c., Feb. I8.)

Williams, S. Bittern near St. David's; Wild Swans at St. David's. 2 notes. (Op. cit., Jan 2I) ; Quails in Pembrokes. (T.c., Mar. 4) ; The Cornish Chough [at St. David's.] (T.c., Jan. 2I) ; Note on Landrail, Hoopoe, etc. (Op. cit., Sept. 16.)

I872. Williams, S. Raven in Wales. (Op. cit., Apr. 6.)

1873. Evans, M. Ornitholog. Notes from Pembrokes. (Op. cit., June 7.)

Salmon, E. Solitary Snipe in S. Wales. (Op. cit., Sept. 6.)

Williams, S. Missel Thrushes Nesting in Rocks [at St. David's]. (T.c., Aug. 2.)

1877. Propert, W. P. Night Heron at St. David's, Pembrokes. cit., June I6.)

I879. "Taffy," Smith, C., and Williams, S. Breeding Stations of Guillemot [in Pembrokes.]. (Field, May ro, 3I.) 3 notes.

I88I. "T. G." A Visit to Ramsey Island. (Op. cit., Dec. 24.)

1882. Mathew, M. A. A Visit to Ramsey Island. (Zool.)

1883. Mathew, M. A. Fauna of a Welsh village church, etc. (Op. cit.) Smith, C. American Bittern in Pembrokes. (Op. cit.)

I884. "M. C." White Swallow at Milford Haven. (Field, Oct. I8.) Mathew, M. A. The Birds of Pembrokes. (Zool.) [39I]; A Visit to Skomer Island. (T.c.) 
Phillips, E. C. Birds of Pembrokes. (T.c.) [Mainly refers to Brecons.]

I886. Macpherson, H. A. Storm Petrel at Shomer Island. (Zool.)

Mathew, M. A. Supposed Occurrence of Icterine Warbler in Pembrokes. (Op. cit.)

I888. Barrington, R. M. The Manx Shearwater on Skomer Island. (Zool.)

"E. K. B." Increase of Sea Birds in Pembrokes [Skomer]. 3 notes. (Field, Aug. 25, Sept. I, 8.)

Evans, H. W. Bonaparte's Gull in Pembrokes. (T.c., Oct. 20.)

Harvey, G. Pallas's Sand Grouse. (Op. cit., June 30.)

Mathew, M. A. Bewick's Swan and Pallas's Sand Grouse in Pembrokes. 2 notes. (Zool.)

Reid, G. Hoopoe near Tenby. (Field, May 5.)

Slater, M. J. Curious Capture of Manx Shearwater. (Op. cit., Sept. I.)

I889. "G. B. B." Hoopoe in N. Pembrokes. (Field, Sept. 2I.)

Nicholl, D. S. W. Chough in Pembrokes. (Zool.)

I8go. Propert, M. D. Spoonbill in Pembrokes. (Field, Nov. 8.)

I89I. Aplin, O. V. Distribution in British Isles of Spotted Crake. (Zool.) [partim.] [24.]

I892. Aplin, O. V. On Distribution of Cirl Bunting in Great Britain. (Op. cit.) [partim.] [25.]

"H. C. O." Bitterns in Pembrokes. (Field, Feb. 20.)

Jeffreys, C. Sabine's Gull in Pembrokes. (Zool.)

I893. Evans, H. W. Crane in Pembrokes. (Field, June Io.)

I894. Mathew, M. A. The Birds of Pembrokeshire. 8vo. Also Large Paper edit. 4to. Lond. : I894. [39I.]

I895. Mathew, M. A. Pembrokeshire Birds in I603. (Zool.) [39I.] I896. "F. H." Bee-Eater in Pembrokes. (Field, May 23.)

I898-99. Drane, R. A Pilgrimage to Golgotha [Skomer.] (Rep. Cardiff Nat. Soc., XXXI.)

I899. Webb-Bowen, G. Red-necked Phalarope in Pembrokes. (Field, Mar. I8.)

I902. Woosnam, R. B. Attacks by an Owl. (Op. cit., June I4.)

I903. Goodall, F. C. Unusual Site for Crow's Nest. (Field, June 20.) Watkins, W. Odd Materials in Cormorant's Nest. (T.c., June I3.)

I904. Gurney, J. H. On Birds of Pembrokeshire Islands. (Tr. Norf. \& Norw. Nat. Soc., VII.) [263.]

I905. Brooke, A. R. Great Snipe in Pembrokes. (Field, Oct. I4.)

[Editorial.] Gannets on Grasholm. (T.c., Oct. I4.)

"M. A. W[right]." Quail in S. Wales. (T.c., Nov. 4.)

Reid, D. P.S. Bewick's Swan in Pembrokes. (Op. cit., Mar. II.) 
1907. Bowen, G. B. Tutted Duck. ... (Op. cit., Feb. 23.)

Harries, H. Landrail in December. (Op. cit., Dec. I4.)

"Sylvan." Grey Phalarope in W. Wales. (T.c., Nov. I6.)

I908. C[ongreve], W. M. Short-eared Owl breeding in Pembrokes. (Op. cit., May 23.)

Forrest, H. E. Short-eared Owl Breeding in Pembrokes. (Brit. Birds, II.)

1909. Cave, C. J. P. Alpine Swift in Pembrokes. (T.c.)

Congreve, W. M. Rare Birds in Pembrokes. (T.c.)

Powell, L. N. Grey Wagtail nesting in S. Wales. (Field, June I2.)

I9I0. "E. P." Peregrine and Pigeon. (Op. cit., July 9.)

I9I3. Proger, T. W., and Paterson, D. R. Ornithol. Notes [on Little Bustard at Langham]. (Rept. \& Trans. Cardiff Soc., XLVI., pp. 90-9I.)

I9I4. Proger, T. W., and Paterson, D. R. Ornitholog. Notes, I9r4. [Lesser Spotted Woodpecker at Dinas Powis.] (Op. cit., XLVII., pp. 45-49.)

I915. Congreve, W. M. Snow Bunting in Pembrokes. (Brit. Birds, IX.) Proger, T. W., and Paterson, D. R. Ornitholog. Notes [White Wagtail and Shorteared Owl]. (Rept. \& Tr. Cardiff Soc., XLVIII., pp. 59-62.)

I9r7. Leeds, W. H. M. Glossy Ibis in Pembrokes. (Field, Nov. 3) ; Idem. (Brit. Birds, XI.)

\section{RADNORSHIRE.}

I864. Brydges, Sir H. J. J. Ferruginous Duck in Radnors. (Zool.) 1866. Lloyd, J. W. Great Grey Shrike in Radnors. (Field, Apr. 7.) 1867. "W. B." The Osprey in Radnors. (Op. cit., May 4.) 1869. [Anon.] The Kite in Radnors. (Tr. Woolhope Nat. F. C.) 1870. Lloyd, J. W. Notes on Occurrences of Rare Birds in Herefords. and Radnors. (Op. cit.)

I87x. Brydges, H. J. J. Grey Phalarope at Boultibrook. (Zool.) Newman, E. [Note on Kite in Radnors.] (T.c.)

I872. Brydges, H. J. J. Early arrival of Chiffchaff. (Zool.) I874. [Hereford Journal.] Kite at Nantygroes, near Presteign. $(O p$. cit.)

1882. Ridley, H. N. Gadwall in Radnors. (Op. cit.) Idem by E. C. Phillips. (T.c.)

I89I. "C. H." Bittern in Radnors. (Field, Jan. I7.) 
Swainson, E. A. Garden Warbler in S. Wales. (Zool.) [partim.]

I899. Duprey, F. W. Curious Accident to Young Peewit. (Field, June 24.)

I903. Jourdain, F. C. R., and Salter, J.H. [Letters on Preservation of Kite in Wales.] (Bull. B.O.C., XIII.) [322.]

Millichamp, F. Woodcock nesting in Radnors. (Field, May 30.)

I904. Salter, J. H. Unrecorded Occurrence of Scarlet Grosbeak. (Zool.)

I907. Phillips, E. C. Male Hen Harrier in Radnors. (Field, Jan. I9.) Williams-Vaughan, J. Tufted Duck on the Wye. (T.c., Feb. 23.)

I908. Phillips, E. C. Hooded Crow in Radnors. (Op. cit., Nov. 2r.)

Ig09. Owen, D. E., and Vaughan, A. G. Kite Protection in Wales. (Bull. B.O.C., XXIII.)

rgro. Meade-Waldo, E. G. B. On Preservation of Kite in Wales. (Op. cit., XXV.) [395.]

IgrI. Phillips, E. C. Crossbills nesting in Radnors. (Field, Feb. 25) ; Bird Notes from Radnors. (Op. cit., July 8.)

Witherby, H. F. Crossbills nesting in Radnors. (Op. cit., Mar. 4.)

I9r3. Phillips, E. C. Great Grey Shrike in Radnors. (Field, Nov. I.) I9I4. [Editorial.] Little Owl in Radnors. (Brit. Birds, VIII.)

I9I5. Davis, T. R. Redbreasted Merganser in Radnors. (Field, Dec. I8.) Phillips, E. C. Great Grey Shrike in Radnors. (Op. cit., Apr. 3.) rgr8. Owen, O. R. Gannet in Radnors.; Redshanks apparently breeding ; Lesser Tern in Radnors. (Brit. Birds, XI.) 


\section{SCOTLAND.}

GENERAL WORKS (not including general works on British ornithology, for a brief list of which see p. I).

[1536.] Boethius, H. Hystory and Croniklis of Scotland. Fol. Edinb. : N.D. Idem in Holinshed's Chronicles. Fol. Lond. : 1577. And later edits. [76.]

[I549?]. [Anonymous.] The Complaynt of Scotland. I6mo. [Paris ? I549 ?] [I5.]

1578. Leslæus, J. De origine, moribus, et rebus gestis Scotorum, libri decem. Rome: 1578 [and I675].

I582. Buchanan, G. Rerum Scoticarum Historia. Folio. Edinb. : I582. And other editions.

I684. Sibbald, R. Scotia Illustrata. Fol. Edinb. : I684. [535.]

I75I. [Anonymous.] A Voyage to Shetland, the Orkneys and the Western Isles of Scotland. 8vo. Lond. : I75I. [I6.]

I77I-6. Pennant, T. A Tour in Scotland, MDCCLXIX. I vol. 8vo. Chester: I77I. A Tour in Scotland and Voyage to the Hebrides, MDCCLXXII. 2 vols. 4to. Chester and Lond.: I774-6. Several subsequent edits. [466-67.]

I777. Pennant, W. Sketch of Caledonian Zoology. [In Rev. J. Lightfoot's Flora Scotica.] 8vo. Lond.: I777. 2nd edit. I789. [468.]

I787. Knox, J. A Tour through the Highlands of Scotland and the Hebride Islands in MDCCLXXXVI. 8vo. Lond. : I787. [336.]

I79I-99. Sinclair, Sir J. Statistical Account of Scotland [Old]. 2I vols. 8vo. Edinb. : I79I-99. [538.]

I804. Thornton, T. Sporting Tour through the Northern Parts of England and Highlands of Scotland. 4to. Lond. : I804. [582.]

1823-4. Fleming. J. Gleanings of Natural History, gathered on the Coast of Scotland, during a Voyage in I82I, 3 pts. (Edinb. Phil. Journ.) [210.]

I827. Aikman, J. Hist. of Scotland. Transl. from the Latin of G. Buchanan, with notes. 4 vols. 8vo. Glasg. : 1827 .

I83r. Fayrer, J. On the Passage of Birds between Scotland and Ireland. (P.Z.S.)

I833. Scouler, J. Grey Phalarope in Scotland. (Loudon's Mag. N. H.) "W. L[aidlaw]." On Migration of a Species of Thrush. (T.c.) Idem Identified as the Redwing by E. Blyth. (T.c.) 
1834. Anderson, G. and P. Guide to the Highlands and Islands of Scotland. 8vo. Lond. : I834. [I2.]

Salmon, J. D. The Redwing a Resident in extreme North of Scotland and the Isles. (Loudon's Mag. N.H.)

"W. L[aidlaw]." The Small Dark Brown Thrush of the Western Isles, etc. (Loudon's Mag. N. H.) Idem by E. Blyth. (T.c.)

I834-45. New Statistical Account of Scotland, by the Ministers of the Respective Parishes. I5 vols. Edinb. : 1834-45. 8vo. [434.]

I835. Jardine, W. Wigeon breeding in N. of Scotland. (Loudon's Mag. N. H., VIII.)

I836. S[elby, P. J.] Woodcock breeding in Scotland. (Mag. Zool. E Bot.)

I837. Fairholme, G. On Woodcocks and Fieldfares breeding in Scotland. (Charlesw. Mag. N. H.)

MacGillivray, W. On Nat. Hist. of Central Portion of Transition Range of S. Scotland. (Nat. [Neville Wood's], II.) [370.]

I838-9. Thompson, W. Nat. Hist. of a Portion of S.W. Scotland, 2 pts. (Charlesw. Mag. N. H.) [579.]

I840. Colquhoun, J. The Moor and the Loch. 8vo. Lond. : 840. And later edits. [I4O.]

I842. Wilson, J. A Voyage round the Coasts of Scotland and the Isles. 2 vols. 8vo. Edinb. : 1842 . [653.]

I846. St. John, C. Short Sketches of the Wild Sports and Natural History of the Highlands. 12mo. Lond. : 1846. Another edit. 1847 ; and later edits. [502.]

I849. Newman, E. Abundant Occurrence of Crested Tit in Scotland. (Zool.)

1850. Gordon, G. Waxwing in var. localities in Scotland. (Zool.)

I85I. Smith, J. Notices of Rarer Birds found in S. of Scotland. (Ann. \& Mag. N. H.)

McIntosh, J. [and others]. Heronries in England, etc. [partim.] (Nat. [Morris's], I.)

I852. Smith, J. Ornitholog. Notes. (Ann. \& Mag. N. H.)

I859. Jamieson, T. F. List of Birds of N. of Scotland, with their Distribution. (Rep. Brit. Assoc.)

I862-3. Smith, J. A. Ornitholog. Notes, 2 pts. (Edinb. Nerw Phil. Journ., I862-3.)

I862-68. Blackburn, Mrs. Hugh. Birds drawn from Nature. Fol. Edinb. : I862. Idem, with pt. 2 added. Glasg. : I868. [67.]

I863. Moore, T. J. Pallas's Sand Grouse in Scotland. (Zool. ; Hawick Advertiser); Gyrfalcon shot in S. of Scotland. [Tandlaw Moss]. (Field, Oct, 24.) 
I865. Roche, J. Osprey Breeding in Scotland. (Ibis.)

Tegetmeier (W. B.). Quail in Scotland. (Field, Dec. 2.)

I867. Hancock, H. Letter relating to Several Birds of Scotland. (Ibis.)

I868. Harvie-Brown, J. A. Gt. Northern Diver [?] breeding in Scotland. (Zool.)

[Anon.] Rare Birds in Highlands. (Field, XXXII., p. 329.)

I870. Gray, R. Letter on Occurrence of Astur atricapillus and Totanus chloropygius. (Ibis.)

Harvie-Brown, J. A. On Sites of Nests of Peregrine Falcon in Scotland. (T.C.)

I87I. Gray, R. The Birds of the West of Scotland, including the Outer Hebrides. 8vo. Glasg. : I87I. [25I.]

I87I-2. Gray, R. The Capercaille [in Scotland]. (Scott. Nat., I., I87I-2.)

I872. Harting, J. E. Existing Heronries in Great Britain [Scotland]. (Field, Feb. I7, Mar. 9.)

1873. Dalgleish, J. J. Range of Mistle Thrush in Scotland. (Field, June I4.)

Gray, R. Sea Gulls in Firth of Forth. (Pr. N. H. Soc. Glasg., II. ; Ibis, I873.)

1873-6. Harvie-Brown, J. A. Iceland Gull in the Estuary of the Forth. (Pr. N. H. Soc. Glasg., I873-76.)

1876. Gray, R. Birds. [In Fauna and. Flora of West of Scotland.] (Brit. Assoc, Handbook.) Cr. 8vo. Glasg.: 1876. [25I.]

Clark-Kennedy, A. Unusual Quantity of Buzzards in Scotland. (Zool.) Idem by J. A. Harvie-Brown. (T.c.)

Lumsden, J. On Recent Occurrence in Scotland of Rough-legged, Buzzard. (Pr. N. H. Soc. Glasg., III.) ; On Distribution of Common Jay in Scotland. (Scott. Nat., III., I875-6.)

Harvie-Brown, J. A. Velvet Scoters in Scotland in summer. (T.c.)

I877. Newton, A. The Hawfinch in Scotland. (Zool.)

I877-8. Thompson, D'Arcy W. Birds of S.E. of Scotland. 2 pts. (Scott. Nat., IV., I877-8.) [Incomplete.]

Brotherston, A. Idem [Corrections.] (T.c.)

1878. Booth, E. T. Habits of Kite as observed in Scotland. (Field, Oct. I2.)

Gray, R. Blackcap Warbler in Scotland; On Occurrence of Waxwing in Scotland. (Pr. N. H. Soc. Glasg., III.)

Harvie-Brown, J. A. On the Capercaillie in Scotland. (T.c.)

I879. Gray, R. On Occurrence of Velvet Scoter during Summer of I876. (Op. cit.)

Booth, E. T. Habits of Kite as observed in Scotland. (Zool.) 
Brotherston, A. Notes on Effects of past Winter in S.E. of Scotland. (Scott. Nat., V., I879-80.)

Harvie-Brown, J. A. Ornitholog. Journal of Winter of I878-79. (Proc. N. H. Soc. Glasg.)

Harvie-Brown, J. A. The Capercaillie in Scotland. 8vo. Edinb. : I879. [28I.]

I880. G-, G. C. Notes of a Naturalist on the W. Coast of Scotland. (Field, Mar. 27., Apr. 3.)

Harvie-Brown, J. A. On Decrease in Scotland of Greater Spotted Woodpecker. (Zool.) The Capercaillie in Scotland. (Scott. Nat., V., I879-80.)

Clark-Kennedy, A. Scarcity of Golden Plover in S. of Scotland. (Zool.)

I880-8I. Harvie-Brown, J. A. Second and Third Reports on Scottish Ornithology, I879-80 and r880-8r. (Pr. N. H. Soc. Glasg.) [28I.]

I88 I. Dalgleish, J. J. Skuas on the Coasts of Scotland. (T.c.)

I882. Buchanan, J. Hamilton. History of the Chough in Scotland. (Pr. R. Phys. Soc. Edinb.)

I883. Dalgleish, J. J. Distribution of Tree Sparrow in Scotland. (Pr. R. Phys. Soc. Edinb.)

Seebohm, H. Great Grey Shrike in Scotland. (Pr. Phys. Soc. Edinb.)

r885. Gray, R. Bird Life of Firth of Forth during Storm of Oct. and Nov. I88I. (Hist. Berw. Nat. Cl., X.)

I886. Harvie-Brown, J. A. Snow Bunting Breeding in Scotland. (Zool.)

I886-7. Drummond-Hay, H. M. Report on Ornithology of E. of Scotland. (Scott. Nat., VIII., I885-86.) Idem. Additional Remarks. (Op. cit., IX., I887-8.) [Also reprinted separately. 8vo. Perth. : N.D. [I82.]

I887. Seebohm, H. On the Breeding of Arctic Birds in Scotland. (Zool.)

Service, R. Former Existence of Ptarmigan in S.W. Scotland. (T.c.)

I888. Grieve, S. Recent Information about the Great Auk or Garefowl. (Tr. Edinb. F. N. Soc.) [254.]

I889. Evans, W. Notes on Pallas's Sand Grouse in Scotland during the Recent Great Westward Movement. (Pr. R. Phys. Soc., Edinb., I888-9; Zool., I888.) Great Crested. Grebe Breeding in Scotland. (Zool.)

[Editorial.] Breeding of Pallas's Sand Grouse in Britain [N. Scotland] in I889. (Field, Sept. I4.)

Macpherson, H. A. The Visitation of Pallas's Sand Grouse to Scotland in I888. 8vo. Lond. : 1889. [374.] 
I890. Tegetmeier, W. B. Breeding of Pallas's Sand Grouse in Scotland [Moray]. (Field, April I9.)

I89r. Clarke, W. E. The Reed Warbler [etc.] as Scottish Birds. (Scott. Nat., XI.)

Clarke, W. E. [Birds of Forth Basin in] Pollock's Dictionary of the Forth, I89I.

Macpherson, H. A. The Gt. Grey Shrike as a Scottish Bird. (Scott. Nat., XI.)

I892. Adair, P. The Short-eared Owl and Kestrel in the Vole Plague Districts. (Ann. Scott. Nat. Hist.)

Aplin, O. V. Distribution of Cirl Bunting. (Zool.) [partim.] [25.]

Evans, W. Wrynecks on East Coast of Scotland; Unusual Numbers of Fork-tailed Petrel on Scottish Coasts. (Ann. Scott. Nat. Hist.)

Harvie-Brown, J. A. The Great Spotted Woodpecker in Scotland. (T.C.)

I893. Harvie-Brown, J. A., and Bartholomew, J. G. Naturalists' Map of Scotland. Edinb.: I885. [282.]

1893-97. Hinxman, L. W. Report on Movements and Occurrence of Birds in Scotland during I892-96, 5 pts. (Ann. Scolt. N. H., II.-VI.) [Continued from I 897 by T. G. Laidlaw.]

I894. Harvie-Brown, J. A. On Extension of Distribution of Stock Dove in Scotland. (Op. cit.) [282.]

Raeburn, H. Present Status of Hooded Crow in S. Scotland. (Zool.)

1895. Clarke, W. E. On Recent Visitation of Little Auk to Scotland. (Ann. Scolt. Nat. Hist.)

Evans, W. Waxwings in S.E. of Scotland. (T.c.)

Harvie-Brown, J. A. The Starling in Scotland: Its Increase and Distribution. (T.c.) The Marsh Tit in Scotland. ( $T r$. Perths. Soc.) [282.]

Paterson, J. On the Tufted Duck in S.W. Scotland. (Ann. Scott. N. H.)

Traquair, R. H. Remains of Great Auk in Edinburgh Museum. (T.c.)

I896. Crauford, J. H. The Wild Life of Scotland. Cr. 8vo. Lond. : I896. [I54.]

Godfrey, R. Bird Life on a Lowland Loch. (Sci. Gossip.)

Harvie-Brown, J. A. The Tufted Duck in Scotland: Its Increase and Distribution. (Ann. Scott. Nat. Hist.; Pr. R. Phys. Soc. Edinb.) Idem by W. Evans. (Some Notes on the Tufted Duck.) (Ann. Scott. N. H.)

Harvie-Brown, J. A., and Buckley, T. E. A Vertebrate Fauna of the Moray Basin. 2 vols. 4to. Edinb. : I896. [282.] 
Paterson, J. Notes on Irruption of Little Auk in Winter of I894-5 on West of Scotland. (Tr. Geol. Soc. Glasg.)

I897. Clarke, W. E. On Occurrence of Frigate Petrel on W. Coast of Scotland. (Bull. B.O.C. ; Ann.Scott. N.H.)

Lee, O. A. J. Nesting of Great Crested Grebe in Valley of the Forth. (Ann. Scott. N. H.)

Macpherson, H. A. Little Gull on W. Coast of Scotland. (T.c.)

1898. Paterson, J. The Garden Warbler South of Grampians, $(O P$. cit.)

Tegetmeier, W. B. Occurr. of Golden Eagle. (Field, Dec. I7.)

I898-I904. Laidlaw, T. G. Report on Movements and Occurrence of Birds in Scotland during I897-I903, 7 pts. (Ann. Scott. N. H., I898-I904.)

[Continued from 1904 by J. Paterson.]

1899. Clarke, W. E. On Macqueen's Bustard in Scotland. (Bull. B.O.C.) ; On Occurrence of Asiatic Houbara in Scotland. (P. R. Phys. Soc. Edinb.; Ann. Scott. N. H.)

Evans, W. The Greater Spotted Woodpecker in S.E. Scotland. (Ann. Scott. N.H.)

Harvie-Brown, J. A. Scaup Duck Nesting in Scotland. (T.c.)

I900. Newton, A. The Great Shearwater in Scottish Waters. $(O p$. cit.)

I901. Campbell, C. Breeding of Great Spotted Woodpecker in S. of Scotland. (Op. cit.)

Evans, W. Notes on White Wagtail in S.E. of Scotland. (T.c.)

Millais, J. G. The Wildfowler in Scotland. 4to. Lond. : Igor. [406.]

St. John, Admiral H. C. Charles St. John's Note Books, I846-53. 8vo. Edinb. : I90I. [502.]

I902. Harvie-Brown, J. A. Waxwings in Scotland. (Ann. Scott. N. H.) [283.]

Workman, W. H. Ornitholog. Notes from W. of Scotland. (Zool.)

I903. Blathwayt, F. L. On Highland Lochs. (Avicult. Mag.) [70.] Clarke, W. E. On Occurrence of Phylloscopus viridamus [errore for borealis?], etc., at Scottish Light-stations. (Ann. Scott. N. H.)

Macleay, W. Glossy Ibises in Scotland. (T.c.)

Payne, J. W. Late Occurrence of Swift and Cuckoo in Scotland. $($ Zool.)

I904. Harvie-Brown, J. A. Approaching Extinction of the Osprey in Scotland. (Ibis.)

I905. Forbes, A. R. Gaelic-English and English-Gaelic Names of Animals, Birds, etc. Edinb. : 1905. 
I905-9. Paterson, J. Report on Scottish Ornithology, I904-8, 5 pts. (Ann. Scott. N. H., I905-9.)

[Continued from Igro by Baxter, E. V., and Rintoul, L. J.]

I906. Clarke, W. E. Some Rare Birds from Scottish Stations. (Op. cit.)

Gordon, S. P. Scottish Ptarmigan. (Field, Apr. 7.)

Gordon, Seton P. Birds of the Loch and Mountain. Roy. 8vo. Lond. : I907. [237.]

Harvie-Brown, J. A. Spring Return of the Woodcocks in Forth and Clyde ; Great Spotted Woodpecker in "Forth and Tay." (Ann. Scott. N. H.)

McClymont, J. R. Provincial Names and Resorts of Certain Birds in S. of Scotland. (Zool.)

1907-8. Witherby, H. F., and Ticehurst, N. F. On more Important Additions to Knowledge of Brit. Birds since I899. (Brit. Birds, I., II.) 20 pts. [656.] [partim.]

I908. Anderson, P. Probable Nesting of White Wagtail in N.W. Highlands. (Ann. Scott. N. H.)

Bedford, Duchess of. Notes on Birds observed in Scottish Islands during Spring and Autumn, 1907. (Ann. Scott. N.H.)

Dobbie, J. B. Turnstone in Scotland in June. (Ann. Scott. N. $H$.)

[Editorial.] Blacktailed Godwits in Scotland. (Brit. Birds, I.)

Evans, W. On Origin of Present Colony of Scottish Greater Spotted Woodpeckers. (Ann. Scolt. N. H.)

Gladstone, H. S. Gadwall in W. of Scotland; Protection of Woodcock in S.W. of Scotland. (Ann. Scott. N. H.)

Harvie-Brown, J. A. Distribution of Woodcock in Central Districts of Forth Area in Spring of Igo8; Increase of Goldfinches and Siskins Nesting; Pintails increase in Scotland; Great Spotted Woodpecker's Resuscitation in Scotland since I84I or I85I. (T.c.) Morning Flight of Gulls across Central Scotland. (Irish Nat.) Distribution of Common Scoter in Scotland. (Brit. Birds, I.)

Maxwell, H. Nesting of Quail in Scotland. (Ann. Scott. N. H.)

Ogilvie-Grant, W. R. Two supposed Hybrids between Red Grouse and Ptarmigan. (Brit. Birds, I.)

Robinson, H. W. Great Grey Shrike in Scotland; Distribution of Common Scoter in Scotland. (Brit. Birds, II.)

Witherby, H. F. Great Grey Shrikes in Scotland; Great Spotted Woodpecker as a Breeding Bird in Scotland. (Brit. Birds, II.)

Ig08-Ir. Watt, H. B. A List of Scottish Heronries, Past and Present. (Amn. Scott. N. H., I9o8.) Idem Suppl., 2 pts. (Op. cit., I9I0-II.) [6rg.]

[For another article on same see Field, June 14, I9I3.] 
I909. Clarke, W. E. The Recent Remarkable Visitation of Crossbills. (Ann. Scott. N.H.) Idem, Further remarks. (Op. cit., Igro.)

Evans, W. Our Present Knowledge of Fauna of Forth Area. (Pr. R. Phys. Soc. Edinb.)

Rintoul, L. J., and Baxter, E. V. Nesting of Gadwall in Scotland. (Ann. Scott. N. H.)

Wilson, D. W. Bird-life in Early Scottish Literature. (Pr. Edinb. F. Nat. Soc., VI.)

Igro. Clarke, W. E. Another arrival of Crossbills in Scotland. (Ann. Scott. N. H.)

Gladstone, H. S. American Bittern in Scotland. (T.c.)

Harvie-Brown, J. A. Crossbills on N.E. Coast. (T.c.)

Harvie-Brown, J. A., and Clarke, W. E. Greenland Falcons in Scotland. (T.c.)

I9I0-I8. Baxter, E. V., and Rintoul, L. J. Report on Scottish Ornithology in Igog and Igro. (Op. cit., IgIo-II.) Idem in IgII, I9I2 and I9r3. (Scott. Nat. Extra Publ. Nos. I-3, I9I2-I4.) Idem in I9I4 and I9I7. (Scott. Nat. I9I5 and I9I8.) Idem in I9I6 by A. C. Jackson. (Op. cit., I9I7.)

Igri. Evans, W. Mealy Redpolls in Scotland, Autumn, Igro. (Proc. R. Phys. Soc. Edinb., XVIII.)

I9I2. Alston, C. H. Wild Life in the West Highlands. 8vo. Glasg.: IgI2. [II.]

Clarke, W. E. Some New Scottish and Brit. Birds. (Scott. Nat.)

[Evans, W.] Little Auk Visitation of rgr2. (Scolt. Nat.)

Gordon, S. P. The Charm of the Hills. 8vo. Lond. : I9I2. [237.]

I9I2-I4. Thomson, A. L. Aberdeen Univ. Bird Migration Inquiry. Ist and 2nd Interim Repts. (Igog-I4.) 8 pts. (Scott. Nat.)

I9r3. Clarke, W. E. Greenland Falcons at Scottish Islands. (Scott. Nat.)

Watt, H. B. The Heron in Scotland. (Field, June I4.)

I9I4. Jackson, A. C. Occurr. of Iceland Gulls in the North. (Scott. Nat.)

Maxwell, $\mathrm{H}$. Increase of Goldfinch in Scotland. (T.c.)

Ritchie, J. The Spread of the Starling in Scotland. (T.c.)

I9I4-I5. Bedford, Duchess of. Spring Bird Notes from various Scottish Islands. 3 parts. (Scott. Nat., I9I4; Avicult. Mag., I9I5, 2 parts.)

I9I5. Evans, W. The Fulmar on S.E. Coast of Scotland in Summer. (Scott. Nat.)

Gordon, S. Hill Birds of Scotland. 8vo. London : I9I5.

r917. Chapman, A. Brent Geese in Scotland. (Scott. Nat.) Idem by J. G. Millais. (T.c.) 


\section{ABERDEEN.] OF BRITISH ORNITHOLOGY}

Jackson (A. C.) On Movements of Birds in rgr6. (T.c.)

Rintoul, L. J. On Pale-breasted or American Brent Goose in Scotland. (T.c.)

I9I8. Jones, K. H. The Nesting of the Hen Harrier in Northern Scotland. (Avicult. Mag., pp. 205-7.)

\section{ABERDEENSHIRE.}

Note.-Exhaustive indices of the birds of each county and parish in the Statistical Account of Scotland, I79I-9, and New Statistical Account, I834-45, are given in the biographical section of this work, the first under "Sinclair (Sir John)," the second under "New." They should therefore be referred to for each county, as they cannot be repeated here.

I829. "A. C. R." Birds on Sea Coast of Gomrie. (Loudon's Mag. N. H., II.)

I833. "Subscriber." Rarer Birds observed about Vale of Alford. (Op. cit., VI.)

I842. MacGillivray, J. On Mammalia, Birds, etc., lately observed in neighbourhood of Aberdeen. (Ann. Mag. N. H.)

I847. Smith, J. Ivory Gull in Aberdeens. (Zool.)

I849. Smith, J. American Greater Northern Shrike and Purple Heron near Aberdeen, 2 notes. (Op. cit.)

I850. Edward, T. Birds and Birds' Nests in Aberdeens. (Op. cit.) [193.]

Smith, J. Pied Flycatcher in Aberdeens. (T.c.)

I85I. Ferguson, W. Waxen Chatterer in Aberdeens. (Nat. [Morris's], I.)

Smith, J. White Stork in Scotland. (Zool.)

I852. Ferguson, T. Bee Eater in Aberdeens. (Nat. [Morris's], II.)

x853. Longmuir, J. [Rare Birds in Aberdeens.] etc., 4 notes. (OP. cit., III.)

Taylor, J. Rare Land Birds in Aberdeens. (T.c.)

1854. Edward, T. The Birds of Strathbeg and its Neighbourhood, 2 pts.; Crossbill at Craigston; Red-necked Phalarope in Aberdeens. (Op. cit., IV.)

Longmuir, J. The Findhorn Heronry. (T.c.)

1855. Edward, T. Little Stint at Fraserburgh. (Op cit., V.)

MacGillivray, W. Natural History of Deeside and Braemar. 8vo. Lond. : I855. [37I.]

1860. Edward, T. Great Ash-coloured Shrike in Aberdeens. (Zool.) 
I866. Angus, W. C. Osprey, Golden Eagle, Wood Sandpiper and Black Tern in Aberdeens., 3 notes. (Op. cit.)

S- - G. Little Bittern [seen at Aberdeen]. (Sci. Gossip.)

I867. Angus, W. C. Honey Buzzard and Red-legged Partridge in Aberdeens., 2 notes. (Zool.)

" R. S." Bittern shot in Aberdeens. (Field, Dec. 28.)

I868. Angus, W. C. Bittern in Aberdeens. (Zool.) Idem by G. Sim. (Sci. Gossip.)

Sim, G. Hoopoe in Aberdeens. (Sci. Gossip.)

I869. Angus, W. C. Whitethroated Sparrow in Aberdeens. (Zool.) Idem by A. Newton. (P.Z.S., I870.)

I87I-2. Burnett, S. M. Notes on certain Aberdeens. Birds. (Scott. Nat., I., I87I-2.)

Forbes, H. O. Birds of N.W. Aberdeens. (T.c.) Idem. Additions by J. Garrow. (T.c.)

Sim, G. Rare Birds in Aberdeens., etc., 2 notes. (T.c.)

Sim, G. Rare Birds in Fyvie. (T.c.)

I872. Harting, J. E. British Heronries. (Zool.) [partim.]

I873-4. Forbes, H. O. Purple Heron [in Aberdeens.]. (Scott. Nat. II., I873-4.)

Sim, G. Occurrence of Little Bustard in Aberdeens. (T.c.)

Sim, G. Honey Buzzard and Green Woodpecker [near Fyvie], 2 notes. (T.c.)

I875. Pope, C. E. Spotted Crake in Aberdeen. (Field, Nov. I3.)

I875-6. Sim, G. Ivory Gulls at Aberdeen ; Little Gull [near Aberdeen] ; Goshawk and other Rare Birds in Aberdeens. (Scott. Nat., III., I875-6.)

Sim, G. Turtle Dove in Aberdeens. (T.c.)

I876. Gray, R. Ornitholog. Notes, 2 pts. (Hist. Berw. Nat. Cl., VII., pp. 463-7 ; VIII., pp. I55-9.)

1877. Edward, T. Bearded Tit and Hawfinch in Aberdeens. (Zool.) I877-8. Trail, J. W. H. On Occurrence of Picus major in Aberdeens. (Scott. Nat., IV.)

I878. "T. C." Solitary Snipe in Aberdeens. (Field, Oct. 26.)

Trail, J. W. H. On Progress of Zoology in Aberdeen and its Neighbourhood. (Tr. Nat. Hist. Soc. of Aberdeen.)

r879. Harting, J. E. Esquimaux Curlew in Aberdeens. (Zool.)

Sim, G. Esquimaux Curlew [at Slains]; Effect of late storm in N.E. of Scotland. (Scott. Nat., V.)

I88I. Horn, W. Collected Notes on Birds of Buchan. (Pr. Nat. Hist. Soc. of Glasg., IV.)

"L. P." Great Snipe in Aberdeens. (Field, Oct. 29.)

Sim, G. Glossy Ibis in Aberdeens. (Zool.) Occurrence of Rare Birds. (Scott. Nat., VI., I881-2.) 
I883. Whitaker, J. Grey Shrike and Waxwings in Aberdeens. (Zool.) I884. Sim, G. Rare Birds in Aberdeens. (Scott. Nat., VII., I883-4.) I885. Sim, G. Zoological Notes from Aberdeen. (Op. cit., VIII., I885-6.)

I886. Sim, G. Tengmalm's Owl [near Peterhead]. (T.c.)

I886-8. Drummond-Hay, H. M. Report on Ornithology of E. of Scotland, from Fife to Aberdeens. 3 papers. (Op. cit., VIII., I885-6, IX., I887-8.) [I82.]

I887. Borrer, W. Breeding of Tufted Duck in Aberdeens. (Zool.) Idem by W. Evans. (T.c.)

Brown, G. Waxwing in Aberdeens. (T.c.)

Wilson, W., junr. On Columba livia in Central Aberdeens. (Scott. Nat., IX., I887-8.)

I888. Leslie, G. A. Pallas's Sand Grouse [in Aberdeens.]. (Field, June 9.)

1889. Sim, G. Pallas's Sand Grouse in Aberdeens., I888. 8vo. Aberd. : I889. [536.]

I890-9I. Aplin, O. V. Distribution, etc., of Spotted Crake. 2 pts. (Zool., I890-9I.) [partim.]

I89I. Muirhead, G. Notes on Birds in Parishes of Methlick and Tarves. (Scott. Nat., XI.)

Sim, G. Hoopoe in Fyvie; Scops Owl in Aberdeens. 2 notes. (Scott. Nat., XI., I89I.)

1894. Sim, G. Smew in Aberdeens. (Ann. Scott. N. H.)

Serle, W. Great Crested Grebe on Aberdeens. Coast. (T.c.)

I895. Serle, W. Roller in Aberdeens.; Ivory Gull in Aberdeens. (Op. cit.)

Sim, G. Tree-Sparrow in Aberdeens. (T.c.)

Wilson, W. Ring Ouzel in Aberdeens. (Proc. E. Scotl. Union Nat. Soc., I89I-5.) Perth: I895.

I897. Harvie-Brown, J. A. The Deveron Valley and its Bird Life. Post 8vo. Banff : I897.

Serle, W. Osprey near Peterhead. (Ann. Scott. N. H.)

Sim, G. Red-footed Falcon in Aberdeens. (T.c.)

I898. Sim, G. Lesser Kestrel in Aberdeens. (Op. cit.)

Wilson, W. Cuckoos recently observed in Aberdeen. (Zool.)

I899. Clarke, W. E. [Houbara macquceni in Aberdeens.] (Bull. B.O.C. VIII., I898-9.)

Serle, W. Honey Buzzard and Gt. Spotted Woodpecker at Peterhead, 2 notes. (Knowledge.)

Walker, J. G. Little Bustard [errore for Houbara macqueeni] in Aberdeens. (Ann. Scott. N. H.)

Wilson, W. Abnormal Occurrence of Pied Wagtail through the Winter; Ornitholog. Notes from Aberdeen. (Zool.) 
I900. Sim, G. Black Redstart in Aberdeen. (Ann. Scott. N. H.) Wilson, W. Observations on Cuckoo in Aberdeen. (Zool.)

I90I. Sim, G. On Occurrence of Black Kite at Aberdeen. (Ann. Scott. N. H.)

I902. Wilson, W. Kingfisher near Aberdeen. (Zool.)

I903. Sim, G. The Vertebrate Fauna of Dee. 8vo. Aberd. : I903. [536.]

Watt, H. Boyd. Swift Nesting on Lochnagar, etc. (Ann. Scott. N. H.) (Idem, reprinted in Cairngorm Cln!b Journ. I905.)

Wilson, W. Ornitholog. Notes from Aberdeen, Aug. (Zool.)

I904. Pycraft, W. P. Occurr. of Killdeer Plover in Scotland. (Bull. B.O.C.)

Serle, W. Hawfinch at Peterhead. (Ann. Scott. N. H.)

Wilson, W. Ornitholog. Notes from Aberdeen; Migratory Notes, May and June. (Zool.)

I906. Wilson, W. Migratory Notes from Aberdeen. (Zool.)

Ig08. Gurney, J. H. Marsh Titmouse in Aberđeens. (Ann. Scott. N. H. ; Brit. Birds, I.)

Paton, E. R. Scops Owl off Aberdeens. (Brit. Birds, II.)

Ramsay, L. N. G. Probable Breeding of Blue-headed Wagtail near Aberdeen. (Ann. Scott. N. H. ; Brit. Birds, II.)

Ramsay, L. N. G., and Thomson, A. L. Gadwall in Aberdeens. (Ann. Scott. N. H.)

Sim, G. Glossy Ibis in Aberdeens. (Zool.)

Thomson, A. L. Leach's Petrel in Aberdeens. (Ann. Scott. N. H.)

Igro. Thomson, A. L. Sandwich Tern in "Dee." (Scott. Nat.)

Thomson, J. A. The Fauna of Buchan. (In the Book of Buchan, etc.) 4to. Peterhead: I9ro. [580.]

I9II. Davy, Hamilton. Continental Gt. Spotted Woodpecker in Aberdeens. (Ann. Scott. N. H.)

Mackie, A. Aberdeenshire. (Cambridge County Geographies.) 8vo. Camb. : IgII. [Sketch of Bird Life of County.]

Ramsay, L. N. G. Lesser Redpoll in Aberdeens. (Ann. Scott. N. H.)

Thomson, A. L. Heronries in the Dee Area. (Ann. Scott. N. H.)

I9I3. Ogilvie-Grant, W. R. Redfooted Falcon reported from Aberdeens. (Brit. Birds, VII.)

Thomson, A. L. An Unrecorded Heronry in "Dee." (Scott. Nat.)

Wormald, H. Curlew Sandpiper in Scotland in Winter. (Brit. Birds, VI.)

I9r4. Thomson, A. L. Rare Birds in Aberdeens. in I9I3. (Scott. Nat.)

I9r5. Thomson, A. L. Ornith. Records from "Dee" Area. (Op. cit.) 
Wilson, W. Observations of Bird Life in Aberdeens.; Some Migratory Incidents in May and June. (Zool.)

I9I7. Tait, T. Stock Dove in Aberdeens. (Scott. Nat.)

I9I8. Macdonald, A. Stock Dove in Lower Deeside; New Nesting Site for Larus ridibundus. (Op. cit.)

Paterson, C. G. Snowy Owl, etc., in Aberdeens. (T.c.)

\section{ARGYLLSHIRE}

(and the following islands of the Inner Hebrides:-Mull, Coll, Tiree, Islay, Jura, etc.).

I829. J[ardine ?], W. Nat. Hist. in Scotland; Redbreasted Merganser [breeding on Loch Awe]. (Loudon's Mag. N. H., II.)

1837. Drew, W. Siskin Breeding on Ground [near Inverary]. (Nat. [Wood's], II.)

1852-3. Graham, H. D. Notes on the Birds of Iona, 5 pts. (Nat. [Morris's], II., III.) ; Letters of an Ornithologist, 6 pts. (OP. cit.)

I862. Smith, J. A. Capture of Redcrested Whistling Duck. (Edinb. Nere Phil. Jnl., N.S., XVI.)

I863. "J. K." Tameness of Pipits on Loch Fyne. (Field, Oct. I7.) I864. "Cob." Bittern on W. Coast of Scotland [Islay]. (Op. cit., Feb. I3.)

Chapman, T. Bohemian Waxwing on W. Coast of Argyll. (Zool.)

I865. Argyll, Duke of. [Great] Grey Shrike in Scotland [Argylls.]. (Field, Dec. 23.)

I870. Ward, H. Hen Harrier in Argylls. (Op. cit., May 2I.)

I87I. [Graham, J.] "Podiceps." Goosander Breeding on Loch Awe. (Field, July 29, Aug. I2.)

1872. Harting, J. E. British Heronries. (Zool.) [partim.]

"W. R. P." Snowy Owl in Islay. (Field, June I.)

1876. Booth, E. T. Birds on Loch Tarbert. (Op. cit., Feb. 5.)

Charbonnier, H. J. Greenland Falcon in Scotland. (Zool.)

Dalgleish, J. J. Velvet Scoter in Mull. (T.c.)

Gray, R. Velvet Scoter in Scotland in Summer of 1876 . (Hist. Berw. Cl., VIII., pp. 75-6) ; Ornitholog. Notes. (T.c., pp. I55-9.)

Lumsden, J., junr. American Bittern in Islay. (Field, Jan. 22.)

1877-97. Dalgleish, J. J. List of Birds observed in District of Ardnamurchan. (Pr. Nat. Hist. Soc. of Glasgow, III., I877) Notes and Additions. (Op. cit., I897.) 
I878. Gray, R. Ornitholog. Notes. (Hist. Berw. Cl., VIII., pp. 499502.)

1878-80. Skirving, R. Scott. The Birds of Islay, 2 pts. (Pr. Roy'. Soc. Edinb., I878, I880.)

I879. Graham, R. C. Woodcock Nesting in Argylls. (Field, May 3I.)

I882. Grieve, S. Discovery of Remains of Great Auk on Oronsay. (Linn. Jnl. Zool., XVI., I882.)

Pike, T. M. A Visit to Loch Sweyn. (Zool.)

I883. Butler, E. A. Jerfalcon in Argylls. (Field, Dec. I.)

Carter, J. Birds on the Island of Staffa. (T.c., Nov. ro.)

1884. Bidwell, E. Sabine's Gull in Adult Plumage from Mull. ( $P$ r. R. Phys. Soc. Edinb.)

Butler, E. A. Common Buzzard in Mull. (Field, May 3.)

1885. Bidwell, E. Occurrence of Sabine's Gull in I. of Mull. (Ibis.)

I887. Legge, J. Woodcocks Breeding in Argylls. (Field, Sept. Io.)

Murray, F. Summer in the Hebrides. 8vo. Glasg. : I887.

Smith, W. A. Loch Creran. Cr. 8vo. Paisley: 1887.

1888. Campbell, J. Sand Grouse in Argylls. (Field, Sept. 22.)

Plat, H. Roller in I. of Mull. (T.c., Sept. I5.)

"Vignon." Bittern in Argylls. (Op. cit., Feb. II.)

I889. Brunner, H. R. Redlegged Partridge in Argylls. (Op. cit., Sept. 28.) Idem by A. G. Cameron. (T.c., Oct. 5.)

I8go. Graham, H. D. The Birds of Iona and Mull. 8vo. Edinb. : I89o. [244.]

Macpherson, A. N. Increase of Redstart in W. Scotland [Ballachulish]. (Zool.)

I89I. Clarke, W. E. American Redbreasted Snipe in Argylls. (Scott. Nat., XI.)

Campbell-Orde, J. W. P. Bewick's Swan in Argylls. (Ibis.)

Lawrie, A. D. Fork-tailed Petrel in Argylls. (Field, Oct. I7.) Malcolm, G. H. American Red-breasted Snipe in Argylls. (Zool.)

Maclaine of Lochbuie. Land Rail in Mull and Jura in Winter. (Scott. Nat., XI.)

I892. Argyll, Duke of. Snowy Owl in Argylls. (Ann. Scott. N. H.)

Buckley, T. E., and Harvie-Brown, J. A. Vertebrate Fauna of Argyll and the Inner Hebrides. Sq. 8vo. Edinb. : I892. [105.]

Evans, H. On Occurrence of Wilson's Petrel in Jura. (Ann. Scott. N. H.)

Harvie-Brown, J. A. Great Shearwater in Tiree; Wild Swans in Tiree. (T.c.)

1893. Anderson, P. On Sand Martin and Carrion Crow in Tiree; Jackdaw in Tiree. (Op. cit., II.)

Buckley, T. E. Goshawk in Mull. (Op. cit.) 
Hamilton, E. On Occurrence of Red-breasted Snipe in Argylls. (T.c.)

Irby, L. H. Carrion Crow in Island of Coll. (Zool.)

1894. Gilmore, J. F. The Chough in Islay. (Sci. Gossip, N.S., I.)

M'Vean, C. A. Kingfisher in Mull. (Ann. Scott. N. H., III.)

1895. Blackburn, Mrs. Birds from Moidart and Elsewhere. 8vo. Edinb. : 1895. [67.]

Skirving, R. S. Carrion Crow, Hen Harrier and Eagles in Islay. (Ann. Scott. N. H.)

I8g6. Irby, L. H. Observations on Birds of Island of Tiree and Coll. (Ann. Scott. N. H.) [308.]

Paterson, J. Spotted Crake in Argylls. (Op. cit.)

1897. Clarke, W. E. [Frigate Petrel on Colonsay.] (Bull. B.O.C., VI., $x 896-7$.

Davison, R. R. Yellow Wagtail in Argylls. (Zool.)

Harvie-Brown, J. A., and Clarke, W. E. Barred Warbler at Dhu Heartach Rock. (Ann. Scott. N.H.)

Witherby, H. F. The Birds of Oban's Isles. (Knowledge.) [656.]

I898. Anderson, P. On Birds observed on Island of Tiree. (Ann. Scott. Nat.)

Frohawk, F. W. Great Northern Diver in Argyll. (Field, Jan. 28.)

"F. F. L." Capture of a Golden Eagle. (Field, Sept. 3.)

Craig, A. W. Gt. Northern Diver in Argyll. (T.c., Sept. I7, Oct. I, I5, Nov. 5.)

I899. Irby, L. H. On Birds of Islands of Tiree and Coll. (Amn. Scott. N. H.)

I900. Gilmour, T. F. Long-eared Owl in Islay. (Op. cit.)

Watt, H. B. Heronries, Past and Present, in the Clyde Faunal Area. (Tr. N. H. Soc. Glasg., N.S., V.) [partim.]

Igor. Phillips, E. L. Carolina Crake in Tiree. (Bull. B.O.C., XII., IgOI-02.)

I903. Kirk, C. Honey Buzzard in Argylls. (Ann. Scott. N. H.)

Irby, L. H. Notes from Coll. (T.c.)

Harvie-Brown, J. A. Black-tailed Godwits in Tiree. (T.c.)

I906. Alston, C. H. Marsh Titmouse in Argylls. (Op. cit.)

Millais, J. G. [Exhib. of Black Game $\times$ Pheasant Hybrid from Ross of Mull.] (Bull. B.O.C., XVI., I905-6.)

Russell, F. Whoopers in Islay. (Zool.)

1907. Anderson, P. Rush of Golden Plover in Tiree. (Ann. Scott. N. H.)

Baird, - Rose-coloured Starlings in Argylls. (Oban Times, Aug. 3I, I907; Brit. Birds, I., I908.) 
Cripps, W. H. Jer-Falcon in Argylls. (Field, Feb. 6.)

Mackenzie, A. Greenland Falcon in Argylls. (T.c., Jan. 26.) Tomison, J. Bird-Life as observed at Skerryvore Lighthouse. (Ann. Scott. N.H.)

Ig08. Alston, C. H. Pintails in Argylls. $(O p$. cit. $)$

Anderson, P. Increase of Shovelers in Tiree. (Brit. Birds., II.) Dixon, J. S. Wood and Garden Warblers at Loch Awe. (Ann. Scott. N. H.)

[Editorial.] Spoonbills in W. of Scotland. (Brit. Birds, I.)

Noble, Heatley. Supposed Wild Swans on Coll. (OP. cit., II.)

Ig08-9. Anderson, P. Bird Notes from Tiree, 3 pts. (Ann. Scott. N. H., Ig08-9.)

I9I0. Baxter, W. R. Summer Notes on Birds of Garelochhead. (Glasg. Nat.)

Gladstone, H. S. American Yellow-billed Cuckoo in Argylls. (Ann. Scott. N. H.)

McNeill, M. Colonsay, one of the Hebrides ..... 8vo. Edinb. : rgro.

IgIr. Alston, C. H. Wigeon nesting on Loch Awe. (Ann. Scott. N. H.) Harvie-Brown, J. A. Phylloscopus neglectus in Tiree. (Ibis.) Bird Notes from Tiree. (Amn. Scott. N. H.)

I9r3. Alston, C. H. The Jay in Argylls. (Scott. Nat.)

Anderson, P. Birds of the Is. of Tiree (5 pts.). (T.c.) Idem addit. by Jackson and Robinson. (Op. cit., IgI4.)

Beveridge, F. S. Sea Eagles in Argyll. (Scott. Nat.)

Harris, C. K. Glossy Ibis in Argyll. (T.c.)

Ingram, C. The Ruff in the Is. of Islay. (Zool.)

Kirk, C. Hybrid Capercaillie $\times$ Blackcock in Argyll. (Scott. Nat.)

Ross, A. Birds of Islay. (Glasg. Nat., VI., pp. 7-32.) Idem addit. (Op. cit., I9I5, pp. 97-IOI.)

I9I5. Robertson, J. Iceland Gull on Loch Fyne. (Scott. Nat.)

Igr8. Boughton-Leigh, P. W. P. Observations in the Is. of Mull. (Rept. Rugby School N. H. Soc. for I9I7, pp. 75-6.)

Grieve, S. Vanishing Game Birds in Argylls. (Op. cit.)

\section{AYRSHIRE.}

I830. "Z. Z." Facts and Queries as to Birds in W. of Scotland. (Loudon's Mag. N. H., III.)

I833. Scouler, J. Grey Phalarope [at Largs]. (Op. cit., VI.)

1837. Maclagan, P. W. Upupa epops [shot near Colyton]. (Mag. Zool. \& Bot., I., p. 49I.) 
1854. Donaldson, G. Arrival, Nesting Habits, etc., of Seafowl at the Craig of Ailsa, 2 pts. (Nat. [Morris's], IV.)

1858. "D. F. P." Hybrid Pheasant and Grey Hen [at Culzean]. (Field, Nov. 27.)

I864. Gray, R. Ailsa Craig and its Birds. (Intellectual Observer.) "M." Honey Buzzard shot in Ayrshire. (Field, Oct. I.)

r868. Walker, T. C. Remarks on Birds of Ailsa Craig, 2 papers. (Zool.) I869. Gray, R., and Anderson, T. The Birds of Ayrshire and Wigtownshire. 8vo. Glasg. : 1869. (Reprinted from the Proc. Nat. Hist. Soc. of Glasgow.) [25I.]

I872. Gray, R. Letter on Occurrence of Balearic Crane (Ibis) ; Letter on Occurrence of Sand Grouse (Ibis ; Field, July 27.)

I878. Gray, R. Ornitholog. Notes. (Hist. Berw. Cl., VIII., pp. 499502.)

I880. Gray, R. American Night Heron in Ayrshire. (Pr. R. Phys. Soc. Edinb.)

I883. "L. A." Kingfishers in Ayrshire. (Field, Jan 20.)

I886. Macfie, R. Stock Dove in Ayrs. (Op. cit., Feb. 20.)

I888. Lawson, R. Ailsa Craig, its History and Natural History. Post 8vo. Paisley: 1888. New edn. enlarged: I895. [343.]

I889. Sargent, J. Sand Grouse in Ayrs. (Zool.)

I894. McConnell, R. F. A Visit to Ailsa Craig. (Nat. Journ.)

I895. Pringle, J. Great Bustard washed up on Ayrshire Coast. (Ann. Scott. N. H.)

I896. Paterson, J. Common Buzzard in S. Ayrs.; Tufted Duck in S. Ayrs. ; Probable Nesting of Red-breasted Merganser in Buteshire and Ayrs. (Op. cit.)

I897. Fairbairn, A. List of Rarer Birds Found in Upper Reaches of Valley of Ayr. (Ann. Scott. N.H.)

I898. Paterson, J. Waxwing in Ayrs. (Op. cit.)

rgoo. Watt, H. B. Heronries, Past and Present, in the Clyde Faunal Area. (Op. cit.; N. H. Soc. Glasg., N.S., V.)

Paterson, J. Bittern in Ayrs.; (Op. cit.)

Smith, J., Paterson, J., and Watt, H. B. Nat. Hist. of Ailsa Craig. (Trans. Anders. Nat. Soc., II., pp. I35-42.) [Aves by J. Paterson.]

I90I-4 Rose, G. Ornitholog. Notes and Records. (Ann. Kilmarnock Glenfield Rambl. Soc., IV., I9oI-4, pp. 64-66.)

Barr, M., and Craig, J. Beith Ornitholog. Notes. (T.c., pp. 62-63.)

IgoI-7. Fairbairn, A. Descrip. Cat. of Brit. Birds. Glenfield Rambler's Coll. in Dick Inst. Mus., Kilmarnock. (Op. cit., IV., pp. 49-6I ; V., pp. 8I-90.) 
I904-Io. Rose, G. List of Birds of Ayrs. (Op. cit., V., I904-7, pp. 558o.) Suppl. (Op. cit., Igro.)

I907. Ailsa, Marquis of. On Birds of Ailsa Craig. (Bull. B.O.C.)

Rothschild, W. On Threatened Extinction of Breeding Home of Gannets on Ailsa Craig. (T.c.)

I907-8. Young, M. Pied Flycatcher Nesting in Ayrs. (Ann. Scott. N. H., I907; Brit. Birds, I908.)

I908. Robertson, J. Glossy Ibis in Ayrs. (Ann. Scott. N. H.)

1909. Paterson, J. Notes on the Eagles of Ayrs. (Glasg. Nat.)

Ig09-I4. Paterson, J. Return of Summer Birds to Clyde Area in I908-I4, 5 repts. (Glasg. Nat., I909-I4.)

I9I0. Wilson, R. W. S. Mealy Redpoll in Ayr. (Op. cit.)

I9I2. Wilson, R. W. S. Greenland Wheatear in Ayrs. (Op. cit.)

Craig, J., and Barr, M. Birds of Parish of Beith and Neighbourhood. (Op. cit.)

I9r3. Bedford, Duchess of. Manx Shearwater inland in Ayrs. (Scott. Nat.)

Gurney, J. H. The Gannet. 8vo. Lond.: IgI3. [Incl. Ailsa Craig.]

Graham, G. Bartailed Godwit in Ayrs. (Scott. Nat.)

Kirk, C. Razorbills and Guillemots deserting their Breeding Places at Ailsa Craig. (Brit. Birds, VII. ; Scott. Nat.)

Wilson, R. W. S. Bewick's Swan in Ayrs. (Glasg. Nat., V., pp. 79-80.)

Igr4. Kirk, C. Nesting of Twites on Ailsa Craig. (Scott. Nat.)

Nash, J. K. Razorbills and Guillemots in Ailsa Craig. (T.c.)

I9I5. Craig, J. Ornithol. Notes from Beith. (Glasg. Nat., VIII., pp. 22-24.)

Paton, C. R. Glaucous Gulls inland in Ayrs. (Brit. Birds, VIII.)

I9r6. Paton, E. R. Supposed Eagle Owl in Ayrs. (Op. cit., IX.)

Ritchie, J., junr. On an Ayrshire Great Grey Shrike. (Glasg. Nat., VIII., pp. 42-3.)

I9I7. Craig, J. Persecution of Rooks by Carrion Crows at Beith. (Scott. Nat.)

Hopkins, N. Hen-Harrier in Ayrs. (T.c.)

Robertson, J. Pale-breasted Brent Goose in Ayrs. (T.c.)

IgI8. Clarke, W. E. Variety of Red Grouse in Ayrs. (Op. cit.)

\section{BANFFSHIRE.}

1847. Smith, J. Bartailed Godwit near Banff. (Zool.)

I848. Smith, J. Remarks on Birds visiting River Deveron. (Zool.) 
185I. Edward, T. Zoological Notes, on Rarities occurring near Banff. (Nat. [Morris's], I.) [I93.]

1852. Newton, E. Harlequin Duck in Banffs. (Zool.)

[Corrected to Longtailed Duck. (Op. cit., I859).]

1853. Edward, T. A Day's Ramble by the Seashore. (Nat. [Morris's], III.) [193.]

Donaldson, G. Merlin near Banff. (T.c.)

Macduff, W. Mountain Finch [near Banff]. (T.c.)

1854. Edward, T. Honey and Rough-legged Buzzards in Banffs., and Ornitholog. Notes. (Op. cit., IV.) ; Occurr. of Common Crossbill in higher districts of Banffs. (T.c.)

1855. Edward, T. An Ornithological Rarity in the North [Spurwinged Goose]. (Op. cit., V.)

1856-60. Edward, T. List of the Birds of Banffs., 8 pts. (Zool.) [I93.]

1857. Edward, T. Kite near Banffs; Rose-coloured Pastor in Scotland. $(O p$. cit.)

1858. Edward, T. Ring Ouzel near Banffs. ; Rare Birds near Banffs. (Op. cit.) [I, [I94.]

"Ridibundus." The Ivory Gull [in Banffs.]. (Field, Dec. II.)

1859. Edward, T. Great Ashcoloured Shrike in Banffshire. (Zool.)

I861. Edward, T. Waxwing, Great Spotted Woodpecker and Ivory Gull in Banffs. (Zool.)

I866. Edward, T. Red-winged Starling in Scotland. (Zool.) Idem. (Field, June 30.)

1876. Edivard, T. Selections from the Fauna of Banffshire. (Appendix to Smiles's Life of a Scotch Nuturalist.) 8vo. Lond. : I876. And subsequent edits. [I94.]

I879. Edward, T. Waxwing at Banff. (Zool.)

1885. B[ird], M. C. H. Spotted Flycatcher in Banffs. (Field, Aug. 22.)

1892. Hinxman, L. Nesting of Stock Dove in Banffs. (Ann. Scott. N. H.)

1893. Hinxman, L., and Clarke, W. E. Nesting of Snow Bunting in E. Cairngorm. (Op. cit.)

Ogilvie-Grant, W. R. Dotterel Breeding in S. Banffs.; Snow Bunting Breeding in S. Banffs. (Bull. B.O.C.)

1907. Clay, Sir Arthur. [Exhibit by Ogilvie-Grant, W. R.] Corncrake in Banffs. in Dec. (Op. cit., XIX.)

I908. Yates, J. Waxwing in Banffs. (Amn. Scott. N. H.)

I9I7. Gowan, J. Albino Ringed Plover at Cullen; Migration in Banffs. (Scott. Nat.)

IgI8. Mahood, A. E. Banffshire Birds. (Op. cit.) 


\section{BERWICKSHIRE.}

I832. Johnston, G. Pres. Address. (Hist. Berw. Nat. Cl., I., pp. 4-I2.) 1833. Selby, P. J. On Birds observed in Neighbourhood of Coldbrandspath and St. Abb's Head, I832-3, 2 pts. (T.c., pp. I8-22.)

1834-5. Selby, P. J., and Embleton, R. Pres. Addresses, 2 pts. (T.c., pp. 33-9, 65-9.)

I84I. Selby, P. J. Report on Ornithology of Berwicks. and District. (T.c., pp. 250-62.)

I847. Johnston, G. Miscellanea. (Op. cit., II., pp. 219-20.)

1851. Hepburn, A. Notes on Mammalia and Birds found at St. Abb's Head. (Op. cit., III., Pp. 70-77, I850-56.)

1852. Gray, R. White Stork in Berwicks. (Nat. [Morris's], II.)

I856. Hardy, J. Twite in Berwicks. (Hist. Berw. Nat. Cl., III., p. 258.)

I860-78. Zoological Notes and Miscellanea, I2 pts. (Op. cit., IV., p. 2 II ; V., pp. I8I-2, 232-3, 282 ; VI., pp. $84,247,424,433$; VII., pp. 290-8, 509-I9; VIII., pp. I89-97, 527-32.)

I862. Duns, J. On Nesting Birds of Linlithgows. and Berwicks. (Edinb. Nere Phil. Jul.; Pr. R. Soc. Edinb.)

I867. " J. H." Landrail in January in Berwicks. (Field, Feb. 23.) Campbell, W. Watson. Notice of Caprimulgus europaus. (Hist. Berw. Cl., V., p. 306.)

Stuart, C. Great Spotted Woodpecker. (T.c., pp. 409-ro); On Missel Thrush. (T.c., p. 442.)

I869. Binning, Lord. On Birds of E. Lothian and Berwicks. (Abstract of paper read Nov. 27th, 1866, in Pr. N. H. Soc. of Glasg.)

Smail, J. Zoological Notes. (Hist. Berw. Cl., VI., pp. 96-7.)

I870. Oliver, W. Notes on Nat. Hist. (T.c., pp. I27-8.)

I872. Wilson, J. Remarks on Some Berwicks. Birds. (T.c., pp. 399400.)

I872-9. Brotherston, A. Zoological Notes, 7 pts. (Op. cit., VI., pp. 434-5; VII., pp. I32-5, 285-9, 500-06 ; VIII., pp. I80-8, 520-6; IX., pp. I75-7.)

I872-5. Elliot, Sir Walter. Notices of Some Rare Birds, 2 pts. (Op. cit., VI., pp. 3I8-25, 524-5.)

I872-84. Hardy, J. Arrival and Departure of Migratory Birds, 8 pts. (Op. cit., VI., pp. 383-4; VII., pp. Iog-I2, 277-83, 484-6 ; VIII., pp. I52-4 ; IX., pp. 387-409, 549-63; X., pp. 556-72.)

I873. Anderson, J. Goosander at Preston. (Op. cit., VII., p. I27.) Ferguson, J. On Kingfisher, etc. (T.c., pp. r20-I.) 
Muirhead, G. Common Crossbill at Paxton. (T.c., pp. I07-8) ; Pied Flycatcher in Berwicks. (Field, Mar. 29.)

Stuart, J. A. Erskine. Food of Heron. (Hist. Berw. Cl., p. 284.)

Watson, C. Bohemian Waxwing at Duns; Ruff near Burnmouth. (T.c., p. I27.)

1873-4. Brotherston, A. Turtle Dove near Berwick. (Scott. Nat., II., I873-4.)

1874. Ferguson, J. Zoological Notes. (Hist. Berw. Cl., p. 284.)

I874-82. Gray, R. Ornitholog. Notes, 7 pts. (Op. cit., VII., pp. 257-6r, 463-7 ; VIII., pp. I55-9, 353-5, 498-502 ; IX., 365-8 ; X., I97200.)

1874-6. Kelly, Andrew. On Some Birds of Lauderdale, 3 pts. (Op. cit., VII., pp. 30I-6, 520-3 ; VIII., pp. I42-8.)

1875-8. Muirhead, G. On Birds in Neighbourhood of Paxton, 2 pts. (Op. cit., VII., pp. 379-95 ; VIII., pp. 503-9.)

I876. Muirhead, G. Notes on Birds. (Op. cit. VIII., pp. I78-80.) M[uirhead], G. Hen Harrier in Berwicks. (Field, Oct. 30.)

1877. Knight, V. Ornitholog. Notes. (Hist. Berw. Cl., pp. 258-63.) Smail, J. Zoological Notes. (T.c., pp. 99-I06.)

I878. Brotherston, A. White's Thrush in Berwicks. (Hist. Berw. Nat. Cl., VIII., pp. 5I8-20; Zool. ; Scott. Nat., V., I879-80.) Idem by J. E. Harting. (Zool.)

Hardy, J. Goldfinches in Berwicks. (Hist. Berw. Cl., VIII, p. 494.)

I878-I903. Bolam, G. Ornitholog. Notes, 8 pts. (Op. cit., VIII., pp. 495-8 ; IX., pp. I65-70 ; X., pp. 384-96, 58I-9; XI., pp. $258-63$; XIII., pp. $345-68$; XVII., pp. 89-I08; XIX., pp. 69-72.)

1879. Hardy, J. Effects of Winter I878-9. (Op. cit., IX., pp. 122-57.) Idem by C. Stuart. (T.c.)

I882. Gray, R. Bird Life of Firth of Forth. (Op. cit., X., pp. 84-7.) Smail, J. Rooks and Rookeries. (T.c., pp. I59-84.) [partim.)

1883. Smail, J. Border Heronries. (T.c., pp. 330-34.) [partim.]

1884. Harvie-Brown, J. A. St. Abb's Head and its Bird Life. (Pr. N. H. Soc. Glasg.) [28I.]

I884-92. Stuart, C. Migrations, etc., and Notes on Birds, 4 pts. (Hist. Berw. Nat. Cl., X., pp. 572-9; XI., pp. 236-45, 562-79; XIV., pp. I7I-6.)

1887. Hardy, J. On Wild Pigeons of Coast of Berwichs. (OP. cit., XII., pp. I49-5I.)

I880. Bolam, G. Pallas's Sand Grouse Visitation. (Op. cit., XII., p. 532.) 
I889-9I. Barrie, J. Birds seen at Preston. (Op. cit., XII., p. 532 ; XIII., p. 4I2.)

1889-95. Muirhead, G. The Birds of Berwickshire. 2 vols. 8vo. Edinb. : I889-95. [426.]

I89o. Aplin, O. V. Distribution of Spotted Crake. (Zool.) [partim.] I89I. Evans, A. H. Preliminary List of Birds of Melrose District, 2 pts. (Scott. Nat., XI.) ; Bittern in Berwicks. (T.c.)

I892. Service, R. Waxwing in Berwicks. (Ann. Scott. N. H., I.)

I894. Ferguson, J. List of Birds at Dunglass, etc. (Hist. Berw. Cl., $\mathrm{XV}$., pp. 50-2.)

1894-5. Stuart, C. Nesting of Great Spotted Woodpecker in Berwicks. (Ann. Scott. N. H., I894.) Idem by W. Evans. (Op. cit., I895.)

1895. Stuart, C. Notes on Birds of Eastern Borders. (Hist. Berw. Cl., XV., pp. 325-3I.)

1896. Evans, W. Sandwich Tern and Whimbrel on Berwicks. coast. (Ann. Scott. N. H.)

1896-99. Bolam, G. List of the Birds of Berwick-on-Tweed, 4 pts. (Ann. Scott. N. H., 1896-7, I899.) [78.]

1897. Stuart, C. Mealy Redpoll and Great Grey Shrike in Berwicks. (Op. cit.)

1898. Stuart, C. Jay in Berwicks. (Op. cit.)

I902. Coburn, F. [Exhibit. of Curious Bean Goose from St. Abb's Head.] (Bull. B.O.C., XII.)

I906. Douglas, W. A. A Bit of the Berwickshire Coast and Its Birds. (Scott. Mountaineering $\mathrm{Cl}$. Jnl., VIII.)

I907. Chapman, A. Bird Life of the Borders. 8vo. Lond.: I907. [I24.]

I908. McConachie, W. The Birds of Lauderdale. (Hist. Berw. Cl., XX., pp. 316-22.) Hawfinch in Berwicks. (Ann. Scott. N.H.) Donaldson, R. P. Black Tern on the Tweed. (T.c.)

IgIr. Evans, A. H. A Fauna of the Tweed Area. Sq. 8vo. Edinb.: IgII. [200.]

I9I2. Bolam, G. Birds of Northumberland. Alnwick: Igr2. [78.] [partim.]

Chapman, A. Spring Notes on the Borders, IgII-I2. (Brit. Birds, VI.) [I24.]

Evans, W. Greater Wheatear in Berwicks. (Scott. Nat.)

Igr3. McConachie, W. Nesting of Dunlin in Berwick. (Scott. Nat.)

I9I4. Laidlaw, T. G. Supposed Hybrid between Mallard and Wigeon in Berwicks. (Op. cit.)

McConachie, W. Yellowbrowed Warbler in Berwicks.; Nesting of Dunlin in Berwicks. (T.c.) 
I9I5. Bolam, G. Tree Sparrow in Lauderdale. (T.c.)

Evans, W. Fulmar on S.E. coast in summer. (Scott. Nat.)

McConachie, W. Hawfinches in Lauderdale. (T.c.)

Igr7. Laidlaw, T. G. Unusual Birds in Berwicks.; Rare Birds in Berwicks. (Op. cit.)

\section{BUTESHIRE.}

I847. Landsborough, D. Arran: a Poem, etc. Lond: I847. [338.] I852. Landsborough, D. Excursions to Arran. Second series. Fcap. 8vo. Edinb. : 1852. [338.]

1854. Norman, A. M. Rose-coloured Pastor in Is. of Cumbrae. (Zool.) [-?] Barry, M. List of Birds that have been observed to Breed in the I. of Arran. I2mo. S. 1. et a. [45.]

[See also résumé in Ibis, I863, pp. 477-8.]

I866. Alston, E. R. Zoolog. Notes from Arran. (Zool.)

Colquhoun, J. Observations on the Birds of Bute. (In his Sporting Days.) 8vo. Lond., etc. : I866. [I40.]

1872. Gray, R. Birds of Arran. (In Bryce's Geology of Arran, 4th ed.) Cr. 8vo. Glasg., etc. : I872. [25I.]

1875. Glennon, J. Rare Birds., etc., shot in Ireland [includes an Iceland Gull from Arran]. (Field, Feb. 20.)

Landsborough, D., and D., junr. Arran: its Topography, etc. 8vo. Ardrossan, etc. : I875. [Also contains list by R. Gray.] [338.]

1895. Evans, W. Ornitholog. Notes made in Island of Bute in Midwinter. (Ann. Scott. N. H.) [200.]

I898. Paterson, J. Sabine's Gull in Arran. (Op. cit.)

I900. Craig, A. Birds of Bute and Arran. (Tr. Edinb. F. N. Soc., IV.) Watt, H. B. Heronries, Past and Present, in the Clyde Faunal Area. (Tr. N. H. Soc. Glasg., N.S., V.) [partim.]

Robertson, J. List of Birds of Island of Bute. (Tr. Edinb. F. N. Soc.)

I907. Harvie-Brown, J. A. Fulmar Petrels at Dunnet Head. (Op. cit.)

Igr4. MacKeith, T. T. Quails Nesting in Bute. (Scott. Nat.)

I9I7. McWilliam, J. M. The Brent Goose in Bute. (Op. cit.)

Robertson, J. Pale-breasted Brent Goose in Bute. (T.c.)

IgI8. McWilliam, J. M. Notes on Some of the Birds of Bute, including Records of their Passage to Mainland. (Op. cit.)

Robertson, J. Yellow Wagtail in Bute. (T.c.) 


\section{CAITHNESS-SHIRE.}

1850. Foottit, W. F. Snowy Owl in N. of Scotland. (Zool.)

I855. Murray, A. Extract of Letter from W. Jardine on Capture of Pagophila eburnea. (Edinb. Nere Phil. Jnl.)

1858. "Scaraben." Bohemian Chatterer and Little Bustard in Caithness. (Field, Apr. 24) ; Ivory Gull shot near Wick. (Op. cit., Nov. 27, Dec. Ir.)

1859. O[sborne], H. Rare Birds in Caithness. (Op. cit., Oct. r5) ; Peregrine [near Wick]. (Op. cit., May 7.)

"Scaraben." Glaucous Gull [in Caithness]; Redshanks [and Common Sandpiper Breeding in Caithness]. (Op. cit., Jan. 22.)

I860. O[sborne], H. The Peregrine Falcon. (Op. cit., Nov. 3.)

I86I-3. Osborne, H. [and Others.] Ornitholog. Notes from Caithness. (Op. cit., I861, May 4, Sept. 28 ; I862, May I7, Nov. I, 29, Dec. 5 , I2 ; 1863, Dec. 26.)

Shearer, R. J., and Osborne, H. Notes on Ornithology of Caithness. (Pr. R. Phys. Soc. Edinb., II., III., I86I-3.)

I862. "M. A. S." American Bittern Shot in Caithness. (Field, Dec. 6.)

I863. Osborne, H. Blackcap in Caithness (Op. cit., XXII., pp. 559, $579,62 \mathrm{I})$; Large Flight of Goldcrested Regulus in Caithness. (T.c., p. 559; Op. cit., XXIII., p. x9) ; Waxwing in Caithness (Op. cit., Dec. 26$)$; Pallas's Sand Grouse in Scotland. (Zool. ; Field, June 27.)

1864. Osborne, W. Great Arrival of Golden-crested Regulus at Wick; Waxwing at Wick; Sand Grouse and Grey Phalarope at Caithness (Zool.) ; Arrival of Migratory Blackbird in Caithness ; Migratory Birds seen in Caithness. (Field, Jan. 9.)

1865. (John o' Groats Journal.) Great Grey Shrike in Caithness. (Field, Oct. 2I.)

I867. Ward, H. Snowy Owl [in Caithness]. (Op. cit., July 20.)

I870. Houdish, W. S. Carr. Quail in N. of Scotland [Thurso]. $(O p$. cit., Sept. 24.)

I876. Cooke, H. Wood Wren in Caithness. (Zool.)

M'Nicol, N. Iceland Falcon in Caithness. (Field, Apr. I5.)

I878. M'Nicol, N. Turtle Dove in Caithness. (Field, Nov. 9.)

1879-80. Smith, J. A. Notice on the Remains of the Great Auk or Gare Fowl (Alca impennis) found in Caithness, etc. 4 to. (Reprint from Pr. Soc. Antiq. Scot., 1879.) Idem. Addit. Notes. (T.c., I880.)

I885. "Terræ Filius." Gerfalcon in Caithness. (Field, June 20.) I886. Reid, W. Ivory Gull and Little Auk in Caithness. (Zool.) 
I887. Harvie-Brown, J. A., and Buckley, T. E. Vertebrate Fauna of Sutherland, Caithness, etc. Sq. 8vo. Edinb. : I887.

I889. Sutherland, J. Round About the Northern Cliffs. (Tr. Edinb. F. C., II., I886-9I.)

I890. "L. D." Honey Buzzard in Caithness. (Field, July I2.)

I892. Dunbar, L. Waxwing in Caithness; Rollers in Caithness; Hen Harrier in Caithness. (Ann. Scott. N. H., I.)

I897. Dunbar, L. Bee-eater in Caithness. (Op. cit.)

I898. Arkwright, W. Baillon's Crake in Caithness. (Field, Oct. 8.) Godfrey, J. Goldfinch in Caithness. (Ann. Scott. N. H.)

Sutherland, J. Pied Flycatcher and Red-backed Shrike in Caithness, 2 notes. (Knowledge.)

Igor. Buckley, T. E. Pintail in Caithness in August. (Zool.)

I902. Buckley, T. E. Stock Dove in Caithness. (Ann. Scott. N. H.) I908. Hughes-Onslow, A. Rose-coloured Pastor near Reay in July. (Field, July II; Brit. Birds, II.)

[Editorial.] Purple Heron in Caithness. (Brit. Birds, II. ; Ann. Scott. N. H.)

IgIo. Cairnie, C. Velvet Scoter in Caithness in Summer. (Brit. Birds.) IgIr. Meiklejohn, A. H. Fulmars Nesting in Caithness. (Op. cit.) [IgII ?] Horne, - History of Caithness. [Not seen: "Contains Account of Birds." W. Eagle Clarke.]

19x3. Alston, C. H. Gadwall in Caithness. (Scott. Nat.) Bain, G. Hoopoe off Caithness. (T.c., ; Brit. Birds, VII.) Jackson, A. C. Gadwall Nesting in Caithness. (Scott. Nat.)

I9I5. Bain, G. Northern Bullfinch in Caithness. (Op. cit.) Jackson, A. C. Blacktailed Godwit in Caithness; Gadwall Nesting in Caithness. (T.c.)

\section{CLACKMANNANSHIRE.}

I872. Harting, J. E. British Heronries. (Zool.) [partim.]

1877. Gray, R. Ornitholog. Notes. (Hist. Berw. Nat. Cl., VIII., p. 354.)

1880. Gray, R. Night Heron in Clackmannans. (Pr. R. Phys. Soc. Edinb.)

I881. Dalgleish, J. J. On the Desert Chat killed at Alloa. (P.Z.S.) Idem. (Pr. R. Phys. Soc. Edinb.)

I885. Dalgleish, J. J. Night Heron and Pied Flycatcher in Clackmannans. (Zool. $)$ 
I886-8. Drummond-Hay, H. M. Rept. on Ornithology of E. of Scotland, 3 pts. (Scott. Nat., VIII., I885-6 ; IX., I887-8.) [I82.]

I89I. Dalgleish, J. J. Sabine's Snipe in Clackmannans. (Op. cit., XI.) I900. Evans, W. Goldfinch in Clackmannans. (Ann. Scott. N. H.)

\section{CROMARTY (See ROSS-SHIRE).}

\section{DUMBARTONSHIRE.}

1852. Leith, G. H. Occurrence of Various Birds at Ross. (Zool.) I87I-2. Lumsden, J., junr. The Wood Warbler [near Loch Lomond]. (Scott. Nat., I., I87I-2.)

I873-4. Lumsden, J., junr. Wood Sandpiper [on Loch Lomond]. (Op. cit., II., I873-4.)

1876. Gray, R. Ornitholog. Notes. (Hist. Berw. Nat. Cl., VIII., pp. I55-9.)

Lumsden, J. Sketch Paper on Birds of Loch Lomond and Neighbourhood. (Pr. N. H. Soc. Glasg., III. [I875-8].) Additions. (T.c., I88I-3.) [364.]

I878. "W. C." Grey Shrike in Dumbartons. (Field, Dec. I4.)

I88I-3. Lumsden, J. Ornitholog. Jottings from Loch Lomond, 2 pts. (Pr. N. H. Soc. Glasg., IV. [I88I] ; V. [1883].)

1882-3. Buchanan, G. H. L. Pectoral Sandpiper in Perths. [errore for Dumbartons.] (Field, Dec. 2, I882; Mar. 24, I883.)

I883. Colquhoun, J. Grey Shrike in Dumbartons. (Op. cit., Feb. Io.) Harting, J. E. Pectoral Sandpiper in Dumbartons. (Zool.)

I885. Lumsden, J. Marsh Harrier in Dumbartons. (OP. cit.)

[I889.] [Boyd, D. A.] Birds of the Clyde Valley. [In Pollock's Dict. of the Clyde, pp. 63-65.] Glasgow : [I889.]

I89I. Lumsden, J. Hybrid Between Pheasant and Capercailzie [near Alexandria]; Bewick's Swan on Loch Lomond. (Scott. Nat., XI.)

I895. Lumsden, J., and Brown, A. Guide to the Natural History of Loch Lomond. 8vo. Glasg. : I895. [364.]

Ripley Ker, T. Green Sandpiper in Dumbartons. (Ann. Scott. N.H.)

1898. Lumsden, J. Waxwings at Loch Lomond. (Op. cit.)

Igoo. Watt, H. B. Heronries, Past and Present, in the Clyde Faunal Area. (Tr. N. H. Soc. Glasg., N.S., V.)

I909-I4. Paterson, J. Return of Summer Birds to Clyde Area in I908-I4, 5 repts. (Glasg. Nat., I909-I4.) 
I9I0. Paterson, J. Flamingo at Dumbartons. (OP. cit.)

I9I3. Stout, G., and Duncan, H. Green Sandpiper in Dumbartons. (Scott. Nat.)

Westell, W. P. Autumn Notes on Birds of the Gareloch. (Glasgow Nat., VI., pp. I-7.)

\section{DUMFRIESSHIRE.}

I8I7-52. McDiarmid, J. Ornitholog. Notes [in Dumfr. \& Galloway Courier]. I817-52.

I829. J[ardine], W. Rare Birds Shot in Dumfriessh.; Nat. Hist. in Scotland; Solan Goose [inland up Moffat Water]; Blackcock [variety in Annandale]. (Loudon's Mag. N. H., II.)

I845. Jardine, Sir W. List of Birds of Parish of Applegarth and Sibbalddie. (New Statist. Acc. Scotl., IV.) [3Ir.]

1849. J[ardine], W. Gallinago brehmi at Jardine Hall. (Ann. Mag. N. H.)

I854. Johnstone, W. G. A Few Notes on the Nesting of Birds [in Dumfriessh.]. (Nat. [Morris's], IV.)

1857. Gibson, W. G. Gray Phalarope and Wryneck in Dumfriessh. 2 notes. (Nat. [Morris's], VII.)

I858. Gibson, W. G. Birds Shot in Dumfriessh.; Blue-winged Teal. 2 notes. (Op. cit., VIII.)

"G." European Bittern. (T.c.)

1859. Armstrong, T. Rare Birds near Carlisle [Stock Dove near Ecclefechan]. (Zool.)

1866. Aird, T. Notes on Birds taken in I864, at Mountainhall, a mile east from Dumfries. (Tr. Dumfr. \& Gall. N. H. Soc., Feb. 2, I864.)

I867. Harvie-Brown, J. A. Rough-legged Buzzard in Dumfriessh. (Zool.) I867-9. Corrie, J. Notes on Birds . . observed at Ashbank, Maxwelltown. (Tr. Dumfr. N. H. Soc., VI., I867-9.)

I868-7I. Jardine, Sir W. Note of Rare Birds. 2 pts. (Tr. Dumfr. N. H. Soc., I868-7I.)

I872. Harting, J. E. British Heronries. (Zool.) [partim.]

I873. Simpson, J. Fieldfares Nesting in Scotland. (Field, May 24, 3I.) I873-4. White, F. B. Golden Oriole [in Dumfriessh.]. (Scott. Nat., II.) I874-5. Gray, R. Ornith. Notes. (Hist. Berw. Cl., VII., pp. 257-6I, 463-7.)

1875. Elliott, Sir W. Rare Birds. (T.c., pp. 524-5.)

1876. Gurney, J. H., junr. American Bittern in Dumfriessh. (Zool.) 
1878-89. Hastings, W. Ornitholog. Notes, 1878-88, 9 pts. (Tr. Dumfr. N. H. Soc., Oct. 4, I878; Dec. 5, 1879; Nov. 3, I882 ; Dec. 7, I883; Nov. 9, I884; Dec. 4, I885; Nov. 5, I886 ; Nov. 5,1887 ; Feb. I, I889.)

188x. Chrystie, S. Birds that Breed in the Parish of Dumfries. $(O p$. cit., Dec. 4.)

Service, R. Buffon's Skua in Dumfriessh. (Zool.)

I882. Service, R. Notes on Local Ornithology. (Tr. Dumfr. Soc., Feb. 3.)

1885. Brown, T. List of Birds of Tynron Parish. (Op. cit., Dec. 4.) 1885-6. Armistead, J. J. Notes on Some Birds Occurring in Solway District, 2 pts. (Nat., I885-6.)

1886. Armistead, J. J. Notes on Birds in Solway District. (Nat.) I888. Corrie, J. An Ornitholog. List for the Parish of Glencairn. (Tr. Dumfr. N. H. Soc., Nov. Io.)

Davidson, A. The Birds of Upper Nithsdale. (T.c., Nov. ro.)

I\&go. Hammond, W. O. Reported Nesting of Black Redstart in Dumfriessh. (Zool.)

Service, R. The Vertebrates of Solway-A Century's Changes. (Tr. Dumfr. N. H. Soc.)

I8go-94. Corrie, J. Notes on Birds, 2 pts. (Tr. Dumfr. N. H. Soc., Feb. 6, I89o; Feb. I6, I894.)

I8gI. Corrie, J. Leach's Petrel. (Op. cit., Dec. 3.)

Davidson, A. Flora and Fauna. [In J. Brown's History of Sanquhar.] 8vo. Dumfries: I8gI. [I63.]

Macpherson, H. A. Wildfowl in Scottish Solway Faunal Area. (Scott. Nat., XI.)

Murray, T. G. Leach's Petrel in Dumfries. (Field, Oct. 24.) Shaw, J. The Avifauna of Upper Nithsdale. (Sci.Gossip, Aug.)

I892. Service, R. Grey Phalarope in S.W. Scotland; Buffon's Skua in Solway District. (Ann. Scott. N. H., I.)

I893. Armistead, J. J. Black Guillemot on Solway Firth. (Zool.) I893-4. Mackay, H. Ornitholog. Notes, I892-3. (Tr. Dumfr. Soc., May I2, I893; April 20, I894.)

I894. Mackay, H. Bird Notes from Dumfriessh. (Nat. Journ.) Whiskered Tern in Dumfries. (Zool.)

Macpherson, H. A. Pink-footed Goose in Dumfriessh.; Waders and Little Gull on Solway Firth. (T.c.)

Service, R. Black Guillemot on Solway Firth; Short-eared Owl in Solway. (T.c.)

I894. Service, R. Great Grey Shrike in Solway District; Whiskered Tern in Solway. (Ann. Scott. N. H., III.)

I895. Service, R. The Starling in Solway. (Op. cit., IV.) The Marsh Tit in Dumfriessh. (Zool.) 
I896. Armstrong, R. Notes from Dumfries. (Ornithologist.)

Macpherson, H. A. Long-tailed Duck on Solway Firth. (Ann. Scott. N.H.)

1897. Godfrey, R. A Night on the Dumfriessh. Hills. (Nat. Chron., June.)

Service, R. Solitary Snipe in Solway District; Pied Flycatcher in Dumfriessh. (Op. cit.)

I898. Armstrong, R. Pied Flycatcher in Mid-Nithsdale. (Op. cit.) Campbell, B. List of Birds observed in District of Moffat, Oct., I896 to Feb., I897. (Zool.)

Macpherson, H. A. Long-tailed Duck in Dumfriessh. (Ann. Scott. N.H.)

Maxwell, W. J. Natural History Notes. (Tr. Dumfr. N. H. Soc., Jan. I4.)

Service, R. Jay in Dumfriesshire. (Ann. Scott. N. H.) ; Marsh Harrier in Dumfriessh. (T.c.)

1899. Shaw, J. Avifauna of Upper Nithsdale. [In R. Wallace's A Country Schoolmaster.] Cr. 8vo. Edinb.: I899. [53I.]

I900. Corrie, J. On Nesting of the Nightjar in Glencairn. (Tr. Dumfr. Soc., Mar. 9.)

Service, R. Ornithol. Notes from Solway. (Ann. Scott. N. H.)

Igor. Bell, R. Some Bird Notes from Eskdale. (Tr. Dumfr. Soc., Apr. I7.)

IgoI-2. Martin, Dr. List of the Birds of Glencairn. (Op. cit., Dec. I3, Igor.) Idem. Fauna of Glencairn. (T.c., Feb. 2I, Ig02.)

I903. Bartholomew, J. Hawfinch in N. Dumfriesshire. (Ann. Scott. N. H.)

Service, R. Pomatorhine Skua on the Nith. (T.c.)

Service, R. Diurnal and Nocturnal Raptorial Birds of Solway Area. (Repr. from Dumfries \& Galloway Courier.) Idem in Dumfr. N. H. Soc., Igo6.

Service, R. Bird Migration in Solway. (Amn. Scott. N. H.) I904-5. Service, R. Changes in Avifauna of Solway Area. (Tr. Edinb. F. N. Soc., I904-5.)

I905. McCall, R. Birds Observed on the Solway. (Tr. Dumfr. Soc., Feb. I0.)

Service, R. The Sylviida of Solway. (Op. cit.) The Rarer Birds of the Solway Area. (T.c., Apr. 20.)

1905-6. Service, R. The Waders of Solway. (Op. cit., I905-6.)

I907. Gladstone, H. S. Bird Notes from Thornhill. (Ann. Scott. N. H.) Johnston, T. A. Notes on Birds on Moffat District. (Tr. Dumfr. N. H. Soc., Apr. 5.)

Payne, J. W. Natural History Notes from Annandale. (T.c., Feb. I.)

Service, R. Notes on Bird Migration in the District. (T.c., Jan. I8; Apr. I8.) 
I908. Gladstone, H. S. Smew in Dumfriessh. (Ann. Scott. N. H.)

Marriott, C. H. The Study of Bird-Life. (Tr. Dumfr. N. H. Soc., Apr. 3.)

Maxwell, H. Woodcocks and Black-game in Dumfriessh. (Ann. Scott. N. H.)

Service, R. The Bar-tailed Godwit as a Solway Bird. (T.c.) Bird Notes. (Tr. Dumfr. N. H. Soc., Mar. 20). The British Skuas, with Special Reference to Local Occurrences. (T.c., Nov. 6.)

1909. Service, R. Recent Occurrences of Rare Birds. (Op. cit., Feb. I9.)

Stout, G. Yellow-browed Warbler in Dumfriessh. in Spring. (Ann. Scott. N. H.)

I9Io. Gladstone, H. S. The Birds of Dumfriesshire. 8vo. Lond. : I9Io. [233.]

Gladstone, H. S. Golden Oriole in Dumfriessh. (Ann. Scott. N. H.) Twobarred Crossbill in Scotland. (Brit. Birds, III.)

IgII. Gladstone, H. S. Addenda and Corrigenda to "The Birds of Dumfriesshire." (Tr. Dumfr. N. H. Soc., Oct. 20.)

Payne, J. W. Bird Life in the South of Scotland. (T.c., Mar. 3r.)

I912. Gladstone, H. S. A Catalogue of the Vertebrate Fauna of Dumfriesshire. 4to. Dumfries: IgI2. [233.]

I9I3. Gladstone, H.S. Ornithol. Notes from Dumfriessh. (Scott. Nat.)

I9I4. Bartholomew, J. Ringed Grouse in Dumfriessh. (Scott. Nat.) Douglas-Menzies, N. E. Gt. Spotted Woodpecker in Dumfriessh. (T.c.)

Gladstone, H. S. Willow Tit in Dumfriessh. (Brit. Birds, VII.)

I9I5. Gladstone, H. S. Pied Flycatcher in Dumfriessh. (Scott. Nat.)

\section{EAST LOTHIAN (See HADDINGTONSHIRE).}

\section{EDINBURGHSHIRE (MIDLOTHIAN).}

I820. Stark, J. Pictures of Edinburgh. I2mo. Edinb. : I820.

1835. Rhind, W. Excursions Illustrative of the Geology and Natural History of the Environs of Edinburgh. 2nd ed. Post 8 vo. Edinb. : I835. [490.]

I837. MacGillivray, W. Winter Excursions from Edinburgh to Peebles; Birds found around Edinburgh in Winter. (In his History of British Birds, I.) 8vo. Lond. : 1837.

1839. MacGillivray, W.-Pseudonym "Ornithologus."] Migratory Birds of Midlothian. (Op. cit., II.) 8vo. Ib.: I839. 
I851. Cobbold, S. Waxen Chatterer near Edinburgh. (Nat. [Morris's], I.)

McIntosh, J. Heronries in England, etc. (T.c.) [partim.]

I853. Broughton, R. H. Little Auk near Edinburgh. (Zool.)

1856. Smith, J. A. Ferruginous or White-eyed Duck near Musselburgh. (Edinb. New Phil.Jnl., N.S., III.)

I862. Saxby, H. L. Ornitholog. Notes from Edinburgh. (Zool.)

I87I. "C. J. W." American Bittern [errore for Common Bittern, $c f$. Saunders] in Midlothian. (Field, Mar. 4.)

I87I-2. Wedderburn, Lt.-Col. List of Birds found at Rosslyn and Neighbourhood. (Scott. Nat., I., I87I-2.) Idem. Corrections by Author, H. Doubleday and G. Norman. (T.c.)

I872. Harting, J. E. British Heronries. (Zool.) [partim.]

I873. Hardy, J. Crossbills near Edinburgh. (Hist. Berw. Cl., VII., p. I08.)

I874-82. Gray, R. Ornitholog. Notes, 7 pts. (Op. cit., VII., pp. 257-6I, 463-7 ; VIII., pp. I55-9, 353-5, 498-502 ; IX., pp. 365-8; X., pp. $197-200$ )

I875. Elliot, Sir Walter. Rare Birds. (Op. cit., VII., pp. 524-5.)

I876. Smail, J. Zoological Notes. (Op. cit., VIII., pp. 99-106.)

I878. Hardy, J. Miscellanea. (T.c., p. 532.)

1879. Douglas, D. Iceland Falcon at Edinburgh. (Sci.Gossip.) Idem. (Scott. Nat., V.)

Evans, W. Occurrence of Grasshopper Warbler in Midlothian; Nesting of Woodcock in Midlothian. (Pr. R. Phys. Soc. Edinb.)

Hardy, J. Effect of Winter I878-9. (Hist. Berw. Cl., IX., Pp. I22-57.)

I880. Chambers, C. Shore Birds in East and Midlothian. (Zool.)

Hardy, J. Migrations, etc., for I880. (Hist. Berw. Cl., IX., pp. $387-409$.)

I88I. Gray, R. Effects of severe winter I880-3I. (T.c., pp. 498-503.) I882. Gray, R. Bird Life of Firth of Forth. (Op. cit., X., pp. 84-87.) I886. Evans, W. Great Crested Grebe in Forth near Granton. (Pr. Berw. Nat. Cl.)

Stewart, R. Peregrine Falcon on St. Mary's Cathedral, Edinburgh. (Tr. Edinb. Nat. F. C., I. [I88I-6.].

I889. Stewart, R. Notes on Bird-Life [in Royal Botanical Garden, Edinburgh]. (Op. cit., II. [I886-9I.]

I8go. Aplin, O. V. Distribution, etc., of Spotted Crake. (Zool. [partim.] 
1893. Adair, P. Goldfinch near Edinburgh; Quail in Midlothian. (Ann. Scott. N. H., II.)

Evans, W. Quail in Edinburgh District. (T.c.)

Godfrey, R. The Water Rail. (Sci. Gossip, Mar.)

I894. Clarke, W. E. On Probable Nesting of Hawfinch in Midlothian. (Ann. Scott. N. H., III.) [r33.]

I896. Clarke, W. E. Tree Sparrow in Midlothian and in Forth Area. (Op. cit.) I dem by R. S. Skirving. (T.c.)

Evans, W. Ray's Wagtail nesting near Edinburgh; Nesting of Stock Dove on Pentland Hills. (T.c.)

I897. Godfrey, R. Merlin nesting in a tree in Midlothian. (Op. cit.) The Dipper. (Sci. Gossip, Apr.)

I898. Clarke, W. E. Hawfinch in Midlothian. (Ann. Scott. N. H.)

Evans, W. Waxwing in Midlothian. (T.c.)

Godfrey, R. Pochard in Midlothian in Summer. (T.c.)

Nicholson, W. A. Late Arrival of Winter Birds. (Sci. Gossip, Nov.)

I899. Smail, J. Birds in Edinburgh. (Hist. Berw. Cl., XVII., pp. IO9-IO.)

I900. Campbell, C. Remarkable Flocking of Starlings to Cramond Island. (Ann. Scott. N. H.)

Igor. Evans, W. Greater Spotted Woodpecker breeding in Midlothian. $(O p$. cit.)

I902. Campbell, C. The Starling Roosting on Cramond Island. $(O p$. cit.)

Evans, W. Siskin in Edinburgh District; Waxwing in Edinburgh. (T.c.)

I904. Campbell, C. Antiquities and Natural History of Cramond District. (Tr. Edinb. F. N. Soc., V.)

Evans, W. Rough-legged Buzzard in the Lothians. Midlothian Chiefly. (Ann. Scott. N.H.)

I905. Evans, W. Black Tern, etc., in Forth; Pied Flycatcher Nesting in Midlothian. (Op. cit.)

I908. Campbell, P. M. Land Rail at Edinburgh in Winter. (Op. cit.)

I909. Serle, W. Great Crested Grebe at Duddingston Loch. (T.c.)

I9I2. Evans, W. Greater Wheatear in Midlothian; Tree Sparrow Breeding in Midlothian; Sabine's Gull on Firth of Forth, Midlothian ; Late Stay of Swifts about Edinburgh. (Scott. Nat.) Wild, O. H. Serin Finch near Edinburgh. (T.c.)

I9I3. Nash, J. K. The Nightjar in Edinburgh. (Scott. Nat.) Tomlinson, R. The Hobby in Midlothian. (T.c.)

Wild, O. H. Waxwing near Edinburgh. (T.c.)

I9I4. McConachie, W. Bird Notes from Lauderdale; Increase of Tree Sparrow in Lauderdale. $(O p$. cit.) 
May, A. McL. Woodcock in City of Edinburgh. (T.c.)

Page, R. Bird Notes from Leith. (T.c.)

Serle, W. Common Snipe at Duddingston Loch. (T.c.) Smew Inland near Edinburgh. (Brit. Birds, VII.)

Tomlinson, M. R. Richard's Pipit in Midlothian. (Scott. Nat.)

Igr5. Beveridge, F. S. Whimbrels at Musselburgh. (Scott. Nat.)

r916. Evans, W. Gadwall in Midlothian. (T.c.)

I9I7. Sykes, C. Hawfinches and Goldfinches near Musselburgh. (Op. cit.)

I9I8. Serle, W. Stonechat Nesting in King's Park, Edinburgh. ( $O p$. cit.) Tufted Duck Nesting on Duddingston Loch. (T.c.)

\section{ELGINSHIRE \& NAIRN.}

I775. Shaw, L. History of the Province of Moray. 4to. Edinb.: I775. And later editions. [53I.]

I844. Gordon, Rev. G. A Fauna of Moray. II.: Birds. (Zool., pp. 502-I5.) Idem. Additions. (T.c., p. 55I.) Repr. with additions. Elgin : 1889 .

Gordon, G. Arrival of Summer Birds at Elgin in I844. (Zool.)

I85I. McIntosh, J. Heronries in England, etc. (Nat. [Morris's], I.) [partim.]

1853. Thurnall, C. Note on the Nest and Eggs of the Wood Sandpiper [in Elgin]; Note on the Nest and Eggs of the Dotterel [in Elgin]. (Op. cit., III.)

I854. Longmuir, J., junr. The Findhorn Heronry. (Op. cit., IV.)

1860. Gordon, G. Great Grey Shrike at Forres. (Zool.)

I861. Gordon, G. Little Bustard in Moray. (Op. cit.)

1863. St. John, C. Nat. Hist. and Sport in Moray. 8vo. Edinb. : I863. [502.]

1864. Hadfield, H. Birds observed during a Year's Residence on N.E. Coast of Scotland. (Zool.)

1865. "Scotsman." Occurrence of the Iceland Falcon in Elgin. (Field, Apr. 29.)

I868. Norman, G. Nat. Hist. Notes from Morayshire. (Zool.)

I869. Norman, G. Great Spotted Woodpecker in Moray. (Op. cit.) Watson, J. Some Local Wild Birds to be found in the Vicinity of Elgin. 8vo. Elgin: N.D.

I872. Harting, J. E. British Heronries. (Zool.) [partim.] [274.] Knox, A. E. Autumns on the Spey. Post 8vo. Lond.: I872. 
1873. Grant, G. M. The Hobby in Scotland [near Ballindalloch]. (Field, July I9.)

I874. "J. B. D." Nesting of the Wigeon in Moray. (Op. cit., May 9.) 1886. Dunbar, A. Notes from Morays. (Op. cit., Jan. I6.)

I888. Newbigging, W. C. The Present Visitation of [Pallas's] Sand Grouse. (OP. cit., June 2.)

I889. "J. W." Crossbill and Crested Tit Nesting in Elgin. (OP. cit., Dec. I4.)

18go. Aplin, O. V. Distribution, etc., of Spotted Crake. (Zool.) [partim.]

Brander, J. B. D. Occurrence of American Bittern in Elgin. (Field, Jan. 25.)

Harting, J. E. Breeding of Pallas's Sand Grouse in Moray. (Zool.)

I89I. “A. D." Bittern in Co. Nairn. (Field, Nov. 28.)

1893. Brooke, H. B. Bluethroat in Moray. (Ann. Scott. N. H.)

1894. Harvie-Brown, J. A. Quail in Elgins. (Op. cit.)

1896. Harvie-Brown, J. A., and Buckley, T. E. A Vertebrate Fauna of the Moray Basin. 2 vols. Sq. 8vo. Edinb. : 1896. [282.]

I897. Brown, J. Honey Buzzards in Moray. (Ann. Scott. N. H.)

Buckley, T. E. Spotted Crake in Moray. (T.c.)

Harvie-Brown, J. A. Buffon's Skua in Moray. (T.c.)

Warrand, H. [Exhibition of Perdix montana from Nairn.] (Bull. B.O.C., VI., I896-97.)

I898. Brown, J. Waxwing in Elgins. (Ann. Scott. N.H.); Leach's Petrel and Little Auk in Moray. (T.c.)

Buckley, T. E. Gadwall in Moray; Great Sliua in Moray Firth. (T.c.)

1899. Evans, W. Note on Eggs of Wood Sandpiper taken in Elgins. in I853. (OP. cit.) [201.]

I900. Buckley, T.E. Bittern in Nairn. (Op.cit.)

Mackessack, H. Grasshopper Warbler nesting in Moray. (T.c.)

I906. Dunbar, J. B. Jack Snipe in Elgins. (Field.)

I907. Menzies, W. E. Capercaillie and Willow Grouse in Moray. (Ann. Scott. N. H.)

I908. Muirhead, G. Glossy Ibis at Speymouth. (Op. cit.)

I9I0. Evans, W. The Supposed Eggs of Wood Sandpiper taken in Elgins. in $x 853$. (Op. cit.) [201.]

IgII. Davidson, J. Hobby in Elgin. (Op. cit.)

I9I2. Wilson, A. Birds of Nairn. (Tr. Edinb. F. N. Soc., VI.)

Igr5. Blackwood, G. G. Crested Tit in Nairns. (Scott. Nat.)

Ogg, W. M. Great Snipe in Elgins. (T.c.) 
I9I8. Mackessack, R. H. Crested Tit breeding in W. Elgin. (Brit. Birds, XII. ; Scott. Nat.)

Ogg, W. Snowy Owl in Elgin. (Scott. Nat.)

\section{FIFESHIRE.}

17ro. Sibbald, R. History of the Sheriffdoms of Fife and Kinross. Fol. Edinb. : I710. New edit. 8vo. I803. [535.]

I828. Pithie, - . Sea Birds, etc., of I. of May. (Edinb. Nere Phil. Jnl.)

1838. Buist, H. Notes on Ornithology of St. Andrews. (Nat. [Neville Wood's], III.); Kingfisher shot near St. Andrews. (T.c.)

1840. MacGillivray, W. Scene from the Fifes. Coast in March. (In his British Birds, III.) 8vo. Lond. : I840.

I863. "Roebuck." Jer Falcon shot in Fifes. (Field, Apr. 25.)

1864. [Anon.] Pair of Black Guillemots shot at Firth of Forth. (Field, XXIII., p. 325.)

I87o. Ramsay, R. G. W. Shore Lark at St. Andrews. (Zool.)

1871-2. Scott, A. T. Waxwing in Fifes. (Scott. Nat., I., I87I-2.)

Walker, R. Notes on some of the Rare Birds obtained in E. of Fife during recent years. (T.c.)

I872. Harting, J. E. British Heronries. (Zool.) Idem. Additions. (Op. cit., I873.) [partim.]

I873. R-, J. S. G. Fieldfare nesting in Scotland. (Field, May 3r.) Walker, R. King Ducks in St. Andrews Bay, etc. (Scott. Nat., II.)

I874-82. Gray, R. Ornitholog. Notes, 7 pts. (Hist. Berw. Cl., VII., pp. 257-6I, 463-7 ; VIII., pp. I55-9, 353-5, 498-502 ; : IX., pp. $356-8$; X., p. I97.)

I876. Gray, R. Velvet Scoter in Scotland in Summer of I876. $(0 p$. cit., VIII., pp. 75-6.)

I877. Kerr, W. J. Ornitholog. Notes from St. Andrews. (Zool.)

I878. Hardy, J. Miscellanea. (Hist. Berw. Cl., VIII., p. 532.)

1879. Dalgleish, J. J. Hoopoe in Fifes. (Zool.)

I880. Hardy, J. Migrations, etc., for I880. (Hist. Berw. Cl., IX., pp. $387-409$.)

I881. Drummond-Hay, H. M. The Grallatores and Natatores of the Estuary of the Tay, etc. 8vo. Dundee: I88I. [I82.]

"J. D." Honey Buzzard in Fifes. (Field, Oct. 8.)

1882. Harvie-Brown, J. A. Occurrence in Scotland for first time of Whitespotted Bluethroat [I. of May]. (Ibis; Scott. Nat.) 
1883. "J. D." Turtle Dove in Fifes.; Great [Grey] Shrike in Fifes. (Field, Oct. 6.)

I884. "J. B. F." Quail in Fifes. (Op. cit., Oct. II.)

I885. Fortune, E. F. Spotted Flycatcher in Fifes. (Op. cit., Aug. I.) I886-8. Drummond-Hay, H. M. Report on Ornithology of E. of Scotland, from Fife to Aberdeenshire inclusive, 3 papers. (Scott. Nat., VIII., I885-86 ; IX., I887-88.)

I887. "M. J. C. M." Eider Duck in Fifes.; British Heronries; [Fifeshire.] (Field, Feb. I9.)

I888. Harvie-Brown, J. A. The Isle of May: Its Faunal Position and Bird Life. (Pr. R. Phys. Soc. Edinb.) [282.]

I889. Henderson, P. Sand Grouse in Fifes. (Zool.)

I89I. Drummond-Hay, H. M. Notes on Birds recently observed in Tay District. (Scott. Nat., XI.)

1893. Godfrey, R. A Shore Walk in April. (Sci. Gossip, Mar.)

I894. Briggs, A. Great Crested Grebe nesting in Fifes. (Ann. Scott. N. H.) Idem by W. Evans. (T.c.)

I895. Bruce, G. The Land Birds in and about St. Andrews. 8vo. Dundee : I895. [IOI.]

I896. Evans, W. Nesting of Pochard in Fife. (Ann. Scott. N. H.)

I897. Cook, J. E. M. Great Snipe near St. Andrews. (Op. cit.)

I899. Berry, W. White-fronted Geese in Fife. (Op. cit.)

Harvie-Brown, J. A. King Eider in St. Andrews Bay. (T.c.)

Igoo. Harvie-Brown, J. A. An Old Record of the Kite in Fifeshire. $(O p$. cit.)

Evans, W. Pintails at Edenmouth. (T.c.)

I904. Berry, W. Nesting of Hawfinch in Fifes. (Op. cit.)

I906. Evans, W. Wrynecks in Forth [Fife and E. Lothian]. (Op. cit.) 1907. Jeffrey, L. Quail in Fife. (Op. cit.)

I908. Evans, W. Scops Owl in Forth; Sabine's Gull in Firth of Forth. $(O p$. cit.) Goldcrests from East Coast Lighthouses [Isle of May, etc.] (Brit. Birds.)

I908-I2. Baxter, E. V., and Rintoul, L. J. Bird Notes from Isle of May for I907-I4, 8 pts. (Amn. Scott. N. H., I908-II; Scott. Nat., I9I2-I4.) [49.]

r909. Berry, W. Gadwall in Fife. (Ann. Scott. N. H.) Evans, W. Heronries in Forth [Fife, etc.]. (T.c.)

Rintoul, L. J., and Baxter, E. V. Black Redstart in Tay Area. (Ann. Scott. Nat.) 
I9I0. Baxter, E. V., and Rintoul, L. J. Occurrence of Eastern Pied Chat in Scotland. (Ann. Scott. N.H.)

Dalgleish, J. J. Nesting of Great Spotted Woodpecker in IW. Fife. (Op. cit.)

IgIx. Berry, W. Wood Sandpiper in Fifes. $(O p$. cit. $)$

Baxter, E. V., and Rintoul, L. J. Occurrence of Nightingale on Isle of May. (T.c.)

Evans, W. Turtle Dove on Isle of May. (T.c.)

I9I2. Evans, W. Wood Sandpiper in Fife; Continental Thrush and Goldcrest at Isle of May. (Scott. Nat.)

Berry, W. Broad-billed Sandpiper in Fifes. (T.c.)

Rintoul, L. J., and Baxter, E. V. Lapland form of Bluethroat on I. of May; Occurrence of Woodchat Shrike in Forth Area. [I. of May.] (T.c.)

I913. Begg, W. Blackthroated and Redthroated Divers in Firth of Forth. (Scott. Nat.); Black Grouse on Inchkeith, Firth of Forth. (T.c.) ; Storm Petrels in Firth of Forth in summer. (T.c.)

Campbell, J. Little Bittern in Fifes. (T.c.)

Evans, W. Scandinavian Lesser Blackbacked Gull in Forth. (T.c.)

Kirk, D. J. B. Hoopoe in Fife. (T.c.)

Rintoul, L. J., and Baxter, E. V. Grey-headed Wagtail in Forth. (T.c.)

rgI4. Baigrie, S. Kingfisher at I. of May Lantern. (Op. cit.)

Baxter, E. V. Little Gull in Forth in June. (T.c.)

Braid, C. H. Dotterel at I. of May Lantern. (T.c.)

Kirke, D. J. B. Quails in Fife. (T.c.)

Rintoul, L. J., and Baxer, E. V. Increase in Cliff-breeding birds on I. of May. (T.c.)

I9I5. Baxter, E. V., and Rintoul, L. J. Absence of Eider in E. Fife, winter I9I4-I5. (Op. cit.)

I9I7. Baigrie, S. Red-breasted Flycatcher and Black Redstart on I. of May. (Op. cit.)

Baxter, E. V. Hen Harrier in Fife. (T.c.)

Brown, A. Birds killed by oil at St. Andrews in I9I5. (T.c.)

Erskine, M. Light-bellied variety of Brent Goose in Fife. (T.c.)

Evans, W. Brent Geese, both dark and light-breasted in Forth. (T.c.)

Rintoul, L. J. Rednecked Grebe in Largo Bay. (T.c.)

Igr8. Baxter, E. V., and Rintoul, L. J. Scarcity of Winter Visitors in Fife. $(O p$. cit.); The Birds of the Isle of May, a Migration Study. (Ibis, p. 247.)

Berry, W. Gadwall nesting in Fife. (Scott. Nat.)

Evans, W. Early references to the Bird-Life of I. of May. (T.c.) 


\section{FORFARSHIRE.}

I8r3. Don, G. Account of .... County of Forfar and the animals to be found there [In Headrick's Agriculture of Angus or Forfarshive.] 8vo. Edinb.: I8I3. [I72.]

1835. Gardiner, W. Siskins breeding about Dundee. (Loudon's Mag.
N. $H$. .)

1858. "D. F. P." Hybrid Capercailzie and Blackcock [at Alyth].

1863. Walsh, C. F. Rough-legged Buzzard [near Dundee]. (Op. cit.,
Jan. I7.)

I864. Gordon, G. Red-backed Shrike in Forfarshire. (Zool.)

I872. Harting J. E British Heronries (Zool.) [partim.]

1875-8. Gray, R. Ornitholog. Notes. 2 pts. (Hist. Berw. Nat. Cl., VII., pp. 463-7; VIII., pp. 499-502.)

1881. Drummond-Hay, H. M. The Grallatores and Natatores of the Estuary of the Tay, etc. 8vo. Dundee: r881. [I82.]

Watson, C. H. Early appearance of Wild Swans [near Invergowrie]. (Field, Mar. 5.)

I886-88. Drummond-Hay, H. M. Report on Ornithology of E. of Scotland, from Fife to Aberdeenshire inclusive, 3 papers. (Scott. Nat., VIII., I885-86; IX., I887-88.)

1888. Simpson, A. N. The Ornithology of Arbroath, 2 pts. (Scott.
Nat., IX., I887-8.)

I89I. Drummond-Hay, H. M. Notes on Birds recently observed in Tay District. (Op. cit., XI.)

Peel, S. [Forktailed Petrel inland in Forfar.] (Field, Oct. 3.)

I892. Dewar, T. F. Buzzard in Forfars. (Ann. Scott. N. H.)

1893. Dewar, T. F. Black-tailed Godwit in Forfars. (Op. cit.)

1894. Dewar, T. F. Stock Dove in Forfars. (Op. cit.)

Simpson, A. N. Sketches in Angus. 8vo. Arbroath : 1894.

1896. Dewar, T. F. Red-legged Partridge in Forfars. (Ann. Scott. N.H.)

I898. Dewar, T. F., and W. J. Golden Oriole in Forfar ; Red-backed Shrike in Forfar. (Op. cit.)

1900. Dewar, T. F. Pratincole near Montrose. (Op. cit.)

I903. Harvie-Brown, J. A. Honey Buzzard in Forfars. (Op. cit.)

I904. Campbell, J. M. Notes on the Natural History of the Bell Rock. 8vo. Edinb. : I904. [II8.]

1907. Dewar, T. F. Lesser Whitethroat nesting in Forfar. (Ann. Scott. N. H. ; Brit. Birds, I.) Idem. [Correction.] (Ann. Scott. N. H. ; Brit. Birds, II., Igo8.) 
Igo8. Clarke, W. E. Red-breasted Flycatcher at Bell Rock Lighthouse. (Ann. Scott. N.H.)

Igr3. Dewar, T. F. Hoopoe in Forfar. (Scott. Nat.)

Scrymgeour-Wedderburn, H. Quail in Forfar. (T.c.)

I9I8. Boase, H. Description of aberrant Hen Capercailzie from Afleck. (Scott. Nat.)

Ewart, R. W. T. Bird Notes from Montrose district. (T.c.)

\section{HADDINGTONSHIRE (E. LOTHIAN).}

1839. Hepburn, Archibald. Summer Birds of E. Lothian. (In MacGillivray's History of British Birds, II.) Svo. Lond. : I839.

I843. Hepburn, A. Arrival of Summer Birds of Passage in E. Lothian, I84I-2. (Zool.)

1846. Hepburn, A. On Partial Migration, etc., in E. Lothian. (Op. cit.) 1847. Fleming, J. Zoology of the Bass Rock. (In Rev. T. Macrie's Bass Rock.) I2mo. Edinb.: I847.

I848. Hepburn, A. Notes on the Wood Pigeons; Description of Female Bridled Guillemot, 2 papers. (Hist. Berw. Cl., II., pp. 272-77.)

I850. Hepburn, A. Habits of the Rook in E. Lothian. (Op.cit., III., pp. 48-50.)

Nelson, J. Spoonbill in E. Lothian. (Zool.)

I851. Gray, R. Notes from the Rocks; On Nat. Hist. of Dunbar Shore, 2 pts. (Nat. [Morris's], I.) Notes on the Puffin. (T.c.)

1857. Hepburn, A. Habits of the Rook in E. Lothian. (Hist. Beriv. Cl., III.)

I859. Moffat, A. Pied Flycatcher [shot near North Bervick]. (Field, June 4.)

I86r. "H. O." Smew [shot at Tynninghame]. (Op. cit., Jan. 26.)

1867. Balfour, F. M. Glaucous Gull near Dunbar. (Sci. Gossip.)

Turnbull, W. P. The Birds of E. Lothian and a Portion of the Adjoining Counties. Roy. 8vo. Glasg. : I867 ; and L.P. 4to. [595.] [Ist ed. Philadelphia : I863.]

I873. Romanes, R. Excerpts trom Books of John, Duke of Lauderdale respecting price of Solan Geese I674-8. (Hist. Berw. Cl., VII., pp. 90-92.)

I873-4. Lumsden, J., junr. Notes on Birds of Bass Rock. (Scott. Nat., II., I873-4.) [364.]

[Editorial.] Purple Heron in Haddingtons. (T.c.) 
1874-82. Gray, R. Ornitholog. Notes, 7 pts. (Hist. Berw. $\mathrm{Cl}$., VII., pp. 257-6I, 463-7 ; VIII., pp. I55-9, 353-5, 498-502 ; IX., pp. 365-8; X., pp. I97-200.)

1875. Elliot, Sir W. Rare Birds, etc. (Op. cit., VII., pp. 257-6x.)

Hardy, J. Miscellanea. (T.c., pp. 509-I9.)

I876. Gray, R. Ornithology of Dunbar Coast. ( $O p$. cit., VIII., pp. 48-56) ; Velvet Scoter in Scotland in Summer of I876. (T.c., pp. 75-6.)

Hardy, J. Zoological Miscellanea. (T.c., pp. I89-97.)

Muirhead, G. Notes on Birds. (T.c., pp. I78-80.)

I878. C- R. Birds of the Bass Rock. (Field, June I5.)

Chambers, C. Sea Birds near N. Berwick. (Op. cit., Aug. 24.) Chambers, C. E. S. Great Shearwater, etc., at N. Berwick. (Zool.)

I879. Chambers, C. E. S. Birds on E. Lothian Coast. (Zool.)

I879-8I. Hardy, J. Effect of Winter I878-9; Migrations, etc., I880-8I. (Hist. Berw. Cl., IX., pp. I22-7, 387-409, 549-63.)

I880. Chambers, C. E. S. Shore Birds in E. and Mid Lothian. (Zool.) Muirhead, F. Cormorant in Haddingtons. (Field, May 29.) S- C. F. The Nest of the Solan Geese, Bass Rock. (Op. cit., May 8.)

1882. Gray, R. Bird Life of Firth of Forth. (Hist. Berw. Cl., X., pp. 84-87.)

Hepburn, A. On Birds found in Neighbourhood of Pressmenan Lake. (Op. cit., IX. [I879-8I], pp. 503-6.)

I884. Tegetmeier, W. B. The Bass Rock and the Solan Geese. (Field, Aug. 9.)

1885-6. Pow, Geo. Occurrence of Birds in E. Lothian, I885. (Hist. Berw. Cl., XI., pp. 248-50) ; Rarer Birds observed at Dunbar. (T.c., pp. 544-6.)

I886. Evans, W. Stock Dove and White Wagtail in E. Lothian. (Pr. R. Phys. Soc. Edinb.)

Pow, G. S. Unrecorded Occurrence of Bluethroat in E. Lothian. (Zool.) Idem by W. Evans. (Pr. R. Phys. Soc. Edinb.)

I888. Chalmers, G. Birds of the Bass Rock. [In his Caledonia, New edit., III., pp. 40I-2.] 4to. Paisley: I888.

I889. Newton, W. A. Hybrid Mallard and Pintail [in E. Lothian]. (Field, Nov. 30.)

I89I. Christy, C. Eared Grebe on Firth of Forth [at Aberlady]. (Scott. Nat., XI.)

I892. Evans, W. Black Tern in Firth of Forth [E. Lothian]; Hoopoe in E. Lothian ; Undomed Nest of Long-tailed Tit [in E. Lothian]. (Ann. Scott. N.H.) 
1893. Evans, W. Curlew Sandpiper in Summer Plumage in Firth of Forth [E. Lothian]. (Op. cit.)

1894. Bruce, D. On Fulmar, Gt. Northern Diver and Dotterel, 3 notes. (Hist. Berw. Cl., XV.)

1895. Bruce, D. Shore Lark near Dunbar; Red-necked Grebe at Dunbar. (Ann.Scott. N. H.)

Evans, W. Fulmar Petrel off Dunbar; Red-necked Grebe on E. Lothian coast. (T.c.)

1896. Evans, W. Sabine's Gull and Roseate Tern in Aberlady Bay. (Op. cit.)

Godfrey, R. The Eider Duck. (Sci. Gossip, Dec.)

I897. Bruce, D. Little Gulls at Dunbar. (Ann. Scott. N.H.)

Evans, W. Little Gull in E. Lothian in May; Little Auks in the Forth. (T.c.)

Godfrey, R. Shoveler in E. Lothian. (T.c.)

I898. Rothschild, W. Birds of Bass Rock. (Nineteenth Cent., XLIV.)

1899. Evans, W. Rough-legged Buzzard in E. Lothian; Pied Flycatcher in E. Lothian. (Ann. Scott. N. H.)

Laidlaw, T. G. Whimbrel in Firth of Forth in Winter. (T.c.)

I90I. Evans, W. Spotted Crake in E. Lothian. (Op. cit.) [20I.]

[Report of Meetings.] Birds of Bass Rock. (Hist. Berw. Cl., XVIII., pp. 28-35.)

I903. Bonar, H. N. Nesting of Great Spotted Woodpecker in E. Lothian. (Ann. Scott. N.H.)

Evans, W. Sooty Shearwater in Firth of Forth. (T.c.)

1904. Evans, W. Wryneck in E. Lothian; Waxwings in the Lothians ; Blacktailed Godwit in Forth Area. (Op. cit.) The Blackbacks of the Bass. (Pr. R. Phys. Soc., XVI.)

I905. Clarke, W. E. Breeding of Storm Petrel on Bass Rock. (Ann. Scott. N.H.)

I906. Chambers, C. E. G. Pallas's Sand Grouse in E. Lothian. (Field.) Evans, W. Wrynecks in Forth [E. Lothian and Fife]. (Ann. Scott. N.H.)

I907. Buchan-Hepburn, A. Hawfinch in E. Lothian. (Op. cit.)

I908. Evans, W. Black Tern in Tweed and Forth; Bittern in E. Lothian. (Op. cit.; Brit. Birds, I.) Idem by H. N. Bonar. (Ann. Scott. N. H. ; Brit. Birds, II.)

Evans, W. Continental Crossbill in Scotland, E. Lothian; Goldcrests at E. Coast Lighthouses. (Brit. Birds, I.); Little Auk in Firth of Forth in March. (Ann. Scott. N. H.)

Malloch, W. and T. Fulmar Petrel in Firth of Forth. (Zool.)

I909. Bonar, H. N. Hawfinch in E. Lothian. (Op. cit.)

Clarke, W. E. On Occurrence of Brünnich's Guillemot in Firth of Forth. (Ann. Scott. N. H.) 
Evans, W. Nesting of Hawfinch in E. Lothian. (T.c.); Cole Tit on Bass Rock. (T.c.) ; Heronries in Forth, E. Lothian, Fife, etc. (T.c.)

I9Io. Evans, W. Greater Wheatear in Forth [E. Lothian]. (Op. cit.) ; "Ringed" Arctic Tern at Barns Ness Lighthouse. (T.c.)

IgIr. Evans, W. Northern Bullfinch and Holböll's Redpoll in E. Lothian. $(O p$. cit.)

Bonar, H. N. Nesting of Pied Flycatcher in E. Lothian. (T.c.)

I9I2. Evans, W. Continental Song Thrush; Northern WillowWarbler; Shore Larks in Haddington; Little Gull near Dunbar; Whimbrel in Forth [E. Lothian] in Winter. (Scott. Nat.)

Ritchie, R. L. Black Tern in Haddington. (T.c.)

IgI3. Bonar, H. N. Hawfinch in E. Lothian. (Op. cit.)

Evans, W. Continental Robin in Haddingtons. (T.c.)

Robinson, H. W. Wild Geese in Aberlady Bay. (T.c.)

Wild, O. H. Grey Lag-Goose in E. Lothian. (T.c.)

I9I4. Balfour, A. Nesting of Eider Duck in Tynninghame Woods; Lesser Tern in E. Lothian. (OP. cit.)

Igr6. Evans, W. Blacktailed Godwit in Forth. (T.c.)

\section{HEBRIDES (OUTER).}

(For St. Kilda see separate heading.)

I703. Martin, M. Description of the Western Isles of Scotland. 8vo. Lond. : I703. 2nd edit. Ib. : I716. [389.]

I75I. [Anon.] A Voyage to Shetland ... and the Western Isles. 8vo. Lond. : I75I. [I6.]

I774-6. Pennant, T. Tour in Scotland and Voyage to the Hebrides. 2 vols. 4to. Chester and Lond.: I774-6. [466-7.]

I787. Knox, J. Tour through the Highlands .... and the Hebride Isles. 8vo. Lond. : I787. [336.]

I793. Buchanan, J. L. Travels in the Western Hebrides. 8vo. Lond. : I793. [103.]

I82I. MacGillivray, W. List of Birds found in District of Harris. (Edinb. Phil. Journ.) [370.]

I837. MacGillivray, W. Birds found in Outer Hebrides in Winter. (In his Hist. of Brit. Birds, I.) 8vo. Lond. : I837.

I842. MacGillivray, W. Notes on Zoology of Outer Hebrides. (Ann. \& Mag. N. H.)

[I843.] MacGillivray, W. Report on Present State of Outer Hebrides. (Prize Essay; Trans. Highland Soc., VIII.) 


\section{O. HEBRIDES.] OF BRITISH ORNITHOLOGY}

I848. Milner, W. M. E. Some Account of People of St. Kilda and Birds of Outer Hebrides. (Zool.)

1852. Duns, Prof. Birds of Lewis. (Pr. Roy. Soc. of Edinb.)

I857. Graham, D. Snowy Owls in the Western Islands. (Zool.)

I859. Orde, J. W. P. On Several Birds observed in the Hebrides. (Ibis.)

r86r. Orde, J. W. P. On Occurrence of Gyrfalcon in N. Uist ; Quail Breeding in N. Uist. (Ibis.)

I865. “C. M." Quail in Is. of Lewis. (Field, Nov. I8.)

I869. [Anon.] Grey Lag-Goose [on Loch Seaforth]. (Op. cit., Oct. 30.)

Elwes, H. J. Bird Stations of Outer Hebrides. (Ibis.)

I870-7x. Walker, T. E. Bird Haunts of Outer Hebrides, 4 papers. (Zool., I870-7I.)

I87I. Gray, R. Birds of the West of Scotland, including the Outer Hebrides. 8vo. Glasg. : 1871. [251.]

1873-4. Fust, H. J., junr. Nesting of Hedge Accentor in Outer Hebrides. (Scott. Nat., II.)

I874. Keegan, P. Q. The Great Northern Diver. (Sci. Gossip, Nov.)

I875. Smith, W. A. Lewsiana. Post 8vo. Lond. : I875. [55I.]

1877. Rocke, J. Snowy Owl in the Lews. (Zool.)

I878. Gray, R. Ornitholog. Notes. (Hist. Berw. Cl., VIII., pp. 499502.)

I879. Chase, R. W. White-tailed Eagle and Golden Eagle in Lewis. (Op. cit.)

Harvie-Brown, J. A. The Shiant Isles and their Bird Life. (Tr. Norf. \& Norw. Soc.) [28I.]

I88I. Maclachlan, G. Barra Head and its Bird Life. (Pr. Nat. Hist. Soc. of Glasg., IV.)

1884. Harvie-Brown, J. A. The Flannan Isles and their Bird Life. (Pr. Nat. Hist. Soc. of Glasg.) The Islands and Rocks of Haskeir, off N. Uist, and their Bird Life. (T.c.) Little Gull in North Uist. (Pr. R. Phys. Soc, Edinb., I883-4.)

I884-6. Swinburne, J. Notes on Islands of Sula Sgeir and North Rona, with List of Birds. (Pr. R. Phys. Soc. Edinb., I884.) Additions by J. A. Harvie-Brown. (OP. cit., I886.)

I886. Cowan, J. The Eider Duck in Harris. (Field, Aug. 2I.)

1887. Campbell-Orde, J. W. P. Cypsehus apus in N. Uist. (Ibis.) Murray, F. Summer in the Hebrides. 8vo. Glasg. : I887.

Wilson, T. Wood-pigeon in Outer Hebrides. (Field, Dec. 3.)

I888. Campbell-Orde, J. W. P. Occurrence of Pallas's Sand Grouse in Outer Hebrides. (Ibis.) 
Harvie-Brown, J. A., and Buckley, T. E. A Vertebrate Fauna of the Outer Hebrides. Sq. 8vo. Edinb. : $x 888$.

Macpherson, H. A. Crossbill in the Hebrides. (Zool.)

Plumbe, T. H. Pallas's Sand Grouse [in Lewis]. (Field, June Ió.) Idem by R. F. Cook. (Op. cit., Sept. 22.)

I89I. Campbell-Orde, J. W. P. Nesting of Woodcock and Occurrence of Phalaropus fulicarius in Outer Hebrides, 2 letters. (Ibis.)

I89I-2. Clarke, W. E. On Occurrence of Siberian Crane in Outer Hebrides. (Scott. Nat., XI., I89I.) [I33.] Idem. (Ann. Scott. Nat., I892.) Idem by E. W. Marshall. (Field, Nov. I4, I89I.)

I892. Macrury, J. Grey Phalarope in Barra ; Ruff in Outer Hebrides ; Whimbrel Wintering in Barra; Notes on Birds in Barra. (Ann. Scott. N. H.)

I893. Campbell-Orde, J. W. P. Occurrence of Goldfinch and Tree Sparrow in N. Uist. (Ibis.)

Macrury, J. Grey Plover, Knot, etc., in Barra. (Amn. Scott. N. $H$.)

Walters, R. Ruff in Outer Hebrides. (T.c.)

I894. Buckley, T. E. Great Skua in Outer Hebrides. (Op. cit.)

Harvie-Brown, J. A Redbreasted Flycatcher in Outer Hebrides. (T.c.)

I894-8. Macrury, J. The Birds of the Island of Barra, 2 pts. (OP. cit., I894.) Idem Addit. Notes. (Op. cit., I896, I898.)

I895. Jones, W. B. Winter in the Hebrides. (Sci. Gossip, June.)

I896. Mackensie, D. Chough in the Outer Hebrides. (Ann. Scott. N. H.)

Campbell-Orde, J. W. P. Bewick's Swan in Outer Hebrides. (T.c.)

Walters, R. The Fauna of the Outer Hebrides. (Zool.)

I897. Peel, C. V. A. Night Heron in Barra. (Ann. Scott. N. H.)

1898. Irby, L. H. Long-eared Owl in Outer Hebrides. (T.c.)

I899. Clarke, W. E. On Occurrence of Lesser Whitethroat in Outer Hebrides. (Pr. R. Phys. Soc. Edinb. ; Ann. Scott. N. H.)

Guthrie, D. Bewick's Swan in S. Uist. (Field, Aug. I2.)

I900. Frost, W. E. Bewick's Swan in N. Uist. (Op. cit., Jan. 20.) MacGillivray, W. L. Chiffchaff and Long-eared Owl in Barra. (Ann. Scott. N. H.)

I90I. MacGillivray, W. L. Barred Warbler in Barra; Lesser Tern Nesting at Barra. (Ann. Scott. Nat. Hist.)

Peel, C. V. A. Wild Sport in the Outer Hebrides. 8vo. Lond. : IgOI. [464.]

IgoI-2. Clarke, W. E. On Occurrence of Greenland Redpoll in Barra. 2 notes. (Ann. Scott. N. H., IgoI-2.) 


\section{O. HEBRIDES.] OF BRITISH ORNITHOLOGY}

1902. Buckley, T. E. Osprey in Outer Hebrides. (Ann. Scott. N. H.) Harvie-Brown, J. A. Further Notes on Birds of Outer Hebrides. (Ibis.) Waxwing in Outer Hebrides. (Ann. Scott. N. H.)

Macrury, J. Green Sandpiper in Outer Hebrides. (T.c.)

Ig02-3. Harvie-Brown, J. A. On Avifauna of Outer Hebrides, I888I902, 4 pts. (OP. cit., I902-3.)

1903. Guthrie, D. Notes on Birds of South Uist; Canada Goose in the Outer Hebrides. (Op. cit.)

Harvie-Brown, J. A. Bean Goose in Outer Hebrides ; Greenland Falcon in Outer Hebrides; Teal Nesting in Lewis; Shoveler and Tufted Duck Nesting in S. Uist. (T.c.)

Morrison, W. [Natural History in] Mackenzie's History of the Outer Hebrides. Paisley: 1903. 8vo.

I904. Clarke, W. E. Short-toed Lark and Lapland Bunting in Outer Hebrides. (Ann. Scott. N. H.)

Clarke, W. E. On Short-toed Lark in Flannan Islands. (Bull. B.O.C., XV., Ig04-05.) [Exhibit. by H. Saunders.]

Harvie-Brown, J. A. Heron Nesting in Outer Hebrides. (Ann. Scott. N. H.)

I905. Bruce, D. List of Birds Observed on Eight Visits to Loch Roag, in June and July, r886-I902. (Tr. N. H. Soc. Glasg.)

Clarke, W. E. Birds of Flannan Islands; 3 pts. (Ann. Scott. N. H.)

Ig06. Gladstone, H. S. Notes on Some Birds seen in N. Uist. (Op. cit.)

Rowlands, A. W. Spotted Crake in Lewis. (Field, Nov. ro.)

I907. Bunyard, P. F. Nesting of Lesser Tern in N. Uist. (Field, Sept. 2I; Brit. Birds, I.) Idem by Duchess of Bedford. (Brit. Birds, I.)

Bedford, Duchess of. Blacktailed Godwit in Barra. (Brit. Birds, I.)

Corbett, E. M. Occurrence of American Wigeon in Benbecula. (Ann. Scott. N. H.) Idem. Exhib. by R. B. Sharpe. (Bull. B.O.C., XIX.)

Hartert, E. Birds Represented in Brit. Isles by Peculiar Forms. (Brit. Birds, I.) [partim.]

Kinnear, N. B. Notes on Birds seen in Outer Hebrides during Spring of I906. (Ann. Scott. N.H.)

MacGillivray, W. L. Velvet Scoter at Barra. (T.c.)

I907-8. Bahr, P. H. Some Bird Notes from Outer Hebrides, May-June, I907, 2 pts. (Op. cit., I907-8.)

Ig08. Adam, J. C. Bird Life of an Outer Island. (Tr. Edinb. F. N. Soc.) Bahr, P. H. On Nesting of Scaup Duck in Scotland. (Brit. Birds, II.)

Clarke, W. E. Greenland Falcon at Flannan Islands. (Ann. Scott. N. H.) Pratincole at Flannan Islands. (T.c.) Tufted Duck in Scotland. (Brit. Birds, II.) 
Harvie-Brown, J. A. Snowy Owl in Outer Hebrides. (Ann. Scott. N. H. ; Brit. Birds, II.) Tufted Ducks Nesting in Outer Hebrides. (Brit. Birds, II.)

I909. Bedford, Duchess of. Some Autumn Bird Notes from Outer Hebrides. (Ann. Scott. N.H.)

Clyne, R. Red-breasted Flycatcher and other Birds at Butt of Lewis. (T.c.)

Smalley, F. W. White-throated Sparrow at Flannan Islands. (Brit. Birds, II.)

I9I0. Bedford, Duchess of. On Visits to N. Rona. (Ann. Scott. N. H.) Newton, H. Glossy Ibis in S. Uist. (Field, Dec. Io.)

Workman, W. H. Quail at Stornoway. (Brit. Birds, IV.)

I9II. Ritchie, A. T. A. Green Sandpiper in Outer Hebrides. (Field, Aug. 26.)

[IgII ?] Clyne, R. S. [Bird Life in Lewis in] Guide to Stornoway and the Lews. N.D.

I9I2. Clarke, W. E. [List of Birds of Flannan Isles in his] Studies in Bird Migration. 2 vols. 8vo. Lond. : I9I2. [I35.]

Clyne, R. Winter Movements of Gannet in Outer Hebrides. (Knoroledge ex Glasg. Herald.)

Harvie-Brown, J. A. The Fulmar, 2 pts. (Scott. Nat.) Idem. (Zool.; Brit. Birds, VI.)

I9r3. Beveridge, F. S. Black-tailed Godwit in Outer Hebrides. (Scott. Nat. ; Brit. Bds., VII.)

Clyne, R. Fulmar Breeding in Lewis. (Brit. Birds, VII.); Squacco Heron in Outer Hebrides; Fulmar and Common Guillemot in Lewis. (Scott. Nat.)

Clarke, W. E. The Song Thrush of the Outer Hebrides (Turdus musicus hebridensis). (Scott. Nat.)

Harvie-Brown, J. A. An Early Reference to Hebridean Thrushes. (Scott. Nat.)

Haviland, M. D. Grey Plover in Outer Hebrides. (Brit. Birds, VII.); Black Tern in Outer Hebrides. (T.c.); Albinistic Lapwing in Outer Hebrides. (T.c.)

MacGillivray, W. L. Iceland and Greenland Falcons at Barra. (Scott. Nat.)

McLean, J., and McGilvray, J. D. Note on Kittiwakes at Flannan Is. $\left(T . c_{.}\right)$

Noble, H. Scaup Duck nesting in Outer Hebrides. (T.c.)

Ogilvie-Grant, W. R. Carolina Crake in Outer Hebrides. (Brit. Birds, VII. ; Bull. B.O.C., XXXIII.)

I9I4. Bedford, Duchess of. Sparrow Hawk and Mistle Thrush as Migrants at Barra. (Scott. Nat.)

Best, M. G. S., and Haviland, M. D. Notes on Red-necked Phalarope in Outer Hebrides. (Brit. Birds, VIII.); Notes on Bird Life in Outer Hebrides. (Scott. Nat.) 
Beveridge, F. S. Probable breeding of Tufted Duck in N. Uist; Carrion Crow in N. Uist. (T.c.)

Clyne, R. Fulmars [etc.] at Butt of Lewis (2 notes). (Scott. Nat.) Gray, W. A. Ruff in Outer Hebrides. (T.c.)

Hony, G. B. Carrion Crows in Outer Hebrides. (Brit. Birds, VIII.)

I9I5. Clyne, R. Notes on Birds observed at the Butt of Lewis. (Scott. Nat.); Birds of Lewis. (Brit. Birds, IX.)

Wilson, R. Enormous rush of Redwings at Skerryvore Lantern. (Scott. Nat.)

IgI6. Clarke, W. E. Brit. Tree Creeper in Lewis. (Brit. Birds, X.)

I9I7. Beveridge, F. S. Bird Notes from N. Uist. (Scott. Nat.)

Campbell, J. Black-headed Gulls at Flannan Isles. (Scott. Nat.) Holmes, H. White-winged Black Tern in S. Uist. (Field, Aug. II.)

Mackenzie, D. Bittern in Is. of Lewis; Spoonbill in Outer Hebrides. (T.c.)

Igr8. Beveridge, F. S. The Grey-Lag Goose in N. Uist (2 notes); Birds of N. Uist. (Scott. Nat.) ; Little Stint in Outer Hebrides. (Scott. Nat.; Brit. Birds, XII.)

Chapman, A. Notes on Birds of N. Uist, May I883. (Scott. Nat.)

Holmes, H. Wood Warbler and Little Stint in Outer Hebrides. (T.c.)

\section{INVERNESS-SHIRE.}

I775. Shaw, L. History of Province of Moray. 4to. Edinb. : I775. And later editions. [53r.]

I837. MacGillivray, W. Beauly Firth and Birds seen on it. (In his History of British Birds, I.) 8vo. Lond. : 1837.

I844. Gordon, G. A Fauna of Moray. II. : Birds. (Zool.) Idem. Additions. (T.c.) Reprinted with Additions. Elgin: I889. 1848. Hepburn, A. Notes on Quadrupeds and Birds of Northern Districts of Inverness-sh. (Zool.)

I856. Dessauville, P. A. Notice of Arctic Skua shot in Skye. (Edinb. New Phil. Jnl., III.)

I859. McL-, W. A. Rare Birds [Goshawk, etc., near Inverness]. (Field, Jan. I) ; Snowy Owls in N. of Scotland [Skye, etc.]. (T.c., July 23.)

I862-8. Blackburn, Mrs. H. Birds drawn from Nature [at Moidart]. Fol. Edinb. : I862. Idem. with Pt. 2 added. Glasg. : I868. [67.] 
I863. Saville, S. P. Honey Buzzard in Inverness. (Zool.)

St. John, C. Nat. Hist. and Sport in Moray. 8vo. Edinb. : 1863. [502.]

1865. Newcombe, E. C. Buteo lineatus at Kingussie. (Ibis.)

Smith, S. Cream-coloured Grouse in Neighbourhood of Spey. (Field, Sept. I6.)

I868. [Anon.] Snowy Owl, Roller, etc. in Inverness-sh. 2 notes. $(O p$. cit., Oct. I7, 24.)

I869. Rowley, G. D. Great Snipe shot in Skye. (Op. cit., Sept. 25.)

I87I. Gurney, J. H. Crested Tit on the Spey. (Zool.)

I874. Snowie, T. B. Spotted Crake near Inverness. (Field, Dec. I2.)

I875. "Lincoln's Inn." Goosanders in Inverness. (Op. cit., Mar. I3.)

Hills, R. S. Cranes near Inverness. (Op. cit., Dec. 4.)

I876. Fenton, J. Cormorant Inland [near Kingussie]. (Op. cit., Sept. I6.)

1877. Cooke, N. Birds observed in Glen Spean. (Zool.)

I879. R_ , W. E. Hoopoe in Inverness-sh. (Field, May 3.) Idem by " J. H. C," and F. B. Snowie. (T.c., May Io.)

I880. Hamilton, E. Ornitholog. Notes from S.W. Sutherland [= Inverness]. (Zool.)

"J. M." Hoopoe in Skye. (Field, Nov. 27.)

M'Camm, J. B. Eagles in Skye. (T.c., Sept. 4.)

I88I. "M. R. D." Ring Ouzel in Inverness in December. (Op. cit., Dec. 3I.)

Mactier, W. F. Crossbills in Inverness-sh. (T.c., Sept. I7.)

1882. Macpherson, H. Rough Notes in Sliye and Eigg. (Zool.)

Snowie and Sons. Great Grey Shrike in Inverness. (Field, Dec. 2.)

I883. Craig, A. On Birds of Glenurquhart. (Pr. R. Phys. Soc. Edinb.) Harvie-Brown, J. A. Hysgeir, off Canna, and its Birds. (T.c.) [28I.]

Macpherson, H. A. Ornitholog. Notes from Skye. (Zool.)

Duns, Prof. Zoology of Mid-Lochaber. (Pr.R. Phys. Soc. Edinb.)

I884. Macpherson, H. A. Greenland Falcon in Skye. (Zool.)

Thursby, J. H. Solitary Snipe near Kingussie. (Ficld, Sept. I3.)

I884-5. "Tantara." Orpheus [errore for Barred] Warbler in Skye. (Op. cit., I884, Sept. 20.) Idem by W. E. Beckwith. (Op. cit., I884, Sept. 27 ; I885, July 4.) Idem by G. S. Dunville Lees. (Op. cit., I884, Nov. I ; I885, June 27.)

1885. Evans, W. Notes on Birds of Island of Eigg. (Pr. Roy. Phys. Soc. Edinb., VIII.) [200.]

Macpherson, H. A. Glaucous Gull in Skye ; Greater Shearwater on Skye Coast. (Zool.) 
I886. Macpherson, H. A. Glaucous Gull in Skye, 4 notes. (Op. cit.) Lees, G. D. Jack Snipe in Skye. (Field, Oct. I6.)

I888. Macpherson, H. A. On Birds of I. of Eigg; Manx Shearwater in Skye. (Zool.) The Birds of Skye. (Pr. Roy. Phys. Soc. Edinb., I885-6). Idem. Notes by J. A. Harvie-Brown. (T.c.) Snowie, W. M. [and others]. Sand Grouse [in Inverness-sh.]. 4 notes. (Field, June I6, 23.)

Swinburne, J. An Ornitholog. Visit to Ascrib Islands, Loch Snizort, Skye. (Pr. Roy. Phys. Soc. Edinb.)

I889. Craig, A., junr. Birds of the Great Glen. (Tr. Edinb. Nat. F. C., II. [I886-9I].)

I89o. Gurney, J. H. The Sea-lochs of Inverness-sh. (Zool.)

Macpherson, H. A. The Black Guillemot [in Skye]. (Field, Aug. 2.)

I89r. Evans, W. List of Birds observed in Valley of Spey, Aug. and Sept. I889. (Scott. Nat., XI.)

"F. A. S." Supposed Occurrence of Snow Geese in Skye. (Field, Feb. 2I.) Idem by H. A. Macpherson. (T.c., Feb. 28.)

Wolseley, M. The Birds of Fort Augustus. (Sci. Gossip, May.)

I893. Evans, W. Marsh Titmouse in Strathspey. (Ann. Scott. N.H.)

I894. Buckley, T. E. Little Gull in Inverness-sh. (Ann. Scott. N.H.)

1895. Buckley, T. E. Pied Flycatcher breeding in Inverness-sh. (Op. cit.)

1896. Buckley, T. E. Greenland Falcon in Skye. (Ann. Scott. N. H.) Harvie-Brown, J. A., and Buckley, T. E. A Vertebrate Fauna of the Moray Basin. 2 vols. Sq. 8vo. Edinb. : I8g6. [282.]

1897. Buckley, T. E. Osprey in Inverness-sh. ; Bittern at Invergarry. (Ann. Scott. N. H.)

Raeburn, H. Birds observed on Corrie Arder. (Scott. Mountaineering $\mathrm{Cl}$. Journ., IV.)

Watt, H. B. Alpine Swift in Scotland. (Ann. Scott. N. H.)

I898. Blathwayt, F. L. Bird Notes from the Northern Cairngorms. (Zool.)

Buckley, T. E. Hybrid Capercaillie and Black Cock near Inverness. (Ann. Scott. N.H.)

" J. B. G." Destruction of Ospreys. (Field, May 2I.)

I900. Harvie-Brown, J. A. Former Presence of Ptarmigan in Rum. (Ann. Scott. N. H.)

Hinxman, L. W. Yellow Wagtail at Beauly. (Ann. Scott. N. H.)

Buckley, T. E. Spotted Crake in Inverness-sh. (T.c.)

I903. Cash, C. G. The Loch-an-Eilein Ospreys. (Op. cit.)

Kinnear, N. B. Crested Tit in Lower Strathspey. (T.c.)

Raeburn, H. Fauna of Ben Nevis. (Scott. Mountaineering Cl. Journ., VII.) 
I904. Collier, C. Birds of Is. of Raasay. (Ibis.)

Harvie-Brown, J. A., and Buckley, T. E. A Fauna of the N.W. Highlands and Skye. 8vo. Edinb.: I904. [282.]

Kinnear, N. B. Notes on Some Birds observed in Loch Arkaig district, W. Inverness-sh. (Ann. Scott. N. H.)

I905-8. Cash, C. G. The Loch-an-Eilein Ospreys, 2 pts. (Cairngorm Club Journ., IV., V.)

Ig08. Milne, W. Little Bittern in Inverness-sh. (Ann. Scott. N. H. ; Brit. Birds, I.)

I9I0. Witherby, H. F. Irruption of Crossbills-Scotland. (Brit. Birds, III.)

Ogilvie-Grant, W. R. Sclavonian Grebe breeding in Inverness-sh. (Bull. B.O.C., XXV., I909-Io.)

Ross, A. Experience with a Storm Petrel near Portree. (Glasg. Nat.)

I913. Geddie, A. Late Breeding of Crossbill in Speyside. (Scott. Nat.) Harvie-Brown, J. A. Glossy Ibis in Skye. (T.c.)

Jackson, A. C. Uncommon birds on Beauly Firth; White var. of Lapwing in Beauly Firth. (T.c.)

I914. Nash, J. K. Bird Life on Is. of Eigg. (Zool.)

I9I5. Jackson, A. C. Uncommon birds on Beauly Firth; Young Wigeon seen on Loch Inch. (Scolt. Nat.)

\section{KINCARDINESHIRE.}

1828. [Anon.] Large Eagle on Hills above Balnakettle. (Loudon's Mag. N. H., ex Edinburgh Courant.)

I853. Longmuir, J., junr. The Hawfinch [nr. Upper Banchory]. (Nat. [Morris's], III.)

I855. Longmuir, J. Occurrence of Esquimaux Curlew in Scotland. (Nat. [Morris's], V.]

I859. Adams, D. and A. L. On Ornithology as a branch of liberal education [contains list of birds of Kincardine]. 8vo. Aberdeen : 1859 .

I872. Harting, T. E. British Heronries. (Zool.) [partim.]

I873-4. Forbes, H. O. Hybrid between Blackcock and Capercailzie [at Fetteresso]. (Scott. Nat., II.)

I874-6. Gray, R. Ornitholog. Notes, 2 pts. (Hist. Berv. Nat. Cl., VII., pp. 257-26I ; VIII., pp. I55-9.)

I880. Sim, G. Esquimaux Curlew in Kincardine. (Zool.) 
I886-88. Drummond-Hay, H. M. Report on Ornithology of E. of Scotland, from Fife to Aberdeenshire inclusive. 3 papers. (Scott. Nat., VIII., I885-86 ; IX., I887-88.) [I82.]

I898. Sim, G. Dark Form of Barn Owl in Kincardinesh. (Ann. Scott. N. H.)

I900. Simpson, A. N. Contribution to Ornithology of Kincardinesh. 2 pts. $(A n n$. Scott. N. H.)

I902. Sim, G. Little Owl in Kincardinesh. (Op. cit.)

1903. Milne, J. Great Grey Shrike in Kincardinesh. (Op. cit.)

I909. Evans, W. Irruption of Crossbills [Kincardineshire, etc.]. (Brit. Birds.)

I9I0. Gladstone, H. S. Hybrid Blackcock and Capercaillie in Kincardinesh. (Ann. Scott. N. H.)

I9I4. Macdonald, A. Young Goatsucker at Durris. (Scott. Nat.)

Rintoul, L. J., and others. Fulmars at Fowlsheugh. (T.c.)

I9I5. Macdonald, A. Pied Flycatcher at Stonehaven. (Op. cit.)

\section{KINROSS-SHIRE.}

I7I0. Sibbald, R. History of the Sheriffdoms of Fife and Kinross. Fol. Edinb. : I7Io. New Edit. 8vo. I803. [535.]

I872. Harting, J. E. British Heronries. (Zool.) [partim.]

1875. "H." Greenshanks in Kinross-sh. (Field, Jan. 2.)

I878. Gray, R. Ornitholog. Notes. (Hist. Berw. Cl., VIII., pp. 499502.)

I879. Adam, K. Little Auk Inland. (Field, Jan. 25.)

I886-8. Drummond-Hay, H. M. Rept. on Ornithology of E. of Scotland, 3 pts. (Scott. Nat., VIII., IX.) [I82.]

I898. Evans, W. On Nesting of Pintail in Forth Area [Kinross-sh.]. (Ann. Scott. N. H.) [20I.]

I908. Evans, W. Gadwall in Scotland in Breeding Season. (Op. cit.) Idem. (Brit. Birds.)

I909. Evans, W. Goldeneyes in Forth Area in Summer [Kinross and Stirlings.]. (Ann. Scott. N. H.)

I9Io. Evans, W. Nesting of Gadwall and Wigeon in Forth [Kinross-sh.]. (Op. cit.) 


\section{KIRKCUDBRIGHTSHIRE.}

I853. Lee, T., junr. Ornitholog. Notes. (Nat. [Morris's], III.)

I859. "W. G. G." The Woodcock [nesting in Kirkcudbrightsh.]. (Field, June 25.)

I872. Harting, J. E. British Heronries. (Zool.) [partim.]

I875. Gray, R. Ornitholog. Notes. (Hist. Berw. Nat. Cl., VII., pp. 463-7.)

I878. Kennedy, A. Clark. Common and Rough-legged Buzzards in Kirkcudbrights. (Zool.)

I880. Armistead, J. J. Jackdaw versus Chough. (Op. cit.)

Kennedy, A. Clark. Shoveler Breeding in S. of Scotland [near Gatehouse]. (Field, May 29.)

Service, R. Breeding of Shoveler. (Zool.)

I881. Harvie-Brown, J. A. Late Stay of Wheatear. (Op. cit.) Idem by J. Cordeaux. (T.c.)

Service, R. Occurrence of Rough-legged Buzzards and Montagu's Harrier, 2 notes. (T.c.)

I882. Armistead, J. J. Ornitholog. Notes from Solway Firth. (Op.cit.) I884. Service, R. The Birds of Kirkcudbright. (In Maxwell's Guidebook to Stewartry of Kirkcudbright, $4^{\text {th }}$ edit.) 8vo. Castle Douglas : I884, and later edits. [523.]

1885. Service, R. Disappearance of Chough from Kirkcudbright. (Tr. N. H. Soc. Glasg., I., I884-5.)

I885-6. Armistead, J. J. Notes on Birds of the Solway District, 2 pts. (Nat.)

I887. Service, R. On Nesting of Tufted Duck in Kirkcudbrightsh. (Zool.)

1889. Wilkinson, J. Roller in Kirkcudbrightshire. (Field, Sept. 2I.) I89I. [Anon.] Buffon's Skua on the Solway [Carsethorn]. (Scott. Nat., XI., ex Rod \& Gun, Nov. 8, I890.)

Service, R. Bird Notes from Solway Dist.; Sand Grouse in Kirkcudbrightsh. (Scott. Nat., XI.)

I894. Mackie, J. Recent Zoological Additions to Kirkcudbright Museum. (Tr. Dumfr. Nat. Hist. Soc., Feb. I6.)

Mackay, H. Bird Notes from Kirkcudbright. (Nat. Journ.)

I895. Service, R. The Starling in Solway; Mealy Redpoll in Kirkcudbright. (Ann. Scott. N. H.)

I896. Service, R. Bird Migration in Solway District in Autumn of I895; Spotted Crake in Kirkcudbright; Black Terns in Kirkcudbright. $(O p$. cit.)

I897. Service, R. Solitary Snipe and Grey Phalarope in Solway District; Tufted Duck in Solway. (Op. cit.) 
I898. Service, R. Long-tailed Duck in Kirkcudbright. (Op. cit.)

1899. Service, R. Golden Oriole in Solway District. (Op. cit.)

I900. Service, R. Ornitholog. Notes from Solway. (Op. cit.)

I903. Service, R. Bird Migration in Solway. (Op. cit.)

I904. Service, R. From a Solway Notebook. (Op. cit.)

I905. Service, R. Some Changes in Avifauna of Solway Area. (Tr. Edinb. Field Nat. Soc.) Vertebrates of Solway-A Century's Changes. (Tr. Dumfries N. H. Soc.)

rg06. Pycraft, W. P. [Exhib. of Black Game $\times$ Pheasant Hybrid from Ringford.] (Bull. B.O.C., XVI.)

Service, R. The Sylviidce of Solway. (Tr. Nat. Hist. Soc. Glasg.)

I907. Service, R. Bird Notes from Solway District. (Ann. Scott. N. H.)

I908. Bedford, Duchess of. Great Grey Shrike and Eider Duck in Kirkcudbright. (Brit. Birds.)

Cummings, S. G. Bean Geese on the Dee Marshes. (Zool.)

Harvie-Brown, J. A. Capercaillie in Dee. (Ann. Scott. N. H.)

Service, R. Bird Migration at Southerness. (Tr. Dumfr. Nat.

Hist. Soc.) Bar-tailed Godwit as a Solway Bird; Pied Flycatcher Nesting in Kirkcudbright; Eider Duck in Solway Waters; Red-necked Phalarope in Solway Area; Hawfinch in Galloway. (Ann. Scott. N. H.) The Waders of Solway. (Tr. N. H. Soc. Glasg.)

I909. Ogilvie-Grant, W. R. [Exhib. of Red Grouse $\times$ Black Grouse Hybrid from Glen Trool. (Bull. B.O.C., XXIII.)

I9I0. Service, R. Albino Reed Bunting in Solway Area. (Ann. Scott. N.H.) British Skuas, with Special Reference to their Local Occurrences; Rare Birds of Recent Occurrence. (Tr. Dumfr. N. H. Soc.)

IgII. Bedford, Duchess of. British Willow-Tit in Kirkcudbright. (Brit. Birds.)

I913. Bedford, Duchess of. Movements of Migratory Birds in Kirkcudbright. (Scott. Nat.)

Mackay, H. Spotted Redshank in Solway. (T.c.)

I9I4. Bartholomew, J. Yellowbrowed Warbler in Kirkcudbright. (Op. cit.)

I9I5. Gladstone, H. S. Hen Harrier in Kirkcudbright. (Op. cit.)

I917. Begg, W. Autumn Migration at Little Ross Lighthouse; Siberian Chiffchaff at Little Ross Lighthouse. (OP. cit.)

I918. Gladstone, H. S. Curlew Sandpiper in Kirkcudbright. (Op. cit.) 


\section{LANARKSHIRE.}

1854. Colquhoun, H. Occurr. of Rose-coloured Pastor near Glasgow.
(Nat. [Morris's], III.) I865. "R. B., junr." Occurr. of [Great] Grey Shrike in Lanarks.
(Field, Dec. 9.) I865-6. Alston, E. R. Ornitholog. Notes from Lanarks. 8 papers. I868. Lees, H. Capercailzie in Lanarks. (Field, Dec. I9.)

"S." Cream-coloured Courser [in Lanarks.]. (T.c., Dec. I9.) I875. Dixon, J. S. Birds Frequenting Possil Marsh. (Pr. N.H. Soc.
Glasg.) I876. Gray, R. On the Birds of Glasgow and its Vicinity. (In Notes on Fauna and Flora of W. of Scotland, by R. Gray and Others.)
$\mathrm{Cr}$. 8vo. Glasg. : I876. [25I.]

Young, H. C. List of Birds which breed in Vicinity of Glasgow. (In Contrib. towards a Complete List of Fauna and Flora of Clydesdale and $W$. of Scotland.) 8vo. Glasg. : 1876. [673.]

[I889.] [Boyd, D. A.] Birds of the Clyde Valley. [In Pollock's

Dictionary of the Clyde, pp. 63-65.] Glasg. : [I889.]
Campbell, J. M. Spotted Crake near Glasgow. (Zool.)

I89x. Lingford, G. Solitary Snipe in Lanarks. (Field, Sept. I9.)

Read, R. H. Scaup Inland near Glasgow. (Scott. Nat., XI.) I893. Paterson, J. Red-backed Shrike Nesting in Lanarks. (Ann.
Scott. N. H.)

Watt, H. B. The Return of the Swallow [at Bailleston House, I855 onwards.] (Ann. Anders. Nat. Soc., I.)

I893-I900. Paterson, J. Waste Ground and Suburban Bird Life.

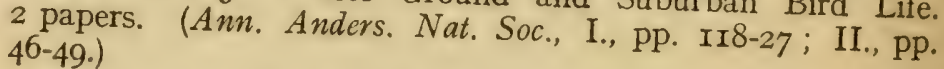
I894. McLellan, D. [List of Birds in] Glasgow Public Parks. 4to.
Glasg.: I894. [372.]

I895. Paterson, J. The White Wagtail, Yellow Wagtail and Garden Warbler in Clyde Area; Montagu's Harrier in Lanarks. (Ann.
Scott. N. H.)

Read, R. H. Nesting of Water Rail near Glasgow. (T.c.) I896. Paterson, J. Great Grey Shrike and Rough-legged Buzzard in
Lanarks. (Op. cit.)

1897. Paterson, J. Little Stint in Clyde Area; Brent Goose in Clyde Area. (Op. cit.)

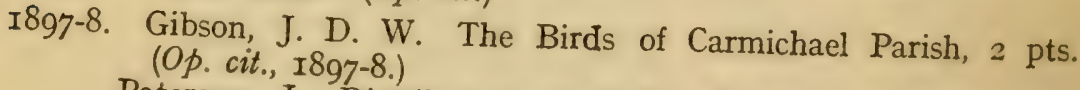

Paterson, J. Distribution of Chiffchaff in Clyde Area. (Tr. N. H. Soc. Glasg.) 
I898. Paterson, J. Blue-headed Wagtail in Lanarks. (Ann. Scott. N. H.)

I899. Paterson, J. Lesser Whitethroat as a Clyde Species. (Op. cit.) 1900. Watt, H. B. Heronries, Past and Present, in the Clyde Faunal Area. (Tr. N. H. Soc. Glasg., N.S., V.)

Igor. Watt, H. B. A Census of Glasgow Rookeries. (OP. cit.)

Gibson, J. D. W. Mealy Redpoll in Upper Clyde. (Ann. Scott. N. H.)

Paterson, J. Birds [in Fauna, etc., of the Clyde Area]. Post 8vo. Glasg. : rgor. [458.]

I903. Paterson, J. Little Gull in "Clyde." (Ann. Scott. N. H.)

I905. Paterson, J. Birds of the Clyde between Glasgow and the Red Bridge, Uddingston. (Tr. N. H. Soc. Glasg.)

Ig08. Dixon, J. S. Extension of Nesting of the Woodcock in Clyde Area. (Ann. Scott. N.H.)

I909. Rennie, W. Notes on Sedge-Warbler at Possil Marsh in Ig08 and I909. (Glasg. Nat.)

I909-I4. Paterson, J. Return of Summer Birds to Clyde Area in I908-I4, 5 reports. (Glasg. Nat., Igog-I4.)

I9I0. Paterson, J. On Birds of Glasgow District; The Great Spotted Woodpecker near Glasgow, 2 notes. (Glasg. Nat.)

Stout, G. Arctic Bluethroat in Clyde Area. (Amn. Scott. N. H.) Wilson, R. W. S. Mealy Redpoll in Ayr, Lanark and Renfrew. (Op. cit.)

IgII. Stewart, W. Dotterel in Lanarks. (Brit.Birds.) British Willow Tit in Lanarks. (T.c.)

Igr3. MacKeith, T. T. Sandwich Tern Nesting in Clyde Area. (Scolt. Nat.)

Rennie, W. The Birds of Possil Marsh. (Glasg. Nat., V., pp. 49-65, pl, ii.) Greenland Wheatear at Possil. (Op. cit., IV., p. 32.)

IgI5. Hopkins, N. Little Stint at Hogganfield Loch. (Op. cit., VII., p. II9.)

Macdonald, D. Green Sandpiper in "Clyde" in Spring. (Scott. Nat.)

Rennie, W. Arrival of Summer Visitors in Possil Marsh, I9I5. (Glasg. Nat., VII., p. 64.) The Mute Swan at Possil Marsh. (T.c., p. 79-88.)

Robertson, J. Arctic Skua in Lanarks. (Scott. Nat.)

I9r6. Macdonald, D. On the Little Gull and other Rare Birds near Glasgow. (Glasgow Nat., VIII., pp. 35-37.)

Rennie, W. Bird Notes from Possil Marsh, Jan.-June, IgI6. (T.c., pp. 56-63.)

I9I7. Maxwell, $H$. Nesting of Kingfisher within the Glasgow Boundaries. (Scott. Nat.) 
I9I8. Bartholomew, J. Black Tern near Glasgow. (Op. cit.)

Macdonald, D. Swans on Possil Marsh. (T.c.)

Robertson, J. Swift near Glasgow in Sept. ; Nesting of Woodcock within Glasgow boundaries; Oct. Swift at Glasgow. (T.c.)

\section{LINLITHGOWSHIRE (WEST LOTHIAN).}

1837. Weir, "Mr." Siskin breeding in Scotland. (Edinb. Journ. N. H., March, I837.)

I839. Weir, T. D. Summer Birds observed in the Vicinity of Bathgate. (In MacGillivray's History of British Birds, II.) 8vo. Lond. : 1839.

I860. Duns, J. On Birds of Linlithgows. (Edinb. New Phil. Mag.).

"W. H. H." Osprey shot [in Linlithgows.]. (Field, June I6.) Idem by " H. O." and Editor. (T.c., June 23.)

x862. Duns, J. On Nesting Birds of Linlithgowshire and Berwickshire. (Edinb. New Phil. Mag.) [Revised and extended version of last paper, with annotations; also reprinted in Pr. Roy. Soc. of Edinb., I862.]

I878. Gray, R. Ornithol. Notes. (Hist. Berw. Cl., VIII., p. 498.)

I9I0. Brock, S. E. Willow Wrens of a Lothian Wood. (Zool.)

I9I3. Brock, S. E. Notes on a Carrion-Crow Roost at Bathgate Hills. (Scott. Nat.; Brit. Birds, VII.)

19I4. Campbell, B. Whimbrel in Forth Dist. in Jan. (Scott. Nat.) Page, H. S. Late Swallow in W. Lothian. (Scott. Nat.)

19r5. Adam, J. C. A Pair of Long-eared Owls. (Tr. Edinb. F. N. Soc.) I9I6. McWilliam, J. M. Notes on Birds of Linlithgow Loch. (Zool.) I9r7. Campbell, B. Hawfinch in Linlithgow. (Scott. Nat.) I9r8. Campbell, B. Late Swift near Dalmeny House. (Op. cit.)

MIDLOTHIAN (See EDINBURGHSHIRE).

MORAYSHIRE (See ELGINSHIRE).

NAIRN (See under ELGIN). 


\section{ORKNEY ISLANDS.}

I693. Wallace, J. Description of the Isles of Orkney. 8vo. Edinb. : I693. And later editions. [609.]

I7or. Brand, J. A Brief Description of Orkney, etc. Sm. 8vo. Edinb.: I70I. And later editions. [90.]

I7II. Sibbald, Sir R. [edited by.] Robert Menteith's MS. Description of the Isles of Orkney and Zetland. Fol. I7II. [536.]

I75I. [Anon.] A Voyage to Shetland, the Orkneys, [etc.]. 8vo. Lond. : I75I. [I6.]

I775. Fea, J. Present State of the Orkney Islands. 8vo. I775. Idem, reprint. I884. [205.]

I805. Barry, G. History of the Orkney Islands, etc. 4to. Edinb., etc. : I805. And later editions. [44.]

1806. Neill, P. Tour through some of the Islands of Orkney, etc. 8vo. Edinb. : I806. [43I.]

I8I2. Bullock, W. Account of Four Rare Species of Brit. Birds. (Limn. Soc. Tr.) [partim.] [684.]

I8I3. Low, G. Fauna Orcadensis. 4to. Edinb. : I8I3. [36r.]

I8I4. Neill, P. [Great Auk at Papa Westray.] (Scots. Mag., Mar.)

1830-3I. Drosier, R. Ornitholog. Visit to Islands of Shetland and Orkney in Summer of 1828,2 pts. (Loudon's Mag. N. H., III., IV., I830-3I.)

I83I. Wilson, J. Illustrations of Zoology. Fol. Edinb. : I83I. [653.]

1832. Salmon, J. D. On Eggs and Birds met with in Three Weeks' Sojourn in Orkney Islands. (Loudon's Mag. N. H., V.)

I834. Anderson, G. and P. Guide to the Highlands and Islands of Scotland. 8vo. Lond. : I834. [12.]

1835. Neill, P. Snowy Owl taken alive in Orkney. (Loudon's Mag. N. H., VIII.)

I837. Dunn, R. The Ornithologist's Guide to the Islands of Orkney and Shetland. Post 8vo. Lond.: I837. [186.]

I848. Baikie, W. B., and Heddle, R. Historia Naturalis Orcadensis. Pt. I. 8vo. Edinb. : I848. [36.]

I853. Baikie, W. B. Additions to List of Birds of Orkney and Shetland. (Zool.) [36.]

1857. Dunn, R. Rare Birds in Orkney. (Op. cit.) [I86.]

I859. Dunn, R. Adult Glaucous Gull in Orkney. (Op. cit.) Idem. (Field, Feb. 26.)

“J. G. H." Rare Visitors, Spoonbills, etc (Field, Nov. 26.)

"H." Rare Visitors. (Op. cit., June 4.) 
Reid, W. Black Redstarts and Spoonbills in Orkney. (Op. cit., Dec. 3I.)

"Scaraben." Snowy Owl [in Sanday]. (Op. cit., Jan. I5.)

I860. Charlton, E. On the Great Auk. (Zool.)

Dunn, J. Grey Phalarope, Little Auk and Glaucous Gull in Orkney. (T.c.)

I86r-2. Crichton, A. W. A Ramble to the Orcades in 1860 . Io pts. (Field, I86I-2.)

I862. Clouston, C. Guide to the Orkney Islands. I2mo. Edinb. : I862. [137.]

1863. Cowan, W. Eared Grebe shot in Orkney. (Field, Apr. 30.) Idem by Ray and Gurney. (T.c., May 7, I4.)

Dunn, J. H. Pomarine Skuas in the Orkneys. (Zool.)

[Ex John o' Groats Journal.] Numidian Crane shot in Orkney. (Field, June 6.)

I865. Dunn, J. H. Sea-Fowl at Stromness. (Op. cit., July 29.)

I866. Crichton, A. W. A Naturalist's Ramble to the Orcades. I2mo. Lond. : I866. [I55.]

" J. S." Goshawk in Orkney. (Field, Sept. 8.)

I867. Gurney, J. H. Iceland Gull in Orkney. (Zool.)

"J. G. H." Ivory Gull in Orkney. (Field, June 15.)

I868. Gorrie, D. Summers and Winters in the Orkneys. Post 8 vo. Lond.: I868. [238.]

I870. "Inquirer." Demoiselle Crane [at Dearness]. (Field, Sept. 3.) Idem by W. C. Horsfall. (T.c., Sept. Io.)

I87I. Saxby, H. L. Roller in Orkney. (Zool.)

I872. Harting, J. E. British Heronries. (Op. cit.) [partim.] [274.]

I873. "J. C." Iceland Gulls at Kirkwall. (Field, Dec. I3.)

I874. Kennedy, A. Clark. Ornithology of the Orkneys. (Zool.)

1875. Barnett, J. Goosander in Orkney. (Field, Mar. 6.)

Gray, R. Ornitholog. Notes. (Hist. Berw. Cl. VII., pp. 463-7.)

" J. M." Destruction of Rare Birds in Orkney. (Ficld, May 8.) Idem. by A. Clark Kennedy. (T.c., June 5) ; by W. Reid. (Op. cit., July 3$)$; by R. Smee. (T.c., July Io.)

Reid, W. Great Auk in Orkney. (Op. cit., May 8.)

I876. Bruce, J. Great Bustard in Orkney. (Op. cit., Apr. 8, 22.)

Kennedy, A. Clark. Surf Scoter in Orkney. (T.c., Mar. II.) Idem by J. Rae. (T.c., Mar. I8.)

Pike, T. M. Occurrence of Surf Scoter in Orkney. (T.c., Feb. I9.)

I877. Barnett, J. Kite in Orkney. (Op. cit., May 5.)

Harper, R. P. King Duck in Orkneys. (Zool.)

Pike, T. M. Puffins and Little Auks in Orkney. (Field, Feb. 24.)

Trail, J. W. H. Bird Names in Orkney. (Scott. Nat., IV.) 
1879. Low, G. A Tour through the Islands of Orkney and Shetland in I774. 8vo. Kirkwall : I879. [362.]

Pike, T. M. Surf Scoter in Orkney. (Zool.)

I880. Pratt and Sons. Surf Scoter in Orkney. (Field, Dec.II.)

Tomlinson, H. G. Ornitholog. Notes from Orkneys. (Zool.)

I88I. Fortescue, W. I. Gadwall in Orkney. (Field, Jan. I); Habits of Starling in Orkney. (T.c., Mar. I2.)

Langton, H. Surf Scoter in Orkney. (Zool.)

Traill, W. Wild Swans in N. Ronaldshay. (Field, Jan. 29.) Idem by "R. M." (T.c., Feb. 26.)

I882. Morgan, A. M. Cormorants in Orkney. (Op. cit., Apr. 22.)

1883. Aplin, O. V. Supposed Nestling Grey Plover from Orkneys. (Zool.) Idem by Rev. H. A. Macpherson. (T.c.)

Spence, R. F. Birds of Orkney. [Unfinished.] 4to. [556.] Tudor, J. R. The Orkneys and Shetlands. Cr. 8vo. Lond.: I883. [59I.]

1884. Harvie-Brown, J. A. Black Redstart shot in Pentland Firth. (Ibis.)

S-, J. Manx Shearwater in Orkney. (Field, Sept. 20.)

1885. Buckley, T. E. A Few Notes on Mammals and Birds of Rousay. (Tr. N. H. Soc. Glasg., I883-4.) [I05.]

r886. Fortescue, W. I. Wild Swans [in Orkney]. (Field, Apr. ro.) Idem by. E. G. Cameron. (T.c., Apr. I7.)

I887. Millais, J. G. Asiatic Golden Plover in Orkney. (Op. cit., Dec. Io.)

1888. Trail, J. W. H. Ring Ouzel [breeding] in Orkney. (Scott. Nat., IX., I887-8.)

I889. Gunn, T. E. Pectoral Sandpiper in Orkney. (Zool.)

Reid, W. Sand Grouse near Kirkwall. (Field, Mar. 30.)

Trail, J. W. H. Ring Ouzel breeding in Orkney. (Zool.)

I8gr. Buckley, T. E., and Harvie-Brown, J. A. A Vertebrate Fauna of the Orkney Islands. Sq. 8vo. Edinb.: I8gI. [282.]

1892. Buckley, T. E. Blue-throated Warbler in Orkney. (Ann. Scott. N. H.)

Harvey, W. Shoveler nesting in Sanday. (T.c.)

Peace, T. S. Ruff in Orkney; Great Bustard in Orkney; Albino Cormorant in Orkney. (T.c.)

1893. Harvie-Brown, J. A. Snowy Owl in N. Ronaldshay. (Op. cit.) Harvey, W. Golden Oriole in Orkney. (T.c.)

Skelton, A. N. Curlew Sandpiper in Orkney. (T.c.)

I893-4. Briggs, A. Bird Notes from N. Ronaldshay, and Further Notes. (Op. cit., I893-4.)

I894. Rankes, T. W. Buffon's Skua in Orkney. (Op. cit.) 
1895. Briggs, A. White-winged Crossbill in Orkney. (Op. cit.)

Dunbar, L. Black-tailed Godwit in Orkney. (T.c.)

Harvie-Brown, J. A. Albatross in the Orcadian Seas. (T.c.)

I896. Buckley, T. E. Pochard and Tufted Duck breeding in Orkney. (Op. cit.)

Cursiter, J. W. Roller in Orkney. (T.c.)

Wheat, J. B. Orcadia. (Ornithologist.)

1897. Briggs, A. Bird Notes from N. Ronaldshay. (Ann. Scott. N. H.)

Godfrey, R. Tufted Duck, etc., in Orkney in Summer. (T.c.)

McCrie, T. Wryneck in Orkney. (Ann. Scott. N.H.)

I897-8. Godfrey, R. Orcadian Rambles. (Sci. Gossip, Dec., I897, Jan.-May, I8g8.)

1898. Newton, A. On the Orcadian Home of the Gare Fowl. (Ibis.) I900. Ticehurst, N. F. On Birds seen in S.E. part of Mainland of Orkney, Oct., I899. (Zool.)

I90I. Ticehurst, N. F. Rednecked Phalarope Breeding in Orkney. (Bull. B.O.C., XI., Ig00-I.)

I902. Buxton, C. S. Wood Sandpiper in Orkney Islands. (Zool.) Clarke, W. E. On Occurrence of Phylloscopus viridanus [errore, vide Igog] in Suleskerry. (Bull. B.O.C., XIII., I902-03; Ann. Scott. N. H., I903.)

I903. Grant, J. Greenland Falcon in Orkney. (Ann. Scott. N. H.) Tomison, J. Crane, etc., at Pentland Skerries. (Tr. Edinb. F. N. Soc.)

I904. Clarke, W. E. On Occurrence of Little Bunting in Orkney. (Op. cit.) [134.]

Ig05. Marwick, John G. H. Observations on Some Birds on the Mainland of Orkney. (Orcadian Papers.)

Tomison, James. Habits of Birds frequenting Sule Skerry; The Migration of Birds as observed from Sule Skerry. (Orcadian Papers.)

Robinson, H. W. The Identification of Rare Orcadian Birds. (Illustrated.) (Orcadian Papers.)

I905-6. Robinson, H. W. Albino Shag in Orkney. (Field, Mar. 4, I905, Dec. 29, I906.)

I905-7. Sharpe, R. B. [Exhibition of] Supposed Pacific Eider in Orkney Islands. (Bull. B.O.C., XV.) Idem by H. W. Robinson. (Zool., I905; Field, Mar. 7, I906.) Idem by F. Smalley. (Brit. Birds, I., I907.)

Ig06. Clarke, W. E. Siberian Chiffchaff in Suleskerry. (Ann. Scott. N. H.) Idem, (Bull.B.O.C., XIX.)

Robinson, H. W. Hoopoe in Orkney. (Ficld, Nov. 24.) King Eider in Orkney. (Ann. Scott. N. H.; Ficld, Mar. I7.) Surf Scoter in Orkney. (Ann. Scott. N.H.) Sclavonian Grebes in Orkney in Summer Plumage. (Field, Dec. 29.) 
Saunders, H. On a Remarkable Specimen of an Eider Duck from Orkneys. (Bull. B.O.C., XVI.)

Smalley, F. King-Eider in Orkney. (Zool.)

I907. Robinson, H. W. Early Nesting of Shag in Orkney; Glossy Ibis in Orkney. (Brit. Birds); Migration of Wild Swans through Orkney. (Field, April 27.)

1907-8. Clarke, W. E. On Occurr. of Siberian Chiffchaff in Scotland. 2 notes. (Ann. Scott. N. H., I907-8.)

1908. Robinson, H. W. Flock of Glossy Ibis in Orkney; White Wagtail in Orkney. (Ann.Scott. N. H.) ; Gt. Grey Shrike in Orkney. (Brit. Birds, p. I65) ; Large Assemblage of Gt. Northern Divers in Orkney. (Ann. Scot. N. H., 2 notes; Field, March 2I, April 25.)

Ticehurst, N. F. On Some Bird Remains from Broch of Ayre. (Brit. Birds, I.)

I909. Clarke, W. E. Little Bunting and Other Birds at Suleskerry; Phylloscopus borealis, not $P$. viridanus at Sule Skerry; A Correction; Ruddy Sheld-Duck at Sule Skerry. (Ann. Scott. N. $H$.)

Cowan, W. Little Bittern in Orkney. (Brit. Birds, III.)

Evans, W. Food of Common Eider [in Orlkney]. (Bvit. Birds, III.)

Hale, J. R. Increase of Wood Pigeons in Orkney. (Brit. Birds, II.)

Robinson, H. W. Fork-tailed Petrels in Orkney. (Ann. Scott. N. H.) Food of Eider (Brit. Birds) ; Moult of Gt. Northern Diver (Ann.Scott. N.H.) ; Gadwall in Orkney (T.c.) ; Longtailed Duck in Summer (T.c.); Rednecked Grebe in Orkney. (T.c.)

IgIo. Clarke, W. E. Rock Thrush in Orkney. (Ann. Scott. N. H.; Brit. Birds, IV.)

Robinson, H. W. Nesting of Grey Lag Goose in Orkney. (Brit. Birds, April.)

Hale, J. R., and Aldworth, T. P. Notes on Birds in Orkney in I9I0. (Brit. Birds, IV.)

IgII. Aplin, O. V. Longtailed Duck Breeding in Orkney. (Brit. Birds, V.)

Clarke, W. E. Lanceolated Warbler in Scotland. (Ann. Scott. N. H.)

Dunlop, E. B. Fulmars Breeding on Hoy. (T.c.)

Ground, T. Fulmars in Orkney and Shetland. (Brit. Birds, V.) Robinson, H. W. Migration of Whooper Swans in Orkney. (Ann. Scott. N. H.)

IgII-I2. Aplin, O. V. Long-tailed Duck Breeding in Orkney. (Zool.) Idem, editorial. (Brit. Birds, VI., I9I2.) 
IgI2. Clarke, W. Eagle. [List of Birds of Suleskerry in] Studies in Bird Migration [Vol. II.] 8vo. 2 vols. Lond. : IgI2. [I35.] Smalley, F. W. Sooty Shearwater in Orkney. (Brit. Birds, VI.) Robinson, H. W. Fulmars in Orkney. Idem, Addit. Notes. (Op. cit., V.) Herons Nesting in Orkney. (Ann. Scott. N. H.) Harvie-Brown, J. A. The Fulmar, 2 pts. (Scott. Nat.) Idem. (Zool.; Brit. Birds, VI.) [partim.] [284.]

Kirke, W. J. B. Fulmars Breeding in Orkney. (Brit. Birds, V.)

1913. Bain, J. On Occurr. of Gullbilled Tern in Orkney. (Scott. Nat.) Bedford, Duchess of. Bartailed Godwits in Orkney. (Brit. Birds, VI.)

Clarke, W. Eagle. On Occurr. of Phylloscopus fuscatus in Orkney Is. (Scott. Nat.)

Hale, J. R. Green Sandpiper and Bartailed Godwits in Orkney. (Brit. Birds, VI.) ; Green Sandpiper in Orkney; Orkney Breeding Record of Longtailed Duck. (Op. cit., VII.) [Exhib. of] Golden Plover and Velvet Scoter from Orkneys. (Bull. B.O.C., XXXIII.)

Kirk, C. Snowy Owl of Sule Skerry. (Scott. Nat.)

Laidlaw, H. Ringed Plovers Nesting under Stones in Orkney. (Scott. Nat.)

Robinson, H. W. Orkney Breeding Records of Grey Lag Goose and Longtailed Duck. (Brit. Birds, VI.); Great Mortality among Shags in Orkneys. (T.c.); Inequality of Sexes among Diving Ducks in Orkney. (Op. cit., VII.); The Life of the Longtailed Duck in the Orkneys. (T.C.)

Witherby, H. F. The Dusky Warbler in Orkney. (T.c.)

I9I4. Bain, J. Icterine Warbler in Orkney. (Scott. Nat.)

Clarke, W. E. Rare and Interesting Migratory Birds observed at Orcadian Is. of Auskerry in Autumn I9I3. (Scott. Nat.); Northern Bullfinches in Orkney. (T.c.); White Wagtail in Orkneys. (T.c.)

Laidlaw, H. Woodchat Shrike in Orkney. (T.c.)

Robinson, H. W. Arrival of Pied Wagtail in Orkney. (Scott. Nat.); Lesser Blackbacked Gull in Orkney. (T.c.)

I9I5. Aplin, O. V. Gannet Nesting in Orkney. (Zool.)

Robinson, H. W. Goosander in Orkney. (2 notes.) (Scott. Nat.); Unrecorded Ivory Gull from Orkney. (Scott. Nat.; Brit. Birds, IX.) ; Linnet in Orkney. (Scott. Nat.)

I9I6. Aplin, O. V. Reported Nesting of Gannet in Orkney. (Zool.) Bain, J. Redbreasted Flycatcher and Shorelarks in Orkney; Yellowbrowed Warblers in Orkney, etc. (Brit. Birds, IX.)

I9I7. Robinson, H. W. Status of Brent Goose in Orkney and Shetland (Scott. Nat.); Status of Whitefronted Goose in Orkney. (T.c.)

I9I8. Jourdain, F. C. R. First Nesting Record of Great Skua in Orkneys. (Brit. Birds, XII.) 


\section{PEEBLESSHIRE.}

1864. Chambers, W. History of Peeblessh. 8vo. Edinb., etc. : I864. [122.]

1867. Harvie-Brown, J. A. Waxwings in Peeblessh. (Zool.) 1874-77. Gray, R. Ornitholog. Notes, 4 pts. (Hist. Berw. Cl., VII., pp. 257-6I, 463-7; VIII., pp. I55-9, 353-5.)

I875. Elliot, Sir W. Rare Birds, etc. (Op. cit., VII., pp. 524-5.)

I876. Smail, J. Zoological Notes. (Op. cit., VIII., pp. 99-I06.)

I878. Hardy, J. Miscellanea. (Op. cit., VIII, p. 53I.)

I882-3. Smail, J. Border Heronries. (Op. cit. X. pp. 330-34.) ; Rooks and Rookeries. (T.c., pp. I59-84.)

I886. Thomson, J. Notes on Birds of Stobo and Neighbourhood. (Hist. Berw. Nat. Club, XI., pp. 546-58.)

I889. Thompson, J. The Rarer Birds of Stobo. (Tr. Edinb. Nat. F. C., II. [I886-gI].)

I89I. Evans, A. H. Preliminary List of Birds of Melrose Dist. 2 pts. (Scott. Nat., XI.) [partim.]

1895. Evans, W. Hoopoe in Peeblessh. (Ann. Scott. N. H.)

Laidlaw, T. G. Stock Dove nesting in Peeblessh. (T.c.)

I898. Laidlaw, T. G. Great Spotted Woodpecker in Peeblessh. (OP. cit.)

Igor. Laidlaw, T. G. Tree Sparrow in Peeblessh. (Op. cit.)

I906. Marshall, H. B. Gadwall Nesting in Peeblessh. (Field, July 28.)

rgı. Evans, W. A Peeblesshire Specimen of the Chough. (Ann. Scott. N.H.)

IgIr. Bonhote, J. L. [Exhib. of Continental Blue Tit from Peeblessh.] (Bull. B.O.C., XXVII.)

IgI2. Evans, W. Great Crested Grebe in Peeblessh., etc. (Scott. Nat.) I914. Blackwood, W. T. Nesting of Pied Flycatcher in Peebles. (Scott. Nat.)

Currie, T. Forktailed Petrel in Peebles. (T.c.)

I9I8. Simpson, H. D. Hawfinch in Peebles. (Op. cit.)

\section{PERTHSHIRE.}

I835. Adam, W. Turtle Dove in Perths. on Oct. 20, I834, etc., 2 notes. (Loudon's Mag. N. H., VIII.)

I848. Lawson, G. Hoopoe or Wild Swan on the Tay. (Zool.) 
1859. Various Writers. The Capercailzie [common in Perths.]. (Field, Jan. I5.)

I860. Twinn, G. K. Capercally breeding in Scotland. (Zool.)

I86I. "T. B. L." Goosander shot on Tay. (Field, Feb. 9.)

Orde, J. W. P. Breeding of Golden Eagle in a fir tree in Perths. (Ibis.)

I867. Hopegood, F. V. Quails breeding in Perths. (Field, Aug. 3.)

1868. [Anon.] Stormy Petrel in Perths. (Op. cit., Nov. 28.)

I870. Gray, R. American Goshawk in Perths. (Ibis.)

I87I. Eedle, T. Birds observed at Rannoch. (Zool.) Idem by J. H. Gurney. (T.c.)

I872. Harting, J. E. British Heronries. (Op. cit.) [partim.] [274.] I873. Yuille, S. Quails in Scotland. (Field, Oct. 25.)

I873-4. Cameron, W. Birds at Balquhidder. (Scott. Nat., II., I873-4.)

I875-8. Gray, R. Ornitholog. Notes, 4 pts. (Hist. Berw. Nat. Cl., VII., pp. 463-7 ; VIII., pp. I55-9, 353-5, 499-502.)

1876. Cooke, H. Wood Wren in Perths. (Zool.)

Cordeaux, J. Great Snipe in Perths. (T.c.)

Levett, W. Goosander nesting in Perths. (Field, May 27.)

Whitaker, J. Ornitholog. Notes. (Zool.)

I877. Booth, E. T. Nesting of Brambling in Perths. (Op. cit.)

Brooke, A. B. Canada Geese near Dunkeld. (T.c.)

I877-8. Drummond-Hay, H. M. On Occurrence of Porphyrio smaragdonotus [near Errol.] (Scott. Nat., IV.)

Herdman, W. Kites. Idem. [at Blair Athol.] (T.c.)

1878. Marshall, T. Wryneck in Perths. (Zool.)

White, F. B. Glen Tilt: its Fauna and Flora. (Scott. Nat., IV.)

I879. Brooke, A. B. Stock Dove breeding in Scotland [near Dunkeld]. (Op. cit., V.)

Buchanan, J. H. Great Spotted Woodpecker in Perths. (Zool.)

I879-8I. Drummond-Hay, H. M. Notes on Birds of Basin of Tay and its Tributaries, 6 pts. (Scott. Nat., V., VI., I879-8I.) [I82.]

I880. Marshall, T. Notes on Birds near Stanley in Perths. (Op. cit., V., I879-80.)

Buchanan, Hamilton. List of Birds seen in Parish of Callander. (Pr. Roy. Phys. Soc. Edinb.)

I880-83. Horn, W. Notes on Birds of N.W. of Perths., 2 pts. (Pr. N. H. Soc. Glasg., IV. [I878-80], I880; V. [I882-4], I883.)

I88I. Arnold, E. L. Redwing nesting in Perths. (Zool.)

Dalgleish, J. J. Late Appearance of Great Grey Shrike in Perths. (T.c.)

Drummond-Hay, H. M. The Grallatores and Natatores of the Estuary of the Tay, etc. 8vo. Dundee: I88I. 
Drummond-Hay, H. M. Storm Petrels found in Perths. (Scott. Nat., VI., I88I-82.)

1884. Marshall, T. Stock Dove in Perths. (Zool.)

1885. Dalgleish, J. J. List of Birds of Culross and Tulliallan. (In Appendix to Dr. Beveridge's Culross and Tulliallan.) 8vo. Edinb. : I885. Also separately. [I60.]

White, F. B. W. On Occurrence and Probable Nesting of Parrot Crossbill. (Pr. Perths. Soc., I884-5.)

I886. Craig, A., junr. Pitlochry and its Bird Life. (Tr. Edinb. Nat. F.C.)

Drummond-Hay, H. M. Occurr. of Red-shouldered Starling in Rannoch. (Scott. Nat., VIII.)

O[gilvie] G[rant], W. R. A Raid on the Herons. (Field, Aug. I4.) I886-88. Drummond-Hay, H. M. Report on Ornithology of E. of Scotland, from Fife to Aberdeens. inclusive. 3 papers. (Scott. Nat., VIII., I885-6; IX., I887-88.)

I886. Millais, J. G. Parrot Crossbill probably breeding in Perths. (Pr. Perths. Soc., I884-5.)

Nillais, J. G. Richard's Pipit shot near Perth; Charadrius virginicus shot near Perth. (Zool.)

1887. Drummond-Hay, H. M. On Rare Perthshire Birds lately placed in the Museum. (Tr. Perths. Soc. Nat. Science, I.)

I888. Skirving, R. S. Greenland Falcon in Ross-shire [errore for Perths.]. (Field, June I6, 30 ; July 7.)

I889. Drummond-Hay, H. M. Turdus atrigularis near Perth. (Ibis.) Marshall, T. Smew in Perths. (Zool.)

White, F. B. W. Notes on Birds at Perth. (Tr. Perths. Soc., I888-9.)

I89o. Aplin, O. V. Distribution, etc., of Spotted Crake. (Zool.)

Millais, J. G. Hybrid Wigeon and Pintail [near Perth]. (Field, Feb. I5.)

I89r. Drummond-Hay, H. M. Notes on Birds recently observed in Tay district. (Scott. Nat., XI.) ; Notes on Additions to Birds and Nests recently placed in Perth Museum. (Tr. Perths. Soc.)

Duthie, W. H. M. List of Birds that breed on a Moorland Loch in Perths. (Scott. Nat., XI.)

Gurney, J. H. Lesser Redpoll in Perths. (T.c.)

I892. Duthie, W. H. M. Water Rail nesting in Perths. (Ann. Scott. N. H.)

I893. Drummond-Hay, H. M. Hoopoe and Buff-coloured variety of Snipe in Tay Basin; Ring Ouzel in Winter. (Op. cit.)

I895. Campbell, A. J. Distribution of Birds included in Avifauna of Perths. (Tr. Perths. Soc.)

Cordeaux, J. Garden Warbler in Perths. (Ann. Scott. N. H.) 
Drummond-Hay, H. M. Ruđdy Sheld-Duck, etc., in Tay District. (T.c.) Bird Life within Banks of Tay. (Tr. Perths. Soc.)

Duthie, W. H. M. The Home of the Dipper. (T.c.)

I896. Drummond-Hay, H. M. Ornitholog. Notes from Tay district. (Ann.Scott. N. H.)

1897. Evans, W. Nesting of Grasshopper Warbler in Upper Forth. (Ann. Scott. N. H.) ; The Marsh Tit in the Tay Valley. (Tr. Perths. Nat. Soc.)

Lee, O. A. J. Notes on nesting of Great Crested Grebe in Valley of Forth. (Ann. Scott. Nat.)

1898. Ellis, G. Longtailed Ducks in the Tay. (Field, Dec. I7.)

Evans, W. Goldfinch in Mid Perth. (Ann. Scott. Nat.)

1899. Campbell, B. Notes on Birds of Ballinluig District. (Ann. Scott. N. H.)

Campbell, J. Increase and Decrease of Certain Species in Tay Area. (T.c.)

Duthie, Lt.-Col. The Grey Lags of Blair Drummond. (T.c.)

Taylor, D. A. E. Hoopoe in Perths. (Field, June 3.)

I900. Davidson, R. G. Blackcap in Perths. in Dec. (Ann. Scott. N. H.)

Harvie-Brown, J. A. Crested Tit in "Tay." (T.c.)

Igor. Macpherson, H. A. Bernicle Goose in Perths. (Op. cit.)

I902-3. Campbell, B. The Birds of Ballinluig, Blair Atholl and Fossoway and Additional Notes. (Tr. Edinb. Field Soc., IV., V.)

I903. Laidlaw, T. G. Supposed Occurrence of Larus melanocephalus at Perth. (Ann. Scott. N.H.)

I905. Rodger, A. M. Illustr. Handbook to Perthshire Nat. Hist. Mus. 8vo. Perth: I905. [495.]

I906. Harvie-Brown, J. A. A Fauna of the Tay Basin and Strathmore. 8vo. Edinb.: I906. [282.]

I908. Marshall, J. M. L. Breeding of Tree-pipit in Glenshee District. (Ann. Scott. N. H.)

I910. Bedford, Duchess of. Crossbill in Perths. (Op. cit.)

I9I2. Noble, H., and Millais, J. G. Gadwall in Perths., 2 notes. (Brit. Birds, V.)

I9I3. Borrer, C. Green Sandpiper in Perths. (Op. cit., VII.)

Wedderburn, C. S. Osprey in Tay. (Scott. Nat.)

I9I5. Coates, H. Little Auks in and around Perth. (Op. cit.); Tengmalm's Owl in Perths. (T.c.)

Dewar, J. M. Relation of Oystercatcher to its natural environment in N. Perths. 5 pts. (Zool.)

I917. Baxter, E. V., and Rintoul, L. J. Little Gull in Tay area. (Scott. Nat.) ; Migration by river at Aberfoyle. (T.c.)

Boase, $\mathrm{H}$. Observations on some habits of Coot in Perth. (T.c.) 
Murray, G. E. G. Note on singular nesting of Tree Creeper near Dunkeld. (T.c.)

IgI8. Boase, F. Westward Flight of Swallow [etc.] on Tay Estuary in Autumn. (Op. cit.)

Bonar, H. N. Extension of Range of Gt. Spotted Woodpecker in Tay area. (T.c.)

Webster, P. Kite in Perths. (T.c.)

\section{RENFREWSHIRE.}

I793. Ure, D. History of Rutherglen and East Kilbride. 8vo. Glasg. : I793. [602.]

I83I. "X. Y. Z." [Bree, W. T.] Birds, either resident or occasional visitors of Renfrew and its Neighbourhood from Nov. to Feb. I, I83I. (Loudon's Mag. N. H., IV.)

1832. Duncan, G. Birds of Renfrew and its Neighbourhood. (OP. cit., V.)

I863. "Ossian." Sand Grouse [in Renfrew]. (Field, Aug. I.)

I877. "H. L. H." Great Grey Shrike at Lochwinnoch. (Op. cit., July 28.)

[1889.] [Boyd, D. A.] Birds of the Clyde Valley [In Pollock's Dictionary of the Clyde, pp. 63-65.] Glasg. : [I889.]

1893. Paterson, John. Records of Excursions in Renfrewshire. ( $4 \mathrm{nn}$. Anders. Nat. Soc., I.) [Cont. bird observ.]

I893-I900. Paterson, J. Waste Ground and Suburban Bird Life. 2 papers. (Op. cit., I., pp. II8-27 ; II., pp. 46-49.)

1894. Paterson, J. Nesting of Tufted Duck in Renfrews. (Ann. Scott. N.H.)

I895. Paterson, J. Pintail, Great Grey Shrike and Jay in Renfrews. (Op. cit.)

Paterson, J., and Robertson, J. List of Birds of E. Renfrews. (T.c.)

I896. Paterson, J. Great Snipe and Grey Plover in Renfrews. (Op.cit.)

Paterson, $\dot{J}_{\text {., }}$ and Robertson, J. Blackcap and Scaup Duck in E. Renfrews. (T.c.)

I897. Paterson, J., and Robertson, J. Curlew Sandpiper and Marsh Tit in E. Renfrews. $(O p$. cit. $)$

Paterson, J. Baillon's Crake in W. Renfrews. (T.c.)

I898. Paterson, J., and Robertson, J. Chiffchaff, Wood Wren and Black-throated Diver in E. Renfrews. (Op. cit.)

I900. Paterson, J., and Robertson, J. Spotted Redshank and Blacktailed Godwit in E. Renfrew. (Op. cit.) 
Watt, H. B. Heronries, Past and Present, in the Clyde Faunal area. (Tr. N. H. Soc. Glasg., N.S., V.)

IgoI. Watt, H. B. A Census of Glasgow Rookeries. (T.c.)

I908. Robertson, J. Birds of Ranken Glen Park. (Ann. Anders. Nat. Soc., III., pp. 63-70.)

I908-9. MacKeith, T. T. Notes on Birds of W. Renfrews., 2 pts. (Zool., I908-9.)

I909. Horton, W. Golden Oriole in Renfrews. (Ann. Scott. N. H.) I909-I4. Paterson, J. Return of Summer Birds to Clyde area in I908I4. 5 repts. (Glasg. Nat., Igog-I4.)

I9I0. Paterson, J. Common Guillemot Inland; Bar-tailed Godivit in E. Renfrew. (Glasg. Nat.)

Robertson, J. Ruff and Spotted Redshank in E. Renfrew. (T.c.)

Wilson, R. W. S. Mealy Redpoll in Rentrew. (T.c.)

IgII. Wilson, R. W. S. Willow Tit in Renfrews. (Brit. Birds.)

Robertson, J. Birds of E. Renfrews. (Glasg. Nat., III.); Waders observed at Balgray Dam. (T.c.)

IgI2. MacKeith, T. T. Stonechat inland. (Op. cit., IV.)

I913. Paterson, J. Whiteheaded Chaffinch. (Op. cit., V.)

Robertson, J. Wood Sandpiper in E. Renfrew.; Spotted Redshank in E. Renfrew. (T.c., pp. I30-3I.)

Wilson, R. W. Turtle Dove in E. Renfrew. (T.c., p. I30.)

Igr4. MacKeith, T. T. Quails nesting in Renfrew; Willow Tit nesting in Renfrew. (Scott. Nat.)

I9I5. Robertson, J. Migration of Ringed Plover in E. Renfrew ; Green Sandpiper in E. Renfrew; Knot inland; Waders in E. Renfrew. $(O p$. cit. $)$

Robertson, J., and MacKeith, T. T. The Birds of Renfrewshire. (Scott. Nat.)

I9I6. Robertson, J. Grey Plover, Ruff, etc., in Renfrews. (Brit. Birds, IX.)

I9r7. MacKeith, T. T. Acanthis cannabina nesting in Renfrews. (Scott. Nat.)

Robertson, J. Early Appearance of Swift. (T.c.); Palebreasted Brent Goose in Renfrews. (T.c.)

Wilson, H. W. Redbreasted Merganser in E. Renfrews. (T.c.)

I9I8. Robertson, J. Slavonian Grebe in Renfrews. (Op. cit.)

\section{ROSS-SHIRE (AND CROMARTY).}

1833. Mackenzie, F. Breeding of Scolopax rusticola at Conan. (L. E E. Phil. Mag., II. ; P.Z.S., July 24.) 
x837. MacGillivray, W. Sea Birds of Cromarty Firth. (In his Hist. Brit. Birds, I.) 8vo. Lond. : I837 ; Brent Goose on Cromarty Firth. (Edinb. Jnl. N. H., May.)

I838. "W. L." Woodcocks breeding in Ross-shire. (Charlesw. Mag. N. H., II.)

I848. Milner, Sir W. M. H. Birds of Sutherlands., Ross., etc. (Zool.) 1850. Smith, J. On Sea-Fowl breeding in Moray Firth. (Op. cit.)

I85I. Bond, F. Iceland Falcon in Ross-shire. (Op. cit.)

1853. Longmuir, J., junr. Additional Heronries. [partim.] (Nat. [Morris's], III.)

I86r. Buxton, E. C. Golden Eagle nesting in Scotland. (Op. cit.)

r867. Legge, W. V. Ornithology of Firth of Cromarty. (Zool.)

r869. Hugel, Baron A. de. Snowy Owl in Ross-shire. (Op. cit.)

I872. Harting, J. E. British Heronries. (Zool.) [partim.]

I876. Cooke, H. Wood Wren in Ross-shire. (Zool.)

Mackenzie, O. H. Nesting of Goosander in Ross-shire. (Field, May 20.)

1879. Marshall, E. S. Hoopoe in Ross-shire. (Field, May r7.)

I88I. "T. M'K." Pied Flycatcher in Ross-shire. (Op. cit., May 7.)

I886. Dixon, J.H. Gairloch in N.W. Ross-shire. 8vo. Edinb. : I886. [ITI.]

I887. Harvie-Brown, J. A., and Buckley, T. E. A Vertebrate Fauna of Sutherland, Caithness and W. Cromarty. Sq. 8vo. Edinb.: I887. [282.]

I889. Harvie-Brown, J. A. Priest Island and its Bird Life. Norf. \& Norw. Soc.)

1890. "C. W." Golden Eagles in Ross-shire. (Field, July I2.)

I892. Evans, A. H. On Supposed Breeding of Sclavonian Grebe in Ross. (Ann. Scott. N. H.) [I99.]

Hinxman, L. W., and Clarke, W. E. Wood Wren in West Ross. (T.c.)

1894. Hinxman, L. W., and Clarke, W. E. Contribution to Vertebrate Fauna of West Ross. (Pr. Roy. Phys. Soc. Edinb., XII.) Idem. Addit. Notes. (Ann. Scott. N. H., I903.) [I33.]

Bell, R. B. Roller in E. Ross. (Ann. Scott. N. H.)

Buckley, T. E. Sea Eagle in W. Ross. (T.c.)

Marshall, E. S. Hoopoe in W. Ross. (T.c.)

I896. Evans, A. H. Notes on Birds of W. Ross. (Op. cit.)

I897. Craig, A. Birds of Kintail. (Tr. Edinb. F. N. Soc., III.) Morley, J. Golden Eagle in Ross. (Zool.)

I898. Dobbie, J. B. Contribution to Avifauna of W. Ross. (Amn Scott. N. H.) 
Cameron, D. Great Spotted Woodpecker in Ross. (Field, Nov. 26.)

Fowler, J. A. Rose-coloured Pastor in W. Ross. (Ann. Scott. N. H.)

I90I. Fowler, M. T. Lesser Whitethroat nesting in W. Ross. (Op. cit.)

I904. Harvie-Brown, J. A., and Buckley, T. E. A Fauna of the N.W. Highlands and Skye. 8vo. Edinb. : 1904. [282.]

I907. Rickett, C. B. White Wagtail in E. Ross.; Wood Wren in E. Ross. (Brit. Birds, I.)

I908. Murray, Col. W. H. E. Hoopoe in Ross. (Field, Oct. I2 ; Brit. Birds, II.)

Igro. Jackson, Miss A. C. Occurrence of Yellow-browed Warblers in E. Ross. (Ann. Scott. N. H.) Idem by H. S. Gladstone. (Iois.)

I9I2. Jackson, Miss A. C. Continental Redbreasts in E. Ross. (Scott. Nat.)

1913. Fowler, C. M. Iceland Gull in W. Ross-shire. (Scott. Nat.)

Harvie-Brown, J. A. Tree-Sparrow in E. Ross. ; Shoveler in Moray Firth; Fulmars in Moray Firth. (Op. cit.)

Jackson, A. C. Scarlet Grosbeak in Moray Area ; Roseate Terns and Smews, etc. in Moray Area. (T.c.) 6 notes.

I9I4. Jackson, A. C. Nesting of Pintail in Moray Area; Nesting of Great Crested Grebe in Moray Area ; Honey Buzzard in Rossshire. (Scott. Nat.)

Oldham, C. Goldfinch in Moray Area. (T.c.)

I9I5. Allan, T. Glaucous Gulls and Little Auks off E. Coast of Ross. (Op. cit.)

Fowler, A. Little Auk on W. Coast of Ross. (T.c.)

Jackson, A. C. Great Grey Shrike in E. Ross. (T.c.)

Ogilvie-Grant, W. R. Scottish Crested Tit in E. Ross. (Brit. Birds, IX.) Idem. (Bull. B.O.C., XXXVI.)

IgI6. Ogilvie-Grant, W. R. Extension of known range of Scott. Crested Tit in E. Ross. (Brit. Birds, IX.)

I9I7. Jackson, A. C. Occurr. of Red-necked Grebe in Moray Area. (Scott. Nat.) Idem by C. Oldham. (T.c.)

I9I8. Mackenzie, O. H. Vanishing birds ... on W. Coast of Ross. (Op. cit.)

\section{ROXBURGHSHIRE.}

1843. Jerdon, Archibald. Arrival of Summer Birds at Boujedward, near Jedburgh; White-winged Crossbill in Scotland; Note on Siskin; Habits of Black-headed Gull; Cream-coloured Grouse. (Zool.) 
I844. Jerdon, A. Notes on the Dipper; Song of Missel Thrush; On Song Thrush ; Note on Wagtails; On the Siskin, etc. (Op. cit.)

1847. Jerdon, A. On Partial Migration of Birds in Roxburghs. ; Arrival of Summer Birds in 1846 and 1847 . (Op. cit.)

I850. Jerdon, A. List of Birds of Roxburghs. ; Unnecessary Destruction of Rare Birds. (Op. cit.)

I865. Robson-Scott, J. Notice of a Heronry. (Hist. Berw. Cl., V., p. 220.)

I871. Douglas, Dr. Francis. Breeding of Woodcock in Roxburghs. (Op. cit., VI., p. I96.)

1872. Elliot, Sir W. Notice of Goshawk and other Rare Birds. $(O p$. cit., VI., pp. 3I8-25.)

I872-4. Hardy, J. Zoological Miscellanea. (Op. cit., VI., pp. 424-33 ; VII., pp. 290-8.)

1872-9. Brotherston, A. Zoological Notes, 7 pts. (Op. cit., VI., pp. 434-5 ; VII., pp. I32-5, 285-9, 500-06; VIII., pp. I80-8, 520-6 ; IX., pp. I75-7.)

1873. Hardy, J. Crossbills shot near Jedburgh. (Op. cit., VII., p. 108.)

1873-4. Brotherston, A. Osprey on Tweed. (Scott. Nat., II.)

1874. Forrest, A. O. Parrot Crossbills near Jedburgh. [errore?] (Field, May I6.)

Jerdon, A. On Birds at Mossburnford. (Hist. Berw. Cl., VII., pp. 292-3.)

Scott, R. Arrivals of Migratory Birds at Belford. (T.c., p. 276) ; Note on Oystercatcher. (T.c., p. I92.)

1875. Elliot, Sir W. Rarer Birds in Neighbourhood of Hawick. (T.c., pp. 524-5.)

I875-82. Gray, R. Ornitholog. Notes. (Op. cit., VII., pp. 463-7; VIII., pp. I55-9, 498-502 ; X., pp. I97-200.)

I876. Knight, V. On Occurrence of Rare Birds in this [Kelso] District. (Op. cit., VIII. [I876-78], pp. I09-Io.)

Smail, J. Zoological Notes. (T.c., pp. 99-106.)

Webster, T. Goosander near Hawick. (Field, May I8.)

I877. Knight, Valentine. Ornitholog. Notes. (Hist. Berw. Cl., VIII., pp. 259-63.)

I878. Brotherston, A. Effects of Winter. (T.c., pp. 535-8); White's Thrush in Roxburghs. [suspected]. (T.c., p. 5I8.)

Hardy, J. Miscellanea. (T.c., p. 532.)

I879. "A. E.." Shovelers in Roxburghs. (Field, May I7.)

I879-8r. Hardy, J. Migrations, etc. (Hist. Berw. Cl., IX., pp. I22-57, $387-409,549-63), 3$ papers.

Robson-Scott, J. Arrivals of Migrants at Belford. (T.c., pp. 409-ro.) 
I882. Robson-Scott, J. A Deserted Heronry. (Op. cit., X., p. 87.) Smail, J. Rooks and Rookeries. (T.c., pp. x59-84.) [partim.]

1883. Bolam, J. Ornitholog. Notes. (T.c., pp. 384-96.) [78.]

Smail, J. Border Heronries. (T.c., pp. 33p-4.) [partim.]

I884. Bolam, G. Arrivals and Departures of Birds. (T.c., pp. 58I-89.) I885. Thomson, J. Nat. Hist. Observations at Maxton. (Op. cit., XI., pp. 25I-8.) Habits of Ox-Eye [Blue Tit]. (T.c., p. 250.)

1886. Evans, W. Ornitholog. Notes. (T.c., p. 542.)

1888. Evans, W. On Redfooted Falcon in Roxburghs. (Op. cit., XII., p. 394.)

I889. Elliot, A. Crossbills in Roxburghs. (Field, May I8.)

I89I. Bolam, G. Ornitholog. Notes. (Hist. Berw. Cl., XIII., pp. 34568.)

Evans, A. H. Preliminary List of Birds of Melrose District, 2 pts. (Scott. Nat., XI.)

1894. Douglas, C. Carrion Crow versus Rooks. (Hist. Berw. Cl., XV., pp. I93-4.)

I899. Bolam, G. Ornitholog. Notes. (Op. cit., XVIII., p. 96.)

Smail, J. Longtailed Tit. (T.c., p. III) ; Country Bird Rhymes. (T.c., pp. I23-5.)

I903. Simpson, H. D. Great Spotted Woodpecker in Roxburghs. (Ann. Scott. N. H.)

Steel, A. Glossy Ibis in Roxburghs. (T.c.)

I907. Clarke, W. E. Supposed Occurrence of Yellow-shanked Sandpiper near Hawick. (Op. cit.)

I9Ir. Blackwood, G. G. Wigeon Breeding in Roxburghs. (Op. cit.)

1912. Chapman, A. Spotted Crake Nesting in Roxburghs.; Spring Notes on the Borders (I9II-I2.) (Brit. Birds.)

Waldron, P. L. Montagu's Harrier in Roxburghs. (Scott. Nat.)

I913. Bolam, G. Jays in Roxburghs. (Nat.)

\section{ST. KILDA.}

(Cf. also Hebrides (Outer), some of the items under that heading containing references to St. Kilda.)

I698. Martin, M. A Late Voyage to St. Kilda. 8vo. Lond. : I698. And subsequent edits. [388.]

I752. Buchan, A. A Description of St. Kilda. I2mo. I752. Idem. Another edit. I773. [I02.]

I764. Macaulay, K. The History of St. Kilda. 8vo. Lond. : I764. 2nd edit. I765. [366.] 
I787. Knox, J. Tour through the Highlands of Scotland and the Hebride Islands. 8vo. Lond. : I787. [336.]

I793. Buchanan, J. L. Travels in the Western Hebrides. I2mo. Lond. : I793. [IO3.]

I8II. Macdonald, J. [Birds of St. Kilda in] General View of the Agriculture, etc., of the Hebrides. 8vo. Edinb.: I8II. [367.]

I824. Jardine, Sir W. Notice regarding the Island of . . . . St. Kilda. (Edinb. Phil. Journ.)

I832. Atkinson, G. C. Notice of Island of St. Kilda ...... with Notes on its Birds. (Tr. Nat. Hist. Soc. of Northumbd., etc.)

1834. Martin, M. Rock Birds. Extracted by J. D. Salmon. (Loudon's Mag. N. H., VII.)

I84I. MacGillivray, J. Account of the Island of St. Kilda. (Edinb. Nere Phil. Journ.)

Wilson, J. Additional Notes regarding St. Kilda. (T.c.)

I842. Wilson, J. J. A Voyage round the Coasts of Scotland and the Isles. 2 vols. 8vo. Edinb. : I842. [653.]

I848. Milner, W. M. E. Some Account of the People of St. Kilda and the Birds of the Outer Hebrides. (Zool.)

1869. Elwes, H. J. Bird Stations of Outer Hebrides. (Ibis.)

[I876.] Sands, J. Out of the World; or the Life in St. Kilda. 8vo. Edinb., etc. : N.D. 2nd edit. I877. [507.]

I878. Seton, G. St. Kilda : Past and Present. Sq. 8vo. Edinb., etc. : I878. [525.]

1884. Barrington, R. M. The St. Kilda Wren. (Zool.)

Seebohm, H. On a New British Wren. (T.c.) [5I7.]

I885. Dixon, C. The Ornithology of St. Kilda (and further notes on the same), 2 pts. (Ibis.) [I6g.]

I886. Dresser, H. E. On the Wren of St. Kilda. (Op. cit.) [I79.] I894. Sharpe, R. B. [Exhib. of Subalpine Warbler from St. Kilda. (Bull. B.O.C., IV.)

Elliott, J. S. Exhibition of Birds, etc. from St. Kilda. (Jnl. B'ham N. H. \& Phil. Soc., Oct.) ; Notes from St. Kilda. (T.c., Dec.)

I895. Elliott, J. S. Observations on Fauna of St. Kilda. (Zool.) ; St. Kilda and the St. Kildans, 2 pts. (Jnl. B'ham N. H. \& Phil. Soc., Mar., Apr.)

Macpherson, H. A. White-fronted Goose in St. Kilda. (Zool.) Idem by W. E. Clarke. (Ann. Scott. N. H.)

I898. Evans, H. Great Shearwater at St. Kilda. (Ann. Scott. N. H.) I900. Heathcote, N. St. Kilda. 8vo. Lond. : I900. [290.]

I903. Wiglesworth, J. St. Kilda and its Birds. 8vo. Liverpool : I903. [649.] 
I905. Mackenzie, N. Notes on Birds of St. Kilda. (Ann. Scott. N. H.) I9II. Clarke, W. E. American Water Pipit at St. Kilda. (Ann. Scott. Nat. Hist.)

I9I2. Clarke, W. E. Baird's Sandpiper at St. Kilda. (Scott. Nat. ; Brit. Birds, V.) ; [List of Birds of St. Kilda in his] Studies in Bird Migration. 8vo. 2 vols. Lond. : rgr2. [I35.]

I9I4. Wade, E. W. Great Shearwaters at St. Kilda. (Brit. Birds, VIII. ; Field, July II.)

I9r5. Clarke, W. E. The Wren of St. Kilda : its Status, Plumages and Habits. (Scott. Nat.)

I9I6. Read, R. H. Land Rail on St. Kilda. (Brit. Birds, IX.)

\section{SELKIRKSHIRE.}

I837. "W. L." Breeding of Woodcocks in Selkirks., etc. (Charlesw. Mag. N. H.)

I873. Brotherston, Andr. Zoological Notes. (Hist. Berw. $\mathrm{Cl}$., VII., pp. I32-5.)

1875. Elliot, Sir W. Rare Birds in Neighbourhood of Hawick, etc. (T.c., pp. 524-5.)

I876. Kerss, J. On the Ornithology of Bowhill. (Op. cit., VIII., pp. I97-8.)

I876-82. Gray, R. Ornitholog. Notes, 4 pts. (Op.cit., VIII., pp. I55-9, 498-502 ; IX., pp. 365-8; X., pp. I97-200.)

I879. Hardy, J. Effect of Winter, I878-9. (Op. cit., IX., pp. I22-57.)

I880. Hardy, J. Migrations, etc., I880. (T.c., pp. 387-409)

I882. Smail, J. Rooks and Rookeries. (Op. cit., X., pp. I59-84.)

I883. Anderson, T. Bewick's Swans in Selkirks. (T.c., pp. 334-8.) Smail, J. Border Heronries. (T.c., pp. 330-34.)

I884. Trefusis, W. R. Pied Flycatcher at Selkirk. (Field, May I7.)

I886. Lindsay, J. The Haining, Selkirks., with Notices of its . . . Nat. Hist. (Tr. Edinb. Nat. F. C., I., I88I-6.)

I889. Evans, W. Drumming of the Snipe [on Ettrick Pen]. (Zool.)

I89I. Evans, A. H. A Preliminary List of the Birds of the Melrose district, 2 pts. (Scott. Nat., IX., I89I.)

r893. Evans, W. Tufted Duck and Wigeon breeding in Selkirks. (Ann. Scott. N. H.)

Marshall, E. S. Tufted Duck breeding in Selkirks. (T.c.)

1895. Adair, P. Wigeon breeding in Selkirks. (Op. cit.)

I898. Adair, P. Notes on Birds of Ettrick. (Op. cit.) 
1899. Alexander, D. Carnegie. Birds observed in Selkirks. (Hist. Berw. Cl., XVII., pp. 44-46.)

Igor. Marshall, J. M'L. Notes on Birds of St. Mary's Loch District. (Ann.Scott. N. H.)

Ig08. Evans, W. Drumming of the Snipe [on Ettrick Pen]. (Zool.)

Igr2. Chapman, A. Spring Notes on the Borders (IgII-I2). (Brit. Birds, VI.) [I24.]

IgI5. Brown, R. Alpine Black Grouse in Selkirks. (Scott. Nat.)

\section{SHETLAND ISLANDS.}

I7rI. Sibbald, Sir R. [edited by]. Robert Monteith's MS. Description of the Isles of Orkney and Zetland. Fol. I7II. [536.]

I75I. [Anonymous.] A Voyage to Shetland, the Orkneys, etc. 8vo. Lond. : I75I. [I6.]

I786. Gifford, T. Historical Description of the Zetland Islands. 4to. Lond. : I786. Reprinted I879. 8vo. [227.]

I806. Neill, R. A Tour through some of the Islands of Orkney and Shetland. 8vo. Edinb. : 1806.

I809. Edmondston, A. View of the Ancient and Present State of the Zetland Islands. 2 vols. 8vo. Edinb. : I80g. [I92.]

I8I5. Laing, J. Account of a Voyage to Spitzbergen. 8vo. Edinb. : I8I5. 2nd edit. I2mo. I8I8. [336.]

I8I8. Edmondston, L. Observations on Natural History of Colymbus immer. (Mem. Wernerian N. H. Soc., II.)

1822. Edmondston, L. Observations on the Snowy Owl ; Account of a New Species of Larns [Iceland Gull] shot in Zetland; Additional Account of Iceland Gull ; Observations on Immer Goose of Zetland. (Op. cit., IV., pt. I.)

Vetch, Capt. Account of the Island of Foula. (T.c.)

I823. Edmondston, L. List of Birds observed in Zetland Is. $(O p$. cit., IV., pt. 2.)

Edmondston, L. List of Additional Birds in Zetland. (Edinb. Phil. Journ., VIII.)

Edmondston, L. Notice of Larus eburneus, or Ivory Gull, shot in Zetland; and further remarks on Iceland Gull. (Mem. Wernerian N. H. Soc., IV., pt. 2.)

Edmondston, L. Observations on Lesser Guillemot and Blackbilled Auk. (Op. cit., V., pt. I.)

I830-3I. Drosier, R. Ornitholog. Visit to Is. of Shetland and Orkney in Summer of I828. 2 parts. (Loudon's Mag. N. H., III., IV.) 
1834. Anderson, G. and P. Guide to the Highlands and Islands of Scotland. 8vo. Lond.: I834. [I2.]

I837. Dunn, R. Ornithologist's Guide to the Islands of Orkney and Shetland. 8vo. Lond. : I837. [I86.]

I843. Edmondston, T., junr. Capture of Sea Eagle in Shetland; Note on the Northern Diver. (Zool.)

I844. Edmondston, T., junr. Fauna of Shetland. (Zool.) Idem. Additions to Birds. (T.c.)

I848. Dunn, R. Surf Scoter in Shetland; Glaucous Gull and Iceland Gull ; Note $r e$ Grey Phalarope, etc. ; Some Notes on Birds of Shetland. (Op. cit.)

I849. Wolley, J. Common Crane in Shetland. (Zool.)

I851. Dunn, R. Waxwing in Shetland. (Zool.)

I853. Dunn, R. Rook in Shetland; Little Gull in Shetland. (Op. cit.) I856. Edmondston, Eliza. Sketches and Tales of the Shetland Islands. Fcap. 8vo. Edinb. : 1856 . [I92.]

1859. Edward, T. Var. of Common Bunting in Shetland. (Zool.)

I86I. Crotch, W. D. Notes on the Fauna of Shetland, and Postcript to same. (Zool.) [I57.]

Saxby, H. L. Additions to Mr. Crotch's Notes; Nest of Snow Bunting in Shetland; Occurrence of Uncommon Birds at Balta Sound. (T.c.)

I862. Saxby, H. L. Note on Spotted Woodpecker [in Shetland]. (Zool.)

I863. Martyn, C. Sand Grouse [in Shetland]. (Field, Nov. 2I.)

Saxby, H. L. Occurrences in Shetland, I8 notes. (Zool.)

Morris, F. O. Rose-coloured Starling [shot in Shetland]. (Field, Nov. 7.]

I864-7I. Saxby, H. L. Ornithological Notes from Shetland, 2I papers. (Zool., I864, I867, I869, I87I.) [5I0.]

I865. Saxby, H. L. Cranes in Shetland. (Op. cit., I865.)

I868. Gurney, J. H., junr. Snowy Owls in Shetland. (Op. cit.)

I871. Harting, J. E. Red-throated Pipit at Unst. (Field, Aug. 26.) Saxby, H. L. Great Grey Shrike in Shetland. (Zool.)

I874. Saxby, H.L. The Birds of Shetland. 8vo. Edinb., etc. : I874. I875. Newman, E. Birds of Shetland. (Notice of Saxby's Work.) (Zool.)

Saxby, S. H. Whitebacked Woodpecker. (Zool.)

I878. Wolstenholme, C. D. Redthroated Diver in Shetland. (Sci. Gossip.)

I879. Low, G. A Tour through the Islands of Orkney and Shetland in I774. 8vo. Kirkwall: I879. [362.] 


\section{Selection of Books from WITHERBY \& CO.'S List.}

\section{BRITISH BIRDS.}

An Illustrated Monthly Magazine devoted to the Birds on the

British List. Edited by H. F. Witherby, M.B.E., F.Z.S., M.B.O.U. Assisted by Rev. F. C. R. Jourdain, M.A., M.B.O.U., and N. F. TICEHURST, O.B.E., M.A., F.R.C.S., M.B.O.U. Illustrated with beautiful and useful photographs. Provides a current history of British Birds. Annual Subscription, 20s. post free; Monthly, Is. 9d. net. Vols. I-XII. (unbound), I2s. each; bound, I5s. 6d. each net.

\section{TROPICAL WILD LIFE IN BRITISH GUIANA.}

Being Zoological Contributions to Science, from the Tropical Research Station of the New York Zoological Society, at Kalacoon, rgi6. By William Beebe, G. Inness Hartley and Paul G. Howes, with an Introduction by Colonel THeOdORE RoOsevelT. Octavo. Cloth. 504 pages. 4 Coloured Plates, and I 40 other Illustrations. $2 \mathrm{~s}, 6 \mathrm{~d}$, net:

\section{A MONOGRAPH OF THE PHEASANTS.}

By William BeEBE. With Numerous Coloured Plates by A. Thorburn, C. R. Knight, G. E. Lodge, L. A. Fuertes, H. GronvoLD, and H. JONES. Together with Maps and Numerous Photographs by the Author, depicting the Pheasants of the World, their Haunts, their Changes of Plumage and their Nests and Eggs. Limited Edition of 600 Numbered Sets, only a portion of which are available for sale in the British Empire. Royal 4 to. In Four Volumes, Volume I now ready. Prospectus and Specimen Plate on application:

\section{A HAND-LIST OF BRITISH BIRDS.}

By Ernst Hartert, F.C. R. Jourdain, N. F. Ticehurst, and H. F. Witherby. Demy 8vo. 7s. 6d. net. Interleaved ros. net.

THE BIRD-LOVER'S HOME-LIFE SERIES.

I. The Home-life of the Golden Eagle. 2. The Home-life of the Spoonbill, the Stork and some Herons. 3. The Home-life of the Osprey. 4. The Home-life of the Terns or Sea-Swallows. Each Volume contains 32 beautiful plates, artistically mounted from PHOTOGRAPHS DIRECT FROM NATURE, with 40-60 pages of letterpress. Crown 4to. Cloth $75.6 \mathrm{~d}$ net each.

\section{GAME BIRDS AND WATER-FOWL OF SOUTH} AFRICA.

By the late MAjor BOyd Horsbrugh, F.z.s., M.B.O.U. With 67

beautiful Coloured Plates. Half morocco. $£ 4$ I4S. net, or unbound parts.

\section{INDIAN PIGEONS AND DOVES.}

By E. C. Stuart BAKer, F.z.S., M.B.O.U. With 27 beautiful

Coloured Plates. Imp. 8 vo. Half bound morocco. $£^{2}$ ros. net.

PHOTOGRAPHY FOR BIRD-LOVERS.

By Bentley Beetriam, f.z.s. I 6 full-page Plates. A practical guide to the pursuit of bird-photography in all its branches. Demy 8vo. Cloth. 5s, net.

JUNGLE PEACF.

By WILLIAM BEEBE, Contains records of extraordinary scientific interest. The author tells of bird, beast, plant and insect life of the British Guiana jungle. Crown 8vo, illustrated. 8s. net.

THE BUZZARD AT HOME.

By ARTHUr BRook. The photographs, which are here first published, have special interest to Ornithologists. Twelve plates. 3s. $6 \mathrm{~d}$, net: 


\section{DE NOW READY Volume I. (Passeres).}

\section{A PRACTICAL HANDBOOK OF BRITISH BIRDS.}

Edited by H. F. WITHERBY, M.B.E., M.B.O.U., F.Z.S., F.R.G.S. Contributors:-E. Hartert, PH.D., M.B.O.U., F.z.S. ANnIE C. Jackson, H.M.B:O.U. Rev, F:C. R. Jourdatn, M:A., M.B.o.u. C. Oldham, F.Z.s., M.B̈.O.U, N. F.TICEHURST, О.B.E., M.A., F.R.C.S., M.B.o.U.

Specially arranged for quick reference. Distinguishing characters simplifying identification, full description of all plumages. 13reeding liabits (nest, eggs, season, incubation, etc.). Food. Distribution and Migration.

WITH COLOURED

MONOCHROME 'PLATES:

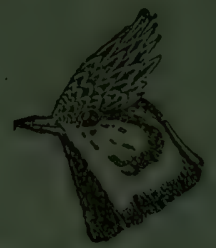

NUMEROUS TEXT FIGURES. PRACTICAL ORIGINAL. UP-TO-DATE.

VOL. I. Bound in Buckram, Gilt Top, ... ... Price 408. Thin Paper Edition (bound in rexine), useful for Field Naturalists and Travellers. ... ... Price 48s.6d.

VOL. II. 10 parts (completing the work) now in progress. Price 48. 6d. (5s:6d. Thin Edition) each:

\section{A HANDBOOK TO THE VERTEBRATE FAUNA OF NORTH WALES \\ By H, E. FORREST.}

This book not only brings up to date the information contained in the Author's "Vertebrate Fauna of North Wales," but also gives under each species a brief summary showing its status in the district.

Deny 8 vo.

Cloth.

6s, net.

\section{METEOROLOGY FOR ALL.}

\section{BEING SOME WEATHER PROBLEMS EXPLAINED}

By DONALD : IV. HORNER, 'F.R.MET.SOC., etc. Author of "Observing and Forecasting the Weather."

"Weather Instruments and How to Use Them.".

With Text and Half-Tone Illustrations.

A compendium of information about the Weather as it daily affects the. lives of everyone. The "ciry" terseriess of the text-l,ook has been avoided, but the information given is comprehensive and reliable, and of a practical nature.

Crown 8vo.

Cloth

xllustrated.

6s. net,

326, HIGH HOLBORN, LONDON, W.C.I. 
A

\title{
GEOGRAPHICAL BIBLIOGRAPHY
}

OF

\section{BRITISH ORNITHOLOGY}

\author{
FROM THE EARLIEST TIMES \\ TO THE END OF 1918 \\ ARRANGED UNDER COUN'TIES
}

BEING A RECORD OF PRINTED BOOKS, PUBLISHED ARTICLES, NOTES AND RECORDS RELATING TO LOCAL AVIFAUNA

By

W. H. MULLENS, M.A., LL.M., F.L.S., M.B.0.U ,

H. KIRKE SWANN, F.Z.S., M.B.O.U., AND

REv. F. C. R. JOURDAIN, M.A., M.B.o.v. 2492.57

"Men that undertake only one district are much more likely to advance natural knowledge than those that grasp at more than they can possibly bo acquainted with; every kingdom, every provinee, should have its own monographer."

Grlbert Warte- " The Natural History of Selborne." 7th Lettor to Barrington.

WITHERBY \& CO.

326, HIGH HOLBORN, LONDON 

Edmondston, T. Hoopoe in Inverness-sh. [and Shetland]. (Field, May Io.)

Garriock, J. Fulmar Petrel breeding in Isle of Foula. (Zool.)

Gifford, T. Historical Description of the Zetland Islands in the year I733. 8vo. Edinb. : I879.

Purnell, W. Great Skua in Shetland. (Zool.)

Vaughan, M. Reported Nesting of Golden Eagle in Shetlands. (T.c.)

I88o. Garriock, J. T. Nat. Hist. Notes from Lerwick. (Op. cit.)

I88I. Saunders, H. On Skuas and other Birds observed in Shetland, Is. $(O p$. cit.)

Sim, G. Hoopoe in Shetland. (T.c.)

I882. Chambers, C. Spotted Crake on Island of Fetlar. (Op. cit.)

I883. Tudor, J. R. The Orkneys and Shetlands. Cr. 8vo. Lond. : I883. [59I.]

I884. Edmondston, T. Rough-legged Buzzard in Shetland. (Zool.)

I886. Harvie-Brown, J. A. Yellow-browed Warbler in Shetland. $(O p$. cit.)

Harvie-Brown, J. A. Phylloscopus superciliosus at Sunburgh Head Lighthouse. (Pr. R. Phys. Soc. Edinb., 1885-6; Zool.)

I887. Garriock, J. T. Curlew Sandpiper and Spotted Crake in Shetland. (Zool.)

Russell, John. Three years in Shetland. I vol. 8vo. Paisley : I887.

I888. Anderson, C. A. Wryneck in Shetland. (Zool.)

I888-gr. Raeburn, H. The Summer Birds of Shetland, with Notes on their Distribution, etc. (Pr. Roy. Phys. Soc. Edinb., I888.) Idem. Further Notes, 2 pts. (Op. cit., I8gI.)

I89o. Barrington, R. M. Great Skua in Foula, and Additional Note; List of Birds observed in Shetland, June I900; The Shetland Wren. (Zool.)

Harvie-Brown, J. A. Great Skua on Foula. (T.c.) Idem by H. Raeburn. (T.c.)

Harting, J. E. Baltimore Oriole in Shetland. (T.c.)

Lloyd, H. D. Baltimore Oriole in Shetland. (Field, Nov. I5.) Idem by $\mathrm{T}$. Edmondston. (T.c., Nov. 29.)

Raeburn, H. Honey Buzzard in Shetland. (Zool.)

I89I. Evershed, H. A Trip to Foula. (Field, May 2.)

Horsfield, H. K. The Great Skua in Shetland. (T.c., Jan. I7.)

Idem by J. E. Harting. (T.c., Apr. 4.)

"N. B. C." Turtle Dove in Shetlancl. (Op. cit., Sept. I9.)

Raeburn, H. The Birds of Papa Stour, with Account of Lyra Skerry; Wren of Shetland. (Zool.) The Great Skua: its Present Status as a British Bird. (Scott. Nat., XI.) Little Bittern in Shetland. (T.c.) 
Seebohm, H. Common Wren of Shetland Is. (Zool.)

Skirving, R. S. The Advent of certain Birds to Shetland. (Field, May 23.)

1892. Harvie-Brown, J. A. Spotted Crake in Shetland. (Ann. Scott. N. H.)

I892-3. Clarke, W. E. Report on Great Skua in Shetland in I89I and I892. (Op. cit., I892-3.) [I33.]

1893. Blagg, E. W. H. Notes on Nesting of some Shetland Birds. (Ibis.)

Clarke, W. E. Ivory Gull in Shetland. (Ann. Scott. N.H.)

Harvie-Brown, J. A. Contributions to a Fauna of the Shetland Is., Autumn Notes. (T.c.) Idem, Correction, Lapland Bunting. (T.c.)

Saxby, J. M. E. Birds of Omen in Shetland. Cr. 8vo. IS93. [5II.]

Traill, A. H. Fulmar Petrel Breeding in Papa Stour. (Ann. Scott. N. H.)

r894. Clarke, W. E. The Persecution of the Great Skua. (Op. cit.) Harvie-Brown, J. A. Stock Dove in Shetland. (T.c.)

I895. Henderson, R. and T. Snowy Owl in Shetland. (Ann. Scott. N. H.) Raeburn, H. Red Grouse in Shetland. (T.c.)

I896. Godfrey, R. Richardson's Skua in its Nesting Haunts (Ornithologist); In Quest of the Erne (Ornithologist; Sci. Gossip, Oct.); The Stormy Petrel at Home. (Ornithologist.)

Godfrey, R. Bird Life on Rona's Hill. (Field, Sept. 26.) In the Wilds of North Roe. (T.c., Nov. 2I) ; Bird Life at Fethaland. (T.c., Dec. I9.)

Buckley, T. E. Greenland Falcon in Shetland. (Ann. Scott. N. H.)

Godfrey, R. Notes on Birds observed in Shetland during Summer of I8g6. (T.c.)

I897. Aplin, O. V. Nesting of Great Northern and Black-throated Divers in Shetland. (Zool.)

Buttress, B. A. List of Birds observed in Shetland, May and June I897; Nesting of Great Northern and Black-throated Divers in Shetland. (T.c.)

Godfrey, R. Cuckoo in Shetland. (Ann. Scott. N. H.); The Islands of Yell Sound. (Field, Jan. 9) ; Unst and its Bird Life. (T.c., Jan. 30) ; Bird Life around Walls. (T.c., May I) ; Rambles around Mossbank. (T.c., June I9.)

1898. Clarke, W. E. Whinchat, Ortolan Bunting and Pied Flycatcher in Shetland. (Ann. Scott. N. H.)

Godfrey, R. Fulmar Petrel Breeding on Noss. (T.c.)

Henderson, T. Remarkable Visitation of Migratory Birds to Shetland. (T.c.)

"Thule." Iceland Falcon in Shetland. (Field, Oct. I5.) 
I898-9. Harting, J. E. King Eider in Shetlands. (Ann. Scott. N. H., I898-9.)

I899. Graves, F. S., and Ralfe, P. Notes on Shetland Birds. (Zool.)

Kearton, R. Rare Birds of the Shetlands. (Field, Jan. 7.)

Edmondston, T. Rednecked Phalarope in Shetland. (T.c., Jan. 28.)

Harting, J. E. King Eider in Shetland. (T.c., Mar. II.) Idem by J. P. Chaworth Musters. (T.c., Mar. I8); by E. Bankart. (T.c., Apr. 8.)

Henderson, T. Occurr. of Blackbellied Dipper in Shetland. (Ann. Scott. N. H.)

Evans, A. H., and Buckley, T. E. A Vertebrate Fauna of the Shetland Islands. Sq. 8vo. Edinb. : I899. [105, I99.]

Whitaker, J. Pied Flycatcher in Shetland. (Field, June I7-24.) Idem by W. E. Clarke. (July 8.)

Igoo. Buckley, T. E. Smew and White-fronted Goose in Shetland. (Ann. Scott. N.H.)

Clarke, W. E. Scops Owl in Shetland. (T.c.)

Saxby, T. E. Ornitholog. Notes from Shetland. (Zool.)

r9oI. Aplin, O. V. The Robin in Shetland. (OP. cit.)

Clarke, W. E., and Laidlaw, T. G. On Some Migratory and other Birds in S. Shetland in Sept. (Ann. Scott. N. H.)

Sturrock, C. A. On Nesting of Redstart and Willow Wren in Shetland in Igor. (T.c.)

I902. Clarke, W. E. Common Tern Nesting in Shetlands. (Op. cit.) Harvie-Brown, J. A. Great Snipe in Shetland. (T.c.)

Inkster, A. Tengmalm's Owl in Shetland. (T.c.)

I902-6. Saxby, T. E. Ornitholog. Notes from Shetland, 6 pts. (Zool., I902-6.)

I903. Godfrey, R. Richardson's Skua Wintering in Shetland. (Ann. Scott. N. H.)

Henderson, T. Snowy Owl and Spring Migrants in S. Shetland. (T.c.)

I903-7. Saxby, E. Bird Notes from Shetland, 5 pts. (Op. cit., I903-7.)

I905. Henderson, T. Remarkable Visitation of Migratory Birds to Shetland. (Op. cit.)

Selous, E. Bird-Watcher in the Shetlands. 8vo. Lond. : I905. [522.]

Ig06. Clarke, W. E. Red-rumped Swallow at Fair Isle. (Ann. Scott. N. H.)

Clarke, W. E., and Kinnear, N. B. Rare Birds at Fair Isle. (T.c.)

Haldane, R. C. Supposed Breeding of Jack Snipe in Shetland. (T.c.)

Tulloch, J. S. Occurrence of Bullfinch in Shetland. (T.c.) 
Ig06-Io. Clarke, W. E. The Birds of Fair Isle, Native and Migratory. 7 pts. (Op. cit., Ig06-IO.)

I907. Clarke, W. E. Interesting Birds at Fair Isle. (Op. cit.)

Harvie-Brown, J. A. Garden Warbler in Shetland. (Ann. Scott. N. H.)

Henderson, T. Grey Plover, Woodcock and Great Crested Grebe in Shetland. (T.c.)

Hamilton, Erik. Tengmalm's Owl in Shetland. (Field.) Idem. (Brit. Birds, I908.)

I908. Clarke, W. E. Rare Birds at Fair Isle; Little Bunting on Fair Isle. (Ann. Scott. N. H.)

Tulloch, J. S. Chiffchaff in Shetland. (Brit. Birds, I.)

Hamilton, E. Tengmalm's Owl in Shetland. (Brit. Birds, I.)

Harvie-Brown, J. A. Pintails in Shetland. (Ann. Scott. N. H.)

I909. Clarke, W. E. Eversmann's Warbler at Fair Isle. (Ann. Scott. N. H. ; Brit. Birds, II.)

Tulloch, J. S. Long-eared Owls near Lerwick. (Ann. Scott. N. H.)

I9I0. Hamilton, E. Some Rare Birds in Unst. (Op. cit.)

Henderson, T. Whooper Swans breeding in Shetland. (T.c.) Tulloch, J. S. Northern Bullfinch in Shetland. (Brit. Birds.)

Witherby, H. F. Irruption of Crossbills in Shetland. (Brit. Birds, III.)

rgIr. Clarke, W. E. Blyth's Reed Warbler at Fair Isle. (Ann. Scott. N. H.)

Tulloch, J. S., and Evans, W. Holböll's Redpoll in Shetland. (Ann. Scott. N.H.)

Tulloch, J. S. Siberian Chiffchaff in Shetland. (Op. cit.)

Russell, G. W. Icterine Warbler in Shetland. (Op. cit.)

IgI2. Clarke, W. E. Pine Bunting, etc., at Fair Isle. (Scott. Nat.; Brit. Birds, V.)

Clarke, W. E. [List of Birds of Fair Isle in his] Studies in Bird Migration. 2 vols. 8vo. Lond. : I9I2. [I35.]

Saxby, T. E. Tengmalm's Owl in Shetland. (Scott. Nat.)

Bedford, Duchess of. Lapland Bunting at Fair Isle, etc. (T.c.) Harvie-Brown, J. A. The Fulmar, 2 pts. (Scott. Nat.) Idem. (Zool.; Brit. Birds, VI.) [partim.] [284.]

I9r3. Bain, J. Notes on Arctic Terns at the Pentland Skerries. (Scott. Nat.)

Bruce, S. Quail nesting in Shetland. (T.c.)

Clarke, W. E. Occurr. of Sykes's Blueheaded Wagtail at Fair Isle. (T.c.)

Ford-Lindsay, H. W. Barrow's Goldeneye and Common Goldeneye in Shetlands. (Brit. Birds, VII.)

Kay, T. Barred Warblers and other Birds in Shetland. (Scott. Nat.)

Russell, G. W. Notes on Shags and Fulmars in Shetland. (T.c.) 
Saxby, E. Honey Buzzard in Shetland. (T.c.)

Tulloch, J. S. Bird Notes from Shetland. (T.c.)

I9I3-I5. Clarke, W. E. Notes on Migratory Birds observ. at Fair Isle, I9I2-I4. (3 pts.) (Op. cit., IgI3-I5.)

I9r4. MacDougall, P. Fieldfares in Shetland. (Scott. Nat.)

Nicholson, A. J. Spotted Crake in Shetland. (T.c.)

Russell, G. W. Some Bird Notes from Shetland. (T.c.) ; Siberian Chiffchaff in Shetland in Winter. (T.c.)

Selous, E. Ornithological Observations [etc.] in Shetland. (T.c.) Tulloch, J. S. Redbreasts in Shetland; Grey Shrike in Shetland ; Bird Notes from Shetland. (T.c.)

White, A. Longeared Owl in Shetland. (Scott. Nat.)

I9I5. Bruce, S. Uncommon Bird Visitors in Shetland; Barred Warbler in Shetland in June. $(O p$. cit. $)$

Clarke, W. E. Eastern Short-toed Lark at Fair Isle; A new Scottish Bird; The Aquatic Warbler at Fair Isle. (T.c.)

Gurney, J. H. Gannets Breeding on Bressay. (Brit. Birds, IX.) Kirk, C. Siberian Chiffchaff in Shetland. (Scott. Nat.)

Robinson, H. W. Tengmalm's Owl in Shetland. (T.c.)

Tulloch, J. S. Nesting of Gannet in Shetland; Disappearance of Terns from the Skerries. (T.c.)

IgI6-I7. Selous, (E.) Ornithol. Observations [etc.] in Shetland, 4 pts. (Scoll. Nat., IgI6-I7.)

IgI7. Greenaway, W. H. Cuckoo at Foula Isle. (Op. cit.)

Saxby, T. E. Little Bittern in Shetland. (T.c.)

IgI8. Selous, E. Ornithol. Observations and Reflections in Shetland, 6 pts. (Nat., Apr., May, Sept.-Dec.)

\section{STIRLINGSHIRE.}

1833. Scouler, J. The Egyptian Goose [at Campsie]. (Loudon's Mag. N. H., VI.)

I838. "W. M. G." [MacGillivray ?] Birds observed on the Firth of Forth in Dec. I837. (Edinb. Journ. N. H., Feb. 1838.) [371.]

1858. Gould, J. Exhibition of Regulus calendula shot on Loch Lomondside. (P.Z.S.)

I864. Gray, R. Zoology of the Banks of Loch Lomond and its Vicinity. (In The Guide to the Trossachs and Loch Lomond). 8vo. Glasg. : I864. Appendix, I867.

Harvie-Brown, J. A. Kingfishers on the Carron; Reeve near Grangemouth. (Zool.)

I865. Harvie-Brown, J. A. Water Rail in Stirlings. (Op. cit.) 
I866. Harvie-Brown, J. A. List of Birds observed in two adjoining Parishes of Dunipace and Larbert; Great Grey Shrike in Stirlings. (Op. cit.) [280.]

I867. Harvie-Brown, J. A. Ornitholog. Notes from Stirlings., 2 pts. ; Ornitholog. Notes from Falkirk; Collected Observations on Birds of Stirlings.; Goosander and other Birds on the Firth; Kite in Stirlings. $(O p$. cit. $)$

Feilden, Capt. H. W. Nesting of Peregrine. (T.c.)

I868. Harvie-Brown, J. A. Curlew Sandpiper, etc., at Grangemouth; Birds of Stirlings. ; Notes from Stirlings., 2 pts. Storm Petrels, etc., in Firth of Forth; Rare Birds in N. of Scotland, etc. $(O p$. cit.)

"S." [Osprey near Falkirk.] (Field, Dec. I9.)

1869. Harvie-Brown, J. A. Ornitholog. Notes. (Op. cit.)

I872. Harting, J. E. British Heronries. (Zool.) [partim.]

1873. Harvie-Brown, J. A. Curlew Sandpiper, Ruffs and Reeves, etc. (Zool.)

Gray, R., and Harvie-Brown, J. A. On Sea Gulls and Iceland Gull in Firth of Forth. (Pr. N. H. Soc. Glasg.)

Lumsden, J., junr. Wood Sandpiper [on Loch Lomond]. (Scott. Nat., II.)

I874. Yuille, S. Redbacked Shrike in Scotland. (Field, Oct. I7.) I875-6. Gray, R. Ornitholog. Notes, 2 pts. (Hist. Berw. Nat. Cl., VII., pp. 46.3-7 ; VIII., pp. I55-9.)

1876. Lumsden, J. Sketch Paper on the Birds of Loch Lomond and Neighbourhood. (Pr. N. H. Soc. Glasg., III.) Additions. (T.c., IV., V., I88I-3.) [364.]

I877. Harvie-Brown, J. A. Green Sandpiper in Stirlings. (Zool.)

I878. Harvie-Brown, J. A. Plover-shooting on Stirlings. Coast ; Provincial Names in Scotland, 2 pts. (OP. cit.)

I879-8I. Harvie-Brown, J. A. Ornithol. Journal of Winters of 1878-79, I879-80 and I880-8I, 3 pts. (Pr. N. H. Soc. Glasg., I879-8I.)

I88I. [Harvie-Brown, J. A.] The Stirlingshire Coast and its Bird Life, by "Pickerel." I2mo. Falkirk : I88r.

I883. Lumsden, J. Ornitholog. Jottings from the Neighbourhood of Loch Lomond for I88I. (Pr. N. H. Soc. Glasg.)

1885. Evans, W. On Breeding of Marsh Tit in Stirlings. (Pr.R. Phys. Soc. Edinb., VIII.)

I89o. Aplin, O. V. Distribution, etc., of Spotted Crake. (Zool.) [24.] I892. Laird, F. Great Spotted Woodpecker in Stirlings. (Ann. Scott. N. H.)

I893. Harvie-Brown, J. A. Pintail Ducks in Forth District. (Op. cit.) I894. Harvie-Brown, J. A. Pochard on River Carron. (Op. cit.) 
I895. Lumsden, J., and Brown, A. Guide to Natural History of Loch Lomond and Neighbourhood. [Birds by J. Lumsden.] 8vo. Glasg. : I895.

I8g6. Evans, W. Nesting of Chiffchaff in Upper Forth. (Ann. Scott. N. H.)

Lumsden, J. Birds of Loch Lomond : a Correction. (T.c.)

I898-9. Sword, J. Notes on Avifauna of District [Stirlings.]. (Tr. Stirling N. H. \& Archceol. Soc., I898-9.)

Igoo. Harvie-Brown, J. A. The Great Snipe in Stirlings.; Bittern in Stirlings. (Ann. Scott. N.H.)

I903. Kirk, C. Pomatorhine Skua at Loch Lomond. (Op. cit.)

Ig08. Harvie-Brown, J. A. Canary Serin in Scotland. (Brit. Birds, II.)

I909. Evans, W. Goldeneyes in Forth Area in Summer [Stirlings. and Kinross.]. (Ann. Scott. N. H.)

I9ro. Evans, W. White Siberian Crane near Stirling. (Field, -

I9I2. Evans, W. Food of Common Partridge [in Stirlings.]. (Scott. Nat.)

I9I3. Evans, W. Pochard in E. Stirling in Breeding Season. (Scott. Nat.); Scandinavian Lesser Blackbacked Gull in Stirlings. (Brit. Birds, VII.)

rgr4. Macdonald, D. Green Sandpiper in W. Stirlings. (Glasg. Nat., VI., p. IOO.)

I9I6. Bodenham, H. Waterhens on Salt Water. (Field, Feb. 26.)

I9I8. Hay, L. C. Cuckoo Reared in a Window Box in Stirlings. (Scott. Nat.)

\section{SUTHERLANDSHIRE.}

I8r3. Gordon, Sir Robt., Bt. Genealogical History of the Earldom of Sutherland. Fol. Edinb. : I8I3. [237.]

I835. Selby, P. J. Notice of Birds observed in Sutherland, June I834. (Rep. Brit. Assoc. Adv. Sci., I834.) [52I.]

Jardine, W. Wigeon Breeding in N. of Scotland. (Loudon's Mag., N.H., VIII.)

(Hull Advertiser.) The Honey Buzzard [near Brandon]. (T.c.)

I836. Selby, P. J. On . . Birds Inhabiting Co. of Sutherland, observed during an Excursion in Summer of I834. (Edinb. New Phil. Jnl., I836.) (Repr. in Tr. N. H. Soc. Northd., etc.)

I837. Selby, P. J. Distribution of Cirl Bunting in Britain. (Nat. [Wood's], II.) [partim.]

I846. Buzzard, Dr. The Ornithology of Sutherlands., etc. (Zool.; Leeds Phil. \& Lit. Soc. Ann. Rept., I880-I.) 
I849. St. John, Chas. Tour in Sutherlandshire. 2 vols. 8vo. Lond. : I849. New edit. I884. [502.]

1853. Buxton, E. C. Woodcocks Nesting in Sutherlands, etc. (Zool.) 1855. Milner, Sir W. M. E. Snowy Owl in Sutherlands. (Op. cit.) 1859. M'L- W. A. Snowy Owl in N. of Scotland. (Field, July 23.) I862. Devoniensis. The Great Bustard seen in Sutherlands. $(O p$. cit., Feb. 22.)

I863. McLeay, W. A. Sand Grouse [at Dornoch]. (Op. cit., June I3.) Saville, S. P. Snowy Owl in Sutherlands. (Zool.)

r865. Snowie, T. B. Iceland Falcon in Sutherlands. (Field, May 6.) r866. Colquhoun, J. Sporting Days [List of Birds in]. 8vo. Edinb.: I866. [I40.]

I867. Harvie-Brown, J. A. Extracts from Journal of a Nesting Tour. (Zool.) [280.]

1867-72. "T. M. K." Tree Sparrow in Sutherlands. (Field, July 27, I867; June I, I872.)

I868. Harvie-Brown, J. A. Ornitholog. Notes for last six months, including Extracts from Journal of a Nesting Tour. (Zool.)

I869. Bateson, J. Destruction of Rare Birds. (Field, Mar. 27.)

I872. Harting, J. E. British Heronries. (Zool.) [partim.]

I874. M'K- T. Blackcap in Sutherlands. in Feb. (Field, Feb. 28.) I875-8. Harvie-Brown, J. A. On Birds found breeding in Sutherlands. (Pr. N. H. Soc. Glasg., I875.) Idem, Suppl. Notes. (Op. cit., I878.)

1876. Clifton, Lord. Wood Wren and Greenshank in Sutherland. (Zool.) Notes from Sutherland. (Field, Dec. 2.)

I877. Dennistown, A. Iceland Falcon in Sutherland. (Field, Apr. I4.) Idem by W. Hamilton. (T.c., Mar. 24.)

I878. Mackenzie, T. Crossbill nesting in Sutherlands. (Zool.)

I880. "C." Sea Eagle at Cape Wrath. (Field, May 22.)

Hamilton, E. Ornitholog. Notes from S.W. Sutherland $[=\mathrm{S} . \mathrm{W}$. Inverness, q.v.] (Op. cit.)

Crosfield, J. B. Notes on Nesting of Golden Eagle. (Proc. Holmesdale N. H. Club, I879-80.) Reigate: [I880.]

I882. Buckley, T. E. On the Birds of Sutherland. (Pr. N. H. Soc. Glasg., V.) [104.]

I884. Buckley, T. E., and Harvie-Brown, J. A. The Vertebrate Fauna of Sutherlandshire. [In St. John's Tour in Sutherlandshire, and edit.] 2 vols. 8vo. Edinb.: I884. [I04, 28I.] Macpherson, H. A. Rose-coloured Pastor in Sutherlands. (Zool.)

I885. Harvie-Brown, J. A. The N.W. Coasts of Sutherlands. and their Bird Life. (Pr. R. Phys. Soc. Edinb., I883-5.) 
1887. Harvie-Brown, J. A., and Buckley, T. E. A Vertebrate Fauna of Sutherland, etc. Sq. 8vo. Edinb. : r887. [282.]

I888. Griffith, H. Sand Grouse [in Sutherlands.]. (Field, June 23.)

I892. Buckley, T. E. Contributions to Vertebrate Fauna of Sutherland and Caithness. (Ann. Scolt. N.H.)

1897. Buckley, T. E. Snowy Owl in Sutherland. (Op. cit.)

Clarke, W. E. Fulmar Petrels at Cape Wrath in Breeding Season. (T.c.)

1899. Noble, H. Letter on Breeding of Scaup Duck in Sutherlands. (Bull. B.O.C., VIII.)

I90I. Saunders, H. Fulmar Breeding at Cape Wrath. (Ann. Scott. N. H.)

Saunders, H. Phylloscopus viridanus off Coast of Sutherlands. (Bull. B.O.C.)

I907. Whitehead, C. H. T. Nesting of Scoter in Sutherlands. (Field, July I8.)

I909. Henderson, J. T. Brambling in W. Sutherland. (Op. cit.)

I9I2. Alexander, H. G. Green Sandpiper in Sutherlands. (Brit. Birds, V.)

Mayall, A. Number of Fulmars on Handa. (Op. cit., VI.)

I9I3. Brooksbank, G. Wood Warbler in N. Sutherland. (Op. cit., VII.)

Gunnis, F. G. Hawfinch in Sutherland. (Scott. Nat.)

I9I7. Chase, R. W. Clutch of three Golden Eagle's eggs from Sutherlandshire. (Bull. B.O.C., XXXVII.) Idem. (Brit. Birds, XI.)

\section{WIGTOWNSHIRE}

I837. Thompson, W. On Hybrids... between Black Grouse and Pheasants [example shot at Lochnaw]. (Mag. Zool \& Bot., I.)

I859. " R. F. S. S." Quail [breed in Galloway]. (Field, Nov. 26.) I859-60. Bell, T. B. Notes from Neighbourhood of Stranraer and Leswalt, 2 papers. (Pr. Phys. Soc. Edinb., 1859-60.)

I864. Henry, J. S. Bewick's Swans in Wigtowns. (Field, Oct. 29.) r869. Gray, R., and Anderson, T. The Birds of Ayrshire and Wigtowns. 8vo. Glasg. : I86g. [25I.]

I875. Gray, R. Ornitholog. Notes. (Hist. Berw. Nat. Cl., VII., pp. 463-7.)

I888. Kennedy, A. Clark. The Longeared Owl in Scotland. (Field, Dec. I5.) 
I89I. Maxwell, H. Nutcracker in Wigtowns. (Scott. Nat., XI.)

1892. Adair, P. On Former Abundance of Quail in Wigtowns. (Ann. Scott. N. H.)

Maxwell, H. Bittern in Wigtowns. (T.c.)

I894. Maxwell, H. Wigeon on White Loch of Myreton. (Op. cit.)

I895. Maxwell, H. Shoveler in Wigtowns. (Op. cit.)

Paterson, J. Great Crested Grebe in Wigtowns. (T.c.)

I897. Maxwell, H. Great Crested Grebe and other Birds on White Loch of Myreton. (Op. cit.)

IgoI. Maxwell, $\mathrm{H}$. Sclavonian Grebe in Wigtowns. (Op. cit.)

I909. Bedford, Duchess of. Black-tailed Godwit in Wigtowns. (Brit. Birds, III.)

IgrI. Kennedy, J. N. Black Redstart in Wigtowns. (Brit. Birds, IV.) I9I2. Portal, M. Red-backed Shrike in Wigtowns. (Op. cit., VI.) I9I3. Gordon, J. G., and Witherby, H. F. Northern Willow Warblers in Wigtowns. (Brit. Birds, VII.) Dotterel in Wigtowns.
$($ T.c.) Gordon, J. G. Ornithological Notes from Wigtowns. (Scott. Nat.)

Igr4. Braid, C. H. Dotterel at the Mull of Galloway Lantern. (OP. Cowan, R. C. Ringed Grouse at Loganhouse. (T.c.)

I9I5. Holmes, G. Alpine Swift in Wigtowns. (T.c.) Idem. (Field,
Aug. 2I.) 


\section{IRELAND.}

1587. Giraldus de Barri (Cambrensis). Topography of Ireland. [MS. II87.] Fol. Lond. : I587. And later edits. [230.]

I652. Boate, G. Ireland's Naturall History. 8vo. Lond. : I652. Other edits. I726 and I755. [75.]

I739. Keogh, Rev. J. Zoologia Medicinalis Hibernica. 8vo. Dublin : I739. Also I744. [326.]

I774. Browne, Patrick. A Catalogue of the Birds of Ireland, etc. (In Exshaw's Gentleman's and London Magazine.) Dublin : I774.

1824. Vigors, N. A. Occurrence of Rare Birds in Ireland. (Zool. Jul.)

I829. [Anon. "J. D. M."] Rare Birds killed in different parts of Ireland. (Loudon's Mag. N. H., II.)

I83I. Fayrer, - - On Passage of Birds between Scotland and Ireland. (P.Z.S.)

I833. Thompson, W. Blackheaded Gull and Sandwich Tern in N. of Ireland. (P.Z.S.)

1834-35. Thompson, W. Catalogue of Seventeen Birds new to Irish Fauna. (P.Z.S., II., I834); Additions to British Fauna. (Op. cit., III., I835.) [578.]

I835. Thompson, W. On Herring Gull of N. of Ireland. (P.Z.S., III.) I836. Blyth, E. On Occurrence of Carrion Crow and Nightingale in Ireland. (Loudon's Mag. N. H., IX.)

I837. Templeton, R. Irish Vertebrate Animals, selected from papers of late John Templeton. (Charlesw. Mag. N. H., I.) [578.]

Thompson, W. Birds new to Ireland. (P.Z.S.)

I837-38. Thompson, W. Contributions to Natural History of Ireland. 4 pts. (Mag. of Zool. \& Bot., I., II., I837. Continued in Ann. Nat. Hist., I., I838, 2 pts.) [578.]

1838. Thompson, W. Notes on Irish Birds. (Ann. N. H., I.) [579.] I839. Thompson, W. On Effects of Hurricanes of January in Ireland on some Birds, etc.; On Breeding of Woodcock in Ireland. (Op. cit., III.) [579.]

I840-48. Thompson, W. Additions to Fauna of Ireland, 6 pts. (Op. cit., I840-4I, I845-48.) [579.]

I84I-53. Thompson, W. Report on Fauna of Ireland; div. Vertebrata. (Rep. Brit. Assoc. Adv. Sci., I840.) Suppl. Rept. (Op. cit., I852.) [579.] 
I84I-43. Thompson, W. The Birds of Ireland, I2 papers. (Ann. Mag. N. H., I84I-43.) [579.]

I844. Thompson, W. On Breeding of Woodcock in Ireland. (Rept. Brit. Assoc. Adv. Sci. for I843.)

1845. McCoy, F. Contributions to Fauna of Ireland. (Ann. Mag. N. H.)

1846. Thompson, W. American Bittern in Ireland; Surf Scoter on Coast of Ireland. (Op. cit.)

I849. Thompson, W. On Physical and Geographical Distribution of the Birds of Ireland. (Edinb. New Phil. Jnl., XLVI.) [579.]

1849-56. Thompson, W. The Natural History of Ireland. 4 vols. 8vo. Lond. : I849-56. [579.]

I853. Watters, J. J. Natural History of the Birds of Ireland, etc. I2mo. Dublin : I853. [6I9.]

I854. Montgomery, R. J. Exhibition of Irish-killed Specimens of Great Cinereous Shrike and Black-capped Warbler; Remarks on Exhibition of Three Specimens of Irish Birds. (Nat. Hist. Reviere.)

Wright, E. P. Notes on Occurrence of Rare Birds in Ireland. (T.c.)

I855. Andrews, W. Notes on South-west Coast and on Occurrence of Great Shearwater; On Occurrence of Crane in Ireland. (Nat. Hist. Reviere.)

Davis, R. On Breeding of Podiceps auritus in Ireland. (T.c.) Watters, J. J. On Habits and Varieties of Irish Laride. (T.c.)

I856. Burkitt, Dr. Occurrence of Rare Birds. (Nat. Hist. Review.) Carte, A. Bridled Guillemot in Ireland. (T.c.)

Montgomery, R. J. Chenalopex agyptiacus in Ireland. (T.c.)

I857. Ussher, R. J. Remarks on Preservation of Curruca atricapilla and Totanus ochropus shot in Ireland. (Nat. Hist. Review.)

I858. Clive, H. The Osprey [in Ireland]. (Field, Feb. 27.)

Williams, R. P. On an Irish Specimen of Cygnus olor. (Nat. Hist. Rev.)

I859-60. [Anon. "A Good Observer."] Grey and Golden Plover [in Ireland]. (Field, Nov. I2, I859.) Thick-knee Plover [and Longtailed Duck in Ireland]. (Op. cit., Apr. 28, I860.)

I860. Leadbeater, - Lestris cepphus from Ireland. (P.Z.S.)

I861. Gatcombe, J. Mountain Linnet [resident in Ireland]. (Field, Apr. I3.)

1862. [Anon. "A Good Observer."] Firecrested Wren in Ireland. (Field, May 3, Io.)

"Sancho." Hobby in Ireland. (Op. cit., Dec. 20, I862.)

Newman, E. Idem. (Op. cit., Feb. 2I, r863.) 
I865. Kinahan, G. H. [I829-I908.] Nat. Hist. Notes. (Pr. N. H. Soc. Dubl., I863-64.)

Whyte, J. Night Heron in Ireland. (Field, Dec. 9.) Idem. (Op. cit., pp. 296, 396, 426.)

Williams, R. P. Roller in Ireland. (Pr. N. H. Soc. Dubl., I863-64.)

I866. Hutchinson, J. Hely. The Wigeon in Ireland. (Field, Aug. 4.)

1867. Hackett, W. A. Goosander and Shoveller Duck in S. of Ireland. (Field, Feb. 9.)

Saunders, H. A Bird-nesting Trip to North of Ireland. (Zool.) [Various Writers.] Wood Warbler in Ireland. (Field, Feb. 2, I6, 23, May 25.)

I87I. Blake-Knox, H. [Black-billed] American Cuckoo in Ireland. (Ibis.) Idem by Lord Clermont: (T.c.)

Blake-Knox, H. American Bittern in Ireland; Swans in Ireland in Winter of I870-7I. (Zool.)

Bree, C. R. Sanderling breeding in Ireland [errore]. (Field, June 24.)

1872. Harting, J. E. Existing Heronries in Great Britain. (Field, Feb. I7, Mar. 9.) (partim.]

1875. Glennon, J. Rare birds and varieties shot in Ireland. (Op. cit., Feb. 20.)

Hackett, W. H. Gannets in S. of Ireland. (T.c., June I2.)

1876. Douglas-Ogilby, J. American Bittern in Ireland. (Field, Jan. r.)

I877. Harting, J. E. On Occurrence of the Hobby in Ireland. (Zool.)

1878. Benson, C. W. Provincial Names [in Ireland]. (Zool.)

Hart, H. C. Wood Wren in Ireland. (T.c.)

Saunders, H. Notes from Ireland. (Field, Aug. 3I, Dec. 7, 28.)

Thompson, P. Rare Birds in Ireland. (Sci. Gossip.)

I880. Friedel, E. German View of Fauna of Ireland. (Zool.)

I881. Harting, J. E. Annals of Irish Zoology, 2 pts. (Zool.) [275.]

1882. Payne-Gallwey, Sir R. W. F. The Fowler in Ireland. 8vo. Lond. : I882. [462.]

I883. Darling, J. F. Ornitholog. Notes from Ireland. (Zool.)

Palmer, J. E. The Hooded Crow in Ireland. (T.c.)

1885. [Editorial.] The Irish Avifauna. (Field, July I8.)

More, A. G. List of Irish Birds. 8vo. Dublin: I885. 2nd edit., I890. [4I3.]

Scott, J. D. The Irish Avifauna. (Field, Aug. I.)

I886. Benson, Rev. C. W. [ob. I9I9.] Our Irish Song Birds. Post 8vo. Dublin : I886. [57.]

I888. Ellison, Rev. A. Autumnal Migration in Ireland; Distribution of Jay in Ireland. (Zool.)

Scharff, R. F. Pallas's Sand Grouse in Ireland. (T.c.) 
I889. Dunne, J. The Nightingale in Ireland. (Field, Aug. Io.) Idem by R. Warren. (T.c., Sept. 7.)

Scharff, R. F. Occurrences of Syrrhaptes paradoxus in Ireland. (Sci. Pr. R. Dubl. Soc.)

r89o. Aplin, O. V. Distribution, etc., of Spotted Crake. (Zool.) [partim.] [24.]

Barrington, R. M., and Others. The Birds of Ireland. (T.c.) Ellison, A. Breeding of Woodcock in Ireland. (T.c.) Idem by Rev. W. W. Flemyng. (T.c.) Idem by R. J. Ussher. (T.c.)

Harting, J. E. Green Sandpiper in Winter in N. of Ireland. (T.c.)

More, A. G. The so-called "Martinico Gallinule" in Ireland. (T.c.)

Ussher, R. J. On the Coast of Connaught. (T.c.)

I8gI. Barrett-Hamilton, G. E. H. Introduction of the Magpie into Ireland. (Zool.)

Barrington, R. M. Rare Additions to Irish Avifauna. (T.c.)

Palmer, J. E. Breeding of Woodcock in Ireland. (T.c.)

Patterson, R. Notes from N. of Ireland [p. II3] ; Fork-tailed Petrels in N. of Ireland. (T.c.)

Seebohm, H. Notes on Irish Ornithology; On Some Recent Additions to the List of Irish Birds. (Ibis.)

Williams, E. Sabine's Snipe and Parrot Crossbill in Ireland. (Zool.)

I892. Ussher, R. J. Crossbill in Ireland. 2 pts. (Irish Nat.)

r893. Ussher, R. J. Birds of the Midland Lakes and Bogs. 2 pts. (Irish Nat.)

1893-94. Praeger, W. E. American Bird-visitors to Ireland at Home. 6 pts. (Irish Nat.)

1894. Barrett-Hamilton, G. E. H. On Occurrence in Ireland of American Redbreasted Snipe. 2 notes. (Ibis); English and Irish Jays. (Zool.)

Gurney, J. H., junr. Irish Rock Birds. (Tr. Norf. \& Norw. Soc., V.)

I895. Barrett-Hamilton, G. E. H. Sabine's Snipe [in Ireland]. (Irish Nat.)

Trumbull, J. Scarcity of Mistle Thrush in Ireland. (Nat. Jnl.)

I896. Barrett-Hamilton, G. E. H. The Great Auk as an Irish Bird. (Irish Nat., May.)

Moffat, C. B. The Quail in Ireland. (T.c., Aug.)

Williams, E. Irish Bird Notes. (T.c., Feb.)

I897. Harvie-Brown, J. A., and Barrington, R. M. On the Ornithology of Rockall. (Tr. R. Irish Acad.)

Praeger, R. Ll. Notes on an Expedition to Rockall. (Irish Nat., Dec.) 
Ussher, R. J. Distribution of Birds breeding in Ireland. (T.c., Mar.)

I898. Coburn, F. Ferruginous Duck in Ireland. (Zool.)

Gyles, L. The Wryneck in Ireland. (Irish Nat., Jan.)

More, A. G. Life and Letters of. 8vo. Dublin: I8g8. [4I3.] Saunders, H. On Puffimus assimilis in Ireland; Migration of Motacilla alba in Ireland. (Bull. B.O.C.)

I899. Barrett-Hamilton, G. E. H. Introduction of Black Grouse and some other Birds into Ireland. (Irish Nat., Feb.)

Barrington, R. M. On Rare Visitors to Ireland. (Ibis.)

Moffat, C. B. The Woodcock as an Irish-breeding Bird. (Irish Nat., May.)

Ussher, R. J. The Great Auk once an Irish Bird. (Irish Nat., Jan.); Green Woodpecker in Ireland (Correction). (T.c., June.)

I900. Barrington, R. M. The Migrations of Birds as observed at Irish Lighthouses and Lightships, I88I-97. 8vo. Lond.: I900. [43.]

Patten, C. J. Nat. Hist. of the Ruff [in Ireland]. (Irish Nat., Aug.) Addenda by R. J. Ussher. (T.c., Oct.) Addenda by C. J. Patten. (T.c., Nov.)

Patten, C. J., and Williams, W. J. On Distribution of some Birds observed in Ireland and Switzerland. (Zool.)

Ussher, R. J., and Warren, R. The Birds of Ireland. 8vo. Lond. : I900. [604.]

Igor. Patten, C. J. Nat. Hist. of the Grey Phalarope. (Iris/ Nat., Mar.)

I902. Ussher, R. J. The Avifauna of Ireland as affected by its Geo graphy. (Rept. Brit. Assoc. Meeting, Belfast; Irish Nat. Nov.)

I903. Forrest, H. E. Birds of N.W. Wales and Opposite Counties of Ireland. (Zool.) Idem. (Tr. Caradoc Cl., I904.)

Phillips, E. L. On a Buff Variety of Scolopax rusticola from Ireland. (Bull. B.O.C.)

Williams, E. Breeding of Red-necked Phalarope in W. Ireland. (Irish Nat., Feb.) Idem by J. A. Harvie-Brown. (T.c., Apr.)

I903-04. Williams and Sons. Snow Geese in Ireland. (Field, Dec. I9, I903; Jan. 30, I904.) Idem by H. W. Robinson. (T.c., Jan. 2, I904.)

I904. Patterson, R. Waxwings in N. of Ireland. (Zool.) Idem by W. H. Workman. (Ibis.)

I905. Foster, N. H. Eggs of Irish Breeding Birds. (Rep. Belfast Nat. F. Club.) 
Ussher, R. J. Birds met with on Connaught Lakes. (Irish Nat., June) ; Common Scoter breeding in Ireland. (T.c., Sept.)

Williams, E. On Occurrence of Greenland and Iceland Falcons in Ireland during Spring of $1905 . \quad$ (T.c., Oct.)

I906. Patterson, R. Birds of Ireland and Isle of Man. (Irish Nat., July.)

Warren, R. A New Irish Breeding Haunt of Sandwich Terns. (Zool.)

Workman, W. H. Glossy Ibis in Ireland. (Avicult. Mag.) Idem by W. J. Williams. (Irish Nat., Dec.)

I907. Bond, J. Walpole. Irish Golden Eagles. (Field, Mar. 2.)

Gladstone, H. S. Red-neckeed Phalarope in Ireland. (Brit. Birds, I.)

Moffat, C. B. Problems of an Island Fauna. (Irish Nat., Apr.)

Ussher, R. J., Hamilton, W. A., and Creaghe-Howard, L. C. Carrion Crow in Ireland. (Field, Mar. 2, 23, 30.)

Wright, W. C. Attempted Nesting of Redthroated Diver in Ireland. (T.c., Nov. 7.)

I907-09. Witherby, H. F., and Ticehurst, N. F. On More Important Additions to Knowledge of Brit. Birds since I899. 20 pts. (Brit. Birds, I., II.) [partim.]

I908. Ussher, R J. A List of Irish Birds, showing the Species contained in the National Collection. Dublin : Igo8. 8vo. [605.]

Ussher, R. J. Supposed Black Grouse and Ptarmigan from Irish Caves. (Brit. Birds, II.) ; Some Unrecorded Birds of Prey (Irish Nat., Apr.) Idem. Correction. (T.c., July.)

Warren, R. Pied Flycatcher in Ireland. (Zool.)

Williams, W. J. Short-eared Owls in Ireland. (Brit. Birds, I.) ; Richard's Pipit in Ireland; Night Heron in Ireland. (Zool.)

Ig09. Barrington, R. M. A New British and two New Irish Birds. (Sc. Proc. R. Dubl. Soc.)

Witherby, H. F. Irish Birds. (Brit. Birds, II.)

Igro. Farren, W., and Wright, W. C. Glossy Ibises in Ireland. $(O p$. cit.)

Ogilvie-Grant, W. R. Blue-winged Teal taken in Ireland. (Bull. B.O.C.) Idem by H. F. Witherby. (Brit. Birds, IgII.)

Ussher, R. J. Jays in Ulster. (Irish Nat.) ; Temminck's Stint in Ireland. (T.c.)

Warren, R. Sandwich Terns and White Wagtails in Ireland. $($ Zool.)

IgIr. Barrington, R. M. The Great Rush of Birds on night of March 29-30 in Ireland; The Irish Coal-Tit; Introduction of Nuthatches and Marsh Tits into Ireland. (Irish Nat.)

Bedford, Duchess of. Sooty Shearwaters off the W. Coast of Ireland. (Brit. Birds.) 
Hart, W. E. [I844-IgIg.] The Ulster Coal Tit. (Irish Nat.) Jourdain, F. C. R. Extermination of Sea-Eagle in Ireland. (Brit. Birds, V.)

Nichols, A. R. The Irish Dipper, Jay and Coal Tit. (Irish Nat.)

Ogilvie-Grant, W. R. Parus hibernicus, new Irish subspecies of Coal Tit. (Bull. B.O.C., XXVII.)

Warren, R. White-tailed Eagle no longer breeding in Ireland. (Zool.)

Witherby, H. F. The Irish Coal Tit. (Brit. Birds, IV.)

Witherby, H. F., and Hartert, E. The Irish Jay. (T.c.)

I9I2. Barrington, R. M. The Dartford Warbler in Ireland. (Iris/2 Nat. ; Brit. Birds.)

Patten, C. J. Some Birds new to Ireland, 3 pts. (Irish Nat.)

Robinson, H. W. First Nesting of Common Eider in Ireland. (Brit. Birds, VI.)

Ussher, R. J. Barnacle Geese on S. Coast of Ireland. $(O p$. cit., V.)

I9r3. Farran, G. P. Nightjars at Sea. (Irish Nat.)

I9I4. Barrington, R. M. Waxwings in Ireland. (Irish Nat.)

Benson, C. W. Our Irish Warblers. (T.c.)

Humphreys, G. R. Breeding of Roseate Tern in Ireland. (Brit. Birds, VII.) ; Roseate Terns in Ireland. (T.c.: Irish Nat.)

Warren, R. On Some Gulls observed in Ireland. (Zool.)

I9I5. Barrington, R. M. Occurrences of Common and Black Redstarts at Light-stations in Ireland. (Brit. Birds, IX.); The last (?) Irish Golden Eagle. (Irish Nat.)

Scharff, R. F. On the Irish Names of Birds. (Irish Nat.)

Williams, W. J. The Carrion Crow in Ireland. (Irish Nat.); Blacknecked Grebe breeding in Ireland. (Brit. Birds, IX.)

Witherby, H. F. [Exhib. of Young Blacknecked Grebe and hybrid Linnet Greenfinch obtained in Ireland.] (Bull. B.O.C., XXXVI.)

rgr6. Carroll, C. J. Extermination of Golden Eagle in Ireland. (Brit. Birds, IX.)

McWilliam, J. M. Bartram's Sandpiper in Ireland; Notes on some Irish Birds. (Zool.)

Williams, W. J. Eagles in Ireland. (Irish Nat.)

I9I7. Carroll, C. J. On newly-discovered Irish Colonies of Roseate and Sandwich Terns. (Brit. Birds, XI.)

Williams, W. J. The Jays in Ireland. (Irish Nat.)

Igr8. Kerr, H. M. Rait. Field Notes on the Kingfisher in Ireland. (Brit. Birds, XII.)

Renshaw, C. J. Bird and Nature Notes in Ireland. (Avicult. Mag.) 


\section{CO. ANTRIM.}

I8Io. MICSkimin, Saml. The History and Antiquities of the County and Town of Carrickfergus. I8ro. Idem. 3rd edit. Belfast: I829. [Catalogue of Birds, pp. 352-7.]

I8r2. Dubordieu, Rev. John. Statistical Survey of County of Antrim. [Birds, pp. I26-8 and 573-5.] 8vo. Dubl. : I8I2.

I832. M[arshall], J. D. List of Rare Birds killed near Belfast. (Loudon's Mag. N. H., V.)

I835. Marshall, J. D. Observations on Zoology of I. of Rathlin. (Lond. E Edinb. Phil. Mag. ; Rept. Brit. Assoc.)

I848. Newman, E. Little Gull and Bonaparte's Gull at Belfast. (Zool.)

1859. (Ex North British Daily Mail.) Rare Birds [on Rathlin Island]. (Field, Mar. I9.)

I863. Gage, R. C. List of Birds found in Rathlin Island. (Pr. N. H. Soc. Dublin, I860-62; Dublin Qtly. Jnl. Sci., II., I862.)

I865. Brunton, T. Peregrine Falcon breeding on Antrim Coast. (Zool.) I865-73. Brunton, T. Birds observed at Glenarm, 5 papers. (Zool., I865-73.)

1866. Saunders, H. Alpine Swift and Buff-breasted Sandpiper in Ireland. (Zool.)

Blake-Knox, H. Buff-breasted Sandpiper in Belfast. (T.c.)

I868. Blake-Knox, H. Eared Grebe in Antrim. (Zool.)

1870. Kerr, J. A. Bird Notes from Donegore. (Sci. Gossip.)

1872. M-, A. W. Cormorants at Giant's Causeway. (Sci. Gossip.)

I874. [Robinson, Rev. G.] Aves. [In Guide to Belfast and Adjacent Counties.] I2mo. Belfast: I874. [Vide Addenda.] [678.]

1875. Patterson, R. Lloyd. Great Northern Diver on Belfast Lough. (Field, Apr. 3.)

I876. Patterson, R. Ll. Notes on Swimming Birds of Belfast Lough. (ex Belfast N. H. Soc. Repts., I874-76). 8vo. Priv. ptd., I876. [46I.]

I877. Darragh, T. Grey Shrike and Goosander in Co. Antrim. (Zool.) I880. Brunton, T. Wildfowl at Larne. (Zool.)

Cox, H. G. Breeding of Pochard and Scaup. (T.c.)

Patterson, R. L1. Birds, etc., commonly frequenting Belfast Lough. 8vo. Lond., etc. : I880. 2nd edit. I88I. [46I.]

I88I. Patterson, Sir R. L1. Forktailed Petrel in Co. Antrim. (Zool.) I883. Patterson, Sir R. Ll. Scops Owl at Belfast. (Field, Nov. 24.) 1884. Butler, E. A. Hen Harrier in Antrim. (Field, May 3.) I885. Smith, Rev. W. S. [ob. IgI2.] Gossip about Lough Neagh. Belfast: I885. [Birds at pp. 33-36.] 
I887. Cunningham, R. O. Gull-billed Tern in Belfast Lough. (Zool.) I887-88. Dickson, G. The Birds of Fort William Park, Belfast. (Pr. Belf. N. H. \& Phil. Soc., I887-88.)

I888. Knox, G. B. Spotted Crake in Ireland [near Portrush]. (Field, Nov. 3.)

I889. Holmes, Rev. J. G. Stock Dove nesting in Co. Antrim. (Zool.)

I89I. Patterson, R. Roller in Co. Antrim. (Zool.)

Patterson, R. Ll. Osprey in Co. Antrim. (Field, June I3.)

I892. Barton, H. D. M. Stock Dove in Co. Antrim. (Irish Nat.)

[Belfast Nat. F. C.] Peregrine Falcon's Nest at the Gobbins. (Ann. Rep. \& Pr. Belf. Nat. F. C.)

Patterson, R. Birds of Rathlin Island, 3 pts. (Irish Nat.)

Patterson, Sir R. Ll. Grey Phalarope in Ireland. (Zool.); Forktailed Petrel in Antrim. (Irish Nat.)

Siviney, J. H. H. Corncrake. (T.c.)

I893. Patterson, R. Night Heron near Belfast. (Zool.); Little Auk in Belfast. (Irish Nat.)

I894. Brenan, Rev. Samuel Arthur. [I837-I908.] Birds at Cushendun. (Irish Nat.)

I895. Brenan, Rev. S. A. Summer Visitants at Knocknacarry. (Irish Nai.)

I896. Barton, H. D. M. Razorbills on Lough Neagh; Nesting Habits of Cormorants. (Irish Nat.)

Brenan, Rev. S. A. Seasonable Notes from Cushendun. (T.c.)

Christen, Madame S. N. Feathered Pensioners. (T.c.)

1897. Warren, P. Birds of Rathlin and Ballycastle. (Irish Nat.)

I898. Barton, H. D. M. Hawfinch in Co. Antrim. (Irish Nat.)

Patterson, Sir R. Ll. Longtailed Duck on Belfast Lough, etc. (T.c.)

I899. Knowles, W. J. Remains of the Great Auk from Whitepark Bay. (Irish Nat.)

Igor. Brenan, Rev. S. A. Spring Migrants in Co. Antrim. (Irish Nat.) Cunningham, Chas. M. [ob. IgI4.] Instinct in Young Coots. (T.c.)

Patterson, Sir R. Ll. Swans on Lough Neagh. (T.c.)

Stewart, S. A. [I826-I9Io.] Nightjar near Belfast. (T.c.)

Workman, W. H. Nightjar on Cave Hill. (T.c.)

I902. Brenan, Rev. S. A. Spring Migrants in Co. Antrim. (Irish Nat.) [Patterson, R.] [Birds in] Guide to the Counties of Antrim and Down [pp. I53-70]. By the Belfast Nat. F. C. Post 8vo. Belfast: I 902 .

Patterson, R. White Wagtail in Antrim; Turnstones on Lough Neagh. (Irish Nat.)

Warren, R. Wild Swans in Antrim. (T.c.) 
Workman, W. H. Departure of Swallows. (T.c.)

Wright, W. C. Ravens in Co. Antrim. (T.c.)

I902-03. Wright, W. C. Ravens nesting in Co. Antrim, 2 notes. (Zool., I902-03.)

I902-[16.] [Belfast Nat. F. C.] Birds observed [by members of]. I3 pts. (Ann. Repts. \& Pr. Belf. Nat. F. C., Ig02-I6.)

1903. Patterson, R. Iceland Gull at Lough Beg. (Irish Nat.)

Workman, W. H. Merlin on Colin Mountain. (T.c.)

Wright, W. C. Waxwings in Co. Antrim. (Zool.)

I904. Patterson, Sir R. Ll. Herons in Belfast Lough. (Irish Nat.)

Smith, W. S. The Rook; An Ornithological Eviction; The Flycatcher; Wild Birds in Confinement; Nesting Boxes. (Northern Whig.)

Tomlinson, W. J. C. Waxwing in Co. Antrim. (Irish Nat.)

Workman, W. H. Spotted Crake in Co. Antrim; Curious Nesting Site of Starlings (T.c.) ; On an exceptional migration of Waxwings to Ireland. (Ibis); Birds and Nests. (Rept. Belf. N. F. C.)

Wright, W. C. Spring Rivalry of Birds. (Zool.)

I905. McCleery, Hamilton. [viv.] Curious Accident to a Sand Martin. (Irish Nat.)

McClintock, Rev. Edwy L. L. [viv.] Whooper Swan at Lough Neagh; Turnstones on Lough Neagh; A Light Buff Skylark. (T.c.)

Patterson, Sir R. L1. Early Arrival of Eider Duck. (T.c.)

Pycraft, W. P. Spotted Crake in Co. Antrim. (Knowledge.)

Smith, W. S. Wild Duck's Nest in a Tree ; Late Migrants ; The Nesting Season of I905; Birds singing at Night; Birds and Fruit; Birds Feigning Injury. (Northern Whig.)

Wilson, G. Birds' Nests. (Pr. Belf. N. F. C.)

Workman, W. H. With the Breeding Birds on Lough Neagh. (Avicult. Mag.)

I906. Patterson, R. Iceland Gull at Belfast. (Irish Nat.)

Smith, W. S. The Siskin (Northern Whig, Jan. 20) ; Early Birds (T.c., Feb. Io) ; Siskin and Kingfisher. (T.c., Feb. 3); The Bleating of the Snipe. (T.c., Mar. 3I); A Word about the Jackdaw. (T.c., Apr. 7) ; Larks. (T.c., May 5) ; Rookeries. (T.c., June 30); Young Starlings leaving the Nest. (T.c., July 7); The Nesting Season of Igo6. (T.c., Aug. I8); The Jay. (T.c., Dec. I) ; The Song of the Thrush. (T.c., Sept. 29.)

Workman, W. H. Greenland Falcon in Co. Antrim. (Zool.) Idem by R. Patterson. (Irish Nat.); Blackbird laying twice in same Nest. (Irish Nat.)

I907. Donaldson, D. Local Names of Birds. (Northern Whig, Nov. 30.) Henry, Samuel. [viv.] A Visit to Rathlin. (T.c., Aug. 3I.) 
Smith, W. S. Return of Swallow. (Op. cit., Apr. 27) ; Do Birds Reason? (T.c., June I) ; Nesting Season of I907. (T.c., Aug. 3) ; An Oological Curiosity. (T.c., Oct. I9) ; Hooliganism among Birds. (T.c., Dec. 23.)

Workman, W. H. Eared Grebe in Belfast Lough. (Irish Nat.)

Wright, W. C. Glaucous Gull in Co. Antrim. (T.c.)

I908. Nevin, J. L. The Starling. (Northern Whig, Feb. 22, July 4); The Sea Gull. (T.c., Mar. I4) ; Birds' Nests. (T.c., Apr. 4); Migration of Birds. (T.c., May 2) ; Identification of Birds. (T.c., May 9); How long Birds live. (T.c., May 30); Our Songsters. (T.c., July I8) ; Birds of Prey. (T.c., Aug. I5); A Plea for our Birds. (T.c., Dec. 5) ; The Sparrow. (T.c., Aug. 29) ; Starling as a Mimic. (T.c., Oct. 3.)

Nicholson, William Weir. [I883-I9I2.] Antrim and its Birds. (T.c., Oct. 3.)

Smith, W. S. The Owl. (Op. cit., Feb. 29) ; Rooks at Antrim. (T.c., Apr. 25) ; The Coming of the Birds. (T.c., June I3); The Starling : ought it to be exterminated? (T.c., June 27); Nesting Notes, Ig08. (T.c., Aug. 8); Departure of some of our Migrants. (T.c., Nov. 7) ; Bird Migration. (T.c., Nov. 27.) Wright, W. C. Bird Distribution. (Op. cit., Nov. I4.)

I909. Glover, James. [viv.] Bird Names from Portrush. (Op. cit., Oct. 23.)

Henry, S. Dunlin nesting in Co. Antrim. (T.c., June I2.)

Nevin, J. L. Our Birds in Winter. (T.c., Jan. 2); Siskin and Redpoll. (T.c., Jan. I6) ; Ornithological Rambles. (T.c., Feb. 20) ; Grey Wagtail. (T.c., Apr. I7) ; Maternal attachment. (T.c., May 8); An Early Ramble. (T.c., May 22); The Hawk Hunting. (T.c., June 5); The Willow Wren. (T.c., July IO) ; A Curious Propensity. (T.c., July 3I); Birds in Flight. (T.c., Aug. I2) ; Autumn Migration. (T.c., Oct. 23); The Great Tit. (T.c., Oct. 30) ; A November Night. (T.c., Nov. 27.)

Orr, H. L. Cairncastle Birds. (Northern Whig, May I5.)

Smith, W. S. Are Rooks Weatherwise? (T.c., Jan. 28) ; Occurrence of Bittern. (T.c., Jan. 23) ; Snipe Drumming at Night. (T.c., Feb. 6); Birds and Grease Boxes at Antrim Station. (T.c., Feb. 27) ; Curious Flight of Starlings. (T.c., May I); An Excursion into Birdland. (T.c., May 29); A Cycle Run in search of the Curious. (T.c., June I2); Antrim Rooks again. (T.c., June 26); The Nesting Season of Igog. (T.c., Aug. I4); The Sparrowhawk. (T.c., Oct. 30); The Blackbird: What is to be done with it? (T.c., Nov. 27); A Fight between Hawks. (T.c., Nov. 20.)

Stendall, J. A. S. Rare Birds in the Municipal Collection. (Pr. Belf. N. F. C.)

Tomlinson, W. J. C. The Rook, friend or foe? (Northern Whig, Jan. 23.) 
Williams, W. J. Rare Birds in Ireland-Buffon's Skua. (Brit. Birds, II.)

Wright, W. C. Food of Terns. (Northern Whig, July 3I) ; Honey Buzzard in Co. Antrim; Arctic Terns feeding on Craneand Mayflies. (Brit. Birds.)

I9I0. Foster, Jane Wallace. [ob. I9I8.] The Birds of a City Garden. (Northern Whig, Jan. I.)

Nevin, J. L. The Birds of long ago. (T.c., Jan. I5); The Mistle Thrush. (T.c., Jan. 22) ; The Balance in Nature. (T.c., Mar. I2) ; Spring Migrants. (T.c., May 7); Uncertain Visitants. (T.c., July 23) ; Combativism in Birds. (T.c., Sept. 3.)

Smith, W. S. Rooks and Fog. (T.c., Jan. 8); Squirrel and Magpies. (T.c., Jan. 22) ; Protection of Wild Birds. (T.c., Mar. 5) ; A Swift in Trouble. (T.c., July 9) ; Great Tit. (T.c., July 16.$)$

Tomlinson, W. J. C. The Chiffchaff and other Notes. (T.c., Apr. I6) ; Migrants. (T.c., Apr. 23.)

Williams, W. J. Great Skua near Portrush. (Irish Nat.)

Wright, W. C. Greenland Falcon in Co. Antrim; Glossy Ibis near Belfast. (Brit. Birds.)

I9II. Foster, N.H. The Birds of Ballycastle. (Northern Whig, Sept. 9.) Nevin, J. L. Protective Colouring. (Op. cit., Feb. I 8 ); The Material Instinct. (T.c., Apr. 22); The Jackdaw. (T.c., May 27) ; The Bird of many Mysteries. (T.c., June Io) ; The Wheatear. (T.c., July I); The Rookery. (T.c., Nov. 4); A Local Aviary. (T.c., Nov. I8); An Interesting Visitor. (T.c., Dec. 9.)

Patterson, R. Longtailed Duck in Belfast Lough. (T.c., Dec. 9.) Smith, W. S. Hawk and Blackbird. (Northern Whig, Mar. 25); A White Chaffinch. (T.c., Apr. 8) ; A Little Grebe's Nest. (T.c., May 27) ; Spring Migrants. (T.c., June Io); Bushmills and thereabouts. (T.c., July I5); Bird Notes. (T.c., Oct. 28); The Swift Roosting. (T.c., Dec. 2.)

Swiney, J. H. H. Landrail in December. (Irish Nat.)

I9I2. Foster, Lydia Mary. [viv.] Birds bathing. (Northern Whig, Apr. 6.)

Nevin, J. L. Is it Cruel to keep British Birds? (T.c., Jan. 20) ; Singing of Birds in Winter. (T.c., Jan. 27); The Brambling. (T.c., Apr. 27) ; Flight of the Swift. (T.c., June I) ; The Bird of many Mysteries. (T.c., June 8) ; Some Nat. Hist. Gleanings. (T.c., June 22) ; Kingfishers. (T.c., June 29) ; Was it a Nightingale? (T.c., July 27); Unnatural Perching. (T.c., Aug. 3); The Great Crested Grebe. (T.c., Oct. 5) ; Superstitions among Animals. (T.c., Oct. I2); The Yellowhammer. (T.c., Nov. 2.) Wright, W. C. Honey Buzzard in Co. Antrim. (Brit. Birds.)

I9r3. Best, M. G. S., and Haviland, M.D. The Sparrow of Rathlin Is. ; Migration Notes from Rathlin Is. (Brit. Birds, VII.) 
Nevin, J. L. Quails. (Northern Whig, Feb. I) ; Chaffinches in Winter. (T.c., Feb. 8) ; Birds Congregating. (T.c., Feb. 22) ; The Lapwing. (T.c., Mar. 22); Spring Migration. (T.c., June 7) ; Our Wild Geese. (T.c., July 5); The Fallen Swift. (T.c., Sept. 27) ; Bird Companionships. (T.c., Oct. I8) ; Habits of the Heron. (T.c., Nov. 22.)

Igr4. Malcomson, H. T. Honey Buzzard. (Brit. Birds, VIII. ; Field, Nov. 28.)

Metcalfe, H. M. Breeding of Canadian Geese at Dunmurry. (Irish Nat.)

Nevin, J. L. Difficulties of identification. (Northern Whig, Jan. I7) ; Seasonable experiences. (T.c., Apr. II) ; Scarcity of Birds. (T.c., Aug. 9); When the Swallows homeward fly. (T.c., Oct. 3I) ; Wheatear and Chats. (T.c., Dec. I2.)

Patten, C. J. Missel Thrushes, Fieldfares and Redwings at Maidens Lighthouse ; Lapwings and Redwings at ditto. (Irish Nat.)

I915. Foster, N. H. Tree Sparrow nesting in Co. Antrim. (Brit. Birds, IX.; Irish Nat.); Birds at Ballycastle. (Northern Whig, Sept. 4.)

Nevin, J. L. Birds singing in flight. (Northern Whig, Apr. 24) ; The Mistle Thrush again. (T.C., May 8); Noise produced by flight. (T.c., May I5); Birds' Nests. (T.c., May 29); Birds pecking at Windows. (T.C., June I2) ; Nature Study in June. (T.c., June 26); Thrush as a foster-parent. (T.c., July 3); The Cuckoo bent on prey. (T.c., July Io) ; Cuckoo or Hawk. (T.c., July 3I) ; Bird Legends. (T.c., Dec. 24.)

Patten, C. J. Redshanks, Rock Pipit, Greenland Wheatears, Pied Flycatcher and Lesser Whitethroat on Migration at Maidens Lighthouse, 4 notes. (Irish Nat.)

Scharff, R. F. Some Irish Bird Names heard on Rathlin Is. (T.c.)

IgI6. Cunningham, J. Crossbills in Co. Antrim. (Brit. Birds, X.)

Foster, J. W. Belfast Bird Notes. (Northern Whig, Jan. I5.)

Nevin, J. L. An Early Nest. (T.c., Mar 27) ; Daily Visitors. (T.c., Apr. I5); Strange Nesting Places. (T.c., May 6); Birds we Know. (T.c., Sept. 9) ; The Hedge Sparrow. (T.c., Sept. 23); An Interesting Trio. (T.c., Sept. 30); Owls. (T.c., Nov. II) ; Blood lust of the Hawk. (T.c., Dec. 9.)

I9I7. Cunningham, J. Crossbills in Co. Antrim. (Brit. Birds, XI.) Nevin, J. L. Roosting Posture. (Northern Whig, Mar. 26); Winter Birds. (T.c., Mar. 3I) ; Beauty of Spring Plumage; Albinos. (T.c., June 2.)

Patten, C. J. Quails and Wren, and Wood Warbler on Migration at Maidens Lighthouse, 2 notes. - (Irish Nat.)

Workman, W. H. Snowy Owl in Co. Antrim. (T.c.) Idem. (Brit. Birds, XI., I9I8.) 


\section{CO. ARMAGH.}

I804. Coote, Sir Chas., Bt. Statistical Survey of the County of Armagh. 8vo. Dublin : I804. [Birds, p. II2.]

I868. Blake-Knox, H. Honey Buzzard at Lurgan. (Zool.)

I874. [Robinson, Rev. Geo.] [I824?-I894.] Guide to Belfast and the Adjacent Counties. By the Belfast Naturalists' Field Club. Post 8vo. Belfast: I874. [Aves by Mr. Robinson, pp. 95-I04.]

1877. Clermont, Lord. Stock Dove in Ireland. (Zool.)

I878. Jones, J. C. Ring Ouzel in Ireland in Winter [near Armagh]. (Field, Feb. 2.)

I882. Robinson, G. Eider Duck on Lough Neagh. (Op. cit., Dec. 2.) I893. Jamison, Henry Lyster. Bewick's Swan near Loughgilly. (Irish Nat.)

I893-95. Johnson, W. F. Spring Migrants at Armagh, 3 notes. (Irish Nat., I893-95.)

I896-I90o. Johnson, W. F. Spring Migrants at Poyntzpass, 5 notes. (Irish Nat., 1896-I900.)

I898. McEndoo, Rev. William. [viv.] Tame Gulls. (Irish Nat.)

Patterson, R. Hoopoe at Lurgan. (T.c.)

I902. Johnson, W. F. Spring Migrants; Siskin near Poyntzpass; Owl v. Starling; Magpies fishing for Eggs. (Irish $N^{\top} a t$.)

I904. Johnson, W. F. A Late House Martin. (Irish Nat.)

I906. Johnson, W. F. Grey Crow at Jerrettspass; Pied Blackbirds near Poyntzpass. (Irish Nat.)

McEndoo, Rev. W. Quails in Co. Armagh. (T.c.)

I908. Gordon, Samuel A. A Strange Bird Adventure. (Northern Whig, July 25.)

I909. Gordon, S. A. Loughgilly Notes. (Op. cit., Jan. 25.)

Johnson, W. F. Blackbirds and Fruit; Hawks and Falcons. (T.c., Dec. 6.)

IgIo. Darling, J. S. Birds of Lough Neagh. (Irish Nat.)

Johnson, W. F. Winter Flocks of Birds. (Northern Whig, Jan. 22) ; A Winter Corncrake. (T.c., Jan. 29) ; Blackbirds and Thrushes. (T.c., Feb. 5); Irregular Occurrences of Birds. (T.c., Feb. I9) ; A Baldheaded Robin. (T.c., Mar. II) ; Harbingers of Spring and a Luminous Bird. (T.c., Apr. 9); Birds and Flowers. (T.c., Apr. I6) ; Migrants. (T.c., May 7); Butterflies and Birds. (T.c., May 28) ; A Young Owl. (T.c., Aug. I3) ; The Last Switt. (T.c., Sept. 3.)

IgII. Johnson, W. F. Signs of Spring. (Northern Whig, Mar. II.) 
I912. Johnson, W. F. Distribution of Wheatear. (Northern Whig, Jan. I3) ; Birds Washing. (T.c., Mar. 30) ; Spring Migrants; The Jackdaw. (T.c., May I8); A Snipe Perching. (T.c., June 29) ; A Curious Bird. (T.c., Nov. 2.)

IgI3. Johnson, W. F. Spring Notes. (Northern Whig, Apr. 5) ; Wood Pigeons useful. (T.C., June 2I.)

IgI4. Johnson, W. F. Long Journeys of Birds. (Northern Whig, Apr. I8) ; Birds' Food in Manure. (T.c., June I7) ; Scarcity of Migratory Birds. (T.c., July I8) ; A Sacrilegious Hawk. (T.c., Aug. 3I) ; Gannets. (T.c., Oct. 3.)

Nichols, A. R. Waxwing in Co. Armagh. (Irish Nat.)

I9I5. Johnson, W. F. Song on the Wing. (Northern Whig, Apr. 24); Robin and Mouse. (Irish Nat.)

IgI6. Johnson, W. F. Robin's crepuscular eye. (Northern Whig Apr. 8) ; Starlings. (T.c., Apr. 29, June I2) ; Long-tailed Tit. (T.c., June 3); Stoat and Magpie. (T.c., July 22); Nature Notes of Olden Days. (T.c., Oct. 2I.)

IgI7. Johnson, W. F. Swans. (Northern Whig, Nov, Io.)

CO. CARLOW.

I825. [Anon. "V."] [Waxwing in Co. Carlow.] (Zool. Jnl., I., p. 590.) I872. Williams, A., and H. E. Leach's Petrel in Co. Carlow. (Field, Dec. 7.)

I888. Dowling, J. J. Occurrence of Garganey. (Zool., p. I87.)

I892. Patterson, R. Grey Phalarope in Ireland. (Zool.)

I895. Barrett-Hamilton, G. E. H. Stockdove and Crossbill in Carlow. (Irish Nat.)

Carey, C. Little Bittern in Co. Carlow. (Land \& Water, June I.)

I9II. Pack-Beresford, D. R. Mealy Redpoll in Co. Carlow; The Quail in Ireland. (Irish Nat.)

\section{CO. CAVAN.}

I879. Hamilton, W. J. Curious Haunt for Snipe ; Hawfinch in Ireland. (Zool.)

I896. Praeger, R. L1. The Field Clubs in Cavan. (Irish Nat.)

IgII. Foster, N. H. Among the Cavan Lakes. (Northern Whig, May 20) ; Birds of Cavan. (Pr. Belf. Nat. F. C.) 
CO. CLARE.

I833. "T. K [nox.]" Whinchat at Killaloe. (Loudon's Mag. N. H., VI.)

I836. "T. $\mathrm{K}$ [nox.]" The Hoopoe [at Tinnerana]. (Op. cit., IX.)

I856. [Anonymous- "Hesperus."] A Glance over the Cliffs of Moher. (Zool.)

I863. [Anon. "Mother Carey's Chicken."] Stormy Petrel breeding in Co. Clare. (Field, Aug. I5.)

I872. M[ore ?] A. G. Snow Bunting in May [near Kilkee]. (Op. cit., May 18.)

I889. Williams, E. Pallas's Sand Grouse in Co. Clare. (Zool.)

I8gI. Hibbert, R. F. Forktailed Petrel in Clare. (Field, Oct. 3.) Idem by H. Martin. (T.c., Oct. Io.)

1892. [Anon.] Occurrence of Bittern. (Land \& Water, Dec. 3I.) I896. Hibbert, R. F. Longtailed Duck in Co. Clare. (Irish Nat.) I902. Patten, C. J. Gadwall in Co. Clare. (Irish Nat.)

Ussher, R. J. Great Auk in Co. Clare. (T.c.)

I906. Barrington, R. M. The American Snowbird in Ireland. (Irish Nat.) ; Pomatorhine Skua from Loop Head. (T.c.)

Newton, E. T. Exploration of Caves of Co. Clare. (Tr. R. Irish Acad.)

Ussher, R. J. Remains of Hawfinch in Co. Clare Caves. (Irish Nat.)

I908. Macnamara, H. V. Ruff in Co. Clare. (Field; Brit. Birds.) Parkinson, D. C. Scarcity of Sparrows in Co. Clare. (Irish Nat.)

Igog. Witherby, H. F. Irish Birds-Crane. (Brit. Birds, II.)

Igro. Ussher, R. J. Remains of Birds in an Irish Cave. (Irish Nat.) Williams, W. J. Rare Birds in Ireland-Snowy Owl. (Brit. Birds, III.)

I9I7. Carroll, C. J. Little Bustard in Co. Clare. (Op. cit., X. ; Irish Nat.)

CO. CORK.

I750. Smith, C. Ancient and Present State of County and City of Cork. 2 vols. 8vo. Dublin: I750. Idem. and edit. ib. : I774. New edit. Cork: I8I5. [547.]

I844. Harvey, J. R. Abstract of a Catalogue of Vertebrata of Co. Cork. (Rep. Brit. Assoc. Adv. Sci. for I843.) 
1845. Davis, R. Smaller Eagle (A. navia) in Ireland. (Zool.)

Harvey, J. R. Vertebrata. [In Contributions towards a Fauna and Flora of County of Cork.] 8vo. Lond., etc.: I845. [277.]

1846. Harvey, J. R. Occurrence of White Stork near Fermoy, etc. (Zool.) Idem. (Ann. Mag. N.H.)

Newman, E. Description of Spotted Eagle. (Zool.)

1847. Glencon, M. Black and White Mottled Swan at Castle Martyr, 2 notes. (Ann. Mag. N. H.)

I857. Bulger, G. E. Lesser Spotted Woodpecker near Fermoy. (Zool.) I858. "A Cork Man." Ivory Gull [at Danemark]. (Field, Dec. II.) "Long Tom." Quails [in Co. Cork]. (Op. cit., June 5) ; Blackcap, in Winter. (Op. cit., July 3.) Idem by "Good Observer." [Coal Tits and Stonechats called Blackcap.] (T.c., July Io.)

I859. Hackett, W. A. Spoonbill in Cork. (Field, Dec. 3.)

1861. Armstrong, G. Ivory Gull [seen in Cork Harbour]. (Field, Mar. 2.)

Clermont, Lord. Little Bustard in Co. Cork. (Zool.)

(Cork Constitution.) Bittern shot in Cork. (Field, Jan. I2.)

"W. L." Spotted Rail near Cork. (Op. cit., Nov. 9.)

Williams, R. P. Spoonbill in Co. Cork. $(P r . N$. H. Soc. Dubl., I859-60.)

Williams, S. P. On Occurrence of Spoonbill in Co. Cork. (Zool.)

I862. Hackett, W. A. The Hoopoe [in Co. Cork]. (Field, Mar. 8.)

I865. Hackett, W. A. Night Heron in Co. Cork. (Field, Oct. 2I.)

Williams, R. P. Exhib. of Squacco Heron and Little Bittern. (Pr. N. H. Soc. Dubl., I863-4.)

I866. Howard, J. Oystercatchers shot Inland. [Bandon.] (Field, Mar. 24.)

Hackett, W. A. Stork killed at Cork. (Op. cit., Sept. 22).

I867. [Editorial.] Osprey near Cork. (Field, July 6.)

Hackett, W. A. Avocet in Cork. (Op. cit., Jan. I2); Redbreasted Merganser [on Bandon River]. (T.c., Jan. 26); Golden Oriole taken in Co. Cork. (T.c., May 25); Goosander and Shoveler Duck in S. Ireland. (Zool.)

Warren, A. R. Woodcock breeding in Ireland [in Co. Cork]. (Field, May 4.)

I868. [Anon. "L."] Little Bittern in Co. Cork. (Field, June 20.) I870. Hackett, W. A. Golden Oriole in Co. Cork. (Field, Apr. 30.) I872. Harting, J. E. British Heronries. (Zool.) Idem. Additions. (Op. cit., I873.) [partim.]

1875. Hackett, W. A. Bittern in Co. Cork. (Field, Jan. I6, Oct. I6, Nov. 6.) [Cf. also Op. cit., Jan. 23, Oct. 23.] 
Harvey, J. R. American Bittern in Co. Cork. (Op. cit., Dec. I8.)

I876. Hackett, W. A. Bittern in Co. Cork. (Field, Jan. I) ; Golden Oriole in Co. Cork. (T.c., May 27); Avocet near Cork. (Op. cit., Dec. 9.)

I877. Hackett, W. A. Egyptian Goose in Co. Cork. (Field, Mar. Io) ; Great Northern Diver in Ireland. (T.c., Jan. 20.) Idem by R. Warren. (T.c., Feb. 3.)

I878. Hackett, W. A. Golden Eagle in Cork. (Field, Dec. 28.)

1879. Abbott, C. C. Sabine's Snipe near Cork. (Field, Jan. I8.) Hackett, W. A. Winter Birds in S. of Ireland. (T.c., Jan. II) ; Goosander in Co. Cork. (T.c., Feb. I5) ; Bittern in Co. Cork. (T.c., Mar. 8, Apr. I2) ; Golden Eagle in Cork. (Op. cit., Nov. I.)

Hardy, C. Hoopoe at Queenstown. (T.c., Oct. 4.)

I880. " S. C." The Turtle Dove in Ireland [Co. Cork]. (Field, Sept. 25.)

I88r. Robson, W. R. Forktailed Petrel near Youghal. (Field, Dec. Io.) I882. Flemyng, W. W. Breeding Habits of Gannet in Ireland [Bull Rock]. (Zool.)

I883. Allin, H. F. Little Bustard in Co. Cork. (Field, Dec. 8.)

Darling, J. F. Yellow Wagtail in Ireland. (Field, July 7, I4, Aug. I8.)

Donovan, C., junr. Blue-headed Yellow Wagtail in Co. Cork; Grey Crow in Co. Cork; Choughs in S. of Ireland; Black Guillemot in Co. Cork. (Zool.)

Ussher, R. J. Nightingale in Ireland. (Zool.)

I884. Barrington, R. M. Irish Breeding Stations of the Gannet. (Zool.) Idem by R. J. Ussher. (T.c.)

Donovan, C., junr. Little Bustard in Cork; Siskin and Great Snipe in Co. Cork. (T.c.)

O'Connell, D. Gannets [breeding] at Dunsey Island. (Field, Aug. I6.)

1885. Carbery, A. L. Bittern near Youghal. (Field, Dec. 26.)

Donovan, C., junr. Crossbills in Co. Cork. (Zool.)

I886. Kinhew, E. Spoonbill in Co. Cork. (Field, Feb. 20.)

I887. Brooks, E. P. Solitary Snipe in Co. Cork. (Field, Jan. I.)

I888. Barrington, R. M. Pied Flycatcher in Ireland, 2 notes. (Zool.) Scharff, R. F. Bee-eater in Co. Cork, 2 notes. (T.c.)

I889. [Editorial.] Reported Occurrence of Nightingale in Ireland [Co. Cork]. (Field, May I8.)

I892. Barrington, W. B. Ruddy Sheldrake in Co. Cork. (Irish Nat., Oct.)

Donovan, G. E. Longeared Owl [in Co. Cork]. (T.c., Sept.) Popham, H. L. Iceland Gull in Kinsale Harbour. (Zool.) 
1893. Barrington, W. B. Osprey and Quail in Co. Cork. (Irish Nat., July.)

Donovan, G. E. Goosander in Co. Cork. (T.c., Mar.)

I894. McArthur, H. Notes from W. Cork. (Sci. Gossip, N.S., I., I894-95.)

Smith, J. C. Garden Warbler in Ireland; Crossbills in Co. Cork, (Irish Nat., Feb.)

1895. Barrington, W. B. Rare Birds in Co. Cork. (Irish Nat., June.) Longfield, C. Smew in Co. Cork. (T.c., Apr.)

I896. Barrington, W. B. Bird Notes from Co. Cork. (Irish Nat., Dec.) Horsbrugh, C. B. Night Heron in Co. Cork. (T.c., Oct. ; Zool.) Macpherson, H. A. Supposed Buff-backed Heron in Co. Cork. (Zool.)

Swan, A. P. Quail in Co. Cork. (Irish Nat., July.)

I897. Wolfe, J. J. Spring Migration, Co. Cork. (Irish Nat., May.)

I898. Wolfe, J. J. Little Bittern in Co. Cork. (Irish Nat., Feb.)

r899. Crawshay, W. T. White Wagtail in Co. Cork. (Irish Nat., Oct. ; Zool.)

Ussher, R. J. The Rufous Warbler, a Bird new to Ireland. (Irish Nat., Feb.); Gannets on the Bull Rock. (T.c., Nov.)

I900. [Anon.- "S."] Bittern in Co. Cork. (Field, Jan. 20.)

Wolfe, J. J. Crossbills nesting in S. Cork. (Irish Nat., Dec.)

Igor. Ussher, R. J. Great and Sooty Shearwaters on South Coast. (Irish Nat., Feb.); Rare Irish Birds in the National Museum. (T.c., Nov.)

Ig03. Barrington, R. M. The Aquatic Warbler, a New Irish Bird. (Irish Nat., Nov.)

Warren, R. Harvey Collection of Irish Birds. (T.c., Feb.)

Igo6. Barrington, R. M. Melodious Warbler in Ireland. (Irish Nat., July.)

I907. Nichols, A. R. Canadian Crane in Co. Cork. (Irish Nat., June.) Idem by H. F. Witherby. (Brit. Birds, I.)

Patterson, R., and Foster, N. H. Irish Field Club Conference at Cork-Vertebrata. (Irish Nat., Sept.)

Ussher, R. J. Roughlegged Buzzard in Co. Cork. (T.c., Apr.)

I908. P[ycraft, ] W. P. Sabine's Snipe in Co. Cork. (Brit. Birds, I.)

I909. Rohu, F. R. Golden Oriole in Co. Cork. (Irish Nat., Aug.)

Ussher, R. J. Birds seen from the "Helga" off S.W. Coast. (T.c., Mar.)

IgIo. Ogilvie-Grant, W. R. [Exhib. of Amer. Bluewinged Teal from Ballycotton.] (Bull. B.O.C., XXVII.)

Seppings, J. W. H. Blacktailed Godwits in Co. Cork. (Brit. Birds, III.) 
Warren, R. Blacktailed Godwits in Co. Cork; Rare American Teal in Co. Cork. (Zool.)

IgIr. Witherby, H. F. American Bluewinged Teal in Ireland. (Brit. Birds, IV.)

I9r3. Barrington, R. M. Siberian Skylark in Co. Cork. (Irish Nat.; Brit. Birds, VI.)

Cummings, S. G. Whinchat breeding in Co. Cork. (Brit. Birds, VII.) Idem by J. H. Stenhouse, (T.c.)

Rohu and Sons. Stone Curlew and Ivory Gull in Co. Cork. (Irish Nat.)

Warren, R. Sabine's Snipe and Great Northern Diver in Co. Cork; Rare Arctic Visitor made known by a Falcon; Stone Curlew in Co. Cork ; Squacco Heron in Co. Cork. (Zool.)

I9I4. Barrington, R. M. Pied Flycatcher at Ballycotton. (Irish Nat.)

Jourdain, F. C. R. Whinchat breeding in Co. Cork. (Brit. Birds, VII.)

I9I5. Abbott, W. M. Jays in Co. Cork. (Irish Nat. ; Brit. Birds, IX.) Igr8. Abbott, W. M. Jays feeding on Wheat [Fermoy]. (Irish Nat.)

\section{CO. DONEGAL.}

1832. Stewart, J. V. List of .... Birds met with in Three Years preceding Dec. 4th, I828, on N. Coast of Donegal. (Loudon's Mag. N.H., V.)

I839. Thompson, W. On migration of the Snowy Owl [one shot at Killybegs]. (Ann. Nat. Hist., III.)

1853. Gatty, Edmund. In Memoriam Gulielmi Thompson. The History and Antiquities of Tory Island. Priv. printed, Belfast: I853. [List of Birds by George C. Hyndman.]

I858. "Diver." The Holland Hawk. [Divers so called in Donegal.] (Field, Feb. 27.)

1859. Kerr, R. Two Golden Eagles caught. (Ficld, Apr. 9.)

1863. Cox, M. B. Pallas's Sand Grouse in Ireland. (Zool. ; Field, July I8.). Idem by W. Sinclair. (Field, June 20,27.)

I869. [Anon. "R. A."] Great Northern Diver on Lough Swilly. (Field, Jan. 9.)

I870. Davies, T. E. A White Curlew [shot near Carrigart]. (Op. cit., Mar. 26.)

I87r. Sinclair, A. L. Iceland Gull in Donegal. (Op. cit., Jan. I4.)

I872. Harting, J. E. British Heronries. (Zool.) Idem, Additions. (Op. cit., I873.) Idem by W. E. Hart. (T.c.) [partim.] 
I877. Mahoney, J. A. Natural History of Donegal. (Zool.) Idem. Criticisms by R. M. Barrington, J. Douglas-Ogilby, J. E. Harting. (T.c.)

"Punt Gun." Scaup and Shoveler breeding [?] in Ireland. (Field, May 26.)

1878. [Anon. "Shelah."] Rose-coloured Pastor in Donegal. (Sci. Gossip.)

I879. Kennedy, A. Clark. Golden Oriole in Donegal. (Zool.)

I880. Harting, J. E. Greenland Falcon in Donegal. (Zool.) Idem by "Innishowen." (Field, Aug. 2I.)

I88x. Barton, H. D. M. Little Stint in Co. Donegal. (Op. cit., Oct. I.)

Hart, H. C. Occurrence of Blackcap in Donegal. (Zool.)

Williams and Son. Golden Eagle in Donegal. (T.c.)

1882. Dames, T. L. Iceland Falcon in Donegal. (Field, Sept. 23.)

1883. More, A. G. Snowy Owl in Donegal. (Zool.)

1884. More, A. G. Greenland Falcon in Donegal. (Zool.)

Norman, R. W. Great Northern [?] Diver breeding in Co. Donegal. (Field, Aug. 30, Sept. I3.) Idem by E. A. Butler. (T.c., Sept. 6.)

I885. Harting, J. E. Breeding of Redthroated Diver in Ireland. (Zool.) Idem by R. Ll. Patterson. (Field, May 30.)

I887. Ussher, R. J. Redthroated Diver breeding in Co. Donegal. (Zool.)

I888. “Keswal." Pallas's Sand Grouse [in Co. Donegal]. (Field, Aug. II.)

r889. Wallis, H. M. Notes upon Natural History of Arran More and "The Rosses." (Tr. Norf. \& Norw. Soc., IV.)

Young, J. Notes on a Visit to Arran More. (T.c.)

I89I. Patterson, R. Ll. Golden Oriole in Co. Donegal. (Field, Oct. 20.)

Sinclair, W. Forktailed Petrel in Ireland. (T.c., Oct. I7.)

I89I-93. Hart, H. C. Notes on Birds of Donegal, 5 pts. (Zool., I89I.) Additions to Avifauna of Donegal, 4 pts. (Op. cit., r892.) Addit. Notes. (OP. cit., I893.)

I892. Beecher, H. Whooper and Roughlegged Buzzard at Horn Head. (Irish Nat.)

Bland, D. T. Little Stint at Inch. (T.c.)

Campbell, D. C. Breeding of Sheld Duck at Inch ; Ruffs at Inch. (T.c.)

Elliott, J. Steele. Additional Notes on Birds of Donegal ; Ruddy Sheldrake in Co. Donegal. (Zool.)

Hamilton, W. A. Ruddy Sheldrake at Coolmore. (Irish Nat.) Hart, H. C. Ruddy Sheldrake, Black-tailed Godwit and Iceland Gull in Co. Donegal. (Zool.); Iceland Gull in Lough Swilly. (Irish Nat.) 
Hart, W. E. Parrot Crossbill at Kilderry. (T.c.)

Jamison, H. L. Fulmar in Donegal. (T.c.)

Leebody, J. R. Notes on Birds of Lough Swilly; Black-tailed Godwit at Lough Swilly. (T.c.)

Norman, R. W. Great Northern Diver in Donegal in August. (Zool.)

Patterson, R. Roller in Co. Donegal; Pinkfooted Goose in Ireland; Grey Phalarope in Ireland. (T.c.); Glaucous and Iceland Gulls in Co. Donegal. (Irish Nat.)

I893. Elliott, J. S. Curlew Sandpiper in Co. Donegal. (Zool.)

Hamilton, W. A. Buff-coloured Snipe at Ballyshannon. (Irish Nat.)

Hart, H. C. Sabine's Gull in Co. Donegal. (Zool.)

Jamison, H. L. Additions to Birds of Donegal. (T.c.)

Swiney, J. H. H. The Birds of Lough Swilly. (Irish Nat.)

I894. Campbell, D. C. Notes on Breeding Birds of Lough Swilly; Grey Phalarope at Inch. (Irish Nat.)

Hart, H. C. Cuckoos calling on Wing. (Zool.)

I896. Barrett-Hamilton, G. E. H. Notes from Co. Donegal. (Ornithologist.)

Campbell, D. C. Crane at Inch. (Irish Nat.)

Hamilton, W. A. Spring Migrants. (T.c.)

I897. Hart, H. C. Wood Wren in Co. Donegal ; Nesting Habits of Cormorants as observed in Co. Donegal. (Zool.)

I898. Campbell, D. C. Knot at Portsalon. (Irish Nat.)

I899. Campbell, D. C. Eider Duck in Inishowen; Rose-coloured Pastor near Inch in Donegal. (Irish Nat.)

rgoo. Fahy, M. Egyptian Goose at Toomebridge. (Irish Nat.)

Hamilton, W. A. Longtailed Duck in Donegal Bay. (Field, Mar. I7.)

I901. Campbell, D. C. Roller in Donegal. (Irish Nat.)

Patterson, R. Snowy Owl at Falcarragh. (Irish Nat.)

I902. Campbell, D. C. Sea and Golden Eagles in Donegal. (Irish Nat.)

Hart, W. E. Woodcock breeding in Co. Donegal; Wild Swans in Donegal and Antrim. (T.c.)

Howard, C. E. Cirl Bunting in Ireland. (T.c.)

Warren, R. Wild Swans in Donegal. (T.c.)

Workman, W. H. Golden Eagle in Co. Donegal. (T.c. ; Zool.)

Ig03. Campbell, D. C. Wild Swans in Donegal; Ruff at Inch. (Iris/s Nat.)

Leebody, J. R. Wild Swans in Donegal. (T.c.)

Wright, W. C. Ornitholog. Notes from Co. Donegal. (Zool.)

I904. Campbell, D. C. Stone Curlew in Donegal. (Irish Nat.)

Hart, H. C. Grasshopper Warbler at Lough Swilly. (T.c.)

Leebody, J. R. Hawfinch in Donegal. (T.c.) 
Parker, A. Notes on Birds of Lough Derg and its Shores. (T.c.) Pycraft, W. P. Greenland Falcon in Donegal. (Knowledge.) I905. Patterson, R. Greenland Falcon in Co. Donegal. (Irish Nat.) Wright, W. C. The Redthroated Diver. (T.c.)

I906. Elliott, J, Steele. Some Notes on Birds of Donegal. (Zool.)

I907. Campbell, D. C. The Birds of Horn Head; Inch and Lough Swilly. (Northern Whig, Sept. 2I.)

Elliott, J. Steele. Iceland Gulls in Donegal. (Zool.)

Patterson, R. Nesting of Tree Sparrow in Co. Donegal. (Irish Nat.)

Wright, W. C. Donegal Birds. (Northern Whig, Sept. 7); Attempted Breeding of Redthroated Diver. (Irish Nat.)

I908. Campbell, D. C. Smew reported in Summer; Great Crested Grebe breeding. (Op. cit.; Brit. Birds, I.)

Warren, R. Breeding of Redthroated Diver. (Irish Nat.)

Ig09. Campbell, D. C. Glossy Ibis in Co. Donegal; Ruff at Inch. (Irish Nat.)

Foster, N. H. Bundoran Birds. (Northern Whig, Sept. 4.) Idem by R. Patterson. (T.c., Apr. 24.)

IgIo. Campbell, D. C. Greenland Falcons in Donegal. (Northern Whig, Mar. 26); Notes from Dunfanaghy. (T.c., July 23); The Birds of Inch and Upper Lough Swilly; Greenland Falcon in Donegal. (Irish Nat.)

Hart, W. E. Crossbills at Kilderry; The Jay in Ulster. (T.c.) Ussher, R. J. Birds of Donegal. (T.c.)

Igrr. Campbell, D. C. The Wood Sandpiper. (Northern Whig, Feb. I8); Wood Sandpiper, Supposed Spoonbill, Scops Owl in Co. Donegal, Greenland Falcon in Ireland, 4 notes. (Irish Nat.)

Hart, W. E. The Ulster Coal Tit. (T.c.)

I9I2. Campbell, D. C. Black-tailed Godwit and Avocet at Lough Swilly. (Irish Nat.) Idem (Northern Whig, Feb. 3 and Oct. 5.)

Foster, N. H. Notes on Birds observed at Bundoran. (T.c.)

Robinson, H. W. First Nesting of Eider Duck in Ireland, 2 notes. (Brit. Birds.)

Stoney, C. V. Fulmar in Ireland. (Irish Nat.)

I9I3. Barrington, R. M. Snowy Owl on Tory Is. (Op. cit.) ; Ivory Gull in Co. Donegal. (T.c.; Brit. Birds, VI.) ; Little Auk in Co. Donegal ; Iceland Gull in July and Mealy Redpoll on Inishtrahull. (Irish Nat.)

Campbell, D. C. Voices in the Night. (Northern Whig, Aug. 9.) Patten, C. J. Discovery of Colony of Tree Sparrows on Inishtrahull Is. (Brit. Birds, VII.) ; White Wagtails on Migration at Inishtrahull. (Irish Nat.)

Stoney, C. V. Tree Sparrow in Co. Donegal. (Irish Nat.)

Ussher, R. J. Fulmars and Great Shearwater on Tory Is. (T.c.) 
I9r4. Campbell, D. C. Evening Calls. (Northern Whig, July 25) ; Longtailed Skua in Donegal. (T.c., Oct. 24; Irish Nat.)

I9r5. Campbell, D. C. The Golden Eagle. (Northern Whig, Jan. 23.) McWilliam, J. M. Notes on Tree Sparrow in Donegal. (Zool.) Patten, C. J. Fulmar Petrel on Inishtrahull Is. (T.c.) ; Eider Ducks on Inishtrahull. (Irish Nat.)

Rathbone, H. B. Chiffchaff in Dec. (Irish Nat.)

rgr6. Campbell, D. C. A Rough Day at Lough Swilly. (Northern Whig, Nov. II.)

Hart, W. E. Hawk and Heron. (Irish Nat.)

I9I7. Campbell, D. C. Hoopoe in Co. Donegal. (Irish Nat. ; Northern Whig, Oct. 29.)

Patten, C. J. Arctic Skuas on migration at Moville. (Irish Nat.)

Williams, W. J. Blackwinged Stilt in Ireland. (Brit. Birds, X.) Workman, W. H. Hoopoe in Co. Donegal. (Op. cit., XI. ; Irish Nat.)

Igr8. Workman, W. H. Hoopoe in Co. Donegal. (Brit. Birds, XI.)

\section{CO. DOWN.}

I744. [Harris, W., I686-I76r.] Ancient and Present State of the County of Down. 8vo. Dublin: I744. [269.]

I802. Dubourdieu, Rev. J. Statistical Survey of the County of Down. 8vo. Dublin: I802. [Birds at pp. 316-I7.]

1838. Thompson, W. On the Snowy Owl shot on Scrabo mountain. (Ann. N. H., II.)

I868. Blake-Knox, H. Sabine's Gull in Co. Down. (Zool.)

1874. Belfast Nat. Field Club, Members of. Aves. [In Givide to Belfast and the Adjacent Counties.] Post 8vo. Belfast: I874. [678.]

I875. Knox, A. A History of Co. Down. 8vo. Dublin : I875. [333.] Patterson, R. Ll. Great Northern Diver on Belfast Lough. (Field, Apr. 3.)

I876. Clermont, Lord. Stock Dove in Ireland. (Zool.)

Patterson, R. L. Notes on Swimming Birds of Belfast Lough. (ex Belfast N. H. Soc. Repts., 1874-76.) 8vo. Priv. printed: I876. [46I.]

I877. Warren, R. Stock Dove in Ireland [breeding near Comber]. (Field, July I4.)

I878. Darragh, T. Red-backed Shrike in Ireland. (Zool.)

I879. Benson, C. W. Spotted Crake in Co. Down. (Zool.) 
I880. Patterson, R. L. Birds, etc., commonly frequenting Belfast Lough. 8vo. Lond. : I880. 2nd edit. I88I. [46I.]

I88r. Marshall, H. Spotted Crake and Landrail near Newry. (Field, Dec. IO.)

I882. Patterson, R. Ll. Crane near Killyleagh. (Field, May 27.)

I883. Duffin, W. E. L.'Estrange. Siskin in Co. Down. (Zool.)

Lett, H. W. Black Stork in Ireland [errore for Heron]. (Sci. Gossip.)

Patterson, R. L1. American Bittern in Co. Down. (Field, Nov. IO); Upland Geese in Co. Down. (T.c., Nov. 24.) Idem by E. A. Butler. (Op. cit., Dec. 8, I883; Jan. I2, I884.)

I884. Butler, E. A. Grey Shrike in Ireland [near Lisburn]. (Field, Jan. I2); Great Northern Divers in Summer Plumage. $(O p$. cit., July 5.)

I886. Patterson, R. L1. Great Spotted Woodpecker in Co. Down. (Field, Oct. 30 ; Dec. 4.)

I889. Butler, E. A. Snowy Owl in Co. Down. (Field, Mar. 30.)

I89o. Patterson, R. Bittern in Co. Down. (Zool.)

I89r. Patterson, R. Wilson's Petrel in Co. Down. (Zool.) Idem. (Field, Oct. Io.)

I892. Patterson, R. Grey Phalarope in Ireland; Forktailed Petrel in Ireland. (Zool.); Goosander in Strangford Lough. (Irish Nat.)

I893. Barrington, R. M. Antarctic Sheathbill on Irish Coast. (Zool.) Idem by J. E. Harting. (T.c.) ; Idem by R. O. Cunningham. (Irish Nat.)

Canning, A. S. G. Ob. Stock-Doves at Rostrevor. (Irish Nat.) Ellison, A. Great Crested Grebe nesting at Hillsborough. (T.c.) Patterson, R. Among the Birds of Strangford Lough. (T.c.)

I894. Horsbrugh, C. B. Nesting of Great Crested Grebe in N. Ireland. (Zool.)

Patterson, R. Waxwing in Co. Down. (Irish Nat. ; Zool.)

Praeger, R. L. Spring Migrants in Co. Down. (Irish Nat.)

Stelfox, J. Spring Migrants in Down. (T.c.)

r896. Waddell, C. H. [ob. I9I9.] Scarcity of Landrail in Co. Down. (Irish Nat.)

1897. Stelfox, J. A Blackbird's Nest. (Irish Nat.)

I898. Barton, H. D. M. Stock Doves in Co. Down. (Irish Nat.)

Evans, H. E. Spotted Crake in Co. Down. (Field, Dec. 3.)

Patterson, Sir R. L. Longtailed Duck on Belfast Lough. (Irish Nat.)

Patterson, R. Roughlegged Buzzard at Portaferry; Grey Phalarope at Ballymoney; Hawfinch at Hillsborough; Marsh Harrier at Cullybackey. (T.c.) 
1899. Orr, H. L. Maternal Affection of Wild Birds and Vitality of Some Eggs. (Irish Nat.)

Ig0o. Burton, Rev. J. G. [viv.] Curious Note of a Cuckoo. (Irish Nat.)

Patterson, R. Bittern at Groomsport. (T.c.)

IgoI. Brown, John. [ob. IgI2.] Bird Notes from the Mourne Mountains. (Irish Nat.)

Cottney, J. [I869-IgIo.] Wigeon [errore] breeding in Ireland. (Zool.) Idem by R. Patterson. (Irish Nat.) Idem by the same [correction]. (T.c.)

Patterson, R. Tawny Owl at Belvoir Park; Snowy Owl at Falcarragh; King Eider Duck at Donaghadee; Tawny Owls in Co. Down; Corncrake in January ; Tawny Owl at Dunmurry. (T.c.)

I902. Brown, J. Quails in Co. Down. (Irish Nat.)

Foster, N. H. Late Breeding of Corn Bunting. (T.c.)

Patterson, R. Birds in Belfast Nat. F. C. Guide to Antrim and Down. (Brit. Assoc. Guide.)

I903. Foster, N. H. Rambles among and about the Mourne Mountains. (Pr. Belf. Nat. F.C.). Partial Migration of Sparrows; Merlins and Peregrines. (Irish Nat.)

Patterson, Robert Michael. Deception on part of a Thrush. (Irish Nat.)

Patterson, R. Late Stay of Swift. (T.c.)

I904. Cottney, J. Time Occupied by Birds in Building and Laying. (Irish Nat.)

Foster, N. H. The Birds of a Neighbourhood; Roughlegged Buzzard in Co. Down. (T.c.)

Patterson, R. Waxwing in Ulster. (T.c.)

Patterson, Sir R. Ll. Manx Shearwater. (T.c.)

I905. Cottney, J. The Water Rail; The Bullfinch; A Winter Corncrake; Jerry-building; Vagaries in Egg-laying. (Northern Whig.)

Foster N. H. Bird Watching. (Pr. Belf. Nat. F. C.) ; Scaup Duck in Inland Waters. (Irish Nat.); Ballywalter Birds; Bangor Birds ; Local Bird Names. (Northern Whig.)

McEndoo, W. Quails in Co. Down. (Irish Nat.)

Orr, H. L. [I853-I9r3]. Strange Fatality to a Kingfisher. (Northern Whig.)

Patterson, R. A White Water Rail; Corncrake in Winter (Irish Nat.) ; A Co. Down Lake ; Fatalities to Rooks; Gannet Inland ; Waxwing in Ireland ; Fatal Accidents to Cormorants ; The Corncrake; Curious Nesting Sites; Irish Bird Names; Autumn Migration of Birds ; Nesting Boxes for Birds. (Northern Whig.) 
I906. Cottney, J. Bramblings near Hillsborough. (Northern Whig, Mar. I0) ; Wagtails. (T.c., Mar. I7) ; Shrikes. (T.c., Apr. 7.) Foster, N. H. Siskins in Co. Down. (T.c., Jan. 27.); The Brambling. (T.c., Feb. 3.)

Malcomson, H. T. Storm Petrel in Co. Down. (Irish Nat.)

Orr, H. L. Local Bird Names. (Northern Whig, June I6) ; A Museum Specimen. (T.c., July 7); Ornithomyia in Starlings. (Irish Nat.)

Patterson, R. Sandwich Tern Breeding in Co. Down; Glossy Ibis in Co. Down. (Irish Nat.)

I907. Cottney, J. Local Names of Birds. (Northern Whig, Nov. 30.) Foster, A. B. Early Swallows. (T.c., Apr. I3) ; A Late Swallow. (T.c., Nov. I6.)

Foster, N. H. Notes from Hillsborough. (T.c., Feb. 9, Mar. 9, Apr. 6, May 4, June 8, July 6, Aug. Io, Sept. 7, Oct. 5. Nov. 9, Dec. 7.) Birds' Nests. (T.c., May 4.)

Patterson, R. My Bird Table. (T.c., Jan. I2, Dec. 23) ; Return of the Starling. (T.c., Sept. 2I) ; Nuptial Changes in Bill of Common Puffin. (Irish Nat.)

Wilson, Alec George, J.P. [viv.] A Gigantic Woodcock. (Irish Nat.)

I908. Cottney, J. Wild Swans. (Northern Whig, Feb. 8) ; Increase of Wood Pigeons. (T.c., Feb. 8) ; A Word for the Rook. (T.c., Dec. 26.)

Foster, A. B. An Unusual Observation. (Op. cit., Dec. 26.)

Foster, N. H. Notes from Hillsborough. (T.c., Jan. 4); Birds' Nests. (T.c., Apr. II) ; Departure of Summer Migrants. (T.c., Oct. 3I) ; Arrival of Winter Migrants. (T.c., Nov. 7.)

Patterson, R. A Disaster on Migration. (Irish Nat.) ; Markings of Nestling Birds ; Economic Value of Birds to the State. (Pr. Belf. Nat. F.C.)

I909. Cottney, J. Re an Unusual Observation. (Northern Whig, Feb. I3); Rooks and Corn. (T.c., Jan. 2) ; Eviction by the Cuckoos. (T.c., July I7.)

Foster, N. H. A New Year's Ornithological Ramble, etc. (T.c., Jan. 9) ; Our Winter Migrant Thrushes. (T.c., Feb. I3); Birds in Snow: February Bird Notes. (T.c., Mar. I3); The Quail. (T.c., July 3, Io) ; Crossbills in Co. Down. (T.c., July I7) ; Autumn Migrants. (T.c., Nov. 6.) ; The Birds of Hillsborough. (Pr. Belf. Nat. F.C.)

Langtry, Ross H. A Summer Fieldfare in Co. Down. (Irish Nat.)

Patterson, R. White Wagtail on the East Coast. (Irish Nat.) A White Water-rail. (Northern Whig, Jan. I6) ; A Winter Corncrake. (T.c., Mar. 6); Winter Visitors. (T.c., Nov. 6) ; A November Corncrake. (T.c., Nov. I3.)

Workman, W. H. Crossbill in Co. Down. (Brit. Birds, III.) 
IgI0. Cottney, J. Starlings. (Northern Whig, Jan. 8); Magpies. (T.c., Feb. I9); The Mistle Thrush. (T.c., Mar. I2); The Wren. (T.c., June 4); Food of Owl and Kestrel. (T.c., Mar. 26) ; Magpies and Chickens. (T.c., Ang. 6.)

Ellison, A. Breeding Habits of the Siskin in Ireland. (Irish Nat.)

Foster, N. H. Oystercatcher following the Plough. (Brit. Birds, IV.) ; Some of our Rarer Birds. (Pr. Belf. Nat. E P. Soc.); Winter Flocks of Birds. (Northern Whig, Jan. I5); The Mystery of Migration. (T.c., Apr. I6) ; Flocks of Birds. (T.c., July 23); Departure of Swifts. (T.c., Aug. 20); Departure of Summer Visitants. (T.c., Oct. I) ; Crossbills in Co. Down. (Brit. Birds, III.)

Orr, H. L. Ring Dove feeding on Ivy berries. (Irish Nat.) ; A Large Flock of Birds. (Northern Whig, Jan. 8); Birds at Ballywalter. (T.c., May 28.)

Patterson, R. The Chiffchaff. (Northern Whig, Apr. 2); Hoopoe in Co. Down. (T.c., Oct. 8; Irish Nat.)

Smith, J. B. Late Stay of Bramblings. (Brit. Birds, IV.)

I9II. Foster, N. H. Nest Building. (Northern Whig, Apr. 29, May 6) ; Departure of Summer Birds. (T.c., Nov. II); The Night Movements of Redwings. (T.c., Dec. 9, I6) ; Ornithological Puzzles. (T.c., Dec. I6) ; A Talk about Birds. (Pr. Belf. Nat.F.C.)

I9I2. Foster, N. H. Late Stay of Swifts. (Irish Nat.); Abnormal Breeding Habit of Sheld-Duck. (Brit. Birds) ; The Singing of Birds. (Northern Whig, Jan. I3) ; The Redwing. (T.c., Feb. 3); New Irish Birds. (T.c., Mar. 23); The Jackdaw. (T.c., May I8); Spring Migrants in Igr2. (T.c., May 25); Snipe perching, and Grebes. (T.c., July 6) ; Bird Notes from Hillsborough. (T.c., Aug. Io); Albinism. (T.c., Oct. 26); A Rare Winter Visitor, and the Mistle Thrush. (T.c., Dec. 7.)

Patterson, R. The Grey Phalarope. (Northern Whig, Jan. 20) ; Effect of Wintry Weather. (T.c., Dec. 7.)

I9I3. Foster, N. H. Quails. (Northern Whig, Jan. I8); A NestRobber. (T.c., June 7); Wood-pigeons, useful or otherwise. (T.c., June I8) ; Departure of Spring Migrants. (T.c., Oct. 4) ; Swallows and House Martins. (T.c., Nov. I5); Curious nesting site. (T.c., Dec. 27); Whooper Swan in Co. Down. (Irish Nat.)

Orr, H. L. Corncrake in January. (Northern Whig. Feb. I) ; The return of the Starlings. (T.c., Sept. I3.)

Workman, W. H. Black Guillemots nesting at Ballywalter. (T.c., Oct. II.)

I9I3-I4. Workman, W. H. On peculiar nesting site of Black Guillemot. (Brit. Birds, VII., I9I3 ; Irish Nat., I9I4.) 
I9I4. Foster, N. H. Departure of Spotted Flycatchers. (Irish Nat.) ; Moorhen carrying Eggs. (Brit. Birds); The Sedge Warbler. (Northern Whig, Jan. 3) ; A Ringed Cormorant. (T.c., Jan. Io) ; Another Ringed Bird recovered. (T.c., Jan. I7) ; Waxwing, and Kestrel near Water. (T.c., Feb. 2I) ; The Nightingale. (T.c., Apr. 4); Domed Nests. (T.c., June 6) ; Scarcity of Birds. (T.c., Aug. I) ; Passing of the Summer. (T.c., Aug. 3I) ; Departure of the Swallows. (T.c., Oct. Io); Breeding of Canada Goose at Hillsborough. (Irish Nat.)

Orr, H. L. A very rare visitor. (Northern Whig, Mar. 21, 28.)

I9I5. Foster, N. H. Bird recording at its best. (Op. cit., Jan. 9); The Birds of Hillsborough. (T.c. Jan. I6) ; Spring's approach. (T.c., Mar. I3) ; Song during Flight. (T.c., Apr. I7); The Tree Pipit. (T.c., May I); Mistle Thrush singing on Wing; Curious habit of Landrail. (T.c., June I2) ; The Quail. (T.c., June 26); A Contrast: Two Broods from one Nest. (T.c., Aug. I4); Mistle Thrush singing in Winter. (Brit. Birds); Pied Wagtail nesting on Ground. (T.c.)

Malcomson, H. T. Honey Buzzard at Knock. (Irish Nat.); Note on Honey Buzzard in Ireland. (Brit. Birds.)

Orr, H. L. Early recollections. (Northern Whig, June 26) ; The Grouse. (T.c., Sept. II); The Siskin. (T.c., Nov. I3.)

Igr6. Foster, N. H. Hillsborough Birds. (Northern Whig, Jan. 8) ; How to take notes on Birds. (T.c., Jan. 22) ; Song of the Fieldfare. (T.c., Feb. Ig) ; A Pretty Sight. (T.c., Mar. II) ; The Goldeneye. (T.c., June I2); A Voice from the Past. (T.c., Dec. 2.)

Orr, H. L. A Robin Transfixed. (Op. cit., Jan. I5); The Raven. (T.c., Aug. I9.)

Wright, W. C. Lapland Bunting in Co. Down. (Brit. Birds, IX.)

I9I7. Foster, N. H. The Tit Family. (Northern Whig, Feb. Io) ; Waxwing in Co. Down. (Irish Nat.); The Winter of I9I6-I7 and its Effect on Bird Life in Co. Down. (T.c.) ; Some Migrant Notes. (T.c.) ; Departure of Swifts. (T.c.)

Malcomson, H. T. Mortality among Great Crested Grebes. (Irish Nat.)

Orr, H. L. Answers to Bird Questions. (Northern Whig, July 9) ;

Sparrow Clubs. (T.c., Aug. I8.)

\section{CO. DUBLIN.}

I772. Rutty, J. An Essay towards a Natural History of the County of Dublin. 2 vols. 8vo. Dublin: I772. [500.] 
1832. $\mathrm{K}[\mathrm{nox}], \mathrm{T}$. Rarer Birds taken in Ireland, principally in Vicinity of Dublin, in Winter of I83I-32. (Loudon's Mag. N.H., V.); Crested Cormorant near Dublin. (T.c.) ; Hawfinch or Grosbeak shot in Phœnix Park. (T.c.)

I833. $\mathrm{K}[\mathrm{nox}], \mathrm{T}$. Rose Ouzel (Pastor roseus) shot near Dublin. (Op. cit., VI.)

I836. "W. R." [W. H. Russell.] Crested Lark at Taney. (Dublin Penny Jnl., Feb. 27.)

I848. Montgomery, R. J. Reed Warbler and Blackcap near Dublin. (Zool.)

1853. Kinahan, J. R. On Singing of Birds in Spring and Summer in Ireland. (Zool.)

I854. Irby, L. H. Rose-coloured Pastor near Dublin. . (Zool.)

Tristram, H. B. Little Olivaceous Gallinule at Balbriggan. (T.c.)

Warren, R. Charadrius minor from Clontarf Is. (Nat. Hist. Rev.)

I855. Kinahan, J. R. [ob. I863.] Local List of Birds found in Co. Dublin. (Nat. Hist. Rev.)

Powys, Hon. T. L. Bonaparte's Gull on Irish Coast. (Zool.)

I860. Dombrain, J. R. Occurrence of Rose Ouzel (Pastor roseus) near Dublin. (Pr. N. H. Soc. Dubl., II., I856-59.)

Kinahan, J. R. Black Redstart and Whinchat in December near Dublin. (Zool.); Black Redstart near Dublin. $(\mathrm{Pr}$. N. H. Soc. Dubl., I859-6o.)

I862. Blake-Knox, H. Egyptian Goose near Dublin; Black Redstart in Co. Dublin ; Sabine's Gull in Dublin Bay. (Zool.)

I863. Blake-Knox, H. Skuas on Coast of Dublin; Black Redstart in Co. Dublin; Purple Sandpiper, etc., at Dalkey, etc., 9 notes. (Zool.)

Montgomery, R. J. Snowy Owl near Swords. (Pr. N. H. Soc. Dubl., I860-62.)

r864. Blake-Knox, H. Nesting of Lesser Redpoll at Dalkey; Storm Petrel in Dublin Bay; Scarcity of Red-throated and plenty of Great Northern Divers in Dublin Bay; Spoonbill in Dublin. (Zool.)

I865. Blake-Knox, H. Ornitholog. Notes taken on the Kish Bank, Dublin Bay; First Arrival of Snow Bunting and Purple Sandpiper in Co. Dublin. (Zool.)

"Gillaro." Night Heron in Co. Dublin. (Field, Dec. 2.)

I866. Blake-Knox, H. Ornitholog. Notes from Dublin; Sabine's Gull in Dublin Bay; Migratory and Wandering Birds, 3 notes ; Nesting of Lesser Redpoll, etc., at Dalkey. (Zool.)

Legge, W. V. Sea Birds at Malahide. (T.c.)

I867-69. Blake-Knox, H. Ornitholog. Notes from Co. Dublin, 3 pts. (Zool., I867-69.) 
I868. Blake-Knox, H. Sabine's Gull and Little Auk in Dublin Bay ; Thick-kneed Plover, Whitewinged Crossbill, Nightjar, etc., in Co. Dublin; Effects of Frost and Snow upon Common Birds ; Blackthroated Diver, Iceland and Glaucous Gulls off Dublin Coast, etc., I8 notes. (Zool.)

I869. Blake-Knox, H. Glaucous and Iceland Gulls in Kingstown Harbour, 2 notes. (Zool.)

I870. Blake-Knox, H. Six Additions to List of Migratory and Wandering Birds of Co. Dublin; Black Redstart, Eider Duck, etc., in Co. Dublin, II notes. (Zool.)

I87r. Blake-Knox, H. Little Stint, Brünnich's Guillemot, etc., on Dublin Coast, etc., 5 notes. $(O p$. cit.) Wood Wren and Melodious Willow Warbler in Ireland. (Field, May 6.)

I872. Harting, J. E. British Heronries. (Zool.) [partim.] Williams, E. Common Sandpiper in Co. Dublin. (Field, Apr. I3.)

I876. Benson, C. W. Ornitholog. Notes from Dublin; Sparrowhawk and Mistle Thrush; Blackcap in Ireland. (Zool.)

Douglas-Ogilby, J. Arrival of Spring Migrants; Golden Oriole in Co. Dublin. (T.c.)

"Vagans." Golden Oriole near Dublin. (Field, May I3.)

I878. Benson, C. W. Summer Migrants near Dublin; Tree Pipit in Ireland. (Zool.)

More, A. G. List of Birds of Dublin and Wicklow. (In a Guide to County of Dublin, repr. from Sci. Proc. R. Dublin Soc.) 8vo. Dublin : 1878 . [4I3.]

Shackleton, J. F. Blackcap in Co. Dublin. (Zool.)

I879. Benson, C. W. Notes from Dublin. (Zool.)

Cox, H. L. Birds of Dublin and Wicklow. (T.c.)

I880. Hart, H. C. Supposed Occurrence of Tawny Owl. (Zool.)

I88I. Hart, H. C. Supposed Occurrence of Crane on Promontory of Howth. (Zool.)

More, A. G. Sabine's Gull near Dublin. (Field, Oct. I ; Zool.)

I88I-82. Williams, A. Ornitholog. Notes from Dublin, 2 pts. (Zool., I88I-82.)

I882. Gurney, J. H., junr. Little Crake in Ireland. (Zool.)

More, A. G. Cape Pigeon shot near Dublin. (Ibis.)

I883. Graham, N. Bittern in Phœnix Park. (Field, Feb. I7.)

Hart, H. C. Birds of Lambay Island. (Zool.)

Royston, J. Yellow Wagtail in Co. Dublin. (T.c. ; Field, June 9.)

I884. Dowling, J. J. Sabine's Gull in Dublin Bay, (Zool.)

I886. Dowling, J. J. Cormorant in City of Dublin. (Zool.) 
I887. Nourse, W. E. C. Birds near Dublin. (Sci. Gossip, Apr.) Correction by A. Hollis. (T.c., June.) By C. B. Moffat. (T.c., Oct.)

I888. Templar, G. Garganey in Co. Dublin. (Field, May 5.)

I889. Dowling, J. J. Early nesting of Little Grebe in Co. Dublin. (Zool.)

I89I. More, A. G. Lesser Kestrel in Ireland. (Zool.)

I892. Cooke, S. V. Ivory Gull in Co. Dublin. (Zool.)

More, A. G. American Robin and Lesser Kestrel in Co. Dublin. (Irish Nat., Apr.)

Palmer, J. E. Birds of Lambay Island. (T.c., Sept.)

Waddilove, E. G. Ivory Gull [said to have been seen] in Co. Dublin. (Zool.)

Williams, E. Spotted Redshank and Ruddy Sheldrake in Co. Dublin. (T.c.); Sand Grouse at Portmarnock. (Irish Nat., July.)

I893. Dowling, J. J. Quails in Co. Dublin. (Irish Nat., July.)

Williams, E. Serin in Ireland. (Zool.)

I894. Williams, E. Spotted Redshank in Dublin Bay. (Irish Nat., Oct.)

1895. Trumbull, H. Dead Razorbills. (Nat. Jnl.)

I896. Bullock, H. Quail [nesting] in Co. Dublin. (Irish Nat., Oct.) Farran, G. P. Grasshopper Warbler in Co. Dublin. (T.c., July).

Moffat, C. B. Migration of Curlews. (T.c., Apr.)

Pim, G. Kingfisher in Co. Dublin. (T.c., Dec.)

Trumbull, J. Arrival of Spring Migrants at Malahide. (Ornithologist); Stock Dove in Co. Dublin. (Irish Nat., Jan.)

I897. Knox, E. Blake. Notes from a Trip to Ireland's Eye. (Irish Nat., Aug.) Idem. Correction. (T.c., Sept.)

I898. Benson, C. W. Whinchat in Co. Dublin. (Zool.) Patten, C. J. Birds of Dublin Bay. (Irish Nat., Oct.)

Williams, E. Notes from Dublin Bay. (Knowledge.)

1899. Moffat, C. B. Little Tern in Dublin Bay. (Irish Nat., Nov.) Patten, C. J. Recent Observations on Sea-fowl of Dublin Coast. (T.c., Dec.)

Trumbull, J. Hawfinch and Longtailed Duck in Co. Dublin. (T.c., Jan.)

I90o. Patten, C. J. Reed Buntings on the Sea-beach. (Irish Nat., May.)

Igor. Williams, W. J. Wood Sandpiper in Co. Dublin; Turtle Dove in Co. Dublin. (Irish Nat., Oct.)

I903. Benson, C. W. White Wagtail at Balbriggan. (Irish Nat., Nov.)

Williams, E. Eider Duck at Malahide. (T.c., Apr.) 


\section{DUBL.IN.]}

I905. Benson, C. W. Notes on Birds observed at Balbriggan in I903-4. (Zool.) ; Quails in Co. Dublin. (Irish Nat., July.)

I906. Tunstall-Moore, C. B. Spotted Crake in Co. Dublin. (Field, Dec. I.)

Williams, W. J. Lapland Bunting in Ireland. (Irish Nat., May.)

I907. Patterson, R. Tree Sparrows in Co. Dublin. (Irish Nat., Oct.) ; Nat. Hist. of Lambay-Birds. (T.c., Jan.)

Trumbull, J. Heron breeding at Portmarnock. (T.c. Oct.)

I908. Barrington, R. M. Pallas's Grasshopper Warbler in Ireland; Little Bunting in Ireland. (Brit. Birds, II. ; Bull. B.O.C., XXIII., I908-09.)

Hunter, R. H. Breeding of Crossbill in Co. Dublin. (Brit. Birds, II.)

Praeger, R. L1. Morning Flight of Sea-birds over Dublin. (Irish Nat., Mar.)

Williams, A. Increase of Terns Nesting. (Brit. Birds, II.); Bird Life in Dublin Bay. (Irish Nat., Sept.)

Williams, W. J. Richard's Pipit in Co. Dublin. (Zool.); Seagulls in Dublin. (Irish Nat., Apr.)

Witherby, H. F. Black Redstart near Dublin. (Brit. Birds, I.)

I909. Patten, C. J. Migratory Movement of Certain Shore Birds as observed on Dublin Coast. (Nat., I909; Irish Nat., Nov. I908; Rep. Brit. Assoc., Igo8); Ornithology of Skerries. (Irish Nat., Sept.) Idem. Correction by W. J. Williams. (T.c., Nov.) Patterson, A. H. Some Mud-flat Bird Notes. (Zool.)

Williams, A. The White Wagtail in Co. Dublin. (Irish Nat., June ; Brit. Birds, III.)

Williams, W. J. Crossbills around Dublin; Montagu's Harrier in Ireland. (Brit. Birds, III.)

Witherby, H. F. Irish Birds-Water Pipit. (Op. cit., II.)

IgIo. Campbell, D. C. Greenland Falcons in Co. Dublin. (Irish Nat.) Ogilvie-Grant, W. R. [Parus hibernicus: new Irish subspecies of Coal Tit.] [partim.] (Bull. B.O.C., XXVII.)

Williams, A. Observations on Sanderlings of Dublin Bay. (Irish Nat.)

Williams, W. J. Rare Birds in Ireland-Ruff. (Brit. Birds, III.)

IgII. Williams, W. J. Nuthatch in Ireland. (Irish Nat. ; Brit. Birds, V.)

I913. Barrington, R. M., and Others. The Carrion Crow at Lambay, 4 notes. (Irish Nat.) ; Lesser Whitethroat in Ireland. (Brit. Birds, VII.)

Barrington, R. M. Tree Pipit and Pied Flycatcher at Rockabill ; Lesser Whitethroat at Rockabill. (Irish Nat.)

Benson, C. W. Turtle Dove in Co., Dublin. (Brit. Birds, VII.) 
I9I4. Benson, C. W. Hawfinch at Balbriggan. (Irish Nat.)

May, G. C. Carrion Crow at Ireland's Eye. (T.c.)

I9I5. Crawford, G. B. Black Redstart and Roseate Tern in Co. Dublin. (Irish Nat.)

I9I6. Benson, C. W. Quails in Co. Dublin. (Brit. Birds, IX.) ; Turtle Doves in Co. Dublin. (Irish Nat.)

Crawford, G. B. Some Notes on Winter Birds near Dublin.

(Irish Nat.) A few Notes on Birds about Kingstown. (T.c.)

May, G. C. Carrion Crow at Ireland's Eye. (T.c.)

Patten, C. J. Hedge Sparrow [etc.] on Migration at Rockabill Light Station, 5 notes. (T.c.)

I9I7. Benson, C. W. Summer Migrants at Balbriggan in IgI6. (Irish Nat.)

May, G. C. Jays in Co. Dublin; Carrion Crow nesting at Ireland's Eye. (T.c.)

Shaw, F. W. Night Heron near Dublin. (T.c.)

I9I8. Wilson, J. M. Corncrake in Trinity College Park [Dublin]. (Irish Nat.)

\section{CO. FERMANAGH.}

I864. Clermont, Lord. Pallas's Sand Grouse in Ireland. (Zool.)

I869. S-, H. Garganey Teal [Lough Erne]. (Field, Feb. 6.)

1872. Harting, J. E. British Heronries. (Zool.) [partim.]

1873. Brooke, A. B. Gadwall in Ireland. (Zool.)

1875. Williams and Son. Bittern in Ireland [near Lough Erne]. (Field, Jan. 23.)

r876. Murray, H. B. Snowy Owl in Co. Fermanagh [near Sack]. (Field, Mar. 4.)

I882. H-, J. H. Local Names of Birds. (Sci. Gossip.)

I889. Brooke, D. Reported occurrence of Nightingale in Ireland [Co. Fermanagh]. (Field, May I8.)

I89r. Williams, E. Wilson's Petrel in Co. Fermanagh. (Zool.)

I892. Praeger, R. Ll. In Camp on Lough Erne. (Irish Nat.)

1893. Collins, Arthur J. Bittern near Enniskillen; Arrival of Spring Migrants. (Irish Nat.)

I894. Collins, A. J. Spring Migrants. (Irish Nat.)

I895. Collins, A. J. Unusual Retreat for Grouse. (Irish Nat.) Langham, Sir Charles, Bt. Two-barred Crossbill in Ireland. [Editor's Note.] (Zool.)

McMillan, W. Quail at Newtownbutler. (Irish Nat.) 
I900. Warren, R. A Visit to Lough Erne. (Irish Nat.)

I902. Parkinson-Currie, J. G. Spring Migrants. (Op. cit.)

Patterson, R. Dunlin breeding on Lough Erne. (T.c.)

Igo6. Langham, Sir C., Bt. Forktailed Petrel in Fermanagh. $(O p$. cit.)

Igo8. Trevelyan, H. Abnormal Eggs of Blackheaded Gull; Unusual Nesting Sites and Incubation Period of the Tufted Duck; Abnormal Eggs of Ringed Plover. (Brit. Birds, II.)

I909. Trevelyan, $H$. Notes on Flocking of the Redbreasted Merganser ; Common Scoter breeding in Ireland. (Op. cit., II.)

I9Io. Trevelyan, H. Flocking of Redbreasted Merganser. (Field, Sept. 3.)

Williams, W. J. Rare Birds in Ireland-Osprey. (Brit. Birds, III.)

Igro-rr. Trevelyan, H. Notes on Common Scoter breeding in Ireland, 2 notes. (Op. cit., IgIO-II.)

IgIr. Trevelyan, H. Breeding of Great Black-backed Gull in Ireland. (Op. cit., V.)

I9I2. Trevelyan, H. Flocking of Redbreasted Mergansers in Autumn. (Op. cit., V.)

I9I3. Langham, Sir C., Bt. Stock Doves in Fermanagh. (Irish Nat.) I9I4. Patterson, R. Waxwing in Co. Fermanagh. (Northern Whig, Jan. 3I.)

I9I5. Burkitt, J. P. The Great Crested Grebe. (Irish Nat.) I9I6. Burkitt, J. P. Dummy nests of Whitethroat and Garden Warbler. (Irish Nat.) ; Blackcap in Co. Fermanagh. (T.c.); The Nightjar. (T.c.)

I9I7. Burkitt, J. R. Some Migrant Notes. (Irish Nat.); Note on the Long-eared Owl. (T.c.) ; The effect of the rgr6-I7 Winter on Birds. (T.c.); Wood Wren in Fermanagh. (T.c.)

\section{CO. GALWAY.}

I836. Lingwood, R. M. List of Birds, etc., observed in Connemara, August I835. (Loudon's Mag. N. H., IX.)

I85I. McIntosh, J. Heronries in England, etc. [partim.] (Nat. [Morris's], I.)

I864. [Anon. "R. J. M."] Leach's Petrel in Co. Galway. (Field, Jan. 9.)

I865. Foot, F. J. Flights of Swans seen. (Pr. N. H. Soc. Dubl., I863-64.) 
r868. Whyte, J. The Hawfinch [in Co. Galway]. (Field, July 4.) r869. Templer, R. B. Buff-coloured Woodcock. (Field, Jan. 2.) I871. [Anon. "A."] Wild Swans in Ireland. (Field, Jan. I4.) 1872. Harting, J. E. British Heronries. (Zool.) [partim.] I873. Persse, A. Sabine's Snipe in Co. Galway. (Field, Dec. 6.) I876. Kendall, J. Snowy Owl [near Clifden]. (Field, Dec. 9.) I877. Warren, R. Shoveler breeding in Ireland [near Portumna]. (Field, June 2.)

I881. "P. A. K." Shoveler on Lough Corrib. (Field, Jan. 22.) I882. "P. A. K." Woodcock nesting in Co. Galway. (Field, Apr. 29.) 1885. Ussher, R. J. Two Days in the Connemara Mountains. (Zool.) I887. H- W. C. Turtle Dove in Co. Galway. (Field, Nov. I9.) T—, G. Nightjars in Co. Galway. (T.c., Aug. 27.)

I888. Keatinge, P. Pallas's Sand Grouse [in Co. Galway]. (Field, June 16.$)$

I889. Williams, E. Golden Eagles in Co. Galway; Pectoral Sandpiper in Ireland; Solitary Snipe in Ireland. (Zool.)

I89r. Burke, J. Forktailed Petrel [in Co. Galway]. (Field, Oct. ro.) Idem by R. M. Barrington. (T.c., Nov. I4, 28, Dec. 5.)

Williams, E. Golden Oriole in Co. Galway. (Zool.)

1892. Patterson, R. Grey Phalarope in Ireland. (Zool.)

Williams, E. Golden Eagle in Co. Galway. (Irish Nat.)

1893. Coburn, F. Female Merganser assuming Male Plumage. (Zool.) I894. [Anon.] Occurrence of Eider. (Field, Jan. 6.)

Johnston, J. N. White Variety of Sparrow in Co. Galway. (Irish Nat.)

I896. Hibbert, R. F. Stock Dove in Co. Galway. (Irish Nat.)

Palmer, J. E. Birds of Connemara. (T.c.)

Witherby, H. F. Irish Bird Notes; A Fortnight with the Birds of Connemara. (T.c.)

1898. [Anon.] Occurrence of Shoveler. (Field, Oct. I5.)

Gilmore, R. M. Bittern in Co. Galway. (Irish Nat.)

I899. Hamilton, D'A. I. Landrail in Galway in December. (Field, Jan. I4.)

I902. Dillon, R. E. Snow Bunting in Co. Galway. (Irish Nat.)

I904. Congreve, L. H. A Winter Corncrake in Co. Galway. (Irish Nat.)

Williams, W. J. Tree Pipit in Ireland. (T.c.)

I905. Pycraft, W. P. Iceland Falcon in Co. Galway. (Knowledge.)

1907. Nichols, A. R. Tufted Duck breeding on Lough Mask. (Irish Nat.) 
I909. Bahr, P. H. Crossbills in Galway. (Brit. Birds, III.)

I9ro. Williams, W. J. Rare Birds in Ireland-Little Auks. (T.c.)

I9I2. Barrington, R. M. Wryneck at Aran Island. (Irish Nat.)

I9I5. Humphreys, G. H. Arrival of Chiffchaff. (Irish Nat.)

rgr6. Carroll, C. J. Cream-coloured Whimbrel in Ireland. (Brit. Birds.)

I9I7. Patten, C. J. Arctic Skuas on migration on Mutton Is. ; Sandwich Terns breeding on Mutton Is. (Irish Nat.)

Ruttlidge, R. F. Migration at Mutton Is. (T.c.)

IgI8. Ruttlidge, R. F. Sandwich Terns breeding in Co. Galway ; Migration on Lough Mask; Snow Geese at Mutton Is. (Irish Nat.)

\section{CO. KERRY.}

I756. Smith, C. Ancient and Present State of County of Kerry. 8vo. Dublin : I756. 2nd edit. ib., N.D. [I774.] [548.]

I853. Yarrell, W. Petrel new to Britain on W. Coast of Ireland. (Zool.) I854. Sabine, Sir E. Birds [in Ainsworth's Caves of Ballybunion]. 8vo. Dublin : 1854. [5oI.]

1857. Andrews, W. Notes on Ornithology of Co. Kerry. (Nat. Hist. Rev.)

I858. “B. H. H." A Rare Bird [Roller, etc., in Kerry]. (Field, Oct. I6.) 1859. Kinahan, G. H. On Remarkable Destruction caused among Birds in Kerry by Winter of I854-55. (Nat. Hist. Rev.)

"Tralee." Hooper and Bewick's Swans [near Dingle]. (Field, Apr. 23.)

1860. Andrews, W. Notes on Ornithology of Co. Kerry. (Pr. N. H. Soc. Dubl., II. [1856-59.]

Kinahan, J. R. On Remarkable Destruction among Birds caused by Winter of $1854-55$. (T.c.)

1864. Neligan, J. C. Letter on Migration of Skuas, etc. (Pr. N. H. Soc. Dubl., I862-63.)

1867. Hackett, W. A. Goosander in Co. Kerry. (Field, Feb. I6.)

I869. Sweeney, E. Sheldrakes on Cara Lake. (Killarney.) (Field, Oct. 2.)

I870. Brooke, A. B. Natural History of Wicklow and Kerry. (Zool.) Blake-Knox, H. Ruddy Shieldrake near Tralee; Osprey in Co. Kerry. (T.c.) 
I87I. [Anon. "M. R. I. A."] Longtailed Duck in Co. Kerry. (Field, Feb. II) ; Peregrine in Co. Kerry. (T.c., Mar. II.)

I872. Harting, J. E. British Heronries. (Zool.) [partim.]

I875. [Anon. "A.”] Squacc Heron in Co. Kerry. (Field, June I9.)

I876. Bowles, A. H. Golden Eagle shot near Killarney. (Ficld, Dec. I6.)

I877. Bowles, A. H. Golden Eagle near Killarney; Squacco Heron in Killarney. (Zool.)

Hackett, W. A. Goosander in S. of Ireland. (Ficld, Jan. 20.)

Ilderton, C. E. Polish Swan in Ireland. (Field, Apr. I4.)

"Beverley." Idem. (T.c., Apr.2I.)

I878. Hackett, W. A. Golden Eagle in Kerry. (Field, Dec. 28.) [Correction $=$ White-tailed Eagle, by "Inisclure"] (Op. cit., Jan. II, I879.)

I88I. Benner, W. Rare Visitants to Tralee. (Sci. Gossip.)

C- , J. C. Wild Swans on Lake of Killarney. (Field, Feb. I9.)

Gallwey, R. Payne. Red-crested Duck in Kerry. (Zool.) Idem. (Field, Mar. 5.)

$\mathrm{M}-$, E. Golden Oriole in Co. Kerry. (Field, June 4.)

More, A. G. Sooty Shearwater in Ireland. (Zool.)

I884. Barrington, R. M. Irish Breeding Stations of the Gannet. (Zool.) Idem by R. J. Ussher. (T.c.)

1885. "Camballo." Notes from Kerry. (Field, Dec. 26.)

I886. Warren, R. Spoonbill in Co. Kerry. (Zool.)

[Anon.] Golden Oriole in Kerry. (Field, June 4.)

I886-87. Ussher, R. J. Breeding of Fork-tailed Petrel on Blasquets, 2 notes. (Zool., I886-87.)

1888. Barrington, R. M. Pied Flycatcher in Ireland. (Zool.)

C—, J. C. Goosander at Killarney. (Field, Apr. 2I.)

I889. O'Connell, D. Spoonbill in Co. Kerry. (Op. cit., Oct. 5.)

I89o. Candler, C. and H. Notes on Bird-Life of Skellig Rocks. (Tr. Norf. \& Norw. Soc., V.)

Courtney, J. C. Golden Eagle shot at Killarney. (Fielu, Dec. 6.)

I89I. Barrington, R. M. Breeding of Fork-tailed Petrel [on Tearaght Rock]. (Field, Nov. I4.)

Turle, W. H. A Visit to the Blasket Islands and Skellig Rocks. (Ibis.)

1892. More, A. G. Lesser Whitethroat and Yellowbrowed Warbler at Tearaght Rock. (Irish Nat., Apr.)

1893. Tank, J. Little Bustard in Kerry. (Irish Nat., Feb.) 
I894. Flemyng, W. W. A Visit to Puffin I., Co. Kerry. (Zool.) Scharff, R. F. The Dusky Shearwater. (Irish Nat., July.)

1895. McCormick, T. W. Osprey in Kerry. (Land \& Water, Mar. 2 ; Irish Nat., Apr.)

I896. Barrett-Hamilton, G. E. H. Pomatorhine Skua in Kerry. (Ornithologist.)

1897. Barrington, R. M. Mealy Redpoll off coast of Kerry ; Supposed Occurrence of Great Spotted Cuckoo in Kerry. (Zool.)

Scharff, R. F. Carrion Crow in Ireland. (Irish Nat., Feb.)

Teesdale, J. H. Montagu's Harrier breeding in Ireland. (T.c., Oct.) Idem. (Zool.) [=Hen Harrier (Irish Nat., Feb. I898.)]

1898. Crawshay, W. T. Rooks feeding on Elvers. (Zool.)

Saunders, H. Exhibition of Puffinus assimilis from Valentia Is. (Bull. B.O.C., VII.)

I899. M'Carron, E. Notes on the Razorbill. (Irish Nat., June.)

IgoI. Ussher, R. J. Great and Sooty Shearwaters on South Coast. (Irish Nat., Feb.)

I902. Patten, C. J. List of Birds observed west of Dingle. (Irish Nat., June.)

I905. Ussher, R. J. Great Shearwaters and Sooty Shearwaters in Igor. (Irish Nat., Feb.)

Igo6. Barrington, R. M. Gannets on the Little Skellig. (Irish Nat., Oct.)

Delap, M. J. Birds of the Skelligs. (T.c., June.)

I907. Dennehy, T. J. Wild Swans in Kerry. (Field, Mar. 23.)

I909. Ussher, R. J. Birds seen from the "Helga" off S.W. Coast. (Irish Nat., Mar.)

I9I0. Williams, W. J. Rare Birds in Ireland-Greenland Falcons and Spoonbills. (Brit. Birds, III.)

I913. Abbott, W. M. Gannets on the Skelligs in I700. (Irish Nat.)

Barrington, R. M. Fulmar Petrel breeding in Co. Kerry. (Brit. Birds, VII.)

Creaghe-Howard, L. C. Swallows in Co. Kerry in Jan. (Field, Feb. I.)

Macginley, P. J. Notes from the Skelligs. Idem by R. J. Ussher. (Irish Nat.)

Praeger, R. Ll. Ravens on Brandon. (T.c.)

I914. Barrington, R. M. Fulmars, Gannets [etc.], on the Skelligs. (Op. cit.)

Dennehy, T. J. Starlings in S.W. Kerry. (Field, Nov. 28.) 
I9I5. Barrington, R. M. Fulmars on the Skelligs. (Irish Nat.)

Dennehy, T. J. Arrival of Wild Geese in Kerry. (Field, Oct. I6.)

I9r6. Moffat, C. B. Fulmars on the Skelligs. (Irish Nat.)

\section{CO. KILDARE.}

I833. K[nox], T. Remarkable Variety of Peewit [shot in Kildare]. (Loudon's Mag. N. H., VI.)

185I. Clarke, G. B. Additional Heronries [at Carton, Maynooth]. (Nat. [Morris's], I.)

I868. Blake-Knox, H. Crossbill breeding in Co. Kildare. (Zool.)

I876. Coates, W. H. Pallas's Sand Grouse in Ireland. (Field, Oct. 2r.) Haughton, W. J. Occurrence of Mealy Redpoll. (Field, Feb. I9 and Mar. 4.)

I877. Williams and Son. Reappearance of Pallas's Sand Grouse in Ireland. (Zool.)

I881. Becher, E. F. Snow Buntings in Co. Kildare. (Zool.)

"Calypso." Goosander on the Liffey [at Harristown]. (Ficld, Feb. I2.)

I882. Freke, P. E. Crossbills in Co. Kildare. (Zool.)

Williams and Son. Ornitholog. Notes [Honey Buzzard]. (T.c.)

I884. Palmer, J. E. Tufted Duck in Co. Kildare ; Scarcity of Summer Birds; Hooded Crow Wading. (Zool.)

I89o. Scharff, R. F. American Bittern in Co. Kildare. (Zool.) Idem by E. Williams. (Op. cit., I8gI.)

I892. Connell, W. Woodpecker in Ireland. (Irish Nat.)

More, A. G. Parrot Crossbill in Ireland. (Zool.)

r894. Hasted, A. W. Snow Buntings in Co. Kildare. (Zool.)

I898. Palmer, J. E. Lesser Black-backed Gull nesting in Co. Kildare. (Irish Nat.)

I902. Burbidge, F. W. Hawfinch breeding in Straffan. (Irish Nat.)

r903. Palmer, J. E. Hawfinches in Co. Kildare. (Irish Nat.)

Williams, -. Little Crake in Co. Kildare. (Zool.)

1905. Neale, F. Quail in Co. Kildare. (Irish Nat.)

I.906. Nichols, A. R. Little Owl in Ireland. (Irish Nat.)

IgIo. Horsbrugh, B. R. Crossbills in Co. Kildare, 2 notes. (Brit. Birds, III.)

I9I3. Metcalfe, H. M. Notes on the Tree Sparrow. (Irish Nat.)

I9I4. Metcalfe, H. M. Green Sandpiper in Co. Kildare. (T.c.) 
CO. KILKENNY.

I862. "An Old Subscriber." The Hoopoe in Ireland [Co. Kilkenny]. (Field, Mar. I5.)

I898. Barrett-Hamilton, G. E. H. Ornithological Notes from Kilkenny. (Irish Nat.)

Igr6. Nash, W. J. Snipe carrying Young [W. Kilkenny]. (Irish Nat.)

\section{KING'S COUNTY.}

I86I. "Brosna." The Bittern [shot near Frankford.] (Field, Aug. 3r.) I865. Whyte, J. Night Heron in Ireland [at Barnard Castle]. (Field, Dec. 9.)

I868. Fox, W. W. Flock of Crossbills in Ireland [near Tullamore]. (Field, Dec. I9.)

I87I. Brooke, A. B. Occurrence of American Goshawk. (Zool.)

I872. Harting, J. E. British Heronries. (Zool.) [partim.]

1875. Dames, T. L. Waxwings in King's Co. (Field, Sept. 4.)

I877. Williams and Son. Squacco Heron in King's Co. (Zool.; Field, Aug. 4.)

I883. "M. S. S." A [Great Northern] Diver picked up in a town [Tullamore]. (Field, Oct. 27.)

1889. More, A. G. Parrot Crossbill in Ireland. (Zool.)

I892. [Anon.] Occurrence of Ruddy Sheldrake. (Irish Sportsman, Oct. I5.)

I894. Digby, - . Occurrence of Shag. (Field, Feb. 3.)

I898. Witherby, H. F. Black Redstart in King's Co. (Irish Nat.)

I909. Witherby, H. F. Irish Birds-Water Pipit. (Brit. Birds, II.)

IgIo. Williams, W. J. Rare Birds in Ireland-Glossy Ibis. $(O p$. cit., III.)

IgI8. Kerr, H. M. R. Green Sandpiper in King's Co. (Op. cit., XI. ; Irish Nat.)

\section{CO. LEITRIM.}

1877. Williams and Son. Roller in Ireland. (Zool.) I884. Butler, E. A. Marsh Harrier breeding in Ireland [Co. Leitrim]. (Field, Aug. 30.)

I885. Hamilton, W. J. Golden Eagle in Co. Leitrim. (Zool.)

I900. Palmer, H. M. Crossbill in Co. Leitrim. (Field, Mar. 29.) 


\section{CO. LIMERICK.}

1842. Thompson, W. Blackwinged Stilts in Co. Limerick. (Proc. Dubl. N. H. Soc., I84I-2, p. 9.)

1858. Kinahan, G. H. Starling Roost at Rathkeale. (Zool.) Idem. (Pr. N. H. Soc. Dubl., II. [1856-59].)

I872. Harting, J. E. British Heronries. (Zool.) [partim.]

I875. Williams, [E.] White-winged Black Tern in Co. Limerick. (Field, June 5.)

I880. Flemyng, W. W. Heronries in Ireland. (Zool.)

I883. Flemyng, W. W. Note of the Long-eared Owl. (Zool.)

I885. Henniker, F. Blacktailed Godwit in Co. Limerick. (Field, Nov. 7.)

I886. Williams, E. Ruddy Sheldrake near Limerick. (Zool.)

I889. Pentland, G. H. Woodcock breeding in Co. Limerick. (Ficld, Sept. 29.)

I89I. Martin, H. Forktailed Petrel [near Limerick]. (Op. cit., Oct. I0.)

I892. Doddy, D. White Snipe. (Irish Sportsman, Mar. I9.)

I894. [Anon.] Woodcocks in May. (Limerick Chronicle, May 3.)

I896. Bevan, J. V. A White Swallow. (Limerick Chronicle, Aug. 28.)

I902. Coburn, F. [Exhib. of Anser rubrirostris Hodgs., from Limerick.] (Bull. B.O.C., XII.)

I908. Bridgeman, H. G. O. Supposed Spoonbill in Co. Limerick.] (Irish Nat. ; Brit. Birds, II.)

-... Tr, R. J. Snowy Owl-A Correction. (Irish Nat.) ett-Hamilton, G. E. H. Former occurrence of Goshawk Ireland. (T.c.)

\section{CO. LONDONDERRY.}

I802. Sampson, Rev. G. Vaughan. Statistical Survey of County of Londonderry. 8vo. Dublin : 1802 . [Catalogue of Birds, pp. 224-35.]

I83r. "H. N." Birds at and near Londonderry. (Loudon's Mag. N. H., IV.)

I87x. Blake-Knox, H. Little Gull in Londonderry. (Zool.)

I872. Ross, J. T. Spotted Crake in Co. Londonderry. (Ficld, Sept. 7.)

1873. Hart, W. E. Heronries in Ulster. (Zool.) 
I876. Douglas-Ogilby, J. Notes from Portrush. (Zool.)

Gatcombe, J. Chough, Curlew Sandpiper and Little Stint at Portrush. (T.c.)

I882. Bond, T. A. Uncommon birds near Londonderry. (Field, July 8.)

I884. Butler, E. A. Sabine's Snipe in Co. Londonderry. (Op. cit., Nov. I.)

I888. Patterson, R. L1. Pallas's Sand Grouse [in Co. Derry]. $(O p$. cit., June 9.)

I89o. Patterson, R. American Bittern in Co. Londonderry. (Zool.)

I892. Campbell, D. C. Ruddy Sheldrakes in Ireland. (Zool.)

Patterson, R. Forktailed Petrel in Ireland. (T.c.)

I893. Campbell, D. C. Waxwing at Derry; Iceland Gull at Londonderry; Spring Migrants at Londonderry; Reappearance of Quail near Londonderry. (Irish Nat.)

Warren, R. Supposed Iceland Gull at Londonderry. (T.c.)

I894. Campbell, D. C. Arrival of Spring Migrants. (Irish Nat.)

I895. Campbell, D. C. Arrival of Spring Migrants. (Irish Nat.)

I896. Campbell, D. C. Arrival of Spring Migrants; Forktailed Petrel near Londonderry. (Irish Nat.)

Henry, Samuel. [viv.] White Swallow at Coleraine. (T.c.)

1897. Campbell, D. C. Iceland Gull at Londonderry; Mass Migration of Birds at Londonderry. (Irish Nat.)

I898. Campbell, D. C. Fulmar and Manx Shearwater at Londonderry. (Irish Nat.)

Patterson, Sir R. L1. Longtailed Duck in Derry. (T.c.)

I899. Campbell, D. C. Iceland Gull at Londonderry. (Iris/ Nat.)

Igoo. Campbell, D. C. Roughlegged Buzzard at Campsie; Bittern at Bunfoot; Grey Phalarope in Lough Foyle. (Irish Nat.) D- D. Bittern in Derry. (Field, Jan. 20.)

Igor. Campbell, D. C. Arrival of Swift in Londonderry; Hawfinch at Garshuey; Breeding of the Dunlin. (Irish Nat.)

I902. Campbell, D. C. Waxwing at Bridgend; Albino Curlew at St. Johnston; Iceland Gull at Londonderry; Pomatorhine Skua on Inniskell Is. (Irish Nat.)

I903. Campbell, D. C. Birds: Their Structure, Flight and Habits. (Pr. Belf. N. F. C.)

Ig04. Campbell, D. C. The Dunlin in the Breeding Season; Gadwall at Londonderry. (Irish Nat.)

I905. Campbell, D. C. Ornitholog. Notes from Londonderry. (Irish Nat.) 
I906. Campbell, D. C. Iceland Gull at Londonderry. (Irish Nat.) Foster, N. H. On Nesting of Tree Sparrow in Co. Derry. (T.C.)

1907. Campbell, D. C. Cleverness of Chough; Homing Instinct in Gull. (Northern Whig, Sept. 2I) ; Friendship of a Robin. (T.c., Dec. 23.)

Henry, S. English Translation of Gaelic Bird-names. (T.c., Nov. 30.)

Kevin, W. H. Local Names of Birds. (T.c.)

I908. Campbell, D. C. Ornitholog. Notes from Londonderry. (Irish Nat.) ; The Lark's Song. (Northern Whig, May 30); Two Common Songs. (T.c., June 6) ; Nature Notes from Magilligan. (T.c., Sept. I2.)

Fletcher, E. H. Shorteared Owls. (Irish Nat.)

Henry, S. Lough Neagh Birds. (Northern Whig, May 23); Birds on Lough Neagh. (T.c., June 6); Wood Wren in Co. Derry. (T.c., June I3) ; The Clever Rook. (T.c., Apr. I8) ; General Notes. (T.c., May 2); The Way of the Cuckoo. (T.c., June 20); The Study of Unnatural History. (T.c., Aug. 22.)

Nicholson, William Weir. [I883-IgI2.] Photographing Birds. (Northern Whig, Oct. 3); The Turnstone. (T.c., Oct. Io.)

I909. [Anon.] Crossbill at Coleraine. (Field, July I7).

Campbell, D. C. Turtle Dove near Londonderry; Wood Wren at Londonderry. (Irish Nat.); Glossy Ibis in Co. Derry. (Irish Nat.; Northern Whig, Oct. 23) ; Nature's Voices. (Northern Whig, Apr. I7); The Gull's Early Meals. (T.c., May I5) ; The Lark's Song. (T.c., June I9) ; Rival Fishers (T.c., Aug. 28) ; Late Nests in I909. (T.c., Sept. I8.)

Henry, S. The Longeared Owl. (Northern Whig, Apr. I7) Identifying a Bird. (T.c., Aug. 2I.)

Nicholson, W. W. Winter Bird Watching. (T.c., Jan. 2); Migration of Sheld Duck. (T.c., Jan. I6); Blue Tits among the Reeds. (T.c., Mar. 6) ; Stock Dove's Nest. (T.c., May I5) ; Where the Raven lives. (T.c., July 3) ; A Dead Fulmar. (T.c., Sept. I8.)

I9I0. Campbell, D. C. Ruffs in Co. Derry. (Irish Nat.); The Purple Sandpiper. (Northern Whig, Mar. I2) ; Homes of the Waders. (T.c., Apr. 30) ; Nature's Voices. (T.c., May 2I) ; An Old Road. (T.c., July Io).

Henry, S. The Blackbird. (Northern Whig, Jan. 29); The Grasshopper Warbler. (T.c., May 28) ; Corvus corax. (T.c., May 28.)

Nicholson, W. W. Purple Sandpipers. (Northern Whig, Jan. I5) ; Early Builders. (T.c., Apr. 9) ; Grey Wagtail. (T.c., Apr. 23); Getting to know the Nightjar. (T.c., June 25);

A Duck Rendezvous. (T.c., Nov. 28.) 
I9II. Campbell, D. C. Ornitholog. Notes from Londonderry. (Irish Nat.); Wanderers. (Northern Whig, Jan. 2I); Strange Companionships among Birds. (T.c., Jan. 28); A Rare Visitor. (T.c. Aug. I9.)

Nicholson, W. W. Early Singers. (Northern Whig, Jan. 28); The Redwing's Song. (T.c., Mar. 4) ; Diary Extracts. (T.c., Mar. II) ; Nature's Music. (T.c., Apr. I) ; September Seaside Birds. (T.c., Oct. 7) ; Birds and Fresh Water. (T.c., Oct. 28); The Waders. (T.c., Nov. 23.)

IgI2. Campbell, D. C. The Birds of Inishduff. (T.c. Feb. Io); The Early Season. (T.c., May 25); Strange Nesting Places. (T.c., Aug. 3I.)

Henry, S. Our Smallest Falcon. (Northern Whig, June 8); The Peregrine's Eyrie. (T.c., June I5); Buffon's Skua. (T.c., Nov. 2.)

I913. Campbell, D. C. Voices in the Night. (Northern Whig, Aug. 9.) Henry, S. The Dunlin. (Op. cit., May I 7$)$; A Mystery of the Night. (T.c., Aug. 22.)

Wright, W. C. Greenland Falcon in Co. Derry. (Brit. Birds, VII.)

I914. Campbell, D. C. Evening Calls. (Northern Whig, July 25.)

I915. Campbell, D. C. A persevering pair. (Northern Whig, June I2) ; Quails. (T.c., July 3I) ; The Cuckoo's departure. (T.c., July $3 \mathrm{I}$ ) ; Herons in the Foyle. (T.c., July 3I.)

IgI6. Henry, S. The Little Auk. (Northern Whig, Mar. I8.)

I9I7. Campbell, D. C. The Owl's Nest; Late Nests. (Op. cit., July 28.)

\section{CO. LONGFORD.}

1825. "V." [Glossy Ibis in Co. Longford.] (Zool. Jnl., I., p. 590.) 1852. Powys, T. L. Glossy Ibis in Ireland. (Zool.)

I860. "Gael." Woodcock's Nest in Co. Longford. (Field, Apr. 7.) I87o. Blake-Knox, H. White Thrush at Ballymahon. (Zool.)

1883. [Anon.] Occurrence of Little Bustard. (Ficld, Mar. 9.)

I895. Powell, L. Little Bustard in Co. Longford. (Irish Times, Mar. 2.)

I899. Curtis, F. [Exhibition of Spotted Sandpiper from Co. Longford.] (Bull. B.O.C., VIII.)

I903. Williams, -. Snow Geese in Longford. (Zool.) 
I9r3. Fetherstone, Rev. Sir G. R. Occurrence of Dipper in Co. Longford. (Morning Post, Sept. - -)

rgr8. Wilson, J. M. Bird Life at Currygrana. (Irish Nat.) ; Jay in Co. Longford. (T.c.)

\section{CO. LOUTH.}

I848. Montgomery, R. J. Night Heron in Louth. (Zool.)

1856. Clermont, Lord. Eared Grebe, etc., in Ireland; Mute Swans in Dundalk Bay. (Op. cit.)

I858. Clermont, Lord. On Capture of a Mute Swan in Dundalk Bay. (Nat. Hist. Rev.)

I860. Clermont, Lord. Eared Grebe near Dundalk; On Capture of Mute Swan in Dundalk Bay. (Pr. N. H. Soc. Dubl., II., 1856-59.)

I869. Clermont, Lord. American Bittern in Ireland. (Zool.)

1872. Harting, J. E. British Heronries. (Zool.) [partim.]

1892. Barton, H. D. M. Spotted Crake in Co. Louth. (Irish Nat.)

r896. Pentland, G. H. Nesting of Goldcrest. (Zool.)

I897. Pentland, G. H. Stock Dove at Drogheda. (Irish Nat.)

I899. Mitchell, A. T. Grey Wagtail in Co. Louth. (Field, July I.)

I906. Swan, Allan P. Quail in Co. Louth. (Irish Nat.)

I909. Williams, W. J. Rare Birds in Ireland-Honey Buzzard. (Brit. Birds, II.)

I9I0. Pentland, G. H. Abundance of Great Northern Divers. (Irish Nat.)

I912. Pentland, G. H. Notes on Increase and Decrease of Some (Irish Nat.) $^{\circ}$

I9I3. Pentland, G. H. A Blackbird's Note. (Irish Nat.)

I9I5. Foster, N. H. Nat. Hist. Notes from Carlingford. (Irish Nat.)

I9I7. Pentland, G. H. Swans and their Nests. (Irish Nat.)

CO. MAYO.

1857. Warren, R. Notes on Natatores of Killala. (Nat. Hist. Rev.) I859. "Curiosity." Snowy Owl [in Co. Mayo]. (Field, Jan. 29.) I86o. Warren, R. Rare Birds in Co. Mayo. (Nat. Hist. Rev.) 
More, A. G. Arctic Tern nesting on fresh water. (Zool.)

I86r. Newton, A. On Occurrence of Snowy Owl in Co. Mayo. (Zool.) Idem. (Pr. N. H. Soc. Dubl., I859-60.)

Warren, R., junr. Rare Birds, etc., in Co. Mayo. (Zool.)

I863. Warren, R., junr. List of Birds of Prey, Perchers and Waders, and of Swimming Birds observed to frequent the districts of Mayo and Sligo which border on Killala, 2 pts. $(\operatorname{Pr} . N . H$. Soc. Dubl., I860-62.)

Williams, R. P. On Occurrence of Golden Oriole, etc. [Eared Grebe near Killala.] (T.c.)

I864. Warren, R., junr. On winter migration of the Pomarine Skua, etc. $(P r$. N. H. Soc. Dubl., 1862-63); Occasional Notes on Occurrence of Birds on shores of Killala Bay. 2 pts. (T.c.)

r866. Blake-Knox, H. White-bellied Swift in W. Islands of Mayo. (Zool.)

I867. Harvie-Brown, J. A. Bald-headed Eagle in Achill. (Zool.)

I87I. Ashby, R. Snowy Owl in Co. Mayo. (Field, Apr. 8.)

Carr, M. A. Sabine's Snipe in Co. Mayo. (T.c., Jan. 2I.)

I872. Harting, J. E. British Heronries. (Zool.) [partim.]

1873. More, A. G. Green Sandpiper in Aug. (Field, Sept. I3.)

I874. Warren, R. Iceland and Glaucous Gulls in Ireland. (Field, Jan. 3.)

I875. Pike, W. Climate and Ornithology of Achill. (Zool.)

Warren, R. Avocets in Ireland. (Field, Nov. 27); Pied Flycatcher in Co. Mayo; Autumnal Migration of Skuas. (Zool.); Greenland Falcon in Co. Mayo. (Field, May I, I5.)

Williams and Son. Bewick's Swan in Ireland [at Belmullet]. (Field, Jan. 23.)

I876. Warren, R. Dusky Redshank in Co. Mayo. (Field, Nov. II.)

1877. Pike, W. On Habits of Golden Eagle. (Zool.)

Warren, R. Freshwater breeding haunt of Sandwich Tern. (T.c.) Eiders in Estuary of the Moy ; The Birds of the Moy Estuary, 3 papers. (T.c.) Summer Migrants. (Field, May 5); Wild Swan in June. (OP. cit., July I4); Glaucous and Iceland Gulls in Ireland. (Op. cit., Mar. 3r.)

I878. Warren, R. Terns and Skuas in Estuary of the Moy, 2 pts.; Ornitholog. Notes from the Moy Estuary; Spotted Redshank in Co. Mayo. (Zool.) Spotted Redshank and Iceland Gull in Co. Mayo (Field, Jan. 5.)

I878-80. Harting, J. E. On Occurrence in Ireland of Lesser Snow Goose. (Zool., I878; Field, Oct. 26, I878.) Idem. (Zool., I880.) 
I879. Warren, R. Wildfowl in Co. Mayo. (Zool.) Summer Birds in Co. Mayo. (Field, June 7); Gadwall in Co. Mayo. (T.c., Jan. II) ; Fulmar Petrel on Coast. (T.c., Feb. I.)

I88o. Sheridan, J. R. Rare Birds at Achill Island. (Field, Apr. 24.)

Warren, R. Widgeon in Moy Estuary. (Zool.) Glaucous Gull in Co. Mayo. (Field, Mar. 20.)

I880-9r. Warren, R. Ornitholog. Notes from Mayo and Sligo, II pts. (Zool., I880-83, I886-9I.)

I88I. Knapp, A. H. An Ornithological Ramble in Island of Achill. (Field, Aug. 27.)

More, A. G. Iceland Falcon in Ireland. (Zool.)

I882. Darling, J. J. F. Cormorants breeding on inland lake [Lough Attymas]. (Zool.)

Ward, H. S. The Islands of Inniskea. (Field, July 22.)

I884. Ussher, R. J. Crane in Mayo. (Zool.)

Warren, R. Notes from Mayo. (Field, May I7.)

I885. More, A. G. White's Thrush in Mayo. (Zool.)

Warren, R. Summer Birds in Mayo. (Field, June I3.)

I888. "Glendarary." Solitary Snipe on Achill. (Field, Oct. 6, 20.)
[Editorial.] Idem. (T.c., Nov. Io.)

Scharff, R. F. Little Bustard in Co. Mayo. (Zool.)

Warren, $R$. The Wildfowl and Wildfowl shooting of Killala Bay and Estuary of Moy. (Field, Mar. 3, I7.)

I889. Cradock, T. The Ruff in Co. Mayo. (Field, Sept. 2I.)

I89o. Barrington, R. M. Wood Wren in Co. Mayo. (Zool.)

Garvey, J. Pomatorhine Skua on Lough Conn. (Field, Nov. I.)

I89r. [Anon. "H. J. W."] Birds of the West. (Sci. Gossip, Apr.)

Scroope, H. Forktailed Petrel [in Co. Mayo]. (Field, Oct. Io.)

Warren, R. J. Pomatorhine Skua in Co. Mayo. (Zool.)

Skua in Co. Mayo. (Zool.)

1892. Barrington, R. M. Greenland Falcon in Achill. (Zool.)

More, A. G. Barred Warbler and Short-toed Lark in Co. Mayo.
(Irish Nat., Apr.)

Warren, R. Iceland Gulls and Wild Swans in Moy Estuary. (Zool.) Iceland and Glaucous Gulls in Ireland. (Irish Nat.,
Oct., Nov.)

I893. Burkitt, R. J. Abundance of Wild Swans in Mayo, I892-93.
(Irish Nat., May.)

Harvey, R. Snowy Owl on Achill Island. (T.c.)

Scharff, R. F. Mealy Redpolls on Achill Island. (T.c., Apr.)
Sheridan, J. R. King Duck in Achill Island. (T.c., June.) 
Warren, R. White Wagtail in Co. Mayo. (Irish Nat., July; Zool.)

Williams, E. Solitary Snipe in Co. Mayo. (Zool.)

I894. Sheridan, J. R. King Eider, Buffon's Skua and Surf Scoter off Achill Island; Mealy Redpoll and American Goldfinch on Achill Island, 5 notes. (Zool.) Rare Birds in Achill Island. (Irish Nat.)

Warren, R. Great Shearwater in Killala Bay; Sand Martins nesting in a Ruin. (Zool.)

Williams, E. American Golden Plover in Ireland. (Zool.; Irish Nat.) ; Snowy Owl in Co. Mayo. (Irish Nat.)

r895. Warren, R. The Breeding Birds of Loughs Conn, Carra and Mask; Birds observed breeding on coasts of Sligo and Mayo, 2 papers. (Irish Nat.)

I8g6. Warren, R. The Terns of Killala Bay. (Irish Nat., June); The Skuas of Killala Bay. (Ornithologist; Irish Nat., July); The Gulls of Killala Bay. (Irish Nat., Oct.). Early Nesting of Herons. (Zool.)

I897. Warren, R. Surf Scoter in Co. Mayo ; Unusually large numbers of Pintails in Co. Mayo; On Breeding Range of Yellow Wagtail. (Zool.) Surf Scoter in Killala Bay. (Irish Nat.) Idem. (Field, May I.)

I898. Gilmore, R. M. Nightjar in Co. Mayo. (Irish Nat.)

Saunders, Howard. White Wagtail in Co. Mayo. (Bull. B.O.C., VII.) ; Exhibition of Wood Sandpiper from Co. Mayo. (OP. cit., VIII.)

Warren, R. White Wagtail in Ireland. (Zool.; Irish Nat., July); Long-tailed Duck in Killala Bay and Estuary of Moy. (Irish Nat., May); White Wagtail on Bartragh Is. (Field, May 2I) ; Idem in Co. Mayo. (T.c., June II.)

I899. Jourdain, F. C. R. Cormorants nesting on Trees. (Field, Sept. Io) ; Idem by R. J. Ussher. (Irish Nat.)

Lindsay, J. Forktailed Petrel and Landrail in Mayo in Dec. (Field, Jan. 28.)

Sharpe, R. B. Larger Snow Goose in Co. Mayo. (Bull. B.O.C., $\mathrm{X}$.)

Ussher, R. J. Cormorants breeding in Trees. (Irish Nat., Aug.) Warren, R. Ornitholog. Notes from N.W. Ireland. (Zool.) White Wagtails at Bartragh. (Irish Nat., Aug.); Bartailed Godwits, etc., in Moy Estuary. (T.c., Aug.)

I900. Saunders, H. Pectoral Sandpiper in Co. Mayo. (Bull. B.O.C., XI.)

Ussher, R. J. Snow Goose in Ireland. (Irish Nat., April.)

Warren, R. Bewick's Swans in Moy Estuary (T.c., Jan.); Rose-coloured Pastor in Co. Mayo. (T.c., Jan.); Golden Plover and Lapwings in Moy Estuary. (T.c., Feb.) 
I90I. Coburn, F. Redthroated Pipit in Ireland. (Zool., July ; Irish Nat., Oct.) ; Idem by R. J. Ussher. (Irish Nat., Nov.); Exhibition of Rare Birds from Mayo. (Bull. B.O.C., XII.)

Warren, R. White Wagtail at Bartragh. (Irish Nat., July); Blacktailed Godwit. (T.c.)

I902. Coburn, F. Holboell's Redpoll in Ireland. (Zool., July; Irish Nat., Aưg.)

Warren, $\mathrm{R}$. Increase in numbers of Breeding Birds in Mayo and Sligo. (Irish Nat., Oct.) ; Ruff in Co. Mayo. (T.c., Dec.); The White Wagtail in Killala Bay. (T.c., July) ; Iceland Gull at Moyview. (T.c., Aug.)

I903. Knox, Godfrey. Green Sandpiper at Foxford. (Irish Nat.)

Warren, R. White Wagtail visiting Bartragh Island, Killala Bay. (Zool.) ; Blacktailed Godwit in Moy Estuary. (Irish Nat., Apr.) ; Some Ornitholog. Notes from Moyview. (T.c., July.)

I904. Knox, Godfrey. Snow Geese. (Irish Nat.)

Warren, R. Snow Geese in Co. Mayo; Ornitholog. Notes from Killala Bay and Moy Estuary. (Zool.); White Wagtails. (Irish Nat., July); Great Increase of Arctic Terns in Killala Bay. (T.c., Nov.)

I905. Warren, R. Tree Sparrow in Belmullet. (Irish Nat., Mar.); Iceland Gull in Moy Estuary. (T.c., June) ; Tufted Duck breeding on Lough Conn. (T.c.); Corncrakes in Winter. (T.c.)

I906. Warren, R. White Wagtails in Co. Mayo. (Zool.)

Williams, W. J. Snowy Owl in Co. Mayo. (T.c.)

I907. Nichols, A. R. Tufted Duck breeding on Lough Mask. (Irish Nat., May.)

Warren, R. Some Rare Visitors to Bartragh Island, Killala Bay ; Spring Arrival of Sandwich Terns in Killala Bay; Breeding of Tree-Sparrows and Dunlins in Co. Mayo. (Zool.)

I908. Patten, C. J. Rambles on Achill Island. (Irish Nat., Oct.)

Warren, R. Some Ornitholog. Notes from Mayo and Sligo. (Zool.)

I909. Campbell, D. C. Reeve in Co. Mayo. (Irish Nat.)

I9II. Ussher, R. J. Fulmar Breeding in Ireland. (Irish Nat.)

Warren, R. White-tailed Eagle no longer breeding in Ireland. (Zool.); Gull breeding in Mayo. (T.c.).

I9I2. Ussher, R. J. Clare Island Survey. Aves. (Pr. R. I. Acad.)

I9I3. Nichols, A. R. Squacco Heron in Co. Mayo. (Irish Nat.)

Warren, R. Greenland Falcon in Co. Mayo. (Zool.); On Migration of White Wagtail in I. of Bartragh. (Irish Nat.); Blackthroated Diver in Co. Mayo; White Wagtails in Co. Mayo. (Zool.)

I9I4. Warren, R. Iceland Gull in Co. Mayo. (Zool.) 
1915. Barrington, R. M. Waxwings in Co. Mayo. (Irish Nat.)

Warren, R. White Wagtails in Co. Mayo. (T.c.)

I9I6. Ruttlidge, R. F. The Birds of Lough Carra; Nightjar on the Black Rock (Irish Nat.); Ornitholog. Notes from S. Mayo. (Zool.) ; Idem. (Irish Nat., I9I7.)

I9I7. Ruttlidge, R. F. Arctic Skua and Black Tern on Lough Mask. (Irish Nat.)

I9I8. Ruttlidge, W. Black Terns on Lough Carra. (Irish Nat.)

\section{CO. MEATH.}

1846. Newman, E. Great Belted Kingfisher in Ireland. (Zool.)

I868. Clifton, Lord. Nuthatch in Ireland. (Zool.)

1872. Harting, J. E. British Heronries. (Zool.) [partim.]

I874. Williams, E. Osprey in Co. Meath. (Field, Aug. 8.)

I875. Dillon, Sir John F. Black-winged Kite in Ireland [at Bog of Horsestown near Slane]. (Field, Apr. Io; Zool.)

I880. Benson, C. W. Blackcap in Co. Meath. (Zool.)

I89o. Dyer, F. Ferruginous Duck in Co. Meath. (Field, Jan. 4.)

I892. Benson, J. Bittern in Co. Meath. (Zool.)

r894. Dillon, J. Heron carrying off Waterhen. (Zool.)

Palmer, J. E. Blackcap in Co. Meath. (Irish Nat.)

I899. Saunders, H. [Exhib. of Sociable Plover from Co. Meath.] (Bull. B.O.C., X.)

Williams, E. Occurrence of the Sociable Plover in Ireland. (Irish Nat.)

I906. Foster, N. H. Great Grey Shrike in Co. Meath. (Irish Nat.)

Ig08. Williams, W. J. Night Heron in Co. Meath. (Zool.)

I9o9. Barrington, R. M. Little Gull in Co. Meath. (Irish Nat.)

Igr2. Benson, C. W. Unrecorded Great Skua in Meath. (Brit. Birds.)

I9r3. Metcalfe, H. Notes on the Tree Sparrow. (T.c.)

Igr6. Benson, C. W. Turtle Doves in Co. Meath. (Irish Nat.)

CO. MONAGHAN.

1878. Hibbert, J. C. Osprey at Castleblaney. (Field, May 25.)

1884. Butler, E. A. Bittern in Ireland [near Monaghan]. (Field, Jan. I2.)

IgI6. Kane, W. F. de V. [ob. IgI8] The Crossbill and its Diet. (Irish Nat.) 


\section{QUEEN'S COUNTY.}

I824. [Vigors, N. A. Scolopax sabini in Queen's Co.] (Zool. Jnl., I., p. 280.)

I848. Montgomery, R. J. Tawny Owl in Ireland; Redstart in Queen's Co. (Zool.)

1872. Young, W. Great Spotted Woodpecker in Ireland. (Field, Feb. I7.)

I88x. "T. G. R. H." White-fronted Goose in Queen's Co. (Field, Feb. I2.)

I882. Reeves, R. E. Habits of Woodchat as observed in Ireland. (Zool.)

I883. Ussher, R. J. Montagu's Harrier in Ireland [correction of error]. (Zool.)

Young, J. W. Landrail in Dec. (Field, Dec. 29.)

I888. Young, J. W. Stock Dove in Ireland [Queen's Co.]. (Field, Jan. I4.)

I889. Williams, E. Breeding place of Blackheaded Gull in Queen's Co. (Zool.)

I892. More, A. G. Reported Occurrence of Ferruginous Duck in Queen's Co. incorrect. (Field, Mar. 26.)

Williams, E. Ruddy Sheldrake in Ireland. (Zool.)

1893. Williams, E. American Redbreasted Snipe in Ireland. (Zool.) Idem by by G. E. H. Barrett-Hamilton. (Bull. B.O.C., III. [1894].)

I894. Richardson, H. Spring Migrants. (Irish Times, Apr. 7.)

I895. Young, J. W. Occurrence of Osprey. (Field, Apr. 27.)

r897. Ussher, R. J. Blacktailed Godwit in Queen's Co. (Irish Nat.)

r898. Miller, R. M. Stock Dove in Queen's Co. (Irish Nat.)

Young, W. Green Woodpecker in Ireland. (Field, May I4.)

I905. Young, J. W. Green Woodpecker in Queen's Co. (Field, Dec. 23.)

I908. Ussher, R. J. Montagu's Harrier in Ireland. (Brit. Birds, II.) Young, J. W. Gadwall in Queen's Co. (Field, Feb. I5.)

I909. Ussher, R. J. Montagu's Harrier in Ireland. (Brit. Birds, II.) Williams, W. J. Rare Birds in Ireland-Black Redstart. (T.c.)

I9I0. Stephens, V. E. The Jay in Queen's Co. (Irish Nat.) Williams, W. J. Rare Birds in Ireland-Little Auks. (Brit. Birds, III.) 


\section{CO. ROSCOMMON.}

1863. Crane, J. R. On migration of Buffon's Skua, etc. (Pr. N. H. Soc. Dubl., I860-62.)

I864. Foot, F. J. Little Auk at Athlone. (Op. cit., I862-63.)

I865. Foot, F. J. Flights of Swans seen during Winter of r863-4. (OP. cit., $1863-64$.

I872. Harting, J. E. British Heronries. (Zool.) [partim.]

1873. " L. D." Shorteared Owl in Roscommon. (Field, Nov. I5.)

I875. " L. D." Migrants in Co. Roscommon; Notes from Roscommon. (Field, May I.)

I888. Keatinge, P. Sand Grouse [in Co. Roscommon]. (Field, June 23.)

I896. Windham, F. H. Bittern in Co. Roscommon. (Op. cit., Feb. I.) I908. Bridgeman, H. G. O. Pinkfooted Goose in Co. Roscommon. (Irish Nat. ; Brit. Birds, I.)

I9I5. Darling, J. Ff. Lesser Spotted Woodpecker in Co. Roscommon. (Irish Nat.) Idem by R. M. Barrington. (T.c.)

Igr6. Darling, J. Ff. Velvet Scoter on Lough Ree. (Irish Nat.)

\section{CO. SLIGO.}

Note.-Many entries under Mayo refer also to Sligo.

I851. Amherst, Rev. F. K. Description of Guillemot shot on coast. (Zool.)

I863. Warren, R. List of Birds of Prey, Perchers and Waders, and of Swimming Birds, observed to frequent districts of Mayo and Sligo which border on Killala, 2 pts. (Pr. N. H. Soc. Dubl., I860-62); Snowy Owl in Co. Sligo. (T.c.)

I87r. Brooke, Sir V. On a specimen of Numenius borealis from Sligo. (P.Z.S.)

I872. Harting, J. E. British Heronries. (Zool.) [partim.]

I876. Warren, R. Avocet in Ireland. (Zool.)

Whyte, J. J. Pochard breeding in Co. Sligo. (Field, June 2.)

I878. Whyte, J. J. Eagles in Co. Sligo. (Field, Sept. 28.)

I879. Cooper, E. H. Attempted introduction of Nuthatch. (Zool.)

I88I-9I. Warren, R. Ornitholog. Notes from Mayo and Sligo, II pts. (Zool. I88I-3; I886-9I.) 
I884. Warren, R. Spotted Redshank and Long-tailed Duck in Co. Sligo. (Zool.); Ruff and Green Sandpiper in Co. Sligo. (Field, Sept. 20.)

I885. Warren, R. Spotted Redshank in Co. Sligo. (Zool.)

I888. Warren, R. Turtle Dove in Co. Sligo. (Zool.); Wildfowl of Killala Bay, etc. (Field, Mar. 3, I7.)

I889. Warren, R. Fulmar and Spotted Redshank in Co. Sligo. (Zool.)

I89I. Gore, J. E. Bittern in Co. Sligo. (Field, Jan. 3.)

1892. Jameson, H. L. Whinchat in Co. Sligo. (Irish Nat.)

Warren, Amy. Sea Birds in Sligo. (T.c.)

I894. Warren, R. Little Auk in Co. Sligo. (Zool. ; Irish Nat.) Idem by R. M. Clellon $[=$ R. M'Clean.] (Zool.)

I895. Langham, Sir Chas., Bt. Iceland Gull at Mullaghmore (Irish Nat.)

Warren, R. Birds observed breeding on coasts of Sligo and Mayo, 2 pts. (Irish Nat., July and Aug.)

I896. Langham, Sir C. Iceland Gull on Sligo Coast. (Irish Nat., July ; Zool.)

Warren, R. The Terns of Killala Bay. (Irish Nat., June ); The Skuas of Killala Bay. (T.c., July ; Ornithologist) ; The Gulls of Killala Bay. (Irish Nat., Oct.); Ruff in Co. Sligo. (Zool.)

I897. Warren, R. Fulmar in Co. Sligo. (Zool.)

I898. Warren, R. Iceland Gull in Co. Sligo in Summer. (Field, July 9 ; Zool. ; Irish Nat., Aug.)

I902. Warren, R. Increase in numbers of Breeding Birds. (Irish Nat., Oct.)

I904. Patterson, R., and Foster, N. H. Conference and Excursion at Sligo-Vertebrata. (Irish Nat., Sept.)

Warren, R. Ornithology at the Field Club Conference. (T.c., Oct.); Great increase of Arctic Terns in Killala Bay. (T.c., Nov.)

I905. Warren, R. Glaucous Gull at Moyview. (Irish Nat., Mar.)

I908. Warren, R. Some Ornitholog. Notes from Mayo and Sligo; Migration of Small Birds in Co. Sligo. (Zool.)

Williams, W. J. Ospreys in Co. Sligo. (T.c.)

I909. Henderson, J. Osprey in Sligo. (Irish Nat., Nov.)

Warren, R. Some Bird Notes from Ballina. (Zool.)

Williams, W. J. Rare Birds in Ireland-Great Northern Diver. (Brit. Birds, II.)

I9I0. Ogilvie-Grant, W. R. [Parus hibernicus: new Irish subspecies of Coal Tit.] (Bull. B.O.C., XXVII.) [partim.]

Williams, W. J. Rare Birds in Ireland-Snowy Owl. (Brit. Birds, III.) ; Rare Birds in Ireland-Little Auks. (T.c.) 
IgII. Warren, R. Extermination of the Sea-Eagle in Ireland. (Zool.) Idem by F. C. R. Jourdain. (Brit. Birds, IV.)

Warren, R. White Wagtail on Migration visiting Killala Bay. (Zool.)

I9I3. Perceval, P. D. Observations on the Movements of the Woodcock. (Irish Nat.)

I9I4. Dockray, J. A. Longtailed Skua in Ireland. (Brit. Birds, VIII.) Metcalfe, H. M. Richardson's Skua in Co. Sligo. (Irish Nat.); Skuas on Lough Arrow. (T.c.)

I918. Burkitt, J. P. Some Notes on Birds, especially the Whitethroat. [Mullaghmore.] (Irish Nat.)

Workman, W. H. The Migration of Woodcocks. (T.c.)

\section{CO. TIPPERARY.}

I846. Davis, R., junr. Sabine's Snipe near Clonmel. (Zool.)

I860. "A Good Observer." The Lesser Redpoll [nesting near Roscrea]. (Field, June 30.)

I86r. [Anon.] Falconry at Clonmel and Thurles. (Field, pp. 353, 397.)

I867. M[urray], H. B. Hobby in Co. Tipperary. (Ficld, June I5.) $^{2}$

1869. Murray, H. B. Hobby in Ireland. (Field, July Io.)

I870. Blake-Knox, H. American Bittern at Cahir. (Zool.)

Brooke, Sir Victor. American Goshawk in Tipperary. (Ibis.)

1874. Williams, A. and E. White-rwinged Black Tern in Ireland [Co. Tipperary]. (Field, May 30.)

I880. Grant, T. B. The Little Auk in Ireland [Co. Tipperary]. (Field, Mar. 13.)

1883. Ussher, R. J. Hobby in Co. Tipperary. (Zool.)

1887. Tegetmeier, W. B. Occurrence of the Black Marsh Tern in Ireland Co. Tipperary]. (Field, Sept. Io.)

I888. Purefoy, W. B. Nesting of Redwing in Tipperary. (Field, Apr. 28.)

I8go. Ellison, A. Crossbills in Ireland. (Zool.)

I89I. [Anon.] Occurrence of Little Bittern. (Land \& Water, May I6.) Bicknell, P. The Forktailed Petrel [in Co. Tipperary]. (Field, Oct. IO.)

1892. Ussher, R. J. Arrival of Summer Migrants. (Irish Nat.)

1893. Barrett-Hamilton, G. E. H. Western Variety of the Red-breasted Snipe in Ireland. (Irish Nat.) 
I894. Barrett-Hamilton, G. E. H. [American Red-breasted Snipe in Co. Tipperary.] (Bull. B.O.C., III.)

Coburn, F. Red-breasted Snipe in Ireland. (Zool.)

Patterson, R. Green Sandpiper in Co. Tipperary. (Irish Nat.)

I897. Miller, R. M. Whitefronted Goose near Roscrea, (Irish Nat.)

I898. Johnston, W. Crane in Co. Tipperary. (Irish Nat.)

I899. Gleeson, M. Bird Records in Co. Tipperary. (Irish Nat.)

Parker, A. Woodcock nesting in Tipperary. (Ficld, Apr. 8.)

Warren, R. Bird Records in Tipperary. (Irish Nat.)

Igoo. Gleeson, M. Summer Migrants. (Irish Nat.)

Ussher, R. J. Supposed Reed Warbler in Co. Tipperary. (T.c.)

Williams, E. Ospreys in Ireland. (T.c.)

rgo2. Gleeson, M. Summer Migrants. (Irish Nat.)

I903. Williams and Son. Great Bustard in Tipperary. (Irish Nat.) Williams, E. Great Bustard in Ireland. (Zool.)

I904. Parker, A. Notes on the Birds of Lough Derg and its Shores. (Irish Nat.)

I906. Carroll, C. J. A Rare Bird in Co. Tipperary. (Clonmel Chron., Dec. 22.)

1909. Williams, W. J. Honey Buzzard in Ireland. (Brit. Birls, III.)

I9Io. Williams, W. J. Rare Birds in Ireland--I.ittle Auks. (T.c.)

IgII. Barrington, R. M. Introduction of the Marsh Tit and Nuthatch into Ireland. (Irish Nat.)

Massey, H. Nesting of Grey Wagtail far from Water. (Brit. Birds.)

I9r6. Carroll, C. J. The Crossbill in Co. Tipperary. (Irish Nat.) ; Ravens in Co. Tipperary. (T.c.); A Siskin Colony in Co. Tipperary. (Brit. Birds, IX.); Green Sandpipers in Co. Tipperary. (T.c.); Quail in Co. Tipperary and Waterford. (T.c.) ; Increase of Tufted Ducks in Co. Tipperary. (T.c.)

\section{CO. TYRONE.}

I839. Thompson, W. On migration of Snowy Ow] [one shot near Omagh]. (Ann. N. H., III.)

1859. [Anon. "Hob."] Grey Plover breeding in Ireland [Strabane]. (Field, Oct. 2, Nov. I2.)

I867. Harting, J. E. Goshawk in Ireland. (Zool.)

I888. Patterson, R. Spotted Crake in Ireland [near Coalisland]. (Field, Nov. I0.)

I894. Ussher, R. J. Redstart breeding in Co. Tyrone. (Zool.) 
I898. Patterson, Sir R. L. Longtailed Duck in Tyrone. (Irish Nat.)

I900. Patterson, R. Early Redwings at Coagh. (Irish Nat.)

I907. Kempton, A. D. Local Names of Birds. (Northern Whig, Oct. 26.)

I9r3. Foster, N. H. Golden Oriole in Co. Tyrone. (Irish Nat.) Idem by W. C. Wright. (Brit. Birds.)

Igr4. Foster, N. H. Waxwing in Co. Tyrone. (Irish Nat.)

I9I7. Workman, W. H. Bittern in Co. Tyrone. (Iris/ Nat.) Idem by W. C. Wright. (Brit. Birds.)

\section{CO. WATERFORD.}

I746. Smith, C. Ancient and Present State of County and City of Waterford. 8vo. Dublin: I746. 2nd edit. I774. [547.]

1845. Poole, J. Norfolk Plover in Wexford [and Waterford]. (Zool.) 1847. Glennon, R. Hoopoe in Ireland. (Zool.)

I848. Clibborn, J. Migration of Plovers; Whitefronted Goose at Waterford. (Zool.)

r858. "Long Tom." Quails [in Co. Waterford]. (Field, June 5.)

I860. " J. H. K." Woodcock breeding in Ireland. (Field, May 5.)

1863. Williams, R. P. On Occurrence of Golden Oriole, etc. (Pr. N. H. Soc. Dubl., I860-62.)

I872. Harting, J. E. British Heronries. (Zool.) [partim.]

1873. Chearnley, R. A. White Woodcock in Co. Waterford. (Field, Dec. I3.)

I875. Jacob, E. Osprey in Co. Waterford. (Field, Sept. -. )

1876. Gurney, J. H., junr. Waterford Great Auk. (Zool.)

1877. "J. H." Black Redstart in Waterford. (Field, Nov. 30.)

I879. Ussher, R. J. American Summer Duck in Co. Waterford. (Zool.)

I880. White, E. A. Black Redstart in Co. Waterford. (Field, Apr. $3 ;$ Zool.)

I88I. Ussher, R. J. Wildfowl in Co. Waterford; Supposed occurrence of Virginian Horned Owl. (Zool.)

I882. Baker, J. C. Buffon's Skua and Little Auk in Co. Waterford. (Zool.)

More, A. G. Baillon's Crake in Co. Waterford. (T.c.)

I883. Ussher, R. J. Choughs in Co. Waterford. (Zool.)

I884. Harting, J. E. Sabine's Snipe near Waterford. (Zool.)

Ussher, R. J. Black Redstart in Co. Waterford. (T.c.) 
I886. Malcomson, J. Occurrence of Landrail in Winter [near Waterford]. (Field, Feb. 6.)

Ussher, R. J. Black Guillemot breeding in Co. Waterford. (Zool.)

1887. Flemyng, W. Black Redstart in Co. Waterford. (Zool.)

Ussher, R. J. Blackcap in Co. Waterford. (T.c.)

I888. Ussher, R. J. Autumn Migration in Co. Waterford; Crossbills, Bramblings and Black Redstart in S. Ireland; Hoopoe and Turtle Dove in Co. Waterford. (Zool.)

I889. Ussher, R. J. Crossbill breeding in Co. Waterford; Redstart in Co. Waterford. (Zool.)

I89o. Ellison, A. Crossbills in Ireland; Extraordinary Abundance of Corn Crake near Waterford. (Zool.)

Seebohm, H. Notes on Irish Ornithology.-I. : Co. Waterford. (Ibis.)

Ussher, R. J. Long-tailed Duck and Eared Grebe in Co. Waterford. (Zool.)

I89I. Box, N. Spoonbill in Co. Waterford. (Field, Nov. 2I.)

"T. D." Grey Phalarope in Co. Waterford. (T.c., Dec. 5.)

Ussher, R. J. Crossbills and Siskins breeding in Co. Waterford. (Zool.)

I896. Ussher, R. J. On reported occurrence of Goldvented Thrush and Spotted Eagle Owl in Ireland. (Zool.)

I897. Flemyng, W. W. Green Sandpiper in Co. Waterford; Nest of the Reed Bunting. (Zool.)

Ussher, R. J. Discovery of Bones of Great Auk in Co. Waterford. (Irish Nat., Aug.)

I899. "T." Remains of Great Auk in Ireland. (Ficld, June ro.) Williams, E. Wood Sandpiper in Co. Waterford. (Irish Nat., Oct.)

I904. Flemyng, W. W. Bittern in Co. Waterford. (Irish Nat., May.)

I905. Ussher, R. J. Decrease of Crossbills; Quail in Co. Waterford. (Irish Nat., Dec.)

I909. Hamilton-Hunter, R. Early breeding of Nightjar. (Brit. Birds, II.)

Uissher, R. J. Black Redstarts in Co. Waterford ; Turtle Doves in Co. Waterford. (Irish Nat., Jan. ; Brit. Birds, II.)

I9I0. Hamilton-Hunter, R. Breeding Habits of Siskin. (Brit. Birds, III.)

Ussher, R. J. Crossbills in Ireland. (T.c.)

IgII. Ussher, R. J. Blacktailed Godwits in Co. Waterford. (Irish Nat.)

19r3. Flemyng, W. W. Spotted Flycatchers at Portlaw. (Irish Nat.)

I9r5. Warren, R. Hoopoe in Co. Waterford. (Irish Nat.) 
IgI6. Carroll, C. J. Quails in C.o. Waterford. (Brit. Birds, IX.) ; Ravens in Co. Waterford. (Irish Nat.)

I9r7. Flemyng, W. W. Hoopoes in Co. Waterford. (Irish Nat.)

\section{CO. WESTMEATH.}

I863. Crane, J. R. On Migration of Buffon's Skua, etc. (Pr. N. H. Soc. Dubl., I860-62.)

I864. Foot, F. J. Occurrence of Little Auk at Athlone. (Op. cit., I862-63.)

1872. Harting, J. E. British Heronries. (Zool.) [partim.]

I888. Battersby, F. J. Crossbills in Co. Westmeath. (Zool.)

Keatinge, P. Sand Grouse [in Co. Westmeath]. (Field, June 23.) Idem by "W. Y." (Op. cit., July 7.)

Keatinge, P. Storm Petrel near Athlone. (Op. cit., Dec. 8.)

189o. Adamson, G. A. G. Long-tailed Tit in Co. Westmeath. (Field, Jan. 4.)

I892. Battersby, F. J. Wild Geese and Starlings in Co. Westmeath ; Shoveler breeding in Co. Westmeath. (Zool.)

More, A. G. Jays in Co. Westmeath. (Irish Sportsman, Mar. I2.)

I893. Taylor, J. Crossbill and Grey Phalarope nr. Mullingar. (Irish Nat.)

Williams, E. Ferruginous Duck in Ireland. (Zool.)

I898. Battersby, F. J. Ferruginous Duck in Ireland. (Knowledge, Jan.) Idem by G. E. H. Barrett-Hamilton. (Irish Nat., June.)

H. F. W[itherby]. Ferruginous Duck in Westmeath. (Knowledge.)

"J. J. W." Great Northern Diver in Westmeath. (Field, Dec. I7.)

Igor. Knox, E. Blake. The Dunlin breeding in Ireland. (Irish Nat.) I9I0. Williams, W. J. Rare Birds in Ireland--Grey Phalaropes. (Brit. Birds, III.)

I9I8. Beveridge, F. S. Green Sandpiper in Co. Westmeath. (Irish Nat.)

\section{CO. WEXFORD.}

1825. [Anon. "V."] Bee-eater, Rose-coloured Pastor and Golden Oriole in Co. Wexford. (Zool. Jnl., I., pp. 589, 590.)

I845. Poole, J. Late Migration of some Summer Birds; Norfolk Plover in Wexford. (Zool.) 
1847. Glennon, R. Hoopoe in Ireland. (Zool.)

I848. Poole, J. Scops-eared Owl near Wexford; Bewick's Swan in Wexford Harbour. (Zool.)

1862. "Sancho." Hobby Hawk in Ireland [at Newtown Barry].) (Field, Dec. 20). Idem by E. Newman. (Op. cit., I863, Feb. 2I.)

I863. Crane, J. R. On Migration of Buffon's Skua, etc. ; [Redstart etc., in Wexford.] (Pr. N. H. Soc. Dubl., I860-62.)

1865. "H. D." Occurrence of the Great Northern Diver [near Newtown Barry]. (Field, May 13.)

1866. Blake-Knox, H. Ornithological Scraps from Wexford. (Zool.)

1869. Hall-Dare, R. W. Hobby in Ireland. (Field, July 3.)

I870. Power, J. T. Little Bittern in Co. Wexford. (Field, May 7.)

1872. Harting, J. E. British Heronries. (Zool.) [partim.]

Saunders, H. On introduction of Anser albatus of Cassin into Brit. avifauna. (P. Z. S.)

1880. Ogle, T. A. Eagle in Co. Wexford. (Field, May 15.)

I884. White, J. N. Spoonbill in S. of Ireland. (Zool.)

1885. Moffat, C. B. Nesting of Mountain Linnet. (Sci. Gossip, Nov.)

Paskins, J. Osprey in Co. Wexford. (Field, Sept. 26.)

I886. Ussher, R. J. Bird Life on the Saltees and the Keraghs; Lesser Tern breeding on the Keraghs. (Zool.)

x888. Barrett-Hamilton, G. E. H. Jay in Co. Wexford. (Zool.)

Barrington, R. M. Pied Flycatcher in Ireland. (T.c.)

Ussher, R. J. Pallas's Sand Grouse in Wexford. (T.c.)

1889. Barrett-Hamilton, G. E. H. Ornitholog. Notes from Co. Wexford, 3 pts. (Zool., I889-9r.)

1890. Barrington, R. M. Manx Shearwater on Saltee Is.; Hobby on Irish Coast. (Zool.)

Ellison, A. Crossbills in Ireland. (T.c.)

Williams, E. Montagu's Harrier and Honey Buzzard in Co. Wexford. (T.c.)

I892. Moffat, C. B. Woodpecker in Ireland; Wood Warbler in Co. Wexford. (Irish Nat., Aug.) Idem by G. E. H. BarrettHamilton. (T.c.)

1893. Barrett-Hamilton, G. E. H. Hoopoe and Black Redstart in Co. Wexford. (Irish Nat., June.)

Williams, E. Honey Buzzard in Co. Wexford. (T.c., Jan.)

1894. Barrett-Hamilton, G. E. H. Bittern in Co. Wexford. (Irish Nat., Feb.) ; Longtailed Ducks in Wexford. (T.c., July); Common Scoter and Longtailed Duck at Wexford Harbour. (Ibis, July.)

Moffat, C. B. The Crossbill at Ballyhyland. (Irish Nat., Oct.) 
1895. Gibbon, E. A. Rare Birds near Wexford. (Irish Nat., Nov.) I896. Guinness, H. R. Longtailed Duck in Co. Wexford. (Field, Nov. I6.)

1898. Barrett-Hamilton, G. E. H. Spotted Crake in Co. Wexford. (Irish Nat., May); Little Bittern in Wexford. (T.c., June.)

Moffat, C. B. Spring Migrants. (T.c., June.)

I899. Barrett-Hamilton, G. E. H. Golden Oriole and Night Heron in Co. Wexford. (Irish Nat., Oct.)

Williams, E. Montagu's Harrier in Co. Wexford. (T.c., Oct.)

I90I. Barrett-Hamilton, G. E. H. Blacktailed Godwit in Co. Wexford. (Irish Nat., Apr.) Idem by R. Warren. (T.c., May). Idem by R. J. Ussher. (T.c., Oct.)

I903. Williams, E. Hoopoe in Co. Wexford; Glossy Ibis in Ireland. (Irish Nat., Apr.)

I905. Johnston, J. H. Common Bittern in Co. Wexford. (Irish Nat., May).

I908. Banks, R. C. Grey Phalarope in Co. Wexford. (Brit. Birds, II.)

Barrett-Hamilton, G. E. H. Stock Dove in Co. Wexford. (Irish Nat., Oct.)

1909. Williams, W. J. Rare Birds in Ireland-Osprey. (Brit. Birds, II.)

I910. Ogilvie-Grant, W. R. [Parus hibernicus: new Irish subspecies of Coal Tit.]. (Bull. B.O.C., XXVII.)

Witherby, H. F. White Wagtail in Co. Wexford. (Brit. Birds, IV.)

I9II. Nichols, A. R. Barnacle Goose in Wexford. (Irish Nat.)

Ussher, R. J. Blacktailed Godwits in Wexford. (T.c.)

Witherby, H. F. White Wagtails in Autumn in Ireland. (Brit. Birds, V.)

I9I2. Patten, C. J. Occurrences on Migration at Tuskar Rock and Lighthouse, 3 notes; Sandwich Tern at Wexford Bay. (Irish Nat.) ; Reported Occurrence of Dartford Warbler at Tuskar Light Station. (Nature.)

I9I3. Barrett-Hamilton, G. E. H. Grey Lag Goose in Wexford. (Irish Nat.)

Nichols, A. R. Common Eider Duck in Co. Wexford. (T.c.)

Patten, C. J. Wren, Grasshopper Warbler, Pied Wagtail, Black Tern, Aquatic Warbler, etc., on Migration at Tuskar Light Station, 6 notes. (T.c.) ; Robin on Migration and Diurnal Migration of certain Birds at Tuskar Rock, 2 notes. (Zool.)

I9I5. Patten, C. J. Icterine Warblèr, Pied Flycatcher and Tree Pipit on Migration at Tuskar Light Station, 3 notes. (Irish Nat.) ; Idem. Aquatic Warbler. (Zool.) 
I9I6. Patten, C. J. Missel Thrush, Icterine Warbler, Blackeared Wheatear, Roseate Tern, on Migration at Tuskar Rock, 5 notes. (Irish Nat.) Idem. Icterine Warbler. (Zool.)

I9I7. Cunningham, J. Abnormal varieties of Rook and Cuckoo. (Brit. Birds, XI.)

Moffat, C. B. Black Redstart in Co. Wexford ; An Exterminating Winter: Quail in Wexford. (Irish Nat.)

Patten, C. J. Western Blackeared Wheatear off Co. Wexford. (Brit. Birds, XI.)

I9I8. Moffat, C. B. Return of the Goldcrest. (Irish Nat.)

\section{CO. WICKLOW.}

I852. Kinahan, J. R. Siskin breeding in Ireland. (Zool.)

1859. "Kingston." Landrail in Winter [Wicklow]. (Ficid, Jan. I.)

I860. Powerscourt, Lord. Eggs and Nest of Woodcock [at Powerscourt]. (Op. cit., Apr. I4.)

I863. Williams, R. P. On Occurrence of Golden Oriole, etc. N. H. Soc. Dubl, I860-62.)

I867. Barrington, R. M. Arrival of Summer Visitants. (Zool.)

r87o. Brooke, A. B. Natural History of Wicklow and Kerry. (Zool.) Additions. (Op. cit., I87r.)

1872. Harting, J. E. British Heronries. (Zool.) [parlim.]

1874. Barrington, R. M. Siskin breeding in Ireland; Golden Fagle at Powerscourt; Migrations of Spring Immigrants. (Zool.) Carter, C. S. Blackcap at Bray in Feb. (Field, Feb. 28.)

Williams and Son. Montagu's Harrier in Ireland [near Enniskerry]. (Field, Sept. 26.)

I875. Barrington, R. M. Migration of Redwings. (Zool.)

I876. Barrington, R. M. Siskin breeding in Wicklow. (Zool.)

I877. Barrington, R. M. Blackcap in Co. Wicklow. (Zool.)

I878. More, A. G. List of Birds of Dublin and Wicklow. [In Guide to Co. of Dublin, repr. from Sci. Pr. R. Dubl. Soc.] 8vo. [Dublin : I878.]

1879. Cox, H. L. The Birds of Dublin and Wicklow. (Zool.)

Hart, H. C. Wood Wren in Co. Wicklow. (T.c.)

r88o. Flemyng, W. W. Lesser Terns breeding on Coast of Wicklow. (Zool.)

Hart, H. C. Blackcap in Ireland. (T.c.)

I88r. Flemyng, W. W. Early Arrival of Chiffchaff. (Zool.) 
I885. $M[$ assy], C. Redstart breeding in Co. Wicklow. (Field, June 27.) Idem. (Op. cit., May 8, I886.)

More, A. G. Redstart breeding in Ireland [in Co. Wicklow]. (Field, July 4); Wood Sandpiper in Co. Wicklow. (T.c., Nov. 7 ; Zool.)

I886. Ellison, A. Supposed Occurrence of Icterine Warbler in Wicklow ; Siskin a resident in Wicklow; Blackcap and Grasshopper Warbler in Wicklow. (Zool.)

1887. Ellison, A. Albino Birds in Co. Wicklow; On Breeding Habits of Siskin as observed in Co. Wicklow. (Zool.)

I888. Barrington, R. M. Redbreasted Flycatcher in Ireland. (Zool.) Dowling, J. G. Garganey in Co. Wicklow. (T.c.)

I890. Benson, C. W. Wood Wren in Co. Wicklow; Siskin breeding in Ireland. (Zool.)

Ellison, A. Dunlin breeding in Co. Wicklow. (T.c.)

I892. Williams, E. Bee-eater in Co. Wicklow. (Zool.)

I893. Barrington, E. C. Quails in Co. Wicklow. (Irish Nat., Aug.)

Barrington, R. M. Stock Dove in Co. Wicklow. (Zool.)

Hart, H. C. Wood Wren and Blackcap in Co. Wicklow. (T.c.) Johnston, J. Autumnal Disappearance of Woodcock. (Irish Nat., Mar.)

Williams, E. Waxwing in Co. Wicklow. (Zool.)

I894. Bayly, H. L. Woodcocks nesting in Co. Wicklow. (Zool.)

Hunter, J. Woodlarks breeding in Co. Wicklow. (Irish Nat., June.)

I895. Knox, E. Blake. Ruff in Co. Wicklow. (Field, Sept. 7) ; Wood Sandpiper in Co. Wicklow. (Irish Nat., Oct.)

I898. Knox, E. Blake. The Stock Dove in Co. Wicklow. (Irish Nat., Aug.); Woodlark in Co. Wicklow. (T.c., Oct.); Curlew breeding near Bray. (T.c., Nov.)

I900. Williams, E. Montagu's Harrier in Wicklow. (Irish Nat., Jan.)

I904. Flemyng, W. W. Siskin breeding in Co. Wicklow. (Irish Nat., Feb.); Idem by E. Blake-Knox. (T.c., Apr.)

I907. Williams, W. J. Rough-legged Buzzard in Co. Wicklow. (Irish Nat., Apr.)

I909. Hamilton-Hunter, R. Late Nest of Crossbill. (Brit. Birds, III.) ; Notes on breeding of Siskin in N. Wicklow. (Irish Nat.)

Williams, W. J. Montagu's Harrier in Ireland. (T.c.)

I9I0. Barrington, R. M. Crossbills in Wicklow. (Irish Nat.); Shore Lark in Ireland. (Brit. Birds, IV.): Redbacked Shrike in Ireland. (Irish Nat.)

Ellison, A. Breeding Habits of Siskin in Ireland. (Brit. Birds, III.) 
Williams, W. J. Rare Birds in Ireland-Greenland Falcons. (T.c., III.)

IgII. Ussher, R. J. Blacktailed Godwits in Wicklow. (Irish Nat.)

19r4. Metcalfe, Helen M. Shorteared Owl [in Co. Wicklow]. (Irish Nat.)

I9I5. Barrington, R. M. Nest Material used by Blackcaps in Wicklow. (Brit. Birds, IX.)

Carroll, C. J. Common Buzzard in Co. Wicklow. (T.c., IX.)

I9I7. Williams, W. J. Ring Ouzel in Co. Wicklow in Winter. (Brit. Birds, XI.)

\section{A DDENDA.}

\section{BERKSHIRE.}

I9r6. Pettitt, E. E. The Pochard in Berkshire. (Wild Life, VIII.) I9I8. Pettitt, E. E. Common Sandpiper in Thames Valley. (Wild Life, X.)

\section{CHESHIRE.}

I9I5. Wilkinson, O. J. The Great Crested Grebe, Its Habits and Distribution in Cheshire, 3 pts. (Wild Life, VII.)

\section{CORNWALL.}

I916. Whitaker, A., and Fowler, T. M. The Storm Petrel, and Manx Shearwater [on Annet, Scilly Is.]. (Wild Life, VIII.) Atchison, G. T. Cormorants on the Scilly Isles. (Wild Life, VIII.)

I9I7. Atkinson, J. The Great Black-backed Gull [Scilly Is.]. (Wild Life, IX.)

\section{DEVONSHIRE.}

I9I7. Wynne, Owen. The Wood Lark in N. Devon. (Wild Life, IX.) 
ESSEX.

I9I3. Hubbard, A. The Tufted Duck at Epping. (Wild Life, II.) I9r6. Owen, J. H. Little Owls in Essex. (Wild Life, VIII.)

\section{KENT.}

I9r3. Knight, C. W. R. The Robin-Wagtail Episode at Hulsewood. (Wild Life, II.)

\section{LANCASHIRE.}

I9r3. Taylor, A. The Golden Plover [Ribble Valley]. (Wild Life, I.) ; The Woodcock as a Parent [Ribble Valley]. (Wild Life, II.) I9I4. Booth, G. A. The Nightjar in Lancashire. (Wild Life, III.)

\section{NORFOLK.}

I9I4-I6. Farren, W. Birds of the Breck. (Wild Life, III.-VIII.) I9I6. Rowan, W. The Little Tern [at Blakeney]. (Wild Life, VIII.)

\section{NORTHUMBERLAND.}

I9I3. Fortune, R. Great Bird Resorts [The Farnes]. (Wild Life, I.) I917. Mason, Charlotte. A Haunt of Sea Fowl [The Farnes]. (Wild Life, IX.)

\section{SUFFOLK.}

I9I4-I6. Farren, W. Birds of the Breck. (Wild Life, III.-VIII.)

\section{SURREY.}

IgI6. Pettitt, E. E. The Dartford Warbler in Surrey. (Wild Life, VIII.)

I9I8. Pettitt, E. E. On Some Birds of N.W. Surrey. (Wild Life, X.) 


\section{SUSSEX.}

I9r4. Turner, E. L. The Nightjar in Sussex. (Wild I.ife, III.)

\section{YORKSHIRE.}

I9I3. Grabham, Oxley. The Woodcock in Yorkshire; The Stonechat in Yorkshire. (Wild Life, II.)

I9I4. Grabham, Oxley. The Pied Flycatcher in Yorkshire. (Wild Life, IV.)

\section{ANGLESEY.}

I9I7. Chislett, R. A Welsh Sea-bird Resort [Priestholm]. (Wild Life, IX.)

\section{BRECONSHIRE.}

I89I. Price, J. Hyde. The Rarer Hawks of Breconshire. (Rept. and Trans. Cardiff Nat. Soc, XXIV.)

Ig06-I2. Proger, T. W., and Paterson, D. R. Ornith. Notes : Bittern and G. North. Diver in Brecons. (Op. cit., XXXIX.); Little Bittern, and Bittern. (Op. cit., XLIII.); Black Tern. (Op. cit., XLII.) ; White-winged Black Tern. (Op. cit., XLIII.); Black-necked Grebe. (Op. cit., XLV.)

\section{CARDIGAN.}

I908. Proger, T. W., and Paterson, D. R. Ornith. Notes [Honey Buzzard]. (Rept. and Trans. Cardiff Nat. Soc., XLI.)

\section{GLAMORGANSHIRE.}

r868. [Anon.] Hobby, Kittiwake, and Buzzard in Glam. (Rept. and Trans. Cardiff Nat. Soc., I., I867-8.)

I874. Drane, R. Four British Birds. (Op. cit., VII.)

I88I. Knight, E. Dodridge. List of Birds killed near Newton Nottage. (Op. cit., XIV.) 
1883. Drane, R. Little Bittern, Golden Oriole, Rock Thrush, Rusty Grackle, Pallas Grey Shrike, Snow Bunting, and Black Redstart, in Glam. (T.C.N.S., XVI.)

1889. Proger, 'T. W. Remarks upon Some of the More Unfrequent Local Birds. (T.C.N.S., XXII.)

I896. Drane, R. Stray Notes on Natural History. (Op. cit., XXIX.) I899-I9I6. Proger and Paterson. Ornith. Notes. (T.C.N.S., XXXII.$\mathrm{XLIX}=1899$ to $19 \mathrm{I} 6$.

I904. Evans, C. E. Note on Sully Island. (Op. cit., XXXVII.)

1905. Proger, T. W. Guide to Roath Park. [List of the Birds] (Pub. I905.)

I907. Williams, J. E. Guillemots on Worms Head. (T.C.N.S., XL.) I9r3-I4. Salmon, H. M. The Blackheaded Gull [in Glam.] (Wild Life, II.); The Nightjar in Glams. (Op. cit., III.)

I9I5-I6. Ingram, G. C. S. Some Field Notes on the Nightjar [in Glams.]. (T.C.N.S., XLVIII.; Wild Life, VIII.).

\section{PEMBROKESHIRE.}

I889. Thomas, T. H. A Visit to the Gannet Settlement, Grassholm. (T.C.N.S., XXII.)

I893. Drane, R. Natural History Notes upon Grassholm. (Op. cit., XXVI.)

I895. Drane, R. An Island Holiday [Grassholm]. (Op. cit., XXVIII.)

I900. Drane, R. Olla Podrida. [Notes on Birds of Skomer.] ( $O p$. cit., XXXIII.)

1905. Proger and Paterson. The Gannets on Grassholm. (Op. cit., XXXVIII.)

I908. De Winton, W. E. Notes from Pembrokeshire. (Op. cit., XLI.) Proger and Paterson. Ornith. Notes. [Alpine Swift. Great Snipe in Pembs.]. (Op. cit., XLI.)

I9I3. Proger and Paterson., [p. 403.] Ornith. Notes. For "Langham" read "Laugharne."

I9I4. Proger and Paterson (ib.) This should be under Glamorganshire. IgI5. Proger and Paterson (ib.) This should be under Glamorganshire.

\section{RADNORSHIRE.}

I9or. Birkenhead, G. A. Natural History Notes on the Elan Valley District. (T.C.N.S., XXXIV.) 


\section{HADDINGTONSHIRE.}

I9I3. Atkinson, J., and Fortune, R. The Unique Gannet of IgIo. [Bass Rock.] (Wild Life, I.)

Fortune, R. Great Bird Resorts. [Bass Rock.] (Wild Life, I.)

\section{INVERNESS-SHIRE.}

I9I3. Macpherson, H. B. The Buzzards of Badenoch. [Inverness.]; The Woodcock in the Highlands. [Inverness.] (Wild Life, II.) Blackwood, G. G. The Crested Tit. [Spey Valley.] (Wild Life, II.)

I9I7. Fowler, T. M. Crossbills. [Inverness.] (Wild Life, IX.)

\section{ORKNEYS AND SHETLANDS.}

I9I3. Ferguson, G. D. The Fulmar. [Orkney and Shetlands.] (Wild Life, I.)

Stewart, A. M. The Black Guillemot. [Orkney and Shetlands.] (Wild Life, I.)

\section{PERTHSHIRE.}

1856. F[eilden], H. W. Peregrine Falcon [captured at Glenogle]. (Naturalist, p. 185.)

\section{SUTHERLAND.}

I9I4. "Coaster." The Eastern Coastline of Sutherland, and some of its Breeding Birds. (Wild Life, V.) 
PRINTED BY WITHERBY \& $\mathrm{CO}$.

AT THEIR PRINTING PRESS,

MIDDLE ROW PLACE, LONDON. 



\section{Selection of Books from WITHERBY \& CO.'S List.}

BRITISH BIRDS.

An Illustrated Monthly Magazine devoted to the Birds on the British List. Edited by H. F. WirherBy, M.B.E., F.Z.S., M.B.O.U. Assisted by REV. F. C. R. JOURDAIN, M.A., M.B.O.U., and N. F. TICEHURST, O.B.E., M.A., F.R.C.S., M.B.O.U. Illustrated with beautifu) and useful photographs. Provides a current history of British Birds. Annual Subscription, 20s. post free; Monthly, Is. 9d. net. Vols. I-XII. (unbound), I2s. each; bound, ${ }_{55}$. 6d. each net.

TROPICAL WILD LIFE IN BRITISH GUIANA.

Being Zoological Contributions to Science, from the Tropical Research Station of the New York Zoological Society, at Kalacoon, igio. By William Beebe, G. InNess Hartley and Paul G. Howes, with an Introduction by COLONEL THEODORE ROOSEVELT. Octavo. Cloth. 504 pages. 4 Coloured Plates, and I40 other Illustrations, 12s. $6 \mathrm{~d}$. net.

\section{A MONOGRAPH OF THE PHEASANTS.}

By William Beebe. With Numerous Coloured Plates by A. Thorburn, C. R. KNiGht, G. E. LodGe, L. A. Fuertes, H. GronvolD, and H. Jones. Together with Maps and Numerous Photographs by the Author, depicting the Pheasants of the World, their Haunts, their Changes of Plumage and their Nests and Eggs. Limited Edition of 600 Numbered Sets, only a portion of which are available for sale in the British Empire. Royal 4to. In Four Volumes, Volume I now ready. Prospectus and Specimen Plate on application.

Per. Vol. ¿Ir ros. net.

\section{A HAND-LIST OF BRITISH BIRDS.}

By ERnst HARTERT, F.C.R. Jourdain, N. F. Ticehurst, and H. F. Witherby. Demy 8vo. 7s. 6d, net. Interleaved ros. net.

THE BIRD-LOVER'S HOME-LIFE SERIES.

I. The Home-life of the Golden Eagle. 2. The Home-life of the Spoonbill, the Stork and some Herons. 3. The Home-life of the Osprey. 4. The Home-life of the Terns or Sea-Swallows. Each Volume contains 32 beautiful plates, artistically mounted from PHOTOGRAPHS DIRECT FROM NATURE, with 40-60 pages of letterpress. Crown 4to. Cloth 75. 6d, net each.

GAME BIRDS AND WATER-FOWL OF SOUTH AFRICA.

By the late MAJOR BOYD HORSBRUGH, F.z.s., M.B.o.U. With 67 beautiful Coloured Plates. Half morocco. £4 I4s. net, or unbound parts.

INDIAN PIGEONS AND DOVES.

By E. C. STUART BAKER, F.Z.S., M.B.O.U. With 27 beautiful Coloured Plates. Imp. 8vo. Half bound morocco. $\hbar^{2}$ ros. net. PHOTOGRAPHY FOR BIRD-LOVERS.

By Bentley Beetham, F.z.s. I 6 full-page Plates. A practical guide to the pursuit of bird-photography in all its branches. Demy 8vo. Cloth. 5s. net.

JUNGLE PEACE.

By WrLlian BEEBE. Contains records of extraordinary scientific interest. The author tells of bird, beast, plant and insect life of the British Guiana jungle. Crown 8 vo, illustrated. 8s. net.

THE BUZZARD AT HOME.

By Arthur Brook. The photographs, which are here first published, have special interest to Ornithologists. Twelve plates, jo, id. net. 


\section{A Practical Handbook}

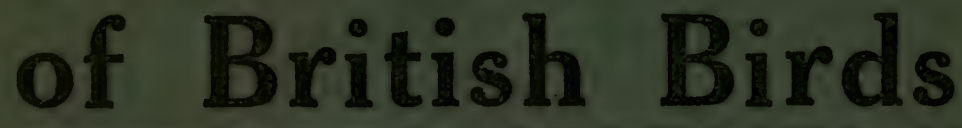

Edited by H. F. WITHERBY, M.B.E., M.B.O.U., F.Z.S., F.R.G.S.

\section{CONTRIBUTORS-}

E. HARTERT, pH.D., м.в.o.u., f.z.s. ANNIE C. JACKSON, «.м.в.о.u. REv. F. C. R. JOURDAIN, M.A., M.z.o.U. C. OLDHAM, F.z.s, N.,....v. N. F. TICEHURST; 0.B.E, M.A., E.R.C.s., M.B.o.U.

Specially arranged for quick roference. Distinguishing characters simplifying identification, full description of all plumages. Breeding habits (nest, eggs, season, incubation, etc.). Food. Distribution and Migration.

VOLUME 1.--Strongly bound in Buckram. Cilt Top. 550. Pages. 140 Illustrations. 40s.

Thin Paper Edition, bound in Rexine. Useful for Field Naturalists and Travellers. 48s. $6 \mathrm{~d}$.

\section{PRESS OPIRIONS.}

IBIS: "We feel gure that the work, when completed, will prove of the Ereateut valuo to all working ormitbologiats."

AUK: "We shall look forward with interest to the succeeding parts of this important work, which should easily bocome the authoritative bouk of reference upon British avifauna."

SCIENCE PROGRESS:"Here, for the first time, we find completo accounta of British birds in all their various plumages from nestling to aduli-an enormous undertakiag."

FIELD: "What is at once apparent on turning over the pages is the nove! plan of fguring in colours the immolure plumages of well-known British apecien."

COUNTRY LIFE : "Eminently practical and valuable guido for the field naturalist:

CONDOR: "About the most thoroughly satinfying book we bave yet seen on the birds of any one country."

\section{LONDON:}

WITHERBY \& CO., 326 High HolboRn, W.C.1 





SMITHSONIAN INSTITUTION UBRARIES 